\title{
DIREITOS SOCIAIS E POLÍTICAS PÚBLICAS
}

VOL. 1 


\section{PEMBROKE COLLINS CONSELHO EDITORIAL}

PRESIDÊNCIA Felipe Dutra Asensi

CONSELheiros Adolfo Mamoru Nishiyama (UNIP, São Paulo)

Adriano Moura da Fonseca Pinto (UNESA, Rio de Janeiro)

Adriano Rosa (USU, Rio de Janeiro)

Alessandra T. Bentes Vivas (DPRJ, Rio de Janeiro)

Arthur Bezerra de Souza Junior (UNINOVE, São Paulo)

Aura Helena Peñas Felizzola (Universidad de Santo Tomás, Colômbia)

Carlos Mourão (PGM, São Paulo)

Claudio Joel B. Lossio (Universidade Autónoma de Lisboa, Portugal)

Coriolano de Almeida Camargo (UPM, São Paulo)

Daniel Giotti de Paula (INTEJUR, Juiz de Fora)

Danielle Medeiro da Silva de Araújo (UFSB, Porto Seguro)

Denise Mercedes N. N. Lopes Salles (UNILASSALE, Niterói)

Diogo de Castro Ferreira (IDT, Juiz de Fora)

Douglas Castro (Foundation for Law and International Affairs, Estados Unidos)

Elaine Teixeira Rabello (UERJ, Rio de Janeiro)

Glaucia Ribeiro (UEA, Manaus)

Isabelle Dias Carneiro Santos (UFMS, Campo Grande)

Jonathan Regis (UNIVALI, Itajaí)

Julian Mora Aliseda (Universidad de Extremadura. Espanha)

Leila Aparecida Chevchuk de Oliveira (TRT 2a Região, São Paulo)

Luciano Nascimento (UEPB, João Pessoa)

Luiz Renato Telles Otaviano (UFMS, Três Lagoas)

Marcelo Pereira de Almeida (UFF, Niterói)

Marcia Cavalcanti (USU, Rio de Janeiro)

Marcio de Oliveira Caldas (FBT, Porto Alegre)

Matheus Marapodi dos Passos (Universidade de Coimbra, Portugal)

Omar Toledo Toribio (Universidad Nacional Mayor de San Marcos, Peru)

Ricardo Medeiros Pimenta (IBICT, Rio de Janeiro)

Rogério Borba (UVA, Rio de Janeiro)

Rosangela Tremel (UNISUL, Florianópolis)

Roseni Pinheiro (UERJ, Rio de Janeiro)

Sergio de Souza Salles (UCP, Petrópolis)

Telson Pires (Faculdade Lusófona, Brasil)

Thiago Rodrigues Pereira (Novo Liceu, Portugal)

Vanessa Velasco Brito Reis (UCP, Petrópolis)

Vania Siciliano Aieta (UERJ, Rio de Janeiro) 


\section{DIREITOS SOCIAIS E POLÍTICAS PÚBLICAS}

VOL. 1 


\title{
Copyright @ 2020 Daniel Giotti de Paula, Diego Machado Monnerat, Lucas Manoel Silva Cabral, Rosangela Tremel (orgs.)
}

\author{
DIREÇÃo EDITORIAL Felipe Asensi \\ EDIÇÃo E EDITORAÇÃo Felipe Asensi \\ REVISÃo Coordenação Editorial Pembroke Collins \\ projeto grafico e capa Diniz Gomes \\ diagramaçäo Diniz Gomes
}

DIREITOS RESERVADOS A

\section{PEMBROKE COLLINS}

Rua Pedro Primeiro, 07/606

20060-050 / Rio de Janeiro, RJ

info@pembrokecollins.com

www.pembrokecollins.com

TODOS OS DIREITOS RESERVADOS

Nenhuma parte deste livro pode ser utilizada ou reproduzida sob quaisquer meios existentes sem autorização por escrito da Editora.

FINANCIAMENTO

Este livro foi financiado pela Fundação de Amparo à Pesquisa do Estado do Rio de Janeiro, pelo Conselho Internacional de Altos Estudos em Direito (CAED-Jus), pelo Conselho Internacional de Altos Estudos em Educação (CAEduca) e pela Pembroke Collins.

Todas as obras são submetidas ao processo de peer view em formato double blind pela Editora e, no caso de Coletânea, também pelos Organizadores.

D598

Direitos sociais e políticas públicas / Daniel Giotti de Paula, Diego Machado Monnerat, Lucas Manoel Silva Cabral e Rosangela Tremel (organizadores). - Rio de Janeiro: Pembroke Collins, 2020.

v. 1; 920 p.

ISBN 978-65-87489-52-0

1. Direitos sociais. 2. Direitos fundamentais. 3. Direitos políticos. 4. Políticas públicas. I. Paula, Daniel Giotti de (org.). II. Monnerat, Diego Machado (org.). III. Cabral, Lucas Manoel Silva (org.). IV. Tremel, Rosangela (org.). 


\section{SUMÁRIO}

ARTIGOS.

EDUCAÇÃO E POLITICAS PÚBLICAS: OS CAMINHOS DA EDUCAÇÃO ESPECIAL NO BRASIL. .19

João Vitor Coêlho Braga

Matheus Barbosa de Oliveira

A EDUCAÇÃO E OS DIREITOS HUMANOS NO CONTEXTO DO

COVID-19: PROBLEMÁTICAS E POSSIBILIDADES.....................................36

José Fernando Lima de Oliveira

Genivaldo dos Santos

CURRÍCULO ESCOLAR E ATO DISCRICIONÁRIO: UMA REFLEXÃO JURIDICA SOBRE A MATRIZ CURRICULAR. .48

Paulo de Tarso Lopes

METODOLOGIAS E ESTRATÉGIAS DE AVALIAÇÃO EDUCACIONAL APLICADAS NA DISCIPLINA DE LINNGUA PORTUGUESA: UM ESTUDO DE CASO EM UMA TURMA DE 9 ANO DO ENSINO FUNDAMENTAL. .65 Maria Nádia Alencar Lima

Eraldo Pereira Madeiro

SISTEMAS ADAPTATIVOS COMPLEXOS NA APRENDIZAGEM DE INGLÊS CAÓTICA. .82

Isabelly Raiane Silva dos Santos

O PAPEL DA MOTIVAÇÃO NA APRENDIZAGEM DE LÍNGUA INGLESA. Isabelly Raiane Silva dos Santos

EDUCAÇÃO EMOCIONAL: DIREITO SUBJETIVO QUE NECESSITA REFLEXÃO. 
A EDUCAÇÃO DE DIREITOS HUMANOS ORIUNDA DA ESCOLA: O BERÇO PARA A LUTA CONTRA DESIGUALDADES .123

Genivaldo dos Santos

José Fernando Lima de Oliveira

"GENTE O QUE É MACUMBA? MACUMBA SÓ PEGA EM QUEM ACREDITA?": UM ESTUDO SOBRE INTOLERÂNCIA RELIGIOSA NO CONTEXTO ESCOLAR......

Cintia Quina da Silva

EDUCAÇÃO EM DIREITOS HUMANOS E A VIOLÊNCIA NA ESCOLA .152 Lohane Borges Leal Lima

A MOTIVAÇÃO NAS AULAS DE EDUCAÇÃO FÍSICA NO ENSINO MÉDIO: UM 169

Victor Matheus Lopes Martinez

A GEOGRAFIA CRÍTICA COMO ABORDAGEM DE ENSINO NA CONSCIENTIZAÇÃO POLÍTICA DOS OPRIMIDOS E NA DEFESA DA EDUCAÇÃO EM DIREITOS HUMANOS. Magno Henrique de Medeiros Rodrigues

EXPERIÊNCIA DE ESTÁGIO DOCENTE NA EDUCAÇÃO BÁSICA. 203 Roberto Ramon Queiroz de Assis

A NOVA ERA NA EDUCAÇÃO BRASILEIRA. 221 Alessandra de Freitas Kechichian

A PRODUÇÃO DA DISCRIMINAÇÃO CONTRA OS NEGROS NA PUBLICAÇÃO DOS LIVROS DIDÁTICOS DE HISTÓRIA E DE LÍNGUA PORTUGUESA NO BRASIL. .230

Ricardo José Clevelande Ferriera

EDUCAÇÃO EM DIREITOS HUMANOS: UM ESTUDO DE CASO COM JOVENS DO CURSO "IAÔ APRENDIZ EM CENA".... 248 Israel Marques Campos

ENEM: O DESCASO DO GOVERNO FEDERAL FRENTE A EDUCAÇÃO E ESTUDANTES.. 265

Dalline Cristine Ligabo Marton 
O CURRÍCULO ESCOLAR COM O TEMA EDUCAÇÃO PARA A

CIDADANIA DIGITAL.................................................................276

Luís José Câmara Pedrosa

UMA PROPOSTA DE FORMAÇÃO DOCENTE PARA O USO SEGURO

E RESPONSÁVEL DAS TECNOLOGIAS DIGITAIS, GARANTINDO A

CIDADANIA DIGITAL DE CRIANÇAS E ADOLESCENTES...........................290

Ana Gicélia do Nascimento Sousa

EDUCAÇÃO E GÊNERO: A IMPORTÂNCIA DA EDUCAÇÃO EM

DIRETIOS HUMANOS NO ENFRENTAMENTO A VIOLÊNCIA CONTRA A

MULHER.

Amanda Silva de Jesus

AS RELAÇÕES ENTRE INCLUSÃO E EXCLUSÃO SOCIAL COM A

EDUCAÇÃO INCLUSIVA: REVISÃO DE LITERATURA.

Carlos Antonio Furtado Dutra

A MASCULINIZAÇÃO DO FRACASSO: UM OLHAR SOBRE A QUESTÃO

DE GÊNERO NA EDUCAÇÃO.

Viviane Chaves Tibães

Fabio da Costa Tibães

CONTRIBUIÇÕES PARA A CONSTRUÇÃO DA ORALIDADE A PARTIR DE UMA EXPERIÊNCIA LEITORA COM CRIANÇAS PEQUENAS. 353

Mariana Lopez Exposito

EDUCAÇÃO INCLUSIVA: PROTAGONISMO JUVENIL EM ESCOLAS DE PERNAMBUCO,BRASIL. 368

Ana Beatriz Medeiros Ferreira

A QUALIDADE DAS INSTITUIÇÕES DE ENSINO SUPERIOR

CONTROLADAS POR COMPANHIAS LISTADAS NA BOLSA DE VALORES.....378 Dalliane Vanessa Pires Andrade

OLHARES NEGROS NA EDUCAÇÃO FÍSICA: EM DEFESA DO DIREITO

DE SER NEGRA .400

Carolina Cristina dos Santos Nobrega

CRIANÇAS NEGRAS NO BRASIL ESCRAVISTA: UMA INFÂNCIA NEGADA......418 Luana Fernanda Rodrigues dos Santos 
VIOLÊNCIA ESCOLAR: UMA ANÁLISE BIBLIOGRÁFICA ACERCA DAS CONSEQUÊNCIAS DA PRÁTICA DO BULLYING NAS RELAÇÕES INTRA E INTERPESSOAIS.

Rafael Ramos Longuinhos

SALA DE INTEGRAÇÃO E RECURSOS: SERVIÇO DE APOIO AO

DIREITO À EDUCAÇÃO.

Itaara Gomes Pires

Kira Pires Capaverde

ENSINO MÉDIO POLITÉCNICO: A POLITECNIA COMO DISTORÇÃO!?.......466 Itaara Gomes Pires

Kira Pires Capaverde

ACESSO À EDUCAÇÃO SUPERIOR POR PESSOAS COM DEFICIÊNCIA NO BRASIL E DIREITOS HUMANOS EM INSTRUMENTOS NORMATIVOS INTERNACIONAIS E NACIONAIS.

Victor Martins Ramos Rodrigues

Leandro Garcia Pinho

O DIREITO À EDUCAÇÃO SEXUAL: DESAFIOS E POSSIBILIDADES

POSTOS À EDUCAÇÃO SEXUAL DE CRIANÇAS E ADOLESCENTES NO

AMBITO FAMILIAR.

Fabiola Francielle de Jesus

Welton Vinícius Santos Silva

A RELAÇÃO ENTRE O PÚBLICO E O PRIVADO E O CONSEQUENTE DIREITO A EDUCAÇÃO.

Thais Maria dos Santos Silva

EXPERIÊNCIAS DE CONTEXTOS DE VULNERABILIDADE SOCIAL E SEUS IMPACTOS SOBRE OS PROCESSOS DE APRENDIZAGEM.

Marina Taís Gabriel da Silva

Matheus de Oliveira Guimarães

Poliane Marta Rezende Pádua

EDUCAÇÃO EM DIREITOS HUMANOS PARA UMA CULTURA DE PAZ:

A PRÁTICA DA DANÇA COMO CAMINHO DE RESGATE DA INTEIREZA

HUMANA.

Marilia Cristina da Costa e Silva

Fernanda Ferfila Minnone 
OS SENTIDOS DA AVALIAÇÃO DAS REDES DE ENSINO NA

DEMOCRACIA BRASILEIRA .558

Sandra Vidal Nogueira

AS CONTRIBUIÇÕES DA EDUCAÇÃO A DISTANCIA NO ACESSO

AO CONHECIMENTO E NAS APRENDIZAGENS MEDIADAS PELAS

TECNOLOGIAS REMOTAS E DIGITAIS

Sandra Vidal Nogueira

EDUCOMUNICAÇÃO E DIREITOS HUMANOS .589

Debora Amorim Radanovitsck

A MICRORRESISTENNCIA A PARTIR DE MICHEL DE CERTEAU E O

BIOPODER DE MICHEL FOUCAULT NA HIPERCOMPLEXIDADE DA

PRÁTICA PEDAGÓGICA DOCENTE...

Ivonete da Silva

O DIREITO À EDUCAÇÃO A PARTIR DA PERSPECTIVA DOS DIREITOS

HUMANOS.

Fabiana Bazilio Farias

Juliana Carvalho de Araujo de Barros

A TRANSDISCIPLINARIDADE ENTRE FILOSOFIA, PEDAGOGIA E PSICOLOGIA PARA UM ENSINO ÚTIL, HUMANO E SENSÍVEL 641

Walfrido Monteiro Júnior

A SALA DE AULA INVERTIDA: UM ESTUDO DAS VANTAGENS E

DESAFIOS DO MÉTODO...

Roberta Maciel Campolina

ENSINO DE LIBRAS: ANÁLISE BIBLIOMÉTRICA NA WEB OF SCIENCE. 672

Jocilene Alves Sousa

Eliuvomar Cruz da Silva

Laury Vander Leandro de Souza

UM OLHAR SOBRE OS DIREITOS DE CRIANÇAS E EQUIPE DOCENTE

NO RETORNO ÀS INSTITUIÇÕES EDUCACIONAIS PÓS-PANDEMIA .694

Mariana Lopez Expósito

Pâmela Elisabete Julião 
A EDUCAÇÃO EM DIREITOS HUMANOS PARA CRIANÇAS E ADOLESCENTES: PISTAS A PARTIR DAS INSTITUIÇÕES DE ENSINO FORMAIS E NÃO-FORMAIS .714

Nei AlBerto Salles Filho

Vania Fernandes Machado

Evenilson Silvestre da Luz

TRABALHANDO MÚSICA NA ESCOLA - UMA REFLEXÃO SOBRE DESIGUALDE. .731

Nilton Alex Fernandes Ribeiro

UNIDADE, AFETO, COGNIÇÃO E A FORMAÇÃO DA PERSONALIDADE COLETIVISTA: A EDUCAÇÃO DE JOVENS E ADULTOS NO SISTEMA PRISIONAL BRASILEIRO. .750

Francisco Carneiro Braga

Hellyegenes de Oliveira

Tarciana Cecilia de Souza Ferreira

Vanessa Amellyne de Souza Ferreira

REPRESENTAÇÕES SOCIAIS NA INTERFACE DA EDUCAÇÃO ESPECIAL: DISCUSSÕES EPISTEMOLÓGICAS ...............................................767 Igor Belo dos Santos

EDUCAÇÃO MATEMÁTICA: O ENSINO POR MEIO DA RESOLUÇÃO DE PROBLEMAS .786

José Antônio de Oliveira Júnior

O DIREITO À EDUCAÇÃO PÓS COVID-19 E A IGUALDADE DE CONDIÇÕES SOB A PERSPECTIVA CONSTITUCIONAL. .799

Daniele Messias Corrêa Luiz

Caio Silva de Sousa

PERCEÇÃO DOS ESTUDANTES DO ENSINO SUPERIOR SOBRE OS

DIREITOS DA CRIANÇA: CURSOS DE EDUCADORES DE INFÂNCIA E

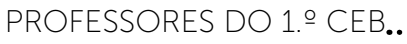
.814

Maria Fernanda dos Santos Mendes Sampaio

Maria Filomena Tomaz Henriques Serrano Caldeira

A EDUCAÇÃO COMO DIREITO E A QUALIDADE DO ENSINO JURÍDICO......827 Roselaine Andrade Tavares 
LEVANTAMENTO DOS ATOS NORMATIVOS DO CONSELHO

NACIONAL DE EDUCAÇÃO- CNE, QUE TRATAM DA FORMAÇÃO DE PROFESSORES:REFLEXÕES ACERCA DAS VIOLÊNCIAS E DIREITOS HUMANOS-PERIODO ANALISADO 1997 A 2016.

Maria Cristina E. E. Stival

DIREITO EDUCACIONAL E POLITICAS PÚBLICAS: CAMINHO PARA UMA EDUCAÇÃO DEMOCRÁTICA.

Heryda Carolyne Ferreira Sousa

A PRATICA DOCENTE JUNTO AO SISTEMA PRISIONAL (QUANDO

A EDUCAÇÃO ROMPE GRADES E CADEADOS): UM RELATO DE EXPERIÊNCIA NA PENITENCIÁRIA JOSÉ DE DEUS BARROS SITUADA NA CIDADE DE PICOS - PI. .849

Maurício Pereira Barros

EDUCAÇÃO E DIREITOS HUMANOS: OS JOVENS MULTIPLICADORES NA CONSTRUÇÃO DO BEM COMUM. .853

Ralph Schibelbein

O "BIOHACKING" COMO ALTERNATIVA NA EFETIVAÇÃO DO DIREITO À EDUCAÇÃO INCLUSIVA: O CASO DOS ALUNOS SUPERDOTADOS COM AUTISMO LEVE. .857

Guilherme Carneiro Leão Farias

A ESCOLA PÚBLICA ENQUANTO ESPAÇO DE EXPRESSÃO

DA LIBERDADE E DE (RE)CONSTRUÇÃO DE SABERES: UMA ANÁLISE À LUZ DOS DIREITOS E GARANTIAS FUNDAMENTAIS DA CONSTITUIÇÃO FEDERAL DO BRASIL. .864

Rafael Ramos Longuinhos

REFLEXÕES SOBRE O ESPAÇO DAS PESSOAS TRANS NO PROCESSO EDUCACIONAL: UM LUGAR DE EXCLUSÃO...

Ana Carolina Rodrigues de Assis

Bruna Alves de Almeida

Estefânia Moreira dos Reis

Giovanna Rodrigues de Assis 
O PAPEL DOS DIREITOS HUMANOS NO ENSINO PRÉ-ESCOLAR. .872 Ana Laura de Azevedo Oliveira

ALFABETIZAÇÃO E LETRAMENTO: UM RELATO DE EXPERIÊNCIA SOBRE ESTRATÉGIAS DE ENFRENTAMENTO DE DIFICULDADES DE LEITURA E ESCRITA NO ENSINO FUNDAMENTAL. .876 Ana Paula Rocha da Silva

A EDUCAÇÃO COMO UM DIREITO HUMANO PARA FORMAÇÃO DA CIDADANIA NA SOCIEDADE BRASILEIRA EM TRANSFORMAÇÃO DIGITAL...879 Vanessa Maria de Oliveira Accioly Maia

Thais do Nascimento Cortez

A DOCÊNCIA COMO PROMOTORA DE DIREITOS HUMANOS EM ESPAÇOS DESUMANOS. .884 Rosidalva Pereira Almeida

A IMPORTÂNCIA DAS METODOLOGIAS ATIVAS NOS CURSOS DE DIREITO890 Fabiana David Carles

Vitória Caroline Brandão da Costa Siqueira

A EDUCAÇÃO SUPERIOR E A PANDEMIA DO CORONAVÍRUS:

PERSPECTIVAS SOBRE O ENSINO JURÍDICO À LUZ DAS TEORIAS CRÍTICAS E LIBERTADORAS DO DIREITO............................................894 Maria Gabrielle Araujo de Souza

DIREITO À EDUCAÇÃO E EMANCIPAÇÃO HUMANA PARA JOVENS E ADULTOS..

Adriana de Almeida

ESCOLA PÚBLICA: PELO DIREITO DE "SER ALGUÉM NA VIDA".... .905 Janaína da Conceição Santos Dias Almeida

A EJA - A EDUCAÇÃO DE JOVENS E ADULTOS E ADOLESCENTES EM SITUAÇÃO DE ACOLHIMENTOS INSTITUCIONAIS: CLAMORES E INQUIETAÇÕES .911 João Francisco Ferraz de Lima 


\section{CONSELHO DO CAED-Jus}

\begin{tabular}{ll}
\hline Adriano Rosa & (Universidade Santa Úrsula, Brasil) \\
\hline Alexandre Bahia & (Universidade Federal de Ouro Preto, \\
& Brasil) \\
\hline Alfredo Freitas & (Ambra College, Estados Unidos) \\
\hline Antonio Santoro & (Universidade Federal do Rio de Janeiro, \\
& Brasil) \\
\hline Arthur Bezerra de Souza Junior & (Universidade Nove de Julho, Brasil) \\
\hline Bruno Zanotti & (PCES, Brasil) \\
\hline Claudia Nunes & (Universidade Veiga de Almeida, Brasil) \\
\hline Daniel Giotti de Paula & (PFN, Brasil) \\
\hline Danielle Ferreira Medeiro da & (Universidade Federal do Sul da Bahia, \\
Silva de Araújo & Brasil) \\
\hline Denise Salles & (Universidade Católica de Petrópolis, \\
& Brasil) \\
\hline Edgar Contreras & (Universidad Jorge Tadeo Lozano, \\
& Colômbia) \\
\hline Eduardo Val & (Universidade Federal Fluminense, Brasil) \\
\hline Felipe Asensi & (Universidade do Estado do Rio de Janeiro, \\
& Brasil) \\
\hline Fernando Bentes & (Universidade Federal Rural do Rio de \\
& Janeiro, Brasil) \\
\hline Glaucia Ribeiro & (Universidade do Estado do Amazonas, \\
& Brasil) \\
\hline Gunter Frankenberg & (Johann Wolfgang Goethe-Universität - \\
Frankfurt am Main, Alemanha) \\
\hline João Mendes & (Universidade de Coimbra, Portugal) \\
\hline
\end{tabular}




\begin{tabular}{ll}
\hline Jose Buzanello & $\begin{array}{l}\text { (Universidade Federal do Estado do Rio de } \\
\text { Janeiro, Brasil) }\end{array}$ \\
\hline Klever Filpo & (Universidade Católica de Petrópolis, \\
& Brasil) \\
\hline Luciana Souza & (Faculdade Milton Campos, Brasil) \\
\hline Marcello Mello & (Universidade Federal Fluminense, Brasil) \\
\hline Maria do Carmo Rebouças dos & (Universidade Federal do Sul da Bahia, \\
Santos & Brasil) \\
\hline Nikolas Rose & (King's College London, Reino Unido) \\
\hline Oton Vasconcelos & (Universidade de Pernambuco, Brasil) \\
\hline Paula Arévalo Mutiz & (Fundación Universitária Los Libertadores, \\
& Colômbia) \\
\hline Pedro Ivo Sousa & (Universidade Federal do Espírito Santo, \\
& Brasil) \\
\hline Santiago Polop & (Universidad Nacional de Río Cuarto, \\
& Argentina) \\
\hline Siddharta Legale & (Universidade Federal do Rio de Janeiro, \\
& Brasil) \\
\hline Saul Tourinho Leal & (Instituto Brasiliense de Direito Público, \\
& Brasil) \\
\hline Sergio Salles & (Universidade Católica de Petrópolis, \\
& Brasil) \\
\hline Susanna Pozzolo & (Università degli Studi di Brescia, Itália) \\
\hline Thiago Pereira & (Centro Universitário Lassale, Brasil) \\
\hline Tiago Gagliano & (Pontifícia Universidade Católica do \\
& Paraná, Brasil) \\
\hline Walkyria Chagas da Silva Santos & (Universidade de Brasília, Brasil) \\
\hline
\end{tabular}




\section{SOBRE O CAED-Jus}

\section{O Conselho Internacional de Altos Estudos em Direito}

(CAED-Jus) é iniciativa consolidada e reconhecida de uma rede de acadêmicos para o desenvolvimento de pesquisas jurídicas e reflexões interdisciplinares de alta qualidade.

O CAED-Jus desenvolve-se via internet, sendo a tecnologia parte importante para o sucesso das discussões e para a interação entre os participantes através de diversos recursos multimídia. O evento é um dos principais congressos acadêmicos do mundo e conta com os seguintes diferenciais:

- Abertura a uma visão multidisciplinar e multiprofissional sobre o direito, sendo bem-vindos os trabalhos de acadêmicos de diversas formações

- Democratização da divulgação e produção científica;

- Publicação dos artigos em livro impresso no Brasil (com ISBN), com envio da versão ebook aos participantes;

- Galeria com os selecionados do Prêmio CAED-Jus de cada edição;

- Interação efetiva entre os participantes através de ferramentas via internet;

- Exposição permanente do trabalho e do vídeo do autor no site para os participantes

- Coordenadores de GTs são organizadores dos livros publicados 
O Conselho Científico do CAED-Jus é composto por acadêmicos de alta qualidade no campo do direito em nível nacional e internacional, tendo membros do Brasil, Estados Unidos, Colômbia, Argentina, Portugal, Reino Unido, Itália e Alemanha.

Em 2020, o CAED-Jus organizou o seu tradicional Congresso Interdisciplinar de Direitos Humanos (INTERDH 2020), que ocorreu entre os dias 29 a 31 de julho de 2020 e contou com 63 Áreas Temáticas e mais de 1100 artigos e resumos expandidos de 73 universidades e 43 programas de pós-graduação stricto sensu. A seleção dos trabalhos apresentados ocorreu através do processo de peer review com double blind, o que resultou na publicação dos livros do evento.

Esta publicação é financiada por recursos da Fundação de Amparo à Pesquisa do Estado do Rio de Janeiro (FAPERJ), do Conselho Internacional de Altos Estudos em Direito (CAED-Jus), do Conselho Internacional de Altos Estudos em Educação (CAEduca) e da Editora Pembroke Collins e cumpre os diversos critérios de avaliação de livros com excelência acadêmica nacionais e internacionais. 
ARTIGOS 



\section{EDUCAÇÃO E POLÍTICAS PÚBLICAS: OS CAMINHOS DA EDUCAÇÃO ESPECIAL NO BRASIL}

João Vitor Coêlho Braga

Matheus Barbosa de Oliveira

A Declaração Universal de Direitos Humanos (DUDH), documento criado em 1948 pela Organização das Nações Unidas (ONU), tem em seu escopo os direitos que são fundamentais para todas as pessoas simplesmente por serem humanas, e que são ideais a serem alcançados pelas nações signatárias à ONU.

Esses direitos, dentre os quais estão inclusos o direito à vida, à saúde, à alimentação, ao meio ambiente, ao trabalho, à liberdade, à religião, e à educação, são reconhecidos internacionalmente e são garantidos por todos os sistemas sociais os quais os indivíduos fazem parte. Tal qual é ratificado pelo $1^{\underline{a}}$ artigo da DUDH, explicitando que "Todos os seres humanos nascem livres e iguais em dignidade e em direitos." (ONU, 1948).

Esses direitos prescritos na DUDH não são tratados como direitos regularizados interiormente dentro dos Estados/nações. Antônio Joaquim Severino (2019) coloca que os direitos humanos são "direitos naturais", regularizados para que sejam exigidos o seu cumprimento e para garantir a sua inviolabilidade, além de estabelecer normas procedimentais para os Estados e explicitar a sua existência de forma normativa.

No rol desses direitos, se faz presente o direito à educação, que dentro da DUDH se faz presente no Art. 26, onde salienta que: 
1. Todo ser humano tem direito à instrução. A instrução será gratuita, pelo menos nos graus elementares e fundamentais. A instrução elementar será obrigatória. A instrução técnico-profissional será acessível a todos, bem como a instrução superior, esta baseada no mérito.

2. A instrução será orientada no sentido do pleno desenvolvimento da personalidade humana e do fortalecimento do respeito pelos direitos humanos e pelas liberdades fundamentais. A instrução promoverá a compreensão, a tolerância e a amizade entre todas as nações e grupos raciais ou religiosos, e coadjuvará as atividades das Nações Unidas em prol da manutenção da paz. (ONU, 1948)

Através do excerto retirado do texto original da DUDH, é possível observar que a ONU procurou abranger, dentro do Art. 26, diversas demandas que hoje somente são observadas em sociedade devido à educação.

Voltando-se para a análise do artigo, é possível observar que a ONU propõe às nações signatárias a existência de uma educação que seja para todos, além de determinar que a educação seja gratuita para os graus elementares e fundamentais.

Infere-se, a partir da leitura do artigo, que o intuito da normativa é tornar a educação mais acessível a todos, principalmente em seus primeiros graus, porque são nestes que a base educacional do cidadão se iniciará na vida escolar, sendo eles primordiais por permitirem a consolidação do segundo inciso do artigo.

Esse inciso é voltado para a formação do cidadão e pelo exercício da cidadania, orientando que a instrução ultrapassará a esfera da educação no âmbito escolar, girando também em torno do desenvolvimento de uma sociedade mais justa, compreensiva e pacífica. Ou seja, a educação não se trata somente de um processo de obtenção de conhecimento, mas sim de "um investimento formativo do humano, seja na particularidade da relação pedagógica pessoal, seja no âmbito da relação social coletiva" (SEVERINO, 2006).

Dado o exposto, é notável o quanto a educação é necessária para o desenvolvimento do ser humano e para o exercício da cidadania dentro 
da sociedade. Nesse liame, o presente trabalho tem por objetivo analisar o contexto em que estão inseridas as leis que regem a educação inclusiva no Brasil e compreender o papel do Estado e da escola no processo de inclusão dos alunos que apresentam deficiências educacionais especiais nas escolas de ensino regular.

Neste sentido, este trabalho propõe uma nova leitura e interpretação dos documentos (Declaração Universal dos Direitos Humanos, Constituição Federal, Declaração de Salamanca entre outros) que orientam acerca do direito à Educação e a Educação Especial no Brasil, assim como pesquisa de revisão bibliográfica.

\section{Breve histórico dos princípios Legislativos sobre a Educação Especial no Brasil}

No Brasil, a Constituição Federal, no Art. 205 especifica que

A educação, direito de todos e dever do Estado e da família, será promovida e incentivada com a colaboração da sociedade, visando ao pleno desenvolvimento da pessoa, seu preparo para o exercício da cidadania e sua qualificação para o trabalho. (BRASIL, 1988)

Verifica-se no fragmento da Constituição que assim como regulamentado na Declaração Universal de Direitos Humanos, o constituinte entende que a educação é direito de todos e dever estatal, sendo este o responsável por garantir que a educação esteja disponível para toda a população, incluindo as pessoas com deficiência física e/ou intelectual, como ratifica a Carta Magna no artigo 208, inciso III,

Art. 208. O dever do Estado com a educação será efetivado mediante a garantia de:

III - atendimento educacional especializado aos portadores de deficiência, preferencialmente na rede regular de ensino; (BRASIL, 1988)

Isso significa que atendendo as normativas apresentadas pela DUDH e as próprias demandas constitucionais, o governo brasileiro 
deve fornecer àqueles que necessitam uma educação especial e inclusiva, pautada na transversalidade e na oferta de direitos sociais básicos, que garanta a prevalência dos direitos humanos, como também é requerido no $4^{\circ}$ artigo da Constituição.

Além disso, é de salutar importância mencionar a Declaração de Salamanca, afirmada em 1994, na Espanha. Esta trata-se de princípios, políticas e práticas na área das necessidades educativas especiais, que asseguram que a educação de pessoas com deficiências seja uma parte que integra o sistema educacional dos países signatários.

A Declaração menciona que toda criança tem direito fundamental à educação, e que todas as suas características são únicas e devem ser bem desenvolvidas/exploradas por um sistema de ensino que leve em conta a diversidade dessas qualidades, e que a escola seja capaz de acomodá-la com uma pedagogia capaz de satisfazer suas necessidades.

Ou seja, a resolução das Nações Unidas propõe que sejam adotados procedimentos e políticas públicas voltadas para a inclusão, desenvolvimento e valorização das deficiências inerentes àqueles que as possuem.

Com base no que foi apresentado, serão elencadas leis voltadas para a educação de pessoas com deficiências educacionais especiais, criando-se assim uma trajetória da educação especial e de sua evolução na legislação brasileira, voltando-se para o cumprimento do que é proposto da Declaração Universal de Direitos Humanos e na Constituição.

Deste modo, uma das primeiras normativas voltadas para o trabalho de pessoas com deficiência foi a Portaria n⿳0 1.793 , de dezembro de 1994. Em sua matéria, foi recomendada a inclusão da disciplina de “Aspectos Ético-Político-Educacionais da Normalização e Integração da Pessoa Portadora de Necessidades Especiais" nos cursos de Pedagogia, Psicologia e nas Licenciaturas.

Além disso, foi recomendado que outros cursos tivessem aspectos relacionados a disciplina supracitada, de acordo com suas especificidades, bem como nos cursos do grupo de Ciências da Saúde e no Curso de Serviço Social. Fora isso, em seu 3o artigo é recomendada "a manutenção e expansão de estudos adicionais, cursos de graduação e de especialização já organizados para as diversas áreas da Educação Especial.” (BRASIL, 1994). 
Entretanto, é cabível citar que essa portaria não interfere diretamente dentro das salas de aula, visto que inicialmente o estudo de conceitos que englobam pessoas com necessidades especiais ainda era pequeno e voltado para o ensino superior, incluso na disciplina citada acima. Ou seja, tratava-se da complementação curricular dos docentes que futuramente poderiam (ou não) ter contato com pessoas portadoras de necessidades especiais.

Passando para o ano de 1996, a educação especial recebeu um grande passo com a introdução da Lei 9.394, de 20 de dezembro de 1996, que estabelece as diretrizes e bases da educação nacional (Lei de Diretrizes e Bases da Educação Nacional). Em seu rol de artigos, a lei possui dois dirigidos à educação especial.

É interessante ressaltar que os principais artigos que fomentam sobre a educação especial (Art. 58 e Art. 59) sofreram alterações pela Lei 12.794, de 2013. Essa alteração de redação foi realizada com o intuito de acrescentar à lei original novas designações capazes de abranger o grupo de pessoas com deficiência.

A partir da leitura dos artigos, constata-se que a modalidade da educação especial é implementada na lei, tornando-se um dever do Estado executá-la nas condições que são impostas nos parágrafos do Art. 58, com as orientações que são feitas no Art. 59, que asseguram

I - currículos, métodos, técnicas, recursos educativos e organização específicos, para atender às suas necessidades;

II - terminalidade específica para aqueles que não puderem atingir o nível exigido para a conclusão do ensino fundamental, em virtude de suas deficiências, e aceleração para concluir em menor tempo o programa escolar para os superdotados;

III - professores com especialização adequada em nível médio ou superior, para atendimento especializado, bem como professores do ensino regular capacitados para a integração desses educandos nas classes comuns;

IV - educação especial para o trabalho, visando a sua efetiva integração na vida em sociedade, inclusive condições adequadas 
para os que não revelarem capacidade de inserção no trabalho competitivo, mediante articulação com os órgãos oficiais afins, bem como para aqueles que apresentam uma habilidade superior nas áreas artística, intelectual ou psicomotora;

V - acesso igualitário aos benefícios dos programas sociais suplementares disponíveis para o respectivo nível do ensino regular. (BRASIL, 1996)

Interpretando os incisos do Art. 59, observa-se o intuito do legislador de assegurar a qualidade e a boa execução do ensino para pessoas com necessidades especiais ou superdotação, além de demonstrar a intenção de tornar o sistema de educação eficaz e efetivo aos educandos.

Já em 1999, o presidente em vigência de mandato Fernando Henrique Cardoso publica o Decreto $n^{\circ} 3.298$, que acrescenta algumas providências a fim de expandir o alcance da educação especial para os que dela necessitam, definindo-a como uma modalidade transversal a todos os níveis e etapas de ensino.

Além disso, o Decreto ainda ratifica a inclusão da educação especial dentro do sistema educacional, sendo esta de oferta gratuita e obrigatória no sistema público de ensino, como rege o inciso IV, do Art. 24. Ademais, o decreto exige em seu Art. 29 que

Art. 29. As escolas e instituições de educação profissional oferecerão, se necessário, serviços de apoio especializado para atender às peculiaridades da pessoa portadora de deficiência, tais como:

I - adaptação dos recursos instrucionais: material pedagógico, equipamento e currículo;

II - capacitação dos recursos humanos: professores, instrutores e profissionais especializados; e

III - adequação dos recursos físicos: eliminação de barreiras arquitetônicas, ambientais e de comunicação. (BRASIL, 1999)

Com base no trecho citado, verifica-se a necessidade da escola se adaptar para atender as particularidades dos alunos que possuem neces- 
sidades especiais ou superdotação, sendo a instituição, responsável por realizar o atendimento especializado para com o educando.

No ano de 2001, as modificações legislativas acerca do ensino educacional especial foram mais brandas, dentre as quais estão a Resolução $\mathrm{CNE} / \mathrm{CEB} \mathrm{n}^{\circ} 2$ e o Parecer CNE/CP n 17.

Quanto a Resolução, esta ratifica que a inclusão de alunos com necessidades especiais é obrigatória, cabendo às escolas a responsabilidade de se adaptarem e se organizarem à realidade do educando; ratifica também o que é a modalidade de ensino educacional especial e como funcionará, ambos já descritos na LDB.

Sendo assim, a Resolução auxilia ao trazer diretrizes que promovem uma melhor compreensão de como identificar um aluno que necessita de atendimento especial (Art. $5^{\circ}$ ) e qual o procedimento a ser tomado para qualificar essa identificação (Art. $6^{\circ}$ ), e como será procedido o atendimento educacional do estudante (Art. $7^{\circ}$ ).

Quanto ao Parecer, este em seu item 4 afirma que

A política de inclusão de alunos que apresentam necessidades educacionais especiais na rede regular de ensino não consiste apenas na permanência física desses alunos junto aos demais educandos, mas representa a ousadia de rever concepções e paradigmas, bem como desenvolver o potencial dessas pessoas, respeitando suas diferenças e atendendo suas necessidades. (BRASIL, 2001)

Perante o que foi apresentado, é notório o envolvimento do Estado na promoção e execução de políticas públicas que assegurem uma educação democrática e acessível a todos os alunos que apresentam necessidades educacionais especiais. A partir dessas peças legislativas, devem ser desenvolvidos mais projetos públicos que busquem a valorização de uma educação mais inclusiva, comprovando o compromisso das instituições públicas com a educação especial.

\section{A Educação Especial no cenário educacional brasileiro}

A Constituição Federal (BRASIL, 1988), em seu artigo 205, define a educação como um direito de todos. Nessa perspectiva, a Lei de 
Diretrizes e Bases da Educação Nacional nº 9.394, de 20 de dezembro de 1996, determina a inclusão de alunos com necessidades especiais nas salas de aulas das escolas de ensino regular e delega para o Estado o dever de disponibilizar educação especial gratuita, com início na educação infantil, e quando necessário proporcionar atendimento educacional especializado nas escolas regulares para atender as peculiaridades dos alunos. Inclusive, oferecer aos educandos que não se integram à sala de aula regular, a possibilidade de atendimento em classes, escolas ou serviços especializados.

Ainda conforme a Lei 9.394/96, em seu artigo 58, e a Resolução CNE/CEB no 2, de 11 de setembro de 2001 que institui Diretrizes Nacionais para a Educação Especial na Educação Básica, Artigo 3º, nessa ordem, entende-se por educação especial

Art. 58 [...] a modalidade de educação escolar oferecida preferencialmente na rede regular de ensino, para educandos com deficiência, transtornos globais do desenvolvimento e altas habilidades ou superdotação (BRASIL, 1996).

Art. $3^{\circ}$ [...] modalidade da educação escolar, entende-se um processo educacional definido por uma proposta pedagógica que assegure recursos e serviços educacionais especiais, organizados institucionalmente para apoiar, complementar, suplementar e, em alguns casos, substituir os serviços educacionais comuns, de modo a garantir a educação escolar e promover o desenvolvimento das potencialidades dos educandos que apresentam necessidades educacionais especiais, em todas as etapas e modalidades da educação básica. (BRASIL, 2001)

No Brasil a Lei no 13.146, de 6 de julho de 2015, conhecida como Lei Brasileira da inclusão, em seu Art. $2^{\circ}$ define

[...] pessoa com deficiência aquela que tem impedimento de longo prazo de natureza física, mental, intelectual ou sensorial, o qual, em interação com uma ou mais barreiras, pode obstruir sua participação plena e efetiva 
na sociedade em igualdade de condições com as demais pessoas.

Deste modo, o decreto 7.611, de 17 de novembro de 2011, que versa sobre a educação especial, o atendimento especializado e outras providências, em seu artigo $2^{\circ}$ e parágrafo 2 respectivamente delibera que

Art. $2^{\circ}$ A educação especial deve garantir os serviços de apoio especializado voltado a eliminar as barreiras que possam obstruir o processo de escolarização de estudantes com deficiência, transtornos globais do desenvolvimento e altas habilidades ou superdotação. (BRASIL, 2011).

$\$ 2^{\circ} \mathrm{O}$ atendimento educacional especializado deve integrar a proposta pedagógica da escola, envolver a participação da família para garantir pleno acesso e participação dos estudantes, atender às necessidades específicas das pessoas público-alvo da educação especial, e ser realizado em articulação com as demais políticas públicas. (BRASIL, 2011).

Assim sendo, a Lei 12.796, de 4 de abril de 2013, em seu $4^{\circ}$ artigo, inciso III, determina

atendimento educacional especializado gratuito aos educandos com deficiência, transtornos globais do desenvolvimento e altas habilidades ou superdotação, transversal a todos os níveis, etapas e modalidades, preferencialmente na rede regular de ensino (BRASIL, 2013).

Simone Mainieri Paulon (2005) diz que a definição feita pela Lei 9.394/96 nos permite desvincular "educação especial" de "escola especial", e tomar a educação especial como um recurso que favorece todos os educandos e que perpassa o trabalho do educador com a diversidade que compõe o seu grupo de alunos, sendo necessário apresentar novos caminhos inclusivos para a educação e não apenas para a escola. 
Afirma Paulon, que a partir daí, a educação especial baseou-se em uma ideia de reeducação através de métodos comportamentais e seu surgimento está associado ao discurso social posto em circulação na modernidade para dar conta das crianças que não se adaptavam aos contornos da escola. E a partir dessa concepção, com apoio médico e pedagógico, que as deficiências começaram a ser organizadas, diagnosticadas e classificadas.

Assim, para as escolas especiais caberia o papel de apoio complementar no processo de inserção/inclusão, frequência e acompanhamento do processo educacional dos alunos com necessidades educacionais especiais às salas de aulas das escolas regulares comuns, dessa maneira as unidades escolares também se encarregariam das responsabilidades relativas às dificuldades de seus alunos não se atendo ao simples ato de encaminhá-los para atendimentos especializados.

A Declaração de Salamanca (1994) propõe que os alunos com necessidades educacionais especiais tenham acesso às escolas de Ensino Regular e orienta que a expressão "necessidades educacionais especiais" faça referência a cada criança ou jovem cujas necessidades educacionais especiais se originem em função de deficiências ou dificuldades de aprendizagem.

Desta forma, muitas crianças e adolescentes possuem e/ou apresentarão alguma necessidade educacional ao longo da sua vida escolar, cabendo às escolas se adequarem, buscarem métodos e formas para educar e atender os alunos diagnosticados com dificuldade de aprendizagem, pois as escolas "constituem os meios mais capazes para combater as atitudes discriminatórias, construindo uma sociedade inclusiva e atingindo a educação para todos" (ONU, 1994). Portanto, a educação especial

incorpora os mais do que comprovados princípios de uma forte pedagogia da qual todas as crianças possam se beneficiar. Ela assume que as diferenças humanas são normais e que, em consonância com a aprendizagem de ser adaptada às necessidades da criança, ao invés de se adaptar a criança às assunções pré-concebidas a respeito do ritmo e da natureza do processo de aprendizagem. (ONU, 1994). 
Partindo desse princípio, as escolas devem acolher todas as crianças sem julgar suas condições emocionais, sociais, intelectuais, físicas, linguísticas e de grupos étnicos, culturais ou nômades. Assim, as escolas de Ensino Regular e demais instituições de ensino devem se adequar a essa nova demanda.

A fim de proporcionar acesso as escolas regulares, ao currículo da educação básica e nortear os sistemas de educação inclusiva, o Conselho Nacional de Educação - CNE/CEB, em outubro de 2009, publicou a resolução № 4 que institui sobre Diretrizes Operacionais para o Atendimento Educacional Especializado na Educação Básica, modalidade Educação Especial. Fazendo-se saber em seu Art. 3ำ que a Educação Especial se realiza em todos os níveis, etapas e modalidades de ensino, tendo o AEE como parte integrante do processo educacional.

Para efetivar medidas de implementação da educação inclusiva nas escolas de ensino regular, o artigo $1^{\circ}$ da Resolução CNE/CEB no 4 de 2009 descreve que os sistemas de ensino devem matricular os alunos com deficiência nas salas de aula comuns das escolas regulares e ofertar Atendimento Educacional Especializado (AEE) em salas de recursos multifuncionais. O AEE, segundo o artigo $2^{\circ}$ da mesma resolução, tem como função

complementar ou suplementar a formação do aluno por meio da disponibilização de serviços, recursos de acessibilidade e estratégias que eliminem as barreiras para sua plena participação na sociedade e desenvolvimento de sua aprendizagem. (BRASIL, 2009).

$\mathrm{O}$ atendimento educacional especializado (AEE), como proposto na Política Nacional de Educação Especial na Perspectiva da Educação Inclusiva (BRASIL, 2008), tem por finalidade

identificar, elaborar e organizar recursos pedagógicos e de acessibilidade que eliminem as barreiras para a plena participação dos alunos, considerando suas necessidades específicas. As atividades desenvolvidas no atendimento educacional especializado diferenciam-se daquelas realizadas na sala de aula comum, 
não sendo substitutivas à escolarização. Esse atendimento complementa e/ou suplementa a formação dos alunos com vistas à autonomia e independência na escola e fora dela.

Cabe ressaltar que apenas a matrícula de alunos que apresentam necessidades educacionais especiais nas escolas de ensino regular não configura inclusão, esse processo educacional não se limita a presença do aluno no ambiente escolar. Este é apenas o primeiro passo, em função disso é essencial que a escola reconsidere sua estrutura organizacional, cultural e pedagógica para atender as especificidades dos novos alunos.

Neste sentido, torna-se relevante que haja nas escolas uma reestruturação no seu sistema educacional, a flexibilização e adequação do currículo, alteração nos métodos de ensinar e avaliar, e a criação de ambientes acolhedores e interativos. A educação inclusiva deve ser compreendida por toda unidade escolar como um princípio de educação para todos, de respeito e valorização das diferenças.

No âmbito escolar, um obstáculo significativo para a efetivação da educação inclusiva está relacionado à ausência de professores capacitados e especializados para atuar nas salas de aulas comuns e na educação especial. Que de acordo com a Resolução CNE/CEB no 2, de 11 de setembro de 2001, que institui Diretrizes Nacionais para a Educação Especial na Educação Básica, em seu artigo 18, parágrafo 1º são considerados professores capacitados "aqueles que comprovem que, em sua formação, de nível médio ou superior, foram incluídos conteúdos sobre educação especial adequados ao desenvolvimento de competências e valores para:"

I - perceber as necessidades educacionais especiais dos alunos e valorizar a educação inclusiva;

II - flexibilizar a ação pedagógica nas diferentes áreas de conhecimento de modo adequado às necessidades especiais de aprendizagem;

III - avaliar continuamente a eficácia do processo educativo para o atendimento de necessidades educacionais especiais; 
IV - atuar em equipe, inclusive com professores especializados em educação especial. (BRASIL, 2001)

\section{E professores especializados àqueles que}

desenvolveram competências para identificar as necessidades educacionais especiais para definir, implementar, liderar e apoiar a implementação de estratégias de flexibilização, adaptação curricular, procedimentos didáticos pedagógicos e práticas alternativas, adequados ao atendimentos das mesmas, bem como trabalhar em equipe, assistindo o professor de classe comum nas práticas que são necessárias para promover a inclusão dos alunos com necessidades educacionais especiais. (BRASIL, 2001)

Logo, percebemos a urgência de introduzir tanto modificações na formação inicial dos educadores nas universidades, quanto a formação continuada ao longo da carreira dos profissionais da educação. Nesse sentido, a Resolução CNE/CEB nº 2, de 2001, no Artigo 18 parágrafo $4^{\circ}$, garante aos "professores que já estão exercendo o magistério devem ser oferecidas oportunidades de formação continuada, inclusive em nível de especialização, pelas instâncias educacionais da União, dos Estados, do Distrito Federal e dos Municípios."

Além da reorganização da estrutura escolar e da formação do corpo docente, outro obstáculo encontrado para a efetivação da educação inclusiva, está associado à família. Grande parte das famílias dificultam o processo de inclusão e alfabetização de seus filhos por falta de informações e por não reconhecerem e aceitarem as possibilidades que a educação especial pode trazer por meio do AEE. Na mesma direção, Paulon destaca como obstáculo, principalmente nas escolas públicas, o contexto socioeconômico que algumas famílias estão inseridas, ao passo que

Para estas, a escola é um dos poucos lugares de cuidado e acompanhamento de suas crianças, quando não de sobrevivência direta, pela possibilidade de alimentação e cuidados primários 
e, indireta, pela viabilidade do afastamento dos adultos para o trabalho. (PAULON, 2005)

Diante disso, a responsabilidade do sucesso da implementação de uma educação inclusiva não está diretamente vinculada à escola. Mas sim, a toda a comunidade, ao Estado, às famílias e à sociedade de modo geral, que devem se unir em prol de um objetivo comum voltado para a inclusão escolar das pessoas com necessidades educacionais especiais e a plenitude do sistema educacional.

\section{Considerações finais}

O presente trabalho se propôs a analisar a trajetória jurídica das Leis que versam sobre a Educação Especial no Brasil e o papel do Estado e da escola como agentes diretos na implementação de políticas públicas que auxiliam na eficácia de um sistema educacional voltado para a inclusão de pessoas com necessidades educacionais especiais.

Consideradas essas questões, podemos perceber que existem no Brasil avanços significativos no que refere as redações das leis que regem sobre a implementação da Educação Especial. Entretanto, diferentemente do que ocorre nos processos legislativos, ainda há muitos desafios e dificuldades a serem superados para assegurar a efetividade de uma educação inclusiva, democrática e com qualidade para todos.

Vale ressaltar que durante o processo educacional das crianças com necessidades especiais, existem papeis determinados para escola e família. À família, cabe participar de forma ativa na educação de seus filhos orientando, incentivando e acompanhando as tarefas escolares, impondo limites e através do exemplo, ensinar para a criança sobre a autoridade da escola. Da mesma forma que a escola precisa manter vínculos e relação próxima das famílias dessas crianças, no sentido de orientar os pais quanto ao seu papel no processo educacional da criança. Esta proximidade é indispensável para o fortalecer a relação família/ escola e para a aprendizagem destes alunos.

Como se pode notar, a trajetória não foi e ainda não é simples. Portanto, observa-se que a promoção de uma educação especial é um 
desafio de todos e que exige mudanças árduas, tanto da sociedade quanto da escola. Esta, enquanto instituição de ensino, deve repensar suas práticas pedagógicas e estruturais para que a educação não seja somente acessível, mas que seja de qualidade para todos aqueles que a frequentam, mitigando discriminações e possibilitando o ensino de qualidade aos educandos.

\section{Referências}

BRASIL. Constituição Federal de 1988. Disponível em <http://www. planalto.gov.br>. Acesso em 6 de maio de 2020.

BRASIL. Decreto 7.611, de 17 de novembro de 2011. Dispõe sobre a educação especial, o atendimento educacional especializado e dá outras providências. Brasília, DF, nov 2011. Disponível em: http://www.planalto.gov.br/ccivil_03/_Ato2011-2014/2011/Decreto/D7611.htm. Acesso em: 6 de maio de 2020.

BRASIL. Decreto no 3.298, de 20 de dezembro de 1999. Regulamenta a Lei no 7.853, de 24 de outubro de 1989, dispõe sobre a Política Nacional para a Integração da Pessoa Portadora de Deficiência, consolida as normas de proteção, e dá outras providências. Brasília, DF, dez 1999. Disponível em: http://www.planalto.gov. br/ccivil_03/decreto/D3298.htm. Acesso em: 6 de maio de 2020.

BRASIL. Lei 12.794, de 2 de abril de 2013. Brasília, abril 2013 Disponível em: http:/www.planalto.gov.br/CCIVIL_03/_Ato20112014/2013/Lei/L12794.htm. Acesso em: 6 de maio de 2020.

BRASIL. Lei 12.796, de 4 de abril de 2013. Altera a Lei no 9.394, de 20 de dezembro de 1996, que estabelece as diretrizes e bases da educação nacional, para dispor sobre a formação dos profissionais da educação e dar outras providências. Brasília, DF, abril 2013. Disponível em: http://www.planalto.gov.br/ccivil_03/_Ato20112014/2013/Lei/L12796.htm. Acesso em: 6 de maio de 2020.

BRASIL. Lei 13.146, de 6 de julho de 2015. Institui a Lei Brasileira de Inclusão da Pessoa com Deficiência (Estatuto da Pessoa com 
Deficiência). Brasília, DF, jul 2015. Disponível em: http://www. planalto.gov.br/CCIVIL_03/_Ato2015-2018/2015/Lei/L13146. htm. Acesso em: 6 de maio de 2020.

BRASIL. Lei de Diretrizes e Bases de Educação Nacional, Lei n ${ }^{\circ}$ 9394/1996. Disponível em: <http://www.planalto.gov.br/Ccivil_03/leis/L9394.htm>. Acesso em: 6 de maio de 2020

BRASIL. Parecer CNE/CEB no 17, de 17 de agosto 2001. Diretrizes Nacionais para a Educação Especial na Educação Básica. Brasília, DF, ago 2001. Disponível em: http://portal.mec.gov.br/cne/arquivos/pdf/CEB017_2001.pdf. Acesso em: 06 de maio de 2020.

BRASIL. Política Nacional De Educação Especial Na Perspectiva Da Educação Inclusiva. Brasília, DF, jan 2008. Disponível em: http:// portal.mec.gov.br/arquivos/pdf/politicaeducespecial.pdf. Acesso em: 6 de maio de 2020 .

BRASIL. Portaria n. ํ 1793, de dezembro de 1994. Brasília, DF, dez 1994. Disponível em: http://portal.mec.gov.br/arquivos/pdf/portaria1793.pdf. Acesso em: 6 de maio de 2020.

BRASIL. Resolução CNE/CEB nº 2, de 11 de setembro de 2001. Institui Diretrizes Nacionais para a Educação Especial na Educação Básica. Brasília, DF, set 2001. Disponível em: http://portal.mec. gov.br/cne/arquivos/pdf/CEB0201.pdf. Acesso em: 6 de maio de 2020 .

BRASIL. Resolução CNE/CEB no 4, de 2 outubro de 2009. Institui Diretrizes Operacionais para o Atendimento Educacional Especializado na Educação Básica, modalidade Educação Especial. Brasília, DF, out 2009. Disponível em: http://portal. mec.gov.br/dmdocuments/rceb004_09.pdf. Acesso em: 6 de maio de 2020.

ONU. Declaração de Salamanca: Sobre Princípios, Políticas e Práticas na Área das Necessidades Educativas Especiais, 1994, Salamanca-Espanha. 
ONU. Declaração Universal dos Direitos Humanos. Disponível em <https://www.ohchr.org/EN/UDHR/Pages/Language.aspx?LangID=por $>$. Acesso em 6 de maio de 2020.

PAULON, Simone Mainieri. Documento subsidiário à política de inclusão / Simone Mainieri Paulon, Lia Beatriz de Lucca Freitas, Gerson Smiech Pinho. -Brasília : Ministério da Educação, Secretaria de Educação Especial, 2005. 48 p.

SEVERINO, Antônio Joaquim. A busca do sentido da formação humana: tarefa da filosofia da educação. Uninove: 2006.

SEVERINO, Antônio Joaquim. O compromisso da educação com os direitos humanos. In: NUNES, César A.; POLLI, José R. (orgs). Educação e direitos humanos: uma perspectiva crítica. Jundiaí: Edições Brasil/Editora Fibra/ Editora Brasílica, 2019. p. 43-52. 


\section{A EDUCAÇÃO E OS DIREITOS HUMANOS NO CONTEXTO DO COVID-19: PROBLEMÁTICAS E POSSIBILIDADES}

José Fernando Lima de Oliveira

Genivaldo dos Santos

\section{INTRODUÇÃO}

Os direitos humanos hoje se configuram como pedras angulares para o funcionamento não só de nações inteiras, mas para todo o mundo. Desde a sua fundamentação mundial, os direitos humanos tem funcionado como agente transformador para situações sociais, haja vista observarem seus objetivos da melhoria da qualidade de vida, respeitos às diversidades e garantia de diretrizes básicas para a vida. Neste sentido, os direitos humanos garantem acesso e possibilidades à vida, à liberdade, à igualdade, à segurança, à propriedade e a educação, sem distinção quaisquer que possam existir, por isso são observados com isonomia e universalidade. Os direitos humanos também são inalienáveis e jamais podem ser subtraídos de quem quer que seja, salvo sob situações excepcionais.

Nesta perspectiva, os direitos humanos se configuram como prerrogativas garantidoras dos demais direitos da sociedade, cuja regulação torna possíveis à vida digna em sociedade. O direito à educação não foge a estas regras, pois está contido nos direitos humanos e por ser também objeto inseparável das pessoas, em quaisquer situações onde 
não se valer, acabam por se tornarem violações dos direitos. Observamos que todo e qualquer ser humano tem garantido o direito à instrução e a educação gratuita, para os graus elementares e fundamentais, sendo esta última obrigatória. A UNICEF (2020) observa a educação não só como direito, mas como realidade a ser exercida como meta de qualidade, oportunizando, como o mesmo órgão observa, acesso à aprendizagem e oportunidades para redução das desigualdades sociais. A constituição federal do Brasil observa em vários artigos que o acesso à educação é um direito básico garantido pelo Estado. Segundo o pensamento de vários pesquisadores:

O texto da constituição brasileira consolida em 1988 apresenta, no que diz respeito ao direito à educação, uma considerável e significativa valorização, haja que a seção I do capítulo III do título da ordem social é destinada, exclusivamente, a educação. Não obstante a reserva de seção, a norma ainda faz uma breve e introdutório menção a respectiva prerrogativa em seu art. $6^{\circ}$ "são direitos sociais a educação, a saúde, a alimentação, o transporte, o lazer, a segurança, a previdência social, a proteção a maternidade e a infância, a assistência aos desamparados, na forma desta constituição”. (Ribeiro, Silveira e Santos, 2019, p. 3)

O pensamento de vários pesquisadores sobre a educação compreende que se trata de imperativo, posto que os direitos humanos fundamentais confiram as políticas públicas a uma posição ativa, obrigando-se a determinado fornecimento, com fim de dirimir as desigualdades sociais, oportunizando a justiça social, promovendo que os direitos cheguem até àqueles que deles são devidos, para que tornem protagonistas e sujeitos históricos de sua vida e partícipes ativos de uma sociedade. Neste sentido, a educação como direitos humanos, assume grande relevância como agente produtor de possibilidades. (Carapeto Ferreira, 2017)

De toda forma, os pesquisadores do campo do direito, fazendo a leitura sobre a temática concluem o seguinte:

Assim sendo, deduz-se o status de direito fundamental atribuído pelo Superior Tribunal Federal (STF) e, consequente- 
mente, pela norma primária do ornamento jurídico brasileiro, o direito à educação, sujeitando consequentemente, o estado ao cumprimento do seu dever, constitucionalmente previsto, diante da prerrogativa em questão, garantindo, dessa maneira, a subsistência digna em sociedade a pessoa humana detentora desse direito fundamental [...] percebe-se então o direito social a educação, como sendo, concomitantemente, um direito fundamental. Tendo isso em vista o forma de garantir ou receber esse direito deveria ser de forma imediata, conforme descreve o art. $5^{\circ}$, parágrafo $1^{\circ}$, da constituição da república, porquanto se trata de uma norma de eficácia plena [...] (Ribeiro, Silveira e Santos, 2019, p. 4-5)

Como já debatemos, em linhas gerais, a questão da educação é um dos direitos humanos mais básicos da atualidade e mesmo ele tem sofrido diversos ataques nos tempos atuais. $\mathrm{O}$ momento que a pandemia atual requer soluções cada vez mais rápidas para dar conta das problemáticas que vivemos pelas impossibilidades postas em face da mesma.

\section{DESENVOLVIMENTO}

\section{Tempos de pandemia}

Vivemos hoje em tempos de situação atípica para todo mundo. $\mathrm{O}$ alastramento em escala global de uma doença, o novo COVID-19 tem causado transformações em todas as esferas da vida, relações sociais, modos de trabalhos, educação e saúde. Diante desta pandemia, governos de todo mundo passaram a adotar o isolamento social não mais como uma orientação e sim como uma imposição, cujo reflexo tem reverberado na economia mundial. Durante este período, apenas serviços considerados essenciais tem funcionado, assim qualquer outro ramo de negócio que não se enquadre dentro deste crivo não tem autorização para funcionamento, sendo até impostas pesadas sanções aos descumprintes. Do mesmo modo, outros serviços, ditos como não essenciais, fecharam as portas e até mesmos as escolas, assim sendo, não fugiram à regra. 
Diante desta problemática, alguns empreendimentos têm sido muito inventivos, explorando formas antes nunca implementadas, mudando as atividades laborais de in loco para home office. Neste sentido, as pessoas respeitam a quarentena, mas não deixam as engrenagens funcionais pararem, exercendo suas atividades em casa. Os recursos da tecnologia se configuraram como pontes, permitindo que em qualquer lugar haja atividades. Hoje no Brasil, o ministério da educação e as secretarias estaduais liberaram portarias emergenciais que autorizam o ensino básico e superior remoto e a assim os prejuízos acadêmicos aos alunos são, ainda que minimamente, recompensados. Os professores têm ministrado suas aulas em formato $\mathrm{EaD}$ e assim o ano letivo não para.

Como exemplo, várias plataformas de streaming de vídeos, aulas online e podcast estão sendo utilizadas neste instante para dar conta dos conteúdos. Assim sendo, o Enem deste ano está mantido, por isso as escolas têm se movimentado para que seus alunos estejam preparados para a prova.

\section{Direito e a educação}

Não podemos deixar perder de vista que a educação é um dos pilares dos direitos humanos, sendo concebida como um recurso, diante do qual há sustentação para os demais. De acordo com pesquisadores: "[...] é clarividente que a educação de uma forma global e em suas demais modalidades fazem parte das previsões da declaração universal dos direitos humanos". (Xavier, Vasconcelos \& Xavier, 2018, p. 27).

[...] a educação como direito social e humano ganha visibilidade no século XX. Diferentes teóricos sinalizam que neste século evidenciou-se o reconhecimento dos direitos que devem ser garantidos a todo ser humano. Neste sentido, é possível compreender a educação enquanto "um direito social proeminente, como um pressuposto para o exercício adequado dos demais direitos sociais, políticos e civis. (Macedo, 2016, p. 51)

Nem tampouco podemos olvidar que é a partir de um fundamental direito humano como é a educação qual podemos transformar situações, por isso se diz que: 
É neste quadro de referências discursivas que se inserem as ações e formulações no campo das políticas públicas educacionais. Nesse sentido, tomando a política educacional como exemplo, não se pode esquecer que nela se concretiza mas definições sobre a política e o planejamento que a sociedade estabelece para si própria, como um projeto educativo que se pretende colocar em ação. $\mathrm{O}$ direito à educação, sintetizado aqui como direito ao acesso e permanência à escola pública, gratuita e de qualidade, representa o elo final de uma complexa cadeia de ações e formulações que se estabelece para a concretude de uma política de ação. Considerando a política educacional como parte de uma totalidade. maior, é aconselhável pensá-la em sua articulação com o planejamento mais global que a sociedade constrói. (Macedo, 2016, p. 52)

Notamos que o fórum mundial de educação, em 2015, construiu importante documento, a partir do qual, foi declarado que a educação é um direito para todos, entretanto, outros ainda já sustentavam esta ideia, como a declaração de Jomtien em 1990 e a declaração de Dakar de 2000. Os referidos tinham pretensões de antever processos estratégicos em prol da educação, no qual o fossem alcançados os interesses de todas as idades, sejam crianças, jovens ou até mesmo adultos, respeitando-se às necessidades mais básicas num aprendizado com qualidade e eficiência, sem jamais lançar mão de construir novos saberes e na potencialização de modos de ser, cujo reflexo daria recursos para a vida em cidadania como também formaria uma sociedade mais justa.

Em acordo com outros pensamentos, a educação se configura como direito inalienável de todo o ser humano, com efeito, esta diretriz básica anda de mãos dadas com o indivíduo, posto que o ampara desde quando se produz, fazendo parte relevante da constituição humana o direito a todas as possibilidades que lhe são inerentes. (Carapeto Ferreira, 2017)

Outrossim, assinalamos que o direito humano à educação é considerado pedra angular, por se tratar que na ausência dele, o indivíduo é podado de suas capacidades de existir ou incapacitado de se 
desenvolver ou exercer com plenitude a sua vida. Segundo Carapeto Ferreira (2017):

Somente dessa forma, compreende-se a constituição humana, que através da educação - como direito social - se hominiza, como ser liberto, orgânico, emancipado, lúcido, no sentido de sua formação e integral realização humana, enquanto humaniza a sociedade. (p. 984)

Nota-se, mediante esta concepção, que a relação existente entre a constituição da república e a educação é inconteste, através do qual os direitos humanos passam a serem fatores realizáveis apenas, e tão somente, possíveis na operacionalização dos mesmos em que em nossa nação, nos termos desta legislação e desse vínculo são ativos. Portanto, os direitos humanos, a norma constitutiva e a educação funcionam, numa alegoria didática, em elos de uma concisa corrente de potencialidades para o indivíduo.

\section{Problemáticas na sua efetivação}

Muitas são as problemáticas hoje experenciadas na educação, neste sentido há quem observe que a referida política pública vem sofrendo assaltos na sua aplicabilidade:

[...] vivemos em um país onde milhões de pessoas vivem em condições subumanas, sem trabalho, sem teto, sem saúde, sem educação. A política neoliberal, cada dia mais, imprime na sociedade diferentes formas de exclusão, em especial no que sem refere ao direito à educação. Pautado nessa política excludente, ou melhor, de inclusão excludente, o governo federal vem eximindo-se cada vez mais de seus compromissos sociais, transferindo para a população responsabilidades antes não pertencentes a ela. (Macedo, 2016, p. 51)

Entretanto, diante do atual quadro de pandemia, enfrentamos muitas dificuldades de norte a sul do nosso país e até mesmo do mun- 
do. Recentemente, mesmo com todos os protocolos de segurança na saúde, quase 100 escolas fecharam as portas na França, retornando os alunos para casa, uma semana após o retorno às aulas, em razão de medidas de segurança contra a pandemia em face do aumento do número de infectados. Em função desta problemática, o governo do Brasil, assim como de outras nações ao redor do mundo, tem suspendido as aulas presenciais e mandado os alunos para casa.

Recentemente, o estado maior da nação, publicou a medida provisória que desobriga as escolas em relação aos 200 dias letivos, mas se mantendo a carga horária padrão de $800 \mathrm{~h} /$ aula, conforme Lei de Diretrizes e Bases da educação - LDB, e com o atropelamento do ano letivo, cujas aulas perdidas poderão ainda significar expedientes ordinários em sábados, domingos e até mesmo janeiro do ano seguinte, a saída lógica encontrada para diminuir os impasses quanto a reposição de parte das perdas tem sido, como já supracitado, as aulas remotas em ambiente online.

Entretanto, o que poderia significar a "carta na manga" da educação no enfrentamento da problemática, acabou por se tornar um "tiro pela culatra", por configurar-se num dilema do uso da tecnologia no Brasil, em razão de escancarar as desigualdades sociais ainda prevalentes. Neste sentido, estima-se que cerca de $60 \%$ dos alunos no Brasil não dispunha de internet ou mesmo de computador para tal fim, o que significaria uma evasão as aulas escolares de mais da metade dos alunos. Do outro lado, sabe-se ainda de outros alunos que não teriam acesso à banda larga e seriam reféns da internet de telefonia celular com limites nos pacotes de dados, por isso estes teriam restrição a assistir as aulas a partir do instante que atingissem a cota dos dados.

Soma-se a isto, a questão do desemparelhamento tecnológico, cujos professores partilham da mesma sina de não dispor de recursos apropriados para ministrar suas aulas ou ainda o fato de existir professores que jamais receberam treinamentos para manuseio destes mesmos recursos. Outro problema que ainda destacamos, que mesmo que tenham alunos com acesso e equipamento para internet, assim como seus professores, são as escolas que não dispõem de plataforma virtual para aulas ou nem tem infraestrutura e metodologia estabelecida para 
oferecer aulas remotas. É clarividente que isto torna-se apenas mais uma faceta no mundo atual que fere o direito básico a educação.

Algumas escolas têm optado por oferecer a alternativa de aulas por transmissão televisiva por se observar que se há maior cobertura e adentramento nos lares do Brasil, mas ainda esta estratégia não tem dado conta de diminuir a problemática. Uma outra peculiaridade decorrente desta problemática das aulas remotas nesses tempos de pandemia, os momentos ditos estritamente de ordem prática em laboratórios disciplinares mesmo ainda em espaços ou quadras para realização para atividades físicas, consideradas fundamentais para o desenvolvimento saudável dos alunos, também ainda não encontraram soluções efetivas.

Percebe-se que a situação, qual posta aos alunos ao redor do Brasil e ampliada pela ausência de recursos, tem se configurado como uma problemática que tem tornado a educação inacessível a uma parcela significativa dos alunos, isto é, com a orientação contra as atividades educacionais presenciais, uso da tecnologia virtual para substituição e as impossibilidades pessoais postas, ora pelas dificuldades sociais, ou ora ainda pelas falhas na estrutura da política pública da educação, acaba por se gerar um profundo ferimento nos direitos humanos, conforme consta no art. 26 na declaração universal dos direitos humanos, quando esta assinala que a todos tem direito a educação e quando esta, por quaisquer situações, não está nas mãos daqueles que fazem usufruto e necessitam dela.

Conforme preza a declaração universal dos direitos humanos, o exercício da educação é fundamental ferramenta para a plenitude do fortalecimento dos direitos humanos, respeito pelos direitos dos demais seres humanos, para desenvolvimento da personalidade humana e, principalmente em égide das liberdades fundamentais. Neste sentido, a atenta observação do direito à educação, efetivará valores sociais como a compreensão, a tolerância e a amizade entre questões de todas as nações, grupos étnicos e religiosos, funcionando ainda em fortalecimento das atividades da ONU em prol da manutenção da paz.

O ostracismo social imposto pelo avanço da pandemia e, por conseguinte, a imposição de quarentena não podem ser usados como desculpas, como curativas sob a ferida nos direitos humanos, em especial a 
educação, por certo ela chama a atenção para medidas urgentes e pede as políticas públicas uma ação enérgica para que outros, menos favorecidos em função das desigualdades sociais, não fiquem ainda mais à margem da possibilidades de desenvolvimento.

Ideias inteligentes e arrojadas, como as parcerias do governo do Estado de São Paulo com as empresas de telefonia celular, têm feito que os alunos possam usar o pacote de suas operadoras, sem descontar os dados, assim os alunos conseguem assistir as aulas e acompanhar os conteúdos de maneira irrestrita. Outra possibilidade discutida, talvez indique a saída para este problema que possa ser a melhor acessibilização dos recursos tecnológicos à população, mediante ação do governo ao permitir que o valor final do recurso chegue aos compradores de menor poder aquisitivo.

Todavia, estas ideias ainda não dão conta de fazer com que a educação remota chegue ao aluno fora do mapa e do alcance do sinal de internet e telefonia celular, que são muitos. Por esta razão, este momento de crise, enseja a reflexão da educação como política pública e direito humano para todos, dando conta de maturar estratégias eficazes para num momento vindouro estes instantes possam somente estar nos livros de história contando o "como era antes". Ademais, muitos são os questionamentos que ainda restam desta complicada teia de problemáticas e cerceamento de possibilidades, por isso pensa-se:

Embora não possamos negar os avanços experimentados no Brasil quanto ao direito à educação, principalmente a partir da segunda metade do século XX, não podemos negligenciar que a educação como um direito ainda está longe de atingir toda e qualquer pessoa em nosso país. É problemático o acesso à educação infantil, ao ensino médio, à educação de jovens e adultos, ao ensino profissional e ao ensino superior. Disso, resulta o seguinte questionamento: como é possível falarmos em direito à educação e obrigatoriedade de ensino abstraindo sua pretensão de universalidade e ao acesso e permanência em todos os níveis de ensino. (Macedo, 2016, p. 54) 


\section{CONSIDERAÇÕES FINAIS}

Diante da problemática que estamos enfrentando, notamos que os melhores exemplos de enfrentamentos são fruto de situações onde as nações tiveram investimento e preparação da infraestrutura e dos profissionais que compõem seus respectivos sistemas de ensino. $\mathrm{O}$ dilema enfrentado pela educação hoje no Brasil pede medidas urgentes ante ao avanço da problemática e o atraso no cronograma da educação. Por certo, o problema da pandemia apenas revelou um problema latente que é uma grande quantidade de indivíduos em pleno desenvolvimento escolar que não dispõem desta importante ferramenta de aprendizagem.

Entretanto, reconhecemos que a situação atual abre portas para maneiras de aprofundar estratégias educativas para o ensino que vai além da sala de aula. Por certo, a pandemia e a quarentena oferecem o espaço para repensar questões do investimento tecnológico em educação, tanto na capacitação de operadores dos sistemas e plataformas, bem como upgrade dos recursos para tal.

A forma como a atual crise sanitária mundial se apresenta, também chama a atenção, fortemente, para o modelo posto de ensino, assim analisando sua viabilidade não só para o contexto em que vivemos, mas para além deste tempo. Assim sendo o ensino atual não deveria focar esforços na quantidade de conteúdos trabalhados em sala de aula, ou mesmo na carga horária com um único fim de meta a ser atingido, mas e sim nas competências apreendidas. Dito de outra forma, a necessidade quanto a acessibilidade do direito a educação também precisa ser observada quanto ao que pode representar qualidade educacional.

Por certo, acreditamos que a problemática posta possa ainda lançar a atenção para uma maior visibilidade de valorização profissional dos servidores da educação, que em alguns exemplos não tem deixado de empreender esforços diários para que as perdas sejam mínimas.

Por fim, toda e qualquer ação empreendida hoje em prol da educação, certamente reverberará na colheita de frutos num futuro próximo no que tange aos direitos humanos e a melhoria das condições de vida. 


\section{REFERÊNCIAS BIBLIOGRÁFICAS}

CARAPETO FERREIRA, Naura Syria. Gestão da educação na perspectiva dos Direitos Humanos: garantias de possibilidades. Revista diálogo educacional, [S.1.], v. 17, n. 53, p. 979-998, ago. 2017. ISSN 1981-416X. Disponível em: <https://periodicos.pucpr.br/ index.php/dialogoeducacional/article/view/16430>. Acesso em: 31 maio 2020. doi: http://dx.doi.org/10.7213/1981-416X.17.053. AO13.

G1. França fecha 70 escolas uma semana após a volta às aulas devido a novos casos de COVID-19. (Site da internet). Disponível em: https://g1.globo.com/educacao/noticia/2020/05/19/ franca-fecha-70-escolas-uma-semana-apos-a-volta-as-aulas-devido-a-novos-casos-de-covid-19.ghtml - acesso dia 03 de junho de 2020 .

MACEDO, Jussara Marques. Direito à educação no Brasil. RTPS Revista trabalho, política e sociedade. v. 1, n. 1, p. p. 41-60, 30 dez. 2016.

RIBEIRO, Davi José Raicik; SILVEIRA, Rafaella; SANTOS, Rafael Padilha dos. A judicialização e a efetivação do direito à educação à luz do constitucionalismo brasileiro vigente. Revista científica digital do centro universitário católica de Santa Catarina. Anais do III congresso luso-brasileiro de direito constitucional comparado. V.6, n.2, 2019.

SENIW, Rafael Meira; FAGUNDES, Fabiula Campos Falcão; SARMENTO, Dirléia Fanfa Sarmento. Educação em direitos humanos na educação básica: reflexões a partir dos dispositivos legais. SEFIC UNILASALLE. Ciência e tecnologia para redução de desigualdades. 22 a 27 de outubro de 2018.

XAVIER, Antônio Roberto; VASCONCELOS, José Gerardo; XAVIER, Maria Ravelli Cordeiro. Direitos humanos, educação inclusiva e diversidade. In: II Congresso de Educação Instituto 
Dominus (II CEID). Educação inclusiva, diversidade e direitos humanos. Veiçosa: Imprece, 2018. p.17-28.

UNICEF. Objetivos para o desenvolvimento sustentável. Disponível em:https://www.unicef.org/brazil/objetivos-de-desenvolvimento-sustentavel - acesso dia 02 de junho de 2020. 


\section{CURRÍCULO ESCOLAR E ATO DISCRICIONÁRIO: UMA REFLEXÃO JURIDICA SOBRE A MATRIZ CURRICULAR}

Paulo de Tarso Lopes

\section{INTRODUÇÃO}

Esse estudo integra resultado de uma investigação acurada ocorrida na fase de pesquisa do curso de pós graduação strictu sensu do Centro Federal de Educação Tecnológica Celso Suckow da Fonseca (CEFET/ RJ), local em que estudamos a aplicabilidade da Lei 10.639 de 09 de janeiro de 2003, que altera a Lei 9.394 de 20 de dezembro de 1996, pontuando no Artigo 26 A, que trata da obrigatoriedade de ensino e estudo da história e cultura afro-brasileira.

Nosso objetivo foi investigar os indícios e processualidades de cumprimento da Lei 10.639/2003 em âmbito escolar, atravessando aspectos da discricionariedade que cerceia a práxis docente-administrativa no âmbito institucional escolar.

Para essa tarefa, trabalhamos com uma revisão de literatura que incluiu: Di Pietro (2014), Maza (2011), Alexandrino e Paulo (2014), que discutem sobre direito administrativo, autores que trabalharão atos discricionários do Estado; Libâneo, Oliveira e Toschi (2009), Sacristán e Gomes (2007) Connell (1999) e Macedo (2006) que trabalham a concepção de currículo, Guattari e Rolnik (2008), Guattari (2000), Ginzburg (2014), que para além de uma perspectiva metodológica, da- 
rão um contorno filosófico ao texto, além de documentos municipais e estaduais que auxiliarão na compreensão do trabalho.

Nossa metodologia foi qualitativa, do tipo documental, tomando por base estudos de Carlo Ginzburg, a partir do método indiciário e Sueli Rolnik, com o método cartográfico.

Por esse viés, buscamos trabalhar em documentos oficiais, tais como: currículo nacional, estadual (referente ao Espírito Santo) e municipal (Serra), além de calendário escolar, projeto político pedagógico, plano de aula e pautas.

O estudo exploratório apontou para um indício de cumprimento legal, mormente em relação à formação continuada de docentes, oferecida por autarquias do governo federal, seja na Universidade Federal do Espirito Santo (UFES) e Instituto Federal do Espírito Santo (IFES), além de órgãos estatais, vinculados ao governo do estado do Espírito Santo e do município de Serra, que oferecem formação a docentes do ensino fundamental (oferecido pelo município) e médio (ofertado pelo governo do estado do Espírito Santo).

Para além da formação, no âmbito nacional emergiu o Plano Nacional de Implementação de Diretrizes Curriculares Nacionais para Educação das Relações Étnico Raciais e para o Ensino da História e Cultura Afrobrasileira e Africana. As autarquias federais de ensino no Espírito Santo passaram a contar com um Núcleo de Estudos Afrobrasileiros (NEAB), dotados de recursos materiais e humanos que atendem a demandas da mens legis em vigor.

Buscando outros órgãos que pudessem auxiliar nessa investigação, foi realizado diálogo com o Promotor de Justiça da Promotoria de Justiça da Serra, ES, responsável pela questão étnica racial, fomos orientados quanto a possibilidade de Atos Discricionários praticados pelo Estado, que podem funcionar como indício de cumprimento da legislação, o que nos levou ao Conselho Municipal do Negro e ao Departamento de Igualdade Racial (DEPIR) da Secretaria de Direitos Humanos e Cidadania (SEDIR) da Serra - ES.

Foi intensificada a pesquisa documental junto a atas de reuniões dos conselheiros durante o ano de 2012, apenas em três reuniões foram tocadas a questão da aplicabilidade da Lei 10.639/2003, sem quaisquer 
efetivas medidas deliberativas que viessem ao encontro de exigências de fomento de cumprimento da legislação supracitada.

Para este trabalho, traremos à tona os seguintes aspectos: a discricionariedade do Estado na aplicabilidade da Lei supracitada, num viés de diálogo conceitual que nos leve a compreensão dos atos discricionários do Estado; breve histórico do movimento negro no contexto serrano; currículo municipal da Serra, avaliando os aspectos discricionários que fundam este documento, concluindo com os aspectos reivindicatórios dos movimentos sociais, que lutaram para promulgação da mens legis em vigor.

\section{ASPECTOS CONCEITUAIS: REFLETINDO OS ATOS DISCRICIONÁRIOS}

É indispensável encetar pela compreensão conceitual de discricionariedade, num viés de análise da promulgação da Lei 10.639 de 09 de janeiro de 2003. Essa Lei guarda indícios de correção de subjetivações homogeneizantes de mundo que o continente europeu impôs aos latinos americanos, aos africanos, aos asiáticos, entre outros povos. A Lei, por si só, não se institui como Ato Discricionário, reflete as demandas populacionais, com ênfase a mobilizações diversas que reivindicam seus direitos enquanto cidadãos. Tais quais as legislações, Di Pietro (2014) salienta que:

[...] a discricionariedade é indispensável para permitir o poder de iniciativa da Administração, necessário para atender às infinitas, complexas e sempre crescentes necessidades coletivas. A dinâmica do interesse público exige flexibilidade de atuação, com a qual pode revelar-se incompatível o moroso procedimento de elaboração das leis (DI PIETRO, 2014, p. 259).

Se há demandas da coletividade para prática de um ato discricionário, o que de fato é um ato discricionário?

[...] são aqueles que a administração pode praticar com certa liberdade de escolha nos termos e limites da lei, quanto ao seu conteú- 
do, seu modo de realização, sua oportunidade e sua conveniência administrativas (ALEXANDRINO; PAULO, 2014, p. 457).

A administração pública, então, é livre, pode, ou não fazer, sem com isso se esbarrar no princípio da Legalidade, mormente quando a Legislação não se caracteriza como reguladora. Em se tratando da questão étnico racial, ensino da história, cultura e literatura africana e afro-brasileira, a regulação vem da Lei 10.639/2003, que altera o Artigo 26 da Lei 9.394/96 (Lei de Diretrizes e Bases da Educação Nacional).

Maza (2011) define atos discricionários como praticados pela administração dispondo de liberdade para que o agente público decida a partir de sua convicção quanto a melhor maneira de atingir o interesse público. $\mathrm{O}$ autor faz um quadro distintivo entre atos vinculados e atos administrativos, podendo assim resumir os atos discricionários: praticado com margem de liberdade; tem mérito; pode ser anulado e revogado; sofre controle judicial; não se confunde com um ato arbitrário.

Com isso, a apresentação de um currículo municipal, estadual e nacional, a construção de um regimento interno, entre outros documentos que funcionem como atos da administração podem ocorrer de modo discricionário, mormente quando o Estado não envolve setores da sociedade civil para participação direta, ou indireta das processualidades de execução. O cumprimento do artigo 26 A, da Lei 9394/96 pode perpassar por atos discricionários, aniquilando a perspectiva democrática que subjaz o documento, cabendo aos movimentos sociais intervenção (ou interação), no sentido de atender as demandas sociais que a realidade exige.

\section{REFLETINDO A LEI 10.639/2003 SOB ASPECTOS DA DISCRICIONARIEDADE}

Entendemos a Legislação como um “[...] aparelho jurídico da instituição [...]” (LOURAU, 2004, p. 48), não na perspectiva total de instituição em Goffmann ${ }^{1}$ (2008), mas numa relação histórica, social e

1 É válido salientar que no modelo de Goffmann a instituição é física, fixa, ainda presa a perspectiva disciplinar. 
de poder, na qual, na atualidade, vem se alterando de um modelo disciplinar, para um controle, cuja perspectiva, segundo Deleuze (2001) terá que enfrentar tanto a explosão das favelas, quanto à dissipação das fronteiras. Mas o que isso tem a ver com a Lei 10.639/2003? Vejamos, primeiro, o que traduz a Lei na íntegra:

Art. 1ㅇ A Lei no 9.394, de 20 de dezembro de 1996, passa a vigorar acrescida dos seguintes arts. 26-A, 79-A e 79-B:

“Art. 26- A.

Nos estabelecimentos de ensino fundamental e médio, oficiais e particulares, torna-se obrigatório o ensino sobre História e Cultura Afro-Brasileira.

$\int 1$ o $\mathrm{O}$ conteúdo programático a que se refere o caput deste artigo incluirá o estudo da História da África e dos Africanos, a luta dos negros no Brasil, a cultura negra brasileira e o negro na formação da sociedade nacional, resgatando a contribuição do povo negro nas áreas social, econômica e política pertinentes à História do Brasil.

$\int 2^{\circ}$ Os conteúdos referentes à História e Cultura Afro-Brasileira serão ministrados no âmbito de todo o currículo escolar, em especial nas áreas de Educação Artística e de Literatura e História Brasileiras.

\$3(VETADO)

Art. 79-A.(VETADO)

Art. 79-B. O calendário escolar incluirá o dia 20 de novembro como 'Dia Nacional da Consciência Negra'.

Art. $2^{\circ}$ Esta Lei entra em vigor na data de sua publicação (BRASIL, 2003).

Analisando seus únicos dois artigos que a compõem, aparentemente a Lei tenta desterritorializar um conhecimento focado na cultura e história eurocêntrica, para outro viés de inclusão social, trazendo para o currículo a África. Parece também aplacar os ânimos dos mo- 
vimentos sociais, cuja trajetória histórica vem recheada de momentos que culminaram nessa legislação.

A Lei parece comparecer como panaceia frente aos efeitos nevrálgicos vivenciados por afrodescendentes no Brasil, fazendo despontar resistências que vão além da organização em movimentos sociais, como indício de geração de novos desejos, facultando a disseminação de novas culturas e outros bens de consumo que se instauram enquanto possibilidades de atendimento às demandas do mercado, integrando, mesmo que de modo mais contundente, o padrão eurocêntrico imanente às relações sociais vigentes. Com isso, a Lei, aplicada sem discricionariedade, pode possibilitar a formação de currículos que se direcionem no viés da equidade, tangenciando as prerrogativas culturais, históricas e sociais que norteiam o cotidiano discente.

\section{REFLETINDO ASPECTOS DO CURRÍCULO: A SERRA EM DESTAQUE}

Currículo pode ser um Ato discricionário da administração pública? Para responder essa questão é importante entender o que é currículo. Connell (1999) destaca que o conhecimento que é levado para os currículos escolares é moldado e produz consequências sociais. Essas consequências estão atreladas a práticas sociais das quais podemos mencionar: a superioridade masculina sobre a feminina (machismo); eurocentrismo em detrimento de culturas diversas (xenofobia e preconceito racial); valorização da heterossexualidade em detrimento da diversidade de orientações sexuais (produzindo a homofobia); prevalência do cristianismo sobre outros credos religiosos (demonizando religiões de matriz africanas e asiáticas produzindo a intolerância religiosa); entre outros.

O autor destaca que um "currículo democrático" é pensado "[...] em torno dos interesses com menor vantagem” (CONNELL, 1999, p. 21), isso implicaria numa dinâmica em " [...] interessar-se pelo discurso do outro” (GUATTARI e ROLNIK, 2008, p.37), rompendo com os paradigmas homogeneizantes do modo de produção capitalista. A perspectiva democrática de currículo que respeita a diversidade, rompe com o teor discricionário de Estado e abre espaço para uma convivência voltada a inclusão social. 
Etimologicamente a palavra se origina do latim "currere", que implica em carreira, percurso (Libâneo, ett all, 2009). Em âmbito educacional escolarizado traduziríamos currículo enquanto caminhada discente frente aos conteúdos mínimos que deverá se apreender ao longo da carreira estudantil. A Lei 9.394/96 (LDB), Art. 27, direciona o conteúdo mínimo curricular do ensino básico, implicando, assim, em "[...] regular e controlar a distribuição do conhecimento" (SACRISTÁN e GÓMEZ, 2007, p. 125).

É válido destacar que, diante da diversidade que cerceia o Brasil, "[...] o currículo de pretensão monocultural precisa ser negado [...]" (MACEDO, 2006, p. 65), daí a necessidade de uma diretriz curricular para a educação das relações étnico raciais e para o ensino de história e cultura afro-brasileira e africana, cuja demanda advém do texto Legal, onde se adiciona as Leis 10.639 de 09 de janeiro de 2003.

Nessa medida, currículo não é, necessariamente, ato discricionário, cabendo aos agentes públicos socialização da proposta, restando aos movimentos sociais intervenção, ou não nas processualidades de formulação dos currículos.

\section{UMA PROPOSTA CURRICULAR LOCAL}

Quando pensamos sobre o local, estamos nos referindo ao âmbito do Município. Sendo assim, Serra - ES foi escolhida como local de pesquisa. No âmbito da educação institucionalizada o município já dispõe de uma Política Municipal de Educação, aprovado pela Lei Municipal 4.432 de 04 de novembro de 2015, Tal proposta passou pelo crivo do Conselho Municipal de Educação e aponta em sua meta 8 a preocupação com os grupos afrodescendentes:

Meta 8: Elevar a escolaridade da população que não teve acesso à escola na idade considerada regular, de modo a alcançar, no mínimo, 12 anos de estudo no ano de vigência deste plano, priorizando as populações do campo, da região de menor escolaridade do município e dos 25\% mais pobres e igualar a escolaridade média entre negros e não negros declarados à 
Fundação Instituto Brasileiro de Geografia e Estatística - IBGE (SERRA, 2015, p. 15).

O documento corrobora uma prática do município um pouco perigosa, baseando suas informações em dados coletados pelo Instituto Brasileiro de Geografia e Estatística (IBGE), sem um mapeamento da realidade local, podendo, com isso, redundar em equívocos, haja vista as metamorfoses ocorridas pela via da migração, da natalidade, da mortalidade, entre outros aspectos que alteram a cartografia local.

Todavia, algo que traz indícios de reconhecimento da existência da Lei 10.639/2003 é a perspectiva de igualar a escolaridade média dos negros, subentendendo-se aí a compreensão da existência e de uma baixa escolarização entre estes grupos, inexistindo, no contexto da política municipal quaisquer outras menções a tais perspectivas, inclusive a possibilidade de adequar os currículos a realidade diversa que subjaz o contexto africano e afro-brasileiro que intercepta o cotidiano sócio cultural discente.

A proposta curricular do município foi construída antes da promulgação da política municipal de educação. Disponibilizada em 2008, cinco anos após a promulgação da Lei 10.639/2003, no ano de promulgação da Lei 11.645/2008 e doze anos após a LDB, não contempla as prerrogativas traçadas na Lei 10.639/2003, reforçando a condição escravocrata imposta aos afrodescendentes, valorizando o dia 13 de maio, em detrimento do 20 de novembro, não reforçando o teor de resistência de 19 de março (que marca o movimento de Queimados).

Essas notas vêm como uma análise processual do documento que, posterior a algumas outras legislações, já poderia apresentar nuances de vicissitudes frente à proposta curricular, o que de fato, não aconteceu, isso se concretiza na medida em que essas propostas não abarcam a questão étnico racial, tampouco distinguem a realidade urbana das especificidades do campo.

O documento apresenta um teor tecnocrático dirigindo-se a leitores que não participaram da construção desta proposta:

Certamente que outros sujeitos poderiam ser incorporados neste processo (crianças, merendeiras, pais, faxineiras), sobretudo 
se considerarmos a escola como um espaço coletivo, produzido por diferentes sujeitos, mas a escassez do tempo não permitiu ampliar as estratégias metodológicas até então utilizadas, o que certamente aponta para a necessidade de contemplar, em um futuro próximo, outras formas organizativas de participação democrática que inclua outros sujeitos historicamente excluídos do processo de elaboração de orientações curriculares (SERRA, 2009, p 14).

A necessidade de atender a demandas internas da administração faculta ao órgão a exclusão e participação de sujeitos, o documento demonstra reconhecer essa ausência de participação, não submetendo a proposta curricular aos crivos do Conselho Municipal de Educação, para uma apreciação mais intensa, que culminasse numa Resolução de aprovação, favorecendo um olvidar práticas educativas e curriculares que perpassem pela questão étnica racial, tampouco ao Conselho Municipal do Negro, para aprofundamento das questões ausentes no documento.

A proposta curricular elenca o que chama de "enunciados" que não foram contemplados na proposta curricular, a saber: articulação e diálogo entre os diferentes níveis de ensino; fortalecimento de vínculos entre saberes e fazeres escolares, levando em conta a cultura, o trabalho e a sociedade; superação do caráter fragmentário do conhecimento; concepção de currículo que considere os diálogos entre categorias geracionais, bem como dos diferentes sujeitos que compõem a instituição escolar; fortalecimento da dinâmica ensino aprendizagem, com foco na inclusão escolar.

Após essas breves considerações, o documento parte de uma análise da educação especial na educação básica, concomitantemente contextualiza o ensino infantil e o fundamental, seguindo para trajetória de descrição do documento, destacando a participação das unidades de ensino no processo de construção da proposta pedagógica, trazendo indícios de uma perspectiva democrática na sua querela.

O destaque é para realização de fóruns que contou com a participação do Poder Judiciário e do Ministério Público, além do Conselho Municipal de Educação e unidades escolares (educação infantil e en- 
sino fundamental). Cabe salientar que uma questão é a dinâmica de Fóruns, em que há limites no poder de decisão, outra é a distribuição do documento em forma de processo para apreciação pelos diversos atores do Conselho, formados principalmente pela sociedade civil e Poder Público. Eis o caráter venatório de uma instituição que ofusca a comunidade escolar, na pretensão de um "saber" universal que ignora o saber coletivo, num viés discricionário de ostentação do currículo.

Outro aspecto que cabe salientar é o assento da Secretaria $\mathrm{Mu}-$ nicipal de Educação no Conselho Municipal do Negro (vinculado a SEDIR), o que caracteriza de modo fugaz o caráter discricionário do documento. Essa ausência dos Conselhos Deliberativos na querela que impõe a proposta curricular municipal caracteriza-se como um ato discricionário, sem ilegalidade, não obstante, autocrático em face da ampliação das propostas apresentadas no Fórum, citado pelo documento em questão.

Apesar de tomar a teoria sócio interacionista como base curricular, mescla autores como Humberto Maturana para suporte, sem atinar para a perspectiva pós moderna que subjaz o pensamento do autor, cujos estudos voltam-se para perspectiva da complexidade, que subjaz seu pensamento, trazendo a biologia e a autopoiese para o cenário cultural, o que choca-se com a concepção de zona de desenvolvimento proximal defendida por Vigotsky.

Além de Humberto Maturana, recorrem ao existencialismo de Maurice Merleau-Ponty (1908 - 1961) para trabalhar o corpo e a arte, o que não vem ao encontro da perspectiva dos signos trabalhados por Vigotsky.

Ao destacar as premissas para educação, trata ensino infantil e fundamental como produtos de um mesmo processo, sem atinar para as peculiaridades que subjazem a cada nível de ensino. Trata a instituição escolar de maneira autônoma, respeitando atores que participam direta e indiretamente de sua existência.

O documento reconhece a criança como sujeito histórico, marcada pelo contexto social, dotados de cidadania, concebendo currículo como "história do conhecimento", no tocante as relações étnicas raciais, os indícios comparecem quando o texto fala sobre "cultura": 
Tais mudanças precisam estar vinculadas à possibilidade de os sujeitos escolares, conjuntamente, atuarem na definição das estratégias de trabalho, com vistas a abarcar as diferenças culturais, considerando as possibilidades enriquecedoras do trabalho e as necessidades peculiares e singulares que marcam esse contexto (SERRA, 2008, p. 53).

Cultura, para este documento, é a cultura de mídia, capitalista, eurocêntrica. Seria essa a forma subjetiva a se promover no discente de ensino infantil e fundamental, em especial os que compõem os grupos afrodescendentes? Apoiados em Guattari e Rolnik (2008) diríamos que não. $\mathrm{O}$ texto chega a problematizar a ideia de fragmentação do conhecimento, mas não faz a separação por áreas, mantendo as disciplinas isoladas, assim distribuídas: arte, ciências naturais, educação física, ensino religioso, geografia, história, língua inglesa, língua portuguesa e matemática. A proposta curricular não traz conteúdos, mas "Orientações Metodológicas".

\section{REFLETINDO O MOVIMENTO NEGRO NA SERRA SOB PRISMA DA DISCRICIONARIEDADE E DA LEI 10.639/96}

A cidade da Serra - ES, atualmente com aproximadamente 422.569 (quatrocentos e vinte dois mil, quinhentos e sessenta e nove) habitantes (SERRA, 2015), área de 553,5 km2, densidade demográfica 739,8 hab/km2, sendo que, dessa população, 64\% se declara de etnia afrodescendente, é o município da Grande Vitória que mais dispõe de pessoas afrodescendentes.

A cidade encontra-se localizada no estado do Espírito Santo, compondo a Região Metropolitana da Grande Vitória (RMGV), limitando-se ao sul com Vitória, a leste com Fundão e Santa Maria de Jetibá (onde se encontra uma região quilombola, com presença de negros também oriundos da Serra), a norte com Fundão, a oeste com o Oceano Atlântico, o que lhe dá um vasto litoral.

Dentre as Secretarias do poder público municipal que trabalham a questão étnico racial podemos mencionar: Secretaria Municipal de 
Educação (SEDU), a Secretaria de Turismo, Esporte e Lazer (SETUR) e Secretaria Municipal de Direitos Humanos e Cidadania (SEDIR), a qual dispõe de um Departamento de Políticas de Igualdade Racial (DEPIR), estando vinculado a este Departamento o Conselho Municipal do Negro, criado pela Lei Municipal 3.167 de 11 de dezembro de 2007.

O CONEGRO é formado por movimentos sociais da sociedade civil, enquanto órgão colegiado, é representado por órgãos do Poder Público Municipal e integrantes da sociedade civil, em proporções iguais, sendo $50 \%$ do primeiro e $50 \%$ da sociedade civil, fragmentado nos seguintes órgãos: juventude negra, entidades culturais afro-brasileiras; religiões de matriz africana, sendo um do candomblé e um da umbanda; um representante do movimento social negro organizado; um representante da Federação Municipal das Associações de Moradores da Serra. O Planejamento de Ações para o ano de 2012, tem no eixo 1 , referente a políticas públicas, no tema educação, definindo como uma das ações:

Implementação das diretrizes sobre História da África e da cultura afro brasileira, previstas na Lei 10.639 e estimulação de novas iniciativas referentes ao aprimoramento dos currículos e formação dos profissionais na área da educação (SERRA, 2012, P. 1).

As Atas de reuniões do CONEGRO, referente a 2012, trazem os seguintes apontamentos: três reuniões trazem como destaque (não ponto de pauta) a Lei 10.639/2003; numa das reuniões o representante da Secretaria Municipal de Educação (SEDU) destaca que "a SEDU já possui esta temática em pauta e faz parte do planejamento e do plano plurianual” (SERRA, 2013), não tendo esse ponto no documento em questão; em uma das descrições das reuniões, o Conselho se manifesta cobrando ações da SEDU, distinguindo as atribuições desta Secretaria e as do DEPIR, frente ao cumprimento da Lei 10.639/2003; o foco do cumprimento Legal encontra-se na realização de eventos, realizados na chamada Semana da Consciência Negra definida pela Lei 9.394/96 o dia 20 de novembro. 
A ausência de uma querela que permeie a participação de instituições deliberativas como CONEGRO e Conselho Municipal de Educação sobre a discussão curricular possibilita a efetivação de uma com forte teor discricionário, abrindo espaço para um documento estático, fundado em questões tecnocráticas e sem um teor democrático e descentralizado nas discussões.

\section{CONSIDERAÇÕES FINAIS}

Este estudo mostra que a Lei 10.639/2003 desponta como indício de vicissitude no trato a questão étnico racial, por ela o Estado tem que rever sua postura, seja em âmbito nacional, seja em âmbito estadual, seja em âmbito municipal. Com base em sua autonomia institucional, o Estado tem cumprido um papel importante na perspectiva de cumprimento da legislação.

No plano municipal, se há indícios de cumprimento da legislação também tem ocorrido de modo discricionário, sem a participação efetiva dos movimentos sociais, deixando a desejar em aspectos que tocam a emancipação do sujeito afrodescendente. Ao mesmo tempo, os movimentos sociais têm ficado a deriva em sua participação, sem buscar tais propostas para análise e discussão em âmbito deliberativo, permitindo práticas curriculares de cunho tradicional, distanciadas daquilo que funcionaria como resistência afro-brasileira aos ditames do modo de produção escravista, imposto a nossos ancestrais.

Se os movimentos sociais, em sua trajetória histórica, demonstraram grande resistência aos ditames forjados no preconceito, tacitamente recônditos pelo viés da "democracia racial”, urge uma intervenção mais acirrada para fazer cumprir a Lei 10.639/2003, reivindicando junto a órgãos competentes formulação de um currículo mais democrático, menos tecnocrático, mais resistência, menos subserviência, mais diverso, menos unilateral, mais estético, menos eurocêntrico.

Com isso, urge do movimento negro organizado uma estratégia de acompanhamento às processualidades de construção curricular (que em âmbito municipal tem ocorrido como ato discricionário), fazendo valer os interesses de discentes afrodescendentes como cidadãos, re- 
primindo toda forma de subordinação e subserviência que estes documentos possam conter.

Apesar da evidência de vicissitude, a Lei 10.639/2003 não se institui enquanto principal, ela altera algo macro, o que lhe tira o privilégio de se sobrepor a Lei 9.394/96. Com isso, num estado gerido por governos conservadores como o Espírito Santo, a discricionariedade se sobrepõe à equidade, o currículo é apresentado, não debatido, a questão étnico racial acaba por favorecer interesses eurocêntricos, a diversidade se esvai, em detrimento da homogeneização cultural.

Cartografar indícios de vicissitudes foi fundamental para se entender o que se passa nos bastidores do teatro institucional escolar. O currículo que norteia a práxis docente vem forjado de modo monocultural. Para um enfrentamento a esse cenário, é indispensável que a arte contemple outros "olhares", ostentando a diversidade artística cultural, num devir da estética, por este viés a arte africana comparecerá com novos "significados, a história implicaria no viés de resistência, para além da subserviência, a cultura focaria no viés do enfrentamento ao racismo institucional, valorizando a beleza que a África tem, em detrimento do eurocentrismo exacerbado presente na perspectiva curricular.

O movimento cartográfico indiciário demonstra a importância do aspecto curricular ser construído a partir de uma coletividade, indo além das elites tecnocráticas que formam a nossa sociedade, numa perspectiva de diálogo com os movimentos sociais e comunitários, para além de atos discricionários que preservam a segregação.

É indispensável ampliar as marcas de vicissitudes nas práticas sociais e institucionais encetadas pela Lei 10.639/2003, como possíveis cartógrafos, entendemos que tal processualidade se dará na medida que os movimentos sociais de representação afrodescendente cooptarem novos protagonistas para esta empreitada, passando o currículo de um ato discricionário para um ato vinculado, cuja perspectiva é a vinculação legal e democrática da proposta.

O que fica para refletirmos é: em que medida o engajamento dos movimentos sociais podem se consubstanciar em alterações de políticas educacionais locais e estaduais para novas subjetivações, para novos agenciamentos e para novas participações em que o 
indício que comparece é a superação da desigualdade social? Soçobrar esse aspecto pode fomentar novas práticas? Será que novas metas nas propostas políticas estaduais, municipais e municipais fomentarão um despertar para novos planos, novos currículos e novas propostas pedagógicas? A resposta está em novas reflexões, outros estudos, em intervenções dos movimentos sociais que façam soçobrar o cumprimento das Leis 10.639/2003 e 11.645/2008 como reais políticas afirmativas no contexto nacional, estadual, municipal e local.

\section{REFERÊNCIAS}

ALEXANDRINO, Marcelo; PAULO, Vicente. Direito Administrativo descomplicado. 22.ed. Rio de Janeiro: Forense, 2014.

BRASIL. Lei 9.394 de 20 de dezembro de 1996. Dispõe sobre as diretrizes e bases da educação nacional e dá outras providências. Brasília: Senado Federal, 2004.

. Lei 10.639 de 08 de janeiro de 2003. Dispõe sobre alteração do Art. 26 da Lei 9.394/96 e dá outras providências. Disponível em:http://www.seppir.gov.br/publicacoes/pnpir.pdf. Acessado em: 10/04/2015.

\section{Plano Nacional de Implementação das Diretrizes}

Curriculares Nacionais para a educação das relações étnico raciais para o ensino da História e Cultura Afro-brasileira e africana. Brasília: MEC, SECADI, 2013.

CONNELL, R.W. Pobreza e Educação. In: GENTILI, Pablo. Pedagogia da exclusão: crítica ao neoliberalismo em educação. Petrópolis: Vozes, 1999, p. $11-42$.

DELEUZE, Gilles. Pós- Scriptum sobre a sociedade de controle: em conversações. Rio de Janeiro: Editora 34, 2001.

DI PIETRO, Maria Sylvia Zanella. Direito Administrativo. 27.ed. São Paulo: Atlas, 2014. 
GINZBURG, Carlo. Mitos, emblemas, sinais: morfologia e história: 2.ed. São Paulo: Companhia das Letras, 2014.

GOFFMAN, Erving. A representação do eu na vida cotidiana. São Paulo: Perspectiva, 2008.

GUATTARI, Felix; ROLNIK, Sueli. Micropolítica: Cartografias do desejo. 9.ed. Petrópolis: Vozes, 2008.

GUATTARI, Caosmose: um novo paradigma estético. 3 ed. São Paulo: Editora 34, 2000.

LIBÂNEO, José Carlos; OLIVEIRA, João F.; TOSCHI, Mirza S. Educação escolar: políticas, estrutura e organização. 8.ed. São Paulo: Cortez, 2009.

LOURAU, René. Analista institucional em tempo integral. São Paulo: Hucitec, 2004.

MACEDO, Roberto Sidnei. A aula como atos de sujeito do currículo e acontecimento multirreferencial. In: In: SILVA, Ainda Maria Monteiro, ettall(Orgs.). Novas subjetividades, currículo, docência e questões pedagógicas na perspectiva da inclusão social. Recife: ENDIPE, 2006, p. $59-68$.

MAZZA, Alexandre. Manual de Direito Administrativo. São Paulo: Saraiva, 2011.

SACRISTÁN, J. Gimeno. O que são os conteúdos do ensino. In: In: SACRISTÁN, J.GIMENO; GÓMEZ, A. I. P. Compreender e transformar o ensino. 4. Ed. São Paulo: Artmed, 2007, p. $149-195$.

SERRA. Serra em números. Disponível em: http://app.serra.es. gov.br/info_ municipais/index.php?link=fontes. Acessado em: $10 / 04 / 2015$. . Lei no 4.432 de 04 de novembro de 2015. Dispõe sobre a Política Municipal de Educação. Disponível em: http://legis.serra. es.gov.br/ normas/images/leis/html/ L44322 015.html. Acessado em 05/01/2015. 
Orientação Curricular de educação infantil e ensino fundamental: articulando saberes, tecendo diálogos. Serra: Abba, 2009. . Resolução CONEGRO 01/2008. Dispõe sobre o Regimento Interno do Conselho Municipal do Negro. Disponível em: www.serra.es.gov.br. Acessado em: 30/03/2015.

. Lei no 3167, de 11 de dezembro de 2007. Dispõe sobre a criação e organização do conselho municipal do negro - CONEGRO e dá outras providências. Acessado em: 30/03/2015. Planejamento CONEGRO 2012. In mímeo. 


\section{METODOLOGIAS E ESTRATÉGIAS DE AVALIAÇÃO EDUCACIONAL APLICADAS NA DISCIPLINA DE LÍNGUA PORTUGUESA: UM ESTUDO DE CASO EM UMA TURMA DE 9 ANO DO ENSINO FUNDAMENTAL}

Maria Nádia Alencar Lima

Eraldo Pereira Madeiro

\section{INTRODUÇÃO}

Esta pesquisa foi embasada pela abordagem qualiquantitativa fundamentada na revisão bibliográfica e na coleta de dados por meio de aplicação de questionário semiaberto e nasceu de inquietações sobre a problemática que leva ao significativo número de alunos retidos no nono ano do ensino fundamental em Língua Portuguesa e a relação do fenômeno com a avaliação escolar e suas implicações.

O estudo buscou analisar pressupostos avaliativos com bases na Lei de Diretrizes e Bases da Educação Nacional - LDB 9394/1996; as diretrizes curriculares sugeridas pelos PCNs, 1998 para orientar a disciplina de Língua Portuguesa e em teóricos da avaliação escolar. Contudo, esta não é uma pesquisa voltada para distribuir receitas sobre técnicas de ensino, prática pedagógica e ato avaliativo, ainda que todas essas questões sejam partes fundamentais do eixo norteador do traba- 
lho, assim como são partes integrantes do ensino e da aprendizagem enquanto processos paralelos e complementares.

Os argumentos traçados neste ensaio têm, no entanto, a pretensão de servir como fonte de apoio e reflexão não somente em relação a maneira de ver como o aluno se desenvolve dentro do processo para avalia-lo, mas sobretudo que os professores consigam entre outras questões o entendimento, conforme Zabala (1998, p. 10) do "papel que temos como pessoas que ensinam", pois essa compreensão de ensino poderá orientar para uma prática capaz de alcançar não os objetivos do professor, mas tudo o que o aluno foi capaz de aprender durante o processo de ensinagem.

\section{REFERENCIAL TEÓRICO}

O suporte reflexivo e o enfoque na avaliação da aprendizagem consistiram na atuação docente em detrimento a análise da prática pedagógica, vislumbrando que o professor seja capaz de compreender e aceitar que não é mais possível nos dias atuais usar a avaliação para segundo, Zabala (1998, p. 212) “medir ou etiquetar o aluno conforme sua capacidade de ser um vencedor [...]". A avaliação deve servir de instrumento orientador da aprendizagem não um gatilho excludente que interrompe o caminho do progresso escolar do aluno por este não ter conseguido alcançar objetivos pessoais do professor e burocráticos do sistema que prever a obrigatoriedade de vencer as unidades de ensino.

A diversidade de estudos realizados por autores renomados sobre a avaliação escolar por si só revela a complexidade inerente ao instrumento avaliativo enquanto ato integrador da prática pedagógia, nesses termos há de se fazer a reflexão sobrea tirania das provas e trabalhos que tenham apenas o cunho classificatório, para que prevaleça a abordagem qualitativa que direciona o processo de ensino e aprendizagem desconstruindo a figura autocrática velada, mas que ainda hoje se faz presente pela ação pedagógica de muitos professores, pois conforme os Parâmetros Curriculares Nacionais abaixo transcrito: 
A conquista dos objetivos propostos para o ensino fundamental depende de uma prática educativa que tenha como eixo a formação de um cidadão autônomo e participativo. Essa prática pressupõe que os alunos sejam sujeitos de seu processo de aprendizagem e construam significados para o que aprendem, por meio de múltiplas e complexas interações com os objetos de conhecimento, tendo, para tanto, o professor como mediador. (PCN, 1998, p. 81)

Isso implica que a dimensão da prática educativa como ponto de largada para o ato avaliativo e o que isso representa para o aluno enquanto sujeito da sua própria construção de cidadania, coloca em evidência a necessidade de o professor rever com frequência os critérios adequados e reais que sejam capazes de fomentar a autonomia do estudante a fim de desencadear sua participação e interesse em realizar as atividades propostas em sala de aula que obrigatoriamente serão avaliadas ao longo do processo.

A LDBEN 9394/1996, (Lei de Diretrizes e Base da Educação Nacional), Brasil (1996, p.10). Seção I, artigo 24, inciso V parte afirma que a avaliação deve ser "(...) continua e cumulativa do desempenho do aluno, com prevalência dos aspectos qualitativos sobre os quantitativos e dos resultados ao longo do período sobre os de eventuais provas finais (...)" cabendo, no entanto, ao professor colocar as aprendizagens significativas em detrimento de aspectos meramente classificatório.

Freire (2018, p. 94) pontua que "A avaliação é da prática educativa, e não de um pedaço dela". Isso significa afirmar que a avaliação não deve ser aplicada em momentos isolados do processo, mas observando critérios que sobretudo perpassam pelo caminho ético em prol da educação de qualidade conforme orienta a LDB, contudo, vale ressaltar que esta é uma lei indicativa e não resolutiva dos fenômenos que cercam o processo de ensino e aprendizagem.

A avaliação não deve apenas deter-se a priorizar o acúmulo ou a quantidade daquilo que o sistema impõe e que o professor concebe como via principal para avaliar o desenvolvimento do aluno, e que embora essas vaiáveis façam parte do processo de ensino e aprendizagem é possível avançar através das novas práticas pedagógicas que indicam 
métodos e várias metodologias, estratégias e técnicas que são instrumentos capazes de indicar se houve evolução cognitiva do aluno durante o ano letivo sem que o desfecho seja necessariamente uma fonte punitiva, a saber:

Os critérios de avaliação explicitam as expectativas de aprendizagem, considerando objetivos e conteúdos propostos para a área e para o ciclo, a organização lógica e interna dos conteúdos, as particularidades de cada momento da escolaridade e as possibilidades de aprendizagem decorrentes de cada etapa do desenvolvimento cognitivo, afetivo e social em uma determinada situação, na qual os alunos tenham condições de desenvolvimento do ponto de vista pessoal e social. (PCN, 1998, p. 80)

Nesse contexto os PCNs dialogam com LDB 9394/1996, para que a avaliação esteja principalmente a serviço da aprendizagem, e que encontre no professor um profissional comprometido e que realmente se identifique com o trabalho pedagógico sendo um mediador capaz de orientar os alunos no processo evolutivo, de modo que estes alunos consigam ao longo do processo superar as suas limitações com o apoio do professor, pois segundo Freire (2018, p. 68) a "prática educativa demanda a existência de sujeitos, um que, ensinando, aprende, outro que, aprendendo, ensina."

Nesse alinhavar das discussões que compreendem o processo de ensino e aprendizagem como uma via de mão dupla que segue ladeado pelas percepções e concepções da avaliação em tons nem sempre amistosos entre professores e teóricos, o que se sobrepõe é o tom das notas que orientam a orquestra do instrumento avaliativo no sentido de que existem alguns consensos entre ambos como a necessidade de impregnar de sentido a prática pedagógica que estimula a autonomia do aluno para aprender, as redefinições do processo avaliativo desmistificando a avaliação enquanto instrumento classificatório e excludente e as interações sociais que combatem a segregação subjacente nas instituições de ensino brasileiras. 


\section{METODOLOGIA}

O trabalho foi realizado em uma escola " $\mathrm{X}$ ", localizada no município de Castanhal no Estado do Pará, no período de março a abril de 2019, através do estudo de caso que contou com a participação de professores dos nos finais do ensino fundamental, de um universo de 32 foram tomados como amostra 17 professores que aceitaram responder ao questionário. Todas As informações que fundamentaram e tornaram possíveis a realização da pesquisa vieram de fontes diversas como livros, artigos e relatos autorizados pelos professores participantes da pesquisa.

Para a investigação, escolheu-se a abordagem qualiquantitativa a qual foi representa por perguntas abertas e fechadas que subsidiaram a análise dos dados e que culminaram nas mais diferentes expressões literárias que foram captadas, interpretadas e organizadas criteriosamente, com a finalidade de compreender de que forma os professores da escola investigada concebem conceitos sobre metodologia, método e estratégias de ensino e como relacionam ao instrumento avaliativo. A escolha do caminho foi alinhada com o discurso entre qualidade e quantidade tendo em vista que:

A relação entre quantitativo e qualitativo, entre objetividade e subjetividade não se reduz a um continuum, ela não pode ser pensada como oposição contraditória. Pelo contrário, é de se desejar que as relações sociais possam ser analisadas em seus aspectos mais "ecológicos" e "concretos" e aprofundadas em seus significados mais essenciais. Assim, o estudo quantitativo pode gerar questões para serem aprofundadas qualitativamente, e vice-versa (MINAYO; SANCHES, 1993, p. 247).

Nesse sentido, a pesquisa fundamentada pelo Estudo de Caso seguiu seu curso valorizando e espeitando as opiniões/concepções diversas seja pelos depoimentos relatados e redigidos o que configura a subjetividade da pesquisa, seja pela escolha de assertivas mensuráveis no campo da objetividade.

A definição do público se deu com base na problemática levantada neste estudo que teve como eixo norteador a retenção no $9^{\circ}$ (nono) do 
ensino fundamental com vistas a encontrar respostas que fossem capazes de apontar as causas do problema pesquisado.

Foi estimando uma baixa margem de erro para tabulação das amostragens, uma vez que o formato do questionário semiaberto dispõe em parte de perguntas que não são analisadas como certas ou erradas, mas quantificadas baseadas na liberdade de comunicação do participante proporcionando maior liberdade de conceituação e reconceitualização entre teoria e prática.

$\mathrm{Na}$ fase supracitada os encaminhamentos que envolveram a técnica da aplicação do questionário se justifica por esta ser segundo Chizzotti (1995, p. 55) "uma interlocução planejada", que significa que tem em seu corpo interrogativas com sequências lógicas e organizadas de acordo com a proposta do estudo com vias a alcançar os objetivos referenciais do trabalho em pauta observando que:

[...] para que o fenômeno se mostre, não basta vivê-lo, pois, na imersão, a amplitude de visão se restringe. A compreensão exige transcender essa expectativa e espreitar as diferentes possibilidades através da visão e do sentir do outro. (MACHADO, 1997, p. 35).

Nesses moldes as intenções e ideias para desvelar o fenômeno implicador do processo avaliativo deu-se sustentada na impressão da pesquisa pela aplicação do questionário que oportunizou os entrevistados a liberdade de contextualizar seus pontos de vistas sobre o processo avaliativo através de conceitos autorais ou seja, produzidos pelos professores, e apresentar esse cenário democrático de emissão de opiniões por meio do questionário semiaberto é importante haja vista ser este segundo Gil (2006, p. 128) “[...] uma técnica de investigação composta por um número mais ou menos elevado de questões apresentadas por escrito às pessoas. " E foi justamente este o fio condutor para alcançar ou aproximar as respostas dos professores aos objetivos traçados inicialmente para o estudo.

\section{RESULTADOS E DISCUSSÕES}

Os resultados e as discussões foram organizados em esquemas de quadros que distribuíram as respostas por grupos de concep- 
ções convergentes, pois de acordo com Severino (2016, p.59) “A utilidade do esquema está no fato de permitir uma visualização global do texto". O que facilita o encadeamento das ideias e dos argumentos de modo a transmitir a interpretação com mais clareza e objetividade e subsequente em gráficos representativos das respostas objetivas.

QUADRO 1- Função da avaliação da aprendizagem

\begin{tabular}{|c|c|}
\hline RESPOSTAS/DOCENTES & DISCUSSÃO/CONCEPÇÃO \\
\hline $\begin{array}{l}\text { 1. Para comprovação do processo de } \\
\text { ensino e aprendizagem, saber se o } \\
\text { aluno aprendeu os conteúdos; } \\
\text { 2. Avaliar exclusivamente em } \\
\text { que nível está a aprendizagem do } \\
\text { aluno. Se de fato está aprendendo o } \\
\text { conteúdo; } \\
\text { 3. Verificar se os alunos } \\
\text { memorizaram os conteúdos para } \\
\text { que possam avançar no processo de } \\
\text { ensino e aprendizagem e passar para } \\
\text { o ano seguinte; } \\
\text { 4. Averiguar ao final se o que foi } \\
\text { ensinado foi de fato assimilado; } \\
\text { 5. A função é saber se o aluno } \\
\text { aprendeu o que foi ensinado; } \\
\text { 6. Verificar o que o aluno assimilou } \\
\text { dos conteúdos ao longo do bimestre; } \\
\text { 7. Tem a função de promover o } \\
\text { aluno para série ou ano seguinte; } \\
\text { 8. Para avançar no processo de } \\
\text { ensino e aprendizagem. } \\
\text { 9. A função é avaliar todos os alunos } \\
\text { sem distinção, da mesma forma, ou } \\
\text { seja, igualmente. }\end{array}$ & $\begin{array}{c}\text { As respostas apresentam } \\
\text { características da avaliação } \\
\text { classificatória, que é uma herança } \\
\text { do ensino tradicional em que a } \\
\text { metodologia de ensino é centrada e } \\
\text { preocupada apenas com as questões } \\
\text { conteudista, desconsiderando a } \\
\text { necessidade de mobilizar outros } \\
\text { aspectos que poderiam levar ao } \\
\text { desenvolvimento integral do aluno. } \\
\text { Esta concepção também avalia todos } \\
\text { os alunos de uma mesma forma, } \\
\text { com o único objetivo de mensurar o } \\
\text { aprendizado como se todos tivessem } \\
\text { no mesmo nível de desenvolvimento } \\
\text { cognitivo e que sendo assim } \\
\text { pudessem ser avaliados de maneira } \\
\text { generalizada. Esta concepção se } \\
\text { baseia meramente nos conteúdos e } \\
\text { procedimentos de medida como fazer } \\
\text { prova, fazer exame, atribuir notas, } \\
\text { repetir ou passar de ano e evidencia- } \\
\text { se por tratar o aspecto quantitativo } \\
\text { dos acertos mais importantes que } \\
\text { o processo de construção tanto } \\
\text { das aprendizagens quanto dos } \\
\text { conhecimentos. }\end{array}$ \\
\hline
\end{tabular}




\begin{tabular}{|c|c|}
\hline & \\
\hline $\begin{array}{l}\text { 10. É uma forma de verificar o nível } \\
\text { de aprendizagem dos alunos e pensar } \\
\text { em estratégias para trabalhar com } \\
\text { base nas dificuldades dos mesmos; } \\
\text { 11. Diagnosticar para identificar } \\
\text { as fraquezas e as potencialidades } \\
\text { dos estudantes para então avaliar. } \\
\text { 12. A avaliação deve passar pelo } \\
\text { diagnóstico para só então se escolher } \\
\text { o caminho melhor para avaliar a } \\
\text { evolução do aluno; } \\
\text { 13. A função da avaliação é } \\
\text { identificar os erros e os acertos para } \\
\text { fazer as intervenções pedagógicas. } \\
\text { 14. Analisar e acompanhar o quanto } \\
\text { o aluno absorveu do conteúdo } \\
\text { quanto ao uso do mesmo com a } \\
\text { realidade que o cerca, sendo, no } \\
\text { entanto, a função avaliar se o aluno } \\
\text { domina gradativamente ao final de } \\
\text { cada unidade de ensino os objetivos } \\
\text { estabelecidos, ou seja, cada etapa, } \\
\text { antes de passar para outra etapa. } \\
\text { 15. A função é fazer com que o } \\
\text { aluno perceba seus erros e acertos, } \\
\text { ou seja, seus pontos fracos e os } \\
\text { corrijam. }\end{array}$ & $\begin{array}{l}\text { Características da concepção } \\
\text { diagnostica que concebe o processo } \\
\text { avaliativo enquanto um exercício de } \\
\text { reflexão, pois existe a preocupação } \\
\text { de verificar o conhecimento prévio } \\
\text { dos alunos com a finalidade de } \\
\text { tornar o processo de aprendizagem } \\
\text { mais exequível e eficaz, além disso é } \\
\text { através do diagnóstico que se pode } \\
\text { verificar as causas que dificultam } \\
\text { ou impedem a aprendizagem do } \\
\text { aluno. É uma concepção que vai para } \\
\text { além da averiguação dos erros e dos } \\
\text { acertos. } \\
\text { Característica da avaliação formativa, } \\
\text { pois acompanhar o desenvolvimento } \\
\text { das aprendizagens do aluno é } \\
\text { uma forma de aproximar a ação } \\
\text { pedagógica de tudo o que faz parte, } \\
\text { alimenta e facilita o campo daquilo } \\
\text { que é significativo par o aluno; } \\
\text { É também na avaliação formativa que } \\
\text { o professor tem a possibilidade de } \\
\text { detectar e identificar possíveis falhas e } \\
\text { reformular o seu trabalho pedagógico } \\
\text { com base processo contínuo de } \\
\text { aprendizagem do aluno. }\end{array}$ \\
\hline
\end{tabular}

Fonte: Questionário aberto respondido pelos participantes da pesquisa, 2019.

\section{Análise:}

Para responder à pergunta do (Quadro 1) sobre a concepção da função da avaliação, de um total de 17 participantes, (53\%) construíram suas respostas com bases na avaliação classificatória, seguidos de $23 \%$ que apresentaram o discurso que pode ser compreendido dentro do conceito do que é a avaliação diagnóstica, (12\%) revelaram que sua prática pedagógica está correlacionada com a avaliação formativa e (12\%) não souberam ou não quiseram responder. 
O percentual de 53\% representa a maioria entre os entrevistados que disseram lançar mãos do instrumento avaliativo com a finalidade de classificar o aluno. Neste modelo de avaliação de acordo com Luckesi (2011, p. 190) “[...] o estudante é tomado exclusivamente como um sujeito que responde a um instrumento de coleta de dados." Portanto, sua relevância é meramente classificatória visto sua ênfase nos resultados finais do processo de ensino e aprendizagem.

QUADRO 2 - Aspectos que os docentes avaliam os alunos

\begin{tabular}{|c|c|}
\hline RESPOSTAS/DOCENTES & DISCUSSÃO /ASPECTOS \\
\hline \begin{tabular}{|c|} 
1. Aprendizado; \\
2. Participação durante as aulas \\
e atividades extraclasse. No \\
decorrer das aulas observo o uso \\
de argumentos, questionamentos e \\
respostas a perguntas e execução de \\
exercícios propostos; \\
3. Memorização, raciocínio lógico, \\
inteligência, abstração, cultura \\
matemática e cultura em português; \\
4. Assiduidade, participação nos \\
trabalhos principalmente expositivo, \\
respostas organizadas e prova escrita; \\
5. Participação, empenho nas \\
atividades e sobretudo se eles \\
compreendem a essência do \\
conteúdo e prova escrita \\
6. Avalio com base nos conteúdos \\
ministrados ao longo do bimestre. \\
7. Avalio pela participação nas aulas \\
e pelos conteúdos disponibilizados \\
em sala de aula, nos livros e prova \\
escrita.
\end{tabular} & $\begin{array}{l}\text { As respostas deste grupo se } \\
\text { apresentam em conformidade com } \\
\text { a abordagem tradicionalista, pois } \\
\text { apresentam como características } \\
\text { principais a valorização conteudista } \\
\text { com base no processo de ensino } \\
\text { e aprendizagem essencialmente } \\
\text { centradas nas aulas expositivas. } \\
\text { Observa-se que os participantes } \\
\text { fazem insistentemente a correlação } \\
\text { entre os conteúdos e a aprendizagem } \\
\text { enquanto caminhos para a reiteração } \\
\text { do avanço do aluno no processo } \\
\text { educativo. } \\
\text { O controle também está presente } \\
\text { na forma de avaliar através de provas } \\
\text { escritas que primam pela exatidão da } \\
\text { reprodução dos conteúdos e que são } \\
\text { vistas como principal instrumento } \\
\text { para medir o conhecimento do } \\
\text { aluno. }\end{array}$ \\
\hline
\end{tabular}




\begin{tabular}{|c|c|}
\hline RESPOSTAS/DOCENTES & DISCUSSÃO /ASPECTOS \\
\hline $\begin{array}{c}\text { 8. Níveis de aprendizado, } \\
\text { compreensão dos conteúdos } \\
\text { indissociáveis das realidades } \\
\text { dos alunos, formas diversas de } \\
\text { compreensão das respostas, } \\
\text { observando a realidade do aluno e } \\
\text { avaliação formal. } \\
\text { 9. Participação nas aulas, uso de } \\
\text { atividade diversificadas, pré-testes, } \\
\text { seminário, diálogo, pela difusão dos } \\
\text { conteúdos concretos e prova escrita; } \\
\text { 10. Avalio se o aluno está } \\
\text { aprendendo ou não. As aulas são } \\
\text { teóricas e práticas para observar em } \\
\text { que o aluno tem mais habilidade; } \\
\text { 11. Avalio sob os aspectos } \\
\text { que incluem as aquisições de } \\
\text { comportamentos cognitivos, afetivos } \\
\text { e sociais de acordo com a realidade } \\
\text { do aluno e concluindo com a prova } \\
\text { escrita porque é obrigatória. }\end{array}$ & $\begin{array}{l}\text { Este segundo grupo conforme as } \\
\text { respostas impressas encontram- } \\
\text { se sustentado em sua concepção } \\
\text { de avaliação escolar na Pedagogia } \\
\text { Crítico- Social dos Conteúdos que } \\
\text { é uma tendência que se preocupa } \\
\text { segundo Aranha (1996, p. 216) em } \\
\text { "Construir uma teoria pedagógica } \\
\text { a partir da compreensão de nossa } \\
\text { realidade histórica e social, a fim de } \\
\text { tornar possível o papel mediador } \\
\text { da educação no processo de } \\
\text { transformação social”. Constatou- } \\
\text { se que nesse caso além de atender } \\
\text { as diretrizes do sistema tradicional } \\
\text { (prova escrita) estes professores } \\
\text { avaliam priorizando a participação, a } \\
\text { liberdade dos aprendentes e atentos a } \\
\text { diversidade cultural presente em sala } \\
\text { de aula. }\end{array}$ \\
\hline $\begin{array}{l}\text { 12. De acordo com os seguintes } \\
\text { aspectos: leitura, escrita, } \\
\text { compreensão e interpretação de } \\
\text { texto, capacidade para escrever } \\
\text { textos expositivos/informativos, } \\
\text { descobrir aptidões e prova escrita. } \\
\text { 13. Produção escrita: escrever textos } \\
\text { argumentativos, leitura e textos } \\
\text { diversificados, buscando desenvolver } \\
\text { aptidões individuais, organização e } \\
\text { tratamento de informação, prova } \\
\text { escrita. } \\
\text { 14. Leitura, escrita, Interpretação de } \\
\text { texto, participação ativa nas aulas, } \\
\text { atividades em grupo, sempre faço } \\
\text { atividades para revelar as aptidões } \\
\text { individuais e prova escrita. }\end{array}$ & $\begin{array}{l}\text { O terceiro grupo pode-se dizer } \\
\text { que está de acordo com Libâneo } \\
\text { (1992, p. 3) conectado a tendência } \\
\text { liberal renovada haja vista que “[...] a } \\
\text { educação é um processo interno, não } \\
\text { externo; ela parte das necessidades e } \\
\text { interesses individuais necessários para } \\
\text { a adaptação ao meio [...]propõe um } \\
\text { ensino que valoriza a autoeducação } \\
\text { (o aluno como sujeito do } \\
\text { conhecimento) ". Estes professores } \\
\text { demonstraram através das respostas } \\
\text { que estão preocupados em fazer com } \\
\text { que o aluno aprenda fazendo, ou seja } \\
\text { todas atividades estão centradas no } \\
\text { aluno. }\end{array}$ \\
\hline
\end{tabular}

Fonte: Questionário aberto respondido pelos participantes da pesquisa, 2019. 


\section{Análise:}

Esta amostra analisada no (Quadro 2) sobre os aspectos em que os docentes avaliam os alunos se configurou de tal forma em que $41 \%$ dos participantes demonstram fundamentar sua prática pedagógica com base na abordagem tradicionalista, 23\% na pedagogia crítico- social dos conteúdos tendo em vista, os professores apresentarem em suas respostas argumentos característicos dessa tendência, como a preocupação pela compreensão dos conteúdos correlacionados a realidade sociocultural do aluno, 18\% construíram suas respostas externando inquietação sobre as tentativas em descobrir as propensões individuais dos alunos em relação as habilidades/competências, reflexo do elóquio da tendência liberal renovada, enquanto que outros 18\% não responderam, nem justificaram a negativa.

QUADRO 3- Em relação a reprovação dos alunos.

\begin{tabular}{|c|c|}
\hline RESPOSTAS/DOCENTES & DISCUSSÃO \\
\hline $\begin{array}{l}\text { 1. Adaptação ao conteúdo. } \\
\text { 2. Existem vários fatores: déficit } \\
\text { de atenção, deficiência nutricional, } \\
\text { ausência de limites e rotina de } \\
\text { estudo em casa. Em alguns casos } \\
\text { falta interesse causado por problemas } \\
\text { externos. } \\
\text { 3. Por causa do sistema de ensino. } \\
\text { 4. Falta de conhecimentos básicos } \\
\text { que o aluno deveria saber ao passar } \\
\text { de um ano para o outro e não sabe. } \\
\text { As vezes a defasagem de conteúdo } \\
\text { prejudica toda a trajetória escolar do } \\
\text { aluno. } \\
\text { 5. Por causa das defasagens dos } \\
\text { conteúdos. } \\
\text { 6. Pode ser por falta de critérios mais } \\
\text { adequados para cada caso. } \\
\text { 7. Por causa do sistema de ensino } \\
\text { que é excludente. }\end{array}$ & $\begin{array}{c}\text { Os docentes ponderam o } \\
\text { reconhecimento de parte da } \\
\text { responsabilidade para si, ao } \\
\text { mesmo tempo em que atribuíram } \\
\text { o fracasso/reprovação a dinâmica } \\
\text { burocrática do sistema de ensino } \\
\text { e até mesmo a situações externas, } \\
\text { porém é somente o professor } \\
\text { que tem condições concretas, } \\
\text { autonomia, e mecanismos para fazer } \\
\text { e refazer o percurso metodológico. } \\
\text { Acreditar que todos os alunos } \\
\text { podem aprender independente } \\
\text { de defasagem de conteúdo ou de } \\
\text { imposições do sistema e tomar } \\
\text { posse da avaliação contínua como } \\
\text { forma de aproveitar tudo aquilo que } \\
\text { o aluno produz intelectualmente em } \\
\text { sala de aula ao longo do ano letivo. }\end{array}$ \\
\hline
\end{tabular}




\begin{tabular}{|c|c|}
\hline RESPOSTAS & DIS \\
\hline $\begin{array}{l}\text { 8. Aulas desinteressantes, aulas } \\
\text { desconexas de sua realidade, aulas } \\
\text { com pouco uso de tecnologia. } \\
\text { 9. penso que um motivo forte para a } \\
\text { reprovação do aluno são as aulas sem } \\
\text { compatibilidades com o seu centro } \\
\text { de interesse, ou seja, sem ligação } \\
\text { com a sua realidade. } \\
\text { 10. Aulas expositivas e cansativas } \\
\text { sem atrativos didáticos, que não faz } \\
\text { nenhuma ponte com a realidade do } \\
\text { aluno. } \\
\text { 11. Aulas sem criatividades e sem } \\
\text { referência do cotidiano do aluno, } \\
\text { isso muitas vezes é um problema na } \\
\text { sala de aula. } \\
\text { 12. Aulas completamente fora da } \\
\text { realidade do aluno. }\end{array}$ & $\begin{array}{l}\text { Esse grupo aponta que a } \\
\text { problemática que envolve a } \\
\text { reprovação escolar está relacionada } \\
\text { ou vinculada aos modelos ou } \\
\text { formatos de aulas que não estão } \\
\text { adequadas a realidade do aluno } \\
\text { sendo este, portanto o maior } \\
\text { entrave para a progressão do aluno, } \\
\text { importante ressaltar que hoje } \\
\text { crianças, jovens e adultos sofrem } \\
\text { a influência das novas tecnologias } \\
\text { como por exemplo a realidade } \\
\text { digital que dá um feedback em tempo } \\
\text { real e que poderia ser usado pelo } \\
\text { professor enquanto instrumento } \\
\text { didático para subsidiar a estrutura } \\
\text { da aprendizagem, a fim de superar } \\
\text { as aulas essencialmente expositivas } \\
\text { que podem contribuir para o efeito } \\
\text { negativo do processo de ensino e } \\
\text { aprendizagem. }\end{array}$ \\
\hline $\begin{array}{l}\text { 13. Existe um duplo motivo, } \\
\text { problemas na escola e ou com o } \\
\text { próprio aluno. } \\
\text { 14. Na minha opinião há um pouco } \\
\text { de falta de interesse em participar } \\
\text { das atividades. O aluno as vezes é } \\
\text { desinteressado e sem compromisso } \\
\text { com os estudos e consequentemente } \\
\text { com o próprio futuro. } \\
\text { 15. Reprova porque só deixa para } \\
\text { estudar na véspera da prova. Muitas } \\
\text { vezes a culpa é do próprio aluno que } \\
\text { não se interessa para acompanhar as } \\
\text { aulas. Excessos de faltas etc. }\end{array}$ & $\begin{array}{l}\text { Estes participantes conferem } \\
\text { a reprovação como uma } \\
\text { responsabilidade da escola e do } \\
\text { aluno, mais do aluno do que da } \\
\text { escola como revelam as respostas } \\
\text { concedidas por eles em que } \\
\text { colocam a culpabilidade pelos } \\
\text { acontecimentos negativos no aluno, } \\
\text { e que em nenhum momento das } \\
\text { falas demonstram reconhecer } \\
\text { que também têm parte nesse } \\
\text { contexto negativo que eles apontam } \\
\text { como fator principal que leva a } \\
\text { reprovação. }\end{array}$ \\
\hline
\end{tabular}

Fonte: Questionário respondido pelos participantes da pesquisa, 2019.

\section{Análise:}

Em síntese em relação aos docentes que estão representados no (Quadro 3) e que respondem as causas que levam a reprovação dos 
alunos. 41\% disseram que a reprovação ocorre por conta da defasagem de conteúdo, do sistema de ensino e fatores externos. 29\% atribuíram ao formato das aulas expositivas. 18\% apontaram que a culpa é dos próprios alunos que são desinteressados e $12 \%$ não responderam.

Vale ressaltar aqui que 18\% que atribuíram a culpa da reprovação ao aluno corresponde em média a três professores entre os 17 participantes da pesquisa e isso é um número preocupante e que pode ser considerado representativo sobre como é concebido o instrumento avaliativo por estes professores no binômio ensino e aprendizagem e a inversão de responsabilidade sobre o processo educativo. De acordo com Hoffmann:

O aluno não aprende porque não tem oportunidade de revelar o que pensa, discutir suas ideias, elucidar suas dúvidas! E somente uma resposta aponta a necessidade de se repensar a formação dos professores: o professor apresenta falta de conhecimento quanto a questões de aprendizagem (HOFFMANN,1995, p.47).

Nestes casos, professor precisa ter clareza, objetivos e imparcialidade no processo, saber mobilizar os recursos que estão a suas mãos de modo que sirvam como eixo orientador para o que se pretende alcançar. É fundamental unir teoria e prática, porque já não é mais possivel, nem aceitável que siga uma lógica para ensinar e outra para avaliar e o desdobramento dessa ação recaia equivocadamente sobre o aluno.

GRÁFICO 1 - Estratégias utilizadas no processo de ensino e aprendizagem

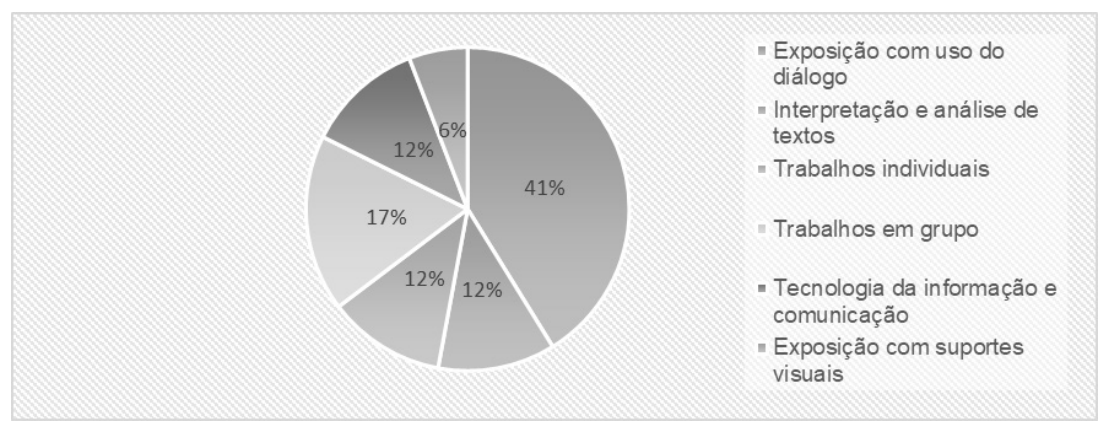

Fonte: Questionário respondido pelos participantes, 2019. 


\section{Análise:}

O questionamento levantado pelo (Gráfico 3) em relação as estratégias utilizadas pelo professor no processo de ensino e aprendizagem obteve-se os seguintes índices: $12 \%$ dos participantes responderam que usam os trabalhos individuais. 12\% tecnologia da informação e comunicação. 12\% interpretação e análise de textos. 17\% trabalhos em grupo. $6 \%$ exposição com suportes visuais. $41 \%$ exposição com uso do diálogo. Esses números representam escolhas múltiplas, pois alguns dos docentes marcaram mais de uma alternativa.

Vale pontuar que por serem as estratégias de ensino, técnicas constantemente questionadas quando o assunto é a prática docente intrinsicamente ligada a ação pedagógica que mobiliza os conhecimentos para favorecer a aprendizagem, é comum encontrar essa multiplicidade de pavimentação de olhares dentro do processo de ensinagem.

Contudo, é sabido que lançar mãos de diferentes estratégias para mobilizar o ensino é valioso de tal forma que este seja condicionante para que as aprendizagens sejam mais significativas, e essa ação pode significar sair da zona de conforto tanto o aluno quanto o professor .

GRÁFICO 2 - Metodologias aplicadas para potencializar a autonomia do aluno.

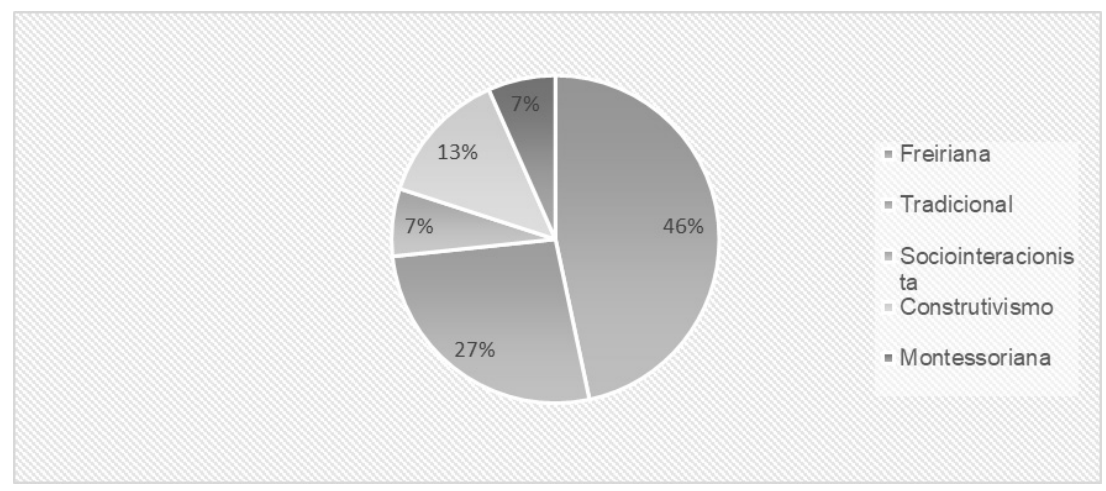

Fonte: Questionário respondido pelos participantes, 2019.

Análise:

Ao serem questionados sobre as metodologias aplicadas para potencializar a autonomia do aluno (Gráfico 2), 46\% identificaram-se com a metodologia Freiriana (voltada para alfabetização de adul- 
tos) $13 \%$ disseram ser Construtivista (se dá pela interação do aluno com o ambiente) 7\% afirmaram que se apoiam na metodologia Sóciointeracionista (pela interação social que favorece a aprendizagem) 7\% se perceberam como mobilizadores da Montessoriana (promove o ambiente organizado para o aluno e respeita o ritmo e as preferências de cada um) e $27 \%$ afirmaram lançar mãos da metodologia tradicional (transmissão de conhecimentos, aulas expositivas, exercícios sistematizados e memorização).

Vale aqui um adendo para pontuar que os participantes por não dominarem os conceitos que sustentam ou fundamentam as metodologias de ensino, acabaram por se perceberem se apropriando de várias delas de modo fragmentado. As metodologias de ensino de acordo com Haydt (2001, p. 126) "são importantes à medida que constituem a tessitura básica sobre a qual o aluno constrói e reestrutura o conhecimento". Não podendo, portanto, o professor está alheio ao feedback sobre a construção e fomentação da autonomia do aluno.

\section{CONSIDERAÇÕES FINAIS}

O estudo buscou somente analisar os motivos que elevam o número de alunos a reprovação no $9^{\circ}$ (nono) ano do ensino fundamental, embora não aja como negar que o assunto abrange dimensões bem maiores que circundam a vida escolar do aluno do $9^{\circ}$ ano, tanto o que aconteceu em sua trajetória até aqui, quanto como será para adiante, e tudo isso perpassa pela análise da pesquisa, pois o tempo todo percebeu-se a fragilidade na formação dos professores no sentido de permanecerem presos a um modelo avaliativo que já não corresponde mais as necessidades reais do aluno e que sendo assim depreende-se que é preciso abrir caminhos para o docente que o leve à possíveis mudanças na prática pedagógica.

Infere-se também, que quando se fala em avaliação, muitas vezes por falta de informação, conhecimento, leituras específicas entre outras barreiras, logo o professor se reporta para os números em ou mesmo na própria avaliação enquanto objeto e não instrumento, e quando isso acontece o que foi possível compreender nesse percurso analítico 
é de que o vínculo entre o ensino e aprendizagem que não deve ser mecânico, mas estreitado pela relação dialógica, pela parceria, respeito mútuo, pela construção de significados e inclusive do fazer epistemológico social, histórico, estrutural e cultural a fim de superar a busca incessante por aferições de resultados quantitativos, se perde mediante os discursos que não se conectam as práticas.

Inevitável foi a constatação de que os professores estão desamparados no que concerne as novas práticas pedagógicas que norteiam entre outras coisas o ato avaliativo e seus enlaces no processo de ensino e aprendizagem e isso pode-se ver pelas declarações dadas nas respostas que foram organizadas no quadro $1 \mathrm{em}$ que as respostas foram construídas com base nos conhecimentos reais dos professores participantes deste estudo e que demonstraram em sua maioria não saber a função da avaliação da aprendizagem.

Constatou-se também que para muitos deles a reprovação se dá por culpa do próprio aluno que tem problemas de defasagem de conteúdo, contudo a maioria não respondeu sobre o que a correlação da avaliação com o planejamento de ensino e de que forma as respostas obtidas pelo instrumento avaliativo podem influenciar ou levar a repensar este planejamento, a fim de que este sirva para sustentar a orientação que a avaliação deve proporcionar ao trabalho pedagógico no sentido de pontuar as fraquezas para superá-las e potencializar tudo aquilo que o aluno aprendeu, assim como revisitar a própria prática docente.

\section{REFERÊNCIAIS}

ARANHA, M. L. História da educação. $2^{\underline{a}}$ Ed. São Paulo: Moderna, 1996.

BRASIL. Ministério de Educação e Cultura. LDB - Lei no 9394/96, de 20 de dezembro de 1996. Estabelece as diretrizes e bases da Educação Nacional. Brasília: MEC, 1996.

BRASIL. Secretaria de Educação Fundamental. Parâmetros curriculares nacionais: terceiro e quarto ciclos do ensino fundamental: língua portuguesa/ Secretaria de Educação Fundamental. Brasília: MEC/SEF, 1998. 
CHIZZOTI, Antonio. A pesquisa qualitativa em Ciências sociais: evoluções e desafios. 2 ed. São Paulo: Vozes, 1995.

FREIRE, Paulo. Pedagogia da autonomia: saberes necessários à prática educativa. 56 ${ }^{\mathrm{a}}$ ed. Rio de Janeiro/São Paulo: Paz e Terra, 2018.

GIL, A. C. Métodos e técnicas de pesquisa social. São Paulo: Atlas, 2006.

HAYDT. Regina Célia Cazaux. Curso de didática geral. 7. ed. São Paulo: Ática, 2001.

HOFFMANN, Jussara Maria Lerch. Avaliação Mediadora. Porto Alegre: Editora Mediação, 1996.

LIBÂNEO, José Carlos. Democratização da escola pública, São Paulo, Edições. Loyola,1992.

LUCKESI, Cipriano Carlos. Avaliação da aprendizagem: componente do ato pedagógico. 1. Ed. São Paulo: Cortez, 2011.

MACHADO, M. N. M. Entrevista de pesquisa: a interação entrevistado/entrevistador. Tese. (Doutorado) - Belo Horizonte, 1997.

MINAYO, M. C. S; SANCHES, O. Quantitativo-qualitativo: oposição ou complementaridade? Cadernos de Saúde Pública, Rio de Janeiro, v. 9, n. 3, p. 239-262, jul./sep.1993.

SEVERINO, Antonio Joaquim. Metodologia do trabalho científico. 24. Ed. rev. e atual. São Paulo: Cortez, 2016.

ZABALA, Antoni. A prática educativa: como ensinar. (Tradução de Ernani F. da F. Rosa. Porto Alegre: Artmed, 1998. 


\section{SISTEMAS ADAPTATIVOS \\ COMPLEXOS NA APRENDIZAGEM DE INGLÊS CAÓTICA}

Isabelly Raiane Silva dos Santos

\section{INTRODUÇÃO}

A noção de complexidade é consideravelmente abrangente, por isso pode ser aplicada a diversas áreas. Esta teoria parte do princípio de que o comportamento do sistema complexo é maior que a soma dos comportamentos de seus componentes. O termo "complexo" é explicado devido ao grande número de componentes e agentes em interação (LARSEN-FREMAN, 1997).

Apesar do estudo sobre a complexidade relacionada à aprendizagem de línguas ser relativamente novo no Brasil, autores como Nascimento e Paiva (2011) e Paiva $(2002 ; 2005)$ se destacam no cenário científico do campo da Linguística Aplicada.

Em aplicações mais recentes, autores buscam relacionar a teoria da complexidade e os sistemas adaptativos complexos (SACs) aos diversos aspectos da aprendizagem, como por exemplo: aconselhamento linguageiro, identidades, autonomia, motivação, crenças, entre outros, possibilitando cada vez mais a ampliação dos estudos sob esse paradigma. Isso demonstra que o crescimento significativo de trabalhos na área contribui para analisar o ensino e a aprendizagem de línguas a partir de um novo prisma.

O objetivo geral desta pesquisa é entender aspectos teóricos os quais possibilitem um melhor entendimento acerca do paradigma 
da complexidade e que evidenciem a interdependência dos aspectos contidos em um sistema adaptativo complexo, associando-o ao processo de aprendizagem de línguas estrangeiras. Dentre os objetivos específicos é possível citar: compreender e detalhar o sistema de aprendizagem de línguas de uma estudante de língua inglesa; observar, nesses sistemas, a existência de dois fenômenos descritos pela teoria da complexidade: a formação de atratores e a emergência de novos comportamentos, e ainda, averiguar fatores que contribuíram para o surgimento desses fenômenos.

Na primeira seção deste artigo são discutidos aspectos relacionados ao referencial teórico pertinente. Para isso, foram utilizados conceitos de diversos autores, dentre eles: Larsen-Freeman e Cameron (2008) e Paiva (2014). Em seguida, a metodologia empregada durante o processo investigativo é detalhada. Por fim, o resultado da análise do corpus e suas implicações para a aprendizagem da língua inglesa é exposto.

\section{REFERENCIAL TEÓRICO}

Nas seguintes subseções serão abordados, primeiramente, conteúdos introdutórios relacionados à definição e à caracterização dos SACs, evidenciando suas particularidades e sua natureza. Posteriormente, são apresentados aspectos que validam a aprendizagem de língua como um SAC, para isso, são enfatizadas questões sobre a aquisição de segunda língua e cognição.

\subsection{CARATERÍSTICAS DOS SACS}

Segundo Paiva (2014), os SACs possuem certas características que os definem. De acordo com a autora, eles são abertos devido à capacidade de receber energia do meio. Esta energia alimenta o sistema e o mantém em harmonia. São complexos, pois há uma gama de elementos e subsistemas que interagem continuamente entre si de maneiras distintas, o que gera modificações as quais influenciam no comportamento desse sistema como um todo. São não-lineares, ou seja, os efeitos não são necessariamente proporcionais às causas. São caóticos, pois passam por certos períodos de instabilidade. São imprevisíveis, visto 
que passam por períodos de aleatoriedade. Dinâmicos, ou seja, mudam com o tempo e há uma dependência, embora não garantia, do estado futuro para com o estado presente.

Por meio de interações e adaptações, os agentes do sistema fazem com que espontaneamente surja uma ordem a partir de uma aparente desordem, evidenciando mais uma de suas características: a auto-organização. Por serem auto organizáveis e terem a capacidade de se modificar, os sistemas são adaptativos. Ainda, pequenas mudanças no estado inicial do sistema podem gerar consequências inesperadas. A sensibilidade às condições iniciais é conhecida como o efeito borboleta, um fenômeno proposto e analisado por Edward Lorenz no ano de 1963, cujos postulados defendiam a ideia de que pequenas perturbações no sistema poderiam causar consequências grandiosas e inesperadas. Para isso, o autor adotou como metáfora a ideia de que o bater de asas de uma borboleta em algum lugar pode ser responsável por causar um tornado em outra parte do planeta. Por fim, são sensíveis a feedback e apresentam atratores.

\subsection{A APRENDIZAGEM DE LÍNGUAS COMO UM SAC}

A aprendizagem de línguas pode ser caracterizada como um SAC, visto que é considerada um processo não linear e sujeito à mudança. Outro aspecto relevante diz respeito às inúmeras interações nas quais os elementos se encontram e à gama de interferências observadas dentro deste sistema instável. De acordo com Paiva (2014, p. 146), “a aquisição da segunda língua não é vista como tendo começo e fim, em uma progressão sequencial, mas como um fenômeno irregular, não linear, iterativo e auto organizado".

O conselheiro linguageiro é outro elemento do sistema aprendizagem de línguas. Segundo Carson e Mynard (2011), o aconselhamento linguageiro é definido como um processo em que se oferece ajuda aos alunos com a intenção de direcioná-los para seus próprios caminhos, a fim de torná-los mais autônomos na aprendizagem de línguas, por isso é estabelecida uma relação entre conselheiro (facilitador) e aconselhado (aprendente). Sua relação com os SACs se dá a partir do momento em 
que esse agente está incluído no sistema de aprendizagem de línguas, por isso, também pode ser considerado um subsistema complexo, gerando uma relação de interdependência entre seu sistema e aquele de seu aconselhado.

A seguir são expostas concepções fundamentais da Teoria da Complexidade e conceitos-chave para consolidar esta pesquisa. O primeiro deles, tratado na primeira subseção, são os atratores, também chamados de bacias atratoras. Na segunda e última subseção o foco está voltado para a emergência de novos comportamentos e para a mudança de fase.

\subsubsection{ATRATORES OU BACIAS ATRATORAS}

Atrator ou bacia atratora é um comportamento que um sistema dinâmico prefere, em outras palavras, é um padrão no qual esse aparentemente se estabiliza, pelo menos por um tempo (LARSEN-FREMAN, 1997).

Os atratores exibem diversos comportamentos dinâmicos e qualquer mudança na trajetória do SAC poderá acarretar a variação deles. Larsen-Freeman e Cameron (2008) exemplificam: os cavalos possuem quatro maneiras naturais de se deslocarem: passo, trote, cânter e galope. As variações em relação a esses movimentos são notadas não somente por meio da velocidade, mas também pelo emprego das articulações do animal. A partir do momento em que o cavalo aumenta sua velocidade e muda de movimento, o sistema se move rumo a outro atrator.

Os atratores não representam o movimento em um único ponto fixo, mas sim em uma região limitada. Também é visível a região possível, aquela não desejada, que por algumas razões, como, doença ou falta de motivação, por exemplo, poderá fazer parte da trajetória do sistema, já que esse se deslocará até ela. Essa tomada de rumos inesperados, mesmo que seja causada por mudanças pequenas e temporárias, poderá trazer tanto pontos positivos, como a intensificação dos exercícios, quanto negativos, como a estagnação e morte do sistema.

De acordo com hipóteses que envolvem a relação entre tempo e estado, é admitido que o estado futuro seja consequência do estado atual, tornando ambos interdependentes. Portanto, analisando o 
presente, seriam possíveis e previsíveis diversas especulações acerca do futuro. A partir disso, para prever um sistema em algum momento no futuro, seria necessário descrever precisamente seu estado atual. Todavia, isso seria algo impossível dada a imensurável quantidade de componentes em interação. Daí, se dizer que o futuro de um SAC não pode ser predito com certeza porque são inúmeros os elementos, processos e subsistemas em interação que podem alterar sua trajetória. Como fruto dessa interação, sistemas passam por diversas mudanças de fase, o que garantem sua movimentação. Ainda, a partir da interação entre seus componentes, após uma mudança de fase é observada a emergência de comportamentos, conceitos, estes, abordados na próxima subseção.

\subsubsection{EMERGÊNCIA E MUDANÇA DE FASE}

Devido às propriedades dinâmicas e à capacidade de adaptação, após mudanças, há evidências de auto-organização e um novo padrão de comportamento é adotado pelo sistema, com a possibilidade de movimentar-se ao longo do espaço-estado, gerando uma nova paisagem topográfica. O que emerge como resultado de uma mudança de fase possui escala ou nível diferente da fase anterior. Portanto, emergência é o aparecimento, em um sistema complexo, de um novo estado que se encontra em um nível de organização mais alto que o anterior (LARSEN-FREEMAN; CAMERON, 2008).

Um dos exemplos clássicos relacionados à emergência diz respeito às formigas, que também pode ser aplicado às abelhas. No momento em que elas estão sozinhas, são vistas apenas como animais simples, muitas vezes suas vidas são relacionadas à ausência de rumo e de liderança para guiá-las. Entretanto, quando as formigas são vistas como parte de uma colônia, é notada a presença de uma sociedade extremamente perspicaz e organizada no desempenho de diversas funções. Portanto, nota-se que o todo é maior e mais inteligente que a soma das partes, ou seja, o nível de organização do sistema atual é bem mais elevado que aquele observado no sistema em seu estado anterior. Para Larsen-Freeman e Cameron (2008), a mudança em um sistema é vista como movimento. 
Larsen-Freeman e Cameron (2008) relatam que a aprendizagem de uma língua não consiste em um único processo de emergência, mas sim em uma sucessão de ciclos de emergência de diversos processos simultâneos interligados. Constantemente há a reestruturação de diversos aspectos da linguagem, apesar do processo de aquisição envolver o estudo da gramática e aquisição de vocabulário que certamente não mudarão de função e significado futuramente.

As variações relacionadas à linguagem podem partir tanto por meio de processos sociais e pressões externas quanto por processos internos, evidenciando o caráter não fixo e não estático da língua. Desse modo, a mudança de fase gera um comportamento emergente.

\section{METODOLOGIA}

A metodologia desta pesquisa de cunho qualitativo interpretativo consistiu em, além de estudos teóricos, recorrer às sessões de aconselhamento linguageiro, realizadas na própria universidade. Os dados coletados são provenientes de uma estudante de língua inglesa.

A aconselhada, AC1CL22, possuía grau básico de proficiência no idioma alvo. Era aluna da pós-graduação de um curso na área de Ciências Exatas e procurou estudar inglês nos Cursos Livres de Línguas Estrangeiras (CLLE) da UFPA visando o sucesso profissional.

Os instrumentos usados para coletar e analisar os dados foram: registros escritos, questionários, ficha de metas, produções da aconselhada, gravações de voz, narrativa de aprendizagem e relatos orais.

A análise dos dados coletados teve como principal foco a verificação de aspectos relacionados aos atratores e à emergência. Para realizar a análise, os dados foram organizados a partir de sua relação com a teoria.

\section{RESULTADOS E DISCUSSÃO}

A partir do primeiro contato com a aconselhada, foi possível notar o quanto a aprendizagem da língua inglesa, em sua concepção, era algo extremamente difícil. Possivelmente isso é apenas uma consequência de inúmeras crenças que ela possuía em relação à aprendizagem. Nesse momento, foi possível observar a presença de uma bacia atratora que a 
impedia de avançar na trajetória e continuar buscando aprender o idioma estrangeiro. Grande parte dessas crenças é advinda de seu contato anterior com o inglês.

Um dos primeiros contatos da AC1CL22 com a língua alvo deu-se quando ela se matriculou em uma escola de idiomas. Após estudar por um ano neste curso de idiomas privado, a aconselhada resolveu abandoná-lo, pois estava bastante desmotivada devido ao horário inconveniente, à falta de qualificação da professora e à baixa qualidade do curso.

No período da coleta de dados, aconselhada era aluna de mestrado em um curso na área das Ciências Exatas e sentia a necessidade de aprender a língua para futuramente ingressar no doutorado. Por isso, resolveu matricular-se nos CLLE da UFPA. Mudando sua concepção, relatou estar disposta a fazer o necessário para sanar suas dificuldades. Relatou ser pouco autoconfiante. Além disso, sente muito medo ao falar inglês em público porque possui receio em errar. Em sua opinião, é uma das piores alunas da turma. Por isso, foi percebida a necessidade de incentivar a aconselhada e de mostrar maneiras úteis para que ela abandonasse essa concepção que tanto a prejudicava.

Além do mais, foi discutida a importância de tomar atitudes relevantes à aprendizagem, como por exemplo: assistir filmes e séries com a legenda e áudio em inglês, baixar aplicativos, vídeos e podcasts, ler notícias de países cujo idioma nativo é a língua alvo, entre outras.

Sendo assim, tomada pelo desejo de mudança, AC1CL22 estabeleceu, inicialmente, uma meta: ser aprovada no CLLE passando pelo período turbulento de provas do modo mais brando possível. Para isso, comprometeu-se a fazer resumos das unidades do livro para não acumular matéria, assim como resolver exercícios que constavam na parte final do material didático. Além do mais, para fazer uma ótima prova oral, treinaria sua pronúncia com a ajuda de um aplicativo de tradução.

Em um terceiro encontro, a aconselhada aparentava uma felicidade extrema. O motivo foi sua nota "oito" na prova oral. A partir desse momento, ela pôde notar o quanto seu esforço culminou em resultados positivos. Ademais, a aconselhada afirmou que estava confiante, pois percebeu a existência outros alunos os quais cometeram mais erros 
que ela na prova oral. Nesse momento, notamos a emergência de novos comportamentos, o que reflete a elevação da motivação intrínseca e um forte sentimento de perseverança. As interações e adaptações possibilitam que os agentes de um sistema de auto organizem, levando, assim, à emergência de novos padrões e comportamentos (MARTINS; BRAGA, 2007).

Segundo Paiva (2011), devido às novas construções identitárias, o sistema se adapta e move-se para outra fase ou atrator quando se estabiliza até que uma nova mudança aconteça, o que pode ser percebido ao analisar a aconselhada antes de estudar nos CLLE (desmotivada) e depois (treinando sua pronúncia, resolvendo exercícios do livro e se comprometendo a estudar inglês).

Cumprindo sua meta e superando suas expectativas, AC1CL22 foi aprovada no CLLE com conceito "bom”. Segundo ela, isso foi consequência de muito esforço e estudo. Como havia dito, fez os resumos dos capítulos os quais seriam abordados na prova escrita, também assistiu um episódio em inglês de uma série chamada The Vampire Diaries. Assim, foi possível unir a necessidade de aprender o idioma aos seus gostos pessoais.

No ano seguinte, com a ajuda do aconselhamento linguageiro, a aprendente pretendia descobrir estratégias para aprender inglês de modo mais agradável e sem pressão. Segundo Oxford (1990), as estratégias buscam tornar o aprendizado mais rápido, mais prazeroso, mais autodirigido, mais eficaz e mais transferível para outras situações. Além disso, a aconselhada gostaria de assistir mais episódios de séries e escutar canções em inglês, retirando de cada uma delas cinco palavras novas e empregando-as em algum contexto significativo para a aprendizagem. Ainda, tentaria ser aprovada na seleção para ganhar uma bolsa de estudos integral nos CLLE.

No mês de janeiro do novo ano, no primeiro encontro para o aconselhamento linguageiro, ela estava radiante. Havia começado a pôr em prática seus planos para o novo ano e estava mais conectada às séries. Com a canção Hello da cantora Adele, aprendeu cinco palavras e as empregou em um contexto. Seria o início de uma nova etapa com mais metas a serem cumpridas, desafios superados e vitórias alcançadas. 
No contexto do estado-espaço dos CLLE, é possível observar que por um determinado momento a trajetória de aprendizagem de AC1CL22 encontrava-se na bacia atratora a qual focava em aspectos do listening e priorizava atitudes como: escutar músicas e assistir séries. Este foi o comportamento estabelecido a longo prazo, o que garantiu certa estabilidade temporária.

Dias depois, infelizmente, ela relatou que não foi uma das alunas selecionadas para ganhar a bolsa de estudos integral. Além disso, devido aos problemas com a saúde de sua mãe e a necessidade de terminar urgentemente a dissertação do mestrado para obtenção do título, ela trocaria seu horário de aula, passando agora a estudar aos sábados, colocando em risco suas metas e dedicação em relação à aprendizagem.

Apesar de afirmar que trocaria de horário, isto não aconteceu, uma vez que AC1CL22 tomou a iniciativa de abandonar os estudos relacionados à língua inglesa e dedicar-se somente à conclusão de sua dissertação de mestrado. Além disso, não manifestou interesse em voltar a estudar o idioma futuramente. Por esses motivos, resolveu afastar-se e finalizar a prática do aconselhamento linguageiro. Isso nos leva a observar uma das características do sistema adaptativo complexo, a imprevisibilidade (LARSEN-FREEMAN, 1997).

Desse modo, devido às crenças sobre as impossibilidades de aprendizagem e à redução da motivação, observa-se que no início, o sistema da aconselhada encontrava-se em um atrator caótico. Este a fazia ficar desmotivada sempre que pensara em estudar o idioma estrangeiro ou colocar em prática algo aprendido no curso de inglês de sua cidade natal. Sua trajetória conseguiu deixar este atrator caótico quando se matriculou nos CLLE e apresentou uma atitude de mudança. Em seguida, seu sistema foi atraído por um novo atrator: aquele que priorizava a dissertação e deixava a aprendizagem de língua inglesa em segundo plano. Isso diminuiu o contato da aconselhada com o idioma alvo. Este fator levou à impossibilidade de deixar este novo atrator. Ao final, devido ao fato de AC1CL22 ter abandonado o curso e não mais estudar inglês, o seu sistema estagnou-se e extinguiu-se. Em relação a isso, Vetromille-Castro (2009) enfatiza que a aprendizagem - de modo 
geral - não acompanha uma ordem, uma sequência de passos pré-estabelecidos que se encaixa em todo e qualquer contexto educacional.

As trajetórias de aprendizagem estão sujeitas a se moverem por diferentes atratores, uma vez que comportamentos dinâmicos distintos são observados, já que cada aprendente segue sua própria rota, de acordo com a variação de seus comportamentos (PAIVA, 2013).

\section{CONCLUSÃO}

A partir do contato com a aconselhada, sob o paradigma da complexidade, foi possível descrever seu sistema de aprendizagem, enfatizando agentes e elementos que o compõem e focando em aspectos como: a emergência e a formação de bacias atratoras.

No sistema, foram verificadas características comuns aos SACs. Essas possuem natureza diferente. Isso mostra que, a partir das escolhas feitas pelos aprendentes, cada sistema adota uma rota.

No caso analisado, as escolhas resultaram no abandono do curso de línguas e interrupção da trajetória. Apesar de AC1CL22 interromper seus estudos, a sucessiva emergência de comportamentos foi algo positivo, pois o sistema continuou prezando pela aprendizagem naquele momento.

Nesse contexto, a aprendizagem é cercada por incertezas, aleatoriedade e obstáculos que devem ser superados. Ademais, é guiada por escolhas, sendo o futuro incerto e dependente delas, no qual um pequeno aspecto pode levar o aprendente ao sucesso ou fracasso na aprendizagem de segunda língua.

Portanto, tornou-se evidente que a compreensão de um sistema de aprendizagem como um SAC nos permite constatar a relação da aquisição de segunda língua com o paradigma da complexidade.

\section{REFERÊNCIAS}

LARSEN-FREEMAN, D. Chaos / Complexity Science and Second Language Acquisition. Applied Linguistics. Oxford, v.2, n.18, p. 141-165, 1997. 
LARSEN-FREEMAN, D.; CAMERON, L. Complex Systems and Applied Linguistics. Oxford: Oxford University Press, 2008.

MARTINS, A.; BRAGA, J. Caos, complexidade e Linguística Aplicada: diálogos transdisciplinares. Revista Brasileira de Linguística Aplicada. Campo Grande, v.7, n.2, p. 215-235, 2007.

MYNARD, J.; CARSON, L. (Ed.) Advising in Language Learning: dialogue, tools and context. Harlow: Pearson, 2012.

OXFORD, R. Language Learning Strategies: What Every Teacher Should Know. Boston, Heinle \& Heinle, 1990.

PAIVA, V. Aquisição de segunda língua na perspectiva da complexidade. In: PAIVA, V. Aquisição de segunda língua. São Paulo: Parábola Editorial, p. 141-151, 2014.

PAIVA, V. Chaos and the complexity of second language acquisition. In: BENSON, P.; COOKER, L. (Ed.). The applied linguistic individual: sociocultural approaches to identity, agency and autonomy. Sheffield; Bristol: Equinox, p. 59-74. 2013.

PAIVA, V. Linguagem e aquisição de segunda língua na perspectiva dos sistemas complexos. In: BURGO, V.; FERREIRA, E.; STORTO, L. Análise de textos falados e escritos: aplicando teorias. Curitiba: Editora CRV, p. 71-86, 2011.

VETROMILLE-CASTRO, R. A entropia sócio-interativa e a sala de aula de (formação de professores de) língua estrangeira. In: PAIVA, V.; NASCIMENTO, M. (Orgs.) Sistemas adaptativos complexos: lingua(gem) e aprendizagem. Belo Horizonte: Faculdade de Letras/FAPEMIG, p. 113-129, 2009. 


\section{O PAPEL DA MOTIVAÇÃO NA APRENDIZAGEM DE LÍNGUA INGLESA}

Isabelly Raiane Silva dos Santos

\section{INTRODUCTION}

A motivação é pertinente para muitas áreas do conhecimento e possui um extenso conceito a ser discutido. Desde 1950, autores têm concentrado diversas pesquisas nesse campo. Esses mostraram que fatores cognitivos estão relacionados aos fatores afetivos quando se trata da aprendizagem de idiomas.

A aprendizagem é um processo que envolve muitos aspectos. Crenças, emoções, autonomia e motivação são alguns desses aspectos que podem influenciar a aprendizagem. Dessa maneira, a motivação, é uma abordagem bastante significativa para diversos campos de pesquisa (DANTAS, 2008).

Sendo assim, foi verificado que o fomento da motivação é válido em qualquer contexto de aprendizagem de línguas estrangeiras, especialmente em sala de aula. Os alunos podem contar com motivação para acompanhar o desempenho de tarefas e aumentar a conscientização acerca de seus próprios mecanismos de aprendizagem.

Alunos motivados obtêm melhores resultados quando estabelecem um objetivo: algo que desejam alcançar. Para fazer isso, eles precisam estabelecer etapas para concretizar suas aspirações. 
A pesquisa relatada neste artigo teve como objetivo compreender o papel da motivação em uma sala de aula de inglês por meio da identificação e explicação de aspectos que influenciaram o aprendente quando esse decidiu estudar inglês. Outro objetivo de pesquisa é detalhar como esses aspectos são importantes para o momento atual de aprendizagem.

Além desta introdução, este artigo está organizado da seguinte forma: na primeira seção, serão expostos aspectos relacionados ao referencial teórico relevante. Para isso, foram explorados conceitos de diversos autores com relevância neste campo de estudo, entre eles: Lile (2002), Brown (2007) e Dantas (2008). Em seguida, serão detalhados os métodos utilizados durante o processo investigativo. Finalmente, os resultados e algumas de suas implicações para o ensino da língua inglesa serão discutidos.

\section{FUNDAMENTAÇÃO TEÓRICA}

Um dos aspectos envolve o processo de ensino e de aprendizagem de uma língua estrangeira é a motivação. Por isso, desde os anos 60, as pesquisas vêm avançando de maneira significativa, desenvolvendo, em particular, diferentes teorias sobre esse assunto (DANTAS, 2008).

Conforme sustentado por Oxford e Shearin (1996), a motivação é uma determinante crucial no processo de aprendizagem, uma vez que mantém os discentes ativamente envolvidos na aprendizagem de uma língua estrangeira. Estudos extensos foram realizados para examinar o papel da motivação na aprendizagem de idiomas, uma vez que não apenas os professores, mas também os pesquisadores, principalmente no âmbito da Linguística Aplicada, têm um interesse considerável nessa variável.

Segundo Masgoret e Garder (2003), um aprendiz motivado demonstra esforço, é persistente e atento às tarefas destinadas a ele, possui objetivos, desejos e aspirações, faz atribuições quanto ao seu sucesso e/ ou fracasso no contexto da aprendizagem, e faz uso de estratégias para ajudar a alcançar seus objetivos.

Um aluno é motivado quando está ciente de suas decisões e age em direção à aprendizagem emocional e cognitiva. A motivação é im- 
portante, uma vez que o aluno será capaz de desenvolver estratégias eficazes para melhorar suas habilidades linguísticas e emocionais. Dörnyei e Otto (1998, p. 64) afirmam que

a motivação pode ser definida como a mudança dinâmica na qual uma pessoa inicia, dirige, coordena, amplifica, termina e avalia os processos cognitivos e motores pelos quais os desejos são selecionados, priorizados, operacionalizados e (com ou sem sucesso) realizados.

Seguindo a mesma linha de pensamento, Brown (2007, p. 85) relata que "motivação é a medida em que indivíduos fazem escolhas sobre (a) objetivos a serem perseguidos e (b) o esforço dedicado a essa busca". Dantas (2008), também explica que a motivação é conhecida como um processo dinâmico e flutuante que acompanha a trajetória de estudo de um aluno e influencia a tomada de decisão e sua execução.

Segundo Dantas (2008), a motivação pode ser classificada em duas categorias diferentes: extrínseca e intrínseca. Esses tipos de motivação, seus benefícios e empecilhos têm sido alvo de discussões entre os pesquisadores. Muitos deles postulam que apenas a aprendizagem intrínseca traz benefícios à aprendizagem, entretanto, outros relatam que ambas as categorias motivacionais são desejáveis e complementares.

Um aluno extrinsecamente motivado é guiado por impulsos externos, como uma recompensa. Um aluno que deseja obter boas notas se presenteará ao atingir o objetivo, por exemplo. Nesse sentido, Deci e Ryan (1985, p. 30) apontam que "quando uma pessoa perceber que a causa é externa a si mesma [...] ela considerarse-á extrínsecamente motivada".

Um aluno intrinsecamente motivado tem satisfação pessoal ao aprender. Em outras palavras, esse aluno está aprendendo porque gosta e porque não há fatores externos que o influenciam. Como afirmam Deci e Ryan (1985, p. 66), “'a teleologia da motivação intrinseca envolve fazer uma atividade por si mesma, isto é, por seu interesse inerente e pelos afetos e cognições espontâneos que a acompanham”. Ainda, os mesmos autores relatam que "quando uma pessoa vivencia o fato 
de ser a causa de seu próprio comportamento [...] ela considerar-se-á intrinsecamente motivada” (p. 30). Dessa maneira,

"a motivação intrinseca é baseada nas necessidades naturais do organismo para competência e autodetenninação. Ela energiza uma grande variedade de comportamentos e processos psicológicos para os quais as recompensas primárias são experiências de eficiência e autonomia. [...] As necessidades intrinsecas para competência e autodeterminação motivam um processo progressivo de buscar a conquista de desafios […" (p. 32).

Assim como Dantas (2008), Lile (2002) também classifica a motivação nas mesmas categorias. Além disso, o autor diz que formar um aluno intrinsecamente motivado é o objetivo de todo o desenvolvimento motivacional. Witter e Lomonaco (1984, p. 45) relatam que a "aprendizagem baseada apenas em motivação extrínseca tende a deteriorar-se, tão logo seja satisfeita a necessidade ou alvo extrínseco. $\mathrm{Na}$ motivação intrinseca, ela tende a se manter constante".

Existe um forte vínculo entre a motivação e o desenvolvimento da autonomia do aluno. O processo de aprendizagem de línguas estrangeiras é irregular e lento, por isso torna-se útil um estímulo externo para fomentar e impulsionar o sucesso, uma vez que a motivação é a chave para toda a aprendizagem (LILE, 2002). Segundo o autor, a falta de motivação é talvez o maior obstáculo enfrentado por professores, conselheiros, administradores de escolas e pais.

Conforme relatado por Dantas (2008), outro conceito relevante para na aprendizagem de línguas é a autonomia. Essa é válida em qualquer contexto no qual a linguagem esteja envolvida, especialmente quando se trata de aprender uma língua estrangeira. Essa implica uma tomada de consciência acerca do processo de aprendizagem pelo aluno, portanto, é necessário que ele assuma a responsabilidade pela sua própria aprendizagem.

Ushioda (1996, p. 40) afirma que "sem motivação não há autonomia”. Essa associação entre motivação e autonomia também é apoiada por Spratt, Humpheys e Chan (2002). Os autores afirmam que discen- 
te motivados estão predispostos a ter mais autonomia no processo de aprendizagem.

Nas últimas décadas, a aprendizagem autônoma foi considerada crucial por várias razões, já que ela auxilia aprendentes a se tornarem alunos independentes. Por isso, se constitui uma meta educacional crucial (SMITH, 2008).

Como é possível verificar, a motivação é um aspecto muito relevante a ser investigado, pois pode afetar profundamente o processo de aprendizagem, permitindo que o aluno seja bem-sucedido e alcance seus objetivos. A autonomia permite que os alunos adquiram a experiência de serem autodeterminados em vez de serem controlados (LIU, 2015).

\section{METODOLOGIA}

Conforme mencionado anteriormente, os objetivos da pesquisa relatada neste artigo foram: a) identificar e explicar as atitudes dos participantes em relação à motivação; b) analisar como essas atitudes afetaram a decisão dos participantes de aprender inglês.

As questões de pesquisa que orientaram a pesquisa foram: a) quais são as atitudes dos participantes em relação à motivação? b) como essas atitudes afetaram a decisão dos participantes de aprender inglês?

Esta pesquisa foi realizada na perspectiva do paradigma qualitativo (SELIGER; SHOHAMY, 1989): os resultados foram analisados por meio de interpretação e comparação.

\subsection{CONTEXTO}

\subsubsection{Local e período}

A pesquisa foi realizada em curso de inglês durante o primeiro semestre de 2017.

\subsubsection{Participantes}

Os participantes são três alunos do terceiro e quarto nível. Os alunos foram escolhidos porque não têm a obrigação de terminar o curso, 
pois estão em um ponto em que poderiam ter desistido, mas não o fizeram. Por isso, este estudo busca investigar o porquê deles permanecem em sala de aula.

\subsection{INSTRUMENTOS E PROCEDIMENTOS DE PESQUISA}

\subsubsection{Questionário}

O questionário (BROWN; RODGERS, 2002), que foi administrado ao longo de quatro semanas, continha itens de resposta aberta (ver APÊNDICE). Esse visou conhecer as razões dos alunos para permanecer no curso e o modo como a motivação afetou suas decisões. Antes de serem administrados, os questionários foram refinados por um pesquisador e tradutor.

\section{ANÁLISE DE DADOS E DISCUSSÃO}

Esta seção está dividida em dois tópicos principais. No primeiro, são discutidas algumas razões que levaram os participantes da pesquisa a aprender inglês. Para analisar essas razões, este primeiro tópico foi organizado em duas subseções: motivação intrínseca e motivação extrínseca. No segundo tópico, são mostrados exemplos de fatores que promovem a motivação ao aprender inglês.

\subsection{RAZÕES PARA ESTUDAR INGLÊS EM UM CURSO DE LIINGUA}

\subsubsection{Motivação intrínseca}

Um aluno pode começar a estudar inglês devido a várias razões que podem desencadear um gatilho motivacional. Como afirma Lile (2002), os interesses podem ser suscitados por fatores internos ou externos. Considerando os questionários respondidos pelos participantes (estudantes de um curso de idiomas), um desses participantes, Anilatan, relatou que: 
[1] Anilatan: Eu ainda adolescente tentava cantar músicas oriundas do inglês, procurava por meio de dicionários a tradução das palavras. Certamente, a música foi a maior influência, foi uma força motriz para que eu procurasse aprender mais e mais. (Questionário)

Como é possível notar, Anilatan aprende inglês para satisfazer uma aspiração pessoal. Ela queria entender algo que era divertido para ela. A participante reconhece a música como um fator motivacional para aprender inglês e se mantém predisposta a continuar estudando. Da mesma forma que Anilatan, Engenheiro credita à música sua vontade de aprender inglês:

[2] Engenheiro: Desde a minha infầncia ouvindo música nesse idioma que foi muito bom e me levou a buscar conhecimento em livros, dentre outros. (Questionário)

De acordo com Dantas (2008), é possível observar uma reação em cadeia da ação que foi originada devido à motivação ativada, o que foi constatato nos dois trechos acima, ter algo - como música - como força interna levou o aluno a buscar conhecimento.

Como observado nos parágrafos anteriores, Lile (2002) e Dantas (2008) concordam sobre a existência da motivação intrínseca, bem como sobre seu papel e sua importância. O processo de aprendizagem não é estático e, às vezes, a motivação dos alunos simplesmente desaparece, deixando o aluno sem vontade. É por isso que a motivação intrínseca precisa ser preservada o máximo possível.

\subsubsection{Motivação extrínseca}

Além da motivação interna, Dantas (2008) descreve um segundo tipo de motivação: extrínseca. Isso ocorre quando há um fator externo como prêmio, como: ter sucesso em um teste ou a possibilidade de conseguir um emprego. Analisando os questionários, ao mencionar sua maior motivação para aprender, Lúcia afirma: 
[3] Lúcia: O mercado de trabalho, visto que ele está cada vez mais exigente e competitivo. (Questionário)

De acordo com a percepção de Lúcia, ter essa capacidade extra (falar inglês fluentemente) pode proporcionar uma oportunidade para alcançar uma boa ocupação. Esse fator é importante no contexto da globalização instaurado atualmente, já que muitas pessoas não conseguem o emprego que desejam porque não possuem habilidades suficientes para serem considerados capacitados. Lúcia acredita que conhecer o inglês é uma das maneiras de mudar essa realidade.

Como Dantas (2008), Brown (2007, p. 172) supõe que "a motivação externa é influenciada por algum tipo de incentivo externo, como dinheiro, prêmio, notas, feedback positivo". Nesse caso, o incentivo externo visto no discurso de Lúcia é a carreira profissional. Em relação à motivação intrínseca, essa também é significativa em um contexto de aprendizagem de um segundo idioma, visto que contribui positivamente para o desenvolvimento do aluno como um falante não-nativo bem-sucedido de inglês.

\subsection{MATERIAIS E FATORES QUE MOTIVAM O PROCESSO DE APRENDIZAGEM}

\subsubsection{Motivação e influência de materiais}

Conforme relatado por Anilatan e Engenheiro, os materiais utilizados pelo professor os incentivam a aprender. Livros e recursos audiovisuais, como apresentações em PowerPoint os ajudam a estudar. Por outro lado, Lúcia diz que sua professora usa apenas livros e, por isso, não se sente motivada.

Continuar estudando inglês não é uma tarefa fácil. Como o inglês e o idioma nativo, o português, são completamente diferentes, muitas pessoas que estudam o idioma estrangeiro em um curso de idiomas desistem de alcançar fluência. Por outro lado, existem algumas pessoas que possuem dificuldades extremas, mas continuam tentando. Nesse sentido, Dantas (2008) argumenta que a motivação é um desenvolvimento contínuo e não é seguro e estagnado, por isso, aluno precisa nutri-lo. 
Elementos como: jogos, vídeos e apresentações de slide em PowerPoint têm um papel considerável nesse mecanismo. Às vezes, esses elementos podem ser decisivos para garantir o envolvimento do aluno na sala de aula. Lúcia destaca que, fora da sala de aula, ela gosta de acessar sites, baixar aplicativos e ouvir música para continuar aprendendo inglês.

\subsubsection{Agentes relacionados à motivação do aluno}

Certamente, aprender um segundo idioma é uma prática cercada por muitos agentes que influenciam diretamente a percepção do aluno sobre seu processo cognitivo. Entre esses agentes, é possível citar: professor, família, amigos e colegas de classe.

Anilatan e Engenheiro acreditam que os professores de inglês os motivaram por meio da metodologia de ensino, confiança, estímulo e vontade de atingir o nível de fluência do professor. Por outro lado, Lúcia afirma que nunca se sentiu motivada por uma professora.

[4] Lúcia: Na realidade, minha maior motivação é para a minha carreira profissional e para me ajudar nas viagens para o exterior. (Questionário)

A motivação é motivada por aspirações e, para mantê-la existente, é preciso agir, estabelecer metas e alcançar um resultado (DANTAS, 2008). Lúcia estuda inglês porque é motivada por sua carreira profissional e por seu grande desejo de viajar para o exterior.

Como verificado, os participantes possuíam diferentes tipos de motivação: intrínseca e/ou extrínseca. As pessoas se relacionam com diferentes razões para aprender uma língua estrangeira, mas todas convergem para o mesmo objetivo: ter fluência na língua-alvo. Os materiais utilizados dentro e fora da sala de aula, bem como a interferência de agentes como professores, amigos e familiares também são elementos que influenciam o processo de aprendizagem.

Apesar da pouca quantidade de participantes, este estudo mostra resultados valiosos e cumpre com o objetivo de indicar a motivação como um fator de alta prioridade em um processo de aprendizagem 
de idiomas. Dito isto, ainda é necessário realizar pesquisas tendo como base um universo mais amplo.

\section{CONCLUSÃO}

A partir do estudo aqui exposto, conclui-se que o processo de aprendizagem autônoma pode ser realizado de inúmeras maneiras, porém, para que esse seja realmente eficaz, o aprendente, principal elemento e alvo deste processo, deve primeiramente sentir-se motivado e consciente de sua capacidade. Esse também precisa compreender que suas habilidades podem e devem ser aprimoradas na medida em que as etapas evoluem.

Ao longo deste estudo, foi observado que, embora os alunos possam encontrar dificuldades e desafios, o aprendente bem-sucedido insiste em aprender uma língua estrangeira e a encontrar estratégias para manter-se motivado.

Conforme explicado anteriormente neste artigo, a motivação é conhecida como um estado de alerta emocional e cognitivo que influencia constantemente os comportamentos dos discentes. Esse impulso interior impele o aluno a realizar suas aspirações. É importante mencionar que, para se motivar, é necessário estabelecer objetivos claros.

Os resultados observados nas respostas dos participantes ao questionário mostraram que os indivíduos têm experiências diferentes com o idioma-alvo. Alguns são movidos por razões emocionais, como a satisfação de entender uma música que costumavam ouvir, outros são movidos por motivos externos - um trabalho melhor, por exemplo.

Apesar de suas diferentes trajetórias, todos os participantes continuam a frequentar as aulas do curso de idiomas. Pode-se atribuir isso ao fato de que esses alunos ainda se mantêm motivados.

Portanto, chega-se à conclusão que mais pesquisas sobre esse assunto devem ser realizadas. Uma delas diz repeito às percepções dos alunos em relação à motivação. Isso poderia ajudar a entender melhor o impacto da motivação em estudantes de inglês.

Embora o fomento do aumento da motivação possa ser extremamente desafiador para professores de inglês como língua estrangeira, nutrir e manter a motivação é fundamental. De fato, motivar os alunos 
a se tornarem alunos mais independentes ao longo da vida deve ser o objetivo final dos professores de idiomas (LIU, 2015).

\section{REFERÊNCIAS}

BROWN, J. Teaching by principles: An interactive approach to language pedagogy. Englewoods Cliffs: Prentice Hall Regents, 2007.

BROWN, J.; RODGERS, T. Doing second language research. Oxford: Oxford University Press, 2002.

DANTAS, L. Gêneros textuais acadêmicos e ensino da língua inglesa: um caminho para a motivação e a autonomia. 2008. 174 f. Dissertação (Mestrado em Estudos Linguísticos) - Instituto de Letras e Comunicação, Universidade Federal do Pará, 2008.

DECI, E.; RYAN, R. Intrinsic Motivation and Self-Determination in Human Behavior. New York and London: Plenum Press, 1985.

DÖRNYEI, Z.; OTTO, I. Motivation in action: A process model of L2 motivation. Working papers in Applied Linguistics. Thames Valley University, London, v. 4, 1998. p.43-69. Disponível em: <http://eprints.nottingham.ac.uk/39 /0/Motivation in_action.pdf>. Acesso em: 20 de maio de 2019.

LILE, W. Motivation in the ESL Classroom. The Internet TESL Journal, v. 1, v. 8, 2002. Disponível em: <http://iteslj.org/Techniques/Lile-Motivation.html>. Acesso em: 15 de maio de 2019.

LIU, H. Learner Autonomy: The Role of Motivation in Foreign Language Learning. Journal of Language Teaching and Research, Londres, n. 6, v. 6, 2015, p. 1165-1174.

MASGORET, A.; GARDNER, R. Attitudes, motivation, and second language learning: A meta-analysis of studies conducted by Gardner and Associates. Language Learning, Michigan, n. 53, v. 1, p. 123-163, 2003. 
OXFORD, R.; SHEARIN, J. Language learning motivation: Expanding the theoretical framework. The Modern Language Journal, Hoboken, n. 78, v. 1, p. 12-28, 1994.

SELIGER, H.; SHOHAMY, E. Second language research methods. Oxford: Oxford University Press, 1989.

SMITH, R. Key concepts in ELT: Learner autonomy. ELT journal, Oxford, n. 62, v. 4, p. 395-397, 2008.

SPRATT, M.; HUMPHREYS, G.; CHEN, V. Autonomy and motivation: which comes first? Language Teaching Research, 2002.

USHIODA, E. Learner autonomy: The role of motivation. Dublin: Authentik, 1996.

Witter, G.; LOMONACO, J. Psicologia da Aprendizagem. São Paulo: Editora Pedagógica e Universitária Ltda., 1984. 


\author{
APÊNDICE \\ Universidade Federal do Pará \\ Instituto de Letras e Comunicação \\ Faculdade de Letras Estrangeiras Modernas
}

\title{
QUESTIONÁRIO
}

1. O que o levou a optar pelo curso de inglês?

2. Como foi seu primeiro contato com a língua inglesa? A maneira como esse contato ocorreu influência em sua aprendizagem?

3. Os materiais usados por seus professores motivam você?

Não ( )

$\operatorname{Sim}(\quad$ ) Cite exemplos desse materiais: 
4. Que recursos (ex. sites, aplicativos etc.) você geralmente usa para aprender inglês fora da sala de aula?

5. A atitude de algum professor de inglês já motivou você a aprender esse idioma? Quais atitudes? 


\section{EDUCAÇÃO EMOCIONAL: DIREITO SUBJETIVO QUE NECESSITA REFLEXÃO}

Ana Cristina dos Santos Siqueira

\section{INTRODUÇÃO}

A reflexão sobre o direto subjetivo à educação emocional de adolescentes, como um tema a ser desenvolvido e trabalhado na rotina escolar, considera como ponto de partida três estudos que tratam de encaminhamento de alunos ao serviço de saúde, por apresentarem comportamento indesejado nas aulas escolares, como por exemplo, manifestações de indisciplina, recusa realizar as atividades, atitude de contravenção e até desrespeito aos professores e demais adultos da escola, assim como com os colegas, se envolvendo constantemente em desentendimentos e brigas corporais.

Esses casos, foram encaminhados designados como alunos que apresentam dificuldade de aprendizagem, para o setor da saúde mental, com a solicitação de diagnósticos e atendimento especializado.

O primeiro estudo foi publicado em 2001, o segundo em 2004 e o último em 2015, e discursam sobre a conceituação e contextualização do termo "dificuldade de aprendizagem" para a fundamentação quanto a ineficácia do trato ao assunto, como sendo um fenômeno independente das interações escolares e um problema centrado no aluno.

Explicitando melhor, o estudo de 2001é um artigo publicado em revista acadêmica que relata sobre um projeto de atendimento paras 
escolas que encaminham alunos com queixas de comportamento indesejado e desinteresse nas atividades escolares, para avaliação e atendimento de psicoterapia. Após muita discussão interessante sobre o cenário em que se estabelece a relação professor aluno e as demandas de desenvolvimento da interação, do prazer e da criatividade, o artigo conclui com a alarmante análise quantitativa de que 66\% (2001, p. 134) dos encaminhamentos - ao longo do ano de 2000, em São Paulo - finalizaram o processo de avaliação sem a necessidade de intervenção da psicoterapia.

No segundo estudo em 2004, trata-se de dissertação de Programa de Mestrado, que aborda o termo "dificuldade de aprendizagem" à luz das produções científicas e literárias para ir afunilando os equívocos que se apresentam no senso comum e, também, debruça-se sobre situações nas quais o aluno não apresenta nenhuma necessidade educacional especial, porém apresenta o comportamento indesejado que gera a indisciplina, os desentendimentos e o desinteresse pelas atividades escolares. Neste caso, foram entrevistados 30 professores de uma mesma escola situada numa cidade do interior de São Paulo. Verificou-se que 50\% dos professores entrevistados associam o comportamento indesejado com o desinteresse do aluno (2004, p. 111) e $47 \%$ identificam que o problema apresentado é com os alunos do gênero masculino (2004, p. 136).

No terceiro estudo, publicado em 2015, trata-se de um artigo em revista acadêmica, que relata um projeto piloto, no Rio de Janeiro, em um semestre no ano de 2012. Dos 285 casos atendidos na triagem, do Instituto de Psiquiatria da Universidade federal do Rio de Janeiro, 92 "chegaram com alguma queixa referida a escola" (2015, p. 185). $\mathrm{E}$ as queixasse repetem, mesmo em cidade ou Estado diferente e em períodos diferentes, os relatos tratam do comportamento indesejado na escola e do desinteresse pelas atividades escolares. Neste caso, o que também se apresenta é o maior número de meninos em relação as meninas (p. 187).

As três produções, de formas diferentes, consideram que o processo de aprendizagem está para além da relação aluno X conteúdo escolar. É necessário considerar as inter-relações que se estabelecem 
entre professor aluno, no Setting da aprendizagem, as situações sociais e familiares que refletem no ambiente escolar e que o desenvolvimento de um sujeito imaginativo, criativo, disposto a interagir, compartilhar, trabalhar no coletivo, colaborativo, com empatia e segurança emocional é assunto da escola, pois o desenvolvimento de um sujeito pleno e competente para transformar e melhorar o meio em que vive é um objetivo estampado nas produções institucionais e legislação brasileira.

\section{A EDUCAÇÃO EMOCIONAL É ASSUNTO DA ESCOLA}

Diante desse cenário apresentado, é preciso considerar que a escola, com todos os seus defeitos e limitações, é o espaço de experimentação do saber e do conviver, onde propicia experimentar as atitudes cidadãs e a interação com as diferenças, envolvendo reflexão sobre respeito, tradição e humanidade.

No entanto, é passível de observação no cotidiano das aulas um alto empenho no desenvolvimento das habilidades cognitivas, sem considerar que um sujeito cognoscente também é formado por corpo, mente e espirito:

Talvez a ênfase da nossa cultura no pensamento abstrato e no raciocínio lógico rigoroso provoque um declínio na sensibilidade às propriedades estéticas, embora também seja possível que tal declínio preceda (ou até cause) uma mudança para modos de expressão e comunicação mais abstratos. De qualquer forma, vários estudos, inclusive o meu, documentaram a extensão em que o adolescente parece deficiente nas tarefas que requerem sensibilidade à nuança e a suspensão do pensamento abstrato (GARDNER, 1997, p. 265).

No Brasil, de acordo com a Lei de Diretrizes e Bases da Educação Nacional (1997), privilegia-se o conhecimento cognitivo, contudo o Relatório organizado por Delors (2001), indica os quatro pilares da educação Para o século XXI: "Saber Ser; Saber Conviver; Saber Fazer; Saber Aprender". O autor critica, no relatório, que 
Ajudar a transformar a interdependência real em solidariedade desejada, corresponde a uma das tarefas essenciais da educação. Deve, para isso, preparar cada indivíduo para se compreender a si mesmo e ao outro, através de um melhor conhecimento do mundo (DELORS, 2001, p. 47).

Delors considera que "a compreensão deste mundo passa, evidentemente, pela compreensão das relações que ligam o ser humano ao seu meio ambiente" (2001, p. 47). Porém, mesmo esse relatório ser referência em muitas pesquisas sobre a educação brasileira, deduz-se que sua ideia não foi ainda compreendida, pois procura-se desenvolver as habilidades do "Saber Ser" e do "Saber conviver" sobre a égide do estruturalismo (GLENDAY, 2009).

Para o saber ser e o saber conviver pressupõe-se o desenvolvimento emocional e as habilidades de reflexão e síntese das coisas que se sente, mas não se decodifica sem a experiência criativa. E, para tanto, faz-se necessária a inclusão de todos os sujeitos envolvidos na aprendizagem, assim como o sentimento de pertencimento no processo.

Nesse caso, os conteúdos curriculares do ensino da Arte, ou Educação Artística, na escola tem potencial para tornar-se um percurso facilitador desse desenvolvimento, no intuito de promoção de saúde emocional e a inclusão dos alunos, que não apresentam dificuldades de aprendizagem, nos termos regidos pela Educação Especial, mas que se recusam a participar produtivamente de um processo natural de aprendizagem escolar, provocando desacordos ou letargia, nos procedimentos naturais de aprendizagem.

E aqui, se afirma o processo natural de aprendizagem, porque de acordo com Morin:

A educação deve favorecer a aptidão da mente em formular e resolver problemas essenciais e, de forma correlata, estimular o uso total da inteligência geral. Este uso total pede o livre exercício da curiosidade, a faculdade mais expandida e a mais viva durante a infância e a adolescência, que com frequência a instrução extingue e que, ao contrário, se trata de estimular ou, caso esteja adormecida, de despertar. 
Dessa forma, é passível o entendimento que estar à postos diante de um processo de aprendizagem é um movimento natural nos adolescentes, público das produções científicas que dão base a esse artigo.

Silva, (2018), membro do Grupo de Estudos Edgar Morin, na Universidade Federal de Campina Grande, discursa sobre a necessidade de se praticar uma educação para o futuro, que tenha como premissa uma formação humana, embasada nas discussões dos tratados que fizeram surgir A Declaração dos Direitos Humanos (1948).

No caso do estudo publicado de Silva, o discurso é voltado para a formação profissional do Direito, contudo suas ponderações podem ser refletidas nas ações pedagógicas da educação básica, pois os três estudos apresentados no início pontuam a necessidade de ver o aluno como um todo e no contexto complexo, que compõe o individual, o social e escolar.

A humanização do Direito poderá ocorrer através das artes, isso é, através da reconexão de saberes proposta pela transdisciplinaridade. As artes são o reflexo do humano, pois, por meio delas, o ser humano apresenta a condição humana, a complexidade, o cotidiano, os sentimentos e constrói o conhecimento aceca do passado ou do futuro. Ensinar a condição humana e compreender sua influência no processo de construção das normas, como observado nos Direitos Humanos, pode auxiliar nesse processo de humanização. (SILVA, 2018, p. 20)

Assim sendo, cabe o entendimento de que, por meio da arte se promove a inclusão. Sem perder de vista o termo inclusão numa amplitude, que vai além de se ter necessidades educacionais especiais, mas abarcando, nesse sentido amplo do termo inclusão, os alunos na faixa-etária dos 11 aos 15 anos, ou seja, alunos que cursam o ensino fundamental, nos anos finais desta etapa, e que passam pelo natural movimento de transição da infância para a fase adolescente e que apresentam comportamentos contrários ao comportamento necessário para a aprendizagem escolar.

O período da adolescência tem um peso fundamental na determinação de um futuro bem-sucedido ou cheio de obstáculos. 
O significado específico desta fase da vida está, basicamente, na dependência de duas vertentes: a) variações sociais relacionadas ao contexto sócio histórico; b) experiências com pessoas significativas (GÜNTHER, 1993).

A autora citada discorre sobre a necessidade de a escola atentar para a saúde emocional dos adolescentes e, pelo sentimento de concordância a ela, foi decidido tratar desta faixa-etária, neste artigo, no sentido de abordar sobre a saúde emocional dos alunos, como meio de superação nas que se apresentam na rotina escolar, auxiliando a sua inclusão nas atividades e visto como um sujeito de direito à proteção e orientação, assim como o pleno desenvolvimento humano, considerando seu corpo físico, seu intelecto e seu emocional, atendendo aos pressupostos dos direitos humanos.

Essas dificuldades, observadas nas atitudes de recusa do aprender, na resistência apresentada por meninos e meninas que, comumente são rotulados de "não quer fazer nada", nem sempre está ligado à deficiência ou a transtornos, porém, na maioria das vezes está relacionado aos problemas emocionais como, por exemplo, baixa estima, falta de sentimento de pertencimento ou, até mesmo, falta de compreensão do conteúdo diante da metodologia escolhida pelo professor.

No estudo de Osti (apud: TOREZAN, 1993) é apontado que “os professores buscam solucionar os problemas de aprendizagem encaminhando o aluno para atendimento específico, ou orientando os pais, mas não na alteração de sua prática em sala de aula nem na reflexão de sua postura pedagógica" (2004, p. 89). Essa ideia vem promover o estímulo em trazer a discussão em torno das dificuldades de relacionamento com os processos de aprendizagem, considerando os(as) alunos(as) que apresentam alguma resistência em atender aos anseios de seus professores, logo na fase de transição da infância para a adolescência, que equivale ao $6^{\circ}$ ano do ensino fundamental, na educação básica brasileira.

As considerações dos autores, até o momento, permitiram a compreensão que por meio da arte é possível desenvolver as várias habilidades humanas e sociais, entre estas as emocionais, porque o ensino da arte na escola é visto como um grupo de conteúdo específico para 
a decodificação das linguagens artísticas e a compreensão da comunicação não verbal.

Nesse sentido, Barbosa e Cunha organizaram uma coletânea de teóricos que tratam sobre "o ensino das artes", na qual Rita Bredariolli comenta:

A alfabetização defendida por Ana Mae Barbosa - sem acaso, familiar a de Paulo Freire - se realiza pelo exercício de "leitura" como análise crítica articulada no contexto. Esse seria o caminho para o exercício e desenvolvimento de um "olhar ativo" (apud BOSI, 2002, p.66) sobre o mundo e para as imagens que o constituem. Nesse sentido o aluno é considerado leitor, intérprete e autor. (BABOSA, CUNHA, in: BREDARIOLLI, 2010, p. 35)

Ela apresenta, em seu texto, o histórico do ensino da Arte, a partir das concepções e abordagens de Ana Mae Barbosa, personalidade expoente no Brasil que dedicou sua carreira em pesquisa sobre arte-educação.

\section{BREVE HISTÓRICO DO ENSINO DA ARTE NA ESCOLA}

Barbosa (1978) faz crítica sobre a entrada da arte no Brasil ter sido com o status de supérfluo, ou seja, só pode interessar a quem tem tempo para dispor, porque não necessita prover seu próprio sustento, ou para a formação das jovens, com intuito de conseguir bom casamento. E, mesmo com suas obras influenciando a demanda de pesquisa sobre o ensino do componente curricular Educação Artística ou Arte, na educação básica, nos últimos 20 anos, o tratamento da linguagem e a comunicação foi compreendida sem a preocupação em inter-relacionar as ideias, as pessoas e os pontos de vista na criação de um objeto artístico, haja vista a formação inicial do professor da Educação Básica, na licenciatura em Arte no Brasil, ser totalmente voltada para a especialização em uma linguagem artística, constituindo uma ideia elitizada e antiga, em que só se interessa por arte o pretendente artista com talento inato. 
Aparentemente, essa raiz cultural persiste, pois, esse componente curricular é um dos que são ministrados com o número de duas aulas semanais, em São Paulo/BR. Sem comentar que constantemente é cogitado não ser imprescindível à formação do sujeito.

Diante desse histórico, o ensino da arte não é explorado como facilitador da inclusão e do sentimento de pertencimento dos alunos à rotina das atividades escolares, nem como conhecimento e saúde emocional, auxiliando o desenvolvimento cognitivo e as habilidades não cognitivas, para a formação do sujeito "Planetário" como defende Morin (2000), capaz de promover atitudes cidadãs ao meio em que vive.

Nas reflexões de Gardner (1994), sobre o desenvolvimento de habilidades artísticas, considera que

Falando de modo bastante geral, o desenvolvimento artístico envolve a educação dos sistemas de fazer, perceber e sentir; o indivíduo se torna capaz de participar do processo artístico, de manipular, compreender e relacionar-se com os meios simbólicos de maneiras especificáveis (p. 286).

No seu discorrer, traz a compreensão da possível relação entre a criatividade empenhada na produção artística e a criatividade necessária para as decisões e encaminhamentos em qualquer outra atividade profissional, pois não importa o caso, todos precisamos dominar o meio em que estamos inseridos, no sentido de compreender, absorver e reverter em ação criativa, que o transforma e comunica com os demais sujeitos envolvidos neste meio.

Assim sendo, os autores trazidos para a composição da ideia a ser apresentada corroboram com o entendimento de que a escola é um conceito muito mais profundo do que um espaço físico. Ela é um lugar, onde se pode vivenciar, experienciar e se relacionar com os seus iguais, enquanto espécie, e com os seus diferentes, enquanto concepções.

Esse lugar, transpõe conceitualmente o espaço/tempo explicado pela física. Parece que a escola nos transporta para um tempo/espaço próprio, construído coletivamente, orgânico, portanto mutável, adaptável às novas realidades que se apresentam neste lugar. 
Por mais que se reconheça a sua estrutura, ao longo da história, assim como as situações que se reproduzem de forma igual, porém com sujeitos diferentes, cada lugar/escola tem sua singularidade, pois as relações que se estabelecem lá é como se fossem digitais, ou seja, são ímpares e inigualáveis.

Essa construção coletiva do lugar/escola inevitavelmente implica no desenvolvimento da relação afetiva, de cada sujeito implicado no lugar. E a maneira que se vivencia essa relação afetiva e emocional pode determinar a relação com o bairro, a cidade, o país; nos seus diversos papeis a ser desempenhado na fase adulta dos meninos e meninas que passam pela escola.

Então, se Delors (2001) organizou a construção de uma ideia de sujeito capaz de transformar o meio onde vive e ser produtor de sua própria história, formado pela escola, isto significa que a saúde emocional desse sujeito também é assunto da escola.

\section{A EXPERIENNCIA DOS SENTIDOS}

Por essa linha, se quer discutir, com base em estudos que versam sobre o trabalho empenhado na saúde emocional dos alunos, em período escolar, a importância de abrangermos as competências, que vão para além do cognitivo, no sentido, até mesmo, de fortalecer o sujeito cognoscente e diminuir as atitudes de violência nesse lugar/escola.

Pressupõe-se, como hipótese, que os conteúdos relacionados aos processos de criação artística, além de envolver a experiência emocional e a percepção de si e do outro, torna significativo a relação da arte como representação da realidade e inclui a todos num processo coletivo, sem desmerecer as individualidades.

Os processos de criação artística, seja visual, corporal ou musical acionam sistemas cerebrais, em ambos hemisférios, promovendo experiências cognitivas e emocionais simultaneamente (ZAIDEL, 2016). Não é à toa, que a arte se tornou meio para terapia, na busca do autoconhecimento, trazendo para a contemporaneidade um outro espectro de visão, com o surgimento da Arteterapia.

Não se pretende fazer terapia com os alunos e alunas, nem com os professores, mas se pretende refletir sobre os conhecimentos que 
fundamentam os diversos campos no espectro da arte, para defender a importância de abordar metodologias que propiciam a promoção da saúde emocional nas escolas.

Da mesma forma, a educação básica não tem a pretensão de formar artistas, ou matemáticos, ou cientistas, contudo tem como premissa desenvolver sujeitos capazes de fazer escolhas e de construir os caminhos necessários para atingir os objetivos pessoais, o que culmina na apresentação dos profissionais, na sociedade.

Viégas (2015) nos apresenta em seu artigo os percentuais promissores de alunos aprovados no ensino fundamental em 2011, no Estado de São Paulo, contudo o Índice de Desenvolvimento da Educação Básica (IDEB) divulgou que menos de 50\% desses alunos não apresentaram bom aproveitamento nas avaliações de Língua Portuguesa e Matemática na Prova Brasil, no mesmo ano. O seu estudo trata de uma discussão sobre a progressão continuada, implantada por meio de legislação nacional que visa o aproveitamento dos alunos, no seu desenvolvimento da leitura, escrita e raciocínio lógico em ciclos. Contudo, apresenta a entrevista que realizou com professores que relatam ter alunos com dificuldade de aprendizagem, devido ao comportamento inadequado e a necessidade de acompanhamento psicológico (p. 155156). Desta forma foi fácil encontrar ressonância do estudo de Viégas com este proposto.

Estão surgindo novos paradigmas sobre aprendizagem, aluno e escola. E, demandas de produção científica estão contribuindo para que as discussões cheguem aos diversos "universos" escolares no planeta Terra.

Encontra-se no estudo de Faria (2019), da Universidade do Porto, o seu olhar sobre a Escola da Ponte, que é trazido aqui como um exemplo de mudança do pensamento sobre aprendizagem, aluno e escola.

No discurso apresentado por Faria contém a história do surgimento da Escola da Ponte e suas concepções, em que ele brilhantemente resume como:

A Escola da Ponte baseia-se então no pressuposto de que o conhecimento adquire-se pelo fazer e pela utilidade dada à práti$\mathrm{ca}$, facilitando proximidades às necessidades individuais e pos- 
sibilitando que a criança construa os seus próprios significados, baseados nos seus interesses, capacidades e no seu trajeto único de aprendizagem. (p. 25)

Desta forma, nem é preciso citar partes do seu discurso que discorre sobre o sujeito ser construtor do seu próprio conhecimento, quando se envolve nos processos que aguçam o seu interesse, fazendo sentir-se pertencente a um processo de construção de saberes, que lhe desenvolve potenciais pessoais e como se auto percebe em desenvolvimento com os seus pares, bem como nem é preciso conduzir a relação que tudo isto tem com a ideia do Morin (2000) sobre a curiosidade ser inerente a criança e ao adolescente, pois estas ideias, apesar de distintas em sua origem e com diferença de dezenove anos, são intrínsecas e em transdiplinaridade.

Outro exemplo que se encaixa nessa discussão é Caldas \& Vasques, que apresentam suas reflexões no decorrer do Projeto-Piloto de Educação Artística, para um Currículo de excelência (Clube UNES$\mathrm{CO}$ ), em uma escola de Lisboa. Dentre as muitas reflexões destaca-se “a Expressão Dramática compromete a totalidade do indivíduo, conduzindo-o à descoberta de si, na interação consigo, com os outros e com o meio" (2014, p. 34).

Santos (2008), construiu ensaios sobre o ensino da arte na escola, publicados pela Fundação Calouste Gulbenkian, e logo no início do seu primeiro ensaio encontra-se:

Conhecida a influência que a afectividade desempenha no desenvolvimento da criança e do adolescente, e sendo as manifestações artísticas aquelas que mais se inserem, compreende-se a atenção que as reformas do ensino dedicam à esfera da Arte. É que, além do mais, múltiplas são de facto as funções da arte no harmonioso desenvolvimento da personalidade infanto-juvenil, e, na opinião de Piaget, se na vida da criança há duas necessidades essenciais que são, por um lado, a adaptação à realidade material e social, e, por outro, o conjunto das realidades individuais que se exprimem pelos jogos simbólicos, a arte, na criança, seria um esforço de conciliação entre essas duas neces- 
sidades, como uma síntese entre expressão do eu e as formas de atividades adequadas (p. 19).

Damásio (2010), explica por meio da neurociência como se processa a construção da consciência humana. Apesar de ser um conteúdo, numa locução que se distancia das Ciências da Educação, ou melhor, encontra-se presente nos fenômenos da aprendizagem, porém vem de uma linguagem que precisa ser traduzida, foi encontrada ressonância com as considerações desse projeto, quando menciona que

A arquitetura neural que permite os qualia fornece ao cérebro percepções sentidas, uma sensação de experiência pura. Quando a este processo se junta um protagonista ao processo, a experiência é clamada pelo seu recém-criado dono, o eu (p. 324).

O autor explica que o termo qualia é utilizado na neurociência para organizar os problemas as serem tratados nas pesquisas e na construção do discurso do conhecimento. Da mesma forma que as Ciências da Educação são repletas de termos específicos, que constituem uma linguagem própria, as outras ciências também os têm, contudo são olhares diferentes para solucionar problemas e melhorar o cotidiano humano, isto é que se têm em comum.

Como os problemas de aprendizagem, em diversos níveis e categorias, afeta o cotidiano humano, como a exemplo dos primeiros estudos apresentados, em diferentes cidades do sudeste brasileiros, é plausível que o fenômeno seja abordado por diferentes olhares das Ciências.

Entretanto, até o momento, o que se pretendeu apresentar aqui foram as produções científicas que defendem a abordagem dos sentidos, para o acesso ao eu e, assim, desenvolver as potencialidades geradoras da paz, da criatividade a favor da melhoria para si e todos que convivem no mesmo ambiente, seja ele a casa, o bairro, o país ou o planeta.

Como já foi citado, nos documentos brasileiros sobre os pressupostos e objetivos da educação, a formação de um sujeito competente, para transformar o meio em que vive, ser construtor do seu próprio conhecimento e da sua própria história, e assunto de escola. 


\section{CONSIDERAÇÕES FINAIS}

Nas práticas desenvolvidas, que visam os desempenhos escolares, tem um pensamento pedagógico de não considerar o bem-estar, a felicidade e a criatividade no desenrolar dos processos de aprendizagem, tratando o processo com mercantilismo, ou seja, uma negociação que vai driblando os comportamentos indesejados, sem se preocupar em encantar quem não está encontrando sentido.

É direito subjetivo do sujeito em formação passar por experiências saudáveis que o conecte com suas sensações, emoções e que o ajude a encontrar sentido na experiência e na construção do conhecimento nos processos escolares.

A escola é um lugar que tem potencial para promover essas experiências que trazem consciência corporal, espacial e de sua existência enquanto sujeito; o reconhecimento do outro como sujeito; o sentimento de pertencimento, que vai da atividade escolar até a espécie humana; o desenvolvimento dos sentidos e o amadurecimento emocional. Nela, podemos experimentar o lugar dos outros, para compreender o nosso, igual a experiência que temos ao ouvir um conto de fadas.

Os alunos, os professores, a gestão, os funcionários, todos estabelecem uma ligação afetiva com o espaço escolar. Uns acham que não há outro lugar, como a escola, que os faça bem. Outros estabelecem uma relação conflituosa com aquele espaço físico. O que importa é que enquanto houver a presença, ou seja, a disponibilidade em vivenciar o nível de afetividade estabelecida com a escola, haverá a possibilidade de se construir uma relação afetiva proveitosa e libertadora, ou ressignificar esse afeto para o mesmo objetivo de aproveitar e libertar.

O ambiente escolar é construído por relacionamento humano, por ações e ruído humano. Não é mais possível desconsiderarmos o aluno que se recusa a aprender e a realizar as tarefas escolares, pois desta forma lhe tiramos o direito de descobrir suas próprias potencialidades e os benefícios que elas podem trazer para o meio ao qual pertence e a si próprio.

O pensamento ético, o protagonismo e a competência para ser o autor da própria história precisa ter como princípio o senso de auto- 
preservação e o pertencimento ativo, com autonomia para transformar a sua realidade e buscar os conhecimentos necessários para melhorar o cotidiano de si e dos que convivem com sigo.

Dessa forma, o desenvolvimento de um sujeito pleno, que considera habilidade cognitivas e socioemocionais, precisa, efetivamente, entrar nas discussões pedagógicas e culminar em novas abordagens que garantam o direito de todos os participantes no processo ensino/ aprendizagem. E, neste caso, por meio da arte pode-se construir um ambiente acolhedor e inclusivo, transformador dos comportamentos contrários à aprendizagem.

\section{REFERENCIAL TEÓRICO}

BARBOSA, Ana Mae Tavares Bastos; DA CUNHA, Fernanda Pereira. A abordagem triangular no ensino das artes e culturas visuais. Cortez Editora, 2010.

BARBOSA, A. M. Arte-Educação no Brasil: das origens ao Modernismo. São Paulo: Perspectiva, 1978.

BRASIL/MEC. Lei de Diretrizes e Bases da Educação Nacional. Brasil, 1997.

CARNEIRO, C; COUTINHO, L G. Infância e adolescência: como chegam as queixas escolares à saúde mental? Educar em Revista, Curitiba, Brasil, n. 56, p. 181-192, abr./jun. Editora UFPR, Rio de Janeiro, 2015.

DELORS, J., CHUNG, F., GEREMEK, B., GORHAM, W., KORNHAUSER, A., MANLEY, M., ... \& SURHR, M. W. Relatório para a UNESCO da Comissão Internacional sobre Educação para o século XXI. Educação um tesouro a descobrir, 6, 1996.

FELLER, C.C. (vários autores). Orientação à queixa escolar. Psicologia em estudo, v. 6, n. 2, p. 129-134, jul./dez. Maringá, 2001.

FARIA, Diogo Ludgero Almeida. Da Linha e da Trama: A produção do sujeito autónomo, o projeto e a economia dos sentidos 
nos grupos de artes da Escola da Ponte. Dissertação: U.PORTO, 2019.

GLENDAY, Candice. A Linguística de Chomsky em contraposição ao Estruturalismo e ao Behaviorismo. Inter Sience Place, revista cientifica internacional, indexada ISSN 1679-9844, D.O.I. 106020, ano 2, no 8, 2009.

GARDNER, Howard. As artes e o desenvolvimento humano: um estudo psicológico artístico. Trad.: Maria Adriana Veríssimo Veronese. Porto Alegre: Artes Médicas, 1997.

MORIN, E. Os setes saberes necessários à educação do futuro. São Paulo: Cortez Editora, 2000.

OSTI, Andréia. As dificuldades de aprendizagem na concepção do professor. Unicamp, Campinas, SP, 2004.

OSTROWER, F. Universos da Arte. Ed. Campus, 24를 ed. Rio de Janeiro, 2004.

DA SILVA, Camilla Isabely Gomes. A EDUCAÇÃO DO FUTURO: O DIREITO. LEOPOLDIANUM, v. 44, n. 123, p. 19, 2018.

ZEIDEL, D, W. Neuropsychology of Art: Neurological, Cognitive, and Evolutionary Perspectives. Second edition. Los Angeles: Routledge, 2007.

http://repositorio.unicamp.br/bitstream/REPOSIP/253593/1/Osti_ Andreia_M.pdf Acesso em 20 nov. 2019.

http://repositorio.unicamp.br/jspui/handle/REPOSIP/253593

GUNTHER, Isolda de Araújo. As necessidades emocionais do adolescente e a escola. Disponível em:

http://pepsic.bvsalud.org/scielo.php?script=sci_arttext\&pid=S1413-389X1993000100007 Acesso em 20 nov. 2019

VIÉGAS, Lygia de Souza. Progressão Continuada e Patologização da Educação: um debate necessário. Psicol. 
Esc. Educ. vol.19 no.1 Maringá Jan./Apr. 2015. On-line version ISSN 2175-3539. Disponível em http:// www.scielo.br/scielo.php? script $=$ sci_arttext\&pid=S1413-85572015000100153 Acesso em 20 nov. 2019.

1 으 estudo

FRELlER, C. C., SOUZA, B. D. P., ANGELUCCI, C. B., BONADIO, A. N., DIAS, A. C., LINS, F. R. S., MACÊDO, T. E. C. R. D. (2001). Orientação à queixa escolar. Psicologia em Estudo, 6(2), 129-134.

2ㅇ estudo

OSTI, A. M. (2004). As dificuldades de aprendizagem na concepção do professor. Dissertação de Mestrado. Disponível em: http://repositorio. unicamp.br/jspui/handle/REPOSIP/253593. Acesso em 20 nov. 2020.

3으 estudo

CARNEIRO, C., COUTINHO, L. G. (2015). Infância e adolescência: como chegam as queixas escolares à saúde mental? Educar em Revista, (56), 181-192. 


\section{A EDUCAÇÃO DE DIREITOS HUMANOS ORIUNDA DA ESCOLA: O BERÇO PARA A LUTA CONTRA DESIGUALDADES}

Genivaldo dos Santos

José Fernando Lima de Oliveira

\section{INTRODUÇÃO}

Os tempos atuais revelam uma sociedade imersa numa cultura dos valores líquidos, onde tudo que é valorizado, não oferece potencialidades ou mesmo condições consideradas dignas para os indivíduos, com vistas muito aquém do que poderia e, neste sentido, grupos sociais tem enfrentado dificuldades, seja por sua condição étnica, financeira ou mesmo sexual. O ferimento aos direitos humanos ocorrido todos dias, deflagra toda sorte de situações nos quais o desrespeito a condição humana dos indivíduos é deixada a margem, configurando-se numa problemática que vivemos no passado, que estamos enfrentando no presente e não deixaremos de lidar no futuro. Entretanto, na mesma medida em que está problemática emerge diante de nós nas mais variadas situações, nos cabe refletir em estratégias para promoção dos direitos humanos e valorização da vida.

Em diversas situações do dia a dia ocorrem problemáticas de desrespeito aos direitos, cujos exemplos não raras vezes são registrados ao redor do mundo, sejam em estádios de futebol onde atletas são discriminados em função de seu tom de pele, perdendo por assim dizer 
seu valor, sejam em situações em que a indignidade humana atinge ao status de coisificação diante a negligência de crianças, ao atentado a liberdade de expressão, aos conflitos ambientais e ao cerceamento e tabu aos debates de orientação sexual.

A ONU tem enxergado que estas situações são como doenças sociais que atingem a humanidade de hoje e várias são as vítimas do ódio e da intolerância diante dos quais o poder da democracia tem sido, paulatinamente, minado e as minorias tem sido intensamente vulnerabilizadas. Por certo, os equipamentos sociais que são considerados fecundos de possibilidades de transformações não tem dado conta de empreender os debates necessários ainda na formação da básica dos indivíduos. A escola, por sua vez, age de maneira assaz negligente ao escapar às seus papéis responsabilidades sociais no que tange a trabalhar as reflexões sobre a problemática, com efeito, os direitos humanos que são prerrogativas que efetivam os demais direitos em sociedade não tem atingindo os seus objetivos.

Por certo, a ferramenta da educação se constitui como porta de entrada para acesso aos demais direitos inerentes à condição humana, tendo assim um dever moral, estético e social, sendo neste sentido um processo de socialização ou humanização que parte do princípio em urgente necessidade que todos os seres humanos tem absolutos pesos de valor, com fins incondicionais. Assim sendo, a educação não possui preço ou equivalente, sendo um dos mais valoráveis processos de conquista da dignidade pelos seres humanos. (Rodrigues, Nozu e Neto, 2019)

Nota-se com esta concepção, que a educação em direitos humanos e sua condição inalienável, por vezes, não tem ido além da letra morta escrita nos documentos legais ao ser posta a margem da atuação escolar, deixando de ganhar vida nos discursos e pensamentos como de fato o deveriam. Por certo, ainda acreditamos que a proposta de uma educação libertadora que transforma as condições sociais e diminui as desigualdades, não se esquece de seus objetivos e tarefas, pelo contrário, logram êxito dia a dia em se papel de promover os direitos humanos.

Sem duvidas, há o consenso entre os estudiosos dos direitos humanos, qual entendimento impera que para eles, acaba por ser funda- 
mentais para a existência do mundo e das pessoas, permitindo para o desenvolvimento pleno e participativo da vida em sociedade. Ressaltam eles que para todo e qualquer ser humano deve ser asseguradas as condições fundamentais que permitam a interação útil em sociedade e a capacidade de poder receber benefícios que deles sejam necessários e para que eles mesmos possam fazer usufruto. Compreendem ainda que os direitos humanos são um coletivo de condições primordiais que ensejam e possibilidades, associando assim características naturais de todos os seres humanos com o resultado da organização justa posta as necessidades de uma vida em sociedade com qualidade e equanimidade.

Neste sentindo, atualmente muitas são as questões levantadas pelos pesquisadores sobre o tema e buscando dar conta disto, Schiling (2014):

Uma primeira questão a ser debatida: se a sociedade é desigual e injusta, é possível sequer imaginar uma escola igualitária e justa? seria possível imaginar que as funções da escola, de integração, distribuição e subjetivação, não reproduzissem cega e mecanicamente os preconceitos, a pobreza e a injustiça da sociedade em geral? indo além: o que acontece hoje com as escolas, vistas por muitos analistas como perdendo sua centralidade em relação a estas funções, vivendo, assim, como outras instituições centrais da modernidade, situação de crise? a escola, como meio de confinamento central (quando universalizada), que, ao definir e inventar um lugar - a infância e a adolescência -, com seus tempos específicos de preparação (aposta no futuro), de modelagem dos imaturos em um meio separado dos adultos, ao concentrar, distribuir no espaço, com sua ordenação específica do tempo, com sua forma tão peculiar, com suas disciplinas/ disciplina, tão eficazes em meio alguns momentos históricos na produção dos homens e mulheres necessários para uma sociedade, estaria passando por crise de seus modelos, parecendo hesitante, perdendo funções. Que lugar a escola pode ocupar, na sua tarefa de reprodução da sociedade (tal como 
é), quando esta sociedade parece revolucionar-se novamente, mudar seus regimes de controle social e de produção dos sujeitos? (p. 5)

Conforme os questionamentos postos acima, a escola como espaço produtor de modos de ser e estar em sociedade teria, nestes tempos presentes, estado espelhando as problemáticas oriundas dos contatos sociais que emergem dos processos e mecanismos subjacentes às desigualdades inerentes às configurações dos grupos que circundam a escola. A escola ainda é ainda observada como perdendo o poder central de trabalhar estas problemáticas, cuja crise de função também reverbera sobre os diretos humanos. Entretanto, para o que defendemos aqui, a escola não pode se eximir destas responsabilidade, lançando mão do seu potencial de mudanças, ao contrário, deve ir ao encontro de todas as possibilidades que permitam a recuperação deste poder em prol da promoção desta potencialidade. Cabe salientar que importa também, primordialmente, empoderar os atores sociais envolvidos nesta situação, sejam os professores, gestores pedagógicos, sem se esquecer do destino final deste processo, os alunos, quanto as políticas públicas e os direitos humanos fundamentais.

Portanto, importa assinalar que, não obstante, não falamos apenas e tão somente no direito humano à educação, vamos além disso, isto é, no direito de todos há a necessidade de conhecimento produzido historicamente, mas também na educação em direitos humanos, pressupondo assim que, ao exercer uma vida digna ativamente, todos necessitam passar por um processo educativo, crítico e reflexivo de que são, sim, sujeitos de direitos inalienáveis: direitos humanos, universais e indispensáveis, pelos quais todos precisamos lutar no cotidiano.

Por fim, baseados nas análises realizadas, observando ainda as pesquisas empreendidas pelos autores que dialogamos mediante este estudo, compreendemos que a escola, apesar de todas problemáticas que até este tempo são postas na atualidade, ainda é espaço circunstancial para o florescimento e maturação conceitual acerca de direitos humanos. Destarte, por meio deste salutar espaço é que se funda saberes, conceitos e discussões necessários para uma justa cidadania. 


\section{DESENVOLVIMENTO}

A educação é compreendida como um direito inalienável de todo indivíduo, posto que faz parte constituinte da condição humana, neste sentido o direito e todas as possibilidades que lhe são inerentes, não podem se distanciar, se desagregar das potencialidades sociais. Dada a sua natureza, a discussão em torno da problemática traduz questões inerentes ao valor da vida,

[...] inclusive do direito à educação inclusiva e a diversidade, setores historicamente prejudicados, sobretudo nos países e coletividades não democráticos e/ou de democracias tardias e não consolidadas”. (Xavier, Vasconcelos \& Xavier, 2018, p. 24)

Neste sentido, a educação como direito fundamental humano vai muito além dos pensamentos que, a priori, povoam o discurso social, se consistindo como importante ferramenta para exercício de outros possibilidades. Segundo vários pesquisadores, é normativa que regula igualdade de condições posto que:

Dessa forma, a educação é, verdadeiramente, um direito humano, que, através do processo de educar em direitos humanos, humaniza e contribui para o exercício da cidadania. Isso porque a cidadania é entendida como "um conjunto de direitos que dá à pessoa a possibilidade de participar ativamente da vida e do governo de seu povo. Quem não tem cidadania está marginalizado ou excluído da vida social e da tomada de decisões, ficando numa posição de inferioridade dentro do grupo social. (Rodrigues, Nozu e Neto, 2019, p.178)

Outrossim, a prática da promoção aos direitos humanos na escola abriria portas para compressão, tolerância e ao fortalecimento de laços entre grupos sociais ou até mesmo nações, funcionando em conjunto as ações das nações unidas. Assim, esta instrução tem fins a ser orientada, a priori, no ensejo do exercício pleno do desenvolvimento das potencialidades humanas e, principalmente, no sentido da estruturação e 
a dignidade aos direitos do ser humano, cujas liberdades fundamentais dão maior vazão a vida. Por outro lado, a educação em diretos humanos tem se fortalecido como uma ferramenta para a redemocratização, contribuindo com ações de instrução e promoção. Neste sentido, a educação, mediante as escolas, assume salutar missão ao se apresentar como ferramenta por excelência para este fim, contudo:

[...] existem muitas leis, normas, diretrizes e convenções nacionais e internacionais que sustentam e preceituam a educação em sua totalidade como fator preponderante para o desenvolvimento tecnológico, pacífico e humanístico da sociedade em suas diferentes e diversas formas de sobrevivência. (Xavier, Vasconcelos \& Xavier, 2018, p. 27)

Dito de outra forma, importa considerar que, em sua égide primordial, a educação para além dos direitos humanos possibilita a apreensão de valores inacessíveis por outros formas. Segundo autores (Rodrigues, Nozu e Neto, 2019):

[...] a educação é um instrumento de aprendizagem e aperfeiçoamento dos conhecimentos transmitidos por outros sujeitos. Enfatiza que a inteligência e memória ganham melhores contornos, a individualização do sujeito é aprimorada, propiciando a preparação para a vida. Finaliza dizendo que "a educação torna possível a associação da razão com os sentimentos, propiciando o aperfeiçoamento espiritual das pessoas. (p.176)

Segundo pesquisas (Carapeto Ferreira, 2017), essa é forma pela qual podemos compreender a constituição da vida humana, que mediante a educação, entendida a luz do direito social, se desenvolve, como ser liberto, emancipado, e sobretudo lúcido, no sentido de sua formação e integral realização humana, enquanto humaniza a sociedade. Destarte, torna-se clarividente entender que a educação, num olhar macro, através de suas demais modalidades, faz parte contextual das presciências contidas da declaração universal dos direitos humanos. Por certo, nos cabe ainda indagar como a escolarização poderia con- 
tribuir para tal. A resposta para esta questão pode estar um pouco atrás, assim voltemos um passo na história para que possamos avançar dois adiante no discurso ao lembra que a lei 9.394/1996, de 20 de dezembro de 1996 ao assinalar no seu artigo $2^{\circ}$ que a educação é uma responsabilidade e dever da família e do estado, cuja inspiração bebe nas fontes dos princípios basilares da liberdade e nos ideais humanos de solidariedade humana, age por fim tendo vista o pleno desenvolvimento do educando, por conseguinte, seu preparo para a prática da cidadania e sua qualificação para o trabalho. Do mesmo modo, o plano nacional de educação em direitos humanos - PNEDH prevê a articulação das dissensões de apreensão de conhecimentos historicamente construídos, a afirmação de práticas, valores e e atitudes sociais, a formação da consciência cidadã, desenvolvimento de processos metodológicos participativos e o fortalecimento de individuais e sociais, sendo todos nestes a educação o fator de promoção privilegiado. com Assim sendo, a pavimentação para a estrada na orientação quanto a estes princípios se funda nos anos da escolarização básica, sendo a escola o seu berço.

Ainda assim, custa lembrar que pontos significativos dos documentos norteadores de toda a discussão merece contextualização em conformidade com os temos de hoje, logo:

Para iniciar essa reflexão, segundo a qual a escola deverá incluir nos seus objetivos a convivência pacífica entre todos os seus personagens, pautada em relações de valorização do outro, de respeito e de equidade, é preciso que se destaque um documento que foi elaborado em 1948, cujas prerrogativas ainda se mantêm válidas, atuais e desafiadoras. Trata-se da declaração universal dos direitos humanos, que foi aprovada pela Organização das Nações Unidas (ONU), em dezembro de 1948. Há que se considerar que o documento é datado, por isso não dá conta de algumas especificidades da atualidade, como as questões da sustentabilidade, do papel da mulher no mundo contemporâneo, do desenvolvimento acelerado das tecnologias, do direito à diversidade cultural que inclui as diferenças, entre outros. (Zluhan \& Raitz, 2014, p. 33) 
Tendo em vista a referida contextualização e atualização, o conhecimento de direitos humanos não encontraria lugar melhor para nascer do que na própria escola, nem mesmo na família, posto que há homogeneidades dentro do seio familiar e somente com a diversidade oriunda do ambiente escolar que propricia terreno fértil para as singularidades sociais que os direitos humanos requerem. Todavia, existem contingências quais determinam a efetividade:

[...] para que a temática acerca dos direitos humanos seja discutida e executada no ambiente escolar é necessário rever a estrutura da própria escola enquanto instituição para que a mesma promova uma educação em direitos humanos na perspectiva intercultural crítica que afete todos os atores e dimensões do processo educativo, assim como os diferentes âmbitos em que ele se desenvolve. (Seniw, Fagundes \& Nascimento, 2017, p. 5)

Ainda diante desta possibilidade, outra questão relevante é a necessidade de uma maior aproximação da escola com a comunidade, havendo um diálogo entre ambos, posto que neste movimento de simbiose que se faz efetiva as bases presentes no ideário educativo em direitos humanos. Não se pode perder de vista que a comunidade está munida da capacidade de trazer para dentro da própria escola um leque de valores e saberes salutares para a formação do indivíduo, sendo mediante ela que alunos vão, fundamentar e, sobretudo, participar da prática de valores vivenciados no ambiente escolar. (Seniw, Fagundes \& Nascimento, 2018)

Entretanto, mesmo que não represente a totalidade, observamos que escola tem falhado dia a dia a promover, ao menos da maneira como se necessitava, a questão dos direitos humanos em suas salas de aula, em seus recursos pedagógicos e, principalmente, de como tudo isso deveria educar os indivíduos. Por certo a questão da violação de direitos ocorridos até mesmo dentro da escola não pode ser dissociada das questões ocorridas em sociedade. Reconhecemos ainda que toda possibilidade pedida dentro de sala de aula pode representar uma batalha na qual os direitos humanos se ficam cristalizados, permanecendo apenas ativos nos documentos. 
Sabe-se ainda de situações em que os próprios educadores tem negligenciado o papel na referida temática e isto tem adicionado uma camada de complexidade a problemática. A falta de posicionamento ante a questão, somada a irrestrita possibilidade de se trabalhar nesta linha, tem minado as possibilidades de fortalecimento dos direitos. Por certo, a educação voltada para os diretos humanos ainda não faz parte da prática, nem, tampouco, do currículo das escolas como deveria. As necessidade de se rever esta problemática é urgente, pois trata-se do plantio de hoje para a colheita num futuro vindouro, pois assim nos valemos a humanidade tendo perspectivas para assegurar condições mínimas de proteção, sobrevivência e dignidade.

Em momentos de violações e crises ante aos direitos humanos torna-se uma necessidade urgente que tal questão não faça parte só dos textos legais, mas sobretudo da prática e dos discursos e mentes das pessoas, de modo a potencializar as questões de dignidade humana e justiça com a sociedade.

\section{CONSIDERAÇÕES FINAIS}

A missão do ambiente escolar vai muito além dos conteúdos expostos nos livros e precisa impactar sobremaneira as pessoas extra muros da escola, ela precisa atuar transformando vidas e possibilidades. Para tanto, os chanceladores da educação inclusiva e da diversidade na perspectiva dos direitos humanos não podem se esconder para a missão a qual foram delegados, fazendo com que os direitos humanos não permanecerem apenas presos nos discursos e na letra morta da lei, mas se tornem em práticas. Por isso, é necessário que compreendamos que os direitos fundamentais sociais se consolidam em uma posição ativa da escola e dos que a compõem, a fim de hajam possibilidades para diminuição das desigualdades sociais, intolerância quaisquer que sejam, atuando em prol da justiça social, dando potencialidades a todos os indivíduos no que se tange os direitos para que se torne pleno como sujeitos, protagonista de sua história, de sua vida e partícipe ativo de uma sociedade mais igualitária e digna. Por isso, torna-se relevante assinalar que é cada vez mais necessário revisitar os documentos normativos que 
dão subsídios legais sobre a problemática, de modo a fazer releitura dos referidos, levando em conta que haja, tanto quanto possível, uma discussão crítico reflexiva para os tempos atuais e como estes são implicados pelas políticas públicas e os direitos humanos.

Torna-se relevante ainda lembrar que os atores envolvidos no processo necessitam, fortemente, não se omitir, abraçando a missão qual fora posta ante a educação em direitos humanos, compreendendo que ambos, educação e os direitos como fora tratados acima, tem uma relação indissociável. Nisto, dia após dia, compreendendo que uma sociedade mais justa com práticas sociais e lugares de protagonismo fundam-se em pequenos momentos em sala de aula, mas que fazem toda a diferença para a atualidade. Sob um outro olhar, empreender esforços hoje no cotidiano escolar, significativa cumprir o papel na efetivação prática das condições de respeito aos direitos humanos de uma maneira global, não se limitando a grupos ou representações sociais particularmente, ou seja, compreende -se que importa desenvolver possibilidades para equilíbrio de condições, tendo-se em vista que não se deixa para trás marcas omissões, mas de produções transformadoras de cidadania, modos de ser e estar no mundo.

Por fim, torna-se relevante recordar que ao pensar-se sobre a educação em direitos humanos trabalhados no ambiente escolar, necessitamos compreender que a temática se faz através de variadas instâncias do sistema educacional no Brasil e arroga-se, a priori, uma reinvenção de pilares centrais do processo educativo. Portanto, é imperativo se repensar os tempos pelos quais os espaços escolares, as práticas e os atores envolvidos interagem entre si, articulando-se saberes curriculares e atitudinais, objetivando a colaboração da formação de uma sociedade mais justa.

\section{REFERÊNCIAS BIBLIOGRÁFICAS}

BRASIL. Diretrizes e bases da educação nacional. Lei 9.394 de 20 de dezembro de 1996.

CARAPETO FERREIRA, Naura Syria. Gestão da educação na perspectiva dos Direitos Humanos: garantias de possibilidades. 
Revista diálogo educacional, [S.1.], v. 17, n. 53, p. 979-998, ago. 2017. ISSN 1981-416X. Disponível em: . Acesso em: 31 maio 2020. doi:http://dx.doi.org/10.7213/1981-416X.17.053.AO13.

RODRIGUES, Fernanda M. C; NOZU, Washington, C. S; NETO, João P. C. Educação, direitos humanos e cidadania: fundamentos para a inclusão escolar da pessoa com deficiência. RIDH | Bauru, v. 7, n. 1, p. 173-190, jan./jun., 2019. (12).

SCHILING, Flávia. Educação e direitos humanos [livro eletrônico: percepções sobre a escola: resultados de uma pesquisa / Flávia Schiling. -1. Ed. Cortez. São Paulo, 2014].

SENIW, Rafael Meira; FAGUNDES, Fabiula Campos Falcão; SARMENTO, Dirléia Fanfa Sarmento. Educação em direitos humanos na educação básica: reflexões a partir dos dispositivos legais. SEFIC UNILASALLE. Ciência e tecnologia para redução de desigualdades. 22 a 27 de outubro de 2018.

UNICEF. Objetivos para o desenvolvimento sustentável. in:https:// www.unicef.org/brazil/objetivos-de-desenvolvimento-sustentavel - acesso dia 02 de junho de 2020.

XAVIER, Antônio Roberto; VASCONCELOS, José Gerardo; XAVIER, Maria Ravelli Cordeiro. Direitos humanos, educação inclusiva e diversidade. In: II Congresso de Educação Instituto Dominus (II CEID). Educação inclusiva, diversidade e direitos humanos. Veiçosa: Imprece, 2018. p.17-28.

ZLUHAN, Mara Regina; RAITZ, Tânia Regina. A educação em direitos humanos para amenizar os conflitos no cotidiano das escolas. Rev. bras. Estud. pedagog. (online), Brasília, v. 95, n. 239, p. 31-54, jan./abr. 2014. 


\section{"GENTE O QUE É MACUMBA? \\ MACUMBA SÓ PEGA EM QUEM \\ ACREDITA?": UM ESTUDO SOBRE \\ INTOLERÂNCIA RELIGIOSA NO \\ CONTEXTO ESCOLAR}

Cintia Quina da Silva

\section{INTRODUÇÃO}

A produção das desigualdades ocorrida em nossa sociedade apresenta características marcantes dentre elas àquelas que se referem à raça e a cor da população. Tais diferenças são notadamente visíveis entre a população negra e a branca e tem origens e explicações históricas que podem ser compreendidas como decorrentes de nossa trajetória escravagista e o legado deixado por ela. Sobre esse assunto, Silva (2014) nos mostra que a afirmação da identidade e a enunciação da diferença, expressam o desejo de diversos grupos sociais e, a definição de identidade, assim como a marcação da diferença, não deve ser vista de forma separada das relações mais amplas de poder, com isso podemos pensar que as relações de subalternidade ganharam novas configurações.

Vygotsky (2007) aponta que a constituição do ser humano e os processos de identidade ocorrem tendo como base as complexas interações que se dão nos contextos de desenvolvimento. A partir do materialismo histórico dialético, o autor argumenta que a consciência individual se faz a partir das várias possiblidades de internalização dos elementos presentes no meio social e a apropriação das relações 
sociais, sobretudo mediada pela linguagem. Sendo assim, significados e sentidos são processados a partir dos processos de internalização do meio, pelo sujeito em desenvolvimento, de modo partilhado e mediado nas intensas relações com os outros. Assim, os vários discursos sociais ao qual o indivíduo constantemente está exposto desde o seu nascimento poderá produzir determinadas identidades e possibilidades de agir no mundo. E é a partir da linguagem e dos signos que entendemos como Vygotsky aponta que o discurso social pode ser um poderoso instrumento que historicamente vem configurando a evolução cultural das sociedades humanas. Nessa direção, a escola tem tido um papel central nos processos de internalização cultural, como espaço privilegiado da acentuação das diferenças e desigualdades entre os diversos grupos e indivíduos.

Nessa mesma direção, Bourdieu (1978) aponta que o sistema educacional pode ser compreendido como um instrumento de reprodução da cultura dominante no espaço escolar, com isso a escola não se coloca enquanto um ambiente mediador e justo ao tratar do processo de ensino aprendizagem, mas como uma instituição carregada de parcialidade onde as diferenças são reafirmadas, com um discurso dominante e tendencioso, ou seja, o ambiente escolar acaba se tornando um espaço de reprodução de desigualdades sociais.

Compreendendo, portanto, que a escola é uma das instituições responsáveis pelo desenvolvimento das crianças e onde se evidenciam as diferenças e desigualdades sociais, como apontadas por Bourdieu (1978), o debate sobre as relações étnico-raciais e a questão das religiões de matrizes afro-brasileiras, tem ganhado força na última década. Nessa esteira, Nilma Lino Gomes ${ }^{2}$ (2012) nos chama a atenção para a existência de poucos estudos que tratam sobre a presença de crianças e adolescentes no candomblé sendo que para a continuidade do culto a presença desses grupos se faz imprescindível. Tal apontamento nos direciona para que possamos nos questionar e refletirmos a respeito de nosso universo de pesquisa: a escola. Será que as jovens dos terreiros

2 Nessa pesquisa se fez a escolha citar de forma diferenciada as autorias femininas negras com o intuito de enfatizar a importância delas no contexto da educação das relações étnico-raciais. 
de candomblé e de outras religiões de matrizes africanas que lá estão inseridas sofrem com alguma forma de inserção marginal? Será que essas jovens omitem sua pertença religiosa como meio de se proteger de situações de preconceito, discriminação e intolerância?

Sobre esse assunto, Gomes (2012) assinala que a escola brasileira vem promovendo uma prática pedagógica deseducativa no que diz respeito ao tratamento que vem sendo dada a questão da diversidade religiosa e, com isso, grupos religiosos hegemônicos apoiados no artigo 33 da Lei 9394/96 de Diretrizes e Bases, extrapolam o que diz a própria lei e com isso implantam o proselitismo religioso associado à discriminação racial e ao racismo contribuindo para a humilhação e negação do direito a educação e a liberdade de expressão de crianças e adolescentes.

Para Bakke (2011) quanto mais nos aproximamos da sala de aula das escolas, maior é o distanciamento, a visibilidade e legitimidade referente à temática das religiões de matrizes africanas, ao contrário do que ocorre na academia e nos movimentos sociais negros onde esse já se coloca como objeto legítimo de estudo ou de representação e aponta como esse distanciamento se dá em discursos e práticas. Para a autora:

A argumentação de um ensino público laico é o primeiro argumento mobilizado para se negar a trabalhar com esses conteúdos, embora seja intrigante que a defesa do ensino laico não se contraponha às práticas de rezar pai nosso antes da aula (...). Quando se mobilizam as religiões afro brasileiras no contexto do ensino de história e cultura afro-brasileira, os conflitos latentes de intolerância religiosa presente no contexto escolar tornam-se explícitos. Boicotam-se trabalhos de professores, pais vão a escola reclamar, há tensões no interior do corpo docente, entre outros. (BAKKE, 2011, p 202)

Com isso podemos analisar o quanto é recorrente nas escolas brasileiras a chamada prática pedagógica deseducativa apontada por Gomes (2012) quando um (a) professor (a) se propõe a fazer um trabalho referente ao tema e tem seu trabalho boicotado ou ainda, quando pais vão a escola reclamar de discriminações sofridas por seus filhos ou para 
proibir a sua participação em determinadas atividades por conta de sua pertença religiosa. Observa-se também, algo que é muito marcante dentro dessa chamada prática deseducativa concretizada no boicote da equipe gestora e principalmente de seus pares, ou seja, parece não haver o interesse em se discutir as religiões de matrizes africanas alegando-se ser desnecessário e, também por conta da laicidade do Estado, porém a questão religiosa é vista de forma desigual, pois nada impede que se reze um pai nosso antes de começar a aula como nos mostra Bakke. Tais argumentos, nos leva a pensar acerca da naturalização de determinadas práticas que se mostram hegemônicas nesse contexto e que constantemente buscam mecanismos para inviabilizar práticas e silenciar vozes dissonantes.

Freyre (2001) aponta que "se aprende ensinando e se ensina aprendendo" e que ensinar exige risco, aceitação do novo e rejeição a qualquer forma de discriminação, portanto é importante pensar como tem sido feita abordagem em relação à religião em um Estado laico, como essas questões são ou não são tratadas dentro do cotidiano da escola e em que momentos podem ser percebidas práticas que dizem respeito à posturas intolerantes e se estas se dão de forma direta ou indireta, em que o individuo sofre represálias das mais variadas formas, sendo objeto do ódio, negação e invisibilização.

Um clássico estudo sobre racismo no ambiente escolar realizado por Eliane Cavalleiro (2000) nos mostrou que um dos grandes impactos desse racismo institucional é o chamado silêncio escolar. O silêncio escolar para a autora se caracteriza por uma conduta que tem sido assumida por alunos (as) negros, mas também por diferentes sujeitos negros (as) que estão ligados à escola, no qual esses sujeitos se propõem a uma retração, silenciamento, isolamento, ostracismo durante sua estada na escola, que em casos extremos pode incutir uma profunda negação de si mesmo e de suas práticas religiosas. Com isso podemos perceber que, além do estigma da cor e de gênero, a população negra adepta de religiões de matrizes africanas ainda carrega o estigma da religião, o do (a) "macumbeiro (a)".

Sobre esse assunto, Araújo (2015) assinala que independente de quando surgem e como se instalam, a cadeia de preconceito, discriminações, intolerância e racismo se inter-relacionam e se retroalimentam 
e que, portanto se faz necessário refazer o percurso, onde se observe e se ouça os sujeitos que circulam entre o terreiro e a escola, para que esses sujeitos tenham voz e vez que historicamente foram silenciadas.

Partindo dessas inquietações, esse trabalho consistiu em um estudo cujo propósito é compreender como ocorrem as interações escolares de meninas negras e brancas que são adeptas e não adeptas de religiões de matrizes africanas no espaço escolar. Nessa perspectiva, buscamos dados que pudessem nos dar subsídios para a reflexão acerca de como são marcadas as diferenças e as desigualdades nesse contexto.Com essa proposta procuramos compreender como ocorreram as mediações entre essas jovens e os adultos em consonância com os posicionamentos adotados em relação às religiões de matrizes africanas e, as reflexões construídas no sentido de enfrentamento e combate a essas desigualdades nesses espaços.

\section{METODOLOGIA}

Buscando atingir os objetivos dessa pesquisa de caráter qualitativo, optamos pela utilização de uma metodologia de tipo etnográfica. Para o que se propôs essa pesquisa, observou-se tal metodologia como uma possibilidade de investigação bastante promissora nos espaços escolares.

As pesquisas etnográficas em educação ou pesquisas do tipo etnográfico, conceito esse desenvolvido por André (2000) para explicar que, na atualidade tem sido realizada uma adaptação da etnografia à educação, pois ao se trabalhar com uma perspectiva de tipo etnográfico, o pesquisador passa a fazer uso de metodologias que estão associadas à etnografia como a observação participante, a entrevista intensiva além da análise de dados. Essa pesquisa para o seu desenvolvimento se utilizou da observação participante, entrevistas com professores e gestores e rodas de conversa com as estudantes.

Desse modo, o local de pesquisa para desenvolvimento deste trabalho foi uma escola da Rede Pública de Ensino do Estado de São Paulo, localizada em um município da grande São Paulo. Participaram da pesquisa nove estudantes, entre 16 e 17 anos matriculadas na $2^{\underline{a}}$ e $3^{\underline{a}}$ série do Ensino Médio, sendo seis autodeclaradas pretas, uma bran- 
ca, uma indígena e uma parda. Do grupo de participantes, apenas três delas se declararam adeptas de religiões de matrizes africanas. Duas estudantes do grupo, disseram ter mais identificação com o espiritismo kardecista, uma sem definição religiosa, e as demais participantes confirmaram a sua aderência a religiões de influência cristã católica e/ ou evangélica. Participaram também o diretor da escola, uma das coordenadoras pedagógicas, dois professores e uma professora.

Todos os (as) participantes da pesquisa assinaram termos de consentimento livre e esclarecido, e no caso das estudantes menores, ${ }^{3}$ que voluntariamente integraram a pesquisa, os termos foram assinados pelos responsáveis.

Nos dois primeiros encontros de rodas de conversa com as estudantes, a discussão girou em torno de qual era o posicionamento dessas jovens acerca de questões como raça e gênero, onde elas puderam trazer suas experiências referentes à baixa autoestima provocada pelo racismo e o quanto isso interfere em questões como os relacionamentos afetivos, por exemplo, no caso das estudantes pretas, além de preconceitos relacionados à sua orientação sexual no caso das estudantes que se declararam lésbicas.

Já na terceira roda de conversa, a discussão que foi proposta para as estudantes tratava-se da temática "religião". Nessa ocasião, o recurso utilizado para que fossem feitas as discussões foram imagens que faziam referência às religiões em geral, em especial as religiões de matrizes africanas.

\section{RESULTADOS INICIAIS E DISCUSSÃO}

Os procedimentos de análise deste trabalho foram orientados pelas proposições apontadas por Aguiar e Ozella (2013) que a partir da teoria histórico-cultural nos proporciona uma forma de organização dos dados que trata dos núcleos de significação. Nessa perspectiva os núcleos, devem expressar os pontos centrais e fundamentais acerca do sujeito, que o envolvam emocionalmente e que revelem

3 Essa pesquisa foi aprovada pelo Comitê de ética em pesquisa com seres humanos da Unifesp e seguiu a orientação legal para investigações dessa natureza. 
as suas determinações constitutivas. Após a constituição dos núcleos que entendemos fazer parte de um sentido do todo no fenômeno investigado, procuramos discuti-los a partir do referencial teórico da Teoria Histórico-Cultural. Ao citar os depoimentos das estudantes e dos docentes reforçamos o cuidado em apresentar nomes fictícios, respeitando o sigilo das informações.

É importante ressaltar que de acordo com a perspectiva da teoria histórico- cultural o significado é elaborado a partir da relação entre o homem e o mundo social, mediado por signos e instrumentos. Portanto, não podemos desconsiderar que a cada interação do indivíduo com o meio, este vai mudando suas percepções sobre o mundo em que vive e que as relações se estabelecem dessa maneira atribuindo novos sentidos acerca da sua realidade cultural, econômica e política, assim como, das suas relações sociais. Desse modo questionamos como se dão as interações escolares de jovens adeptas e não adeptas de religiões de matrizes africanas no espaço escolar a partir da perspectiva teórica aplicada para a interpretação de dados. . Com tal objetivo, construímos os seguintes núcleos de significados a seguir:

\section{Os sentidos e significados construídos acerca das religiões de matrizes africanas}

Apesar da pluralidade religiosa existente no Brasil, podemos notar que os adeptos (as) de religiões de matrizes africanas são os que têm vivenciado de forma cada vez mais constante as mais variadas expressões do preconceito. A religião socialmente aceita ainda é a de matriz cristã e, assim outras religiões ferem a única e indubitável verdade daqueles que tem preconceito contra pretos e pardos, como é expressa pelas estudantes participantes:

(...) seria tipo, muitas vezes a gente ouve de pessoas racistas, é preto é da macumba, coisas do tipo que ferem muito as pessoas, inclusive quando elas são de uma religião que foi criada por elas e tipo é muito difícil, não muito, mas é um pouco difícil ver pessoas brancas no candomblé, porque elas já são mais criadas naquela, Jesus, Deus, Maria, Maria criou Jesus e é isso, não 
mostrando essa realidade pra elas (...) (Keila, branca, Umbandista, $2^{\underline{a}}$ série do Ensino Médio)

A fala da estudante Keila nos traz a perspectiva de um conjunto de padrões sociais que estão estabelecidos que vê as religiões cristãs como sendo "o normal" a ser seguido e tudo que diz respeito as questões afro-brasileiras sobretudo as religiões de matrizes africanas serem constantes alvos de preconceito .

Diante disso, percebemos que os preconceitos diante das religiões de matrizes africanas tendem a gerar relações de violência simbólica entre estudantes como aponta o professor João:

(...) como nós estamos todos dilacerados nesse processo de violência, violência ela pode ser de múltiplas formas, simbólica e num primeiro momento havia uma violência física, em sala é violência ,quando acontece é violência física, mas as sutilezas está na violência psicológica mesmo e tem constantemente tem, mas eu posso te garantir que nos últimos 8 anos é uma violência silenciosa, que eu acredito que é uma das piores que é a do afastamento, do isolamento, do separar grupos de alunos pra cá, grupos de alunos pra lá, não tem mais uma afronta " esse é o meu deus você precisa crer e que você acredita é macumba, é coisa de demônio", isso não tem, esse tipo de fala eles não propagam na escola não.(...) (João, negro, espírita, professor de Química, atual vice-diretor da unidade escolar).

Muitas vezes o discurso vem em forma de ações, como retrata bem o excerto acima e, não é preciso à utilização de palavras. Apenas as atitudes são necessárias para que uma pessoa compreenda como ela pode ser vista por um grupo. Partindo dessa perspectiva também reconhecemos que as palavras e seus significados não são fechados e que o sentido múltiplo de uma única palavra num mesmo período histórico poderia revelar uma série de conflitos e acordos sociais que foram sendo constituídos num determinado momento e sentido, como por exemplo, a palavra macumba.

Convencionou-se dizer que "macumba" é algo ruim, mas que na verdade quando perguntado as estudantes o que seria de fato o termo 
"macumba" e a que elas estariam se referindo, verificou-se que não existe um consenso quanto ao que de fato seria como podemos observar na fala de Gessica:

(...) gente o que é macumba? Pensei que era aquele negócio que põe farofinha (...) (Gessica, espírita, parda, 3ª série do Ensino Médio).

O mesmo também ocorre na fala de Helida:

(...) é o pessoal falando da galinha preta e não sei o que (...) eu já vi tanta coisa de macumba, que macumba só pega em quem acredita, se você botar a mão lá na macumba, você pega a macumba. (...) (Helida, sem definição religiosa, branca, $3^{\underline{a}}$ série do Ensino Médio).

Partindo desses relatos podemos perceber que se trata de dois possíveis significados para uma mesma palavra, pois na perspectiva de Gessica a palavra "macumba" estaria relacionada aquilo que compreendemos como oferenda, já para Helida pode-se perceber que tem mais a ver com uma questão de crença, uma espécie de experiência espiritual.

De acordo com Amorim (2013) sabemos que a origem da palavra "macumba" é bastante questionável. E que por essa razão é possível notar que algumas das definições atribuídas para esta palavra ficaram limitadas ao dicionário, isto é, não representando, portanto, um uso corrente feito dela, em especial, em espaços de construção e legitimação de conhecimento como os jornais e os textos acadêmicos.

Nesse trabalho observou-se que essas diferenças de enunciado geram uma forma não apenas de ver e compreender o ato religioso, mas também influencia o comportamento que se constrói atrelado a essa palavra, como demonstra a fala de Keila:

Keila: isso já aconteceu comigo, quando as pessoas descobriam minha fé, achando que eu ia "' tacar macumba nelas ', nas paredes da casa delas. 
Pesquisadora: então você já perdeu muitas amizades Keila?

Keila: é achou que eu ia " tacar galinha morta " no terreiro dela, primeiro que eu nem gosto de matar animal, vou matar um animal na sua casa? Não tem sentido, é difícil as pessoas acham que esses rituais que fazem com animais são coisas fúteis sabe? Que não tem significado, mas tem, é complicado

Ao se referir à linguagem Fanon (2008) assinala que falar significa existir absolutamente para o outro, com isso é estar em condições de empregar certa sintaxe, ter um conhecimento morfológico de tal ou qual língua, mas para, além disso, significa principalmente assumir uma cultura, com isso um homem que possui a linguagem possuirá em compensação o mundo que essa linguagem retrata e o que está implícito nela.

Ao levantar essa problemática Fanon argumentava que a colonização exige muito mais do que a submissão material de um povo, ela também fornecerá os meios pelos quais as pessoas são capazes de se expressarem e se entenderem e com isso podemos compreender o processo de hierarquização entre povos e culturas, a construção dessa subalternidade que será implementado de diversas maneiras, dentre elas a linguagem, o que ele chamará de colonialismo epistemológico.

Com isso verificamos que as diferentes formas de apropriação e a construção de sentidos e significados que foram dadas as religiões afro-brasileiras, nos permitem compreender as relações de poder que se estabeleceram nos espaços de legitimação de enunciados, que atribuíram a palavra "macumba" a sua atual conotação.

Vygotsky (2007) por sua vez nos aponta que os sentidos são formados a partir de um processo de internalização das atividades e signos socialmente construídos e que estão cristalizadas historicamente em determinados grupos. Percebemos, portanto, em nossa análise sobre os sentidos e significados atribuídos às religiões de matrizes africanas a existência de constituição de uma cristalização negativa a partir de uma palavra que induziu a construção de um comportamento que se atrelou a ela. 


\section{A influência da família na construção da pertença religiosa}

Para Martins e Cândido (2016) a família representa aquilo que é essencial para a constituição biológica, social e cultural dos indivíduos, o que corresponde para a criança ao processo de socialização primária, onde são apreendidos valores e normas sociais e a internalização da cultura no contexto no qual está inserido. Atrelado a esse primeiro momento ocorre a socialização secundária, quando se dá a socialização da criança fora do espaço familiar, como, por exemplo, com os vizinhos e as pessoas da escola.

Com base nas narrativas apresentadas acerca de como se deu a escolha por determinada religião pudemos observar que tanto estudantes como docentes tiveram de forma muito marcante a participação da família nessa tomada de decisão, sendo que em muitos casos, a inserção em determinada religião ter se dado desde a infância, permanecendo a mesma até a idade adulta como foi relatado, pela professora Deise quando lhe foi perguntado se ela praticava alguma religião:

Pesquisadora: Você pratica alguma religião?

Deise: Sim pratico

Pesquisadora: Desde que idade?

Deise: Desde sempre. Quando eu nasci minha mãe já pertencia a uma igreja e sempre...

Pesquisadora: igreja evangélica?

Deise: sim, igreja evangélica

(Deise, branca, evangélica, Professora de Língua Portuguesa e Literatura).

O mesmo pode ser observado, também no relato do Professor Edson quando ele afirma ser espírita desde sempre, mas aponta também que o fato de ele ter uma família numerosa propiciou que tivesse contato com diversas correntes religiosas antes de fazer a sua escolha: 
(...) Eu nasci em berço espírita, mas assim frequentei muitas religiões, por causa da família, como te falei minha família é grande, então tem tudo isso, tem pessoas que são católicas, ai quando você estava na casa de alguém ou eles vinham pra sua casa ai falavam: " vamos pra igreja " "vamos pra igreja", já fui pra igreja evangélica, já fui pra igreja católica, já fui para o candomblé, então onde tem um parente à gente... já transitei por tudo e vejo assim em todos eles a mesma raiz dentro daquilo que tem que ser acreditado(...) (Edson, pardo, espírita, Diretor da Escola)

Quanto ao contato com diversas correntes religiosas, é uma experiência que também é vivida por Gessica, porém no seu caso essa escolha ainda se encontra em construção:

(...) gente já" fui em tanto lugar" pra ver onde eu me achava religiosamente , tanto lugar, eu já fui no candomblé e na umbanda , no candomblé que eu vi isso dai , na umbanda foi mais suave (...) (Gessica, parda, espírita, 3ํㅗérie do Ensino Médio)

A partir desses relatos podemos compreender aquilo que Vygotsky aponta sobre o processo de internalização das atividades, pois o sujeito constitui as suas formas de ação e da sua consciência em suas relações sociais. Desse modo, a criança acaba por ser inserida em um mundo de objetos culturais pela família, muitas vezes sem saber ao certo quais os significados ou os sentidos que estão sendo defendidos, como no caso de Gessica e Helida:

Gessica: lá em casa o meu pai é católico, só que a minha mãe já rodou em tanta igreja por ai, tanta religião e junto com a minha mãe eu fui conhecendo já fui para o espiritismo, mas a que eu mais gosto, mais me identifico, mais vou lá é o espiritismo, já fui no candomblé, já fui na umbanda , na católica, na da graça , na universal ,já fui naquela que, sabe na porta ficam homens de um lado e mulheres do outro ?

Helida: na congregação 
Gessica: isso na congregação, vixi! um monte de religião.

Helida: já usei até véu na cabeça, que minha tia obrigava.

Pesquisadora: sua tia te obrigava a usar véu? E ai como era isso?

Helida: não entendia nada, só ia

Em muitos casos, vimos que os pais realizam o processo de mediação entre a criança e a religião. O processo de mediação diz respeito a uma característica tipicamente humana que consiste na ação de grupos sobre determinados indivíduos com o intuito de integra-los numa determinada rede de relações sociais e culturais que serão responsáveis pelo seu processo de humanização.

É importante ressaltar que os processos de internalização podem se dar de diversas formas e há casos em que geram sofrimentos para os sujeitos como no caso de Keila que vinha de uma família neopentecostal e passa a frequentar a Umbanda e ao falar da demonização das religiões de matrizes africanas afirma:

(...) isso se aprende dentro de casa, que ser do candomblé é errado, que você vai para o inferno, que santo é puta, que orixá é drogado, essas coisas sabe? É sempre ensinado assim, eu fui ensinada assim, e a pessoa às vezes quando não tem a mente forte, ela reflete aquilo como uma coisa ruim, ela não percebe que tem diferenças entendeu? E ela acaba sendo esse tipo de pessoa escrota que a gente vê nesses dias (...) (Keila, branca, umbandista, 2aㅗérie do Ensino Médio).

Ou no caso de Tais que se via obrigada a ir aos cultos na igreja com seu pai:

(...) Eu ia obrigada né? Não gostava muito não (...) ficava um monte de gente caindo no chão, eu falava para o meu pai, " quero embora! Pelo amor de Deus!"(...) ai meu pai caia também e eu falava: "meu Deus!" (Tais, negra, espirita, 3 a série do Ensino Médio). 
Com isso podemos perceber que a construção de uma pertença religiosa mediada pela família apresenta processos de permanências e rupturas que podem ocasionar em alguns casos, sofrimento para os sujeitos, sobretudo no processo de revolução que se vivencia na adolescência. Sofrimentos esses que podem permanecer e gerar determinados comportamentos fossilizados ou serem ressignificados em outros momentos da vida.

\section{A não-formação docente para uma educação antirracista}

Tanto nas narrativas dos (as) docentes quanto das estudantes a questão levantada foi a de que uma discussão mais consistente acerca das questões étnico-raciais não ocorria na escola. As estudantes relataram que de vez em quando um professor ou outro trazia essa questão para a sala de aula, entre os docentes a fala recorrente foi no sentido de que a maioria dos professores carece de formação nessa temática.

De acordo com o estudo feito por Gomes e Jesus (2013) o desinteresse que alguns docentes apresentam pelas questões étnico-raciais, não diz respeito "apenas" à questão do racismo, mas também está relacionado a outros fatores. E quando se trata de religiões de matrizes africanas sequer se toca nesse assunto.

Quando se realiza alguma discussão sobre as questões étnico-raciais verifica-se que ela ocorre de maneira bastante superficial, podemos até dizer estereotipada, o que nos é perceptível a partir da fala de Jaqueline:

(...) Vejo que o assunto é muito comentado e o empoderamento da cultura negra, é muito apoiado quando o assunto é cabelo, moda, música etc.”. Mas quando é religião é visto de outra forma, como algo maligno (...) (Jaqueline, negra, candomblecista, 3a série do Ensino Médio).

Para Araujo (2017) o tratamento dado ao negro e a sua cultura na escola apontam que essa relação tem se dado por práticas e condutas que revelam o quanto a escola ainda se pauta por valores eurocêntricos, pois: 
(...) continua presa à disseminação, ideologicamente enviesada, de valores ligados aos grupos historicamente majoritários, a saber, as classes social e economicamente mais favorecidas e aos valores religiosos e culturais relacionados com o universo cristão- católico e evangélico (...) (ARAÚJO, 2017, p.182).

Com isso podemos compreender que os poucos docentes que sabem da importância do desenvolvimento do trabalho, acabam vindo a esbarrar no racismo institucional existente que tende a inviabiliza-lo, pois como afirma Araujo:

(...) a escola como mantenedora e reprodutora das estruturas sociais existentes e da cultura hegemônica [...] ela tende a reproduzir esse racismo no âmbito de suas relações e seu funcionamento, começando pelo currículo, passando pela cultura da escola e se estendendo até os seus mecanismos de promoção ou retenção. (...) (ARAÚJO, 2017, p.183)

À medida que temos um racismo que se reproduz de várias formas no espaço escolar é cada vez mais potencializada a ideia de uma escola excludente e que estigmatiza de todas as formas os (as) jovens negros (as) seja com relação a sua estética, aprendizado ou comportamento.

\section{Considerações Iniciais}

Pensar os processos de silenciamento, invisibilização e a demonização atribuído às religiões de matrizes africanas, foi o ponto de partida para que desenvolvêssemos essa pesquisa e com isso começássemos a refletir como esse processo se dava dentro das escolas, tendo a compreensão da existência de um racismo estrutural que pauta as relações sociais em nosso país. Para isso pautamo-nos na concepção do materialismo histórico-dialético apresentado pela teoria histórico cultural de Vygotsky e outros colaboradores que têm como um de seus princípios que os processos sociais e psicológicos humanos são formados por ferramentas sociais ou por formas de mediação. Sendo assim, os dados foram analisados por meio de uma perspectiva histórica e dialética para 
que pudéssemos compreender o desenvolvimento do comportamento humano em relação às religiões no espaço escolar.

Dentro daquilo que foi proposto como o objetivo para essa pesquisa compreendemos que foi possível verificar inicialmente como se davam as relações entre as jovens no caso especificamente as adolescentes adeptas de religiões de matrizes africanas e as que não são adeptas, a partir de suas interações nas escola. Os dados da pesquisa nos oferecem subsídio para a compreensão de que tais interações são mais restritas no caso das meninas adeptas às religiões de matrizes africanas, em decorrência da sua pertença religiosa, o que as coloca numa condição de silêncio e isolamento, enquanto que para as jovens não adeptas, essas interações ocorrem de forma mais ampla.

Outro elemento que foi possível observar é que mesmo as jovens pretas que não se declararam adeptas de religiões de matrizes africanas compartilham de experiências religiosas diversas em seus núcleos familiares. Percebemos que a questão da escolha da religião, é um fenômeno social mediado pelas famílias, em muitos casos. Desse modo, o fato de parte dos familiares serem adeptos de determinadas religiões implica em uma convivência familiar permeada por conflitos em decorrência de divergências que se estabeleceram em virtude de escolhas religiosas distintas.

Para finalizar, consideramos que ainda que essa investigação poderá contribuir para as discussões relativas à intolerância religiosa nos espaços escolares, a pesquisa apresenta algumas lacunas importantes, que poderão ser preenchidas com o auxilio de novos estudos dessa natureza, no sentido de ampliar o debate e a implementação de políticas públicas para a população negra nos espaços educativos em busca de uma educação antirracista.

\section{REFERENNCIAS}

AGUIAR, Wanda Maria Junqueira de; OZELLA, Sergio. Apreensão dos sentidos: aprimorando a proposta dos núcleos de significação. Revista Brasileira de Estudos Pedagógicos, v. 94, n. 236, p. 299322, 2013. 
AMORIM, Marcos Paulo. Macumba no imaginário brasileiro: a construção de uma palavra.http://www.fespsp.org.br/seminario2013/ artigos/IISeminarioPesquisa_MarcosAmorim. pdf. Acesso em, v. 15, p. 12,2015

ANDRÉ, Marli Eliza Dalmazo Afonso de. Etnografia da prática escolar. Campinas, SP: Papirus, 2000.

ARAÚjO, Patrício Carneiro. Entre o terreiro e a escola: Lei 10.639/2003 e a intolerância religiosa sob o olhar antropológico (Tese de Doutorado em Ciências Sociais- Antropologia) PUC/ SP, São Paulo, 2015.

. Entre ataques e atabaques: intolerância religiosa e racismo nas escolas. São Paulo: Arché Editora, 2017.

BAKKE, Rachel R. B. Na escola com os orixás: o ensino das religiões afro-brasileiras na aplicação da Lei 10.639. São Paulo: Universidade de São Paulo, Departamento de Antropologia Social, tese de doutorado, 2011.

BOURDIEU, Pierre; PASSERON, Jean-Claude. A reprodução elementos para uma teoria do sistema de ensino, Lisboa: Editorial Vega, 1978.

CAVALLEIRO, Eliane. Do silencio do lar ao silêncio escolar: racismo, preconceito e discriminação na educação infantil, São Paulo, Contexto, 2000.

FANON, Frantz. Pele negra, máscaras brancas. Salvador: EDUFBA, 2008

FREIRE, Paulo. Pedagogia da autonomia: saberes necessários à prática educativa. 43. ed., São Paulo: Paz e Terra, 2011.

GOMES, Nilma Lino. Prefácio in: Educação nos terreiros- e como a escola se relaciona com as crianças de candomblé. São Paulo, Editora Pallas, 2012. 
; DE JESUS, Rodrigo Ednilson. As práticas pedagógicas de trabalho com relações étnico-raciais na escola na perspectiva de Lei 10.639/2003:

MARTINS, Edna; CANDIDO, Renata Marcilio. Práticas educativas de famílias negras e relações étnico-raciais: uma experiência em formação de professores. ETD-Educação Temática Digital, v. 18, n. 3, p. 690-709, 2016.

SILVA, Tomaz Tadeu Da. A produção social da identidade e da diferença In: Identidade e diferença: a perspectiva dos estudos culturais. Tomas Tadeu da Silva (org.). Stuart Hall, Kathryn Woodward. 15. ed.- Petrópolis, RJ : Vozes,2014

VYGOTSKY. L.S. A formação social da mente: o desenvolvimento dos processos psicológicos superiores, 7aㅡ edição, São Paulo, Martins Fontes, 2007.

A construção do Pensamento e da Linguagem. São Paulo, Martins Fontes, 2001. 


\section{EDUCAÇÃO EM DIREITOS HUMANOS E A VIOLÊNCIA NA ESCOLA}

Lohane Borges Leal Lima

\section{INTRODUÇÃO}

A educação atenta ao ensino dos direitos humanos permite o reconhecimento da pluralidade humana, respeito ao próximo nas relações sociais, e traduzida na concepção de ensino, é essencial para a formação cidadã do aluno, numa realidade de respeito mútuo. É necessário tratar sobre a temática Violência e Direitos Humanos da Infância na Educação Infantil, pois as maiores mazelas sociais, violência, bullying dentro e fora da escola, estão ligadas direta e indiretamente a discriminação, preconceito, que demonstra como o homem em sua existência peca em não perceber o próximo como igual, detentor de direitos na mesma medida.

O objetivo é demonstrar a importância dos professores da Educação Infantil estarem aptos a reconhecer e identificar se a criança sofre alguma violência, seja na escola, seja no âmbito familiar, demonstrar, por exemplo, como lhe dão com a temática Violência na Infância e Direitos Humanos, na sala de aula, integrando o conteúdo em aulas, com intuito de orientar aos alunos, nessa fase terna da Educação Infantil.

Assim surge o questionamento: O professor da educação infantil está preparado para identificar os mais diversos tipos de violência? E deve/pode a escola inserir a temática violência e direitos humanos como meio de formação cidadã? Para isso será necessário conceituar 
direitos humanos, e analisar quais são os aspectos de devem direcionar ações sobre a temática em sala de aula, e como corpo discente pode inserir ações e projetos direcionados ao respeito, diferenciando de tolerância, visando a não discriminação, do pré conceito, com intuito de uma formação cidadã.

A pesquisa será desenvolvida através de uma abordagem teórica, fundamentada numa pesquisa bibliográfica sobre direitos humanos, para propiciar um embasamento teórico de confiabilidade na produção textual, assim foram utilizados dados oficiais do Ministério da Educação, além do uso de autores que trazem a temática.

A revisão bibliográfica da pesquisa busca de forma organizada demonstrar os pensamentos de cientistas educacionais e da área jurídica, além de órgãos oficiais sobre a necessidade de trazer o tema direitos humanos. A pesquisa traz ainda como o ensino e o respeito ao próximo irão mudar a realidade brasileira, onde não é o através de presídios, de punições, de legislação protetivas, que apesar de serem essenciais, o que mudará o mundo é a educação.

\section{DIREITOS HUMANOS E A ESCOLA}

E educar em direitos humanos é formar a consciência sobre a pertença cultural, o que significa o cidadão ser imerso no sio de sua cultura e ser estimado a "perceber-se como integrante, como criador, como participe de todo o processo cultural, e não como mero expectador dele", explica Brochado (2015, p 69). Nesse sentido, o conhecimento sobre direitos humanos é vital para um saudável dinamismo social, porém o direito demanda respeito, por consequência o respeito é diferente de tolerância, quando se trata de entender o indivíduo dotado de capacidade de possuir direitos e deveres.

Por exemplo, o que é comum nos discursos escolares e sociais, quanto ao uso do termo tolerância, não habitual, nem sempre está ligado à más intenções, porém deve e pode ser substituída por respeito/ empatia, a ideia de tolerância está ligada ao fato de suportar, com indulgência, clemência. O dicionário traz que a tolerância é a disposição para admitir modos de pensar, de agir e de sentir diferentes dos nossos 
ou mesmo a liberação de uma regra, preceito, norma; licença: tolerância de prazo, mas também define como favor feito a alguém em determinadas circunstâncias: isto não é um direito, é uma tolerância, ora não é favor o dever de se respeitar o outro, nesse caso deve-se substituir a palavra tolerância por respeito, já que existe uma negatividade em seu conceito.

A escola tem papel decisivo na possibilidade de alteração da realidade social, inclusive da diminuição das diferenças, com acesso a uma educação igualitária e que respeite o indivíduo, onde o ensino sobre direitos humanos seja visto como possibilidade de amadurecimento humano. $\mathrm{O}$ professor, desde os anos iniciais, deve trabalhar aspectos como: respeito mútuo como condição necessária para o convívio social democrático; respeito ao outro e a exigência de igual respeito para si; respeito ao direito seu e dos outros à discordância; repúdio a toda forma de humilhação ou violência na relação com o outro, (TEIXEIRA, 2015).

O etnocentrismo, estereótipo, preconceito e discriminação são ideias e comportamentos que negam humanidade àqueles e àquelas que são suas vítimas, a situação tem melhorado graças à atuação dos movimentos sociais e de políticas públicas específicas. Gomes (2014, p 32) refletindo sobre educação afirma que "todos os problemas sociais são resultantes de uma crise presente em todos os setores de nossa sociedade". Pode haver dificuldades em praticar o desprendimento de preconceitos, pois muitas coisas foram passadas culturalmente durante gerações - notável em expressões racistas como: serviço de preto, feito nas coxas; questões sexuais com expressões pejorativas: viado, bicha; ou religiosas: macumbeiros, crentes. Devemos policiar essas atitudes, pois podem ofender em algum momento determinada pessoa, e praticar diariamente a cidadania, sendo instrumento para melhora da vida em sociedade, o professor é um transformador social.

\subsection{A Diversidade Humana na Escola e os Direitos Humanos}

O ambiente escolar traz uma condição de adequação de conteúdos diversos, de maneira a alcançar o objetivo proposto respeitando as diferenças, pois a pluralidade de indivíduos é condição humana, e isso deve 
direcionar a ação e o discurso sobre a igualdade e a diferença, e proporcionar o atingimento de inserir os Direitos Humanos ao currículo vivo da escola. No âmbito pedagógico de formação do indivíduo trabalhar com Direitos Humanos é trazer que a pluralidade dos seres permite sua evolução, social, psicológica, ética, moral, o que define a capacidade de mudar, alterar, e se moldar as mudanças sociais. O ensino interdisciplinar na Educação Infantil sobre Direitos Humanos está relacionado com as relações humanas na busca de oportunidades iguais e de respeito à dignidade.

Há uma necessidade de entender a diversidade para introduzir os direitos que resguardam as crianças, Santos (2008, p. 48) afirma "denominar diversidade como as diferenças e condições éticas e culturais, as desigualdades socioeconômicas, as relações discriminatórias e excludentes presentes em nossas escolas e que compõem diversos grupos sociais”. Direitos humanos são direitos essenciais, explicitamente ou implicitamente fundamentados em tratados internacionais ou constituições (considerados formais), à dignidade da pessoa humana. $\mathrm{O}$ Estado tem a obrigação de proteger a dignidade da pessoa humana, sendo que deve, no primeiro momento coibir ações estatais que ferem a dignidade humana e, em um segundo momento, garantir ações de promoção da dignidade da pessoa humana, (RAMOS, 2015).

Uma sociedade que defende os direitos humanos é considerada uma sociedade inclusiva, reconhecendo que o direito fundamental de qualquer indivíduo e o direito a ter direitos, uma escola que permite ações sobre o respeito aos indivíduos e que trabalhe junto aos professores atividades afirmativas da criança tende a modificar o mundo.

No âmbito escolar deve haver ações direcionadas ao ensino de direitos humanos com intuito de informar, proteger e combater a violência, promover a igualdade real de oportunidades e implantar ações afirmativas, reforçando a necessidade de implantação de um ensino cidadão, modificador social.

Quando se trabalha com Direitos Humanos desde o Ensino na Educação Infantil há a oportunidade de trazer à tona diversos temas inseridos nesse contexto como a criança aprender a identificar quando sofre a violência (sexual, moral, psicológica) ou mesmo sobre o respeito à diversidade, buscando a igualdade para grupos excluídos, 
nesse sentido o professor / formador traz consigo a oportunidade de alterar as realidades sociais trabalhando, além de igualdade de raça, etnia e gênero, as pessoas com deficiência, e outras de minorias marginalizadas.

O espaço educativo dever trazer a preocupação com o crescimento do grupo, considerando sua unidade, com possibilidade de revisar a diversidade de ideias do grupo, a escola não deve se ater a transmissão de conteúdo didático, mas teve ter o compromisso com uma formação integral, "rica em indagações e disposta a repensar suas ações” (MOTTA, 2011, p. 22).

A escola com sua função social deve agir com intuito de ensinar e instruir o discente, informar sobre quais são as violências, combater o preconceito, combater a discriminação, implantar ações afirmativas, na busca pela valorização do indivíduo, promovendo a igualdade de oportunidade, reconhecendo a pluralidade, e acima de tudo respeitando as diferenças.

Considerando que Brasil tem dimensões continentais, durante a formação histórica brasileira houve a influência de várias culturas e povos, europeus, africanos, isso permite verificar quão rica é nossa diversidade cultural, visualizada através das regiões do país e suas características, como música, culinária, e até mesmo religiosa.

Quando o professor trabalha Direitos Humanos, pode atender diversos aspectos de formação cidadã do indivíduo, não somente no sentido de instruir as crianças sobre a violência, e também formar cidadão que respeitem ao próximo, enxergando a igualdade entre os homens, no que tange ao direito ao respeito, educação, segurança e saúde, direitos sociais mínimos, garantidos pela Constituição Federal de 1988 e ainda na Declaração Universal de Direitos Humanos.

O desconhecido causa estranheza, cabe aos professores, assim como a família, permitir o pleno desenvolvimento do indivíduo, respeitando-o como ser humano, detentor de direitos, que conhecer e respeitar são os comportamentos que se espera de um cidadão ser desprovido de estereótipos e preconceitos, a valorização do indivíduo é oportunidade para o enriquecimento cultural, social e pessoal.

Isso significa dizer que toda pessoa deve poder participar na vida cultural que escolha e exercer suas próprias práticas culturais, dentro 
dos limites que impõe o respeito aos direitos humanos e às liberdades fundamentais, a escola deve transmitir esse pensamento, pela pluralidade cultural brasileira e pelo respeito ao próximo. Em sala de aula o professor deve, de maneira interdisciplinar, demonstrar que respeitar a diversidade cultural significa que não se deve impor uma cultura sobre outras, onde cada grupo deve ter garantido, como direito humano, o direito de ser diferente.

Os professores devem se atentar para conhecimentos múltiplos sobre a criança, como suas características (físicas, psicológicas, sociais), o entendimento de sua realidade social, como sujeitos de direitos, como cidadãos. O fato é que se deve discutir o currículo, a metodologia, e os recursos pedagógicos, adequando-os às necessidades e peculiaridades da comunidade, entendendo as diferentes infâncias e culturas existentes, (MOTTA, 2011).

\subsection{Do Professor da Educação Infantil e a Educação Cidadã}

$\mathrm{Na}$ escola o conceito de direito humano deve ser trabalhado de diferentes maneiras, há discussão sobre entender o indivíduo não apenas como uma questão de raça, etnia e gênero, porém é mais complexo envolvendo o conceito de direito, e que esses direitos alcançam, ou devem alcançar todos os tipos de pessoas, inclusive as relacionadas à aparência, comportamento, crenças, orientação sexual e orientações pessoais. O ambiente escolar deve buscar o crescimento e ao escolher ou selecionar seus colaboradores, deve promover também a igualdade entre os indivíduos, para que não perpetue preconceitos e desigualdades existentes na sociedade. Lopes (2014, p. 6) ensina:

A educação para cidadania surge, então, no contexto da gestão flexível do currículo, como componente obrigatório do mesmo e como um espaço de diálogo e reflexão sobre as experiências vividas, as preocupações sentidas e os temas e problemas relevantes da comunidade e da sociedade, objetivando proporcionar a construção de identidade e o desenvolvimento 
da consciência cívica dos alunos, pois ser cidadão, é também, construir-se como sujeito.

Exercer a cidadania desde os anos iniciais que o aluno é inserido na escola é a garantia que ao aluno seja dada a oportunidade do exercício pleno de seus direitos e consequentemente dos seus deveres, ensinando desde a infância que todo direito tem em contrapartida, o cumprimento de deveres.

Para Hora (2012, p. 4) "aprender a relacionar-se consigo e com o outro na sociedade é a principal finalidade desta educação cidadã, que concentra seus esforços na formação de sujeitos ativos na escola e na sociedade". O professor e a escola deve praticar a cidadania, o indivíduo está inserido em vários seios sociais, no trabalho, na escola, na família, na igreja, ou mesmo em grupos de amigos. A cidadania e os bons costumes são inerentes ao ser em qualquer ambiente que esteja se relacionando, não há como separar o comportamento do meio social.

Oliveira e Fraz (2012, p. 14) dizem "a educação é o fator primordial na regeneração da moral em uma sociedade, busca-se aqui defendê-la da concepção positivista que vai contra uma proposta de ensino autônomo e liberador". A criança um espaço social, interagindo diretamente, colaborando não apenas com os espaços físicos, mas também com o bem-estar das pessoas com as quais dividimos esses espaços, considerando, inclusive, o nosso ambiente de trabalho e todas as vivências que trazemos do ambiente familiar.

\subsection{Ensinando direitos humanos como ferramenta no combate a violência na escola.}

As crianças / alunos desde os anos iniciais já questionam situações que geram curiosidade, os direitos devem ser tratados com naturalidade, nas escolas públicas, considerando o número de alunos, e o acesso muitas vezes tem em sua formação uma variedade de perfis, tanto de alunos, quanto de professores, esse aspecto deve ser aliado ao ensino interdisciplinar dos direitos humanos, visando orientação sobre os aspectos inerentes o exercício do direito humano, seja ele na proteção 
contra violência, na diversidade, no papel dos responsáveis, no papel do Estado e da Escola, materializada na ação do professor.

A realidade da sociedade capitalista, que muitas vezes erroneamente liga a pobreza ao fracasso, é fato que a desigualdade social é fruto das relações, onde classes sociais "inferiores" são subjugadas, isso deve ser trazido à sala de aula como tema a ser discutido a fim de minimizar as diferenças, numa educação igualitária e inclusiva.

Infelizmente, apesar dos esforços da sociedade, do poder público, e todas alterações sociais efetuadas em torno da diminuição do racismo, esse ainda direciona ações de violência contra negros no Brasil. Crianças são condicionadas a reproduzir estereótipos sociais, com manifestações sobre a cor da pele, o cabelo, e o empoderamento de crianças negras deve ser executado na escola. Lima (2014, p. 9) explica que preconceito "é uma opinião que formamos das pessoas antes de conhecê-las, o julgamento apressado e superficial e perigoso, acaba trazendo muitas situações complicadas e até mesmo violentas".

Esse preconceito enraizado na educação das crianças tendem a transformá-las em racistas, que acredita numa "superioridade" de determinada raça e por consequência "inferioridade" de outra, crianças manifestam esses comportamentos através do bullying na escola, com comportamentos pejorativos com os colegas, motivados pela cor, cabelo, ou outras características.

A Lei 10.639/2003, visando a valorização do negro na escola, determina o ensino obrigatório da cultura e história afro-brasileira na Educação pública e privada. Em 2015 o Censo Escolar, INEP, demonstrou que um quarto das escolas públicas não abordam o racismo no currículo; 4 em cada 10 instituições não pautam o tema da desigualdade social e $52 \%$ do total não tratam da diversidade religiosa.

Daí a possibilidade de tratar de diversas diferenças, como sociais, e socioeconômicas, incentivando o aluno a enxergar o outro com empatia, entender a realidade diferente da sua, e acima de tudo o respeito ao próximo como o direcionador de todas as ações afirmativas de minorias, seja pela cultura, pela posição social, pela cor, pela sexualidade, pelo gênero, pautada numa educação cidadã como direcionadora de uma mudança social. 
Outro direito humano que deve ser respeitado, na escola pode e deve ser abordado, está relacionado a religião/credo/crença, e apesar de o Brasil é um país laico, de acordo com a Constituição Federal de 1988, em art. 5, VIII, diz que - ninguém será privado de direitos por motivo de crença religiosa ou de convicção filosófica ou política, salvo se as invocar para eximir-se de obrigação legal a todos imposta e recusar-se a cumprir prestação alternativa, fixada em lei.

Salla (2013, p. 27) afirma que tais ações e que "apesar de ser permitida pela Lei de Diretrizes e Bases da Educação Nacional (LDB), desde que não sejam obrigatórias para os alunos e a instituição assegure o respeito à diversidade de credos e coíba o proselitismo". Isso significa que a escola deve formar cidadãos mediadores de conhecimento qualificado sobre as religiões, independentemente de sua própria e utilizem a interdisciplinaridade como ferramentas para abordar a diversidade religiosa dentro da escola de maneira crítica e respeitosa, respeitando o que traz a Constituição Federal e a Declaração Universal dos Direitos Humanos.

Muitas vezes no ambiente escolar, as próprias crianças são agentes causadores de violência, claro que induzidas pelo comportamento social que lhe fora ensinado, a criança então é o autor e a vítima do dano causado pela violência. Como fator social que muitas vezes gera a violência é a não aceitação do outro como possuidor de direitos na mesma medida, não aceitação do outro como igual, a não aplicação da empatia, acredita-se que motivada pela cultura social que lhe fora passada, muitas vezes no meio social, seja família ou escola.

Infelizmente vemos a discriminação na escola motivada pelo gênero, entende-se a equidade de gênero é o equilíbrio que deve se ter entre mulheres e homens em termos de direitos legais, participação política, remuneração e relações pessoais. O que se pretende pela equiparação de gênero é o alcançar o objetivo do tratamento igualitário, respeitando suas diferenças.

De acordo Lêda Gonçalves de Freitas, coautora do livro Ser Menina no Brasil Contemporâneo - Marcações de Gênero em Contexto de Desigualdades, em entrevista a Paiva (2018, p. 42) diz que "[...] a desigualdade de gênero é um fato em nosso país. Sabemos das desi- 
gualdades na divisão das tarefas domésticas, no mundo do trabalho, as hierarquias de gênero, o machismo e o patriarcado", esse comportamento social dificulta o desenvolvimento integral de meninas, daí a necessidade de trabalhar a temática.

O professor e a escola como formadora de cidadãos deve promover o diálogo, incentivar o questionamento, à criticidade e ao convívio com a diferença em suas diversas manifestações, extinguindo atitudes e pensamentos nocivos e pela construção de novas formas de relações pautadas no respeito.

Existe nesse sentido o Portal Equidade de Gênero nas Escolas (PEGE) é um ambiente virtual de educação à distância desenvolvido pelo Promundo, esse portal busca sensibilizar e formar profissionais de educação sobre o tema da promoção da equidade de gênero, pois tratar da temática gênero ainda traz tabus.

O desconhecimento do tema também está em torno da tão temida "diversidade sexual" ou "ideologia de gênero", principalmente no que é direcionado à Educação Infantil, ainda é comum que os pais em sua maioria sejam contra essa temática nas escolas, e acreditam ser de decisão, interferência somente da família discutir o assunto.

Alguns autores como Campos (2015), Jesus, et. al. (2008), Bortolini (2006) são coerentes em tratar na temática de forma interdisciplinar e na fase de formação de adolescentes, não tratam da temática na Educação Infantil. Campos (2015, p. 67) afirma que tal temática deveria ser abordada somente na construção do jovem, na adolescência:

[...] A abordagem de sexualidade, gênero e diversidade sexual na escola precisa contribuir para esse processo de humanização, sendo fundamental romper ideias cristalizadas e construídas na sociedade, formando um ser humano consciente das relações sociais a que está submetido, principalmente considerando esse ser humano no período da adolescência.

Nota-se que o desconhecimento de como isso deve ser tratado na escola é a maior preocupação dos pais, pois interferiria na inocência de suas crianças, que devem ser protegidas da "cultura homossexual", numa idade da Educação Infantil, onde não teriam 
maturidade para analisar o comportamento sexual diverso, seja homo ou heterossexual.

Campos (2015, p. 65) diz que [...] é preciso que pesquisadores da área de ensino de Ciências reflitam sobre a temática e que resultados de pesquisas fundamentem as discussões em torno do tema". Isso é necessário pois há controvérsia diante do assunto, e demanda mais estudos sobre sua aplicação em sala de aula, de maneira a respeitar as crianças, instruindo de modo cidadão sem interferência em sua formação ou desenvolvimento sexual.

O tema ao ser levado a escola pode gerar desconforto às famílias, mas esse desconforto é pelo medo, pelo desconhecimento, trazer a família para escola minimizaria os aspectos negativos que a temática tem em torno do tema, e o trabalho em conjunto determinaria como seria tratado o assunto em sala, não como forma de orientação sexual, mas de forma a apenas ensinar aos alunos na infância sobre o respeito ao próximo, já que é inegável que a maior causa de bullying atualmente está relacionada com a sexualidade.

A equidade de gênero e a sexualidade estão inseridos como temas inerentes a dignidade da pessoa humana, e integram o rol dos Direitos Humanos, cabe ao professor conseguir trabalhar de forma a respeitar aos responsáveis e trazê-los para a escola, com intuito de participação, integração e ação, no seio escolar, pois transmitir dos direitos humanos tende a proteger as crianças como atos violentos, seja na escola, na família, ou em qualquer outro ambiente social.

O direito a educação e pautada nos Direitos Humanos, além dos sociais previstos na Constituição, traz o deficiente como possuidor dos mesmos direitos, e ainda de questões especificas direcionadas a permissão do exercício de seus direitos, na escola é possível perceber que houve um aumento significativo no número de alunos deficientes inseridos nas escolas, e isso se deu a partir do estabelecimento de novas formas de inclusão na educação.

Esse aumento de crianças com deficiência inseridas nas escolas fez com que as instituições adaptassem suas instalações físicas e investissem no desenvolvimento profissional do seu corpo docente por meio da facilitação ao acesso a computadores e mudanças na forma avaliativa de tais profissionais, (GUIMARÃES, 2015). 
Se toda pessoa deve ter todos os direitos e liberdades garantidos pelo Estado, esse por sua vez deve permitir e atuar para que o cidadão realmente consiga usufruir de seus direitos e liberdades, podendo ser o simples acesso a uma escola com rampas, ou sinalização adequada, por exemplo, mas caso a escola ou instituição de ensino não possua o mínimo de acessibilidade o direito a educação não será permitido, já que sua execução se torna impossibilitada.

O Atendimento Educacional Especializado (AEE) realiza um trabalho de educação inclusiva, onde fazem uma orientação especial aos professores e alunos sobre os métodos diferenciados de avaliação na escola, que também busca trazer meios de acessibilidade onde eliminem obstáculos para que todos os alunos possam participar das atividades propostas pela escola sem maiores dificuldades, o trabalho direcionado de forma a atender esse público esta de acordo do a aplicabilidade dos direitos humanos.

Para incentivar a especialização dos professores, foi criado o Currículo em Movimento da Educação Básica, de forma a orientá-los no processo de aprendizagem, educação diversificada, educação sobre os direitos humanos, educação sobre sustentabilidade e cidadania.

Porém as ações devem ser conjuntas do Estado, da Escola, e do Professor como agente atuante de mudança, que irá além de receber o aluno com deficiência, vai integrá-lo na turma, e de modo que haja integração entre o aluno deficiente e o não deficiente, considerando que deve adaptar os alunos do grupo considerando suas especificidades, e ensinar aos alunos a igualdade de direitos dos cidadãos que compõem o grupo escolar.

Para que o professor trabalhe com essa perspectiva, os alunos, a escola, precisam preparar-se para receber o aluno com deficiência, pois necessita de um ambiente adequado para seu atendimento, no mais crianças da Educação Infantil notam as diferenças e essas não podem ser negadas, porém cabe ao profissional responsável a integração entre alunos.

Ações afirmativas, tarefas em conjunto, trabalhar a empatia entre as crianças são projetos que tendem a ter um sucesso considerável, pois a criança nasce sem conceito ou preconceito, essas discriminações são 
inseridas em sua formação, esse trabalho não é simples demanda tempo e comprometimento, trabalhar com direitos humanos é um fator determinante para mudança social.

De acordo com o Currículo Referência da Rede Estadual de Goiás, traz, por exemplo, no currículo mínimo de História seja entendido como ponto de partida para se iniciar os estudantes no processo de compreensão histórica, o qual não pode ser aplicado como um roteiro de conteúdos fixos a serem transmitidos em sala de aula.

Pode-se trabalhar na Educação Infantil, por exemplo com poemas/músicas/filmes além de títulos infantis que permitem ao grupo o desenvolvimento, análise e interpretação, além de outras atividades sobre o tema direitos humanos de maneira interdisciplinar.

Ainda de acordo com o documento as expectativas de aprendizagem está em "identificar direitos e deveres do cidadão (criança), no bairro, e sua importância na garantia de qualidade devida aos indivíduos; Reconhecer realidades sociais mais amplas do seu cotidiano; Identificar desigualdades e desrespeito aos direitos do cidadão (criança)" (SEDUC/GO, 2016).

Desse modo, espera-se que o ensino e a aprendizagem de tais conteúdos contribuam para que os estudantes desenvolvam uma reflexão crítica sobre a sociedade onde estão inseridos, bem como do mundo em sua complexidade, e, saibam exercer a sua cidadania fortalecendo a democracia.

\section{CONSIDERAÇÕES FINAIS}

O ambiente escolar é a segunda célula social em que é inserido a criança, daí é inegável que o professor e outros profissionais da escola são parte da formação da criança e fato de que as crianças também são integrantes desse ambiente.

As manifestações de violência são comuns dentro da escola, nas suas mais variadas formas, físicas, psicológicas ou oriundas de preconceitos. Os alunos muitas vezes são a vítima e o autor da prática de violência, porém reproduzem comportamentos de outros ambientes sociais. 
O professor esta nesse meio, pode e deve atuar para que essa prática seja extinta, daí necessário um plano de ação para capacitação dos professores que trabalhem no atendimento de crianças e adolescentes, e possam além de identificar comportamentos violentos, aplicando uma didática de ensino voltado para o ensino interdisciplinar sobre direitos humanos.

A prática docente orientada para modificação social tende a obter mais resultados do que as políticas de segurança públicas tradicionais em somente retirar no meio social o indivíduo que pratica a violência.

O comportamento violento em muitas situações é reproduzido, pois em seu ambiente (familiar, social) essa prática se torna comum, e se torna comum o desrespeito ao próximo, onde a empatia não lhe foi apresentada. Como esperar que um indivíduo veja o outro como semelhante se a sociedade tem praticado a indiferença às minorias, indiferença às diferenças, indiferença para o caos que tem se tornado a sociedade.

Até mesmo os professores devem ser ajudados na melhor execução de ações sobre a temática em seu profissão, a valorização e o respeito à classe de profissionais que realmente podem ser transformadores sociais através de uma educação ativa, não fique somente em discursos, manifestações a vontade de mudar, que se transformem em ações, voltadas para uma Pedagogia Inovadora que respeita, pratica e ensina os Direitos Humanos.

\section{REFERÊNCIAS}

BORTOLINI, Alexandre. Diversidade Sexual na Escola. Universidade Federal do Rio de Janeiro (2006). Disponível em: https:// social.stoa.usp.br/articles/0037/3024/diversidade_sexual_na_escola.pdf> Acesso em: 10 Out. 2018.

BROCHADO, Mariá. Educação em Direitos Humanos como formação da cidadania cultural, p. 61-80. In: CULTURA E EDUCAÇÃO EM FOCO - Coleção Olhares e Reflexões sobre. Direitos Humanos e Justiça SociaL. Volume II. 1ª Edição Revisada, FURG, 2015.

CAMPOS, Luciana Maria Lunardi. Gênero e diversidade sexual na escola: a urgência da reconstrução de sentidos e de prá- 
ticas. Disponível em: http://www.scielo.br/scielo.php?scrip$\mathrm{t}=$ sci_arttext\&pid=S1516-73132015000400001> Acesso em: 10 Out. 2018.

GOMES, Emmanoel. Artigo: Educação, respeito e conhecimento escolar. 2014. Rondônia em Pauta. Disponível em: http:// rondoniaempauta.com.br/nl/educacao/artigo-educacao-respeito-e-conhecimento-escolar/> Acesso em: 24 Out. 2018.

GUimARÃES, Mariana Pires Duarte. A inclusão escolar de pessoas com deficiência física. Trabalho de Conclusão de Curso em Curso de Especialização na Universidade de Brasília - UnB. Brasília/DF, 2015.

HORA, Emile Reis da. Educação na Cidadania: Uma análise da experiência da Escola da Ponte em Santo Tirso, Portugal. Universidade do Estado da Bahia. Salvador - Bahia. 2011. Disponível em: http://www.uneb.br/salvador/dedc/files/2011/05/ Monografia-Emile-Reis-Da-Hora.pdf $>$ Acesso em: 24 Out. 2018.

LOPES, Suelita de Azevedo Xavier. Relação Educação e Cidadania naEscola. Universidade Estadualda Paraíba. 2014. Disponívelem: http://dspace.bc.uepb.edu.br/jspui/bitstream/123456789/9332/1/ PDF\%20-\%20SUELITA\%20DE\%20AZEVEDO\%20XAVIER\%20LOPES.pdf> Acesso em: 10 Out. 2018.

MOTTA, Silvia Lacouth. Diversidade e Diferença: Um desafio da educação infantil. Eixo 03. /universidade de São Paulo. 2011. Disponível em: http://www3.fe.usp.br/secoes/inst/novo/agenda_ eventos/inscricoes/PDF_SWF/14940.pdf> Acesso em: 10 Out. 2018.

OLIVEIRA, Luiz Carlos de. FRAZ, Joeanne Neves. Educação e Respeito: Uma questão social. 2012. Disponível em: https:// pedagogiaaopedaletra.com/educacao-e-respeito-uma-questao-social/> Acesso em 12 Out. 2018. 
PAIVA, Thais. Como a desigualdade de gênero se manifesta na educação das meninas. 2018. Centro de Referências em Educação Integral. Disponível em: https://educacaointegral.org.br/ reportagens/como-a-desigualdade-de-genero-se-manifesta-na-educacao-das-meninas/> Acesso em: 10 Out. 2018.

RAMOS. André de Carvalho. Curso de direitos humanos. 2. ed. São Paulo: Ed. Saraiva, 2015. p. 28.

SALLA, Fernanda. Ensino Religioso e escola pública: uma relação delicada. Nova Escola. 2013. Disponível em: https://novaescola.org.br/conteudo/74/ensino-religioso-e-escola-publica-uma-relacao-delicada> Acesso em: 01 Out. 2018.

SANTOS, Ivone Aparecida dos. Educação para Diversidade: uma prática a ser construída na educação básica. Cornélio Procópio - PR, 2008. Produção didático Pedagógica no Programa de Desenvolvimento Educacional do Estado do Paraná. Disponível em: http://www.diaadiaeducacao.pr.gov.br/portals/pde/arquivos/2346-6.pdf> Acesso em: 01 Out. 2018.

TEIXEIRA, Silvania. Importância de ensinar respeito mútuo nas escolas. 2015. Disponível em: https://www.cpt.com.br/serie-professor-eventual/artigos/importancia-de-ensinar-respeito-mutuo-nas-escolas> Acesso em 26 Out. 2018.

BRASIL. Constituição Federal (1988). Constituição da República Federativa do Brasil. Brasília, DF: Senado; 1988. Disponível em: https://www2.senado.leg.br/bdsf/bitstream/handle/id/518231/ CF88_Livro_EC91_2016.pdf> Acesso em 04 jan. 2019.

. Novo Código Civil. Lei no 10.403 de 10 de janeiro de 2002. Aprova o novo código civil brasileiro. Brasília, DF, 2002. Disponível em: https://edisciplinas.usp.br/pluginfile.php/2466926/ mod_folder/content/0/C\%C3\%B3digo\%20Civil\%20Brasileiro. pdf?forcedownload=1> Acesso em 14 fev. 2019. 
. INEP. Ministério da Educação. Série Documental: Textos para discussão. Brasília - Distrito Federal. 2016. Disponível em: http://portal.inep.gov.br/documents/186968/485287/A+Cor + ou $+\mathrm{Ra} \% \mathrm{C} 3 \% \mathrm{~A} 7 \mathrm{a}+$ nas + Estat $\% \mathrm{C} 3 \%$ ADsticas + Educacionais ${ }^{+-}+$uma + an $\%$ C3\%A1lise+dos+instrumentos + de+ ${ }^{+}$pesquisa ${ }^{+-}$ do+Inep/ef7cf854-0b12-4b6f-945f-4bb8946a7274?version=1.3> Acesso em 26 Out. 2018.

. Ministério da Educação. Gênero e Diversidade na Escola: Formação de Professoras / es em gênero, orientação sexual e relações étnico raciais. Livro de Conteúdo, Versão 2009 Rio de Janeiro: CEPESC, Brasília SMP, 2009. Disponível em: http://estatico.cnpq.br/portal/premios/2014/ig/pdf/genero_diversidade_escola_2009.pdf> Acesso em: 12 Out. 2018.

. PROMUNDO. Portal Equidade de Gênero nas Escolas

(PEGE). Disponível em: https://promundo.org.br/programas/ portal-equidade-de-genero-nas-escolas/> Acesso em: 08 Out. 2018.

SEDUC - GO. Currículo Referência da Rede Estadual de Educação de Goiás. Secretaria de Estado da Educação (SEDUC), do Estado de Goiás. Disponível em: http://www. seduc.go.gov.br/imprensa/documentos/arquivos/Curr\%C3\%ADculo\%20Refer\%C3\%AAncia/Curr\%C3\%ADculo\%20Refer\%C3\%AAncia\%20da\%20Rede\%20Estadual\%20de\%20 Educa\%C3\%A7\%C3\%A3o\%20de\%20Goi\%C3\%A1s!.pdf> Acesso em: 12 out. 2018. 


\section{A MOTIVAÇÃO NAS AULAS DE EDUCAÇÃO FÍSICA NO ENSINO MÉDIO: UM}

Victor Matheus Lopes Martinez

\section{INTRODUÇÃO}

A Educação Física, bem como a Educação em geral no nosso país, vem sendo "sucateada", "deixada de lado" em diversos contextos, algo que posso observar na realidade escolar diariamente. No entanto, nós enquanto docentes, estamos sempre em busca de melhores condições educacionais para os educandos, buscando ao mesmo tempo sempre entender os alunos e compreender os fatores que os motivam a participar das aulas.

Ross e Gilbert (1985) demonstram em seu estudo que a desmotivação para as aulas de Educação Física e atividades físicas em geral é gradativa ao longo das séries escolares e do avanço da idade maturacional.

Tive a oportunidade de vivenciar esta situação no período em que fui aluno do Ensino Médio em uma Escola Pública (2013 - 2015) e quando fui estagiário de Educação Física em atividades extracurriculares, também em uma Escola Pública (2018), onde tive a oportunidade de realizar algumas intervenções pedagógicas com alunos deste nível de ensino. Tais vivências me motivaram a pesquisar sobre esta temática agora em meu Trabalho de Conclusão de Curso.

Tinha-se inicialmente o intuito de investigar a motivação em dois contextos escolares, o público e o privado, no entanto, a Escola do 
contexto privado não se mostrou em nenhum momento receptiva para a execução da pesquisa, o que acarretou em alterações no projeto de pesquisa, permanecendo apenas o contexto público para ser feita a investigação proposta.

Portanto, o estudo em questão apresenta como objetivo geral buscar entender quais são os fatores motivacionais envolvidos na participação de alunos nas suas aulas de Educação Física no Ensino Médio em uma Escola Pública de Porto Alegre/RS. Já, como objetivos específicos, foram elencados os seguintes: Investigar as motivações intrínsecas dos alunos nas aulas de Educação Física no Ensino Médio; investigar as motivações extrínsecas dos alunos nas aulas de Educação Física no Ensino Médio; identificar possíveis fatores que desmotivam os alunos nas aulas de Educação Física no Ensino Médio.

Sendo assim, podemos perceber a relevância do presente estudo ao entendermos que, com os resultados que serão obtidos, podemos identificar aspectos e problemas motivacionais dos alunos no referido nível de ensino, e com base nesses aspectos identificados, buscar uma maior participação destes nas aulas de Educação Física.

$\mathrm{O}$ artigo apresenta inicialmente um referencial teórico sobre o contexto da Educação Física no Ensino Médio, sobre a Motivação e a Desmotivação. Na sequência é apresentado o processo metodológico utilizado para a realização deste estudo, seguido da análise e discussão dos dados coletados. Por fim, são apresentadas as considerações finais a que foram possíveis chegar com a realização deste estudo.

\section{CONTEXTO DA EDUCAÇÃO FÍSICA NO ENSINO MÉDIO}

O Brasil tem em sua última etapa educacional de obrigatoriedade o Ensino Médio. Com duração de três anos, é o período que antecede o ingresso à Universidade e cursos de cunho superior em geral (KRAWCZYK, 2011).

A Educação Física por sua vez é componente curricular da grade escolar desde o Ensino Fundamental, promovendo a saúde corporal e mental e a consciência corporal dos seus alunos. 
Segundo as Orientações Curriculares para o Ensino Médio (BRASIL, 2006), nas aulas de Educação Física neste nível de ensino, não se deve somente ensinar as diferentes práticas corporais aos alunos, mas também fazer com que os mesmos reflitam sobre quais as importâncias e os significados culturais nelas presentes, entendendo mais que o simples jogo ou brincadeira, partindo para a significância sociocultural e a origem do mesmo.

Outro documento de suma importância para a Educação brasileira é a Base Nacional Comum Curricular (BNCC) que foi homologada em 2018 (BRASIL, 2017). Com esse advindo (BNCC) a Educação brasileira teve recentemente uma atualização em seus parâmetros, a qual passa a reger então a Educação Nacional.

No entanto, no que se remete a área de Educação Física, a BNCC é mais explícita no Ensino Fundamental (anos iniciais e finais). Já na etapa do Ensino Médio, a Base acaba relacionando a Educação Física à área de linguagem onde busca o resgate e consolidação dos aprendizados ao longo da trajetória escolar do educando, nos campos da Língua Portuguesa, Arte, Educação Física e Língua Inglesa.

A premissa agora passa também a se instigar os educandos a refletirem sobre tais práticas executadas por eles, fazendo-os entender a importância de criar e manter um estilo de vida ativo para a manutenção da Saúde, assim como também levá-los a exercerem suas cidadanias, questionando-os sobre os espaços públicos e privados em que possam executar as suas atividades aprendidas no âmbito escolar.

Já, o Novo Ensino Médio (BRASIL, 2018) busca considerar o aluno como foco principal, onde os currículos passam a ser compostos pela BNCC e pelos itinerários formativos, buscando uma maior noção de corporeidade e motricidade para com isso angariar uma maior noção de pertencimento do aluno para com suas origens socioculturais.

\section{A MOTIVAÇÃO}

A palavra "motivação" origina-se do verbo em latim "movere", que significa mover para realizar determinada ação. Motivar é apresentar razões para executar ou não determinadas ações, a motivação, portanto, envolve fenômenos emocionais, biológicos e sociais. (MAXIMIANO, 2004). 
Para Weinberg e Gould (2001) a motivação consiste na direção e na intensidade do esforço, sendo a direção do esforço o fato de um indivíduo procurar, se aproximar ou ser atraído por certas situações e a intensidade do esforço refere-se a quanto uma pessoa coloca em determinada situação.

Os autores ainda dividem a motivação em três abordagens: a centrada no traço (defendem que a motivação parte de características individuais, a personalidade), a centrada na situação (ambiente favorável para a motivação) e a visão interacional (que consiste na interação entre indivíduo e situação).

Esta última visão remete a fatores pessoais e fatores situacionais, gerando assim a motivação que parte do indivíduo (a intrínseca) e a que provém do meio externo (a extrínseca).

Samulski (1992) também apresenta a motivação como um processo ativo e intencional dirigido a uma meta, dependendo de fatores pessoais (intrínsecos) e de fatores ambientais (extrínsecos).

\subsection{A Motivação Intrínseca}

A motivação intrínseca condiz a fatores internos do indivíduo em questão, a fatores de personalidade. Samulski (1992) defende então que o ensino deve ser objetivado para o desenvolvimento da automotivação (motivação intrínseca), e com isso ele apresenta algumas técnicas de automotivação, à saber:

- Técnicas cognitivas: Culminam em determinar metas individuais, auto recompensa, imaginação das próprias capacidades;

- Técnicas motoras: Trazem com exercícios isométricos, rítmicos, com base na inspiração, a motivação almejada;

- Técnicas emocionais: Trata sobre o prazer pelo movimento, sensação de sucesso e identificação com o grupo.

Já, o aparecimento da motivação intrínseca, segundo Weinberg e Gould (2001), pode ser dividido em conhecimento, realização e estímulo. Conhecimento remetendo-se a aprender com estímulos novos, realização referindo-se a satisfação pessoal em realizar alguma 
tarefa e estímulo explicitando às sensações provenientes da atividade executada.

Fatores psicológicos são preferidos no que compete à motivação gerada de forma autotélica, porém fatores sociais e externos ao indivíduo podem também alterar a motivação intrínseca, pois como mostra o Continuum de autodeterminação e níveis de auto regulação explicitado por Fernandes e Vasconcelos-Raposo (2005), o indivíduo, em tese, sai de um momento de falta de motivação ou amotivação, migrando para a motivação extrínseca (como dito anteriormente, muitas vezes é o caminho para evoluir à motivação intrínseca), chegando a motivação intrínseca, buscando a autodeterminação.

Autodeterminação, ou self-determination theory (SDT), criada por Deci e Ryan (1981), apresentam a motivação por meio de um continuum saindo da desmotivação até a motivação extrínseca e a intrínseca. Nesta teoria, os autores fazem referência de três necessidades humanas básicas para a SDT, a competência, o relacionamento e a autonomia, sendo, portanto, o nível de satisfação dessas necessidades que causarão no indivíduo a motivação intrínseca, avançando para a autodeterminação do mesmo.

\subsection{A Motivação Extrínseca}

Esse tipo de motivação ocorre quando a atividade é executada por indivíduos que preconizam mais os resultados do que a atividade propriamente dita, ao ponto que caso essas recompensas sejam retiradas, o nível motivacional também será retirado em conjunto. (BIDDLE et al., 2001 apud PIZANI et al., 2014).

Segundo Deci e Ryan (1985), a motivação extrínseca pode ser classificada em três níveis, à saber:

- Motivação Extrínseca Regulação identificada (MERID): É a motivação por meio de benefícios oriundos de uma determinada atividade, pode ser pautada pela expressão "porque quero aprender novas habilidades";

- Motivação Extrínseca Regulação Introjetada (MERIN): a qual condiz com pressões internas, com base na culpa e an- 
siedade, geração de conflitos internos, com medo do fracasso entendido como castigo por não se esforçar;

- Motivação Extrínseca Regulação Externa (MERE): Cuja qual é controlada por recompensas e ameaças, pelo medo da rejeição ou do fracasso. Conforme também apontam Weinberg e Gould (2001), é o nível de motivação mais próximo da desmotivação (amotivação), quase no limite inicial do continuum da autodeterminação.

Para Deci $(1971,1972)$ apud Weiberg e Gould (2001), pessoas recompensadas monetariamente para participar de determinada atividade (extrinsecamente motivadas) participam com um menor tempo do que pessoas que não estavam sendo pagas (motivadas intrinsecamente).

\subsection{A Desmotivação/Amotivação}

A desmotivação ou amotivação também um dos principais sintomas para a não prática ou o simples desinteresse das atividades físicas. Para Deci e Ryan (1985) na teoria da autodeterminação, ou self-determination theory (SDT), a amotivação é a o ponto mais extremo à esquerda do Continuum da Autodeterminação, como já citado, tendo opostamente à direita como extremo a autodeterminação (indivíduo motivado intrinsecamente). Então como citado na teoria da autodeterminação existe os estágios motivacionais, o primeiro deles é a inexistência, ou seja, a desmotivação, seguido de motivação extrínseca (e suas variáveis), intrínseca (e suas variáveis) e autodeterminação.

A falta de motivação, portanto, acontece quando há falta de estímulos oriundos do ambiente externo e interno ao indivíduo (motivação extrínseca e intrínseca), experimentando sentimentos difusos de incompetência e de falta de controle, quando não se importa mais com o que está sendo feito. (WEINBERG e GOULD, 2001).

\section{METODOLOGIA}

Para o desenvolvimento deste estudo, foi utilizada uma metodologia de cunho qualitativo (POPE e MAYS, 2009). A coleta de informa- 
ções foi realizada em uma Escola Pública da Zona Norte de Porto Alegre/RS (Colégio Estadual Carlos Fagundes de Mello). Para a escolha dos alunos que seriam investigados, utilizou-se de uma amostragem não probabilística intencional. (OLIVEIRA, 2005).

Foram investigados 20 (vinte) alunos de duas turmas do $3^{\circ}$ (terceiro) ano do Ensino Médio, sendo 10 (dez) alunos e 10 (dez) alunas, onde foram adotados os seguintes critérios de inclusão: Estar regularmente matriculado(a) no $3^{\circ}$ ano do Ensino Médio; ser aluno(a) da Escola investigada desde o $1^{\circ}$ ano do Ensino Médio; aceitar participar do estudo.

Para a realização da pesquisa, primeiramente foi solicitado à Direção da Escola a autorização para realizar meu estudo, mediante a assinatura de um Termo de Autorização Institucional (TAI). Já, para a análise dos dados obtidos, foi utilizado o método de Análise de Conteúdo, que de acordo com Bardin (1977), é um método dependente do tipo de "fala" e do modo de interpretação. Com esse método realizou-se o cruzamento dos dados das entrevistas com o referencial teórico do estudo.

Quanto aos procedimentos éticos, os participantes do presente estudo não foram submetidos a qualquer transtorno, constrangimento ou desconforto durante as entrevistas, uma vez que tiveram seus dados pessoais preservados. As entrevistas aconteceram de forma consentida pelo participante ou pelo seu responsável legal, nos casos de menores de idade, mediante assinatura do Termo de Consentimento Livre e Esclarecido (TCLE).

A participação na pesquisa ocorreu de modo voluntário, sem remuneração financeira ou de qualquer outro tipo, sendo então os participantes livres para desistirem ou negar a sua participação na investigação em questão.

\section{ANÁLISE E DISCUSSÃO DOS DADOS}

A partir da realização das entrevistas, bem como a obtenção das informações dos autores pertencentes ao referencial teórico e com base nos objetivos específicos, foi possível organizar as seguintes categorias de análise: A motivação Intrínseca nas aulas de Educação Física; A mo- 
tivação extrínseca nas aulas de Educação Física; A desmotivação nas aulas de Educação Física.

\subsection{A motivação intrínseca nas aulas de Educação Física}

Ao questionarmos os estudantes entrevistados sobre como ou o que os motivam a participar das aulas de Educação Física, as respostas obtidas no que se referem à motivação intrínseca nos apontam que, a maioria, exceto os quadros de amotivação, se motiva intrinsecamente por dois principais vieses: A motivação relacionada com determinada atividade física ou Esporte da preferência do aluno e com o prazer proporcionado pela experimentação desta atividade; e, a motivação baseada na consciência dos benefícios provenientes da atividade física para o bem-estar social, emocional e físico (qualidade de vida do ser humano).

Podemos identificar a motivação intrínseca baseada na execução de determinada atividade ou esporte, quando perguntado aos alunos entrevistados o que os motiva a participar e o que gostam nas respectivas aulas. Algo de possível observação nas seguintes falas:

[...] prazer mesmo, eu gosto de jogar futebol, de atividade física, de[...] é eu gosto de jogar. (ALUNO 1).

Ah, corrida né, para manter o ritmo que é um negócio que está sempre no nosso dia-a-dia, e um futebol por causa que tá no sangue [risos] né. (ALUNO 7).

Já, quanto à citada motivação intrínseca pautada nos benefícios físicos, sociais e emocionais (qualidade de vida) oriundos da prática de atividades físicas, podemos identificá-la nos seguintes relatos abaixo:

O que me motiva acho que é a questão de me manter bem de saúde, para não ter nenhum tipo de problema futuro. (ALUNO 13).

Hã porque eu fico pensando "que faz bom né", tipo, pra saúde, porque se parar para pensar eu não faço isso em casa e se não tem 
aula para fazer isso eu não tenho, não tenho hora para fazer... daí eu me sinto bem, daí eu faço com vontade. (ALUNA 16).

As falas dos alunos entrevistados vão ao encontro do que Weinberg e Gould (2001) explicam sobre a motivação intrínseca, acerca da divisão da mesma em: Conhecimento, como forma de aprender novas habilidades e de Estímulos, oriundos do ambiente e da atividade, ou seja, as causas da ação motivam a agir.

Essas duas formas relacionam-se diretamente com a motivação intrínseca obtida por meio do saber, da conquista do bem-estar, algo perceptível na fala abaixo do aluno 15 , por exemplo.

É os colegas, os amigos ali, a professora também, que tá sempre ali brincando com a gente né, hã incentivando ali, 'ah façam esporte, é bom pra saúde', e também porque é uma atividade da Educação Física, ela ajuda muito o nosso organismo né, a manter o açúcar equilibrado, o corpo saudável, para não ficar todo, como é que se diz? ...todo entrevado, e ficar sempre com disposição para fazer as coisas, porque sem esporte as pessoas, elas são pessoas bem sonolentas, não tem vigor para fazer nada, mesmo sendo jovens, só gostam de ficar dentro de casa, não gostam de se relacionar com outras pessoas, através do esporte, além do esporte ser uma inclusão social né, todo mundo consegue ser amigo, hã perder a timidez através dos esportes. (ALUNO 15).

Há ainda outra situação que envolve a Motivação Intrínseca, a qual Weiberg e Gould (2001) explicam que é a Realização, funcionando como uma forma de satisfação própria do indivíduo, algo identificável na apresentação dos alunos frente à motivação pautada na execução de determinados esportes ou atividades físicas, das quais os mesmos têm um nível de prazer em executá-las, e com isso realizando-se pessoalmente.

O simples fato da realização de tais práticas corporais pelos alunos já os aproximam da Self-Determination Theory (SDT) sobre o continuum da autodeterminação de Deci e Ryan (1985), no momento em que estes autores consideram que a SDT é esse continuum, cujo qual parte da desmotivação, passando pela motivação extrínseca até a mo- 
tivação intrínseca e automotivação. Sendo assim, para migrar de uma extremidade para a outra, se faz necessário satisfazer três necessidades básicas inerentes ao ser humano, a competência, o relacionamento e a autonomia.

Quanto à SDT ou automotivação, uma das necessidades para se tê-la, como explicado, é o relacionamento, relacionamento este com os demais praticantes, mas, sobretudo com a ação a ser realizada, algo identificável em um trecho da entrevista com aluna 3, citado abaixo.

Eu gosto de me alongar, primeiro a gente caminha assim ou corre assim e depois se alonga [pausa longa] é bom né por daí “coiseia” os músculos e estrala o corpo. (ALUNA 3).

Ou seja, com tal afirmação podemos perceber que sim, há um relacionamento da aluna em questão para com a prática citada pela mesma, há envolvimento, ela sente a melhora em sua qualidade de vida, algo extremamente essencial para a SDT defendida por Deci e Ryan (1985), pois relacionar-se e entender os benefícios alcançáveis é um grande fator incentivador, uma vez que se o indivíduo percebe e apropria-se do motivo para se executar algo e este motivo é positivo, a motivação é gerada.

Com base no exposto acima, percebemos que quando se gosta do que se executa, ou ainda, quando se entende e se percebe os benefícios inerentes à determinada ação, a motivação sempre será maior.

Portanto, se a motivação gerada de forma intrínseca se dá pelo entendimento dos benefícios que a atividade trará ou pelo gosto particular de determinado esporte ou exercício físico, entendemos que o professor de Educação Física deve buscar ser o principal motivador do ambiente externo (aula), para assim potencializar a motivação interna nos alunos.

\subsection{A motivação extrínseca nas aulas de Educação Física}

A motivação extrínseca, como descrita por Pizani et al. (2014) é todo e qualquer comportamento que pode induzir determinado indivíduo a realizar uma tarefa subsidiado em uma recompensa posterior. 
Ao analisarmos as falas presentes nas entrevistas, é possível identificar principalmente a motivação extrínseca sobre o viés descrito por Samulski (1992), onde explica este tipo de motivação como sendo passível de duas principais atribuições externas, por meio incentivos e por dificuldades e problemas, situações estas determinantes para a prática ou não de qualquer atividade física.

A motivação extrínseca está presente no meio do continuum da autodeterminação, entre a desmotivação e a motivação intrínseca, com isso entende-se que a mesma faz parte do processo propulsor para se atingir os estágios mais elevados de motivação nos indivíduos.

A motivação extrínseca como pode ser percebida, é o ponto de partida rumo à motivação intrínseca e posteriormente para a automotivação, porém é um ponto "perigoso", pois um indivíduo que executa qualquer ação baseado em ganhos posteriores, por exemplo, quando não tiver mais tais ganhos, a motivação acabará.

Com esse fato, tal meio de motivação é criticado por diversos autores (DECI e RYAN, 1985; WEINBERG e GOULD, 2001; PIZANI et al., 2006), pois além de estar muito distante da preferida SDT, não é um motivação autentica do indivíduo, como Deci e Flaste (1995) esclarecem que, além de não haver necessariamente esta identificação da pessoa para com a prática, o que pode levar a prática antiéticas para se obter os resultados, a busca e os resultados inerentes a motivação extrínseca são muito menores do que em indivíduos motivados intrinsecamente.

No que se refere a motivação extrínseca, mais especificamente em relação a motivação extrínseca identificada- MERID (DECI e RYAN, 1985), na qual a motivação está baseada nos benefícios dos meios externos em relação ao indivíduo, identificamos este tipo de motivação nas seguintes falas dos alunos entrevistados abaixo, quando os mesmos reconhecem que a professora exerce um papel de motivador nas aulas:

Acho que é por causa da professora mesmo, ela é muito carismática, puxa com a pessoa para participar, ela não fica forçando. (ALUNO 8).

Eu vejo a preocupação da professora só, de querer que a gente se enturme, querer que a gente tenha, hããn, como eu já disse 
ser saudável, porque ela diz que vê um pessoal ai muito jovem só em casa nas redes sociais sem fazer nada da vida e o esporte motiva as pessoas a querer mais, buscar mais, as vezes as pessoas começam, bem devagarinho, má daqui a pouco já tão naquele pique chamando mais gente, é isso que eu vejo mais a sora fazer, incentivando caminhada, caminhar eu acho muito importante porque ajuda nós a como é que se diz?... A nossa, eu só estou usando saúde (risos) mas é o que mais vejo assim, a Educação Física como algo saudável. (ALUNO 15).

Já, baseando-se também a motivação extrínseca conforme a motivação extrínseca regulação externa - MERE (DECI e RYAN, 1985), entendida como o medo do fracasso e pautada em recompensas, foi observar sua incidência em poucos alunos entrevistados, conforme os relatos abaixo:

Eu acho que eu participo só por causa da nota. (ALUNA 2).

Eu acho que é a mais a questão [pausa] no momento é questão de que, de que tem que fazer [...]porque senão eu não faria. (ALUNA 6).

No entanto, há ainda outro ponto de suma relevância a ser ressaltado, que é a variação das atividades ministradas nas aulas. Segundo os relatos obtidos com as entrevistas, a maioria dos alunos citou que se motivaria mais se a professora variasse as metodologias, os esportes e as práticas corporais em geral aplicadas nas aulas, isto é, saísse da mesmice apontada pelos alunos. Algo perceptível em algumas das seguintes falas abaixo:

Acho que poderia motivar um pouquinho mais, como sempre os guris que [risos] que dominam [...] acho que se ela (a professora) fosse um pouco mais exigente acho que daria para dar uma variada nas aulas... nos jogos às vezes um basquete, um vôlei, um handebol [...]. (ALUNO 4).

Procurar fazer esportes diferentes, tipo basquete a gente não joga muito, vôlei é só às vezes, é mais futebol mesmo, e tipo, a 
gente poderia até jogar tênis no caso... eu jogo tênis fora daqui e eu acho que seria no mínimo interessante a gente praticar um pouco. (ALUNA 11).

Portanto, entende-se que a participação dos alunos nas aulas, levando em conta o viés extrínseco, se dá com base no professor (a) (MERID), na nota (MERE) e na aula em si, ou seja, o professor com sua didática e variedade nas propostas apresentadas em aula motiva os alunos a executarem as respectivas as aulas, fugindo da motivação baseada na simples aprovação na atividade curricular e na sua obrigatoriedade.

Desta forma, acredito que a função do professor, na busca de deixar os seus alunos mais motivados à participarem de suas aulas, seria a de desenvolver diferentes metodologias em suas aulas, para variar não somente os conteúdos, mas também a forma de ministrá-los, para com isso apresentar uma maior gama de atividades física, das quais os alunos possam se interessar para posteriormente levá-las para a vida adulta.

\subsection{A desmotivação nas aulas de Educação Física}

Ao perguntarmos aos alunos sobre o que os desmotivavam a participar das aulas de Educação Física, e até mesmo no que diz respeito ao que os motivava, uma minoria apresentou respostas condizentes com a presença de desmotivação. Percebi também que alguns outros alunos entrevistados, que apresentavam a motivação extrínseca em participar de suas aulas de Educação Física, apresentavam também certa desmotivação em determinados momentos em participar das aulas.

Segundo estes alunos entrevistados, a desmotivação viria relacionada à metodologia praticada pela sua professora nas aulas e devido a alguns acontecimentos que porventura ocorrem no desenvolvimento das aulas, como por exemplo, brigas e discussões entre os alunos. Estas situações foram possíveis de ser identificadas nas seguintes falas abaixo dos alunos:

Éééé... o que me desmotiva? Talvez seja só caminhar, daí fica, bah coisa chata só caminhar, não tem outra coisa, não tem variedade. (ALUNA 9). 
Quando tem alguma briga, uma discussão entre eles no caso, isso desmotiva. (ALUNO 11).

Porém, tive também a possibilidade de identificar alguns alunos com total desmotivação para participar das suas aulas de Educação Físi$\mathrm{ca}$, principalmente quando foi perguntado aos alunos sobre o que mais gostam nas suas aulas de Educação Física, conforme pode ser observado nos relatos a seguir:

Nada, não gosto de exercício físico porque me canso muito e, é chato. (ALUNA 10).

O desinteresse do pessoal, isso sim, a desmotivação do pessoal me desanima. (ALUNO 8).

Neste sentido, levando em consideração o exposto sobre a motivação e a desmotivação presente nos alunos conforme a entrevista podemos perceber que tal falta de motivação se dá com base na inexistência de identificação e significância que os alunos têm para com as atividades físicas, assim como Weinberg e Gould (2001) descrevem que a amotivação é algo decorrente de um déficit de auxílios e estímulos provenientes do ambiente externo e interno em relação ao ser humano, sendo assim uma falta de importância do indivíduo para com o que se está fazendo.

Diferente do que ocorre em indivíduos motivados intrinsecamente e extrinsecamente, os indivíduos desmotivados não tem qualquer tipo de ligação que os façam querer executar a prática em questão. Conforme Deci e Ryan (1985), também esclarecem no continuum da autodeterminação, a desmotivação é o ponto limítrofe, ou seja, para sair dela é necessário gerar uma motivação extrínseca no indivíduo fazendo o mesmo enxergar um sentido na prática, e então somente após se almejar uma motivação intrínseca.

Com base nos relatos dos alunos entrevistados e na relação com o referencial teórico acerca da desmotivação, tive o entendimento que a falta de motivação nos alunos se dá por uma não conexão destes com as atividades realizadas nas aulas de Educação Física, e até mesmo por uma baixa motivação extrínseca, isto é, quando o que é ofertado pelo 
ambiente da aula é insuficiente, conforme o ponto de vista dos alunos, para motivar suas participações.

Outro ponto de relevância a ser citado, é o fato de que os alunos que apresentaram quadros de completa desmotivação são todos do sexo feminino, o que pode indicar, ao menos no contexto estudado, que a desmotivação nas aulas de Educação Física se faz presente mais fortemente no público feminino. Algo que pode ocorrer por uma série de fatores não estudados no presente estudo, desde fatores sociais e de gênero, como em respeito às vivências ao longo da vida estudantil destas alunas.

Portanto, se fortalece ainda mais a importância do professor desenvolver em suas aulas uma diversidade de conteúdos e de propostas inovadoras, para que desta forma ele tenha a possibilidade de resgatar aqueles alunos que apresentam quadros de desmotivação nas suas aulas, demonstrando para estes que as aulas de Educação Física podem ser prazerosas e que podem contribuir para o bem estar social, físico e mental deles.

\section{CONSIDERAÇÕES FINAIS}

Com base na realização do presente estudo sobre a Motivação nas aulas de Educação Física no Ensino Médio, foi possível identificar que, dentre os alunos investigados, a motivação para a participação nas aulas de Educação Física se dá majoritariamente pelo viés intrínseco, onde estes se sentem motivados principalmente pelo gosto da prática de determinado Esporte ou então pelo entendimento dos benefícios atribuídos à prática regular de atividades físicas.

Referente à motivação extrínseca, percebi que, mesmo com a incidência deste tipo de motivação ser menor em relação à motivação intrínseca, a mesma apresentou forte influência nos alunos, tendo como principais aspectos relacionados a esta motivação: As aulas e seus acontecimentos (exercícios propostos em aula e a participação dos demais alunas nas respectivas atividades), a motivação gerada pela própria professora e a recompensa da nota a ser atribuída pela professora no boletim escolar. 
Já, quanto à desmotivação dos alunos para participarem das aulas de Educação Física, identifiquei poucos alunos apresentando desmotivação. Esta desmotivação identificada vinha da falta de diversidade nos conteúdos aplicados no decorrer das aulas de Educação Física, às quais acabavam contemplando na maioria das vezes a prática do futebol/futsal e voleibol, sem muitas variações.

Frente ao cenário investigado em relação ao modo como os alunos se apresentavam motivados e desmotivados a participarem de suas aulas de Educação Física, penso que deva ocorrer na Escola investigada uma maior conscientização para a importância de cuidar do corpo, além de uma maior variedade nos conteúdos a serem ensinados.

Neste sentido, sugere-se que haja um maior número de investigações desta mesma natureza, na busca de estarmos desenvolvendo as aulas de Educação Física no Ensino Médio para alunos que estejam cada vez mais motivados e envolvidos com o este processo.

\section{REFERÊNCIAS}

BALBINOTTI M. A. A., ZAMBONATO F., M. L. L. BARBOSA, R. P. SALDANHA \& C. A. A. BALBINOTTI. Motivação à prática regular de atividades físicas e esportivas: um estudo comparativo entre estudantes com sobrepeso, obesos e eutróficos. Motriz, Rio Claro, v.17 n.3, p.384394, jul./set. 2011.

BARDIN, Laurence. Análise de conteúdo. Lisboa: Edições 70, 1977.

BRASIL. Secretaria de Educação Básica. Ministério da Educação. Orientações Curriculares para o Ensino Médio - Linguagens, códigos e suas tecnologias. Brasília, 2006.

BRASIL. Base Nacional Comum Curricular (BNCC). Educação é a Base. Brasília, MEC/CONSED/UNDIME,2017. Disponível em: < 568 http://basenacionalcomum.mec.gov.br/images/ BNCC_publicacao.pdf>. 
BRASIL. Ministério da Educação. Novo Ensino Médio. Brasília, 2018. Disponível em: http://novoensinomedio.mec.gov.br/

DA SILVA, Ana Beatriz. A motivação dos alunos nas aulas de Educação Física no Ensino Médio. Monografia (Trabalho de Conclusão de Curso) - Universidade do Vale do Rio dos Sinos, São Leopoldo, RS, 2017.

DECI, E, RYAN, RM. Intrinsic motivation and self-determination in human behavior. New York: Plenum Press; 1985.

DECI; FLASTE. Why We Do What We Do: understandig self-motivation. Penguin Books, 1995.

ENGELMANN, Erico. A motivação de alunos dos cursos de artes de uma Universidade Pública do Norte do Paraná. Dissertação (mestrado) - Universidade Estadual de Londrina, PR, 2010

FERNANDES, Helder Miguel; VASCONCELO-RAPOSO, José. Continuum de Auto-Determinação: validade para a sua aplicação no contexto desportivo. Estud. psicol. (Natal), Natal, v. 10, n. 3, p. 385-395, Dec. 2005.

KOBAL, Marilia Correa. Motivação intrínseca e extrínseca nas aulas de Educação Física. 1996. 176f. Dissertação (mestrado) - Universidade Estadual de Campinas, Faculdade de Educação Física, Campinas, SP.

KRAWCZYK, Nora. Reflexão sobre alguns desafios do ensino médio no Brasil hoje. Cadernos de pesquisa v.41 n.144 set./ dez. 2011.

MAXimiano, A. Teoria Geral da Administração. São Paulo. Editora Atlas, 2004.

OLIVEIRA, Eduardo Henrique de. Motivação nas Aulas de Educação Física: perspectiva dos alunos do ensino fundamental. 2018. Dissertação (Mestrado em Educação) - Faculdade de Filo- 
sofia, Ciências e Letras de Ribeirão Preto, Universidade de São Paulo, Ribeirão Preto, 2018.

OLIVEIRA, Maria de. Como fazer pesquisa qualitativa. 3. Ed. Revista e ampliada - Petropólis, RJ: Vozes, 2005.

PALUDO, Daniela Prado. A motivação das Aulas de Educação Física para Estudantes do Ensino Médio. Monografia (Trabalho de Conclusão de Curso) - Universidade Federal do Rio Grande do Sul, Porto Alegre, RS, 2015.

PIZANI et al. (Des) motivação na Educação Física escolar: uma análise a partir da teoria da autodeterminação. Revista Brasileira de Ciências do Esporte, vol. 38, n. 3, p. 259 - 266, jul - set. 2016.

POPE C, MAYS N, organizadores. $3^{\underline{a}}$ ed. Pesquisa Qualitativa na Atenção à Saúde. Porto Alegre: Artmed, 2009.

ROSS, J.G.; GILBERT, G.G. The national children and youth fitness study: a summary of finding. Journal of Physical Education, Recreation and Dance, v.56, n.1, p.45-50, 1985.

SAMULSKI, Dietmar Martin. Psicologia do Esporte: teoria e aplicação prática. 1. Ed. Belo Horizonte: Universidade Federal de Minas Gerais, 1992. 167 p.

SILVA, Adriana Lúcia Leal da. Fatores Motivacionais a Prática das Aulas de Educação Física dos Estudantes do Ensino Médio, das Escolas Públicas Estaduais da Cidade de Humaitá-AM. 2018.174 f. Dissertação (Mestrado em Ensino de Ciências e Humanidades) - Instituto de Educação, Agricultura e Ambiente, Humaitá, Amazonas, 2018.

WEINBERG, Robert S.; GOULD, Daniel. Fundamentos da Psicologia do Esporte e do Exercício. 2. Ed. Porto Alegre: Artmed, 2001. 


\section{A GEOGRAFIA CRÍTICA COMO ABORDAGEM DE ENSINO NA CONSCIENTIZAÇÃO POLÍTICA DOS OPRIMIDOS E NA DEFESA DA EDUCAÇÃO EM DIREITOS HUMANOS}

Magno Henrique de Medeiros Rodrigues

\section{INTRODUÇÃO}

O artigo tem como principal premissa esclarecer os desafios que a educação se encontra por causa de um ensino tradicionalista que proporciona a perpetuação do preconceito e alienação perante os problemas sociais, econômicos e políticos que afetam todas classes populares, inclusive os alunos da rede pública. Destarte, a pesquisa discorre sobre a importância da atuação dos professores em se opor a essas circunstâncias através da conscientização política e da manutenção dos direitos humanos.

Dessa maneira, a tarefa de conscientizar não é fácil. Há inúmeros óbices que limitam e enfraquecem as instituições de ensino no papel emancipatório, principalmente no setor político que sabe o poder que a educação tem em tornar uma sociedade transformadora do mundo em sua volta. Por isso, os educadores também são oprimidos por parte de leis que tentam coibir e limitar sua forma de ensinar através de movimentos como a "escola sem partido", pela falta de investimento 
em determinadas áreas como as ciências humanas e pela desvalorização salarial e profissional da classe.

Diante dos problemas citados, manter as pessoas alienadas em face da intensificação das desigualdades em prol da permanência das classes burguesas, ao mesmo tempo que inibem escolas com capacidade de formar uma classe oprimida consciente dos males que os afligem, são atitudes que governos opressores utilizam para se manterem no poder. Nesse seguimento, entende-se que quanto mais a população se afasta das questões políticas, maior a liberdade que políticos mal-intencionados têm de governar. Mas, para isso, o controle da educação se torna crucial para favorecer os interesses dos exploradores, e é nessa lógica, que Saviani e Duarte assumem um posicionamento contrário, quando afirmam:

O que marca a educação escolar em contraposição em uma sociedade capitalista, é favorecer os interesses das classes trabalhadoras através da produção de conhecimento sobre a educação e no plano da construção teórica e prática de uma pedagogia que fortaleça o trabalho de produção direta e intencional, em cada aluno e em todos os alunos, do domínio dos conhecimentos necessários ao seu pleno desenvolvimento como seres humanos. (SAVIANI E DUARTE, p. 2-3, 2012)

Face ao exposto, os diálogos bibliográficos decorrentes na pesquisa se dividem em três campos teóricos: Primeiro, nos desafios que a educação, especificamente os professores de geografia se deparam através da didática tradicionalista e como essa forma de ensinar prejudica o empoderamento dos oprimidos e das minorias; segundo, como relacionar os conteúdos com a realidade dos alunos, para assim, eles se tornarem politizados e transformadores do seu mundo; e por fim, terceiro, mostrar como s abordagens de ensino devem agir baseada nos pressupostos do direitos humanos para construir uma classe que lute por esses direitos, mobilizando-se e recalcitrando contra toda forma de opressão.

Portanto, torna-se "imperioso e urgente substituir esta educação tradicional por uma outra educação orientada por disposições críticas 
e permeáveis, favoráveis à participação, à deliberação coletiva, favoráveis à democratização da vida social" (BEISIEGEL, 2010, p. 36). Em outras palavras, continuar com o ensino neutro consiste em legitimar a banalização do discurso de ódio, o ressurgimento de políticos de vieses fascistas e a contínua manutenção de uma sociedade alienada que defende, contraditoriamente, o corte dos seus próprios direitos por causa de discursos demagogos.

Sabendo disso, é importante compreender que a educação deve se centralizar como agente libertador e emancipatório através do entendimento político e na defesa dos direitos humanos. Pois, ensinar conteúdos por si só não são mais suficientes para formação dos cidadãos, até porque, como se explica a um determinado aluno sobre os impactos ambientais, se não correlacionar esse problema com a política neoliberal da flexibilização das leis ambientais?

\section{REFERENCIAL TEÓRICO}

\subsection{OS DESAFIOS DA GEOGRAFIA CRÍTICA PARA A SUPERAÇÃO DO ENSINO TRADICIONALISTA}

O tradicionalismo no ensino foi um método vigente que perdurou por décadas em todas as áreas da educação, inclusive na ciência geográfica que se tornou, no decorrer do tempo, conteudista e neutra diante de todos os problemas sociais contemporâneos em que o país apresentava. Além disso, essa forma de ensinar consistia principalmente na memorização de informações com a direção e determinação limitada e centralizada pelo professor, fazendo com que o aluno fosse apenas um agente passivo de um conhecimento alienante da realidade em sua volta. (VLACH, 2013)

Vale lembrar que a sociedade vive de acordo com o sistema capitalista que se reflete numa educação tradicionalista que esteve na maior parte do tempo vinculada ao ensino neoliberal, isto é, atendendo apenas as demandas técnicas e profissionais a favor dos poderosos em detrimento da desvalorização do conhecimento crítico-reflexivo por parte dos alunos, porém, com as novas demandas da sociedade e fracasso de tal sistema, essa metodologia se tornou ultrapassada. (FREIRE, 2011) 
Em vista disso, segundo Straforini (2008), é notável que esse método tradicionalista ainda persiste nas escolas mesmo diante de todos os esforços por parte dos docentes. E muitos alunos percebem essa falta de aprofundamento da sua realidade social por causa de um ensino que só se preocupa com a memorização específica de conteúdos transmitidos pelo docente através de suas aulas expositivas.

Essa perspectiva se agrava ainda mais com os recursos restritos que os professores das áreas sociais se encontram perante a falta de investimentos governamentais ou pela escassez da disponibilização de suporte, os quais, às vezes as escolas só oferecem mapas ou globos, tornando o ensino cada vez mais incapaz de integrar e abarcar todo o dinamismo por trás dos seus conceitos, tornando-se, assim, uma disciplina apática à reflexão do mundo. Para Rincón:

Os jovens e adultos que já estudaram geografia acham que é uma disciplina de memorização, que só tem objetivo oferecer informações básicas sobre a localização e a distribuição de fatos e fenômenos geográficos locais, estatais, nacionais, mundiais e/ou universais. Ressaltam que os conhecimentos que adquirem não têm aplicação em sua vida diária. (RICÓN, p. 56, 2013)

Outro ponto possível de questionamento, de acordo com Penna (2018) ocorre através da imposição na forma como o professor deve ser expressar em sala de aula a partir da escola sem partido. Ou seja, a educação crítica encontra diversos óbices no seu trajeto pedagógico, pois além da desvalorização da classe, a defesa da escola sem partido constitui uma grave ameaça ao pensamento reflexivo dos alunos. Pois, esse movimento defende apenas que a família e a religião podem educar, enquanto os professores devem se restringir a instruir os alunos com o único objetivo de qualificá-los para o trabalho.

Posto isso, as ciências humanas ainda têm que se preocupar pelos embargos e desvalorização que governos de vieses repressores aplicam na categoria em prol das outras ciências que não se envolvem com política ou questões sociais. Segundo Pontuschka (2013, p. 282) "as chamadas ciências exatas e biológicas sempre receberam maiores estímulos 
e financiamentos, que permitiram maior avanço, em detrimento das ciências ditas humanas".

Partindo desse ponto, os investimentos em ciências que tem retorno lucrativo e que são neutras perante a política e economia vigente são mais atrativas para políticos corruptos. Todavia, há grandes consequências quando o conhecimento científico mostra neutralidade diante dos assuntos dessa plenitude, pois, além de distanciar os alunos desse contexto, as pessoas que determinam os recursos para as pesquisas são as próprias entidades políticas ou agentes privados que querem privar a liberdade do professor. Assim, de acordo com Harari:

A maioria dos estudos científicos são financiados porque alguém acredita que eles podem ajudar a alcançar um objetivo político, econômico ou religioso, ou seja, a ciência é incapaz de estabelecer suas próprias prioridades. Também é incapaz de determinar o que fazer com suas descobertas o que, geralmente, são condicionadas por governos mal-intencionado". (HARARI, 2018, p. 281 e 284)

Contudo, contrapondo-se a todos os obstáculos expostos, ainda assim, Vesentini (2013) reflete que as ciências humanas não podem deixar de serem contundentes e inseridas no contexto social da sua escola e do seu país. Proporcionalmente, não deve permitir que o conhecimento se direcione no caminho da justificação do abuso de poder. Por isso que a geografia tradicionalista foi combatida pela geografia crítica, que procurou substituir os aspectos mnemônicos das abordagens pragmáticas de seus conteúdos pelo desenvolvimento de competências que permitem saber observar o espaço de forma crítica e ter a capacidade de atuar na solução dos problemas, seja lutando pelos seus direitos, seja combatendo as desigualdades sociais. Partindo desse quadro teórico, o autor continua:

Desde o seu nascedouro, a geografia crítica encetou um diálogo com a teoria crítica (isto é, com os pensadores da Escola de Frankfurt), com o anarquismo (Réclus, Kropotkin), com Michel Foucault, com Marx e os marxismo ( em particular os 
não dogmáticos, tal como Gramsci, que foi um dos raros marxistas a valorizar a questão territorial), com os pós-modernistas e várias outras escolas de pensamento inovadoras. (Vesentini, 2013, p.223)

É importante dizer que esse novo método geográfico está vinculado com os movimentos sociais que buscam ampliar os direitos humanos através da luta pela moradia, pelo acesso à terra ou à educação de boa qualidade, pelo combate a pobreza, aos preconceitos de gênero, de cultura ou etnia tanto de alunos da zona urbana quanto rural. Ribeiro e Oliveira (2017, p. 2) acrescenta: “é necessário uma reflexão da forma como o Ensino de Geografia aparece como pratica pedagógica voltada para emancipação do aluno, fornecendo meios para pensar criticamente e olhar o mundo ao seu redor forma diferenciada"

A partir dessas análises, Santos (2004) esclarece que o surgimento de novos problemas que a sociedade se encontra, novas teorias apareceram para abranger e incluir esse novo setor que não é mais devidamente explicado pela teoria tradicional. Uma vez que, chegou o tempo em que uma nova geografia foi criada para reconhecer no espaço, trabalhado pelo homem, uma causa de tantos males que o afligem no mundo atual. Ao discorre sobre o assunto, Santos conclui:

Os geógrafos, ao lado de outros cientistas sociais, deve se preparar para colocar os fundamentos de um espaço verdadeiramente humano, um espaço que una os homens por e para seu trabalho, mas não para em seguida os separar entre classes, entre exploradores e explorados; um espaço matéria inerte trabalhado pelo homem, mas não para se voltar contra ele; um espaço, a natureza social aberta à contemplação direta dos seres humanos, e não um artifício; um espaço instrumento da reprodução da vida, e não uma mercadoria trabalhada por uma mercadoria, o homem artificializado. (SANTOS, 2004, p. 267)

Assim, essa nova geografia deve ser entendida como a leitura da realidade do aluno, da não-neutralidade, da não-omissão diante da opressão política, do engajamento do comprometimento da manutenção da justiça social e da correção das desigualdades, mas para isso, 
deve-se mostrar aos alunos que o fracasso não é natural, e que pessoas nesse núcleo de ofendidos não tem escolha a não ser, ter a consciência da sua realidade para intervir e transformá-lo. (FREIRE, 2017)

\subsection{AS PRINCIPAIS ABORDAGENS CRÍTICAS DA GEOGRAFIA NA CONSCIENTIZAÇÃO E EMANCIPAÇÃO DOS OPRIMIDOS}

O discurso atual que predomina no panorama da política nacional consiste, abertamente, na propagação do ódio e do preconceito. Para completar, as pessoas com pensamentos similares estão se sentindo cada vez mais representadas, sentindo-se no direito de tiranizar. É nesse contexto, que a geografia crítica deve se tornar um agente para o combate contra a banalização dessa cultura opressora, ao mesmo tempo que estabeleça em sua base uma filosofia que não permita que essas condutas alcancem ou se tornem comum em sala de aula. Pois de acordo com Verdi, há dois pressuposto que se deve considerar na difusão do ódio no Brasil:

Primeiro, e mais evidente, a situação política em que o país se encontra hoje, quando nos deparamos com a ascensão do fascismo e, com ele, a escalada da violência, cuja representação máxima é a figura do presidente eleito Jair Bolsonaro; segundo, a necessidade de pensarmos sobre a relação entre o movimento do pensamento e o movimento da realidade, ou seja, sobre as exigências que a realidade impõe aos que nos propomos a desvendá-la. (VERDI, 2018, p. 3)

A autora deixa claro que são nesses cenários o qual o fascismo persiste em ressurgir que a educação mostra sua competência em combater tais movimentos antidemocráticos. No caso do Brasil, foi no surgimento da ditadura civil-militar que a geografia crítica se fortaleceu e se proliferou em um momento de repressão, fazendo um contrapeso ao reelaborar epistemologicamente como um conhecimento que produz uma explicação da realidade social, econômica e política do país (VERDI, 2018). 
Seguindo essa vertente, a classe docente não deve se omitir em explanar ao aluno a situação política nas contextualizações dos seus conteúdos, alertando sobre todo tipo de desigualdade, injustiças e ineficiências das políticas públicas em mudar esse quadro. Paulo Freire (2017, p. 78) acrescenta: "não posso proibir que os oprimidos numa favela votem em candidatos reacionários, mas tenho o dever de adverti-los do erro que cometem”. Em vista disso, Luckesi também afirma que esse é o papel do professor quando afirma que:

Tanto do ponto de vista do sistema educativo (governo federal, estadual e municipal) quanto do educador "é preciso estar interessado em que o educando aprenda e de desenvolva, individual e coletivamente". A nosso ver, esse é um princípio político-social importante da atividade escolar. (LUCKESI, p. 140, 2011)

Por isso, uma maneira de enfrentar a opressão advindas tanto do meio político quanto de outra instituição consiste na conscientização desde da base, pois defender a democracia garante que nossos direitos e proteção sejam assegurados. Assim sendo, a emancipação política, primeiramente deve se iniciar na escola pública, proporcionando uma escolarização gratuita, assegurando a todos as condições de assimilação dos conhecimentos que sustente os princípios de igualdade e da diversidade, além de difundir uma base científica para que os alunos se tornem críticos e independentes. (LIBÂNEO, 2013)

Ainda nesse contexto, é necessário que o professor se expresse livremente e que proporcione essa liberdade de expressão ao aluno, incentivando-o a problematizar os acontecimentos ao seu redor e instigar que tenham críticas argumentativas, ao mesmo tempo que tenha atitude em modificar tal realidade, pois Libâneo continua:

O trabalho docente constitui o exercício profissional do professor e este é o seu primeiro compromisso com a sociedade. Sua responsabilidade é preparar os alunos para se tornarem cidadãos ativos e participantes na família, no trabalho, nas associações de classe, na vida cultural e política. (LIBÂNEO, 2013, p.48) 
Nessa proposição, a soberania dos oprimidos consiste principalmente na atuação dos professores em criar um ambiente escolar que contribua em desenvolver, além dos aspectos cognitivos, a capacidade dos alunos enxergarem as correntes que os oprimem, para assim, lutarem pelos seus direitos. Pois, a formação transformadora das crianças e jovens só terão sua plenitude se a conscientização política advir das incumbências democráticas das própria escolas públicas que estarão intrinsicamente ligadas com a participação ativa dos mesmos no futuro. Tal autonomia, de acordo com Freire (2017, p. 30-31), "está contido na conduta do professor democrático que sempre reforça a capacidade crítica, a curiosidade e a insubmissão do alunado".

Dessa forma, pode-se entender que a permanência da metodologia tradicionalista nas escolas é uma forma de legitimar a opressão, a desigualdade e o preconceito através da alienação dos conteúdos pragmáticos. Em contrapartida, um professor com princípios progressista deve se sentir mal com as injustiças e discriminações, ao mesmo tempo que deve mostrar nitidez na sua luta contra a impunidade que assola a realidade local, nacional ou global. (FREIRE, 2017)

\subsection{ENSINO EMANCIPATÓRIO ATRAVÉS DA EDUCAÇÃO EM DIREITOS HUMANOS}

A história da humanidade, antes da oficialização dos Direitos Humanos, passou por terríveis experiências, principalmente no século XX refletidas em duas guerras mundiais (1914-18 e 1939-45) que provocaram massacres de milhares de pessoas, paralelamente com o surgimento de regimes totalitários na Europa que deturparam e desviaram os estudos "científicos" para justificar o extermínio de judeus e de outros povos considerados inferiores pelos nazistas. Para piorar, foi uma época que foi marcada pelas bombas atômicas jogadas em Hiroshima e Nagasaki. (TOSI e FERREIRA, 2014)

Os próprios Tosi e Ferreira (2014), já citado, afirmam que foi nesse contexto histórico que os líderes das grandes potências vencedoras sentiram a necessidade de criar um órgão que impedisse que novos crimes contra a humanidade ressurgissem. Em 1945, foi formada a Organização das Nações Unidas (ONU) o qual confiaram a tarefa de evitar 
uma terceira guerra mundial e promover a paz entre as nações. Mas, para que se alcançasse tais objetivos, os países fundadores consideraram a promoção dos "direitos naturais" de base para que todas as pessoas nascessem livres e iguais em dignidade e direitos, sem discriminação por raça, cultura, classe, gênero ou outra especificação.

Fundamentando-se nessa perspectiva, Ansara (2009) afirma que o Brasil passou por seus períodos sombrios, principalmente sob a ditadura militar (1964-1981) que infringiu e violou todas as diretrizes dos direitos humanos através de práticas de desrespeito, torturas e desaparecimentos de opositores do governo. E mesmo que essa fase tenha sido superada, atualmente, ainda é perceptível o esquecimento histórico através de certas ações que a população pratica em relação a eleger ou defender representantes políticos que denigrem e ameaçam as premissas dos Direitos Humanos. Esse período foi tão marcante na história do país que se reflete até no espaço escolar. Em vista disso, a autora reflete:

O autoritarismo presente na organização política da sociedade brasileira, apesar do avanço da democracia, pós-ditadura militar, se reproduz, ainda hoje, em outras instituições sociais como a escola, que mantém, em sua grande maioria uma relação absolutamente autoritária entre seus pares, direção, professores e alunos, baseada na ameaça, na punição e medo. Os problemas na escola, infelizmente, ainda são resolvidos no grito, na imposição de normas e não por meio do diálogo. (ANSARA, 2009, p. 238)

Nessas concepções, os quadros de violência que está posto na sociedade contemporânea são resultado de muitos e complexos fatores, o que torna o desafio de educar de forma progressista muito grande, mas não impossível. Enfrentar as questões que surgem no cotidiano da sala de aula pode ser o começo do caminho a ser trilhado, com vistas à construção de uma cultura de paz na sociedade, por meio de uma educação em e para os direitos de todos. E diante das discriminações, preconceitos, e violência, fortemente presentes no cotidiano escolar, fica patente a necessidade de ações mais efetivas para a implementação da Educação em Direitos Humanos. (SILVEIRA, 2014) 
Partindo desse quadro teórico a respeito da luta por direitos igualitários, os movimentos sociais estudantis que serviram de base para a redemocratização do Brasil foram alicerçados pelas premissas dos direitos humanos, tanto nas questões das denúncias contra as atrocidades militar quanto as reivindicações por direitos, liberdade e garantias individuais que ganharam força nos anos 80, mas enfraqueceu no decorrer dos anos. No entanto, aquele discurso conservador que deturpava os direitos das minorias está retornando rapidamente. Por isso, que os educadores devem reconstruir projetos educativos voltados para o esclarecimento sobre os direitos iguais e, assim, implementar uma cultura de solidariedade, de tolerância, de valorização das diversidades e da emancipação para a manutenção do Estado de direito. (VIOLA, 2010)

Segundo Almeida e Reis (2018) a educação tem o papel em combater todas as formas de opressão e dominação que persistem em estar presente no panorama brasileiro, para que dessa forma se abra possibilidades para formação de uma sociedade igualitária, livre de preconceitos e participativa. Para isso, o espaço escolar privado ou público devem fazer com que as diretrizes dos Direitos Humanos não permaneçam apenas na teoria, mas no desenvolvimento da prática através de uma didática coletiva e emancipadora.

Por isso, a prática pedagógica consiste na capacidade de criar uma ética fundada no diálogo que integre a diferença e admita o conflito, mostrando uma abordagem crítica, moral e de contestação para que permita uma mobilização de uma vida melhor para todos, tanto no combate à homofobia e a luta por direitos LGBT quanto contra qualquer forma de discriminação que diz respeito a grupos isolados e minorias. (CABRAL, 2015)

Contudo, entende-se que a docência deve prover de seus conteúdos uma cultura de respeito as diferenças, os quais os materiais pedagógicos a serem trabalhados em sala de aula sejam alicerçados em métodos que estimulem a autonomia e empatia das pessoas. Em razão disso, Freire (2017, p. 37) acrescenta: “o professor deve optar pela rejeição mais decidida a qualquer forma de discriminação: a prática preconceituosa de raça, de classe, de gênero ofende a democratização”. 
Então, não há nenhuma dúvida de que um sistema escolar, não só a disciplina geográfica, mas como as demais, devem se adequar e se preparar para os desafios do século XXI, mesmo que seja no embate contra governos opressores através de uma educação autônoma e libertadora. Nesse caso, Vesentini (2013, p. 9-10) conclui que o ensino “deve levar em conta a 'compreensão do espaço/ tempo', a valorização das escalas global ao local, a expansão dos direitos humanos, a necessidade do educando de aprender a conviver com os 'outros' e a questão ambiental".

\section{CONSIDERAÇÕES FINAIS}

O ensino de geografia crítica como abordagem de ensino é a principal premissa na conscientização política e na indução de formar alunos que sejam ativos na luta por seus direitos. Para essa finalidade, é necessário nortear a conduta em sala de aula por meio de uma criticidade enraizada na educação em direitos humanos em detrimento do tradicionalismo alienante. Por isso, essa nova forma de ensinar tem por objetivo embasar as novas gerações pelo entendimento que os seus direitos não são privilégios, mas conquistas ganhas através de mobilizações e lutas contra o sistema político opressor.

Partindo desse campo teórico de compreensão de classes, existem vastas reflexões científicas sobre o tema que relaciona uma sociedade consciente e fortemente atuante nas decisões a partir de uma didática voltada pela socialização dos problemas que atingem a todos. Ou seja, o compromisso do educador com a sociedade é formar cidadãos empáticos pelas minorias, defensores dos direitos para todos e recalcitrantes contra todo tipo de repressão.

É importante dizer que a proposta de uma nova geografia se vincula com a formação de uma geração reflexiva e transformadora dos problemas sociais em que se encontram. Mas, para isso, tal metodologia precisa ir além de conteúdos pragmáticos, buscando sempre contextualizar os assuntos escolares com a realidade local, nacional e mundial. Em vista disso, essa conduta deve começar pelos próprios educandos em sala de aula, expondo sua indignação perante a discriminação de raça, de gênero ou de classe através da sua luta pelos direitos iguais. 
Ainda em relação ao educador, as diversidades e a valorização da igualdade social devem estar presentes na sua conduta como construtor da cidadania, que engloba o respeito as diferenças, guiando-se na construção da dignidade humana. Por isso que para alcançar a tal emancipação, necessita-se reconhecer que não é suficiente ensinar conteúdos ou regras, mas comportamentos, atitudes e posturas que não toleram nenhum tipo de opressão. Isto é, educar a partir da sensibilização das pessoas sobre a importância de ter solidariedade pelo próximo, ao mesmo tempo que humaniza a conduta de todos que recebem essa educação, seja através da própria prática de ensino, seja por pesquisa ou projetos que embarquem as virtudes do respeito, compromisso e fraternidade, juntamente com a família e a comunidade.

Nesse sentido, esta pesquisa bibliográfica tem como principal foco complementar através de argumentos metodológicos e teóricos sobre a formação cidadã emancipatória. E para que outros docentes que também lutam pela liberdade de se expressar politicamente na sala de aula, além de argumentar que, em condições em que a política justifica qualquer tipo de repressão, a classe docente deve se unir para combater todo o tipo de opressão. Portanto, que esse artigo sirva de debate e discussões acerca da conscientização dos alunos norteadas pela educação em direitos humanos.

\section{REFERÊNCIAS}

ALMEIDA, Camila Nunes de; REIS, Helena Esser dos; A educação em direitos humanos como ferramenta em direitos humanos. Revista interdisciplinar de direitos humanos, Bauru, v.6, n.1, p. 45-59, jan./jun., 2018.

ANSARA, Soraia. Memória política, Repressão e Ditadura no

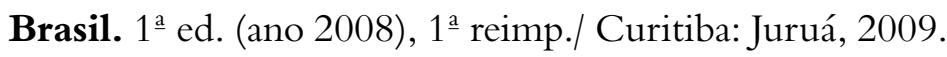

BEISIEGEL, Celso de Rui. Paulo Freire. Recife: Fundação Joaquim Nabuco, Editora Massangana, 2010.

CABRAL, Thiago Baptistella. Homossexualidade, educação e direitos humanos. In: ROSA, Claúdia Santa; SILVA, Frederico Ho- 
rie (org.). Diálogos em defesa da escola pública. Natal/RN: IDE, 2015, p. 174-175.

FREIRE, Paulo. Pedagogia da Autonomia: saberes necessários à prática educativa. 55. ed. Rio de Janeiro/São Paulo: Paz e Terra, 2017.

FREIRE, Paulo. Pedagogia do oprimido. 50. ed. São Paulo: Paz e Terra, 2011.

HARARI, Yuval Noah. Sapiens: Uma breve história da humanidade. Porto Alegre: L\&PM Editores S. A., 2018.

LIBÂNEO, José Carlos. Didática. - 2. ed. - São Paulo: Cortez, 2013

LUCKESI, Cipriano Carlos. Avaliação da aprendizagem escolar: estudos e proposições. - 22. Ed. - São Paulo: Cortez, 2011.

PENNA, Fernando. O discurso reacionário de defesa de uma "escola sem partido". In: GALLEGO, Esther Solano (org.). O ódio como política: a reinvenção das direitas do Brasil. São Paulo: Boitempo, 2018, p. 109-113.

PONTUSCHKA, Nídia Nacib. O conceito de estudo do meio tranforma-se... em tempos diferentes, em escolas diferentes, com professores diferentes. In: VESENTINI, José William (org.). O ensino da geografia no século XXI. 7.ed. Campina, SP: Papirus, 2013. p. 249-287.

RIBEIRO, M. V. A; OLIVEIRA, I. S. O ensino de geografia como prática pedagógica emancipatória no contexto da educação do campo. Revista Científica Semana Acadêmica, Fortaleza, v. 01, n. 162, p. 1-15. mar. 2019.

RICÓN, Javier Castañeda. O ensino da geografia no México: Educação básica (primária e secundária). In: VESENTINI, José William (org.). $\mathbf{O}$ ensino da geografia no século XXI. 7.ed. Campina, SP: Papirus, 2013. p. 49-86. 
SALVIANI, Dermeval; DUARTE, Newton. Pedagogia histórico-crítica e luta de classes na educação escolar. In: SALVIANI, Dermeval; DUARTE, Newton (org.). Pedagogia histórico-crítica e luta de classes na educação escolar. Prefácio. Campinas, SP: Autores associados, 2012.

SANTOS, Milton. Por uma geografia nova da crítica da geografia a uma geografia crítica. - 6. ed. - São Paulo: Editora da Universidade de São Paulo, 2004.

SILVEIRA, Rosa Maria Godoy. Ambiente escolar e Direitos Humanos. In: FLORES, Elio Chaves; FERREIRA, Lúcia de Fátima Guerra; MELO, Vilma de Lurdes Barbosa (org.). Educação em direitos humanos \& educação para os direitos humanos. João Pessoa/PB: Editora da UFPB, 2014, p.203-234.

STRAFORINI, Rafael. Ensinar Geografia: O desafio da totalidade- mundo nas séries iniciais. 2 ed. São Paulo: Annblume, 2008.

TOSI, Giuseppe; FERREIRA, Lúcia de Fátima Guerra. Educação em Direitos Humanos nos sistemas internacional e nacional. In: FLORES, Elio Chaves; FERREIRA, Lúcia de Fátima Guerra; MELO, Vilma de Lurdes Barbosa (org.). Educação em direitos humanos \& educação para os direitos humanos. João Pessoa/PB: Editora da UFPB, 2014, p. 33-60.

VERDI, E. F. Pensar radicalmente sob a repressão: a geografia crítica brasileira no contexto da ditadura civil-militar. Geousp - Espaço e Tempo (Online), v. 22, n. 3, p. 539-558, dez. 2018. ISSN 2179-0892.

VESENTINI, José Willian. Realidades e perspectivas do ensino de geografia do ensino de geografia no Brasil. In: VESENTINI, José William (org.). $\mathbf{O}$ ensino da geografia no século XXI. 7.ed. Campina, SP: Papirus, 2013. p. 219-248. 
VIOLA, Solon E. A. Políticas de educação em direitos humanos. In: TAVARES, Celma et al. Políticas e Fundamentos da Educação em Direitos Humanos. São Paulo, Cortez Editora, 2010.

VLACH, Vânia Rubia Farias. O ensino de geografia no Brasil: Uma perspectiva histórica. In: VESENTINI, José William (org.). O ensino da geografia no século XXI. 7.ed. Campina, SP: Papirus, 2013. p. 187-218. 


\section{EXPERIÊNCIA DE ESTÁGIO DOCENTE NA EDUCAÇÃO BÁSICA}

Roberto Ramon Queiroz de Assis

\section{Introdução}

$\mathrm{Os}^{4}$ sentimentos e competências de ser professor foram sendo construídos com as experiências em sala de aula, e fora dela, proporcionadas pelas disciplinas de Estágio supervisionado I e Metodologia do Ensino de História.

Mais especificamente, o campo de estágio está sendo uma experiência rica, pois essa ação de observar e ir até a escola estar me proporcionado vivências no espaço que ocuparei enquanto futuro professor. Principalmente quando concebo o estágio enquanto um momento que pode me possibilitar pesquisas que irão trazer contribuições para minha formação docente, nos ajudando a superar as dicotomias que envolvem a teoria e a prática, e concebendo a teoria como um instrumento que mobilizam saberes que contribuem para análises situacionais do ambiente escolar e consequentemente da sala de aula (PIMENTA, 2012, p. 44).

As experiências aqui expostas foram problematizadas e construídas as luzes da teoria pertinente às temáticas abordadas, nos dando contribuições, ajudando nas reflexões e construção de problemáticas e análise situacional do ser professor; sempre levando em conta as re-

4 As discussões aqui apresentadas são frutos das observações e práticas da disciplina de Estágio Supervisionado I do curso de Licenciatura plena em História, da Universidade federal de Campina Grande, que foi realizado no ano de 2018. 
lações que mantém com os sujeitos envolvidos no processo de ensino: aluno/professor em um dos espaços em que atuamos: ambientes de aprendizagem formal.

O artigo está organizado em cinco tópicos que buscam discutir: Constituição do espaço escolar e sua função (PAIVA, 2005); o planejamento de ensino como mobilização de saber/poder (CORAZZA, 1997); Os saberes que envolvem as práticas docentes (PIMENTA, 1996); As relações aluno/professor (MÜLLER, 2002) e os processos avaliativos do conhecimento (ROCHA, 2015; GATTI, 2003). Estes pontos foram trabalhados separadamente, neste relatório, levando em consideração as experiências vivenciadas no estágio observacional feito na escola E. E. F. M. Bonifácio Saraiva de Moura na cidade de Monte Horebe-Pb nos dias 16, 23, 30 de Maio; 6 e 13 de Junho; 11 e 18 de julho no ano de 2018.

\section{Espaço escolar}

O espaço escolar é constituído por um conjunto de ambientes que estão articulados entre si e que se tornam lugares que comportam sociabilidades. É o lugar onde é praticada a burocracia de gerir a instituição e também espaço de aprendizagem; é o local onde são perpassadas as relações sociais entre os sujeitos que atuam na instituição escolar que, em seu fazer, está alicerçada por leis e normas que norteiam suas ações e funções que são de caráter intervencionista da realidade social.

Devemos entender o espaço escolar como um ambiente que está sofrendo constantes mudanças; e suas funções bem como as políticas educacionais, também mudam para atender as necessidades da sociedade.

Esse fluxo de mudanças é contínuo e nos ajudam a (re) significar o espaço escolar, passando a compreendê-lo como local de sociabilidades mais amplas que vai além da relação ensino-aprendizagem; apresentam-se, também, como um espaço de amparo e proteção as jovens e adultos que ela frequenta ${ }^{5}$.

5 Para uma maior reflexão acerca do espaço escolar e as constantes mudanças que estão ocorrendo na escola pública brasileira nos últimos séculos, ver o livro: LOMBARDI, 
Caracterizando o campo do estágio: espaços, funções e usos da escola Bonifácio Saraiva de Moura.

E. E. E. F. M Bonifácio Saraiva de Moura (BSM) está localizada na cidade de Monte Horebe Paraíba, foi criada por meio do decreto n¹1.871 de 10 de Março de 1987. Desde então se caracteriza por ser uma instituição de ensino que oferta educação básica nas modalidades de ensino: fundamental dois e médio, atendendo tanto a população urbana quanto a rural; na cidade é a única escola que comporta o ensino médio atendendo todos os alunos egressos do ensino fundamental dois do município, a instituição tem a capacidade de atender mais de quatrocentos e cinquenta alunos conforme os dados do Projeto Político Pedagógico do ano de 2018.

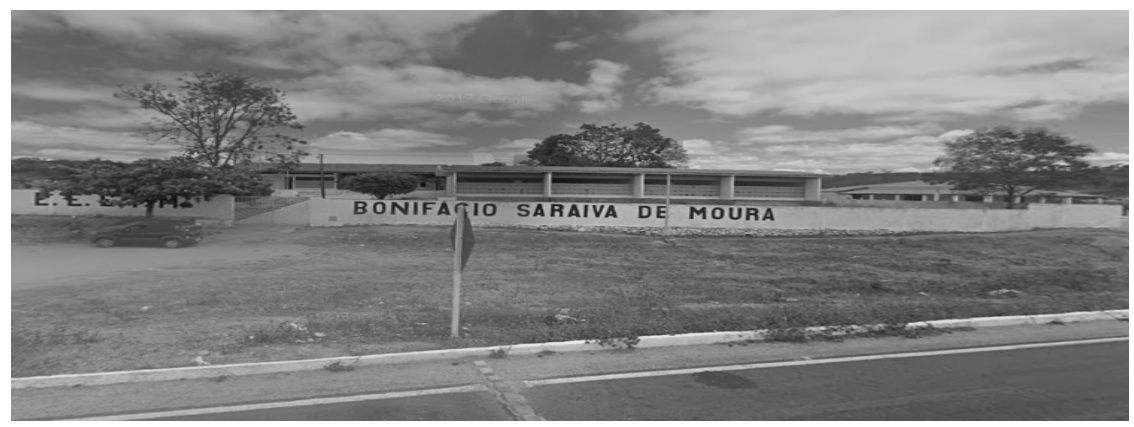

IMAGENS 01: Fachada da escola Bonifácio Saraiva de Moura. Monte Horebe-Pb, 2018.

A escola está divida em oito salas de aulas, possui uma ampla estrutura com quadra poliesportiva e espaço de recreação. Entre os espaços pedagógicos, para além das salas de aulas, podemos citar a biblioteca que apesar do espaço ser pequeno, impossibilitando de realizar leituras no local, os professores utilizam como espaço onde os alunos podem encontrara leituras complementares aos assuntos vistos em sala. $\mathrm{O}$ incentivo a leitura na escola é permanente e reforçado por cada professor, sendo que a procura por parte dos alunos não existe, durante os meus dias de estágio pouco vi alunos se direcionar a biblioteca atrás de leitu-

José C.; SAVIANI, Dermeval; NASCIMENTO, Maria Isabel Moura. A escola pública no Brasil: história e historiografia. Autores Associados, 2005. 
ras, em relação à quantidade de alunos no laboratório de informática que é superior àqueles que frequentam a biblioteca.

O laboratório de informática que dispõe de 12 computadores, é o espaço mais procurado pelos alunos, podemos atribuir o desinteresse a biblioteca por parte alunos pelo fato de encontrem na sala de informática um ambiente interativo que produz respostas mais rápidas as suas demandas de pesquisa. O laboratório também dispõe de um Datashow, que é utilizado por todos os professores, sendo necessário, para fazer o uso do mesmo, reservar com antecedência; que tanto pode ser utilizado em sala de aula ou então dentro do laboratório de informática.

A escola BSM é uma unidade articuladora do ProEMI (Programa Ensino Médio Inovador) dentro das ações busca desenvolver educação, bem como o alcance das metas do Plano Nacional de Educação(PNE), dentro dos objetivos do ProEMI destaca-se por

[...] apoiar e fortalecer o desenvolvimento de propostas curriculares inovadoras nas escolas de ensino médio, ampliando o tempo dos estudantes na escola e buscando garantir a formação integral com a inserção de atividades que tornem o currículo mais dinâmico, atendendo também as expectativas dos estudantes do Ensino Médio e às demandas da sociedade contemporânea ${ }^{6}$.

A participação neste programa, ao menos, implica dizer que a referida escola proporciona aos alunos, nela matriculados, uma experiência extracurricular que pode abordar temas e proporcionar momentos que no dia a dia escolar não seria contemplada.

A análise in locos da sala de aula, que está inserida dentro do espaço contextualizado, foi feita a partir da observação da turma do $8^{\circ}$ anos tarde; que é constituída por 32 alunos regularmente matriculados, com idade variada de 13 a 17 anos, onde as aulas de história estão dispostas no cronograma dos escolares duas vezes por semana com duração de 45 min. A professora que acompanha os alunos é formada em geografia, porém, atua na área de história no ensino fundamental.

6 ProEMI- Ministério da Educação- Portal do MEC disponível em : http://portal.mec.gov. br/index.php?option=com_content\&view=article\&id=13439\&ltemid=10. 
Durante as observações realizadas nos dias 09 e 16 de Maio, pouco se viu os alunos usarem dos espaços pedagógicos que a escola dispõe. As aulas tem um caráter tradicional com o uso do livro didático, quadro e pincel. A turma em si é muito numerosa e não dispõe de livro didático para todos os alunos. Os poucos que tem são compartilhados e fotografados para os alunos estudarem em casa. Essa minha primeira observação na escola revelou um preocupação, o quanto está precário a qualidade do ensino público ofertado para os jovens da cidade de Monte Horebe- $\mathrm{Pb}$.

Essa realidade não é isolada no cenário nacional, onde este princípio de "igualdade" que é preconizada nas políticas educacionais por si só já expressa à desigualdade, quando na realidade deveríamos utilizar do conceito de equidade para que possa haver uma distribuição equânime da educação promovendo desse modo o acesso e permanência dos jovens na escola. Bem como oferta qualidade e condições para que possa haver um ato de ensinar que seja efetivo para os alunos.

Porém pensar nestes aspectos está mais próximo de um sonho do que uma realidade, como nos mostra Paiva (2005, p. 182) ao dizer que nossa sociedade é marcada por grandes e profundas desigualdades, onde está se tornando cada vez mais difícil assegurar tais diretos, como o acesso e qualidade do conhecimento a todos que o sistema educacional logra acesso.

\section{Planejamento}

O Plano de aula/ensino é um instrumento que possibilita sistematizar e organizar o conhecimento a ser aplicado e tratado em sala de aula, contudo, apesar do seu caráter de rigor, este instrumento é maleável e molda-se conforme o contexto em que está sendo usado. É um espaço onde o professor lida diretamente com suas escolhas e recorte temáticos é um instrumento oportuno para o docente expor suas ideias, pensamentos e visão de mundo e por meio deste coloca-las em prática. Neste aspecto, o plano de aula é um instrumento onde se efetivam as relações saber-poder que envolve o ato de planejar o ensino. 
Pensando o planejamento na/para sala de aula: entendimento, vivências, práticas e recursos aplicados em sala de aula pelo professor

Nos dias 23 e 30 de maio me detive a observar um dos momentos mais criteriosos, conforme minha experiência neste estágio observacional, que está sendo as questões voltadas para o Planejamento de Aula, principalmente pelo fato de conceber o plano de aula enquanto uma "estratégia política cultural" e ser um recurso próprio e essencial na práxis docente.

O planejamento, por parte dos professores e coordenadores, é uma prática renegada; que por ser atravessado por alguns dilemas como o de conceber o plano de aula enquanto uma "atividade inútil" que "beira puramente a teoria" onde na "pratica é outra realidade" torna o planejamento como algo difícil de ser praticado nas escolas. Esses e outros dilemas são corriqueiros em sala de aula, e as observações feitas foram levadas em consideração tais aspectos tendo por base observacional a atuação do professor de história junto ao $8^{\circ}$ ano do ensino fundamental da escola Bonifácio Saraiva de Moura.

A escola possui um cronograma específico de ações pedagógicas, porém não os vivenciei durante o período de estágio. A professora que acompanhei em sala me relatou que esses momentos costumam acontecer e que ao seu vê esses encontros são valiosos, pois os professores discutem o desempenho e futuras ações para com os alunos.

Os momentos de planejamento vivenciados na escola, como relatado pelo professor, não participei ou ao menos não fui convidado, são as reuniões pedagógicas que ocorrem anualmente para discutir o ano letivo e as reuniões bimestrais e aquelas mensais, estas acontecem ordinalmente. Esses momentos de vivências são propostos para os docentes de a instituição trocar ideias, experiências e refletir suas práticas docentes.

Umas das dificuldades que o professore enfrentam com a construção do planejamento na/para sala de aula inicia-se por parte da coordenação pedagógica. Como observado, o plano de aula é visto apenas como um requisto burocrático que o sistema de Diários Eletrônico, implantado pela Secretaria de Estado da Educação da Paraíba pede para ser alimentado com essas informações, e a figura do coordenador cobra o seu preenchimento bimestralmente. 
Desse modo, posso perceber que a visão do planejamento que é pregada, ou ao menos absorvida pelos docentes, é de apenas como um elemento burocrático que deve ser cumprido. E sua função enquanto um instrumento norteador e essencial para o exercício da docência em a sala de aula fica secundarizado no momento de construção do plano. Não havendo, como observado, a construção de objetivos interligados a metas e conteúdos.

A ausência de um desses aspectos torna o planejamento frágil. E os planos que pude observar contem apenas as temáticas a serem trabalhadas nas unidades, ficou ausente a forma que seria aplicada esses conteúdos, e quais as competências básicas e os objetivos a serem desenvolvida pelo professor e alunos.

Essas afirmações, da falta de um planejamento eficaz e de como a aula deve ocorrer, se fez presente na sala de aula pelo fato de que nas observações das aulas notei que elas assumiram um caráter expositivo exacerbado, chagando às vezes ao desinteresse dos alunos levando a dispersão da turma. Os momentos de dialogo foram poucos, não observei um conhecimento problematizador das "verdades" tragas no livro didático. Uma educação, que arisco dizer: assume um aspecto bancário, pois o conteúdo e sua transmissão eram supervalorizados na sala de aula. Já a qualidade e forma que o aluno apreende os conteúdos ficam secundarizados, e avaliado apenas em provas.

Nesse sentido, traçar ou apontar as falhas torna-se uma questão complexa, pois envolve duas dimensões/concepções pedagógicas, sendo uma delas a do apoio pedagógico, do qual a escola dispõe, que em sua grande maioria não vivencia a realidade da sala de aula, mas mesmo assim assume o papel de fornecer apoio aos professores a partir de seus relatos. Neste sentido podemos notar outra dimensão/ concepção pedagógica, que está é inerente à concepção de ensino que o professor adquiriu ao longo de sua formação e atuação profissional. Por vez o modelo praticado em sala, pelo professor, pode ser tido como o "correto", bem como o do apoio pedagógico que coloca seus modelos como os ideais para trazer soluções sem ao menos fazer uma analise situacional in locos. Sendo assim os conflitos podem existir, tanto por parte do professor, que concebe sua pedagogia como "ide- 
al" e não reconhece suas falhas; como do apoio pedagógico que não tem a vivencia em sala de aula junto com os alunos e professor, mas mesmo assim traça possíveis soluções.

Neste aspecto, seria exitoso para o professor, fazer da sua atuação docente também um laboratório de pesquisa de sua própria práxis, essa investigação de si dentro de seu espaço de atuação possibilitaria revelar questões que façam o professor repensar o seu trabalho, ou seja, o professor que pesquisa e reflete sobre sua própria ação educativa, que sempre está questionando sua prática e relação com os alunos.

\section{Prática docente (saberes)}

Os saberes docentes são um conjunto de competências /valores/ conhecimentos essências para qualquer educador. Como defendido por Pimenta (1999) como sendo, também, aqueles adquiridos pelo educador ao longo de sua formação e experiência profissional. Estes saberes, a partir da pesquisa da autora, foram divididos em três, onde os saberes:

a) da Experiência: seria aquela adquirida pelo professor ao longo de sua formação desde quando aluno como também produzido na prática a partir do processo de reflexão de sua atuação (didática) bem como pela troca de experiências com os outros professores e leituras teóricas feitas.

b) do Conhecimento: abrange a revisão da função da escola e professor em passar os conhecimentos em suas diversas abordagens, levando sempre em consideração as demandas contemporâneas e o meio social em que o alunado estáinserido.

c) dos Saberes pedagógicos: seria a junção dos dois saberes anteriormente citados englobando as questões do conhecimento juntamente com o saber da experiência e dos conteúdos específicos e que será construído a partir das necessidades reias, seria então a didática adotada pelo professor em sala.

Pimenta (1999) nos mostra ainda que apesar de haver essa fragmentação entre os saberes, é uma pratica que devemos superala, de modo a permitir uma releitura na formação docente possibilitando ver 
o saber docente enquanto uma pratica social com objetivo central de dar uma formação completa onde os saberes andam juntos, e jamais uma prática docente onde um possa ser efetivado sem o outro.

A partir desse estudo (PIMENTA, 1999) que possibilitou uma (re) significação da formação dos professores defende a ideia de que os saberes são elementos a serem considerados nos estudos que busca discutir a identidade do ofício de professor.

A colocação parte do sentido de que a identidade do professor é formada a partir da

Significação social da profissão; da revisão constante dos significados sociais da profissão; da revisão das tradições. Mas também da reafirmação das práticas consagradas culturalmente e que permanecem significativas. Práticas que resistem a inovações porque prenhes de saberes válidos às necessidades da realidade. Do confronto entre as teorias e as práticas, da análise sistemática das práticas à luz das teorias existentes, da construção de novas teorias (PIMENTA, 1999 p. 19).

Nesse sentido, a perspectiva da formação e atuação docente é aquela que seja uma prática que tenha valores holísticos, no sentido de proporcionar uma formação integral ao docente, onde em sua prática possa se efetivar os três saberes docentes de forma que um complemente o outro e jamais os entendê-los de forma isolada.

\section{Os saberes disciplinares, pedagógicos e experiências na docência a partir de observações em salada de aula}

A observação in locos no oitavo ano, feito nos dias 6 e 13 de Junho, junto com a professora regente, mostrou-se de forma efetiva no que diz respeito aos saberes da experiência e pedagógicos. A professora demonstra muita desenvoltura em sala de aula ao abordar temas tragos no livro didático. Observamos que há uma dedicação em ler e estudar os conteúdos antes de trabalha-los em sala, porém as aulas são pouco dialogadas. Mas a todo o momento a professora busca correlacionar os 
conteúdos com exemplos práticos que façam os alunos pensar os conteúdos a partir de suas vivências e saberes prévios.

A principal dificuldade observada por parte do professor diz respeito a sua formação, que é distinta da disciplina a qual ela leciona, se pondo enquanto um limite para aprofundar o conhecimento junto com os alunos. No mais a professora é bastante responsável, apesar do déficit citado anteriormente, ela busca organizar suas aulas e faz o possível com os conteúdos; todos os conteúdos que foram previsto no planejamento do livro, durante minhas observações em sala, foram abordados. Este problema é relativizado pelo domínio pedagógico da professora demonstrando eficácia na transmissão do conteúdo, mas como citei anteriormente as aulas tem um caráter conteúdista.

Pela observação em sala, que foi um período relativamente curto de apenas cinco aulas. Compreendo que a vivência em sala de aula seja mais ampla, em apenas cinco aulas não é capaz de conseguiria obervar de forma mais específica à professora e os conteúdos abordados, porém durante as aulas que estive presente não foi abordada nenhum conteúdo extracurricular, isso não significa dizer que a professora não venha tratar futuramente temas transversais na sala.

A professora mostrou o desejo de aborda-los, porém acrescentou ela, em uma conversa, que a dificuldade de seguir um currículo do qual ela é cobrada a impede ou inibe de dar estás aulas com temáticas voltadas à cultura e religião. Diz ela que as disciplina de artes e ensino religioso e até de educação física pode suprir essa necessidade.

Com relação a essas observações posso acrescentar que os conteúdos e a interligação dos saberes da docência são essenciais, e que se o individuo tiver um desejo de trabalhar certo tema, ele pode usar de sua didática e seus saberes da experiência para ver um modo de corelacionar os temas extracurriculares com os temas oficiais preconizados no currículo.

\section{Relação professor/aluno}

Um dos grandes desafios na docência, em tempos líquidos, onde tudo é digital, online é estabelecer um ensino que seja significativo para 
os sujeitos que dele participa. Ou seja, o professor e aluno, enquanto elementos que devem interagir de forma significativa no contexto educativo, pois são essas interações que promovem um ensino e aprendizagem bem sucedida como nos mostra Vilella e Uchoa (2008) que:

Os processos de significação no contexto educativo enfocam as interações sociais na busca da compreensão de situações nas quais se desenvolve um processo ensino e aprendizagem bem sucedido, relacionando isto a processos de significação do conhecimento por parte do aluno, exige que sejam analisados os aspectos motivacionais que permitem perceber se o aluno está disposto a dar atenção e se empenhar nas atividades propostas pelo professor (VILELLA; UCHOA, 2008 p, 41).

A afetividade, que é abordada pelos autores anteriormente citadas, refere-se ao conjunto de interações estabelecidas em sala no momento do ensino, ou seja, é a motivação do aluno em prestar atenção ao que o professor fala e ter foco no conteúdo bem como o professor chamar atenção do aluno para as explicações.

Estas relações são consideradas afetivas, pois existe ou ao menos deve existir uma sintonia entre os sujeitos, aluno e professor, devem ocorrer de forma efetiva, desse modo possibilitando uma aprendizagem que seja significativa para ambos e possibilitando a construção de um conhecimento para o aluno que se sente motivado a aprender.

Desse modo, o dialogo entre os sujeitos em sala de aula, como parte das interações dentro da sala é um mecanismo essencial para o ensino, pois desse o professor pode saber como o conteúdo está sendo processado pelos alunos; já uma aula sem dialogo não é possível ter esse feedback, portanto considero essas interações como essenciais.

\section{Processos de interação na relação professor aluno enquanto elementos essenciais para construção do conhecimento}

"O professor como facilitador do aprendizado deverá buscar a motivação de seus alunos. Não é uma tarefa fácil, pois a falta de mo- 
tivação pode ter origem em problemas particulares do aluno como cansaço, necessidades afetivas não satisfeitas e, até mesmo, a fome. $\mathrm{O}$ docente deverá centrar os seus esforços na aprendizagem e, ao trabalhar com ela, tornar o ensinamento significativo para o aluno, fazendo-o sentir que a matéria tem significância para sua vida" (MÜLLER, 2002 p. 279).

Como observado por Müller (2002), vemos que o ato de aprender é atravessado por questões de ordem subjetiva do aluno, e qualquer um dos elementos citado pode comprometer o desempenho do aluno em sala de aula. Ser um professor atento a esses aspectos é essencial no sentido de que ele pode identificar e intervir em qualquer questão que possa comprometer a aprendizagem do aluno, e o dialogo é um dos elementos que também pode ser usado para esse fim.

No $8^{\circ}$ ano da escola Bonifácio, a professora regente busca estabelecer diálogos com a turma a partir de questões relacionadas aos conteúdos em sala. Apesar das aulas terem esse caráter de rigor e que deve chamar a atenção dos alunos, quando o momento está ficando cansativo, ou os alunos se dispersa, a professora busca conversa com os alunos e sempre pergunta o que está acontecendo. As respostas em sua grande maioria se referem ao cansaço, os alunos dizem que estão enfadados de assistir aula e com preguiça de escrever.

De forma geral a professora conhece bem os alunos, os chama pelo nome e sempre busca fazer os alunos falar, pedindo a opinião deles sobre o conteúdo e pergunta e se tem alguma dúvida, que a grande maioria prefere não falar sobre o conteúdo. Obervei que na sala tem em torno de cinco ou seis alunos, do total de 32 , que sempre faz interferências e pedem para falar dando sua opinião.

O tratamento da professora para com os alunos se dá de forma igual, não existe distinção, porém os alunos que sentam na frente são mais participativos e a professora direciona seu olhar mais para eles, não que a aula seja voltada para esse grupo especifico, mas pela disposição tradicional da sala: um quadrilátero de lados iguais e alunos sentados em filas, à comunicação visual fica mais favorecida para as primeiras cadeiras ocupadas pelos alunos que nelas sentam, possibilitando dessa forma um contato mais próximo com o professor. 
Com isso, posso dizer que a relação professor-aluno observada em sala atende as observações de Líbano (1994, p. 251) no que diz respeito à distinção das relações afetivas dentro do espaço escolas:

Não estamos falando da afetividade do professor para com determinados alunos, nem de amor pelas crianças. A relação maternal ou paternal deve ser evitada, porque a escola não é um lar. Os alunos não são nossos sobrinhos e muito menos filhos. $\mathrm{Na}$ sala de aula, o professor se relaciona com o grupo de alunos. Ainda que o professor necessite atender um aluno especial ou que os alunos trabalhem individualmente, a interação deve estar voltada para a atividade de todos os alunos em torno dos objetivos e do conteúdo da aula. (LIBÂNEO, 1994 p. 251)

Com isso podemos considerar que o contato afetivo na sala de aula dever ser baseada enquanto uma relação de aprendizagem e motivação com o único objetivo de proporcionar um conhecimento que seja significativo para o aluno e não uma afetividade relacionada ao amor familiar/parental.

No mais, observo que o comportamento da turma não é regular, os momentos de dispersão existem, mas acredito que seja comum a toda sala de aula. Os alunos são colaborativos e respeitam as professoras, momentos em que foi necessário chamara atenção de aluno existiu, porém foi um único episodio isolado, onde dois alunos estavam com brincadeiras com outro colega e a professora pediu que ele ficasse em silêncio, porém o aluno continuou. Nos mais, quando acontece algo desse tipo na sala de aula o restante dos alunos evita estressar a professora e colaboram com a aula.

\section{Avaliação}

A avaliação, como método aplicado para conhecer o nível de conhecimento que o aluno adquiriu, deve ser de caráter contínuo e não restrito a momentos específicos do planejamento.

$\mathrm{Na}$ grande maioria dos casos de avaliação como nos aponta Rocha (2015), ao fazer uma reflexão sobre o processo avaliativo, ela nos 
mostra que a avaliação assume uma característica particular que é a de "medir" o conhecimento do aluno, sendo esperando que os alunos exteriorizem um conjunto de informações adquiridos ao longo das aulas "Nesse caso, se almeja na avaliação que os alunos sejam capazes de replicar o que lhes foi transmitido, como conjunto de informações" (ROCHA, 2015 p. 90).

Porém a autora ao fazer estes apontamentos sobre a multiplicidade de objetivos que uma avaliação comporta, nos mostra que para alcançar todos os objetivos do processo avaliativo devemos adotar métodos diferenciados bem como a própria exposição do conteúdo também deve mudar:

Se desejarmos que o domínio de informações habilite os alunos a fazer sua crítica, já estaremos em um terreno cognitivo de maior complexidade, que exigirá, seja pela interação verbal ou qualquer outra, que os alunos exercitem sua capacidade analítica e de julgamento. Se almejarmos que os alunos, a partir do domínio do conteúdo factual, sejam implicados, recolham para si elementos identitários da narrativa apresentada, precisaremos propiciar atividades em aula em que eles exercitem tais ações de subjetivação do conhecimento, em sua objetividade. E esse conjunto de atividades deverá fazer parte do planejamento das aulas, que pode se organizar de diferentes formas, contemplando rotinas diárias, sequências didáticas e projetos (ROCHA, 2015 p. 90).

A partir dessas colocações compreendo que o método avaliativo deve variar conforme o objetivo pretendido. Aulas e objetivos diferentes exige também uma avaliação diferenciada.

Ainda como nos mostra Gatti (2003):

O exercício da docência com propósitos claros e consensuais alimenta um processo de avaliação mais consistente e mais integrado na direção de uma perspectiva formativa, voltada para o desenvolvimento dos alunos e não para cumprir uma formalidade burocrática - passa/não passa - ou mesmo para satisfazer o 
exercício de autoritarismos ou autoafirmações pessoais. Nesta perspectiva, a avaliação do aluno é continuada, variada, com instrumentos e elementos diversificados, criativos e utilizada no próprio processo de ensino, como parte deste, na direção de aprendizagens cognitivo-sociais valiosas para os participantes desse processo (GATTI, 2003 p. 111).

Desse posicionamento sobre a avaliação, podemos observamos que o processo avaliativo deve romper com os valores tradicionais que a avaliação carrega, um deles é o de "medir" conhecimento através de nota; a autora nos mostra que a avaliação deve estar comprometida com o desenvolvimento educacional do aluno e deve ser vista para além de um requisito burocrático.

\section{Avaliações no contexto escolar: uma reflexão a partir das observações}

A compreensão de avaliação para o professora de onde realizei meu estágio é ampla, pois ela não limita sua avaliação a um único momento. O processo avaliativo é continuo. A professora possui um caderno com anotações de cada aluno, que no final das unidades os alunos que participa da aula e demonstra ler o conteúdo previamente terá uma melhor nota.

Durante minhas observações não presenciei prova escrita, porém a professor pediu produções textuais sobre o iluminismo, passou exercícios (estudo dirigido) para os alunos fazerem em sua casa. A professora me fala que a avaliação é proposta para testar os conhecimentos dados em sala, porém ressalta que a avaliação escrita não é o único modo de avaliar o aluno, sua participação em sala como suas falas também conta no momento de dar a nota.

A professora utiliza o método de seminários, faz explicação previa dos conteúdos e separa a turma em equipe e divide os conteúdos. Sendo divididas as três notas da seguinte forma: uma prova escrita, um seminário é vistos das atividades feitas em casa e sala de aula, bem como os relatórios dos seminários.

No segundo bimestre os temas abordado para as aulas que foram tanto para as provas escritas como para os seminários foram: 
- O Brasil e os holandeses e o quilombo de Palmares;

- Antigo regime: Europa no tempo do iluminismo;

- A revolução francesa;

- Ouro e pedras preciosas no Brasil.

Os alunos particularmente diz gostar do método avaliativo adotado pela professora, umas das suas principais características é a maleabilidade do método, que varia de prova escrita, avaliação por seminário e somatório de atividades.

No início do bimestre a professora busca conversa com a turma os perguntando como eles querem a avaliação durante o bimestre a turma considera bom, pois vejo que desse modo como preconizado pela professora os alunos é coparticipativo de suas notas, pois ela é uma construção do aluno a partir de sua participação e desempenho nos seminários e organização das atividades e vistos.

\section{Considerações finais sobre o estágio}

A experiência de estágio é importante na medida em que o aluno fica imerso no contexto de sua futura atuação. É no estágio onde entramos em contato com o nosso fazer profissional é neste momento que nos deparamos com os problemas e vantagens da área que pretende futuramente atuar. No nosso caso especifico, no campo da história é no estágio onde buscamos entender os espaços teorizados em sala de aula e vivenciamos na prática, desse modo podendo fazer o balanço entre teoria e pratica, percebendo os distanciamentos e proximidades que envolvem essas duas faces do ensino: a teoria e a pratica docente.

O estágio supervisionado revelasse como um importante instrumento de integração entre universidade, escola e comunidade, importante para o crescimento pessoal e profissional dos discentes estagiário (FILHO, 2010). O estágio supervisionado é ainda o momento em que as teorias aprendidas são aliadas à prática bem como o momento em que o futuro profissional experimenta e atua efetivamente em seu campo de formação.

Observamos desse modo que o ensino de História deve estar integrado com a realidade social em que o aluno mantem suas relações, 
propiciando uma integração com a sociedade possibilitando o crescimento e desenvolvimento do aluno. Desse modo observamos que a incorporação de novas linguagens e tecnologias no ensino da História, como análise de filmes e uso da informática, por exemplo, contribuem para a aproximação do aluno com as mudanças da sociedade, em relação à cultura, política e integração social (NEU, 2014).

\section{REFERÊNCIAS}

CORAZZA, Sandra Mara. Planejamento de ensino como estratégia de política cultural. Currículo: questões atuais. Campinas: Papirus, p. 103-143, 1997.

FILHO, A. P. O Estágio Supervisionado e sua importância na formação docente. Revista P@rtes. 2010. Disponível em: <http:// www.partes.com.br/educacao/estagiosupervisionado.as〉.

GATTI, Bernardete A. O professor e a avaliação em sala de aula. Estudos em Avaliação Educacional, [s.1.], n. 27, p.97-114, 30 jun. 2003. Fundação Carlos Chagas. <http://dx.doi.org/10.18222/ eae02720032179>.

LIBÂNEO, José Carlos. Didática. São Paulo: Cortez Editora, 1994.

LOMBARDI, José C.; SAVIANI, Dermeval; NASCIMENTO, Maria Isabel Moura. A escola pública no Brasil: história e historiografia. Autores Associados, 2005.

MÜLLER, Luiza de Souza. A interação professor-aluno no processo educativo. Revista Integração, USJT-SP, ano VIII, n. 31, p. 547-573, 2002.

NEU, Simone. A disciplina de história no ensino médio: preparação para a cidadania ou para o vestibular? Revista de educação Don Alberto, 2014.

PAIVA, Vanilda A Escola Pública Brasileira no Início do Século XXI. Lições da História. In: LOMBARDI, José Claudinei; SAVIANI, Dermeval; NASCIMENTO, Maria Isabel Moura (Org.). A Es- 
cola Pública no Brasil. História e Historiografia. Campinas: Autores Associados, 2005. P. 161-191.

PIMENTA, S.G. Formação de professores: Identidade e saberes da docência. In: PIMENTA, S.G. (Org.) Saberes pedagógicos e atividade docente. São Paulo: Cortez, 1999.

PIMENTA, Selma Garrido. Formação de professores: saberes da docência e identidade do professor. Revista da Faculdade de Educação, [S.1.], v. 22, n. 2, p. 72-89, jan. 1996. ISSN 18069274. Disponível em: <http://www.periodicos.usp.br/rfe/article/ view/33579/36317>. Acesso em: 08 july 2018. doi: http://dx.doi. org/10.1590/S0102-25551996000200004.

ROCHA, Helenice Aparecida Bastos. Aula de história: evento, ideia e escrita. História \& Ensino, v. 21, n. 2, p. 83-103, 2015. DOI: 10.5433/2238-3018.2015v21n2p83.

VILLELA ROSA TACCA, Maria Carmen; UCHOA DE ABREU BRANCO, Ângela Maria Cristina. Processos de significação na relação professor-alunos: uma perspectiva sociocultural construtivista. Estudos de Psicologia, v. 13, n. 1, 2008. Disponível em: <http://www.redalyc.org/articulo.oa?id=26113105> ISSN: 1413-294X 


\section{A NOVA ERA NA EDUCAÇÃO BRASILEIRA}

Alessandra de Freitas Kechichian

\section{Introdução}

O projeto de pesquisa que se apresenta, tem como objeto de análise, o sistema educacional do Brasil, especificamente a educação básica, com o objetivo de adequar a educação brasileira aos princípios norteadores dos Direitos Humanos.

Segundo a Organização das Nações Unidas (ONU), os direitos humanos são "garantias jurídicas universais que protegem indivíduos e grupos contra ações ou omissões dos governos que atentem contra a dignidade humana"7.

Busca-se em verdade, mudar a grade escolar com o objetivo de formar adultos diferentes, mais humanos e empáticos com o outro e com o meio ambiente.

Muda-se o caminho para se chegar em resultados novos. É preciso a quebra com o sistema educacional que vem sendo "empurrado" durante anos às nossas crianças e adolescentes, sem muita racionalidade, mas por costume e inércia.

Sempre ouvimos ideias esperançosas de que devemos deixar um país melhor para as futuras gerações, mas como estamos formando as bases e raízes? Como estamos cuidando e educando desses novos seres?

7 SOUZA, Isabela. 0 que são Direitos Humanos? Politize! Publicado em 25 de abril de 2017. Atualizado em 03 de dezembro de 2018. Disponível em: <https://www.politize. com.br/direitos-humanos-o-que-sao/> . Acesso em: 17 de junho de 2020. 
Ou mudamos na raiz, na grade curricular das escolas, sejam públicas ou privadas, ou continuaremos no velho sistema falido e arcaico.

Com a mudança na grade curricular, das disciplinas a serem ministradas, consequentemente, deve haver alteração também nas provas para ingresso nas faculdades e universidades. Não é o objetivo deste trabalho de pesquisa ficar só na divagação, reclamação sobre o sistema atual, mas ir além, mostrar a interdisciplinariedade dos Direitos $\mathrm{Hu}-$ manos com a educação escolar, já que a educação familiar é de cunho íntimo e não nos diz respeito.

Não obstante, todos aqueles filhos rejeitados por mães e pais, que são "jogados" na sociedade, seja porque os pais são usuários de drogas, se divorciaram, se arrependeram de ter filhos, foram embora do país, estão presos, trabalham demais e não tem tempo para os filhos, ou até morreram, terão na escola amparo e acolhimento, e qualquer eventual fato que tenha ocorrido na sua vida pessoal não será um trauma a pesar pelo seu caminho.

A escola tem esse poder curativo de formação de caráter, quando sabe usar as ferramentas certas, não no modelo que está hoje.

Mesmo aquele que não recebeu amor em casa, poderá tê-lo na escola, por meio dos colegas e professores. O ambiente deve ser tão agradável que o momento de ir para a escola se torne feliz e leve. Muito tempo da nossa vida é passado entre as paredes da sala de aula, às vezes até mais do que em casa, portanto, deve ser engrandecedor, senão não faz sentido.

Uma Nova Era está chegando. Estamos caminhando para viver com mais consciência, conexão, amor e verdade. Mas para isso acontecer, precisamos fazer algumas mudanças e contribuir com essa transformação no planeta. O mundo precisa de líderes que tenham formação humanística, urgentemente.

\section{Fundamentação teórica}

"A educação é a arma mais poderosa que você pode usar para mudar o mundo" (MANDELA, África do Sul, 2003).

8 (MANDELA, Nelson. Lighting your way to a better future. Planetarium. University of the Witwatersrand, Johannesburg, South Africa. 16th July 2003). 
Estamos vivendo tempos de violência urbana, pandemia e governo perturbado. Precisamos escavar até a raiz desses problemas e vermos onde está o erro.

O Brasil, país lindo, tropical, com povo de diferentes etnias, cores e credos, merece evoluir e sair da mesma roda de problemas. Porém, medidas emergenciais não curam, são somente paliativas.

No fundo, todos nós sabemos que está na educação a cura. Só não nos movimentamos como deveríamos. O medo do novo, a falta de iniciativa, a preguiça, a inércia, ou a falta de energia para fazer diferente nos deixa estagnados e os problemas vão tomando dimensões maiores.

Armar a população, construir mais presídios, liberar a polícia para "varrer" criminosos, fomentar os grandes empresários, oferecer benefícios fiscais para macro empresas, não é a solução, mas um agravamento do sistema que vai de mal a pior.

Devemos cuidar da semente, que são as crianças, para que se tornem adultos diferentes e façam um Brasil melhor, sem tanto discurso prolixo retórico, mas com ação e prática, porque afinal, esperança de que vai melhorar, um dia, a maioria dos brasileiros tem e não adianta o sonho sem a ação.

Temos feito seres humanos para nascer, crescer, trabalhar, pagar contar, casar e ter filhos e serem descartados quando não geram mais lucros. Isso é lamentável, desperdiçar a vida com regras que escolheram para nós, sem nenhuma consciência.

Que seja na forma de pesquisa, reflexão, trazendo o assunto à tona, de forma científica, nos comprometemos a buscar soluções e fazer diferença.

Às vezes, não estaremos vivos para ver florescer a semente que plantamos, mas o coração enche de alegria de saber que estivemos do lado que acreditamos.

Afirmações científicas viram teoria, e quando muitos começam a falar de determinada teoria, ela toma dimensão, vira ciência e passa a ser aceita pela sociedade de bom grado.

\subsection{O cenário atual da educação}

Nós estamos formando alunos, em nossas salas de aula, que odeiam estudar, pensar, estão ansiosos, agressivos, depressivos. Esse sistema de co- 
piar a matéria, decorar e fazer provas tem causado mais repulsa do que interesse em aprender. A pressão pela vaga na faculdade tem desenvolvido ansiedade e depressão nos adolescentes e uma competitividade nociva.

$\mathrm{Na}$ primeira infância, quando de fato é formada a personalidade, não há tempo para ser criança, brincar, conhecer o mundo, explorar os sentidos. A situação se agrava quando as crianças passam período integral na escola, porque geralmente não podem ficar em casa. Alguns pais depositam na escola toda a responsabilidade da criação.

$\mathrm{Na}$ fase do ensino médio, momento bem delicado da vida do adolescente, devido a mudanças hormonais e comportamentais, ele é obrigada a entrar na competitividade ferrenha, aquela que adoece. Não importa a sua saúde, a meta é o vestibular (ENEM) e a tão almejada vaga na faculdade.

$\mathrm{Na}$ graduação, fase em que somos jovens, inseguros, com medo do que está por vir na fase adulta (contas, casamento e filhos) nos jogamos nos prazeres, como se o mundo fosse acabar amanhã. A ideia é viver tudo o que não foi vivido antes, porque teve que ficar fechado estudando, decorando. Não sente a matéria, não raciocina, decora. E o objetivo é aproveitar essa fase rápido, intensamente, antes de ser um "pai ou mãe de família".

No decorrer da faculdade ou logo após formado, começam as crises de identidade, momento em que falam para os pais "acho que fiz um curso que não é para mim”. É quando os pais se desesperam, enlouquecem, não sabem como agir, cobram e pressionam que a "vida não é uma brincadeira, gastaram muito dinheiro pagando escola e faculdade, para jogarem tudo para o ar". Algumas rachaduras na instituição familiar começam a surgir e desmoronar castelos ilusórios.

O problema é que em momento algum aquele jovem teve uma formação humanística, aulas de auto conhecimento em sua formação, olhou para todos as fórmulas matemáticas, de física, decorou a tabela periódica, mas nunca olhou para dentro, escutou o seu coração e seguiu o seu propósito. Afinal, isso não é assunto para a escola. Também não é papel dos pais. Afinal, como ensinar o que eles nem aprenderam?

Nossos pais vieram da geração que tinha que arrumar qualquer trabalho (emprego) e manter uma casa, uma família, a qualquer custo, 
gostando ou não daquele ofício. Uma geração que devemos honrar, que sofreu bastante, sem dúvida, abriram caminhos para que não precisássemos passar pelos mesmos percalços. Muitos sonharam em estudar, mas não tiveram oportunidade ou tempo ou dinheiro...

Os nossos ancestrais (pais, avôs e bisavôs) abriram o caminho da evolução. E nós podemos deixar um mundo ainda melhor para as gerações vindouras. Mas, às vezes, dá a impressão que estamos retrocedendo em alguns aspectos e áreas. Precisamos olhar para isso agora, urgente. Vamos corrigir onde é a base de tudo, a educação.

Somos uma geração de maior consciência, que temos a obrigação de ensinar os novos a pensarem, a refletirem, a não aceitarem nada "imposto" à massa, absolutamente nada, sem pensar, sem ter consciência dos atos e ações, olhar quem está lucrando com tal informação, quais interesses ou setores ou famílias estão por trás de tais medidas...

Se a gente educa diferente, temos um Brasil diferente. Se formamos cidadãos equilibrados, temos um país sem tantas desigualdades.

O Estado deve fornecer meios para o cidadão crescer e escrever a sua história, não limitá-lo ou dificultar o processo de criação, pesquisa e inovação.

\subsection{Uma nova consciência a ser plantada}

Não é de agora que se discute a mudança no sistema educacional do Brasil, essa bandeira é antiga.

Existe informação historiográfica confirmando que algumas das escolas modernas e seus educadores estão em São Paulo, após um período de repressão naquele Estado, porém usando nomes como o de Escola Nova. Além disso, pela cronologia da fundação das escolas modernas no Brasil, sabe-se que elas estão proliferando em outros Estados do Brasil.

Importante mencionar que, temos no Brasil, escolas que seguem o método do pedagogo Waldorf, preocupadas em integrar de maneira holística o desenvolvimento físico, espiritual, intelectual e artístico dos alunos. O objetivo é desenvolver indivíduos livres, integrados, socialmente competentes e moralmente responsáveis. 
Portanto, ainda que poucas, estão surgindo algumas escolas na linha do que estamos propondo, do que acreditamos ser a solução. Só precisamos uniformizar o ensino em todas as escolas públicas e particulares.

Devemos fazer a base educacional sólida, para que tenhamos cidadãos evoluídos e conscientes, o que refletirá na diminuição da violência urbana, da desigualdade social, do sentimento de não ser bom o suficiente, de não merecimento (herança que os portugueses deixaram em nós).

Como dizia Mandela" "uma boa cabeça e um bom coração formam uma combinação formidável. Mas quando você adiciona a isso uma língua ou uma caneta alfabetizada, aí você tem algo realmente muito especial" (MANDELA, África do Sul, 2003).

Com esse novo sistema de educação, as crianças e adolescentes não dependeriam só da educação e amor dos pais para terem saúde emocional. A escola (professores e colegas) podem abraçá-lo e ensinar que a vida é uma grande aventura, e ele não deve se vitimizar, os pais fizeram o que podiam, dentro de suas capacidades (financeiras e mentais), e qualquer tristeza que tenha vivenciado, não o diminui e não deve ser um trauma.

O acolhimento na escola é de suma importância, principalmente para aquele que não teve a estrutura familiar, para que um dia ele possa dizer "meus pais não puderam fazer muito por mim, mas a minha escola me ensinou todos os valores que eu precisava".

\subsection{A mudança efetiva na educação brasileira}

A proposta é que acima de qualquer disciplina (matemática, química, física, português, etc...) esteja a formação humanística e holística.

Deve ser ensinado nas escolas, públicas e privadas, de todo o Brasil, desde os 04 anos de idade até os 17 anos, disciplinas como: inteligência emocional, alimentação consciente, consciência ambiental, cultivo da terra (com o foco em cuidar do meio ambiente, sem tantos agrotóxicos e poluentes), astrologia e astronomia, comunicação não-violenta, sa-

9 (MANDELA, Nelson. Lighting your way to a better future. Planetarium. University of the Witwatersrand, Johannesburg, South Africa. 16th July 2003). 
grado feminino e masculino, colaborativismo, yoga e ayurveda, meditação, terapias holísticas (constelação familiar, reiki, tetahealing, etc...), confecção de produtos naturais (sabonetes, desodorantes, lava louças, etc) e física quântica.

Com isso desenvolve-se a personalidade de forma equilibrada e integrada, estimulando o florescimento na criança e no jovem de: clareza de raciocínio, equilíbrio emocional e iniciativa de ação.

A educação, alinhada às diretrizes dos Direitos Humanos, pressupõe a superação de atitudes de imposição, exclusão, segregação e discriminação, para que todos possam aprender e conviver em harmonia e dignidade.

Educar para os Direitos Humanos é educar para a liberdade, o que significa incluir e conscientizar.

Com o lado humano fortalecido, as outras matérias ficam até mais fáceis de serem digeridas. A ideia não é de competição por vaga, por emprego, para ver quem é mais rico ou melhor, mas de união, de soma de esforços por um bem maior, uma vida digna, próspera, cheia de propósito, alegria e sentimento de contribuição para a nação, para o planeta e gerações futuras.

Para a efetividade da medida, precisamos de todos os poderes interagindo e falando a mesma linguagem, senão um faz e o outro desfaz, e a gente não sai do lugar.

Tudo se inicia no Poder Legislativo, com um projeto de lei, que altera a forma de ensino. A efetividade e ação dependem do Poder Executivo. Ao Judiciário cabe intervir quando problemas surgirem ou forem provocados para resolver alguma lide.

Convém relembrar que, o sistema educacional brasileiro é regido pela Lei de Diretrizes e Bases da Educação (Lei no 9.394/1996) e engloba a Base Nacional Comum Curricular (BNCC), local em que deve ser feita a alteração proposta no presente trabalho.

Conjuntamente, cabe à União, aos Estados e aos Municípios planejar, financiar, manter e executar políticas de ensino que estejam de acordo com a LDB, a BNCC e diretrizes constitucionais.

Com a boa vontade dos três poderes podemos mudar a educação, trazer os Direitos Humanos como espinha dorsal do ensino no Brasil, 
e se tornar um país de pessoas felizes, porque elas poderão ser tudo o que elas quiserem!

A formação ética do brasileiro deve começar no primeiro ano da escola. A gente muda a criança, que formará uma família diferente, e no futuro, em algumas gerações a frente, teremos feito um novo Brasil.

\section{Conclusão}

Conclui-se que o modelo educacional atual, nos referimos à educação básica, é insuficiente para formar um ser humano saudável, emocionalmente. As matérias que constam na grade curricular das crianças e dos adolescentes brasileiros não formam líderes e cidadãos que o nosso país precisa. Forma mais do mesmo.

De violência, intolerância, discriminação, preconceito, prepotência, rigor ditatorial estamos fartos, e não suportamos mais esse velho sistema.

Uma Nova Era na Educação há de surgir, rompendo com velhos sistemas arcaicos que só se preocupam em ensinar fórmulas e cobrar o decoreba na prova, além de estimular a competitividade doentia, para ingresso na educação superior.

Acreditamos que mudando a base escolar, os sistemas de ingresso nas faculdades mudarão automaticamente, e talvez, a inteligência emocional, as ideias empreendedoras serão mais valorizadas do que a tabela periódica (que deve ser decorada sim, mas por estudantes do curso de Química).

Com a mudança na educação, os relacionamentos interpessoais serão aprimorados e a violência diminuirá. Nossos pais nunca ouviram falar em comunicação não-violenta, muitos deles foram criados com gritos, berros, chicotadas e replicaram isso inconscientemente.

A nossa preocupação é com o Brasil, a nossa casa, porque em outros países existem diversos tipos de escolas, métodos de ensino e disciplinas, alguns mais evoluídos, outros nem tanto.

Cuidemos das nossas crianças como joias que precisam ser lapidadas para brilharem, somente assim, teremos adultos mais humanos, saudáveis, com consciência ambiental e planetária, além de todo o au- 
toconhecimento que desenvolverá. Refletirá até no número de abandono dos cursos de graduação, porque os jovens ao se conhecerem melhor, conseguirão escolher uma profissão alinhada ao seu propósito, sem hesitação ou arrependimento.

4. Referências bibliográficas

Livros:

BAZÍLIO, Luiz Cavalieri; KRAMER, Sonia. Infância, Educação e Direitos Humanos. Editora Cortez.

CANDAU, Vera Maria; PAULO, Iliana Aida; ANDRADE, Marcelo; LUCINDA, Maria da Consolação; SACAVINO, Suzana Beatriz; AMORIM, Viviane. Educação em Direitos Humanos e formação de professores(as). Editora Cortez.

FREIRE, Paulo. Direitos Humanos e educação libertadora. 01. ed. São Paulo e Rio de Janeiro: Paz e Terra, 2019.

QUEIROZ, Rafael Mafei Rabelo; FEFERBAUM, Marina. Metodologia da Pesquisa em Direito técnicas e abordagens para elaboração de monografias, dissertações e teses. 02. ed. São Paulo: Saraiva, 2019.

RAYO, José Tuvilla. Educação em Direitos Humanos. Rumo a uma perspectiva global. 02. ed. Penso, 2003.

SILVEIRA, Rosa Maria Godoy. Educação em Direitos Humanos Fundamentos Teórico Metodológicos. Editora da UFPB, 2007. 


\section{A PRODUÇÃO DA DISCRIMINAÇÃO CONTRA OS NEGROS NA PUBLICAÇÃO DOS LIVROS DIDÁTICOS DE HISTÓRIA E DE LÍNGUA PORTUGUESA NO BRASIL}

Ricardo José Clevelande Ferriera

Neste artigo, faremos uma abordagem sobre o problema da discriminação encontrada nos livros didáticos de História e Língua Portuguesa utilizados nas escolas do território nacional. Iremos ater nossa observação nesses dois modelos de livro didático com a finalidade de promover uma análise de como são produzidos e distribuídos nas escolas, assim como os órgãos responsáveis pela sua regulamentação, liberação e distribuição.

Os primeiros estudos sobre a discriminação nos livros didáticos no Brasil tiveram início na década de 1950 com uma pesquisa realizada por Dante Moreira Leite intitulada:

Preconceito racial e patriotismo em seis livros didáticos primários brasileiros, onde o autor destaca indícios discriminatórios contra os negros tais como:

A não representação de personagens negros na sociedade descrita nos livros; a representação do negro em situação social inferior à do branco; o tratamento da personagem 
negra com postura de desprezo; a visão do negro como alguém digno de piedade; o enfoque da raça branca como sendo a mais bela e a de mais poderosa inteligência. (LEITE, 1950).

Esse trabalho de Moreira Leite foi seguido por dois outros intitulados de: - Valores e estereótipos em livros de leitura de Bazzanella (1957) e a pesquisa - Estereótipos e valores nos compêndios de História destinados ao curso secundário brasileiro (HOLLANDA, 1957). Esses estudos foram patrocinados pela UNESCO. Os estudos realizados apresentam uma hostilidade racial ou a defesa da inferioridade natural dos negros seguindo teorias racistas do século XIX. Não apenas sobre o racismo baseiam-se as pesquisas, mas também abordam a questão do estereótipo popularizado pela psicologia social naquele contexto no Brasil.

Uma nova proposta de estudos ocorre no final dos anos 1970 e durante o ano de 1980, buscando tratar de forma direta ou indireta o problema das relações raciais no Brasil, baseiam-se na teoria reprodutivista colocando a escola como reprodutora das discriminações existentes na sociedade contra determinadas categorias étnico-raciais. (PINTO, apud ROSEMBERG, 2003). É possível observar a preocupação já naquela época sobre o problema da discriminação racial contra os negros na produção dos livros didáticos no Brasil, onde é veementemente negado o direito da construção da identidade cultural e social dos negros e a total abdicação do conteúdo de História da África nos mesmos.

No período das décadas de 1980 e de 1990, a partir de pesquisas realizadas em livros didáticos sobre a representação dos negros em textos e ilustrações, percebe-se como ocorria a depreciação de forma sistemática de personagens negros diante da apresentação dos personagens brancos. (PINTO, 1981; SILVA, 1988).

Apresentaremos uma tabela explicativa das pesquisas realizadas sobre a discriminação contra os negros. 
Quando 1: Referências sobre estereótipos e preconceitos na literatura didática brasileira na década de 1950.

\begin{tabular}{|c|c|c|}
\hline Autor & $\begin{array}{c}\text { Pesquisa/ } \\
\text { Publicação }\end{array}$ & Resultados \\
\hline $\begin{array}{c}\text { Dante } \\
\text { Moreira } \\
\text { Leite (1950) }\end{array}$ & $\begin{array}{l}\text { Preconceito } \\
\text { racial e } \\
\text { patriotismo } \\
\text { em seis livros } \\
\text { didáticos } \\
\text { primários } \\
\text { brasileiros. }\end{array}$ & $\begin{array}{l}\text { Chegou-se às seguintes formas assumidas } \\
\text { de preconceito: caracterização de } \\
\text { personagens negros em situação social } \\
\text { inferior; superioridade da raça branca em } \\
\text { beleza e inteligência; postura de desprezo } \\
\text { e/ou piedade em relação aos negros e } \\
\text { combate do preconceito por exemplos da } \\
\text { História do Brasil. }\end{array}$ \\
\hline $\begin{array}{c}\text { Programa de } \\
\text { Atividades } \\
\text { do CBPE e } \\
\text { UNESCO } \\
(1956 \text { e } \\
1957)\end{array}$ & $\begin{array}{l}\text { Projeto de análise } \\
\text { do conteúdo de } \\
\text { livros didáticos } \\
\text { e de manuais } \\
\text { utilizados por } \\
\text { professores e } \\
\text { alunos. } \\
\end{array}$ & $\begin{array}{l}\text { Avaliação do impacto desse material sobre } \\
\text { as crianças leitoras. Como resultado desse } \\
\text { projeto dois artigos foram publicados por } \\
\text { Bazzanella e Hollanda, em } 1957 .\end{array}$ \\
\hline $\begin{array}{c}\text { Bazzanella } \\
\text { (1957) }\end{array}$ & $\begin{array}{l}\text { Valores e } \\
\text { estereótipos em } \\
\text { livros de leitura. }\end{array}$ & $\begin{array}{l}\text { Análise de dez livros de leitura } \\
\text { destinados à 4a série primária, em busca } \\
\text { de estereótipos e valores explícitos. } \\
\text { Os resultados: incidência mínima de } \\
\text { preconceito explícito (duas vezes). A } \\
\text { partir de observações, detectou- se que a } \\
\text { figura do negro estava associada a funções } \\
\text { subalternas, escravidão e à figura do } \\
\text { contador de histórias. }\end{array}$ \\
\hline $\begin{array}{c}\text { Hollanda } \\
\text { (1957) }\end{array}$ & $\begin{array}{l}\text { A pesquisa de } \\
\text { estereótipos } \\
\text { e valores nos } \\
\text { compêndios } \\
\text { de História } \\
\text { destinados ao } \\
\text { curso secundário } \\
\text { brasileiro. }\end{array}$ & $\begin{array}{l}\text { Análise de } 20 \text { manuais do antigo curso } \\
\text { ginasial (quatro de História Moderna e } \\
\text { Contemporânea; seis de História da América } \\
\text { e dez de História do Brasil). Os resultados: } \\
\text { cinco manuais referiam-se à escravidão como } \\
\text { algo condenável; quatro aos maus-tratos } \\
\text { durante o tráfico, sendo a figura dos donos de } \\
\text { escravos positiva (não referido aos maus tratos } \\
\text { por eles dispensados). A maioria dos manuais } \\
\text { justificava a escravidão como uma } \\
\text { necessidade econômica. }\end{array}$ \\
\hline
\end{tabular}

(NEGRÃO, apud ROSEMBER, 2003). 
Além dos dados apresentados acima, vejamos as características detectadas através dos estudos sobre representações das categorias étnico-raciais em livros didáticos exercida pelos pesquisadores. Acompanhe os dados no quadro a seguir.

Quadro 2:

Importância de personagens. Branco como representante da espécie, muito mais freqüente nas ilustrações, representado em quase a totalidade de posições de destaque e ilustrações de capas (Pinto, 1987; Silva, 1987, 1988a, 1988b); negro menos freqüente nas ilustrações, prioritariamente identificado pela etnia, ao passo que o branco por nome próprio e atributos familiares (Pinto, 1987; Silva 1988a). Estudo posterior de Silva (2000, 2001a) aponta maior índice de representação de negros no centro ou em posições de destaque e aumento proporcional de número de personagens, mantendo a sub-representação de negros. Personagens negros aparecem menos freqüentemente em contexto familiar (Pinto, 1987; Silva, 1987, 1988a, 2000, 2001a). Quando apresentada, a família é invariavelmente pobre (Triumpho, 1987). Os papéis familiares são omitidos ou menos numerosos (Silva, 1988).

Personagens negros desempenham um número limitado de atividades profissionais, em geral as de menor prestígio e poder. (Pinto, 1987; Silva, 1987, 1988a, 2000, 2001a). Relata a diversificação de papéis e funções profissionais dos negros, e a representação dos mesmos com poder aquisitivo.

Crianças negras representadas em situações consideradas negativas, raramente em contexto escolar ou desempenhando atividades de lazer (Silva, 1988a, 2000, 2001a) afirma a humanização no tratamento, com menções positivas à criança negra; a utilização de nome próprio para tal criança; a presença em práticas de atividades de lazer e em situação escolar.

Tratamento estético das ilustrações apresenta o negro com traços grotescos e estereotipados (Pinto, 1987; Silva, 1987, 1988a). Silva (2000, 2001a) relata a representação positiva de características fenotípicas.

Apresentação dos negros e mestiços prevalentemente como personagens sem possibilidade de atuação na narrativa, em posição coadjuvante ou como objeto da ação do outro, em contraponto com os personagens brancos, com maiores possibilidades de atuação e autonomia (Pinto, 1987, Chinellato, 1996). 
Contexto sociocultural do negro omitido nos livros analisados, nos quais prevaleceram os valores da cultura européia (Triumpho, 1987; Silva, 1988a,

2000, 2001a; Chinellato, 1996; Oliveira, 2000). A complexidade das culturas africanas não foi abordada (Pinto, 1999).

Livros didáticos mantiveram a população negra confinada a determinadas temáticas que reafirmam o lugar social ao qual ela está limitada (Oliveira, 2000).

Discursos das crônicas transcritas em livros didáticos apresentaram as concepções preconceituosas compartilhadas, ou introjetadas, pelos personagens negros (Chinellato, 1996).

Personagens negros tratados pelas crônicas são pobres ou miseráveis e desempenham os papéis sociais estereotipados ou estigmatizados. Por outro lado, as narrativas das crônicas fazem uso da existência do preconceito e do ridículo a que este submete os agentes preconceituosos. Nota-se a polifonia dos textos, que comunicam mensagens diversas, por vezes contraditórias, por meio de recursos discursivos diversificados (Chinellato, 1996).

Predominância de perspectiva eurocêntrica da história. Negação de outros pontos de vista e omissão de fatos históricos que concorreriam com a visão européia (Triumpho, 1987, Negrão, 1988; Oliveira, 2000).

Oliveira (2000) e Pinto (1999) relatam que os livros didáticos assimilaram determinadas críticas que foram realizadas, passando a tratar de eventos históricos antes relegados, e iniciando a inclusão do negro como participante em processos históricos. Mas ainda encontraram-se, nos textos didáticos, afirmações restritivas e abordagens simplificadoras. Relatam a ênfase na representação do negro escravo, vinculando-o a uma passagem daquela condição à de marginal contemporâneo, pouco tratada a diversidade de sua condição (Oliveira, 2000). No que se refere à resistência negra enfatizaramse manifestações individuais em lugar de coletivas.

(NEGRÃO, apud ROSEMBERG, 2003).

A partir das observações dos quadros apresentados, entendemos que a prática da discriminação aos negros no Brasil permanece de forma intrínseca na sociedade. Já vimos anteriormente que essa prática origina-se do período da colonização portuguesa, quando mudaram drasticamente a cultura africana com o tráfico e comércio de escravos.

Para Rosemberg, os livros de literatura infanto-juvenis apresentam uma relação de desigualdade racial, pois o adulto que o produz está reproduzindo essa prática, e que ao ser lido pelas crianças, transmiti-lhes desde a sua primeira infância o mesmo tipo de atitude preconceituosa 
enraizada na sociedade por séculos. A autora, citando Negrão, relata que se pode encontrar no mesmo livro que trata das igualdades raciais o traços de desigualdade, tornando-se incoerentes em sua abordagem, atribui que essa atitude é justificada pelo fato de que os livros são elaborados para educar as crianças brancas.

É esta dualidade igual-desigual que explica o fato de, num mesmo texto, discursos igualitários coexistirem com representações discriminatórias de personagens. O preconceito veiculado pela literatura se justifica na medida em que tais obras são produzidas para educar a criança branca. (NEGRÃO, apud ROSEMBERG, 2003).

Tanto nos livros de Língua Portuguesa, quanto nos livros de História do Brasil, os pesquisadores encontraram de forma marcante a prática da discriminação e do preconceito racial aos negros. Oliveira ao analisar os livros de História produzidos entre 1978 e 1998, encontra as marcas do eurocentrismo em suas páginas, mesmo sendo visível a tentativa de se promover mudanças em tal prática. Além dos textos possuírem conteúdo discriminatório, as ilustrações contidas nos livros didáticos de história e língua portuguesa estão carregadas do estereótipo de que o negro é inferior e serve apenas para o trabalho braçal entre outras coisas de pequeno vulto. As imagens mais utilizadas nos livros didáticos de história são as produzidas por Debret e Rugendas.

Ao observarmos os livros de história atuais, iremos constatar algumas mudanças no que se refere ao tratamento aplicado na produção desses livros, existe uma preocupação em se diminuir a prática discriminatória não só nos seus textos, assim como, nas ilustrações contidas nos mesmos. Esse processo deve-se a uma mudança na visão historiográfica brasileira, mas mesmo assim, é possível encontrarmos traços mesmo que sutis da prática preconceituosa arraigada em nossa sociedade.

Continuando nossa observação, percebemos que no processo de produção dos livros didáticos de história principalmente, não se valoriza a complexidade da riquíssima cultura africana. Quando há uma referência sobre os negros, num número significativo de livros, é feita de forma a apresentá-los como escravos ou rebeldes, como no caso de 
Zumbi de Palmares, que aparece não representando um sujeito de uma coletividade que luta pelos direitos de liberdade, mas sim um revoltoso que em suas ações não traduz a vontade dos demais negros.

Rosemberg em suas considerações buscando combater a produção dos livros didáticos contendo práticas discriminatórias contra os negros nos apresenta o seguinte:

É curioso que essa produção bastante reduzida de pesquisas e estudos sobre o racismo em livros didáticos e esses frágeis sinais de mudança convivam com um certo alarde em torno do tema na ação política, seja ela governamental ou dos movimentos sociais. A despeito desse interesse, as ações que vêm sendo desenvolvidas por diversos atores sociais — governo, militantes, educadores, pesquisadores - no combate ao racismo em livros didáticos, ainda não suscitaram sistematização. (...) O combate ao racismo nos livros didáticos consubstanciou-se por meio de uma série de ações impulsionadas e desenvolvidas pelos movimentos sociais, especialmente pelo movimento negro, subsidiado por pesquisadores negros e brancos e implantadas pelo Estado. (ROSEMBERG, 2003).

Em pesquisa realizada por Renilson José Menegassi e Neucimara Ferreira de Souza sobre a produção dos livros didáticos da língua portuguesa com conteúdo discriminatório contra os negros, encontramos exemplos dessa prática que influencia os alunos no que tange a continuidade de tais atos, atribuindo mais uma vez a eles (os negros) o papel de causador de problemas, de serviçal, entre outros trabalhos, unicamente dedicados a essa parcela da população brasileira.

Os autores apresentam uma busca por parte da sociedade no intuito de se construir uma consciência contra a prática do preconceito e da discriminação racial contra os negros, mas mesmo diante de tais esforços se percebe que ainda está longe de extingui-la. Referem-se ao ambiente escolar como uma importantíssima instância social utilizada na formação e construção de ideologias, apresenta uma realidade que não respeita as diferenças étnico- raciais, impedindo aos indivíduos que sofrem com esse tipo de atitude a participação ativa na vida cultural que está contida no universo escolar. 
Essa atitude preconceituosa é causadora de profundas marcas nos indivíduos que as sofrem. Devemos nos lembrar que os indivíduos citados anteriormente são crianças em seu processo inicial de formação, sendo assim, esse tipo de agressão poderá causar graves problemas na construção de sua identidade social e cultural, e marcar sua vida como cidadão e como agente de transformação social.

A seguir vamos observar os exemplos apresentados pelos autores de textos contidos em livros de língua portuguesa utilizados pelos alunos em sala de aula. O primeiro exemplo traz um texto de Gilberto Gil intitulado Domingo no Parque, onde o autor e o ilustrador apresentam uma mulher negra como causadora de um conflito entre dois rapazes brancos, o ponto crucial aqui é que no texto de Gil, a referida moça não é apresentada por ele como uma mulher negra. Vejamos o exemplo dos autores:

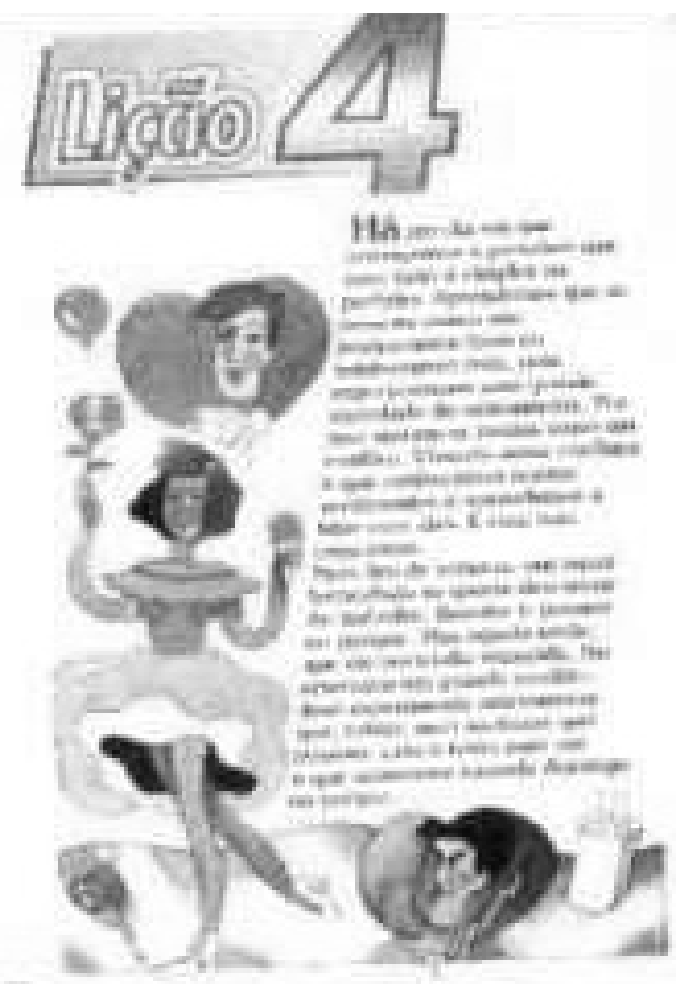

Revista Espaço Acadêmico - no 47 - Abril de 2005 - UNIPAR 
Dando seguimento à sua abordagem os autores apresentam outro exemplo de discriminação em relação aos negros, onde aparece uma senhora negra representada por uma caricatura de mulher negra vista apenas como serviçal nas diversas vezes que aparece em livros tanto de história, como nos demais livros que retratam a posição social do negro no Brasil. Denominada no texto como Dona Durvalina, com nove filhos que aparecem ilustrados ao seu redor utlizando chinelos e roupas remendadas o que remete-nos à situações de pobreza, o que associa o negro a uma situação social completamente desfavorecida, que não tem condições de uma postura melhor diante dos demais membros dessa mesma sociedade em que estão inseridos. Em contracenso ao quadro apresentado sobre os personagens negros, o autor e o ilustrador, apresentam a figura de um homem branco com roupas novas e perfeitas, colocando-o como superior aos demais que dividem a cena com ele.

Chamamos a atenção mais uma vez para a ilustração, apresentada pelos autores do livro de lígua portuguesa, que Menegassi e Souza coloca para observação:

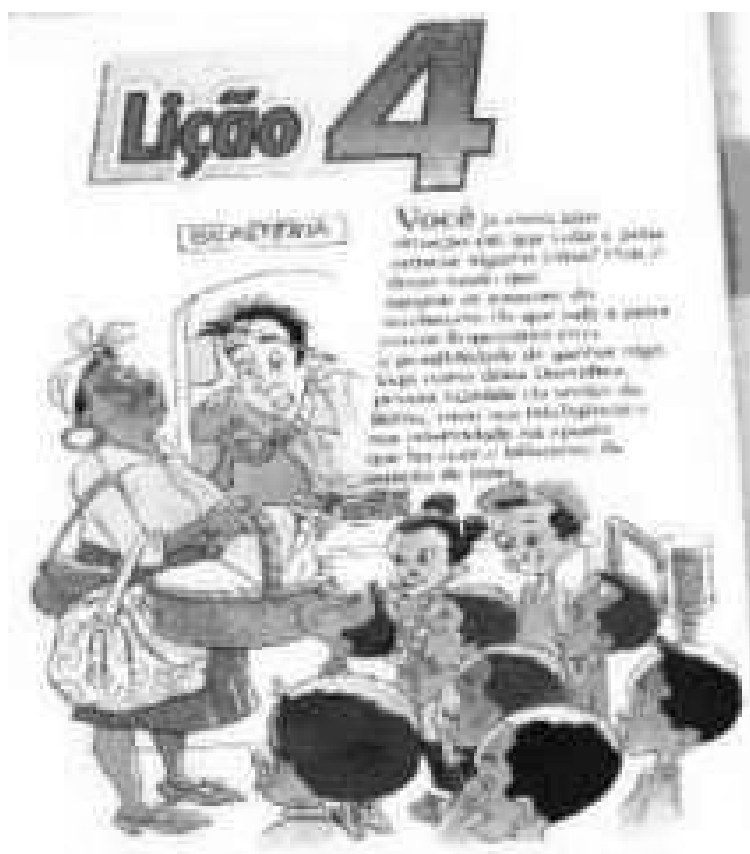

Revista Espaço Acadêmico - no 47 - Abril de 2005 - UNIPAR 
Finalizando nossa abordagem sobre as ilustrações de alguns livros didáticos de língua portuguesa, apresentamos um texto ainda mais marcante no processo de cunho discriminatório ao negro no interior desses livros. Nessa abordagem veremos uma passagem onde um menino branco refere-se ao menino negro como Tiziu. Cabe aqui uma pequena referência ao Dicionário Aurélio (1990), onde apresenta-nos que "o termo Tiziu corresponde a uma ave passeriforme, cujo macho é preto-azulado. (Menegassi, 2004). Evidencia-se aqui a postura tanto do autor como do ilustrador tecendo uma referência entre o menino negro e o pássaro pela cor das penas de um e da pele do outro, quando deveriam atribuir-lhe um nome com o propósito de identificá-lo, e não como uma coisa como um comparativo depreciativo.

Essa atitude contribui para uma postura preconceituosa por parte dos alunos que estarão utilizando esse livro no seu dia-a-dia nas salas de aula, já que possibilita a comparação do menino negro a um pássaro, negando-lhe uma identidade própria como pessoa e não apenas como um animal ou algo de menor vulto e importância. Acompanhemos como Menegassi e Souza definem essa forma textual encontrada por eles em um livro de uma coleção de livros didáticos da Língua Portuguesa onde fixaram sua pesquisa:

O termo utilizado pelas autoras, para nomear o garoto negro, colabora para a propagação do preconceito, pois possibilita a comparação do negro a um animal-pássaro cujas penas ou pêlos são pretos, provocando em alunos pertencentes à mesma etnia uma baixa auto-estima, possibilitando, ainda, que venham a ser denominados de tal forma pelos colegas em sala de aula, uma vez que, para os alunos pertencentes a outras etnias, o fato de chamar o colega negro por apelidos é um ato natural na sociedade brasileira, sendo um costume adquirido em casa através da própria família, explicitando o preconceito existente na sociedade. (...) Diante das análises realizadas da coleção A palavra é português, observa-se que as autoras, bem como o ilustrador do livro didático, retratam o segmento negro e principalmente a mulher negra de forma totalmente caricatural e estereotipada. Esta imagem distorcida da mulher negra contribui para a di- 
fusão da discriminação na sociedade, o que prejudica muito a auto-estima e a valorização dessa categoria da sociedade. (MENEGASSI E SOUZA, 2004).

Segundo os autores da pesquisa, mesmo diante de tais fatos acredita-se que seja possível se construir uma sociedade mais igualitária e justa buscando atenuar as práticas de preconceito e discriminação racial contra os negros no Brasil, iniciando essa busca através da produção de livros didáticos que valorizem a pessoa do negro, sua cultura, sua identidade entre outros fatores primordiais, assim como sua colaboração na construção não apenas cultural, mas na edificação da sociedade brasileira. Parafraseando Menegassi e Souza, utilizamo-nos da sua citação referindo-se ao líder negro Martin Luther King onde diz o seguinte: "Aprendemos a voar como os pássaros, e a nadar como os peixes, mas não aprendemos a conviver como irmãos.

Diante dos fatos apresentados pelos pesquisadores, entendemos que se faz necessário uma maior conscientização de toda sociedade para a obtenção de condições de uma convivência harmoniosa entre as diversas etnias existentes em solo brasileiro, com total respeito às diversidades, através de um sistema educacional comprometido com o fim das práticas discriminatórias interna e externamente ao contexto escolar, sem desvalorizar outras etnias, mas principalmente no que se refere a tal prática sofrida pelos negros no Brasil, que se inicia no período da sua colonização.

Em seu artigo, sobre a produção do livro didático de História do Brasil, as autoras Sônia Regina Miranda e Tânia Regina de Luca, abordam que a questão de sua elaboração e produção está diretamente ligada à questão cultural. Estes livros não apresentam unicamente um conteúdo normativo, mas estão repletos da influência sócio-histórica e política. Sua utilização serve para reedificar a postura governamental vigente. Acompanhemos a visão das autoras sobre o assunto:

Contrariamente à apreensão predominante no âmbito do senso comum, o livro didático é um produto cultural dotado de alto grau de complexidade e que não deve ser tomado unicamente em função do que contém sob o ponto de vista normativo, 
uma vez que não só sua produção vincula-se a múltiplas possibilidades de didatização do saber histórico, como também sua utilização pode ensejar práticas de leitura muito diversas. Tampouco os efeitos da ação avaliativa implementada pelo Ministério da Educação podem ser vistos exclusivamente com base em uma premissa homogeneizadora de práticas e perspectivas quanto à História, sobretudo se considerarmos um breve histórico a respeito do papel regulador e/ou intervencionista do Estado nesse nicho particular de mercado e as circunstâncias políticas contemporâneas resultantes da prática avaliativa. Observando-se a cronologia das ações do governo brasileiro em relação ao livro didático, constata-se que, embora a estruturação de um programa de avaliação determinante dos processos de compra seja algo relativamente recente, o estabelecimento de uma política pública para o livro didático remonta ao Estado Novo, quando se instituiu, pela primeira vez, uma Comissão Nacional de Livros Didáticos, cujas atribuições envolviam o estabelecimento de regras para a produção, compra e utilização do livro didático. (MIRANDA e LUCA, 2004, p.124).

Relatam que a cada governo o controle e distribuição dos livros didáticos, não somente os de história, mas todos os outros utilizados nas escolas, reproduzem o ideal do Estado. Exemplificando, citamos a questão do período do regime militar, que promoveu total controle sobre os livros didáticos, com censura e total falta de liberdade democrática. Promoveu-se uma ampliação da produção escolar de forma massificada com graves consequências que marcaram o sistema de ensino.

Esse tipo de atitude por parte do governo militar resume-se em promover um total controle do processo de formação educacional, onde se destacava o poder do Estado e a afirmação desse poder, evitando dessa forma o questionamento por parte da população das ações promovidas pelos militares.

A partir da década de 1980 diante da reconstrução da democracia no Brasil, depois de muita pesquisa e de debates no campo da produção do livro didático, chegou-se à conclusão de que seria necessário um órgão para orientar a produção e eventual distribuição desse material nas 
escolas. Efetua-se então a criação do PNLD (Programa Nacional do Livro Didático em 1985), que dentre suas atribuições procura ouvir a opinião dos professores que irão atuar nas escolas utilizando esses livros.

No entanto, apenas em 1996 efetiva-se concretamente a avaliação pedagógica dos livros didáticos, em um cenário que não conta mais com a presença de um Estado autoritário. Esse processo é cercado por conflitos de interesses, a partir desses fatos se estipula que a aquisição de livros didáticos no Brasil com a utilização de verbas públicas fica sujeita a uma inscrição respeitando-se as regras contidas em edital próprio. (MIRANDA E LUCA, 2004).

Mesmo com o PNLD, o livro didático é visto apenas como mercadoria de consumo, não preservando a situação da sua dimensão metodológica e/ou a metodologia contida em uma coleção didática. As autoras abordam da seguinte forma este aspecto:

Cumpre destacar que para o segmento voltado para as compras do setor público importa menos a orientação metodológica ou a ideologia contida em uma coleção didática, e mais a sua capacidade de vendagem e aceitação no mercado. Nesse contexto, o livro didático assume claramente sua dimensão de mercadoria, sujeita a múltiplas interferências em seu processo de produção e vendagem. A esse respeito, há que se reconhecer que os pareceres técnicos de exclusão acabaram desempenhando, por vezes, papel primordial no processo de reformulação de coleções, patente no fato de um dos conjuntos excluídos em determinado PNLD vir a ser recomendado com distinção na edição seguinte do programa, o que indica o quanto o processo de avaliação foi tomado a sério por certos autores e editores. Outro ponto sensível, identificado em todas as pesquisas mais recentes a respeito da escolha de livros didáticos, está no desempenho agressivo das editoras no mercado, que se valem de sofisticados esquemas de distribuição e vendas, a ponto de influir decisivamente nos processos de escolha nas escolas de todo o país. Naturalmente, as empresas mais bem estruturadas desfrutam de larga vantagem frente às editoras menores. (MIRANDA E LUCA, 2004. pg. 128). 
Vamos observar a partir do gráfico apresentado abaixo o número de inscrições e aprovações de livros didáticos de história no PNLD apresentados pelas autoras.

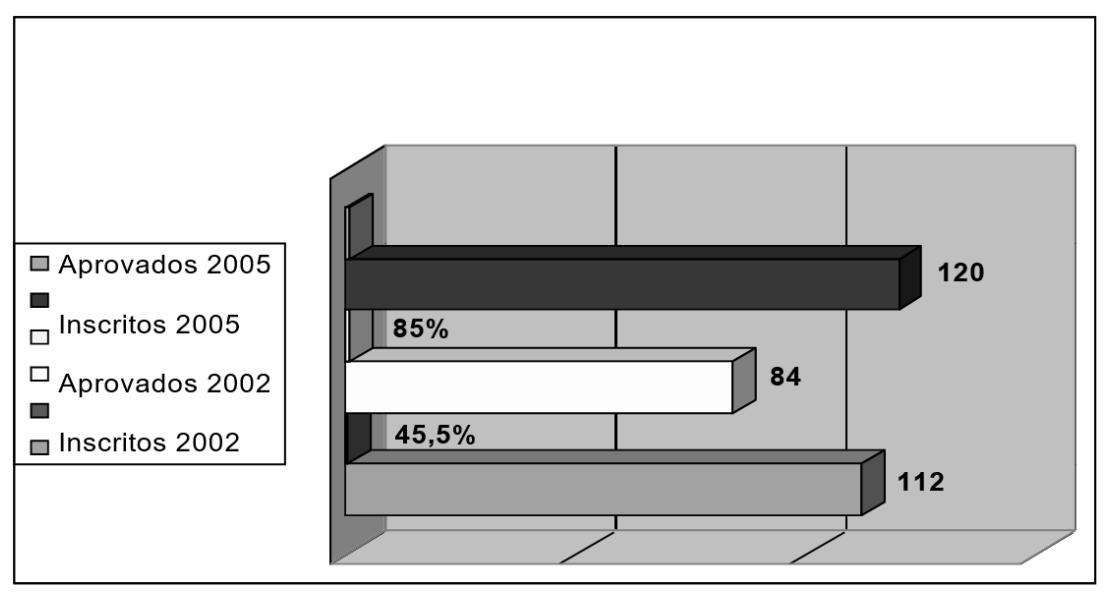

LD - Área de história - histórico de inscrições e aprovações

Miranda e Luca informam que: no PNLD 1999 tanto a inscrição de obras por editora como a avaliação pedagógica foram feitas por volumes isolados, o que não implica a necessidade de a editora possuir uma coleção completa. A partir do PNLD 2002, observa-se a redução no número geral de coleções inscritas, em 2005 há uma alteração no programa, com a elevação do número de inscrições. Em 2002 se inicia a avaliação na área de História incorporando a análise estatística, feita a partir de planilhas de cálculos, nas quais se registrou o desempenho de cada coleção em relação aos quesitos que compunham a ficha de avaliação, sempre divulgada nos Guias. Não se registraram modificações significativas nas fichas de 2002 para 2005, embora tenham sido redefinidos os valores ponderados dos quesitos gerais. (MIRANDA E LUCA, 2004).

É visível a preocupação das autoras no que se refere à forte influência que a editoras proporcionam sobre o PNLD, e as reais consequências desse fato. Não se tem a preocupação sobre o conteúdo abordado nos livros didáticos, talvez por esse motivo, encontramos os fatos men- 
cionados anteriormente sobre a questão do preconceito e da discriminação racial praticados contra o negro nos livros didáticos de História e Língua Portuguesa no Brasil.

Dentro dos relatos supras citados, entendemos que ainda em 2020 existe fortemente uma relação de preconceito e discriminação com relação à população negra no Brasil. Em matéria publicada no jornal A Tribuna de 23 de junho de 2020 encontramos dados e relatos sobre o processo de preconeito e discriminação racial praticada contra os negros no Brasil. Em sua edição o referido jornal trás o seguinte: "Um a cada três brasileiros diz ja ter sofrido discriminação por sua clase social". "A discriminação racial é grave no Brasil e mais de $1 / 5$ dos brasileiros já foi vítima dela. 55\% dos que se autodelcararam negros alegam já ter sofrido preconceito racial, índice 5 vezes maios dos que os que se delcaram brancos (11\%)." - (A Tribuna - 23 junho de 2020).

Em seu artigo no citado jornal Júnior Bozzella, apresenta-nos os seguintes dados: "O brasileiro é fruto da miscigenação de vários povos, negros, indígenas e europeus, que resultaram na alegria colorida de nossa gente. Não nos cabe qualquer que seja o tipo de discriminação. É vergonhoso que no ano de 2020 o preconceito ainda envenene o Brasil e que ainda vejamos pessoas torcendo o nariz quando tocamos no assunto." - (BOZZELLA, Júnior. A Tribuna - 23 de junho de 2020).

Diante dos fatos apresentados, tanto na pesquisa sobre a questão da presença do preconceito e discriminação nos livros didáticos, assim como, no artigo do jornal A Tribuna, entendemos que infelizmente ainda no Brasil o preconceito e a discriminação estão longe de serem extintos.

Analisemos o que relatam os professores Wanderley Valerio e Prof. Dr. Márcio Santos de Santana no caderno PDE do Estado do Pará: A dificuldade dos educandos em visualizar as diversas formas de preconceitos existentes no ambiente escolar faz com que a conscientização e superação desse problema se tornem ainda mais complexa. Diante desse relato apresentamos a Lei no 10.639/03 que estabeleceu uma nova forma de divulgação da cultura africana, possibilitando aos educandos um olhar receptivo a esta cultura, a qual influenciou diretamente a cultura brasileira desde os primórdios da colonização. 
Sim, a lei trás essa perspectiva de que se deve valorizar a pessoa do negro, assim como, dos indígenas no processo de aprendizagem. Mas contudo, vejamos o que Silva nos trás para relfetir:

O livro didático, de modo geral omite o processo histórico e cultural, o cotidiano e as experiências dos segmentos subalternos da sociedade, como o negro, o índio, a mulher, entre outros. Em relação ao segmento negro, sua quase total ausência nos livros e a sua rara presença de forma estereotipada concorrem, em grande parte para o recalque de sua identidade e autoestima (SILVA, 2004, p. 51).

Já Oliveira nos apresenta essa relfexão: "Um dos maiores desafios dos livros didáticos parece ser o trabalho com a diversidade de situações vividas pela população negra. Para tanto, seria necessário sair da visão homogênea predominante, que senão apresenta o negro apenas como escravo ou vitimado nas condições sociais atuais, cai em artificialismos ao retratar com traços sobejamente exóticos sua cultura. Seria importante que as narrativas presentes nos livros didáticos lidassem não apenas com o negro escravo, o negro que vive em condições precárias de sobrevivência, mas também a riqueza e problemas apresentadas por sua cultura, por sua atuação social, ou seja, com a multiplicidade de posições que ocupa ao longo da História. (OLIVEIRA, 2000, p. 170).”

Concluímos a partir dos relatos que ainda será necessário muita relfexão e luta na conquista da igualdade racial e da valorização cultural e social tanto de negros quanto dos indígenas no Brasil. E entendemos que esse processo do preconceito e da discriminação racial estão arraigados no contexto social brasileiro desde o período da colonização e escravização, primeiro dos indígenas e depois do negros. E que esse processo infelizmente está intrinseco na maneira como muitas pessoas vem agindo por séculos no Brasil.

\section{REFERENCIAL BIBLIOGRÁFICO}

BOZZELLA, Júnior. 2020 e o preconceito ainda envenena o Brasil https://www.atribuna.com.br/opiniao/juniorbozzella/2020-e-o-preconceito-ainda-envenena-o-brasil-1.85670. 
HOLLANDA, G. A. A pesquisa dos estereótipos e valores nos compêndios de história destinados ao curso secundário brasileiro. Boletim do Centro Brasileiro de Pesquisas Educacionais, Rio de Janeiro, v.2, n.4, mar. 1957.

LEITE, Dante Moreira. Preconceito racial e patriotismo em seis livros didáticos primários brasileiros. Psicologia, São Paulo, n.3, p.207-31, 1950.

MIRANDA, Sônia Regina; LUCA, Tânia Regina de. O livro didático de história hoje: um panorama à partir do PNLD. Revista Brasileira de História. São Paulo, v. 24, nº 48, pp.123- 144 - 2004.

MENGASSI, Renilson José; SOUZA, Neucimara Ferreira de. A visão do negro no livro didático de português. Revista Espaço Acadêmico - № 47 - Abril de 2005 - Mensal - ISSN 1519.6186 - Ano IV - http://www.espacoacademico.com.br/ - Acesso em 10 de maio de 2007.

MEC - Conselho Nacional de Educação - Lei 10.639/04. http://portal.mec.gov.br/index.php - Acesso em 20 de julho de 2007.

OLIVEIRA, M. A. de. O negro no ensino de história: temas e representações. Dissertação de Mestrado, Faculdade de Educação da Universidade de São Paulo. São Paulo, 2000.

PINTO, R. P. O livro didático e a democratização da escola. 1981. Dissertação (Mestrado) Faculdade de Filosofia, Letras e Ciências Humanas da Universidade de São Paulo. São Paulo, 1981.

ROSEMBERG, Fúlvia. Racismo em livros didáticos brasileiros e seu combate: uma revisão da literatura. Educação e Pesquisa, São Paulo, v.29, n.1, pp. 125-146, jan./jun. 2003.

PINTO, Regina P. Educação do negro: uma revisão da bibliografia. Cadernos de Pesquisa. São Paulo, n. 62, pp. 3-34, ago 1987a. 
- A representação do negro em livros didáticos de leitura. Cadernos de Pesquisa, São Paulo, n. 63, pp. 88-92, nov. 1987 b.

Raça e educação: uma articulação incipiente. Cadernos de Pesquisa, São Paulo, n. 80, pp. 41-50, 1992.

Diferenças étnico-raciais e formação do professor. Cadernos de Pesquisa, São Paulo, n. 108, pp. 199-231, nov. 1999.

SALLES, I. G. Trabalho, progresso e a sociedade civilizada. São Paulo: Hucitec, 1986.

Secretaria Municipal de Educação do Município de Três Rios - Dados sobre projetos de conscientização da relação do preconceito e da discriminação às crianças negras no Brasil desenvolvidos nas escolas do referido município - em 12 de março de 2008

SILVA, Ana Célia da. A Desconstrução da discriminação no livro didático.In: Kabengele Munanga (organizador). Superando o Racismo na escola. 2 ed. Brasília: Ministério da Educação, Secretaria de Educação Continuada, Alfabetização e Diversidade, 2005. 


\section{EDUCAÇÃO EM DIREITOS HUMANOS: UM ESTUDO DE CASO COM JOVENS DO CURSO "IAÔ APRENDIZ EM CENA"}

Israel Marques Campos

Introdução

O Brasil é um país que apresentou e apresenta preocupantes panoramas quanto à violação de Direitos Humanos: em 2019, o Brasil foi o quarto país que mais matou defensores do Direitos Humanos no mundo ${ }^{10}$. Ainda demonstra o agravamento do desrespeito aos Direitos Humanos no país, o fato de que é o local que mais mata pessoas trans e travestis no mundo ${ }^{11}$. O Brasil ainda é o país em que pessoas negras e pobres morrem mais do que as pessoas brancas e de classe social economicamente superior ${ }^{12}$ na Pandemia do Corona Vírus.

Esse artigo, portanto, se justifica principalmente pela urgência de diálogo e difusão de práticas educativas na área de Direitos Humanos no Brasil. O trabalho escolhe a educação como área temática, pois acredita que através da educação é possível dirimir às

10 https://www.cartacapital.com.br/sociedade/brasil-foi-o-4o-pais-que-mais-matou-ativistas-de-direitos-humanos-em-2019/

11 https://www.brasildefato.com.br/2020/01/29/em-2019-124-pessoas-trans-foram-assassinadas-no-brasil

12 https://revistagalileu.globo.com/Sociedade/noticia/2020/05/na-pandemia-de-covid-19-negros-morre m-mais-do-que-brancos-por-que.html 
contínuas violações de Direitos Humanos no mundo, de forma sólida e contínua.

Tendo em vista a relevância da questão abordada, o objetivo desse artigo é ponderar o conceito de Educação em Direitos Humanos (EDH) à luz da bibliografia, programas e planos dessa área dos âmbitos internacionais e nacionais, bem como através de uma experiência concreta de aplicação da EDH com jovens do curso de qualificação técnica em teatro, o "Iaô Aprendiz em Cena".

$\mathrm{O}$ estudo de caso escolhido foi uma experiência vivenciada pelo autor do presente artigo, na condição de educador. O estudo de caso é descrito nesse artigo consoante às anotações realizadas após cada aula no caderno de campo, retratando os principais pontos de todo o processo, em interlocução com a EDH e suas problemáticas.

\section{Metodologia, Métodos e Procedimentos de Pesquisa}

Nesse trabalho, a nível de metodologia, foi realizado um levantamento bibliográfico, um diálogo sobre algumas discussões teóricas sobre Educação em Direitos Humanos e uma descrição e análise das práticas educativas descritas no estudo de caso.

O trabalho conta com um estudo bibliográfico dos autores que discutem a temática de $\mathrm{EDH}$, além de um estudo de caso único e vivencial de uma experiência de EDH para mais de 60 jovens do "Iaô Aprendiz em Cena". O estudo de caso foi escolhido neste trabalho por se tratar de uma aplicação metodológica de EDH que busca investigar conceitos ou fenômenos em seu "contexto natural": "[...] uma pesquisa empírica que investiga um fenômeno contemporâneo em seu contexto natural, em situações em que as fronteiras entre o contexto e o fenômeno não são claramente evidentes, utilizando múltiplas fontes de evidência" (YIN, 1984, p. 23). Uma das técnicas utilizadas neste caso foi a observação direta e participante, muito aplicada na área da antropologia, por ser "[...] a técnica privilegiada para investigar os saberes e as práticas na vida social e reconhecer as ações e as representações coletivas na vida humana" (ECKERT; ROCHA, 2008, p. 2). A técnica do diário de campo foi também utilizada, pois: [...] ele é o espaço fundamental para [...] arranjar o encadeamento de suas ações 
futuras em campo, desde uma avaliação das incorreções e imperfeições ocorridas no seu dia de trabalho de campo, dúvidas conceituais e de procedimento ético (ECKERT; ROCHA, 2008, p. 5).

\section{O início da Educação em Direitos Humanos}

A Educação em Direitos Humanos também carece de discussão por ser uma área de educação mais recente, quando pensamos na consolidação do termo e dos conceitos de EDH produzidos a partir da Década Internacional para a Educação em Direitos Humanos.

Historicamente, a ideia de "Direitos Humanos", com esse nome, nasce através da Declaração Universal dos Direitos Humanos, que é criada após os horrores humanitários da II Guerra Mundial, com o intuito de salvaguardar Direitos básicos a toda pessoa no mundo. A EDH foi pensada, em sua origem, também pelas Nações Unidas (ONU), buscando difundir valores humanitários a nível global, em consequência à maior aderência no cenário global aos Direitos Humanos.

O Programa Mundial e Educação em Direitos Humanos (ORGANIZAÇÃO DAS NAÇÕES UNIDAS, 2007, 2012, 2014), fruto da Década das Nações Unidas para a Educação em Matéria de Direitos Humanos entre 1995 -2004, diz que esse tipo de educação tem em vista o objetivo de "exercitar o respeito, a tolerância, a promoção e a valorização das diversidades (...)”. Esse Programa é uma das primeiras diretrizes globais acerca do assunto.

Segundo a própria ONU, portanto, a educação em Direitos Humanos pode ser definida como o:

“(...)treinamento, disseminação e esforços de informação objetivando a construção de uma cultura universal de direitos humanos através da partilha de conhecimento, competência e habilidades e da moldagem de atitudes, que são direcionados ao fortalecimento do respeito aos direitos humanos e liberdades fundamentais; ao desenvolvimento completo da personalidade humana e de seu senso de dignidade; (...)". (HUMANOS, 1995-2004). 
Nesse trabalho analisaremos a EDH dentro de um curso de qualificação técnica em teatro. O curso, de natureza diferente de uma sala de aula tradicional, é interessante, a priori, para se notar que as possibilidades da EDH são diversas, sendo possível a aplicação do seu ensino não só na educação formal, como a também a não-formal e informal (ORGANIZAÇÃO DAS NAÇÕES UNIDAS, 2007, 2012, 2014).

O Brasil, nos últimos anos, seguiu as diretrizes da ONU e elaborou um Plano Nacional de Educação em Direitos Humanos, buscando difundir cada vez mais os Direitos Humanos no país. Alguns estados, com São Paulo e Bahia, criaram seus próprios planos de EDH, com fundamento nas discussões e produções da Organização das Nações Unidas.

\section{Educação em Direitos Humanos, Juventudes e Interculturalidade}

Pensando no público jovem e na interação entre distintas culturas (a interculturalidade) se faz imprescindível respeitar as características e demandas de cada estudante e isso se faz através da escuta e do diálogo. Nesse artigo, portanto, a educação é encarada como uma perspectiva de construção coletiva, pois “(...)seu êxito sempre depende de uma complexa interação de variáveis entre aquele que ensina, a escolha de seus procedimentos didáticos, aqueles a quem se dirigem as aulas e a natureza daquilo que se busca ensinar". (CARVALHO, 2007, p.476)

É consenso que a educação em Direitos Humanos transcende muros da escola ou formatos, podendo ser caracterizada através de ações cotidianas (SADER, 2007; MAIA, 2007). Um diálogo entre uma pessoa do interior do Brasil, que conheça as violações sistemáticas dos Direitos Humanos, com uma pessoa de uma grande capital do Brasil que nunca ouviu falar do "Movimento dos Sem Terra" é, por exemplo, uma ação de educação em Direitos Humanos.

Dessa forma, o presente trabalho defende que a EDH não se torne uma matéria isolada ou uma "fórmula abstrata ou mesmo vazia". (MELO NETO, 2007, p.430), mas sempre atenta às realidades locais, em uma perspectiva freiriana de construtivismo e da pedagogia do oprimido: "É fundamental (...) partirmos de que o homem, ser de 
relações e não só de contatos, não apenas está no mundo, mas com o mundo. Estar com o mundo resulta de sua abertura à realidade, que o faz ser o ente de relações que é” (FREIRE, 2002, p. 47).

A educação em Direitos Humanos tem, portanto, o pressuposto ético de universalizar através da sua difusão, do seu diálogo e da sua compreensão das realidades de cada grupo ou local, os sujeitos que todos e todas somos ou que devemos ser. Esse enxergar a outra pessoa como sujeito é um exercício contínuo, pois há sempre entraves e dispositivos que impedem esse outro de ser sujeito. Na Europa, por exemplo, se pode pensar através dos refugiados. Em diversos países europeus que recebem refugiados, há o mito de que os refugiados irão "roubas os empregos dos europeus" ou "cometer crimes", pois são perigosos, ou até "imigrar ilegalmente" no país. Ao ensinar e dialogar com a população sobre os refugiados, e dar luz às complexidades que compõem a questão e consequentemente reconstruir conjuntamente as representações sobre "o outro", ampliamos a noção do sujeito refugiado, obtendo mudanças significativas no olhar dessa outra pessoa, de uma nova ética, que “(...) exige propor-se a superar posições e posturas que não tomam em consideração as vítimas" (CARBONARI, 2007,p.173).

O "sujeito vítima", deixa de ser "mais uma vítima" e passa aos olhos da pessoa que absorve a EDH como um sujeito que de fato é vítima; se elimina ou se dirime a "indiferença" (CARBONARI, 2007,p.174) ou até mesmo potenciais conflitos, além do outro poder se tornar concretamente um sujeito de direitos aos olhos sociais, denotando a necessidade do caráter de formação para a cidadania que a EDH deve adotar. (CANDAU, 2007, p.404).

É importante destacar o papel fundamental da educação nesse processo, que ao contrário da justiça, não deve decretar sentenças, mas dialogar, sempre considerando a interculturalidade para a construção de conhecimentos que vão para além de adoções de comportamentos politicamente corretos, mas com o exercício de posturas resultados de um conhecimento também construído por sí, conscientemente enraizado.

A respeito dos Direitos Humanos propriamente ditos e sua relação com a interculturalidade, é pertinente considerar que apesar desses 
direitos serem universais, “(...)a igualdade não está oposta à diferença, e sim à desigualdade, e diferença não se opõe à igualdade e sim à padronização, à produção em série, à uniformização" (CANDAU, 2012, p.239). A EDH, portanto, se alia à igualdade de direitos, sempre em respeito às diferenças; não deve querer "ensinar" com o intuito de padronizar culturas e pessoas; deve ter sempre em vista que a diferença não é um obstáculo, mas uma soma para o aprendizado intercultural, desenvolvendo saberes e práticas de cidadãos e cidadãs.

Por fim, se faz importante dentro desse contexto, explicitar que os conceitos de jovem não se atem a uma unidade homogênea, por isso se deve pensar sempre em "juventudes", pois como existem contextos diversos, existem jovens diversos (PAIS, 1996). Sobre o conceito da juventude, Groppo (2000, p.12) diz que juventude transcende "idade", é uma categoria social reconhecida que "tem uma importância crucial para o entendimento de diversas características das sociedades modernas, o funcionamento delas e suas transformações." (GROPPO, 2000, p.8).

\section{Processos de Educação em Direitos Humanos no curso "laô Aprendiz em Cena"}

O "IAÔ Aprendiz em Cena"13 é um curso de qualificação em teatro com carga horária de 800 horas. Ele ocorreu no centro de economia criativa, o Mercado IAÔ, localizado no final de linha da Ribeira em Salvador/Bahia/Brasil. O curso, em sua primeira versão, pôde acontecer através da realização da Associação Fábrica Cultural (organização presidida pela cantora e compositora Margareth Menezes) em parceria com a Superintendência Regional do Trabalho e Governo do Estado da Bahia, do ano de 2019 ao ano no de 2020. O curso uniu, pela primeira na Bahia, a lei de aprendizagem de contratação para o primeiro emprego e o Programa Trilha do Governo do Estado da Bahia, ou seja: os jovens são contratados por empresas para se qualificarem na área teatral. Em comum, além da faixa-etária, existe a situação de vulnerabilidade social que muitos possuem:

13 Para mais informações sobre o curso e acesso a registros audiovisuais: https://fabricacultural.org.br/iao-aprendiz-em-cena/. Acesso em 26/06/2020. 
recebem o bolsa família ou residem em abrigos. A maioria das(os) jovens que compunham o alunado são negras(os), tem entre dezesseis e vinte e dois anos, sendo a maioria de mulheres.

Oficialmente, o Aprendiz em Cena iniciou no dia 13/05/2019, sendo a primeira aula de educação em Direitos Humanos ministrada nesse dia. O caso aqui estudado compreendeu duas turmas, que possuíam cerca de 30 jovens em cada turma. As aulas ocorreram sempre pelo período matutino, o módulo "Direitos Humanos", com o total de 26 aulas, 13 por turma, e foi finalizado na data de 18/06/2019.

A EDH aplicada no caso aqui estudado mesclou a espontaneidade da sala de aula com um sistema de técnica pedagógicas, jogos, dinâmicas e temáticas. Quanto ao planejamento das aulas, em específico, é pertinente pontuar que ele foi construído em sua totalidade, mas repensado e alterado após cada dia de aulas, com sugestões dos(as) jovens, diálogos permanentes na sala e fora da sala de aula e com a percepção sobre os interesses gerais acerca das temáticas (SACAVINO, 2007, p.457).

No início do curso, a primeira aula, houve as apresentações gerais. Nomes, interesses artísticos (o curso era de teatro), o que esperavam da matéria, foram algumas das questões abordadas. Após essa introdução, a matéria tratou das falácias brasileiras de que "Direitos Humanos é coisa de Bandido" e de que "Bandido bom é bandido morto". Essa discussão é importante, portanto, para início em grande parte dos públicos alvos da educação em Direitos Humanos, bem como em matérias que possibilitam a abordagem da temática, como português, história e geografia, pois é importante desconstruir essas mentiras disseminadas como verdade em boa parte do senso comum. Com a provocação inicial, a aula transcorreu no sentido de pontuar o início dos Direitos Humanos após a II Guerra Mundial, apresentando uma versão física da Declaração Universal dos Direitos Humanos.

Em formato de roda de conversa, a partir dessa aula muitos dos jovens começaram a participar com o repertório que mais dominavam: suas próprias experiências. O engajamento nas aulas, portanto, se iniciou e muito pela dimensão subjetiva que a EDH contempla. Pela sua possibilidade ampla de abordagens temáticas, é possível sondar cada 
jovem, conforme seus interesses, para elaborar ou reformular o plano de aulas, bem como dinamizar constantemente as práticas educativas, com jogos e recursos digitais, para estimular cada jovem a se engajar e fazer com que o conhecimento seja construído da melhor forma possível para cada pessoa.

Na segunda aula, foi iniciado o processo caracterizado nesse artigo como "o levantar da poeira", ou seja, quando a dor ou a violação de Direitos que ora estava adormecida e começa a ganhar contornos e coloração. Trabalhou-se a temática "Raça e Direitos Humanos". Como boa parte das (os) jovens são negros (as) e residem em regiões periféricas e pobres, a aula acabou focando e muito nas violações de Direitos Humanos cometidas por policiais.

Um questionamento sobre se alguém já sofreu ou conhecia alguma pessoa que sofreu violência policial é feito em sala. Todas as mãos são levantadas. Uma jovem relata que sua casa foi invadida pela polícia que estava à procura de drogas. A mãe dela gritava e implorava para que os policiais não implantassem drogas na casa dela, pois a família dela era limpa. Um jovem apresenta outro relato em que estava sem camisa, voltando para casa depois do jogo de futebol no bairro, quando a polícia o aborda, e o agride com cassetete quando ele diz que não tinha droga alguma.

A violência policial foi uma temática recorrente. Um dos desafios ao mediar, no papel de educador, esse tema foi em equilibrar o assunto, no que concerne em apresentar perspectivas de soluções e de resoluções de problemas. Ao falar da temática, por exemplo, a aula tratou de músicas de artistas negras (os), que denunciavam, mas que também exaltavam o povo negro. O estatuto da igualdade racial do estado da Bahia também foi apresentado aos/às jovens.

$\mathrm{Na}$ aula seguinte, sobre religião e Direitos Humanos, uma jovem disse que seu primo estava saindo de um terreiro de candomblé, com as contas (um tipo de colar) sagradas no pescoço, quando um policial o abordou puxando suas contas do pescoço, quebrando os itens religiosos e o agredindo, quando o chamava de "macumbeiro". Como educador é necessário pontuar o quanto é desafiador lidar com esses relatos. Primeiro pela forte carga emocional e psicológica envolvida, 
segundo porque como cidadão, o educador deve se questionas: como denunciar as violências policiais? Os meios formais são efetivos? Um caminho é denunciar com articulação política, midiática e denúncia formal na corregedoria da polícia, outro caminho é fazer tudo isso, mas estar em um bairro vulnerável, em uma condição social desfavorável, em que se sabe que se algo ainda mais extremo pode ocorrer (alguns exemplos: o homicídio, o sequestro e a tortura sistemática), com as chances da impunidade enormes, vistos diversos casos no Brasil.

Durante o "levantar poeira", os (as) jovens foram ganhando mais a confiança do educador e a confiança de cada colega para expor seus casos experienciais ou expressar suas opiniões. O educador, por outra via, também passou a se interessar cada vez mais pela riqueza de cada história e pelas potencialidades que cada um/uma exercia na sala de aula. Educação também é relação.

$\mathrm{Na}$ aula seguinte, foi feita a "corrida por direitos", uma dinâmica muito importante para refletir sobre os privilégios e desigualdades sociais existentes. A atividade é muito pertinente para provocar a empatia, o "sentir na pele" e a reflexão sobre como a sociedade brasileira é desigual. Em termos gerais, funcionou assim: cada jovem pegava um papel, a exemplo "Uma mulher, branca, lésbica e cadeirante" ou "Um índio, professor e solteiro", e andava ou não a cada pergunta sobre direitos que era feita aos/às estudantes. Foram cerca de doze tipos sociais distintos.

Sobre jogos e dinâmicas coletivas como abordagem metodológica nesse caso, é importante destacar que “(...)o enfoque metodológico deve sempre privilegiar estratégias ativas que estimulem processos que articulem teoria e prática, elementos cognitivos, afetivos e envolvimento em práticas sociais concretas". (CANDAU, 2007, p.405).

$\mathrm{Na}$ próxima aula, as participações e, consequentemente, o "levantar da poeira" seguiram. Em uma aula sobre gênero e sexualidade, os diálogos acabam falando sobre as relações familiares. Um jovem relata, com um sorriso, que seu irmão homossexual apanhou e muito do pai, mas que hoje, adulto e bem-sucedido profissionalmente, ajuda o pai financeiramente e o pai respeita sua orientação sexual e seu namoro com outro homem. No momento em que fala das agressões sofridas 
pelo irmão, muitas e muitos da sala gargalham. O jovem então segue, emendando outro relato, no qual ele, heterossexual, também apanhou muito. Ele disse que uma vez, mais novo, chegou com um guarda-chuva quebrado em casa. O pai perguntou o porquê do guarda-chuva estar quebrado, ele responde, dizendo que foi o vento forte e por isso o guarda-chuva quebrou. Então o jovem fala na aula: "Quando eu vi, só recebi a porrada na cara. Caí no chão e continuei apanhando: desmaiei” (JOVEM, 2019). A sala gargalhou, ele mesmo sorria. O educador ficou sério nesse contexto, e disse o porquê estava sério. A violência física não era algo normal, mas uma construção de uma normalidade danosa às pessoas, contrárias à dignidade da pessoa humana. E falou-se sobre dignidade da pessoa humana, e conversou-se sobre direitos das crianças, dos(as) adolescentes e dos(as) jovens.

$\mathrm{Na}$ aula seguinte, uma jovem negra relatou uma violação de direitos, um crime: o estupro. Ela relatou que foi estuprada na Lagoa do Abaeté, uma região turística em Salvador/Bahia. Ela estava grávida, e foi estuprada a noite, por uma pessoa que ela conhece, mas que se viu sem saber como proceder frente ao abuso, a quem ou como recorrer. Foi um momento muito forte, um relato de uma jovem que precisava tratar daquela temática. Falamos sobre machismo e encaminhamentos possíveis (de atendimento psicológico à denúncias em meios legais) para punição do crime.

$\mathrm{Na}$ próxima aula, a temática racial voltou ao centro do diálogo. Uma outra jovem diz que odeia as pessoas brancas, pois elas são responsáveis pelo racismo que as pessoas negras sofrem. Outra jovem eleva o tom de voz e diz achar um absurdo alguém dizer isso, pois as pessoas são diferentes, e todas (os) temos que ter os direitos iguais. As duas começam a elevar os tons das críticas e interrompo a discussão para explicar as diferenças dentro dos próprios movimentos sociais, como o movimento negro brasileiro, que possui vertentes em que consideram todas as pessoas brancas como inimigas sociais e outras que acreditam que existem pessoas brancas aliadas à causa da luta antirracista. Os ânimos se acalmam, porém, na reta final da aula, novamente as duas começam uma discussão. A jovem que disse odiar pessoas brancas, começa a chorar e diz: 
"Você não sabe o que eu passei para você julgar a minha fala, um homem branco me agarrou, me levou para um lugar escuro, abaixou minha roupa e disse: é pra isso que você, neguinha, serve. Ele me estuprou! Eu odeio os homens brancos porque eles nos estupram! E é por isso que eu estou nesse curso, que eu quero ser atriz: pra pegar essa minha dor e transformar minha vida, ajudar outras vidas!” (JOVEM, 2019)

Choque geral. $\mathrm{O}$ educador pede que um colega pegue uma água para a jovem que chorava. Um grupo de meninos faz uma brincadeira entre eles e dão risada, o educador acaba por falar seriamente para que eles respeitassem a colega. Eles se desculpam, dizem que estavam rindo de outra situação. Há um pedido de desculpas pelo educador, pelo meu tom possivelmente muito duro, por conta da emoção. Nesse momento ocorre uma conversa sobre a importância de se falar das dores para achar soluções, estratégias de denúncias dessas violências são apresentadas aos jovens e às jovens.

A aula estava próxima do final e o clima era de impacto pelo relato do estupro. O educador sugere para que todos saíssem melhores daquela aula, que se abraçassem, em especial a jovem que teve coragem de relatar o que sofreu. Abraçaram-se, as(os) jovens fazem uma fila para abraçar a jovem que fez o relato de estupro. Ao final da fila, uma surpresa: a outra jovem (com quem ela havia discutido durante a aula pela questão do ódio aos brancos) estava lá. Ao fim, as duas se abraçam e uma diz para outra: "Você é minha irmã, antes de qualquer coisa". As duas choram, muitos choram, eu, não seguro mais a emoção e também choro. Se emocionar faz parte da nossa humanidade, expressar as emoções é um direito inserido na liberdade de expressão, por que não?

As questões trazidas pelas mulheres, que foram crescendo em participação no decorrer das aulas, em especial sobre as violências sofridas, foi um ponto que chamou a atenção para trazer mulheres que falassem sobre feminismo negro. Foram convidadas então duas ativistas da Anistia Internacional, negras, para realizarem uma roda de conversa sobre feminismo negro.

Foi um momento de aprendizado para o educador, que como homem, não poderia dar uma aula tão rica do ponto de vista da vivência, como elas puderam contribuir. Pela amplitude dos Direitos Humanos, 
se faz muito importante as parcerias com setores da sociedade como as ONGs, para que as aulas tenham ainda mais força sobre suas temáticas e a empatia pela outra pessoa seja desenvolvida.

Esse exemplo de feminismo negro, e todos os fatos marcantes ocorridos nas aulas de EDH do curso "Iaô Aprendiz em Cena" proporciona uma interessante reflexão sobre a teorização da educação em Direitos Humanos, ou seja, como essa área da educação explora ainda mais o terreno fértil da práxis pessoal e coletiva de cada jovem, bem como da educadora/do educador. "Educar é assumir a compreensão do mundo, de si mesmo, da inter-relação entre os dois". (SADER,2007, p.80). A educação em Direitos Humanos potencializa esse fundamento de forma contundente, ao alinhar a subjetividade (individualidade) e o coletivo (sociedade).

Por fim, em pouco mais de um mês, se chegou as últimas semanas e o processo de avaliação. A avaliação ocorreu em dois momentos: na penúltima aula houve a avaliação das(os) jovens sobre o curso e a autoanálise de cada jovem, bem como a avaliação do docente sobre o desempenho das(os) jovens.

O segundo momento de avaliação foi no Sarau dos Direitos Humanos, onde cada jovem teve a responsabilidade de apresentar uma obra artística que falasse dos Direitos Humanos. Houve apresentações musicais, poesias, peças de teatro, cartazes, dança, entre outras expressões.

Voltando à penúltima aula, se tratou rapidamente de algumas temáticas que não foram minimamente discutidas durantes as aulas, mas foi percebido que era importante retratar, como as drogas, o aborto e a privacidade digital. Também se dialogou sobre a autoestima e os Direitos Humanos. Durante as aulas e nesse momento, muitas e muitos jovens apresentaram frases do tipo "sou burro", "não gosto de nada, só gosto de dormir", "não tenho talento nenhum" ou simplesmente não falavam. Houve três jovens ainda que mal olhavam para as aulas, iam ao banheiro e não queriam voltar. Falar sobre a autoestima e os Direitos Humanos foi fundamental para auxiliar em um processo de reversão das depreciações sofridas ao longo da vida, em revisitar dores (levantar poeira) para que se possa achar/processar a cura. A família, a religião e a escola são instituições que aparecem com frequência no discurso geral 
como locais positivos e importantes, mas é importante exercitar em processos educativos que essas instituições são falíveis, e que podem também serem promotoras também de violências.

Após essa primeira parte da aula de avaliação, cada jovem foi instigado a avaliar o curso, avaliar o educador e se auto avaliarem. $\mathrm{Na}$ primeira turma, uma surpresa: um jovem disse que falou pouco, pois é tímido, mas que poderia ter escrito o que pensava, só que não sabia se era permitido. Durante as aulas, se tratou tanto sobre liberdade de expressão, porém não houve atenção do educador de que a participação de cada jovem também poderia se dar de outra forma que não apenas a fala. Falou-se então eu quem estivesse com vergonha de falar, poderia escrever. Duas jovens em uma turma escreveram. As duas jamais falaram qualquer coisa durante todas as aulas, porém ficavam atentas assiduamente. Uma das jovens escreveu uma página de página de caderno, transcrita abaixo:

"Com as aulas de Direitos Humanos, eu conseguir abrandi (SIC) bastante meus conhecimentos, porém teve alguns temas que me deixaram mais confortáveis, mas teve um que me tirou mais na minha zona de conforto, me deixou bem mexida com o tema do abordo (SIC) porque eu sou contra porque eu vivenciei isso. Minha mãe estava grávida de mim ele teve maior apoio, mais mesmo assim ela optou pelo aborto e nessa eu acabei perdendo minha irmã gêmea e tipo eu carrego essa dor comigo dói lembrar que eu sou uma sobrevivente de um aborto e se eu tivesse o conhecimento que eu adiquirir (SIC) aqui nas suas aulas eu poderia ter confrontado minha mãe quando ela me contou. Meus sentimento e gratidão pelo senhor ter aprimorar meus conheicmentos (SIC) obrigado e o senhor é incrível.” (JOVEM, 2019)

Esse depoimento foi um aprendizado para todas e todos presentes. Por vezes, cada pessoa tem tanta convicção sobre o que deve ser feito, como a questão do aborto, que diversas vozes simplesmente não são ouvidas (ou lidas). Todas e todos tem contribuições relevantes a serem compartilhadas, um dos grandes desafios das (os) educadoras e edu- 
cadores é investigar que dispositivo "liga" cada pessoa, para que ela se envolva, interaja e construa coletivamente o conhecimento.

\section{Considerações Finais}

Após a discussão sobre EDH e o estudo de caso aqui explanado, é possível concluir que a EDH é uma área fundamentalmente interdisciplinar e livre quanto ao seu campo de aplicação (formal, não-formal e informal). Houve no mundo (Programa Mundial de Educação em Direitos Humanos e Planos de cada país para a EDH), bem como no Brasil (Plano nacional e os estaduais de EDH), uma forte produção de documentos técnico e conteúdos bibliográficos acerca da temática.

Mesmo com o comprovado avanço dos anos de 1990 aos anos 2010, a EDH parece carecer ainda de mais aplicação, visto a sistemática violação de Direitos Humanos que ocorre no país, bem como a ampliação de governos federais que publicamente atentam e defendem medidas anti-Direitos Humanos, como o governo brasileiro de Jair Messias Bolsonaro.

A EDH aplicada no estudo de caso único aqui discutido explicita uma entrega muito grande do educador para ser aplicada. A construção coletiva do conhecimento é um exercício, e como todo exercício, demanda trabalho. Pesquisa, estatutos, leis, planos, artigos, notícias contemporâneas e escuta ativa permanente são fundamentais para que se cumpra o papel da EDH de desenvolver aspectos subjetivos e coletivos de cada jovem para que ela e ele superem, transgridam, consigam crescer em aspectos diversos de suas vidas.

Como se percebe pelo caso nesse artigo trabalhado, uma dor provocada por uma violação de Direitos é sentida sendo ela consciente ou inconsciente, por isso a EDH pode promover a dor antes sentida, mas incompreendida, para o estágio uma dor sentida e compreendida, possibilitando a assim a sua cura. No caso de ter sido realizado em um curso técnico de artes cênicas, a arte foi um recurso essencial nos processos educativos. As apresentações finais dos jovens em teatros e espaços culturais contaram com forte apelo social, fruto dos seus in- 
teresses, mas sem dúvidas, o componente "Direitos Humanos" teve grande importância nesse processo.

A educação, quando pautada pela valorização e pela luta dos nosso Direitos, notoriamente ganha mais relevância e força para as(os) jovens, categoria essa que é potente de saber, de realização e de desejos. Jovem não quer ser passivo frente ao conhecimento, quer ter poder. Somente se pode aplicar com excelência a Educação em Direitos Humanos a partir da construção coletiva do conhecimento, do "levantar a poeira" e do curar processualmente e em conjunto as dores subjetivas e sociais.

\section{Referências}

BALESTRERI Ricardo Brisola. Direitos Humanos: Coisa de Polícia - Passo fundo-RS, CAPEC, Paster Editora, 1998.

BARBOSA, Marco Antônio Rodrigues. Memória, verdade e educação em direitos humanos. In: SILVEIRA, Rosa Maria Godoy. Et al. Educação em direitos humanos: fundamentos teórico-metodológicos. João Pessoa; Editora Universitária, 2007, p.157-168. CANDAU, Vera Maria Ferrão. Educação em Direitos Humanos: desafios atuais. In: SILVEIRA, R. M. G.; DIAS, A. A.; FERREIRA, L. de F. G.;ALENCAR, M. L. P.; ZENAIDE, M. N. T.. (Org.). Educação em Direitos Humanos: fundamentos teórico-metodológicos. 1ํed.João Pessoa: Editora Universitária Universidade Federal da Paraíba, 2007, v. , p. 414-427.

- Diferenças culturais, interculturalidade e educação em Direitos Humanos. Educ. Soc. [online]. 2012, vol.33, n.118, pp.235-250. ISSN 0101-7330.

\section{CARBONARI, Paulo César. Sujeito de direitos humanos: ques-} tões abertas e em construção. In: SILVEIRA, Rosa Maria Godoy. Et al. Educação em direitos humanos: fundamentos teórico-metodológicos. João Pessoa; Editora Universitária, 2007, p.157-168.

CARVALHO, J. S. F. Uma ideia de formação continuada em educação e direitos humanos. In: Silveira, Rosa; Dias, Adelaide; Ferrei- 
ra, Lúcia; Feitosa, Maria e Zenaide, Maria.. (Org.). Educação em Direitos Humanos: Fundamentos Teórico-metodológicos. 1a.ed. Joâo Pessoa: Editora Universitária/UFPB, 2007, v. , p. 469-486.

CONCIL OF EUROPE. Compasas - Manual para a Educação para os Direitos Humanos comJovens. 2002.

ECKERT, Cornélia; ROCHA, Ana Luiza Carvalho da. Etnografia: saberes e práticas. Revista Iluminuras, v. 9, n. 21, p. 11-43, 2008.

FERREIRA, L. F. G. Memória e Educação em Direitos Humanos. In: SILVEIRA, R.M.G.; DIAS, A.A.; FERREIRA, L.F.G.; FEITOSA, M.L.P.A.M; ZENAIDE, M.N.T.. (Org.). Educação em Direitos Humanos: fundamentos teórico-metodológicos. 1ed.João Pessoa: Ed. Universitária/UFPB, 2007, v. , p. 135-155.

FREIRE, Paulo. Pedagogia do oprimido. 34. ed. São Paulo: Paz e Terra, 2002

GROPPO, Luís Antonio. Juventude: Ensaios sobre Sociologia e História das Juventudes Modernas. Rio de Janeiro: Difel, 2000 GUERREIRO, Goli. A Trama dos Tambores. A música afro-pop de Salvador. São Paulo, Editora 34, 2000.

HUMANOS, C. M. S. D. Decada das Nações Unidas para Educação em Maté-

IGARAPÉ.http://gddc.ministeriopublico.pt, 1995-2004. Disponível em: < encurtador.com.br/cxyz8 >. Acesso em: 17 ago. 2019.

MAIA, Luciano Mariz. Educação em Direitos Humanos e tratados internacionais de direitos humanos. In: SILVEIRA, Rosa Maria Godoy et al. Educação em Direitos Humanos: fundamentos teórico-metodológicos. João Pessoa: Ed. Universitária/UFPB, 2007, p. 85-101.

MELO NETO, José Francisco de. . EDUCAÇÃO POPULAR EM DIREITOS HUMANOS. In: Rosa Maria Godoy Silveira;Adelaide Alves Dias;Lúcia de Fátima Guerra Ferreira;Maria Luíza Pereira de Alencar Mayer Feitosa;Maria de Nazaré Tavares Zenaide. (Org.). Educação em direitos humanos: fundamentos teórico- 
-metodológicos. 1ed.João Pessoa-PB: Editora da Universidade Federal da Paraíba, 2007, v. , p. 9-513.

ORGANIZAÇÃO DAS NAÇÕES UNIDAS . Plano de Ação: Programa Mundial para Educação em Direitos Humanos; primeira fase. Paris: UNESCO, 2006. Disponível em: . Acesso em: 13 mar. 2017.

. Plano de Ação: Programa Mundial para Educação em Direitos Humanos; segunda fase. Paris: UNESCO, 2012.

. Plano de Ação: Programa Mundial para Educação em Direitos Humanos; terceira fase. Paris: UNESCO, 2014. Disponível em: . Acesso em: 13 mar. 2017.

PAIS, J. M. Culturas juvenis. Lisboa: Imprensa Nacional Casa da Moeda, 1996.

SACAVINO, Susana. [Direito humano à educação no Brasil: uma conquista para todos/as?]. Direitos Humanos na Sala de Aula. Rio de Janeiro, Novamerica, ano 7, n.71, jun.2006

SADER, Emir. Contexto histórico e educação em direitos humanos no Brasil: da ditadura à atualidade. In:Educação em Direitos $\mathrm{Hu}-$ manos: fundamentos teóricos metodológicos. João Pessoa, Editora UFPB. 2007.

Santos, Boaventura de Sousa. Towards a multicultural conception of human rights. In: Lash, S.; Featherstone, M. (Ed.). Sapces of Culture: city - nation - world. London: Sage, 1999. p. 214-229.

Silva, A. A. "Direitos Humanos para Bandidos": representações sociais dos direitos humanos por reeducandos do sistema penitenciário do estado de Pernambuco. Dissertação (Mestrado em Direitos Humanos). Universidade Federal de Pernambuco. 2016

Yin, R. K. Case study research: design and methods. Londres: Sage, 1984. 


\section{ENEM: O DESCASO DO GOVERNO FEDERAL FRENTE A EDUCAÇÃO E ESTUDANTES}

Dalline Cristine Ligabo Marton

\section{INTRODUÇÃO}

Durante toda a história do Brasil, os estudantes foram vilipendiados e deixados de escanteio, haja vista a catequização forçada dos povos nativos brasileiros, a privatização do acesso à educação pelos escravizados, a falta de estrutura, vagas e material didático de boa qualidade na grande maioria das escolas públicas, os inúmeros projetos de reestruturação da grade curricular do ensino que não beneficiam o aprendizado e a falta de organização do ministério da educação são alguns exemplos dessa triste realidade.

De acordo com Carneiro (s/d) "nos primeiros anos do nosso país a educação era aquela promovida pelos Jesuítas" e o objetivo da mesma era a catequização dos índios e passar o ensino básico para os filhos dos colonos. Como o serviço na colônia era em sua grande maioria de ordem braçal, o ensino e a educação não eram vistos como algo importante na época. A elite brasileira por sua vez, quando se interessava nos estudos, tinha possibilidade de estudar na Europa. Sendo assim, é fácil notar que a educação era privilégio da grande elite brasileira. Aos poucos, alguns cursos acabaram se instalando no Brasil, porém, a elite ainda era a única que poderia usufruir dos mesmos. 
Parafraseando Carneiro (s/d), ainda no século XX o grau de educação no Brasil era muito baixo e somente começou a se expandir com o final da Primeira Guerra Mundial, no qual inúmeros imigrantes vieram para o Brasil e investiram no mercado brasileiro. Apesar de tal fato, a educação no Brasil só começou a se tornar popular nos anos 60, quando houve inúmeros movimentos sociais e sindicais a favor do ensino público no país.

Atualmente a educação é reconhecida como um direito fundamental pela Constituição da República Federativa do Brasil de 1988, um direito básico que possibilita o acesso aos demais direitos necessários para o exercício pleno da cidadania.

\section{A IMPORTÂNCIA DA EDUCAÇÃO DE QUALIDADE}

O direito à educação faz parte de um conjunto de direitos denominados direitos sociais, que tem como inspiração a igualdade entre os cidadãos. Para garantir determinado direito, a Constituição Federal da República do Brasil de 1988 traz inúmeros artigos que visam assegurar e o regulamentar.

De acordo com o art. 205 da Constituição Federal do Brasil de 1988 "A educação, direito de todos e dever do Estado e da família, será promovida e incentivada com a colaboração da sociedade, visando ao pleno desenvolvimento da pessoa, seu preparo para o exercício da cidadania e sua qualificação para o trabalho".

Além de a Constituição Federativa brasileira assegurar o direito à educação, existe também o Estatuto da Criança e do Adolescente (ECA) e a Lei de Diretrizes e Bases da Educação (LDB) que tem como objetivo implementar, regularizar e assegurar o acesso ao direito à educação.

Quando essas leis e estatutos supramencionados são analisados, é possível salientar alguns pontos importantes dos mesmos, uma vez que faz parte do direito de crianças e adolescentes: a) ter acesso à escola pública e gratuita próxima de sua residência; b) ser respeitado por seus educadores; c) ter igualdade de condições para o acesso e permanência na escola; d) direito de contestar os critérios de avaliação, podendo recorrer às instâncias escolares superiores. 
O papel do Estado também fica evidente na Constituição da República Federativa do Brasil, no ECA e na LDB, uma vez que os mesmos regulamentam que é dever do Estado assegurar: a) ensino fundamental (da 1aa 8 série), obrigatório e gratuito, inclusive para os que a ele não tiveram acesso na idade própria; b) ampliar gradativamente a oferta do ensino médio (colegial); atendimento educacional especializado aos portadores de deficiência (de preferência na rede regular de ensino); c) atendimento em creche e pré-escola às crianças de zero a seis anos de idade; d) acesso aos níveis mais elevados do ensino, da pesquisa e da criação artística; e) oferta de ensino noturno regular, adequado às condições do adolescente trabalhador; f) atendimento no ensino fundamental, através de programas que garantam material didático-escolar; g) transporte, alimentação e assistência à saúde.

O direito à educação é um mecanismo que deve ser garantido para todos uma vez em que ajuda no desenvolvimento não só de cada indivíduo, mas também de todo um país. Com a educação é possível combater a pobreza, pois quanto mais as pessoas estudarem, mais oportunidades terão no mercado de trabalho e consequentemente terão um salário melhor.

A importância do direito à educação é tamanha que, caso a garantia do ensino público obrigatório e oferecido de maneira regular seja ameaçada ou descumprida, o art. 209, $\$ 2^{\circ}$ da Constituição Federativa do Brasil de 1988 prevê que o Poder Público pode ser responsabilizado e, dependendo do caso, até o chefe do executivo pode ser deposto.

De acordo com o representante da ONU Nassir Abdulaziz Al-Nasser em entrevista ao Portal Terra (2013) “a Educação é fundamental para tratar da ignorância e desconfiança que estão no cerne do conflito humano. A Educação ajuda a superar estereótipos e intolerância, e a vencer a batalha contra a ignorância."

A Organização das Nações Unidas para Educação, Ciência e Cultura (UNESCO) através do Relatório de Monitoramento Global de Educação Para Todos de 2011 demostrou que a cada ano extra de escolaridade, a renda individual aumenta em até 10\%. Com melhores empregos e maior renda, os indivíduos dependem menos de políticas públicas contra a pobreza e passam a consumir mais, aumentando as- 
sim os impostos coletados pelo governo que poderão ser aplicados em melhorias sociais.

O mesmo relatório mostrou que cada ano adicional de escolaridade a média anual do PIB de um país aumenta em 0,37\%. Países como a Irlanda e a Coreia do Sul que priorizam o ensino de qualidade registram um crescimento econômico acima da média. Além disso, a educação tem o poder de reduzir a mortalidade infantil, diminuir a taxa de fecundidade e melhorar a saúde da população, pois de acordo com a UNESCO, uma criança cuja mãe sabe ler tem 50\% mais chances de sobreviver após os cinco anos de idade.

\section{AVANÇOS E RETROCESSOS DA EDUCAÇÃO BRASILEIRA}

Ao analisar a educação brasileira nos últimos anos, pode-se compreender que o maior avanço nessa esfera foi a obrigatoriedade no fornecimento de escolas públicas por todos os estados e municípios do Brasil. A oferta de escolarização pelo Estado manifesta-se com base na oferta de condições à escolarização, de acesso à escola e da permanência dos jovens na mesma, embora esse fato não tenha se tornado realidade para todos.

Em outra ótica, segundo Carneiro (s/d) "em todo esse período, talvez o que possamos apresentar como o grande problema da educação nacional tenha sido e continue sendo o da desvalorização do profissional da educação". Tal desvalorização pode ser notada pelos baixos salários e na grande dificuldade de acesso ao ensino público superior, uma vez que o vestibular impede a grande maioria da população de ingressar na faculdade.

Conforme os ensinamentos de Segura (2001) na prática, percebe-se que é difícil para os professores desenvolverem suas aulas de forma proveitosa, já que as salas de aulas estão sempre lotadas, a infraestrutura em sua grande maioria é péssima, a escassez de material é uma realidade e a falta de investimentos para os projetos é notória, principalmente nas escolas públicas. Devido a todo esse caos, muitas vezes não é obtido os resultados esperados e os estudantes saem do ensino básico e médio sem assimilar todo o conteúdo de maneira efetiva. 
A dificuldade de acesso ao ensino público superior se deve então a um ensino básico e médio de má qualidade e à grande falta de vagas nas faculdades e nas universidades públicas em todo o país. A falta de vagas nas instituições públicas é a consequência de um Estado que não é capaz de criar e manter vagas necessárias para todos terem acesso à escolarização a nível superior, fato esse que torna o próprio Estado descumpridor da lei e da constituição, uma vez que a mesma assegura o acesso à educação em todos os níveis.

\section{DESEMPENHOS DA EDUCAÇÃO BRASILEIRA E SUAS IMPLICAÇÕES}

Conforme os anos foram passando e os processos de educação mudando, houve a necessidade de se ter um indicador de qualidade de ensino, que tem por objetivo medir a qualidade aferida de estudantes em testes padronizados e de larga escala. Foi a partir de tal situação que a denominada SAEB (Sistema de Avaliação da Educação Básica) e o Exame Nacional do Ensino Médio (ENEM) surgiram. Além desses dois programas, emergiram também o PISA (Programa Internacional de Avaliação de Estudantes) e a Prova Brasil (que nada mais é do que o SAEB reformulado) com os mesmos propósitos.

Salienta-se que alguns dos pontos que interferem no desempenho de crianças e jovens nesses testes é o número de alunos por sala de aula, o grau de ensino dos professores e o material didático. Porém, a merenda escolar, o transporte escolar e o contexto social podem interferir e serem fatores cruciais no desempenho escolar de crianças e adolescentes.

Segundo Oliveira, M.L e Pessoa (2013), de modo geral, houve um aumento no desempenho dos alunos do ensino fundamental nos testes da Prova Brasil nas edições de 2005, 2007 e 2009, porém, comparando os resultados obtidos nesse exame, pode-se observar que a rede privada possui um desempenho superior em relação à rede pública de ensino.

Para Marchelli (2010) o PISA é uma avaliação padronizada que tem como finalidade comparar a efetividade dos sistemas de ensino entre os países associados à OCDE.

Em relação ao PISA, o Brasil desde a sua primeira participação no teste não registrou nenhum desempenho exemplar. Em relação aos re- 
sultados obtidos pelo Brasil no ano de 2009, foi constatado que o melhor desempenho do país se refere às redes de ensino federal e privada.

De acordo com os dados divulgados pela ONG Todos pela Educação em 2011, apenas 12\% dos alunos do ensino fundamental possuíam um rendimento adequado em matemática, enquanto o rendimento adequado em língua portuguesa foi de 23\%.

Ademais, pode-se constatar que o Brasil participa de diversos programas capazes de medir a educação do país, mas esta não se encontra em boas condições. Conforme os dados apresentados, percebe-se que os melhores desempenhos são de alunos da rede de ensino privada, enquanto os alunos da rede de ensino pública sofrem com uma enorme defasagem no conhecimento.

Constata-se que há uma série de fatores capazes de interferir nos resultados de tais dados, uma vez que muitas das redes de ensino públicas sofrem com a falta de investimentos por parte do estado e do município, que acabam não podendo oferecer uma estrutura capaz de incentivar e melhorar os rendimentos dos alunos, como por exemplo, a inexistência de um material didático de boa qualidade, a falta de uma merenda regular balanceada e a dificuldade do acesso à escola pelo transporte escolar, que acabam por aumentar a evasão dos alunos.

De acordo com Dias (2013) 'sabemos que as causas da evasão escolar no Brasil são inúmeras, como a falta de transporte, de alimentação, de documentação para a matrícula, de recursos como materiais escolares e uniformes, e algumas de extrema gravidade como o trabalho infantil e a prostituição".

Conforme estudo do Fundo das Nações Unidas para a Infância (UNICEF, 2014), nas regiões mais pobres como Nordeste e o Norte, apenas $40 \%$ das crianças terminam o ensino fundamental. Alguns aspectos que podem ter interferência nesses números são os gastos relacionados ao transporte e alimentação, pois grande parte de crianças e jovens moram longe da área urbana onde ficam localizadas as escolas.

O Censo Escolar de 2015 mostrou que houve uma queda nas matrículas em todas as etapas de ensino. São aproximadamente três milhões de crianças e jovens de quatro a dezessete anos fora das salas de aula, resultado que reflete os inúmeros desafios que crianças e jovens enfrentam todos os dias para ter acesso ao ensino. Demostrou-se tam- 
bém que as matriculas das pré-escolas tiveram uma redução de 1\% em relação a 2014.

Sem dúvidas, a crise orçamentária é um fator que dificulta simultaneamente o acesso à educação, mas existem outros fatores que colocam em risco a educação de crianças e jovens. De acordo com o Censo Escolar de 2015, a maior parte dos jovens que estão no ensino médio reside em áreas urbanas, enquanto na pré-escola, a maioria está no campo.

De acordo com a União Nacional dos Dirigentes Municipais de Educação (2016) "a maioria das crianças de quatro e cinco anos que estão fora da escola está no campo. O pai não manda porque acha que é muito pequena. O fechamento de escolas rurais pode ser um dos fatores que contribuiu para a redução das matrículas, não podemos descartar essa possibilidade".

Em conformidade com Costa (1996), apenas a presença de escolas não garante o acesso ao direito da educação. Para que este direito seja garantido, é necessário que haja mecanismos que auxiliem nesse processo, tal como a merenda escolar, um bom material didático, o uniforme escolar e o transporte escolar, que devem ser providenciados pelos municípios e estados. Portanto, é extremamente necessário que exista programas específicos a fim de garantir o direito à educação, principalmente no que diz respeito a diminuição da evasão escolar e a melhoria da qualidade de ensino como forma de contribuir e proporcionar o acesso dos estudantes ao ensino superior no Brasil.

\section{O EXAME NACIONAL DO ENSINO MÉDIO E SUAS PROBLEMÁTICAS}

Como forma de garantir maior acesso ao ensino superior, foi criado no governo do Fernando Henrique Cardoso (1998) o ENEM que, com uma história de erros e acertos, é a principal porta de acesso ao ensino superior no Brasil. Através da nota obtida no Enem, é possível entrar em uma Universidade Federal por meio do Sistema de Seleção Unificada (SISU), conseguir uma bolsa de estudos em uma Universidade Particular com o Programa Universidade para Todos (PROUNI) ou até mesmo financiar essa Faculdade através do Fundo de Finan- 
ciamento Estudantil (FIES), sendo notória a importância deste exame para os estudantes, principalmente aqueles de baixa renda que não podem arcar com as despesas de uma faculdade particular.

Mesmo com tamanha importância, o ENEM tem sido tratado com descaso por todo esse tempo. Um dos episódios que mais marcou a avaliação até agora ocorreu em 2009 e 2015 com o vazamento da prova, tendo o Ministério da Educação que cancelar e remarcar o exame.

O governo Dilma manteve e ampliou alguns dos programas, como Sistema de Seleção Unificada (SISU), o Fundo de Financiamento Estudantil (FIES) e o Programa Universidade para Todos (PROUNI). Porém, ao decorrer de seu mandato, a mesma realizou cortes no MEC, o que prejudicou as verbas destinadas para tais programas, gerando greves, paralisações e deixando milhares de brasileiros sem acesso aos supracitados.

Dados do Ministério da Educação (MEC) divulgados pelo Portal de Notícias da Globo (2015) constatou que no ENEM de 2014, 529 mil redações tiraram nota zero e apenas 250 milhões de estudantes alcançaram a nota máxima no exame, sendo 38\% dos estudantes universitários analfabetos funcionais (não conseguem interpretar textos e sabem o mínimo de matemática).

Desde que Bolsonaro assumiu a presidência, além dos escândalos envolvendo os ministros da educação, muito tem se especulado sobre a desobrigação em respeitar os direitos humanos no Exame Nacional do Ensino Médio (ENEM) e, com a pandemia do COVID-19, muito se discutiu nos últimos dias o posicionamento do até então ministro da educação, Abraham Weintraub.

Abraham Weintraub, no auge da pandemia do COVID-19 no Brasil, era contrário ao cancelamento ou adiamento do ENEM, pois segundo o mesmo em entrevista à CNN (2020) "a prova não é feita para atender as injustiças sociais e, sim, para selecionar os melhores candidatos". Além disso, quando questionado sobre as inscrições serem realizadas somente pela internet e a mesma não é acessível a muitos brasileiros, o mesmo ressaltou que "se a pessoa não tem internet nenhuma em casa, ela não consegue se inscrever no Enem”.

A pandemia do Coronavírus fez com que milhões de estudantes ficassem sem acesso à educação, uma vez que as escolas foram fechadas 
e muitas delas sequer possuem mecanismos para transmitir aulas online. Aliado a tal circunstância, o ex-ministro também fez questão de esquecer que muitos estudantes não possuem acesso à internet, sendo assim impossível de acompanhar as aulas em formato EAD. A irresponsabilidade de Weintraub foi tamanha que o mesmo ignorou que o ENEM é realizado em sua maioria em escolas precárias, com poucos recursos e em salas de aula lotadas, o que facilitaria o contágio do COVID-19.

Com a pressão dos estudantes, mídia e de alguns parlamentares, Weintraub acabou cedendo e adiando o ENEM e, com uma imagem desgastada, deixou o ministério da educação no dia 18 de junho de 2020 .

\section{CONCLUSÃO}

Sendo o direito à educação um direito básico que assegura o cumprimento de diversos outros direitos, deveria ser melhor tratado pelos nossos governantes. A educação ajuda a formar cidadãos mais críticos e conscientes de seus direitos e deveres, além de ser a única solução para a diminuição da violência e da desigualdade. É por meio da educação que se garante o desenvolvimento econômico, social e cultural de cada indivíduo e assim, de toda uma nação.

Diante deste cenário, muito se indaga sobre a razão o Governo Federal tratar a educação brasileira com tamanho descaso. Não há outra resposta a não ser os ensinamentos que Darcy Ribeiro nos passou a tantos anos: "a crise da educação no Brasil não é uma crise: é um projeto". Projeto esse que escolhe e prefere continuar com um país no qual os cidadãos não sejam seres pensantes, não sejam críticos de sua realidade e não sejam capazes de obter sua liberdade intelectual pelo simples fato de que assim, é mais fácil de se governar.

Nas palavras de Carneiro (s/d), para que a educação brasileira avance e corrija as falhas da mesma, é necessário que haja uma ampliação nas condições de acesso e permanência nas escolas, a valorização dos profissionais da educação e a garantia da qualidade do ensino oferecido pela nação, pois como brilhantemente expôs Paulo Freire: "se a educação sozinha não transforma a sociedade, tampouco sem ela a sociedade muda". 


\section{REFERÊNCIAS}

BRASIL. Censo Escolar, 2015. Disponível em: <http://portal.inep. gov.br/web/guest/resultados-e-resumos>. Acesso em: junho de 2020.

BRASIL. Constituição da República Federativa do Brasil, 1988. Disponível em: < http://www.planalto.gov.br/ccivil_03/Constituicao/Constituiçao.htm>. Acesso em: junho de 2020.

BRASIL. Estatuto da Criança e do Adolescente, 1990. Disponível em: <http://www.planalto.gov.br/ccivil_03/leis/18069.htm>. Acesso em: junho de 2020.

BRASIL. Lei de Diretrizes e Bases da Educação Nacional, 1996. Disponível em: <http://www.planalto.gov.br/ccivil_03/leis/19394. htm>. Acesso em: junho de 2020.

CARNEIRO, Neri de Paula. A educação no Brasil; avanços e problemas (s/d). Disponível em: <https://meuartigo.brasilescola. uol.com.br/educacao/a-educacao-no-brasil-avancos-problemas. htm>. Acesso em: junho de 2020.

CNN. Ministro da Educação não descarta adiar data do ENEM, 2020. Disponível em: <https://www.cnnbrasil.com.br/politica/2020/05/15/ministro-da-educacao-nao-descarta-adiar-data-do-enem>. Acesso em: junho de 2020.

COSTA, Antônio Carlos Gomes da. É possível mudar: a criança, o adolescente, e a família na política social do município. Série Direitos das crianças. São Paulo: Malheiros, 1996.

DIAS, Mirian Viviane. Evasão escolar no ensino fundamental. Machado, 2013.

JUSTINO, Guilherme. Educação ajuda a superar a intolerância, defende Nações Unidas. Portal Terra, 2013. Disponível em: <https:// www.terra.com.br/noticias/educacao/educacao-ajuda-a-superar-a-intolerancia-defende-nacoes-unidas, ecd41bcc590d0410Vg- 
nVCM20000099cceb0aRCRD.html>. Acesso em: junho de 2020.

MARCHELLI, P. S. Expansão e qualidade da educação básica no Brasil. Cadernos de Pesquisa, v.40, n.140, p. 561-585, maio/ago. 2010.

OLIVEIRA, M.L.; PESSOA, H.C. Avaliação da qualidade na educação básica. In: Justiça pela qualidade na educação. ABMP, todos pela educação (Organização). São Paulo: Sarava, p. 613-629, 2013.

SALOMÃO, Lucas. 529 mil alunos ficaram com nota zero na redação do Enem 2014, diz MEC. Portal de Notícias Globo, 2015. Disponível em: <http://g1.globo.com/educacao/noticia/2015/01/ 529-mil-alunos-obtiveram-nota-zero-na-redacao-do-enem-2014-diz-mec.html>. Acesso em: junho de 2020.

SEGURA, Denise de S. Baena. Educação Ambiental na escola pública: da curiosidade ingênua à consciência crítica. São Paulo: Annablume: Fapesp, 2001. p. 71

TODOS PELA EDUCAÇÃO. Anuário da Educação Básica do Brasil, 2011. Disponível em: <http://www2.senado.leg.br/bdsf/ bitstream/handle/id/496112/Relatoria\%20educacao\%20.pdf?sequence $=1 \&$ is Allowed $=y>$. Acesso em: junho de 2020 .

UNDIME. Censo Escolar: 3 milhões de alunos entre 4 e 17 anos estão fora da escola, 2016. Disponível em: <https://undime.org.br/ noticia/28-03-2016-11-51-censo-escolar-3-milhoes-de-alunos-entre-4-e-17-anos-estao-fora-da-escola>. Acesso em: junho de 2020.

UNESCO. Relatório de Monitoramento Global de Educação Para Todos, 2011. Disponível em: <http://www.unesco.org/new/fileadmin/MULTIMEDIA/HQ/ED/pdf/gmr2011-summary-pt. pdf> Acesso em: junho de 2020.

UNICEF. 10 desafios do Ensino Médio no Brasil, 2014. Disponível em: <http://www.crianca.mppr.mp.br/arquivos/File/publi/unicef/10desafios_ensino_medio.pdf $>$. Acesso em: junho de 2020 . 


\section{O CURRÍCULO ESCOLAR COM O TEMA EDUCAÇÃO PARA A CIDADANIA DIGITAL}

Luís José Câmara Pedrosa

\section{INTRODUÇÃO}

Os Direitos Humanos são uma das competências e habilidades transversais mais importantes para a formação da cidadania global nas sociedades contemporâneas. Se até meados do século XX, o trabalho com as disciplinas foi imprescindível para a efetivação do projeto homogeneizador do Estado Nação, pode-se dizer que, em tempos de globalização econômica, os temas transversais e contemporâneos ocupam um lugar central para a constituição de currículos flexíveis que contemplem as diversidades culturais, ambientais, gêneros, étnicas e etárias.

Com a Declaração Universal dos Direitos Humanos da Organização das Nações Unidas (ONU), de 1948, desencadeou-se um processo de mudança no comportamento social e na produção de instrumentos e mecanismos internacionais que incorporaram os direitos humanos ao ordenamento jurídico dos países signatários, sobretudo, em suas legislações educacionais.

Nessa direção o Estado brasileiro afirma o princípio que os direitos humanos são universais, indivisíveis e interdependentes e, para sua efetivação, todas as políticas públicas, devem considerá-los, na perspectiva da construção de uma sociedade assentada na promoção da igualdade de oportunidades e da equidade, no respeito à diversidade e na consolidação de uma cultura democrática e cidadã. 
Com isso, a educação tem uma tarefa importante para proporcionar o acesso aos conhecimentos estruturantes sobre os Direitos $\mathrm{Hu}-$ manos. Sendo a educação um direito em si mesmo, torna-se também um meio indispensável para o acesso a outros direitos que favorecem o pleno desenvolvimento humano e as potencialidades das crianças e adolescentes.

Para tanto, torna-se fundamental que, as escolas encontrem espaço em suas programações curriculares, buscando efetivar a cidadania global com a construção de conhecimentos, o desenvolvimento de valores, atitudes e comportamentos, além da defesa socioambiental e da justiça social, irredutíveis aos preceitos mercadológicos e do mundo do trabalho.

O fortalecimento do regime democrático, a sustentação às ações de promoção, proteção e defesa dos direitos humanos, e de reparação das violações. Inclusive, as violações que se referem às práticas sociais com o uso da internet. Essas violações têm caracterizado o fenômeno que ficou conhecido como "fracasso escolar": a persistência de altas taxas de evasão e repetência.

O Curso Educando para Boas Escolhas On-Line ofertado pelo ofertado pelo Escolas Institucionais do Ministério Público Federal (no caso específico, a Escola Superior do Ministério Público do Maranhão) e a SaferNet Brasil (associação civil de direito privado, fundada em 2005) possui 40 horas de formação on-line, além de um seminário introdutório sobre o uso seguro da internet, tendo em vista, a Cidadania Digital, tópico especial dos direitos humanos e, consequentemente dos novos documentos orientadores da constituição de currículos flexíveis.

Sendo assim, este trabalho propõe que, os conteúdos do Curso Educando para Boas Escolhas On-Line favoreçam a constituição dos novos componentes da atual reforma educacional, prevendo a flexibilidade curricular e favorecendo o trabalho pedagógico transversal e interdisciplinar.

\section{OS MARCOS LEGAIS DA EDUCAÇÃO PARA A CIDADANIA DIGITAL}

Uma das tarefas fundamentais da escola contemporânea é possibilitar o acesso aos conteúdos dos direitos humanos. Vivemos a passagem 
das nações homogêneas às sociedades multiculturais e à economia global. De forma que, a educação é o melhor e principal instrumento para ajudar as pessoas a se prepararem para uma vida plena, uma cidadania participativa, uma posição econômica digna e suficiente, uma convivência não conflituosa. Por isso, a educação é um direito social que pode assegurar os demais Direitos Humanos. (FERNÁNDEZ ENGUITA;2004).

T.H. Marshall (1950, p. 1-85) considera que, os Direitos Humanos surgem em momentos diferentes na história da humanidade. Há uma sequência que marca o surgimento dos direitos da cidadania no mundo contemporâneo: primeiro, os direitos civis, depois, os direitos políticos e, por fim, os direitos econômicos e sociais.

No século XX, mais especificamente, nos anos 1960, em decorrência dos direitos sociais, aparece uma terceira geração de direitos humanos, norteada pelo ideal de fraternidade ou solidariedade. Trata-se dos direitos difusos - ou seja, direitos cujos titulares não se pode determinar, nem mensurar o número exato de beneficiários - entre os quais encontram-se a proteção à vida.

Os direitos humanos da terceira geração tratam, fundamentalmente, do direito ao desenvolvimento, o direito à paz, o direito de comunicação, o direito de autodeterminação dos povos, o direito à defesa de ameaça de purificação racial e genocídio, o direito à proteção contra as manifestações de discriminação racial, direito ao meio ambiente e à qualidade de vida, o direito à proteção em tempos de guerra ou qualquer outro conflito armado.

Entretanto, Boaventura de Sousa Santos (2013) considera que, os direitos humanos no eixo do conhecimento-emancipação, tornou-se impossibilitado por causa do pensamento liberal que por sua vez, estrutura as relações sociais com foco nas atividades econômicas.

Esse seria o motivo pelo qual os direitos sociais e difusos não tenham avançado, tornando-se objetos de constantes reparações por parte da gestão dos Estados nacionais. Segundo Santos (2013), na maioria dos países, a história dos diferentes tipos de direitos humanos é uma história muito contingente, acidentada, cheia de descontinuidade, com avanços e recuos. 


\section{OS MARCOS LEGAIS DA CIDADANIA DIGITAL NO BRASIL}

No Brasil, a terceira geração de direitos configura-se pelo direito ambiental, direitos do consumidor, da criança, adolescente, idosos e portadores de deficiência, bem como a proteção dos bens que integram o patrimônio artístico, histórico, cultural, paisagístico, estético e turístico. Essas temáticas passaram a constituir as legislações auxiliares em outras leis correlatas seguem a essência dos acordos e orientações internacionais assumidas por diversas nações em todo o mundo.

Os governos brasileiros têm o compromisso de promover uma educação, de qualidade para todos, entendida como direito humano essencial. Assim, a universalização do ensino fundamental, a ampliação da educação infantil, do ensino médio, da educação superior e a melhoria da qualidade em todos esses níveis e nas diversas modalidades de ensino são tarefas prioritárias.

A denominação de Educação Básica, direito social, abrangendo a educação infantil, o ensino fundamental e o ensino médio, os quais propiciam uma formação basilar imprescindível para a formação do indivíduo, bem como, para o efetivo exercício da cidadania, conforme preconiza a Constituição Federal Brasileira e a Lei de Diretrizes e Bases da Educação Nacional - LDB (Lei Federal n 9.394/1996).

Além disso, é dever do governo garantir a educação de pessoas com necessidades especiais, a profissionalização de jovens e adultos, a erradicação do analfabetismo e a valorização dos (as) educadores (as) da educação, da qualidade da formação inicial e continuada, tendo como eixos estruturantes o conhecimento e a consolidação dos direitos humanos.

A Constituição da República Federativa do Brasil de 1988, no seu artigo 205 dispõe que a educação é um direito de todos, dever do Estado e da família, que será promovida e estimulada com a cooperação da sociedade, determinando o integral desenvolvimento da pessoa, seu preparo para o exercício da cidadania e sua qualificação para o trabalho.

Já a lei de no 9.394, de 20 de dezembro de 1996 - Diretrizes e Bases da Educação Nacional (LDB) que preconiza no seu Art. 35ำ que o ensino médio, como etapa final da educação básica, cuja duração mínima será de três (03) anos e tem como desígnio: I - a consolidação e o 
aprofundamento dos conhecimentos adquiridos no ensino fundamental, possibilitando o prosseguimento de estudos; II - a preparação básica para o trabalho e a cidadania do educando, para continuar aprendendo, de modo a ser capaz de se adaptar com flexibilidade a novas condições de ocupação ou aperfeiçoamento posteriores; III - o aprimoramento do educando como pessoa humana, incluindo a formação ética e o desenvolvimento da autonomia intelectual e do pensamento crítico; IV - a compreensão dos fundamentos científico-tecnológicos dos processos produtivos, relacionando a teoria com a prática, no ensino de cada disciplina.

Nessa direção as Diretrizes Curriculares Nacionais da Educação Básica preconizam que a base comum nacional e a parte diversificada são organizadas e geridas de tal modo que também as tecnologias de informação e comunicação perpassem transversalmente a proposta curricular desde a Educação Infantil até o Ensino Médio, imprimindo direção aos projetos político-pedagógicos.

Ainda temos o desafio de educar para a apropriação crítica das tecnologias digitais na pauta da nova Base Nacional Comum Curricular (BNCC), aprovada com o Ensino Médio em 14 dezembro de 2018. Algumas das dez competências gerais previstas na Base podem ser associadas a essa discussão sobre Direitos e Deveres na Internet, contemplando o tema Educando para a Cidadania Digital.

A Educação para a Cidadania digital é um tópico desse universo temático em decorrência da consciência sobre a necessidade de que os direitos coletivos e difusos sejam acessados por meio da educação. Porém, contrariando o que se diz a internet não é uma "terra sem Leis". Éric Schmidt se reporta a essa questão da seguinte forma: "a internet é a primeira coisa que a humanidade construiu, mas que não compreende. É a maior experiência de anarquia que algum dia tivemos".

Os marcos legais específicos do Tema Educação para a Cidadania Digital são: Plano Nacional de Educação em Direitos Humanos, Estatuto da Criança e do Adolescente e o Marco Legal da Internet.

O Plano Nacional de Educação em Direitos Humanos (PNE$\mathrm{DH}$ ) é fruto do compromisso do Estado com a concretização dos direitos humanos e de uma construção histórica da sociedade civil 
organizada. Ao mesmo tempo em que aprofunda questões do Programa Nacional de Educação em Direitos Humanos com os seguintes objetivos, no seu artigo $2^{\circ}$ : a) fortalecer o respeito aos direitos humanos e liberdades fundamentais; b) promover o pleno desenvolvimento da personalidade e dignidade humana; c) fomentar o entendimento, a tolerância, a igualdade de gênero e a amizade entre as nações, os povos indígenas e grupos raciais, nacionais, étnicos, religiosos e linguísticos; d) estimular a participação efetiva das pessoas em uma sociedade livre e democrática governada pelo Estado de Direito; e) construir, promover e manter a paz.

A Educação em Direitos Humanos é compreendida como um processo sistemático e multidimensional que orienta a formação do sujeito de direitos, articulando as seguintes dimensões: a) apreensão de conhecimentos historicamente construídos sobre direitos humanos e a sua relação com os contextos internacional, nacional e local; b) afirmação de valores, atitudes e práticas sociais que expressem a cultura dos direitos humanos em todos os espaços da sociedade; c) formação de uma consciência cidadã capaz de se fazer presente em níveis cognitivo, social, ético e político; d) desenvolvimento de processos metodológicos participativos e de construção coletiva, utilizando linguagens e materiais didáticos contextualizados; e) fortalecimento de práticas individuais e sociais que gerem ações e instrumentos em favor da promoção, da proteção e da defesa dos direitos humanos, bem como da reparação das violações.

O Estatuto da Criança e do Adolescente (ECA), Lei 8.069/1990, tem o objetivo de proteger a integridade da criança e do adolescente, aplicando as diretrizes da Declaração dos Direitos Humanos. O ECA representa um avanço no direito das pessoas ao explicitar os princípios da proteção integral e da prioridade absoluta, já previstos na Constituição Federal de 1988. Para os efeitos dessa Lei, criança é a pessoa de até doze anos de idade incompletos. Já o adolescente é a pessoa que possui de doze a dezoito. Tanto a criança como o adolescente estão sob a responsabilidade dos pais e dos educadores escolares, de acordo com o Art. 5: "Nenhuma criança ou adolescente será objeto de qualquer forma de negligência, discriminação, exploração, violência, crueldade e opressão, punido na forma da lei qualquer atentado, por ação ou 
omissão, aos seus direitos fundamentais". Art. 15, determina que, "a criança e o adolescente têm direito à liberdade, ao respeito e à dignidade como pessoas humanas em processo de desenvolvimento e como sujeitos de direitos civis, humanos e sociais garantidos na Constituição e nas leis".

As crianças e adolescentes têm direito a se informar, a se divertir, interagir e brincar no mundo digital, devendo toda sua singularidade de pessoa em desenvolvimento também ser preservada na Internet. De acordo com o ECA, no seu Art. 17, determina que, "o direito ao respeito consiste na inviolabilidade da integridade física, psíquica e moral da criança e do adolescente, abrangendo a preservação da imagem, da identidade, da autonomia, dos valores, ideias e crenças, dos espaços e objetos pessoais. E ainda, no Art. 18, "é dever de todos velar pela dignidade da criança e do adolescente, pondo-os a salvo de qualquer tratamento desumano, violento, aterrorizante, vexatório ou constrangedor".

A partir de 25 de novembro de 2008, os artigos 240 e 241 passaram a incluir novas formas de abuso e exploração sexual por meio da Internet, aumentando a pena e criminalizando novas práticas. Inclusive, o Art. 241-t trata da questão da distribuição, posse e produção de pornografia infantil.

Já o Marco Civil da Internet, Lei 12.965/2014 estabeleceu direitos e os deveres para quem usa a rede. No seu Art. $1^{\circ}$ a Lei estabelece princípios, garantias, direitos e deveres para o uso da internet no Brasil e determina as diretrizes para atuação da União, dos Estados, do Distrito Federal e dos Municípios em relação à matéria. No seu Art. $2^{\circ}$ trata que a "disciplina do uso da internet no Brasil tem como fundamento o respeito à liberdade de expressão, bem como: I - o reconhecimento da escala mundial da rede; II - os direitos humanos, o desenvolvimento da personalidade e o exercício da cidadania em meios digitais; III - a pluralidade e a diversidade; IV - a abertura e a colaboração; V - a livre iniciativa, a livre concorrência e a defesa do consumidor; e VI - a finalidade social da rede.

No Artigo 21, trata dos casos de conteúdos de nudez e sexo não autorizados, de modo que, a vítima pode solicitar remoção diretamente aos provedores de aplicações na Internet. 
Sendo assim, os marcos legais são também conteúdos específicos que compõem o tema Educando para a Cidadania Digital, como ficou demonstrado no Curso Educando para Boas Escolhas On-Line.

Esses conteúdos se orientam pelos estudos em torno da proteção integral à criança e ao adolescente, adotada pelo Estado brasileiro, consoante com uma formação para além do domínio conceitual e técnico, contemplando, portanto, a formação para a cidadania global.

\section{A PROPOSTA DE CURRÍCULOS FLEXÍVEIS PARA A FORMAÇÃO DA CIDADANIA DIGITAL}

A atual reforma da educação, leia-se reforma curricular, elegeu a etapa do Ensino Médio como o momento mais deficiente da formação da Educação Básica. Essa etapa teria ficado sem sentido para os estudantes, resultando em alto índices de evasão e reprovação.

Nessa direção surge a questão sobre como equacionar o conceito de mínimo de educação a ser garantido para os estudantes, aspecto este que, não há um consenso nem entre os organismos internacionais.

A Base Nacional Comum Curricular (BNCC), os Referenciais para a Elaboração dos Itinerários Formativos, a Lei no 13.415 , de 16 de fevereiro de 2017 e a Resolução № 3, de 21 de novembro de 2018 que atualiza as Diretrizes Curriculares Nacionais para o Ensino Médio compõem os documentos orientadores para a elaboração propostas curriculares flexíveis que garantam o mínimo para os estudantes.

As competências gerais no campo da educação são compreendidas como um direito em si mesmo e um meio indispensável para o acesso a outros direitos, e, portanto, outras competências. Esse é o principal argumento, decorrente da Constituição Federal, para que se tenha as bases nacionais. O contra-argumento dessa proposta é a transformação da prática pedagógica em uma prática gerencial em torno de conteúdos mínimos.

Philippe Perrenoud (2002) concebe as competências como um conjunto de domínios. Para tanto, formar competência é mobilizar conhecimentos, habilidades, atitudes e valores para resolver demandas da vida cotidiana, do exercício da cidadania e do mundo do trabalho. As competências decorrem de vários saberes teóricos e experienciais que devem possibilitar a problematização das práticas sociais. 
É essa compreensão que, cinco competências retiradas do Texto da BNCC homologado em 14 de dezembro 2018 (Introdução, p. 9-10) estão relacionadas diretamente ao tema Educando para a Cidadania Digital, a saber:

a) Compreender, utilizar e criar tecnologias digitais de informação e comunicação de forma crítica, significativa, reflexiva e ética nas diversas práticas sociais (incluindo as escolares) para se comunicar, acessar e disseminar informações, produzir conhecimentos, resolver problemas e exercer protagonismo e autoria na vida pessoal e coletiva;

b) Valorizar a diversidade de saberes e vivências culturais e apropriar-se de conhecimentos e experiências que lhe possibilitem entender as relações próprias do mundo do trabalho e fazer escolhas alinhadas ao exercício da cidadania e ao seu projeto de vida, com liberdade, autonomia, consciência crítica e responsabilidade;

c) Argumentar com base em fatos, dados e informações confiáveis, para formular, negociar e defender ideias, pontos de vista e decisões comuns que respeitem e promovam os direitos humanos, a consciência socioambiental e o consumo responsável em âmbito local, regional e global, com posicionamento ético em relação ao cuidado de si mesmo, dos outros e do planeta;

d) Exercitar a empatia, o diálogo, a resolução de conflitos e a cooperação, fazendo-se respeitar e promovendo o respeito ao outro e aos direitos humanos, com acolhimento e valorização da diversidade de indivíduos e de grupos sociais, seus saberes, identidades, culturas e potencialidades, sem preconceitos de qualquer natureza;

e) Agir pessoal e coletivamente com autonomia, responsabilidade, flexibilidade, resiliência e determinação, tomando decisões com base em princípios éticos, democráticos, inclusivos, sustentáveis e solidários. 
Sendo assim, as competências (o que se deve alcançar com o aluno) e as habilidades (os caminhos para atingir objetivos) geram um conjunto geral de direitos relacionados ao aprendizado, à cidadania e à consciência crítica.

As competências devem ser práticas e não técnicas. Portanto, o foco é a realidade, sendo contextualizada e problematizada para que o ensino se efetive de forma significativa, preparando os educandos para resolver problemas, de modo cooperativo, de forma técnica, cidadã e ética.

A BNCC propõe uma reelaboração curricular, contemplando carga horária, alguns itinerários formativos, a definição de Matriz com o projeto de vida e as disciplinas eletivas, além da Formação continuada.

A proposta pedagógica, na sua concepção e implementação, deve considerar os estudantes, neste caso, os adolescentes com suas experiências com o mundo real e o mundo virtual, sujeitos históricos e de direitos, participantes ativos e protagonistas na sua diversidade e singularidade.

De acordo com a pesquisa global EU Kids Online os nativos digitais têm muitas experiências com o mundo digital. No entanto, não se pode dizer o mesmo em relação aos conhecimentos estruturantes do tema Educação para a Cidadania Digital.

Por isso, ao trabalhar a formação de competências práticas deve-se considerar as demandas e necessidades do mundo contemporâneo, os interesses dos estudantes, ampliando as aprendizagens das áreas do conhecimento que possibilitam o rompimento com o trabalho isolado apenas em disciplinas. Além disso, cada unidade escolar a elaboração da sua proposta pedagógica em consonância com o documento curricular definido pelo seu sistema de ensino.

As escolas precisam compreender que são as crianças e adolescentes que estão nas salas de aulas. Que muitas vezes incomodam por ser diferentes por causa das transformações culturais, dos valores, formas de pensar, de lidar com o corpo, com a sexualidade. São outros porque sem futuro, sem lugar. (ARROYO, 2011)

A constituição de currículos flexíveis é uma proposta que busca se aproximar das diversas identidades de crianças e adolescentes. Para tanto, deverá trilhar a Base Nacional Comum Curricular e os itinerários formativos, de acordo com a oferta de diferentes arranjos curriculares 
por cada unidade de ensino na luta por um espaço para seus componentes: os projetos de vida, as disciplinas eletivas e o aprofundamento dos estudos oriundos das quatro áreas dos conhecimentos.

Com isso, objetiva-se uma flexibilidade nos espaços e tempos que se expressam na distribuição da carga horária destinada à formação geral básica e nas propostas dos itinerários formativos que deve contemplar as diversidades do contexto histórico, econômico, social, ambiental, cultural, do mundo do trabalho e da prática social.

Dessa forma, torna-se necessário identificar as crianças e jovens presentes no território escolar como cidadãos de direitos, sociais e difusos, para com isso, repolitizar os currículos para a prática do conhecimento-poder-cidadania. Essa luta por espaço inicia na luta por espaço no currículo das escolas que contemplem os interesses de aprendizagem das crianças e adolescentes. (ARROYO; 2011).

Nessa direção, a Educação Digital está contemplada na legislação e norma específicas, na forma transversal e integradora, conforme a Resolução CNE/CEB № 3/2018 que determina que as escolas trabalhem com "práticas que contribuam para a igualdade e para o enfrentamento de preconceitos, discriminação e violência sob todas as formas".

Para o trabalho pedagógico o componente curricular flexível com a temática Educação para a Cidadania Digital deve conter uma ementa com a seleção de conhecimentos técnicos e práticos, metodologias, tempos, espaços, arranjos alternativos e formas de avaliação. Os conteúdos estruturantes dessa temática são: as pegadas digitais, a reputação digitação, a informação viralizada, a cidadania digital, cyberbullying, pegada digital e Uso seguro da internet.

De acordo com a proposta do Curso Educando para Boas Escolhas On-Line o Tema transversal nas diferentes disciplinas; os Projetos interdisciplinares; as Feiras e gincanas com alunos no Dia da Internet Segura; os Eventos com convidados externos; as Palestras, seminários e reuniões; a Inclusão do tema nas aulas de computação e no trabalho com o apoio de cartilhas, vídeos e materiais paradidáticos, assim como, a "Cartilha Diálogo Virtual 2.0" favorecerão o desenvolvimento das atividades para a constituição de currículos flexíveis na Educação Básica. 


\section{CONSIDERAÇÕES FINAIS}

Uma análise da proposta de trabalho com o tema Educação para a Cidadania Digital contida no Curso Livre, oferecido pelo Ministério Público, Educando para Boas Escolhas On-line, observa-se que há uma ênfase nos conteúdos sobre o uso seguro da internet, cujo maior desafio que não é jurídico nem técnico, mas educacional. Trata-se de um conteúdo relativo aos direitos humanos, conforme fica evidenciado nos marcos legais. Porém, torna-se importante destacar que os conteúdos deveriam possibilitar a participação efetiva na elaboração do Regimento Interno e dos Combinados Pedagógicos que muitas vezes desprezam os direitos das crianças e adolescentes contidos nos marcos legais.

Essas atividades devem estar articuladas ao projeto político-pedagógico, a comissão de direitos humanos da escola, assim como com a definição dos componentes curriculares flexíveis constitutivos dos itinerários formativos, a saber: as disciplinas eletivas, o aprofundamento de estudos e os projetos de vida dos estudantes. Que por sua vez, favorecerão a formação das competências complexas da formação para a cidadania digital desde a escola.

O Curso Educando para as Escolhas de Boas Práticas On-Line está direcionado para gestores, coordenadores e professores das escolas da Educação Básica. Mas, também contempla conteúdos orientados para os pais ou responsáveis que podem fazer o papel de "mediadores parentais", aspecto este, bastante salutar para enriquecer a participação das famílias nas escolas. Como dissemos anteriormente, não se trata de um problema apenas técnico. Mas, sobretudo, um problema prático causado pela ausência da Educação em Direitos Humanos, especificamente o tópico da Cidadania Digital.

\section{REFERÊNCIAS}

ARROYO, Miguel G. Currículo, território em disputa. 2aed. Petrópolis, RJ: Vozes, 2011. 
Constituição Federal de 1988, de 5 de outubro de 1988. Disponível em http://www.planalto.gov.br/ccivil_03/constituicao/constituição.htm. Acesso em 07 de maio de 2020.

BRASIL. Base Nacional Comum Curricular. Brasília: MEC, 2017. Disponível em: http://basenacionalcomum.mec.gov.br/ images/BNC C_20dez_site.pdf. Acesso em: 22 de abril de 2020.

Brasil. Comitê Nacional de Educação em Direitos Humanos. Plano Nacional de Educação em Direitos Humanos: 2007. Brasília: Secretaria Especial dos Direitos Humanos, 2007.

BRASIL. Lei no 12.965, de 23 de abril de 2014. Estabelece princípios, garantias, direitos e deveres para o uso da Internet no Brasil. Lei do Marco Legal da Internet. Brasília. 2014. Disponível em: http://www.planalto.gov.br/ccivil_03/_ato20112014/2014/lei/112965.htm Acesso em: 12 de junho de 2020

BRASIL. Lei Federal n. 8069, de 13 de julho de 1990. ECA Estatuto da Criança e do Adolescente. Acesso em 10 de maio de 2020.

Diretrizes Curriculares Nacionais para a Educação Básica: diversidade e inclusão / Organizado por Clélia Brandão Alvarenga Craveiro e Simone Medeiros. - Brasília: Conselho Nacional de Educação: Ministério da Educação, Secretaria de Educação Continuada, Alfabetização, Diversidade e Inclusão, 2013.

FERNANDÉZ ENGUITA, Mariano. Educar em tempos incertos. Tradução: Fátima Murad. Porto Alegre. Artmed, 2004.

Leis de Diretrizes e Bases. Lei no 9.394. 1996. Disponível em: <http://portal.mec.gov.br/seed/arquivos/pdf/tvescola/leis/lein 9394.pdf> Acesso em: 06 de abril de 2020.

MARANHÃO, Escola Superior do Ministério Público do. Disponível em: <https://mpma.mp.br> Acesso em 02 de abril de 2000 . 
PERRENOUD, Philippe (1997). Construir as competências desde a escola. Porto Alegre: Artes Médicas Sul, 1999.

RAJBER, Rachel; SATO, Michèle. Escolas Sustentáveis: incubadoras de transformação nas comunidades. REMEA Revista Eletrônica do Mestrado em Educação Ambiental, v. especial. set. 2010. (29.04.2020)

SANTOS, Boaventura de Sousa. Direitos Humanos, democracia e desenvolvimento. São Paulo: Cortez, 2013. 


\section{UMA PROPOSTA DE FORMAÇÃO DOCENTE PARA O USO SEGURO E RESPONSÁVEL DAS TECNOLOGIAS DIGITAIS, GARANTINDO A CIDADANIA DIGITAL DE CRIANÇAS E ADOLESCENTES}

Ana Gicélia do Nascimento Sousa

\section{INTRODUÇÃO}

Nos últimos anos tem se tornado cada vez mais evidente que a internet e os meios digitais em geral trouxeram novas e múltiplas informações, abrindo um leque de possibilidades de acesso a dados e ao trabalho com o conhecimento, o que acaba por transformar o modo de se relacionar das pessoas e a maneira como veem o mundo. A partir dessa revolução no campo da informação e da comunicação, o processo de inclusão digital avança para o ambiente escolar e deve ser objeto de discussão de todos os envolvidos no processo de ensino aprendizagem.

Nesse contexto a internet se apresenta como novo espaço social e como todo qualquer espaço que propicie as relações humanas apresenta preocupação com as situação de risco e danos que ocorrem, tal como no meio físico também no ambiente virtual, atingindo pessoas de diferentes faixas etárias onde um crescente número de crianças e adolescentes que na atualidade são conhecidos como nativos digitais - todos os nascidos de 1980 para cá, que vivem conectados entre si 
através da cultura tecnológica e que devido à facilidade de acesso a essa cultura passam a sofrer ataques de diversas naturezas no ambiente virtual. Então, a principal pergunta a ser respondida é: como tornar seguro o uso da internet para crianças e adolescentes?

Tudo isso vai depender de um trabalho articulado entre família e escola em que sejam levados em consideração as escolhas individuais, as referências que se tem e a maturidade para evitar esses riscos e também possíveis danos partindo de propostas de conscientização em que pais e educadores possam despertar nas crianças e adolescentes atitudes para o uso crítico e seguro da internet, uma temática básica para o fortalecimento da cidadania digital que só poderá ser efetivamente garantida a partir de uma sensibilização promovida por educadores e demais profissionais de educação em todos os níveis de ensino, embasados nos princípios da lei 13.185/2015 que institui o Programa de Combate à Intimidação Sistemática e que em seu artigo $5^{\circ}$ preconiza o dever do estabelecimento de ensino, dos clubes e das agremiações recreativas em assegurar medidas de conscientização, prevenção, diagnose e combate à violência e à intimidação sistemática.

Levando em consideração todas essas questões é preciso estabelecer uma formação docente centrada em uma proposta de educação voltada para a cidadania, criando métodos e estratégias de intervenção que garantam um uso crítico, ético e seguro das tecnologias tanto no contexto da sala de aula, quanto fora dela.

\section{A SOCIEDADE CONTEMPORÂNEA: INFORMAÇÃO, COMUNICAÇÃO E CIDADANIA}

Há bastante tempo ouvimos a expressão "sociedade da informação" para fazer referência à nova configuração de mundo global, caracterizado principalmente pelo encurtamento das distâncias e acesso rápido aos acontecimentos ao nosso redor, tendo como suporte principal o uso das tecnologias digitais. A referência a esse termo surge a partir de 1975 quando a OCDE (Organização de Cooperação e de Desenvolvimento Econômico) estreia a noção. Já em 1977, a IBM desenvolveu a primeira campanha publicitária em torno do advento da era da informação. 
Tudo isso gira em torno de uma coalizão de forças que pensam o futuro a partir da chamada revolução da informação que, embasada no desenvolvimento de Inteligências artificiais sejam capazes de orientar novas práticas de relação entre as chamadas aldeias globais a partir do uso da Internet, que por sua vez configura-se como a nova rede de acesso público e uma das principais pontes na construção geopolítica do mundo contemporâneo. $\mathrm{O}$ crescimento acelerado das redes de informação começam a trazer preocupação no tocante à proteção de dados.

Como resultado dessa preocupação em 1980, depois de um extenso trabalho, o Conselho da Europa adota uma convenção para a proteção dos dados pessoais, estabelecendo que pessoas de qualquer nacionalidade se prevalecessem das garantias e dos direitos enunciados.

Em 1987, o Livro Verde estabelece a convergência das Telecomunicações com o Audiovisual e a Informática, sendo o primeiro passo para o ajuste entre os países-membros da União Europeia, preconizando a abolição dos monopólios nacionais e serve de base para diretrizes que construirão o caminho rumo à liberalização, a plena concorrência e ao serviço universal.

$\mathrm{Na}$ construção desse espaço de ampliação do acesso às redes de informação surgem termos como democracia interativa que é representada principalmente pelos projetos de cidades interconectadas, pela desmassificação das mídias, pelo pluralismo e pela flexibilidade. Surgindo também nesse contexto de democratização as primeiras e fundamentais discussões sobre a necessidade de conectar as escolas nessa rede dotando-as de equipamentos em tecnologias da informação e da comunicação e sobre o desenvolvimento e a fabricação de programas educacionais de formação de multimídias, assim como a necessidade de formar professores que estejam diretamente envolvidos no desenvolvimento desses programas. A respeito disso, Mattelart (2002) destaca que não faltam exortações que insistem em estimular ativamente a aquisição de conhecimentos e de competências com o fim de transformar a sociedade da informação emergente em uma sociedade do saber. No relatório final encomendado pela Comissão Europeia a um grupo de especialistas de alto nível, exteriores à instituição, sobre a "sociedade europeia da informação para todos" publicado em 1997, 
destaca-se o estabelecimento de uma rede educativa em tecnologias da informação e da comunicação.

Em março de 2000, em Lisboa, a União Europeia propõe estrategicamente o objetivo de "tornar-se a economia do conhecimento mais competitiva e mais dinâmica". O que, infelizmente, não significou um destaque específico sobre os conteúdos e sobre os usos desse conhecimento tecnológico na escola, a não ser pelo fato de destacar a necessidade de os professores se transformarem em usuários da Internet. Assim como a constituição da Europa social permanece limitada a prescrições mínimas, a Europa da educação não é consensual. As políticas educacionais, a exemplo das políticas sociais, continuam a ser responsabilidade dos Estados-membros onde, segundo Mattelart, "a subordinação às políticas econômicas de curto prazo, pontuadas por uma série de encontros (liberalização dos mercados de capitais em 1990, mercado único em 1992, moeda única em 1997, depois em 1999) está estruturalmente inscrita na "Constituição da Europa". O que sugere que a educação fica em segundo plano, em detrimento das questões macroeconômicas.

No que se refere ao Brasil, as políticas públicas relacionadas ao uso das tecnologias educacionais estão diretamente ligadas ao conceito de qualidade de ensino partindo do pressuposto que o seu uso em sala de aula amplia as possibilidades de aprendizagem dos alunos quando a LDB (lei 9.394/96) que estabelece as Diretrizes e Bases da Educação Nacional, define em seu parágrafo IX do artigo $4^{\circ}$, a garantia de padrões mínimos de qualidade de ensino, definidos como a variedade e quantidade mínimas por aluno, de insumos indispensáveis ao desenvolvimento do processo ensino-aprendizagem, destacando também que o processo didático em que se realizam as aprendizagens fundamenta-se na diretriz que assim delimita o conhecimento para o conjunto de atividades em que os conteúdos curriculares da Educação Básica observarão diretrizes como a difusão de valores fundamentais ao interesse social, aos direitos e deveres dos cidadãos, de respeito ao bem comum e à ordem democrática.

No mesmo sentido, a elaboração das Diretrizes curriculares Nacionais destaca que é preciso que se estimule a criação de novos métodos didático-pedagógicos, que tais recursos e métodos sejam inseridos 
no cotidiano escolar. Isto porque o conhecimento científico, nos tempos atuais, exige da escola o exercício da compreensão, valorização da ciência e da tecnologia desde a infância e ao longo de toda a vida, em busca da ampliação do domínio do conhecimento científico: uma das condições para o exercício da cidadania (BRASIL, 2013), construindo uma cultura de intersecção dos direitos humanos na escola, em que valorizem o acesso à ciência e a tecnologia como um dos princípios da Educação Básica.

\section{A FORMAÇÃO CONTINUADA PARA PROFISSIONAIS DA EDUCAÇÃO: NA ESCOLA}

As tecnologias digitais trazem muitos desafios quanto à sua inserção no ambiente escolar, principalmente devido às dificuldades de avançar nesta temática desde a formação inicial dos professores, que na sua maioria busca atualização por conta própria já que a instituição escolar ainda precisa vencer diversos problemas como a ausência de políticas públicas que garantam o acesso à internet banda larga nas escolas, falta de inclusão do tema em sala de aula, de maneira transversal, e não apenas nas aulas de informática e o mito ainda frequente de que as tecnologias atrapalham a aprendizagem, para citar apenas alguns.

Imbernón (2011) destaca que o mito da sociedade da informação deixa muitas pessoas desinformadas, ao passo que outras acumulam o capital informativo em seu próprio benefício e no de alguns poucos. E de nada adianta sujeitos bombardeados por todos os lados com uma gama infindável de informação, se não souberem fazer um uso crítico das mesmas. O profissional de educação deve influenciar diretamente nesse processo de forma a contribuir com a autonomia de seus alunos e alunas, tornando-os menos dependentes do poder econômico, político e social. O docente precisa se munir de meios que o façam avançar de um conhecimento comum para o conhecimento especializado, que unido à prática é capaz de transformar a realidade em que se insere.

A aceleração do conhecimento científico pressupõe mudanças que chegam na escola alterando também o fazer docente na busca por uma nova cultura profissional que esteja embasada na colaboração e no progresso social, visando uma maior percepção do ambiente escolar e 
possibilitando a inovação e a capacidade de gerar novos conhecimentos pedagógicos.

As novidades que se apresentam na instituição educativa e que se fundamentam na pesquisa e na prática docente devem fomentar uma formação que ofereça condições de o professor criar diferentes estratégias de implementação de inovação e mudança no contexto educativo. $\mathrm{Na}$ sociedade globalizada a formação deve preocupar-se em desenvolver os conhecimentos, habilidades e atitudes que tornem os professores e professoras cada vez mais reflexivos e investigadores, devendo estar centrada na sistematização desse processo e na tomada de decisões para interpretar as situações complexas que se apresentam dentro e fora da sala de aula. Para Imbernón (2011, p. 41) trata-se de formar um profissional prático reflexivo que se defronta com situações de incerteza, contextualizadas e únicas, que recorre à investigação como uma forma de decidir e de intervir praticamente em tais situações, que faz emergir novos discursos teóricos e concepções alternativas de formação.

A formação é um elemento fundamental para o desenvolvimento profissional do professor quanto ao uso crítico e seguro das novas tecnologias na escola e deve ampliar-se para além dos aspectos pedagógicos, estando vinculada também a aspectos não formativos que terminam por permitir aos docentes a intervenção direta na melhoria de sua estrutura social e profissional, atuando como agentes sociais capazes de criar processos de intervenção autônomos.

Deve-se então pensar em uma proposta de formação que busque assegurar a aquisição de competências para a mediação no campo da orientação das crianças e adolescentes sobre noções básicas de cidadania como: direitos, deveres, prevenção e segurança no mundo digital, para a partir disso identificar possíveis violações de direitos e também para contribuir no desenvolvimento de um projeto político pedagógico direcionado ao trabalho com a difusão de informações seguras para esse público.

A partir disso, a intervenção dos educadores nesse processo torna-se imprescindível ao assumir seu papel de mediadores como adultos de referência na vida dos alunos, na busca por um embasamento acerca das leis que asseguram os direitos e deveres na internet estando devida- 
mente capacitados para discutir as temáticas de segurança no uso dessas tecnologias e quanto à implementação de ações que direcionem os alunos quanto às boas práticas on-line e, consequentemente para o uso cidadão das tecnologias digitais, garantindo acesso crítico e seguro dos ambientes virtuais utilizados em casa ou no caso específico da escola, a partir de uma perspectiva pedagógica.

Atualmente, entende-se que a formação proposta na escola a esse respeito, precisa discutir a natureza do que está exposto na BNCC documento que define o conjunto orgânico e progressivo de aprendizagens essenciais que todos os alunos devem desenvolver ao longo de todas as etapas e modalidades da Educação Básica, de modo a que tenham assegurados seus direitos de aprendizagem e desenvolvimento - em conformidade com a LDB e com as Diretrizes Curriculares Nacionais da Educação Básica (DCN), que fundamentam a construção de uma sociedade justa, democrática e inclusiva que seja orientada pelos princípios éticos, políticos e estéticos que visam à formação humana integral. Nesse sentido, o trabalho realizado pelas equipes de assessoria e/ou coordenação pedagógica da escola devem se preocupar em discutir em conjunto com os professores a proposta de um plano de formação continuada a partir da ampliação das reflexões sobre as competências necessárias à prática docente e ao redimensionamento do trabalho pedagógico no desenvolvimento de práticas inovadoras que colaborem significativamente na aprendizagem dos estudantes.

Frente às adequações necessárias ao currículo em ação na escola, as formações ocorridas nesse espaço em relação ao uso das TIC's na Educação precisam ainda considerar a autonomia das próprias instituições escolares, como também o contexto e as características dos alunos no uso e acesso à essas tecnologias dentro e fora da sala de aula, como orientado na BNCC, que propõe que é preciso contextualizar os conteúdos, tornando-os significativos, com base na realidade do lugar e do tempo nos quais as aprendizagens estão situadas, decidindo sobre as formas de organização interdisciplinar dos componentes curriculares, fortalecendo a competência pedagógica das equipes pedagógicas para adotar estratégias mais dinâmicas, interativas e colaborativas em relação à gestão do ensino e da aprendizagem (BRASIL, 2017). 
Assim ao discutir o trabalho com as tecnologias na escola, é preciso salientar que esse não é um assunto específico dos professores de informática, por se tratar de um tema contemporâneo transversal que se conecta diretamente com os conteúdos de vários componentes curriculares, sendo de fundamental importância que o processo formativo nesse campo garanta ao professor um trabalho mais efetivo na compreensão, utilização, e criação de tecnologias digitais de informação e comunicação de forma crítica, significativa, reflexiva e ética nas diversas práticas sociais para se comunicar, acessar e disseminar informações, produzir conhecimentos, resolver problemas e exercer protagonismo e autoria na vida pessoal e coletiva como um direito de aprendizagem e desenvolvimento assegurados entre as dez competências gerais da BNCC.

A formação na escola e a partir da escola deve ter como objetivo principal, estimular ativamente a aquisição de conhecimentos e competências que ajudem a transformar o fazer pedagógico em ferramenta que contribua com o desenvolvimento de um trabalho pensado e direcionado para o uso crítico e responsável das tecnologias na educação, fomentando uma prática reflexiva que facilite relações construtivas no compartilhamento das inovações, buscando soluções coletivas para os possíveis problemas e conflitos que se apresentarem, refletindo, planejando e avaliando as demandas de aprendizagem nesse campo para a ressignificação do seu conhecimento e da sua prática, levando em consideração os contextos dessas transformações e as necessidades específicas de cada escola e de cada aluno.

\section{A FORMAÇÃO DO CURSO EDUCANDO PARA BOAS ESCOLHAS ONLINE: A CIDADANIA DIGITAL}

A formação continuada aplicada nas escolas da rede municipal de São Luís - MA traz em seu plano formativo a proposta de redimensionar o trabalho pedagógico a partir da proposição de um programa de formação que se inicia com a Jornada Pedagógica no início do ano letivo e continua ao longo do ano em encontros mensais, onde os professores e a coordenação pedagógica de cada escola se reúnem por área do conhecimento para discutir ações que possibilitem inovações 
no ensino e na aprendizagem. Dentre as reflexões levantadas, pode-se destacar a discussão sobre a atual implementação da Base Nacional Comum Curricular que traz mudanças que exigem a adoção de novas ferramentas de ensino aprendizagem e também sobre as possibilidades de trabalho com os temas contemporâneos transversais, que passaram a ser considerados a partir da BNCC, conteúdos essenciais para a Educação Básica e, que trazem consigo, o questionamento recorrente de como articulá-los aos demais conteúdos de forma contextualizada com enfoque na relevância dessas temáticas para a formação do cidadão.

Essa articulação passa então a ser um objetivo importante para o desenvolvimento de uma formação continuada que possibilite um trabalho de direcionamento dos alunos na aquisição de habilidades vinculadas aos componentes curriculares num processo pedagógico que possa ser construído em cooperação com todos os profissionais da escola e que contemple o trabalho com essas temáticas de acordo com o contexto, sendo importante destacar que cabe aos sistemas e redes de ensino, assim como às escolas, em suas respectivas esferas de autonomia e competência, incorporar aos currículos e às propostas pedagógicas a abordagem de temas contemporâneos que afetam a vida humana em escala local, regional e global, preferencialmente de forma transversal e integradora (BRASIL, 2017).

Entre as temáticas que afetam diretamente a vida de crianças e adolescentes, é imprescindível que se dê destaque à sua relação com o uso das tecnologias digitais por se apresentarem como um dos desafios da atualidade tanto para os pais quanto para os profissionais da Educação Básica, principalmente devido à carência de formações específicas que orientem o trabalho com esse tema. As poucas propostas nesse sentido encontram ainda diversos obstáculos de serem efetivadas pelos sistemas de ensino devido às dificuldades na implementação de políticas públicas direcionadas especificamente aos programas de inserção de TIC's na escola.

No entanto, existem algumas iniciativas organizadas por entes públicos e sociedade civil organizada buscando preencher essas lacunas, como e o caso do curso de Formação a Distância Educando para as Boas Escolhas Online ofertado pelas Escolas Institucionais do Ministério Público Federal (no caso específico, a Escola Superior do Ministério 
Público do Maranhão) e a SaferNet Brasil (associação civil de direito privado, fundada em 2005, com foco na promoção e defesa dos Direitos Humanos na Internet no Brasil) em vista de responder às demandas sociais a partir dos desafios que se apresentam nos campos da educação, saúde, direito, segurança pública, ciência e tecnologia e, nesse curso trazem a temática da Educação em Direitos Humanos com foco na cidadania digital, objetivando a capacitação de professores para o uso crítico e seguro das tecnologias dentro e fora do ambiente escolar, além de oferecer embasamento sobre direitos e deveres fundamentados no Estatuto da Criança e do Adolescente e no artigo 26 do Marco Civil da Internet que garante que é dever do Estado tratar da educação para o seu uso consciente e seguro em todos os níveis educacionais.

A sua proposta está fundamentada nas bases do Plano Nacional de Educação em Direitos Humanos(PNEDH) que visa, sobretudo, difundir a cultura de direitos humanos no país a partir da divulgação ampla dos valores solidários, cooperativos e de justiça social, consolidando um projeto de sociedade democrática e garantindo o respeito às diversidades. Uma das principais linhas de ação do PNEDH é a promoção de formação inicial e continuada em direitos humanos dos profissionais da educação nos vários níveis e modalidades de ensino. A estrutura do PNEDH, estabelece concepções, princípios, objetivos, diretrizes e linhas de ação, contemplando cinco grandes eixos de atuação: Educação Básica, Educação Superior, Educação Não-Formal, Educação dos Profissionais do Sistema de Justiça e Segurança Pública e Educação e Mídia (BRASIL, 2018).

A temática se apresenta de maneira bem estruturada no curso e pode integrar a proposta de formação continuada complementar das escolas da rede municipal de ensino de São Luís, dando suporte ao desenvolvimento de processos metodológicos participativos, que possam discutir sobre a complexa relação da cultura digital com as escolas e as diferentes abordagens que norteiam os projetos de inclusão das tecnologias digitais nesse ambiente, aprofundando a reflexão sobre os conceitos e princípios que amparam algumas das estratégias de inclusão das tecnologias digitais na educação num processo pedagógico que possa ser construído em cooperação com todos os profissionais da escola, a fim de desenvolver habilidades socioemocionais que sejam efetivas no combate às práticas 
de Intimidação Sistemática e repetitiva e, estando os professores devidamente capacitados para lidar com tais questões, serão fundamentalmente uma referência para que os alunos tenham melhores condições de reconhecer as situações de risco, evitar sofrer ou causar danos on-line, refletindo constantemente sobre as práticas de respeito à diversidade, atitudes de cooperação e capacidade de resolução de conflitos.

Tendo como suporte o portfólio de excelentes materiais que incluem cartilhas, campanhas, jogos e vídeos, todos com linguagem acessível e direta que despertam o interesse nos alunos e tomam por base todas as leis e documentos que fundamentam as políticas de proteção à crianças e adolescentes, os professores estarão preparados para trabalharem esses temas de forma transversal, por meio de abordagens intra, inter e transdisciplinares como orienta a BNCC. E esses materiais podem ser utilizados na ressignificação do uso das tecnologias no ambiente escolar, onde os próprios alunos, com a mediação dos professores, podem se tornar os protagonistas na produção de materiais similares baseados no seu próprio contexto, o que contribuirá significativamente no desenvolvimento de competências e habilidades que ajudarão no enfrentamento das questões relacionadas à Intimidação Sistemática na internet (Cyberbullying) e a todos os outros problemas virtuais que ameacem a garantia de seus direitos fundamentais.

Gatti e Barreto (2009) destacam que, no que se refere à formação continuada, é possível afirmar que seu principal propósito é "a atualização e aprofundamento de conhecimentos como requisito natural do trabalho em face do avanço nos conhecimentos, as mudanças no campo das tecnologias, os rearranjos nos processos produtivos e suas repercussões sociais", o que possibilita a criação de uma proposta de ensino e aprendizagem bem estruturada, tomando por base os conhecimentos e orientações compartilhadas na formação promovida pela Escola Superior do MPMA em conjunto com a SaferNet Brasil, onde os docentes, além dos gestores e coordenadores da rede municipal de São Luís podem criar estratégias de planejamento que incluam projetos interdisciplinares e aulas que potencializem as oportunidades e os benefícios que as tecnologias digitais e seus usos podem trazer para sua formação pedagógica, científica e cultural. 


\section{CONSIDERAÇÕES FINAIS}

A internet é um espaço que apresenta uma dimensão pública e, por isso representa um enorme desafio para pais e educadores na mediação de seu uso para uma apropriação crítica, segura e responsável por parte de crianças e adolescentes. Nesse sentido, é preciso um trabalho voltado para o desenvolvimento das competências socioemocionais que ajudarão os estudantes na resolução de conflitos e na aquisição das noções de cidadania no mundo digital que devem ser a base de conhecimentos das noções gerais relacionadas ao uso de uma rede que pode apresentar diversas situações de risco, principalmente devido ao fato de serem considerados nativos digitais, o que por si só não garante que eles possam reconhecer e gerenciar os riscos que correm, precisando de referências que lhes deem melhores condições de reconhecer essas situações, evitando que sofram danos na Internet.

Os profissionais da educação precisam aproveitar as possibilidades de acesso ao conhecimento e às relações interativas proporcionadas pelas tecnologias digitais para desenvolver um trabalho preocupado e engajado na construção de um processo educativo de fortalecimento da autonomia e do pleno exercício da cidadania, colaborando com o desenvolvimento integral do ser humano.

À escola cabe então, o papel de promover a sensibilização, a conscientização e a prevenção dos casos de Intimidação Sistemática na Internet para que, quando essas situações forem identificadas entre os alunos no contexto escolar, haja protocolos claros de enfrentamento do problema a fim de mediar os conflitos e, em casos que fujam do controle, possam seguir com processos de orientação às famílias para denúncia formal às autoridades. Dentro de seus limites, as escolas têm um papel central em criar ambiente seguro e positivo, melhorando o relacionamento entre pares, ampliando a conscientização e reduzindo oportunidades e recompensas para os agressores, através de um projeto pedagógico bem estruturado para esse enfrentamento.

O curso de formação a distância Educando para as Boas Escolhas Online se apresenta como proposta de formação complementar que dará suporte para essa intervenção nas práticas virtuais de crianças 
e adolescentes, estimulando-os a se questionar e a pensar de forma crítica sobre o próprio uso da rede mundial de computadores, maximizando as oportunidades e os benefícios que as tecnologias digitais podem trazer para sua formação intelectual e social e enfatizando que a mediação é fundamental nesse processo em que o professor representa a referência mais experiente no reconhecimento das situações de risco nesse ambiente.

Para fins de construir uma formação sistematizada que se habilite em desenvolver o conhecimento profissional mais direcionado para essa área de atuação as propostas irão subsidiar os debates da temática, a partir de uma reflexão crítica de vídeos e textos que ajudem a promover uso seguro e responsável das tecnologias, o envolvimento dos alunos na criação e revisão das políticas de uso das Tecnologias Digitais na Escola e o planejamento de ações do Projeto Político Pedagógico das escolas, entre outras ações educativas.

\section{REFERÊNCIAS}

BRASIL. Comitê Nacional de Educação em Direitos Humanos. Plano Nacional de Educação em Direitos Humanos-PNEDH. Brasília: Ministério dos Direitos Humanos, 2018. Disponível em http://www.gov.br. Acesso em 30 de maio de 2020.

BRASIL. Ministério da Educação. Base Nacional Comum Curricular. MEC, 2017. Brasília, DF, 2017. Disponível em <http:// basenacionalcomum.mec.gov.br> Acesso em 21 de abril de 2020.

BRASIL. Ministério da Educação. Diretrizes Curriculares Nacionais Gerais da Educação Básica / Ministério da Educação. Secretaria de Educação Básica. Diretoria de Currículos e Educação Integral. Brasília: MEC, SEB, DICEI, 2013. Disponível em <http://portal.mec.gov.br>. Acesso em 25 de maio de 2020.

GATTI, Bernadete Angelina (Coord.); BARRETO, Elba S. de S. Professores do Brasil: impasses e desafios. Brasília, DF: UNESCO, 2009. Disponível em <https://www.fcc.org.br>. Acesso em 28 de maio de 2020. 
IMBERNÓN, Francisco. Formação docente e profissional: formar-se para a mudança e a incerteza. 9a ed. - São Paulo: Cortez, 2011. - (Coleção questões da nossa época; v.14).

MATTELART, Armand. História da sociedade da informação. São Paulo: Edições Loyola, 2002. 


\section{EDUCAÇÃO E GÊNERO: A IMPORTÂNCIA DA EDUCAÇÃO EM DIRETIOS HUMANOS NO ENFRENTAMENTO A VIOLÊNCIA CONTRA A MULHER}

Amanda Silva de Jesus

\section{INTRODUÇÃO}

Presenciamos nos últimos anos um crescimento vertiginoso dos índices de violência, tendo como base ações fecundadas pela desigualdade de classes - arcabouço central do capitalismo - em que gestam as mais diversas formas de segregação e preconceitos/ discriminação encovados nos traços históricos do patriarcado, racismo, misoginia, sexismo dentre outros. Safiotti (2004) conceitua violência como sendo a ruptura de qualquer forma de integridade da vítima que pode ser de ordem física, psíquica, sexual ou moral. Partimos do pressuposto de que a maioria esmagadora das mulheres são vítimas de algum tipo de violência, e o aumento da violência contra a mulher no Brasil já vinha sendo apontado por diversas pesquisas e órgãos de proteção à mulher.

Com o contexto resultante da pandemia do novo coronavírus (COVID-19), vimos esses números aumentarem de forma alarmante. Um dos fatores são as medidas de isolamento social, adotadas pelos países com vistas a retardar a disseminação do vírus que na contramão obrigam vítimas a conviverem com seus agressores 
por longos períodos. Um boletim vinculado à Secretaria de Transparência do Senado Federal "Violência doméstica em tempos de Covid-19" aponta um aumento de aproximadamente 50\% dos casos de violência doméstica nesse período. Cabe apontar que além da violência doméstica, outras violências como as intrafamiliares ${ }^{14}$ em que se enquadra o abuso sexual de crianças e adolescentes também sofrem aumento com abusadores mais presentes no ambiente familiar, sendo as meninas as maiores vítimas dos abusos sexuais infantis.

Entre os países com o maior índice de violência contra a mulher no mundo, o Brasil ocupa o $5^{\circ}$ lugar no ranking. Segundo o Instituto Brasileiro de Geografia e Estatística (IBGE) a cada ano, cerca de 1,3 milhão de mulheres são agredidas no Brasil. Em 2018, de acordo, com o Fórum Brasileiro de Segurança Pública (FBSP) registrou-se no Brasil 66 mil vítimas de estupros sendo que, a maioria das vítimas 53,8\% foram meninas de até 13 anos. Registrou-se também que, em 2018, 1.206 mulheres foram vítimas de feminicídio, alta de 4\% em relação ao ano anterior e a cada dez mulheres mortas, seis eram negras.

Segundo dados do Senado (2016), obtidos através de um diagnóstico dos estados brasileiros, há uma taxa maior de violência letal contra mulheres pretas e pardas do que contra mulheres brancas. Alguns estados em 2014 chegaram a apresentar taxa de homicídio de mulheres pretas e pardas mais de três vezes superior à de mulheres brancas, como é o caso de Amapá (mulheres brancas 1,1\% pardas e negras 6,7\%), Pará ( mulheres brancas 2,2\%,mulheres pardas e negras 7,0\%) Roraima (mulheres brancas 1,8\% pardas e negras 5,5\%), Pernambuco ( mulheres brancas $1.9 \%$, mulheres pardas e brancas 6,5\%), Piauí (mulheres brancas 1,0\% mulheres negras 4,1\%) e Espírito Santo (mulheres brancas $2,8 \%$ e mulheres pardas e negras $9,2 \%)$.

14 “Em primeiro lugar, violência doméstica não é o mesmo que violência intrafamiliar, usadas como sinônimos [...]Enquanto na segunda à violência recai exclusivamente sobre membros da família nuclear ou extensa, não se restringindo, portanto, ao território físico do domicílio, cabem na primeira vítimas não-parentes consanguíneos ou afins" (SAFFIOTI, 2001, p. 130). 
O mapa da violência (2019) mostra que o homicídio de mulheres negras aumentou no país em 29,9\% de 2007 a 2017, enquanto isso, no mesmo período o homicídio de mulheres brancas cresceu 1,7\%. Mulheres negras transexuais também são em maior número vítimas de violência o "Dossiê dos assassinatos e da violência contra travestis e transexuais no Brasil” em 2018, apontou para o homicídio de 163 pessoas em 2018. Dessas, 82\% eram negras.

Estamos, portanto, falando de uma violência de gênero com recorte de raça. É irrefutável o fato de que mulheres negras sofrem mais com a violência estrutural, reflexo de um "racismo estrutural", este decorrente da própria estrutura social em que se constituem as relações políticas, econômicas, jurídicas e familiares que estão impregnadas no seio social. " $[\ldots]$ o racismo como processo histórico ${ }^{15}$ e político, cria as condições sociais, para que, direta ou indiretamente, grupos radicalmente identificados sejam discriminados de forma sistemática" (ALMEIDA, 2019, p. 39). Estamos falando portanto, de um enfoque da violência que se dá em três eixos - classe, raça, e gênero - uma tríade da violência contra a mulher.

O que esses dados mostram, de forma nociva, é a reprodução naturalizada da desigualdade de gênero a partir de modelos tradicionais fundados nos estereótipos da força e do poder masculino versus a submissão feminina, em que a dominação masculina vem denunciada como "regime de dominação-exploração das mulheres pelos homens" (SAFFIOTI, 2004, p.44). Esse modelo contribui para manter viva uma ideologia de posse/controle pelos homens sobre os corpos e vida das mulheres.

É dever portanto, de toda uma sociedade pensar em meios de desconstrução dessa cultura nociva à vida das mulheres. Nessa perspectiva o objetivo deste artigo é questionar "Como a educação pode ser um

150 processo histórico que resulta da escravidão, dos ciclos de morte e destruição do colonialismo operam como fundamentos irremovíveis da sociedade contemporânea. A classificação/separação dos seres humanos por raça serviu para além de um conhecimento filosófico como uma das tecnologias empregadas pelo colonialismo e depois Neocolonialismo para a destruição dos povos da América, Oceania, África e da Ásia (ALMEIDA, 2019). 
vetor de enfrentamento a violência contra a mulher?" E desenvolve a reflexão a partir de revisão de literatura sobre o tema.

Assim, o presente artigo discute a importância da questão de gênero ser debatida, refletida e pensada dentro e fora das nossas escolas, pois, entendemos que o ambiente escolar enquanto uma instituição social, reproduz uma lógica de educação meritocrática, funcional ao sistema vigente. Mas, esse mesmo espaço pode ser precursor de mudança, propício à desconstrução da normalização e criação de um espaço que fomente um aprendizado balizado na ação e na ética como salienta Freire, sendo elementos fundamentais no processo de aprendizagem, pois possibilita uma compreensão profunda de mundo e, portanto, mudanças no agir que possibilita a transformação (com base em um pensamento crítico) e que deve estar em consonância com os direitos humanos, numa construção coletiva do conhecimento.

Portanto, novas formas de construção do conhecimento podem gerar mudanças na forma de pensar, olhar e agir de uma geração de educandos. A educação sozinha não muda a estrutura, mas, ela pode fomentar mudanças na forma de pensar que desencadeia mudanças na forma de agir. É necessário mudar a educação de homens e mulheres para o enfrentamento à violência de gênero. Os meninos e meninas de hoje serão os homens e mulheres do amanhã. E nos cabe a seguinte indagação: Uma base diferenciada de educação pode criar sujeitos humanamente diferentes?

\section{GÊNERO E EDUCAÇÃO}

O gênero refere-se à construção social relacionado à hierarquia e distinção entre o masculino/feminino, separando os corpos pelo sexo biológico que possuem macho ou fềmea, e as relações de poder advindas dessa separação e estruturação social. $O$ gênero não se restringe apenas à diferenciação que existe entre homens e mulheres ${ }^{16}$, a utilização do termo refere-se às relações de poder presentes na sociedade como um todo, dimensão política, econômica, social e cultural, ca-

16 Aqui se inclui as mulheres trans./as transexuais que se reconhecem e se identificam como mulheres com o sexo feminino. 
bendo destacar que a dimensão do conceito de gênero também diz de uma categoria histórica. Assim, temos que as desigualdades produzidas entre mulheres e homens na nossa sociedade é um constructo social, onde o androcentrismo ${ }^{17}$ e o machismo ${ }^{18}$ vêm sendo reproduzidos há séculos em nossa sociedade e continuamos a recria-los. São ações preconceituosas e discriminatórias que tendem a levar a atos de violência como os presenciados diariamente contra milhares de mulheres no Brasil e no mundo.

Esse é um problema de ordem social e política que adquire visibilidade especialmente a partir dos movimentos feministas e de mulheres na década de 1970, no Brasil, em que as demandas e pautas levantadas colocam essa questão na agenda pública da necessidade de políticas de enfrentamento à violência contra as mulheres e punições aos agressores, em que notam-se avanços como a promulgação da Lei Maria da Penha 11.340 de 2006 que oferece como aparato legal, coibir a violência doméstica e familiar, e a Lei do feminicídio 13.104 de 13 de março de 2015 que coloca esse crime no rol de hediondos com penas mais severas.

Apesar das mudanças sociais ocorridas nas últimas décadas, impulsionadas pelos avanços dos direitos das mulheres e de sua emancipação sexual, política e econômica, ainda impera de forma perniciosa, uma cultura sexista e patriarcal que contribuem para manter ativo um ideário de que as mulheres devem viver subordinadas aos desejos masculinos de posse e controle sobre sua autonomia. Os dados estatísticos mencionados anteriormente, não são apenas números, são vidas de mulheres que foram ceifadas, ou transformadas drasticamente pela violência. Essas mulheres são ou foram as mães de alguém, as filhas, as irmãs, as amigas e, quando vemos diariamente nos noticiários o aumento no número de feminicídio, da violência doméstica e da vio-

17 Está intimamente ligado a noção de patriarcado. É a concepção que visa valorizar o pensamento masculino, estabelecendo uma visão de mundo a partir do ponto de vista masculino, em que nas descrições do comportamento, sociedade e situações o foco é o homem e são controladas por uma perspectiva masculina.

18 Ideologia que justifica/defende os processos de inferiorização, desigualdade e dominação baseados no gênero, favorecendo e enaltecendo o sexo masculino sobre o feminino. 
lência sexual, é veementemente primordial entender que não se trata apenas de quantificar, mas, de reconhecer que essa sociedade é nociva à vida das mulheres que ela e sua cultura estão matando-as.

A criação das leis e de um sistema jurídico de proteção à mulher é fundamental, é um avanço e simboliza uma conquista, mas, associado a isto precisamos criar uma compreensão, assimilação uma transmissão pela qual os sujeitos se apropriem da cultura desse direito humano adquirido socialmente e o internalizem, enquanto modus de vivência sui generis.

Vemos que apesar dos avanços das leis de proteção à mulher, os números da violência não diminuíram. A cultura da violência estrutural que impregna as instituições, a esfera social e a relações sociais não foi alterada. $\mathrm{O}$ direito humano adquirido, nesse caso, "os direitos das mulheres", requer "um processo de reflexão crítica, deliberação e formação desse direito humano. Nesse sentido, há um valor intrínseco a esse processo, pois é um compromisso com o indivíduo na criação da unidade social da qual faz parte" (Mc Cowan, 2015, p.38). Tendo assim, a educação em direitos humanos um papel fundamental nesse processo de levar os sujeitos a refletirem e a construírem coletivamente estratégias de como lidar com a discriminação e preconceito e suas formas de eliminação.

Mas, porque se faz necessário discutir e refletir acerca dos direitos das mulheres na sociedade?

Cabe inferir que a questão de gênero faz parte da ordem social, o sexismo e o androcentrismo estão presentes na vida cotidiana e são reproduzidos e naturalizados de forma corriqueira e se manifestam muitas vezes através da violência simbólica, como tratada por Bourdieu (1998), que tende a ratificar a dominação masculina na qual se funda através da divisão sexual do trabalho, da divisão social e relações sociais atribuindo a cada um dos sexos seu lugar, momento, instrumentos etc.

A violência simbólica institui-se por meio da adesão que o dominado não pode deixar de conceder ao dominador (logo, à dominação), uma vez que ele não dispõe para pensá-lo ou pensar a si próprio, ou melhor, para pensar sua relação com ele, senão de instrumentos de conhecimento que ambos têm em 
comum e que, não sendo senão a forma incorporada da relação de dominação, mostram esta relação como natural; ou, em outros termos, que os esquemas que ele mobiliza para se perceber e se avaliar ou para perceber e avaliar o dominador são o produto da incorporação de classificações, assim naturalizadas, das quais seu ser social é o produto (BOURDIEU, 2002, p. 41).

A dominação simbólica constitui uma violência simbólica, impregnando as categorias dominadas e seus sistemas cognitivos, tentando conforma-los atravessando as relações sociais, onde o projeto masculino de dominação-exploração se traduz em estruturas hierarquizadas, em objetos no próprio senso comum, em que num sistema aquém da consciência vemos a produção da violência de gênero por toda uma sociedade inclusive pelas próprias mulheres (não se tratando aqui de cumplicidade feminina ou algo do tipo, mas de uma reação muitas vezes reflexo de uma ação não refletida, e encoberta de aparatos simbólicos). (SAFFIOTI, 2001). Mas cabe ressaltar que há espaços para a operação de sistemas cognitivos capazes de tornar transparentes a tela do androcentrismo na sociedade, em que mulheres podem oferecer resistência ao processo de exploração-dominação, e muitas o fazem, não somente referente a questão de gênero, mas também étnica, racial e de classe (SAFFIOTI, 2001).

A linguagem, os pensamentos androcêntricos, interpretações negativas muitas vezes apoiadas em concepções científicas a respeito da mulher ou de algum comportamento sexual desviante da norma heteronormativa, os procedimentos pedagógicos e conteúdos curriculares transmitidos aos jovens por meio da educação, vão influenciando preconceitos ideológicos. Assim, vão determinando pensamentos e padrões de conduta, reproduzindo preconceitos como o androcentrismo que, segundo Moreno (1999), é um dos preconceitos mais graves de que padece a humanidade. Por tanto tempo e séculos se pensando de uma maneira pode levar a crer em um determinismo e imutabilidade de ideias, acreditando não haver outra maneira de pensar, e perpetuando verdades que parecem ser inalteráveis, impossibilitando assim, a capacidade de se refletir e critica-las. 
$\mathrm{O}$ androcentrismo consiste em considerar o ser humano do sexo masculino como o centro do universo, como a medida de todas as coisas, como o único observador valido de tudo o que ocorre em nosso mundo, como o único capaz de ditar as leis, de impor a justiça, de governar o mundo. É precisamente esta metade da humanidade que possui a força (os exércitos, a polícia), domina os meios de comunicação de massas, detém o poder legislativo, governa a sociedade, têm em suas mãos os principais meios de produção e é dona e senhora da técnica e da ciência (MORENO, 1999, p. 23).

Portanto, é preciso refletir, pensar e repensar esses mecanismos de dominação, pois somente ao entender e desvelar esse processo é possível se criar meios que gerem alteração do mesmo.

Há uma necessidade iminente de se intervir no modelo de sociedade existente, pois a liberdade não nos é dada, é preciso aprender a construí-la. A educação e a escola podem contribuir, analisando com as alunas e alunos (geração do agora e do futuro), os papeis que a sociedade atribui a cada sexo, analisando livros, filmes, histórias, ajudando-os a descobrirem as limitações e os estereótipos que a sociedade impõe a cada gênero, e que lhe são atribuídos como capacidades inatas, mas que na verdade, as formas de comportamento são reprodução do modelo existente. É possível educar para que meninos e meninas apreendam a e na diversidade.

Candau (2012) ressalta que para os direitos humanos serem verdadeiramente ressignificados, numa perspectiva que não nega sua história, mas os colocam na problemática contemporânea, é necessário passar por um processo de reconceitualização, articulando igualdade e diferença, isto é, “[...] a passagem da afirmação da igualdade ou da diferença para a da igualdade na diferença. Não se trata de, para afirmar a igualdade, negar diferença, nem de uma visão diferencialista absoluta, que relativize a igualdade" (p.719). Nessa perspectiva, "temos o direito a ser igual, sempre que a diferença nos inferioriza; temos o direito de ser diferente sempre que a igualdade nos descaracteriza" (SANTOS, 2006. p. 462). 


\section{A EDUCAÇÃO COMO MECANISMO FUDAMENTADOR PARA O ENFRENTAMENTO À VIOLÊNCIA DE GÊNERO}

Ao se pensar em educação, deve-se ter uma compreensão da realidade social, à qual, essa se encontra imersa, pois a forma como se estrutura a sociedade influi na forma como se organiza o sistema educacional. Os fatores econômicos, políticos sociais e culturais interferem no desenvolvimento e organização do ensino.

[...] a prática educativa, enquanto uma prática social contraditória, à medida que se efetiva no interior de uma sociedade de classes marcada por interesses antagônicos, se articula com os interesses burgueses e com os daqueles que constituem a classe dominada (FRIGOTTO, 2010b, p.33).

Atualmente, o saber se encontra aprisionado em um sistema de ensino que inibe a capacidade criativa e autônoma dos indivíduos. Promove a fragmentação do conhecimento e das ciências, leva a uma incapacidade de compreensão da totalidade e à formação de sujeitos acríticos, apenas reprodutores de ideias e não criadores. Moreno (1999) demarca que a escola possui uma dupla função segundo ela;

A escola tem marcada uma dupla função: a formação intelectual e a formação dos indivíduos, ou seja, seu adestramento nos próprios modelos culturais. Porém, caso se limite a isto, terá feito um pequeno favor à sociedade. Não será mais que um aparelho reprodutor de vícios e virtudes de sabedorias e de mediocridades. Sua missão pode ser muito diferente. Em lugar de ensinar o que os outros pensaram, pode ensinar a pensar; em lugar de ensinar a obedecer, pode ensinar a questionar, a buscar os porquês de cada coisa, a iniciar novos caminhos, novas formas de interpretar o mundo e de organiza-lo (MORENO, 1999, p.17).

Assim cabe destacar a importância do ensino não ser transmitido de forma isolada ou fragmentada, mas de forma que o indivíduo possa 
agregar e ligar o conhecimento, sendo capaz de também produzi-lo. Freire (1967, p. 42), nos adverte sobre a necessidade da liberdade da consciência como prática criativa, “[...] E, é por isso que, minimizado e cerceado, acomodado a ajustamentos que lhe sejam impostos, sem o direito de discuti-los, o homem sacrifica imediatamente a sua capacidade criadora".

Para Gramsci (2006), é imprescindível que se fuja de um conhecimento mecânico ou livresco. Ele vê a necessidade de aquisição de um conhecimento histórico que possibilite olhares e concepções críticas, permitindo ao indivíduo desvelar mecanismos de poder que envolve a sociedade. Diz, ainda, que é preciso desenvolver uma consciência social em que o indivíduo se perceba e se enxergue como participante e construtor desse coletivo.

Gramsci (2006) propõe, portanto qualidade e acesso livre e igualitário à educação e, portanto a uma formação política e cultural essencial para garantir a participação política das massas na luta pela conquista de seus direitos. Para Gramsci (2006), a escola ${ }^{19}$ tem um papel fundamental na formação e construção dos sujeitos, ele defende a criação de uma "escola humanística", que possibilita ao indivíduo desenvolver, livremente, à vontade, a inteligência e a formação consciente.

É necessário, para tanto, o respeito à diversidade ao diferente, e que alunas e alunos possam desfrutar da riqueza que a variedade oferece. Uma educação não-sexista ultrapassa os limites da escola, mas por meio desta é possível realizar um trabalho para uma educação plural. É preciso sensibilizar, orientar o corpo docente com atividades e discussões sobre esse tema, é também necessário realizar um trabalho com alunas e alunos analisando a imagem e o papel de mulheres e homens em nossa sociedade, realizando um estudo crítico dos modelos feminino e masculino que são mostrados na televisão, nos livros escolares,

19 "A escola é o instrumento para elaborar os intelectuais de diversos níveis. A complexidade da função intelectual nos vários Estados pode ser objetivamente medida pela quantidade das escolas especializadas e pela sua hierarquização: quanto mais extensa for a 'área' escolar e quanto mais numerosos forem os 'graus verticais' da escola, tão mais complexo será o mundo cultural, a civilização, de um determinado Estado." (GRAMSCI, 2006, vol. II, p. 19). 
nas leituras infanto-juvenis, nas visões androcêntricas expressas no facebook por alguns sujeitos etc. "Não se pode mudar a sociedade a partir da escola, mas podem-se lançar alternativas, desenhar novas possibilidades, ensinar a abrir caminhos e mostrar que nós, os seres humanos, podemos escolher" (MORENO, 1999, p.80 grifo nosso).

Faz-se necessário desconstruir no espaço escolar essa separação de gênero, trabalhando com alunas e alunos não a superioridade de um sexo sobre o outro, mas o sentido de igualdade, construção coletiva, capacidades igualitariamente construídas e desenvolvidas. É preciso trabalhar para o combate a estereótipos de gênero presentes na sociedade e arraigados ao machismo, ao padrão social e cultural dominante que leva a fenômenos como violência contra a mulher no âmbito doméstico, discriminação e violências nos espaços de trabalho (cargos e salários inferiores, assédio sexual), abuso sexual e moral, visão passada pela mídia da mulher como objeto e mercadoria de consumo (CANDAU, 2003).

Temos que, os padrões e os modelos de conduta, não podem ser mudados com imposição, ou apenas pela força de uma lei. Para que a mudança ocorra, se faz necessária uma transformação profunda na mentalidade dos indivíduos, tomando consciência dos mecanismos inconscientes de transmissão do modelo que queremos mudar e que estão introjetados. É preciso desconstruir ideias, formas de pensar, de agir e de se relacionar, é preciso desconstruir comportamentos e construir o novo, e a escola pode auxiliar nesse processo de transformação (Moreno, 1999).

A mudança nos currículos é primordial, para interação e permanência da educação em direitos humanos no ensino. O tema da questão de gênero ainda é pouco presente no cotidiano e currículo escolares, em 2014 presenciamos uma séria polêmica, tanto no Plano Nacional de Educação (PNE) (com diretrizes a serem trabalhadas e alcançadas nos próximos 10 anos da educação no país 2014 a 2024), quanto nos planos estaduais e municipais às metas relacionadas à discriminação e desigualdade de gênero.

O PNE foi sancionado em 2014, e teve vetados temas como sexualidade e identidades de gênero nas escolas, isso demonstra um retrocesso e um fechar de olhos para temas tão relevantes. As intensas 
polêmicas e discussões se prolongaram, pois mesmo após o PNE ter sido aprovado, os municípios e Estados tinham até 26 de junho de 2015 para implementarem os seus próprios planos, e, o que se viu, foi a reprodução do conservadorismo em âmbito local, tendo os temas (referente ao gênero) vetados e retirados dos planos.

Portanto, se faz necessário questionar os estereótipos e refletir sobre o modo velado e reducionista que a questão de gênero aparece nos documentos (currículos pedagógicos). Pois o currículo não é apenas um conceito, mas também uma construção social e cultural, que é ordenada, operada e lecionada de acordo com o moldes sui generis (SACRISTÁN, 2000), por isso precisa ser revista a forma como o currículo delimita o conhecimento escolar.

Temos que, as políticas educacionais não foram suficientemente desenvolvidas no enfretamento eficaz quanto às desigualdades de gênero no espaço escolar. Ainda nas escolas, as relações de gênero ganham pouca relevância entre educadores e educadoras, e nos cursos de formação docente esse vácuo também se faz presente. O olhar dos profissionais da educação é pouco treinado para a reflexão, não apenas referente às desigualdades entre os sexos, mas ao significado que perpassa essa desigualdade que se encontra pouco contemplada pelas políticas públicas do sistema educacional (VIANNA; UNBEHAUM, 2004). Cabe ainda, destacar que a política pública de educação precisa ser colocada como pauta prioritária nesse país, melhores salários, condições de trabalho e educação continuada para professores, melhoria na infraestrutura das escolas, transporte adequado aos alunos, merenda escolar de qualidade, reforma dos currículos e protocolos pedagógicos dentre outros elementos centrais para uma educação de qualidade.

Temos que, apesar dos barramentos, entendemos que o campo da educação e o espaço da escola são fundamentais para a formação das novas gerações, e, sendo instituições presentes na sociedade e que perpassam as relações sociais, são mecanismos fundamentais para a mudança sociocultural. Vimos no decorrer deste trabalho que no espaço escolar se presencia expressões de preconceito e discriminação, no entanto, tal espaço pode ser também terreno fértil para a construção do respeito e da igualdade. 
Tomamos que, as desigualdades de gênero, sexualidade e raça, complexificadas pelas relações de poder presentes na sociedade formam campos de força na demarcação de normalização/normatização dos indivíduos. Assim, cabe discutir, pensar, repensar os significados e maneiras como isso ocorre, contribuindo para a consolidação de novas práticas e intervenções que podem ser realizadas dentro da escola e da sala de aula, assim como pode se expandir para fora dos muros da escola. Almeida (2019) ressalta que uma instituição que se preocupe com a questão racial, e aqui, acrescento de gênero deve investir em políticas internas que visem:

a) promover a igualdade e a diversidade em suas relações internas e com o público externo [no caso da escola chamo a atenção a pais e comunidade];

b) remover obstáculos para a ascensão de minorias em posição de direção e de prestigio na instituição;

c) manter espaços permanentes para debates e eventual revisão de práticas institucionais;

d) promover o acolhimento e possível composição de conflito raciais e de gênero (ALMEIDA, 2019, p. 37)

A escola pode se tornar um lugar privilegiado de discurso, de diálogo, de reflexão de interpretação de experiências trazidas e vividas por professores e alunos. É preciso, portanto, que reflexões sobre o enfrentamento ao preconceito e discriminação de gênero, orientação sexual, religião, classe, raça dentre outros, sejam levadas para dentro das salas de aula, passem a integrar os currículos pedagógicos, devendo ser parte para a formação cidadã na perspectiva de construção de uma sociedade mais democrática. “[...] A escola não muda a sociedade, mas pode, partilhando esse projeto com segmentos sociais que assumem os princípios democráticos, articulando-se a eles, constituir-se não apenas como espaço de reprodução, mas também como espaço de transformação (BRASIL, 1997, v.08, p. 23)". 


\section{CONCLUSÃO}

O tecido sociocultural da nossa sociedade se encontra impregnado de preconceitos, discriminação, intolerâncias e hierarquias, configurando relações sociais desiguais. Esses fatores são incompatíveis com uma educação igualitária baseada em valores éticos, em que, para construirmos uma sociedade e uma escola mais justa, solidária e livre de preconceitos, é necessário identificar e enfrentar as dificuldades para promover os direitos humanos. Assim, para uma educação comprometida com a formação de sujeitos de direitos, faz-se necessário o reconhecimento da diversidade como elemento pertencente e constituinte do espaço escolar e da sociedade de modo geral.

Como afirma Candau (2012) não é preciso o reconhecimento de direitos de igualdade, mas de direitos da diferença, formando sujeitos de direitos a partir do reconhecimento da diversidade de orientação sexual, religiosa, gênero, raça, etnia e classe social, dentre outras.

Cabe assim, pontuar a importância de processos educativos pensados no horizonte do diverso, pois a educação se constitui a partir da ação e das relações humanas para as quais se destina.

A cultura hegemônica machista, androcêntrica, heteronormativa supõe um conjunto de discriminação contra a mulher que se encontra presente na sociedade e que são produzidas e reproduzidas cotidianamente em vários âmbitos das relações sociais, sendo a escola um desses espaços. É necessário, portanto, que cada vez mais questões ligadas à construção de gênero na sociedade sejam amplamente discutidas e debatidas com profissionais ligados à educação, com o intuito de dar ênfase e visibilidade a essa questão para que se possa mudar maneiras de pensar e, portanto, de agir.

O debate de gênero é necessário em nossa educação, e as nossas escolas precisam, cada vez mais, se constituírem num espaço aberto para essa discussão. Se quisermos um ensino que abarque a diversidade, necessitamos de abertura para que a mudança aconteça. Sabemos que a educação sozinha não transforma a sociedade e que a escola não é a única responsável por auxiliar na mudança, mas cabe destacar que ela é um espaço fundamental, pois auxilia na formação e, portanto, tem 
muito a contribuir para novas formas de pensar, e novas maneiras de enxergar e construir a vida social.

\section{REFERÊNCIAS}

ALMEIDA, Silvio. Racismo Estrutural. Pólen Produções Editoriais. São Paulo,2019.

Anuário Brasileiro de Segurança Pública. Fórum Brasileiro de Segurança Pública, 2019.

Atlas da violência. Organizadores: Instituto de Pesquisa Econômica Aplicada; Fórum Brasileiro de Segurança Pública. Brasília: Rio de Janeiro: São Paulo: Instituto de Pesquisa Econômica Aplicada; Fórum Brasileiro de Segurança Pública, 2019.

BOURDIEU, Pierre. A dominação masculina. Tradução de: Maria Helena Kuhner. $-2^{\circ}$.ed. - Rio de Janeiro: Bertrand Brasil, 2002.

BRASIL. Ministério da Educação e do Desporto. Secretaria de Educação Fundamental. Parâmetros curriculares nacionais: ensino fundamental. Brasília: MEC/SEF, 10 volumes, 1997.

CANDAU, Vera Maria; MOREIRA, Antônio Flavio Barbosa. Educação Escolar e cultura(s): construindo caminhos. Revista Brasileira de Educação, n 23, p. 156-168, maio/jul. 2003.

CANDAU, Vera Maria (Coord.). Somos Tod@s Iguais? Escola, discriminação e educação em direitos humanos. Rio de Janeiro. DP\&, 2003.

CANDAU, Vera Maria. Diferenças Culturais, cotidiano escolar e práticas pedagógicas. Currículo sem Fronteiras, v.11, n.2, p.240-255, Jul/Dez. 2011.

Direito a Educação, diversidade e educação em direitos humanos. Revista Educação e Sociedade, v.33, $\mathrm{n}^{\circ}$ 120, p. $715-726$, jul/set. 2012a. 
CANDAU, Vera Maria (Org.). Reinventar a escola. 8.ed. Rio de Janeiro: Vozes, 2012b.

DOSSIÊ: ASSASSINATOS E VIOLÊNCIA CONTRA TRAVESTIS E TRANSEXUAI NO BRASIL EM 2018. Bruna G. Benevides; Sayonara Naider Bonfim Nogueira (Org.). Brasil, 2019.

FREIRE, Paulo. Educação como pratica da liberdade. Rio de Janeiro: Paz e Terra, 1967.

FREIRE, Paulo. Pedagogia do Oprimido. $17^{\circ}$ ed. Rio de Janeiro: Paz e Terra, 1987.

FRIGOTTO. A produtividade da escola improdutiva: um (re) exame das relações entre educação e estrutura econômica-social capitalista. - 9.ed.- São Paulo: Cortez, 2010b.

GRAMSCI, Antônio. Cadernos do Cárcere; volume 2; edição e tradução de Carlos Nelson Coutinho; co- edição, Luiz Sergio Henriques e Marco Aurélio Nogueira. - $3^{\circ}$ ed.- Rio de Janeiro; Civilização Brasileira, 2006.

McCowan, Tristan. O direito humano à aprendizagem e a aprendizagem dos direitos humanos. Educar em Revista (UFPR), Curitiba, Brasil, n. 55, p. 25-46, jan./mar. 2015.

MORENO, Montserrat. Como se ensina a ser menina: O sexismo na escola. Tradução de Ana Venite Fuzatto. São Paulo: Moderna, 1999.

Panorama da violência contra as mulheres no Brasil: indicadores nacionais e estaduais. -- N. 1. Brasília: Senado Federal, Observatório da Mulher contra a Violência, 2016.

SAFIOTTI, Heleiet. Contribuições feministas para o estudo da violência de gênero. Cadernos Pagu, n¹6, p.115-136, 2001.

SACRISTÁN, José Gimeno (Org.). Saberes e Incertezas sobre o currículo. Universidade de Valência: Editora Penso, 2000. 
SAFIOTTI, Heleieth. Gênero, patriarcado e violência. São Paulo: Editora Fundação Perseu Abramo, 2004.

SANTOS, Boaventura de Sousa. A gramática do tempo. Para uma nova cultura política. São Paulo: Editora Cortez, 2006.

VIANNA, Claudia; UNBEHAUM Sandra. O gênero nas políticas públicas de educação no Brasil:1988-2002. Cadernos de Pesquisa, v. 34, n. 121, jan./abr. 2004. 


\section{AS RELAÇÕES ENTRE INCLUSÃO E EXCLUSÃO SOCIAL COM A EDUCAÇÃO INCLUSIVA: REVISÃO DE LITERATURA}

Carlos Antonio Furtado Dutra

Introdução

Considerando-se que uma área temática tão extensa como é o processo de inclusão de pessoas com deficiência na educação brasileira, pode proporcionar origem a inúmeras questões e a diversos problemas de pesquisa, este estudo estabelece uma linha de investigação literária em que levanta a seguinte interpelação: Como a literatura aborda as relações entre os processos de inclusão e exclusão social na educação inclusiva?

Desta forma, analisando os fundamentos teóricos implicados nos debates sobre a inclusão e exclusão social e acompanhando o desenvolvimento de implantação da proposta de inclusão no sistema de ensino do Brasil, determinaram-se como objetivo da pesquisa, os seguintes propósitos: o objetivo geral do estudo que se desenvolveu é demonstrar uma revisão de literatura pautadas em obras que contenham diretrizes e modelos sobre à educação inclusiva e produções literárias que abranjam as premissas das ciências sociais, quanto a inclusão e exclusão social. Especificando as suas relações para as práticas inclusivas na educação. Os objetivos específicos apresentados são: (I) identificar e especificar as relações entre inclusão e exclusão; (II) averiguar as premissas teóricas 
quanto a educação inclusiva; (III) entender de que maneira a educação especial é preconizada.

Para atingir esse propósito realizou-se uma busca meticulosa em produções acadêmicas nas bases de dados da Biblioteca Virtual Pearson. Fazendo-se uso a palavra-chave inclusão social, exclusão social e educação inclusiva, essa pesquisa foi realizada entre os meses de março e abril de dois mil e dezenove, e para debater, na análise dos resultados, com base no referencial teórico exposto, as relações da inclusão e exclusão social com a educação inclusiva, relatando-se assim, as ponderações apropriadas a esse trabalho cientifico e acadêmico.

\section{A relação entre Inclusão e Exclusão}

É imprescindível situar, nesta parte introdutória desse artigo, algumas concepções acerca de inclusão que direcionam a pesquisa e, incorporado a outras, compõem as orientações que percorre o registro aqui efetuado. Tais concepções foram selecionadas fundamentadas em análises e discussões que pesquisadores produziram sobre o tema e que trazem informações para o entendimento do discurso da inclusão e da educação inclusiva.

Incluir significa que podemos deixar pertencer, adaptando uma pessoa em todos os aspectos, mostrando-os o que fazer, para que e com quem utilizar suas habilidades, fazendo-o aprender por intermédio de atividades não somente específicas, mas transformadoras e adaptáveis, trabalhando, assim, o agrupamento do processo intelectual, físico, social e emocional e aplicar, esses aspectos em conjunto, pois o propósito, é auxiliar, é ajudar, este ser, reconhecer, conhecer, socializar e se emocionar por meio da aprendizagem.

Diversas investigações dissertam sobre as concepções que abrangem a complexidade e as controvérsias a respeito do termo inclusão, pois, dependendo da maneira como é aplicado e da conjuntura onde é usado, o termo pode sofrer variações de significado; portanto, a definição de inclusão, como esclarece Garcia (2014), tem sido utilizado por argumentos tanto progressistas quanto conservadores, da mesma forma que tem atendido a vários posicionamentos político-ideológicos, 
sendo abordado como detentor de qualidades para superar o conjunto de condições sociais que são qualificadas de exclusão social. Essa mesma pesquisadora esclarece que existe inúmeras compreensões teóricas a respeito desse assunto, compreendendo-se de um lado, os que pressupõem a inclusão como proposta de solução para o grupamento de problemas sociais, delineado como exclusão, e, de outro, aqueles que compreendem a relação inclusão/exclusão como constituidor da realidade no momento histórico.

Precisamente, as concepções iniciais a respeito de inclusão estiveram presentes transpassaram-se em diferentes setores da sociedade em decorrência à dimensão conseguida pelas forças de exclusão, especialmente a pobreza, desigualdades sociais e os indivíduos em situação de vulnerabilidade, e dissertar sobre essas concepções requer, em conformidade com a ideia de Libâneo (2015), a compreensão do atendimento às necessidades sociais, culturais e de inclusão da população requer um sistema de ensino de qualidade social e pedagógica que socialize os aspectos culturais, científicos e sociais como direitos universais, sendo o ambiente escolar, um reflexo da conjuntura social em que está inserida. Assim, compreende-se que, para debater sobre a inclusão, e, mais precisamente, a educação inclusiva, é inevitável fazê-lo em um contexto histórico de transformações econômicas, políticas, ideológicas e sociais.

Desse modo, a definição de inclusão dever ser compreendida no vínculo estabelecido pelos indivíduos com a conjuntura histórico-social. Este vínculo é representado por uma prática complexa e contraditória proferida com sentido de luta, de enfrentamento, convive com o seu oposto, a exclusão, todavia, é conduzido a indagar as práticas sociais alicerçadas na desigualdade e a sobrepuja-las (Garcia, 2014). A mesma autora evidencia a imprescindibilidade de considerações sobre os processos de inclusão/exclusão que, figurativos dos processos sociais, econômicos e políticos, devem ser entendidos e analisados, como acima se assinalou, de maneira homogênea, uma vez que decorrem nas relações sociais desiguais.

O tema exclusão não se limita somente a conjuntura nacional, pois, também, tem sido debatido pela comunidade europeia, com base 
nas mudanças geográficas e políticas que os países desse continente passaram, tampouco essa temática recente, uma vez que é discutido desde a década de 60, associado às questões da pobreza e da marginalização social dele desinente (Kassar; Arruda e Benatti, 2007).

O teórico Martins (2015), determina o entendimento de exclusão relacionado à sua dimensão social certificando ser um momento da compreensão que cada indivíduo e todos podem ter daquilo que definitivamente se expressa em privação: privação de meios de compartilhar do mercado consumidor, assim, como a privação ao mercado de trabalho formal, privação de direitos, privação de bem-estar, privação de esperança e privação de liberdade. O qual os indivíduos se encontram afastados do processo de formação da sociedade, da participação ativa, da existência e garantias dos seus direitos de cidadão.

De fato, de acordo com os esclarecimentos da autora, é necessário refletir que, para que aconteça uma viabilidade real de inclusão, primeiramente há a necessidade de se realizar uma análise crítica para se recusar e solucionar a exclusão social. Seguindo essa mesma diretriz de pensamento, Oliveira e Duarte (2015) estabelecem que a política social intromete-se no hiato proveniente dos desequilíbrios na disseminação em favorecimento da acumulação de bens do capitalismo e em prejuízo da satisfação de necessidades sociais básicas, tal como na efetivação da igualdade.

Todavia, no Brasil, essas políticas sociais otimizaram-se em um contexto de muita contradição, demarcado pela desigualdade no acesso e na extensão, e pela peculiaridade fragmentária, setorial e emergencial na sua realização vindo a ter um desenvolvimento mais universal somente por meio da Constituição de 1988. Com base nessa premissa, compreende a educação, como uma das significativas e fundamentais políticas sociais, atinge, nessa circunstância uma posição dual e contraditória, à proporção que, mesmo dispondo de peculiaridade universal por procurar a amplificação e o crescimento do contingente de pessoas atendidas, tem, concomitantemente, enfatizado seu atendimento na busca de garantir o acesso e a permanência de grupos mais desamparados socialmente (Oliveira e Duarte, 2015).

No Brasil, o parâmetro excludente é exemplificado por motivos como a herança de concentração agrária, vestígios da escravidão apre- 
sentando como consequência a desvalorização do trabalho e salários, baixos investimentos na área da educação e a discriminação racial. Este mesmo parâmetro permaneceu-se nos períodos históricos seguintes, em que não ocorreu melhorias em questões como a redistribuição de moradias, ou restruturação de direitos e também como alusão à concepção de uma equidade básica civilizatória.

Assim, em decorrência da falta de distribuição de renda, o que se evidencia é uma acentuada diferença social na população brasileira, onde os altos índices de riquezas se centralizam nas mãos de uma pequena parcela da sociedade enquanto uma fração bem maior encontra-se excluída dos proventos do crescimento econômico, miserável e empobrecida, sem acesso ao mínimo essencial para uma vida mais humana e digna. A essas causas econômicas devem-se incorporar as peculiaridades culturais da sociedade brasileira na qual predominam, ainda, as discriminações raciais, étnica, de gênero e outras, características de verdadeiros impedimentos aos processos de mobilidade social (Lucidio e Correia, 2011).

A relação que existe entre educação e exclusão é regulamente mencionada em diversos estudos, aparecendo muitas vezes como circunstância da condição de acesso aos sistemas de educação Tardif (2014) especificam para o fato de que a desigualdade de renda tem a maior associação com o nível de educação da pessoa, assim como a probabilidade de serem pobres, contudo, é correto que essas pesquisas, ao detectarem o fenômeno, não especificam o que é causa e o que é consequência e, obviamente, essas pesquisas relacionam-se a uma posição política.

Entretanto, Lucidio e Correia (2011) preconizam que defendendo a concepção de inclusão pela educação, de maneira desprendida das condições sociais que originam a exclusão, estamos efetivamente tratando o fenômeno por meio de suas aparências, culpando o próprio sistema por seus insucessos, e esquivando-se assim a discussão sobre os mecanismos de construção e reconstrução das classes sociais em sociedades como a brasileira. Para este autor, políticas e estratégias que alterem o ingresso e permanência dos excluídos, associados às políticas de diminuição das desigualdades educacionais e outras que intercalam 
a sociedade são resultados que podem, se bem aplicados, possibilitar e desenvolver um enfrentamento dos problemas da exclusão.

Como observado nesse item do artigo, confere-se de relevância o fato de que, para entender o processo a que se tem presenciado da exclusão na área da educação é necessário a compreensão do problema das desigualdades sociais de maneira generalizada, assim como do entendimento e reflexão acerca das controvérsias existentes em um contexto histórico mais abrangente.

\section{EDUCAÇÃO INCLUSIVA E SUA RELAÇÃO COM A INCLUSÃO SOCIAL}

O desejo por uma sociedade mais justa e solidária tem feito com que diversas correntes político-ideológicas apoiem convicções humanitárias que largamente envolvem os mais diversos segmentos da sociedade, reconhecendo os direitos políticos e sociais num ponto de vista mais democrático. A apreensão com a questão social daqueles que, por circunstâncias particulares, encontram-se em condição de desvantagem, levou à articulação de diferentes grupos da sociedade, procurando maneiras de garantir a igualdade de direito de acesso aos recursos e serviços sociais. No ramo educacional, já que a educação é apontada como condição de crescimento pessoal e de desenvolvimento do cidadão para transforma-lo em indivíduo participante efetivo da sociedade.

A educação tem apresentando bastante relevância em registros históricos de fóruns de debates e acordos internacionais com destaque na luta pelos direitos humanos universais. Singularmente, alguns desses documentos, decorrentes de encontros internacionais, são marcos significativos da perspectiva educacional da sociedade contemporânea, e, portanto, de interesse desta investigação, que objetiva, aqui, uma breve apreciação do movimento pela educação inclusiva de uma fração da população em que se encontram crianças, jovens, mulheres e homens com deficiência e aos quais corriqueiramente tem sido negado o direito à participação efetiva na sociedade.

Desde muito tempo, as organizações internacionais governamentais e não-governamentais vêm pretendendo conseguir o reconhecimento dos direitos humanos de cada indivíduo e sua consecutiva 
efetivação na sociedade; por esse motivo vêm, também, concedendo atenção aos direitos dos indivíduos com deficiência mental e não somente para os deficientes físicos, buscando modificar a realidade de segmentos sociais historicamente marginalizados, propiciando-lhe, assim, maior crescimento humanitário.

A Declaração dos Direitos das Pessoas Deficientes, aprovada em 09 de dezembro de 1975 na Assembleia Geral da Organização das Nações Unidas, proclama que as pessoas com deficiência têm o direito inerente de respeito por sua dignidade, além de reconhecimento quanto aos direitos essenciais, o que acarreta, a princípio, o direito de usufruir de uma vida digna. Tem, ainda, a intenção de convocar os países membros a se interessarem com a prevenção das deficiências e proporcionar real auxílio aos indivíduos com deficiência, auxiliando-os no aprimoramento de suas capacidades para constituírem-se à vida normal.

No ano de 1981 foi marcado como o Ano Internacional das Pessoas Deficientes e, nessa ocasião, a Organização das Nações Unidas (ONU) lançou os princípios da educação inclusiva ao preconizar o Programa Mundial de Ação Relativo às Pessoas com Deficiência, que se assegurava a todos os indivíduos, independentemente de suas particularidades ou condições sociais, o direito à participação e desenvolvimento nas conjunturas da sociedade. Da experiência alcançada pela ONU, por meio de seus especialistas, com o emprego do programa, associada ao produtivo debate realizado nos anos dedicados à Década das Nações Unidas para as Pessoas com Deficiência (1983 - 1992), emergiu a necessidade de propor a descrição de uma ideologia orientadora que designasse o direcionamento de atuações futuras, prioritárias, pautadas no reconhecimento dos direitos dos cidadãos com deficiência.

O propósito não era apenas empreender orientações de medidas eficientes com a finalidade de que as pessoas pudessem conquistar e preservar um emprego e nele desenvolver-se, mas também, sempre que possível e apropriado, empregar os serviços existentes para os empregados em geral, com as adequações necessárias promovendo assim, a inclusão social destes indivíduos. A inclusão dessa anotação correlaciona-se ao encadeamento da educação escolar com serviços de diretrizes e formação profissional, ocupação, emprego e outros que abranjam a 
preparação para o trabalho, e a necessidade iminente de atenção, pois a esta área da educação também é estabelecida as diretrizes da educação inclusiva, uma vez que o estado brasileiro garante um sistema de ensino inclusivo a ser empregado em todos os níveis da educação nacional.

No ano de 1990 na realização da Conferência Mundial de Educação para Todos, realizada em Jomtien, foi admitida a presença de obstáculos na área da educação de diversos países. Percebe-se também que a educação desenvolvida nessas nações demonstra significativas deficiências, mas insiste que ela precisa estar plenamente disponível a todo cidadão. Reforça o direito de todo indivíduo à educação, direito primeiramente certificado pela Declaração Universal dos Direitos Humanos, e preconiza, por meio de seus artigos, as obrigações em relação a: "satisfazer as necessidades básicas de aprendizagem; expandir o enfoque; universalizar o acesso à educação e promover a equidade; concentrar a atenção na aprendizagem; ampliar os meios e o raio da educação básica; propiciar um ambiente adequado à aprendizagem; fortalecer as alianças" (UNESCO, 1990).

Em Salamanca com a realização da Conferência Mundial sobre Necessidades Educativas Especiais: Acesso e Qualidade que ocorreu no ano de 1994, organizações e governos se reuniram com o objetivo de viabilizar a educação para Todos. Esse propósito apresentado foi realizado por meio da apreciação das modificações de política para compreender a educação de todos com necessidades educacionais especiais. Influenciada nas convicções de integração e na indispensabilidade de instituições de ensino que incluam a todos, entendendo as diferenças, e propiciando a aprendizagem e assistência às necessidades de todos os indivíduos e de cada pessoa, a Declaração compreende que o princípio essencial da inclusão está na resposta educativa que a instituição de ensino possibilita ao ser humano após reconhecer suas efetivas necessidades, possibilitando-lhe uma educação inclusiva de qualidade. Nesse aspecto conclama todos os governos e empreende que estes "atribuam a mais alta prioridade política e financeira ao aprimoramento de seus sistemas educacionais no sentido de se tornarem aptos a incluírem todas as crianças, independentemente de suas diferenças ou dificuldades individuais" (UNESCO, 1994). 
Quando se trata de educação inclusiva, ressalta-se que a Declaração de Salamanca passou a ser considerada como um marco histórico e que, a partir de então, passa a ser a diretriz educacional de diversos países, especialmente daqueles que assinaram esta declaração após o encontro em 1994. Através das políticas de educação, os governos dessas nações assumem o compromisso com os propósitos e orientações da proposta de Educação para Todos, procurando conseguir um sistema de educação com orientação inclusiva em todos os níveis educacionais.

Para o teórico Mittler (2003), algumas considerações fazem da Conferência de Salamanca um marco histórico: (1) foi bem sucedida em relembrar as nações que os indivíduos com deficiência devem ser integrados na agenda da Educação para Todos e ofertou um fórum para debate e troca de ideias e de práticas sobre como o desafio estava sendo enfrentado em nível global; (2) crianças com dificuldades de aprendizagem e com deficiência mental foram observadas como parte de um grupo mais abrangente, a qual estavam sendo negados seus direitos à educação. Esse grupo mais abrangente compreende as crianças: que vivem nas ruas das cidades ou que são obrigadas a trabalharem em situações, frequentemente, aterradoras; que são mártires de guerras, doenças e de diversos abusos; que vivem em comunidades nômades e longínquas; pertencentes a outros grupos sociais em desvantagem ou em grupos sociais marginalizados, e com deficiência mental ou com altas habilidades (Mittler, 2003).

Por último (3), a Declaração de Salamanca, é considerada como um marco histórico por ter esclarecido a filosofia e a prática da inclusão que ocasionou em um comprometimento por parte da maioria dos governos para trabalharem pela efetivação da educação inclusiva em seus países. A preferência por conduzir os sistemas educacionais pelas pressuposições de caráter filosófico, ético, social e político que constituem a proposta de inclusão fez com que: os países, por meio de seus governos, definissem, em cada setor de sua operação, que ocorresse o reconhecimento da condição dos indivíduos com deficiência; que se adotassem as deliberações que garantissem o ingresso imediato e a participação desses indivíduos nos serviços e recursos existentes em cada setor da atenção pública; se possibilitassem as estruturas ne- 
cessárias para proporcionar esse acesso e participação; se procedesse à preparação de profissionais para gerenciar a atenção pública em uma instituição inclusiva; se incentivasse a compreensão dos cidadãos para a sua responsabilidade no desenvolvimento de construção de uma sociedade mais inclusiva.

$\mathrm{Na}$ esfera educacional esse compromisso governamental acarreta na promoção de obrigações efetivas e necessárias que asseguram aos alunos com deficiência o direito a se matricularem e participarem em todos os níveis do sistema educacional e a frequentá-lo. (Ministério da Educação - MEC, 2005). Assim, o artigo da Declaração sancionado pelo Congresso brasileiro por intermédio do Decreto de Lei no 198 , de 13 de junho de 2001, apresenta em seu âmago deliberações sobre o que considera deficiência e discriminação, e, igualmente, a determinação do que compreende como não-discriminatório. Recomenda-se na efetuação de seus objetivos a tomar as providencias necessárias que compreendam questões legislativas, educacionais, trabalhistas, sociais, ou de qualquer outra natureza para acabar com a discriminação e, concomitantemente, possibilitar perfeita agregação das pessoas com alguma deficiência à sociedade. Estabelece em suas cláusulas o compromisso dos estados integrantes com a erradicação da discriminação, em todas suas proporções e manifestações, a que são sujeitados indivíduos com deficiência, reiterando igualmente a obrigação de realizar ações e medidas com o propósito de melhorar a condição dos indivíduos com deficiência.

Por compreender que a educação trespassa os limites de uma instituição de ensino, é imprescindível mencionar, mesmo que de maneira breve, que também a sociedade tem ponderado a respeito da concepção da educação inclusiva, uma vez que suas prerrogativas alcançam, de fato, toda a comunidade. Por esse motivo rememorasse aqui a Declaração de Montreal sobre Inclusão, realizada no Canadá, em 5 de junho de 2001 e reconhecida pelo Congresso Internacional "Sociedade Inclusiva", a qual reconhece as prerrogativas que o padrão acessível e inclusivo de ambientes, produtos e serviços acarretam nas mais diversas áreas da sociedade e ainda ressalta a premência de agregar aos currículos de todos os programas de educação e treinamento os fundamentos do desenho inclusivo. Verificasse, portanto, uma nova perspectiva das 
necessidades humanas reconhecidas pela sociedade por meio do direito dos indivíduos com deficiência, posto que, à formação dos mais diversos profissionais são acrescentados conhecimentos do campo da educação especial, transmitindo esses conteúdos, a agregar os currículos dos cursos.

A ONU ratifica, e, em 2006, ocorre a Convenção sobre os Direitos das Pessoas com Deficiência, que inovando ao ponderar a deficiência como um preceito em desenvolvimento como o resultado da interação entre os indivíduos com deficiência e os obstáculos encontrados, obstáculos que lhes impedem uma completa e verdadeira participação na sociedade com os demais indivíduos. Reconhece o direito dos indivíduos com deficiência e procura proporcionar a conscientização da sociedade quanto a esses direitos. Para conseguir esses parâmetros, a Convenção determina: “[...] combater estereótipos, preconceitos e práticas nocivas em relação a pessoas com deficiência, inclusive os baseados em sexo e idade, em todas as áreas da vida; e Promover a consciência sobre as capacidades e contribuições das pessoas com deficiência”. (ONU, 2006).

Compreende-se como sistema de educação inclusivo aquele no qual não ocorra a ações discriminatórias, e se asseguram possibilidades iguais. Sendo assim, percebe-se que o direito à educação é realizado por meio de um sistema educacional inclusivo e garantido em todos as circunstâncias e no decorrer da vida, o que, por se tratar de uma assertiva abrangente pode ser empregada contra os processos de exclusão social. (Fávero, 2010). Com o intuito de que se atenda o direito à educação são indispensáveis atribuições igualmente delineadas no artigo 24, parágrafo 2, através das cláusulas de A a E:

a. As pessoas com deficiência não sejam excluídas do sistema educacional geral sob alegação de deficiência e que as crianças com deficiência não sejam excluídas do ensino primário gratuito e compulsório ou do ensino secundário, sob alegação de deficiência;

b. As pessoas com deficiência possam ter acesso ao ensino primário inclusivo, de qualidade e gratuito, e ao ensino secun- 
dário, em igualdade de condições com as demais pessoas na comunidade em que vivem;

c. Adaptações razoáveis de acordo com as necessidades individuais sejam providenciadas;

d. As pessoas com deficiência recebam o apoio necessário, no âmbito do sistema educacional geral, com vistas a facilitar sua efetiva educação;

e. Medidas de apoio individualizadas e efetivas sejam adotadas em ambientes que maximizem o desenvolvimento acadêmico e social, de acordo com a meta de inclusão plena. (Organização das Nações Unidas, 2006).

A observação acima realizada corresponde com o que concebem Santos e Carvalho ao declararem que: "Factualmente a cinesia pela inclusão pode ser ponderada como parte de uma série de processos em favor do direito da equidade dos direitos sociais de participação, acesso e permanência nos vários bens e serviços sociais, abrangendo a educação”. (KASSAR, 2007, p. 59).

Fica claro, que o Brasil, ao concordar com o comprometimento de transformar o sistema de educação em uma sistemática inclusiva, objetiva um sistema que respeite as diferenças de qualquer natureza e reestruture o ambiente escolar de modo a assegurar a convivência na heterogeneidade e democratização do conhecimento, corroborando com a minimização dos processos de exclusão social. Esta compreensão pauta-se na proteção dos direitos de acesso, ingresso e permanência do aluno em uma instituição de ensino de qualidade, de agregação com colegas e docentes, de adequação e composição de saberes e, acarreta em mudança de procedimentos à frente das diversidades, desenvolvendo-se o entendimento de que somos todos distintos uns dos outros e de nós mesmos, visto que evoluímos e nos transformamos (Glat, 2011).

A educação inclusiva demonstra mais que uma orientação de ensino, ela pondera como uma concepção de estabelecimento de ensino que procura por respostas educativas inclusivas e não exclusivas que repliquem às necessidades apresentadas por seus discentes, em conjunto, e a cada um deles em especifico, incluindo isso em um método de 
reorganização das suas concepções características. "Proporcionar uma educação de qualidade para todos os alunos, inclusive para os que apresentam algum tipo de deficiência ou transtorno mental como preconiza a Educação Inclusiva não é trabalho fácil”. (Glat, 2011, p. 24).

Esta é a função e o desafio a serem realizados na descrição das direções das políticas educacionais que contornam essa asserção. Após a observação realizada no início deste tópico a respeito dos documentos que provieram dos recentes acordos internacionais, orientadores das políticas educativas para os países membros e signatários, como o Brasil, resta caracterizar que os fundamentos normativos neles pactuados foram reconhecidos pelo ordenamento jurídico brasileiro. Nessa perspectiva, tornam-se orientações das políticas de educação instauradas no Brasil e explanadas nas mais recentes leis, que, gradativamente, estão dando corpo a essa composição histórica aos processos de inclusão social.

Como retratado aqui nesse item do artigo, fica garantido, através dos documentos normativos, um sistema de educação inclusivo em todos os níveis de ensino brasileiro. Consequentemente, torna-se, a cada dia, um desafio maior para as instituições de ensino executarem uma reformulação da educação no Brasil, pois, o Estado brasileiro estabelecendo seu engajamento com a implantação da educação inclusiva expressa essas concepções tornando-a um direito irrefutável.

\section{CONSIDERAÇÕES FINAIS}

No percorrer deste artigo, buscou-se inscrever as análises que foram realizadas acerca das questões que norteiam as relações da Educação Inclusiva com os processos de Inclusão e Exclusão social, em circunstância da educação especial.

Demonstrou-se que o debate sobre o tema tem gradativamente compreendido um maior número de pesquisadores que se dedicam em investigações que objetivam compreender os aspectos relacionados à implantação da proposta de inclusão na educação, e não sem razão, embora ela tenha como motivo fundamental entender a educação de todos, independentemente de circunstâncias raciais, culturais, socioeconômicas ou de desenvolvimento, proporcionan- 
do o acesso ao ensino, a permanência nela e especialmente uma educação de qualidade.

Baseando-se na revisão de literatura realizada, comprovou-se que o sistema formativo que se deposita as relações sociais, ocasionam ainda, uma característica de dificuldade, até então, maior com a implantação do processo de inclusão, expandindo assim, a dimensão de seu atendimento para introduzir os indivíduos com deficiência. Desta forma, para proporcionar a todos um aprendizado social e inclusivo, e realizar as práticas educacionais em concordância com as concepções que conduzem o processo de inclusão.

Como compreendido ao longo do artigo, confere-se de pertinência do fato de que, para entender o processo a que se tem presenciado da exclusão na área da educação inclusiva é necessário a compreensão do problema das desigualdades sociais de maneira generalizada, assim como do entendimento e reflexão acerca das controvérsias existentes em um contexto histórico mais abrangente.

Portanto, entende-se que as concepções que conduzem o processo de inclusão são fundamentadas na procura de uma sociedade mais humana e mais justa para todas as pessoas, representado no atendimento de qualidade para todos os discentes, compreendendo e atendendo as necessidades e diferenças inerentes a cada indivíduo, e, as convicções de igualdade de direitos igualmente em vinculação a uma educação inclusiva e de qualidade. Essas concepções são demonstradas e legalizadas em diversos documentos, como apresentado no referencial teórico desta produção científica.

\section{REFERÊNCIAS}

BRASIL. Ministério da Educação. Projeto Escola Viva: garantindo o acesso e permanência de todos os alunos na escola, necessidades educacionais especiais dos alunos. Brasília: Ministério da Educação, 2005.

BRASIL. Ministério da Educação. Secretaria de Educação Especial. Diretrizes Nacionais para a Educação Especial na Educação Básica. Brasília: MEC, 2001. 
GLAT, R. (Org.). Educação inclusiva: cultura e cotidiano escolar. Rio de Janeiro: 7 Letras, 2011.

GARCIA, R. M. C. Políticas públicas de inclusão: uma análise no campo da educação especial brasileira. 215 f. Tese (Doutorado) - Centro de Ciências da Educação, Universidade Federal de Santa Catarina, Florianópolis, 2014.

KASSAR, M. M.; ARRUDA, E. E.; BENATTI, M. M. S.; Políticas de inclusão: o verso e o reverso de discursos e práticas. In: JESUS, D. M. et al. (Org.). Inclusão, práticas pedagógicas e trajetórias de pesquisa. Porto Alegre: Mediação, 2007. p. 21-31.

LIBÂNEO, José Carlos; OLIVEIRA, João Ferreira de; TOSCHI, Mirza Seabra. I Educação Escolar: políticas, estrutura e organização. 10ํe․ São Paulo: Cortez, 2012.

LUCIDIO, Bianchetti; CORREIA, José Alberto. In/exclusão No Trabalho e Na Educação - Aspectos Mitológicos, Históricos e Conceituais. 1ำ ed. São Paulo: Papirus, 2011.

MARTINS, J. S. Exclusão social e a nova desigualdade. $6^{\circ}$ ed. São Paulo: Paulus, 2015.

MITTLER, P. Educação inclusiva: contextos sociais. Porto Alegre: Artmed, 2003.

OliVEIRA, D. A.; DUARTE, A. Política educacional como política social: uma nova regulação da pobreza. Perspectiva, Florianópolis, v. 23, n. 2, p. 279-301, jul./dez. 2015.

ORGANIZAÇÃO DAS NAÇÕES UNIDAS. Convenção sobre os direitos das pessoas com deficiência. 1994.

ORGANIZAÇÃO DAS NAÇÕES UNIDAS. Convenção sobre os Direitos das Pessoas com Deficiência. New York: ONU, 1990. 


\section{A MASCULINIZAÇÃO DO FRACASSO: UM OLHAR SOBRE A QUESTÃO DE GÊNERO NA EDUCAÇÃO}

Viviane Chaves Tibães

Fabio da Costa Tibães

\section{INTRODUÇÃO}

No Brasil, milhões de estudantes da educação básica estão em situação de distorção idade-série. Ou seja: têm no mínimo dois de atraso escolar. São principalmente adolescentes matriculados no segundo segmento do Ensino Fundamental ou no Ensino Médio que, em algum momento, foram reprovados ou evadiram e retornaram à escola em uma série não correspondente à sua idade. Esse tipo de fenômeno também atinge as séries iniciais no Fundamental, porém em menor proporção.

A distorção idade-série deixa os alunos atados ao ciclo do fracasso escolar (AGUILAR JUNIOR, 2019; ORTIGÃO; AGUIAR, 2013; PATTO, 2003). Esse fenômeno pode estar relacionado com várias questões: a vulnerabilidade das camadas da população, as possibilidades de abandono da escola para ingressar no mercado de trabalho de modo prematuro, sem concluir os estudos, questões de gravidez precoce ou casamento, além da obrigatoriedade de alistamento militar pelas pessoas do sexo masculino, etc. Mas, principalmente, podem ser resultado 
das políticas de gestão de sistemas e de avaliação implementadas das redes públicas de ensino.

Tendo como objetos de pesquisa os processos de avaliação, mais precisamente, a gestão do sistema e os processos de avaliação nas unidades escolares da Rede Municipal do Rio de Janeiro, pretendemos aqui abordar essa temática, considerando as taxas de distorção idade-série do município supracitado, as políticas gestoras, os processos avaliativos e a formação das turmas de projetos de correção de fluxo.

Traremos ainda, como aporte teórico, algumas discussões que se fazem necessárias e que, de certa forma, são recorrentes na literatura educacional. Conceitos como reprovação/repetência e fatores associados, fracasso escolar e correção de fluxo demandam uma discussão.

Este artigo também abordará questões relacionadas às turmas de Correção de Fluxo da rede Municipal do Rio de Janeiro direcionadas para os alunos em situação de distorção matriculados no segundo segmento do Ensino Fundamental, conhecidos atualmente como projetos Cariocas I e II. Esta rede está subdividida em onze Coordenadorias Regionais de Educação. Sendo assim, é importante esclarecer que, para recorte de pesquisa, foram utilizados dados adquiridos apenas na 4를 Coordenadoria de Ensino.

A partir dos levantamentos realizados, foi possível perceber que estas turmas são predominantemente compostas por elementos do sexo masculino (além disso, pardos e negros - marcas que se apresentam). Portanto, a pesquisa busca analisar as ações das políticas de avaliação da rede de forma a tentar compreender o que pode resultar nesse "gargalo". Considerar-se-á algumas hipóteses como a falta de interesse desse público, as medidas avaliativas e as próprias políticas de gestão.

Em seguida, serão abordados os aspectos especificamente inerentes do Município do Rio de Janeiro, como as políticas de avaliação, os resultados dessas políticas, as ações de gerenciamento do sistema municipal de educação que dão origem a composição das turmas de correção de fluxo e que ratificam a presença de marcas (raça e gênero). Serão inseridos tabelas e dados estatísticos como aporte de argumentação e para embasamento teórico serão utilizados como argumentos os estudos sobre Ciclo de Políticas de Stephen Ball. 


\section{DESENVOLVIMENTO}

\section{Distorção idade-série:}

O Censo Escolar promovido pelo Ministério da Educação, assim como os relatórios de dados gerados a partir da análise dos processos de avaliações externas originam os Indicadores Educacionais que, segundo a perspectiva adotada pelo órgão permitem que se agregue valor de análise e de pesquisa sobre o desempenho dos alunos. Esses indicadores são utilizados para o monitoramento dos sistemas educacionais, considerando o acesso, a permanência e a aprendizagem dos alunos. Em outras palavras, são instrumentos de avaliação diretamente ligadas com a criação e o acompanhamento de políticas públicas voltadas para a "melhoria" e para a "qualidade" da educação e monitoramento das ações oferecidas pelas instituições escolares e monitoradas pelo próprio ministério.

Dentre os vários indicadores originados nesse processo, o de Taxa de Distorção Idade-Série demonstra o percentual de alunos que tem dois ou mais anos de idade acima do recomendado em determinada série (considerando que a idade estabelecida para ingresso no ensino fundamental é de seis anos). A tabela abaixo foi publicada no ano de 2018 e teve como base de dados o Censo Escolar do ano de 2017. Ela refere-se ao fragmento do Município do Rio de Janeiro, devido ao recorte dado à pesquisa que será direcionada para está região.

Tabela 1: Taxa de distorção idade-série por segmento e ano escolar Rede Municipal do Rio de Janeiro

\begin{tabular}{|c|c|}
\hline Segmento e ano escolar & Em \% \\
\hline AnosIniciais & 14,4 \\
\hline $1^{\circ}$ ano & 0,6 \\
\hline $2^{\underline{o}}$ ano & 2,9 \\
\hline $3^{\circ}$ ano & 18,7 \\
\hline $4^{\circ}$ ano & 22,7 \\
\hline AnosFinais & 29,2 \\
\hline $5^{\circ}$ ano & 24,9 \\
\hline $6^{\circ}$ ano & 30,9 \\
\hline $7^{\circ}$ ano & 31,3 \\
\hline $8^{\circ}$ ano & 29,8 \\
\hline 9 $^{\circ}$ ano & 24,5 \\
\hline
\end{tabular}

Fonte: Instituto Nacional de Estudos e Pesquisas (INEP) 
Como se pode perceber, esses dados se referem a todo o município, sendo os maiores índices de distorção encontrados a partir do $3^{\circ}$ ano do ciclo e se mantendo bastante expressivos nos anos referentes ao segundo segmento do Ensino Fundamental, o que não é diferente na $4^{\underline{a}}$ Coordenadoria de Educação. Tal situação apresenta enorme relevância e merece destaque, posto que, segundo Ortigão e Aguiar (2013, p. 369), a organização da escolaridade em ciclos é uma política que tem sido apontada como uma das responsáveis pelo deslocamento de maiores percentuais de repetência para os anos mais avançados do Ensino Fundamental.

Ainda considerando a organização em ciclos, os mesmos autores recorrem à pesquisa de doutoramento de Claudia Fernandes (2003), onde a autora fez uso dos dados do SAEB 2001 com o intuito de compreender algumas relações a serem estabelecidas entre escolas cicladas e o contexto mais geral no qual as políticas foram implantadas. Para ela,

[...] os ciclos foram implementados em contextos sociais particularmente difíceis, marcados pela violência. Esse fato concorre para uma maior rotatividade de docentes nas escolas, fazendo com que as escolas organizadas em ciclos não possuam condições escolares ideais e coerentes com os pressupostos de uma concepção pedagógica de ciclos, por exemplo, a estabilidade do corpo docente das escolas. (FERNANDES, 2003, p. 198. Apud ORTIGÃO; AGUIAR, 2013)

Considerando a pesquisa de Fernandes, é possível associarmos a mesma à realidade da Rede Municipal do Rio de Janeiro. Segundo dados oficiais do Censo de 2010, coletados pelo Instituto Brasileiro de Geografia e Estatística (IBGE), existem 763 favelas na cidade. Cerca de $22 \%$ da população da cidade do Rio de Janeiro mora em favelas, locais marcados por questões sociais muito difíceis e pela recorrente violência. Especificamente a 4를 $\mathrm{CRE}$, atende várias dessas comunidades, sendo considerada uma das coordenadorias que mais atende a tal público, partindo desde complexos como o da Maré, Manguinhos e Alemão, passando pelo complexo da Penha, Parada de Lucas e Vigário Geral, até comunidades menores como as do bairro de Jardim América. Além 
da possível rotatividade de docentes atuantes nessas áreas devido à periculosidade, as unidades escolares são obrigadas a lidar com fatores externos como o tráfico de drogas e tiroteios constantes, fatores esses que refletem diretamente no desenvolvimento acadêmico dos estudantes.

Traremos ainda, a título de percurso teórico, algumas discussões que se fazem necessárias e que são fortemente presentes na literatura educacional. Conceitos como reprovação/repetência e fatores associados, fracasso escolar e correção de fluxo demandam uma presença, ainda que introdutória.

\section{Reprovação/Repetência, Fracasso Escolar e Correção de Fluxo:}

Começamos pelo conceito de reprovação que, a partir da leitura de Coimbra (2008), entende-se como o resultado de um processo avaliativo em que o estudante não se habilitou para sequência de seus estudos escolares na série/no ciclo posterior àquele em que o estudante está. Ainda segundo o autor, a reprovação carrega também um sentido excludente e demarcador de fracasso por parte do estudante: o de que o(a) estudante reprovado(a) não se enquadrou nas regras da escola, não conseguiu se adequar ao processo avaliativo e se inserir na lógica avaliativa da escola. Rocha (2016) e Coimbra (2008) reforçam em suas análises a pecha negativa que o termo "reprovado" apresenta, vinculando-se à incapacidade de o estudante se habilitar à série seguinte.

Aguilar Júnior (2019), em sua tese de doutoramento, faz um levantamento sobre tais conceitos, afirmando que a literatura educacional faz referência à repetência - repetir a mesma série/ciclo de estudos no trajeto escolar - como fenômeno decorrente do retorno à mesma série devido à ruptura do fluxo escolar, ocasionada por questões e situações referentes à evasão/abandono/desistência e a outros fatores que impedem a permanência do educando na escola (condições sociais e econômicas desfavoráveis, entrada prematura no mercado de trabalho, violência doméstica, bulling escolar, gravidez na adolescência, marginalidade e criminalidade juvenil, adoecimento na família ou do próprio estudante, dentre outros). 
Apoiando-se em Gil (2015), o autor anteriormente citado, apresenta a distinção que se pode estabelecer entre estes dois conceitos:

A reprovação corresponde ao resultado nos exames ou nas avaliações finais que indica que o aluno não teve o desempenho mínimo estabelecido como desejável. A retenção é decorrência dessa reprovação, visto que determina, assumido o modelo de escola seriada, a impossibilidade de o aluno seguir no fluxo normal de uma série a outra. Já a repetência aponta para o fenômeno da permanência na escola dos alunos retidos em determinada série, que vão se submeter a cursá-la novamente (p. 3 Apud Aguliar Júnior, 2019).

Sendo assim, compreendemos que a reprovação escolar estaria ligada ao desempenho escolar do aluno. Por outro lado, a repetência escolar está conectada com a idéia do aluno que cursa novamente a mesma série em que parou seus estudos, em decorrência das inúmeras situações que o impedem ou prejudicam a sua permanência na escola, estando dentre as situações a reprovação.

Nesse sentido, Ribeiro (1991) diz que "parece que a prática da repetência está contida na pedagogia do sistema como um todo. É como se fizesse parte integral da pedagogia aceita por todos os agentes do processo de forma natural" (p. 18). A afirmação do autor me soa bastante atual, pois, apesar dos índices de reprovação terem apresentado uma diminuição em relação aos apresentados nas décadas de 1980 e 1990, a cultura da reprovação constantes nas políticas de avaliação ainda se faz muito presente e está intimamente ligada ao discurso de qualidade. Entretanto, como afirma Aguilar Júnior (2019) qualidade pode ser entendida sob diversos vieses, de acordo com as negociações resultantes da disputa entre grupos políticos e as traduções e interpretações das políticas que os agentes políticos realizam. Desse modo, não é fácil estabelecer aquilo que se entende por qualidade da educação (p. 29).

O conceito de fracasso da escola em cumprir seu papel social e educativo traz maior tensão em sua demarcação, considerando o fato de ser decorrência de fatores tanto internos quanto externos à escola. Entretanto, algo que é claro e visível quanto ao fracasso escolar são 
os altos índices de reprovações. De acordo com Patto (1996), algumas concepções sobre fracasso escolar se confundem com a história da formação do Estado e da sociedade brasileira, tais como fracasso escolar centrado em questões relativas ao método de ensino-aprendizagem e processos de cognição da criança; fracasso escolar associado a questões de origem social e econômica; fracasso escolar relacionado com etnia e raça.

Ainda de acordo com Patto (1996) e a partir de contribuições escolanovistas, a autora identifica que o fracasso escolar se dá por: a) fatores intraescolares, que localiza a fonte das dificuldades de aprendizagem nos métodos de ensino empregados; b) fracasso escolar associado a distúrbios do desenvolvimento psicológico e c) fracasso escolar associado a condições de saúde. Podemos mencionar também, a falta de credibilidade em gozar de melhores condições de vida baseada nos estudos, uma vez que os profissionais da educação são desvalorizados como pessoas e como profissionais em nosso país, os espaços físicos das escolas públicas são carentes quanto à manutenção e quanto às matérias-primas para que se possa dar uma aula no nível adequado ao desenvolvimento do público alvo, além do fato da educação assumir uma perspectiva de resultados a longo prazo, sendo as necessidades pessoais imediatas.

Diante do apresentado, conclui-se ser uma função hercúlea convencer um adolescente, em sua maioria, morador da comunidade e que muitas das vezes é recrutado pelo trafico local, onde lhe pagam em média 1(um) salário mínimo semanal, que ele deve investir em sua educação, com a qual obterá resultados a longo prazo.

Ortigão e Aguiar (2013) apresentam os resultados de um estudo exploratório sobre a repetência escolar de alunos dos anos iniciais do ensino fundamental. Usando os dados dos estudantes do $5^{\circ}$ ano avaliados na Prova Brasil 2009, em Matemática, eles programaram um modelo de regressão logística (modelo de risco à reprovação) para investigar quais características dos alunos e de suas famílias estão associadas à repetência.

Em suas considerações finais, os autores afirmam que a repetência está associada a alguns fatores como, por exemplo, gênero. Meninos estão mais propensos a repetência, principalmente em 
Matemática. Meninos têm cerca de 54,4\% mais chances de repetência do que as meninas e que meninas apresentam melhor desempenho em Leitura ou Língua Portuguesa. Esses fatores podem estar relacionados com aspectos da cultura escolar que implicam comportamentos como o de conter-se sentado para assistir às aulas e realizar tarefas de casa. Estudos de Baudelot e Establet (1991. Apud Ortigão e Aguiar, 2013) indicam que as meninas têm uma socialização primária e familiar que favorecem um comportamento mais ordeiro e obediente. Por isso, elas são mais organizadas e disciplinadas e tal comportamento facilita o "ser aluno".

A cor declarada do aluno é outro fator que impacta a reprovação escolar. Estudantes autodeclarados pretos estão mais sujeitos à reprovação do que os brancos e pardos. Ortigão e Aguiar (2013) afirmam que, mesmo dentro da escola e controlado pelo seu nível socioeconômico, o aluno negro tem um pior desempenho de aprendizado. Num contexto onde políticas afirmativas começam a ser debatidas no país, os autores acreditam ser necessária uma investigação cuidadosa e detalhada dos aspectos raciais da prática educacional nas escolas brasileiras. Indagam: Existe alguma forma de discriminação - ainda que sutil e talvez inconsciente - na alocação do aluno negro à sala de aula? Ou por parte do professor em sua atenção individual? Existe algum problema de relevância cultural do currículo ou do material didático que possam torná-los menos interessante ou apropriado para alunos de minorias raciais? Questões muito relevantes e fundamentais para que se compreenda tal fenômeno.

O apoio familiar oferecido aos estudantes também é apontado nos resultados da pesquisa. Alunos cujas famílias auxiliam nas tarefas escolares e que incentivam e acompanham a frequência escolar, são menos propensos a repetência. Ainda quanto à questão familiar são apontados fatores como maior escolaridade dos pais e participação dos responsáveis nas reuniões escolares como influenciadores dos resultados e desempenho dos alunos.

Por fim, o apoio econômico disponibilizado pelas famílias está associado à possibilidade de repetência. Estudantes pertencentes a grupos com maiores recursos econômicos apresentam 40\% menos 
chances de serem reprovados em relação àqueles cujas famílias dispõem de baixos recursos.

O Brasil ainda é um dos países em que mais se reprova. Em leitura atenta de pesquisas de Ortigão e Aguiar (2013), percebe-se que

Embora já seja possível afirmar os avanços conseguidos no acesso à educação básica, principalmente no ensino fundamental, cuja taxa de escolarização bruta das crianças de 6 a 14 anos chega a 97,6\% em 2009 (IBGE. PNAD, 2009), e, consequentemente, na democratização da composição social do público escolar, ainda persistem disparidades entre as condições das escolas frequentadas por alunos de origens sociais diversas, relacionadas a desempenhos escolares diferenciados, reforçando as distinções sociais preexistentes (Brasil. Inep, 2004). Nesse contexto, insere-se o tema da repetência ou reprovação escolar. Apesar de ter caído de 30\% na década de 1990 para os atuais 18,7\%, essa taxa ainda coloca o Brasil na condição de país que mais reprova na educação básica entre os 41 países da América Latina e Caribe, segundo relatório da Organização das Nações Unidas para a Educação, a Ciência e a Cultura (Unesco) sobre a educação mundial publicado em 2010. (p: 367)

Esse processo de reprovação resulta em outro fenômeno não menos importante: a distorção idade - série, que no Brasil, como já apresentado anteriormente, apesar de demonstrar diminuição, ainda é significativo. A distorção idade-série é a consequência mais impactante para o desenvolvimento do estudante no processo educativo, pois retrata a profundidade dos problemas sociais e decorre da reprovação, como sinalizam Crahay e Baye (2013 apud AGUILAR JUNIOR, 2019). Entendo, portanto, que a distorção enfrentada pelos alunos a partir da cultura de reprovação pode ser um dos fatores mais expressivos quanto aos registros de evasão, compreendendo que quanto maior o distanciamento idade - série, maiores são as dificuldades de adaptação dos alunos à estrutura escolar.

Recorrendo a Sampaio (2010, p. 62), não relegando a importância do desperdício de recursos públicos que a reprovação e a distorção 
idade-série proporcionam, a proposição de projetos e turmas de aceleração de estudos deve primar por um processo pedagógico e de ensino e aprendizagem que possibilite experiências diferenciadas, que se distingam daquelas que não foram eficientes em evitar o fracasso escolar e que efetivamente possibilitem aos alunos em contexto de atraso superar essa realidade, aprendendo com qualidade e tendo acesso ao conhecimento escolar, assim como os demais alunos. O processo pedagógico se identifica como as ações planejadas, articuladas e realizadas pelo professor visando à promoção de um ambiente em que a aprendizagem dos estudantes possa ocorrer da maneira mais efetiva possível.

Passemos então para o conceito de correção de fluxo que se faz de extrema importância. A partir da leitura de Ortigão e a Aguiar se pode afirmar que:

A atual fase dos sistemas de avaliação em larga escala, com a introdução de programas de responsabilização, tem aumentado a preocupação com a qualidade das escolas e proporcionado novo fôlego aos debates sobre os fatores a ela associados. Prova disso é a criação do Índice de Desenvolvimento da Educação Básica (Ideb), que conjuga o fluxo escolar, medido por meio das taxas de aprovação, e os resultados dos alunos, pela Prova Brasil. Até a criação do Ideb, esses dois importantes indicadores vinham sendo tratados de forma independente. Com sua instituição, as escolas se vêem diante de um novo desafio: ao mesmo tempo que é necessário garantir que os alunos aprendam, é fundamental assegurar também que avancem em sua escolaridade. (p: 365)

Ou seja, o que percebemos a partir da leitura de Ortigão e Aguiar (2013) é que os projetos acelerativos ou composição de turmas para correção do fluxo escolar tomou outro vulto no cenário educacional brasileiro a partir da introdução de políticas de avaliação em larga escala e da criação do Ideb. Afinal, o fluxo escolar passa a ser indicador fundamental para estabelecimento do índice. Em outras palavras, redes escolares passam a contar com essa possibilidade de estratégia.

A reprovação implica, como já sinalizava Ribeiro (1991), a distorção da idade do educando em relação à série. Em uma situação de dis- 
torção muito elevada, acima de dois anos, a tendência é que o estudante não reconheça a importância da escola na/para sua formação, evadindo-se do ambiente escolar para ingressar de forma precoce no mercado de trabalho, em posições de subemprego, com condições de trabalho e salários precarizados, reproduzindo situações de exclusão social, que se inserem em contextos de total vulnerabilidade e marginalidade social (SILVA, 2009), e também em outras relacionadas ao atendimento de necessidades econômico-familiares (LEON e MENEZES-FILHO, 2002. APUD AGUIAR JUNIOR, 2019. p: 17).

\section{O caso do Município do Rio de Janeiro: Ciclo de políticas e Correção de Fluxo.}

No ano de 2019, a partir do acompanhamento da composição das turmas dos Projetos Cariocas I e II da 4aㅡ Coordenadoria Regional de Ensino (Turmas de correção de fluxo), pude perceber que o fenômeno da masculinização da distorção série X idade é real e claramente comprovado como pode ser visualizado na Tabela 2.

\begin{tabular}{|ccc|}
\hline Gênero & Alunos matriculados & Percentual \\
\hline Feminino & 1131 & $40,80 \%$ \\
\hline Masculino & 1693 & $59,20 \%$ \\
\hline Total & 2770 & \\
\hline
\end{tabular}

Fonte: Equipe de Acompanhamento 4a Coordenadoria Regional de Educação

Quase 60\% dos alunos matriculados nas turmas de correção de fluxo, especificamente do segundo segmento, são do gênero masculino. Visualiza-se uma diferença de 508 alunos do gênero masculino a mais do que do gênero feminino. Esses meninos apresentam idades a partir dos 12 anos, obedecendo a seguinte orientação para enturmação: Indicados para Carioca I - Aprovados de 5ำ ano, com defasagem e completando ano civil até 31/12/2007; Reprovados de 6⿳a ano, com defasagem e completando ano civil até 31/12/2007. Indicados para Carioca II - Aprovados de $7^{\circ}$ ano, com defasagem e completando ano civil até 31/12/2006; Reprovados de $8^{\circ}$ ano, com defasagem e completando ano civil até 31/12/2006. 
Segundo Marcondes (2013), a permanente busca pela qualidade no ensino público fundamental tem levado estados e municípios brasileiros a utilizar os chamados sistemas apostilados, orientações prescritivas para o trabalho dos professores, adotadas com o objetivo de direcionar a atividade docente, em busca de uma melhoria dos resultados dos alunos em testes padronizados. Ou seja, uma série de ações que são componentes de uma política que visa a "qualidade" da educação e que giram entorno do currículo e da avaliação têm resultado não só na reprovação de muitos alunos, mas também na masculinização desse fracasso.

No entanto, após os estudos realizados sobre políticas públicas e currículo, não é possível conceber políticas educacionais que sejam formuladas por especialistas e implementadas nas escolas. Assim, como afirma Ball (apud MAINARDES; MARCONDES, 2009), "Quero rejeitar completamente a idéia de que as políticas sejam implementadas, pois isso sugere um processo linear pelo qual elas se movimentam em direção à prática de maneira direta (...). O processo de traduzir políticas em práticas é extremamente complexo”.

Com o objetivo alcançar a tão sonhada "qualidade" da educação na educação municipal, considerando uma perspectiva de gestão gerencial, a Secretaria investe em um Plano Estratégico (2009 -2012) no qual metas e premiações têm o intuito de desenvolver alta performatividade dos servidores. Um projeto de meritocracia baseado no desempenho dos alunos em avaliações externas como o Ide-Rio e o Provinha Brasil. Segundo Ball (2001), o Estado assume um papel regulador: embora a formulação das normas e leis continue centralizada, a gestão das políticas aparece descentralizada e o princípio da avaliação, como um aspecto fundamental para que o Estado exerça o controle dos resultados dessas mesmas políticas.

No caso do município do Rio de Janeiro, percebemos que esse processo tem início no ano de 2009, com a publicação da Resolução no 1.014, de 17 de março de 2009. Ela apresenta um sistema de avaliação da aprendizagem para as escolas da rede, instituindo a conversão de notas em conceitos, a reprovação dos alunos que não atingiram a média necessária e a aplicação de provas bimestrais, elaboradas no órgão central e distribuídas nas escolas para aplica- 
ção dos professores junto aos seus alunos. Desde então a avaliação escolar passou a exercer um papel principal, onde o mecanismo de responsabilização é legitimado.

Apesar da característica de continuidade do ciclo de políticas, o contexto de influência é concebido como onde "normalmente as políticas públicas são iniciadas e os discursos políticos são construídos" (MAINARDES, 2006). No caso especifico do município do Rio de Janeiro, há a participação de professores atuantes em sala de aula nesta etapa. Segundo a própria secretaria, isso acontece para influenciar a definição das finalidades sociais e as particularidades das escolas (o que talvez não seja uma garantia). É também onde os conceitos adquirem legitimidade e formam um discurso de base para a política. Ou seja, é aqui que se preenche o conceito "vazio" de qualidade (como diria Laclau) e se elabora a política educacional que se discorreu até o momento.

O contexto da produção de texto está interligado com o de influência, pois os textos políticos são vistos como a representação da política. Mas podem ser lidos de diferentes formas, de acordo com as demandas da prática. Como textos políticos pode-se considerar as Orientações curriculares e os Cadernos pedagógicos, formulados pela $\mathrm{SME} / \mathrm{RJ}$ com a intenção de criar um currículo para esta disciplina e direcionar o trabalho do professor.

Segundo Bowe; Ball e Gold (1992), é no contexto da prática que acontecem as experiências com os textos políticos. É nele que "a política está sujeita à interpretação e à recriação e onde a política produz efeitos e consequências que podem representar mudanças e transformações significativas na política original" (apud Spindola; Moraes, 2017). É por isso que se afirma que as políticas não podem ser simplesmente implementadas. Ao contrário, os sujeitos têm um papel ativo no processo reinterpretação das políticas educacionais. "O que quero dizer com isso é que as questões políticas não são meras questões técnicas a serem resolvidas por especialistas. As questões propriamente políticas sempre implicam decisões que requerem de nós que façamos uma escolha entre alternativas em conflito”. (Mouffe, 2011. Apud Borges; Lopes, 2019) 


\section{Considerações Finais}

Segundo Ball (apud MAINARDES; MARCONDES, 2009), o processo de traduzir políticas em práticas é extremamente complexo, é uma alternação entre modalidades. Assim, na modalidade textual, na qual os Cadernos pedagógicos são elaborados, o objetivo do material é ser um instrumento de apoio pedagógico para o professor, que pode utilizá-lo de acordo com o seu planejamento. No entanto, referindo-nos à prática, acontece uma modificação. O professor pode utilizar integralmente ou parcialmente, ou pode ainda não utilizar, como uma manifestação de "insubordinação" 20 .

Quando se fala em tradução, é impossível não relacionar com os estudos pós-coloniais de ressignificação de Homi Bhabha. Ou seja, toda tradução é uma traição. (grifos próprios)

A priori, nos pareceu contraditório utilizar Russel como aporte teórico. No entanto, em seu texto "A reconciliação da individualidade e da cidadania", o autor afirma que a rotina administrativa e os cargos gerenciais que preconizam autoridade são mais bem executados e/ou ocupados pelos piores professores. Ou seja, o que Russel quis dizer com isso é que, em sua maioria, profissionais da educação que apresentam um perfil mais administrativo se adequam melhor à questão da uniformidade, à busca de resultados, a elaboração de políticas que deverão ser traduzidas para a prática. Esses professores denotam um amor pela classificação e pela estatística, reverberando as concepções neoliberais para a educação.

A “implementação" dessas políticas não necessariamente atende às demandas das unidades escolares, professores e alunos. Segundo Lopes (2014, apud Borges; Lopes), demandas são também da ordem do desejo, objetos que não conhecemos e ainda assim almejamos ou que sequer sabemos definir que desejamos. Demandas por estar em um grupo, pelo sentimento de pertencer a uma causa - mudar o mundo, formar cidadãos críticos, garantir a qualidade na educação, por exemplo. Ou seja, são demandas diferenciadas dos objetivos das

20 Insubordinação sendo entendida como tomada de responsabilidade na tradução das políticas por parte dos docentes. (Ortigão e Frangella, 2015) 
políticas e que podem representar um impedimento à transformação a qual ela se propõe.

As demandas dos alunos, principalmente meninos, que são maioria nas turmas de correção de fluxo da rede municipal, também têm de ser consideradas. Sejam demandas sociais e econômicas, como a necessidade de entrar mais precocemente no mercado de trabalho, seja a necessidade do serviço militar obrigatório, ou ainda a questão de serem público alvo dos cargos de execução nas comunidades dominadas pelo tráfico (situação muito comum nas comunidades pertencentes à região da 4- Coordenadoria).

Segundo Carvalho (2009) é possível afirmar que para compreender as trajetórias dos alunos do sexo masculino era preciso levar em conta a variabilidade dos próprios critérios de avaliação das professoras. Em sua pesquisa há indícios de meninos que precisam de reforço escolar, pois fracassaram na tarefa de construção de um padrão de masculinidade percebido pelas professoras como compatível com o sucesso escolar.

Ainda que a escola projete educação, ainda que esteja tentando estruturar sujeitos, vidas, tempo e espaço e que não consiga nada com isso, o fato é que a escola ainda é um lugar de encontros. O lugar onde, ainda que volátil, o conceito de cultura pode assumir-se como ampliação dos processos de identificação (de manifestações identitárias). Lugar onde seja possível lidar com as diferenças e não meramente submeter-se ao apagamento das mesmas em função de uma política educacional.

\section{Referências Bibliográficas}

AGUILAR JÚNIOR, C. A. Reprovação e política de avaliação na escola: um estudo na rede pública de Niterói. Tese (291f. Doutorado em Educação - Universidade do Estado do Rio de Janeiro, 2019. Disponível em: http://www.bdtd.uerj.br/tde_busca/arquivo.php?codArquivo=15621. Acessado em 01/072020.

BALL, S. J., MAINARDES, J. (Org). Políticas Educacionais: Questões e Dilemas. São Paulo: Editora Cortez, 2018. 
BORGES, V. LOPES, A. C.. O político e a política: implicações para a formação docente. In: Currículo, política e cultura: Conversas entre Brasil e Portugal. Curitiba: CRV, 2019.

COIMBRA, S. R. S. Reprovação e Interrupção Escolar: Contribuições para o debate a partir da Análise do Projeto Classes de Aceleração. 2008. 228f. Tese (Doutorado em Educação) - Universidade Federal de Santa Catarina, 2008. Disponível em: https://repositorio.ufsc.br/bitstream/handle $/ 123456789 / 91150 / 254511$. pdf? sequence $=1$ \&isAllowed $=y$. Acessado em 01/06/2020.

D’AMBROSIO, B.S; LOPES, C. E. Vertentes da subversão na produção científica em educação matemática. Campinas, SP : Mercado de Letras, 2015. - (Coleção Insubordinação Criativa)

FERNANDES, C. O.Uma breve análise das políticas de avaliação e sua relação com a organização escolar por ciclos: resultados de pesquisa. Educ. rev. n.spe1, Curitiba: 2015.

FRANGELLA, R. MENDES, J. O que é bom resultado? Indagando o sentido da avaliação e suas articulações curriculares. Ensaio: Pol. Aval. Públ. Educ. Rio de Janeiro, v: 26, n: 99, p. 296-315, abr/ jun, 2018.

MAINARDES, J. Abordagem do Ciclo de Políticas: Uma contribuição para a análise de políticas educacionais. In: Educação e Sociedade, Campinas, v. 27, n. 94, p. 47-69, jan/abr, 2006.

MAINARDES, J; MARCONDES, M. I. Entrevista com Stephen J. Ball: um diálogo sobre justiça social, pesquisa e política educacional. Educação \& Sociedade, Campinas, v. 30, n. 106, p. 303-318, jan./abr. 2009.

ORTIGÃO. M. I. R.; AGUIAR, G.S. Repetência escolar nos anos iniciais do ensino fundamental: evidências a partir dos dados da Prova Brasil 2009. Rev. Bras. Estud. Pedagog. ( online ), Brasília, v. 94, n. 237, p. 364-389, maio/ago. 2013. 
; FRANGELLA, R. C. P. Assumindo o risco da decisão currículo e avaliação sob o signo da insubordinação. In: D'AMBROSIO, B.S; LOPES, C. E. Vertentes da subversão na produção científica em educação matemática. Campinas, SP : Mercado de Letras, 2015. - (Coleção Insubordinação Criativa)

PATTO, M. H. S. A Produção do fracasso escolar: histórias de submissão e rebeldia. São Paulo: T.A. Queiroz, 1996.

RUSSEL, B. Educação e ordem social. São Paulo: Editora Unesp, 2018.

SAMPAIO, M. M. F. Aceleração de estudos: uma intervenção pedagógica. Em aberto, v. 17, n. 71, P. 57-73, Brasília, 2000. Disponível em: http://www.rbep.inep.gov.br/index.php/emaberto/ article/view/2103/2072. Acessado em 29/06/2020. 


\section{CONTRIBUIÇÕES PARA A CONSTRUÇẤO DA ORALIDADE A PARTIR DE UMA EXPERIÊNCIA LEITORA COM CRIANÇAS PEQUENAS}

Mariana Lopez Exposito

\section{INTRODUÇÃO}

O trabalho que apresentaremos aqui vem sendo construído, pensado e executado desde o segundo semestre de 2018, mas não significa que esteja pronto, entretanto, busca mostrar em sua essência, como ações intencionais e sistemáticas, desde os primeiros anos de vida, em torno da Língua, são fundamentais para a construção do ser humano em todos os seus aspectos.

Apoiando-nos concepção de educação posta no documento: Plano Nacional para Educação em Direitos Humanos, que diz:

... a educação é compreendida como um direito em si mesmo e um meio indispensável para o acesso a outros direitos. A educação ganha, portanto, mais importância quando direcionada ao pleno desenvolvimento humano e às suas potencialidades, valorizando o respeito aos grupos socialmente excluídos. Essa concepção de educação busca efetivar a cidadania plena para a construção de conhecimentos, o desenvolvimento de valores, atitudes e comportamentos, além da defesa socioambiental e da justiça social. (2007, p. 12). 
E em outros documentos oficiais como a BNCC - Base Nacional Comum Curricular - que define aprendizagens fundamentais durante toda a trajetória escolar do aluno, desde a Educação Infantil ao Ensino Médio, documento que guia e orienta a elaboração e atualização dos currículos escolares, de caráter normativo que estabelece objetivos de aprendizagens definidos por meio de competências e habilidades essenciais.

Considera, para a Educação Infantil, a especificidade deste segmento, propondo dois eixos estruturantes para as práticas pedagógicas: Interações e Brincadeiras. Define direitos de aprendizagens e desenvolvimento que devem ser garantidos e, estabelece cinco campos de experiência como base para as organizações curriculares.

O arranjo curricular para a primeira etapa da Educação foi pensado a partir do fazer e agir das crianças, centrado na perspectiva da criança, mas não apenas nela, tampouco no professor, mas nas relações que ocorrem entre as crianças, o professor, os familiares, a comunidade, os saberes, as linguagens, o conhecimento, o mundo.

Assim, o que se considera é o sentido do campo - Campos de Experiência - como horizontes, janelas, área extensa que se abre a possibilidades.

Os Campos de experiência são então os eixos do currículo para a Educação Infantil, a saber, cinco: o eu, o outro e o nós; corpo gestos e movimentos; traços, sons cores e formas; escuta, fala, pensamento e imaginação; espaços, tempos, quantidades, relações e transformações.

Esses Campos guardam uma relação estreita com as áreas de conhecimento do Ensino Fundamental e Ensino Médio.

Considerando assim a criança como ser integral, que se relaciona com o mundo a partir do seu corpo em experiências concretas com diferentes parceiros e em distintas linguagens.

Apoiamo-nos também no Currículo da Cidade, que materializa os princípios e diretrizes da Educação Infantil paulistana, baseia suas práticas em políticas de equidade e educação inclusiva, com propósito de orientar o trabalho nas unidades educacionais.

Anteriormente a estes documentos, temos as DCN, formulada pelo CNE, portanto, também de caráter mandatório, orientando a formulação de políticas para a educação. 
Pautada em princípios éticos, estéticos e políticos. Define a função das instituições de Educação infantil: sociopolítica e pedagógica. A visão de currículo e marca a visão de criança como sujeito histórico e de direitos, centro do processo de educação.

Já introduz aí a necessidade de organizar a proposta curricular em experiências de aprendizagens:

“... sustentado nas relações, interações e práticas educativas intencionalmente voltadas para as experiências concretas da vida cotidiana, para a aprendizagem da cultura, pelo convívio no espaço da vida coletiva e para a produção de narrativas, individuais e coletivas, através de diferentes linguagens" (DCNEB, 2013, p.93).

Assim, para nós esses aportes, favoreceram a construção deste trabalho. Que pautou-se na interlocução, entre os campos o eu, o outro e o nós e escuta, fala, pensamento e imaginação e na garantia dos seis direitos de aprendizagens: conviver, brincar, explorar, participar, expressar e conhecer-se.

Bem como a base em uma educação pautada em direitos humanos, que segundo o documento Plano Nacional em Direitos Humanos:

Deve abarcar questões concernentes aos campos da educação formal, à escola, aos procedimentos pedagógicos, às agendas e instrumentos que possibilitem uma ação pedagógica conscientizadora e libertadora, voltada para o respeito e valorização da diversidade, aos conceitos de sustentabilidade e de formação da cidadania ativa (2007, P.31)

\section{SUSTENTO A VOZ}

É incontestável o poder da palavra, desde sempre “... Sem a voz das crianças não há descoberta possível...” (Naranjo, 2018, p.7).

Os povos constroem sua cultura pela palavra e é através da oralidade que o sujeito se torna capaz e potente para construir sua identidade. A forma mais antiga de se conhecer histórias é pela oralidade. 
A humanidade, desde os mais remotos tempos, narrava, fatos e acontecimentos, numa ânsia de saber e domínio sobre a vida. Narrava o que não compreendia, para compreender a vida, para guardar na memória, para nos humanizar porque as histórias falam de nós.

Walter Benjamin (1993, p. 204) conforme citado por Jorge (2003, p.95) nos diz que contar histórias sempre foi a arte de contá-las de novo.

Quanto mais o ouvinte se esquece de si mesmo, mais profundamente se grava nele o que é ouvido (...) ele escuta as histórias de tal maneira que adquire espontaneamente o dom de narrá-las. Assim se teceu a rede em que está guardado o dom narrativo. (Benjamin 1993, p. 204)

Ainda assinala que a arte de narrar está em vias de extinção, enfatizando a raridade que é encontrar pessoas que sabem narrar. O que vemos claramente, ainda segundo o autor, quando pedimos num grupo que alguém narre alguma coisa, no embaraço que se instala. $\mathrm{O}$ autor ainda compara com a privação de uma "faculdade que parecia segura e inalienável: a faculdade de intercambiar experiências.”.

Larossa contribui com a reflexão, em seu artigo: Notas sobre a experiência e o saber da experiência, 2002, e a construção do conceito de experiência como algo que nos acontece, e o saber que dela deriva, tem a relação com a elaboração do sentido do que nos acontece. Parece um pouco confuso a primeira vista, mas o saber da experiência é um saber único, singular, subjetivo, particular.

$\mathrm{O}$ acontecimento, o que acontece, acontece de uma maneira geral, comum, mais de uma pessoa pode enfrentar o mesmo acontecimento, mas a experiência será diferente para cada uma.

Talvez a narração e a experiência estejam influenciadas pelas correrias, atribulações, agilidades e ritmos velozes da contemporaneidade.

Mas e a escola? E os professores? As crianças da primeira infầncia?

Também estamos todos sofrendo pelas imposições de Cronos, cuja força implacável, invencível, assolando e devorando todo tempo, efềmero e rapidamente findável? 
Ou podemos transformar em Kairós como um convite a leveza, ações despojadas, fluidez, sentido e medido pelas batidas do coração?

Jorge nos convida a refletirmos sobre a importância da narrativa:

... a fim de reintegrá-la de forma dinâmica e criativa ao cotidiano escolar e educacional. Para tanto, é imprescindível não só reconstruir e organizar práticas que possibilitem o contato com essa experiência, resgatando-a como forma essencial de educação, mas ajustada às condições do mundo contemporâneo que exige o reconhecimento da fala de cada um (2003, p.97).

Assim, sabemos que há inúmeros e valorosos trabalhos e pesquisas que se dedicam aos estudos sobre as linguagens ou sobre a língua e os direitos da primeira infância em usufruir e fruir da literatura, em cada segmento da educação, com olhares únicos e generosos.

Gostaríamos de contribuir com, mas um olhar, singular, sobre uma prática, um fazer pedagógico, curricular, intencional, um trabalho prático que estamos desenvolvendo desde o segundo semestre de 2018 e nossas observações das entregas e potencialidades das crianças.

Os encadeamentos seguintes foram naturais no grupo, eu não diria que foram automáticos ou que sucederam-se sozinhos, mas fluíram a partir dos desejos e demandas das crianças.

"O bebê frequentemente necessita de três coisas fundamentais: leite, carícias e muita linguagem. E é fundamental dar-lhe linguagem. Há dois tipos de linguagem: a da vida cotidiana, a língua das ordens ('Venha cá', 'não mexa nisso', 'faça isso', 'abra a boca', 'coma') e a língua do relato, a língua que não está contida no dia a dia. O bebê necessita das duas línguas para constituir-se como sujeito, porque a língua para obedecer implica uma relação da criança com o adulto, e para esse adulto que está guiando a criança é a via para introduzi-lo à cultura, às limitações e também dar-lhe algo. No entanto, a língua do relato, da história e do conto é para ser escutada, não para obedecer. O bebê se põe em posição de escuta quando lhe contam uma história, quando 
lhe cantam, e é preciso alimentar a competência da escuta.". (Evelio Cabrejo-Parra, Revista Emilia, 2011).

Ler é isso: uma experiência de presença. A leitura conclama a presença.

\section{VOZ OUVIDA}

Antônio Cândido defende a literatura como direito básico do ser humano, pois segundo ele, ela atua no caráter e formação do sujeito; "literatura desenvolve em nós a quota de humanidade na medida em que nos torna mais compreensivos e abertos para a natureza, a sociedade, o semelhante" (Cândido, 1988).

Complementar ao pensamento de Antônio Candido, temos o artigo vigésimo sexto da Declaração Universal dos Direitos Humanos, publicada em 1948, após a segunda guerra mundial:

A educação deve visar à plena expansão da personalidade humana e ao reforço dos direitos do Homem e das liberdades fundamentais e deve favorecer a compreensão, a tolerância e a amizade entre todas as nações e todos os grupos raciais ou religiosos, bem como o desenvolvimento das atividades das $\mathrm{Na}-$ ções Unidas para a manutenção da paz (ONU, 1948).

A leitura é a experiência do afeto. A leitura do adulto para a criança, na primeira infância, é um importante instrumento para a socialização e para a construção de vínculos.

Sabendo que é inegável o impacto da leitura no desenvolvimento do indivíduo. Desde a infância até a vida adulta. Em vários aspectos: desenvolvimento da linguagem oral, aquisição e ampliação de vocabulário, escuta, escrita, compreensão - texto e mundo, para além do código da língua. Pensamos num trabalho com as crianças neste aspecto: a linguagem.

Enfatizamos o pensar sobre os importantes, distintos e complementares papéis que os mediadores de leitura: famílias e escola têm acerca da leitura com as crianças, cabem às famílias: 
- Incentivar a leitura;

- Ser exemplo;

- Criar, construir uma cultura leitora;

- Valorizar a experiência da leitura;

- Visitar espaços de formação de leitores.

A escola é responsável, sim, pela formação de leitores, para tanto é imprescindível que promovam ações como:

- Desenvolver um trabalho intencional com práticas de linguagem: falar, ler, escrever e ouvir;

- Manter um acervo adequado - diverso em autor, títulos e editoras;

- Potencializar as experiências de leitura;

- Promover a conversa entre os leitores.

É sobre este último ponto que gostaríamos de conversar: a promoção de conversa entre os leitores e sua contribuição para a aquisição, domínio e ampliação da oralidade, a partir das experiências com as leituras feitas em casa e compartilhadas na escola, em roda.

Ao compreender que um indivíduo, quando utiliza a língua, constrói sobre o mundo uma (re) apresentação, entende-se que ele age sobre o outro, interagindo, e sobre o mundo, constituindo-se como sujeito do discurso, formando o enlace entre o social e o cognitivo. (Carvalho. 2011, p.43)

Começamos com um grupo de crianças em idades mistas, de 1 ano e seis meses a 4 anos, denominado na escola de Interidades.

Em princípio, nosso foco estava em qualificar as visitas semanais a biblioteca da escola.

Para tanto, o empréstimo de livros para levar para casa foi o texto.

Construímos sacolas para acondicionar e transportar o livro entre escola-casa-escola, que foram estilizadas, personalizadas pelas crianças com suas marcas e registros próprios.

Pensamos que esta ação traduz o cuidado com o objeto livro, afinal, somos nós adultos que estamos apresentando o mundo às crianças, 
e acreditamos que estávamos contribuindo para que as crianças construíssem esta noção, de cuidado, mobilizando nelas este olhar, cuidadoso com o objeto livro.

Após a produção das sacolas, enviamos um bilhete às famílias apresentando a proposta e convidando-as a esta ação, pois, esta proposta de trabalho já havia sido refletida em reunião entre famílias e escola, com o seguinte texto:

\section{Prezadas famílias}

Rotineiramente, às sextas-feiras, as crianças frequentam a Sala de Leitura que fica no prédio do Fundamental 1. Sempre é uma grande alegria ir até lá, ouvir histórias, manusear diferentes títulos, vislumbrar que imensidão de livros que ampliam muito o repertório de uso diário na sala.

A partir de então, acrescentaremos a esse trabalho de leitura com as crianças pequenas o empréstimo de livros. Semanalmente, levarão um livro que deve ser devolvido (ou renovado) no dia da próxima visita à biblioteca que acontece uma semana depois, sempre às sextas-feiras.

Os livros serão transportados numa sacolinha especialmente confeccionada para esse fim. As crianças estão dando mais um passo rumo à autonomia no manuseio dos materiais escolares.

Esta é uma importante oportunidade para leitura em família e em conexão com os fazeres escolares.

Podem nos procurar se houver dúvida sobre este procedimento.

$\mathrm{Na}$ devolutiva dos livros a escola, as crianças mostravam para os amigos em roda, incialmente mostravam apenas e contavam quem havia lido, depois passaram a contar sobre o livro, o assunto da história, do que tinham gostado, achado mais interessante, ou não, no livro.

Numa dinâmica que proporcionava escuta e falas interessadas, genuínas, criando significado para si mesmas. Pois, como bem o disse Morato:

... a linguagem não é apenas transmissão de pensamento, não é apenas código lingüístico, não é apenas comunicação interpessoal, mas é, sobretudo, um processo de produção da signifi- 
cação; nesse sentido, a linguagem é percebida, também, como lugar de ação, caracterizada por uma dinamicidade. (2000, p. 5 apud Carvalho 2011, p.44).

Para o ano seguinte, 2019, elaboramos uma pasta, visando propor os registros acerca das experiências com as leituras para as crianças.

Inicialmente, na escola, após a leitura em voz alta feita pelo professor as crianças produziam um registro sobre aquela experiência.

Fazíamos previamente uma cópia colorida da capa do livro e dispúnhamos os materiais gráficos e alguns artísticos para os registros de suas memórias da leitura

- Uma cor, duas cores, todas elas - Lalau e Laurabeatriz;

- Jardins - Roseanna Murray

- Um jardim de A a Z - Glaucia de Souza;

- Passarinhos do Brasil - Lalau e Laurabeatriz;

- Bem brasileirinhos - Lalau e Laurabeatriz.

Posteriormente, a proposta foi estendida as famílias, assim, junto com o livro escolhido pela criança nas sextas-feiras a pasta de experiência leitora ia junto para casa e, após a leitura em família, as mesmas produziam um registro, que apoiava a fala das crianças quando compartilhavam com o grupo, na sexta feira seguinte suas experiências com a leitura.

$\mathrm{Na}$ volta do livro a escola a necessidade de conversar sobre a leitura feita em casa, veio das próprias crianças.

A própria leitura é um convite às conversas. Quando falamos sobre um livro, falamos sobre como ele nos tocou, nos afetou, qual efeito produziu em nós, quase como se o relêssemos.

Por vezes, as crianças relatavam os meios que usaram para os registros, como: eu fiz com adesivo e canetinha; eu pintei com canetinha; minha mãe escreveu e eu desenhei, fiz dobradura.

Pois o objetivo da leitura não termina quando lemos o livro e o fechamos.

Concordamos com Ana Garralón quando nos diz em seu artigo: A arte de conversar com as crianças sobre suas leituras (2012), 
que o ato socializador daquilo que lemos é tão importante quanto a própria leitura.

Aidan Chambers (2007, p. 19, in Ser docente na educação infantil: entre o ensinar e o aprender), nos diz que o ato de ler consiste em grande medida na conversa sobre aquilo que lemos, cita uma criança de oito anos que diz: "não sabemos o que pensamos sobre um livro até que tenhamos falado dele".

Posso ler para mim mesmo ou para alguém, no caso das famílias, dos professores e mediadores, para alguém - as crianças. Neste sentido a leitura invoca e provoca laços, interações. Ou, como diria Evelio Cabrejo- Parra: é o sentido de buscar um pouco do que somos (A formação dos mediadores, 2015, p.30.)

\footnotetext{
"Não creio que tenha uma imagem mais poderosa que essa: um livro, uma criança e um terceiro que conecta criança e livro, alguém que está no meio, um triângulo amoroso... Um adulto que conta o mundo a criança a partir dos primeiros livros... Pensa-se que as crianças não falam, as crianças falam porque há outro que lhes fala, as crianças leem porque há outro que lhes lê, que lhes decifra". Yolanda Reyes (A Formação dos mediadores, 2015, p. 38).
}

No ato de compartilhar com os amigos, fomos seguido às dicas de Ana Garralón.

Iniciando a conversa, com perguntas sobre o livro ou sobre a impressão da criança sobre o livro, buscando evitar respostas rápidas, mas sim instigar o pensamento e a conversa;

Procurávamos também relacionar o tema do livro com algum assunto que tratamos em sala, ou pessoal, ou ainda outra criança trazia a tona - muitas vezes outras crianças faziam alguma relação com suas experiências;

Buscávamos dar sentido à história dirigindo algumas perguntas;

Ou reformulando perguntas, no sentido de contribuir com o entendimento do texto e o uso das palavras para se expressar melhor, facilitando um maior domínio da língua pelas crianças;

Fazendo conexões pessoais com a história, visando colocar a criança na trama; 
Deixando que a criança encontre sua maneira de se expressar;

Escutando, dando tempo para a criança pensar e responder;

Ouvimos falas cada vez mais complexas e o vocabulário cada vez mais rico. Neste momento, já sistematizado e interiorizado pelas crianças, elas se colocam numa posição de escuta ao amigo, interessadas nas falas, faziam por vezes perguntas aos amigos sobre o livro, e ainda em muitas ocasiões já chegavam à biblioteca com o livro que o amigo mostrou na roda em mente para levar emprestado.

Vimos a criança constituir-se como sujeito, nas interações sociais a partir de um contexto comunicativo, o que implicou aspectos cognitivos, linguísticos, discursivos, sociais, históricos e culturais.

- Olha eu fiz o livro Toc toc, foi muito legal o que eu fiz, eu aprendi a fazer o corpinho deste menino. Eu gosto desta porta.

- Eu levei o livro dos Três porquinhos e fui eu que li!

- O nome do meu livro é Feita de Pano, olha foi minha tataravó que fez esta colcha de retalhos é porque também tem no livro. É muito legal ter colcha de retalhos, esta coberta é muito especial é porque na primavera pode usar, no mês quente.

- O nome do meu livro é Filhotes de bolso indo pra praia, eu gostei que as sereias se fantasiavam.

- Eu levei este livro, achei divertido, ele tem ratos e pássaros, a menina tava na neve e o urso também, eles se encontraram e se conheceram. Se apresentaram, falaram o nome.

- Meu pai desenhou eu pintei.

- Aqui o urso tava dormindo.

Ainda na trilha, citada anteriormente, das dicas de Ana Garralón:

Consideramos que todas as respostas são boas, são diferentes pontos de vista, dar suas próprias opiniões, considerando mais o que a criança pensa sobre o livro;

Direcionamos a conversa se a resposta for rápida ou óbvia demais, a conversa é mais como um passeio do que como a chegada;

Procuramos não sair do assunto, não é possível dimensionar as inúmeras relações possíveis a partir de um assunto, assim, podemos fazer perguntas para trazer de volta a conversa aos temas do livro; 
Uma conversa não tem fim, não precisamos chegar a um ponto final, muitas vezes finalizamos a conversa devido às demandas do grupo, ainda assim as crianças podem retomar na roda seguinte.

"A literatura nasce dentro de cada um de nós e se completa e perpetua quando alguém a escuta ou lê, portanto ela se realiza na relação...” Isso “... só acontece no próprio exercício: não há receita, tem que viver, tem que ouvir o outro, negociar com a cultura do outro por meio das palavras e dos enlaces que se estabelecem no momento." Patrícia Boherer Pereira Leite - I Seminário internacional: Arte, palavra e leitura na 1를 infância. São Paulo. Instituto Emília, 2019.

\section{CONSIDERAÇÕES FINAIS}

Se soubéssemos tudo o que se passa no momento de uma leitura em voz alta quando se está lendo um texto a uma criança, teríamos a maior admiração, o maior respeito por esse momento. (Evelio Cabrejo-Parra. A formação dos mediadores, 2015,p.36).

Penso que o desafio maior deste trabalho se deu no inicio, nos momentos de socialização como: a garantia de uma boa conversa entre as crianças, tão pequenas, mas ao mesmo tempo tão vorazes em apreender o mundo ao seu entorno, de modo que todos pudessem ouvir o que os colegas diziam, aguardar sua vez, reconectar todos e trazê-los de volta ao assunto quando outros assuntos surgiam. Com o tempo, as crianças encontraram sua própria maneira de se expressar e essa dificuldade foi minimizada.

Inicialmente quando perguntávamos sobre o livro, as crianças queriam responder rapidamente e suas respostas eram invariavelmente "sim, porque sim", ao final de três meses observamos frases mais completas e coerentes.

E mais, as crianças puderam estabelecer relações entre o livro e suas experiências de vida. Valorizaram a memória individual e coletiva.

Promovemos mais e diferentes interações entre suas famílias, os amigos, os livros e entre nós todos, incluindo as professoras. 
Vimos, pelos nossos registros que as ações da escola, em visitas a biblioteca, estimular as escolhas das crianças, promover a conversa entre os leitores, contribuiu para desenvolver a fala das crianças. Nossas ações enfocavam:

- O compartilhar as leituras feitas em casa, a fala e a escuta - dos amigos e professor;

- O que e como a criança comunicava suas ideias e impressões do texto lido e a escuta como ações de apropriação e aprendizagem sobre a Língua;

- Observávamos e intervínhamos na produção das falas, de frases completas e seu uso com adequação;

- É um trabalho não se esgota, pois esta ação da escola, intencional, contribuiu e contribui para desenvolver a fala das crianças.

A escola precisa propiciar o acesso de todos à leitura e a experiências com a leitura que configurem práticas sociais reais, nas quais a comunidade de leitores possa indicar livros, comentar suas impressões sobre as obras, selecionar o que gostariam de ler, sugerir autores e livros.

O contato com a palavra é a chave para o conhecimento, supõe a abertura para o mundo dos afetos, da criatividade, é o alimento emocional, fundamental para a construção do ser humano.

Afinal, a criança constrói a sua linguagem nas vozes dos outros.

Enfatizamos que a vida é este intercambio entre o que damos e o que recebemos e o que deixamos e isso, ocorre na e pela linguagem!

\section{REFERÊNCIAS BIBLIOGRÁFICAS}

BONDIA, Jorge Larossa. Notas sobre a experiência e o saber da experiência, Revista Brasileira de Educação. Rev. Bras. Educ. [online]. 2002, n.19.

BRASIL. Ministério da Educação. Secretaria de Educação Básica. Base Nacional Comum Curricular. Brasília, MEC/ SEB, 2017.

BRASIL. Ministério da Educação. Secretaria de Educação Básica. Secretaria de Educação Continuada, Alfabetização, Diversidade 
e Inclusão. Secretaria de Educação Profissional e Tecnológica. Conselho Nacional da Educação. Câmara Nacional de Educação Básica. Diretrizes Curriculares Nacionais Gerais da Educação Básica/Ministério da Educação. Secretaria de Educação Básica. Diretoria de Currículos e Educação Integral. Brasília: MEC, SEB, DICEI, 2013.

BRASIL. Ministério dos Direitos Humanos. Plano Nacional de Educação em Direitos Humanos. 3ำ reimpressão, simplificada. Brasília, 2018. DisponíveI em: https://www.gov.br/mdh/ pt-br/navegue-por-temas/educacao-em-direitos-humanos/DIAGRMAOPNEDH.pdf. Acesso em 09.07.2020.

BRASIL. Ministério da Educação. Secretaria de Educação Básica. Ser docente na educação infantil: entre o ensinar e o aprender / Ministério da Educação, Secretaria de Educação Básica. - 1.ed. - Brasília: MEC/SEB,2016.

CANDIDO, Antonio. Direitos Humanos e literatura. DisponíveI em: <http://www.casadasrosas.org.br/centro-de-apoio-ao-escritor/manual-a-literatura-como-direito-do-ser-humano>. Acesso em 09.05.2020.

DIAS, Marina Célia Moraes e NICOLAU, Marieta Lucia Machado (orgs) Oficinas de sonho e realidade na formação do educador da infância, Campinas. SP. Papirus, 2003.

FERREIRA, Edna. Tempo Cronos e tempo Kairós. Disponível em: <https://administradores.com.br/artigos/tempo-cronos-e-tempo-kairos>. Acesso em 09.05.2020.

FONSECA, Edi. Interações: com olhos de ler, apontamentos sobre a leitura para a prática do professor de educação infantil. São Paulo. Blucher, 2012.

GARRALÓN, Ana. A arte de conversar com as crianças sobre suas leituras. Disponível em: $<$ Revista emilia.com.br $>$ Acesso em 15.12.2018. 
NARANJO, Javier. Casa das estrelas, o universo contado pelas crianças. Tradução: Carla Branco. Ed. Rio de Janeiro: Foz, 2013.

PRADES, Dolores e LEITE, Patricia Pereira B. (orgs) A formação de mediadores. São Paulo, Livros da Matriz. 2015. Conversas ao pé da página.

PRADES Dolores, MEDRANO Sandra; [Coord.] Seminário internacional 2018 / 1. ed. ilustração de Laura Teixeira. São Paulo: Instituto Emília, 2019.

SÃO PAULO. Secretaria Municipal de Educação. Coordenadoria Pedagógica, Currículo da Cidade: Educação Infantil - São Paulo: SME/COPD, 2019.

UNIVERSIDADE ESTADUAL PAULISTA. Pró-Reitoria de Graduação U58c Caderno de formação: didática dos conteúdos formação de professores / Universidade Estadual Paulista. Pró-Reitoria de Graduação; Universidade Virtual do Estado de São Paulo, vol. 3 - São Paulo: Cultura Acadêmica, 2011. 


\section{EDUCAÇÃO INCLUSIVA: PROTAGONISMO JUVENIL EM ESCOLAS DE PERNAMBUCO,BRASIL}

Ana Beatriz Medeiros Ferreira

\section{INTRODUÇÃO}

A Educação Inclusiva no âmbito educacional,ao longo da história está se tornando cada vez mais necessária e discutida. O Programa de Protagonismo Juvenil nas escolas do Estado de Pernambuco Brasil, vem se desenvolvendo de maneira eficaz promovendo uma qualidade de ensino aprendizagem, bem como a elevada auto estima dos estudantes protagonistas.

O objetivo da pesquisa transformado em artigo é: Qual o perfil do protagonismo na educação integral de ensino médio no Estado de Pernambuco? Através do tema: Protagonismo Juvenil,temos uma educação inclusiva, voltada para os "marginalizados", que estão às margens da sociedade.

A busca de uma forma inovadora, onde está acontecendo nas escolas da rede pública no Brasil, a ênfase é dada ao Programa de Protagonismo Juvenil, que junto com outros programas como Projeto de Vida e Empreendedorismo, desenvolve através de uma política pública voltada para a diminuição da desigualdade e da inserção no mundo do trabalho.

Através de entrevistas semiestruturadas com estudantes protagonistas e uma observação participante,com uma análise de conteúdo com o pressuposto de Laurence Bardin, o estudo pode se respaldar e 
encontrar algumas conclusões acerca do trabalho desenvolvido na educação integral.

\section{DESENVOLVIMENTO}

\section{METODOLOGIA}

A metodologia deste artigo consiste em um estudo de campo, onde a autora foi ao locus da pesquisa,neste momento foi escolhido o estudo de caso, e em um projeto realizado, foi determinado que seria entrevistados, estudantes protagonistas de escolas do município de São Lourenço da Mata, parte da rede Estadual de Pernambuco, na área metropolitana; em uma análise das possibilidades, foram escolhidos estudantes protagonistas pela equipe gestora de cada escola, para a realização de entrevistas semi estruturadas,a análise para este artigo foi realizada uma análise de conteúdo com medida frequencial de acordo com os pressupostos de Bardin. Este artigo surgiu com um apêndice de projeto sobre protagonismo Juvenil, que foi aprovado no conselho de ética em Pernambuco.

\section{REFERENCIAL TEÓRICO}

\section{EDUCAÇÃO INTEGRAL, RUMO A UMA EDUCAÇÃO INCLUSIVA}

A visão da educação tradicional que até algumas décadas atrás estava pautada em uma educação bancária, a educação tradicional jesuíta, ao longo dos tempos, vem sendo substituída por uma educação mais inovadora.Segundo Cavaliere (2002), “ Este processo deu-se em bases de um esvaziamento das responsabilidades da escola expresso,(...), pela redução da jornada e multiplicação dos turnos, pela desorientação didático-pedagógica e pela baixa qualidade da formação dos professores."

Em meio de tantas dificuldades e falta de compromisso com a educação, a sociedade se mobilizou para uma escola de qualidade, com menos injustiça social e menos desigualdade. Movimentos eram deflagrados em prol a uma educação de qualidade, leis eram aprovadas para que 
se cumprissem a constituição de 1988, e servindo de diretrizes de base para uma educação de qualidade. A LDB,(Lei nº9.394, de 20 de dezembro de 1996). Aprovada de modo controverso, com a participação ativa do senador Darcy Ribeiro, recentemente falecido, nela está reiterado o princípio constitucional de gratuidade do ensino público em estabelecimentos oficiais, art. $3^{\circ}$, inciso VI. A Lei de Diretrizes de base respaldou diversos setores da educação, estudantes, professores e disciplinas, foram dispostos em seus artigos, que mostra indicações à seguir.Sua proposta de uma educação igualitária, com estudantes mais autônomos.

\section{O PROGRAMA DE PROTAGONISMO JUVENIL NAS ESCOLAS INTEGRAIS EM PERNAMBUCO}

A Educação Integral em Pernambuco foi implementada como política pública no ano de 2008. Fundamentando-se em um modelo de concepção da educação interdimensional,criado pelo filósofo Antonio Gomes da Costa, suas principais premissas a cidadania e o protagonismo Juvenil,base para um desenvolvimento do jovem mais autônomo, solidário, desenvolvendo suas competências e produtivo. Segundo Ferreira (2019)"O jovem, autônomo, possui seus próprios interesses, ao passo que busca interagir e se relacionar com seus pares com um grau de liderança de um protagonista." Ao concluir o ensino médio nas escolas integrais, com o programa que é desenvolvido, terá uma qualificação de continuidade na vida acadêmica e profissional.
“As políticas de Educação Integral e em tempo integral foram invocadas e retomadas, neste momento histórico, com suas condições conjunturais e estruturais, desta primeira década dos anos 2000, graças ao reconhecimento de seu papel como política positiva para enfrentamento das desigualdades sociais e, consequentemente, das desigualdades educacionais."( LE- CLERC,2012, p.97)

Nesta visão, a educação de Pernambuco sua política pública voltada para inclusão de Jovens, vem cada vez mais se destacando como Estado com índices que estão aumentando nas provas externas. 
"Além de atribuir ao potencial do aluno o seu sucesso pessoal e profissional, abstraindo os fatores econômicos e sociais que condicionam tal ou qual trajetória escolar e social, cabe ainda observarmos que, tal como se apresenta, o ENEM tende, no limite, a penalizar os alunos oriundos de escolas que contam com precárias condições de funcionamento, oferecidas pelo poder público, que, tradicionalmente, atendem a população pobre."(SOUZA,2003,p.884)

As escolas integrais de Pernambuco,tem um diferencial, a avaliação integralizada, que é a avaliação interdimensional, que tem um direcionamento sistemático, baseada em quatro dimensões da pessoa, que é a afetividade, corporeidade, racionalidade e espiritualidade. Associada às premissas a tecnologia empresarial aplicada à educação, trata-se do planejamento estratégico que são aplicados nas escolas integrais. Através de programas e direcionamento para uma gestão mais democrática, onde são compartilhadas as ações com professores e estudantes protagonistas.

\section{RESULTADOS E DISCUSSÃO}

Em uma análise de medida de frequência,com os pressupostos de Bardin,o locus foram duas escolas, situadas em São Lourenço da Mata,município da área metropolitana do Recife, capital de Pernambuco, chamadas de escola A e escola B, com grupo de estudantes protagonistas de série diferentes, de escolas integrais, ensino Médio, os resultados foram obtidos através de entrevistas semi estruturadas e observação participante.

Ao perguntar aos entrevistados sobre o tempo e a experiência no protagonismo Juvenil, a modalidade de frequência obtida foi a Co-Ocorrência, onde Bardin (1977) nos fala: "A co-ocorrência: a co-ocorrência é a presença simultânea de duas ou mais unidades de registo, numa unidade de contexto." onde 90\% dos entrevistados,mostraram que têm um interesse grande no protagonismo e que é motivado na comunidade escolar. Carvalho (1998) nos diz: " Criar condições e meios para se atingir os objetivos da educação básica é a razão de ser dos profissionais da educação”. 
A motivação está diretamente ligada em se sentir aceito pela escola, seus pares e seus professores, este conceito de motivação, mesmo sendo bastante amplo e complexo, se tornou claro nas respostas da entrevista semi estruturada e na observação participante, o mesmo para o de experiência, com sentido de "está pronto", vivência no que desempenha na escola e que servirá para uma liderança no meio da trabalhabilidade.

\begin{abstract}
"Os estudos sobre as mudanças que o auto-conceito e a auto-estima apresentam, ao longo do desenvolvimento dos indivíduos, mostram que existem períodos em que as mudanças são mais marcantes, períodos estes que parecem implicar alterações de contexto, que obrigam a transformações internas, fundamentais na avaliação das situações e na forma de encontrar meios para lhes fazer face. "(AZEVEDO, 2006,p.8)
\end{abstract}

O ser protagonista com a modalidade frequencial co-ocorrência. Encontrar um estudante comprometido com os seus pares e ver o protagonismo como troca de saberes entre os pares, sua interação com todo o corpo da escola, professores e equipe gestora.Seu olhar voltado como um ser inovador,se preparando para o "mundo do trabalho". Segundo Cassiolato, (2005) "A capacidade inovativa de um país ou região é vista como resultado das relações entre os atores econômicos, políticos e sociais, e reflete condições culturais e institucionais próprias", o empreendedorismo nas escolas em tempo integral em Pernambuco, se dar em forma de disciplina e experiências criadas para o desenvolvimento dessa habilidade, despertando assim o autodidatismo, com a disciplina projeto de vida, leva os protagonistas a buscar novos caminhos, e que caminhos seriam esse para sua vida? Dolabela nos faz pensar com esta resposta:

“Ele se sente protagonista e integrante do processo educacional. Já a segunda pergunta leva o aluno a criar caminhos, estratégias, e a escolher processos para transformar seu sonho em realidade. Essa pergunta dispara um processo de criação, de criatividade, pondo em uso todo o patrimônio existencial do aluno, que é diverso, que é único. Assim, ele se sente capaz e 
comprometido com a criação de seus próprios caminhos. Tudo isso é notável durante o processo educacional. As crianças e os professores mudam" (DOLABELA, 2004,p. 129)

A mudança de toda comunidade escolar em prol a uma educação de qualidade, sem as "amarras" da exclusão, é o que o sistema educacional almeja, para isso os projetos que levam os estudantes à uma liberdade de pensamento, de ações e de escolhas, são refletidos e integrados a essa escola inovadora, que deseja promover inclusão. Muito caminho são percorridos e com avanços e retrocessos, o sistema educacional está sendo mudado.

\section{CONSIDERAÇÕES FINAIS}

A Promoção de atendimento aos estudantes protagonista é uma prática da educação integral, dificuldade sócio emocional,cognitivas, podem vim a ser minimizadas com o processo de auto estima e auto realização, capacitações com os professores mostrando o programa de protagonismo Juvenil, sua filosofia e incentivando com as ferramentas que possam facilitar o desenvolvimento em atividades que possa ter a contribuição do protagonista juvenil.Temas sócio emocionais, estimulando a auto estima além dos conteúdos educacionais, focados em palestras durante o ano letivo.

Esta pesquisa tem um enfoque analítico e seu principal eixo a atividade interdisciplinar direcionando a pesquisa para vários caminhos, o teórico, normativo e indutivo,nas escola integral em Pernambuco.O alcance da pesquisa são as escolas integrais, estudantes e comunidade científica.

\section{REFERÊNCIAS}

AZEVEDO, ngela Sá; FARIA, Luísa. Motivation, Success, and Transition to University. Psicologia, Lisboa, v. 20, n. 2, p. 69-93, 2006 . Disponível em <"http://www.scielo.mec. pt/scielo.php?script=sci_arttext HYPERLINK "http:// www.scielo.mec.pt/scielo.php?script=sci_arttext\&pi$\mathrm{d}=$ S0874-20492006000200004\&lng=pt\&nrm=iso"\& HYPER- 
LINK "http://www.scielo.mec.pt/scielo.php?script=sci_arttext\&pid=S0874=20492006000200004-\&lng=pt\&nrm=is" "pidS0874-20492006000200004 HYPERLINK "http://www.scielo. m e c.pt/s cielo.ph p ? c ript=s ci_art text\&pi$\mathrm{d}=$ S0874-20492006000200004\&lng=pt\&nrm=iso"\& HYPERLINK “http://www.scielo.mec.pt/scielo.php?script=sci_arttext\&pid=S0874-20492006000200004\&lng=pt\&nrm=iso"lng=pt HYPERLINK "http://www.scielo.mec.pt/scielo.php?script=sci_arttext\&pid=S0874=20492006000200004-\&lng=pt\&nrmiso"\& HYPERLINK "http://www.scielo.mec.pt/scielo.php? script=sci_arttext \&pid=S0874-20492006000200004\& lng=pt\&nrm=iso"nrm=iso"nrm=iso>. acessos em 28 jun. 2020.

BRASIL. [Constituição (1988)]. Constituição da República Federativa do Brasil de 1988. Brasília, DF: Presidência da República, [2016]. Disponível em: http://www.planalto.gov.br/ccivil_03/ Constituicao/ Constituiçao.htm acesso em : 09 jul 2020.

BRASIL. Lei de Diretrizes e Bases da Educação Nacional. Lei número 9394, 20 de dezembro de 1996

CARVAlHO, Djalma Pacheco de. A Nova Lei de Diretrizes e Bases e a formação de professores para a educação básica. Ciênc. educ. (Bauru), Bauru, v. 5, n. 2, p. 81-90, 1998 . Available from"http://www.scielo.br/scielo.php?script=sci_arttext\&pid=S1516=73131998000200008-\&lng=en\&nrm=is" "pidS1516-73131998000200008 access on 10 July 2020. http:// dx.doi.org/10.1590/S1516-73131998000200008.

CASSIOLATO, José Eduardo; LASTRES, Helena Maria Martins. Sistemas de inovação e desenvolvimento: as implicações de política. São Paulo Perspec., São Paulo , v. 19, n. 1, p. 3445, mar. 2005 . Disponível em <"http://www.scielo.br/scielo. php?script=sci_arttext. acesso em 28 jun. 2020. http://dx.doi. org/10.1590/S0102-88392005000100003.

CAVALIERE, Ana Maria Villela. Educação integral: uma nova identidade para a escola brasileira ?. Educ. Soc. , Campi- 
nas, v. 23, n. 81, p. 247-270, dezembro de 2002. Disponível em <http://www.scielo.br/scielo.php?script=sci_arttext HYPERLINK "http://www.scielo.br/scielo.php?script=sci_arttext\&pid=S0101-73302002008100013\&lng=en\&nrm=iso" \& HYPERLINK "http://www.scielo.br/scielo.php?script=sci_arttext\&pid=S0101=73302002008100013-\&lng=en\&nrm=is" "pid-

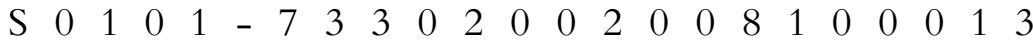
HYPERLINK "http://www.scielo.br/scielo.php?script=sci_arttext\&pid=S0101-73302002008100013\&lng=en\&nrm=iso" \& HYPERLINK "http://www.scielo.br/scielo.php?script=sci_arttext\&pid=S0101=73302002008100013-\&lng=en\&nrm=is""lngen HYPERLINK "http://www.scielo.br/scielo.php?script=sci_ arttext\&pid=S0101-73302002008100013\&lng=en\&nrm=iso" \& HYPERLINK "http://www.scielo.br/scielo.php?script=sci_arttext\&pid=S0101=73302002008100013-\&lng=en\&nrm=is""nrmiso>. acesso em 13 de julho de 2020. https://doi.org/10.1590/ S0101-73302002008100013 .

DORABELA,Fernando (site: www.dolabela.com.br Revista de Negócios, Blumenau, v. 9, n. 2, p. 127-130, abril/junho 2004.http:// diadorim.ibict.br. http://pkp.sfu.ca/node/3747

FERREIRA,A.B.M; Identidades culturais no contexto de sala de aula, educação integral. EIXO: 1. EDUCAÇÃO E POLÍTICAS PÚBLICAS.Educon, Aracaju, Volume 13, n. 01, p.2-8, set/2019 | www.educonse.com.br/xiiicoloquio http://dx.doi. org/10.29380/2019.13.01.02

LECLERC, Gesuína de Fátima Elias; MOLL, Jaqueline. Programa Mais Educação: avanços e desafios para uma estratégia indutora da Educação Integral e em tempo integral. Educ. rev., Curitiba , n. 45, p. 91-110, Sept. 2012 . Available from <"http://www.scielo.br/scielo.php?script=sci_arttext HYPERLINK "http://www.scielo.br/scielo.php?script=sci_arttext\&pid=S0104-40602012000300007\&lng=en\&nrm=iso” \& HYPERLINK “http://www.scielo.br/scielo.php?script=sci_arttext\&pid=S0104=40602012000300007-\&lng=en\&nrm=is" "pid- 
S0104-40602012000300007 HYPERLINK "http://www.scielo. br/scielo.php?script=sci_arttext\&pid=S0104-4060 $2012000300007 \& \operatorname{lng}=$ en \&nrm=iso" \&HYPERLINK "http://www.scielo.br/scielo.php?script=sci_arttext\&pi$\mathrm{d}=$ S0104-40602012000300007\&lng=en\&nrm=iso"lng=en HYPERLINK "http://www.scielo.br/scielo.php?script=sci_arttext\&pid=S0104-40602012000300007\&lng=en\&nrm=iso" \& HYPERLINK “http://www.scielo.br/scielo.php?script=sci_arttext\&pid=S0104=40602012000300007-\&lng=en\&nrm=is"'"nrm=is" "nrmiso>. access on 27 June 2020. https://doi.org/10.1590/S010440602012000300007.

ROCHA FILHO, Romeu C .. Editorial - A nova LDB: perspectivas e desafios. Quím. Nova, São Paulo, v. 20, n. 4 de agosto de 1997. Disponível em <"http://www.scielo.br/scielo.phpscript=sci_arttext\%26pid=S0100-4042 HYPERLINK "http://www.scielo. br/scielo.phpscript=sci_arttext\%26pid=S0100-4042\%3E” >. acesso em 20 de junho de 2020. https://doi.org/10.1590/S010040421997000400001 .

SOUZA, Sandra Zákia Lian de; OLIVEIRA, Romualdo Portela de. Políticas de avaliação da educação e quase mercado no Brasil. Educ. Soc., Campinas, v. 24, n. 84, p. 873-895, Sept. 2003 - Available from <http://www.scielo.br/scielo.php?script=sci_arttextaccess on 28 June 2020. https://doi.org/10.1590/S010173302003000300007.

TOMMASI, Livia De. Tubarões e peixinhos: histórias de jovens protagonistas. Educ. Pesqui. São Paulo, v. 40, n. 2, p. 533-548, junho de 2014. Disponível em < "http:// www.scielo.br/scielo.php?script=sci_arttext HYPERLINK "http://www.scielo.br/scielo.php?script=sci_arttext\&pi$\mathrm{d}=$ S1517-97022014000200015\&lng=en\&nrm=iso" \& HYPERLINK "http://www.scielo.br/scielo.php?script=sci_arttext\&pid=S1517=97022014000200015-\&lng=en\&nrm=is" "pid$\begin{array}{lllllllllllllllllllllll}\mathrm{S} & 1 & 5 & 1 & 7 & - & 9 & 7 & 0 & 2 & 2 & 0 & 1 & 4 & 0 & 0 & 0 & 2 & 0 & 0 & 0 & 1 & 5\end{array}$ HYPERLINK "http://www.scielo.br/scielo.php?script=sci_ar- 
ttext\&pid=S1517-97022014000200015\&lng=en\&nrm=iso" \& HYPERLINK "http://www.scielo.br/scielo.php?script=sci_arttext\&pid=S1517=97022014000200015-\&lng=en\&nrm=is" "lngen HYPERLINK "http://www.scielo.br/scielo.php?script=sci_ arttext\&pid=S1517-97022014000200015\&lng=en\&nrm=iso" \& HYPERLINK “http://www.scielo.br/scielo.php?script=sci_arttext\&pid=S1517=97022014000200015-\&lng=en\&nrm=is" "nrmiso" $\&>$ acesso em 18 de junho de 2020. Epub 15 de outubro de 2013. https://doi.org/10.1590/S1517-97022013005000025 . 


\section{A QUALIDADE DAS INSTITUIÇÕES DE ENSINO SUPERIOR CONTROLADAS POR COMPANHIAS LISTADAS NA BOLSA DE VALORES}

Dalliane Vanessa Pires Andrade

\section{INTRODUÇÃO}

As Instituições de Ensino Superior (IES) buscam agregar atividades que possam favorecer a sua permanência no mercado competitivo. O poder aquisitivo da população afeta o aluno do ensino superior, momento em que apenas o Programa Universidade para Todos (ProUni) foi preservado como programa social relevante, enquanto que o Fundo de Financiamento Estudantil (Fies) se apequenou, em função de situações financeiras não favoráveis.

Segundo o último Censo do INEP (2018), no Brasil, 88\% das IES são privadas, oferecendo mais de 75\% das matrículas da graduação, revelando-se como dominante na educação superior no Brasil. Enquanto que as instituições públicas são menos de 12\% e oferecem pouco mais de 25\% das matrículas em cursos superiores.

Mudanças na Legislação contribuíram para a caracterização desse cenário na educação superior do País. Como consequência, a partir de 2007 noticiou-se vários investimentos no segmento através do capital estrangeiro e aquisição de ações na antiga Bolsa de Valores BM\&FBOVESPA com a compra de parte de instituições educacionais brasileiras ou até, aquisição total. 
As primeiras empresas atuantes na Bolsa são a Estácio de Sá e a Kroton Educacional, seguidas pelo grupo SER Educacional e o grupo Anima Educação, logo, consolidaram-se gigantes do ensino, concentrando fatia significativa do mercado. Atualmente estão listadas na Brasil Bolsa Balcão - B3, as empresas Anima Holding S.A, Cogna Educação S.A, Ser Educacional S.A e Yduqs Participaçoes S.A

Diante desse contexto, busca-se responder ao seguinte problema de pesquisa: as Instituições de Ensino Superior controladas por Companhias que possuem ações na Bolsa de Valores B3 apresentam desempenho superior diante às concorrentes na avaliação a qual está submetida?

Para responder ao questionamento norteador desta pesquisa, o presente artigo tem como objetivo apresentar as instituições de ensino que possui ações na Brasil Bolsa Balcão - B3, e avaliar a qualidade das mesmas através dos indicadores do Índice Geral de Cursos da Instituição (IGC). Outro objetivo secundário do estudo é evidenciar o atual panorama da Educação Superior no Brasil.

Logo, o presente artigo se justifica por apresentar o novo modelo de mercado educacional, que desde seu surgimento tem provocado várias críticas, principalmente acerca da qualidade dos serviços oferecidos por essas Instituições. Bem como, por compor um estudo contendo informações relevantes aos seus acionistas, tornando-se um objeto de análise para futuros investidores, e alunos que queiram ingressar nestas instituições futuramente.

Após esta introdução, o presente trabalho encontra-se estruturado da seguinte forma: a segunda seção corresponde à fundamentação teórica e na terceira é apresentada a metodologia de pesquisa. Na quarta seção são apresentados os resultados. Por sim, a conclusão com as reflexões e contribuições da pesquisa.

\section{REFERENCIAL TEÓRICO}

\subsection{O ENSINO SUPERIOR PRIVADO NO BRASIL}

A partir dos anos 90, a promulgação da Constituição de 1988 já havia mantido o ensino livre à iniciativa privada, como postulado na Constituição republicana de 1893, sempre que respeitadas as normas 
gerais da educação e com a autorização e avaliação do poder público (art. 209). Também, declara-se a gratuidade do ensino público em estabelecimentos oficiais e a autonomia didático-científica, administrativa e de gestão financeira e patrimonial para as universidades; assim como a não dissociação entre ensino, pesquisa e extensão (art. 206 e 207).

Para um contingente cada vez maior da população, a formação superior passava a fazer parte de seus projetos de realização pessoal e de ascensão social. A iniciativa privada, atenta às demandas de novos e potenciais consumidores, respondeu de forma ágil (SAMPAIO, 2011). A Tabela 1 apresenta de maneira simplificada a evolução das matrículas de alunos nas instituições de ensino superior privadas, entre os anos de 2008 e 2018.

Tabela 1 - Matrículas nas IES privadas

\begin{tabular}{|c|c|c|}
\hline Ano & Matrículas & Evolução \\
\hline 2008 & 4.255 .064 & - \\
\hline 2009 & 4.430 .157 & $4 \%$ \\
\hline 2010 & 4.736 .001 & $11 \%$ \\
\hline 2011 & 4.966 .374 & $17 \%$ \\
\hline 2012 & 5.140 .312 & $21 \%$ \\
\hline 2013 & 5.373 .450 & $26 \%$ \\
\hline 2014 & 5.867 .011 & $38 \%$ \\
\hline 2015 & 6.075 .152 & $43 \%$ \\
\hline 2016 & 6.058 .623 & $42 \%$ \\
\hline 2017 & 6.241 .307 & $47 \%$ \\
\hline 2018 & 6.373 .274 & $50 \%$ \\
\hline
\end{tabular}

Fonte: Adaptado Inep (2020)

Percebe-se, a partir da Tabela 1, a evolução no número de matrículas ao longo dos 10 anos. Apesar do ano de 2016 ter um percentual reduzido quando comparado ao ano anterior, em todos eles houve crescimento no número de matrículas nas IES Privadas, não sendo observada redução de matrículas.

Para Laus e Morosini (2005), havia a necessidade de flexibilidade do sistema, redução do papel exercido pelo governo, ampliação do 
sistema e melhoria nos processos de avaliação com vistas à elevação da qualidade.

A partir de mudanças na legislação brasileira, foi permitido que as mantenedoras privadas pudessem se transformar em organizações com fins lucrativos, como sociedade civil por quotas de responsabilidade, sociedade comercial e até como donos individuais.

A partir dessa expansão, ocorreu uma evolução no número das IES privadas, mostrando a sua significância na educação superior brasileira, mesmo com as divisões de classificações, entre Universidade, Centro Universitário e Faculdade, conforme detalhada na Tabela 2.

Tabela 2 - Instituições de Educação Superior no Brasil

\begin{tabular}{|c|c|c|c|}
\hline \multirow{2}{*}{ Ano } & Universidade & $\begin{array}{c}\text { Centro } \\
\text { Universitário }\end{array}$ & Faculdade \\
\cline { 2 - 4 } & Privada & Privada & Privada \\
\hline 2008 & 86 & 119 & 1.811 \\
\hline 2009 & 86 & 120 & 1.863 \\
\hline 2010 & 89 & 119 & 1.892 \\
\hline 2011 & 88 & 124 & 1.869 \\
\hline 2012 & 85 & 129 & 1.898 \\
\hline 2013 & 84 & 130 & 1.876 \\
\hline 2014 & 84 & 136 & 1.850 \\
\hline 2015 & 88 & 140 & 1.841 \\
\hline 2016 & 89 & 156 & 1.866 \\
\hline 2017 & 93 & 181 & 1.878 \\
\hline 2018 & 92 & 217 & 1.929 \\
\hline TOTAL & 947 & 1.265 & 19.685 \\
\hline
\end{tabular}

Fonte: Adaptado Inep (2020)

Segundo Colombo e Rodrigues (2011) esse crescimento substancial é motivado após a abertura ao segmento empresarial, que proporcionou impulso ao setor, o que permitiu forte crescimento das matrículas por meio da abertura de campi.

Com as reformas implantadas, os números apresentados no último Censo da Educação Superior de 2018 mostram a forte expansão do segmento privado, ao comparar com as IES públicas conforme apresentado no Gráfico 1. 
Gráfico 1 - Evolução do número de Instituições de Educação Superior no Brasil - 2008 a 2018

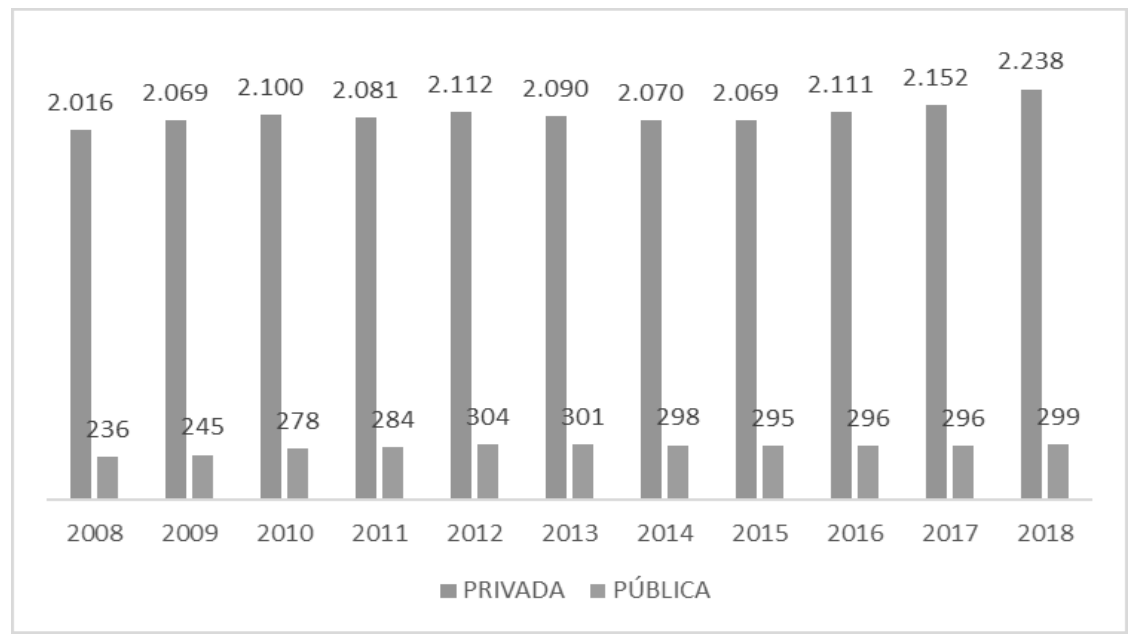

Fonte: Adaptado Inep (2020)

Ainda segundo o Censo 2018, o ensino superior privado representa $88,2 \%$ dos cursos oferecidos no País, de modo geral, têm-se as estatísticas de Graduação Pública x Privada no Brasil descritas na Tabela 3.

Tabela 3 - Estatísticas de Graduação Pública x Privada - Brasil 2018

\begin{tabular}{|c|c|c|c|}
\hline Estatística da Graduação & Total & Pública & Privada \\
\hline Instituições & 2.537 & 299 & 2.238 \\
\hline Cursos & 37.962 & 10.526 & 27.436 \\
\hline Matrículas de Graduação & 8.450 .755 & 2.077 .481 & 6.373 .274 \\
\hline Ingressos (todas as formas) & 3.445 .93 & 580.936 & 2.864 .999 \\
\hline Concluintes & 1.264 .288 & 259.302 & 1.004 .986 \\
\hline $\begin{array}{c}\text { Funções Docentes em } \\
\text { Exercício }\end{array}$ & 397.893 & 183.669 & 214.224 \\
\hline
\end{tabular}

Fonte: Adaptado Inep (2020)

Os dados mostram que as IES privadas fixaram de vez sua presença como marco referencial da educação superior no Brasil, e a abertura ao segmento empresarial proporcionou esse avanço, entre outros, através dos investimentos e do capital estrangeiro. O novo mercado da educação passa pela solidificação, os grupos consolidadores apresentam 
estrutura profissional de gestão, acesso a capital de baixo custo e busca pela escala em suas operações.

Segundo Wildavski (2010) as instituições privadas podem ser analisadas como o melhor veículo de acesso maciço ao ensino superior profissionalizante para milhões de alunos que, de outra forma, não teriam essa oportunidade. Para Zhong (2011), a expansão das IES privadas pode fornecer informações úteis sobre a qualidade da educação, na medida em que a demanda corresponde oferta no mercado de trabalho.

Destarte Santos e Vásquez (2012) destacam a promoção do ensino superior como medida sustentável global, pois, em uma sociedade de informação e conhecimento, a evolução dos sistemas educacionais e o aumento do nível de formação dos indivíduos tornam-se fatores de progresso, força produtiva e motor de desenvolvimento econômico das nações.

\subsection{O CAPITAL ESTRANGEIRO E OS INVESTIMENTOS NA EDUCAÇÃO PRIVADA}

Na Lei no 5.540/68 até o ano de 96 encontravam-se as definições das organizações do ensino superior como entidades mantenedoras, organizações que manteriam as unidades, os institutos, as faculdades, os centros universitários e as universidades, que ofereceriam cursos superiores para a matrícula dos alunos interessados.

Após a vigência da Lei no 9.870/99, que ampliou os dispositivos da lei $\mathrm{n}^{\mathrm{o}} 9.131 / 95$, se permitiu que as entidades mantenedoras particulares se transformassem em organizações com fins lucrativos. Em seu artigo 9o A dispõe: As pessoas jurídicas de direito privado, mantenedoras de instituições de ensino superior, previstas no inciso II do art. 19 da Lei $\mathrm{n}^{\mathrm{o}}$ 9.394/96 poderão assumir qualquer das formas admitidas em direito, de natureza civil ou comercial e, quando constituídas como fundações, serão regidas pelo disposto no art. 24 do Código Civil Brasileiro.

Nesse contexto, o Brasil permitiu que grupos privados abrissem o capital no mercado financeiro, iniciando um novo ciclo no setor, baseado em fusões, aquisições, levando à consolidação de gigantes do ensino, buscando melhorias na sua infraestrutura através de investidores que visam lucros. 
Segundo Petta (2011), verifica-se a crescente presença dos grupos estrangeiros na educação superior: a rede universitária global Whitney Internacional University System; a ex-Sylvan Inc. e a Laureate International Universities; o Grupo Lusófona de Portugal, e dezenas de fundos de investimentos estrangeiros - detentores de ações das empresas de educação de capital aberto (Estácio, SEB SA e Kroton) e também de ações de empresas de capital fechado, como o Grupo IBMEC e Ser Educacional (Maurício de Nassau).

Ainda segundo a autora, o capital estrangeiro está presente (direto ou indiretamente) em um conjunto de instituições que respondem por quase $20 \%$ do alunado superior do país (sem contar sua participação nas editoras) e junto já movimenta cinco bilhões de reais por ano na educação privada (PETTA, 2011).

Conforme Colombo e Rodrigues (2011), os novos recursos vieram de várias fontes, dentre elas dois tipos de internacionalização de recursos financeiros: venda parcial ou total da entidade para corporações estrangeiras (fundos privados, fundos de pensão ou empresas e sociedades educacionais) que fizeram grandes investimentos para a obtenção do controle da companhia ou de parte dela; e, oferta de ações da BM\&FBovespa atualmente B3, com internacionalização dos recursos para o desenvolvimento de suas atividades educacionais.

Com mais capital estas companhias atuam em grande escala: ampliam a base de alunos por meio da expansão interna de matrizes e filiais; concluem fusões e aquisições das concorrentes em nível nacional e internacional; expandem seus negócios no ramo da compra e venda de serviços e mercadorias (assessoria pedagógica, marketing, informática, educação a distância) (OYAMA, 2009).

A educação superior ascende, no qual as empresas listadas na bolsa de valores conseguiram enorme aporte de recursos, proporcionando condições privilegiadas e supremacia no setor, tornando-se grandes conglomerados. No entanto, se faz necessário equilibrar a função social exercida pela educação, com a expectativa de retorno financeiro de investidores e analistas e sua intrínseca pressão por redução de custos, a fim de garantir a qualidade do serviço oferecido. 


\subsection{QUALIDADE NO ENSINO SUPERIOR}

A definição de qualidade no ensino superior ainda não foi definida, sendo necessário considerar as opiniões das partes interessadas relevantes (GREEN, 1994). Em outras palavras, um sistema de classificação deve refletir diferentes ângulos, a fim de oferecer uma visão abrangente da complexidade do ensino superior moderno. (TANG; WU, 2010)

Cheng e Tam (1997) chegou à conclusão de que, com base em diferentes concepções de qualidade da educação e as diferentes preocupações sobre a sua conquista, várias pessoas podem usar diversos indicadores para avaliar a qualidade da educação e estratégias diversas para alcançar a qualidade da educação.

Oldfield e Baron (2000) sugerem que há três fatores da qualidade do ensino superior: (1) os elementos necessários (encontros que são essenciais para capacitar os alunos a cumprirem as suas obrigações de estudo); (2) elementos aceitáveis (que são desejáveis, mas não essencial para estudantes); e (3) elementos funcionais (que são de natureza prática ou utilitária).

Neste caso, os indicadores brasileiros estão correlacionados com o processo de avaliação das IES conforme observado na Legislação (BRASIL, 1996) e em alguns estudos científicos, como: Cartele e Favaretto (2008); Polidori (2009); Zoghbi, Oliva e Marconi (2010); Ribeiro (2011); Peixoto (2011).

Assim, Freitas (2004) observa que o desenvolvimento e a implementação de um sistema de avaliação das IES, são um dos procedimentos utilizados para o monitoramento das informações relativas a estas instituições e que visa assegurar que a qualidade do ensino fornecida por estas instituições atenda aos padrões recomendados.

Para Vieira e Freitas (2010), a avaliação encontra-se na centralidade das políticas públicas voltadas para a educação superior, referenciadas em contextos internacionais e nacionais, geralmente com ênfase no papel do Estado de monitorá-las e orquestrá-las junto aos Estados e municípios.

A avaliação do ensino superior não é fato recente, existe há mais de 20 anos, e podem ser organizadas em quatro ciclos. O método de ava- 
liação anterior ao SINAES foi o Exame Nacional de Cursos - provão, que teve duração 1996 a 2003.

Segundo Polidori et al., (2007) a criação do SINAES - Sistema Nacional de Avaliação da Educação Superior no Brasil, em 2003, propôs uma mudança na metodologia da avaliação das IES brasileiras, mudando de uma avaliação totalitária e que utilizava a metodologia do ranqueamento, para um processo que respeita as diversidades e as especificidades das IES, além de aperfeiçoar os procedimentos e os instrumentos de avaliação até então utilizados.

Conforme Stadtlober (2010), através do SINAES as avaliações das IES são integradas com provas para acadêmicos, avaliação institucional e do curso com alunos, professores e colaboradores. Os componentes do SINAES são destacados no Quadro 1.

Quadro 1- Componentes do SINAES

\begin{tabular}{|c|c|}
\hline $\begin{array}{c}\text { Avaliação } \\
\text { Institucional }\end{array}$ & $\begin{array}{c}\text { Auto avaliação (pelas CPAs e avaliação externa in loco, } \\
\text { desenvolvida pelos avaliadores institucionais capacitados } \\
\text { pelo INEP nos moldes do SINAES). }\end{array}$ \\
\hline $\begin{array}{c}\text { Avaliação de pares na avaliação in loco, pelos estudantes, } \\
\text { Curso } \\
\text { através do ADES (questionário de Avaliação Discente } \\
\text { da Educação Superior que é enviado aos estudantes da } \\
\text { amostra do ENADE), pelos coordenadores de curso, } \\
\text { mediante questionário dos coordenadores e avaliações } \\
\text { realizadas pelos professores dos cursos e a CPA. }\end{array}$ \\
$\begin{array}{c}\text { Através de um exame em larga escala aplicado aos } \\
\text { Avaliação do } \\
\text { dosempenho estudantes } \\
\text { ingressantes e } \\
\text { concluintes }\end{array}$ & $\begin{array}{c}\text { estudantes que preenchem os critérios estabelecidos pela } \\
\text { legislação vigente. O Exame Nacional de Desempenho } \\
\text { dos Estudantes (ENADE) é composto pela prova, o } \\
\text { (ADES) (antigo questionário socioeconômico), o } \\
\text { questionário dos coordenadores de curso e a percepção do } \\
\text { aluno sobre a prova. }\end{array}$ \\
\hline
\end{tabular}

Fonte: Adaptado de Brito (2008)

Conforme Bittencourt (2010) ao acompanhar o Enade, desde a sua primeira edição, percebe-se que as modificações promovidas pelo Instituto Nacional de Estudos e Pesquisas Educacionais Anísio Teixeira (INEP) foram motivadas por críticas que partiram de IES, especialmente as privadas. 
No escopo do SINAES, existem indicadores como Conceitos Preliminares de Cursos - CPC e Índice Geral de Cursos - IGC criados recentemente para mensurar o desempenho das instituições e dos cursos. O CPC combina o desempenho obtido pelos estudantes no Enade com os resultados do Indicador de Diferença de Desempenho (IDD) e com as informações de infraestrutura e instalações físicas, recursos didático-pedagógicos e corpo docente oferecida pelo curso de uma determinada Instituição de Ensino Superior.

Para Gramani e Duarte (2011), apesar de importantes mudanças realizadas nos últimos anos, como a introdução de exames nacionais para avaliação da qualidade do ensino, o Brasil ainda é caracterizado como um país de baixo nível educacional, tanto em termos de quantidade como em termos de qualidade da educação.

O Índice Geral de Cursos (IGC) é um indicador que combina os resultados da avaliação dos cursos de graduação no ENADE com os resultados da avaliação dos cursos de pós-graduação das IES, além de fatores como as características da formação acadêmica e do regime de trabalho dos professores (PEIXOTO, 2011; POLIDORI, 2009; RIBEIRO, 2011). Para ponderar os conceitos, utiliza-se a distribuição dos alunos da IES entre os diferentes níveis de ensino (graduação, mestrado e doutorado).

Segundo Bittencourt et al., (2009) o índice IGC é calculado através da média do CPC e, em menor grau, da média dos conceitos dos programas de pós-graduação de cada IES. O CPC, por sua vez, apresenta a seguinte composição e ponderações: ENADE (40\%), IDD (30\%), Instalações e infraestrutura (3\%), Recursos didáticos (8\%), Percentual de doutores (12\%), Percentual de professores com tempo integral (7\%).

Os resultados do último IGC, ano de 2018, em âmbito nacional, revelam disparidades entre as IES públicas e privadas. Entre as 42 IES que obtiveram conceito 5, 64\% são públicas e 36\% privadas. Em relação a nota 4, 79\% das instituições privadas possuem esse conceito, enquanto na pública apenas 21\%. As IES que possuem IGC 3, nas instituições públicas $11 \%$ estão nessa faixa e nas privadas $89 \%$. Quanto as IES que obtiveram conceito 2, 93\% delas são privadas e 
$7 \%$ são públicas. Ao tratar das IES com conceito 1 e sem conceito 100\% delas são privadas. Em síntese, a Tabela 4 apresenta a distribuição de IES por IGC.

Tabela 4 - Distribuição de Instituições por IGC

\begin{tabular}{|c|c|c|c|}
\hline Nota & Pública & Privada & Total \\
\hline 5 & 15 & 27 & 42 \\
\hline 4 & 92 & 346 & 438 \\
\hline 3 & 145 & 1.161 & 1.306 \\
\hline 2 & 17 & 242 & 259 \\
\hline 1 & 0 & 7 & 7 \\
\hline Sem Conceito & 0 & 19 & 19 \\
\hline Total & 269 & 1.802 & 2.071 \\
\hline
\end{tabular}

Fonte: Inep/MEC (2020)

A partir dessas informações, constatou-se que os resultados do IGC apresentam valores discrepantes entre as instituições públicas e privadas, no entanto, se compararmos sobre o total de instituições privadas e públicas separadamente, é possível observar que a maioria das instituições apresenta conceito 3. Portanto, as IES deverão acompanhar a estrutura organizacional para atender às expectativas de avaliação do índice, com intuito de atingirem o conceito máximo.

\section{METODOLOGIA}

Ao considerar os objetivos da pesquisa, adotado por Gil (2010), o tipo de pesquisa realizada é exploratória e descritiva, considerando-se os "procedimentos técnicos" utilizados na pesquisa, foi realizada uma pesquisa bibliográfica, documental e estudo multicaso.

Segundo Vergara (2000), a pesquisa descritiva expõe características de determinada população ou de determinado fenômeno. Para Gil (2010), pesquisas exploratórias têm como objetivo proporcionar maior familiaridade com o problema, com vistas a torná-lo mais explícito ou a constituir hipóteses.

Foi realizado inicialmente um estudo documental com o objetivo de evidenciar a atual situação do ensino privado no País, em seguida exploratório com o intuito de obter a identificação das IES 
de capital na Bolsa de valores e seus indicadores de qualidade conforme SINAES.

A pesquisa ainda se caracteriza como um estudo de multicaso, que segundo Yin (2010), possibilita a investigação de um fenômeno e seus conteúdos na vida real, quando as fronteiras entre o fenômeno e o contexto ainda não são claramente evidentes e o pesquisador tem pouco controle sobre os acontecimentos. Portanto, a estratégia metodológica escolhida para poder responder às diferentes questões deste trabalho foi o Estudo de multicaso com a utilização de dados quantitativos.

O universo desta pesquisa é composto por uma amostra escolhida por conveniência das Instituições Ensino Superior, controladas direta ou indiretamente pela Anima Holding S.A, Cogna Educação S.A, SER Educacional S.A e Yduqs Participações S.A, sociedades de capital aberto que possuem ações na Brasil Bolsa Balcão - B3 S.A.

A coleta de dados foi realizada durante o mês de julho/2020, abrange o período do IGC de 2018, 2017 e 2016, e foram tratados estatisticamente no Microsoft Excel.

Para descrever os principais resultados e características dessas Instituições de Ensino, utilizou-se como fonte os relatórios da administração mantidos pela Brasil Bolsa Balcão - B3 S.A disponíveis em seu site (http://www.b3.com.br).

\section{RESULTADOS MULTICASO}

\subsection{ANIMA HOLDING S.A}

A Ânima Holding S.A., ("ÂNIMA" ou "sociedade"), com sede e foro na cidade de São Paulo, estado de São Paulo, é uma sociedade anônima de capital aberto registrada Brasil, Bolsa, Balcão - B3 S.A, sob o código ANIM3.

Com sua trajetória iniciada em 2003 e 17 anos de experiência no setor de ensino superior brasileiro, a Ânima reúne uma Universidade (Universidade São Judas Tadeu) no Estado de São Paulo; uma rede de sete Centros Universitários (Una, Una Bom Despacho, UniBH, Centro Universitário São Judas Tadeu, UniSociesc, UniSociesc Curitiba, Centro Universitário UniAGES), nos estados de Minas Gerais, São 
Paulo, Paraná, Santa Catarina, Sergipe e Bahia; além de Faculdades e unidades acadêmicas nas cidades de Betim, Contagem, Divinópolis, Pouso Alegre, Sete Lagoas, Itabira, Uberlândia, Nova Serrana, Conselheiro Lafaiete (Una - Minas Gerais), Jataí, Catalão e Itumbiara (Una - Goiás), Florianópolis, Blumenau, Balneário Camboriú, São Bento do Sul, Jaraguá do Sul, Itajaí (UniSociesc - Santa Catarina), além de Jacobina, Jeremoabo, Senhor do Bonfim, Tucano, Irecê (AGES - Bahia) e Lagarto (AGES - Sergipe).

A Holding possui 8 instituições e 37 unidades, no entanto, nos resultados do IGC foram identificadas apenas 17 IES. O IGC apresentado pelas Instituições de Ensino controladas pela Ânima Holding S.A, mostra que 59\% delas obtiveram conceito 4 no ano de 2016, 70\% em 2017 e 76\% em 2018, e que no mesmo ano a Faculdade Sociesc obteve nota máxima na avaliação, atingindo conceito 5 , conforme gráfico abaixo.

Gráfico 2 - IGC Ânima Holding S.A

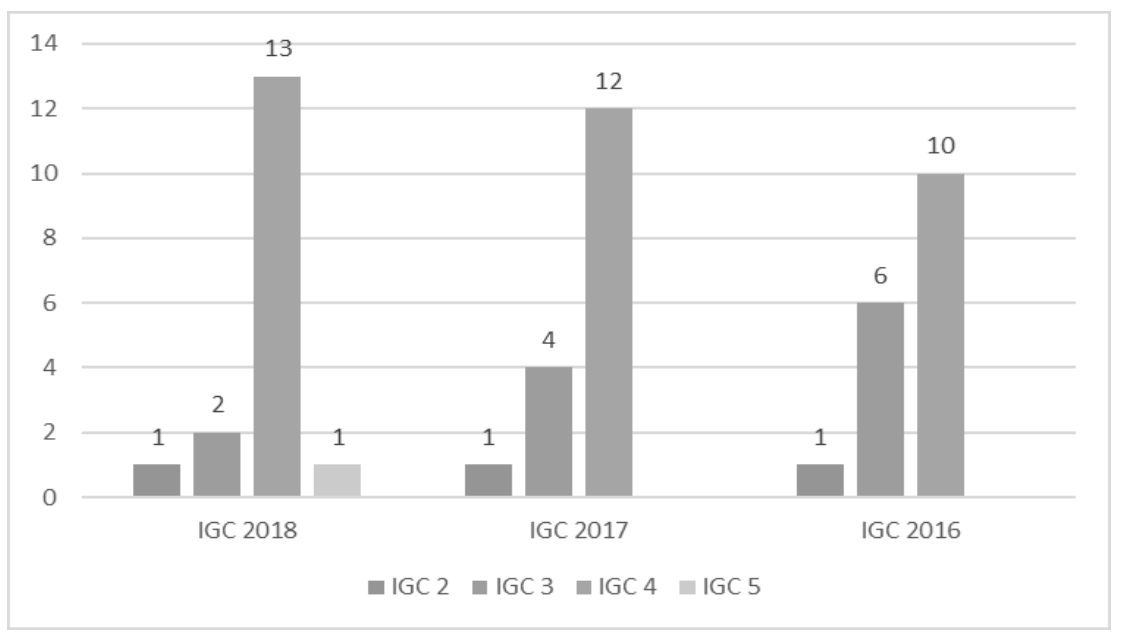

Fonte: Inep/MEC (2020)

Observa-se uma contradição em relação aos dados evidenciados na tabela 4, em que a maioria das IES privadas apresenta conceito 3, também é possível identificar que as notas do IGC da Anima vêm melhorando com o passar das avaliações, confirmando seu comprometimento com a qualidade do ensino em busca de melhores resultados. 


\subsection{COGNA EDUCAÇÃO S.A}

A Cogna Educação S.A. (anterior denominação de Kroton Educacional S.A), aqui denominada "Companhia", "Controladora" ou "Cogna”, com sede na Rua Santa Madalena Sofia, 25, na cidade de Belo Horizonte - MG, e suas controladas (em conjunto, o "Grupo") têm como principais atividades a oferta de cursos de ensino superior e pós-graduação presencial e à distância.

O Grupo possui 73 empresas, incluindo a Controladora, e é composto por 18 mantenedoras de instituição de ensino superior, 176 unidades de Ensino Superior, presentes em 24 estados e 132 cidades brasileiras, além de 1.510 Polos de Graduação EAD credenciados pelo MEC, localizados em todos os estados brasileiros e no Distrito Federal. A Companhia é listada na B3 - Brasil, Bolsa, Balcão, no segmento especial denominado Novo Mercado, sob o código COGN3 onde negocia suas ações ordinárias.

A Companhia possui marcas como a Anhanguera, Fama, Pitágoras, Unic sob seu controle. Quanto a sua qualidade segundo o Índice Geral de Cursos (IGC) em pesquisa realizada com as IES controladas pela Cogna, por meio de dados disponibilizados pelo MEC, percebeu-se que 83\% obtiveram em 2018 conceito 3, em 2017 esse percentual era maior 91\% e 2016 era de $87 \%$, conforme gráfico a seguir.

Gráfico 3 - IGC Cogna Educação S.A

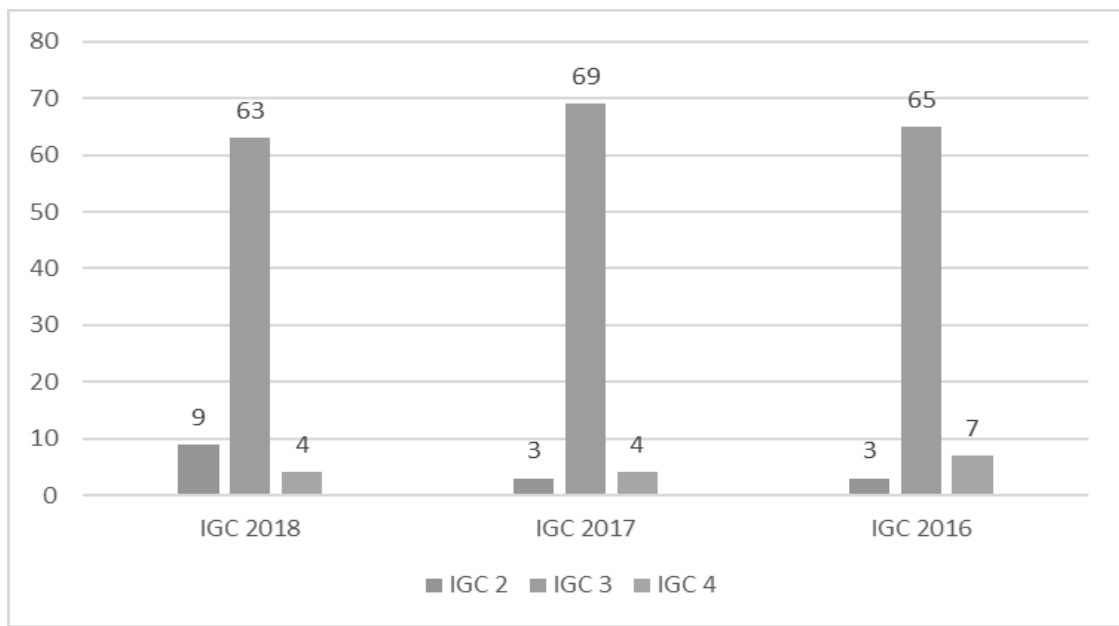

Fonte: Inep/MEC (2020) 
As instituições controladas pela Cogna, confirmam o resultado apresentado na tabela 4, em que a maioria das IES privadas exibem conceito 3. No entanto, analisando os três anos observa-se que as Instituições com conceito 4 caiu ao passo que as com conceito 2 subiu, o que merece destaque, para que a organização avalie a estrutura organizacional das controladas para que possam elevar seus resultados do IGC.

\subsection{SER EDUCACIONAL S.A}

A Companhia é uma sociedade anônima de capital aberto com sede em Recife, Estado de Pernambuco. É listada na B3 S.A. - Brasil Bolsa Balcão, no segmento especial denominado Novo Mercado,sobo código SEER3 onde negocia suas ações ordinárias.

A Ser Educacional S.A. ("Companhia”) e suas controladas (conjuntamente, "Grupo") têm como atividades principais o desenvolvimento e administração de atividades nas áreas de ensino, de graduação presencial e à distância, pós-graduação, educação profissional e outras áreas associadas à educação e aparticipação, como sócio ou acionista, em outras sociedades empresariais, no Brasil.

O Grupo possui ainda vinte e uma empresas constituídas sob a forma de sociedades empresariais de responsabilidade limitada, que atuam na forma de duas universidades, dez centros universitários, 90 faculdades credenciadas e 273 polosde ensino à distância (EAD), todos em operação, constituindo um dos maiores grupos privadosde educação do Brasil e com a presença mais relevante nas regiões Nordeste e Norte em número de alunos matriculados.

O Grupo está presente em todos os 26 estados da federação e no Distrito Federal, com uma base consolidada de aproximadamente 185 mil alunos, operando sob as marcas UNINASSAU -Centro Universitário Maurício de Nassau, UNINABUCO - Centro Universitário Nabuco, UNG - Universidade Guarulhos, UNAMA - Universidade da Amazônia, UNIVERITAS -Centro Universitário Universus Veritas, UNINORTE - Centro Universitário do Norte, Faculdades UNINASSAU, Faculdades UNINABUCO e Escolas Técnicas Joaquim Nabuco e Maurício deNassau, por meio das quais oferece aproximadamente 1.904 cursos, através dos campi e dos polos de EAD. 
O IGC das Instituições de Ensino Superior controladas pelo grupo Ser Educacional, obtiveram em sua maioria conceito 3 nos 3 anos avaliados, conforme apresentado no Gráfico 4.

Gráfico 4 - IGC Ser Educacional S.A

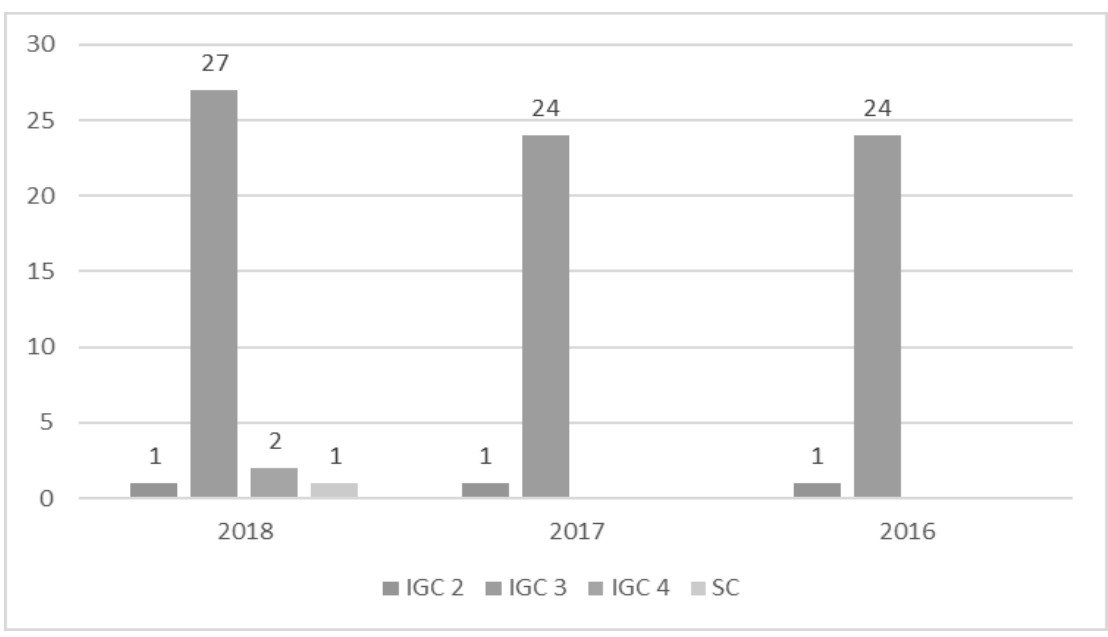

Fonte: Inep/MEC (2020)

As instituições controladas pelo grupo Ser Educacional estão em sua maioria com o mesmo padrão, como a maioria das IES privadas (ver Tabela 4). O grupo poderá identificar se a estrutura organizacional das IES é semelhante, e assim buscar uma solução em conjunto para elevar seus resultados do IGC.

\subsection{YDUQS PARTICIPAÇÕES S.A}

A YDUQS Participações S.A. ("Companhia" ou "Grupo") e suas controladas (conjuntamente, o "Grupo") têm como atividades preponderantes o desenvolvimento e/ou administração de atividades e/ou instituições nas áreas de educação de nível superior, educação profissional e/ou outras áreas associadas à educação, a administração de bens e negócios próprios, e a participação, como sócio ou acionista, em outras sociedades simples ou empresárias, no Brasil. 
A Companhia é uma sociedade anônima com sede localizada na Avenida Venezuela, 43, na Cidade e Estado do Rio de Janeiro, constituída por subscrição particular de ações em 31 de março de 2007, e atualmente listada no Novo Mercado. O Grupo possui vinte e três empresas, incluindo a YDUQS Participações, sendo vinte mantenedoras de instituição de ensino superior, constituídas sob a forma de sociedades empresárias de responsabilidade limitada, e reúne uma Universidade, treze Centros Universitários e cinquenta e duas Faculdades, credenciadas e distribuídas em vinte e três estados do país e no Distrito Federal.

As Instituições de Ensino controladas pelo grupo YDUQS é composto por nomes como Estácio, Wyden Educacional e Unitoledo. No seu IGC observa-se que a maioria delas obtiveram conceito 3 no triênio analisado, conforme apresentado no Gráfico 5.

Gráfico 5 - IGC YDUQS Participações S.A

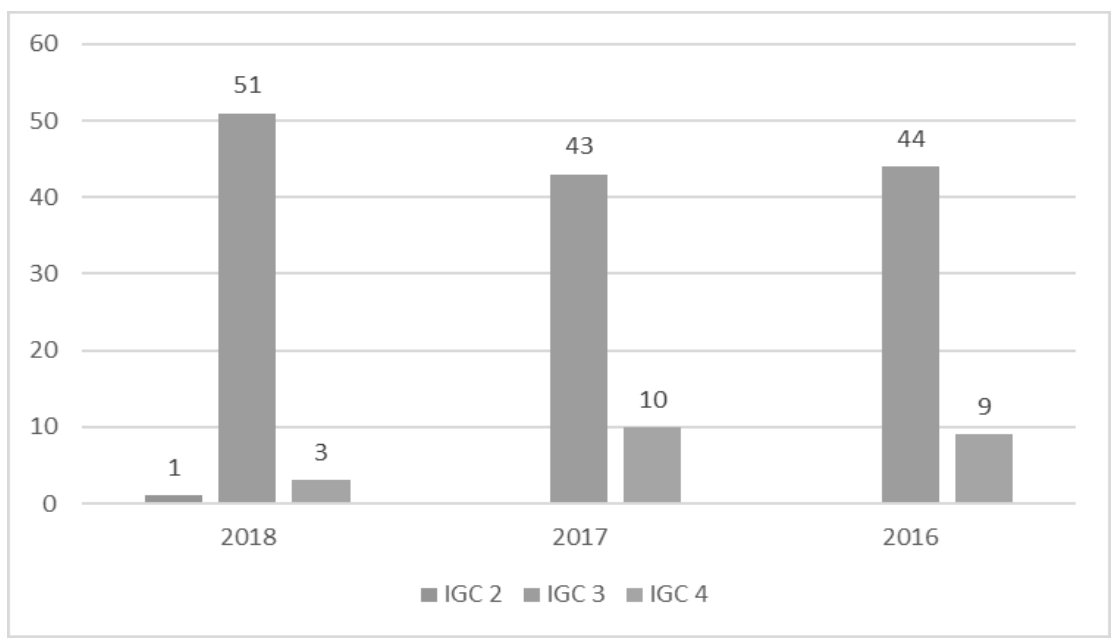

Fonte: Inep/MEC (2020)

Também foi possível observar que algumas instituições como a Universidade Estácio de Sá do Rio de Janeiro, Faculdade Estácio de Sá de Vila Velha, Faculdade Estácio de Sá de Ourinhos entre outras tiveram sua nota do IGC reduzida no decorrer dos anos. O grupo também ratifica o que apresenta a tabela 4 , onde a maioria das IES privadas possuem conceito 3 . 


\section{CONCLUSÃO}

Este trabalho se propôs a identificar e avaliar a qualidade das Instituições de Ensino Superior (IES) que possuem ações na Brasil Bolsa Balcão - B3 S.A, mediante os indicadores do Índice Geral de Cursos da Instituição (IGC), além evidenciar o atual panorama da Educação Superior no Brasil.

Inicialmente foi feito um levantamento documental para demonstrar a atual situação da Educação superior no Brasil, percebendo que as IES privadas são maioria, com maior número de Instituições, matriculas e alunos.

Em seguida, identificou-se as IES que possuem ações na Bolsa, em seguida, foi realizou-se um mapeamento das Companhias, e as empresas listadas foram Anima Holding S.A, Cogna Educação S.A, Ser educacional S.A e YDUQS Participações S.A.

Para avaliar a qualidade dessas IES, utilizou-se como indicador o IGC das Instituições controladas direta ou indiretamente pelas Companhias listada na B3. Logo, os resultados apresentados por essas instituições que são controladas por empresas de capital aberta possuem características semelhantes às demais, visto que a maioria das IES do Brasil apresenta IGC 3.

No entanto, as IES controladas pela Companhia Anima Holding S.A foram na contramão desses resultados. Obtiveram IGC 4 em sua maioria em todos os anos avaliados, apresentando um desempenho superior as concorrentes na avaliação submetida, é importante evidenciar que o grupo possui o menor número de Instituições se comparado as suas concorrentes listadas na Bolsa.

No que se refere aos principais resultados e características das IES, observou-se que a Cogna Educação S.A é a Companhia que possui maior número de alunos, maior número de instituições.

A partir do estudo percebe-se que as Instituições de Ensino Superior controladas pelas Companhias listadas na bolsa, possui grande quantidade de discentes e unidades espalhadas por todo País, mostrando sua força no ensino superior. Por fim, conclui-se que essas avaliações são de fundamental importância para traduzir as expectativas dos 
seus clientes (funcionários, alunos, professores e acionistas), servindo de auxílio para seus gestores estruturarem planos de ação e melhorias para que a instituição consiga crescer e manter-se competitiva frente às mudanças que ocorrem no mercado, além de mostrar credibilidade e o fator qualidade que tanto se busca.

\section{REFERÊNCIAS}

BITTENCOURT, H. R.; CASARTELLI, A. O.; RODRIGUES, A. C. M. Sobre o Índice Geral de Cursos (IGC). Rev. Avaliação, Campinas, v. 14, n. 3, p. 667-682, nov. 2009.

BITTENCOURT, H. R.; et al. Mudanças nos Pesos do CPC e seu Impacto nos Resultados de Avaliação em Universidades Federais e Privadas. Rev. Avaliação, Campinas, v. 15, n.3, p. 147-166, 2010.

BRASIL. Lei no 5.540, de 28 de novembro de 1968. Fixa normas de organização e funcionamento do ensino superior e sua articulação com a escola média, e dá outras providências. Diário Oficial, Brasília, 28 nov. 1968. Disponível em: <http://www.planalto.gov.br/ ccivil_03/leis/L5540.htm>. Acesso em: 03 Jul. 20.

. Lei no 9.131, de 24 de novembro de 1995. Altera dispositivos da Lei no 4.024, de 20 de dezembro de 1961, e dá outras providências. Diário Oficial, Brasília, 24 nov. 1995. Disponível em: <http://www.planalto.gov.br/ccivil_03/leis/L9131.htm>. Acesso em: 03 Jul. 20.

. Lei no 9.870, de 23 de novembro de 1999. Dispõe sobre o valor total das anuidades escolares e dá outras providências. Diário Oficial, Brasília, 23 nov. 1999. Disponível em: <http://www. planalto.gov.br/ccivil_03/leis/L9870.htm>. Acesso em: 03 Jul. 20.

BRITO, M. R. F. O SINAES e o ENADE: da concepção à implantação. Rev. Avaliação, Campinas, v.13, n.3, p. 841-850, 2008.

CHENG, Y. C.; TAM, W. M. Multi-models of quality in education. Quality assurance in Education, v. 5, n. 1, p. 22-31, 1997. 
COLOMBO, S. S.; RODRIGUES, G. M. Desafios da gestão universitária contemporânea. Penso Editora, 2011.

DAVID, M. V. Transformações na Educação Superior no Brasil e seus impactos na estrutura, estratégia e governança: o caso de três Universidades Federais de Minas Gerais. 2009. 232 f. Tese (Doutorado em Administração) - Universidade Federal de Lavras, Minas Gerais, 2009.

FREITAS, A. L. P. A auto-avaliação de instituições de ensino superior: uma importante contribuição para a gestão educacional. Revista Iberoamericana de Educación, Madrid, v.1, p. 1-15, 2004.

FREITAS, A. A. S. M. Avaliação da educação superior no Brasil e Portugal homogeneização ou diferenciação? Rev. Avaliação, v.17, n.1, p. 119-136, 2012.

GIL, A. C. Como elaborar projetos de pesquisa. 5. ed. São Paulo: Atlas, 2010.

GRAMANI, M. C. N.; DUARTE, A. L. de C. M. O impacto do desempenho das instituições de educação básica na qualidade do ensino superior. Revista Ensaio: Avaliação e Políticas Públicas em Educação, v.19, n.72, p. 679-702, 2011.

INSTITUTO NACIONAL DE ESTUDOS E PESQUISAS EDUCACIONAIS - INEP, Brasília, 2011. Disponível em: <http://inep.gov.br>. Acesso em 03 de jul. 2020.

LAUS, S.; MOROSINI, M. C. Internacionalización de la educación superior em Brasil, Colômbia: Banco Mundial em coedición com Mayol Ediciones, 2005.

OLDFIELD, B. M.; BARON, S. Student perceptions of service quality in a UK university business and management faculty. Quality Assurance in education, v. 8, n. 2, p. 85-95, 2000.

OYAMA, E. R. O negócio da educação superior: da educação-mercadoria ao capital financeiro. In: $6^{\circ}$ Colóquio Internacional Marx e Engels, 2009. 
PEIXOTO, M. C. L. Avaliação institucional externa no SINAES: considerações sobre a prática recente. Rev. Avaliação, Campinas, v. 16, n. 1, p. 11-36, 2011.

PETTA, M. C. L. O novo modelo de expansão privatista da Educação Superior: Desafio Sindical na Educação privada. Revista Conteúdo, n. 10, 2011.

POLIDORI, M. M. Política de avaliação de educação superior brasileira: provão, sinais, IDD, CPC, e ... outros índices. Rev. Avaliação, Campinas, v. 14, n. 2, p. 267-290, 2009.

POLIDORI, M. M.; FONSECA, D. G.; LARROSA, S. F. T. Avaliação institucional participativa. Rev. Avaliação, v.12, n.2, p. 333-348, 2007.

RIBEIRO, J. L. L. S. Avaliação das Universidades Brasileiras as possibilidades de avaliar e as dificuldades de ser avaliado. Rev. Avaliação, Campinas, v. 16, n. 1, p. 57-71, 2011.

SAMPAIO, H. M. S. Ensino superior no Brasil - o setor privado. São Paulo: Fapesp/Hucitec, 2000.

O setor privado de ensino superior no Brasil: Continuidades e transformações. Revista Ensino Superior Unicamp, n. 4, 2011.

SANTOS, L. C.; VASQUEZ, O. C. A pesquisa de clima organizacional como instrumento de suporte à avaliação nas instituições de ensino superior. Rev. Avaliação, v.17, n.1, p. 43-63, 2012.

STADTLOBER, S. C. Qualidade do Ensino Superior no Curso de Administração: A Avaliação dos Egressos. 2010. 132 f. Tese (Doutorado em Educação) - Faculdade de Educação, Porto Alegre, 2010.

TANG, C-W; WU, C-T. Obtaining a picture of undergraduate education quality: a voice from inside the university. Higher Education, v. 60, n. 3, p. 269-286, 2010. 
VERGARA, S. C. Projetos e Relatórios de Pesquisa em Administração. São Paulo: Altas, 2000.

VIEIRA, R. L. B.; FREITAS, K. S. de. O SINAES na universidade pública estadual: análise do processo de construção da avaliação interna na Universidade do Estado da Bahia (UNEB). Revista Ensaio: Avaliação e Políticas Públicas em Educação, v.18, n.68, p. 443-464, 2010.

YIN, R. K. Estudo de caso: planejamento e métodos. 4 ed. Porto Alegre: Bookman, 2010.

ZHONG, H. Returns to higher education in China: What is the role of college quality? China Economic Review, v. 22, n. 2, p. 260275, 2011.

ZOGHBI, A. C. P; OLIVA, B. T.; MARCONI, G. M. Aumentando a eficácia e a eficiência do ensino superior: a relação entre Enem e o Enade. Revista Est. Aval. Educação, v. 21, n. 45, p. 45-66, 2010. 


\section{OLHARES NEGROS NA EDUCAÇÃO FÍSICA: EM DEFESA DO DIREITO DE SER NEGRA}

Carolina Cristina dos Santos Nobrega

Introdução

O olhar negro na educação física é um olhar crítico de resistência, constituído nos movimentos sociais pela valorização da negritude, e, por meio da experiência ativista-pedagógica, exige a responsabilidade e o posicionamento político da área no enfrentamento e combate ao racismo. Assim, chama-se a atenção para a importância da centralidade no antirracismo; isso significa admitir a categoria "raça”, ou seja, a percepção racializada de docentes, de discentes, da comunidade escolar na recuperação das raízes, da identidade afro-brasileira, do passado, da história, e reconstruir a negritude a partir da rica herança africana (GUIMARÃES, 1995). Aqui, delineia-se a contribuição da educação física na educação antirracista, sendo este um elemento relevante na luta pelos direitos humanos, pela construção dos espaços de conscientização negra, pelo desenvolvimento dos saberes, narrativas, conceitos do movimento negro, pelo reconhecimento dos conhecimentos do eixo Sul na educação básica.

A conquista de direitos é uma luta constante no cotidiano histórico das vidas negras, e as nossas conquistas estão sempre em risco. Nós, negras(os)/pretas(os) e aliadas(os), na luta antirracista, percebemos um racismo mais explícito e violento. Diante disso, as relações raciais já 
não correspondem mais à ideia do mito da democracia racial; e com um agravamento, isto é, está cada vez mais presente o genocídio da juventude negra/preta brasileira, pois nascemos suspeitos. Somos sempre um corpo negro suspeito. Assim, naturaliza-se a morte (CARNEI$\mathrm{RO}, 2017)$.

Nesse ativismo pedagógico, percebem-se as estratégias de enfrentamento na educação - em especial, na educação física -, através de múltiplas vozes e iniciativas, principalmente a ação das mulheres-professoras negras, no combate ao genocídio, ao epistemicídio, às violências e à subalternização de culturas. Temos, aqui, a reeducação, a partir da contribuição do pensamento feminista negro, do movimento mulheres negras, na formação de sujeitos históricos antirracistas que exercem o direito à diferença, à diversidade; na produção de ciência, conhecimento; no protagonismo negro, logo, efeitos positivos na luta pela formação antirracista e pelo desenvolvimento da negritude nas instituições. Por isso, o debate a respeito das diferenças, diversidades e desigualdades, sob a perspectiva racial, é um desafio complexo, contínuo e necessário, que extrapola a letra da lei, exigindo um movimento dinâmico-dialético, na prática docente, entre a ação e o pensamento crítico a respeito da ação.

Nessa circunstância, a ideia de acoplamento (educação física escolar "e" relações étnico-raciais) é dispensável, uma vez que os conflitos raciais estão presentes na educação física, atualizam-se, legitimam-se, perpetuam-se e isso exige muito mais que práticas pedagógicas esporádicas, superficiais ou/e um tema isolado no projeto direitos humanos que afirma a branquitude, pois falamos sobre a condição negra nas escolas, no contexto acadêmico e na sociedade brasileira.

\section{Os caminhos para entender o racismo}

A nossa luta antirracista é contínua. A violação institucionalizada dos nossos direitos esteve presente durante quase 400 dos 500 anos na história deste país, portanto, é inquestionável a existência do racismo, sendo este uma violência extremamente perversa que nos desumaniza o tempo todo, alertando para a ausência de reconhecimento da nossa própria condição humana. Assim, 
Nós e nossa realidade com o racismo nos tornamos visíveis, faladas/os e até mesmo escritas/os, não porque [...] possamos estar em perigo ou em risco, ou precisar de proteção legal, mas sim porque tal realidade desconfortável perturba a estável imunidade branca. (KILOMBA, 2019, p. 72).

É um desafio e uma complexidade para as ciências humanas compreenderem a origem e o desenvolvimento do racismo na História; por isso, o presente texto ressalta o debate entre os estudos que discutem raça, relações raciais e o fenômeno do racismo no Brasil. Nesse enfoque, enfatizaremos a identidade, a representatividade e a imagem do corpo negro, e a relevância desses elementos na formação antirracista.

Nessa perspectiva, apresenta-se o fenômeno racismo num espaço histórico e social a partir da categoria raça na modernidade, no qual o racismo pode ser compreendido como uma construção ideológica. Percebe-se os seus sinais a partir do século XVI, com a compreensão sistemática de conceitos e valores construídos pela civilização europeia, quando estes se relacionam com a diversidade humana, e, posteriormente, concretiza-se com as ideias científicas sobre a categoria raça no século XIX (SCHUCMAN, 2010). Segundo Guimarães (1999), adotou-se a errônea visão sobre a biologia humana, expressa pelo conceito "raça". Isso significa justificar a subordinação permanente de indivíduos e populações, quer dizer, as desigualdades sociais, através da classificação de pessoas com base nos conceitos de raças superiores e inferiores. Porém, a partir do século XX, esses conceitos foram substituídos e alterados através da referência cultural, resultando em culturas superiores e culturas inferiores; assim, conserva-se o processo de hierarquização entre a civilização branca europeia (cultura superior) e as civilizações africanas (cultura inferior) como justificativa-padrão para o tratamento e manutenção da desigualdade, alimentando a interiorização do sentimento de inferioridade.

Moore (2007) expõe outra perspectiva, pois para ele nos condicionamos com a ideia de que o racismo se constituiu, primeiramente, por vias ideológicas, como reflexo de uma manipulação de segmentos interessados na organização, na dominação, no controle social. Mas “[...] o racismo não se estrutura em torno de um conceito biológico de raça, 
nem a partir da escravização dos(as) africanos(as), mas sim a partir de um dado universal inegável, o fenótipo" (MOORE, 2007, p. 22). Portanto, há uma profundidade histórica maior que os quinhentos anos de hegemonia europeia a respeito do mundo. $\mathrm{O}$ autor alerta sobre a necessidade de uma reorientação epistemológica e sinaliza que muitas pesquisas analisam a questão racial e o racismo a partir do século XVI, priorizando o período seguinte, a Segunda Guerra Mundial; portanto, é necessário problematizar o racismo para além deste olhar restrito, pois o projeto moderno (num entendimento sistemático e racializado da diversidade humana, realizado nos séculos XVIII e XIX), "[...] apenas foi possível em função do critério fenotípico em escala planetária" (MOORE, 2007, p. 22).

Segundo Moore (2007), na Antiguidade, o racismo foi continuamente uma realidade sociocultural pautada unicamente no fenótipo (antes de ser político-econômico). É fenótipo, "não os genes, que configura os fantasmas que nutrem o imaginário social; que servem de linha de demarcação entre os grupos raciais e como ponto de referência em torno do qual se organizam as discriminações 'raciais"” (MOORE, 2007, p. 22).

O progresso da ciência (nos últimos cinquenta anos do século XX) explica que o conceito raça na biologia foi um grande equívoco do século XIX, entendendo a sociedade do ponto de vista orgânico, e isso reduz a análise, através do determinismo biológico que anula o processo histórico. Insistir na existência da "raça" do ponto de vista da genética é reafirmar o racismo biológico e, nesse sentido, "raça" é um conceito cientificamente inoperante (GOMES, 2003). "Porém, raça existe: ela é uma construção sociopolítica, o que não é o caso do racismo, um fenômeno que antecede sua própria definição” (MOORE, 2007, p. 38).

Segundo Schucman (2010), o racismo se atualiza, permanece na sociedade, uma vez que há manutenção das desigualdades, conservando as posições de poder e privilégios para brancos, assim como os argumentos, discursos a respeito das diferenças humanas que podem ser ressignificados (considerando o momento histórico do contexto e do jogo político) para legitimar os processos de exclusão e de submissão; portanto, não é necessária a ideia de raça legitimada pela ciência para que exista racismo. 
Segundo Guimarães (2004), a palavra "racismo" tem vários significados diferentes na linguagem do cotidiano, na literatura, na mídia. Refere-se a uma doutrina; sendo essa científica, não científica, afirma a existência das raças humanas diferenciando as habilidades das mesmas num processo hierárquico de qualidades psicológicas, físicas, morais e intelectuais. Para as doutrinas que tratam o racismo na ótica da superioridade ou inferioridade entre as raças, pode-se dizer que essa crença é interpretada como "racialismo", isto é, a justificativa racista, perversa e desumana expressada na diferença de tratamento e de estatuto social entre os diversos grupos étnicos presentes nas sociedades ocidentais e americanas. Além disso, o racismo também se reporta às atitudes, preferências, gostos que são ensinados na concepção da superioridade racial, de acordo com o plano moral, físico, estético, intelectual.

O racismo é " [...] qualquer fenômeno que justifique as diferenças, preferências, privilégios, dominação, hierarquias e desigualdades materiais e simbólicas entre seres humanos, baseado na ideia de raça" (SCHUCMAN, 2010, p. 44).

Segundo Munanga (2006), os racismos contemporâneos dispensam o conceito raça. Muitos países ocidentais praticam o racismo antinegros e antiárabes, dispensando a ideia de raças superiores e inferiores, com base nas diferenças identitárias e culturais. É importante observar que "raça" é somente um conceito (nas propostas de combate ao racismo), não é real; do mesmo modo, na utilização dos termos: etnia, identidade ou diversidade cultural, já que "[...] o racismo é uma ideologia capaz de parasitar em todos os conceitos" (MUNANGA, 2006, p. 53).

Para Moore (2007), o racismo (um fenômeno fundamentalmente antinegro) e o sexismo (antimulher) são dinâmicas construídas historicamente; são fenômenos universais, transversais (atemporais) e transcorrem por todas as culturas e todas as civilizações. A origem de ambos se perde no tempo; portanto, não são ideologias, não são parte de produções intelectuais conscientes.

O autor chama a atenção para a necessidade de perceber a confusão que há entre racismo e preconceito. Isso significa entender que nem sempre o preconceito manifesta o racismo; porém, o racismo causa os 
piores e mais violentos preconceitos, por exemplo, a naturalização da superioridade e inferioridade racial entre os seres humanos (MOORE, 2007). Sendo assim, o racismo tem a ver como uma forma particular de ódio; um ódio direcionado "[...] especificamente contra toda uma parte da Humanidade, identificada a partir do seu fenótipo. É o fenótipo dos povos denominados negros que suscita o ódio: um ódio profundo, extenso, duradouro [...]" (MOORE, 2007, p. 283). Assim sendo, apresenta-se, no racismo, uma consciência mais violenta, pois há a intenção e a vontade de exterminar o(a) outro(a) (o outro negro, a outra negra), de anular a sua humanidade.

Segundo Almeida (2016),

O racismo é uma ideologia, desde que nós possamos entender a ideologia como prática material, ou seja, a ideologia não pode ser considerada única e simplesmente [..] como uma imagem falsa do mundo, mais do que isso, a ideologia tem que ser considerada como um processo de subjetivação, como formação da subjetividade, nossos sentimentos, nossa visão de mundo, a forma com que o imaginário socialmente construído é incorporado [...], é fundamental compreender isso, a ideologia nesse sentido.

Por isso, após este debate, considera-se que, para entender o racismo, é necessário olhar para a questão racial e de gênero. Cabe enfatizar a necessidade de entender que o Estado e o Direito são questões estruturais; para compreender o racismo é preciso ter este entendimento. "Não basta simplesmente estudar relações raciais, os efeitos psicológicos do racismo, sem que nós entendamos como o racismo se reproduz enquanto relação social. O racismo é relação social" (ALMEIDA, 2016). À vista disso, ambas as perspectivas apresentam o racismo com base nas suas formas, expressões sociais e históricas específicas. Porém, há um ponto em comum: o racismo é reproduzido por uma série de mecanismos de poder. Diante disso, chama-se a atenção para o racismo e suas reproduções no capitalismo, que apresenta outra forma, dentro das relações sociais que também têm a sua especificidade histórica (ALMEIDA, 2016). 
O corpo negro e suas trajetórias são marcados pelo racismo, pelas teorias racistas ${ }^{21}$; e essas marcas podem homogeneizar os indivíduos e naturalizar identidades, julgando, limitando quem somos e determinando a nossa condição e o lugar social (FERNANDES; SOUZA, 2016). Segundo Rodrigues (2012), o corpo do(a) africano(a) escravizado(a) e seus descendentes foi considerado uma mercadoria; as características biológicas, físicas do(a) negro(a), o cabelo crespo, o nariz achatado, os lábios grandes e a pele negra foram características marcadas e associadas a seres primitivos e bárbaros que habitavam a África, um lugar repleto de magia. Igualmente, houve a construção da imagem do corpo negro relacionado a "demônios bíblicos". Observa-se que "[...] a ideia de raça dos sujeitos passou a ser deduzida por meio dessas marcas corporais, dedução que resultou na essencialização das identidades" (FERNANDES; SOUZA, 2016, p. 105). Esta visão equivocada sobre o corpo negro sustenta a ideia de que as características físicas e biológicas (marcadas) definem o caráter e a personalidade da população negra/preta.

É preciso intervir criticamente, descolonizar e valorizar a imagem da população negra/preta. Numa sociedade multirracial, há uma referência na qualidade de padrão estético-racial; sendo assim, o controle das imagens é um importante mecanismo para o sistema de dominação racial e os supremacistas brancos identificaram isso (HOOKS, 2019). Na escola, espaço de formação, a insistência na ausência do desenvolvimento dos saberes estético-corpóreos, políticos e identitários legitima a colonização e desvalorização da autoestima e autoimagem negra; assim, crianças e jovens negros se sentem reféns da sua própria imagem, pois

“[...] a dor de aprender que não podemos controlar nossas imagens, como nos vemos (se nossas visões não forem descolonizadas) ou como somos vistos, $[\ldots]$ arrebenta [...] nossos esforços de construir o ser e de nos reconhecer". (HOOKS, 2019, p. 35).

21 "Essas teorias, apesar de serem consideradas ultrapassadas, ainda se fazem presentes em formas de interpretar a realidade racial brasileira" (GOMES, 2017, p. 84). 
Diante disso, o processo de estereotipação expõe que o modelo social não é o corpo negro, pois este é inaceitável (e quando nega a negritude pode ser tolerado); já o corpo branco é o modelo, é a norma, é a expressão de superioridade, universalidade e humanidade.

Então, pergunta-se: “[...] como uma sociedade racista que discrimina com base no fenótipo não pode ser dividida em brancos e não brancos, em brancos e negros?” (MOORE, 2007, p. 16). Pôr à vista essa realidade é perceber que esta divisão é inerente à história e à estrutura da sociedade, no qual o racismo à brasileira institui a insensibilidade humana, fragmenta-nos, pois cria fronteiras simbólicas, materiais, rígidas, estabelecendo binarismo identitários (ser ou não verdadeiramente negro, ser ou não ser verdadeiramente branco); assim, a identidade do que é ser negra(o) (considerado não humano) se opõe ao que é ser branco(a) (modelo social), fundamentado em estereótipos, dificultando o diálogo entre os diferentes grupos humanos (FERNANDES; SOUZA, 2016, p. 106). Nessa perspectiva, o conflito racial é uma contínua realidade experienciada, de tal modo que não é possível escondê-lo, considerando que ele organiza a estrutura de classes sociais na sociedade brasileira, pois há no poder uma hegemonia absolutamente branca e nas bases, nós, uma maioria negra (CARNEIRO, 2017). Do mesmo modo, há desde sempre a contradição racial na sociedade brasileira, pois se percebe na construção do pensamento social brasileiro "[...] seja à direita, com o mito da democracia racial, seja à esquerda, via luta de classes, que em comum obscureceu o valor da raça na estruturação das mazelas sociais, das desigualdades, das contradições desse país" (CARNEIRO, 2017, p. 15). Nessa sociedade contraditória, o Estado (na qualidade de organização política) é a principal instituição do capitalismo; sendo assim fundamental para reproduzir o discurso de unidade, alimentar um discurso nacionalista, por meio de ações de poder e reprodução ideológica, reproduzindo padrões de comportamento, padrões éticos e estéticos, afirmando a branquitude (ALMEIDA, 2016).

A respeito dos binarismos identitários, é preciso superá-los. Isso significa entender a diferença inserida na própria diferença, pois não se questiona as diferenças que existem entre a população branca no 
próprio grupo das pessoas que se autodeclaram brancas, do mesmo modo que há diferenças entre a população negra/preta no próprio grupo das pessoas que se autodeclaram negras/pretas; portanto, diferenças na subjetividade, na experiência de vida, no comportamento, na identidade racial, no caráter, entre outras características. Dessa forma, os rótulos, os estereótipos são construídos, produzidos em cada lado da oposição binária, certificados pela cultura como verdade absoluta, única via de entendimento histórico, ocultando a multiplicidade que há no jogo das diferenças (SCOTT22, 1988 apud SCHUCMAN, 2010; NOBREGA, 2019).

Segundo Stuart Hall, para compreender a identidade é necessário reconhecer a construção da mesma, por meio da diferença. Nesse sentido, percebe-se que as diferenças raciais “[...] não nos constituem inteiramente, somos sempre diferentes e estamos sempre negociando diferentes tipos de diferenças - de gênero, sexualidade e de classe" (HALL, 2003, p. 346). De outro modo, os significados atribuídos às palavras "negro/preto", que desconsideram as diferenças, apresentam uma categoria de essência invalidando a diversidade, a história, o contexto sociocultural, para sustentar a ideia do negro/preto "universal" (FERNANDES; SOUZA, 2016).

Nós, negras(os)/pretas(os), temos um ponto em comum na nossa sobrevivente experiência com o racismo à brasileira, com os estereótipos, com as cicatrizes; desse modo, nós recuperamos as nossas raízes e, em legítima defesa, criamos estratégias de enfrentamento e combate a essas violências; portanto, há nesse processo de construção identitária a "autodefinição". Por outro lado, diante dessas violências (o racismo e o processo de estereotipação) é preciso lembrar-se da identidade estereotipada, atribuída à nós (população negra/preta), quer dizer, a identidade coletivamente atribuída, que é fictícia e está no imaginário social brasileiro e se refere à intenção de inferiorizar esse grupo e suas diferenças (FERNANDES; SOUZA, 2016).

"A identidade atribuída é dotada exclusivamente de um caráter essencializador, na medida em que relações de poder estão envolvidas na

22 SCOTT, Joan. Desconstructing Equality-versus-Difference: or the uses of Poststructuralist Theory for Feminism. Feminist Studies, v. 14, n. 1, p. 33-50, Spring 1988. 
essencialização do que é ser negro" (FERNANDES; SOUZA, 2016, p. 109). De outra maneira, a identidade de autodefinição (autoatribuída) é um posicionamento. É importante evidenciar que a palavra "autodefinição" não se refere à ideia de uma identidade acabada, estável, e sim o reflexo de organização, posicionamento político de um grupo humano, cujo sentimento de pertencimento étnico-racial, negritude e a identificação com a luta antirracista são percebidos como propósito de vida; há a busca por se sentir enraizado na cultura afro-brasileira, a afirmação das matrizes africanas, porém, sem desconsiderar as situações de violência (preconceito, racismo, discriminação) às quais estamos submetidos(as) (NOBREGA, 2019).

Esta reflexão nos aproxima da imagem do racismo, da representação social, evidenciando o papel fundamental que esses elementos têm na formação das relações étnico-raciais, raciais e antirracistas. Na sociedade brasileira, assim como em outras, sabe-se as maneiras pelas quais a população negra/preta e suas experiências foram submetidas, forjadas na narrativa hegemônica e nos regimes dominantes; o efeito disso institui sentidos de "normalidade" e "anormalidade", determinando como norma padrão o branco (homem, branco, proprietário, heterossexual, não deficiente) (FERNANDES; SOUZA, 2016). Assim, a branquitude marca, define os outros grupos humanos, com o privilégio da norma e da normalidade (KILOMBA, 2016). Desse modo, nós, negras/negros, somos os "diferentes", os "outros", pois se naturaliza a lógica da desumanização, os modos de apropriação dos corpos, formas de hierarquização, classificação das diferenças para a produção, manutenção das desigualdades, que autorizam o ato de discriminar e excluir. A branquitude exerceu essa violência, por meio do poder de fazer com que nos olhássemos e experimentássemos a nós mesmos como "outros". Somos sujeitados a esse conhecimento desde as relações coloniais, perpassando todas as esferas da vida social. Mais que dominação, é o ajustamento subjetivo da norma (HOOKS, 2019).

Falar de educação antirracista, educação física antirracista é exigir uma aproximação com a história e atuação político-educativa do movimento negro, bem como potencializar o debate sobre imagem, identidade, representatividade, raça e racismo nos espaços de formação docente e nas escolas brasileiras. Dada a importância da centralidade 
do antirracismo na educação, é fundamental observar que as principais ações de combate ao racismo, de visibilidade à história e cultura afro-brasileira e africana, foram motivadas pela Lei $n^{\circ}$ 10.639/2003, que torna obrigatório o ensino de História e Cultura Afro-brasileira e Africana nos currículos das escolas (públicas e particulares). Essa lei foi regulamentada pela Resolução CNE/CP n 1/2004 e pelo Parecer $\mathrm{CNE} / \mathrm{CP}$ n 03/2004, que instituem as Diretrizes Curriculares Nacionais para a Educação das Relações Étnico-raciais e para o Ensino de História e Cultura Afro- brasileira e Africana. Nesse contexto, destaca-se a Lei Federal no 12.288/2010, que institui o Estatuto da Igualdade Racial (GOMES, 2017). Temos, aqui, as ações do movimento negro que desenvolveram um intenso debate público a respeito do racismo, questionando as políticas públicas e as suas responsabilidades na superação das desigualdades raciais, promovendo a construção de possibilidades de uma vida digna para a população negra/preta; essas reivindicações conquistaram o espaço de existência afirmativa no Brasil.

\section{Educação física e escola}

Esta pesquisa promove uma reflexão sobre a contribuição pedagógica em educação física na construção da educação antirracista, com foco na pedagogia da diversidade. "É no contexto da pedagogia da diversidade que o estudo dos saberes emancipatórios construídos, sistematizados e articulados pelo Movimento Negro pode ser contemplado" (GOMES, 2017, p. 136). Ela tenciona a escola, o currículo tradicional, suas narrativas hegemônicas e sua relação com o poder e o conhecimento, valorizando, assim, os conhecimentos do eixo Sul do mundo (GOMES, 2017).

Do ponto de vista histórico, a pedagogia da diversidade resulta das ações dos movimentos sociais, por exemplo, o movimento da educação popular e a contribuição de Paulo Freire. Pode-se dizer que a luta por essa proposta pedagógica está presente nos movimentos sociais desde os anos de 1950 e 1960, consequentemente, um desafio para a educação (GOMES, 2017). O mencionado processo histórico consiste em perceber que a ação de ensinar é também uma decisão política, isso sig- 
nifica entender o papel da escola na conquista de igualdade de direitos, consequentemente, de cidadania crítica (NOBREGA, 2019).

Nessa perspectiva, enfatiza-se a finalidade de descolonizar o currículo da educação física, considerando a intervenção pedagógica e a necessária mudança epistemológica que propõe a pedagogia histórico-crítica e a pedagogia da diversidade (considerando a adoção de novas posturas pedagógicas) baseadas nos saberes docentes para a discussão criadora de dois aspectos que merecem a atenção dos docentes que debatem a cultura afro-brasileira no Brasil (especialmente na educação física): o corpo, entendido como expressão da identidade afro-brasileira, e a manipulação do cabelo (GOMES, 2003; NOBREGA, 2019).

Nesse movimento, entende-se a prática desse componente curricular como linguagem, com base no pensamento feminista negro, pois se busca uma educação física fundamentada nas epistemologias do olhar negro que produz, apropria-se, vive a prática corporal nos significados e sentidos da negritude.

O conhecimento é poder, e reproduz as relações raciais e de gênero. Nota-se que a teoria não é universal, não é neutra; então, há uma dívida teórica, conceitual da educação física sobre as realidades e histórias negras, escrita por nós, negras/negros, considerando as nossas escrevivências e subjetividades negras, de tempos e lugares específicos.

Falar de epistemologia é defender a ideia de que há várias formas de conhecimento, e de que é preciso escolher a que favorece a criação de imagens despadronizadas e de atitudes de questionamento e inconformismo diante delas (GOMES, 2017). Assim sendo, a epistemologia (a ciência da aquisição de conhecimento) determina os temas, métodos e os paradigmas, "[...] narrativas e interpretações que podem ser usadas para explicar um fenômeno, isto é, a partir de qual perspectiva o conhecimento verdadeiro pode ser produzido" (KILOMBA, 2016).

Assim, cria-se novas configurações de conhecimento e poder para pensar uma educação física antirracista, desenvolvendo relações dialógicas com diferentes grupos humanos, a partir do nosso universo negro. Dessa maneira, compreende-se esse componente curricular a partir das perspectivas dos conhecimentos até então "subjugados”, no qual a diversidade é valorizada nas particularidades que distinguem a 
população negra/preta dos outros grupos étnicos, conforme orienta o Parecer CNE/CP n 3/2004, priorizando os saberes do movimento negro (NOBREGA, 2019).

O racismo é sustentado por práticas do Estado. As instituições são mantidas pelo Estado; logo, relações sociais do capitalismo. "Todo racismo é estrutural e todo racismo tem que ter uma dimensão institucional" (ALMEIDA, 2016). A escola mantém a estrutura, temos, aqui, o racismo institucional que abriga as desigualdades, as discriminações e, nessa lógica, forma os indivíduos. Nessa interpretação, não cabe desconsiderar a problemática dessa violência que não nos reconhece como seres humanos. Nessa condição, as relações étnico-raciais são temas que compõem o projeto de direitos humanos (que afirma a branquitude) ou um projeto específico (com começo, meio e fim); não há valorização da negritude, pois são abordagens isoladas, esporádicas, servindo a lógica que rege o capitalismo (NOBREGA, 2019). É importante lembrar nas escolas que os direitos humanos são resultados temporários na busca pelo acesso aos bens necessários para uma vida digna. Segundo Bento (2011, p. 556),

Portanto, não se trata de "saber conviver", mas considerar que a humanidade se organiza e se estrutura na e pela diferença. Se tivermos essa premissa evidente, talvez possamos inverter a lógica: não se trata de identificar "o estranho" como "o diferente", mas de pensar que estranho é ser igual [...].

À vista disso, é preciso desconstruir a branquitude, entender a dominação do ponto de vista da(o) dominada(o), tratando as situações de contradição e conflito que acontecem nas relações raciais, sem justificá-las, escondê-las, naturalizá-las e normalizá-las. Isto posto, o encontro entre as raças é possível, desde que haja reconhecimento do impacto do racismo na percepção de quem domina e quem é dominado, rompendo o silenciamento (HOOKS, 2019). Pôr à vista essa realidade é exigir uma mudança de posicionamento defendida nas teorias feministas que se tornou fundamental para a construção de uma sociedade antirracista/antissexista/anticapitalista, a necessidade de desenvolver e valorizar a negritude no ambiente escolar. Segundo Gomes (2017, p. 82), 
Embora, tenha a sua origem na cor da pele negra, a negritude não é necessariamente de ordem biológica. Ela se refere à história comum que liga de uma maneira ou de outra todos os grupos humanos que o olhar do mundo ocidental branco reuniu sob o nome de negros.

Segundo Munanga (1990), historicamente, a negritude é consequência e resultado do racismo, é uma resposta racial à violência racial branca. É em legítima defesa que a negritude se transforma num movimento antirracista, ideológico-político para a libertação da população negra/preta. Portanto, é preciso desenvolver a negritude, pertencer a esse mo(vi)mento; para isso, a educação física deve estabelecer uma intimidade entre o conteúdo que se ensina e a experiência racial/social. Isso significa racializar a educação física para politizá-la, pois a mesma abarca questões históricas, culturais, sociais, políticas e econômicas que perpassam o desenvolvimento dos conteúdos, uma vez que esses contribuem para a leitura crítica dos temas de estudo e das práticas corporais das(os) educandas(os) (NOBREGA, 2019). É tarefa fundamental de docentes-pensadoras(es) críticas(os) o rompimento com os modelos hegemônicos, promovendo debates com os discentes sobre a realidade concreta, no qual se associa o conteúdo da área com a realidade em que o racismo e outras violências são constantes. É preciso entender que "o racismo é a nossa pandemia permanente" (PASSOS, 2020).

A nossa representação negra no ensino da educação física tem a ação político-pedagógica de chamar a atenção para o processo de incorporação dos conceitos, movimentos e narrativas do Movimento Negro no desenvolvimento dos conteúdos afro-brasileiros. Sendo assim, observa-se a perspectiva interdisciplinar, isto é, o intenso e profundo diálogo com a história, a arte e literatura na educação física, sem perder a especificidade da área, considerando os seus limites (NOBREGA, 2019). Nesse contexto da história e cultura afro-brasileira e africana, nós começamos a construir linguagens que desobedecem um conceito do conhecimento extremamente patriarcal, masculino e branco. Assim, os temas de estudo na educação física evidenciam outra história possível; são 
eles: "Negritude, Pan-Africanismo, Consciência Negra, Brasil, Quilombismo, Racismo como dispositivo de controle" (LIMA; LIMA, 2016, p. 73).

É preciso ir além da inserção dos conteúdos afro-brasileiros na educação física (ritmos, jogos, danças, capoeira e futebol). É necessário incorporar, desenvolver o sentimento de pertencimento, valorizando as suas narrativas, conceitos, símbolos e significados próprios. Um dos caminhos para essa valorização é a participação nos Núcleos de Estudos Afro-Brasileiros (NEAB) na graduação (licenciatura e bacharelado) e pós-graduação em educação física, bem como a contribuição de pesquisas sobre a temática na pós-graduação stricto sensu e lato sensu na área e na educação para pensar as relações antirracistas, assumindo o compromisso com a educação antirracista e com a formação docente antirracista/antissexista.

\section{Considerações finais}

O olhar negro na educação física é uma perspectiva que busca intervir e introduzir outra dinâmica nas escolas, promovendo pesquisas no contexto dos direitos humanos da população negra/preta, vislumbrando para além da esfera do direito, isto é, o reconhecimento desses seres humanos de histórias possíveis. "História para nós, negros/negras, é determinação e campo de batalha” (ALMEIDA, 2016). Isso exige um ensino político, por meio de reflexões profundas sobre o racismo, que apontam a urgência de potencializar o desenvolvimento da negritude e a desconstrução da branquitude nas práticas pedagógicas (destacando o avanço das relações raciais/sociais no capitalismo). Neste sentido, ao tomar a revisão da literatura como procedimento, percebe-se a importância dos debates a respeito da representatividade, identidade, imagem, raça e representação; conflitos e confrontos raciais, na perspectiva da interseccionalidade (raça, gênero, sexualidade e classe), assim como a relevância do movimento mulheres negras e movimento negro. Portanto, defende-se na área a luta pelo direito à educação antirracista no processo de emancipação social. 


\section{Referências}

\section{ALMEIDA, Silvio Luiz de. Estado, Direito e Análise materialista} do racismo. 2016. Disponível em: https://www.youtube.com/ watch?v=Pyn40G76kBI. Acesso em: 7 jul. 2020.

BENTO, Berenice. Na escola se aprende que a diferença faz a diferença. Revista Estudos Feministas, Florianópolis, v. 19, n. 2, p. 549-559, maio/ago. 2011.

BRASIL. Lei no $\mathbf{1 0 . 6 3 9}$, de 9 de janeiro de 2003. Altera a Lei $\mathrm{n}^{\mathrm{o}}$ 9.394, de 20 de dezembro de 1996, que estabelece as diretrizes e bases da educação nacional, para incluir no currículo oficial da Rede de Ensino a obrigatoriedade da temática "História e Cultura Afro-Brasileira", e dá outras providências. Brasília, DF, 2003. Disponível em: http://www.planalto.gov.br/ccivil_03/Leis/2003/ L10.639.htm. Acesso em: 17 jan. 2017.

. Ministério da Educação. Conselho Nacional da Educação. Pa-

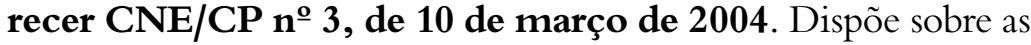
Diretrizes Curriculares Nacionais para a Educação das Relações Étnico-Raciais e para o Ensino da História e Cultura Afro-Brasileira e Africana. Brasília, DF, 2004. Disponível em: http://portal. mec.gov.br/cne/arquivos/pdf/003.pdf. Acesso em: 11 abr. 2017.

CARNEIRO, Sueli. Sobrevivente, testemunha, porta-voz. [Entrevista]. Revista Cult, São Paulo, n. 223, p. 13-20, 2017.

FERNANDES, Barboza Viviane; SOUZA, Maria Cecilia Cortez Christiano de. Identidade Negra entre exclusão e liberdade. Revista do Instituto de Estudos Brasileiros, São Paulo, n. 63, p. 103-120, abr. 2016.

GOMES, Nilma Lino. Cultura negra e educação. Revista Brasileira de Educação, Rio de Janeiro, n. 23, p. 75-85, maio/ago. 2003.

O movimento negro educador: saberes construídos nas lutas por emancipação. Petrópolis: Vozes, 2017. 
guimarães, Antonio Sérgio Alfredo. Preconceito e discriminação: queixas de ofensas e tratamento desigual dos negros no Brasil. São Paulo: Editora 34, 2004.

. Raça e os estudos de relações raciais no Brasil. Novos Estudos CEBRAP, São Paulo, n. 54, p. 149-156, jul. 1999.

Racismo e anti-racismo no Brasil. Novos Estudos CEBRAP, São Paulo, n. 43, p. 26-44, nov. 1995.

HALL, Stuart. Da diáspora: Identidade e mediações culturais. Tradução de Adelaine La Guardiã Resende. Belo Horizonte: Editora UFMG; Brasília, DF: Representação da UNESCO no Brasil, 2003.

HOOKS, bell. Olhares negros: raça e representação. São Paulo: Elefante, 2019.

KILOMBA, Grada. Descolonizando o conhecimento: uma palestra-performance de Grada Kilomba. 2016. Tradução de Jéssica Oliveira. Disponível em: http://www.goethe.de/mmo/priv/ 15259710-STANDARD.pdf. Acesso em: 20 fev. 2020.

Memórias de uma plantação: episódios de racismo cotidiano. Rio de Janeiro: Cobogó, 2019.

LIMA, Maurinete; LIMA, Eugênio. Ocupação Abdias Nascimento. São Paulo: Itaú Cultural, 2016.

MOORE, Carlo. Racismo e sociedade: novas bases epistemológicas para entender o racismo. Belo Horizonte: Mazza, 2007.

MUNANGA, Kabengele. Algumas considerações sobre "raça", ação afirmativa e identidade negra no Brasil: fundamentos antropológicos. Revista USP, São Paulo, n. 68, p. 46-57, dez./fev. 2006.

. Negritude afro-brasileira: perspectivas e dificuldades. Revista de Antropologia, São Paulo, n. 33, p. 109-117, 1990.

NOBREGA, Carolina Cristina dos Santos. Educação antirracista no município de São Paulo: análise das experiências pedagó- 
gicas na área de educação física escolar. 2019. 216 f. Dissertação (Mestrado em Educação) - Universidade Federal de São Paulo, Guarulhos, 2019.

PASSOS, Joana Célia dos. [Racismo institucional]. In: SINDES. Racismo institucional diante da pandemia: live com a participação de Roseni Rodrigues da Silva, Patrick de Assis Rosa, Enedina Martins, Joana Célia dos Passos e Fábio Garcia. 27 jun. 2020. Disponível em: https://www.youtube.com/watch?v=wj-2rjAqNVw. Acesso em: 27 jun. 2020.

RODRIGUES, Joyce Maria. A relação do corpo para a construção da identidade negra. In: FELINTO, Renata (org.). Culturas africanas e afro-brasileiras em sala de aula: saberes para professores, fazeres para os alunos: religiosidade, musicalidade, identidade e artes visuais. Belo Horizonte: Fino Traço, 2012. p. 61-66.

SCHUCMAN, Lia Vainer. Racismo e Antirracismo: a categoria raça em questão. Psicologia Política, São Paulo, v. 10, n. 19, p. 41-55, jan./jun. 2010. 


\section{CRIANÇAS NEGRAS NO BRASIL ESCRAVISTA: UMA INFÂNCIA NEGADA}

Luana Fernanda Rodrigues dos Santos

Introdução

As transformações que perpassaram os conceitos de criança e de infância, ao longo do tempo, deram-se de forma lenta e gradual e revelam não só as ressignificações dos sentimentos e das atitudes humanas, mas as ambições e ambivalências de sociedades elitistas, patriarcais e opressoras. Na perspectiva da escravidão brasileira, a infância das crianças negras foi profundamente (trans)formada pelos interesses econômicos dos senhores de escravos, sem ter a oportunidade de ser legitimada a despeito da cor da pele e do status social desses pequenos.

Para compreender essa realidade da infância escrava no país, inicialmente, pretende-se mostrar, pela historiografia, a defesa da manutenção do sistema escravagista e como isso favoreceu e ou reforçou a invisibilidade da criança negra, principalmente por sua condição cativa. Procura-se entender, também, que a depreciação da infância negra deu-se não só pelo racismo e pela opressão reinantes no Brasil, mas porque a criança em si, histórica e socialmente, por séculos, foi tida como um ser de menor valor, como alguém que não tinha, na sociedade, sua individualização reconhecida, sobretudo nas classes sociais mais baixas, em que essa consciência só chegou tardiamente (JOVI- 
NO, 2008). O preconceito e o cativeiro, possivelmente, só acentuaram ainda mais essa condição.

Em se tratando de infância no Brasil, com foco na negra escravizada e na branca rica, serão expostos os ideais que nortearam a sociedade desigual e preconceituosa da época; a realidade das crianças ricas e seus privilégios, bem como as características que comprovam o acesso negado à infância, ao ensino e à sociabilidade pelas crianças negras.

Serão realizadas, ainda, análises em dois contos da literatura brasileira, um, de Machado de Assis, "O caso da vara", e outro de Monteiro Lobato, "Negrinha". Tais escolhas deram-se pelo fato de retratarem crianças negras escravizadas e ainda de terem grande repercussão na sociedade. Essas obras, pela linguagem e pelo modo como foram expostas essas crianças, permitem levantar hipóteses sobre como a literatura interpretou e exteriorizou a realidade da infância escrava.

Enfim, serão apresentadas as análises linguístico-discursivas realizadas nesses contos, com base no modelo de análise de texto do linguista Bronckart (2003). Em um primeiro momento, será verificado o contexto de produção, destacando-se as informações externas ao texto, como nome do autor, tempo e lugar de produção e circulação, dentre outros aspectos. Em seguida, serão analisados: a infraestrutura do texto, o plano global, verificando e expondo o conteúdo e sua distribuição e observando se houve ou não sua progressão; sequência e organização do conteúdo e coesão nominal. E, ainda, serão detectados os mecanismos enunciativos, que permitem a exibição das vozes presentes nas construções textuais.

Por meio desses apontamentos e dessas discussões, será possível construir uma imagem da criança negra escravizada e visualizar como, por sua condução cativa, sua infância foi ignorada e neutralizada pelos interesses econômicos, pelo preconceito e pela desigualdade social, que tanto marcou e delimitou a vivência dos escravizados no Brasil independente.

\section{A infância escravocrata no Brasil (séculos XIX e XX)}

A colonização no Brasil deu-se e afirmou-se, sobretudo, graças à mão de obra negra escravizada, maciçamente utilizada durante sécu- 
los para o enriquecimento da metrópole lusitana e da classe senhorial brasileira. No ano de 1831, por pressão britânica, houve a promulgação da lei Feijó, que impedia a escravização entre África e Brasil, pondo fim ao comércio transatlântico. Entretanto, anos após essa publicação, constatou-se um aumento significativo da vinda de negros ao Brasil, no século XIX.

Essa lei ficou conhecida com a expressão para inglês ver, já que, na prática, a realidade da escravidão não mudou. Toda essa mão de obra, para a Coroa Portuguesa, foi fundamental para a demanda produtiva cafeeira daquele século. Segundo Parron,

De fato, mais ou menos a partir de 1835 , o contrabando de africanos se avolumou em escala extraordinária, montando a cerca de 700 mil pessoas violentamente trazidas ao país nos anos subsequentes. Ironicamente, foi nos quadros do Estado nacional contemporâneo que a escravidão se expandiu com mais rapidez e força no Brasil, tudo em nome de nosso crescimento econômico e civilizacional $(2009$, p. 5).

Essa nova relação escravagista é conhecida como segunda escravidão, ou seja, aquela que emergiu atrelada ao surgimento do capitalismo industrial, sob um viés liberalista. De acordo com Tomich, "Essa 'segunda escravidão' se desenvolveu não como uma premissa histórica do capital produtivo, mas pressupondo sua existência como condição para sua reprodução" (2011, p. 87). É dessa forma que o Brasil se inseriu na lógica de mercado mundial, por meio da produção cafeeira, e estabeleceu, ainda, pela formação do Estado nacional e pela consolidação de uma classe aristocrata, um defendimento à manutenção do cativeiro humano no país (MATTOS, 1987).

A defesa da escravidão pautou-se em inúmeras ideias, tais como a de que o trabalho escravo é mais produtivo do que o livre e a premissa de que o cativeiro favoreceria a construção e o enriquecimento da nação (MARQUESE; PARRON, 2011). Nessa perspectiva, o objetivo então, com a mão de obra escravizada, não era a formação de cidadãos, mas a de uma massa de trabalhadores que fizesse girar a engrenagem da economia nacional e mantivesse os privilégios sociais. 
Com a promulgação da lei Eusébio de Queirós, em 1850, houve mais uma tentativa de manter o sistema escravista, diante das pressões internacionais. A partir dessa data, ficava proibido o tráfico de escravos. A reprodução natural e as crianças existentes tornaram-se, desse modo, as únicas oportunidades da classe senhorial para manter suas riquezas, produções e seu status econômico-social. As mães negras escravizadas constituíram-se, então, como instrumento de importância fulcral para os seus senhores no processo final da escravatura e sua descendência, como a "herança viva da escravidão" (ARIZA, 2017, p. 419, tradução nossa).

No Brasil escravista, quando se trata de infância, há que se considerar, dentre outra, dois tipos bastante discrepantes, a infância branca rica e a infầncia negra. Nesse contexto de violência e opressão, nem as crianças saíram ilesas do racismo e das injustiças de uma sociedade marcada pelo patriarcalismo e pela desigualdade social.

Em referência à infầncia branca rica, observa-se certa semelhança em relação ao tratamento que as mães tinham com seus filhos e a maneira com que as europeias “criavam” seus descendentes. Quando chegaram ao Brasil, os portugueses utilizaram-se das índias para amamentarem seus filhos. Posteriormente, essa função passou a ser majoritariamente destinada às mães negras escravizadas (mães pretas). As crianças brancas, então, passaram ao cuidado das amas-de-leite e tiveram preferência em sua condição de lactente em detrimento do próprio filho biológico da mãe negra (DEIAB, 2006).

Às crianças brancas de classe abastada foi proporcionada a construção de relações familiares bem como foi concedido o direito de brincar e de desfrutar de uma vida dignamente humana, com condições favoráveis a um desenvolvimento saudável. Também tiveram a oportunidade de estudar, de aprender a tocar instrumentos musicais e também de conhecerem outros idiomas. Vale destacar que o ensino no Brasil era embasado na religião e, antes de tudo, aprendia-se a rezar. Essa prática religiosa/ ideológica já era presente desde o século XVII, como aponta Souza: "1686- Estado do Brasil, capitania da Bahia. Foi principiada a fundação do Seminário de Belém, internato secundário erigido sobre as bases da pedagogia jesuítica. Dedicou-se ao ensino de meninos nas "letras e bons costumes' para a formação de bons cristãos” (2008, p. 10). 
A educação das crianças brancas era vista pelos eclesiásticos como algo de suma importância. Inclusive, era comum a elaboração de manuais de práticas e bons costumes destinados às crianças brancas. $\mathrm{O}$ intento da Igreja Católica, no entanto, transcendia o desejo de uma boa criação. Os manuais foram um dos meios encontrados para difundir seus ideais e inibir as ideologias protestantes (DAMASCENO, 2020).

$\mathrm{Na}$ educação infantil das crianças brancas, o castigo, em alguns manuais, era visto como algo arraigado ao processo disciplinador. Tal premissa também foi detectada por Elizabeth Badinter (1985), quando destacou que alguns pedagogos europeus incentivavam as repreensões e até mesmo certo distanciamento em relação aos pequenos. No Brasil, entretanto, a prática do castigo tinha mais inclinação à classe social a que pertencia determinada criança, uma vez que representava e reiterava as relações de poder estruturalmente existentes. Segundo Damasceno, "A tutela das crianças acabaria quando essas se tornassem adultas, a dos escravos, era permanente. Era como se os escravos fossem eternas crianças, onde erros eram passíveis de ser cometidos durante todo o período do cativeiro" (2020, p. 63).

A infầncia negra, entretanto, não possibilitou às crianças negras escravizadas oportunidades e direitos tão necessários em sua fase pueril. Essas personagens, muitas vezes ignoradas aos olhares aristocráticos, talvez se constituam como a figura mais marginalizada na história do Brasil escravista. Sem poder contar com os cuidados maternos, muitas crianças escravizadas ficavam, logo cedo, sem muitas referências familiares, sendo criadas ao relento, com pessoas estranhas ou por amas-de-leite na Roda dos expostos. Gilberto Freyre, em sua clássica obra Casa Grande e Senzala, afirma: "A escravidão desenraizou o negro do seu meio social e de família, soltando-o entre gente estranha e muitas vezes hostil” (2006, p. 315).

A relação mãe preta e filho branco, criada pela própria experiência escravocrata, interferiu sobremaneira na vida da criança negra. As crianças negras, muitas vezes, eram deixadas de lado para que suas mães pudessem alimentar e cuidar integralmente do seu "sinhozinho". A ambiguidade das amas-de-leite, que assistiam os filhos dos aristocratas, aponta para uma relação dual de afeto e violência que embargava 
os sentimentos da ama e de seu rebento natural. Conforme Deiab, "A figura da ama-de-leite, portanto, não implicava apenas numa exaltação da relação afetiva com o filho branco do senhor, mas também, em algumas ocasiões, num alerta para a crueldade a que ela era submetida ao ser apartada de seu filho natural"” (2006, p. 8).

Outra realidade possível em relação às crianças negras era o abandono. Na época, toda criança que fosse achada em situação de abandono era considerada livre (MATTOSO, 1982). Assim, era comum as mães negras apartarem-se do seu próprio filho logo após o nascimento. De igual modo, o infanticídio era prática adotada por algumas mães escravizadas para que seus pequenos não viessem a ser mais um cativo na história da escravidão nacional (MOTT, 1989). Era um ato de amor e também de resistência.

A lei do Ventre Livre, criada em 1871, declarou livres os filhos das negras escravizadas. Na prática, todavia, essa medida não alterou significativamente a vida dos pequenos. Aqueles que tivessem menos de 21 anos deveriam permanecer sob custódia do seu senhor até essa referida idade, ou, se não, o seu senhor poderia receber uma indenização pela sua propriedade perdida. A maioria dos senhores preferiu manter seus escravos até o tempo limite e, assim, explorá-los das mais intensas e possíveis formas.

Pode-se dizer, então, que essa lei, tragicamente, só encurtou a infância das crianças negras, inserindo-as mais precocemente no mercado de trabalho e distanciando-as de uma vida livre e de direitos. Houve, também, casos em que a condição livre dessas crianças foi omitida, tornando-as novamente propriedades de seus senhores, mesmo após a promulgação da lei de 1871. Relatam-se, ainda, casos de furto e disputas de posse dos pequenos escravizados, como aponta Teixeira (2010).

Não é de se espantar que crianças negras escravizadas fossem impedidas de frequentar as escolas. Havia algum ensino somente se a função que desempenhariam para o seu senhor a requisesse. Damasceno ainda expõe que "As instituições públicas de ensino não seriam, portanto, para todas as crianças do Império. Os filhos dos escravos e os pretos africanos ainda que livres e libertos, por exemplo, eram proibidos de se matricularem nas escolas" (2020, p. 156). 
As formações cultural, social e psicológica dessa criança eram sempre baseadas no medo. Cenas de pessoas escravizadas sendo flageladas e mortas eram expostas às crianças negras de forma intencional para servir como exemplo, a fim de que essas viessem aprender a obedecer aos seus senhores. Quando cometiam alguma "irregularidade", podiam ter suas cabeças raspadas e, às vezes, até o seu próprio corpo marcado a ferro com as iniciais do dono (JOVINO, 2015).

A criança negra como mão de obra escrava foi muito utilizada pelos senhores de engenho. "O menor preço da criança escrava tornava-a uma mercadoria acessível aos pequenos proprietários impossibilitados muitas vezes de investirem na compra do escravo adulto" (MOTT, 1989, p. 88). Essa fase de inserção precoce no trabalho talvez seja a de maior impacto na vida da criança negra. É quando ela se dá conta de sua condição escrava, perto dos 7 ou 8 anos (MATTOSO, 1982).

Distante do ensino, do lazer, do afeto, a infância escravizada foi marcada dia após dia pela indiferença, pela dor e pelo desprezo, direcionando às crianças funções humilhantes e desumanas, como servir de brinquedo e divertimento aos seus donos, principalmente às crianças brancas. É nessa infầncia que se pode detectar que a maior vivência da criança negra está ligada ao mundo do trabalho (JOVINO, 2008). Dificilmente, seriam vistas cenas de crianças negras brincando ou fazendo qualquer outra atividade que as pudesse fazer sentirem-se como outra criança branca aristocrata. A liberdade era algo ambicioso demais para uma criança que, por sua condição cativa, não possuía nem a si própria.

\section{Crianças negras nos contos de Machado de Assis e Monteiro Lobato}

A literatura como Instituição não institucionalizada permite aos seus artífices tecer problematizações acerca da sociedade e de seus membros e ressignificações de conceitos, de fatos. A literatura, nessa perspectiva, está muito próxima daquilo que é produzido nas e pelas relações sociais, tornando-se, pela linguagem, um meio de interferência direta no mundo real, de interpelação a tudo que circunda o ser humano. Constitui-se também, segundo Travassos, 
(...) como uma instituição que traz ao corpo da vida social vozes e interlocuções livres, nas quais podem aparecer diferentes tipos de locutores e as mais diversas possibilidades de ação, e que ele, portanto, impõe certa responsabilidade ética a autores e leitores, uma vez que, sendo política, está invariavelmente atrelada a uma ‘ética de grupo’ (2015, p. 14).

Dessa forma, para essa análise da infância escravizada no país, escolheram-se dois contos da literatura brasileira para ratificar ou não o já exposto pela historiografia nacional. Seguem adiante os resultados obtidos, então, pelas análises linguístico-discursivas no conto "O caso da vara", de Machado de Assis.

Em relação ao contexto de produção, tem-se que o conto "O caso da vara" foi escrito por Machado de Assis, em 1899. Dos grandes nomes da literatura, Machado de Assis é autor de inúmeros contos e romances brasileiros produzidos no século XIX. Eram comuns, em suas obras, críticas às injustiças e aos problemas sociais pouco contraditos. Machado usava, pela linguagem, da sutileza e, às vezes, da ironia e do sarcasmo, para retratar com realismo as injúrias cometidas contra o povo, sendo considerado por isso um bom intérprete de sua época.

$\mathrm{Na}$ infraestrutura do texto, observa-se uma narrativa em terceira pessoa. Nela, o autor vale-se de uma trama familiar para expor a problemática da escravidão no Brasil e as relações senhoriais que se mantinham com os negros. O conto narra a história de um homem, Damião, que foge do seminário e refugia-se na casa de Sinhá Rita, uma senhora viúva que vivia com suas escravas. Lucrécia é a criança escravizada que tem destaque no enredo.

O jovem, lisonjeando a viúva intencionalmente, convence-a de interceder ao padrinho Carneiro para que este persuada seu pai a desistir de fazê-lo seguir o seminário. Ao longo da trama, Damião simpatiza com Lucrécia e deseja apadrinhá-la. No final, a criança, por não ter realizado o trabalho a ela destinado, receberia um castigo. A viúva pede a Damião que lhe entregue a vara. Ele, então, fica entre proteger a menina e desagradar a Sinhá Rita. Em um jogo de interesses, ele cede à indiferença e entrega a vara. Nessa obra, há progressão de conteúdos e 
sequência lógica. O discurso empregado é o relato interativo, da ordem do narrar, imbricado.

Acerca dos mecanismos de coesão, ou seja, as palavras que se referem aos personagens da obra, detectou-se o seguinte léxico. Em relação a Damião, seminarista, medroso, fugitivo, rapaz, Sr. Damião, afilhado, moço, peralta e sinhô moço; em relação ao padrinho João Carneiro, moleiro; em relação à Sinhá Rita, viúva, dona de casa, apessoada, viva, patusca, amiga de rir e brava como o diabo e, em referência à Lucrécia, pequena, negrinha, magricela, um frangalho de nada e malandra.

Quanto aos mecanismos de enunciação, percebe-se a voz de uma sociedade que tenta camuflar seus achaques por meio de interesses individuais e conveniências. Na narrativa, até certo momento, não se detecta o real tema do conto, fazendo os reflexos da escravidão ser percebidos nos detalhes, no que é exposto e, principalmente, naquilo que não é.

A literatura, ao tematizar a realidade da escravidão, mesmo após sua abolição, revela muito mais do que castigos e repressão, mas todo um sistema de apadrinhamento e paternalismo, que, no conto, é exibido nas relações entre Damião, Sinhá Rita e o padrinho João Carneiro. A dependência entre eles confirma que os mecanismos de opressão não se limitavam às relações senhor-escravo, mas se estendiam às pessoas livres, com posição privilegiada na sociedade.

Em relação ao trabalho infantil escravo, o conto apresenta os excessos que os aristocratas cometiam com as crianças. Aquilo que não se vê na narrativa, talvez seja o que mais fala aos leitores. A ausência de momentos de lazer, de afeto, de ensino e de liberdade é perceptível na vida de Lucrécia. Sua vivência na casa não podia nem ser notada, "tossia para dentro, surdamente". A menina de apenas 11 anos era adestrada pelo medo (e pela vara) e recebia castigos com frequência, tinha "uma cicatriz na testa e uma queimadura na mão esquerda".

Ela foi, no conto, a personificação da violência senhorial, sem ter chance alguma de fugir ou de se livrar do castigo, ao contrário de Damião. Quando Sinhá Rita fala para o padrinho sobre a vontade do rapaz em desistir do seminário, ele fala em castigá-lo. A senhora em resposta a ele diz: "Qual castigar, qual nada! Interrompeu Sinhá Rita. 
Castigar por quê??" Na trama, o castigo tem cor e condição social, seguindo a lógica escravagista. Desse modo, percebe-se que "A estratificação da sociedade, a velha divisão dos tempos da escravidão entre os que possuem e os que nada têm, só fez agravar a situação dos nossos pequenos" (PRIORE, 2002, p. 14).

É possível ainda conceber essa narrativa como um espelho de como a sociedade da época mantinha suas relações com os negros recém-libertos. Machado de Assis, no título e também na construção textual, parece, propositalmente, camuflar o racismo e a opressão aos negros. Para um leitor não atento, "O caso da vara", enquanto título, pode parecer somente uma referência a um objeto usado por uma senhora e não um instrumento de violência para delimitar posições e deveres. "O caso da vara”, enquanto conto, por sua vez, pode soar somente como um relato de um jovem que não queria mais seguir a carreira de seminarista e não uma denúncia social em pleno advento da República.

Em relação ao conto "Negrinha”, de Monteiro Lobato (2001), seguem-se os resultados obtidos pelas análises linguístico-discursivas.

Acerca do contexto de produção, tem-se que o autor do conto, Monteiro Lobato, nasceu em Taubaté no ano de 1882. Criador de inúmeras histórias para crianças, ficou conhecido nacionalmente pelas suas obras dedicadas ao público infantil e também pela publicação de seu livro "Urupês". O conto "Negrinha", contido no livro homônimo, foi escrito no ano de 1920, em uma época em que a sociedade brasileira ainda vivia às sombras do preconceito e do racismo, oriundos de quatro séculos de escravidão negra no país. A obra demonstrou, pela narrativa, facetas de uma sociedade hipócrita, elitista e opressora, embora também tenha, nas entrelinhas, ratificado o preconceito e o desprezo presente nas concepções e nas atitudes humanas.

$\mathrm{Na}$ infraestrutura, há uma narrativa escrita em terceira pessoa, que expõe a difícil e desumana vida que Negrinha, personagem principal, leva na casa de D. Inácia. A criança vive em um ambiente extremamente hostil, em que é religiosamente castigada, com ou sem motivo. D. Inácia, antiga dona de escravos, tortura e violenta a menina de diversas maneiras, impedindo-a até mesmo de se locomover pela casa, "aprendeu a andar, mas quase não andava". As sobrinhas da senhora Inácia vieram passar uns dias em sua casa e trouxeram consigo alguns 
brinquedos. Negrinha, ao olhá-los, admirou-se, nunca vira coisa igual. À menina, pelo excêntrico gesto da patroa, é concedida a oportunidade de brincar, pela primeira vez. Após a partida das sobrinhas, Negrinha adoece e vem a óbito, ao delírio de bonecas e anjos. Nessa obra, há progressão de conteúdos e sequência lógica. O discurso empregado é o relato interativo, da ordem do narrar, imbricado.

Nos mecanismos de coesão, observaram-se as palavras que se referem às personagens da trama, a saber, Negrinha, D. Inácia, as sobrinhas e duas escravas que trabalhavam na casa, sobre estas, porém, nada é declarado. A respeito de Negrinha, as palavras são: pobre, órfã, fosca, mulatinha escura, peste, criminosa, diabo, magra, atrofiada, pestinha, diabo, coruja, barata descascada, bruxa, patocha, pinto gorado, mosca morta, sujeira, bisca, trapo, cachorrinha, coisa ruim, lixo, boba, bobinha, martirizinha, triste criança, mendiga, coisa humana, carnezinha de terceira, uma miséria, trinta quilos mal pesados, pobre de Deus, caridade de D. Inácia. Em referência à D. Inácia: patroa, excelente senhora, gorda, rica, dona do mundo, animada dos padres, virtuosa senhora, esteio da religião e da moral, ótima, viúva, virtuosa dama, boa senhora, Santa Inácia, fera. Em relação às sobrinhas: pequenotas lindas, meninas loiras, ricas, dois anjos do céu, alegres, filhinhas, fidalgas, meninas, princesinha.

Quanto aos mecanismos de enunciação, percebe-se a voz de uma falsa crítica do autor em relação à maneira como a sociedade do início do século XX ainda tratava os negros, embora a abolição da escravatura já tivesse sido promulgada ao final do século anterior. O preconceito e o racismo não se prenderam ao cativeiro humano no Brasil, mas transpuseram as leis, o tempo, e a dignidade da vida humana. $\mathrm{O}$ autor, mesmo que motivado a revelar o recôndito dos sentimentos humanos e suas misérias, não deixou de (re)velar a influência da sociedade em si próprio. $\mathrm{O}$ autor está preso a seu tempo e a linguagem não deixa os leitores confundidos em relação a isso. Assim, pode-se dizer que o autor, no conto, constrói uma espécie de metapreconceito/metarracismo, sendo mais uma voz reprodutora da desigualdade social e das injustiças de uma sociedade classista.

A literatura de Lobato, ao tematizar a infância escravocrata, acabou reforçando ainda mais as linhas social e econômica que separam 
negros e brancos. No conto, Negrinha é distanciada do convívio em comunidade e das relações dentro da própria casa em que vivia. A primeira vez que pôde brincar foi com a inusitada permissão de D. Inácia. Após vivenciar algo extremamente novo, a menina se sente humana e percebe que tem alma. A senhora e suas sobrinhas, então, aparecem como aquelas que permitem a humanização da criança negra e constituem-se, ao final do conto, como cidadãs de bem, e não mais os algozes de uma menina indefesa.

Constatam-se então, a partir dessas análises, a ausência de cuidados com a criança, a exploração infantil negra, a invisibilidade da personagem e sua irrelevância na sociedade escravista e patriarcal da época. A criança negra escravizada foi duplamente hostilizada, impedida de ter uma infância como as crianças brancas e destituída, algumas vezes, de seu próprio nome, de sua própria identidade. "A terra papou com indiferença àquela carnezinha de terceira, uma miséria, trinta quilos mal pesados" (MORICONI, 2001, p. 83). Negrinha e Lucrécia podem ser vistas como os expoentes de uma articulação econômica-social, construída ao longo de quatro séculos, em que negros não tinham voz, direitos e liberdade.

\section{Considerações finais}

A invisibilidade da criança pode ser detectada, inicialmente, pelo próprio significado da palavra infância. In, prefixo que indica negação e fante, particípio do verbo latino que significa dizer, falar. A infância, então, é uma fase em que, geralmente, seus atores não têm voz, expressões e rostos construídos e expostos por eles próprios. São quase sempre representados e definidos do lado de fora, sem a oportunidade de ocuparem o lugar de sujeito nos discursos elaborados sobre eles próprios (FREITAS, 2003). Assim, pode-se afirmar que, quando se trata de infância escravocrata, se está diante de crianças duplamente mudas, de testemunhas silenciadas em seu tempo. A escravidão no Brasil modificou drasticamente a vida e o destino de milhares de crianças negras durante séculos. Essas interferências, vividas e sentidas em todos os aspectos da vida infantil, mostram que o que 
o cativeiro humano retirou dos negros escravizados vai muito além do direito à liberdade e ao trabalho digno e humano. Talvez nunca se consiga medir o que foi a experiência da condição escrava para uma criança, mas quem sabe se possa detectar os preconceitos e estigmas à cor negra ainda intrincados na sociedade, na cultura e nas concepções humanas, a fim de impedir que eles façam mais vítimas e causem mais mortes físicas, afetivas e sociais.

\section{Referências:}

ARIZA, Marília B. de A. Bad mothers, labouring children: emancipation, tutelage and motherhood in São Paulo in the last decades of the nineteenth century. Slave \& Abolition. 38:2, 408-424, 2017.

ASSIS, de Machado. 50 contos de Machado de Assis; seleção, introdução e notas John Gledson. São Paulo: Companhia das Letras, 2007.

BADINTER, Elizabeth. Um amor conquistado: o mito do amor materno. 6.ed. Rio de Janeiro: Nova Fronteira, 1985.

BRONCKART, Jean-Paul. Atividades de linguagem, textos e discursos: por um interacionismo sociodiscursivo. São Paulo: EDUC, 2003.

DAMASCENO, Nicole O. A. Disciplina e castigo: normas e práticas sobre tratamento destinado às crianças e escravos na sociedade brasileira (séculos XVII a XIX). 2020. 220f. Dissertação (Doutorado em História Social) - Faculdade de Filosofia, Letras e Ciências Humanas, Universidade de São Paulo, 2020.

DEIAB, Rafaela de. A mãe preta na literatura brasileira: a ambiguidade como contrução social (1880-1950). 2006. 296f. Dissertação (Mestrado em Antropologia Social) - Faculdade de Filosofia, Letras e Ciências Humanas, Universidade de São Paulo, 2006. 
FREYRE, Gilberto. Casa Grande \& senzala. São Paulo: Global, 2006.

FREITAS, Marcos Cezar de (Org.). História Social da Infầncia no Brasil. 5. ed. São Paulo: Cortez, 2003.

JOVINO, Ione da Silva. Crianças negras na história: Fontes e discursos sobre a breve infância permitida pelo escravismo oitocentista brasileiro. Revista Eletrônica de Educação, Ponta Grossa, v.9, n.2, p. 189-225, 2015. Disponível em: <http://www.reveduc.ufscar.br/index.php/reveduc/article/view/1167〉. Acesso em: 10 jun. 2020 .

. Entre o sentimento da infância e a invisibilidade das crianças negras: ambiguidade no século XIX. GT-21: Afro-Brasileiros e Educação, 2008. Disponível em: <http://www.anped.org.br/ sites/default/files/gt21-4281-int.pdf>. Acesso em: 12 jun. 2020.

LOBATO, Monteiro. Negrinha. In: MORICONI, Italo (Org). Os cem melhores contos brasileiros do século. Rio de Janeiro: Objetiva, 2001, p. 78-84.

MARQUESE, Rafael de Bivar; PARRON, Tâmis Peixoto. Internacional escravista: a política da Segunda Escravidão. Topoi (Rio J.). 2011, vol.12, n.23, pp.97-117. ISSN 2237-101X. Disponível em: <https://doi.org/10.1590/2237-101X012023006>. Acesso em: 20 maio 2020.

MATTOS, Ilmar R. de. O tempo saquarema. São Paulo: HUCITEC, 1897.

MATTOSO, Kátia de Queiroz. O filho da escrava. Em torno da Lei do Ventre Livre. Revista Brasileira de História. São Paulo. Vol.8, n.16, março-agosto 1988, p. 37-55. Disponível em: <https:// www.anpuh.org/arquivo/download?ID_ARQUIVO=3674>. Acesso em: 20 maio 2020.

MATTOSO, Kátia de Queiroz. Ser escravo no Brasil. São Paulo: Brasiliense, 1982. 
MOTT, Maria Lucia de Barros. Ser mãe: a escrava em face do aborto e do infanticídio. Revista de História, São Paulo, 120, p. 8596, jan/jul. 1989. Disponível em: <http://www.revistas.usp.br/ revhistoria/article/view/18594/20657>. Acesso em: 12 jun. 2020.

PARRON, Tâmis Peixoto. A política da escravidão no império do Brasil, 1826-1865. 2009. Dissertação (Mestrado em História Social) - Faculdade de Filosofia, Letras e Ciências Humanas, Universidade de São Paulo, São Paulo, 2009.

PRIORE, Mary Del (Org.). História das crianças no Brasil. 3.ed. São Paulo: Contexto, 2002.

SOUZA, Lais Viena de. Educados nas letras e guardados nos bons costumes. Os pueris na prédica do Padre Alexandre de Gusmão S.J. (séculos XVII e XVIII). 2008. 210f. Dissertação (Mestrado em História) - Faculdade de Filosofia e Ciências Humanas, Universidade Federal da Bahia, 2008.

TEIXEIRA, Maria H. Os filhos das escravas: crianças cativas e ingênuas nas propriedades de Mariana $(1850$ - 1888). Cadernos de História. Belo Horizonte, v.11, n.15, 2os. 2010. Disponível em: <http://periodicos.pucminas.br/index.php/cadernoshistoria/article/view/P.2237-8871.2010v11n15p58>. Acesso em: 20 maio. 2020.

TOMICH, Dale. Pelo prisma da escravidão. Trabalho, Capital e Economia Mundial. São Paulo: Edusp, 2011.

TRAVASSOS, Thaís. Da partilha do sensível no Brasil: uma leitura de 'A hora e a vez de Augusto Matraga' e 'Buriti'. 2015. Dissertação (Mestrado em Estudos Comparados de Literaturas de Língua Portuguesa) - Faculdade de Filosofia, Letras e Ciências Humanas, Universidade de São Paulo, São Paulo, 2015. 


\section{VIOLÊNCIA ESCOLAR: UMA ANÁLISE BIBLIOGRÁFICA ACERCA DAS CONSEQUÊNCIAS DA PRÁTICA DO BULLYING NAS RELAÇÕES INTRA E INTERPESSOAIS}

Rafael Ramos Longuinhos

\section{INTRODUÇÃO}

A violência é um tema muito recorrente nos dias atuais, demandando de nós muita cautela e reflexão sobre os fatores que podem estar por detrás de todo ato violento. A escola, extensão da sociedade, não está alheia às consequências da violência. Nela, a violência pode assumir várias faces e ganhar novos nomes. O bullying é um dos exemplos de violência que comumente afeta, negativamente, as relações interpessoais no ambiente escolar.

No Brasil, a lei federal 13.185 de 06 de novembro de 2015 define o termo bullying como sendo uma intimidação sistemática, consistindo em:

todo ato de violência física ou psicológica, intencional e repetitivo que ocorre sem motivação evidente, praticado por indivíduo ou grupo, contra uma ou mais pessoas, com o objetivo de intimidá-la ou agredi-la, causando dor e angústia à vítima, em uma relação de desequilíbrio de poder entre as partes envolvidas. (BRASIL, 2015, n.p.). 
A lei supracitada objetiva instituir um programa de combate à intimidação sistemática em âmbito nacional, norteando, principalmente, as ações futuras do Ministério da Educação (MEC) e das secretarias estaduais e municipais de educação, como prevê o parágrafo $2^{\circ}$ do artigo $1^{\circ}$ da lei em discussão.

A partir dessa lei, as escolas ganham centralidade no combate à prática do bullying, pois como já é de conhecimento geral, tal prática é um ato violento muito comum nas relações interpessoais entre crianças e adolescente em fase escolar, momento em que eles podem estar inseridos em uma relação no qual há desequilíbrio de poder. Nesse contexto de desequilíbrio de poder, uns violentam e outros são violentados, porém, ambos os lados sofrem.

Estudos recentes da Faculdade Latino-Americana de Ciências Sociais (FLACSO) em parceria com o MEC, no ano de 2015, elaboraram o Diagnóstico Participativo da Violência nas Escolas: falam os jovens, executada com a participação de docentes e estudantes das últimas séries do Ensino Fundamental e do Ensino Médio, além dos mediadores, no qual se discutiu a respeito das relações entre os estudantes, chamando-nos a atenção de que "as relações entre os estudantes no universo escolar são complexas e, algumas vezes, mostram aspectos contraditórios." (ABRAMOVAY et. al., 2016), e que

muitas vezes, imperam xingamentos, agressões verbais, que são banalizadas e aceitas pelos alunos de forma corriqueira: "xingamentos, os alunos veem como algo natural, e não se ofendem, parecem aceitar", mas que podem gerar situações de violência. É preciso reiterar o que é considerado "banal" para os adultos não obrigatoriamente coincide com as atitudes dos jovens e pode trazer consequências. (ABRAMOVAY et al., 2016).

Estudos que reverberem em ações práticas para a performance de professores e funcionários da escola precisam ser desenvolvidos para 
ajuda-los a mitigar quaisquer práticas de intimidação sistemática. Para isso, a escola necessita contar com o apoio de toda a sociedade, haja vista que a violência não consiste em um problema que se origina unicamente na escola.

Nesse contexto, o presente estudo pretende fomentar a discussão acerca do bullying como sendo uma das interfaces da violência escolar e de como tal prática pode afetar as relações intra e interpessoais, que são construídas entre crianças e adolescentes, sujeitos em desenvolvimento.

\section{CONSEQUÊNCIAS NEGATIVAS DA PRÁTICA DO BULLYING}

Souza e Almeida (2011) lembram que "durante muito tempo, comportamentos como o de apelidar e/ou 'zoar' alguém podem ter sido vistos como inofensivos ou naturais da infância e da relação entre as crianças e adolescentes na escola”, porém, atualmente, é possível observar por meio dos jornais, os crescentes casos de estudantes que desenvolvem quadros de depressão ou que atentam contra a sua ou a vida de outrem.

Nos dias atuais, é preciso entender que "o bullying é um forte fator de risco para comportamentos antissociais individuais geradores de violência na sociedade.” (SOUZA e ALMEIDA, 2011), bem como perceber que "a violência escolar refere-se a todos os comportamentos agressivos e antissociais, que variam de conflitos interpessoais até atos criminosos de grande relevância." (SOUZA e ALMEIDA, 2011).

No artigo $3^{\circ}$ da lei 13.185/2015, se observa um rol de ações que caracteriza a prática do bullying. Dentre todas as ações, a presente lei tipifica algumas formas de agressão, como é possível verificar no Quadro 01. 
Quadro 01 - Formas de agressão e suas carecterísticas, previstos na Lei 13.185/2015

\begin{tabular}{|c|c|}
\hline $\begin{array}{c}\text { FORMAS DE } \\
\text { AGRESSÃO }\end{array}$ & CARACTERÍSTICAS \\
\hline Verbal & insultar, xingar e apelidar pejorativamente. \\
\hline Moral & difamar, caluniar, disseminar rumores. \\
\hline Sexual & assediar, induzir e/ou abusar. \\
\hline Social & ignorar, isolar e excluir. \\
\hline Psicológica & perseguir, amedrontar, aterrorizar, intimidar, dominar, \\
manipular, \\
Físico & socar, chutar, bater. \\
\hline Material & furtar, roubar, destruir pertences de outrem. \\
\hline Virtual & $\begin{array}{c}\text { depreciar, enviar mensagens intrusivas da intimidade, } \\
\text { enviar ou adulterar fotos e dados pessoais que resultem } \\
\text { em sofrimento ou com o intuito de criar meios de } \\
\text { constrangimento psicológico e } \\
\text { social. }\end{array}$ \\
\hline
\end{tabular}

Fonte: $\mathrm{O}$ autor.

Todas as formas de agressão sinalizadas no Quadro 01 podem prejudicar o desenvolvimento de crianças e adolescentes em vários aspectos de suas vidas, sejam no âmbito da escola como fora dela.

A Fig. 01 apresenta por meio de um infográfico, os resultados divulgados em 2015 pelo Programa Internacional de Avaliação de Alunos (PISA), coordenado pela Organização para a Cooperação e Desenvolvimento Econômico (OCDE). De acordo com a Fig. 01, até o ano de 2015, 17,5\% dos estudantes brasileiros afirmaram sofrer bullying algumas vezes por mês, 9,3\% informaram ser alvo de piadas, 7,9\% foram alvo de rumores maldos, 7,8\% sentiram-se excluídos pelos colegas, $5,3 \%$ disseram que os colegas pegamn e destroem as coisas deles, $4,1 \%$ já sofreram ameaças e 3,2\% dos estudantes já foram empurrados e agredidos fisicamente. 
Figura 01 - Estudantes brasileiros sofrem exposição constante ao bullying

\section{VITIMAS}

\section{Estudantes brasileiros sofrem exposição constante ao bullying}

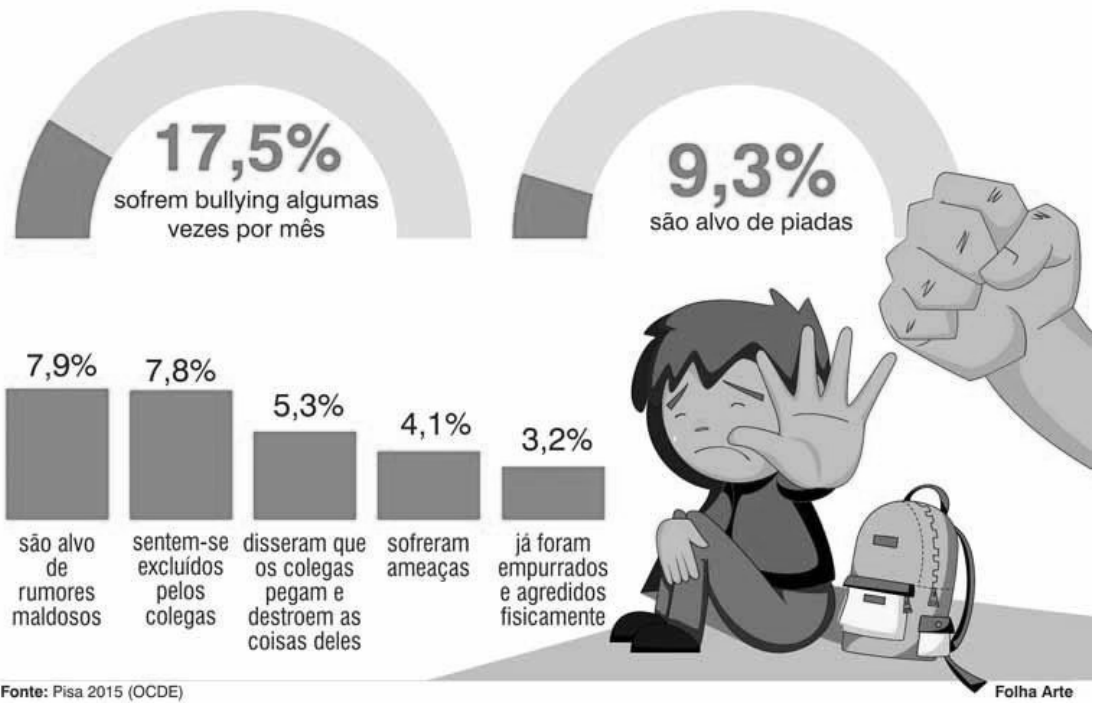

Fonte: Folha Arte, 2020.

Observa-se que o mais comum, no contexto do bullying, são as vítimas acabarem sendo alvo de rumores, de piadas, de sentimento de exclusão por parte dos colegas, terem seus objetos destruídos ou subtraídos, sofrerem ameaças, bem como serem empurrados e agredidos fisicamente.

\subsection{A SEXUALIDADE E O BULLYING NA ESCOLA}

Adolescer é muito mais que se tornar adolescente. É saber atravessar o caminho por qual o corpo e a mente vão amadurecendo de forma constante. É saber que o corpo muda e, com essa mudança, demandas afetivo, sexuais e sociais começam a surgir, requerendo, dessa forma, uma nova postura do adolescente em formação.

Nesse momento de intensas transformações e demandas, dependendo do contexto social, o bullying pode se manifestar de maneira 
veemente em vários campos da vida, especialmente no que concerne à sexualidade. Segundo Barduni Filho, Coelho e Freitas (2011), a sexualidade está ligada ao campo cultural, pois tanto os fatores sociais quanto os culturais, exercem sobre os seres humanos normas de conduta de como a sexualidade deve ser vivenciada, tolerando e proibindo, socialmente, certas práticas.

Percebe-se que a transição da fase de criança para a de adolescente pode gerar muitos conflitos internos entre os adolescentes em desenvolvimento, pois adolescer vai muito além do surgimento dos caracteres sexuais secundários, é um momento de autoafirmação, em virtude de que "a sexualidade não tem o mesmo grau de importância para todos os sujeitos. [...] essa variação é efeito de processos sociais que se originam no valor que a sexualidade ocupa em determinados nichos sociais..." (HEILBORN, 1999).

Durante esse momento de autoafirmação, as primeiras paixões e conflitos tomam conta da nova mentalidade em formação. Alguns sofrem por não verem seus corpos se desenvolvendo da mesma forma como pode ser vista em seus colegas, outros, porém, sofrem por verem seus corpos mudando. Nesse sentido, é comum surgirem nas interações entre os estudantes: os apelidos, os assédios, os abusos, as perseguição, os insultos etc., atos que se configuram como prática de bullying.

Há jovens no período púbere que também sofrem por não se adequarem aos padrões elencados como "normais" pela sociedade. Isso acontece, por exemplo, com jovens que se descobrem afetivo e sexualmente interessados por indivíduos do mesmo sexo biológico.

Ainda, há jovens que sofrem por pressões também de cunho social no que concerne à figura idealizada do que é ser homem na sociedade brasileira, forçando-os, principalmente aqueles que possuem o sexo biológico masculino, a assumirem posturas que foram categorizadas como sendo as que todos os homens devem praticar, como: namorar com várias garotas para demonstrar virilidade, gostar de futebol, não ser estudioso etc. Essas concepções equivocadas reverberam negativa- 
mente no ambiente escolar, inferiorizando, de certa forma, aqueles que não se adequam ao perfil idealizado.

Enfim, tudo isso poderá afetar a maneira como esses jovens lidarão com a questão da afetividade e sexualidade na fase adulta, bem como na forma como interagirão com seus pares.

\section{O PAPEL DA ESCOLA FRENTE À PRÁTICA DO $B U L L Y I N G$}

A escola é uma instituição social, incumbida na formação de novos cidadãos críticos e reflexivos para a sociedade. Essa é a essência da instituição escola, porém, diante da atual conjuntura social, novas demandas sobrecaem no espaço escolar, a exemplo do enfretamento da prática do bullying, prática antiga e que pode deixar marcas por toda uma vida.

Longuinhos (2020, p. 7) destaca que

Inclusive, em certas situações, a escola pública é considerada como um lócus de refúgio para muitos corpos marcados pela rejeição ou ausência de afeto familiar; pela baixa autoestima; pelas diversas formas de violência enfrentadas a cada dia e; pelos olhares de desconfiança de uma sociedade que ao identificar a presença de determinantes sociais em certos grupos, os coloca em uma situação de marginalização.

Silva e Reis (2011) defendem que “[...] as instituições escolares possuem fortes vínculos com o conhecimento e são as responsáveis por grande parte da formação do ser humano. Diante disso, não se pode descartar a influência do ambiente sociocultural durante a aprendizagem da criança" e do adolescente, em virtude de que o Estatuto da Criança e do Adolescente compreende tanto as crianças quanto os adolescentes, como seres que estão em período de intenso desenvolvimento físico, psicológico, moral e social, podendo, ao longo desse processo, experienciar bons e maus momentos. Neste último, temos o exemplo da prática do bullying, que pode influenciar negativamente esse processo de formação. 
Silva et al. (2018) nos indicam que "por ser de difícil identificação pela equipe educacional, o bullying pode ocorrer por longos períodos e, assim, afetar negativamente a escolaridade, a saúde e a qualidade de vida dos estudantes envolvidos (vítimas, agressores e testemunhas)".

Segundo Vygotsky (apud DAVIS e OLIVEIRA,1993, p. 53, apud SILVA e REIS, 2011), "o ser humano cresce num ambiente social e a interação com outras pessoas é essencial ao seu desenvolvimento.", porque nos tornamos seres humanos a partir do convívio e socialização com outros seres humanos, o que é de conhecimento geral da Antropologia.

Mrech (2010, p. 34 apud SILVA e REIS, 2011), baseando-se nos estudos de Wallon, concluiu que "o processo de desenvolvimento da criança diz respeito ao vínculo com a ambiência (meio) que pode apresentar retrocessos, paralisações, acelerações, saltos.", o que nos leva a acreditar que "[...] o ambiente sociocultural pode ser considerado como um complemento do desenvolvimento e aprendizagem do ser humano, quando há interação entre ambos, haja vista que, o desenvolvimento e a aprendizagem são os processos os internos."

Diante disso, ao se projetar a escola como "um agente por excelência na formação do ser humano" (SILVA e REIS, 2011), torna-se imperioso um olhar mais sensível entorno dos casos de bullying registrados e /ou presenciados no âmbito escolar a fim de combatê-los, tendo em vista que

A educação associa-se, pois, a processos de comunicação e interação pelos quais os membros de uma sociedade assimilam saberes, habilidades, técnicas, atitudes, valores existentes no meio culturalmente organizado e, com isso, ganham o patamar necessário para produzir outros saberes, técnicas, valores etc. É intrínseco ao ato educativo seu caráter de mediação que favorece o desenvolvimento dos indivíduos na dinâmica sociocultural de seu grupo [...]. (LIBÂNEO, 2000, p. 24). 
Como é possível observar, o ato educativo desempenhado na escola é capaz de promover mudanças nos indivíduos envolvidos, em especial, os estudantes que reproduzem em suas relações interpessoais, certos preconceitos, que acabam, muitas vezes, culminando em agressões de cunho físico e/ou psicológico, que até então classificamos como a prática de bullying.

Libâneo (1986) apresenta em um dos capítulos de seu livro Democratização da Escola Pública que, a escola é necessária, afirmando que “a prática escolar, entretanto, será compreendida como um processo, ao mesmo tempo, individual e social, de desenvolvimento de indivíduos singulares e de intervenção nas condições sociais." (LIBÂNEO, 1986, p. 54).

Quando Libâneo expõe o fato do desenvolvimento de indivíduos singulares, é possível inferir que o ambiente da sala de aula é lócus da diversidade, no qual as relações interpessoais podem ou não ocorrer de forma conflituosa.

Quando compreendermos que as relações interpessoais “[...] são ingredientes essenciais de qualquer microssistema, ainda mais se for a escola" (SALVADOR et al., 2000, p. 153), conseguiremos nos mobilibar enquanto sociedade em prol de uma sociedade menos violenta, para que dessa forma, tenhamos uma escola cuja premissa maior seja a cultura da paz, do respeito e do diálogo.

\section{CARACTERIZAÇÃO PSICOLÓGICA DOS AGENTES DE BULLYING}

O Ministério Público do estado da Paraíba divulgou por meio de uma cartilha, intitulada Bullying não é legal que "uma característica peculiar do bullying é a proximidade entre o alvo (a vítima) e o autor (o agressor), que geralmente estudam na mesma sala de aula ou moram no mesmo bairro. Em função disso, muitas pessoas subestimam o fato [...]" (ESCOREL, 2009), considerando como uma simples brincadeira de criança ou adolescente. 
Agressor (Bully)

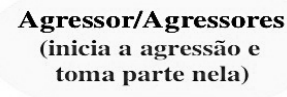

Seguidores

(tomam parte ativa mas não são eles a iniciarem o processo)

Apoiantes

(apoiam a tortura mas não tomam parte nela

São bullies passivos)

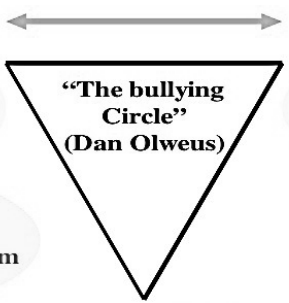

Apoiantes Passivos

(Estão do lado dos bullies mas sem apoio declarado)

\section{Vítima (Bullied)}

\section{Defensores da vítima}

(detestam o bullying

e ajudam ou tentam ajudar a vítima)

\section{Defensores potenciais}

(não gostam dos agressores mas não ajudam a Vítima)

"Voyeurs"

(assistem mas não tomam partido)

\section{Os Espectadores}

\section{Quebrar o Ciclo}

\section{Ilustração 1: Ciclo da Agressão (Neto, 2006)}

Figura 02 - Ações desempenhadas tanto pelo agressor quanto pela vítima de bullying

Para podermos identificar com acurácia os casos de bullying praticados tanto na escola como fora da mesma, precisamos saber discernir o perfil psicológico tanto do agressor quanto da vítima. A Fig. 02, extraída do trabalho dos pesquisadores portugueses da Universidade do Minho, Barros, Carvalho e Pereira produzido ao IX Congresso Nacional de Educação em 2009, organizado pela Pontifícia Universidade Católica do Paraná, encontram-se caracterizados as ações desempenhadas tanto pelo agressor quanto pela vítima de bullying.

Com base na Fig. 02, conclui-se que "os agressores, acham que todos devem realizar suas vontades, e por uma orientação ou educação pouco adequada, querem ser o centro das atenções." (BARROS, CARVALHO e PEREIRA, 2009). E, também, pode ser concluído que "as vítimas geralmente são frágeis, sentem-se desiguais ou prejudicados e dificilmente pedem ajuda, demonstram desinteresse, medo ou falta de vontade para frequentar a escola" (BARROS, CARVALHO e PEREIRA, 2009).

Diante disso, torna-se imperioso atentarmos ao que diz a literatura especializada quando sinaliza "a necessidade de intervir precocemente na violência, com vistas a preveni-la e promover comportamentos saudáveis, evitando o desenvolvimento de problemas escolares e de saúde dela decorrentes." (SILVA, 2018). 


\subsection{PERFIL DO AGRESSOR}

O bullying é uma violência de caráter repetitivo e que envolve indivíduos cuja relação de poder seja desigual. Nesse contexto, tem-se a figura do agressor e o da vítima. De um modo geral, os perfis dos agressores "caracterizam-se por ter uma elevada impulsividade e uma necessidade e gosto por dominar os outros." (CARLOS, 2015).

De acordo com Haber e Glatzer (2009 apud CARLOS, 2015), “o estereótipo de bullying tem vindo a modificar-se, não correspondendo a um perfil prévio de um rapaz não muito inteligente, com excesso de peso e agressividade, que agredia o outro de modo a sentir melhor por uma pura demonstração de agressividade física".

Os agressores apresentam um comportamento difícil de lidar até mesmo para os adultos. Gostam de intimidar, fazer gozações e colocar apelidos maldosos nas pessoas. Assumem a postura de líderes de turma, são populares e temidos pelas humilhações que fazem com os colegas mais frágeis. Quando não recebem tratamento adequado, apresentam grandes chances de se tornarem adultos violentos e antissociais, podem até ter atitudes delinquentes e criminosas. (ESCOREL, 2009).

E umas das consequências negativas para o agressor é que ele "permanece egocêntrico e incapaz de apresentar sensibilidade moral com a dor dos outros"(ESCOREL, 2009), pois os mesmos acabam legitimando "a violência como forma de obter uma boa imagem de si" (ESCOREL, 2009).

Além disso, os praticantes de bullying acabam sendo caracterizados também por possuírem "uma postura arrogante, são conflituosos e sempre querem levar vantagem. Sentem-se superiores a partir do momento em que conseguem humilhar as suas vítimas." (ESCOREL, 2009).

\subsection{PERFIL DAS VÍTIMAS}

Segundo com Pinheiro (2007), em regra geral, “a vítima de bullying não tem noção de que é vítima, porque não sabe o que é o 
bullying. Assim sendo, a vítima pensa, simplesmente, que implicam e se metem com ela na escola.".

Silva e colaboradores (2018) afirmam que "a maioria dos estudantes vitimizados, conhecidos como vítimas-típicas, apresentam características pessoais relacionadas à ausência de condições para autodefesa e para pedidos de ajuda a colegas e professores, tais como timidez, ansiedade e poucos amigos.", nos permitindo compreender que tanto o agressor quanto a vítima do bullying carecem de habilidades sociais. Ou seja, tanto a vítima quanto o agressor necessitam ter a habilidade de quem "[...] inicia e mantém amizades com facilidade, resolve problemas interpessoais de forma a não gerar mais conflitos e possui um bom controle emocional." (SILVA et al., 2018).

\section{CONSIDERAÇÕES FINAIS}

A revisão bibliográfica acerca da intimidação sistemática como sendo uma das interfaces da violência escolar permitiu analisarmos o quão grave são as consequências advindas com a prática de bullying na vida dos agressores e das vítimas. Diante disso, torna-se imperioso que as todas as instituições sociais, em especial a escola, busque meios para detecção e repressão dessas práticas no âmbito escolar.

Observou-se que na literatura especializada, não há indicações sobre uma possível formação continuada dos professores e demais funcionários da escola em prol de um olhar mais sensível aos estudantes que demonstrem sinais de que estão vivenciando agressões de cunho físico e/ou psicológico de maneira intencional e repetitiva de seus pares, dentro e/ou fora da escola.

Considerando todo esse contexto, é de extrema importância o fomento de investimentos que se direcionem à formação inicial e continuada de professores e funcionários para que sejam capazes de executarem ações assertivas diante de um caso envolvendo a prática de bullying. Nessa perspectiva, defende-se que tais ações não devam se fundamentae em apenas punir o(a) agressor(a), mas também em acolhê-lo(a), buscando entender os motivos por detrás dos atos de violência. 
Como é possível peceber, este estudo buscou ser agente motivador para discussões envolvendo as temáticas da violência escolar e do bullying, temas não muito discutidos quando de elaboram os projetos pedagógicos das escolas. É por isso, que surge a necessidade de trazermos à tona o quão violento é a prática do bullying. Neste viés, chamamos a atenção para a necessidade de estudos acerca do enfretamento do bullying no contexto da sexualidade e afetividade dos estudantes.

Por fim, entendemos que a promoção de tais discussões é de vital importância no espaço escolar e em outros espaços que atravessam a realidade cotidiana dos nossos estudantes, seja no bairro, em casa e/ ou nas redes sociais, ambientes onde se origina o que se denomina como cyberbullying.

\section{REFERENCIAS}

ABRAMOVAY, M. (Coord.). Diagnóstico participativo das violências nas escolas: falam os jovens. Rio de Janeiro: FLACSO - Brasil, OEI, MEC, 2016. 97 p. Disponível em: http://flacso. org.br/files/2016/03/Diagn\%C3\%B3sticoparticipativodasviol\%C3\%AAncias-nas-escolas_COMPLETO_rev01.pdf. Acesso em: 08 jun. 2020.

BARDUNI FILHO, J.; COELHO, F. M. G.; FREITAS, H. B. de. Afetividade e Sexualidade, Cultura e Sociedade. 2011.

BARros, P. C.; CARVAlHO, J. E. PEREIRA, M. B. F. L. O. Um estudo sobre o bullying no contexto escolar. IX Congresso Nacional de Educação. III Encontro Sul Brasileiro de Psicopedagogia. 2009. Disponível em: https://repositorium.sdum. uminho.pt/bitstream/ 1822/10169/1/Um\%2520estud\%2 20sobre\%2520o\%2520bully ingEDUCERE2009.pdf. Acesso em: 11 jun. 2020.

BRASIL. LEI № 13.185, DE 6 DE NOVEMBRO DE 2015. Institui o Programa de Combate à Intimidação Sistemática (Bullying). Brasília, DF, 06 set. Disponível em: http://www.planalto.gov.br/ 
ccivil_03/_ato2015-2018/2015/lei/113185.htm. Acesso em: 08 jun. 2020.

CARLOS, J. P. C. S. BULLYING NA ADOLESCÊNCIA: perfil psicológico de agressores, vítimas e observadores. Mestrado Integrado em Psicologia. Universidade de Lisboa: Faculdade de Psicologia. 2015. Disponível em: http://repositorio.ul.pt /bitstream/10451/23170/1/ulfpie047687_tm.pdf. Acesso em: 11 jun. 2020 .

ESCOREL. S. S. N. Bullying não é brincadeira: cartilha. Ministério Público da Paraíba - Procuradoria Geral de Justiça, 2009. Disponível em: http://new.netica. org.br/files/cartilha_bullying. pdf. Acesso em: 23 jun. 2020.

HEILBORN, M. L. "Construção de si, gênero e sexualidade", in: HEILBORN, Maria Luiza. (org.). Sexualidade: o olhar das ciências sociais, IMS/UERJ. Rio de Janeiro: Editora Zahar, 1999, p. 40-59.

LIBÂNEO, J. C. Democratização da Escola Pública: a pedagogia crítico-social dos conteúdos. 3. Edição. São Paulo. Edições Loyola, 1986. 149 p.

LIBÂNEO, J. C. Pedagogia e pedagogos, para quê? 3.ed. - São Paulo, Cortez editora, 2000. 200 p.

PINHEIRO, L. O. (2007). Bullying: o perfil da vítima. [online] http://sites.google.com/site/bullyingemportugal/.

SALVADOR, C. C. et al. Psicologia do Ensino. Tradução Cristina Maria de Oliveira. Porto Alegre: Artes Médicos Sul. 2000. 407 p.

SILVA, J. L. et al. Intervention in social skills and bullying. Rev. Bras. Enferm., Brasília, v. 71, n. 3, p. 1085-1091, Mai 2018. Disponível em: http://www. scielo.br/scielo.php?script=sci_arttext\&pi$\mathrm{d}=$ S0034-71672018000301085\&lng=en\&nr m=iso. Acesso em: 14 jun. 2020. 
SILVA, V. M.; REIS, B. B. A relevância do ambiente sociocultural no desenvolvimento e aprendizagem da criança na perspectiva psicopedagógica. FAZU em Revista, Uberaba, $n$. 8, p. 216-220, 2011.

SOUZA, C. P. ALMEIDA, L. C. P. Bullying em ambiente escolar. Enciclopédia Biosfera, Centro Científico Conhecer - Goiânia, vol.7, N.12; 2011. Disponível em: http://www.conhecer.org. br/enciclop/conbras1/bullying.pdf. Acesso em: 23 jun. 2020. 


\section{SALA DE INTEGRAÇÃO E RECURSOS: SERVIÇO DE APOIO AO DIREITO À EDUCAÇÃO}

Itaara Gomes Pires

Kira Pires Capaverde

\section{INTRODUÇÃO}

As estatísticas do Educacenso - o censo escolar divulgado pelo Instituto de Estudos e Pesquisas Educacionais Anísio Teixeira (INEP) demonstram que houve um acréscimo considerável nas matrículas de pessoas com necessidades especiais em todo o território nacional na ordem de 33,2\% nos últimos cinco anos. Em relação ao estado do Rio Grande do Sul, o número de matrículas da educação especial chegou a 95.508 em 2019, um aumento de 25\% em relação a 2015. O maior número de matrículas está nos anos iniciais do ensino fundamental, que concentra 41,7\% das matrículas da educação especial (INEP, 2020).

Conforme os dados disponibilizados pelo Instituto Brasileiro de Geografia e Estatísticas (IBGE, 2020), o município de Porto Alegre contava em 2010 com 1.409.351 habitantes representando 13,2\% da população do Estado do Rio Grande do Sul. O percentual de pessoas com algum tipo de deficiência investigada em relação ao total da população corresponde a 32,50\%, representando em números absolutos o total de 458.208 pessoas com deficiência (OBSERVAPOA, 2020).

O banco de dados do Fundo Nacional de Desenvolvimento da Educação (FNDE) mantém os números atualizados de matrículas nas 
escolas da rede pública municipal de ensino de Porto Alegre. Assim, são: 14.781 alunos matriculados nos anos iniciais do ensino fundamental e 2.722 matrículas na educação especial desta mesma rede de ensino.

Diante desses dados significativos a pergunta norteadora deste trabalho é: Como o município de Porto Alegre organiza o atendimento aos alunos com necessidades educacionais especiais, a partir da Sala de Integração e Recursos (SIR)?

Portanto, o objetivo geral é apresentar a Sala de Integração e Recursos como um mecanismo essencial na estrutura de atendimento às pessoas com necessidades educacionais especiais (NEE) da rede pública municipal de ensino de Porto Alegre.

Para atingir o objetivo proposto, traçar especificamente o seguinte desenho:

- Identificar algumas diretrizes internacionais e nacionais que contemple o direito à educação das pessoas com necessidades especiais.

- Demonstrar a estrutura organizativa dos serviços de apoio ao atendimento escolar das pessoas com necessidades educativas especiais.

A justificativa se sustenta em dois pontos: o primeiro deles consiste na necessidade de discussão a partir do paradigma da inclusão, que tem servido de base às legislações no campo da educação especial. Assim, a educação especial se faz presente na rede regular de ensino balizada pelos princípios de uma educação democrática, aberta à diversidade, que visualiza no horizonte o direito a uma educação de qualidade para todos. (STAINBACK,S. STAINBACK, W., 1999). O segundo aspecto, parte da premissa de que o comprometimento dos professores com a aprendizagem do aluno perpassa o entendimento do contexto da estrutura escolar com vista à ampliação do escopo de ação a partir de um aprofundamento teórico constante.

Fato é que a presença cada vez mais constante de alunos com necessidades especiais na rede regular de ensino é por si só, uma motivação ao estudo deste tema. A presença de tais alunos potencializa os 
desafios para o professor. Segundo Ferreira e Guimarães (2003) apud Fernandes (2013):

“(...) o processo de inclusão avança ao lançar um olhar para as pessoas com deficiência como interlocutores que desafiam as instituições escolares a inovar suas concepções e práticas pedagógicas perante os processos peculiares de ensino e aprendizagem desses alunos (...)".

Para seguir com a discussão deste tema, este artigo segue a seguinte estruturação: o tópico 1 assinala o lugar de fala da pesquisadora e pontua que o problema de pesquisa não é somente teórico quanto é originalmente um problema de origem empírica. Avança com os esclarecimentos quanto à tipologia da pesquisa e descreve os procedimentos metodológicos utilizados, e complementa com detalhes do levantamento bibliográfico. $\mathrm{O}$ tópico 2 percorre um sentido do geral para o particular - apontando documentos internacionais que versam sobre a educação especial até se aproximar da legislação nacional que culmina com a apresentação dos aspectos organizacionais da Sala de Integração e Recursos - SIR na RME/POA. E por último, registra as considerações finais.

\section{DA DEFINIÇÃO DE CONCEITOS À ESCOLHA DO PERCURSO TEÓRICO-METODOLÓGICO.}

Segundo a resolução do $\mathrm{CNE} / \mathrm{CEB}$ n. ${ }^{\circ}$ 2, de 11 de setembro de $2001 \mathrm{em}$ seu artigo 5을 educacionais especiais os que, durante o processo educacional, apresentarem:

I - dificuldades acentuadas de aprendizagem ou limitações no processo de desenvolvimento que dificultem o acompanhamento das atividades curriculares, compreendidas em dois grupos:

a)aquelas não vinculadas a uma causa orgânica específica; 
b)aquelas relacionadas a condições, disfunções, limitações ou deficiências.

II - dificuldades de comunicação e sinalização diferenciadas dos demais alunos, demandando a utilização de linguagens e códigos aplicáveis;

III - altas habilidades/superdotação, grande facilidade de aprendizagem que os leve a dominar rapidamente conceitos, procedimentos e atitudes. (CNE/CEB 2/2001).

Na docência da educação básica, de um modo geral, até poucas décadas atrás era comum entre os professores, um sentimento de impotência frente a alguns alunos que, não se desenvolviam intelectualmente como os demais. Essa ideia limitadora advinha da crença de que, dada às mesmas oportunidades, todos poderiam aprender igualmente. Ora, muitos que ainda pensam assim não compartilham da lucidez de Pozo (2002, p.19) onde adverte que "todas as aprendizagens infelizes se parecem e as felizes o são cada uma à sua maneira”. Essa exposição, do senso comum, serve também para justificar que este estudo, antes de ser um aprofundamento teórico, é de ordem prática. Tal como se justifica nas palavras de Minayo (2002, p.17):

“(...) embora seja uma atividade teórica, a pesquisa vincula pensamento e ação. Ou seja, nada poder ser intelectualmente um problema, se não tiver sido, em primeiro lugar, um problema da vida prática”. (MINAYO, 2002, p.17).

Para a realização deste trabalho, a tipologia da pesquisa aqui apresentada é de ordem bibliográfico-descritiva. Delineada pela leitura de teóricos do campo da educação envolvidos com a temática da inclusão/ educação especial. Fez-se o levantamento de pesquisas recentes, a partir de publicações em periódico científico. O aspecto descritivo-analítico serve à apresentação das diretrizes legais orientadas ao direito à educação que englobe a todos com equidade.

Os procedimentos metodológicos aplicados ao estudo circunscrevem o tema, mas não se configuram inflexíveis. O rigor metodo- 
lógico não pode ser confundido com rigidez. O ideal é unir o caráter de uma atividade fluída e aprazível ao rigor da investigação científica. (LUNA, 1997).

O levantamento bibliográfico é um processo de reflexão crítica que conduz à delimitação e ao desvelamento do objeto estudado.

A revisão bibliográfica parte da base de dados de periódicos Scielo - Brasil. A escolha da revista Educação e Sociedade se justifica por ser um periódico Qualis A que traz contribuições relevantes à pesquisa em educação. Outros critérios utilizados para a escolha da revista foi a sua periodicidade e a participação de autores com doutoramento no país e fora dele. O levantamento levou em consideração os últimos cinco anos de publicação, de 2015 a 2020. Dito isso, segue uma breve exposição dos resultados desse levantamento.

Em 2015, o volume 37 conta com 53 artigos nas edições de números $130 \mathrm{a} 133$. Tais textos estão associados às temáticas da educação profissional, da internacionalização das políticas, da educação à distância, da formação dos professores, do ensino superior. Destaque a Adriano Henrique Nuernberg (2015) que, em sua resenha "Os estudos sobre deficiência na educação" traz o importante contributo da obra "Ressignificando a deficiência: da abordagem social às práticas inclusivas" na escola, da autoria de Jan W. Valle e David J. Connor, publicado em 2014, pela editora McGraw-Hill. Segundo Nuernberg (2015), trata-se do primeiro livro de caráter internacional, publicado no Brasil, que apresenta o campo acadêmico conhecido como "Estudos sobre Deficiência na Educação, e que traz uma abordagem crítica para o fenômeno da deficiência no contexto educacional". Ainda segundo Nuernberg (2015):

“(...) esse livro contribui para superar a concepção normativa de aluno e os desdobramentos desta nos princípios basilares da Educação em termos das barreiras atitudinais, instrumentais, pedagógicas e programáticas que impedem a participação plena dos estudantes com deficiência".

Em 2016, as quatro publicações anuais totalizaram 66 artigos. De um modo geral, a revista versou sobre cultura e resistência juvenil, avaliações em larga escala, políticas para o ensino médio, privatização 
da educação na América Latina. O editorial da revista apontou para a onda privatista na educação como uma política de alcance global, independente do nível de desenvolvimento econômico ou cultura política dos países. No entanto, não trouxe para o debate acadêmico como esse processo privatista afeta as políticas de educação especial no cotidiano da educação básica, por exemplo.

Em 2017, a revista Educação e Sociedade, volume n⿳⺈ 38, contabilizou 59 artigos. Deste conjunto, destaca-se a edição 141 com o artigo intitulado "Infầncia, normatividade e direitos das crianças: transições contemporâneas", de autoria de Rita de Cássia Marchi e Manuel Jacinto Sarmento (2017). A relevância deste artigo para esta comunicação se expressa na análise que o autor faz sobre o quanto a normatividade infantil reverbera sobre o quanto a desigualdade e o risco social afeta as diferentes condições sociais de vida das crianças, incluindo aspectos geográficos e étnico-raciais distintos (MARCHI; SARMENTO, 2017).

O volume 39 da revista Educação e Sociedade (2018) apresentou o retrocesso da política educacional no então governo Temer. A revista apontou o empobrecimento da escola pública e a negação da formação humanística, sobretudo a partir "do crescente divórcio entre vontade popular e decisão política”, quando em nome de uma pretensa racionalidade econômica, propõe sacrificar a maioria - trabalhadores e desempregados (PINO, 2018).

O volume no 40 da revista (2019) apresentou 28 artigos Em síntese, são trabalhos que conduzem à reafirmação da defesa da ciência e da educação de qualidade a partir de princípios em prol da defesa do patrimônio educacional duramente conquistado em períodos anteriores.

O último volume publicado sob no 41 (2020) traz 18 artigos. São diferentes textos que apontam novas perspectivas de análise sobre as estratégias adotadas para a privatização da educação em diferentes contextos e em crescente movimento em nosso país. Também retrata as políticas educacionais em ascensão na Colômbia e no Chile, a formação inicial de professores. Destaca-se o artigo "Educação universitária e inclusiva: recomendações a partir da voz dos estudantes espanhóis com deficiência”, dos autores espanhóis Anabel Moriña e Rafael Car- 
ballo. Neste texto, os estudantes espanhóis com deficiência propõem recomendações para a educação inclusiva no âmbito do ensino superior. Aponta a necessidade do uso de tecnologias e do incremento na formação de professores em inclusão e deficiência.

O levantamento bibliográfico na revista Educação e Sociedade a partir dos resumos do total de 261 artigos demonstra que há ainda poucos estudos que conversam com a temática do direito à educação inclusiva e à educação especial. Nenhum se referiu aos serviços de atendimento especial, como a SIR na RME/Porto Alegre, por exemplo.

A continuidade do levantamento se fez no site da Associação Nacional de Pós-Graduação e Pesquisa em Educação - ANPED. A partir do Grupo de Trabalho da Educação Especial foi possível ter acesso à Revista Brasileira de Educação Especial, no 17, de 2011 - edição especial, 20 anos. No entanto, apesar de tratar-se de uma revista de igual envergadura acadêmica, nenhum dos 11 artigos tratava sobre o estudo das estruturas municipais de educação pautadas pela legislação no campo da educação especial. De um modo geral, eram artigos que versavam mais especificamente a respeito do entendimento de transtornos globais de desenvolvimento e com altas habilidades e de diferentes deficiências à luz de um espectro mais amplo como as que abordam a deficiência auditiva, visual, física, mental e múltipla.

O artigo em processo de publicação, no "prelo", intitulado "Programa de Trabalho Educativo: autonomia e cidadania da pessoa especial", de autoria de Cássio Luís da Conceição (2019) trata de um programa oferecido pela prefeitura de Porto Alegre às pessoas com necessidades especiais. Neste artigo o autor analisa a relação entre o contexto espacial onde está inserida a escola EMEEF Tristão Sucupira Vianna e o processo de autonomia e cidadania desenvolvido pelos alunos com necessidades especiais a partir do Programa de Trabalho Educativo - PTE.

Diante do exposto, observa-se que há poucos trabalhos que desenvolvem estudos sobre a temática do direito das pessoas com necessidades especiais a partir das normativas legais aplicadas aos sistemas municipais de ensino. Assim fundamentado, o próximo subtítulo consiste em uma breve apresentação das normativas concernentes à educação 
especial e ao histórico de criação da Sala de Integração e Recursos na RME de Porto Alegre.

\section{DIRETRIZES DE UM SISTEMA EDUCACIONAL INCLUSIVO: DO GLOBAL AO LOCAL.}

Vários documentos internacionais inspiraram a Constituição Brasileira de 1988 que, em seu artigo 206, inciso I afirma o direito de todos à educação, "em igualdade de condições de acesso e permanência na escola".

Em um retrospecto histórico é possível apontar para a Declaração Universal dos Direitos Humanos, posta em vigor a partir de uma assembleia da Organização das Nações Unidas (ONU) no ano de 1948. Em um contexto de pós Segunda Guerra Mundial, tal declaração afirma em seu $2^{\circ}$ artigo:

"Todo ser humano tem capacidade para gozar os direitos e
as liberdades estabelecidos nesta Declaração, sem distinção
de qualquer espécie, seja de raça, cor, sexo, idioma, religião,
opinião política ou de outra natureza, origem nacional ou
social, riqueza, nascimento, ou qualquer outra condição".
(DUDH, 1948).

Especificamente em relação à educação, Carlota Boto (2005) sinaliza que frequentemente há discussões em relação a uma possível queda de qualidade no ensino, devido à incorporação de grupos que até então estavam excluídos do sistema educacional.

Por certo, aqueles que assim se posicionam, desconsideram que o direito a uma educação inclusiva e de qualidade, decorre de uma trajetória de lutas sociais. Além disso, é incoerente definir um padrão positivo de qualidade da educação a um sistema que estimula ou permite que parte da população fique fora dele.

Carlota Boto (2005) aponta o direito à educação em três gerações:

- O ensino torna-se paulatinamente direito público quando todos adquirem a possibilidade de acesso à escola pública. 
- A educação como direito dá um salto quando historicamente passa a contemplar, pouco a pouco, o atendimento a padrões de exigência voltados para a busca de qualidade no ensino oferecido e para o reconhecimento de ideais democráticos internos à vida escolar.

- O direito da educação será consagrado quando a escola adquirir padrões curriculares e orientações políticas que assegurem inversão de prioridades, mediante atendimento que contemple - à guisa de justiça distributiva - grupos sociais reconhecidamente com maior dificuldade para participar desse direito subjetivo universal - que é a escola pública, gratuita, obrigatória e laica. (BOTO, 2005, p.779)

O direito à educação em uma perspectiva de $3^{\circ}$ geração, isto é, em um sentido não apenas ético-teórico, mas, sobretudo uma questão político-social, age na direção de proporcionar o acesso a todos, reconhecendo nesse processo a singularidade das chamadas minorias.

No que concerne à legislação educacional se faz necessário sinalizar que o Brasil é signatário de documentos oriundos de Conferências Mundiais. Tais como a Conferência "Educação para Todos”, em Jomtiem/Tailândia, em 1990 e a Declaração de Salamanca (1994) que expressa as diretrizes "Sobre Princípios, Políticas e Práticas na Área das Necessidades Educativas Especiais":

- toda criança tem direito fundamental à educação, e deve ser dada a oportunidade de atingir e manter o nível adequado de aprendizagem,

- toda criança possui características, interesses, habilidades e necessidades de aprendizagem que são únicas,

- sistemas educacionais deveriam ser designados e programas educacionais deveriam ser implementados no sentido de se levar em conta a vasta diversidade de tais características e necessidades,

- aqueles com necessidades educacionais especiais devem ter acesso à escola regular, que deveria acomodá-los dentro de 
uma Pedagogia centrada na criança, capaz de satisfazer a tais necessidades,

- escolas regulares que possuam tal orientação inclusiva constituem os meios mais eficazes de combater atitudes discriminatórias criando-se comunidades acolhedoras, construindo uma sociedade inclusiva e alcançando educação para todos; além disso, tais escolas proveem uma educação efetiva à maioria das crianças e aprimoram a eficiência e, em última instância, o custo da eficácia de todo o sistema educacional. (SALAMANCA, 1994).

Em um retrospecto da política educacional no Brasil, Ferreira (2006) aponta que a educação especial até a década de 1960 centrava-se em iniciativas um tanto restritivas em instituições especializadas principalmente privadas. As poucas escolas públicas com atendimento especial acompanhavam o crescimento do ensino primário e "de seus problemas, tal como o crescente fracasso escolar nas séries iniciais". (FERREIRA, 2006, p.87).

Os discursos da normalização e da integração ocorrerão no Brasil a partir da década de 1970. Sobretudo após a Lei de Diretrizes e Bases da Educação Nacional nº. 5692/71 e a emenda Constitucional de 1978. Desenvolveram-se a partir dos Conselhos Estaduais de Educação as normativas da educação escolar dos excepcionais, estabelecendo a criação das carreiras especializadas em educação especial e também a criação de equipes de reabilitação. (FERREIRA, 2006). Em relação a esta legislação, "a natureza clínico-terapêutica do atendimento revela-se na terminologia tratamento, utilizada ao se referir ao alunado". (FERNANDES, 2013, p.122).

As chamadas classes especiais incorporadas às escolas da rede municipal de POA foram implantadas a partir de 1970, sob o jugo da LDBN $\mathrm{n}^{\mathrm{o}}$ 5692/71 e atendiam alunos com deficiência mental que, segundo a visão da época, eram incapazes de acompanhar a primeira série. (MOSTARDEIRO, 2000).

Mais de vinte anos depois, a LDBN no 9394/96 reverbera a mudança de enfoque dado à deficiência em consequência da deliberação de três artigos que definem conceitos, locais de oferta, matriz político-pedagógico e verbas de financiamento. (FERNANDES, 2013). 
Em Porto Alegre, segundo Conceição (2019) a criação de escolas especiais com este olhar diferenciado em relação às pessoas com necessidades especiais precede a LDBN nº 9394/96 e a Constituição de 1988.

Em 1988 foram criadas a EMEEF Lygia Morrone Averbuck e a EMEEF Prof. Elyseu Paglioli, portanto, já haviam sido planejadas. A EMEEF Prof. Luiz Francisco Lucena Borges foi criada em 1990. E a EMEEF Tristão Sucupira Vianna foi criada em 1991. Portanto, a efetivação de escolas especiais na rede pública de Porto Alegre trata-se de um processo que já estava bastante avançado. Além disso, a preocupação e a demanda das comunidades continuou com a criação da EMEF de Surdos Bilíngue Salomão Watnick em 2008. (CONCEIÇÃO, 2019, p.3).

De acordo com a LDBN 9394/96, em seu capítulo V - artigo 58, a educação especial é assim definida: "Entende-se por educação especial, para os efeitos desta Lei, a modalidade de educação escolar, oferecida preferencialmente na rede regular de ensino, para educandos portadores de necessidades especiais".

A RME/Porto Alegre atualmente tem a oferta de ensino fundamental em 56 escolas municipais da rede própria, sendo que duas destas também ofertam o ensino médio regular. A rede também conta com quatro EMEEFs - Escola Municipal Especial de Ensino Fundamental. São elas: EMEEF Lygia Morrone Averbuck, EMEEF Prof. Elyseu Paglioli, EMEEF Prof. Luiz Francisco Lucena Borges, EMEEF Tristão Sucupira Vianna. Mais recentemente, em 2008, foi criada a escola bilíngue de surdos - EMEF de Surdos Bilíngue Salomão Watnick.

Quanto ao serviço de apoio especializado, segundo a LDBN 9394/96, o artigo 58, parágrafo 1ํ resolve: "haverá, quando necessário, serviços de apoio especializado, na escola regular, para atender as peculiaridades da clientela de educação especial".

$\mathrm{Na} \mathrm{RME} / \mathrm{POA}$, as crianças com necessidades especiais recebem o atendimento especializado nas EMEEFS e nas classes regulares do ensino fundamental. Para tal propósito existe o apoio de profissionais qualificados no âmbito da educação especial que atendem tanto a edu- 
cação infantil quanto o ensino fundamental a partir de uma estrutura de serviços de apoio à inclusão. A saber:

- Educação Precoce (EP) e Psicopedagogia Inicial (PI): Serviço de apoio à inclusão na Educação Infantil para crianças de 0 a 6 anos com Necessidades Educacionais Especiais, com atendimento nas escolas especiais da rede Municipal. Além do atendimento educacional especializado ao aluno, são realizadas assessorias às escolas e creches comunitárias conveniadas, buscando o desenvolvimento do processo de escolarização.

- Projeto de Estágio de Apoio à Inclusão: $\mathrm{O}$ trabalho é desenvolvido por estagiários- alunos graduandos de Licenciaturas- em escolas regulares de Educação Infantil e de Ensino Fundamental, em turmas que tenham alunos público-alvo da educação especial. A proposta prevê uma atuação em parceria com o professor e/ou monitor da turma.

- Programa de Trabalho Educativo (PTE): Esse programa é oferecido para alunos das quatro escolas especiais e alunos do ensino regular atendidos na Sala de Integração e Recursos. O objetivo é preparar alunos com deficiência e/ou transtornos globais do desenvolvimento, em fase de conclusão do Ensino Fundamental para o mercado de trabalho, oferecendo novas possibilidades de aprendizagem para além do espaço escolar.

- Salas de Integração e Recursos (SIR): Serviço de apoio à inclusão no Ensino Fundamental para alunos com deficiência, transtorno global do desenvolvimento e altas habilidades. Caracteriza-se por uma oferta pedagógica que visa facilitar o acesso, a participação e a aprendizagem no ensino regular. $\mathrm{O}$ atendimento dos alunos com deficiência auditiva, visual e altas habilidades acontece em escolas polo. (SMED/POA, 2020)

A relevância desses serviços de apoio é legítimo e corresponsável pelo sucesso da inclusão das crianças com necessidades especiais nas salas de aula de ensino fundamental. Esses serviços ampliam a possibilidade de acesso aos recursos que favorecem a autonomia e a satis- 
fação decorrente do sentido de pertencimento desses alunos frente à sua comunidade.

A SIR foi criada como modelo experimental na RME/POA em 1995. Seu desenvolvimento acompanhou o estabelecimento da reorganização curricular de Ciclos de Formação em detrimento da escola seriada. Este processo deu à SIR uma característica particular que se caracteriza não só pelo atendimento ao aluno com necessidades especiais, mas por uma espécie de assessoria e compartilhamento de saberes que auxilia os professores das salas comuns no desenvolvimento de um olhar diferenciado não só aos alunos com necessidades especiais mas em relação a todo alunado pela inclusão das diferenças.

Para que o aluno seja inserido na SIR, antes ele deve ter passado pelo laboratório de aprendizagem. Se mesmo assim, os déficits de aprendizagem permanecem, ele passa a ser indicado ao atendimento da SIR. O serviço da SIR é oferecido tanto para as crianças da educação infantil, no sentido de avaliar se estas devem ingressar no ano seguinte nas escolas regulares ou em escolas especial quanto aqueles que frequentam o ensino fundamental como um todo e que apresentam necessidades educacionais especiais. Também um aluno que frequenta uma escola especial pode servir-se do atendimento da SIR com o intuito de verificar a possibilidade de acessar o ensino regular. De qualquer modo, o atendimento da SIR ocorrerá sempre na prerrogativa do turno inverso, para que o aluno com necessidade educativa especial não seja alijado do convívio com os demais colegas da turma comum.

Os serviços desempenhados pela SIR envolvem uma avaliação do aluno tanto no sentido de sua permanência neste espaço quanto em relação a um possível encaminhamento a uma escola especial. O atendimento na SIR prima por propostas individualizadas ou em pequenos grupos, potencializando processos de aprendizagens. O encontro periódico com os demais profissionais da escola pautam os planejamentos escolares; e, por fim, a SIR atende pais ou responsáveis, amplificando a voz da comunidade dentro da escola e colaborando com o entendimento das famílias em relação às crianças com necessidades especiais. (BAPTISTA, C.R. \& TEZZARI, M.L., 2009).

Não somente a socialização está no horizonte da inclusão. A SIR age com o intuito de promover a aproximação dos alunos com 
necessidades especiais ao saber escolarizado. Tal tarefa requer a promoção de uma cultura inclusiva na escola "para pensar e discutir sobre estas questões, para pensar o seu fazer diário, desde sua postura ética até sua prática cotidiana, nos planejamentos, os tipos de intervenções, os objetivos". (TEZZARI, M.L. \& SCHROEDER, C.V.C, 2016).

A existência da SIR atualmente em todas as EMEFs da RME/ POA não estanca a necessidade dos professores por mais apoio no trato pedagógico com os alunos, principalmente diante de uma sociedade que propõe a inclusão escolar,mesmo sendo ela própria excludente.

Felizmente, o estudo constante dos profissionais da SIR nas questões ligadas à inclusão escolar promove a sensibilização do ser humano. $\mathrm{O}$ apoio oferecido pela SIR se distancia de prescrições inócuas junto aos professores. Ao contrário, valoriza o conhecimento do professor regular e propõe conjuntamente estratégias viáveis de atendimento nas salas de aula comuns e na Sala de Integração e Recursos.

No entanto, sabe-se que a inclusão dos alunos com necessidades especiais nos anos iniciais, é evidentemente complexa. Requer não somente a atuação dos profissionais da SIR, mas se faz necessária uma infraestrutura para além da organização dos espaços físicos de acessibilidade, por exemplo. Tem relação com uma rede de apoio que envolva a atuação direto do Estado. Que garanta às famílias o acesso dessas crianças à escola e a um conjunto de serviços para além da escola, como de serviço social e atendimento psicológico para todas as crianças. Além disso, há de ter a conjugação entre a formação específica dos profissionais da SIR e a formação continuada de todos os trabalhadores em educação no que tange a presença de crianças com necessidades especiais nos anos iniciais.

\section{CONSIDERAÇÕES FINAIS}

Ao término dessa comunicação faz-se a retomada da questão inicial, a saber: Como o município de Porto Alegre organiza o atendimento aos alunos com necessidades educacionais especiais, a partir da Sala de Integração e Recursos? 
O interesse em respondê-la, justificou-se tanto pela disposição investigativa pessoal, quanto pelo crescente número de matrículas de pessoas com necessidades especiais nas salas de aulas da educação básica. Tal situação decorre, em parte, de uma legislação educacional mais democrática e inclusiva, signatária de diretrizes internacionais no campo dos direitos humanos.

Para responder a questão norteadora, no tópico 1 - Da definição de conceitos à escolha do percurso teórico-metodológico, foi exposto a adoção da pesquisa bibliográfica e a busca de fundamentos em artigos científicos na Revista Educação e Sociedade a partir da plataforma Scielo, bem como o acesso ao site da Associação Nacional de Pós-Graduação e Pesquisa em Educação - ANPED.

Por fim, no item 2 Diretrizes de um sistema educacional inclusivo: do global ao local buscou-se uma discussão a partir de documentos da legislação de cunho internacional, e foram dadas as devidas referências à legislação nacional no que tange ao atendimento de pessoas com necessidades especiais. Por último, o desdobramento da estrutura de apoio às pessoas com necessidades educativas especiais no município de Porto Alegre, com a respectiva ênfase na Sala de Integração e Recursos.

A partir do que foi apresentado e diante da complexidade do tema, não houve a intenção de esgotá-lo. De maneira oposta, a intenção é no sentido de ampliar e contribuir com as discussões teóricas para que estas reflitam em ações concretas em sala de aula.

Mais do que o conhecimento da estrutura de apoio, como a Sala de Integração e Recursos, é importante considerar que o atendimento a essas pessoas não se faz somente a partir da estrutura física ou da legislação.

Sem a intenção de ser um texto prescritivo, é importante que a cultura da inclusão escolar apoie e estimule práticas que se distanciem de discursos homogeneizantes e segregadores. A diversidade está presente e a busca pela igualdade, pelo direito a uma educação de qualidade só se efetivará de fato, se levarmos em consideração as necessidades educacionais de cada um. Segundo Stainback \& Stainback (1999):

"Finalmente, deve ser enfatizado que dizer que a reestruturação pode ser feita não é o mesmo que dizer que é fácil fazê-la. A segregação vem sendo praticada há séculos (...) conseguir a in- 
clusão de todos é um grande desafio. Entretanto, o objetivo de se ter escolas inclusivas onde todos estejam inseridos e tenham amigos e onde sejam utilizados programas e apoios educacionais adequados é importante demais para não se aceitar um desafio.” (STAINBACK \& STAINBACK, 1999, pp.434-435).

As estruturas de apoio à educação inclusiva, tal como a SIR, incluem profissionais que atuam com diferentes abordagens, segundo as demandas de cada comunidade escolar. Mas para que elas possam surtir um efeito mais amplo é necessário que haja uma rede de apoio extraescolar, que inclua um sistema de saúde e políticas sociais abrangentes e inclusivas.

\section{REFERENCIAS}

BAPTISTA, Cláudio Roberto \& TEZZARI, Mauren Lúcia. Construir redes. Serviços de apoio em educação especial no município de POA. R\&A. volume 17.n.1, 2009)

BOTO, Carlota. A educação escolar como direito humano de três gerações: identidades e universalismos. Educ. Soc., Campinas, v. 26, n. 92, p. 777-798, 2005. Disponível em: https://bit.ly/3ecu1GT Acesso: 08/07/2020.

CONSELHO NACIONAL DE EDUCAÇÃO. Câmara de Educação Básica. Resolução CNE/CEB 2/2001. Diário Oficial da União, Brasília, 14 de setembro de 2001. Seção 1E, p. 39-40. Disponível em: http://portal.mec.gov.br/cne/arquivos/pdf/CEB0201.pdf Acesso:02/07/2020.

DUDH. Declaração Universal dos Direitos Humanos. ONU, 1948. Disponível em: https://bit.ly/2ZIhjuz Acesso: 02/07/2020.

FERNANDES, Sueli. Fundamentos para a educação especial. Curitiba: Intersaberes, 2013.

FERREIRA, Júlio Romero. Educação especial, inclusão e política educacional: notas brasileiras. In.: Inclusão e Educação: 
doze olhares sobre a educação inclusiva. David Rodrigues (org.). São Paulo: Summus, 2006.

IBGE. Instituto Brasileiro de Geografia e Estatística. 2020. Disponível em: https://cidades.ibge.gov.br/ Acesso: 30/06/2020.

INEP. Resumo Técnico: Censo da Educação Básica Estadual. 2019 [recurso eletrônico]. \ Brasília: Instituto Nacional de Estudos e Pesquisas Educacionais Anísio Teixeira, 2020. Disponível em: https://bit.ly/2NFIErB Acesso: 30/06/2020.

LDBN. Lei de Diretrizes e Bases da Educação Nacional № 9.394 de 20 de dezembro de 1996. Brasília: MEC. Disponível em: https://bit.ly/38liunz Acesso: 02/07/2020.

LUNA, S. V. de. Planejamento de pesquisa: uma introdução. São Paulo: Educ., 1997.

MARCHI, Rita de Cássia; SARMENTO, Manuel Jacinto. Infância, normatividade e direitos das crianças: transições contemporâneas. Educ. Soc., Campinas, v. 38, n. 141, p. 951-964, 2017. Disponível em: https://bit.ly/31sUnSn Acesso: 29/06/2020.

MINAYO, M $M^{a}$ Célia de Souza. Entre voos de águia e passos de elefante: caminhos da investigação na atualidade. In: MINAYO, M.C.S \& DESLANDES, S.F. (org). Caminhos do pensamento: epistemologia e método. Rio de Janeiro: Fiocruz, 2002, p. 17-27.

MORINA, Anabel; CARBALLO, Rafael. Universidad y Educación inclusiva: recomendaciones desde la voz de Estudiantes españoles com discapacidad. Educ. Soc., Campinas , v.41, 2020. Disponível em: https://bit.ly/2NFHX1h Acesso: 29/06/2020.

MOSTARDEIRO, Guacira Cardoso. Historicizando a educação especial na SMED. Porto Alegre: Cadernos Padagógicos, 2000, p.7-12. 
NUERNBERG, Adriano Henrique. Os estudos sobre deficiência na educação. Educ. Soc., Campinas, v. 36, n. 131, p. 555-558, 2015. Disponível em: https://bit.ly/3g94vnf Acesso: $29 / 06 / 2020$.

OBSERVAPOA. Observatório da Cidade de Porto Alegre. PMPA, 2020. Disponível em: http://www.observapoa.com.br/ Acesso: 30/06/2020.

PINO, Ivany Rodrigues et al . A educação no atual cenário político econômico mundial: a disputa eleitoral e os retrocessos na educação. Educ. Soc., Campinas, v. 39, 2018. Disponível em: https://bit.ly/2ZgRHEG Acesso: 29/06/2020.

POZO, Juan Ignácio. Aprendizes e Mestres: a nova cultura da aprendizagem. Porto Alegre: Artmed, 2002.

SALAMANCA, Declaração de. Sobre Princípios, Políticas e Práticas na Área das Necessidades Educativas Especiais. Espanha, 1994. Disponível em: http://portal.mec.gov.br/seesp/arquivos/pdf/salamanca.pdf Acesso: 02/07/2020.

SMED/POA. Secretaria Municipal de Educação da Prefeitura de Porto Alegre. Serviço de apoio à inclusão. 2020. Disponível em: https://bit.ly/38pY38I Acesso: 02/07/2020.

STAINBACK, Susan e STAINBACK, William. Inclusão - um guia para educadores. Tradução: Magda França Lopes. Porto Alegre: Artmed, 1999.

TEZZARI, M.L. \& SCHROEDER, C.V.C. Sala de integração e recursos e rede de atendimento: parceria necessária à inclusão escolar. SMED: Conhecer, 2016, p.7 - 11. 


\section{ENSINO MÉDIO POLITÉCNICO: A POLITECNIA COMO DISTORÇÃO!?}

Itaara Gomes Pires

Kira Pires Capaverde

\section{INTRODUÇÃO}

A politecnia é vista como uma formação integral, que ao aglutinar diferentes conhecimentos potencializa o ser humano. A atual etapa do desenvolvimento das forças produtivas requer trabalhadores capazes de articular múltiplos saberes. No século XXI, teria a politecnia se transfigurado, tornando-se um instrumento capaz de assegurar o avanço do capital, sob os auspícios da ciência e da técnica?

Este estudo corresponde à parte da pesquisa de doutoramento intitulada O Ensino Médio no RS: regulação institucional e posicionamento docente. Desenvolvida no período 2012-2016, a pesquisa teve como objetivo problematizar, no contexto da internacionalização das políticas, a regulação institucional e o posicionamento docente, a partir da Reforma do Ensino Médio Politécnico no RS (2011-2014). Para atingir tal objetivo, fez-se a opção pelo uso da escala likert como coleta de dados e a análise de conteúdo como técnica teórico-metodológica (BARDIN, 1977). À guisa de considerações finais apontou divergências no que tange à concordância dos professores com um ensino contextualizado, alicerçado na pesquisa e na interdisciplinaridade, em oposição ao modo como se constituiu a implantação da Reforma do Ensino Médio Politécnico no_Rio Grande do Sul.

Para fins dessa comunicação são apresentadas algumas contradições presentes no documento-base do Ensino Médio Politécnico posto 
em prática a partir das ações do plano de governo da administração Tarso Genro (2011-2014). Igualmente, este estudo aborda o conceito de politecnia. Tem por objetivo demonstrar que a Reforma do Ensino Médio Politécnico no RS, proposto por um governo ideologicamente à esquerda, não foi capaz de materializar o conceito de politecnia. Politecnia que representa não somente a apropriação das técnicas que fundamenta o trabalho humano. Mas que engloba uma formação que atenda as diferentes dimensões do ser humano: intelectual, física, psicoemocional e de incorporação tecnológica, para que no transcurso dos processos produtivos, tenha no horizonte o intuito de proporcionar o bem estar social da existência humana.

Para contemplar tal discussão, este artigo segue a seguinte estruturação: o tópico 1 "O Ensino Médio Politécnico: documento base" discute o documento-base da Reforma do Ensino Médio Politécnico. O tópico 2 "Politecnia: Concepção Pedagógica de Formação Humana” retoma o conceito de politecnia associado ao trabalho como princípio educativo. Por fim, à guisa de considerações finais, é apontado a inconsistência da adoção do conceito de politecnia em uma política educacional que não questiona as condições exíguas de sobrevivência de grande parte dos trabalhadores, que não vislumbra uma luta política que seja capaz de projetar, ainda que em um tempo futuro, uma sociedade mais igualitária.

\section{O Ensino Médio Politécnico: documento base.}

O Ensino Médio Politécnico através do documento-base intitulado "Proposta Pedagógica para o Ensino Médio Politécnico e Educação Profissional Integrada ao Ensino Médio" se insere nas ações do plano de governo da administração Tarso Genro (2011-2014). O documento do programa de governo da administração Tarso aponta que para atingir a democratização e a construção da qualidade na educação básica é necessário “(...) o suporte à promoção de uma profunda reestruturação curricular nas escolas, visando à garantia do acesso ao conhecimento para todos os que estão na escola (...)”. (GENRO, 2010,p.18-19).

Esta profunda reestruturação curricular expressa acima no documento do Programa de Governo, veio a se materializar com a "Proposta 
Pedagógica para o Ensino Médio Politécnico e Educação profissional integrada ao ensino médio". Neste documento consta que, a reestruturação curricular seria colocada em prática progressivamente a partir de 2012. Desta forma, em 2012 apenas o 1ำ ano do Ensino Médio (EM) apresentaria a nova feitura curricular, posteriormente o $2^{\circ}$ ano do Ensino Médio em 2013 e, por fim, o ano de 2014 abrangeria o 3o ano, completando assim, ao final do mandato, a integralidade do ensino médio.

Está incluído neste documento, uma análise diagnóstica do ensino médio na rede estadual que, para além de trazer dados estatísticos baseados no Censo Escolar da Educação Básica INEP/MEC, traz o anúncio de uma situação, já conhecida dos professores: as condições precárias de infraestrutura das escolas. Bem como, sinaliza a existência de um currículo "fragmentado, dissociado da realidade sócio-histórica, e, portanto, do tempo social, cultural, econômico e dos avanços tecnológicos da informação e da comunicação" (SEDUC, 2011, p.5).

A proposta curricular do ensino médio politécnico reforça a ideia já presente na LDB 9394/1996 em que consta que o ensino médio é a etapa final da educação básica e que tem como um de seus objetivos "a compreensão dos fundamentos científico-tecnológicos dos processos produtivos, relacionando teoria e prática, no ensino de cada disciplina" (BRASIL, Lei no 9.394/1996, Art.35).

O documento-base do Ensino Médio Politécnico traz o conceito de trabalho como princípio educativo ao afirmar que:

É pelo trabalho que os seres humanos produzem conhecimento, desenvolvem e consolidam sua concepção de mundo, conformam as consciências, viabilizando a convivência, transformam a natureza construindo a sociedade e fazem história. (SEDUC/RS, 2011, p.13).

O documento-base expressa o alvorecer do "novo princípio educativo" (SEDUC/RS, 2011) e, para tanto, faz uma exposição da organização da vida social e produtiva aos moldes do taylorismo/fordismo que exigia um projeto pedagógico societário baseado na "memoriza- 
ção, pela repetição, de conhecimentos fragmentados, tanto na educação geral quanto na profissional" (SEDUC/RS,2011, p.13). Conforme o texto base, a nova fase sócio-produtiva da sociedade, se assenta na dinamicidade decorrente da microeletrônica e, como tal, demanda para a educação "um novo princípio educativo em que o trabalho predominantemente psicofísico passa a ser substituído pelo trabalho intelectual" (SEDUC/RS, 2011, p.13).

É importante definir que a característica do trabalho como princípio educativo decorre do fato de que é o trabalho um atributo intrínseco ao ser humano e, é isto que o diferencia dos outros animais. A própria existência humana só se preserva porque o homem é capaz de criar, a partir da natureza, os instrumentos para cumprir com a tarefa que as necessidades the exigem.

Marx e Engels (1981), em A Ideologia Alemã, esclarecem que a produção dos meios para propiciar a própria existência e cumprir com as necessidades de sua vida material é, em si, o primeiro ato fundamentalmente humano. É o ato de modificar a natureza, que passa a se constituir no momento histórico em que o homem incorpora e desenvolve em si, aspectos de ser racional/social. Logo, este ato que significa a expressão do trabalho é aprendido pelo homem social, constituindo-se em um princípio educativo.

Gramsci (1999) retoma a ideia do devir histórico. Neste sentido, afirma que o homem não é tão somente uma abstração filosófica. Enquanto conceito unitário, o homem é o "conjunto das relações sociais", porque aqui se expressa a ideia de devir. O homem "transforma-se continuamente com as transformações das relações sociais”. (GRAMSCI, 1999, p.245). Portanto, a natureza humana não é biológica, mas sim, o resultado de suas ações para desenvolver as condições materiais que preservem a manutenção de sua existência, isto é, a realização do trabalho.

É com este raciocínio que Dermeval Saviani (2012) retoma o ideário marxiano, ao sustentar que é preciso aprender a trabalhar, no sentido de agir sobre a natureza para que este ato seja a garantia da preservação da própria subsistência e de seus pares. Neste sentido, o trabalho é, em si, um princípio educativo transmitido nas relações sociais estabelecidas do devir histórico. 
O documento-base do Ensino Médio Politécnico parece adaptar o conceito de "trabalho como princípio educativo", uma vez que, afirma que o mundo do trabalho busca um novo princípio educativo que responda às suas demandas.

Dessa forma, utiliza a mudança no processo produtivo, que outrora era pautado pela forma taylorista/fordista, que "demandava uma pedagogia fundada na memorização, pela repetição, de conhecimentos fragmentados, tanto na educação geral quanto na profissional” (SEDUC/RS, 2011, p.13), para justificar no documento-base da reforma do EMP a necessidade que o novo modelo do mundo do trabalho, com o advento da microeletrônica, passou a demandar. Isto é, a indispensabilidade de um "novo" princípio educativo. Neste "novo princípio educativo" proposto pelo EMP, o trabalho humano não se caracteriza como um elemento ontológico do homem, e sim, como um veículo que é "regido pela dinamicidade e pela instabilidade da produção em ciência e tecnologia, que exige uma escola capaz de ensinar o homem a adquirir a resistência ao estresse" e desenvolver a flexibilidade para mudar constantemente a fim de se adaptar ao novo processo produtivo que "amplia o desemprego, a precarização e a intensificação de trabalho”. (SEDUC/RS, 2011, p.13-14).

Muitas interpretações anunciam a superação do capitalismo clássico e o surgimento de um novo modelo de desenvolvimento científico-tecnológico. Este desenvolvimento passa a ser estabelecido a partir da égide de uma economia mais flexível, desregulada, onde a centralidade do trabalho passa a ser substituída por uma nova sociedade do conhecimento (FRIGOTTO, 1995).

Neste sentido, a regulação da Secretaria de Educação do Rio Grande do Sul (SEDUC/RS) para o ensino médio implementada no governo Tarso, deixa claro que, as novas relações sociais e de produção definidas pela reestruturação do capitalismo requerem novos trabalhadores capazes de se "adaptar" a esta fase da economia contemporânea que exige novos modelos de gestão do trabalho devido à desregulamentação dos mercados e a mundialização do capital financeiro.

Visto dessa forma, pelo documento-base do EMP, o trabalho como princípio educativo recebe nova roupagem. A proposta do 
EMP, implicitamente, converte a lógica do trabalho e da educação, ainda que o documento seja recheado de citações de autores da teoria crítica, com base marxista.

O documento-base do EMP passa a ideia de que o novo princípio educativo exigido pelo mundo do trabalho clama por uma educação que seja capaz de atender às necessidades do capitalismo através da formação de um novo trabalhador, polivalente, com resistência à precarização do trabalho, ao aumento do desemprego e de subocupações regidas pela flexibilização das relações trabalhistas. Isso significa dizer que, este novo homem, mais resistente às vicissitudes do "mundo do trabalho", deve ser capaz de lidar, ao mesmo tempo, com um novo maquinário da microeletrônica, da nanotecnologia (o que requer um alto grau de intelectualização das novas formas de produção) e também com o fantasma crescente do desemprego.

Observa-se assim que, este perfil de homem descrito pelo documento-base do EMP, deve ser educado para suprir as necessidades dessa nova etapa do sistema produtivo. O que caracteriza, de certa forma, uma retomada da Teoria do Capital Humano.

A educação politécnica proposta pelo documento-base do EMP assemelha-se a um "investimento", uma "aplicação" em capital humano.

A Teoria do Capital Humano (TCH) foi sistematizada pelo teórico Theodore W.Schultz, professor do departamento de economia da Universidade de Chicago/EUA. A defesa argumenta a tese de que qualquer limitação que se refere à energia, terras ou outras propriedades não são limitadores decisivos da melhoria da situação humana e aponta que, é a instrução adquirida, geradora de melhores aptidões (qualificação), que levaria ao acréscimo da capacidade produtiva, levaria ao progresso econômico da sociedade. Para Schultz (1987):

Minha abordagem da qualidade da população é tratar a qualidade como um recurso escasso, o que implica que ela tem um valor econômico e que sua aquisição acarreta um custo. A chave da análise do comportamento humano que determina o tipo e o volume da qualidade adquirida com o passar do tempo é a relação entre os retornos da qualidade adicional e o custo de sua 
aquisição. Quando os retornos excedem o custo, a qualidade da população aumenta. (SCHULTZ, T.W., 1987, p. 25).

Para o teórico, ao analisar o significado econômico da qualidade da população, nem mesmo os grandes economistas clássicos, como Adam Smith e David Ricardo, teriam calculado que o desenvolvimento econômico das nações é um espiral decorrente da qualidade da população e que esta, estaria atrelada diretamente à capacidade de investir em educação como insumo ao crescimento econômico (SCHULTZ,T.W,1987).

No Brasil, esta teoria foi adotada e direcionada particularmente para o, então chamado, ensino de $2^{\circ}$ grau, durante o período da ditadura militar. Recebeu uma série de críticas que são apontadas por Gaudêncio Frigotto (1999, p.16-17) com destaque à tese de Cláudio Salm: "Escola e Trabalho" que reitera que o sistema capitalista prescinde da instituição escolar, não apresentando, portanto, uma articulação entre educação e economia.

No entanto, para Frigotto (1999) a vinculação da instituição escolar com sistema do capitalista não é inexistente. Tampouco se estabelece do mesmo modo como é apontado pelos adeptos da TCH. O autor anuncia a ocorrência da produtividade gerada pela improdutividade da escola. Ou seja, para o autor, a educação é um campo onde se vê as contradições do capitalismo e pode tanto ser dirigida aos interesses do sistema capitalista quanto para a organização daqueles que são explorados, a classe trabalhadora.

O campo educacional no Brasil, com seu viés nacional-desenvolvimentista dos governos do período militar, localizou, no conteúdo da TCH, uma legitimação para suas políticas. Ao Estado caberia a responsabilidade de garantir o desenvolvimento de mão de obra qualificada, para atender às necessidades do empresariado, que, sozinho, não dava conta de produzi-la. A disponibilidade de oferta educacional passa a ter não somente um cunho social-humanista como também, e principalmente, passa a responder ao campo econômico e político.

No contexto do capitalismo contemporâneo, a demanda por trabalhadores polivalentes, únicos responsáveis pelo próprio sucesso independente das suas condições, recebe o nome de empreendedorismo. 
Isto é capaz de fazer o homem crer que, sozinho está habilitado a dar conta das adversidades econômico-social, desconsiderando a força e o histórico das conquistas oriundas de ações coletivas.

É neste contexto de entendimento das novas relações produtivas do capital que o documento-base do EMP expressa a adoção de um termo que se situa dentro do campo marxista: a politecnia. Traz o pensamento de teóricos associados ao campo marxista, como Gramsci e Saviani, como uma forma de dar base e aproximação com uma linha de pensamento que, de fato, visa à superação da dicotomia do trabalho intelectual e manual.

No entanto, o documento resume a politecnia tão somente como o "domínio intelectual da técnica" (SEDUC, 2011, p.14) e a coloca como a justificativa para a estruturação "de novas formas de seleção e organização dos conhecimentos” (SEDUC/RS, 2011,p.15). O Conselho Estadual de Educação do Rio Grande do Sul (CEED/RS) constata através do parecer $\mathrm{n}^{\mathrm{o}}$ 156/2012 que:

(igualmente em relação ao novo princípio educativo) o termo politecnia ou médio politécnico é elemento acessório, isto é, não essencial ao projeto. Não se nota coerência com o sentido que os demais países do MERCOSUL emprestam ao termo, nem tampouco com o que já se teorizou sobre o assunto. (RIO GRANDE DO SUL, 2012a, p. 5). (os grifos não constam no original).

É nítido o descompasso percebido pelo CEED/RS no que tange ao proposto pelo documento-base do EMP. Tanto que parece demonstrar certa incredulidade quanto à devida concretização da Proposta, pois a situa na esfera do idealizado.

Do material encaminhado a exame e, principalmente, dos encontros realizados restou claro que o resultado final que se espera alcançar se situa no plano do idealizado; sua concretização somente se consubstanciará com a participação das escolas, num processo coletivo de construção de novas alternativas curriculares, individualizadas, por escola e por curso. (RIO GRANDE DO SUL, 2012a, p.5). 
Por certo, passado um distanciamento temporal, desde o processo de implantação do Ensino Médio Politécnico, verifica-se que o CEED/RS analisou corretamente o documento-base posto à exame. O documento-base do EMP não somente permaneceu no campo do idealizado devido a não efetivação de um processo coletivo de construção, quanto também devido a inadequação e/ou distorção do conceito de politecnia presente no documento e inviabilizado na prática.

É em uma tentativa de melhor elucidar o conceito que o próximo tópico aborda o termo politecnia.

\section{Politecnia: Concepção Pedagógica de Formação Humana}

Como uma concepção pedagógica de formação humana, a politecnia deveria apresentar em sua base as proposições refletidas por Marx, adaptando-se ao contexto histórico ao qual está inserida. Por vezes, observamos as ações de organismos internacionais através das políticas educacionais de Estado que distorcem o princípio de educar com o trabalho e não, para o trabalho. Ou seja, as políticas públicas educacionais de governos pretensamente comprometidos com os diferentes grupos sociais de trabalhadores deveriam assegurar o bem estar social aos sujeitos e garantir o desenvolvimento social como um todo.

Ao encontro desta reflexão, Scherer (2014) nos aponta a importância de pensar sobre a Escola de PistraK, que fundamentou-se em uma concepção e prática de politecnia educacional voltada para aperfeiçoamento do homem. Proporcionava não somente um aprender em termos educacionais, mas uma visão crítica e embasada na ação social e na valorização do trabalho humano.

Moyses Pistrak (1888 - 1940) compreendia que o docente deveria posicionar-se de forma ativa e participativa na luta de classe, usando do meio educacional para orientar e elucidar o sujeito, conforme sua realidade. Segundo Scherer (2014):

Na escola (de Pistrak), para a escolha das disciplinas deve-se considerar a importância e como cada qual pode contribuir para a compreensão da realidade. Em outro lado, é preciso identifi- 
car os conhecimentos que podem dificultar tal apreensão, não somente negando e abandonando-os, mas compreender a partir deles, porque estes não dão mais conta e precisam ser superados para a devida apreensão da atualidade. Tal concepção repercute para que toda a antiga atitude de contemplação frente ao estudo das ciências seja suplantada. (SCHERER, 2014, p.46).

Scherer (2014) em seu excerto contribui para um aprofundamento das bases da politecnia, que deve sair do plano superficial de ensino e imergir nos contextos e realidades do trabalho humano, pois este fala da complexidade das relações entre os homens nos diferentes âmbitos da vida social. Como também se deve preparar o estudante para as questões intelectuais, administrativas e profissionais, deixando de lado a ideia de profissionalizante, proposto demasiadamente na esfera da politécnica. Em análise a autora pontua o papel da escola na formação do educando, de forma consistente:

Resumidamente, após tudo o que se viu, para Pistrak: a escola deve dar aos alunos uma formação básica social e técnica suficiente para permitir uma boa orientação prática na vida; Ela deve assumir antes de tudo um caráter prático a fim de facilitar ao aluno a transição entre escola e realidade integral da existência. Deve ainda capacitá-lo a compreender seu meio e a se dirigir autonomamente e também acostumá-lo a analisar e a explicar seu trabalho de forma cientifica ensinando-lhe a se elevar do problema prático para a concepção geral teórica, a demonstrar iniciativa na busca de soluções. (SCHERER, 2014, p.47).

Em consonância com estas reflexões se faz necessário que haja a construção de uma prática política, que conscientize as massas de seu valor humano, bem como social, político e econômico. Assim, as classes trabalhadoras terão mais possibilidades de autogestão. Determinando o curso da sua formação intelectual, embasada na ação social e no desenvolvimento de um processo produtivo que gere condições de bem estar e autodeterminação a todos. 
A concepção de escola unitária de Gramsci é passível de ser associada ao conceito de Politecnia, mas avança ao contemplar além da dimensão intelectual, também uma formação cultural e humanística. É salutar o esclarecimento de que o caráter humanístico em Gramsci está dissociado da formação tradicional e mecanicista, pautada pelo ensino memorístico e instrumental. É antes atrelado à concepção de politecnia que tem no trabalho o princípio educativo e que objetiva a formação dos sujeitos autônomos. Tal formação que leva em consideração ações de rompimento com as sociedades pautadas pelo lucro e exploração. E, sobretudo, se estruturam com vistas à construção de uma sociedade menos desigual.

Contudo, o Estado como instituição, por vezes, falha na garantia dos direitos das classes trabalhadoras, uma vez que acirra a desigualdade entre os diferentes grupos sociais e não cumpre sua responsabilidade social e educacional para com os trabalhadores. Observa-se, que este tipo de ação não contribui para a Escola do trabalho, e sim, para a Escola do emprego, minimizando as potencialidades do trabalhador em atingir seu crescimento social.

Nesse sentido, o Estado e as políticas educacionais postas em prática pelos governos, deveriam ter um olhar atento à questão da politecnia. A não observância e a inexistência da prática concreta da concepção de politecnia acabam por expor os sujeitos a uma educação unilateral, exatamente o oposto que a politecnia se propõe de forma a proporcionar uma formação reflexiva e embasada na luta de classes.

O trabalho como princípio educativo que transforma e agrega valor ao sujeito, altera as relações de produção na sociedade, bem como favorece a uma formação onde o trabalhador torna-se um protagonista social autônomo.

Sendo assim, deve-se pensar sobre o ensino, em específico da politecnia, como um elemento que não aprisione o trabalhador no sistema produtivo e suas demandas, mas que articule saberes e proporcione as massas uma maior conscientização de suas forças, bem como de seus direitos na estrutura social. 
A politecnia como uma ferramenta pedagógica de formação omnilateral deve ser repensada e melhor conduzida de acordo com as necessidades das classes trabalhadoras e não atendendo as exigências do capital. A escola deve ser o espaço de diálogo e debate do fazer pedagógico, articulada a potencialidades as capacidades do ser humano, racional, qualificado e crítico.

\section{CONSIDERAÇÕES FINAIS}

Por certo, o governo Tarso esteve empenhado em difundir estratégias que estimulassem o desenvolvimento de determinadas mudanças curriculares, orientadas pela Reforma do Ensino Médio Politécnico, com o intuito de conduzir ao acesso e à produção de conhecimentos. No entanto, além da necessária gama de recursos indispensáveis para a tentativa de buscar o cumprimento de tal proposta também é indispensável buscar a legitimidade de uma política.

Essa legitimidade pode ser fundada a partir do convencimento da comunidade escolar no que se refere aos valores presentes na concepção de tal reforma. Apoiando-se inclusive de em estudos e modelos internacionais desde que construídos a partir da perspectiva local. $\mathrm{O}$ convencimento, e não a coerção, legitima as políticas educacionais à medida que, faz com que os professores se apropriem dos princípios e conceitos presentes nos documentos.

Neste sentido, o estudo das políticas públicas educacionais requer a análise sobre os documentos que orientam a adoção de práticas como "soluções" para os problemas apontados por estes mesmos relatórios. A politecnia presente como um conceito chave no documento-base da reformulação do ensino médio no Rio Grande do Sul falhou à medida que, seus interlocutores não consideraram ainda que no horizonte da História, o rompimento com a estrutura do capital.

Associar a politecnia a uma adaptação dos trabalhadores a uma nova e mais sofisticada etapa do processo produtivo é desconsiderar sua origem e distorcer sua concepção. Todavia, cruzar os braços diante de uma disputa política em torno de sua efetivação é compactuar com a sua ressignificação arbitrária. 


\section{REFERÊNCIAS}

FRIGOTO, Gaudêncio. Educação e a crise do capitalismo real. SP: Editora Cortez, 1995.

FRIGOTTO, Gaudêncio. A produtividade da escola improdutiva: um (re) exame das relações entre educação e estrutura econômico-social e capitalista. $5^{\mathrm{a}}$ ed. SP: Editora Cortez,1999.

GENRO. Tarso. Programa de Governo - caderno de propostas. Coligação: unidade popular pelo Rio Grande, POA/RS, 2010.

GRAMSCI, A. Cadernos do cárcere. Antonio Gramsci: introdução ao estudo da filosofia. A filosofia de Benedetto Croce. Ed. e trad. de Carlos N. Coutinho. Coed. de Luiz S. Henriques e Marco A. Nogueira. Rio de Janeiro: Civilização Brasileira, 1999. v. 1.

MARX, Karl; ENGELS, Friedrich. A ideologia alemã. Lisboa: Edições Avante, 1981.

RIO GRANDE DO SUL. Parecer n.o156/2012. Conselho Estadual de Educação. Comissão de legislação e normas.RS: SEDUC, 2012.

SAVIANI, Dermeval. Debate sobre educação, formação humana e ontologia a partir da questão do método dialético. In: SAVIANI, D. \& DUARTE, N. (orgs.).Pedagogia histórico-crítica e luta de classes na educação escolar. SP: Autores Associados, 2012.

SCHERER, Susana Schneid. A implantação da Proposta Pedagógica de Ensino Médio Politécnico e Integrado em uma escola da rede estadual do Rio Grande do Sul. 2014. Dissertação de Mestrado. Programa de Pós-Graduação em Educação Física. UFPEL: Pelotas, 2014. 
SEDUC. Proposta Pedagógica para o ensino médio politécnico e educação profissional integrada ao ensino médio. 2011 2014. RS: SEDUC, 2011.

SCHULTZ, Theodore W. Investindo no povo. Tradução: Elcio Cerqueira. RJ: Forense Universitária, 1987 


\section{ACESSO À EDUCAÇÃO SUPERIOR POR PESSOAS COM DEFICIÊNCIA NO BRASIL E DIREITOS HUMANOS EM INSTRUMENTOS NORMATIVOS INTERNACIONAIS E NACIONAIS}

Victor Martins Ramos Rodrigues

Leandro Garcia Pinho

1 Introdução:

A educação é um dos direitos humanos previstos expressamente em diversas normas de natureza internacional, como, por exemplo, a Declaração Universal dos Direitos Humanos - DUDH (ONU, 1948) e, em âmbito nacional, foi abarcado pela Constituição da República Federativa do Brasil de 1988 - CF/88 (BRASIL, 1988) como direito social. Todavia, a definição desse direito é, por sua essência, demasiadamente complexa, eis que se desdobra em diversos aspectos, a exemplo, das noções de educação formal, educação informal e educação não-formal. $\mathrm{O}$ texto não se aprofundará nesses meandros teóricos.

Para fins de delimitação no desenvolvimento do presente trabalho, tão somente a educação formal de nível superior será considerada em termos de ofertas de condições especiais para que pessoas com deficiência possam gozar do pleno direito à educação como direito humano.

Sob outro prisma, é de se admitir que o grande problema referente à efetivação do direito social e humano à educação tem início no déficit ao acesso a tal direito desde os seus níveis mais básicos. Manifestando- 
-se de forma mais enfática na educação superior, a análise do acesso a esse nível de educação por pessoas com deficiência deve considerar os obstáculos e adversidades que influem na sua aprendizagem e que devem ser ultrapassados até que se torne tangível, ao menos formalmente, a inserção dessas pessoas no nível superior de educação.

A análise documental foi uma das metodologias na qual se baseou a pesquisa, através da qual foram reunidos os dispositivos de algumas das principais normas nacionais e internacionais de proteção e promoção da pessoa com deficiência no que diz respeito à educação. Além desta, a pesquisa bibliográfica foi outra técnica metodológica empregada, por meio do levantamento de aportes teóricos que abordam as temáticas gerais da educação, do acesso de pessoas com deficiência ao nível superior e dos direitos humanos. Foi feita uma análise descritiva objetiva dessas disposições normativas no sentido de apontar como a essa temática vem sendo objeto de interesse nas regulações internacional e nacional.

Diante disso, buscou-se verificar a hipótese de que, não obstante a existência de instrumentos normativos tanto no cenário internacional quanto no Brasil, a efetivação do direito de acesso pleno à educação superior pelas pessoas com deficiência ainda deve ser objeto de preocupação, eis que o atendimento igualitário às pessoas ainda é uma meta distante a ser alcançada.

O objetivo geral é o de apontar, sob a ênfase das normas de direitos humanos e seus reflexos no ordenamento jurídico interno, a proteção à pessoa com deficiência com enfoque no exercício do direito ao acesso à educação superior no Brasil. O primeiro objetivo específico é o de elucidar que a pessoa com deficiência conta com um aparato normativo, internacional e nacional, que sustenta formalmente o exercício do seu direito ao acesso à educação superior. $\mathrm{O}$ segundo objetivo específico é o de indicar um aporte dos principais instrumentos normativos nacionais e internacionais sobre o tema.

É possível assim, concluir que, não obstante existirem substanciais instrumentos normativos nos âmbitos internacional e nacional, apenas a esfera normativa de proteção não tem sido suficiente para promover a eficácia plena do exercício igualitário de direito ao acesso à educação superior por pessoas com deficiência. Assim, é preciso que outras ini- 
ciativas sejam implementadas, para que tal direito ao acesso à educação superior por pessoas com deficiência se tornem realidade, efetivando as disposições normativas.

\section{Instrumentos normativos internacionais:}

À guisa de esclarecimento inicial, urge esclarecer que existem possíveis confusões sobre o uso da terminologia mais adequada para se referir à pessoa com deficiência. Conforme alerta Paulo Henrique Gonçalves Portela, em meio a tantas formas de referência a essa classe de pessoas particularmente vulnerável, é preferível a adoção da expressão "pessoa com deficiência":

O termo "deficiência" ainda é empregado no Direito Internacional, não obstante nem sempre ser uma palavra aceitável no convívio social. Por oportuno, também é importante registrar que atualmente é impróprio o uso dos termos "deficiente" e "portador de deficiência", preferindo-se o emprego da expressão "pessoa com deficiência”. (PORTELA, 2017, p. 896).

Se considerada entre chamadas minorias, a classe das pessoas com deficiência se destaca em meio às demais por ser considerada "a maior minoria do mundo". No ano de 2012 a Pesquisa Mundial de Saúde e da Carga Global de Doenças concluiu em seus resultados que cerca $15,3 \%$ da população mundial (o que equivale a aproximadamente 978 milhões de pessoas, dentre a estimativa de 6,4 bilhões de habitantes em 2004) possuía alguma espécie de deficiência grave ou moderada, de acordo com o Relatório Mundial sobre a Deficiência, divulgado pela Organização Mundial da Saúde (OMS, 2012, p. 29).

A começar pelas previsões normativas no cenário internacional, o acesso à educação como direito humano é previsto em diversos deles. Aliados a essa normatização mais abrangente e genérica sobre a educação, outros instrumentos normativos internacionais específicos sobre pessoas com deficiência também abordam tal questão com ênfase nessa classe de pessoas particularmente vulneráveis. 
Para a sistematização objetiva da apresentação dessas normas, foi considerada a abordagem de natureza descritiva, conforme se segue.

Como direito humano universal, a educação é fomentada em nível internacional desde a Carta de São Francisco de 1945, no capítulo pertinente à consecução do objetivo de cooperação internacional nos campos econômico e social. Esse referido instrumento normativo também é conhecido pelo nome de Carta das Nações Unidas (ou Carta da $\mathrm{ONU}$ ) e foi o tratado multinacional que instituiu formalmente a existência das Nações Unidas como organismo internacional de proteção e promoção de direitos humanos.

Articulando-se com os objetivos da Organização das Nações Unidas, com vistas promover e manter relações pacíficas entre as nações, ficou instituído que no artigo 55, itens "a", "b" e "c":

[...] a elevação dos níveis de vida, o pleno emprego e condições de progresso e desenvolvimento econômico e social; a solução dos problemas internacionais econômicos, sociais, de saúde e conexos, bem como a cooperação internacional, de caráter cultural e educacional; o respeito universal e efetivo dos direitos do homem e das liberdades fundamentais para todos, sem distinção de raça, sexo, língua ou religião (CARTA DA ONU, art. 55 , a.,b.,c.) (grifo nosso).

No Brasil, a Carta de São Francisco de 1945 foi promulgado pouco tempo depois, no mesmo ano, pelo Decreto no 19.841, de 22 de outubro de 1945 (BRASIL, 1945).

Ainda no mesmo ano, foi criada uma agência própria, a UNESCO - Organização das Nações Unidas para a Educação, a Ciência e a Cultura, de natureza intergovernamental vinculada às Nações Unidas pelo artigo 57, item 2 da Carta da ONU, para fomentar a realização desses objetivos de cooperação internacional, em especial para a educação e cultura (ONU, 1945).

Compete à UNESCO (UNESCO, 1945), nos termos do artigo I, item 1 de sua Constituição, original sem destaques: 
[...] contribuir para a paz e para a segurança, promovendo colaboração entre as nações através da educação, da ciência e da cultura, para fortalecer o respeito universal pela justiça, pelo estado de direito, e pelos direitos humanos e liberdades fundamentais, que são afirmados para os povos do mundo pela Carta das Nações Unidas, sem distinção de raça, sexo, idioma e religião.

A UNESCO exerce papel fundamental para a efetivação de tais direitos na esfera internacional, com enfoque na busca pelas "oportunidades plenas e iguais de educação para todos, na busca irrestrita da verdade objetiva" (UNESCO, 1945).

Poucos anos depois, a educação também foi prevista expressamente no rol dos direitos humanos elencados na Declaração Universal dos Direitos Humanos, em seu artigo XXVI (ONU, 1948). É direito universal, para todas as pessoas, indistintamente, em qualquer lugar do mundo em que estejam.

O Direito à educação como essencial à dignidade humana é garantido em outras normas gerais internacionais, a exemplo dos direitos sociais do PIDESC - Pacto Internacional Sobre Direitos Econômicos, Sociais e Culturais, em seus artigos 13 e 14 (ONU, 1966), que foi promulgado pelo Estado brasileiro através do Decreto № 591, de 06 de julho de 1992 (BRASIL, 1992).

No artigo 13, item 1 do PIDESC (ONU, 1966) está previsto, sem destaques no original, o seguinte:

Os Estados Partes do presente Pacto reconhecem o direito de toda pessoa à educação. Concordam em que a educação deverá visar ao pleno desenvolvimento da personalidade humana e do sentido de sua dignidade e fortalecer o respeito pelos direitos humanos e liberdades fundamentais. Concordam ainda em que a educação deverá capacitar todas as pessoas a participar efetivamente de uma sociedade livre, favorecer a compreensão [...].

Destacam-se os valores de pleno desenvolvimento, respeito pelos direitos humanos e participação social efetiva, o que no caso das pes- 
soas portadoras de deficiência são constantemente violados e se constituem como desafios ainda mais difíceis de serem efetivados.

No mesmo artigo 13, o item 2 do PIDESC, refere-se expressamente à educação de nível superior, a qual "deverá igualmente tornar-se acessível a todos, com base na capacidade de cada um, por todos os meios apropriados e, principalmente, pela implementação progressiva do ensino gratuito". Dessa forma, constata-se como dever imperativo do Estado Parte, a obrigatoriedade de tornar "acessível a todos" e "por todos os meios apropriados", a educação de nível superior (ONU, 1966).

Verifica-se a recomendação internacional, ainda que não explícita na norma, de os Estados adotarem "todos os meios apropriados" para a efetivação desse direito, e dentre esses meios, as ações afirmativas se mostram plenamente apropriadas para promover o acesso igualitário de todos à educação de nível superior.

No que diz respeito aos instrumentos normativos próprios sobre as pessoas com deficiência, é de se vislumbrar que o direito à educação é assegurado pela Convenção Internacional da ONU sobre os Direitos das Pessoas com Deficiência em seu art. 24, item 1, o qual contém como princípios: a não discriminação e da igualdade de oportunidades. Esse dispositivo determina imperativamente que os Estados Partes assegurem um "sistema educacional inclusivo em todos os níveis". (ONU, 2007). O referido dispositivo prevê ainda no seu item 5 que:

Os Estados Partes assegurarão que as pessoas com deficiência possam ter acesso ao ensino superior em geral, treinamento profissional de acordo com sua vocação, educação para adultos e formação continuada, sem discriminação e em igualdade de condições. Para tanto, os Estados Partes assegurarão a provisão de adaptações razoáveis para pessoas com deficiência. (ONU, 2007, art. 24, item 5) (grifos nossos).

O Estado é obrigado, imperativamente, a assegurar o acesso de pessoas com deficiência à educação de nível superior, sem qualquer discriminação e em igualdade de condições, garantindo adaptações razoáveis para mitigar necessidades de pessoas com deficiências. Deve 
atentar para a necessidade de implementação de ações afirmativas nesse para cumprimento dos objetivos da norma. Essa Convenção foi promulgada no Brasil pelo Decreto no 6.949, de 25 de agosto de 2009. (BRASIL, 2009).

Em 1990 foi realizada a Conferência Mundial de Educação para Todos, na cidade de Jomtien, Tailândia. Como resultado dessa Conferência, foi elaborado um documento que abordou o amparo à educação das pessoas com deficiência nos artigos $3^{\circ}$, item 5; artigo 10; Introdução, item 3; Objetivos e metas, item 5, iii e item 8, I e finalmente na parte que trata dos Princípios e ações, item 45, d.

Noutra conferência realizada em Salamanca, no ano de 1994, foram redigidos os termos da Conferência Mundial sobre Necessidades Educacionais Especiais, Acesso e Qualidade, tratando do tema em seus vários dispositivos.

Há que se destacar a existência do Tratado de Marrakesh Facilitar o Acesso a Obras Publicadas às Pessoas Cegas, com Deficiência Visual ou com Outras Dificuldades para Ter Acesso ao Texto Impresso, de 27 de junho de 2013. No preâmbulo do referido tratado, o direito humano à educação é previsto em dois dispositivos. O primeiro referente aos desafios ao desenvolvimento pleno de pessoas com deficiência visual ou outras dificuldades relacionadas ao acesso a textos impressos, como limitação à suas liberdades de expressão, como por exemplo: a liberdade de procurar, receber e difundir informações e ideias de toda espécie em condições isonômicas com as demais pessoas, além do gozo ao seu direito à educação e da oportunidade de realizar pesquisas (BRASIL, 2018).

Ainda no preâmbulo, a educação é referida no que diz respeito à necessidade de equilíbrio entre a proteção efetiva dos direito autorais e o interesse público mais amplo, especialmente no que pertine à educação, pesquisa e acesso à informação por pessoas com deficiência visual e outras dificuldades para ter acesso ao texto impresso o acesso efetivo e tempestivo às obras (BRASIL, 2018). Tal tratado foi promulgado no ordenamento jurídico brasileiro por meio do Decreto $\mathrm{n}$. 9.522, de 8 de outubro de 2018, cujo anexo evidencia o seu inteiro teor (BRASIL, 2018).

Além do plano global, existem os sistemas regionais de proteção de direitos humanos. Os sistemas regionais, buscam particularizar a 
promoção e proteção de direitos humanos às diferentes realidades de partes distintas do mundo.

Segundo Portela (2017, p. 959), os sistemas regionais de proteção internacional dos direitos humanos, "são esquemas de promoção da dignidade humana que reúnem apenas certos Estados, localizados em determinadas partes do mundo". O autor esclarece:

O objetivo dos sistemas regionais é reforçar a estrutura internacional para a proteção dos direitos humanos por meio da associação entre entes estatais que reúnem maiores afinidades entre si, o que facilitaria o consenso ao redor de interesses comuns e a aplicação das normas que esses mesmos Estados elaboraram, bem como fortaleceria a tutela de valores importantes apenas em algumas regiões do mundo. (PORTELA, 2017, p. 959).

Dentre os sistemas regionais, destaque-se que a OEA - Organização dos Estados Americanos foi a pioneira no nível regional de proteção dos direitos humanos. É o mais antigo organismo regional do mundo. Fundada em 1948, em Bogotá, na Colômbia, a Carta da OEA entrou em vigor em 1951 e estabelece a educação como princípio em seu artigo $3^{\circ}$. A educação é inserida como direito vital à dignidade humana em seus artigos 34, 47, 48, 49, 50, 52 e 95. Especificamente em relação à educação de nível superior, a previsão está no artigo 49, item "c", que estipula: "A educação de grau superior será acessível a todos, desde que, a fim de manter seu alto nível, se cumpram as normas regulamentares ou acadêmicas respectivas" (OEA, 1948).

Dois fatores devem ser destacados nesse dispositivo: o primeiro diz respeito à acessibilidade da educação superior para todos. $\mathrm{O}$ segundo é a condição de que, para isso, as normas regulamentares ou acadêmicas respectivas devem ser cumpridas pelos interessados em prol da manutenção do alto nível desse grau de educação. Vislumbra-se uma condição restritiva menos benéfica que a prevista no já citado artigo 13, item 2 do PIDESC.

O direito à educação é previsto na Convenção Americana sobre Direitos Humanos de 1969 (OEA - 1969), em seus artigos 12, item 4; artigo 26; artigo 42, que devem ser norteados pelo que estabelece o 
artigo 1ํㅡㄹ pelo qual os Estados Partes devem respeitar a convenção e a todos os direitos e liberdades nela reconhecidos, bem como garantir seu livre e pleno exercício a toda pessoa que esteja sujeita a sua jurisdição, “sem discriminação alguma, por motivos de raça, cor, sexo, idioma, religião, opiniões políticas, ou de qualquer outra índole, origem nacional ou social, posição econômica, nascimento ou qualquer outra condição social" (OEA, 1969) no art. 1ํo (grifos nossos).

A Convenção Interamericana para a Eliminação de Todas as Formas de Discriminação contra as Pessoas com Deficiência, como norma específica prevê o amparo de pessoas com deficiência. Em relação ao acesso à educação, essa proteção encontra-se no artigo III, itens 1 e 2 (OEA, 1999). A Convenção foi promulgada pela República Federativa do Brasil através do Decreto № 3.956, de 8 de outubro de 2001 (BRASIL, 2001).

A Carta Democrática Interamericana (OEA, 2001), aprovada na primeira sessão plenária de 11 de setembro de 2001, institui em seu artigo 16 o seguinte:

A educação é chave para fortalecer as instituições democráticas, promover o desenvolvimento do potencial humano e o alívio da pobreza, e fomentar um maior entendimento entre os povos. Para alcançar essas metas, é essencial que uma educação de qualidade esteja ao alcance de todos, incluindo as meninas e as mulheres, os habitantes das zonas rurais e as minorias (grifos nossos).

Desse dispositivo exsurgem diretivas de condutas estatais na orientação das políticas educacionais. Extrai-se o reconhecimento de que a educação é "chave" para promoção do "desenvolvimento do potencial humanos" e, que para tanto, é essencial que uma "educação de qualidade esteja ao alcance de todos", inclusive "as minorias". Atenuou as restrições da Carta da OEA no citado artigo 49, item "c" no que diz respeito ao atendimento de certas condições para acesso à educação superior "de alto nível". A previsão de que uma "educação de qualidade" deva estar "ao alcance de todos", inclusive das "minorias", o artigo 16 da Carta Democrática Interamericana deixou de estipular condições específicas 
para tanto, ampliando a proteção e promoção isonômica do acesso à educação superior "de qualidade" para pessoas com deficiência (OEA, 1948, art. 49, “c”).

A Carta Social das Américas estipula o direito à educação nas suas considerações iniciais e, especificamente, no artigo 19 (OEA, 2012), sem destaques no original, conforme se lê:

Toda pessoa tem direito à educação sem discriminação. O acesso a uma educação de qualidade em todos os níveis e modalidades é vital para se alcançar maior igualdade, melhorar os níveis de vida, promover o desenvolvimento sustentável, desenvolver o capital humano, reduzir a pobreza, fortalecer as instituições democráticas, transmitir valores cívicos e sociais, formar cidadãos responsáveis e comprometidos com a sociedade e promover a inclusão social.

Os Estados membros se comprometem a assegurar o acesso equitativo e universal à educação primária e secundária de qualidade e a promover o acesso à educação em todos os níveis com um enfoque inclusivo, em especial a educação na primeira infância, em conformidade com as legislações internas (grifos nossos).

A Convenção Interamericana contra toda Forma de Discriminação e Intolerância (OEA, 2013), prevê esse direito em suas considerações iniciais e, propriamente, nos artigos, 4º, XI e artigo 7ํ. Está definido no item 1 de seu artigo $1^{\circ}$, o conceito de discriminação e as formas de discriminação, cujo rol exemplifica a discriminação em razão "do nível educacional" ou em razão de "deficiência, característica genética, estado de saúde física ou mental, inclusive infectocontagioso, e condição psíquica incapacitante, ou qualquer outra condição" (OEA, 2013, artigo 1ํㅜ 1).

O Brasil é Estado membro da OEA, sendo, pois, signatário de todas as normas supracitadas e, em relação à última (OEA, 2013). Além de signatário o país teve papel preponderante junto à OEA ao ofertar à Assembleia Geral o projeto de resolução que deu origem ao Grupo de Trabalho encarregado de criar uma Convenção contra o racismo e todas as formas de discriminação. Por quatro vezes, o Brasil presidiu o 
Grupo de Trabalho, desempenhando essencial função de liderança no desenvolvimento das negociações (BRASIL, 2013, a).

O Brasil é um país de dimensões territoriais e variedades socioculturais enormes. Essa característica torna ainda mais árduo o desafio de legislar e implementar normas de proteção dos direitos humanos. Verifica-se nacionalmente a existência de normas federais que regulam o acesso à educação superior por pessoas com deficiência. Ao menos formalmente, tais normas são apropriadas para mitigar evidentes injustiças históricas, culturais e sociais.

É relevante, portanto, analisar a sintonia entre o que regulamentam os referidos instrumentos normativos internacionais de proteção dos direitos humanos e as normas federais que vigoram no país na temática do acesso à educação por pessoas com deficiência no nível superior.

\section{Instrumentos normativos federais no Brasil:}

A Constituição prevê em seu artigo 208, inciso III, especificamente em relação à pessoa com deficiência, que o dever do Estado com a educação das pessoas com deficiência será efetivado mediante a garantia de "atendimento educacional especializado" (BRASIL, 1988).

A Lei no 13.146 de 6 de julho de 2015, que institui a Lei Brasileira de Inclusão da Pessoa com Deficiência, ou simplesmente, Estatuto da Pessoa com Deficiência (BRASIL, 2015) é um importante estatuto legislativo específico para defesa de direitos dessas pessoas. A partir desse diploma, capacidade civil das pessoas com deficiência é plena como via de regra, sendo considerada apenas excepcionalmente, a incapacidade relativa, provocando substancial alteração no sistema das capacidades antes previstas na Lei no $10.406 / 2002$, o Código Civil pátrio (BRASIL, 2002).

O direito à educação deve ser assegurado tanto pelo Estado, quanto pela sociedade e pela família, como prioridade, conforme previsão do artigo $8^{\circ}$. Não obstante, a pessoa com deficiência possui a garantia dos direitos referentes à educação prevista no Capítulo $\mathrm{V}$ da norma, conforme se depreende dos parágrafos e incisos dos artigos 27 ao 30 (BRASIL, 2015). 
O artigo 28, inciso XIII, prevê como dever do poder público, assegurar, criar, desenvolver, complementar, incentivar, acompanhar e avaliar, dentre outros fins, o "acesso à educação superior e à educação profissional e tecnológica em igualdade de oportunidades e condições com as demais pessoas". O inciso XVII do mesmo dispositivo que se refere à "articulação intersetorial na implementação de políticas públicas” (BRASIL, 2015).

A Lei no 13.409, de 28 de dezembro de 2016, que alterou a Lei no 12.711, de 29 de agosto de 2012 ("Lei de Cotas"), dispõe sobre a reserva de vagas para pessoas com deficiência nos cursos técnico de nível médio e superior das instituições federais de ensino (BRASIL, 2012 e 2016). Essa lei foi regulamentada pelo vigente Decreto no 9.034 publicado em 20 de abril de 2017 (BRASIL, 2017), que, dentre outras, incluiu o inciso III ao artigo 9 do mencionado decreto que regulamenta a "Lei de Cotas" (BRASIL, 2012, a). Impôs como atribuição do Ministério da Educação - MEC, a edição de atos complementares necessários para a aplicação do referido Decreto de 2012, com redação atualizada. A referida norma delega ao órgão ministerial o dever de editar atos complementares para avaliar e definir "forma de comprovação da deficiência".

Todavia, o Comitê do Cadastro Nacional de Inclusão da Pessoa com Deficiência e da Avaliação Unificada da Deficiência, instituído pelo Decreto no 8.954/2017 (BRASIL, 2012, a), é organismo próprio que já existe para essa atribuição específica. Esse Comitê possui a finalidade de "criar instrumentos para a avaliação biopsicossocial da deficiência e estabelecer diretrizes". É de se verificar que este decreto é anterior ao que instituiu ao Decreto no 9.034/2017 (BRASIL, 2017) que impôs tal atribuição ao Ministério da Cultura.

O MEC publicou a Portaria Normativa no 9, de 05 de maio de 2017 (BRASIL, MEC, 2017), em atendimento à Lei nº 13.409/2017 (BRASIL, 2017) e seu decreto regulamentador no 9.034/2017 (BRASIL, 2012, a). O artigo $8^{-}-\mathrm{B}$ dessa Portaria Normativa prevê que:

A apuração e a comprovação da deficiência tomarão por base laudo médico atestando a espécie e o grau de deficiência, nos termos do art. $4^{\circ}$ do Decreto $\mathrm{n}^{\circ} 3.298$, de 20 de dezembro de 
1999, com expressa referência ao código correspondente da Classificação Internacional de Doença - CID, no caso dos estudantes que sejam pessoas com deficiência e se inscrevam às vagas destinadas a essas pessoas (grifos nossos).

O MEC, portanto, parece ter solucionado qualquer conflito de competência técnica em razão da matéria ao devolver a obrigação de provar a incapacidade ao médico. Simples e eficaz!

À guisa de ilustração da insegurança jurídica que ainda persiste no país, destaque-se que em 18 de junho de 2020, o MEC revogou a Portaria Normativa no 13, de 11 de maio de 2016 (BRASIL, 2016) que determinava que programas de pós-graduação reservassem vagas para negros, índios e pessoas com deficiência, cuja decisão provocou fortes reações no meios acadêmico, científico e social.

A discussão acadêmica sobre a efetivação do direito humano ao acesso à educação superior por pessoas com deficiência surge como importante movimento agregador para o amadurecimento de normas mais protetivas, e, com muito mais força, para impulsionar a efetivação de previsões normativas, até então, ineficazes.

\section{Conclusão:}

Conclui-se que, ao menos em termos formais, a legislação nacional supera de longe as previsões de instrumentos normativos de abrangência internacional, mesmo os específicos da ONU (2007) e da OEA (1999 e 2013). É possível assim afirmar que a desarmonia das normas federais brasileiras em relação aos regulamentos internacionais, sob esse aspecto meramente formal, é benéfica por ampliar o amparo devido às pessoas com deficiência no exercício de seu direito fundamental de acesso à educação superior na República Federativa do Brasil.

Se comparada à farta regulamentação supranacional, a legislação federal vigente no ordenamento jurídico brasileiro confirma a sua equivalência em termos formais com os instrumentos normativos internacionais, tanto que promulgados internamente. 
4 Referências:

BRASIL. Decreto n. 9.522, de 8 de outubro de 2018. Promulga o Tratado de Marraqueche para Facilitar o Acesso a Obras Publicadas às Pessoas Cegas, com Deficiência Visual ou com Outras Dificuldades para Ter Acesso ao Texto Impresso, firmado em Marraqueche, em 27 de junho de 2013. Disponível em: http://www. planalto.gov.br/ccivil_03/_Ato2015-2018/2018/Decreto/D9522. htm. Acesso em: 10 jun. 2020.

BRASIL. Decreto no 19.841 de 22 de outubro de 1945. Promulga a Carta das Nações Unidas, da qual faz parte integrante o anexo Estatuto da Corte Internacional de Justiça, assinada em São Francisco, a 26 de junho de 1945, por ocasião da Conferência de Organização Internacional das Nações Unidas. Disponível em: http://www.planalto.gov.br/ccivil_03/decreto/1930-1949/ d19841.htm. Acesso em: 10 out. 2018.

BRASIL. Decreto no 3.956 de 8 de outubro de 2001. Promulga a Convenção Interamericana para a Eliminação de Todas as Formas de Discriminação contra as Pessoas Portadoras de Deficiência. Disponível em: http://www.planalto.gov.br/ccivil_03/ decreto/2001/d3956.htm. Acesso em: 10 out. 2018.

BRASIL. Decreto no 591 de 06 de julho de 1992. Atos Internacionais. Pacto Internacional sobre Direitos Econômicos, Sociais e Culturais. Promulgação. Brasília, 1992.

BRASIL. Decreto no 6.949, de 25 de agosto de 2009. Promulga a Convenção Internacional sobre os Direitos das Pessoas com Deficiência e seu Protocolo Facultativo, assinados em Nova York, em 30 de março de 2007. Disponível em: http://www.planalto.gov. br/ccivil_03/_ato2007-2010/2009/decreto/d6949.htm. Acesso em: 10 out. 2018.

BRASIL. Decreto no 7.824, de 11 de outubro de 2012. Regulamenta a Lei $\mathrm{n}^{\circ}$ 12.711, de 29 de agosto de 2012, que dispõe sobre o ingresso nas universidades federais e nas instituições federais 
de ensino técnico de nível médio. Disponível em: http://www. planalto.gov.br/ccivil_03/_Ato2011-2014/2012/Decreto/D7824. htm. Acesso em: 11 out. 2018.

BRASIL. Decreto no $\mathbf{8 . 9 5 4}$, de 10 de janeiro de 2017. Institui o Comitê do Cadastro Nacional de Inclusão da Pessoa com Deficiência e da Avaliação Unificada da Deficiência e dá outras providências. Disponível em: http://www.planalto.gov.br/ccivil_03/_ato2015-2018/2017/decreto/D8954.htm. Acesso em: 11 out. 2018.

BRASIL. Decreto no ${ }^{\mathbf{9}} \mathbf{9 . 0 3 4}$ de 20 de abril de 2017. Altera o Decreto $\mathrm{n}^{\mathrm{o}} 7.824$, de 11 de outubro de 2012, que regulamenta a Lei no 12.711 , de 29 de agosto de 2012, que dispõe sobre o ingresso nas universidades federais e nas instituições federais de ensino técnico de nível médio. Disponível em: http://www.planalto.gov. br/ccivil_03/_Ato2015-2018/2017/Decreto/D9034.htm\#art1. Acesso em: 11 out. 2018.

BRASIL. Lei no 13.146, de 6 de julho de 2015. Institui a Lei Brasileira de Inclusão da Pessoa com Deficiência (Estatuto da Pessoa com Deficiência). Disponível em: http://www.planalto.gov.br/ ccivil_03/_ato2015-2018/2015/lei/113146.htm. Acesso em: 10 out. 2018.

BRASIL. Lei no $\mathbf{1 3 . 4 0 9}$, de 28 de dezembro de 2016. Altera a Lei $\mathrm{n}^{\circ} 12.711$, de 29 de agosto de 2012 (Lei de Cotas), para dispor sobre a reserva de vagas para pessoas com deficiência nos cursos técnico de nível médio e superior das instituições federais de ensino. Disponível em: http://www.planalto.gov.br/ccivil_03/_ato20152018/2016/Lei/L13409.htm. Acesso em: 11 out. 2018.

BRASIL. Lei no ${ }^{\mathbf{*}}$ 12.711, de 29 e agosto de 2012. Dispõe sobre o ingresso nas universidades federais e nas instituições federais de ensino técnico de nível médio e dá outras providências. Disponível em: http://www.planalto.gov.br/ccivil_03/_Ato2011-2014/2012/ Lei/L12711.htm. Acesso em: 11 out. 2018. 
BRASIL. MEC. Gabinete do Ministro. Portaria no 9, de 05 de maio de 2017. Altera a Portaria Normativa MEC no 18 , de 11 de outubro de 2012, e a Portaria Normativa MEC no 21, de 5 de novembro de 2012 e dá outras providências. Disponível em: http://portal.mec.gov.br/cotas/docs/portariaN9.pdf. Acesso em 11 out. 2018.

BRASIL. Ministério da Educação. Instituto Nacional de Estudos e Pesquisas Educacionais Anísio Teixeira. Censo da Educação Superior 2015. Brasília: INEP, 2015. Disponível em: http:// inep.gov.br/web/guest/microdados. Acesso em: 10 out. 2018.

BRASIL. Ministério da Educação. Portaria Normativa no . 13, de 11 de maio de 2016. Dispõe sobre a indução de Ações Afirmativas na Pós-Graduação, e dá outras providências. Disponível em: http://www.in.gov.br/materia/-/asset_publisher/Kujrw0TZC2Mb/content/id/21520493/do1-2016-05-12-portaria-normativa-n-13-de-11-de-maio-de-2016-21520473. Acesso em: 11 jul. 2020.

BRASIL. Ministério das Relações Exteriores. Nota 197. 2013. Disponível em: http://www.itamaraty.gov.br/pt-BR/notas-a-imprensa/2361-oea-aprova-a-convencao-interamericana-contra-o-racismo-a-discriminacao-racial-e-formas-correlatas-de-intolerancia-e-a-convencao-interamericana-contra-toda-forma-de-discriminacao-e-intolerancia. Acesso em: 10 out. 2018.

CARTA DAS NAÇÕES UNIDAS. São Francisco. 1945. Disponível em: https://nacoesunidas.org/carta/. Acesso em: 10 out. 2018.

Declaração mundial sobre educação para todos. Plano de ação para satisfazer as necessidades básicas de aprendizagem. Aprovada pela Conferência Mundial sobre Educação para Todos. Jomiten, Tailândia, 09 de março de 1990.

OEA. Carta Democrática Interamericana. Aprovada na sessão especial da Assembleia Geral da OEA em 11 de setembro de 2001. 
Lima, Perú. 2001. Disponível em: http://oas.org/pt/democratic-charter/pdf/demcharter_pt.pdf. Acesso em: 10 out. 2018.

OEA. Carta Social das Américas. Aprovada na segunda sessão plenária da Assembleia Geral da OEA, em 4 de junho de 2012 e revisada pela Comissão de Estilo. Cochabamba, Bolívia, 2012. Disponível em: https://www.oas.org/consejo/sp/docs/AG05806P05. doc. Acesso em: 10 out. 2018.

OEA. Convenção Interamericana contra toda Forma de Discriminação e Intolerância. Aprovada na $43^{\underline{a}}$ Assembleia Geral Ordinária da OEA em 06 de junho de 2013. Antígua. Guatelama. 2013. Disponível em: http://www.oas.org/en/sla/dil/docs/ inter_american_treaties_A-69_Convencao_Interamericana_disciminacao_intolerancia_POR.pdf. Acesso em: 10 out. 2018.

\section{OEA. Convenção Interamericana para a Eliminação de Todas} as Formas de Discriminação contra as Pessoas com Deficiência. Adotada na Cidade da Guatemala, Guatemala, pela Assembleia Geral da OEA em 07 de junho de 1999. Assinada pelo Brasil em 08 de junho de 1999 e ratificada em 15 de agosto de 2001. Disponível em: http://portal.mec.gov.br/seesp/arquivos/ pdf/guatemala.pdf. Acesso em: 10 out. 2018.

OEA. Departamento de Direito Internacional. Secretaria de Assuntos Jurídicos. Carta da Organização dos Estados Americanos (A-41). 1948. Disponível em: http://www.oas.org/dil/port/tratados_A-41_Carta_da_Organiza\%C3\%A7\%C3\%A3o_dos_Estados_Americanos.pdf. Acesso em: 10 out. 2018.

OEA. Departamento de Direito Internacional. Secretaria de Assuntos Jurídicos. Convenção Americana sobre Direitos Humanos (Pacto de San José). Subscrita na Conferência Especializada Interamericana sobre Direitos Humanos (B-32). San José, Costa Rica, 7 a 22 de novembro de 1969. 1969. Disponível em: http:// www.oas.org/dil/esp/tratados_B-32_Convencion_Americana_ sobre_Derechos_Humanos.pdf. Acesso em 10 out. 2018. 
OMS. Relatório mundial sobre a deficiência. Trad. Lexicus Serviços Linguísticos. São Paulo: SEDPcD, 2012.

ONU. Assembleia Geral. Pacto Internacional sobre Direitos Econômicos, Sociais e Culturais. Adotado pela Resolução n.2.200-A (XXI) da Assembleia Geral das Nações Unidas, 16 de dezembro de 1966.

ONU. Convenção Internacional sobre os Direitos das Pessoas com Deficiência e seu Protocolo Facultativo, assinados em Nova York, em 30 de março de 2007. Disponível em: www. un.org/diabilities/documents/natl/portugal-c.doc. Acesso em: 10 out. 2018.

ONU. Declaração Universal dos Direitos Humanos. Disponível em: http://www.onu.org.br/img/2014/09/DUDH.pdf. Acesso em: 10 out. 2018.

PORTELA, Paulo Henrique Gonçalves. Direito Internacional Público e Privado: Incluindo Noções de Direitos Humanos e Direito Comunitário. $9^{a}$ ed., rev., atual. e ampl. Salvador: JusPODIVM, 2017, 1.136p.

UNESCO. Constituição da Organização das Nações Unidas para a Educação, a Ciência e a Cultura. Adotada em Londres, em 16 de novembro de 1945 e emendas. Brasília: Unesco Brasília Office. Representação da Unesco no Brasil. BR/2002/ PI/H/12. 2002. Disponível em: http://unesdoc.unesco.org/images/0014/001472/147273por.pdf. Acesso em: 10 out. 2018. 


\section{O DIREITO À EDUCAÇÃO SEXUAL: DESAFIOS E POSSIBILIDADES POSTOS À EDUCAÇÃO SEXUAL DE CRIANÇAS E ADOLESCENTES NO ÂMBITO FAMILIAR}

Fabiola Francielle de Jesus

Welton Vinícius Santos Silva

\section{I- INTRODUÇÃO}

Este artigo discute a educação sexual como um direito humano das crianças e adolescentes. O objetivo é assinalar alguns desafios e as alternativas que as famílias podem lançar mão a fim de contribuir com a educação sexual das crianças e adolescentes.

Entende-se que a educação sexual seja um direito humano, embora não esteja explícita na Declaração Universal dos Direitos Humanos de 1948, que menciona de modo geral o direito de todas/os à educação primária gratuita com vistas à promoção do pleno desenvolvimento da personalidade humana, conforme ONU (1948). Entretanto, depreende-se que a educação sexual é inerente aos valores de liberdade e da dignidade da pessoa humana. Estes valores defendidos no texto de 1948 proclamam o reconhecimento de um sistema universal, aceito por quase todos os países. A Declaração possui grande relevância porque

[...] pela primeira vez, um sistema de princípios fundamentais da conduta humana foi livre e expressamente aceito, através 
de seus respectivos governos, pela maioria dos homens que vive na Terra. Com essa declaração, um sistema de valores é - pela primeira vez na história - universal, não em princípio, mas de fato, na medida em que o consenso sobre sua validade e sua capacidade para reger os destinos da comunidade futura de todos os homens foi explicitamente declarado (BOBBIO, 1992, p. 28).

A Declaração Universal dos Direitos Humanos é fruto de uma construção histórica e social que ratifica os valores fundamentais proclamados pela humanidade no século XX, diante da necessidade de reconstrução da ordem internacional no contexto do pós-guerra, ancorada em referenciais éticos e na valorização dos direitos humanos. $\mathrm{O}$ texto constitucional brasileiro de 1988 teve forte inspiração dos valores assinalados na Declaração.

A primazia da família e do Estado no tocante à educação dos seus membros é expressa no artigo 205 da Constituição Federal. Referente às crianças e adolescentes este direito social é assegurado pela Lei 8069, de 13 de julho de 1990 . De fato, o caput do artigo $4^{\circ}$ dispõe que é dever da família, da comunidade, da sociedade em geral e do poder público assegurar, com absoluta prioridade, a efetivação do direito à educação às crianças e adolescentes, em consonância com Brasil (1988) e Brasil (1990).

Vale destacar que o processo educativo transcende a escolarização. Este artigo corrobora com a definição freiriana de educação libertadora, na qual educar pressupõe uma troca de saberes que promove a humanização das pessoas. Nesta perspectiva, educar é uma relação interativa entre pessoas. Assim: "Ninguém educa ninguém, como tão pouco ninguém se educa a si mesmo: os homens se educam em comunhão, mediatizados pelo mundo" (FREIRE, 1983, p. 79).

É prudente assinalar que a educação sexual não se restringe a discorrer sobre o ato sexual, posto que consiste em fomentar o debate sobre o corpo, acerca da gravidez, os variados métodos contraceptivos, os tipos de parto, abuso sexual, os diferentes arranjos familiares, relacionamentos afetivos, dentre outras discussões. Nestas interações, as crianças e adolescentes tem possibilidade de serem orientadas e escu- 
tadas por um adulto responsável pela sua educação, na perspectiva de Figueiró (2017). Tal autora assevera que este processo pode se dar de forma crítica, afetuosa, sistemática e guiada por informações científicas ou arraigadas de moralismos, ideias distorcidas e preconceituosas.

Com isso, dada a dificuldade que os diversos arranjos familiares encontram para abordar este tema com as crianças e adolescentes as mídias assumem um importante papel com vistas a contribuir com este diálogo. Compreende-se por mídia a forma pela qual as linguagens tomam forma e se disseminam. Segundo Santaella (2003, p. 13): “[...] mídias são meios, suportes materiais, canais físicos, nos quais as linguagens se corporificam e através dos quais transitam”.

Não obstante este artigo discutir a educação sexual no âmbito familiar é prudente advertir que tal modalidade de educação não se restringe às famílias. De fato, a educação sexual direcionada a crianças e adolescentes lhes permite posicionar-se na esfera social da sexualidade e está presente em todos os espaços de socialização - especialmente na família, escola, igreja, pares, no universo do trabalho, nas mídias - nos quais os adultos dialogam com as crianças e adolescentes quanto à sexualidade.

Embora não seja objeto deste estudo discutir a educação sexual formal é importante pontuar que as escolas também são grandes responsáveis pela educação sexual de crianças e adolescentes. No cenário brasileiro, os principais parâmetros que norteiam a educação sexual nas escolas brasileiras são a Base Nacional Curricular Comum (BNCC) e os Parâmetros Curriculares Nacionais (PCN).

Este último prevê que o tema da sexualidade seja tratado transversalmente em todos os ciclos de escolarização no que reporta ao uso de métodos contraceptivos, prevenção de Infecções Sexualmente Transmissíveis (IST's) ${ }^{23}$, igualdade de gênero, autoconhecimento, dentre outros. A educação sexual nas escolas pode ser definida como

23 Esta expressão passou a ser empregada para substituir a expressão Doenças Sexualmente Transmissíveis (DST's) uma vez que destaca a possibilidade de uma pessoa ter e transmitir uma infecção, mesmo sem sinais e sintomas (MINISTÉRIO DA SAÚDE, 2020, $s / p)$. 
[...] um programa de ensino sobre os aspectos cognitivos, emocionais, físicos e sociais da sexualidade. Seu objetivo é equipar crianças e jovens com o conhecimento, habilidades, atitudes e valores que os empoderem para: vivenciar sua saúde, bem estar e dignidade; desenvolver relacionamentos sociais e sexuais respeitosos; considerar como suas escolhas afetam o bem estar próprio e dos outros; entender e garantir a proteção de seus direitos ao longo da vida (UNESCO, 2014, p. 11).

A discussão sobre a educação sexual no âmbito escolar é um tema polêmico e incita diversas fake news sobre os supostos "kit gay", "mamadeiras em formato de pênis" e outras (des)informações. Nesta seara, tais falácias contribuem para alardear o medo em grande parcela da sociedade que supõe que educar sexualmente incitaria a prática sexual de crianças e adolescentes.

Consoante a tais ideias, a ministra da Mulher, da Família e dos Direitos Humanos do atual governo, Damares Alves, recomendou que a abstinência sexual até o matrimônio fosse defendida como campanha para o carnaval de 2020, conforme Esquerda Diário (2020). É prudente assinalar que a adoção de medidas que estimulem a abstinência sexual como método contraceptivo não está previsto nem na BNCC nem nos PCN.

Entende-se, pois, que posicionamentos como este contribuem com a deseducação sexual. Este cenário reforça a importância das famílias, independentemente dos seus arranjos, atentarem-se ao seu papel privilegiado no tocante à educação sexual de crianças e adolescentes.

Nesse contexto, reitera-se a Nota Pública do Conselho Nacional dos Direitos da Criança e do Adolescente (CONANDA) a respeito dos direitos sexuais das crianças e adolescentes a qual defende que este público deve ter acesso à informação de cunho científico e de caráter elucidativo sobre os eixos sexualidade, saúde e direitos humanos, através de variadas fontes. A esse respeito, a nota enfatiza o direito à educação sexual emancipadora e condizentes à idade, cientificamente acurada, culturalmente idônea, abalizada nos direitos humanos e na equidade de gênero, na perspectiva de Direitos da Criança (2017). 
Feitas essas considerações preliminares ressalta-se que este artigo possui natureza interdisciplinar, qualitativa, modalidade revisão de literatura, com coleta de dados secundários analisados a partir da técnica de análise de conteúdo proposta por Bardin (2009).

Atinente à relevância desta pesquisa entende-se que este artigo contribui com o debate concernente à educação sexual. Sabe-se que o tema é polêmico e repleto de falácias. Ademais, a sua discussão é importante porque foram encontrados poucos estudos no Brasil relacionados à educação sexual enquanto um direito humano, tendo em vista a materialização da liberdade e da dignidade da pessoa humana.

\section{II- MATERIAIS E MÉTODOS}

Este artigo possui natureza qualitativa, interdisciplinar, de caráter descritivo e exploratório. A escolha da pesquisa qualitativa deve-se em virtude da sua variedade de pontos de vista epistemológicos e teóricos, bem como de técnicas na perspectiva de Poupart, Deslauriers, Groulx, et all (2014).

A bibliografia foi selecionada por meio da consulta de materiais diversos, tais como livros impressos de autores consagrados e emergentes nas discussões em estudo e fontes da internet selecionadas a partir das palavras-chave: educação sexual familiar; educação sexual formal no Brasil; mídias e educação sexual.

A coleta de dados se deu via fontes secundárias, cujos achados foram interpretados por meio da análise de conteúdo proposta por Bardin (2009). Esta técnica é aplicável em pesquisas de natureza qualitativa ou quantitativa e consiste na pré-análise, a exploração do material e o tratamento dos resultados.

Em linhas gerais consiste em decodificar o teor de um conteúdoque deve estar em um documento escrito- tendo em vista identificar as suas significações explícitas e ocultas. A autora apresenta os seguintes critérios de organização de uma análise: a pré-análise, a exploração do material e o tratamento dos resultados. 


\section{III- RESULTADOS E DISCUSSÃO}

\section{III.II- A educação sexual no contexto familiar: notas sobre alguns impasses}

Não obstante os avanços relacionados às transformações nas famílias e no acesso às informações a educação sexual no âmbito familiar ainda é considerada um tabu. Neste artigo compreende-se por educação sexual a forma de oferecer condições para que as pessoas assumam seu corpo e sua sexualidade com atitudes positivas, livres de medo, preconceitos, culpas e vergonha, na perspectiva de Souza (1991).

Por sua vez, a sexualidade supera os aspetos biológicos e reprodutivos, visto que é parte integrante da personalidade e envolve todo o comportamento do indivíduo e se expressa numa diversidade grande de manifestações, tais como: carícias, beijos, abraços, olhares, sentimentos, afetos, fantasias, desejos, sonhos e prazer, conforme Vasconcelos (1991).

Nesta seara, a educação sexual na esfera familiar não se resume a apenas pontuar sobre relações sexuais, métodos contraceptivos e IST's. Reitera-se que a sexualidade e sexo não possuem sinonímia; transcende o ato sexual, posto que envolve o afeto, a saúde, autocuidado, questões de gênero, dentre outros enfoques.

Todavia, dialogar sobre estas questões não é uma tarefa fácil para grande parte das famílias brasileiras nos seus variados arranjos; com isso, a educação sexual é desafiadora. De fato, a literatura consultada indica que é recorrente o desconforto dos adultos responsáveis pelas crianças e adolescentes, especialmente as mães, pais e responsáveis quanto à abordagem destes temas. Consequentemente preferem omitir informações e assumem condutas repressoras para tentar conter as dúvidas e ansiedades dos filhos acerca do assunto. Estas atitudes reverberam a reprodução da deseducação sexual.

A esse respeito, o estudo de Almeida \& Centa (2009) demonstrou que os pais, mães e responsáveis em geral apontaram que uma das causas pela qual se sentem tolhidos em versar sobre a educação sexual com as/os filhos/as diz respeito à forma como foram educadas/os. Com isso, 
a educação recebida teria deixado traumas que persistiam no tocante à relação com as/os filhas/os, sobretudo quanto aos diálogos relativos à sexualidade.

Outro impasse relativo à educação sexual por parte da família deve-se ao mito de que a sua abordagem estimularia e anteciparia os atos sexuais, tal como elucidam Trindade \& Bruns (1999). Entretanto, ao contrário do que se propaga, a educação sexual não contribui com a vivência sexual precoce, ao contrário, corrobora com o seu adiamento, posto que amplia a responsabilidade, entendimento e diminui as possibilidades de abuso sexual, gravidez não planejada e contágio por IST's.

Nesta constante, Costa (1986) considera que pais e mães que tiveram uma educação repressiva e autoritária precisam rever seu posicionamento e ressignificar conceitos equivocados e preconceituosos acerca da sexualidade, com vistas à educação sexual emancipatória. Esta, por sua vez, pressupõe o desenvolvimento de ações voltadas à promoção da autonomia, com vistas a transcender padrões de comportamentos hierarquizados e estereotipados, superando preconceitos e tabus.

É fundamental que as famílias revisem suas dificuldades buscando informações confiáveis por meio das mídias através de leituras, debates, vídeos, reflexões e discussões sobre o tema. Assim, munidos de conhecimento será possível informar e orientar suas/seus filhas/os de forma mais emancipatória que consiste em

[...] abrir possibilidades, dar informações sobre os aspectos fisiológicos da sexualidade, mas principalmente informar sobre suas interpretações culturais, e suas possibilidades significativas, permitindo uma tomada lúcida de consciência. É dar condições para o desenvolvimento contínuo de uma sensibilidade criativa em seu relacionamento pessoal. Esta forma de abordagem da educação sexual deixaria de ser apenas um aglomerado de noções estabelecidas de biologia, de psicologia e moral, que não apanha a sexualidade naquilo que the pode dar significado e vivência autêntica: a procura mesmo da beleza interpessoal, a criação de um erotismo significativo do amor (VASCONCELOS, 1971, p. 111). 
Conforme apresentado anteriormente, pode-se sintetizar que as famílias encontram impasses quanto à promoção da educação sexual, em grande parte devido à forma repressiva pela qual os pais, mães e responsáveis foram educadas/os; por acreditarem que a abordagem do tema estimularia os atos sexuais; ou mesmo por vergonha e pouco conhecimento do tema.

A fim de colaborar com este processo de aproximação com as/ os filhas/os no tocante à educação sexual as mídias podem ser uma ferramenta útil, pois possibilitam abordar as questões relativas à educação sexual de forma lúdica, adequada, criativa e com informações que transcendem conselhos ou experiências particulares doas pais, mães e responsáveis.

\section{III.III- O emprego das mídias vídeo, material impresso e internet como recursos auxiliares à educação sexual de crianças e adolescentes no âmbito familiar}

Nesta seção, reitera-se que a educação sexual promovida pelas famílias é desafiadora e para tanto estratégias devem ser levadas em consideração para contribuir com esta tarefa. A esse respeito, as mídias são recursos que contribuem com o diálogo relativo à educação no tocante à sexualidade.

A literatura atinente às mídias na educação é vasta. Como ilustração destes estudos ressalta-se a pesquisa de Dias e Leite (2014) quanto a este tema. Enfatizam que o material impresso é a mídia mais empregada na educação. Em contrapartida, o rádio e a televisão tem a vantagem de serem imediatos, sendo que o primeiro possui como outra vantagem o seu baixo custo se comparado à televisão. Com o processo de digitalização o vídeo e a internet tem se popularizado cada vez mais no ambiente escolar.

Uma proposta considerada relevante é criticar o paradigma conservador de ensino baseado na transmissão de conhecimento, memorização aprendizagem competitiva e individualista, em prol da educação significante e libertadora. Tais autoras consideram que para alcançar tal finalidade compreende-se que as mídias não devem ser potencialmente utilizadas somente na educação formal, dado que os espaços não esco- 
lares também podem empregá-las com vistas à construção e troca de saberes de forma mais criativa e atrativa.

Neste sentido, compreende-se que as famílias podem lançar mão das mídias como ferramentas auxiliares na educação sexual de crianças e adolescentes. Neste estudo, destaca-se o emprego do material impresso (livros), vídeo (série Sex Education) e internet (site, canal do Youtube) para esta finalidade. Para tanto, serão analisados algumas fontes escolhidas por conveniência para lidar com a educação em sexualidade no âmbito familiar, possibilitando que crianças e adolescentes tenham acesso a informações de boa qualidade, adaptadas e adequadas à faixa etária e estágio do desenvolvimento.

A fim de possibilitar a abordagem sobre o abuso sexual com as crianças a obra de Taubman (2017) apresenta de forma lúdica e com linguagem apropriada ao público infantil o que é a violência sexual e como evitá-la. A personagem principal -Ritoca- é uma coelha e quase fora abusada pelo tio ${ }^{24}$ que queria tocá-la de forma inapropriada. Este livro é uma maneira de fornecer segurança e informação às crianças sem perder o encantamento próprio da literatura.

Arcari (s/d) também desenvolveu uma obra na qual as/os personagens Pipo e Fifi contribuem para que as crianças conheçam as partes do corpo, enfatizando as partes íntimas. Com uma metodologia apropriada e muitas ilustrações a autora corrobora com a prevenção ao abuso sexual e dialoga sobre a afetividade e os cuidados para com o corpo.

A contação de histórias é um importante recurso para atrair a atenção das crianças, notadamente as mais novas. Destaca-se o canal do $Y_{\text {Youtube }}^{25}$ no qual há vídeos relativos a contos da literatura infantil, bem como os livros supracitados. Sugere-se que este canal seja pesquisado,

$24 \mathrm{O}$ abuso sexual ocorre principalmente no âmbito intrafamiliar. A esse respeito o site Childhood é uma importante ferramenta de conhecimento sobre temas relativos à proteção à infância e à adolescência, cujo foco de atuação é o enfrentamento do abuso e da exploração sexual contra crianças e adolescentes. Disponível em: Disponível em: < ttps://www.childhood.org.br/quem-somos?gclid=CjwKCAjw4871BRAjEiwAbxXi29MyVJhL9szMpm0NylOLItQYrl5KxEmfpqnk0849e64imNdRVb1z9BoCh7QQAvD_BwE\#intro >.

25 Canal do Youtube Fafá conta histórias. A esse respeito vide: <"https://www.youtube. com/channel/UC9fxSdFjcz5QWDEhYCk_k1w">. 
pois possibilita que as mães, pais e responsáveis obtenham um norte quanto à contação de histórias para crianças de forma lúdica e criativa. Ademais, os vídeos em questão orientam quanto às lições que podem ser retiradas dos contos e fomentam os diálogos entre as crianças e os adultos responsáveis.

Apesar de possuírem maior acesso às informações as/os adolescentes também precisam de orientação sexual no âmbito familiar. A esse respeito, a mídia televisiva contribui por meio da série original da Netflix denominada Sex Education com a discussão relacionada à transição de gênero, a afetividade e sexualidade binária e não binária, abuso sexual, masturbação, prazer feminino, aborto, métodos contraceptivos e outras discussões a esse respeito de uma maneira extremamente natural.

Nesta série composta até então por duas temporadas Otis e Maeve são jovens estudantes da Escola Moordale High e tornam-se sócios em uma espécie de clínica de aconselhamento sexual criada clandestinamente como forma de vender orientações às/aos demais discentes deste educandário. Otis possui conhecimentos no campo da sexualidade provenientes da influência da sua genitora - Sra. Jean- que é terapeuta sexual, ao passo que Maeve acumulou saber neste ramo dado às suas vivências relacionadas à sua trajetória de vida, tais como iniciação sexual precoce, gravidez na adolescência e aborto (NETFLIX, 2020).

A escola em questão possui um modelo rígido de funcionamento, atenta ao rendimento acadêmico, contudo, alheia à formação integral para além das exigências curriculares tradicionais. Assim, os diversos preconceitos, bullying e demais conflitos entre discentes não possuem encaminhamentos para além das advertências e suspensões.

$\mathrm{Na}$ segunda temporada a Sra. Jean oferece gratuitamente à comunidade escolar orientações no campo da sexualidade, o que não se dá sem ressalvas por parte da direção e de alguns pais e mães das/os alunas/os, alegando que a educação sexual compete à família. Esta atitude da terapeuta sexual possibilitou a discussão dos relacionamentos afetivos e sexuais entre professoras/es, sexo no matrimônio, machismo, relacionamentos abusivos divórcio e outros, tal como assinala Adoro Cinema (2020).

A explanação destas mídias tem por objetivo contribuir com a divulgação de alguns materiais que auxiliam as mães, pais ou responsáveis pela educação em sexualidade de crianças e adolescentes. A proposta é 
que estes momentos sejam realizados de forma natural a fim de evitar maiores constrangimentos- de ambas as partes- e que as histórias sejam contadas de forma lúdica e de forma que cative às crianças. Ressalta-se que a educação sexual precisa ocorrer desde a primeira infância e não se resume a falar sobre sexo. Ademais, os adultos também necessitam aprender sobre este tema, posto que o diálogo deve ir além de aconselhamentos e da experiência pessoal que tiveram.

É prudente reiterar que há uma vastidão de materiais encontrados nas mídias que favorecem o diálogo entre pais, mães, responsáveis e filhas/os sobre a educação sexual, no entanto, dado os limites deste estudo foram selecionados por conveniência as fontes acima destacadas para contribuir com este processo educativo.

Ademais, por mais óbvio que seja, destaca-se que promover uma leitura ou assistir e interpretar um vídeo por si só não garantirá a educação sexual e a proteção das crianças e adolescentes, pois se trata de ações progressivas e que perpassam todo o período do desenvolvimento infanto-juvenil.

\section{IV- CONSIDERAÇÕES FINAIS}

Em consonância com a literatura consultada discutiu-se a educação sexual no âmbito familiar, destacando-se como principais elementos desafiadores a cultura repressora nas quais os pais e mães foram educados/as e a sua perpetuação a partir da educação dos/das filhos/as. A fim de contribuir com este processo educativo no âmbito familiar as mídias são uma possibilidade de aproximação com os temas e contribuírem com o diálogo entre os pais, mães e filhos.

Sabe-se que há muito a se avançar neste contexto, uma vez que o conservadorismo, presentes, sobretudo nas famílias e nos representantes políticos afiliados à bancada cristã, consideram que não compete às famílias tampouco às escolas promoverem a educação sexual, alegando que isto influenciaria as relações sexuais precoces e incitaria a "ideologia de gênero".

Este cenário de desinformações e preconceitos quanto aos objetivos da educação sexual reverberam diversas falácias, algumas delas relatadas nesta pesquisa, tais como o "kit gay", "mamadeiras em for- 
mato de pênis" e cooperam com estratégias igualmente descabidas, a saber: propor a abstinência sexual como forma de prevenir as IST's e a gravidez na adolescência.

Em contrapartida, as mídias contribuem para pensar quão importante e necessária a abordagem da educação sexual pelas famílias. Reitera-se que a educação sexual é um dever a ser compartilhado especialmente pela família, escola e Estado. Portanto, compete aos diferentes arranjos familiares contribuírem com a materialização do direito à educação sexual das crianças e adolescentes de forma crítica e afetuosa, criando espaços para o diálogo coerente e emancipador das crianças e adolescentes nos lares.

\section{REFERÊNCIAS}

Adoro Cinema. Sex Education. Disponível em: http://www.adorocinema.com/noticias/series/noticia-152922/. Acesso em: $27 / 03 / 2020$.

ALMEIDA, Ana Carla Campos Hidalgo de; CENTA, Maria de Lourdes. A família e a educação sexual dos filhos: implicações para a enfermagem.. Acta Paulista de Enfermagem, v. 22, n. 1, p. 71-76, 2009.

ARCARI, Caroline. Pipo e Fifi: prevenção de violência sexual. São Paulo: All Print, s/d. Disponível em: <"http://www.institutoapicedown.org.br/wp-content/uploads/2017/04/Pipo_Fifi.pdf”’. Acesso dia: 03/05/2020.

BARDIN, Laurence. Análise de Conteúdo. Lisboa, Portugal; Edições 70, LDA, 2009.

BOBBIO, Norberto. A Era dos direitos. Rio de Janeiro: Campus, 1992.

BRASIL. Constituição da República Federativa do Brasil de 1988. Disponível em: < http://www.planalto.gov.br/ ccivil_03/constituicao/constituicao.htm >. Acesso dia: 07/05/2020. 
BRASIL. Lei no 8069 de 13 de julho de 1990. Dispõe sobre o Estatuto da Criança e do Adolescente e dá outras providências. Disponível em: < http://www.planalto.gov.br/ccivil_03/leis/ 18069.htm >. Acesso dia: 09/05/2020.

COSTA, M. Sexualidade na adolescência: dilemas e crescimento. 8. ed. São Paulo: L \& PM Editores, 1986.

DIAS, Rosilânia Aparecida. LEITE, Lígia Silva. Educação a distância: da legislação ao pedagógico. 4 ed. Rio de Janeiro: Vozes, 2014.

DIREITOS DA CRIANÇA. Portal dos direitos da criança e do adolescente. Nota pública do Conanda sobre direitos sexuais de crianças e adolescentes. 2017. Disponível em: <https://www. direitosdacrianca.gov.br/documentos/notas-publicas-dos-conanda/nota-publica-sobre-direitos-sexuais-de-criancas-e-adolescentes-14-12-2017\#: :text=A\%20Nota\%20p\%C3\%BAblica\%20 conjunta $\% 20$ entre,por\%20motiva\%C3\%A7\%C3\%B5es\%20 LGBTf\%C3\%B3bicas\%20no\%20Brasil>. Acesso em: 03/07/2020.

ESQUERDA DIÁRIO. Sex Education: uma série necessária em tempos de Damares e abstinência sexual. Disponível em: http://www.esquerdadiario.com.br/Sex-Education-uma-serie-necessaria-em-tempos-de-Damares-e-abstinencia-sexual. Acesso em: 22/03/2020.

FIGUEIRÓ, Marineide Domico (2017). O que é educação sexual. Disponível em: https://www.youtube.com/watch?v=1_YzXUrL6Ls. Acesso em: 04/04/2020.

FREIRE, Paulo. Pedagogia do oprimido. 13. ed. Rio de Janeiro: Paz e Terra, 1983.

MINISTÉRIO DA EDUCAÇÃO. Base Nacional Comum Curricular. Disponível em: http://basenacionalcomum.mec.gov.br/ historico.\%2015/04/2020. Acesso em: 03/04/2020. 
MINISTÉRIO DA SAÚDE. Infecções Sexualmente Transmissíveis (IST): o que são, quais são e como prevenir. Disponível em: <https://saude.gov.br/saude-de-a-z/infeccoes-sexualmente-transmissiveis-ist>. Acesso em: 16/04/2020.

NETFLIX. Série Sex Education. Disponível em: < https://www. netflix.com/br/title/80197526> . Acesso em: 28/03/2020.

SANTAELLA, Claudio de Paiva. Nativos digitais: quem são? Presença Pedagógica, Belo Horizonte, v. 19, n. 111, p. 24-29, mai./ jun.2003.

ORGANIZAÇÃO DAS NAÇÕES UNIDAS (ONU). Declaração Universal dos Direitos Humanos. 1948. Disponível em: < http://www.onu-brasil.org.br/documentos_direitoshu-manos. php>. Acesso em 19/06/2020.

POUPART, Jean; DELSAURIERS, Jean-Pierre; GROULX, Lionel-H.; et all. A pesquisa qualitativa: enfoques epistemológicos e metodológicos. Trad. Ana Cristina Nasser. Petrópolis, RJ: Vozes, 2014.

SOUZA, Hália Pauliv de. Convivendo com seu sexo (Pais e Professores). 2 ed. São Paulo: Paulinas, 1991.

TAUBMAN, Andrea Viviana. Não me toca, seu boboca! Belo Horizonte: Aletria, 2017.

TRINDADE, E.; BRUNS, M. A. T. Adolescentes e paternidade: um estudo fenomenológico. Ribeirão Preto: Holos, 1999.

UNESCO. Orientações técnicas de educação em sexualidade para o cenário brasileiro: tópicos e objetivos de aprendizagem. Brasília : UNESCO. 2014. Consultado a 23/03/2020, em http://www.crianca.mppr.mp.br/arquivos/File/publi/unesco/ orientacoes_tecnicas_sexualidade_unesco_2014.pdf. Acesso dia: 14/04/2020.

VASCONCELOS, Naumi. Os dogmatismos sexuais. Rio de Janeiro: Paz e Terra, 1971. 


\section{A RELAÇÃO ENTRE O PÚBLICO E O PRIVADO E O CONSEQUENTE DIREITO A EDUCAÇÃO}

Thais Maria dos Santos Silva

\section{INTRODUÇÃO}

O debate sobre a participação da iniciativa privada na educação brasileira está presente ao longo da história, desde os embates entre católicos, liberais e positivistas no período da Proclamação da República, passando pela aprovação da primeira LDB, à promulgação da Constituição Federal de 1988, até chegar ao debate atual sobre as Parcerias Público-Privada na Educação - PPPE. (OLIVEIRA, 2005)

Discutir essa temática é importante, sobretudo, em razão desse tema, merece um estudo aprofundado, destacado como uma abordagem que está em pauta e demanda uma discussão mais detalhada no mundo acadêmico, assim como é relevante a sua discussão no âmbito social, pois a partir da década de 1990, o cenário político e econômico do Brasil e o sistema educacional sofreram transformações e a relação público-privado alcançou uma nova configuração no debate nacional.

Essas mudanças acompanharam tanto as transformações do capital internacional, produzidas pela crise do capital que para sua superação gerou um movimento de uma nova ordem econômica mundial, tendo por base a desregulamentação dos mercados e a globalização, quanto às mudanças internas com o processo de redemocratização da sociedade brasileira marcada pelo fim de uma ditadura política e elaboração de uma nova Constituição Federal e de uma nova Lei de Diretrizes e 
Bases da Educação Nacional (LDB), que trouxeram como principais debates a liberdade de ensino, sua laicidade, o financiamento e o papel do Estado na educação. (CURRY, 1992)

Este artigo tem por objetivo analisar a fronteira entre a relação público-privada na educação brasileira a partir da reforma do Estado ocorrida na década de 1990, tentando responder a questão de como se dar a relação público-privada a partir dessa década, que era oferecida pelo Estado e passa a ser ofertada pelo setor privado e suas novas configurações.

No que tange a metodologia realizou-se uma pesquisa bibliográfica e documental, com a finalidade de analisar, à luz da teoria e dos documentos utilizados, a fronteira entre a relação público-privada na educação brasileira, apresentando o movimento da formação das Parcerias Público-Privadas na Educação (PPPE) identificados como "quase-mercado" 26 e público não-estatal.

E para alcançar esse objetivo o artigo foi estruturado nos seguintes tópicos: primeiro um debate sobre a reforma implementada no Estado brasileiro , uma análise das novas fronteiras entre o público e o privado representando as Parcerias Público-Privadas na Educação - PPPE e implicacações da relação do púplico e privado no direito a educação.

\section{A REFORMA E A REDEFINIÇÃO DO PAPEL DO ESTADO BRASILEIRO}

O governo brasileiro também parte do pressuposto de que a crise que afetou o país nas décadas de 1980 e de 1990 era decorrente de uma crise no Estado e não no capital, portanto, propondo como estratégia uma reforma de Estado explicada como:

[...] reforma do Estado deve ser entendida dentro do contexto da redefinição do papel do Estado, que deixa de ser o res-

26 Esse rearranjo da lógica capitalista oportunizou o surgimento do que vem sendo chamado de "quase-mercado. Ou seja, uma forma bastante específica de combinar a regulação do Estado e a lógica de mercado na oferta e gerenciamento de serviços públicos, não havendo contraposição entre as duas lógicas (de público e privado), como ocorria no auge do Estado-Providência" (BAUER, 2008). 
ponsável direto pelo desenvolvimento econômico e social pela via da produção de bens e serviços, para fortalecer-se na função de promotor e regulador desse desenvolvimento (BRASIL,1995, p. 12).

Seguindo o entendimento dos teóricos neoliberais e da Terceira Via, o Estado brasileiro era ineficiente por ser um Estado executor, sendo importante redefinir seu papel, assim, "reformar o Estado significa transferir para o setor privado as atividades que podem ser controladas pelo mercado" (BRASIL, 1995, p. 11)

Assim, a reforma do Estado brasileiro foi implantada, a partir de 1995, pelo governo de Fernando Henrique Cardoso com a criação do Ministério e Reforma do Estado - MARE, que apresentou o Plano Diretor da Reforma do Aparelho do Estado, sob a orientação do ministro Luiz Carlos Bresser Pereira, pautado na premissa da substituição do modelo burocrático por um modelo gerencial mais flexível e capaz de dinamizar o setor público, utilizando para isso elementos do modelo de gestão NPM.

Pretendia alcançar quatro aspectos da administração pública: a delimitação das funções e do tamanho do Estado, através da privatização, terceirização e publicização; a redução do grau de interferência do Estado, através de programas de desregulação; o aumento da governança do Estado, através do ajuste fiscal e o aumento da governabilidade, isto é, do poder do governo (BRESSER PEREIRA, 1998).

A ideia propagada na época para adoção desse modelo de gestão foi baseada em dois elementos centrais da NPM: ineficiência e ineficácia da gestão estatal democrática e a participação de entidades, organizações e movimentos sociais como essenciais ao processo de democratização do Estado (BRESSER PEREIRA, 1998). E também ao fato de que as políticas sociais implementadas pelo Estado do bem-estar social deveriam ser modificadas para seguir a tendência de flexibilização do mercado e as exigências do capital internacional.

A lógica do mercado deveria prevalecer na esfera pública, pois esta:

[...] aloca recursos e benefícios sob o imperativo da eficiência capitalista, racionalizadora na técnica organizacional e produti- 
va (fundindo ciência, tecnologia e organização da produção) e acumuladora de riquezas (CARDOSO, 1998, apud BUENO; KASSAR, 2005, p. 120).

Para a efetivação do gerenciamento da reforma proposta é importante destacar que no documento há uma diferenciação entre aparelho do Estado e Estado. O aparelho do Estado é entendido como “[...] administração pública em sentido amplo, ou seja, a estrutura organizacional do Estado, em seus três poderes (Executivo, Legislativo e Judiciário) e três níveis (União, Estados-membros e Municípios." (BRASIL, 1995, p.11). Enquanto o Estado é entendido de forma mais abrangente, porque inclui também o sistema constitucional legal, que regula a sociedade, sendo esse entendimento essencial para se ter clareza nas funções que o Estado desempenha, e a consequente delimitação de sua área de atuação.

Dessa forma, o papel do Estado deveria ser redefinido, deixando de ser um Estado que promove diretamente o desenvolvimento econômico e social, ou seja, um Estado executor, para um Estado que atue como regulador e facilitador ou financiador a fundo perdido desse desenvolvimento. E para isso teria suas funções delimitadas a partir de três áreas de atuação: as atividades exclusivas de Estado; os serviços sociais e científicos do Estado; e, a produção de bens e serviços para o mercado (BRESSER PEREIRA, 1998).

No plano da reforma às atividades exclusivas de Estado permaneceram dentro do Estado, tendo, verticalmente, no seu topo um núcleo estratégico, e, horizontalmente, as secretarias formuladoras de políticas públicas e as agências executivas e reguladoras. Em relação à produção de bens e serviços para o mercado, temos no século passado, a estatização de certas atividades econômicas, que ocorreram por falta de recursos no setor privado, e que a partir dos anos 1980, com a crise fiscal, passaram a ser privatizadas (BRASIL, 1995).

E, entre as atividades exclusivas de Estado e a produção para o mercado, encontram-se as atividades na área social e científica, que não são atividades exclusivas do Estado, incluindo as escolas, as universidades, os centros de pesquisa científica e tecnológica, as creches, 
os ambulatórios, os hospitais, as entidades de assistência aos carentes, os museus, as orquestras sinfônicas, as oficinas de arte, as emissoras de televisão educativa ou cultural, etc. Entretanto, são consideradas atividades competitivas, que poderiam ser controladas pela administração pública gerencial, mas também pelo controle social e pela constituição de quase-mercado (BRASIL, 1995).

A partir dessas delimitações, entendemos a divisão do aparelho de Estado em quatro setores: o primeiro seria o 'núcleo estratégico', correspondendo ao governo em sentido lato, "o setor que define as leis e as políticas públicas e cobra seu cumprimento” (BRASIL, 1995, p. 39); o segundo correspondia ao setor das 'atividades exclusivas', que reunia serviços que só o Estado poderia realizar, como por exemplo, a cobrança e fiscalização de impostos, o serviço de emissão de passaportes, a polícia, dentre outros; o terceiro setor compreendia os 'serviços não-exclusivos' em que o Estado atua simultaneamente com outras 'organizações públicas não-estatais e privadas; e o quarto setor destina-se a produção de bens e serviços para o mercado, atividades econômicas voltadas para o lucro que ainda permanecem no aparelho de Estado (BRASIL, 1995).

Percebemos, nesse panorama de reformulações de setores e funções, um mecanismo de transferência para o setor privado das atividades que podem ser controladas pelo mercado "o Estado abandona o papel de executor ou prestador direto de serviços, mantendo-se, entretanto, no papel de regulador e provedor ou promotor destes, principalmente dos serviços sociais como educação e saúde" (BRASIL, 1995, p.12).

Assim, de acordo com o Plano Diretor, o redimensionamento do Estado envolvia atividades que precisavam ser descentralizadas, mas que não deviam ser privatizadas, os chamados serviços não-exclusivos, como a educação, saúde, cultura e pesquisa científica, processo identificado como 'publicização' e, que deveriam ser administrados pelo setor público não-estatal. E essa perspectiva traz como consequência a diminuição da atuação do poder público e o aumento da participação privada, redefinindo-se, dessa forma, as fronteiras entre o público e o privado. 


\section{FRONTEIRAS ENTRE O PÚBLICO E O PRIVADO}

Como foi ressaltado anteriormente, a redefinição no papel do Estado, decorrente da crise do capital trouxe como consequência à reconfiguração da fronteira entre o público e o privado, sendo entendida como parte de um contexto histórico e geográfico particular, com contradições, e uma história de lutas pela democratização da educação materializada em direitos (PERONI, 2016).

E essa fronteira vem se modificando na atual conjuntura que o país atravessa, utilizando para superação de sua crise as estratégias do neoliberalismo e da Terceira Via (PERONI, 2012, 2013).

Destacamos também que enquanto o neoliberalismo defende a privatização, o discurso da Terceira Via em democratizar a democracia, favorece a participação da sociedade civil, através da parceria entre o público e o privado. Esse movimento repercute na fronteira entre o público e o privado que alcança uma nova configuração, levando ao fortalecimento do terceiro setor, e tendo o privado uma grande influência na determinação e execução das políticas públicas, capaz de definir, por exemplo, o conteúdo e gestão da educação e impactando na questão da democratização da educação (PERONI, 2012).

E, para entender essa reconfiguração da relação entre o setor público e o setor privado na educação partimos do que foi estabelecido na Constituição Federal de 1988, destacando alguns artigos. O art. 205 ressalta que a educação, como um direito de todos e dever do Estado e da família, será promovida e incentivada com a colaboração da sociedade, visando ao pleno desenvolvimento da pessoa, seu preparo para o exercício da cidadania e sua qualificação para o trabalho, ou seja, deve ser promovida e incentivada com a colaboração da sociedade. Reconhecendo no art. 206 a coexistência dessas instituições com o "pluralismo de ideias e de concepções pedagógicas, e coexistência de instituições públicas e privadas de ensino” (BRASIL, 1988).

E pela primeira vez um dispositivo legal faz uma separação entre a escola pública e a escola privada, e, no âmbito das privadas a destacava a existência de escolas com fins lucrativos e sem fins lucrativos (OLIVEIRA, 2005). O que pode ser observado no art. 209 que faz uma referência às escolas privadas voltadas para o lucro, que serão reguladas 
por acordos entre as partes, mas baseando-se nas normas gerais da educação nacional, submetidas à autorização e avaliação de qualidade do serviço público.

E o art. 213 especifica os diferentes tipos de escolas privadas não-lucrativas, como pode ser visto abaixo:

Art. 213. Os recursos públicos serão destinados às escolas públicas, podendo ser dirigidos a escolas comunitárias, confessionais ou filantrópicas, definidas em lei, que:

I - comprovem finalidade não lucrativa e apliquem seus excedentes financeiros em educação;

II - assegurem a destinação de seu patrimônio a outra escola comunitária, filantrópica ou confessional, ou ao poder público, no caso de encerramento de suas atividades.

$\mathbb{\$} 1^{\text {o }}$ Os recursos de que trata este artigo poderão ser destinados a bolsas de estudo para o ensino fundamental e médio, na forma da lei, para os que demonstrarem insuficiência de recursos, quando houver falta de vagas e cursos regulares da rede pública na localidade da residência do educando, ficando o poder público obrigado a investir prioritariamente na expansão de sua rede na localidade.

$\mathbb{} \$ 2^{\mathbf{o}}$ As atividades universitárias de pesquisa e extensão poderão receber apoio financeiro do poder público (BRASIL, 1988).

O que se observa dessa lógica de coexistência de instituições públicas e privadas com fins lucrativos e sem fins lucrativos na Constituição Federal permanece na atualidade, sendo intensificada a partir da reforma do Estado com a diversidade de possibilidades de instituições educacionais atuarem em parceria com o poder público, e que na maioria das vezes é o poder público que subsidia os serviços prestados pela iniciativa privada, como pode ser comprovado pelo artigo descrito anteriormente.

Dessa forma, percebe-se na atual política educacional uma variedade de formas existentes das relações entre o público e o privado, identificado por Peroni (2010) em um processo de duplo movimento: 
[...] a primeira é a alteração da propriedade, na qual há a passagem do estatal para o público não-estatal ou privado; já na segunda, permanece a propriedade estatal, mas passa a haver a lógica de mercado, reorganizando os processos principalmente de gestão, o que alguns autores têm chamado de quase-mercado (PERONI, 2010, p.216)

Existe além da propriedade privada e da propriedade estatal uma terceira forma de propriedade denominada de pública não-estatal, e essa nomenclatura decorre da perspectiva de Estado proposto pelo Plano Diretor que tinha como encaminhamento um Estado regulador e não executor de alguns serviços públicos, serviços que seriam efetivados pelas instituições denominadas público não-estatal, sendo justificada a partir da:

[...] descentralização para o setor público não-estatal da execução de serviços que não envolvem o exercício do poder de Estado, mas devem ser subsidiados pelo Estado, como é o caso dos serviços de educação, saúde, cultura e pesquisa científica. Chamaremos a esse processo de "publicização" (BRASIL, 1995, p. 12-13)

Observamos que na reforma do aparelho de Estado continuam a existir as duas formas clássicas de propriedade, a pública e a privada, entretanto, a propriedade pública se subdivide em estatal e pública não-estatal, sendo esta última considerada como instituição de direito privado voltada para o interesse público e não para o consumo privado (BRESSER PEREIRA, 1998, p. 67).

E esse foi o entendimento para uma alternativa a privatização, quando uma forma de propriedade em que o financiamento depender de doações e/ou transferências do Estado, ela se constituirá em uma atividade pública, mas que não precisa ser estatal, podendo ser mais diretamente controlada pela sociedade que a dirige.

A propriedade pública não-estatal é entendida por alguns autores como Terceiro Setor, pois, nem representa o Estado, que é considerado o primeiro setor, nem o mercado, o segundo setor. E é a estratégia da 
Terceira Via para repassar para a sociedade civil as políticas sociais antes executadas pelo Estado.

O terceiro setor é considerado um setor que apresenta uma imprecisão na literatura quanto ao seu termo, como pode ser observado em Adrião e Peroni (2005) quando elas ressaltam que:

O termo terceiro setor, ora aproximando-o de uma também genérica definição de sociedade civil, ora referindo-se a um formato específico juridicamente definido de instituição priva$\mathrm{da}$, ora, ainda, identificando-o com as tradicionais entidades de caráter assistencial ou filantrópico. Segue-se que o cerco à sua definição dá-se então por exclusão: o terceiro setor refere-se a esferas da sociedade que não se encontram no mercado ou no Estado (PERONI; ADRIÃO, 2005, p. 142).

Para Montaño (2005) o terceiro setor é responsável por modificar até a questão social no sentido em que transfere a responsabilidade da política social do Estado para o indivíduo, representando, dessa forma, um caráter de individualismo, perdendo o seu aspecto universalista. Também chama a atenção para o fato de que com a descentralização administrativa proposta pela reforma de Estado, as políticas se tornam mais precarizadas, porque são transferidas as competências para a sociedade sem os recursos correspondentes e necessários para executá-las.

É considerado um setor que surge a partir da reconfiguração do Estado, configurando-se como instituições da sociedade civil, conhecido como o terceiro setor, um setor além do Estado e do mercado e que tem como características a diversidade e a complexidade do termo "os três setores [Estado, mercado e terceiro setor] interpretam-se e condicionam-se de tal maneira que a definição exata dos limites é motivo de controvérsias e variações no tempo e no espaço" (FERNANDES, 1994, apud BUENO; KASSAR, 2005).

O marco legal do terceiro setor representa a configuração jurídica dessas instituições e teve como justificativa estimular e fortalecer as instituições da sociedade civil. Compreende a Lei no 9.637, promulgada em 15 de março de 1998, conhecida como a Lei das Organizações Sociais; a Lei no 9.732 de 11 de dezembro de 1998, conhecida com a Lei 
da Filantropia e a Lei no 9.790, promulgada em 23 de março de 1999, referente às Organizações da Sociedade Civil de Interesse Público.

As Organizações Sociais (OS) são as organizações consideradas pessoas jurídicas de direito privado, sem fins lucrativos, para prestar serviços não-privativos do poder público, mas por ele incentivadas e fiscalizadas, e dessa forma, qualificadas após o ajuste de um contrato de gestão. Representando, dessa forma, "a qualificação jurídica de direito privado, sem fins lucrativos, instituída por iniciativas particulares, e que recebe delegação do Poder Público, mediante contrato de gestão, para desempenhar serviços públicos de natureza social" (DI PIETRO, 2009,p.565).

Já as Organizações da Sociedade Civil de Interesse Público (Oscip) são semelhantes as OSs, entidades de direito privado, sem fins lucrativos, instituídas para prestar serviços sociais não privativos do Poder Público, mas por ele incentivadas e fiscalizadas. O instrumento que estabelece a relação com o setor público é um termo de parceria, e seu campo de atuação é mais amplo do que as OSs, abrangendo em seu art. 3o áreas de assistência social, preservação e conservação do patrimônio público, promoção do voluntariado, combate à pobreza, promoção da paz, cidadania e direitos humanos.

Percebemos, portanto, que a propriedade do público não estatal é redefinida, deixando de ser estatal, passando a ser pública de direito privado. E os dois movimentos que concretizam essa passagem da execução das políticas sociais para o público não estatal são representados pelas instituições do terceiro setor, como foi observado anteriormente, quando o público passa a ser de direito privado ou quando o Estado faz parcerias com instituições do terceiro setor para a execução das políticas sociais (PERONI, 2016).

Entretanto, a propriedade pode permanecer sendo estatal, mas a lógica de mercado vai orientar o setor público, é o que denominamos de quase-mercado. E é a teoria neoliberal que fundamenta esse raciocínio, pois, entende que o mercado é mais eficiente do que o setor público.

Assim, a proposta neoliberal é a formação de um quase-mercado, que pode ser entendido como: 
A alternativa encontrada foi a de introduzir concepções de gestão privada nas instituições públicas sem alterar a propriedade das mesmas [...]. Surge, assim, a noção de "quase-mercado" que, tanto do ponto de vista operativo quanto conceitual, diferencia-se da alternativa de mercado propriamente dita, podendo, portanto, ser implantada no setor público sob a suposição de induzir melhorias (SOUZA; OLIVEIRA, 2003 apud PERONI; ADRIÃO, 2005).

A lógica do funcionamento do quase-mercado aplica-se às organizações que mesmo não podendo integrar o mercado, disputariam no mercado, e teriam com isso vantagens adicionais como condição para o aumento de sua eficácia (PERONI; ADRIÃO, 2005).

E essa lógica é aplicada no mercado educacional quando se efetiva o controle estatal sobre os serviços ofertados na escola pública, através, por exemplo, da determinação de currículos e de sistemas de avaliações. Conforme argumenta Apple (1993) "[...] a introdução de um currículo nacional e de uma avaliação também a nível nacional transmitem a idéia de que o governo está preocupado com os consumidores e com a necessidade de elevar os níveis educacionais - o que é, afinal, a principal preocupação do mercado" (APPLE, 2000, p.123).

Para a efetivação desse quase-mercado na esfera educacional temos um discurso baseado na suposta melhoria dos serviços educacionais, com a introdução da lógica de práticas de mercado, onde a educação passou a ser vista como uma área bastante atrativa para a concentração de capital, constituindo-se num verdadeiro mercado educacional.

Diante desse panorama, percebemos que com a reforma do Estado, especificamente no setor educacional, foram utilizadas estratégias do NPM que possibilitaram a maior participação do setor privado na gestão pública, ou seja, formas de redefinir as fronteiras entre o setor público e o setor privado, através da redistribuição de poder, com a participação das organizações da sociedade civil.

E que se configura como as várias formas que se apresentam as Parcerias Público-Privadas na Educação - PPPE, que pode ser entendida como: 
Parceria público-privada é o contrato administrativo de concessão que tem por objetivo (a) a execução de serviço público, precedida ou não de obra pública, remunerada mediante tarifa paga pelo usuário e contraprestação pecuniária do parceiro público, ou (b) a prestação de serviço de que a Administração Pública seja a usuária direta ou indireta, com ou sem execução de obra e fornecimento e instalação de bens, mediante contratação do parceiro público (DI PIETRO, 2007, p. 285).

Portanto, as PPPEs representam, como foi visto anteriormente, uma forma de implementação dos serviços sociais antes desempenhados pelo Estado, ou seja:

[...] a reunião de esforços entre o Poder Público e o setor privado para a concretização de objetivos de interesse público, a partir de iniciativas legislativas (termo de parceria), bem como da sua aceitação pela doutrina no âmbito do Direito Público. Cabe ainda, nesta perspectiva, a designação de todas as formas de sociedade que, apesar de não formarem uma nova pessoa jurídica, se organizam entre os setores público e privado, para a consecução dos interesses públicos. (BEZERRA, 2008, apud ADRIÃO; PERONI, 2009).

Considerada, portanto, como uma forma de descentralização dos serviços sociais e prevista na Lei no 11.079/2004, representa na prática um "[...] afastamento do Estado da oferta direta da educação, mantendo seu foco no financiamento aos provedores (através de vales ou subsídios) e atuando na esfera da regulação e da avaliação dos serviços educacionais.” (ROBERTSON e VERGER, 2012, p.1144)

\section{IMPLICAÇÃO DA RELAÇÃO DO PÚPLICO E PRIVADO NO DIREITO A EDUCAÇÃO}

A educação é um direito fundamental, pois inclui um processo de desenvolvimento individual próprio à condição humana, mas, o direito a educação deve ser visto também de forma coletiva, como um 
direito a uma política educacional através de ações do Estado que ofereçam a sociedade instrumentos para alcançar seus fins.

O direito à educação foi consagrado pela primeira vez em nossa Constituição Federal de 1988 como um direito social no artigo 6. Deste modo, o Estado passou a ter a obrigação formal de garantir educação de qualidade a todos os brasileiros. Em seu artigo 205 contém uma declaração fundamental que, combinada com o artigo 6, eleva a educação ao nível dos Direitos Fundamentais do homem.

Neste sentido, o direito à educação é considerado como parte dos Direitos Fundamentais, já que é indispensável ao alcance da dignidade humana, tendo como base o Princípio da Universalidade sendo, portanto, um direito universal que o Estado não pode impossibilitar ao indivíduo e este por sua vez não pode dispor, tratando ser este um direito indisponível. Ainda, a educação é um dos Direitos Humanos, pois está reconhecida no teor do artigo 26 da Declaração Universal dos Direitos Humanos de 1948.

Já em seu artigo 209, a Constituição Federal faz referência à iniciativa privada, dizendo que o ensino é livre à iniciativa privada, atendidas as condições impostas pela própria norma constituinte e as espécies normativas infraconstitucionais que dispuserem sobre a matéria. E, nesse sentido, o poder público deve oferecer gratuitamente uma educação de qualidade para todos, mas que acaba por ser privatizada diante de uma sociabilidade onde se visa constantemente a produção de lucro, com a finalidade de garantir a reprodução do capital e a consequente manutenção do sistema para atender aos interesses mercadológicos.

O processo de privatização no cenário da educação pública fica cada vez mais controlado pelo capital, ao passo que os conhecimentos, os processos pedagógicos e a organização inclinam-se cada vez mais para atender aos interesses do mercado e do Estado burguês, e, nessa perspectiva, Frigotto ressalta que

Os pacotes de ensino assepticamente programados por especialistas, cuja, forma de veiculá-los é tida como mais relevante que os próprios conteúdos, e a hierarquização e o parcelamento do processo pedagógico constituem-se em formas de controle da produção e divulgação do saber que se processa na escola e, 
enquanto, tais, de controle social mais amplo (FRIGOTTO, 2006, p. 170).

Segundo Freitas o que vem acontecendo é um “controle ideológico do sistema educacional pelas corporações empresariais para colocá-lo a serviço de interesses de mercado, estreitando as finalidades educativas" (2012, p. 387). Deste modo a privatização da educação prejudica a educação como direito social, limitando-a enquanto atende as demandas do mercado capitalista empresarial.

Para Gustavo Paiva no Jornal da Unicamp (2016), o que é perceptível hoje é que o crescimento do setor privado sobre o setor público "afeta o direito humano à educação, tendendo a produzir, na maior parte dos casos, aumento das desigualdades educacionais, com maior prejuízo para as populações em situação de maior vulnerabilidade". Podemos visivelmente perceber que com o aumento da privatização da educação há um impedimento de avanços em relação ao princípio constitucional da gestão democrática, uma vez que a democracia na gestão escolar é impraticável na lógica administrativa empresarial.

Assim sendo, neste momento particular do capitalismo, a educação passa a ser administrada com base em orientações privatistas, o que também não é fato novo no campo dos direitos sociais, e que se baseiam nos princípios que orientam essa lógica, tais como a eficiência, a competitividade e os resultados, independente dos meios utilizados para atingi-los.

\section{CONCLUSÃO}

A redefinição do papel do Estado, a partir da implementação do plano de reforma do Estado na década de 1990, redefiniu a fronteira entre o setor público e o setor privado na esfera educacional.

A relação público/privado, no contexto das políticas educacionais, reforçada pelas transformações ocorridas no mundo do trabalho e nas reformas da administração pública, iniciadas na década de 1990, ganhou novos desenhos e concretizou-se em diversas formas de parcerias, destacando-se as Organizações Sociais. 
Constatou-se que essa mudança também foi reflexo das transformações do capital internacional, produzidas pela crise do capital que para sua superação gerou um movimento de uma nova ordem econômica mundial, com a utilização das estratégias do neoliberalismo com a privatização e a Terceira Via com o público não-estatal.

A educação passa a ser dirigida com fundamento em orientações privatistas, o que também não é fato novo no campo dos direitos sociais, e que se baseiam nos princípios que orientam esse sentido, tais como a eficiência, a competitividade e os resultados, independentemente dos meios utilizados para atingi-los.

O redimensionamento do Estado envolvia atividades que precisavam ser descentralizadas, mas que não deviam ser privatizadas, os chamados serviços não-exclusivos, como a educação, saúde, cultura e pesquisa científica, processo identificado como 'publicização' e, que deveriam ser administrados pelo setor público não-estatal. E essa perspectiva traz como consequência a diminuição da atuação do poder público e o aumento da participação privada, redefinindo-se, dessa forma, as fronteiras entre o público e o privado.

\section{REFERÊNCIAS}

ADRIÃO, Theresa; PERONI, Vera Maria Vidal. A educação pública e sua relação com o setor privado: implicações para a democracia educacional. In: Retratos da Escola. v.3, n. 4, jan/jun 2009.

APPLE, M. W. Política cultural e educação. São Paulo: Cortez, 2000.

BRASIL, Constituição (1988). Constituição da República Federativa do Brasil. Brasília: Ministério da Educação, 1989.

Lei no 11.079 de 30 de Dezembro de 2004. Instituiu normas gerais para licitação e contratação de parcerias público-privada no âmbito da administração pública.

Câmara da Reforma do Estado. Plano Diretor da Reforma do Aparelho do Estado. Brasília, 1995. Disponível em: <www.planalto.gov.br/publi_04/.../plandi.htm > Acesso em: 10 out. 2017. 
BRESSER PEREIRA, L. C. A reforma do Estado dos anos 90: lógica e mecanismos de controle. Brasília: Ministério da Administração Federal e Reforma do Estado, 1998.

Democracia, estado social e reforma gerencial. RAE-Revista de Administração de Empresas, v. 50, n. 1, p. 112-116, 2010 .

BUENO, C, C de O, KASSAR, M. de C. M. Público e privado: a educação especial nas danças das responsabilidades. In: ADIRIÃO, T. e PERONI, V. L.(orgs.) O público e o privado na educação: interfaces entre Estado e sociedade. São Paulo: Xamã, 2005.

DI PIETRO, Maria Sylvia Zanella. Direito administrativo. 20a․ ed., São Paulo: Atlas, 2007.

FREITAS, L. C. Os reformadores empresariais da educação: da desmoralização do magistério à destruição do sistema público de educação. Educação e Sociedade, Campinas, vol. 33, n. 119, p. 379404, jun., 2012.

FRIGOTTO, G. A produtividade da escola improdutiva: um (re)exame das relações entre educação e estrutura econômico-social e capitalista. 8. ed. São Paulo: Cortez, 2006.

MEDEIROS, Sonayra da Silva e RODRIGUES, Melânia Mendonça. O gerencialismo, reforma do Estado e da educação no Brasil. Revista educação em questão. v. 48, n. 34, p. 216-240. jan/abr 2014.

MONTAÑO, Carlos. Terceiro setor e questão social: crítica ao padrão emergente de intervenção estatal. São Paulo: Cortez, 2005.

MOTTA, Paulo Robert de Mendonça. O estado da arte da gestão pública. RAE-Revista de Administração de Empresas, v. 53, n. 1, p. 82-90. jan/fev 2013.

OLIVEIRA, Romualdo Portela de. Educação Pública e Privada na Constituição Federal de 1988. In: PERONI e ADRIÃO (organizadoras). O público e o privado na educação: interfaces entre Estado e sociedade. São Paulo: Xamã, 2005. 
PERONI, Vera Maria Vidal. A educação pública e sua relação com o setor privado: implicações para a democracia educacional. Retratos da Escola, 2009.

A gestão democrática da educação em tempos de parceria entre o público e o privado. Pro-posições, Campinas, v.23, n. 2(68), p. 19-31, maio/ago. 2012.

As relações entre o público e o privado nas políticas educacionais no contexto da Terceira Via. Currículo sem Fronteiras, v. 13, n. 2, p. 234-255, maio/ago. 2013.

PERONI, Vera Maria Vidal e ADRIÃO, Theresa. Público não-estatal: estratégias para o setor educacional brasileiro. In.: PERONI e ADRIÃO (organizadoras). O público e o privado na educação: interfaces entre Estado e sociedade. São Paulo: Xamã, 2005.

ROBERTSON, Susan; VERGER, Antoni. Educação e Sociedade. Campinas, v. 33, n. 121, p. 1133-1156, out.-dez. 2012. Disponível em http://www.cedes.unicamp.br. Acesso em dezembro de 2017. 


\section{EXPERIÊNCIAS DE CONTEXTOS DE VULNERABILIDADE SOCIAL E SEUS IMPACTOS SOBRE OS PROCESSOS DE APRENDIZAGEM}

Marina Taís Gabriel da Silva

Matheus de Oliveira Guimarães

Poliane Marta Rezende Pádua

\section{INTRODUÇÃO}

Pesquisas sobre teorias da aprendizagem (PIAGET, 1974; WALLON, 1968; VYGOTSKY, 1984) nos apontam que o meio de vulnerabilidade não impossibilita o desenvolvimento cognitivo, mas sinaliza que fatores tais como falta de oportunidades e situações de dura realidade familiar podem trazer consequências no processo de desenvolvimento.

Neste artigo, as discussões sobre os fatores sociais que influenciam os processos de aprendizagem dessas crianças em situação de vulnerabilidade serão trazidas à discussão. A intencionalidade deste trabalho é problematizar as relações entre o contexto social do aluno como possível causa de déficits de aprendizagem, com vistas à propositura de orientações para a amenização dos prejuízos sofridos durante o ato pedagógico. Sob o respaldo de Smith e Strick, reforça-se a ideia da influência do meio sobre os processos de aprendizagem: 
Embora supostamente as dificuldades de aprendizagem tenham uma base biológica, com frequência é o ambiente da criança que determina a gravidade do impacto da dificuldade. A ciência ainda não oferece muito em termos de tratamento médico, mas a longa experiência tem mostrado que a modificação no ambiente pode fazer uma diferença impressionante no progresso educacional de uma criança. Isso significa que, embora as dificuldades de aprendizagem sejam consideradas condições permanentes, elas podem ser drasticamente melhoradas, fazendo-se mudanças em casa e no programa educacional da criança (SMITH; STRICK, 2001, p. 20).

Partindo do pressuposto de que o meio influencia de forma significativa a formação e o desenvolvimento do indivíduo, esta pesquisa investiga o resultado da defasagem escolar de sete crianças regularmente matriculadas no quarto ano do Ensino Fundamental de uma escola pública municipal de uma cidade sita no centro-oeste mineiro, com o intuito de propor reflexões que contribuam com o desenvolvimento de ações com vistas à superação dos obstáculos de aprendizagem aos quais diversas crianças em situação de vulnerabilidade social estão expostas. Apesar da considerável produção de pesquisas e investigações sobre o assunto, há, na realidade particular das escolas, situações que carecem de problematizações e reflexões acerca das possibilidades de transformação.

As crianças que compõe o grupo analisado por este trabalho foram acompanhadas durante o período de dez meses, entre fevereiro e novembro de 2017. Os referenciais teóricos utilizados para embasar as reflexões deste estudo foram: Dubet (2008), Cury (2002), Piletti (2010), Wallon (1968) e Vigotski (1984) - dentre outros.

\section{DIREITOS DA CRIANÇA}

Ao longo de boa parte da história, a criança foi vista como um ser sem personalidade e sem importância, que muitas vezes não chegava à fase adulta devido à falta de cuidados e explorações sofridas. O respeito pela infância e pela criança foi construído progressivamen- 
te, juntamente com o reconhecimento de seus direitos (MATIOLLI; OLIVEIRA, 2013, p. 15).

No Brasil, o marco da defesa dos direitos das crianças ocorre com o surgimento de uma legislação específica, o Estatuto da Criança e do Adolescente (ECA), que vem reforçar o artigo 227 da Constituição Federal de 1988, referente ao desenvolvimento integral da criança e do adolescente em seus direitos fundamentais (PAGANINI; DEL MORO, 2011, p. 4).

Observa-se, contudo, que tais direitos nem sempre são respeitados e que se tornem até mesmo irrelevantes frente a situações de vulnerabilidade sofridas pelas crianças acompanhadas durante a pesquisa de campo. Crianças que vivem meio a restrições físicas, emocionais e sociais, sobrevivendo com o pouco que lhes é oferecido, longe dos que lhes referem os artigos legais, que impõem à condição de prioridade absoluta da infância em todas as esferas de interesse, devendo ser assegurada pela família, escola, comunidade e Estado.

\subsection{Direito à Educação}

O direito de todos à educação é previsto por lei e no que diz respeito à criança, é considerado um direito fundamental, que será capaz de transformá-la em um cidadão conhecedor de suas potencialidades como sujeito histórico, autor de sua própria história. O acesso à educação é o que transforma um indivíduo em um cidadão conhecedor de seus direitos e deveres na sociedade:

Hoje, praticamente, não há país no mundo que não garanta, em seus textos legais, o acesso de seus cidadãos à educação básica. Afinal, a educação escolar é uma dimensão fundante da cidadania, e tal princípio é indispensável para políticas que visam à participação de todos nos espaços sociais e políticos e, mesmo, para reinserção no mundo profissional (CURY, 2002, p. 246).

Ainda sob a linha de pensamento de Cury (2015, p. 4), o que norteia o sucesso na educação é a igualdade ao adquirir conhecimento, 
assegurada pelo Estado que deve intervir a fim de promover uma igualdade de condições:

Deste modo, um dos pressupostos das diretrizes que devem nortear os conteúdos curriculares é o da igualdade de condições, assegurada e protegida pelo poder público (cf. art. 206, inciso I). Essa igualdade pretende que todos os membros da sociedade tenham iguais condições de acesso aos bens trazidos pelo conhecimento, de tal maneira que possam participar em termos de escolha ou mesmo de concorrência no que uma sociedade considera como significativo e onde tais membros possam ser bem-sucedidos e reconhecidos como iguais (CURY, 2015, p. 4).

Diante de uma educação intencionalista, que busca promover um preparo para a cidadania e para o trabalho, há vários questionamentos de como essa educação realmente acontece em esferas socioeconômicas desfavorecidas. Sob o apoio de Cury $(2015$, p. 6), ressalta-se que é preciso combater as desigualdades sociais a fim de uma educação efetiva no quesito conhecimento e na construção do cidadão, pois essa mesma educação é que será capaz, através de sua função social, reduzir a discriminação e a desigualdade.

\section{VULNERABILIDADE SOCIAL E RESILIÊNCIA}

Em diversas regiões do país, há uma dura realidade de desigualdades, onde famílias estão desestruturadas e crianças vivem em situação de vulnerabilidade social, sendo muitas das vezes vedados seus direitos como cidadãos.

Segundo Yunes e Szymanski (citado por TEIXEIRA, 2015, p. 8), "a vulnerabilidade opera apenas quando o risco está presente; sem risco, vulnerabilidade não tem efeito”. A abordagem sugerida ao se discutir sua influência no campo social é a de grupo/indivíduo em risco, entendendo que tal conceito não torna necessariamente um sujeito vítima da vulnerabilidade, mas um sujeito vulnerável (GUARESCHI; REIS; HUNING; BERTUZZI, 2007, p. 19). 
Prati e Koller (2009, p. 404) descrevem a abordagem social do termo vulnerabilidade, que cabe no presente trabalho como pressuposto para as observações com relação ao desempenho escolar de alunos nessa situação como "uma denominação utilizada para caracterizar famílias expostas a fatores de risco, sejam de natureza pessoal, social ou ambiental, que coadjuvam ou incrementam a probabilidade de seus membros virem a padecer de perturbações psicológicas".

É importante compreender que a vulnerabilidade social é formada por fatores de vulnerabilidade, que são repartições complexas das mais variadas dimensões relacionadas ao indivíduo, à comunidade ou ao lugar em que esses vivem, como por exemplo, a renda, escolaridade, moradia, vizinhança, acessibilidade e assim por diante. A somatória ou interpolação desses fatores de vulnerabilidade ocasionam uma realidade social mais ou menos excludente (LIMA, 2016, p. 24).

Contudo, é importante ressaltar que boa parte desses alunos consegue superar essas condições negativas, no meio escolar, tornando surpreendente a capacidade de se adaptarem a diversas situações e desenvolverem várias habilidades precocemente, como as motoras e de independência. A essa concepção intitula-se resiliência (MATOS; JESUS, 2011, p.2).

Martineau (citado por Yunes, 2003, p. 77) resume os principais traços encontrados como características consolidadas da resiliência que são: "sociabilidade, criatividade na resolução de problemas e um senso de autonomia e de proposta", que foram características observadas nas sete crianças mencionadas.

\subsection{Fatores de vulnerabilidade e seus efeitos sobre o desempenho escolar}

Observações do desempenho de alunos na Prova Brasil, apuraram que estabelecimentos de ensino inseridos em locais de maior vulnerabilidade social sofrem limitações quanto a qualidade na oferta de ensino, ficando evidente que alunos com baixos recursos e vulneráveis tendem a demonstrar um desempenho escolar insatisfatório (RIBEIRO; VÓVIO, 2017). 
Evidentemente, "a escola não está isolada das influências da sociedade e não deixa de exercer influência sobre esta, em articulação com outras instâncias da vida social" (PILETTI; PRAXEDES, 2010, p. 44), o que remete ao vínculo família, escola e Estado, levando a compreensão da função social da educação e como as desigualdades e o entorno de vulnerabilidade podem atuar tanto nas condições extraescolares quanto nas intraescolares (ALMEIDA; STOCO, 2011).

Relevante em inúmeras pesquisas são os processos sociais relacionados com a educação do aluno em condição de vulnerabilidade e seu desenvolvimento no período de escolarização. Rosa e Mattos (2014), através de uma análise teórica de cem artigos científicos com tematizações relacionados à pobreza, desigualdades e exclusão ligados a Educação, apontaram resultados que mostram uma forte ligação entre o mau desempenho escolar e a exclusão social com os fatores de vulnerabilidade (ROSA; MATTOS, 2014), reforçando fortemente a intencionalidade do presente artigo em problematizar tal assunto.

\subsection{A influência do meio sobre o desenvolvimento humano}

O meio social tem extrema relevância ao tratar-se do desenvolvimento humano, sobretudo do processo ensino/aprendizagem. Teorias da aprendizagem podem esclarecer tal processo e trazer uma reflexão sobre os alunos com dificuldade escolar inseridos em locais de extrema vulnerabilidade.

Psicólogo e pesquisador, Lev Vygotsky (1984) relaciona de maneira aprofundada o ambiente e o desenvolvimento humano esclarecendo que criança e meio externo se influenciam mutuamente. Pode-se afirmar que Vygotsky, em sua teoria sócio interacionista, considera o desenvolvimento cognitivo um processo possibilitado primordialmente pela relação sociocultural.

Piaget, apesar de ter sua teoria centrada na maturação biológica, reconhece, contudo, que sujeito e objeto, a partir de uma interação, constroem a aprendizagem, ou seja, mesmo que o processo cognitivo seja nato e ocorra de "dentro para fora", o meio externo é necessário para desenvolvê-lo (PIAGET; GRÉCO, 1974). Piaget também reco- 
nhece que a afetividade propulsiona a motivação para a aquisição cognitiva, o que pode esclarecer em parte o que a carência afetiva pode ocasionar no ensino (PIAGET, 1973).

Centrado na teoria da afetividade e das emoções no processo de desenvolvimento e de aprendizagem, Wallon (1968) trouxe grandes contribuições, pois para ele a afetividade é essencial para a sobrevivência humana. Fatores como negligência, maus tratos e abandono vindos dos cuidadores durante a infância e adolescência com certeza acarretaram danos irreversíveis ao desenvolvimento da criança, refletindo em todas as áreas inclusive na escola.

Diante de estudos que comprovam o quanto o meio pode ser significativo para uma criança, cabe refletir sobre como a escola pode atuar de forma a amenizar tais impactos.

\section{METODOLOGIA}

\subsection{Local}

A investigação foi realizada em uma escola municipal de uma cidade da região centro oeste de Minas Gerais. A escola exerce suas funções desde 1992 e está situada em um bairro periférico, onde a predominância é de alunos de classe baixa. A escola atende as etapas de ensino nos níveis Fundamental I, Fundamental II nos turno matutino e vespertino e Educação de Jovens e Adultos à noite. Possui boa infraestrutura, com equipamentos e dependências em bom estado. $\mathrm{O}$ critério para escolha da escola foi baseado em seus resultados no IDEB (Índice de Desenvolvimento da Educação Básica) e por se encontrar em uma região de nível socioeconômico baixo.

\subsection{Participantes e período de observação}

Foram observadas sete crianças com as idades de 9, 10 e 11 anos do quarto ano do Ensino Fundamental. Destas, uma é do sexo feminino e os outros seis são do sexo masculino. O procedimento para escolha das crianças foi aplicação de uma prova diagnóstica desenvolvida pela professora regente para a turma de 23 alunos, na qual os sete estudantes 
mencionados demonstraram uma aprendizagem bastante comprometida e, concomitantemente, encontram-se em situação de vulnerabilidade social mais acentuada em relação aos demais. O período de investigação durou dez meses, sendo as visitas à escola realizadas duas vezes por semana, quatro horas por dia.

\subsection{Sobre os sujeitos da pesquisa}

Como instrumento metodológico para o estudo e a descrição dos alunos, foi utilizada observação direta, análise de documentos e relato oral de professores. Os nomes reais das crianças foram substituídos por nomes fictícios.

Álvaro é um menino de nove anos (completando dez durante a observação), branco, cabelo liso e loiro, baixo e magro. Tem dois irmãos. A mãe e o pai moram juntos, porém em constante briga; possuía um bom relacionamento com os irmãos e citava a mãe na maioria de seus comentários, porém ressaltava sempre sentir muito sua ausência. Não falava do pai. Em questão de aprendizagem era muito lento e quase nunca conseguia acompanhar as aulas e as atividades; lia com dificuldade, porém não desenvolveu as habilidades que lhe permitiam fazer uso social desse processo. Diante de atividades apresentava uma mudança de humor repentina, ora eufórico para desenvolver o proposto, ora prostrado com desânimo e desmotivado. Durante o período observado, os pais nunca compareceram a escola, seja em reuniões ou eventos.

André tinha dez anos, é magro de cabelos lisos, castanho claro. Tem uma irmã de doze anos. Os pais eram separados e mantinham um relacionamento difícil. Durante o período observado se separaram e reataram o relacionamento cinco vezes. O aluno dormia um dia com o pai (que mora com o avô da criança) e um dia com a mãe e a irmã. O aluno reclamava muito a ausência da mãe e sempre diz que gostaria que os pais voltassem e vivessem juntos sem brigar. Tinha muita dificuldade em entender as matérias e era muito lento para copiar ou fazer qualquer atividade.

Dimitri era um garoto de dez anos, moreno, magro, alto, cabelo liso e comprido, na altura do ombro, castanho. Morava com a mãe e a 
irmã de cinco anos. Dimitri cuidava da irmã a semana toda durante o período que a mãe trabalhava. Cuidava da casa e dos afazeres domésticos. Era responsável por levar e buscar a irmã na escola todos os dias. Reclamava de poder brincar somente no domingo. Os pais eram separados e o aluno só via o pai nos finais de ano. Sentia muito a ausência da mãe e dizia que gostaria que ela fosse mais presente. Escrevia com dificuldade e copiava muito devagar. Nunca terminava as tarefas. Vivia sempre cansado e desanimado. A mãe nunca compareceu em nenhum evento ou reunião no período observado.

Jaime tinha dez anos, é negro, baixo e corpulento. Morava com a mãe, o padrasto e os irmãos gêmeos de um ano. $\mathrm{O}$ aluno não gostava de falar sobre o padrasto que prezava mais pelos filhos biológicos. $\mathrm{O}$ aluno tinha a responsabilidade de ajudar nas tarefas domésticas, ajudar no cuidado dos irmãos. No terceiro mês da observação, o aluno ficou sem seus óculos, alegando que suas lentes sofreram desgaste, segundo disse o médico em uma consulta oftalmológica, sendo necessário novas lentes. Até o fim da observação o aluno não havia conseguido outro. Alegava que a mãe estava juntando o dinheiro, mas tinha outras prioridades.

O aluno Miguel tinha dez anos (completando onze durante o período observado), pardo, cabelo castanho e liso. Miguel vivia em uma família de seis irmãos. Miguel nunca teve contato com o pai. A relação com a família é hostil e não havia qualquer demonstração de afinidade do aluno para com os familiares, nem mesmo com a mãe. A casa em que viviam se limitava a três cômodos sendo um de lona. Miguel era na maioria das vezes indisciplinado e resistente a ordens e regras, discutia e tratava com hostilidade os colegas. Não copiava, não fazia atividades e tinha pouco interesse nas aulas. $\mathrm{O}$ aluno não era alfabetizado, e contava os números no máximo até 15 , com ajuda. Na maioria dos dias observados alegou fome e dor estomacal. Demonstrava uma estima baixa. Possuía grande porcentagem de faltas e foi preciso intervenção da direção diversas vezes para seu retorno.

Úrsula era uma menina de dez anos, é parda, cabelo liso médio. Morava com a mãe, o pai e quatro irmãs. A briga entre os pais era constante e o pai é um homem muito violento, que agredia a esposa e filhas. 
A moradia era uma casa simples de aluguel e, durante o terceiro mês de observação, a família se mudou para um apartamento de um conjunto habitacional. Após a mudança, as condições pioraram, pois Úrsula ficou distante da escola. Nesse conjunto havia aglomerado de pessoas, algumas delas inclusive traficantes de drogas e usuários, que ofereciam constante risco aos moradores, havendo desde brigas até troca de tiros. Durante o período de observação, no quarto mês, os pais vieram a se separar devido agressões e brigas constantes, ficando o sustento da casa reduzido ao salário da mãe.

O aluno Vitório com dez anos, era moreno de baixa estatura e baixo peso. Usava brinco. Possuía anquiloglossia, que é uma patologia que limita os movimentos da língua, dificultando na pronuncia de certas palavras e letras. Vivia com irmãos (idade e quantidade não identificadas durante a observação) e a mãe. Segundo relatos os irmãos eram usuários de drogas e estavam sempre envolvidos em situações perigosas. Não conhecia o pai. A moradia de Vitório era muito precária segundo professores. A alimentação era regrada e o aluno relatava ir para escola somente para se alimentar. Suas vestes sempre simples e algumas vezes rasgadas, usava chinelo e não tinha roupa de frio, segundo o próprio aluno. $\mathrm{O}$ aluno brigava com frequência na escola e após a aula, precisando ser recorrentemente contido. Segundo relatos, a mãe era alcoólatra e não participava do desenvolvimento do aluno, não lhe impondo limites.

Dessas sete crianças, as seguintes situações foram observadas.

\subsection{Das situações observadas}

Dentre as situações observadas, notou-se violência de cunho moral, físico e psicológico; privação e abandono físico e afetivo. As privações as quais as crianças observadas demonstraram sofrer se referem às necessidades básicas do ser humano como alimentação, vestimentas, materiais escolares e produtos de higiene. Essas crianças em várias ocasiões foram privadas do sono e de seu direito de brincar assumindo responsabilidades demasiadas absurdas.

Dimitri, por ser responsável pela irmã, sofria agressão física por parte da mãe quando algo acontecia com a criança. Observou-se em 
alguns dias dos meses de março, maio, junho e setembro que o aluno estava com hematomas nos braços. Ouvia dos familiares palavras negativas, que acabavam por diminuir sua autoestima e o fazia se sentir como incapaz de aprender ou se desenvolver como as outras crianças. As restrições sofridas por Dimitri eram relacionadas ao seu direito de desenvolver tarefas para sua idade, já que assumia total responsabilidade sobre os cuidados com a irmã. Nos dias sucessivos aos episódios de violência, Dimitri, que já apresentava dificuldades em desenvolver as tarefas e se socializar, apresentou uma regressão no processo de escrita ortográfica e não desenvolveu nenhuma atividade proposta em sala, levando advertências da professora.

Miguel, com frequência estava envolvido em brigas, tanto no âmbito familiar quanto escolar. Devido às desavenças com os irmãos, chegou por sete vezes machucado na escola, e em uma delas com ferimento causado por faca. $\mathrm{Na}$ escola, as brigas com agressões aconteceram por três vezes, no término da aula. No ultimo dia observado, o aluno foi suspenso da escola por uma semana, após agressão verbal e física contra a supervisora. Ao especular o motivo, descobriu-se que o irmão homossexual foi espancado pela mãe na presença dos irmãos e havia fugido de casa. Observou-se que seu comportamento nesses dias que sucediam a violência sofrida, ficava muito alterado, chegando a um quase descontrole. Observou-se que Miguel sofria de restrição alimentar, material e privação de sono, onde lhe faltava vestimentas, produtos de higiene pessoal, calçado e materiais escolares. Seus dentes possuíam cáries severas e o aluno chegou a reclamar de dores inúmeras vezes. Dormia com frequência em sala de aula. Demonstrava muito ressentimento da mãe, Em conversa com a professora que o acompanhava, soube-se que a mãe, além de ausente, tratava-o na maioria das vezes de forma violenta e rude.

Os atos violentos sofridos por Úrsula foram observados nos três primeiros meses com frequência, sendo o pai o autor. Relatos da aluna indicaram que, durante brigas do pai e da mãe, o genitor ficava muito alterado agredindo mãe e filha. As agressões só cessaram após a separação dos pais e reiniciaram no mês de agosto, desta vez sendo cometidos pela irmã mais velha. Foram três episódios de agressão por 
motivos fúteis segundo Úrsula. Nos episódios de agressão, observou-se que a introspecção da aluna tornou-se mais severa. Chorava na maioria dos dias.

Vitorio alegava que sua única refeição do dia era as da $9 \mathrm{~h} 30 \mathrm{~m}$, no intervalo da aula. Suas vestes sempre muito simples e algumas vezes rasgadas. Usava chinelo e não possuía agasalho para o frio, exceto por uma blusa de malha fina com mangas compridas. Material escolar só os oferecidos pela escola e muito mal cuidados. Segundo relatos, a mãe de Vitório é alcoólatra e não contribui positivamente para o desenvolvimento do aluno. Era um aluno agressivo, e usava de um vocabulário chulo na maioria das vezes e não respeitava a professora, precisando haver intervenção do diretor. Fugia com frequência da escola, pulando o muro. Não tinha limites, e segundo relatos da professora passava praticamente todo o dia na rua e às vezes fica até tarde da noite com más companhias já que a rua do aluno é frequentada por usuários de drogas.

Os relatos de Jaime e suas reclamações durante o período observado demonstraram que o aluno sofre com privação de alimentos, material escolar e roupas. Segundo observado, o padrasto era responsável pelo sustento da casa e priorizava os filhos biológicos, ficando o aluno em último plano. As vestimentas de Jaime eram bem simples e sempre as mesmas, assim como seu único tênis, rasgado e cheio de remendos. A privação mais significante para Jaime foi ficar sem seus óculos. Após a perda dos óculos, seu desempenho piorou significativamente. Tornou-se mais arredio e indisciplinado, permanecendo quase todas as aulas de castigo. Jaime relata falta do pai e ficava muito abatido em ocasiões como dia dos pais e apresentações da escola nas ninguém da família aparecia para prestigiá-lo.

Álvaro, um aluno muito carente em sentido de atenção. Era também respeitoso em relação a autoridades e regras. Não causava problemas em sala e trata com educação seus colegas. Às vezes, em que a professora chamou sua atenção foi por conversa paralela em excesso. Os pais são muito ausentes e não acompanham o desenvolvimento escolar do filho. O aluno falava da mãe todo o tempo e reclamava muito sua falta. Não tinha nenhum interesse em conversas que envolviam assuntos sobre família e passeios, desconversando sempre. 
André sofria com restrição do sono, o que lhe deixa extremamente irritado e sem nenhum interesse nas aulas. Os pais eram separados e mantinham um relacionamento difícil, sendo que, nas vezes em que os pais se separavam, o aluno apresentava uma queda na aprendizagem. Nas noites em que dormia com o pai, o aluno não conseguia acompanhar as aulas no dia seguinte, pois dormia quase o tempo todo ou ficava disperso e desanimado, pois o avô tinha transtorno mental (segundo o próprio aluno) e passava toda a noite fazendo barulho. No entanto, quando dormia com mãe, as noites eram melhores, mas ao lado morava a avó que fazia uso constante de bebida alcoólica e acabava por invadir a casa da filha durante a noite, causando transtornos. Suas vestimentas eram bem simples e usava só chinelo. Seus materiais escolares eram os fornecidos pela escola e uma mochila rasgada que usa desde o primeiro ano. $\mathrm{O}$ aluno ficava nervoso sempre que chamado à atenção e debate com a professora, não gosta de ser repreendido. Conversava com tom grosseiro normalmente e falava muitos palavrões.

\section{DISCUSSÃO}

As sete crianças observadas, além dos fatores de vulnerabilidade, sofrem constantemente com a criminalidade, a exposição às drogas ilícitas e com a violência social em seu bairro. Todas têm no entorno de suas casas bocas de fumo onde constantes trocas de tiros e brigas acontecem. Estão recorrentemente expostas a usuários de drogas que oferecem e incentivam o uso de entorpecentes e os pais e familiares dos sete alunos já tiveram as casas invadidas ou foram assaltados.

As crianças observadas e expostas à violência demonstraram problemas no comportamento e agiram de forma agressiva com relação aos colegas. Observou-se também que são por vezes ignorados pelos outros alunos e repreendidos inúmeras vezes pela professora, sofrendo castigos como ficar sem recreio, sem educação física ou fazer cópias, remetendo ao fato de que a violência sofrida ou presenciada em casa é refletida no ambiente escolar como comportamento adequado (BEE, 1997).

Em todos os episódios em que os alunos sofreram com privações, seus desempenhos só pioraram, pois ao ficarem expostos ao frio e à 
fome ou sem dormir bem ficavam muito nervosos e desinteressados em acompanhar a turma, chegando a passar mal ou dormir em sala.

A violência verbal de cunho moral e psicológico e a carência afetiva traz ao aluno a sensação de desvalorização e abandono, refletindo por toda a vida como baixa estima, timidez, agressividade e dependência, o que foi observado nos alunos. A falta das condições básicas para viver, o convívio com uma base familiar insólita e a quebra de laços afetivos são características em comum das famílias das crianças observadas, que são famílias consideradas de risco, expostas ao ambiente de vulnerabilidade em que vivem, sem muitos recursos para mudar a situação. Ataques de ansiedade, mudança de humor e agressividade são apresentadas e também desencadeadas pelo desamparo dessas famílias (PRADO, 2001; TIMOTEO; FALCÃO, 2004; VILELA, GUSMÃO; CAVANA, 2004; PRATI; KOLLER, 2009).

Várias politicas públicas advindas de órgãos que defendem o direito da criança, como ECA, Direitos Humanos e Conselho Tutelar, são geridas pela escola a fim de promover a proteção das crianças observadas, sendo tais órgãos, em especial o Conselho tutelar e Assistência Social, acionados quando a direção escolar achou necessária intervenção, fosse para doação de alimentos e roupas ou averiguação de maus tratos.

O ambiente escolar pode ser o único onde a criança se sente protegida e amparada A escola pode vir a assumir funções que cabem à família a fim de ajudar o aluno na construção de sua identidade como cidadão e, segundo Bee (1997), a metodologia usada pelo professor e sua maneira de aplicá-la, reconhecendo as carências e o contexto histórico e social ao qual está inserido poderão ser determinantes na aprendizagem das crianças. Isso acontecerá somente em uma escola com comunidade escolar preparada e motivada a desempenhar tal função, recebendo por parte do Estado o incentivo e material necessário.

Assim, alunos como os observados são vítimas não só da vulnerabilidade, mas de um sistema de ensino que os considera como ignorantes, incultos, sem valores, a ser moralizados e civilizados, sendo necessária a desconstrução desse pensamento preconceituoso quanto aos grupos populares para avançar com ideias de transformações pedagógicas igualitárias e democratizantes (ARROYO, p. 17, 2012). 
É importante ressaltar a relação escola-família na vida de uma criança, sendo uma relação de culturas e historicidades, podendo ascender o aluno para a vida social ou contribuir para reforçar ou manter as desigualdades sociais e culturais (SILVA, 2012, p. 85), o que requer cuidado maior por parte do educador e da direção escolar.

Em suma, as crianças observadas revelaram-se expostas a constantes fatores de vulnerabilidade como restrição material, fome, violência, abandono entre outros e, durante o período de investigação, passaram por diversas situações que certamente influenciaram seu desempenho escolar, já que, particularmente, nos dias sucessivos aos episódios observados de adversidade, houve evidente regressão pedagógica.

\section{CONSIDERAÇÕES FINAIS}

Os resultados da pesquisa remetem ao entendimento de que as trajetórias de vida dessas crianças, que experienciaram, durante o período em que foram observadas, múltiplas formas de violência (desde situações de fome a agressões de cunho físico, moral e psicológico), impacta de maneira inquestionável seu percurso escolar, explicando de maneira tocante seu baixo desempenho escolar, suas posturas e seus medos e apelos.

Faz-se necessário que investigações acerca do desempenho escolar intrinsecamente relacionado às experiências de contextos de vulnerabilidade continuem sendo desenvolvidas com o intuito de buscar proposições para possíveis intervenções pedagógicas, fomentando a reflexão do papel do corpo docente como agente ativo nos processos atenuantes das consequências geradas pela situação de vulnerabilidade prezando pelo desenvolvimento adequado dos alunos, atentando para os limites enquanto instituição, que deve atuar juntamente com a família para que haja resultado.

Contudo, com relação às escolas, há a indagação sobre sua contribuição para amenização de possíveis atrasos advindos da vivência de vulnerabilidade através de estímulos pedagógicos positivos seguidos de um acompanhamento atenuante de possíveis transtornos. Dubet (2004) discursa sobre a hipótese de se pensar em um modelo de escola justa, onde haja igualdade de oportunidades independente de classe so- 
cial e leva também à reflexão sobre o papel do professor, que é o adulto que passa boa parte do tempo convivendo diretamente com os alunos e que deve ser capaz de reconhecer suas dificuldades e intervir de maneira positiva a fim de promover situações favoráveis à aprendizagem juntamente com o corpo escolar. Dubet (2004), no entanto, reconhece que não há escola que seja imune às desigualdades sociais, o que remete à ideia de que o processo de ensino-aprendizado deve ocorrer de forma integrada com a sociedade e o Estado, reconhecendo que o poder da escola não ultrapassa seus muros e que cada âmbito social deve assumir sua responsabilidade com o intuito de reconhecer situações que careçam de intervenções refletindo sobre possíveis estratégias que possam amenizar os danos provocados pelas desigualdades sociais. As adversidades vividas pelos alunos devem influenciar o trabalho dos profissionais da educação forçando-os a refletir quanto ao preparo necessário para receber essas crianças, considerando o contexto em que vivem sem preconceitos e discriminação, reconhecendo que são sujeitos dependentes de uma pedagogia humana e significativa.

\section{REFERÊNCIAS}

ALMEIDA, Luana Costa; STOCO, Sergio. Desempenho escolar e vulnerabilidade social: elementos para se pensar a formulação de políticas públicas educacionais. In: 35 ${ }^{\mathbf{a}}$ Reunião Anual da ANPED, 2012, Porto de Galinhas. Educação, cultura, pesquisa e projetos de desenvolvimento: o Brasil do século XXI. Rio de Janeiro: Anped, 2012. v. 1. P. 1-17.

ARROYO, Miguel G. Outros sujeitos, outras pedagogias. Rio de Janeiro: Vozes, 2012.

BEE, Helen. O ciclo Vital. Porto Alegre: Artmed, 1997.

BRASIL. O Direito à Educação: Um campo de atuação do gestor educacional na escola. Escola de Gestores. Brasília/DF: MEC, 2005. Disponível em : https://moodle3.mec.gov.br/ufscar/file. php/1/gestores/direito/pdf/jamilcury.pdf. Acesso em: 07 de abril. 2020 . 
CURY, Carlos Roberto Jamil. A educação básica no Brasil. Educação \& Sociedade. Campinas-SP, v. 23, n. 80, setembro/2002, p. 168-200. Disponível em http://www.cedes.unicamp.br. Acesso em: 07 de abril. 2020.

DEL MORO, Rosangela; PAGANINI, J. A utilização dos princípios do Direito da criança e do adolescente como mecanismos de efetivação dos direitos fundamentais. Revista Amicus Curiae, v. 06, p. 1-13, 2009.

DUBET, François. O que é uma escola justa? A escola das oportunidades. São Paulo: Cortez, 2008.

GUARESCHI, N. M. F.; REIS, Carolina dos; HÜNING, Simone Maria; BERTUZZI, Leticia. Intervenção na Condição de Vulnerabilidade Social: um estudo sobre produção de sentidos com adolescentes do Programa SASE - Trabalho Educativo. Estudos e Pesquisas em Psicologia (UERJ. Impresso), v. 7, p. 17-27, 2007.

KOLL, Marta de Oliveira. Vygotsky: Aprendizado e desenvolvimento: um processo sócio-histórico. São Paulo: Scipione, 2010.

LIMA, R. A. G. (2012). Direitos da criança e do adolescente: Desafios atuais. Revista Latino-Americana de Enfermagem, 20(3), 425-426.

MATTIOLI, Daniele D.; OLIVEIRA, Rita de C. da S. Direitos humanos de crianças e adolescentes: o percurso da luta pela proteção. Imagem da Educação. Vol. 3, n. 2, p. 14-26. 2013. Disponível em: Acesso em: 06 abr. 2018.

PIAGET, J. Psicologia e Epistemologia. Rio de Janeiro: Forense, 1973.

PIAGET, J.; GRECO, P. Aprendizagem e conhecimento. Rio de Janeiro: Freitas Bastos, 1974.

PILETTI, Nelson; PRAXEDES, Walter. Sociologia da educação: Do positivismo aos estudos culturais. São Paulo: Editora àtica,2010. 
PRATI, L.; COUTO, M. C. P. P.; KOLLER, S. H. Famílias em Vulnerabilidade Social: rastreamento de termos utilizados por terapeutas de família. Psicol Teor Pesqui. 2009; jul-set, 25(3):403408.

RAPOPORT, Andrea; DA SILVA, Sabrina Boeira. Desempenho escolar de crianças em situação de vulnerabilidade social. Revista educação em rede: formação e prática docente - ISSN 23168919, [S.1.], v. 2, n. 2, abr. 2013. ISSN 2316-8919. Disponível em: <http://ojs.cesuca.edu.br/index.php/educacaoemrede/article/ view/410>. Acesso em: 04 abr. 2020.

RIBEIRO, V. M; VÓVIO, C. L. Desigualdade escolar e vulnerabilidade social no território. Educar em revista (impresso), v. 33, p. 71-87,2017.

ROSA, Antonia Valbênia Aurélio; MATTOS, C. L. G. A exclusão vai à escola: da sociedade ao sistema de escolarização. 2014. (Apresentação de Trabalho/ Comunicação).

SMITH, C.; STRICK, L. Dificuldades de Aprendizagem de A a Z: um guia completo para pais e educadores. Porto Alegre: Artes Médicas, 2001.

TEIXEIRA, E. C. Resiliência e vulnerabilidade social: uma perspectiva para a educação sociocomunitária da adolescência. 1. ed. PETRÓPOLIS- RJ: Vozes, 2015. v. 1.118 p.

VYGOTSKY, L. S. Formação social da mente. São Paulo: Martins Fontes, 1984.

WALLON, H. A evolução psicológica da criança. São Paulo: Martins fontes, 1968. 


\section{EDUCAÇÃO EM DIREITOS HUMANOS PARA UMA CULTURA DE PAZ: A PRÁTICA DA DANÇA COMO CAMINHO DE RESGATE DA INTEIREZA HUMANA}

Marília Cristina da Costa e Silva

Fernanda Ferfila Minnone

O presente artigo parte da percepção histórica da fragmentação entre corpo e mente, vivido ao longo da história da humanidade, sobretudo pela sociedade ocidental ao longo dos séculos XVI ao XX. Ao que tudo indica, “... recuperar a unidade perdida significa reconquistar a paz. Mas, desta vez, o inimigo a derrotar não é estrangeiro. Ele mora dentro de nós" (WEILL, 1993).

Vivemos um momento de crise vital em que a espécie humana corre risco eminente de extinção, “[...]como nunca antes o homem encontra-se esfacelado no seu conhecimento, atomizado no seu coração, dividido no seu pensar e sentir, compartimentalizado no seu viver." (CREMA, 1989, p.22). O paradigma cartesiano nos deixou como legado o abismo da fragmentação, enfatizando as partes ao invés do todo e sua reação é a grande causadora dos conflitos e dos sofrimentos.

A contemporaneidade aponta para a urgência de reiterar o empoderamente como ação necessária para "tomar posse de si”, consciente de sua responsabilidade no âmbito individual, social e planetário, restabelecendo a unidade em busca do estado de plenitude humana. 


\section{Tempos turbulentos, descaminhos da humanidade}

No anseio de construir pilares sustentáveis para uma convivência civilizada entre os povos, foi proclamada pela Organização das Nações Unidas (ONU) em 1948 a Declaração Universal dos Direitos Humanos (DUDH). Nela, considera-se, "que o reconhecimento da dignidade inerente a todos os membros da família humana e dos seus direitos iguais e inalienáveis constitui o fundamento da liberdade, da justiça e da paz no mundo.” (Assembleia Geral da ONU, 1948).

No entanto, somos em pleno século XXI, assombrados por notícias de violações aos Direitos Humanos, em muitos casos, praticados pelas pessoas ou instituições que deveriam ter a função de zelar pela vida e pela integridade do indivíduo, além de atos que se encontram ocultados pela nuvem de fumaça dos homicídios, genocídios e feminicídios.

$\mathrm{Na}$ sociedade brasileira, a questão da violência, atinge exponencialmente a população adolescente, as estatísticas apontam dados significativos entre adolescentes de 16 e 17 anos vítimas de homicídios, de 1980 para 2013 passaram de 506 para 3.749, resultando num aumento de 640,9\%. (WAISELFISZ, 2015).

$\mathrm{O}$ art. 3을 da DUDH declara, que "todo indivíduo tem direito à vida, à liberdade e à segurança pessoal"; e o art. 5º adiciona que "ninguém será submetido a tortura nem a penas ou tratamentos cruéis, desumanos ou degradantes" (Assembleia Geral da ONU, 1948). A educação em Direitos Humanos vive tempos turbulentos, a estatística nos obriga a relembrar a Declaração Universal dos Direitos Humanos, no desejo de defendê-la e reivindicá-la como única esperança de preservação da vida humana, o preâmbulo da DUDH considera relevante a compreensão dos direitos do Homem:

"Considerando que o desconhecimento e o desprezo dos direitos do Homem conduziram a atos de barbárie que revoltam a consciência da Humanidade e que o advento de um mundo em que os seres humanos sejam livres de falar e de crer, libertos do terror e da miséria, foi proclamado como a mais alta inspiração do Homem." (Assembleia Geral da ONU, 1948). 
O caminhar evolutivo da humanidade, cambaleia em passos obscuros em direção à extinção da espécie humana. Vive-se constantemente diante de uma fonte abundante de sofrimentos e tragédias, o indivíduo se adapta ao meio, permitindo que um consenso social, se torne uma norma adotada por muitos tornando-se então, um hábito cotidiano, não percebendo seu caráter patogênico. No entanto, "essas normas deveriam ter a função de preservar nosso equilíbrio físico, emocional ou mental, assim como a harmonia e qualidade de vida." (WEILL; LELOUP; CREMA, 2012).

O conformismo torna a humanidade alvo fácil para a Normose ${ }^{27}$, a patologia da normalidade. Este conceito, refere-se aos conjuntos de hábitos considerados normais, e que, na realidade causam dor e sofrimento à comunidade humana, podendo conduzir até a morte. A estatística apresentada anteriormente é claramente uma categoria de normose, a normose social ${ }^{28}$.

Neste sentido, vale ressaltar que o oposto complementar a paz como muitos acreditam não é a ausência de conflito, e sim a conciliação. O conflito apesar de indesejável, é inevitável, pois manifesta-se nela a ação de preservação diante de uma ameaça. Porém, esta ação se torna perigosa ao constatar que a comunidade humana se encontra estagnada diante de um paradigma fragmentado, exemplo disso é a divisão territorial no qual mata-se e morre-se. Leis objetivas e deterministas sustentaram, e ao que tudo indica ainda sustenta, a idealização do Universo como uma máquina regulável e previsível, fundamentada por uma ideia fragmentada que reverbera em uma sociedade baseada na conquista, na doutrinação, na dominação e na eficácia.

"A objetividade, instituída como critério supremo de verdade, teve uma consequência inevitável: a transformação do sujeito em

27 O conceito de normose foi desenvolvido por Jean Yves Leloup na França e por Roberto Crema no Brasil, ambos na mesma época debruçaram-se sobre o tema a partir de inquietações distintas.

28 Pierre Weil identificando a normose como um conceito fundamental em Psicologia, em Antropologia, em Educação e nas demais disciplinas e áreas da atuação humana, realizou então, a primeira classificação das normoses. 
objeto. A morte do homem, que anuncia tantas outras mortes, é preço a pagar por um conhecimento objetivo. O ser humano torna-se objeto: objeto da exploração do homem pelo homem..." (NICOLESCU, 1999)

A ascensão da violência mundial, se apresenta como uma manifestação explícita da exploração do homem pelo homem e da proliferação de uma sociedade desalmada, desamada e armada. Somos com isso, convidados a edificar uma nova sociedade centrada no ser e no conviver, como saberes a serem fomentados nos processos de desenvolvimento do ser humano, já que “... todas as guerras são projeções, maciças e ampliadas, dos conflitos que existem dentro de cada um de nós." (WEILL; LELOUP; CREMA, 2012).

\section{Movimento de transição da estagnação à transformação}

Tudo está em movimento e, em tempos de mudança, a estagnação parece não ser uma atitude apropriada para o enfrentamento das situações que se apresentam diante de nós, "todo o universo está, em movimento e atividade incessantes, numa permanente dança cósmica de energia" (CAPRA, 1983). Mover é preciso, mover pensamentos, emoções, sensações e intuições em prol de uma dança harmoniosa que integre à unidade de consciência da ecologia individual, social e planetária.

\footnotetext{
“A exploração do mundo subatômico no século XX revelou a natureza intrinsecamente dinâmica da matéria. Mostrou que os componentes dos átomos, as partículas subatômicas, são padrões dinâmicos que não existem como entidades isoladas, mas como partes integrantes de uma rede inseparável de interações." (CAPRA, 1983)
}

Com intenção de garantir o direito à vida, à saúde e à paz, é imprescindível que a comunidade humana resgate a consciência de que estamos conectados em uma rede inseparável de interações, e com isso possibilite a construção de pontes entre o que aparentemente dividi, 
transcendendo o universo infinito das polaridades: mente e coração, espírito e matéria, individual e coletivo, além de promover o encontro entre a inteligência racional e emocional, no sentido da projeção do afeto e da valorização da vida.

\begin{abstract}
"As certezas modernas se abalam, as verdades científicas se relativizam, as instituições na base do poder se desmancham; o controle sobre a natureza sai de rumo, ameaçando a sobrevivência da própria condição planetária do homem... A retomada do lema délfico parece ter um outro sentido, quando o 'conhece-te a ti mesmo' for interpretado como a mais elementar das expressões da arte de amar a si e, portanto, de amar ao outro." (BITTAR, 2008).
\end{abstract}

Uma transformação para ser efetiva, precisa antes de tudo ser afetiva e estar conectada aos processos educacionais focados no desenvolvimento de atitudes pautadas nos Direitos Humanos, ou seja, aos direitos inerentes à própria natureza humana que zelam pela preservação de uma vida digna. A construção de um mundo mais justo, nasce na individualidade e na subjetividade de cada ser humano, incentivando-o a trilhar o seu próprio caminho, assumindo sua dimensão histórica, zelando pela vida, a sua, dos outros e consequentemente de todos.

Torna-se urgente, a educação à Cultura de Paz, não apenas pela perspectiva da afirmação da não-violência, mas acima de tudo, pela preservação do equilíbrio físico, emocional e mental do indivíduo, resgatando um estado de plenitude humana, que seja capaz de despertá-lo de uma provável apatia existencial, já que os descaminhos da humanidade tornou sistêmico o desamor, a corrupção, a alienação e com isso a fragmentação da comunidade humana.

Retomando um conceito já apresentado, normose pode também ser compreendido como ausência de movimento, estagnação. Sendo, o corpo nossa realidade tangível, que abriga aspectos intangíveis como razão, emoção, sensação e intuição, um normótico é aquele que se encontra retido em um ciclo vicioso de alienação de si, estagnado no automatismo inconsciente de suas ações. 
As estatísticas apresentadas no início deste artigo, apontam que a sociedade se encontra em um estado desequilibrado, dotado de certa morbidez e o processo de ajustamento social, têm implicado na aceitação e no conformismo das normas impostas, a isso Pierre Weil denomina um ser normótico, aquele que "atua condizente a uma normalidade patogênica, ou seja que leva ao sofrimento humano, tanto no nível social como planetário." (WEILL; LELOUP; CREMA, 2012).

\begin{abstract}
"A mais ameaçadora de todas as fragmentações, no entanto, foi a que dividiu os homens em corpo, emoção, razão e intuição, por que ela nos impede de raciocinar com o coração e de sentir com o cérebro." (WEIL, 1993)
\end{abstract}

Segundo os dados da pesquisa Violência Letal contra as Crianças e Adolescentes do Brasil (WAISELFISZ, 2015), em um único dia, aproximadamente duas crianças e adolescentes cometem o suicídio, esta estatística não demonstrou mudanças significativas entre as pesquisas realizadas de 2003 a 2013, e não considera as tentativas que não foram sucedidas plenamente. Além disso, observa-se também um alto índice de adolescentes que praticam a automutilação, dentre muitas questões intrínsecas a este ato, é relevante destacar que o adolescente está, com esta dor, buscando uma justificativa à sua dor emocional. Nestes casos, aspectos tangíveis e intangíveis do ser estão literalmente dilacerados.

Em contrapartida, é possível encontrar em diversas instituições, sejam elas educacionais, culturais e religiosas, jovens que anseiam evoluir da estagnação rumo à transformação, "os jovens estão ávidos à uma educação integral que focaliza a dimensão da alma, da consciência, da pessoa..." (WEILL; LELOUP; CREMA, 2012). A unidade deve ser restabelecida, sobretudo do ponto de vista da transformação da alienação e do automatismo em consciência, deslocando os jovens dos papéis de autor, testemunha ou vítima de violências para o de agente de mudanças sociais.

Contudo, é necessário evoluir da fragmentação ao todo, da separação corpo e mente à consciência da unidade e "tomar posse de si”, talvez, seja a mais alta inspiração da contemporaneidade para que o indíviduo não se torne alvo fácil da normose, e o presente artigo 
sugere que este processo de integração e apropriação de si se inicie pelo viés do corpo.

\section{Corpo e a dança do instante}

$\mathrm{O}$ "que aconteceria se, em vez de apenas construirmos nossa vida, tivéssemos a sabedoria ou a loucura de dançá-la?" (GARAUDY, 1980). Em 1700, Pierre Beauchamp foi o responsável pela codificação dos movimentos do balé clássico, inevitavelmente deu-se a estruturação de uma técnica de dança carregada por valores intrínsecos a sociedade daquele momento, como hierarquia, ordem, uniformidade, regularidade, controle e parece ainda, ter reduzido o indivíduo apenas à sua dimensão física, nasce uma arte rigorosa em uma época em que a visão de mundo se pautava no conhecimento racional das coisas e dos homens.

Posteriormente, no início do século XX, os percussores da dança pós-moderna, lançaram um olhar generoso às individualidades ao considerar o potencial criativo como singularidades de cada um, potencial este perdido na massificação dos corpos diante do tecnicismo do balé clássico. Além disso, com o crescente período de industrialização e mecanização do trabalho e da vida, os artistas começaram a reagir contra a mecanização dos processos produtivos e das relações sociais, reverberando na recuperação da relação consigo mesmo a partir do contato consciente com o seu corpo, e de seu corpo com o mundo.

“"'The Mind is a Muscle”, proclamou Yvone Raines quando a dança pós-moderna norte americana abalava o estabilishment. Pensamento e corpo, tão separados na tradição ocidental, não são entendidos como lugares estranhos um ao outro. Até mesmo a ciência já traz evidências de que razão e emoção não são opostos. O pensamento se faz no corpo e o corpo que dança se faz pensamento. Isso não implica uma cerebralização fria, no caminho de uma dança conceitual, nem na biologização vazia da dança. Tal princípio não exime a qualidade técnica, nem o sabor e o prazer de dançar. Ele ressalta a complexidade que precisa ser compreendida”. (TOMAZZONI, 2006). 
No Brasil, tivemos na metade do século XX, a importante contribuição do bailarino, coreógrafo, professor e pesquisador Klauss Vianna que dedicou-se ao ensino da dança entrelaçando harmoniosamente o trabalho técnico, com um processo de refinamento do movimento por meio da consciência corporal e o desevolvimento da expressividade com um trabalho centrado na valorização da subjetividade de cada individuo.

A partir destes breves apontamentos, compreende-se que arte e vida se encontram entrelaçadas, levando a crer que a vida tenha sido sabiamente e loucamente dançada desde os primórdios da humanidade, estabelecendo de maneira direta e indireta um constante diálogo com a vida em sociedade, caminhando juntos "revelando ao longo da história a relação do homem com o mundo e seus diferentes modos de vida (VERDERI, 2009).

O corpo que se move em uma dança, é o mesmo corpo que transita pelas ruas, por esta perspectiva, a arte do movimento tem potencial para estabelecer um diálogo aberto com o mundo, sendo capaz de perceber, interpretar e transformar uma realidade, este processo em si promove desenvolvimento pessoal, transformação social e política.

Quando uma técnica artística não tem um sentido utilitário, se não me amadurece, não me faz crescer, se não me livra de todos os falsos conceitos que me são jogados desde a infầncia, se não facilita meu caminho em direção ao autoconhecimento, então não faço arte, mas apenas um arremedo de arte (VIANNA, 2005)

Restabelecer a unidade em busca do estado de plenitude humana pelo viés do corpo, passa sobretudo pela harmonia entre técnica e expressividade, corpo e mundo, abrindo a possibilidade libertadora de cada indivídiuo transcender dos trilhos das regras, formas e padrões impostos às trilhas do corpo em pleno movimento.

Logo, o processo de refinamento do movimento ocorre tanto no sentido estético quanto ético, para que o movimento, seja também uma possibilidade de manifestação lúcida da realidade. É a transformação da vida individual, social e planetária num ato (est)ético em prol da existência poética de cada um, "num mundo de tantas conquistas e descobertas sobre nós, seres humanos, seria no mínimo redutor ficar 
tratando a dança como apenas uma repetição mecânica de passos bem executados" (TOMAZZONI, 2006). Dança enquanto ação estratégica para viabilizar que as novas gerações possam existir com qualidade, dignidade, ética, saúde e plenitude.

\begin{abstract}
"Que a dança educa o homem como um todo, é hoje uma teoria amplamente reconhecida e já aplicada, em muitos lugares, como um meio educacional funcional. Ela exige adaptação e integração, cria equilíbrio e libertação, dá asas à fantasia, relaxa e solta, e oferece um plano a partir do qual se pode acessar a multiplicidade da educação." (WOSIEN, 2000).
\end{abstract}

Educação em direitos humanos para uma cultura de paz por meio da linguagem da dança, transcende a normose mecanicista e narcisista de formas vazias de sentido e se concretiza em um processo rico de construção de saberes, competências e atitudes, desenvolvidas efetivamente e afetivamente em um espaço de qualidade relacional. "Entre as metas da nova Educação estão a saúde do corpo, o equilíbrio entre mente e coração e o despertar e a manutenção dos valores humanos" (WEIL, 1993), ampliando a capacidade reflexiva e dialógica, permitindo o resgate da auto-estima e a emancipação intrínseca a todos estes processos.

Uma dança “(est)ética”, reconhece o corpo como território de passagem e lugar de transformação, que possibilita a construção do universo simbólico do ser em relação, e explora toda sua potência criativa, alcança dimensões intuitivas que permitem ao indivíduo ir além das manifestações discursivas alcançando as manifestações da dimensão poética dos sentidos. Aprendizado este, necessário para sermos capazes de interpretar a lógica da vida real e ordenar o caos do mundo e da realidade.

\title{
4. Proposições finais
}

A vida do século XXI exige movimento, estagnar-se diante do caos da fragmentação, é o mesmo que praticar um ato passivo de violência. Toda a palpitação do mundo pode ser pressentida pelo corpo, como um diálogo permanente entre o ser humano e o todo. Uma rela- 
ção harmoniosa entre aquilo que está dentro e fora, já que as fronteiras que delimitam tais extremidades são pela consciência, dissolvidas.

Relembrar a Declaração Universal dos Direitos Humanos, defendê-la e reivindicá-la deveria acionar instantaneamente em todos nós um senso de responsabilidade diante das nossas próprias escolhas. Sejamos portanto, artesãos desta nova era tramada por fios resistentes que sustentam atitudes conscientes em prol da valorização dos aspectos essenciais à preservação da vida individual, coletiva e planetária.

Enquanto humanidade, temos um caminho árduo a percorrer, aprendendo a arte de esvaziar do conhecido, para que as velhas certezas deêm lugar às bem-vindas incertezas. Estamos a dançar o instante, pela renovação a cada segundo, já dizia Heráclito de Éfeso “[...] tudo flui, nada persiste, nem permanece o mesmo... nem mesmo o rio em que entrais pela segunda vez não é o mesmo da primeira vez.” Adentrar a dimensão do novo e toda gama de possibilidades existentes na imprevisibilidade da dança do instante, efêmera e fugaz, pelo reconhecimento da dignidade humana e pela edificação de um mundo mais justo e mais harmonioso.

\section{REFERÊNCIAS BIBLIOGRÁFICAS}

Assembleia Geral da ONU. (1948). Declaração Universal dos Direitos Humanos (217 [III] A). Paris. Disponível em: <https://declaracao1948.com.br/declaracao-universal/declaracao/> Acesso em: 20 dez 2018.

BITTAR, Eduardo C. B. Razão e afeto, justiça e direitos humanos: dois paralelos cruzados para a mudança paradigmática. Reflexões frankfurtianas e a revolução pelo afeto. Revista Mestrado em Direito, Osasco, Ano 8, n.1, 2008. Disponível em: <http:// www.dhnet.org.br/direitos/militantes/eduardobittar/bittar_razao_afeto_justica_dh.pdf>.Acesso em: 02 jan. 2019

CREMA, R. Introdução a Visão Holística. São Paulo: Summus, 1989. CAPRA, F. O Tao da Física. São Paulo: Cultrix, 1983.

GARAUDY, R. Dançar a Vida. Rio de janeiro: Nova Fronteira, 1980. 
NICOLESCU, Basarab; O Manifesto da Transdisciplinaridade. São Paulo, SP: TRIOM, 1999.

TOMAZZONI, Airton. Essa tal de dança contemporânea. Digestivo cultural, São Paulo, 24 abr. 2004. Disponível em: https://www. digestivocultural.com/colunistas/coluna.asp?codigo=3972\&titulo=Essa_tal_de_Danca_Contemporanea. Acesso em: 20 jan. 2020 .

VERDERI, E. B; Dança na escola: uma abordagem pedagógica. São Paulo: Phorte, 2009.

VIANNA, K. A Dança. São Paulo: Summus Editorial, 2005.

WAISELFISZ, Julio Jacobo. Violência Letal Contra as Crianças e Adolescentes Do Brasil / Julio Jacobo Waiselfisz. - 2015.

WEIL, Pierre; LELOUP, Jean-Yves; CREMA, Roberto. Normose: a patologia da normalidade. 2. ed. - Petrópolis, RJ: Vozes, 2012.

WEIL, P. A arte de viver em paz: por uma nova consciência, por uma nova educação. São Paulo: Gente, 1993.

WOSIEN, B. Dança: um caminho para a totalidade. São Paulo: Triom, 2000. 


\section{OS SENTIDOS DA AVALIAÇÃO DAS REDES DE ENSINO NA DEMOCRACIA BRASILEIRA}

Sandra Vidal Nogueira

Introdução

No tempo presente da educação brasileira, as exigências por melhorias nos padrões de qualidade das redes pública e privada têm sido frequentes, em meio as crises sucessivas, nos planos das identidades profissional e institucional. Constata-se um momento histórico de intensa transição paradigmática, marcado por incertezas e mudanças contínuas.

Há de se ter um olhar ampliado, que permita visualizar com maior clareza as demandas existentes. Merecem relevo, por um lado, as dimensões democráticas do ensino e aprendizagem e, por outro, os princípios emancipatórios do trabalho educativo, que por sua vez, tornam-se ferramentas importantíssimas. Elas estimulam a criação e consolidação de modelos de gestão educativa, mais dinâmicos e dialógicos.

Desse ponto de vista, os processos de avaliação das redes de ensino no Brasil, representam desafios corporativos e se configuram como estratégias indispensáveis. Nesse sentido, emergem perguntas sobre a função exercida pela própria ideia de avaliar, a partir de epistemologias, que tragam resultados efetivos.

Para tratar dessa temática, o presente trabalho faz um recorte didático, estabelecendo três tópicos principais. São eles: $1^{\circ}$ ) principais ferramentas de avaliação e sua aplicabilidade na Educação brasileira; $2^{\circ}$ ) 
protagonismo curricular: o que, como e para que ensinar? $3^{\circ}$ ) horizontes educacionais de emancipação humana e bem estar comum.

\section{Principais ferramentas de avaliação e sua aplicabilidade na Educação brasileira}

Somente na década de 90 o Brasil conseguiu impulsionar o processo de universalização do Ensino Fundamental. Ao lado dos recentes progressos, no avanço de teorias e métodos, assim como, na formação e qualificação profissional para a Área da Educação, um olhar retrospectivo revela, ainda, lacunas no desenvolvimento da escola de massa no país.

Os estudos revelam as marcas deixadas por mais de três séculos de controle do estado sobre a oferta de educação escolar, ou seja, uma tradição aristocrática herdada da Colônia, com sua ênfase no Ensino Superior e o real abandono dos demais níveis de ensino. Diante dessa situação, evidencia-se a importância estratégica da avaliação das redes de ensino, focalizando indicadores, que possam promover revisões nas formas de conceber os processos e práticas educativas.

Sobre o ato de avaliar vale dizer, que o mesmo é uma prática social polissêmica, que não está circunscrita aos limites da aquisição e produção de conhecimentos ou das relações pedagógicas e de ensino-aprendizagem. Trata-se de um campo semântico mais amplo, que abrange também o mundo dos fazeres educativos e sua ambiência cultural.

Nessa perspectiva, ganham destaque no Brasil, as mudanças introduzidas pela Lei de Diretrizes e Bases da Educação n 9.394/96 (BRASIL/MEC, 1996) e várias ações desencadeadas, (algumas delas já iniciadas na década de 70), pelo Ministério da Educação (MEC) e Coordenadas pelo Instituto Nacional de Estudos e Pesquisas Educacionais Anísio Teixeira (INEP) e pela Coordenadoria de Aperfeiçoamento de Pessoal de Nível Superior (CAPES).

Dentre essas iniciativas, algumas delas fazem parte da aproximação do governo federal com experiências internacionais de avaliação educacional: a) no Programa Estudos Conjuntos para a Integração Latino-Americana (Eciel) nos anos 70 e daquilo que foi conduzido pelo Escritório Regional para a América Latina e o Caribe (Unesco/Orealc), na década de 90; b) a partir de 1994, no Laboratório Latino-Ame- 
ricano de Avaliação da Qualidade da Educação (Llece); c) desde 1997, no Programa Mundial de Indicadores Educacionais (Wei); d) no Fórum Hemisférico de Avaliação Educacional, instalado em 2002, como resultado do Plano de Ação acordado por ocasião da II Cúpula das Américas, realizada no Chile em 1998; e) em 2000, no Programa Internacional de Avaliação de Estudantes (Pisa), talvez um dos mais conhecidos e utilizados como referência na América Latina; f) em 2001, no Projeto Sistema de Indicadores Educacionais do Mercosul (Sem).

No cenário nacional e nos contextos da Educação Básica e da Educação de Jovens e Adultos ocorreram trabalhos significativos: a) o Sistema Nacional de Avaliação da Educação Básica (Saeb); b) o Exame Nacional do Ensino Médio (Enem); c) o Exame Nacional de Certificação para o Ensino de Jovens e Adultos (Encceja). No universo do Ensino Superior, graduação e pós-graduação, há de se mencionar duas ações: a) o Sistema Nacional de Avaliação do Ensino Superior (SINAES); b) a Avaliação dos Programas de Pós-Graduação Stricto-Sensu ${ }^{29}$.

Apresenta-se na seqüência uma síntese identificando aspectos relativos à natureza e finalidade de cada uma dessas iniciativas.

O Saeb, mais voltado para a avaliação dos sistemas estaduais, realiza a cada dois anos, desde 1995, uma avaliação do desempenho dos/ as estudantes das $4^{\underline{a}}$ e $8^{\underline{a}}$ séries do ensino fundamental e $3^{\underline{a}}$ série do ensino médio. A partir de 2005 o Saeb passou a ser composto de duas avaliações. A primeira delas é a Avaliação Nacional da Educação Básica $(\text { Aneb })^{30}$, objetivando avaliar a qualidade, equidade e a eficiência da educação brasileira, focalizando a gestão dos sistemas de ensino. A outra diz respeito a Avaliação Nacional do Rendimento Escolar (Anresc) ${ }^{31}$, mais ampla que a anterior, tem caráter universal e avalia a qualidade do ensino ministrado nas escolas, apresentando resultados globais. (BRASIL/MEC/INEP, 2005a/b; BRASIL/MEC, 2005a/b)

29 Outra iniciativa que funciona como subsídio para as demais experiências é o Censo Escolar. Com base na coleta de informações sobre os(as) alunos(as) e as funções docentes esse procedimento é usado para se obter um conhecimento mais amplo e preciso da realidade educacional do país. (BRASIL/MEC, 2005b)

30 A Aneb recebe o nome de Saeb em suas divulgações.

31 A Anresc recebe o nome de Prova Brasil em suas divulgações. 
O Enem, desde 1998, tem como eixo norteador a avaliação do participante ao término da Educação Básica com ênfase para o desenvolvimento de competências e habilidades fundamentais à vida acadêmica, ao mundo do trabalho e ao exercício da cidadania. (BRASIL/MEC, 1999; 2001; 2002; INEP:1999)

O Encceja, instituído em 2004, objetiva promover uma ampla auto-avaliação de jovens e adultos, residentes no Brasil e no exterior, em nível de conclusão do Ensino Fundamental e do Ensino Médio. A centralidade da avaliação feita pelo Encceja é a aferição de competências e habilidades adquiridas por jovens e adultos no processo escolar e nos processos formativos que se desenvolvem na vida familiar, na convivência humana, no trabalho, nos movimentos sociais e organizações da sociedade civil e nas manifestações culturais. (BRASIL/MEC/INEP, 2006; BRASIL/MEC 2004)

O Sinaes, instituído em 2004, pretende garantir a melhoria da qualidade da educação superior, no que tange a orientação da expansão da oferta, ao aumento da sua eficácia institucional e efetividade acadêmica e social, a promoção dos valores democráticos, ao respeito à diferença e a afirmação da autonomia e identidade institucional. ${ }^{32}$ Para cumprir tal preceito é assegurado pelo Sinaes o desenvolvimento de um processo nacional de avaliação interna e externa, que contempla a análise global e integrada das dimensões, estruturas, relações, compromissos e responsabilidades sociais, atividades, finalidades e responsabilidades so-

32 No âmbito da avaliação dos cursos de graduação, datam de 1983 as primeiras idéias sobre o tema, com a instituição, pelo Ministério da Educação (MEC), do Programa de Avaliação da Reforma Universitária (PARU), que enfatizava a gestão das Instituições de Ensino Superior (IES), a produção e a disseminação dos conhecimentos. Entre o final da década de 80 e início dos anos 90, algumas universidades iniciaram experiências de auto-avaliação, que contribuíram para criar um espaço de interlocução entre o MEC e as instituições federais, representadas pela Associação das Instituições Federais do Ensino Superior (ANDIFES). Pela mediação da ANDIFES, as experiências de auto-avaliação subsidiaram a construção do Programa de Avaliação Institucional das Universidades Brasileiras (PAIUB), que teve o apoio da SESu/MEC, de 1993 a 1994. Em 1996, foi introduzido, em âmbito nacional, o Exame Nacional de Cursos (ENC), popularizado como "Provão" , seguido de outros mecanismos avaliativos, tais como a Avaliação das Condições de Ensino (ACE), e a Avaliação para credenciamento de IES privadas, com a proposta de nivelar as instituições em termos de qualidade. 
ciais das instituições de ensino superior, dos seus cursos de graduação e do desempenho acadêmico de seus estudantes. Integram a sistemática processual do Sinaes alguns componentes: a) Avaliação Institucional, dividida em duas modalidades, a saber - auto-avaliação e avaliação externa; b) Avaliação dos Cursos de Graduação; c) Exame Nacional de Desempenho dos Estudantes (Enade) ${ }^{33}$. (BRASIL, 1996a/b/c; 2001; 2004; BRASIL/MEC, 1994; 2004; BRASIL/MEC/INEP, 2004) $)^{34}$

A Avaliação trienal dos programas de pós-graduação stricto-sensu (atualmente quadrienal) é a única experiência que surge conjuntamente com a criação do próprio Sistema de Pós-Graduação no país, um dos segmentos mais bem sucedidos da educação brasileira nos aspectos atrelados a expansão e qualidade acadêmica. O seu caráter substantivo reside no financiamento público e na institucionalização de um processo contínuo de avaliação criado em meados dos anos setenta, organizado pela CAPES e realizado pelos pares $^{35}$. (BRASIL/MEC/CAPES, 2005)

33 A opção avaliativa do Enade privilegia o desenvolvimento de competências, conhecimentos e habilidades, dentre os aspectos a serem avaliados, tendo como foco o processo no qual elas se constituem e a partir do contexto de ensino e aprendizagem no qual se configuram. Para tal, o Enade considera estratégias e instrumentos avaliativos diversificados, que consigam: a) investigar a forma como os estudantes estão conseguindo estabelecer a relação entre teoria, práticas, realidade e princípios éticos, na busca das competências; b) avaliar de que forma a produção teórica e o saber tácito tomam um novo significado quando mediados por processos socioculturais e relacionais; $c$ ) medir a integralização da dimensão reflexiva à ação, expressa nos atos ou no conjunto de atos, de opções, escolhas, compromissos Este Exame é constituído por uma prova e um questionário socioeconômico e aplicado em grupos amostrais de estudantes dos cursos de graduação que se encontram no final do primeiro e do último ano de formação. (MARINHO-ARAUJO, 2004).

34 Acrescentam-se as experiências de avaliação em desenvolvimento no ensino superior o Censo da Educação Superior, que engloba o Cadastro da Educação Superior e o Cadastro Nacional de Docentes. (Disponível em: http:www.inep.gov.br. Acesso em: 13 de novembro de 2019)

35 No período de 1976-1997, os cursos foram avaliados através de conceitos que variavam de $\mathbf{A}$ até $\mathbf{E}$. A partir de 1998 a escala de conceituação mudou para o sistema numérico de 1 até 7. De acordo com aquilo que é evidenciado no V PNPG "A CAPES e o CNPq, ao longo de suas trajetórias, criaram dois importantes sistemas nacionais de avaliação acadêmica: o primeiro orientado para avaliar a qualidade dos programas de formação 
Todas essas iniciativas têm sido desenhadas a partir de uma nova lógica de conceber os processos e práticas educativas, contemplando mais dimensões da vida e de melhoria das condições ao desempenho escolar. Observa-se, assim, que o foco avaliativo se amplia, de modo a incorporar no domínio de conhecimentos científicos básicos, o exame da capacidade dos estudantes de analisar, raciocinar e refletir ativamente sobre suas experiências, com ênfase para habilidades e competências necessárias à vida em sociedade.

É, pois, uma riquíssima oportunidade histórica para que as redes de ensino possam atuar, de forma proativa, no sentido de mobilizar recursos, inventividade e compromissos na criação de novos modelos de organização institucional, curricular e pedagógica, em prol de um universo conceitual mais orgânico e avançado.

\section{Protagonismo curricular: o que, como e para que ensinar?}

Os estudos sobre o campo de currículo buscam debater sobre a maneira pela qual o currículo é elaborado e avaliado. Em capa época, sofre influência de tendências e matrizes de pensamento.

A abordagem técnica, inspirada no pensamento de Tyler (1949), predominou entre os anos 40 e 80, especialmente nos Estados Unidos e no Brasil. Entre nós, o modelo tyleriano prestou-se ao chamado tecnicismo pedagógico. De acordo com Silva (1999, p.24), embora admita "a filosofia e a sociologia como possiveis fontes de objetivos para o currículo, o paradigma formulado por Tyler centra-se em questões de organização e desenvolvimento".

A predominância dos objetivos e da avaliação, nos moldes do padrão insumo-produto, realizado no contexto industrial, deriva do entendimento de que fazer currículo é planejá-lo, com vistas à eficácia dos processos de ensino e aprendizagem. A noção de Educação para a performance está associada às idéias de universalidade dos conteúdos disciplinares e de linearidade dos processos educativos, elementos vitais para a manutenção da lógica disciplinar. 
No início dos anos 80 surgem debates sobre a necessidade de superar a visão tecnicista e seus imperativos pedagógicos. Os estudos e pesquisas, então realizados, evidenciam as formas assumidas pelas dinâmicas curriculares e suas implicações na maneira de conceber a Educação nas redes de ensino. Constatava-se que não é suficiente acumular informações, mas sim alcançar o domínio dos mecanismos de produção e apropriação do conhecimento sistematizado. Está posto, assim, como principal desafio, entender os impactos do denominado protagonismo curricular.

O foco dos debates passou a ser a capacidade de processar, eleger e aplicar conteúdos de modo significativo, ou seja, buscar respostas relativas ao que, ao como e ao para que ensinar. Diante dessa constatação, a temática do currículo escolar e suas abordagens, assumiu posição, ainda mais evidente, nos cenários das redes de ensino e as questões suscitadas, não podem ser tratadas sem que se recorra, a priori, para uma reorientação conceitual sobre o próprio campo de abrangência do currículo.

Nessa direção, conforme explica Forquin (1993), é possível observar que a denominação "currículo" expressa sentidos diferenciados no vocabulário pedagógico inglês e francês, tanto em termos de riqueza semântica, quanto de usos. No léxico francês, em que é restrito à categoria específica de objetos pertencentes à esfera educativa, currículo equivale à idéia de plano ou programa. Já nos países de língua inglesa, e em outros sob sua influência, abrange noções de prescrição/execução e currículo oculto/contextos culturais, dando a conotação de uma abordagem global aos fenômenos educativos.

Distinções à parte, o conceito de currículo expressa o entendimento de que o mesmo trata da produção humana, instituínte de conhecimentos socialmente válidos e, como tal, produtora de identidades e subjetividades. Está inserida nessa orientação conceitual a compreensão de que pensar/fazer currículo é, antes de tudo, uma atividade que envolve a produção de saberes e a ordenação das coisas humanas ou a elas relacionadas (exercício de poder), que quase sempre assume o viés da legitimação das práticas discursivas. Como consequência desse entendimento, coloca-se a tarefa de superar a lógica disciplinar, como atividade exclusiva, em ambientes escolares. 
A palavra disciplina apresenta um duplo sentido: tanto induz à delimitação de um campo específico como à hierarquização e ao exercício do poder. (...) O processo de disciplinarização pelo qual passa a construção da ciência moderna traz embutida em si esta afirmação da equivalência entre saber e poder. (...) Por detrás dela [disciplinarização], paira o controle: compartimentalizando, fragmentando, é muito mais fácil controlar-se o acesso, o domínio que os alunos terão e também controlar-se o que eles sabem. (Gallo, 1997:117-118).

A preocupação volta-se para o trabalho pedagógico e os mecanismos de combater a desarticulação dos conteúdos, ou seja, não basta saber e saber fazer, mas é preciso analisar e compreender, de maneira coesa e integral, as dimensões antropológicas, sociais, econômicas, políticas e culturais da existência humana.

Com essa tomada de posição sobre os significados do currículo, que é epistemológica por excelência, nota-se um crescente interesse pelo resgate do sentido democrático das escolhas curriculares. Em síntese, a emergência da teoria crítica ao campo de estudos curriculares apresenta relevo na articulação entre conhecimentos, cultura e poder e uma finalidade, ou seja, horizontes educacionais de emancipação e bem estar comum.

\section{Horizontes educacionais de emancipação humana e bem estar comum}

Diante das complexidades da vida humana contemporânea, dominada pelas forças tecnológicas e pelos reflexos econômicos no contexto social, o Estado contemporâneo não consegue encontrar respostas satisfatórias aos anseios das populações. Questiona-se, sobremaneira, as bases de sustentação do mundo e as distopias geradas.

Nessa perspectiva, fazendo uma breve retrospectiva dos acontecimentos das últimas décadas, vislumbra-se situações de conflitos sociais, culturais e religiosos, decorrentes do crescente colapso das ideologias políticas que funcionavam, via de regra, até o século passado, como elementos de agregação. A tríade, democracia, cida- 
dania e identidade nacional aparece, assim, como importante chave de leitura. À título de esclarecimento, Piovesan (2002:86-87) faz o seguinte esclarecimento:

As diferenças ente as novas classes nas sociedades desenvolvidas e subdesenvolvidas são essencialmente quantitativas. Nas primeiras os globalizados são muitos e os excluídos relativamente poucos, enquanto a maioria da população é semiglobalizada. Nas sociedades mais pobres, evidentemente, os números se invertem, com a quantificação de que os semiglobalizados são substancialmente menos 'incluídos', caindo na faixa de exclusão com muita facilidade.

Pensando na pessoa humana e nos processos educativos, uma das principais fontes de identificação cultural são os elos de pertencimento que cada qual possui, desde a trajetória de criança. A identidade nacional se constitui, dessa maneira, a partir de um conjunto de crenças, valores e representações simbólicas que dão sentido real para a noção de cidadania, em cada fase da vida. Resulta, portanto, das simbologias, rituais e rotinas, do qual se faz parte e que vão produzido significados estruturantes para as pessoas, individual e coletivamente.

Usando o recurso metafórico de visualizar uma fotografia em perspectiva, é possível perceber alguns detalhes nesse cenário do tempo presente. A racionalidade contemporânea adentrou à vida social pela porta da economia, alicerçada na lógica dos mercados consumidores e nos índices de crescimento rápido, assujeitando pessoas e coletivos. Como consequência, as metanarrativas têm perdido sua força propulsora, nos níveis analítico e interpretativo. Urgem outras epistemologias para dar conta dessa nova temporalidade!

Para Adolfo (2001, p. 110), o que ocorre é que “(...) o fenômeno da globalização afeta de forma adversa a soberania e o moderno Estado-nação é cada vez mais aceito em diversos círculos acadêmicos, governamentais e internacionais”. A economia de mercado globalizada afeta substantivamente as relações interpessoais e os processos educacionais nas famílias e redes de ensino. A ética sucumbe ao lucro. O que se assiste, então, é, pois, à subjugação de poderes diversos ao fenômeno econômico. 
As fraturas no corpo social são alargadas. Elas são decorrentes da exclusão de gerações e seus perversos efeitos, advindos, por exemplo, das situações de desemprego, analfabetismo, fome, miséria, enfermidades, violência real e simbólica. Esse quadro, releva um situações de crises constantes, que colocam em risco a própria vitalidade da tríade democracia, cidadania e identidade nacional.

Alguns fenômenos marcantes de nossa História expressam bem isso. A História econômica mostra isso. Foi na época da recessão americana de 1870 que Dale Carnegie e John Rockefeller começaram a construir um império nos mercados emergentes de óleo e aço. Outro exemplo é dado nos anos 30, quando no auge da grande depressão, um dos mais renomados pesquisadores da Du Point, Wallace Carothers, descobriu o neoprene, uma matéria prima sintética.

Os interesses do capital acabam se tornando hegemônicos e as regras do mercado são colocadas na centralidade da via moral. Há gerações de excluídos. Gente que transita à margem das conquistas democráticas. Nos denominados países periféricos a violência marca profundamente as interrelações sociais, adquirindo patamares de verdadeiro genocídio.

$\mathrm{Na}$ realidade, a grande utopia de um Estado democrático e social de direito deveria ser a realização da emancipação das subjetividades humanas e a construção do bem estar comum. Para Habermas (1997: 290), "O exemplo dos países em desenvolvimento revela que não existe um nexo entre linear entre o desenvolvimento do Estado democrático de direito e a modernização capitalista."

Pode-se dizer em síntese, corroborando o pensamento e Streck e Morais (2008), que a busca por uma democracia real, mais robusta e alargada em substancia e sentido plural é, pois, a máxima urgência histórica do Brasil. Nessa perspectiva, os processos e as práticas organizacionais (de planejamento e avaliação), precisam ser atualizadas e reinventadas, observando modos mais republicanos de ser e conviver, visto que, não se pode abrir mão dos elementos que vão fazer com que as organizações na sociedade e na Educação, em particular, possam ficar cada vez mais fortes, democraticamente falando, ao longo dos tempos. 


\section{Conclusões}

Vivencia-se, desde o final o século XX, a transição para um modelo de Estado social de direito, baseado numa economia produtiva, com garantia das liberdades individuais. Nessa perspectiva, o Estado deve potencializar formas de garantir a concretude dos direitos fundamentais a que toda pessoa humana faz jus e que está constitucionalmente assegurado. A dignidade humana e o direito à vida com qualidade constituem referentes básicos, com vistas ao acesso e permanência das pessoas num ideário educacional mais coletivo e solidário.

No que diz respeito as experiências de educação escolar, pode-se afirmar o poder inquestionável que os currículos possuem. Eles são territórios, onde efetivamente as coisas acontecem, incluindo modelos de formação humana, perpassados pela subjetividade inerente. Possibilitam, assim, engendrar reais "documentos de identidade" para pessoas e coletividades. Ajudam sobremaneira na superação de mentalidades excludentes, representadas por visões de mundo, muitas vezes unilaterais das políticas, dos processos e das práticas.

Parte integrante dos cenários de ação educativa brasileira, nas últimas décadas, os modelos usados para avaliar as redes de ensino, possuem forte influência dessa matriz que objetiva consolidar uma democracia de alta densidade nos diversos setores da vida nacional. Por isto, não pode ser vista de maneira isolada.

Garantir o sentido plural do processo avaliativo em Educação é condição básica para que a democracia tenha vigor e vice-versa. Uma depende da outra. Ambas convergem para o entendimento sobre a riqueza de vivências oriunda da diversidade humana, ou seja, de que as pessoas diferem em vários aspectos como a inteligência, as habilidades, os esquemas de conhecimento, as estratégias de aprendizagem, os interesses, as expectativas, as motivações e todos esses aspectos incidem sobre os processos de ensino-aprendizagem de forma distinta.

\section{REFERÊNCIAS}

\section{ADOLFO, Luiz Gonzaga Silva. Globalização e estado contempo-} râneo. SP: Memória Jurídica, 2001. 
APPLE, Michael. Aluno à direita: mercados, padrões e desigualdade. Trad. Dinah de Abreu Azevedo. São Paulo: Cortez \& Instituto Paulo Freire, 2003.

CANEN, A. Avaliando a avaliação a partir de uma perspectiva multicultural. Educação Brasileira: revista do CRUB, Brasília, DF, v. 27, n. 54, p. 95-114, 2005.

BOLZAN, José Luis de Morais. O Estado e suas crises. Porto Alegre: livraria do advogado, 2005.

CHÂTELET, F. e outros. História das idéias políticas. Rio de Janeiro: Zahar, 1985.

DALLARI, Dalmo de Abreu. Elementos de Teoria Geral do Estado. $26^{\underline{a}}$ Ed., Editora Saraiva, 2007

DARCY, Azambuja. Teoria geral do Estado. 38. Ed. São Paulo: Globo, 1998.

DEJOURS, Cristophe. A banalização da injustiça social. Trad. Luiz Alberto Monjardin. RJ: Fundação Getúlio Vargas, 4를. ed., 2001.

DIAS SOBRINHO, José. Avaliação: políticas educacionais e reformas da educação superior. São Paulo: Cortez, 2003.

FORQUIN, J. C. Escola e cultura: as bases sociais e epistemológicas do conhecimento escolar. Trad. G. L. Louro. Porto Alegre: Artes Médicas, 1993.

GALLO, Silvio. Conhecimento, transversalidade e educação. Impulso, out. 1997.

GÓMEZ, José Maria. Política e Democracia em Tempos de Globalização. Petrópolis: Vozes: 2000.

GUÉHENNO, Jean-Marie. O futuro da liberdade: a democracia no mundo globalizado. Trad. Rejane Janowitzer. R.J.: Bertrand Brasil, 2003. 
HABERMAS, Jurgem. Direito e democracia: entre factiicidade e validade - volumes I e II. $1^{\circ}$ Ed., Trad. Flavio Beno Siebeneichler. RJ: Tempo brasileiro 1997.

JANELA, Almerindo Afonso. Avaliação educacional: regulação e emancipação: para uma sociologia das políticas avaliativas contemporâneas. São Paulo: Cortez, 2000.

KUHN, Thomas S. A estrutura das revoluções científicas. Trad. B. V. Boeira e N. Boeira. 3. Ed. São Paulo: Perspectiva, 1991.

MARTIN, H.-P. A armadilha da globalização: o ataque à democracia e ao bem-estar. Trad. W. U. E. P. Rose e Clara; C. W. Satkiewicv. Rio de Janeiro: Globo, 1997.

MORAES, Alexandre de. Direito constitucional. 19aㅗ ed., SP: Atlas, 2006.

MORIN, E. A noção de sujeito. In: SCHNITMAN, D. F. (org.). Novos paradigmas, cultura e subjetividade. Trad. J. H. Rodrigues. Porto Alegre: Artes Médicas, 1996.

NASCIMENTO, M. \& BRANT, F. Janela para o mundo. In: Nascimento. Warner Bros. Records Inc. 1997.

PIOVESAN, Flávia (org.). Direitos humanos, globalização econômica e integração regional: desafios do direito constitucional internacional. SP.: Max Limonad, 2002.

REALE, Miguel. Cinco temas do culturalismo. 1를. Ed., SP: Saraiva, 2000b.

. Experiência e cultura. $2^{\underline{a}}$ ed., Campinas: BookSeller, 2000a.

SACRISTÁN, J. G. Currículo e diversidade cultural. In: SILVA, T. T. da \& MOREIRA, A. F. B. (org.). Territórios contestados: o currículo e os novos mapas políticos e culturais. Petrópolis, Vozes, 1995, p. 82-113.

SAVATER, F. Ética para meu filho. Trad. M. Stahel. São Paulo: Martins Fontes, 1998. 
. O valor de educar. Trad. M. Stahel. São Paulo: Martins Fontes, 2000 .

SAUL, Ana Maria A. Avaliação emancipatória: desafio à teoria e a prática de avaliação e reformulação curricular. São Paulo: Cortez, 1988

SCHAFER, Jairo Gilberto. Direitos Fundamentais: proteção e restrições. Porto Alegre: Livraria do Advogado, 2001.

SILVA, Tomaz. Tadeu. da Currículo e identidade: territórios contestados. In: . (org.). Alienígenas na sala de aula: uma introdução aos estudos culturais em educação. Petrópolis: Vozes, 1995, p. 190-207.

. O discurso pedagógico da sociologia da educação: crítica da crítica. In: MOREIRA, A. F. Barbosa (org.). Conhecimento educacional e formação do educador. Campinas, SP: Papirus, 1994, p. 85-100.

. Documentos de identidade: uma introdução às teorias do currículo. Belo Horizonte: Autêntica, 1999.

STRECK, Lenio Luiz; MORAIS, José Luiz Bolsan. Ciência Política e Teoria do Estado. $6^{\mathrm{a}}$ Ed., Porto Alegre: Livraria do Advogado, 2008.

TYLER, Ralf W. Princípios básicos de currículo e ensino. Porto Alegre: Globo, 1974.

WORTHEN, Blaine R.; SANDERS, James R.; FITZPATRICK, Jody. Avaliação de programas: concepções e práticas. Trad. Dinah de Abreu Azevedo. São Paulo: Editora Gente, 2004. 


\section{AS CONTRIBUIÇÕES DA EDUCAÇÃO A DISTANCIA NO ACESSO AO CONHECIMENTO E NAS APRENDIZAGENS MEDIADAS PELAS TECNOLOGIAS REMOTAS E DIGITAIS}

Sandra Vidal Nogueira

\section{Introdução}

Contemplando um conjunto diversificado de dinâmicas de trabalho pedagógico que se realizam em situações educativas não-convencionais, as experiências de educação à distância (EAD) têm em comum o fato de não se desenvolverem no entorno exclusivo das atividades presenciais contínuas que acontecem nos limites das salas de aula. São, pois, definidas na literatura que trata do assunto sob várias perspectivas, a saber: sistema tecnológico de comunicação maciça e bidirecional, modalidade alternativa de ensino, prática educativa mediatizada, etc. (MOORE \& KEARSLEY; VALENTE \& ALMEIDA, 2007)

De acordo com Peters (2002; 2003), as expressões 'Ensino à Distância (Fernunterricht) e 'Educação à Distância' (Ferntsdium) foram empregadas inicialmente na Alemanha nos anos 60 em substituição ao que se denominava, até então, por ensino por correspondência. $\mathrm{O}$ inglês Desmond Keegan, um de seus defensores a introduziu no mundo anglo-saxônico, em 1969, a partir da criação da Open University. 
Da mesma forma que a evolução da escrita provocou mudanças profundas nas maneiras de pensar e de agir da humanidade em várias partes do planeta, ao modificar, principalmente o papel das operações cognitivas vinculadas à memória; as tecnologias de informação e comunicação, usadas pela via dos meios eletrônicos e computacionais e inseridas nos modelos curriculares de educação à distância (EAD), também estão produzindo alterações significativas na estruturação do ato de pensar, e conceber as noções de tempo e espaço educativo, bem como na reorganização do trabalho pedagógico nas instituições educativas.

A principal característica da educação a distância que demonstra a existência um salto qualitativo na História da Educação, em termos da promoção de processos interativos, é sem dúvida alguma, a possibilidade dos estudantes poderem estar em lugares diferentes executando uma série de tarefas, tais como: a) interagir em tempo real; b) fazer uso de ferramentais conceituais e metodológicas que promovam meios eficientes e eficazes para uma cultura de auto-aprendizagens; c) manter contato com um número ampliado de colegas em regiões muitas vezes distantes geograficamente; d) desenvolver habilidades e competências diferenciadas para manipularem mídias variadas.

Para Moran e Kenski (2007), dentre as vantagens oriundas do uso crescente dessas tecnologias pode-se destacar duas delas. A primeira diz respeito a criação de espaços diferenciados de acesso ao conhecimento, através dos quais estudantes podem participar ativamente da busca e construção de seus próprios movimentos de aprendizagem, estimulando canais de diálogos interativos. Acrescentam-se a essa vantagem, o fato das novas tecnologias de informação e comunicação permitirem concomitantemente o aumento da confiabilidade e da qualidade de transmissão das informações.

De maneira sintetizada pode-se afirmar que, mostra-se oportuna e necessária a atuação proativa dos docentes na condição de mediadores das aprendizagens em consonância com a utilização de uma gama de tecnologias disponíveis para a disseminação do conhecimento, bem como o desenvolvimento de sistemas computacionais de apoio ao ensino e processos de formação inicial e continuada, estimulando as pes- 
soas e os grupos a estabelecerem, de modo progressivo, diálogos interativos. (ALMEIDA \& ALONSO, 2007)

Desvela-se, assim, a emergência de rupturas epistemológicas com efeitos substantivos na própria dinâmica da vida contemporânea. As origens dessas rupturas extrapolam, porém, os limites das Áreas da Informática ou da Educação. Na verdade, o pano de fundo desse cenário está localizado nos planos da política e da econômica mundiais e os novos caminhos que estão sendo trilhados nas práticas pedagógicas escolares, até então exclusivamente presenciais, nada mais são do que reflexos de uma situação conjuntural de crise instalada no interior dos Estados Nacionais e que dizem respeito ao papel exercido e o conseqüente lugar ocupado pelos atores sociais nos vários segmentos que integram as esferas da vida pública e privada. Pensando na realidade brasileira, a situação está circunscrita ao que ocorre na tradição latino-americana.

Para tratar desse assunto com maior precisão teórica, superando modismos e contribuindo para os debates sobre o assunto, são ensejadas no traçado deste trabalho reflexões, a partir dos seguintes tópicos: a) revisitando os conceitos de EAD e sua aderência ao ideário pedagógico brasileiro; b) sociedade educativa, princípio da atual dinâmica planetária; c) uma visão metacognitiva da formação profissional; d) limitações e desafios de uma nova modalidade de ensino.

\section{Revisitando os conceitos de EAD e sua aderência ao ideário pedagógico brasileiro}

É um equívoco pensar que a simples introdução das tecnologias da informação e da comunicação nos processos de ensino e aprendizagem se caracterizam, por si só, numa mudança paradigmática. Para que isto aconteça, faz-se necessário ocorrerem transformações significativas nos níveis comportamental, conceitual, de valores, ações e decisões, num dado contexto histórico, social e político.

As tecnologias são apenas e tão somente recursos complementares e sinérgicos na busca e adoção por novos modelos curriculares, constituindo-se, portanto, em atividades/meio e não em algo que se está posto na qualidade de um fim em si mesmo. 
Ao revisitar conceitos sobre EAD no ideário pedagógico internacional, mais especificamente no campo da Educação e dos estudos sobre currículo, constata-se a co-existência de dois grupos de conceituações que foram pioneiras nas discussões sobre EAD nas décadas de 70 e 80 . Uma delas é de inspiração behaviorista e influenciou as experiências didático-pedagógicas norte-americana. Com base numa definição sistêmica e descritiva da EAD, apresenta como principais elementos definidores as tecnologias educacionais e a separação docente/estudante. São representantes desta corrente de pensamento, dentre outros Barberà, Romiszowski, Sangrá \& Simonson (2006); Sancho \& Hernández (2006).

Uma outra vertente conceitual é representada pelos modelos australiano e europeu que buscam explicar o contexto socioeconômico mais amplo e as particularidades da EAD com relação ao ensino convencional e ao mercado de trabalho. Peters $(2001 ; 2003)$ é um de seus defensores e argumenta na direção da tese sob a qual o ato de ensinar à distância coloca-se de maneira similar às fases do desenvolvimento industrial, vislumbrados no mundo das relações de trabalho. Nessa concepção, denominada de economicista, privilegia-se o estilo fordista de produção sendo, pois, os modos de organização dos sistemas e sua estruturação no seio da atividade educativa, elementos essenciais na constituição das políticas e práticas de EAD.

Segundo Barajas \& Alvares (2003) e Citelli (2007), o movimento histórico de reconstrução dos conceitos de EAD, abrangem especificamente quatro gerações de tecnologias: a primeira desenvolvida desde os anos 40, baseada no texto escrito: a segunda, utilizando os recursos televisivos e de áudio, a partir de 1950; a terceira, iniciada em 1960, que incorpora os avanços das gerações anterior, ao sistema de multimeios; e a quarta, desde os anos 80, com a utilização dos sistemas de comunicação mediados pelo computador as propostas de EAD assumem as mais diferentes formas e integram recursos educativos diversos que se distribuem ao longo de um continuum no universo mass-media ${ }^{36}$.

36 Pode-se classificar a EAD segundo a mídia utilizada, em três gerações. Primeira geração: ensino por correspondência, mídia única. Segunda geração: educação a distância por multimídia, modelo industrial. Suas características principais são: usa mídia unidire- 
A sua definição e conseqüente repercussão no ambiente educativo das universidades e no mundo do trabalho, em sentido mais amplo, requer, antes de tudo, um exercício, de natureza curricular, que possibilite revisitar, conjuntamente, dimensões importantes as relações de ensino-aprendizagem, quais sejam: a organização e o planejamento do trabalho pedagógico, as metodologias inovadoras e a produção de materiais didáticos específicos, dentre outras.

De acordo com Santos \& Alves (2006) e Correa (2007), as várias modalidades de utilização da EAD representam uma importante vertente de comunicação para as comunidades universitárias na constituição de experiências curriculares e didático-pedagógicas diferenciadas, concebidas sob a égide dos paradigmas de conhecimento em rede. Assim, o essencial é promover nas salas de aula espaços críticos e criativos de reflexão/debate, mobilizando os estudantes em exercícios significativos para eles, de modo que desenvolvam um olhar 'clínico' sobre os fenômenos sociais.

As possibilidades de uso e as promessas da informática, quer na democratização da informação e da equalização das oportunidades educacionais, quer na direção da auto-instrução e do enriquecimento pessoal, mexeram com os educadores de diferentes matizes teóricos e ideológicos em vários recantos do planeta. Considerando, pois, que os avanços tecnológicos não constituem por si mesmos e isoladamente limitações ao progresso dos veículos de comunicação, é urgente desenvolver, principalmente na América Latina, culturas curriculares que potencializem a socialização de informações por meio do uso e da produção de diferentes mídias, como por exemplo: jornais, murais, programas de rádio, sites na internet, documentários etc.

Essas promessas chegaram ao Brasil, de acordo com Valentini e Soares (2005); Sancho e Hernandez (2006), e se intensificaram nos anos 80 com o desenvolvimento de pesquisas universitárias sobre a efetividade pedagógica da utilização dos computadores e demais ferramentas virtuais nas escolas públicas e, mais recentemente, a

cional (impressos, transmissões de TV, cassetes) com comunicação bidirecional via tutores. Terceira geração: sistemas eletrônicos. A comunicação bidirecional estabelece-se via tecnologia e não tutor. 
partir da instalação de centros de estudo sobre as novas tecnologias da informação.

Em solo brasileiro, os programas de informática educativa viabilizados, desde a Educação Básica até o Ensino Superior, objetivaram provocar mudanças pedagógicas expressivas, mas os indicadores de resultados já obtidos não foram suficientes para sensibilizar ou alterar o sistema educacional como um todo.

Apesar dos apelos da mídia e das qualidades inerentes do computador, até hoje a realidade vigente em nosso país é que a disseminação dos computadores nas instituições educativas está até muito aquém dos níveis desejados. Afora isso, segundo Citelli (2007); Vigneron \& Oliveira (2007), apesar da existência de diversas experiências que provocaram transformações nos modos operandi enraizado na Área da Educação, elas não se alastraram de forma igualitária nas instituições, do ponto de vista regional. Isto pode ser atribuído, provavelmente, ao conservadorismo ainda hegemônico na Área, isto é, à sua forte tendência de reagir às inovações. Quando tal reação torna-se impossível, a escola procura domesticar as inovações, utilizando-as na ótica de reprodução e reforço de práticas pedagógicas tradicionais, que passam a ter uma "nova roupagem", permanecendo em sua maioria inalteradas.

Incentivar o incremento de programa de informática educativa em ambientes escolares não é suficiente. A consolidação de processos e práticas de EAD no Brasil requer um esforço ampliado e articulado, de cunho eminentemente curricular, aliando de modo conjunto, questões operacionais de natureza técnica e pedagógicas, de fundo epistemológico. O que se busca em síntese, é poder dar concretude ao conceito de sociedade educativa, concebida como principio básico na compreensão da atual dinâmica planetária (VALENTE \& ALMEIDA, 2007).

Nesse sentido, deve-se priorizar outras dimensões, tais como a qualidade intrínseca ao trabalho educativo aplicado em programas e ações de EAD, dado esse, que foi de certa forma subestimado na implementação das políticas em sua base de atuação, ou seja, nos sistemas educativos e unidades institucionais. Alguns elementos precisam ser por eles revistos, em sua gênese e constituição. São eles: a) confiabilidade os ambientes virtuais; b) clareza de objetivos e metas; c) organização 
ágil e administração eficiente e eficaz do sistema; d) garantia de suporte tecnológico adequado para a realização de atividades grupais.

\section{Sociedade educativa, princípio da atual dinâmica planetária}

Para tratar da questão relativa as exigências da Educação na era do conhecimento merecem destaque as conclusões apresentadas no "Relatório para a UNESCO da Comissão Internacional sobre Educação para o Século XXI" (DELORS et alii, 2007), realizado no período compreendido entre 1993 e 1996. Sendo, pois configurado como uma importante iniciativa para o fortalecimento da política de educação para todos ${ }^{37}$, em busca de sociedade mais humana e justa, o Relatório prioriza a noção de educação ao longo da vida e a possibilidade de se pensar e construir um destino comum. Ou seja, uma sociedade educativa baseada na aquisição, atualização e utilização dos conhecimentos e que busca o aprender a viver juntos, desenvolvendo o conhecimento acerca dos outros, da sua história, tradições e espiritualidade, a fim de que cada um compreenda melhor a si mesmo.

A noção de educação ao longo da vida, representa assim, um dos eixos fundamentais de ingresso no século XXI e conduz ao conceito de sociedade educativa. Dados os aspectos positivos trazidos com essa noção em termos de flexibilidade, diversidade e acessibilidade no tempo e no espaço é possível, por um lado, rever o entendimento acerca da educação permanente, como sendo uma necessidade de renovação cultural. E por outro, resgatar três dimensões básicas da educação: ética e cultural; científica e tecnológica; econômica e social, de modo a conciliar quantidade e pertinência, eqüidade e qualidade.

Ganham destaque nesse cenário um conjunto de questões relativas à sociedade, que vão desde a liberdade política, econômica e social, à possibilidade de exprimir o poder de criação e à capacidade de produzir, perpassando pela dignidade pessoal e pelo respeito aos direitos

37 As discussões a esse respeito foram desencadeadas, inicialmente, por ocasião da Conferência Mundial de Educação para Todos, em Jomtien na Tailândia, no início dos anos 90 , sobre educação básica e necessidades educativas fundamentais. 
humanos. Para melhor exemplificar essa tendência, podemos citar os dados relacionados à saúde, educação e meio ambiente, tais como as taxas de mortalidade infantil, alimentação e nutrição, acesso à água potável, etc.

Diante do processo de interdependência planetária e de globalização das relações político-sociais, econômicas e culturais consideradas como sendo um dos acontecimentos marcantes desse século e sem dúvida alguma, fatores determinantes no traçado de um novo mapa para o mundo contemporâneo, as políticas educativas têm por principais objetivos contribuir para a melhoria da qualidade de vida, redefinir os critérios de desenvolvimento humano sustentável e estimular vivências concreta da democracia.

Concebidas como um processo constante de aprimoramento do saber-fazer, de gerenciar as transições e do desenvolvimento de talentos, potencialidades e aptidões criativas, a atividade educativa e formativa em todos os seus componentes, torna-se nesse sentido, elemento central na dinâmica social e mola propulsora para um desenvolvimento humano sustentável, devendo superar os limites restritos do contexto nacional e incorporar uma dimensão social e cultural mais abrangente na análise crítica da situação mundial.

Compreender essa nova dinâmica planetária perpassa, substancialmente, pelo conhecimento racional acerca dos diversos modos de vida existentes noutras culturas, das alternativas encontradas para solucionar os graves problemas que afetam a humanidade e da repercussão causada por essas soluções em diferentes contextos sociais (PRATA e NASCIMENTO, 2007).

Todavia, em meio as exigências da vida contemporânea, não se pode deixar de considerar a função exercida pelos sistemas educativos ao fornecer as bases de uma cidadania que incorpora as necessidades oriundas das sociedades da informação. Com o aparecimento e o desenvolvimento dessas sociedades caracterizadas, em essência, pela digitalização da informação ocorreu uma profunda revolução no universo da comunicação, reforçado tanto pela dimensão cada vez mais imaterial do trabalho, quanto pela relevância atribuída às aptidões cognitivas.

Evidencia-se, nesse contexto, a atuação dos docentes como agentes de mudança na formação de pessoas capazes de evoluir, interagir e 
discernir, orientadas num mundo em constantes transformações para pensar e agir de modo crítico e autônomo. A dinâmica imposta pelas sociedades da informação, constitui, desta forma, um elemento primordial ao entendimento da atualidade, na medida em que cria formas diferenciadas de socialização, através da interatividade, que disponibiliza a veiculação de imagens e de palavras em qualquer parte do mundo em tempo real.

A educação deve subsidiar, também o cidadão, para que ele possa ter consciência plena de suas raízes históricas, a fim de dispor de referenciais de análise que lhe possibilitem situar-se no mundo, a partir da leitura crítica e da conseqüente redefinição da noção de identidade individual e coletiva, sob a ótica de "afirmar sua diferença, descobrir os fundamentos da sua cultura, reforçar a solidariedade do grupo" (DELORS et alii, 2007, p. 48).

Afora isso, de acordo com as conclusões apresentadas no Relatório da UNESCO, a educação e as múltiplas formas que pode revestir, ganham espaços, progressivamente nas sociedades contemporâneas, à medida que os recursos cognitivos são considerados fatores de desenvolvimento. Frente a essa constatação, os sistemas educativos precisam estruturar-se na elaboração de programas e na definição de novas políticas educacionais, em torno de quatro pilares do conhecimento considerados como aprendizagens fundamentais e bases da educação na aquisição, atualização e utilização dos saberes. São eles, aprender a conhecer, aprender a fazer, aprender a viver juntos e aprender a ser.

Aprender a conhecer - em decorrência das inovações suscitadas pelo progresso científico e tecnológico e pela emergência de novos paradigmas no campo econômico e social, surge a primeira aprendizagem. Caracterizada como meio e fim último da existência humana, supõe o exercício da atenção, memória e pensamento, ao mesmo tempo em que, traduz os anseios em conciliar tanto a aquisição de uma cultura geral, quanto o domínio dos instrumentos e conceitos resultantes dos avanços do conhecimento em busca de compreender melhor o ambiente em suas múltiplas dimensões.São, pois, ações importantes nesse universo conceitual: despertar a curiosidade epistemológica, estimular o senso crítico na apreensão do real e conquistar a autonomia na capacidade de raciocinar e discernir. 
Aprender a fazer - a segunda aprendizagem está relacionada mais diretamente à questão da formação profissional e requer vínculos mais estreitos entre o universo do trabalho e da escola. $\mathrm{O}$ acesso a cultura científica e acadêmica, incluindo os avanços das tecnologias digitais, trouxeram modificações radicais nas qualificações exigidas pelos novos processos de produção. Além da aprendizagem de uma determinada profissão, há que se adquirir uma visão de conjunto, que possibilite ao cidadão enfrentar toda e qualquer situação e a trabalhar em equipe. Dá-se ênfase, portanto, a noção de qualificação atrelada à idéia de competência evolutiva e capacidade de adaptação, direcionada para os processos de inovação e criação, a partir do desenvolvimento de certas especificidades, tais como: a habilidade de organizar o trabalho coletivo ou grupos de projetos; de julgar, gerir e solucionar conflitos, estabelecendo relações estáveis e eficazes; além da intuição e do poder de comunicação.

Aprender a viver juntos - a educação deve possibilitar aos cidadãos a aquisição de saberes e conhecimentos acerca dos elementos subjacentes ao contexto de diversidade e universalidade no qual está inserida espécie humana. Nesse sentido, a atuação dos sistemas educativos busca superar os valores universais e aprender a conviver com a diferença, com base nos valores de pluralismo, compreensão mútua e paz, como forma de atender a terceira aprendizagem em destaque, numa dupla direção: a descoberta progressiva do outro, aliada a percepção das interrelações e a participação em projetos comuns.

Aprender a ser - a quarta aprendizagem aborda, de modo particular, o papel desempenhado pela educação na formação integral de seres humanos ao elaborar pensamentos autônomos e críticos: corpo, inteligência, sensibilidade, sentido estético, responsabilidade pessoal e espiritualidade; desenvolvendo, simultaneamente, a liberdade de expressão, sentimentos e imaginação, bem como o espírito de iniciativa e o discernimento em seus próprios juízos de valor. $\mathrm{Na}$ condição de processo individualizado e de construção social interativa, as atividades educativas devem dar importância especial às potencialidades das pessoas, em termos de memória, raciocínio, sentido estético, capacidades físicas e intuitivas, facilidades de comunicação, dentre outras. 
Apesar da clareza conceitual em relação ao espaço ocupado pela educação na sociedade contemporânea, existem ainda, algumas barreiras a vencer. Dentre elas podemos citar: as tensões entre o global e o local, o universal e o singular, a tradição e a modernidade, o espiritual e o material, as soluções a curto e longo prazo, a eqüidade em relação às políticas sociais e educativas e a dinâmica da competição, o extraordinário desenvolvimento dos conhecimentos e as capacidades de assimilação pelo homem.

Sob a égide de uma revolução criativa das políticas educativas, há que se reforçar, em síntese, o momento histórico vivenciado nas sociedades com características planetárias: a busca pela promoção de uma cultura da convergência e da cooperação, vislumbrados por meio da coesão social, da mobilidade humana e da aprendizagem da vida em comunidade.

Para estruturar o trabalho pedagógico em educação a distância nas escolas, de modo que tenham ressonância com esse novo contexto que se vislumbra, o campo de currículo pode trazer valiosas contribuições. Cabe, portanto, indagar na seqüência: $\mathrm{O}$ que mudou nesses últimos vinte anos no campo de currículo? O que é necessário reconstruir? Quais são as temáticas emergentes?

\section{Uma visão metacognitiva da formação profissional}

As novas possibilidades curriculares que ora se apresentam vão desde a mais simples e antigas formas de comunicação escrita, como por exemplo o ensino por correspondência sem apoio de tutoria, até os mais sofisticados arranjos que incluem esquemas interativos de comunicação não-presencial, por meio do rádio e da televisão, do telefone e do fax, de computadores e de redes digitais de comunicação, além de satélites artificiais.

O surgimento dessas novas tecnologias interativas, possibilitou a utilização de ferramentas, tais como: e-mail, BB's, internet, áudio-conferência, videoconferências, softwares e vídeo aulas, etc. E mais do eu isso, com o advento das novas tecnologias eletrônicas, através dos sistemas de simulações, de hipertexto, e de multimídias estão sendo 
ultrapassadas as barreiras de espaço e de tempo físico. Abre-se assim, em especial no setor educacional, uma visão metacognitiva do domínio de formação profissional ao potencializar a re-criação do denominado 'conhecimento em rede'.

Para Barberá, Romiszowski, Sangrá \& Somonson (2006), com o uso integrado dessas modernas tecnologias da comunicação e da informática nos processos de escolarização no Brasil, principalmente a partir dos anos 90, a EAD estimula, do em termos de políticos, uma maior abertura dos sistemas educacionais, aliada à flexibilização dos currículos e do ponto de vista micro, cria propicia novas condições metodológicas para o desenvolvimento da autonomia dos/as estudantes e a apropriação coletiva dos saberes. Afora isso, sendo usado de forma adequada, o computador e a internet são recursos eficazes no Brasil contra a disseminação de fotocópias ilegais de livros etc.

A EAD permite, assim, maior agilidade na aquisição de conhecimentos e saberes, bem como versatilidade dos meios para atingir diferentes faixas etárias, níveis de aprendizagem, ambientes urbanos e rurais, criando condições de acesso, permanência, democratização e universalização do saber e da formação continuada de recursos humanos.

Ao introduzir um novo olhar sobre o processo educacional estruturado com base no ensino presencial convencional e desenvolvido sob a forma usual do magister dixt, as iniciativas de EAD trazem, de acordo com Moraes (2007), mudanças substantivas nas noções de tempo e espaço pedagógicos. A valorização dos processos de autoaprendizagem é uma dessas possibilidades

Outra característica importante dessa modalidade de educação é a eficácia das dinâmicas organizacionais e administrativas, contribuindo para a queda das barreiras burocráticas do ensino convencional. Mecanismos de inscrição simplificados, distribuição rápida de materiais de estudo, informações objetivas e orientação pedagógica constante aos alunos, tanto no período inicial dos estudos como no seu transcurso, são bons exemplos do que se constitui em elemento diferenciador.

Vale relembrar contudo, que a constituição de um sistema de educação à distância depende da criação de uma estrutura organizada e complexa a disposição dos estudantes, distribuída por meio de meios 
vários meios de comunicação bidirecional e composta por subsistemas integrados, do tipo: fontes de informação e comunicação, gerenciamento e apoio de um serviço de tutoria, além da produção de materiais didáticos auto-instrucionais, como por exemplo guias de estudo, livros-texto.

A partir da participação interativa do aluno com as fontes de informação nas chamadas infovias, cria-se uma nova ecologia da aprendizagem e que não está restrita apenas ao que se tem denominado de aprendizagem a distancia. Concebida desse modo, a partir de uma visão mais abrangente, as iniciativas de EAD estimulam conjuntamente, os mecanismos cognitivos de conhecer, descobrir e criar e re-criar as habilidades lógicas, comunicativas e participativas. Dessa perspectiva, a EAD se configura como sendo uma prática social, estruturada com base nos processos de aprendizagem auto-dirigida e na idéia de interatividade. Mas concretamente, o que isso representa?

Em termos pedagógicos, a EAD representa a reconstrução dos saberes articulada às experiências vividas em módulos temáticos que propiciam a aprendizagem autônoma dos estudantes de diversas idades, em grupos ou individualmente. Ressalta-se, contudo, que o elemento a distância engloba, ainda, procedimentos didático-metodológicos distintos e flexíveis, que incentivam a capacidade de observação, de crítica e o pluralismo de idéias fundamentados em duas dimensões: temporal e espacial, entre docentes e estudantes.

O distanciamento físico entre os sujeitos não exclui, porém, a possibilidade de que seja previsto no esquema operacional proposto, a execução de atividades presenciais. Em conformidade com esse pensamento, a autora destaca o posicionamento assumido pela Comissão da União Européia, já ao final dos anos 90, ao recomendar a utilização da denominação "aprendizagem aberta e a distância" (open distance learning), que contempla diferentes formas e estruturas de EAD.

\section{Limitações e desafios de uma nova modalidade de ensino}

Do ponto de vista teórico as vantagens da EAD já estão comprovadas, na prática, porém as dúvidas persistem em relação a inserção da 
EAD na estrutura organizacional e curricular das instituições escolares. Pode-se distinguir entre o que sejam problemas da EAD e dificuldades circunstanciais no desenvolvimento de uma abordagem didático-pedagógica específica.

Em relação a isso, é oportuno salientar, que os problemas estruturais ainda persistem na cultura brasileira, apenas conquistaram um status diferenciado. Recente pesquisa atesta que brasileiros lêem pouco, usam mais rádio, televisão e internet. Algumas dessas questões residem numa confusão conceitual entre a utilização das tecnologias da informação e da comunicação, como um conjunto de ferramentas da EAD, e a prática social da EAD em si, ou seja, a abertura das possibilidades de acesso à informação não é equivalente ao acesso ao conhecimento e às oportunidades de educação.

Dentre as limitações apontadas aparece a ênfase na dimensão cognitiva e na padronização de um determinado esquema operacional, práticas essas, fundamentadas numa visão ontológica empirista e numa epistemologia positivista, em detrimento de uma perspectiva relacional da comunicação entre professor-aluno.

Segundo Barajas \& Álvares (2003), a tarefa enfrentada pelos profissionais na modalidade à distância, tendo em vista oferecer criar, implantar e avaliar projetos curriculares para novos cursos, assemelha-se muito, em vários sentidos, à tarefa que enfrentam os educadores na modalidade presencial. Ambas as equipes devem elaborar projetos de curso que desenvolvam temas relevantes, implementar propostas pedagógicas adequadas às necessidades da comunidade, além de enfrentarem o desafio de conceber propostas diferenciadas de avaliação tanto da aprendizagem, quanto institucionais.

A partir de meados dos anos 80 , evidencia-se o incentivo dado principalmente pelos países desenvolvidos, na criação dos sistemas nacionais de educação à distância.

Em relação às iniciativas de estudos e pesquisas nessa área, surgem, dentre outros, trabalhos que apresentam a proposição de novas metodologias fundamentadas na idéia de uma pedagógica andragógica, direcionada obviamente para o público adulto e diferentes daquelas centradas nas práticas vivenciadas com adolescente, por exemplo, que são em essência heteronômicas. 
No rol dessas iniciativas, não se pode deixar de considerar que as aquisições das tecnologias educacionais são de extrema valia para a construção de procedimentos metodológicos e operacionais diferenciados. Subjaz a essa prerrogativa a idéia de que a tecnologia educacional deve ser compreendida no interior dos processos culturais e de comunicação educacional.

O espaço institucional escolar carece de experiências de EAD nos processos curriculares e didático-pedagógicos, que superem as tradições behaviorista e economicista, baseados em sistemas burocráticos de acesso, controle e. e avaliação e com isso, possam se adequar às exigências da sociedade pós-industrial. Entendemos que, assim como a cultura é um instrumento mediador, as ferramentas utilizadas pelo homem também o são, as quais representam produtos da cultura. Ensinar a trabalhar com tecnologias como instrumentos da cultura implica mediatizá-las e, ao mesmo tempo, configurar relações particulares com o meio físico e social.

Fazendo uma análise de caráter didático-pedagógico outros aspectos merecem destaque nesse contexto. O impacto das tecnologias interativas na educação estimula a criação de melhores oportunidades para a aprendizagem, e não simplesmente para prover apenas um acúmulo de informações. O principal desafio da EAD continua sendo seu sentido democratizante, a qualidade da proposta pedagógica e de seus materiais. Sua essência consiste, assim, na criação de um conhecimento compartilhado.

Para finalizar, pode-se dizer que as possibilidades da EAD são de extrema valia para a conquista da autonomia, o que não quer dizer autodidatismo. No cenário de um curso on-line, por exemplo, onde se utilizam as várias funções da web de forma autônoma, os estudantes podem realizar trabalhos coletivos na rede em uma hora determinada pré-estabelecida anteriormente. No mundo em rede as informações não estão embutidas em grandes e complexos módulos, mas sim em unidades específicas e bem delimitadas, envolvendo textos, sons e imagens, acesso a documentos e transferência instantânea de arquivos. Além isso, os processos de qualificação profissional em especial, ao lado das atividades presenciais a criação de ambientes virtuais de 
aprendizagem mostram-se de suma importância para a realização cooperativa de projetos de formação em serviço, continuada e a distância no que diz respeito, tanto à facilitação do acesso à informação quanto à participação interativa na socialização e atualização dos saberes.

Referências

ADOLFO, Luiz Gonzaga Silva. Globalização e estado contemporâneo. SP:Memória Jurídica, 2001.

ALMEIDA, Maria Elizabeth; ALONSO, Myrtes. Tecnologias na formação e na gestão escolar. São Paulo: Avercamp, 2007.

BARAJAS, Mario (Coord.); ALVAREZ Beatriz (Ed.). La tecnologia educativa en la enseiñanza superior: entornos virtuales de aprendizaje. Madrid: McGraw-Hill, 2003.

BARBERÁ, Elena; ROMISZOWSKI, Alexander; SANGRÁ, Albert; SIMONSON, Michael. Educación abierta y a distancia. Barcelona: UOC, 2006.

CITELLI, Adilson. Palavras, meios de comunicação e educação. São Paulo: Cortez, 2007.

CORREA, Juliane (Org.). Educação a distância: orientações metodológicas. Porto Alegre: ArtMed, 2007.

DELORS, Jacques (org.). Educação: um tesouro a descobrir. 5aㅡ Ed., São Paulo: Cortez; Brasília: MEC, UNESCO, 2007.

KENSKI, Vaní M. Educação e tecnologias: o novo ritmo da informação. Campinas: Papirus, 2007.

MOORE, Michael; KEARSLEY, Greg. Educação a distância: uma visão integrada. São Paulo: Thomson, 2007.

MORAES, Ubirajara C. (Org.). Tecnologia educacional e aprendizagem: o uso dos recursos digitais. São Paulo: Livro Pronto, 2007. 
MORAN, Jose M. A educação que desejamos: novos desafios e como chegar lá. Campinas: Papirus, 2007.

PETERS, Otto A educação a distância em transição: tendências e desafios. Trad. Leila F. de Souza Mendes. São Leopoldo. UNISINOS, 2003.

PETERS, Otto Didática do ensino a distância: experiências e estágio da discussão numa visão internacional. Trad. Ilson Kayser. São Leopoldo. UNISINOS, 2001.

PRATA, Carmem L. NASCIMENTO, Anna C. Objetos de aprendizagem: uma proposta pedagógica. Brasília: MEC/Seed, 2007.

SANCHO, Juana M.; HERNÁNDEZ, Fernando et al. Tecnologias para transformar a educação. Porto Alegre: Artmed, 2006.

SANTOS, Edméa; ALVES, Lynn (Org.). Práticas pedagógicas e tecnologias interativas. Rio de Janeiro: e-papers, 2006.

VALENTE, José A.; ALMEIDA, Maria Elizabeth. Formação de educadores a distância e integração de mídias. São Paulo: Avercamp, 2007.

VALENTINI, Carla B.; SOARES, Eliana M. (Org.). Aprendizagem em ambientes virtuais: compartilhando idéias e construindo cenários. Caxias do Sul: Educs, 2005.

VIGNERON, Jacques; OLIVEIRA, Vera Barros. Sala de aula e tecnologias. São Bernardo do Campo. UMESP, 2007. 


\section{EDUCOMUNICAÇÃO E DIREITOS HUMANOS}

Debora Amorim Radanovitsck

“Onde termina a lei começa a tirania” (John Locke 2000, p. 90)

\section{INTRODUÇÃO}

Os processos educomunicativos se dão em diversos aspectos da educação formal e não formal. Porém, com a aceleração do tempo, com a fruição cada vez maior de telas (compreendidas aqui televisão, cinema, computadores e dispositivos móveis), essa utilização e apropriação precisam ser observadas - e testadas - dentro de um fenômeno que a desumanização causada pela virtualidade de mediações, seja com pares, seja com a realidade de mundo propriamente dita, e isso impacta diretamente no conhecimento, empoderamento e valorização dos Direitos Humanos. Esse estudo fomenta-se em referenciais teóricos como alicerce para uma proposta de intervenção por meio de podcast e exemplos práticos.

\section{DIREITOS HUMANOS}

A Declaração Universal dos Direitos Humanos (DUDH) é um documento marco na história dos direitos humanos. Elaborada por representantes de diferentes origens jurídicas e culturais de todas as regiões do mundo, a Declaração foi proclamada pela Assembleia Geral das Nações Unidas em Paris, em 10 de dezembro 
de 1948, estabelecendo, pela primeira vez, a proteção universal dos direitos humanos. Compreendendo que a proposta desse projeto é a apropriação desses valores, torna-se extremamente relevante a citação integral da declaração.

Declaração Universal dos Direitos humanos (1948):

Artigo 1

Todos os seres humanos nascem livres e iguais em dignidade e direitos. São dotados de razão e consciência e devem agir em relação uns aos outros com espírito de fraternidade.

Artigo 2

1. Todo ser humano tem capacidade para gozar os direitos e as liberdades estabelecidos nesta Declaração, sem distinção de qualquer espécie, seja de raça, cor, sexo, língua, religião, opinião política ou de outra natureza, origem nacional ou social, riqueza, nascimento, ou qualquer outra condição.

2. Não será também feita nenhuma distinção fundada na condição política, jurídica ou internacional do país ou território a que pertença uma pessoa, quer se trate de um território independente, sob tutela, sem governo próprio, quer sujeito a qualquer outra limitação de soberania.

Artigo 3

Todo ser humano tem direito à vida, à liberdade e à segurança pessoal.

Artigo 4

Ninguém será mantido em escravidão ou servidão; a escravidão e o tráfico de escravos serão proibidos em todas as suas formas.

Artigo 5

Ninguém será submetido à tortura, nem a tratamento ou castigo cruel, desumano ou degradante. 
Artigo 6

Todo ser humano tem o direito de ser, em todos os lugares, reconhecido como pessoa perante a lei.

Artigo 7

Todos são iguais perante a lei e têm direito, sem qualquer distinção, a igual proteção da lei. Todos têm direito a igual proteção contra qualquer discriminação que viole a presente Declaração e contra qualquer incitamento a tal discriminação.

Artigo 8

Todo ser humano tem direito a receber dos tribunais nacionais competentes remédio efetivo para os atos que violem os direitos fundamentais que lhe sejam reconhecidos pela constituição ou pela lei.

Artigo 9

Ninguém será arbitrariamente preso, detido ou exilado.

Artigo 10

Todo ser humano tem direito, em plena igualdade, a uma justa e pública audiência por parte de um tribunal independente e imparcial, para decidir seus direitos e deveres ou fundamento de qualquer acusação criminal contra ele.

Artigo 11

1.Todo ser humano acusado de um ato delituoso tem o direito de ser presumido inocente até que a sua culpabilidade tenha sido provada de acordo com a lei, em julgamento público no qual the tenham sido asseguradas todas as garantias necessárias à sua defesa.

2. Ninguém poderá ser culpado por qualquer ação ou omissão que, no momento, não constituíam delito perante o direito nacional ou internacional. Também não será imposta pena mais forte de que aquela que, no momento da prática, era aplicável ao ato delituoso. 


\section{Artigo 12}

Ninguém será sujeito à interferência na sua vida privada, na sua família, no seu lar ou na sua correspondência, nem a ataque à sua honra e reputação. Todo ser humano tem direito à proteção da lei contra tais interferências ou ataques.

\section{Artigo 13}

1. Todo ser humano tem direito à liberdade de locomoção e residência dentro das fronteiras de cada Estado.

2. Todo ser humano tem o direito de deixar qualquer país, inclusive o próprio e a esse regressar.

Artigo 14

1. Todo ser humano, vítima de perseguição, tem o direito de procurar e de gozar asilo em outros países.

2. Esse direito não pode ser invocado em caso de perseguição legitimamente motivada por crimes de direito comum ou por atos contrários aos objetivos e princípios das Nações Unidas.

Artigo 15

1. Todo ser humano tem direito a uma nacionalidade.

2. Ninguém será arbitrariamente privado de sua nacionalidade, nem do direito de mudar de nacionalidade.

Artigo 16

1. Os homens e mulheres de maior idade, sem qualquer restrição de raça, nacionalidade ou religião, têm o direito de contrair matrimônio e fundar uma família. Gozam de iguais direitos em relação ao casamento, sua duração e sua dissolução.

2. O casamento não será válido senão com o livre e pleno consentimento dos nubentes.

3. A família é o núcleo natural e fundamental da sociedade e tem direito à proteção da sociedade e do Estado. 


\section{Artigo 17}

1. Todo ser humano tem direito à propriedade, só ou em sociedade com outros.

2. Ninguém será arbitrariamente privado de sua propriedade.

Artigo 18

Todo ser humano tem direito à liberdade de pensamento, consciência e religião; esse direito inclui a liberdade de mudar de religião ou crença e a liberdade de manifestar essa religião ou crença pelo ensino, pela prática, pelo culto em público ou em particular.

Artigo 19

Todo ser humano tem direito à liberdade de opinião e expressão; esse direito inclui a liberdade de, sem interferência, ter opiniões e de procurar, receber e transmitir informações e idéias por quaisquer meios e independentemente de fronteiras.

Artigo 20

1. Todo ser humano tem direito à liberdade de reunião e associação pacífica.

2. Ninguém pode ser obrigado a fazer parte de uma associação.

Artigo 21

1. Todo ser humano tem o direito de tomar parte no governo de seu país diretamente ou por intermédio de representantes livremente escolhidos.

2. Todo ser humano tem igual direito de acesso ao serviço público do seu país.

3. A vontade do povo será a base da autoridade do governo; essa vontade será expressa em eleições periódicas e legítimas, por sufrágio universal, por voto secreto ou processo equivalente que assegure a liberdade de voto. 


\section{Artigo 22}

Todo ser humano, como membro da sociedade, tem direito à segurança social, à realização pelo esforço nacional, pela cooperação internacional e de acordo com a organização e recursos de cada Estado, dos direitos econômicos, sociais e culturais indispensáveis à sua dignidade e ao livre desenvolvimento da sua personalidade.

\section{Artigo 23}

1. Todo ser humano tem direito ao trabalho, à livre escolha de emprego, a condições justas e favoráveis de trabalho e à proteção contra o desemprego.

2. Todo ser humano, sem qualquer distinção, tem direito a igual remuneração por igual trabalho.

3. Todo ser humano que trabalha tem direito a uma remuneração justa e satisfatória que lhe assegure, assim como à sua família, uma existência compatível com a dignidade humana e a que se acrescentarão, se necessário, outros meios de proteção social.

4. Todo ser humano tem direito a organizar sindicatos e a neles ingressar para proteção de seus interesses.

\section{Artigo 24}

Todo ser humano tem direito a repouso e lazer, inclusive a limitação razoável das horas de trabalho e a férias remuneradas periódicas.

\section{Artigo 25}

1. Todo ser humano tem direito a um padrão de vida capaz de assegurar a si e à sua família saúde, bem-estar, inclusive alimentação, vestuário, habitação, cuidados médicos e os serviços sociais indispensáveis e direito à segurança em caso de desemprego, doença invalidez, viuvez, velhice ou outros casos de perda dos meios de subsistência em circunstâncias fora de seu controle. 
2. A maternidade e a infância têm direito a cuidados e assistência especiais. Todas as crianças, nascidas dentro ou fora do matrimônio, gozarão da mesma proteção social.

Artigo 26

1. Todo ser humano tem direito à instrução. A instrução será gratuita, pelo menos nos graus elementares e fundamentais. A instrução elementar será obrigatória. A instrução técnico-profissional será acessível a todos, bem como a instrução superior, esta baseada no mérito.

2. A instrução será orientada no sentido do pleno desenvolvimento da personalidade humana e do fortalecimento do respeito pelos direitos do ser humano e pelas liberdades fundamentais. A instrução promoverá a compreensão, a tolerância e a amizade entre todas as nações e grupos raciais ou religiosos e coadjuvará as atividades das Nações Unidas em prol da manutenção da paz.

3. Os pais têm prioridade de direito na escolha do gênero de instrução que será ministrada a seus filhos.

Artigo 27

1. Todo ser humano tem o direito de participar livremente da vida cultural da comunidade, de fruir as artes e de participar do progresso científico e de seus benefícios.

2. Todo ser humano tem direito à proteção dos interesses morais e materiais decorrentes de qualquer produção científica literária ou artística da qual seja autor.

Artigo 28

Todo ser humano tem direito a uma ordem social e internacional em que os direitos e liberdades estabelecidos na presente Declaração possam ser plenamente realizados.

Artigo 29

1. Todo ser humano tem deveres para com a comunidade, na qual o livre e pleno desenvolvimento de sua personalidade é possível. 
2. No exercício de seus direitos e liberdades, todo ser humano estará sujeito apenas às limitações determinadas pela lei, exclusivamente com o fim de assegurar o devido reconhecimento e respeito dos direitos e liberdades de outrem e de satisfazer as justas exigências da moral, da ordem pública e do bem-estar de uma sociedade democrática.

3. Esses direitos e liberdades não podem, em hipótese alguma, ser exercidos contrariamente aos objetivos e princípios das $\mathrm{Na}$ ções Unidas.

\section{Artigo 30}

Nenhuma disposição da presente Declaração poder ser interpretada como o reconhecimento a qualquer Estado, grupo ou pessoa, do direito de exercer qualquer atividade ou praticar qualquer ato destinado à destruição de quaisquer dos direitos e liberdades aqui estabelecidos. (ONU, 1948, grifo nosso)

\section{EDUCOMUNICAÇÃO}

A Educomunicação pode ser compreendida como um conjunto de práticas que fortalecem a comunicação em uma esfera que engloba os parâmetros sociais e educativos, de maneira democrática, ética e solidária, provendo recursos para que a comunicação, suas linguagens e tecnologias sejam impulsionadores do protagonismo dos comunicantes, bem como um exercício prático do direito universal à expressão.

Uma das utopias dos defensores do conceito é vê-lo adotado em benefício de mais de 50 milhões de estudantes do ensino básico em todo o país, tanto no ensino público quanto no privado, como sinônimo de educação para a plena cidadania ou, ainda, vê-lo colocado a serviço das práticas de sustentabilidade (educomunicação socioambiental), da educação em saúde, da formação de sujeitos em situação de risco, merecendo particular atenção a educação em temas de gênero, raça e etnia. (SOARES, 2011). 


\subsection{EDUCOMUNICAÇÃO COMO PRÁTICA DE ENSINO DE DIREITOS HUMANOS NO ENSINO FUNDAMENTAL ॥}

Tendo como alicerce de pensamento a comunicação, um Direito Humano Universal, e a educação como local de apropriação desse recurso, a Educomunicação se torna um referencial essencial para o educador.

Esse intermédio, pensando em prática docente, se dá não apenas como característica de uma sociedade de produção e consumo de mídias digitais, mas também na formação do cidadão dentro dessa sociedade. Esse processo, que também molda o ser social ética e moralmente, pode e ouso dizer, deve estar alinhado com os Direitos Humanos Universais. Logo, ensinar para a comunicação é ensinar Direitos Humanos.

Soares (2011) defende que a escola deve educar para a incerteza e é necessário que o sistema educativo envolva-se com o mercado, o consumo e o sistema de comunicação que o serve. O homem é um ser de relações e não apenas de contatos, não está apenas no mundo, mas com o mundo. É preciso criar novos modelos de relação pedagógica e comunicativa para que os adultos ensinem não o que os jovens devem aprender, mas como fazê-lo, e não como devem comprometer-se, mas qual é o valor do compromisso. A relação entre educação e educomunicação é direcionada para uma educação emancipatória.

Já Baccega (2011) traz uma visão mais prática do que pode dificultar essa educação para a comunicação, uma vez que as tradicionais agências de socialização, tais como escola e família, vêm se confrontando com os meios de comunicação que se constituem em uma nova agência que permite a socialização. Só é possível construir a cidadania a partir do mundo devidamente conhecido e criticado. Em seus trabalhos, ela aponta alguns desafios, como reconhecer os meios de comunicação como outro lugar do saber, atuando juntamente com a escola e outras agências de socialização. Nesse novo microuniverso, os meios se apresentam como educadores privilegiados, dividindo as funções antes destinadas à escola e ocorre a inclusão de temas como mediação, criticidade, informação e conhecimento, circulação das formas simbólicas, 
ressignificação da escola e do professor, recepção, contextualização sociocultural da realidade, a relação consumo e consumidor, entre muitos outros.

Ainda há a pluralidade de sujeitos, pois a partir da realidade construída e divulgada por eles, é possível conformar nossas identidades, enlaçando-nos. Nesse sentido, jovens e velhos, filhos e pais habitam o mesmo imaginário e usufruem dos mesmos bens simbólicos. Há uma forte incidência dos meios em combinação com as demais agências de socialização sobre a tessitura da cultura, sobre a realidade social. Também a máxima 'estar no mundo e com o mundo' inclui, obrigatoriamente, a possibilidade de leitura do mundo que nos é oferecida pelos meios de comunicação. A mediação que ele exerce entre o leitor da realidade e a sua atuação nela, entre os sujeitos receptores e a sua inserção no processo comunicacional deve ser observada. Já a realidade exige que o conceito de campo cultural seja mais inclusivo. Consta também que o consumo de bens materiais/simbólicos têm predominado o aspecto simbólico, revelando que nesta sociedade da mercadoria só existe valor de troca, e inclui todas as telas, e finalizando, as mídias demandam tempo para sua fruição. (BACCEGA, 2011)

Ao abordar essa educação para os meios, Lopes (2011) diz que com os avanços das pesquisas de recepção orientadas por novas premissas, o processo de recepção é visto para além da relação do sujeito com os meios; ele é captado na trama dos sentidos e tecido pelas mediações que operam no cotidiano das pessoas. Diante dos desafios do neoliberalismo ambiente, torna-se imprescindível que essa perspectiva comunicacional seja integrada à educação para os meios a fim de dar um impulso maior e mais fundamentado em processos pedagógicos, gerando assim maior participação das pessoas na construção cotidiana da cidadania e nos movimentos para a democratização dos meios de comunicação.

Pensando nessa relação mais próxima com o processo educacional, Citelli (2011) reforça que a Licenciatura plena nem sempre instrumentaliza os docentes para esse fim, sendo necessário atualizar as relações entre os sujeitos/agentes professores e alunos, atentando para as mediações patrocinadas pelas múltiplas circunstâncias comunicacionais que os circulam. 
Voltando o olhar para a os educadores, as práticas de Fundamental II e a relativização dos tempos, Costa (2017) diz que os educadores estão absorvendo os fenômenos da contemporaneidade, cifrados por uma dinâmica social mediada pelo universo da comunicação e dinamizada pelas tecnologias. A seu modo, os professores compreendem que as novas temporalidades pedem diferentes formas de ensino-aprendizagem. Igualmente, diante das mutações nos âmbitos social, cultural, político e econômico, entendem a emergência de novas formas de ser, estar e fazer no mundo.

Já Calixto (2017) diz que é necessária uma nova perspectiva para os movimentos de ensino-aprendizagem, explorando fenômenos do ciberespaço em sua mais ampla dimensão, como a compreensão dinâmica das mensagens e informações embutidas em tais recursos. Dados indicam que a velocidade de circulação da informação compromete o tempo/ espaço para reflexões, o que é substancial para a formação de cidadãos. Sem a devida mediação e compreensão da circulação dos mais diversos conteúdos na internet, os fenômenos de aceleração temporal podem impedir que exploremos todas as potencialidades das tecnologias digitais.

Pensando nesses novos espaços cabe uma reflexão acerca da importância da regulamentação da liberdade na rede. O direito à comunicação, bem como a liberdade de expressão, está relacionado com limites à extensão da divulgação de ideias definidos pela lei ou pela tradição de uma sociedade. Segundo Silveira (2014), a rede foi criada a partir da lógica da liberdade prévia e não da necessidade de permissão seja do estado, seja de quaisquer corporações essenciais para o seu funcionamento. Entretanto, a constituição brasileira proíbe o anonimato de se expressar, ou seja, a liberdade de fala só é legal e ampla para quem for civilmente identificado.

O Marco Civil brasileiro é mais do que uma lei que busca defender a internet livre, aberta e regida pela neutralidade e pelo direito à privacidade. Foi elaborado através de um processo inovador, contando com a participação da sociedade civil desde o seu surgimento. Pode-se dizer que é uma lei defensiva.

Nesse sentido de regulamentar e especialmente educar para os Direitos Humanos, foi lançada em 2018, no estado de São Paulo, o Plano 
Nacional de Educação em Direitos Humanos. Esse documento foi elaborado em uma série de plenárias e assembleias nas mais diversas localidades do estado, visando uma ampla participação popular. Entendendo que um dos maiores desafios da sociedade brasileira é construir uma sociedade democrática e popular, por meios de processos que contemplem o pluralismo sem perda da vontade e dos interesses da maioria, o papel estratégico da elaboração da Educação em Direitos humanos é o de assegurar o conhecimento teórico e prático dessas conquistas como forma de resistência à violência e construção de uma cultura de direitos. O Ministério da Educação, junto à Secretaria Especial dos Direitos Humanos, formulou, em 2012, as Diretrizes Nacionais para a Educação em Direitos Humanos, como expressão da materialização dos eixos relativos à Educação Básica e ao Ensino Superior. Segundo o material, as novas gerações têm direito a uma Educação em Direitos Humanos que assegure uma concepção de homem/mulher como sujeitos históricos, a história das lutas sociais e a construção de valores e princípios, como democracia de base, participação ativa, liberdade, dignidade e respeito à diferença como parte da vida social. O plano tem a educomunicação como um de seus pilares, tendo como objetivos a destacar:

Objetivo 1: Ampliar o entendimento do fenômeno comunicativo, nas suas diferentes linguagens, permitindo que as pessoas compreendam que são participantes de ecossistemas comunicativos em suas famílias, grupos de amigos, associações e escolas, neles exercendo importantes direitos, entre os quais, o de expressar-se livremente com responsabilidade e ética.

Objetivo 2: Garantir a oferta de ações educativas em direitos humanos, visando capacitar todos os cidadãos do Estado de São Paulo, desde sua infância, para o exercício da comunicação, incluindo o acesso e uso das tecnologias da informação e da comunicação em seu cotidiano, em benefício pessoal e social.

Objetivo 3: Fortalecer - por meio de editais públicos, programas, premiações, eventos e outras formas de distinção - as iniciativas de comunicação local, em nível comunitário, voltadas 
a favorecer o diálogo sobre diversidade, gênero, questões étnico-racial, LGBT, pessoa com deficiência, idoso, população em situação de rua e infância e juventude, refugiados, pessoas em privação de liberdade e egressos, bem como sobre desigualdades sociais e violações de direitos, entre outras temáticas ligadas aos Direitos Humanos, de modo a dar visibilidade a esses assuntos a partir da visão dos diversos atores sociais.

Objetivo 4: Integrar o sistema público de comunicação e seus canais educativos e culturais ao Plano de Educação em Direitos Humanos do estado de São Paulo, com eles mantendo contato permanente, levando em conta as especificidades de suas respectivas contribuições.

Objetivo 5: . Propor e estimular, nos meios privados de comunicação, a realização de produções midiáticas que contemplem temáticas relativas aos Direitos Humanos, nas diferentes áreas de programação voltadas para a cultura, a informação, o entretenimento e a publicidade.

Objetivo 6: Apoiar o movimento de regularização dos meios de comunicação de caráter alternativo e comunitário como estratégia de ampliar a participação da população na produção cultural sobre os Direitos Humanos.

Objetivo 7: Incluir nos planos de estudo do âmbito formal da educação - do infantil até o final do ensino básico - práticas educomunicativas que facilitem o acesso à formação para o exercício do direito à expressão, assim como para a realização de análises de produtos culturais, de forma a garantir a defesa dos usuários contra eventuais abusos, especialmente na esfera da circulação de mensagens na mídia e nas redes virtuais.

Objetivo 8: Incluir a participação dos órgãos de comunicação mantidos pelos movimentos sociais, de forma a garantir a socialização de informações sobre o tema dos direitos humanos junto à população atendida por estes veículos, favorecendo, especialmente, a divulgação de materiais sobre Educação em Direitos Humanos. 
Objetivo 9: Incentivar a cultura sobre a mídia democrática, responsavelmente conduzida a partir de códigos de ética sintonizados com os valores que dão sustentação ao exercício dos Direitos Humanos.

Objetivo 10: Qualificar a formação inicial e continuada em Direitos Humanos dos profissionais que atuam tanto nos meios de comunicação quanto em sistemas de informação.

Objetivo 11: Publicizar, na formação dos profissionais das áreas de Comunicação e Informação, o tratamento dado pelas pesquisas acadêmicas e setoriais relacionadas ao tema da mídia, infância e juventude.

Objetivo 12: Considerar na definição das políticas públicas de formação em Direitos Humanos, os elementos agregadores advindos das áreas da comunicação e da informação, a partir dos referenciais do eixo "Educomunicação: Educação e Mídia".

Objetivo 13: Promover, como iniciativa dos órgãos públicos, campanhas e ações de comunicação visando o incentivo à disseminação da cultura de respeito aos Direitos Humanos nos meios de comunicação institucional existentes no estado de São Paulo

Objetivo 14: Contemplar nos projetos de formação em Direitos Humanos dos profissionais que trabalham em áreas como Ouvidoria, Segurança, Saúde, Transporte, Assistência Social, Esportes, os elementos relacionados às práticas educomunicativas, com destaque para o diálogo, a solidariedade na aprendizagem, a participação colaborativa de todos os envolvidos nos processos em curso. (São Paulo, 2017)

Pensando nesses objetivos, fica explícita a relevância de práticas educomunicativas para a disseminação e apropriação dos direitos humanos. Portanto, o conhecimento de práticas como a que segue a seguir caminha junto com a responsabilidade docente de sensibilização no assunto. 


\section{SUGESTÃO DE INTERVENÇÃO: PODCAST NA ESCOLA}

Podcast é uma ferramenta de áudio que pode ser produzida com ferramentas comuns no cotidiano e disseminado de acordo com a necessidade de quem o produz. Os áudios gravados e editados podem ser baixados e disponibilizados online, e podem conter os mais diversos conteúdos.

A sugestão que se faz presente é que se utilize a ferramenta podcast para promover debates sobre os Direitos Humanos Universais, com um episódio sobre cada artigo, ou ainda uma conversa mais geral após a leitura de todo o documento.

Com o objetivo de facilitar a prática, segue orientações sobre como fazer a pré-produção de um episódio, bem como sobre equipamentos e publicação do mesmo.

\subsection{PASSO A PASSO PARA A PRODUÇÃO DO PODCAST}

\subsubsection{EQUIPAMENTO}

Os equipamentos necessários para a produção de um podcast são simples. Podem ser utilizados o telefone celular ou tablet com aplicativo de gravação de áudio ou computador com entrada de áudio. Se não houver, pode-se utilizar o microfone embutido dos equipamentos, tais como fone com microfone padrão para chamadas telefônicas, ou microfone externo. É necessário uso de aplicativo de gravação e edição de áudio, que pode ser do próprio celular ou tablet ou software de edição em computador. Como sugestão, recomendamos o Audacity ${ }^{38}$ que é gratuito, intuitivo e é comum em muitos fóruns de usuários, além de possuir vários vídeos tutoriais de fácil acesso.

$38 \mathrm{https}: / /$ audacity.br.uptodown.com/windows 


\subsubsection{PREPARAÇÃO}

Para fazer a preparação, é necessário montar a pauta ${ }^{39}$ da gravação, com abertura; apresentação dos participantes e do mediador (host/ apresentador); introdução ao assunto; tópicos a serem levantados pelos participantes e/ou mediador; conclusão e despedida. Nessa parte, a pesquisa, o domínio do assunto e a clareza nas ideias de cada participante é essencial para a fluidez do programa.

\subsubsection{GRAVAÇÃO}

Procure um local silencioso, com uma acústica que não produza ecos ou outras distorções de som. Uma sugestão é gravar na biblioteca, pois o acúmulo de material isolante como livros ajuda na acústica. Atenção aos avisos sonoros e ao horário de maior fluxo de trânsito nas imediações.

\subsubsection{EDIÇÃO}

Pode ser feita nos próprios aplicativos dos dispositivos onde a gravação foi feita, ou ainda em softwares de edição. Como sugerido acima, o Audacity é gratuito, bastante intuitivo e possui usuários ativos em fóruns e tutoriais disponíveis.

\subsubsection{PUBLICAÇÃO}

O podcast, em formato de áudio MP3, pode ser enviado apenas para um público selecionado. Também pode ser disponibilizado online em uma conta de plataformas de áudio como Soundcloud ou Spotify, ou ainda ser convertido em vídeo com imagem estática e disponibilizado no Youtube.

39 http://mundopodcast.com.br/podcasteando/pauta-criar-podcast/ 


\subsection{EXEMPLOS NA PRÁTICA}

A experiência a seguir foi desenvolvida em 2017, em aulas de curso livre de desenvolvimento de habilidades escritas e comunicacionais, no Centro Educacional Pioneiro, com alunos de sextos e sétimos anos. Os estudantes foram convidados a eleger um tema de seu interesse, pesquisar, montar pautas e roteiros de gravação. Nesse caso, muitos dos alunos se sentiram mais confortáveis lendo o texto que haviam preparado, o que pode ser percebido pela fluidez particular dos programas. Esses episódios foram disponibilizados em playlist no Soundcloud, na conta da escola.

Figura 1 - QR Code do programa "Podcast Oficina Literária"

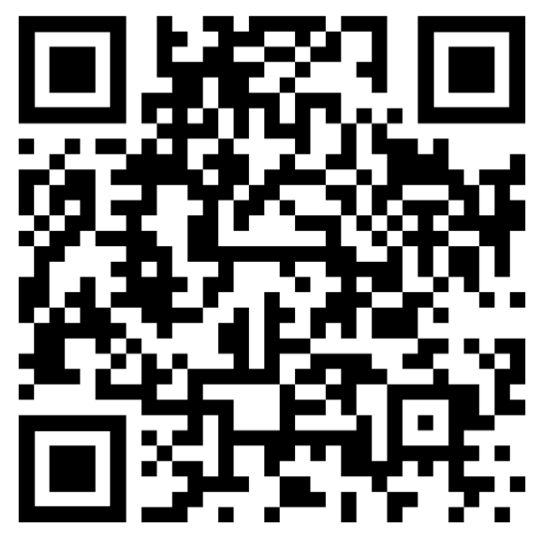

Fonte: Cepioneiro, SoundCloud, 2016.

Outro projeto prático, o episódio Handball (CENTRO EDUCACIONAL PIONEIRO, 2018) teve um trajeto muito parecido com o anterior, porém com publicação no Youtube. A escolha da plataforma fez com que os alunos fossem convidados a elaborar peça gráfica para a imagem do programa. Esses projetos foram gravados em 2018 e estão disponíveis para o público. 
Figura 2 - QR Code do episódio "Handball"

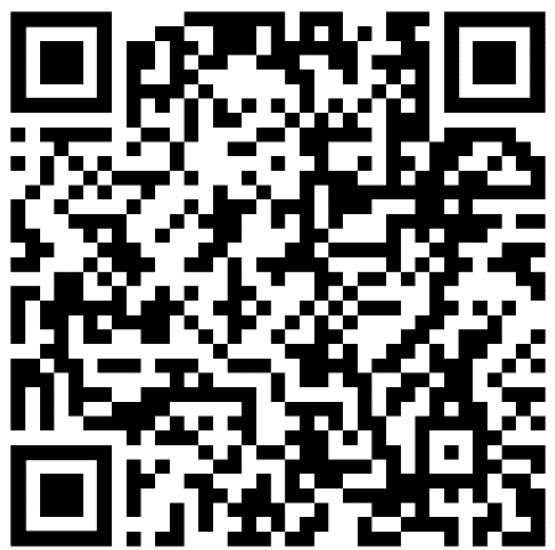

Fonte: Centro Educacional Pioneiro, YouTube, 2018.

\section{CONCLUSÃO}

Com a análise bibliográfica e a vivência prática na realização de podcasts educacionais, se torna latente a necessidade de conciliar as práticas educomunicativas com os processos de apropriação dos direitos humanos. Mídias podem, e devem, humanizar e conscientizar as pessoas, uma vez que permeiam a essência do ser humano do século XXI. Esses processos quando utilizados de maneira responsável e com objetivos assertivos de promoção de debates, apropriação e vivência, com protagonismo de produção de conteúdo, não apenas cumpre o papel da educação enquanto direito humano universal, mas auxiliam que essa educação se torne um efetivo canal de conhecimento e humanização do ser humano. Dessa maneira, convido a ouvir o podcast que foi gravado como complemento desse projeto: 
Figura 3 - QR Code do episódio "Educomunicação e Direitos Humanos - Podcast"

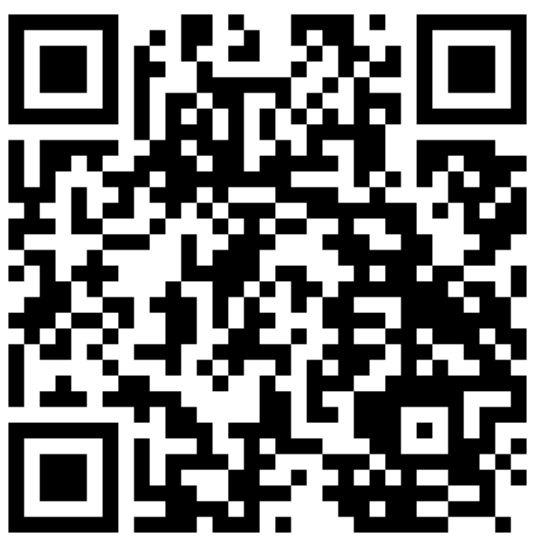

\section{REFERÊNCIAS BIBLIOGRÁFICAS}

BACCEGA, M. Comunicação/educação e a construção de nova variável histórica, In: Educomunicação - construindo uma nova área de conhecimento. São Paulo: Paulinas, 2011.

CALIXTO, D. Dos memes na internet à aceleração temporal entre docentes. In: Educomunicação - comunicação e educação - os desafios da aceleração social do tempo. São Paulo: Paulinas, 2017.

CITELLI, A. Comunicação e educação: implicações contemporâneas. In: Educomunicação - construindo uma nova área de conhecimento. São Paulo: Paulinas, 2011.

CONCEITO. Associação Brasileira de Pesquisadores e Profissionais em Educomunicação. Brasil, 2020. Disponível em: <http://www.abpeducom.org.br/educom/conceito/>. Acesso em: 02 fev 2020.

COSTA, S. A rotina pedagógica na educação básica diante da aceleração social do tempo. In: Educomunicação - comunicação e educação - os desafios da aceleração social do tempo. São Paulo: Paulinas, 2017. 
Declaração Universal dos Direitos Humanos, ONU, 1948. Disponível em: <https://nacoesunidas.org/wp-content/ uploads/2018/10/DUDH.pdf>. Acesso: em 02 fev 2020.

HANDBALL. Produção de Centro Educacional Pioneiro. Brasil, 2018. Disponível em:<https://www.youtube.com/watch?v=sh1iqZxrHLc\&list=PLTKDjJf4SUqoQ06NNZNdALfPt_E1Acwg4>. Acesso em: 15 fev 2020.

LOPES, M. Pesquisa de recepção e Educação para os meios. In: Educomunicação - construindo uma nova área de conhecimento. São Paulo: Paulinas, 2011.

PODCAST Oficina Literária. Brasil, Produção de Cepioneiro. Brasil, 2016. Disponível em: <https://soundcloud.com/user-119069010/ sets/podcast-portugues>. Acesso em: 15 fev 2020.

SOARES, I. Educomunicação: um campo de mediações. In: Educomunicação - construindo uma nova área de conhecimento. São Paulo: Paulinas, 2011.

RADANOVITSCK, D. Educomunicação e Direitos Humanos - Podcast. Brasil, 2020, 17 min. Disponível em: < https://www.youtube.com/watch? $v=n t d d h e H \_w I c>$. Acesso em: 26 fev 2020.

SÃO PAULO (Estado). Plano estadual de educação em direitos humanos de São Paulo. Ministério Público do Estado de São Paulo, São Paulo, 2017. Disponível em: <http://www.mpsp.mp.br/portal/page/portal/cao_civel/Texto\%20Base\%20-\%20Plano\%20 Estadua1\%20Educa\%C3\%A7\%C3\%A3o\%20em\%20Direitos\%20Humanos\%20SP.pdf>. Acesso em 15 fev 2020.

SILVEIRA, S. Regulamentação e liberdade na rede: o Marco Civil da internet. In: LIMA, V; GUIMARÃES, J.; AMORIM, A. (org.). Em defesa de uma opinião pública democrática: conceitos, entraves e desafios. São Paulo: Paulus, 2014.

SOARES, I. Educomunicação: um campo de mediações. In: Educomunicação - construindo uma nova área de conhecimento. São Paulo: Paulinas, 2011. 


\section{A MICRORRESISTENNCIA A PARTIR DE MICHEL DE CERTEAU E O BIOPODER DE MICHEL FOUCAULT NA HIPERCOMPLEXIDADE DA PRÁTICA PEDAGÓGICA DOCENTE}

Ivonete da Silva

\section{Introdução}

[...] apenas onde o dissenso é livre para se manifestar o consenso é real, e que apenas onde o consenso é real o sistema pode proclamar-se com justeza democrática. (BOBBIO, 1986, p. 62)

Respeitando as características regionais de cada Estado brasileiro, no âmbito da educação superior no contexto da sociedade do capital, o modo de circulação da mercadoria educação, marca a radicalização cultural desses dois sistemas de representação a partir da natureza empresarial e social. A educação ao vivenciar a lógica do mercado concorrencial e social, com a tendência de descapitalização das instituições públicas e a apropriação desse mesmo recurso público pelas instituições particulares, sugere como critério em ambos os espaços a eficácia do sistema educacional, pondo em risco a formação do conhecimento plural, crítico em detrimento da informação conteudista e da métrica.

A análise das táticas utilizadas por docentes inseridos em IES-RP/ SP, identificadas ativas no Ministério de Educação e Cultura - MEC entre maio de 2015 a fevereiro de 2016 apreende sujeito social e insti- 
tucional no processo histórico a partir de operações como: ler, escrever, falar, preparar aula contemplando a relação sujeito, espaço e história, inseridos em contexto determinado pelo biopoder (FOUCAULT, 2008) e ao mesmo tempo indeterminado quando vislumbra possibilidades de criar e recriar táticas cotidianas que metaforizam a ordem dominante, transformando e materializando, ainda que numa independência relativa, seu compromisso com uma formação de qualidade em oposição à ideia mercadológica de educação.

\section{A hipercomplexidade da ressignificação na relação sujeito-espaço-história}

Os axiomas identificados no relato das docentes nos permitiu uma breve aproximação etimológica em torno da origem dessas palavras, como foram sendo apreendidas e utilizadas na hipercomplexidade das relações sujeito-espaço-história. Na perspectiva de totalidade ontológica do ser social, são também espaços de interação e ressignificação das relações, bem como da prática pedagógica conforme diagrama a baixo.

\section{llustração 3 - Diagrama da hipercomplexidade da ressignificação na relação sujeito- -espaço-história}
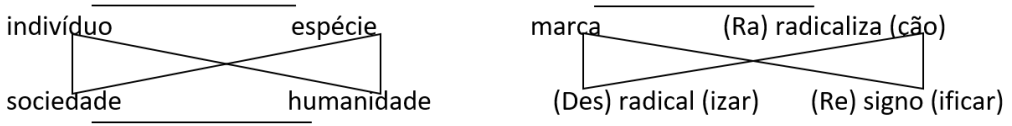

Fonte: Morin, 2015, p. 494 com suporte para criação dos axiomas identificados subjetivamente e/ou de forma objetiva nos discursos dos professores entrevistados nesta tese, 2017.

Nesse caso, o axioma marca, etimologicamente expressa:

'limite, província fronteiriça de um estado' XV. Do lat. Tardio marca, deriv. do germ. Marca 'limite, fronteira', aparentado do lat. margõ -inis 'margem', limite, fronteira'.

Marca "nota, "marca, sinal" "direito de represália' XIV" (CUNHA, 1999, P. 500-501) 
A palavra marca deriva do latim germânico, tanto do século XV quanto do século XIV 1813, cujo significado está em 'assinalar, indicar, determinar, firmar, limitar'. (ibidem,p. 501)

Parece que em todos os espaços há indivíduos, grupos, e uma coletividade que de alguma forma buscaram e buscam uma ressignificação das marcas deixadas pelos acontecimentos. Em todas as representações, se observa a força vital para a subversão, instalada na tensão e na barbárie da cultura dominante. Isso nos aproxima do axioma ressignificar, que vem do radical signo derivado do Latim entre o século XIII-XV, que significa:

'sinal, símbolo, marca' 'cada uma das 12 constelações do Zodíaco' '(Ling.) aquilo que é constituído pelo símbolo e pelo sinal, integrando a significação das formas linguísticas e constituindo, assim, a essência da linguagem' XIII, ssino XIX (ibidem, 1999, p. 721)

A data do aparecimento desse axioma sugere um contexto em que o poder está centrado entre Estado e igreja no início da sociedade política moderna; é possível constatar que no mesmo espaço da barbárie há indivíduos, grupos que buscam a essência, ou seja, outra possibilidade para a existência humana em oposição à aparência exposta pela dogmatização, genocídios e tantas outras barbáries sobre a população subalternizada do poder dominante nos diversos modelos societários, seja no campo das ideias e/ou nas práticas cotidianas.

Portanto, o desejo em propor uma significação em que o axioma ressignificar vem com o prefixo (res), a raiz (signo) e o sufixo (ificar) ocorre na tensão entre a racionalidade da lei natural secularizada e justificada como forma de governança. Tanto no passado quanto no presente, associamos a política de educação do ensino superior, por essa racionalização do ensino. E esse mesmo processo perpassa pela historicidade da profissão do Serviço Social, no que concerne à apropriação da teoria crítica como base para fundamentação das reflexões em torno da desigualdade social, na perspectiva da universalização dos direitos, adotando a teoria social marxista como orientação fundamental. 
É nesse contexto, que surge nosso segundo e terceiro axioma apresentado no discurso das professoras, cuja raiz da palavra razão acompanhada do prefixo (ização) mais sufixo (ização), formam a palavra radicalização e a mesma raiz acompanhada do prefixo (des) mais sufixo (ização) formam a palavra desradicalização. Segundo Cunha (1999) é derivada do Latim, e como as demais surge no final da idade média e início da sociedade política moderna, ou seja, a partir do século XIII, cujo significado remete a:

'faculdade que tem o ser humano de avaliar, julgar, ponderar ideias universais', 'raciocínio, juízo', razó XIII, razon XIII etc. Do lat. radio-onis, Ar razoado, 'conforme a razão', 'discurso oral ou escrito com que se defende uma causa' 1813 (ibidem, 1999, p. 665)

Podemos aferir que o cenário em que surgem os axiomas, expressam sistema cultural, político e social em que predomina o autoritarismo, a centralização do poder. É a partir deste jogo de forças desigual que passamos a compreender nas expressões axiomáticas extraídas das narrativas docentes à evidência da necessidade de ressignificar e desradicalizar as ações nesses espaços. Pressupõe processo constante do conhecimento, exigindo nesse diagrama das trocas uma "performance", na sala de aula, conforme apontado pela professora Dandara,

É uma performance (Risos). Não é tão simples assim! Não é apenas ter conteúdo, você tem que pensar uma forma de acordo com... e observar muito bem a dinâmica do grupo que é a sala, para você adaptar a forma de transmitir esse conteúdo né.

Para Certeau (2013, p. 191) seria em um primeiro momento um "teatro de ações" que legitima as ações efetivas; num segundo momento, as "fronteiras e pontes" entre o organicamente instituído, sendo legitimado os espaços para além do determinado a partir da extensão do capital cultural e simbólico que esse professor alcance com sua performance nesse teatro das ações. Nosso desafio, foi justamente identificar as possibilidades e/ou fronteiras e pontes a partir das entrevistas com as duas docentes. 
As implicações de opressão, coação e subversão ao imposto na sociedade do capital, é um holograma, ou seja, é a imagem é uma projeção recursiva, embora o real seja muito mais do que estas projeções ou dados estatísticos de distinções geográfica e social de cada território em que as professoras ${ }^{40}$ nasceram, mas também apresentam conjunções quando a premissa é a justiça social, pautada na universalidade dos direitos quando remetemos ao conceito de cidade e cidadania.

Ao mesmo tempo, essa mesma dialogia é também percebida no cenário das IESRP na cidade de São Paulo. Para as professoras Dandara e Maria Quitéria, estar na docência é a ponte, é à possibilidade fronteiriça de ultrapassar as barreiras pessoais, mas também o desejo da troca, de aprendizagem contínua e poder dialogar com essa realidade contraditória para o acesso de uma maioria à margem do direito, à cidade em sua completude. Estar na docência, convoca para um posicionamento político em face dessa realidade conforme destacado pela professora Dandara:

Porque é assim: eu gosto de é, é de ensinar, por que? Porque acho o processo da educação, é um processo cíclico, né! De troca, de aprendizagem contínua, de estar pensando a realidade social. Então, eu vejo que a docência é um espaço onde eu consigo dialogar muito mais com a, com a realidade social e traz uma potência para trabalho, né, do Serviço Social. Então, acho que para mim é, me, reabastece né, entendeu! Seja a, é, retroalimenta fisicamente, emocionalmente, espiritualmente, socialmente. Então, você começa, então, você consegue, enfim, entender essa complexidade de, do ser humano. Acho que a docência te convoca a essas coisas né! Te convoca a isso.

40 Exemplos de indicadores sociais dos dois territórios: Capão Redondo, taxa anual de homicídio: 144; mortalidade infantil: 17,64\%; escolaridade: menos 1 ano de escola, $14.507 ; 1^{\circ}$ grau incompleto: $103.307 ; 2^{\circ}$ grau completo, $23.009 ; 3$ / grau completo 3.966; Anos de estudo não determinados, 5.966 ln www.observatóriosampa.prefeitura.com. br acesso em junho/2017. Catolé do Rocha, $1 / 2$ (meio salário mínimo) a um salário mínimo, 8.361 pessoas; $1 / 4$ (um quarto a meio salário mínimo) 6.687 pessoas; $1 / 8$ a $1 / 43.081$ pessoas; sem instrução ou fundamental incompleto 11.477 pessoas; nível superior 967 pessoas. IBGE, 2010 
Docência que convoca, mas também incita a indagação sobre si, sobre suas habilidades e qualidades para a função. Tal postura sinaliza humildade diante do saber, conforme verbaliza a professora Maria Quitéria:

[...] eu fiz o mestrado e depois eu tive uma certa crise assim no mestrado, porque eu não achava que tivesse tido um conhecimento assim ... tão, básico no mestrado ou que o mestrado tinha, trago, ou, às vezes uma crítica pessoal minha, que eu não tinha me dedicado o suficiente né! De ter uma fundamentação teórica mais consistente, enfim... E aí depois que passou isso, acho que depois de uns seis meses, eu comecei a me sentir, que sim, eu conseguia fazer uma boa relação teoria-prática, né, que eu conseguia estabelecer associações né, e foi a partir disso que eu comecei a achar que estou pronta para concorrer a uma vaga de professor.

Observa-se que apesar da ideia da incerteza, do estarem prontas para docência, às professoras demonstram compromisso com as pessoas e não com o mercado. Nesse caso, Nauman (2004) afirma que essa sociedade globalizada tem possibilitado muito mais a corrosão do caráter a partir do fortalecimento da concepção do Estado nação, balizado na centralização do poder, do que com a identidade de uma comunidade enquanto processo contínuo de construção.

\section{O biopoder no âmbito da política de educação superior da rede privada na cidade de São Paulo}

No âmbito da política de educação no ensino superior brasileiro, identificamos concordância das professoras na transnacionalização da educação como fenômeno mundial, considerando nossa topografia social miscigenada. Esse cenário é reiterado no relato da professora Dandara no capítulo II da tese, bem como pela professora Maria Quitéria, quando discorrem sobre a sujeição imposta ao trabalho docente no que tange a prática pedagógica de orientação do Trabalho de conclusão de Curso - TCC em $\mathrm{EAD}$, realizado fora do horário de aula e sem remuneração: 
Então, a gente tem a orientação em EAD dos artigos, eu não tirei minha orientação presencial, mas reduzi a quantidade de orientações presenciais porque também nós não recebemos. Não recebi nenhum real pelos TCC já defendidos, então também não posso trabalhar voluntariamente. O contrato não é esse...

Esse autoafirmar, reduzir a quantidade de orientação para garantir uma qualidade presencial, sem remuneração é considerado uma insubordinação do professor. Essa ação, comporta a possibilidade da exclusão por parte da IESRP, tanto no relato da Professora Maria Quitéria, quanto da Professora Dandara; a tendência do professor com essa postura é de ser desligada da universidade. Para Dandara, o professor ideal é aquele que se adequa à dinâmica mercadológica da IESRP:

O professor ideal para universidade hoje, é aquele que consegue dialogar com essa dinâmica mercadológica de ensino. Quem mais dialoga com essa dinâmica, fica na universidade, quem não dialoga está fora! (Longo silêncio)

O relato nos remete a ideia de opressão, de enquadramento, seja pela regra ou pela ideia. Esta perspectiva nos faz lembrar o conceito de biopoder em Michel Foucualt (2008, p. 03-07) quando dispositivos de segurança são constituídos socialmente como características da sociedade, integrando as perspectivas biológicas e psíquicas de todo ser humano. Esses mecanismos de segurança também são utilizados como estratégias políticas na disputa pelo poder e as IESRP se apropriam com pertinência desses recursos. São dispositivos que devem assegurar a vida da população, pois sua meta é controlar aquilo que possa limitar a vida do homem não em particular, mas no conjunto da espécie humana. Para Foucault o "Biopoder", torna-se uma ferramenta fundamental para a tecnologia de poder que irá controlar as massas.

[...] essa série de fenômenos que me parece bastante importante, a saber, o conjunto dos mecanismos pelos quais aquilo que, na espécie humana, constitui suas características biológicas 
fundamentais vai poder entrar numa política, numa estratégia política, numa estratégia geral de poder. Em outras palavras, como a sociedade, as sociedades ocidentais modernas, a partir do século XVIII, voltaram a levar em conta o fato biológico fundamental de que o ser humano constitui uma espécie humana. É em linhas gerais o que chamo, o que chamei, para lhe dar um nome, de biopoder. (FOUCAULT, 2008, p. 3)

A cultura do sistema de representação institucional se utiliza de diversos mecanismos de biopoder, institucionalizado para a demissão, como: sistema interno de avaliação do professor, não concordar com o modelo de ensalamento dos alunos e até a mudança de coordenação quando essa compreende que o professor não adere a sua proposta, conforme destaca a professora Maria Quitéria:

O novo coordenador busca alinhar sua equipe e ele busca uma equipe dele né, então mudança de coordenador pode ser um motivo. Acho que os processos de avaliação de desempenho que tem um conceito semestralmente que os alunos fazem né! Acho que este também pode ser também um indicador de demissão, mas na universidade aqui, eu penso assim, coisas bem concretas que podem influenciar na demissão de pessoal: o cumprimento de horário pode ser um requisito que eles possam considerar importante para a, fazer a demissão, não cumpriu horário será demitido independente do conteúdo teórico, de quanto você produz com os alunos assim. Acho também, uma tendência de enxugar o quadro de professores, acho que a gente tem essa tendência aqui, porque o ajuntamento de salas; acho que eles, acho que manter vários professores com uma carga horária muito pequena não compensa administrativamente assim...

Para o autor, esse sistema de segurança é considerado moderno, implantado a partir do século XVIII e permanece presente nas relações sociais e institucionais, podendo ser observado no relato da professora Dandara: 
A cada semestre a universidade, ela vai cada vez mais é, é. doutrinando, fiscalizando, monitorando esse espaço. Para você ter uma ideia, por exemplo, os alunos hoje são monitorados o quantas vezes acessam o portal da universidade, se leu o texto, se, se abriu, se mandou trabalho, enfim, monitorados. Se o aluno não entra no portal (Silencio) para universidade, é, é números, é meta. Então, eles pressionam o coordenador pedagógico, que pressionam o coordenador do curso, que pressiona os professores, né. Os alunos têm que acessar o portal, e aí, nesse processo até o professor também hoje está sendo monitorado. Se a gente não lançar a nota em tal prazo, a gente, se não lança falta, se não entra para lê um monte de atividade, e, e cursos que tem on-line para gente também fazer... para o professor... a gente também está perdendo ponto e corre risco de usarem isso como critério para nos desligar no próximo semestre.

Foucault (2008), também dialoga como o laisse-feire, enquanto sistema contemporâneo, partir da ideia de liberdade; utiliza-se de "[...] novas formas de penalidade e do cálculo do custo das penalidades: são as técnicas americanas, mas também europeias que encontramos agora”, (2008, p. 08-09; 59). Para o autor, a ideia de liberdade como disparador dessas novas técnicas, está no jogo que o liberalismo emprega:

O liberalismo, o jogo: deixar as pessoas fazerem, as coisas passarem, as coisas andarem, laisser-faire, laisser-passer e laisser-aller, quer dizer, essencial e fundamentalmente, fazer de maneira que a realidade se desenvolva e vá, siga seu caminho, de acordo com as leis, os princípios e os mecanismos que são os da realidade mesma. (FOUCAULT, 2008, p.62-63)

Nesse caso, deixar que a sociedade se desenvolva por si só, é retirar a responsabilidade do Estado e deixar que o dispositivo global, incorporado pelo mundo a partir do jogo do liberalismo econômico enquanto dispositivo de segurança, se paute pelo conjunto de normas do mercado. 
Desdobra-se daí o pensamento fisiocrata semelhante ao discurso neoliberal da ineficácia do público na gestão, ou seja, o custo é alto para o Estado; refere-se ao chamado "fator trabalho" (Cf. Iamamoto, 2008), que altera as relações entre Estado e sociedade civil. O discurso da ineficácia pública corrobora para regressão dos investimentos públicos no acesso a bens e serviços em detrimento ao privado estabelecendo a relação binária entre o que é proibido, ou seja, não endossado pela Associação Brasileira de Ensino e pesquisa em Serviço Social (ABEPSS) e o permitido pelo MEC, como exemplificado no relato da professora Dandara:

Então, eu recentemente fiquei bem decepcionada com o MEC. O MEC tem sido mais flexível com as instituições privadas porque antes quando a gente teve a mudança no TCC, que eu fiz consulta ao MEC sobre ser legítimo em relação ao TCC. O MEC respondeu que sim, que a faculdade tinha autonomia para fazer a mudança, que não descumpria as exigências da graduação, que poderia ter. Eu fiz por telefone o contato e fiquei bastante decepcionada, porque na hora eu estava na verdade buscando elementos para fazer um enfrentamento com embasamento, colocando, e eu já tinha feito um texto escrito, que eu acabei desprezando o texto, porque eu não me senti nem um pouco apoiada pelo MEC. Pelo contrário, eu senti que a faculdade podia fazer outras reformas que ela ainda não tem anunciado assim, enfim...

Essa perspectiva é favorecida pelo governo através da Parceria Pública Privada e da Lei de Concessão a particulares, que incorpora o discurso paradigmático da ordem fisiocrata e/ou liberal, cuja operação lógica custo/benefício; proibido/permitido; inclusão/exclusão privilegia o privado, conforme reforçou professora Maria Quitéria:

Eu acho que há uma flexibilização de modo geral das normativas em relação ao ensino superior e essa flexibilização permite que as universidades elas façam reestruturações internas dentro de um limite de legalidade. 
A legalidade da ideia de democratizar o ensino para que a população que antes não tinha acesso ao ensino público passe tê-lo, ocorre, porém, pela via do mercado. Sendo assim, é necessário manter o discurso da verdade de ineficácia da gestão pública no chamado "fator trabalho" (Iamamoto, 2008). Com isso, a ideia da liberdade, da autonomia enquanto princípio fundamental da democracia é efetivada pelo mercado, legitimada por normas do Estado. Neste caso, a sociedade do capital é regida por ela mesma, ou seja, acirra os enfrentamentos entre as organizações coletivas, fragiliza as relações de trabalho inclusive nas IES públicas que vão sendo descapitalizadas com a redução de custos.

No âmbito da política educacional do ensino superior privado, o discurso da descapitalização das universidades públicas e a autonomia do privado foi essencial para o jogo do liberalismo econômico. O princípio da "Liberdade, Igualdade, Fraternidade" (Liberté, Egalité, Fraternité) passou a ser compreendido nos modelos tecnocratas de poder, tornando-se um problema do ponto de vista de Foucault (2009), visto que os capitalistas inverteram esses princípios em mecanismos de segurança, inserindo na cultura do sistema de representação institucional as relações de poder e de biopoder legitimadas pelo Estado.

De modo que esse problema da liberdade [...] essa ideologia da liberdade, essa reinvindicação da liberdade foi uma das condições de desenvolvimento de formas modernas ou, se preferirem, capitalistas da economia. [...] na verdade, essa liberdade, ao mesmo tempo ideologia e técnica de governo, essa liberdade deve ser compreendida no interior das mutações e transformações das tecnologias de poder. E, de maneira mais precisa e particular, a liberdade nada mais é que o correlativo da implantação dos dispositivos de segurança. Um dispositivo de segurança só poderá funcionar bem, em todo caso aquele de que lhes falei hoje, justamente se lhe for dado certa coisa que é a liberdade, no sentido moderno [que essa palavra] adquire no século XVIII não mais as franquias e os privilégios vinculados a uma pessoa, mas a possibilidade de movimento, de deslocamento, processo de circulação tanto das pessoas como das coisas. E, é essa liberdade de circulação, no sentido lato de termo, é essa faculdade 
de circulação que devemos entender, penso eu, pela palavra liberdade, e compreendê-la como sendo uma das faces, um dos aspectos, uma das dimensões da implantação dos dispositivos de segurança. (FOUCAULT, 2008, p. 59, 62-64)

Os depoimentos das professoras Dandara e Maria Quitéria suscitam aprofundar a análise da educação e a forma como a ideia de liberdade, equidade e fraternidade vêm sendo apreendida no espaço das IESRP.

Cada vez mais é um ensino, onde a relação é ... com o aluno é uma relação de negócio né. É porque estou numa universidade particular, então é uma relação de negócio. Então, o aluno não é visto como um cidadão, um ser humano que está no seu processo de evolução, de desenvolvimento. Ele é visto hoje como cliente né. Então, o desafio é, é, é conviver com esse contexto mercadológico do ensino.

Nessa relação de negócio, o professor vai se tornando aquele que soluciona as dúvidas e não construtor de um saber no modelo de padronização de aula presencial ou semipresencial. O sentido mercadológico da educação pode fragmentar a didática do professor como forma de mediação da relação ensino aprendizagem entre professor e aluno, que passa ser mediada por novas técnicas como os monitores de tv, que deveriam ser utilizados como recursos complementares e não como fim em si mesmo. Como já mencionamos o professor se transforma em um transmissor de conhecimento e sua identidade passa a ser de monitor; instaura-se uma crise identitária tanto do professor, quanto do aluno conforme relato da professora Dandara:

O professor nesse, nesse formato é apenas um tirador de dúvidas da parte que ele viu lá nessa a aula, nesse modelo de aula (Silêncio). E aí você tem o pós-aula que são questões, reflexões que o aluno depois tem que devolver. Só que o perfil de aluno de Serviço Social é o perfil de aluno trabalhador. Então, como a aluna falou: professora eu saio de casa três (03) e pouco da 
manhã, chego aqui correndo para assistir aula, chego em casa dez (10) horas, meia noite. Que hora que eu vou ver pré-aula e pós-aula? Que eu vou responder essas coisas, né! Então, tiveram alunos que vieram chorando, sofrendo, acho que vou desistir do curso. Porque eu quero um curso presencial, de troca, quero está aqui junto estudando. E aí, como é que fica toda essa demanda de, de maior tempo fora do que dentro de sala de aula. E, uma coisa que uma aluna falou ontem, a gente vai... e, a sua aula professora, a gente não vai ter mais a sua aula? A gente vai ter que ter essa aula que alguém preparou e a sua aula a gente não vai ter mais?

Essa perspectiva de ensino a distância na cultura contemporânea está previsto na modalidade semipresencial, com base no art. 81 da Lei $\mathrm{n}^{\mathrm{o}}$ 9.394, de 1.996, e, mais recentemente, o decreto $\mathrm{n}^{\circ} 9.057$ de 25 de maio de 2017, amplia para instituições de ensino pública e particular o lato sensu na modalidade à distância para as pós-graduação.

Almeida (2013), não descarta essa tecnologia como formação continuada e cada vez mais à interligação via Internet e a recuperação, construção e reconstrução de informações via Web fazem parte de atividades tanto de trabalho, quanto de estudo. Ocorrem mudança significativas nos aspectos cognitivos influenciados pelas tecnologias que pode influenciar na autonomia do processo ensino e aprendizagem enquanto habilidade esperada principalmente nos jovens que ingressam no mercado de trabalho.

Com a forte instauração da EAD aos moldes atuais, regulamentada pela Portaria do MEC N 4.059/2004, a qualidade do ensino é questionada; a tendência não tem sido a autonomia e habilidades dos jovens, mas redução de custos; há preocupação com o aumento dos ambientes virtuais e a defesa do presencial como possibilidade não de conhecimento, mas também de criar laços e redes, como reforça Maria Quitéria:

É então eu vejo que a universidade mantém uma parte importante de ensino presencial e poucas disciplinas em EAD né, então não sei até quando a instituição vai manter o curso presencial, porque gradativamente vai aumentando o número 
de instituições à distância, o que é ruim. Eu sou uma grande defensora do curso presencial, porque a sala de aula não é só um espaço onde você é, passa um texto, passa um conhecimento, mas é um momento de criar laços, redes.

A relação de negócio inviabiliza laços de solidariedade para além da relação custo/benefício; quantidade/redução de risco do investidor na área da educação. Assim, tais princípios de economia liberal são endossados por portarias do MEC, como o modelo seriado ou o ensalamento, seja de alunos de várias séries de um mesmo curso ou de cursos diferentes em disciplinas consideradas comuns pela IES com os decretos n 16.677/1995 classifica o que é seriado.

Para professora Dandara favorece a universidade e ao mesmo tempo desafiador para o professor:

Então, aí você tem a mudança, é, na estratégia metodológica da universidade né! Então, na Anhanguera o que, que pega mais é, é essa questão de você ter o processo pedagógico de ensalamento. Então, todo o semestre você tem, é, é vestibular. Então, você começa com uma turma do $1^{\circ}$ semestre no começo de fevereiro, quando chega em agosto você fez um vestibular em julho, você vai inserir nessa turma de $1^{\circ}$ semestre que agora é segundo semestre os alunos que ... né ... entraram na universidade no meio do ano. Isso para o professor é, é desafiador, porque como é que você vai trabalhar conhecimento com pessoas que estão em níveis diferente de processo de conhecimentos e de formação.

A professora considera que o aluno está mais preocupado com a nota para ter o diploma, sem compreender que o conhecimento vai além de uma preparação para o mercado; o desafio está em quebrar esses paradigmas:

Formação acadêmica hoje no contexto das universidades está muito mais pensando no produtivismo né! De você ter um diploma. Então, os alunos tão preocupados muito mais com a 
nota e aí questionam a nota, mas não entende que é o processo de construção do conhecimento né! Então, é difícil dialogar com isso. Então, isso, isso para mim é algo que é desafiador, de pôr ... quebrar esses paradigmas né, assim constantemente em sala de aula. A gente não pode submeter o nosso trabalho a uma mera questão mercadológica, uma mera questão produtivista, uma mera questão de título para você poder se inserir no âmbito A, B, C no mercado de trabalho. Então não é uma formação para o mercado de trabalho, né. Então, isso é, é isso que me preocupa. Os alunos, eles estão ... Eles veem para a graduação com várias lacunas de formação. Então, nós temos alunos que saíram do EJA, que saíram do supletivo, que ficaram 10 anos, vinte anos sem estudar e agora que tão voltando. Gente que acabou de sair do ensino médio, então eu tenho aluno assim: eu tenho jovem com 20 anos com gente já de 50 a 60 anos estudando numa mesma sala. Então são visões diferentes de... Então tem que ser um diálogo geracional nessa conversa também!

Para a professora Maria Quitéria, muitos buscam uma elevação de seu status:

No Serviço social, a gente tem pessoas que são, são pessoas que estão procurando uma graduação porque querem ter uma ... melhorar sua inserção no mercado de trabalho hoje ou melhorar sua condição de status; querem né, esperam uma graduação como elevação de seu status.

É nessa realidade complexa e na multiplicidade de elementos que está inserido o sistema escolar brasileiro, com as IES da rede privada na cidade de São Paulo.

\section{Considerações finais}

A prática pedagógica docente vai sendo desvelada, politizada, constituindo-se numa prática formativa, criando e recriando habilidades, competências e potencialidades para desenvolver por dentro a cul- 
tura do discente e do docente táticas de microrressistência sem perder sua relação à totalidade histórica, e ao mesmo tempo busca a articulação entre as múltiplas culturas de representação da sociedade através de um saber sistemático e assistemático que metaforiza a ordem dominante. Nesse contexto, as professoras vêm buscando cotidianamente superar suas limitações, empoderam-se e tentam empoderar outros sujeitos inseridos na ambiguidade dos binômios: dualidade/unidualidade; exclusão/inclusão; teoria/prática no ensino superior brasileiro da rede privada na cidade de São Paulo.

Referências Bibliográficas

ANASTACIOU, Léa das Graças Camargo \& PIMENTA, Selma Garrido Pimenta. Docência no Ensino Superior. 4aㅗ ed. São Paulo: Cortez Editora

ALMEIDA, Maria Elisabeth Bianconcini de. Educação a distância: diretrizes políticas, prática e concepções. In SEVERINO, Antônio Joaquim \& FAZENDA, Ivani Catarina Políticas Educacionais,

BARROS, José D’Assunção. "Micro-História" in O campo da história. Petrópolis: Ed. Vozes, 8 ed. 2011, p.152-179

BOBBIO, Norberto. Os intelectuais e o poder: dúvidas e opções dos homens de cultura na sociedade contemporânea. São Paulo: Editora da Universidade Estadual Paulista, 1997

. O futuro da democracia. Uma defesa das regras do jogo. 6 ${ }^{\underline{a}}$ ed. São Paulo: Paz e Terra,1997

CERTEAU, Michel de. A invenção do cotidiano: 1. Artes de fazer. 20 ed. Petrópolis, RJ: Vozes, 2013

A invenção do cotidiano: 2. Morar, cozinhar. 11 ed. Petrópolis, RJ: Vozes, 2012

A escrita da história. Rio de Janeiro: Forense

Universitário, 1982 
A cultura no plural. Campinas, SP: Papirus: 1995.

CUNHA, Antônio Geraldo da. Dicionário Etimológico Nova Fronteira da Língua Portuguesa. 11区 impressão. Rio de Janeiro, 1999

CUNHA, Luiz Antônio. Ensino superior e Universidade no Brasil. In LOPES, Eliane Marta Teixeira et al (org.). 500 anos de Educação no Brasil, 5 a . Ed. -Belo Horizonte: Autêntica, 2011

FAUCAUT, Michel. A arqueologia do saber. $7^{\underline{a}}$ ed - Rio de Janeiro: Forense Universitária, 2008

- Microfísica do poder. Rio de Janeiro: edição Graal, 1979

Vigiar e punir. $16^{\mathrm{a}}$ ed. Petrópolis, Rio de Janeiro: editora Vozes, 1997

- Segurança, Território, População. Trad. Eduardo Brandão. SP: Martins Fontes, 2008.

IAMAMOTO, Marilda V. Serviço Social em tempo de capital fetiche: Capital financeiro e questão social. $3^{\underline{a}}$ ed., São Paulo: Cortez editora, 2008

SILVA, Ivonete. Microrresistência no cotidiano da prática pedagógica docente no curso de graduação em Serviço Social. PUC. SP, 2018

SHENINI, Fátima. Escolas Multisseriadas. Publicado em 01/03/2010 http://portaldoprofessor.mec.gov.br/conteudoJornal. html?idConteudo=1022 acesso as $18 \mathrm{~h} \mathrm{em} \mathrm{16/05/2017}$

TADIF, Maurice. Saberes docente e formação profissional. $6^{\underline{a}}$ ed. Petrópolis: Ed. Vozes, 2006

Decreto № 5.622, DE 19 DE DEZEMBRO DE 2005. Educação à distância 
Decreto $\mathbf{N}^{\circ} \mathbf{9 . 0 5 7 / 2 0 1 7}$. Amplia o ensino a distância para o Latus Sensus

Lei 9.394/1996 de diretrizes Bases da Educação. Brasil, 1996 Portaria do MEC $\mathbf{N}^{\circ}$ 4.059/2004. Educação a distancia 


\section{O DIREITO À EDUCAÇÃO A PARTIR DA PERSPECTIVA DOS DIREITOS HUMANOS}

Fabiana Bazilio Farias

Juliana Carvalho de Araujo de Barros

A educação é a arma mais poderosa que você pode usar para mudar o mundo.

Nelson Mandela

Pretendemos pensar sobre como a Declaração Universal dos Direitos Humanos (DUDH) e as leis brasileiras estão em consonância, principalmente no que diz respeito à igualdade de acesso à educação e à cidadania. A DUDH prevê direitos naturais garantidos a todos os indivíduos, independentemente de classe social, etnia, gênero, nacionalidade ou posicionamento político. De acordo com a ONU, consistem em "garantias jurídicas universais que protegem indivíduos e grupos contra ações ou omissões dos governos que atentem contra a dignidade humana" (TAVARES, 2012). A ONU pretende que os direitos humanos sejam determinados em um ordenamento jurídico, como as constituições, dessa forma, eles serão nomeados como direitos fundamentais. No preâmbulo da DUDH, lê-se:

Considerando que o reconhecimento da dignidade inerente a todos os membros da família humana e de seus direitos iguais e inalienáveis é o fundamento da liberdade, da justiça e da paz no 
mundo; Considerando que o desprezo e o desrespeito pelos direitos do homem resultaram em atos bárbaros que ultrajaram a consciência da Humanidade e que o advento de um mundo em que os homens gozem de liberdade de palavra, de crença, e da liberdade de viverem a salvo do temor e da necessidade foi proclamado como a mais alta aspiração do homem comum;[...] (ONU, 1948)

Dessa forma, percebemos o destaque que é dado à dignidade da pessoa humana. O emancipacionismo - isto é, a defesa da autonomia do indivíduo, de sua liberdade de pensamento e expressão, de sua soberania individual - é a bandeira do Direito Moderno, que defende o absoluto respeito ao livre exercício da vontade. A retórica emancipatória tem como base o conceito de dignidade da pessoa humana.

Na tradição ocidental, o conceito de dignidade remonta à concepção judaico-cristã e à estoica, secularizado pela modernidade e consagrado pela filosofia iluminista de Kant. Assim, entendeu-se que as pessoas devem ser consideradas como fins em si mesmas, e não como simples meios para a consecução utilitária ou hedonista de fins próprios ou alheios; repudiando-se, assim, toda espécie de instrumentalização ou coisificação que inflija qualquer ultraje, aviltamento ou amesquinhamento da condição humana.

O espaço republicano é, por excelência, racional-plural e faz parte de um projeto jurídico que tem como base valores como isonomia, emancipação, pluralidade. Um regime republicano que garanta espaço social e plural é fundamental para a promoção de valores emancipacionistas. Segundo Immanuel Kant, o homem é dotado de razão e liberdade, sendo estas fontes de dignificação. Assim, o destino do homem é a união à moralidade universal. Como todo homem é sujeito racional, tem ele a condição de ser moral.

A consciência moral, isto é, a racionalidade moral conduz à uniformização de condutas, atingindo a coletividade e se exteriorizando no Direito pela juridicização da racionalidade moral. Isso significa que a conduta moral kantiana exerce força centrífuga da esfera subjetiva para a coletividade. Dessa forma, o espaço público, na concepção de Kant, é ocupado por homens racionais, com condições de exercerem 
livremente sua racionalidade moral - o que chamaremos de espaço público racional, firmado na compreensão de que a racionalidade baniria para o âmbito familiar privado o que fosse da ordem religiosa e afirmar-se-ia no secularismo científico.

Entende-se, portanto, que o espaço público deve prezar pela pluralidade humana. Neste entendimento, segundo Danilo Porfírio, espaço público é "espaço comum e difuso aos cidadãos, próprio de sociedades plurais, para a manifestação democrática (participatividade política) e republicana (tutela de bem públicos essenciais e exercício de virtudes cidadãs, como tolerância) de ideias e opiniões. "[...] Na concepção moderna, as ações de homens livres e iguais em uma sociedade plural serão regidas pela "ética da racionalidade", exigência para a constituição do espaço público.” (VIEIRA, 2018, p. 23-5).

A última Constituição Federal do Brasil, datada de 1988, traz em seu bojo valores republicanos, isto é, o espaço republicano é, por excelência, racional-plural e faz parte de um projeto jurídico que tem como base valores como isonomia, emancipação, pluralidade. Um regime republicano que garanta espaço social e plural é fundamental para a promoção de valores emancipacionistas.

\section{Os Direitos Humanos e a Constituição Coragem}

Os direitos humanos se moldam a cada época, a cada contexto histórico. Em 1979, um jurista chamado Karel Vasak criou uma classificação de "gerações de direitos". Os direitos de primeira geração são civis e políticos, que contemplam os indivíduos. Já os direitos de segunda geração impõem uma série de atribuições ao Estado. Os direitos de primeira geração pressupõem uma atuação que corresponde a uma abstenção, chamada liberdade negativa. Os de segunda geração pressupõem uma prestação, a liberdade positiva. É importante frisar que, embora usemos o termo geração, nenhuma se sobrepõe a outra, não existindo hierarquia entre elas ou entre os direitos nelas contemplados.

O pleno exercício dos direitos de primeira geração deve ser reconhecido pelo Estado (atuação legislativa) e haver órgãos que garantam o seu exercício (Poder Judiciário, Polícia etc.). Dessa forma, o Pacto de Direitos 
Civis e Políticos determina que os Estados-partes assumam o compromisso de respeitar e assegurar a todos os indivíduos os direitos previstos no documento internacional, dentro do seu território, e que estejam sujeitos a sua jurisdição, sem que haja qualquer tipo de discriminação.

Assim, os Estados devem assegurar: direito à vida; direito a um julgamento justo; direito à nacionalidade; direito de não ser submetido a tortura ou tratamento cruel, desumano ou degradante; direito a não ser escravizado; direito à privacidade; direito à liberdade; direito à segurança pessoal; liberdade de circulação; liberdade de pensamento; liberdade de consciência; liberdade de religião; liberdade de expressão; liberdade de associação; direito de votar e ser votado etc. Consequentemente, amplia-se o rol de direitos já contemplados na Declaração de Direitos de 1948.

A saber,

Artigo 11: proíbe a detenção por dívidas contratuais;

Artigo 24: direito ao nome e a nacionalidade para a criança;

Artigo 20: vedação da propaganda de guerra e incitamento à intolerância étnica ou racial;

Artigo 27: proteção à identidade cultural, religiosa e linguística; entre outros. (ONU, 1948)

Vale destacar que a vida e a dignidade da pessoa humana passaram a ocupar um lugar de destaque, fazendo com que ocorresse uma grande codificação em matéria de Direitos Humanos e a internacionalização desses direitos, ou seja, os Direitos Humanos deixam de pertencer à jurisdição doméstica ou ao domínio reservado dos Estados. Assim, tem-se que o Pacto de Diretos Civis prevê uma série de direitos para o indivíduo, enquanto o pacto de Direito Econômico consagra um rol de deveres para o Estado.

Com o Pacto de Direito Econômico, Sociais e Culturais, os Estados devem adotar medidas nos planos econômicos e técnicos, que visem assegurar o pleno exercício dos direitos reconhecidos no documento. Exemplos: remuneração justa, trabalho, educação, qualidade de vida, cultura. Ainda, estabelece que os povos podem dispor livre- 
mente de suas riquezas e de seus recursos naturais, sem prejuízo das obrigações de correntes da cooperação econômica internacional.

Dessa forma, entendemos que, independente do contexto, os direitos humanos são objetivos comuns a serem alcançados para todos os indivíduos e em todas as partes do mundo, independentemente de classe social, etnia, gênero, nacionalidade ou posicionamento político, uma vez que tais valores são universais e objetivos. No artigo 26 da Declaração Universal dos Direitos Humanos, afirma-se que:

1. Todo ser humano tem direito à educação. A educação será gratuita, pelo menos nos graus elementares e fundamentais. A educação elementar será obrigatória. A educação técnico-profissional será acessível a todos, bem como a instrução superior, esta baseada no mérito.

2. A educação será orientada no sentido do pleno desenvolvimento da personalidade humana e do fortalecimento do respeito pelos direitos humanos e pelas liberdades fundamentais. A educação promoverá a compreensão, a tolerância e a amizade entre as nações e grupos raciais ou religiosos, e deve desenvolver as atividades da ONU em prol da manutenção da paz.

3. Os pais têm prioridade de direito na escolha do tipo de educação que será fornecida a seus filhos. (ONU, 1948)

Dessa forma, a DUDH torna a educação primária universal gratuita e obrigatória. A Constituição Federal do Brasil (BRASIL, 1988) positiva os direitos humanos. Assim, os direitos humanos estão consolidados na Constituição da República Federativa do Brasil na seção que trata dos princípios fundamentais, em Os direitos e garantias fundamentais, e também no Artigo 225, sobre o meio ambiente. Há outros artigos que abordam temas dos direitos fundamentais.

A Constituição Federal 1988 é conhecida como Constituição Cidadã, pois trouxe à luz direitos e garantias previstos no âmbito internacional na Declaração Universal dos Direitos Humanos da ONU. A nossa Constituição Cidadã trouxe em seu Título II, os Direitos e Garantias Fundamentais: 
a- Direitos individuais e coletivos: são os direitos ligados ao conceito de pessoa humana e à sua personalidade, tais como à vida, à igualdade, à dignidade, à segurança, à honra, à liberdade e à propriedade. Estão previstos no artigo $5^{\circ}$ e seus incisos;

b- Direitos sociais: o Estado Social de Direito deve garantir as liberdades positivas aos indivíduos. Esses direitos são referentes à educação, saúde, trabalho, previdência social, lazer, segurança, proteção à maternidade e à infância e assistência aos desamparados. Sua finalidade é a melhoria das condições de vida dos menos favorecidos, concretizando assim, a igualdade social. Estão elencados a partir do artigo 6º; [...] (BRASIL, 1988)

No entanto, apesar de nossa Constituição positivar os direitos previstos na DUDH e torná-los direitos fundamentais para os cidadãos brasileiros, em nossa sociedade contemporânea, muitos corpos são excluídos do jogo social e perdem o direito básico à saúde e à educação. O Brasil, infelizmente, costuma ocupar os últimos lugares nos rankings mundiais de educação. Apesar de, por causa da democratização da internet, termos muita informação à disposição, isso não significa necessariamente que temos uma população apta para interpretá-la. Dito isso, é importante trazer à baila o seguinte

dado: "De acordo com o Instituto Brasileiro de Geografia e Estatística (IBGE), em 2018, havia 11,3 milhões de pessoas analfabetas com 15 anos ou mais de idade" (EBC, 2020).

Raphael Neves, em "Transformações da Cidadania e Estado de Direito no Brasil", busca refletir sobre o conceito de cidadania e seu real significado pragmático a fim de compreender as lutas políticas no atual contexto brasileiro. Para tanto, parte do ensaio de T.H. Marshall (apud Neves, 2013) - "Cidadania e Classe Social", de 1949 -, que pretende demonstrar que a cidadania precisaria incluir a dimensão social para atacar a desigualdade. Recupera, assim, a noção aristotélica de cidadania como comunidade política (politique koinonia). Para Marshall, a cidadania é uma instituição dinâmica que pode servir tanto para combater como aprofundar desigualdades, uma vez que direitos e deveres não estão definidos a priori. Portanto, são os 
próprios cidadãos que devem buscar a ampliação e aplicação do que conteúdo da cidadania.

A partir dos estudos de Max Weber, Marshall distinguiu três dimensões da estratificação social: econômica (estratificação de acordo com a produção e aquisição de bens), de status social (estratificação segundo os princípios de consumo de bens) e de poder político. $\mathrm{Na}$ Inglaterra, a cidadania evoluiu sob três estágios: cidadania civil (século XVIII), garantindo direitos necessários à liberdade individual; cidadania política (século XIX), garantindo direito ao voto e à participação; cidadania social (século XX), garantindo segurança econômica e direito à vida civilizada de acordo com os padrões sociais. No entanto, tal periodização diz respeito a uma experiência específica: a de homens brancos trabalhadores, excluindo-se hierarquias de raça e gênero.

Sabemos, contudo, que a noção de cidadania está diretamente ligada às lutas sociais em um Estado democrático de direito. No final do século XX, grupos nacionais, raciais, étnicos, de gênero passaram a ocupar um lugar relevante nas disputas políticas, reivindicando justiça na esfera pública. Passa-se a exigir "redistribuição" - comprometimento com o igualitarismo - e "reconhecimento" - uma vez que a subjetividade prevê que, para ser um sujeito individual, faz-se necessário ser reconhecido por outro sujeito (Neves, 2013).

O remédio para o paradigma redistributivo é uma reestruturação econômica, como, por exemplo, redistribuição de renda, reorganização da divisão do trabalho etc. Já a solução para o paradigma do reconhecimento é uma espécie de mudança cultural ou simbólica, como a valorização da diversidade cultural.

Nancy Fraser (apud Neves, 2013) chama a atenção para o caráter bivalente de certos grupos, como os de raça e gênero, por exemplo, uma vez que ambos sofrem injustiças econômicas e sociais, além de falta de reconhecimento. Dessa forma, Fraser propõe o reenquadramento de certos grupos, como o feminismo, classificando uma terceira dimensão: a representação.

Ao levarmos em consideração os direitos políticos no contexto brasileiro, vem-nos à mente a democratização do país. A Constituição de 1988 foi fundamental para a participação democrática, transição do 
regime ditatorial para a democracia. A constituição cidadã, também conhecida como "constituição coragem", criou mecanismos permanentes para a expressão da vontade política, para uma cidadania ativa, em que o cidadão é portador de direitos e deveres, assim como criador de direitos, sempre potencial participante da vida política brasileira.

Para além da representação, a Constituição de 88 também possibilitou inúmeras garantias de direitos sociais, incluindo em seus objetivos "construir uma sociedade livre, justa e solidária", "erradicar a pobreza e a marginalização e reduzir desigualdades sociais e regionais" (art. 3o, I e III). Garante também garantias empregatícias, salário-mínimo, participação dos trabalhadores em lucros das empresas, jornada de trabalho de 8 h diárias, férias remuneradas, licença-maternidade e licença-paternidade etc.

\section{Educação e ética, um par perfeito}

A sala de aula é, por excelência, terreno fértil de esperança e construção de um mundo mais ético, fraterno e justo. Ética e educação têm relação intrínseca e imprescindível. Etimologicamente, ética se origina do vocábulo grego "ethos", que significa "caráter", "modo de ser", "comportamento". Por excelência, ela é a filosofia do questionamento, objetivando fazer-nos refletir sobre nossos modos de ser, habitar, relacionar-nos com o outro de nós mesmo - difícil e inexorável tarefa. Mais ainda, a ética nos é extremamente útil à medida que questiona $\mathrm{e}$ desconstrói preconceitos cristalizados, possibilitando livrar-nos injustiças e amarras.

Ética tem a ver com humanizar o homem, ajudá-lo a repensar os sentidos da vida - múltiplos e inesgotáveis - e a descobrir "em suas próprias inexploradas entranhas/ A perene, insuspeitada alegria/De con-viver" (DRUMMOND, 2020). Ser ético é necessariamente ser crítico, desvelar tanto obscurantismo quanto os absolutismos e permitir um olhar renovado sobre o homem e o mundo.

Segundo Strieder (2000), a ética está diretamente ligada à responsabilidade social; por isso, é imprescindível que o corpo docente reflita sobre como as suas ações podem influenciar positiva ou negativamente 
a sociedade. A ética é inerente à vida em sociedade, ela surge simultaneamente ao convívio humano e deve nortear o mundo da vida a fim de que as ações humanas contribuam para o bem-estar social.

Para Lima (2010), a sociedade está se tornando cada vez mais consciente sobre a importância da responsabilidade social e que as instituições e os profissionais precisam partir para essa mudança por uma questão de sobrevivência da sociedade. Ele acredita que esta mudança não trará apenas efeitos momentâneos, mas duradouros. Dessa forma, as instituições escolares que não estiverem comprometidas socialmente estarão fadadas ao fracasso. O professor tem, portanto, uma notável responsabilidade social, uma vez que ele é aquele que estimula a curiosidade do discente e fomenta nele a construção de uma educação ética e cidadã, pautada em valores humanizados, princípios morais e, sobretudo, amor ao próximo, aquele outro de nós mesmos, nosso semelhante.

A pesquisadora Francisca Severino, em seu artigo "Ética, Responsabilidade Social e Formação de Educadores”, faz a seguinte reflexão sobre a relação intrínseca entre o exercício da docência, a responsabilidade profissional do professor e a necessidade da ética. Para tanto, ela lança mão dos estudos do professor Antonio Joaquim Severino. Leiamo-na:

Destacando o conceito de formação enquanto condição de plena humanidade dos sujeitos - o que subsume a questão dos valores (em especial os éticos e políticos) -, realiza uma síntese abarcando tanto o sentido que atribui à educação quanto o papel que a ética ocupa no processo educativo, identificando esses valores como referências basilares e alicerçadoras para o agir intencionado dos seres humanos, ressaltando o fato de que, uma vez que a educação tem como um de seus deveres transmutar o sujeito em indivíduo autônomo, torna-se premente a necessidade de levá-lo a refletir e reavaliar seus valores morais, a fim de se apoderar de posturas éticas em seu agir. Lembra, ainda, que o envolvimento pessoal de todo educador e sua sensibilidade ética estão articulados a um compromisso com o destino da humanidade na construção de uma sociedade melhor e mais equitativa. (SEVERINO, 2013, p. 316) 
Qualquer aula que valha realmente o tempo despendido é um desafio tanto para o professor quanto para a turma, por isso deve-se buscar continuamente novas formas de fazer com que o aluno veja sentido naquilo que estuda. O maior desafio do professor é ajudar o aluno a se tornar cada dia mais livre, autônomo e consciente. Dessa forma, dar visibilidade a cada estudante a fim de construir uma sala de aula democrática, ética, respeitosa, reflexiva, plural é tanto uma crença quanto um dever do docente enquanto cidadão ético.

\section{Educação em Direitos Humanos}

Em um país como o Brasil, que está entre os líderes mundiais de violência contra o afro-brasileiro, é mister a fim de construirmos uma sala de aula democrática, ética, respeitosa, reflexiva, plural. A sala de aula precisa ser um ambiente alegre e estimulante, aluno deve se sentir acolhido, afinal, só é possível tocá-lo profundamente por meio do acolhimento e da afetividade. Até mesmo o raciocínio mais brilhante do professor só afetará seu público se houver empatia. Uma aula é construção coletiva, portanto, todos devem ter a oportunidade de participar, colocar suas opiniões (desde que elas não desrespeitem ninguém), trocar experiências, conhecimentos, isto é, todos os alunos devem fazer a aula acontecer. Sobretudo, todos os corpos têm que caber na sala de aula, assim como na sociedade.

Por esse viés, jamais a educação pode se afastar dessa arte da pergunta, isto é, da reflexão, do pensamento crítico, que desconstrói preconceitos e busca o conhecimento. Pensar e ser crítico, garantir uma sala de aula em que todos sejam respeitados em suas idiossincrasias, em que todos caibam, é urgente e imprescindível. Já dizia o poeta, "Ninguém é igual a ninguém. Todo o ser humano é um estranho ímpar." (DRUMMOND, 2020).

A recolocação de vozes afro-brasileiras na história nacional precisa, obrigatoriamente, passar pela educação básica - não basta apenas ficar nos restritos e raros círculos acadêmicos -, deve atingir os milhares de meninos e meninas que não se sentem representados pela literatura ensinada nos colégios. Essas crianças são privadas de sua história, de sua 
ancestralidade, que é também a história do Brasil. Rever criticamente a literatura é, nesse sentido, conhecer a próprio passado histórico e tornar possível um futuro digno. Ao pensar o regime colonial brasileiro, Castilho comenta: “A escravidão está entre as principais causas da desigualdade social, permanecendo, infelizmente, até a atualidade na forma de trabalho em condições análogas à de escravo. Seu antônimo natural é a liberdade." (CASTILHO, 2018, p. 77)

É preciso questionar as regras sociais que silenciaram por mais de cem anos - e ainda mantêm apagadas - vozes dissonantes da cultura hegemônica. No Guia de Orientação Cultura e Identidade: Comunicação para a Igualdade Étnico-Racial (UNICEF), é declarado que

Cada criança e cada adolescente, independentemente da raça, etnia ou cor da pele, devem ser estimulados a reconhecer e valorizar as identidades culturais. Ao entender que há tradição e história presentes em aldeias, comunidades ribeirinhas, quilombos, bairros populares, terreiros, assentamentos e outros espaços, eles podem se orgulhar de a cultura de sua localidade integrar a diversidade que caracteriza o Brasil [...] Assim, independentemente da forma como são denominados ou se autodenominam em cada região do País - índios, negros, caboclos, ribeirinhos, habitantes da floresta, quilombolas -, as influências afro-brasileira e indígena podem estar presentes nas formas de ser e de viver, embora as informações sobre essas culturas nem sempre sejam mencionadas no conteúdo escolar, nos meios de comunicação e no dia a dia dos municípios. (UNICEF apud LIMA, 2020, pp. 50-1)

Apesar disso, as próprias escolas brasileiras têm servido de entrave na divulgação da pluralidade literária, acadêmica e no reconhecimento da história de nossos pensadores negros, por variados motivos, entre eles, a falta de investimento na formação continuada de docentes, os cortes de verbas destinados à educação.

No primeiro ano de governo, o presidente Jair Bolsonaro aumentou os gastos com investimentos e custeio da máquina para 
a área de Defesa e reduziu as despesas para a Educação, Saúde e Segurança. O resultado final das contas do governo federal, divulgado pelo Tesouro, mostrou um aumento real (acima da inflação) de 22,1\% das despesas da Defesa em relação a 2018. Um incremento de $\mathrm{R} \$ 4,2$ bilhões de um ano para o outro. (FERNANDES, 2020)

Além disso, o acesso à saúde pública tem sido sistematicamente negado por aquele que deve garantir isso: o Estado brasileiro. São recorrentes os cortes nessas duas áreas, conforme podemos ler na notícia acima.

\section{Considerações Finais}

Pensar uma metodologia e um programa educacional que valorize a pluralidade de corpos é urgente e necessário a fim de promover uma educação que realmente faça jus ao passado histórico brasileiro. Apesar de a Lei de Diretrizes e Bases da Educação Nacional (LDB) já declarar obrigatório "o ensino da história e da cultura afro-brasileira e africana em todos os sistemas e modalidades de ensino" (LIMA, 2020, p. 50), tal aplicação da lei ainda está bastante longe da realidade brasileira. Isso se dá tanto por uma questão metodológica (as historiografias literárias disponíveis no mercado ainda não dão conta da revisão do cânone necessária) quanto por uma defasagem na formação continuada dos professores, que receberam uma bagagem cultural eurocêntrica e não tiveram acesso a autores como Maria Firmina dos Reis, Gilka Machado, Nísia Floresta, entre muitas outras escritoras apagadas de nossa literatura.

Estudar os escritores que construíram nossa literatura está diretamente relacionado com a necessidade de reconhecer nossa história, nossa origem, preservar nossa memória e ir de encontro a uma cultura hegemônica que, por séculos, perpetuou a violência - sob suas mais variadas formas, institucional, cultural, simbólica, física - contra as minorias, principalmente a população negra.

Segundo Le Goff, uma das "grandes preocupações das classes, dos grupos, dos indivíduos que dominaram e dominam as sociedades históricas é tornar-se senhores da memória e do esquecimento". "Os es- 
quecimentos e os silêncios da história são reveladores desses mecanismos de manipulação da memória coletiva" (LE GOFF, 2003, p. 422). É preciso romper o silêncio que humilha e amesquinha a nossa história nacional e a ancestralidade negra, assim, e apenas dessa maneira, pela educação, poderemos construir uma nação realmente consciente do lugar que ocupa no tempo e no espaço e que honre seu povo.

Além disso, deve-se investir em saúde pública, educação e ciência, pois só assim poderemos garantir o direito à vida, preconizado pela ONU, e afastar-nos das noções de "necropolítica" e de "necropoder" desenvolvidas por Mbembe, que nos ajudam a compreender "as várias maneiras pelas quais, em nosso mundo contemporâneo, as armas de fogo são dispostas com o objetivo de provocar a destruição máxima de pessoas e criar 'mundos de morte `, formas únicas e novas de existência social, nas quais vastas populações são submetidas a condições de vida que lhes conferem o estatuto de 'mortos-vivos." (MBEMBE, 2020).

\section{Referências}

ANDRADE, Carlos Drummond de. O homem: As viagens. Disponível em: https://www.ufrgs.br/psicoeduc/chasqueweb/poesia/ drummond1.htm. Acesso em 23 abr. 2020.

BRASIL. Constituição da República Federativa do Brasil. 1988. 28. ed. São Paulo: Saraiva, 2001.

CASTILHO, Ricardo. Direitos humanos. São Paulo : Saraiva Educação, 2018.

EBC. "Analfabetismo resiste no Brasil e no mundo". Disponível em http://agenciabrasil.ebc.com.br/educacao/noticia/2019-09/analfabetismoresiste-no-brasil-e-no-mundo-do-seculo-21 Acesso em 05 maio. 2020.

FERNANDES, Adriana. "Bolsonaro aumenta gastos com Defesa e diminui com Saúde e Educação”. Jornal Estadão. Brasília, 31/01/2020. Disponível em https://economia.uol.com.br/noticias/estadao-conteudo/2020/01/31/bolsonaro-aumenta-gastos- 
-com-defesa-e-diminui-com-saude-e-educacao.htm. Acesso em 12 jul. 2020.

LE GOFF, Jacques. História e Memória. São Paulo: Unicamp, 2003.

LIMA, Gilberto Barros. O olhar da sociedade para a responsabilidade social, 2010. Disponível em: . Acesso em: 01 maio 2020.

LIMA, Paulo. Literatura, Educação e Identidade Étnico-Racial. Brasília: Faculdade Unyleya, 2020.

MBEMBE, Achille. “A era do humanismo está terminando”. Disponível em http://www.ihu.unisinos.br/186-noticias/noticias-2017/ 564255-achille-mbembe-a-era-do-humanismo-esta-terminando. Acesso em 12 jul. 2020.

NEVES, Raphael. “Transformações da Cidadania e Estado de Direito no Brasil”. In Manual de Sociologia Jurídica. SILVA, Felipe; Rodriguez, José (orgs.). São Paulo: Editora Saraiva, 2013.

ONU. Declaração Universal dos Direitos Humanos, 1948. Disponível em https://www.unicef.org/brazil/declaracao-universal-dos-direitos-humanos. Acesso em 12 jul. 2020.

SEVERINO, Francisca Eleodora Santos (Org.). Ética e formação de professores: política, responsabilidade e autoridade em questão. São Paulo: Cortez, 2011, 149 p.

STRIEDER, Inácio. Ética na vida e no trabalho. Perspectiva Filosófica, Volume VII. Recife: UFEP, 2000.

TAVARES, Raquel. Direitos Humanos - de onde vêm, o que são e para que servem? Imprensa Nacional da Casa da Moeda, 2012.

VIEIRA, Danilo. "Ação universalista norte-americana e o desenvolvimento do terrorismo contemporâneo", 2018. Disponível em http://wwws.fclar.unesp.br/agenda-pos/ciencias_sociais/4575.pdf 


\section{A TRANSDISCIPLINARIDADE ENTRE FILOSOFIA, PEDAGOGIA E PSICOLOGIA PARA UM ENSINO ÚTIL, HUMANO E SENSÍVEL}

Walfrido Monteiro Júnior

\section{Introdução}

Sabemos que pode não ser a melhor resposta, mas, para a realidade de hoje, de fato, para que o professor consiga realizar um trabalho de qualidade, deve buscar novos conhecimentos que auxiliá-lo na aula, portanto, dominar outros aspectos cognitivos e agregar outros saberes à sua classe, ser claro em seus propósitos de ensino (Bruner, 1969) principalmente acerca do objetivo de sua aula, de onde está partindo e aonde deseja chegar, conhecer seus alunos e orientá-los da melhor maneira possível, tanto em suas vidas pessoais como ensinar a aprender, deve olhar para os seus alunos, entender suas realidades, seus limites e suas potencialidades, porque geralmente os nossos estudantes não são incentivados por suas famílias a estudarem, este é um outro papel do professor, criar, de acordo com Bruner (1969), estímulos extrínseco

Apesar de ter sido defendida por Piaget nos anos 70, a transdisciplinaridade ainda é desconhecida por muitos professores e achamos que esse modelo de ensino é uma estrutura possível, que auxilia o professor a enfrentar todos esses problemas, pois neste artigo, nossa intenção é unir três estruturas importantes: a Psicologia Cognitiva de Bruner que consiste em trabalhar com os alunos o conhecimento de forma espiral 
transdisciplinar, a Psicologia de Pigeon Riviere sobre o vínculo e a metafísica de Heidegger sobre a observação da coisa (estudantes) para justificar e criar essa analogia sobre a importância de conhecer a realidade, a cultura, as limitações e potencialidades de cada aluno, porque não são meros números, são pessoas.

E, finalmente, apresentar o resultado da aplicação em duas equipes de alunos do ensino fundamental e obteve ótimos resultados de acordo com o IDESP (Índice de Desenvolvimento Educacional de San Pablo).

\section{Desenvolvimento}

Todas las ciencias del hombre funcionan como una unidad operacional enriqueciendo tanto el objeto del conocimiento como las técnicas destinadas a su abordaje. (Pichon Riviere, 1975. p.150).

Neste texto, daremos importância ao uso da transdisciplinaridade, conceito científico defendido por Jean Piaget no 1ํㅗ슨 Semio Internacional sobre Interdisciplinaridade e múltiplos saberes realizado na Universidade de Nice nos anos 70, esse elemento científico também foi defendido por Edgar Morin e principalmente Basarab Nicolesco. Com essa citação de Pichón Riviera podemos perceber que a Transdisciplinaridade defende uma abordagem múltipla e unida entre as disciplinas ou áreas de conhecimento, ou seja, para resolver um problema, podemos criar soluções a partir da ajuda de diversas disciplinas em conjunto.

Bruner (1969) relata em seu livro a experiencia de ter administrado um curso de ciência social para crianças do ensino primário (5ำ ano) sobre o Homem, mas em sua prática pedagógica usa a introdução de Linguística, Geografia, História, Filosofia, Antropologia, Ecologia e outros. Vamos agora explicar uma possível utilização da teoria de Martin Heidegger que, juntamente com as contribuições de Jerome Bruner e Pichon Riviere pode ajudar os professores a entender a importância do olhar e do afeto. 


\section{O olhar do educador de acordo com a teoria da observação de Heidegger.}

Sabemos que o contexto da teoria de Martín Heidegger está relacionado à arte e, ao mesmo tempo, às diferentes formas de observar uma coisa, mas, devido à distinção entre essas coisas, é permitida a possibilidade de usá-las com os alunos. Vamos primeiramente situar o leitor sobre as teorias presentes no livro "A Origem da Obra de Arte", dando enfoque para a "mera coisa" e a "coisa obrada".

Um trabalho que elucidará nosso exemplo será apresentado:

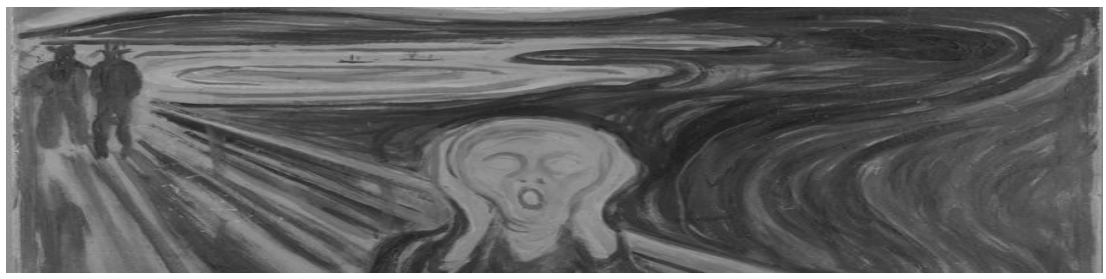

Imagem 1: obra: O Grito, (Edvard Much $\left.{ }^{41}, 1893\right)$.

Quais os sentidos do Ente e do Ser para Heidegger? O Ente é o objeto da obra de arte, podemos perceber na imagem acima: duas pessoas distantes, um rio, uma ponte, um ser com aspecto cadavérico e que olha para nós.

Encontramos apenas esta informação? Se seguirmos os conceitos de Heidegger, provaremos que não! Quando pensamos em uma entidade fora do contexto artístico, percebemos que o objeto é apenas um objeto, um sapato em uma prateleira deve ser usado em um momento conveniente para a proteção dos pés de uma pessoa em particular, isso se refere à vida real, não tem transcendência ou contextualização, no entanto, uma obra de arte pode trazer uma verdade. Sua verdade em um contexto, é como um ser no mundo, pois pode trazer uma grande quantidade de informação, já que um simples sapato na obra, poderia ser o contexto da própria obra.

41 Artista da Noruega, precursor do estilo expressionista alemão, em suas obras os principais conceitos do existencialismo estavam em andamento 
Podemos entender que eles não são "meras coisas" não precisam da nossa lógica para existirem, tem-se a liberdade de ser o que são, olhamos para duas pessoas distantes do nosso observador, que tem a sua própria vida na obra, e ele pede ajuda, seu rosto cadavérico transmite a sensação viva de seu próprio desespero, incapaz de ser ajudado. E por que não podemos dizer que ele é um ser em um mundo temporal e atemporal?

Podemos compreender que, para Heidegger, o momento da criação é comparado com o transcendental, não há criação física ou audível, a obra a ser feita, precisa do artista, da mesma forma que o artista é, de fato, o possibilitador temporário da pré existencia da obra.

No momento em que a obra está terminada, ela ganha a dimensão que ela deseja, sua própria vida, ela tem a liberdade de ser o que ela realmente é, essa revelação não está totalmente terminada, a essência da verdade nos mostra a diferença entre ser e o ser da obra, do ser do mundo na obra, que pode falar com os observadores, pode levar os observadores à sua realidade e ao mesmo tempo transformar aqueles que contemplam a obra. De acordo com (Ferreira, 2006, p. 205), “A reflexão filosófica sobre o carater de arte da obra implica, antes, o estabelecimento da correlação entre arte e verdade, pois, para ele [Heidegger], é próprio da arte comunicar modo de ser do mundo e do homem como expressão da verdade do ser". Com isso, como podemos usar esses conceitos em possíveis comportamentos úteis e aplicáveis em uma aula ou com alunos dentro ou fora de uma sala de aula?

Em um sentido pertencente aos conceitos construtivistas de Bruner ou Pichon Riviera juntamente com teorias de Martin Heidegger sobre as coisas, substituímos as coisas por pessoas (que também são coisas), um estudante pode ser tratado como uma mera coisa, uma coisa sem identidade, realidade, verdade, como uma cadeira que qualquer um pode dizer o que vai ser, não está em seu próprio controle só para seguir as ordens, não tem sonhos, ele está lá apenas para ser mais um e é geralmente bem o que acontece.

Quando olhamos para os nossos alunos, temos que conhecer seus nomes, sabermos sobre a sua realidade, propor livros ou atividades que irão ajudar, não estamos considerando nossos alunos como meras 
coisas, mas coisas obradas que devem ser considerados, observados e ouvir as suas realidades, sem rótulo, são pessoas que devem ser tratadas como pessoas.

Quando entramos em uma loja para comprar alguma coisa, somos tratados muito bem, mas se acontece o contrário, mudamos de loja, quem são nossos clientes? Quem devemos olhar e perguntar qual é a melhor maneira de tratá-los? Nós fazemos isso com nossos alunos? Eles são tratados como pessoas que precisam da nossa ajuda ou como coisas coisificadas, meras coisas?

Assim, entendemos cuanto as teorias de Martin Heidegger podem nos ajudar a entender que nossos alunos são as nossas obras de arte ou coisas obradas, da mesma forma que uma obra de arte só existe por motivos de existir um artista, um artista só existe a partir da obra de arte, da construção da arte, um precisa do outro e para os alunos terem conhecimento e realizações em suas vidas, eles precisam de seus professores da mesma forma que para ser um professor, você precisa ter alunos.

Portanto, deve ser uma relação de união como podemos olhar para a citação de (Bruner, 1969, p.58): "É costumeiro ao discutir as predisposições para aprendizagem, focalizar os Fatores Culturais, motivacionais e pessoais que influem no desejo de aprender, de tente solucionar problemas. [...] por exemplo, a relação professor-aluno [...] “.

Entrar em uma sala de aula e ensinar só para dizer que cumpriu seu papel de professor não é a mesma situação que realmente ajudar as pessoas a alcançar sucesso na vida, não é a melhor maneira de fazer, o professor deve conhecer um conjunto de conhecimentos não só para ensinar, mas para criar estratégias sobre como, de fato, ajudar os alunos em cada dificuldade que vai identificando em seus alunos, estimular, incentivar, dizem que seus alunos também podem ser o que eles querem ser, independentemente de suas situações financeiras, isso é observado na seguinte citação de Bruner:

Referencia apenas passageira foi feita às diferenças individuais: é claro que existem em grande quantidade - na intensidade da predisposição das crianças para poder resolver, no seu grau de interes- 
se, nas habilidades que possuem para as tarefas concretas, na sua forma preferida de representação, e na medida em que são, inicialmente dependentes do esforço extrínseco do professor (p.88).

Segundo (Pérez Lindo, 2010, p.53) nos diz:

[...] La desintegración social y los fenómenos de exclusión nos impulsan a reforzar la solidaridad y la ciudadanía. Las crisis de la familia y de las relaciones interpersonales pone en primer plano la formación afectiva. Estos y otros elementos se han yuxtapuesto a las funciones tradicionales de la escuela: la formación, la instrucción y la socialización.

Bruner utiliza atividades com seus alunos que permitem trazer um reforço para este artigo, um professor que pensa em ensinar matemática ou em ensinar uma língua, seja nativo ou estrangeiro, pode usar conhecimentos de antropologia, sociologia, ciências sociais e filosofia, não cada uma em sua estrutura separada, mas unidas, outra abordagem importante deste autor é o uso do jogo (recurso lúdico).

\section{A Psicologia de Bruner e Pichon Rivière para um ensino de qualidade e sensível}

Esta segunda parte destina-se a ações pedagógicas de transdisciplinaridade que possam auxiliar nas aulas de professores de Humanas, Biológicas e Exatas, ou seja, conhecer outras áreas do conhecimento para ampliar os conteúdos da aula.

Uma definição importante de Pichon Riviere (1975) sobre o vínculo ajuda a construir o seguinte pensamento, a relação construtivista entre o professor e o aluno:

La didáctica interdisciplinaria se apoya en la preexistencia; en cada uno de nosotros, de un esquema referencial (conjunto de experiencias, conocimientos y afectos con los que un individuo piensa y actúa) que adquiere unidad por medio del trabajo grupal, promoviendo simultáneamente en ese grupo o comunidad un esquema referencial y operativo [...] (p.151). 
E ao mesmo tempo Bruner apresenta um bom exemplo de ensino que se divide em quatro temas: Linguagem, organização social, ferramentas de produção e sobre as crianças, com isso, em uma aula de língua estrageira, as crianças não vão saber apenas o estudo da linguagem, devem aprender sobre a estrutura da língua, as histórias desse povo, como vivem, qual a origem desse povo, como são os povos nativos, esses conteúdos são trabalhados com diversas estratégias pedagógicas como o uso de documentários, filmes sobre povos nativos ou antigos, a relação dos nativos que originaram a lingua e a sociedade atual o uso de contrastes com os sentidos de lutar e defender-se, vivendo e matando (caçando) o uso de histórias mitológicas, portanto, uma classe atrativa, estimulante, útil, os estudantes não estarão em uma posição de espectadores, mas produtores de conhecimento, já que em todos os momentos os alunos são colocados para pensar em um determinado problema.

Outro ponto importante sobre o vínculo é defendido por Pichon Riviere que nos diz:

[...] Podemos definir el vínculo como una relación particular con un objeto; de esta relación particular resulta una conducta más o menos fija con ese objeto, la cual forma un pattern, una pauta de conducta que tiende a repetirse automáticamente, tanto en relación interna como en relación externa con el objeto (p.35).

Por fim, segundo Bruner, é importante utilizar como estratégia pedagógica o uso de jogos para estimular, entreter e fazer os alunos pensarem em um problema específico, como podemos ver na citação a seguir (Bruner, p.101):

"Pretendemos, em suma, criar jogos de projetar ferramentas, considerando as variações de custos, função específica técnicas exigidas, para demonstrar a natureza programática das ferramentas, e como representam elas extensões, seletivas das aptidões do homem". 


\section{Uma situação de aprendizagem Transdisciplinar}

Trazemos uma experiência de Transdisciplinaridade que foi aplicado em 2017 na escola estadual Natercia Cremm de Moraes Pedro Prof ${ }^{-}$em duas turmas do ensino fundamental ( $9^{\circ}$ anos), adolescentes que tiveram comportamento belicoso, atitudes transgressoras sem estímulos para estudar, então algo tinha que ser feito, a principio foi realizado um trabalho de estímulo, foi explicado a real função da escola e que o papel do professor é auxiliá-los em seus medos, dificuldades, limites e que no processo de aprender, tais comportamentos eram normais, auto valorização, porque muitos estudantes naquela situação não acreditavam em seu potencial, especialmente aqueles que tiveram problemas familiares, em seguida, houve uma busca por teorias como a Psicologia social, "Pygmalion" para criar condições de estímulos, uso de filmes e documentários para mostrar que outros estudantes com igual realidade conseguiram alcançar exitos.

Os estudantes dessa escola que este projeto foi implantado são muito carentes de recursos financeiros e muitos não têm computadores ou internet em casa, com isso, o segundo passo era transformar a sala de aula em um espaço agradável e tecnológico para fugir da prática tradicional, criando situações para aumentar e otimizar o ensino, promovendo a construção do compartilhamento de conhecimentos prévios e ampliá-los, principalmente por ser um trabalho colaborativo. Veja a imagem abaixo:

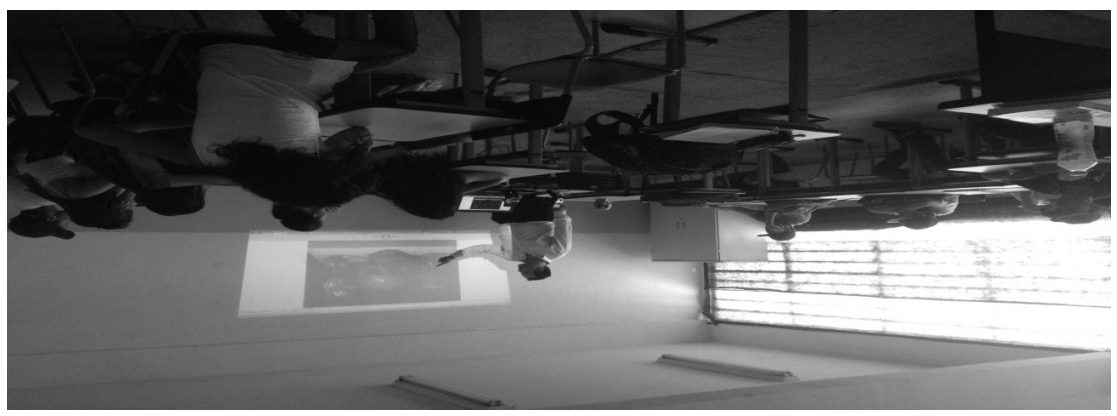

Arquivo pessoal: sala com tapetes, pinturas de arte, recursos multimídia: notebook, projetor, alto-falante, microfone e internet. Por questões de vergonha, alguns estudantes não quiseram aparecer na imagem, escolha que foi respeitada pelo professor. 
Os alunos foram destinados a construir uma planilha de estudos, cujo objetivo era destinar duas horas por dia no estudo de duas disciplinas, de acordo com Cortella (2000) prática do estudo não pode acontecer apenas na escola. Semanalmente o professor construiu vários Quiz em diversos níveis de dificuldade para o treino dos estudantes sobre o conteúdo que já foi estudado durante cada bimestre, com o foco em fixação de conteúdos e teorias, e resolução de problemas, seguindo o mesmo modelo das provas externas (Estaduais e Federais) .

$\mathrm{O}$ uso de mapas conceituais permitiu que os alunos sintetizassem o que foi aprendido e construir relacionamentos entre conteúdo, memorização, praticidade e dinamismo, os alunos foram estimulados a apresentarem os seus pensamentos e contribuições, respeitando os erros e limites de cada indivíduo.

Nessas aulas o quadro negro não é utilizado, já que todas as orientações são criadas no Power Point e são utilizados recursos como vídeos, documentários, filmes e imagens, segundo Magadan (2012) os recursos tecnológicos não podem ser ilustrativos, mas sim recursos que contribuam de forma significativa no processo ensino-aprendizagem.

Outro exemplo de transdisciplinar foi o uso de conhecimentos de psicologia em conjunto com as teorias de Heidegger sobre o olhar, o observador e a obra de arte, todos os alunos foram tratados como coisas obradas, ou seja, cada aluno possui a sua importância, não são números em uma lista de chamada, mesmo aqueles que no início do ano letivo não queriam participar da aula, perceberam que não precisavam ter medo de se exporem, de errar, de brincar, de serem indivíduos visiveis, tais conhecimentos permitiu a construção de um ambiente construtivo, amigável, sensível.

Também foi observado que a agressão verbal ou atitudes transgressoras foram mudando para a união dos estudantes, principalmente porque eles eram respeitados como seres humanos, como pessoas importante e capazes de alcançar sucessos, só faltava incentivo, uma palavra amiga, entendemos que ouvir o outro constrói pontes, cria amigos, não trabalhamos como educador para bater cartão, mas para construir pessoas melhores, tentamos animar a dor e permitir que o sonho se torne realidade. 
Outro resultado importante foi confirmado por uma prova externa realizada em Novembro de 2017 e segundo o IDESP - (Índice de Desenvolvimento da Educação de São Paulo) esses alunos tiveram a pontuação mais alta em comparação com outras escolas da região de Itapecerica da Serra, São Paulo que passou de 1,60 resultado de 2016 para 3,30 em 2017.

\section{Considerações finais}

Concluímos que o professor precisa se adaptar às novas realidades do século XXI, esta nova geração chamada Geração Net acostumada com a velocidade da informação, e ao mesmo tempo vivendo em um "mundo líquido", segundo Zygmunt Bauman, não se seduz com uma aula projetada a partir de modelos da Idade Média, os educadores também precisam saber modelos pedagógicos atuais e conhecimentos psicológico para sabermos com respeito lidar com a nova geração, porque não estamos lidando com meros objetos ou coisas, o profissional da educação também deve ser um estudioso, acompanhar as mudanças, evidenciamos a terceira fase da Revolução Industrial ou Revolução Tecnológica, mas nossos professores ainda estão seguindo construções pedagógicas que hoje estão desuso.

Para os estudantes, eles precisam de informações, precisam ser desafiados a resolver problemas que são reais, de acordo com Dewey, a aula precisa ser útil, o aluno precisa saber por que está aprendendo, qual é o propósito de estar aprendendo tal conhecimento e, ao mesmo tempo, ser tratado com respeito, sensibilidade e principalmente encorajado a pensar que podem sonhar e mais do que isso, que podem alcançar seus objetivos e uma estrutura possível que pode ajudar os professores é a Transdisciplinaridade.

\section{Bibliografia}

BRUNER, Jerome. La fábrica de historias: derecho, literatura, vida. - 2 ed. Buenos Aires, Fondo de Cultura Económica, 2013.

(1996) Cap. 1: Cultura, mente y educación. En La educación, puerta de la cultura. Madrid: Aprendizaje Visor. 
Uma nova teoría de aprendizagem. $1^{\underline{a}}$ ed. Rio de Janeiro, Bloch Editores, Brasil, 1969.

HEIDEGGER, M. El ser y el tiempo. México, Fondo de Cultura, 1967.

A origem da obra de arte. Trad. Maria da Conceição Costa. Lisboa: Edições 70, 1990

MAGADÁN, Cecilia (2012), “Clase 3: Las TIC en acción: para (re)inventar prácticas y estrategias", Enseñar y aprender con TIC, Especialización docente de nivel superior en educación y TIC, Buenos Aires, Ministerio de Educación de la Nación.

PERÉZ LINDO, Augusto, ¿Para qué educamos hoy?: Filosofía y teoría de la educación.- 1aㅡ ed. Buenos Aires: Biblos, 2010.

PICHON RIVIÈRE, E. (1975) Prólogo y Cap. Estructura de una escuela destinada a Psicólogos Sociales. El proceso grupal. Buenos Aires: Nueva Visión.

Teoria del Vículo. Ediciones Nueva Visión, $5^{\mathrm{a}}$ ed. Buenos Aires, República Argentina, 1985. 


\section{A SALA DE AULA INVERTIDA: UM ESTUDO DAS VANTAGENS E DESAFIOS DO MÉTODO}

Roberta Maciel Campolina

\section{INTRODUÇÃO}

Atualmente, o mundo tecnológico trouxe influencia em todos os ramos da vida. E não seria diferente com o processo de ensino e aprendizagem. O professor, que durante muitos anos teve papel central nesse processo, ganha um novo facilitador - a tecnologia.

Usá-la ao seu favor é um grande desafio. Os moldes tradicionais da sala de aula já não se ajustam as necessidades da nova geração de alunos, que já nascem conectados à rede e à tecnologia. Por isso, repensar a sala de aula é um dos grandes desafios da pedagogia atual.

É nesse contexto que o presente trabalho possui como tema a sala de aula invertida, uma metodologia de aprendizagem onde o aluno assume o papel de protagonista, e o professor ganha o papel de conciliador e de facilitador.

A sala de aula invertida é uma estratégia de ensino que surgiu para quebrar paradigmas, modificando a organização tradicional da sala de aula, de modo que o aluno tenha prévio contato com o material da aula e possa discuti-lo com o professor.

Desse modo, o problema que guia o presente trabalho é o seguinte: Considerando o cenário atual, onde a tecnologia se faz cada vez mais presente na vida do homem, é possível que a metodologia da sala 
de aula invertida traga benefícios para os alunos e um aperfeiçoamento do processo de aprendizagem?

A hipótese de pesquisa é que, embora existam inúmeros desafios na aplicação da sala de aula invertida, seus benefícios se demonstram capazes de gerar a motivação nos alunos e desenvolver novas habilidades, aperfeiçoando o processo de aprendizagem.

O objetivo do trabalho é analisar se a metodologia da sala de aula invertida traz benefícios para o processo de aprendizagem. Como objetivos específicos, busca-se estudar a técnica da sala de aula invertida e seus elementos; verificar as vantagens da aplicação da sala de aula invertida; compreender os desafios da técnica.

Justifica-se a realização da presente pesquisa pela relevância do tema nos dias atuais, já que é preciso se pensar em alternativas para o método tradicional de ensino aprendizagem, diante do novo contexto da tecnologia e da educação no Brasil, buscando-se formas de aperfeiçoar o processo.

\section{DA SALA DE AULA INVERTIDA}

Para Bergmann e Sams (2016), a sala de aula invertida consiste em: "o que tradicionalmente é feito em sala de aula agora é executado em casa, e o que tradicionalmente é feito como trabalho de casa agora é realizado em sala de aula".

Assim, seu objetivo é transformar a sala de aula em um local mais dinâmico e interativo, onde a aula expositiva cede lugar para atividades que propiciem debates e discussões, de modo a enriquecer a aprendizagem dos alunos, fixando melhor o conteúdo, já que o aluno deve estuda-lo previamente à aula.

Segundo Moran (2014) esse modelo é uma das teorias mais inovadoras da atualidade, conciliando o método de estudo com a tecnologia, já que o conteúdo pode ser disponibilizado no ambiente virtual, e na sala de aula realizam-se atividades criativas e supervisionadas.

Scheneiders (2018) define a metodologia nos seguintes termos:

Esta metodologia consiste na inversão das ações que ocorrem em sala de aula e fora dela. Considera as discussões, a assimilação e a 
compreensão dos conteúdos (atividades práticas, simulações, testes, ...) como objetivos centrais protagonizados pelo estudante em sala de aula, na presença do professor, enquanto mediador do processo de aprendizagem. Já a transmissão dos conhecimentos (teoria) passaria a ocorrer preferencialmente fora da sala de aula. Neste caso, os materiais de estudo devem ser disponibilizados com antecedência para que os estudantes acessem, leiam e passem a conhecer e a entender os conteúdos propostos (SCHENEIDERS, 2018, p. 7).

A metodologia de aprendizagem inverte as ações na sala de aula, que se torna palco para a discussão e compreensão do conteúdo, com a mediação do professor, sendo que a teoria é estudada fora da sala de aula, por meio de material disponibilizado com antecedência para que o aluno possa entender os conteúdos e conhecimentos.

Desse modo, o papel do professor também sofre alterações, o mesmo deixa de ser o protagonista do processo de aprendizagem:

O professor passa a mediar e orientar as discussões e a realização das atividades, agora executadas em sala de aula, considerados os conhecimentos e conteúdos acessados previamente pelo estudante, isto é, fora do ambiente da sala de aula. Agora o professor pode dedicar o seu tempo de sala de aula, na presença dos estudantes, para consolidar conhecimentos para orientá-lo, esclarecer as suas dúvidas e apoiá-lo no desenvolvimento do seu aprendizado. É, portanto, uma estratégia que propõe mudar alguns elementos do ensino presencial, sugerindo uma alternativa à lógica tradicional (BERRETT, 2012) (SCHENEIDERS, 2018, p. 7).

O papel do professor é mediar e orientar as discussões e as atividades, que são realizadas em sala de aula, e não mais em casa. Já o conteúdo é estudado previamente pelo aluno. O professor apenas consolida o conhecimento, orientando, esclarecendo, contribuindo para o desenvolvimento da aprendizagem.

Assim, complementa o autor:

Nessa abordagem, tanto o professor quanto o estudante devem mudar de postura. O estudante deixa de ser um expectador e 
passa a atuar ativamente, tornando-se o protagonista do seu aprendizado. Já o professor sai do palco, deixa de atuar como palestrante e se posiciona próximo ao aluno, auxiliando-o no processo de aprendizagem, assumindo uma postura de orientador e tutor (SCHENEIDERS, 2018, p. 7).

Por isso se chama sala de aula invertida, os papeis se modificam. O professor deixa de ser o protagonista, e o aluno assume esse papel, o aluno deixa de ser expectador, e passa a atuar ativamente, sendo que o professor passa a ser uma espécie de orientador.

\subsection{A aplicação da metodologia}

Segundo Pereira (2010), a aprendizagem é inerente ao estudante, e não é fácil avaliar em que medida o professor pode, de fato, auxiliar o estudante nesse processo. Por isso, a sala de aula invertida se apresenta como metodologia interessante.

Para sua aplicação, é preciso um planejamento do professor, com a delimitação de cada atividade, organização do tempo e do espaço, com a definição do que será feito em casa e do que será feito em sala de aula.

As atividades do professor fora da sala de aula poderão, a partir deste planejamento, ser maiores e mais importantes do que aquelas realizadas em sala de aula. No âmbito das atividades extraclasse do professor, a elaboração e o detalhamento do plano de aula deve ser uma das prioridades. É necessário que o docente prepare os materiais e os disponibilize aos estudantes antes da aula, objetivando tornar o debate presencial mais qualificado. Essa qualidade está relacionada com a reflexão prévia dos estudantes a respeito do tema a ser abordado em aula (SCHENEIDERS, 2018, p. 7).

O professor elabora cuidadosamente o plano de aula, prepara os materiais e disponibiliza-os aos alunos antes da aula. Assim, o aluno estudo em casa, e promove o debate em sala, o que trará maior reflexão sobre o tema, levando a assimilação do conteúdo. 
Reforça-se esse entendimento:

Para a aplicação dessa abordagem, é necessário que o docente prepare o material e o disponibilize aos alunos por meio de alguma plataforma on-line (vídeos, áudios, games, textos e afins) ou física (textos impressos) antes da aula, de modo a tornar o debate presencial mais qualificado devido à prévia reflexão dos estudantes a respeito do tema que será abordado. Ocorre, portanto, uma inversão no modelo tradicional: as tarefas que costumavam ser destinadas à lição de casa passam a ser realizadas em sala de aula, aplicando-se o que foi estudado anteriormente por meio do material disponibilizado pelo professor. Nesse contexto, a sala se torna um ambiente rico em conhecimento, com a adoção de exercícios, atividades em grupo e discussões (ENSINO INOVATIVO, 2015, p. 15).

O material pode ser disponibilizado on-line ou impresso, antes da aula, para que o aluno estude o mesmo. Em sala de aula, haverá a reflexão sobre o material. Assim, há a inversão, o que seria feito em casa é feito em sala de aula, e vice-versa. Em casa, estuda-se o conteúdo, em sala de aula, realiza-se exercícios, atividades e debates.

Scheneiders (2018) apresenta um quadro com algumas ações que podem ser aplicadas no método da sala de aula invertida, apresentando uma relação entre o papel do aluno e do professor.

Figura 1 - Ações da sala de aula invertida

\begin{tabular}{|c|c|c|}
\hline & 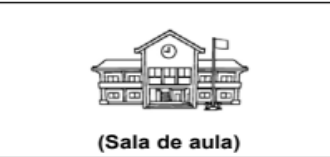 & (Outros espaços) \\
\hline (Modelo Tradicional) & $\begin{array}{ll}\text { - } & \text { Transmissão de informação } \\
\text { e conhecimento } \\
\text { - } & \text { Professor palestrante } \\
\text { - } & \text { Estudante passivo }\end{array}$ & $\begin{array}{l}\text { - Exercícios } \\
\text { - Projetos } \\
\text { - } \text { Trabalhos } \\
\text { - Solução de problemas }\end{array}$ \\
\hline (Sala de Aula Invertida) & $\begin{array}{ll}\text { - } & \text { Debates } \\
\text { - Projetos } \\
\text { - Simulação } \\
\text { - Trabalhos em grupos } \\
\text { - Solução de problemas } \\
\text { - Estudante ativo }\end{array}$ & $\begin{array}{l}\text { - Leituras } \\
\text { - Videos } \\
\text { - Pesquisas } \\
\text { - Busca de materiais } \\
\text { alternativos }\end{array}$ \\
\hline
\end{tabular}

Fonte: Scheneiders, 2018, p. 8. 
Enquanto que no modelo tradicional há em sala de aula a transmissão de informações e do conhecimento, com o professor no papel de palestrante e o estudante no papel de sujeito passivo, no modelo de sala de aula invertida há a promoção de debates, elaboração de projetos, realização de simulação e trabalhos em grupos, proposta de solução de problemas, assumindo o estudante o papel de sujeito ativo.

Em um primeiro momento, dias antes da aula, o professor prepara o conteúdo, compartilha o mesmo com os alunos e estes acessam-no. Durante a aula, os estudantes apresentam as dúvidas, o professor esclarecem-nas, e são realizadas atividades. Assim, depois da aula o professor avalia e planeja o novo tópico e os alunos revisam os conteúdos. Por isso, sugere-se que a aprendizagem será mais efetiva.

\subsection{A transmissão do conhecimento}

Segundo Litto e Formiga (2009), para que a transmissão do conhecimento funcione adequadamente, é necessário a estruturação de apoio ao estudante, por meio de materiais, textos, livros, revistas, entre outros.

Nesse sentido, Scheneiders (2018) elabora algumas ações que auxiliam no planejamento para a aplicação da sala de aula invertida, no aspecto de transmissão do conhecimento:

1. Elabore um planejamento ou programa para começar a trabalhar. Considere que ele pode ser ajustado, dependendo da comprovação do progresso da turma. Considere também a questão de finalizar os conteúdos com atividades práticas, com a definição de múltiplos cenários ou ainda com o método da problematização como elementos viáveis do processo de consolidação da unidade de aprendizagem planejada;

2. Defina os conteúdos-chave, os mais importantes, aqueles que não podem faltar alcançado. Esses conteúdos devem ser fornecidos pelo professor, em diversos formatos e refletir em uma visão compreensiva desses objetivos. Considere aqui o(s) melhor(es) formato(s) para que o estudante efetivamente te- 
nha boas experiências no processo de obtenção da informação. Lembre que estamos no processo de transmissão dos conhecimentos e este é realizado pelo estudante. Ex.: vídeos, infográficos, GIFs, textos não muito longos, reportagens etc.;

3. Sintetize cada um dos conceitos escolhidos, com explicações claras e objetivas, preferencialmente com exemplos que favoreçam e fortaleçam a sua compreensão. As dúvidas podem ser registradas e discutidas em fóruns próprios ou ainda a partir de uma base de perguntas frequentes já respondidas e, preferencialmente, comentadas;

4. Prepare seus próprios vídeos sempre que possível. Eles podem ser produzidos a partir de câmeras do próprio computador, de câmeras externas e/ou a partir do compartilhamento da tela do seu computador. Dica: utilize materiais de apoio, como apresentações, imagens, quadro branco, lousa digital etc.;

5. Certifique-se que todos os materiais estejam disponíveis para os estudantes e que sejam acessados antes de virem para a aula. Isto é, seus vídeos, vídeos de outros, textos, capítulos de livros, reportagens, entrevistas, imagens, fóruns, perguntas frequentes com respostas comentadas etc.;

6. Apresentar desafios de modo a instigar o estudante a pesquisar em fontes alternativas de conteúdos, que vá um pouco além do material fornecido pelo professor (SCHENEIDERS, 2018, p. 9-10).

O primeiro passo é a elaboração do planejamento, posteriormente, a definição dos conteúdos-chaves, aqueles que imprescindivelmente devem ser alcançados, para depois sintetizar os conceitos, por meio de explicações claras, para fortalecer a compreensão.

\subsection{A assimilação do conhecimento}

A etapa de assimilação do conhecimento acontece na sala de aula, com o professor e os demais alunos. Para Litto e Formiga (2009), é 
preciso que o professor avalie a qualidade e profundidade do conteúdo obtido pelo aprendiz, para mediar as discussões sobre o mesmo, verificando se houve a assimilação do conhecimento proposto.

Nesse sentido, Scheneiders (2018) elabora algumas ações que auxiliam no aspecto assimilação do conhecimento:

1. Certifique-se de que os conteúdos foram acessados e compreendidos pelos estudantes. Considere mediar um debate com o objetivo de identificar a leitura dos materiais e também as principais dúvidas resultantes dessa leitura;

2. Utilize métodos que o auxiliem a medir o nível de compreensão e assimilação dos conteúdos. A Problematização, o Problem-Based Learning, o Peering Instruction e o Team-Based Learning são exemplos de métodos que permitem uma rápida e efetiva análise dos conhecimentos obtidos, a identificação de lacunas, bem como abordagens de trabalho e recuperação dos conteúdos que não foram suficientemente assimilados;

3. Organize trabalhos que exijam a aplicação dos conteúdos estudados. Esses trabalhos também podem ser utilizados para gerar colaborações e debates entre os grupos de trabalho e destes com o professor. Também aqui os métodos apresentados acima podem ser facilmente aplicados;

4. Disponibilize atividades e espaços que permitam a consolidação dos conhecimentos a partir dos conteúdos estudados, explorados e aplicados nas tarefas realizadas anteriormente. Mantenha-se na postura de mediador e permita que os estudantes assumam o papel de protagonistas e agentes efetivos do seu aprendizado, de modo que possam produzir significados e apreender os conceitos que você planejou para essa unidade de aprendizagem;

5. Avalie o grau de aprendizagem dos estudantes para cada conteúdo-chave proposto, considerando o cognitivo, o procedimental e o atitudinal (SCHENEIDERS, 2018, p.10-11). 
O primeiro passo é certificar que os alunos acessaram o conteúdo disponibilizado. Posteriormente, é preciso medir o nível de compreensão e assimilação do conteúdo. Para tanto, o professor pode organizar trabalhos que exijam a aplicação do que foi estudado. Poderá, também, disponibilizar atividades para a consolidação do conhecimento. Por fim, é preciso avaliar o grau de aprendizagem dos alunos.

Para que a sala de aula invertida alcance sucesso, Scheneiders (2018) aponta quatro etapas fundamentais:

1- Realizar planejamento prévio de cada unidade de aprendizagem;

2- Produzir os materiais a serem disponibilizados para os alunos antes das aulas;

3- Encorajar o engajamento dos estudantes no sentido de torná-los agentes ativos do seu aprendizado;

4- Engajar o docente de modo que este atue como tutor ou orientador nos momentos de sala de aula, como transmissor dos conhecimentos nos momentos antes da aula e como avaliador ou orientador após o término da aula (SCHENEIDERS, 2018, p.15).

Mas quais são as vantagens e desvantagens dessa metodologia? Esse é o objeto de análise do capítulo seguinte.

\section{AS VANTAGENS E DESAFIOS DA SALA DE AULA INVERTIDA}

Esse capítulo se dedica à análise do objeto central desse trabalho de conclusão de curso, a saber, as vantagens e os desafios da metodologia da sala de aula invertida. A seguir, serão analisadas em tópicos separados.

\subsection{Vantagens da sala de aula invertida}

$\mathrm{Na}$ sala de aula invertida, estuda o conteúdo e casa, antes da aula, para haver discussões durante a mesma, de modo a aumentar o aproveitamento e a aprendizagem. 
Desse modo, uma das primeiras vantagens encontradas é a possibilidade de o aluno adequar sua agenda de estudos, o que lhe dá maior autonomia e responsabilidade sobre o processo de aprendizagem, possibilitando-o um papel ativo nesse caminho (ENSINO INOVATIVO, 2015, p. 15).

Ao chegar na sala de aula com o conteúdo já estudado, o aluno poderá apresentar suas dúvidas, que se tornam mais visíveis, o que possibilitará a orientação pelo professor, o que é outra vantagem (ENSINO INOVATIVO, 2015, p. 15).

Além disso, a sala de aula invertida possibilita que os debates sobre o conteúdo sejam mais profundos e avançados, já que previamente estudado sobre o aluno, fazendo com que a discussão de toda a classe seja mais elevada (ENSINO INOVATIVO, 2015, p. 15).

Segundo Bergman e Sams (2016), a sala de aula invertida possui algumas vantagens, como a flexibilidade do tempo, a maior dedicação do professor para sanar as dúvidas, a intensificação da relação aluno-professor e da relação aluno-aluno, maior envolvimento dos alunos na sala de aula, adequação da aprendizagem ao ritmo do aluno.

Assim sintetizam Martins et. al. (2019):

[...] flexibilidade do tempo, podendo acessar as atividades on-line no horário e lugar que quiserem; permite que o professor se dedique mais em sala de aula atendendo aos alunos com dúvidas; permite aos alunos pausar os vídeos e compreender os conceitos no seu tempo; intensifica a relação entre professor e aluno; aumenta a interação entre alunos, com as atividades em grupo; muda o gerenciamento da sala de aula, deixando os alunos mais envolvidos nas atividades; torna a aula mais transparente; os alunos progridem em ritmo próprio, podendo estudar quando quiserem e levar o tempo que for necessário para finalizar, ver e rever quantas vezes for necessário; possibilidade de reutilização das aulas no ano seguinte pelo professor (MARTINS et. al., 2019, p. 524).

Já para os autores Moran e Milsom (2015), outras vantagens são encontradas. Segundo eles, os alunos melhoram seu desempenho nas 
avaliações, a classe passa a ficar mais envolvida com o conteúdo, os alunos se tornam mais independentes na aprendizagem.

No mesmo sentido, apontam Tune; Sturek e Basile (2013 apud MARTINS et. al, 2019, p. 524), "com a realização das atividades antes das aulas houve uma melhora nas discussões realizadas em sala e que os alunos saíram melhores nas avaliações do que no curso tradicional”.

Pavanelo e Lima (2017) também discorrem sobre as vantagens, para eles, a sala de aula invertida:

Requer mudanças na postura do professor, necessita da escolha, elaboração de materiais didáticos eficientes; mudanças na postura dos alunos da turma; existência de problemas técnicos como não ter acesso à internet e assim não realizar as tarefas; necessidade de muita organização, precisando familiarizar os alunos com um conceito novo e diferente; precisam fazer a transição de um modelo passivo de aprendizagem para um ativo; precisa motivar os alunos para fazer suas tarefas e se preparar para as aulas, senão estes ficarão facilmente distraído por outras coisas; requer muita autodisciplina, precisam saber como estudar, o que leva tempo (PAVANELO; LIMA, 2017 apud MARTINS et. al., 2019, p. 525).

A primeira vantagem é a mudança de postura do professor, que necessita elaborar materiais didáticos mais eficientes. A segunda vantagem é a mudança na postura dos alunos, que se tornam mais ativos.

No mesmo sentido, Valente (2014) também apresenta as vantagens da sala de aula invertida. São elas:

[...] possibilidade dos alunos trabalharem em ritmo próprio e desenvolverem o máximo de compreensão possível; identificação prévia, por parte dos alunos, de pontos que precisam ser mais bem assimilados e formulação de dúvidas que podem ser esclarecidas em sala de aula; possibilidade de customização, por parte do professor, das atividades da sala de aula, de acordo com as necessidades dos alunos; incentivo a trocas sociais, entre colegas, por meio das atividades em sala de aula(VALENTE, 2014 apud MARTINS et. al., 2019, p. 525). 
Como vantagens, os alunos aprendem em seu próprio ritmo, alcançando o maior nível de compreensão possível, e os pontos que restarem dúvidas podem ser sanados em sala de aula. E na sala de aula as atividades podem ser moldadas de acordo com as necessidades dos alunos, incentivando-se as trocas sociais.

Rodrigues, Spinasse e Vosgerau (2015) elaboraram um quadro com os possíveis benefícios da sala de aula invertida:

FIGURA 3 - Benefícios da sala de aula invertida

\begin{tabular}{|c|}
\hline Benefícios da metodologia SAI \\
\hline Substituição da aprendizagem passiva, com aulas \\
participativas. \\
Conteúdo permanentemente disponibilizado ao estudante \\
O professor pode apresentar o conteúdo uma única vez em \\
vídeo \\
Explicação de todo o conteúdo planejado em menos \\
tempo. \\
Ao gravar o vídeo, o professor passa a refletir sobre sua \\
aula. \\
Aumento da interação entre aluno-aluno e aluno-professor \\
Os professores dispõem de tempo para trabalhar com os \\
alunos individualmente. \\
Progresso dos alunos nos testes de avaliação \\
Envolvimento dos pais na educação dos filhos. \\
Aumento da responsabilidade dos estudantes. \\
O aluno trabalha em seu próprio ritmo e estilo. \\
Promove o desenvolvimento de habilidades de \\
comunicação, trabalho em equipe e colaboração de ideias. \\
Permite ao aluno colocar o seu aprendizado em prática. \\
\hline
\end{tabular}

Fonte: Rodrigues; Spinasse; Vosgerau, 2015, p. 39287.

A sala de aula invertida possibilita uma aprendizagem ativa, com a participação dos alunos. O conteúdo permanece à disposição do aluno, que poderá estudar adaptado a sua rotina. E tudo isso pode propiciar um maior rendimento em avaliações, além do aumento de habilidades fundamentais, como a comunicação, o trabalho em equipe e a colaboração de ideias. 


\subsection{Os desafios da sala de aula invertida}

A metodologia tradicional de ensino é composta por meio de aulas expositivas. E isso pode ocasionar um impacto negativo nos alunos. Alguns deles podem ser sentir perdidos, ou desmotivados, ou até mesmo pensar que o professor não desempenha o seu papel, já que não há a aula nos moldes tradicionais. Então, um dos maiores desafios da sala de aula invertida é a adaptação.

Considera-se que:

A busca pela mudança de mentalidade em relação ao que esperar de uma "aula" é um dos principais desafios a serem enfrentados no processo de inovação no ensino. E engana-se quem pensa que ele recai apenas sobre o estudante, porque o professor também precisa aprender a lidar com essas expectativas. Do ponto de vista do docente, pode-se encontrar barreiras especialmente no que diz respeito à perda de parte de sua autoridade em sala, na medida em que ele não é mais o único a ditar o ritmo das interações e a deter o poder do conhecimento. Isto é, ao se adotar essa estratégia, a interação entre professor e aluno é bem diferente das que se estabeleciam quando da utilização do método tradicional (ENSINO INOVATIVO, 2015, p. 16-17).

Então, um dos maiores desafios da sala de aula invertida é a mudança de mentalidade do aluno, pois a metodologia da sala de aula invertida exige uma mudança significativa no comportamento do aluno, dentro e fora da sala de aula, já que o mesmo terá mais autonomia, uma participação ativa e necessitará desenvolver novas habilidades:

Além disso, essa metodologia exige uma brusca mudança de comportamento do discente, tanto dentro quanto fora da sala de aula, já que ele passa a ter maior autonomia, uma participação mais ativa e desenvolve novas habilidades. Para isso, a atuação do professor é extremamente importante, porque, dentre diversas ações, ele precisa refletir melhor sobre suas condutas caso os alunos não realizem o estudo prévio necessário e en- 
contrem dificuldades de acompanhar a interação em classe, o que pode gerar desmotivação e desinteresse pelo conteúdo, interferindo negativamente no aprendizado (ENSINO INOVATIVO, 2015, p. 17).

Por isso, o professor possui atuação de extrema importância, é preciso que incentive os alunos a realizarem os estudos prévios, bem como acompanhar as dificuldades dos mesmos, motivando-lhes a serem os atores do processo de aprendizagem.

Diante do exposto, fica claro que essa estratégia não diminui o trabalho ou a relevância do professor, tampouco significa "não lecionar". Ao contrário, inverter a sala de aula requer grande esforço do docente. Não é à toa que o maior desafio dessa abordagem é o tempo necessário para a preparação de sua implementação, tanto em relação à elaboração do conteúdo a ser disponibilizado aos alunos, quanto à reflexão sobre as dinâmicas e exercícios a serem utilizados em classe. É necessário um bom planejamento dos objetivos de ensino e uma programação detalhada do que será lecionado, o que irá subsidiar a escolha dos conteúdos a serem estudados previamente e das atividades mais adequadas para aplicação em sala de aula (ENSINO INTERATIVO, 2015, p. 17).

O professor continua a ter relevância no processo de aprendizagem, e terá que fazer um grande esforço, para elaborar o conteúdo de qualidade e para conduzir as discussões em sala de aula. Por isso, o planejamento da aula é fundamental.

Os desafios da sala de aula invertida são muitos. E o aumento da carga de trabalho tanto do professor como do aluno é aspecto que se destaca:

Outro ponto desafiador é o aumento da carga de trabalho, não só do professor, mas também do estudante. Preparar-se ou se acostumar a realizar trabalhos antes da aula não é tarefa comum para muitos alunos, uma vez que provavelmente não cursam 
apenas uma, mas várias disciplinas ao mesmo tempo, sendo necessário administrar bem o tempo e dividir suas horas de estudo entre elas. Assim, é preciso que o docente reflita sobre a relação de sua matéria com as demais que compõem o curso, como foi destacado no primeiro artigo (ENSINO INTERATIVO, 2015, p. 17).

O aluno terá que se preparar e fazer atividades antes da aula. $\mathrm{O}$ professor terá que fazer um planejamento extremamente efetivo. O tempo deve ser pensado por ambos, como uma programação anterior.

Valente (2014) também relata desafios da sala de aula invertida:

O mesmo autor também identificou algumas preocupações e críticas sobre a metodologia, como por exemplo: a preocupação dos professores com as dificuldades que os alunos poderão apresentar, devido a forma que esta metodologia é proposta; a dependência da tecnologia para a sua realização, podendo criar um ambiente desigual de aprendizagem e a possibilidade do aluno não se preparar antes da aula, não conseguindo realizar as atividades presenciais (VALENTE, 2014 apud MARTINS et. al. 2019, p. 525).

Assim, verifica-se como desafio as dificuldades que os alunos podem apresentar com a metodologia, além da necessidade de lançar mão da tecnologia para sua implementação, o que pode criar um ambiente desigual de aprendizagem, já que nem todos tem acesso à mesma, o que poderá fazer com que o aluno não se prepare bem para a aula, e as atividades sequenciais não sejam bem desenvolvidas.

Milman (2012), ao aplicar a metodologia da sala de aula invertida, encontrou o mesmo desafio: muitos alunos podem não ter computador em caso, ou até mesmo o acesso à internet, o que dificultaria a administração de materiais em vídeo e outras mídias.

Rodrigues, Spinasse e Vosgerau (2015) elaboraram um quadro com os possíveis desafios da sala de aula invertida: 
FIGURA 4 - Desafios da sala de aula invertida

\begin{tabular}{|c|}
\hline Desafios da SAI \\
\hline Maior tempo para a preparação da aula. \\
Os alunos precisam ser preparados e orientados para o \\
desenvolvimento da aula. \\
Resistência dos alunos ao novo método. \\
Distribuição dos materiais em vídeo. \\
Demanda que a abordagem pode fazer nos computadores \\
de casa. \\
Os alunos não assistirem os vídeos em casa. \\
As condições nas quais os alunos assistem aos vídeos. \\
\hline
\end{tabular}

Fonte: Rodrigues; Spinasse; Vosgerau, 2015, p. 39287.

A sala de aula invertida demanda que o professor dedique mais tempo para a preparação da aula, e que os alunos estejam preparados e orientados para desenvolver as atividades. Tudo isso pode ocorrer em meio a resistência dos alunos com o novo método, que demanda, ainda, a utilização da tecnologia.

É preciso destacar, também, que um grande desafio é o fato de o professor necessitar possuir conhecimento tecnológico para a produção de materiais como vídeo-aulas, com habilidades para lidar com softwares e criar vídeos, o que requer maior tempo para se preparar as aulas (HERREID; SCHILLER, 2013).

Para Fulton (2012), a sala de aula invertida apresenta desafios de para além requerer silêncio em uma aula expositiva. É preciso que se prepare os alunos e oriente-os para que a metodologia tenha sucesso. Os alunos precisam desenvolver as tarefas previamente, ser colaborativos uns com os outros e com os professores, apresentar disposição para solucionar os problemas apresentados, e serem disciplinados, sendo que tudo isso se apresenta como desafios maiores do que a aula tradicional.

Para Demski (2013) o fato de a sala de aula invertida exigir que os alunos se dediquem mais em casa do que na sala de aula, pode ser um dos motivos para a resistência dos mesmos com a metodologia. E Wilson (2013) argumenta que a falta da aula tradicional, nos moldes expositivos, aumenta a responsabilidade do aluno pela sua aprendizagem em casa, o que também pode ser algo prejudicial. Por isso, essa adaptação pode demorar bastante tempo. 
Por fim, Brunsell e Horejsi (2013), destacam a preocupação com o fato de os alunos não estarem suficientemente preparados para participar das atividades em sala de aula, já que podem não estudar os conteúdos disponibilizados, o que frustrará os alunos que estão preparados para a aula.

O que se verifica, assim, é que a sala de aula invertida apresenta inúmeros benefícios para a aprendizagem dos alunos, todavia, também há desafios a serem vencidos, como o acesso e a operacionalização da tecnologia, veículo por meio do qual o material é disponibilizado ao aluno.

\section{CONSIDERAÇÕES FINAIS}

O novo cenário contemporâneo, marcado pelos avanços tecnológicos, demanda um aperfeiçoamento e inovação das técnicas de ensino e aprendizagem, de modo que os alunos se sintam motivados em sala de aula e consigam desenvolver melhor suas habilidades.

Foi nesse contexto que o presente trabalho de conclusão de curso buscou investigar sobre a aplicação da técnica da sala de aula invertida e suas possíveis vantagens o processo de aprendizagem.

A hipótese de pesquisa acabou por ser confirmada, já que verificou-se que, embora existam inúmeros desafios na aplicação da sala de aula invertida, seus benefícios se demonstram capazes de gerar a motivação nos alunos e desenvolver novas habilidades.

Além disso, há entraves operacionais, como a dificuldade no acesso e a operacionalização da tecnologia. O professor necessita de habilidades para produzir o material, e o aluno deve ter recursos mínimos de acesso ao mesmo.

Por já ter estudado o conteúdo em casa, o aluno poderá aproveitar a presença do professor na sala de aula para tirar suas dúvidas. Como consequência, os debates sobre o tema serão mais profundos e avançados, elevando-se o nível de discussão sobre os conteúdos e teorias a serem estudados. Isso tudo intensifica a relação entre aluno e professor e entre os alunos, desenvolvendo habilidades importantes, como a independência, a autonomia, a atitude, o trabalho em equipe. 
Desse modo, conclui-se que a sala de aula invertida pode ser um importante mecanismo para aperfeiçoar o processo de aprendizagem na era tecnologia, trazendo inúmeros benefícios aos alunos e aos professores, sendo necessário um planejamento efetivo para que seus desafios sejam vencidos.

\section{REFERÊNCIAS}

BERGMANN, J.; SAMS, A. Sala de aula invertida: uma metodologia ativa de aprendizagem. Trad. Afonso Celso da Cunha Serra. 1ed. Rio de Janeiro: LTC, 2016.

BRUNSELL, E.; HOREJSI, M. A Flipped Classroom in Action. The Science Teacher, Washington, v. 80, n. 2, p. 8, 2013a. Disponível em: <https://search.proquest.com/docview/1314910685/ 737DC797CD9B4BBFPQ/2?accountid=40>. Acesso em: 01 jan. 2020.

DEMSKI, J. 6 Expert Tips for Flipping the Classroom. Campus Technology, v. 25, n. 5, p. 32-37, 2013. Disponível em: <https:// campustechnology.com/articles/2013/01/23/6-expert-tips-for-flipping-the-classroom.aspx>. Acesso em: 01 jan. 2020.

ENSINO INOVATIVO. Sala de Aula Invertida. EI: Ensino Inovativo, volume especial, 2015. Disponível em: <file://C:/Users/up/ Downloads/57632-122306-1-PB.pdf> Acesso em: 10 jan. 2020.

FULTON, K. Upside down and inside out: Flip Your Classroom to Improve Student Learning. Learning \& Leading with Technology, v. 39, n. 8, p. 12-17, 2012. Disponível em: <https://files.eric. ed.gov/fulltext/EJ982840.pdf>. Acesso em: 01 jan. 2020.

HERREID, C.F.; SCHILLER, N.A. Case Studies and the Flipped Classroom. Journal of College Science Teaching, Washington, v. 42, n. 5, p. 62-66, May 2013. Disponível em: <https://www. aacu.org/sites/default/files/files/PKAL_regional/CRWG-SPEE-REF-01.pdf>. Acesso em: 10 jan. 2020. 
LITTO, F. M.; FORMIGA, M. Educação a distância: o estado da arte. São Paulo: Pearson, vol. 1. 2009.

MARTINS, E. R. et. al. Comparação entre o modelo da sala de aula invertida e o modelo tradicional no ensino de matemática na perspectiva dos aprendizes. Experiências em Ensino de Ciências, v. 14, n.1, 2019. Disponível em: <http://if.ufmt. br/eenci/artigos/Artigo_ID594/v14_n1_a2019.pdf> Acesso em: 23 dez. 2019.

MILMAN, N.B. The Flipped Classroom Strategy: What Is it and How Can it Best be Used?. Distance Learning, Greenwich, v. 9, n. 3, p. 85-87, 2012. Disponível em: <search.proquest.com\%2Fdocview\%2F1140334863\%2FfulltextPDF>. Acesso em: 10 jan. 2020.

MORAN, J. M. Nova personalidade. Brasília: Correio Braziliense. Brasília. Entrevista concedida para Olivia Meireles, 2014. Disponível em: <http://www2.eca.usp.br/moran/wp-content/ uploads/2014/01/Jos\%C3\%A9 Moran.pdf.> Acesso em: 20 dez. 2019.

MORAN, K.; MILSOM, A. The Flipped Classroom in Counselor Education. Counselor Education and Supervision, 2015.

PAVANELO, E.; LIMA, R. Sala de aula invertida: a análise de uma experiência na disciplina de Cálculo I. Bolema, Rio Claro, v. 31, n. 58, p.739-759, 2017. Disponível em: <http://www.scielo.br/pdf/bolema/v31n58/0103-636X-bolema-31-58-0739.pdf> Acesso em: 20 dez. 2019.

PEREIRA, Débora Silva de Castro. O ato de aprender e o sujeito que aprende. Construção psicopedagógica, São Paulo, v. 18, n. 16, p. 112-128, jun. 2010.

RODRIGUES, Carolina Stancati; SPINASSE, Jéssica Fernanda; VOSGERAU, Dilmeire Sant`Anna Ramos. Sala de aula invertida: uma revisão sistemática. XII Congresso Nacional de Educa- 
ção, Curitiba, 2015. Disponível em: <https://educere.bruc.com. br/arquivo/pdf2015/16628_7354.pdf> Acesso em: 20 dez. 2019.

SCHENEIDERS, Luís Antônio O método da sala de aula invertida (flipped classroom). Lajeado: Ed. da Univates, 2018.

TUNE, J.D; STUREK, M.; BASILE, D.P. Flipped classroom model improves graduate student performance in cardiovascular, respiratory, and renal physiology. Adv Physiol Educ, Indianapolis, v. 37, n. 4, p. 316-320, 2013.

VALENTE, J. A. Blended learning e as mudanças no ensino superior: a proposta da sala de aula invertida. Educar em Revista, n. 4, 2014. Disponível em: <https://drive.google.com/file/u/0/ d/0B6ZgHRUWc6JTM1dBM21IZ09OM1U/view>. Acessado em: 25 dez. 2019.

WILSON, S.G. The Flipped Class: A Method to Address the Challenges of an Undergraduate Statistics Course. Teaching of Psychology, Philadelphia, v. 40, n. 3, p. 193-199, 2013. Disponível em: <https://journals.sagepub.com/doi/ pdf/10.1177/0098628313487461>. Acesso em: 15 dez. 2019. 


\section{ENSINO DE LIBRAS: ANÁLISE BIBLIOMÉTRICA NA WEB OF SCIENCE}

Jocilene Alves Sousa

Eliuvomar Cruz da Silva

Laury Vander Leandro de Souza

\section{INTRODUÇÃO}

A comunicação tem sido objeto de estudo em diversas áreas, tendo em vista seu viés multidisciplinar. Comunicar-se é interagir com o ambiente e, diante da diversidade e individualidade, existem diversas formas de fazê-lo. A Língua Portuguesa, oriunda do latim, sofreu alterações em sua pronúncia, vocabulário e na sintaxe, com o passar dos anos. De igual forma, a Língua Brasileira de Sinais (LIBRAS), que se adaptou à atualização do vocabulário e adaptação de sinais.

Almeida (2012) afirma que não se sabe ao certo como surgiu a LIBRAS, mas certamente foi a partir da necessidade da comunidade surda poder realizar a comunicação de forma gestual e visual. Os registros mais antigos do ensino de línguas de sinais datam de 1756, quando Abbé de L'Epée cria em Paris o Instituo Nacional de Jovens Surdos de Paris, após conhecer duas irmãs gêmeas surdas que utilizavam dos gestos para se comunicar. L'Epée interessou-se pela temática e passou a defender a língua de sinais como a linguagem natural para os surdos através dos gestos. Foi o primeiro marco na história dos surdos (ALBRES, 2005). 
Com o passar dos anos, vários países passaram a aprofundar estudos no campo das línguas de sinais e a comunidade surda se fortaleceu. Neste espaço de tempo, governos e iniciativas privadas juntaram-se à causa, considerando o direito de aprender LIBRAS e do surdo conseguir participar de atividades escolares, no trabalho e em diversos contextos. Deste modo, as escolas especiais surgiram e os professores passaram a ensinar e aprender com seus alunos surdos, levando a educação especial a novos caminhos, tanto democráticos como naturais no uso dos sinais (MORI, SANDER, 2015).

A Interpretação da Língua de Sinais se tornou uma profissão regulamentada quando foi reconhecida em 1ํㅡㄹ de setembro de 2010 pela Lei $n^{\circ}$ 12.319. Discussões têm surgido no sentido de repensar a atuação, sindicalização e valorização deste profissional, considerando que o intérprete está inserido em vários contextos, como escolas, empresas, igrejas, ou seja, onde puder existem um membro da comunidade surda.

A presente pesquisa visa então conhecer a literatura existente sobre o Ensino de LIBRAS, tendo em vista conhecer as discussões a respeito da temática. A problemática desta pesquisa está vinculada às particularidades destas publicações, de onde são provenientes, como é formada a rede de pesquisadores sobre o tema e outros aspectos. Para isto, buscou-se na metodologia de análise bibliométrica a resposta para a questão de pesquisa, haja vista que é um método útil para identificar tendências de pesquisa e questões importantes com base em informações de publicações históricas (YE, et al., 2014).

O panorama da literatura científica sobre o Ensino de LIBRAS permite ainda delinear o estado da arte das contribuições sobre o tema, identificando os trabalhos e autores-chave, os principais veículos de difusão da literatura e os subcampos nos quais as contribuições tem se distribuído. A pesquisa traz então um breve referencial teórico sobre LIBRAS e o ensino, a metodologia adotada e uma visão geral sobre o atual estado da literatura sobre o ensino de LIBRAS, a partir da análise bibliométrica, seguidas pelas considerações finais e referências. 


\section{LIBRAS no contexto da comunidade surda}

A Lei da Acessibilidade, Lei no 10.098/2000, prevê ações para a inclusão da pessoa com deficiência na educação, a partir da superação das barreiras linguísticas. A partir disto, considera-se que as escolas atentem para a composição de seu corpo discente, a fim de identificar as necessidades dos alunos de acompanhamento por intérprete, além a capacitação dos professores para atuarem junto ao aluno.

Para Skliar (2010), a surdez implica em uma diferença linguística que pode se tornar uma barreira que dificulta a comunicação entre surdos e ouvintes. Para que esta barreira seja desfeita, cabe reconhecer a importância do intérprete de LIBRAS como uma ponte comunicativa entre as duas línguas (SILVA, KAUCHAKE; GESUELI, 2003).

A Lei $n^{\circ}$ 10.436/2002 reconheceu a Língua Brasileira de Sinais (LIBRAS), regulamentada pelo Decreto $\mathrm{n}^{\mathrm{0}}$ 5.626/05. Esta fundamentação legal é fundamental para amparar os direitos da comunidade surda brasileira, haja vista que a partir do disposto o uso e difusão da LIBRAS nas instituições educacionais públicas e privadas, e dentre outras determinações, tomou visibilidade.

Para Quadros (2002), o tradutor ou intérprete de língua de sinais é aquele que interpreta de uma língua de sinais (língua de partida) para outra língua (língua de chegada), seja essa oral ou sinalizada. Diferencia ainda o tradutor do intérprete, à medida que afirma que o tradutor é a pessoa que traduz de uma língua para outra, assim como faz o intérprete, porém o processo de tradução implica, pelo menos em que uma das línguas esteja na modalidade escrita.

Silva, Kauchakje e Gesueli (2003) definem o Tradutor/Intérprete de Língua de Sinais como uma pessoa bilíngue que domina a língua oral e a Língua de Sinais, e que faz a mediação entre uma e outra língua. Segala (2010) ressalta que além das diferenças linguísticas, surdos e ouvintes possuem diferenças culturais, por isto destaca a importância das transposições culturais realizadas pelos tradutores/intérpretes.

A composição de uma consciência global vem a partir da interpretação desses sinais no contexto de vida de cada um. Os sinais na LIBRAS trazem a significação necessária ao surdo em seu próprio 
contexto. Em contraponto, sabe-se que o ideal seria a existência de tradutores/intérpretes em todos os contextos onde pudesse haver algum membro da comunidade surda, porém a difusão tardia da LIBRAS dentro do contexto da vida de muitos membros desta comunidade, impede que tenham o domínio dela, ou seja, muitos surdos expressam-se por meio de gestos, mas nem todos são todos falantes da LIBRAS.

É comum que surdos, ainda jovens, utilizem sinais elaborados por familiares pela falta de conhecimento da LIBRAS pela própria família, que muitas vezes precisa adaptar-se para poder ensinar. Este suporte nem sempre acontece na juventude e a LIBRAS surge na vida do indivíduo somente na vida adulta.

Spenassato e Giareta $(2009$, p. 3) afirmam que:

Há muito que se fazer para que realmente essa inclusão aconteça, pois é um processo lento e precisa ser vista como um processo social que envolve todos que se preocupam em educar. A sociedade precisa se preparar para lidar com a diversidade humana, estar aberta a diferentes experiências, reconhecendo o potencial de cada cidadão e respeitando suas possibilidades e limites, pois muitas vezes nossa própria ação acaba excluindo as pessoas que consideramos diferentes de nós.

Neste contexto ainda, cabe ressaltar a educação familiar para a aceitação das diferenças no âmbito escolar. Os responsáveis por alunos ouvintes devem conscientizar a criança, desde cedo, sobre o respeito às diferenças e empatia ao próximo. Uma recepção negativa do aluno surdo na escola pode dificultar ainda mais seu processo de inclusão e aprendizagem. Professores devem estar atentos e gerenciar qualquer tipo de ação que vá contra o respeito dos alunos como um todo.

Mantoan et al. (2010, p. 8) relata que:

A inclusão escolar impõe uma escola em que todos os alunos estão inseridos sem quaisquer condições pelas quais possam ser limitados em seu direito de participar ativamente do processo escolar, segundo suas capacidades, e sem que nenhuma delas 
possa ser motivo para uma diferenciação que os excluirá das suas turmas.

A participação ativa do aluno surdo na sociedade vai além de somente ser um telespectador do mundo que o cerca. Em um ambiente ideal, onde o surdo consegue compreender os outros indivíduos e fazer-se compreendido, sua participação torna-se mais ativa no ambiente onde está inserido, seja participando ativamente das atividades em sala de aula, participando de entrevistas de emprego, apresentações no ambiente empresarial, por fim, as barreiras existentes trazem consigo outras barreiras.

Novaes e Trugillo (2011), apoiam a inserção do surdo em sala de aula na escola regular, em conjunto com a inserção do intérprete de LIBRAS, para que esses sejam mediadores entre o aluno-professor. Principalmente na rede pública de ensino, Oliveira (2012) afirma que a superlotação das salas de aula é um problema para o desenvolvimento e o bom funcionamento das escolas inclusivas. Sabe-se ainda que não somente pelos alunos surdos, mas também pelos demais alunos, pois o professor fica impossibilitado de acompanhar o desenvolvimento de muitos alunos ao mesmo tempo.

Com o Decreto no 5626/05, a inserção da disciplina de LIBRAS tornou-se obrigatória nos cursos de licenciaturas.

Artigo 3‥ A LIBRAS deve ser inserida como disciplina curricular obrigatória nos cursos de formação de professores para o exercício do magistério, em nível médio e superior, e nos cursos de Fonoaudiologia, de instituições de ensino, públicas e privadas, do sistema federal de ensino e dos sistemas de ensino dos Estados, do Distrito Federal e dos Municípios.

Como abordam Sell e Neves (2015), essa capacitação objetiva preparar, ainda que de forma básica, os futuros professores. Esta conscientização deve mostrar a importância de buscar conhecimento mais aprofundado sobre o tema, pois certamente no futuro poderão necessitar destes conhecimentos para comunicar-se não somente com os alunos, mas em qualquer contato com a comunidade surda em contextos sociais e escolares. 


\section{METODOLOGIA}

Para a realização da presente pesquisa, que busca obter resultados em bases de dados na web sobre um determinado tema, utilizou-se a bibliometria, conforme Pereira et al. (2018). Para realizar a análise bibliométrica, foi utilizada base de dados da plataforma Web of Science (WoS) da Clarivate Analytics, que é um dos bancos de dados mais amplamente utilizados em tais estudos.

Para que o acesso à base fosse mais amplo, realizou-se primeiro o acesso remoto ao Portal de Periódicos da CAPES, pois a partir deste acesso o conteúdo seria liberado e seriam recuperados resultados mais significativos. Para Palludeto e Felipuni (2019), a análise bibliométrica permite a construção de um mapa abrangente das publicações existentes sobre um tema, sob diferentes perspectivas, o que não seria recuperado pela realização de uma pesquisa bibliográfica tradicional.

A análise bibliométrica permite a visualização de características das publicações e consequentemente sua análise mais detalhada, de forma a traçar linhas e tendências de temas pesquisados, direcionamentos para pesquisas futuras, dentre outras informações.

Após acessar o Portal de Periódicos da CAPES e localizar a base Web of Science, o primeiro passo foi elaborar a estratégia de busca para que se alinhasse ao objetivo da pesquisa. Tendo em vista o interesse em conhecer o que está disponível na base sobre ensino de LIBRAS, buscou-se por artigos que possuíssem a palavra "LIBRAS” AND “Teaching" em seus tópicos. Utilizou-se o operador booleano AND a fim de recuperar documentos que englobassem os dois termos, reduzindo as chances de documentos irrelevantes ao estudo serem recuperados.

Delimitou-se o período temporal de 2010 a 2020, realizando a pesquisa em maio de 2020. O período delimitado foi escolhido para que fosse mostrada a evolução dos estudos científicos nos últimos 10 anos, não excluindo as pesquisas atuais. Após a realização da busca, foram recuperados 47 resultados, dentre os quais 33 eram artigos. Considerando este tipo de publicação compreendia o maior número, decidiu-se examinar os artigos recuperados, delimitando ainda para que estivessem em acesso aberto, resultando em 25 documentos a serem analisados, conforme figura 1. 
Figura 1 - Processo de busca

• "LIBRAS" AND "Teaching"

- 47 documentos

- 25 artigos científicos em acesso aberto no período de 2010 a 2020.

- Resultados prontos para análise aprofundada

Fonte: Próprio autor (2020).

Com os resultados em tela, utilizou-se a ferramenta "Analisar resultados", oferecida pela própria base de dados, haja vista que permitiu visualizar informações relacionadas ao número de publicações, países, áreas de pesquisas e tipos de publicações. A partir dos dados coletados e com o objetivo de analisar mais profundamente os resultados obtidos, o tratamento bibliométrico dos artigos selecionados foi aplicado ao software VOSviewer, um software que atua na construção de redes e permite suas análises. As redes que o software gera mostram os pesquisadores que atuam na temática e sua origem institucional, além de outras variáveis, o que complementa a análise preliminar realizada no WoS.

A ênfase do VOSviewer está na visualização de conjuntos grandes de dados bibliográficos a partir de uma abordagem distance-based, como abordam van Eck e Waltman (2010), haja vista que pequenas redes bibliográficas podem ser representadas graficamente por programas como o Pajek (graph-based).

Os mapas relacionados gerados são caracterizados por pontos ou nodos, cuja distância entre si mostra a aproximação ou distanciamento de sua relação segundo determinados critérios de agregação. O VOSviewer destaca aspectos variados da rede formada pela bibliografia levantada e, para este estudo, delimitou-se os critérios de coautoria, instituição, coocorrência de termos e palavras-chave. 
Com a coautoria, busca-se verificar os profissionais que atuam juntos na realização das pesquisas, mapeando seu relacionamento com o tema e com outros profissionais. Quanto à instituição, busca-se elencar quais estão atuando na temática e seu destaque em relação às demais. O critério de coocorrência procura identificar elementos comuns aos textos da base de dados como termos significativos, de modo que se possa sugerir subáreas dentro da base. Já as palavras-chave estão relacionadas aos termos utilizados pelos autores para identificar o tema principal de suas pesquisas.

Desta forma, o VOSviewer organizou, por meio de algoritmos e funcionalidades, estes pontos em comum em relação à literatura recuperada. Para Romanelli et al. (2018) os pontos fortes das conexões entre os itens ajudam a compreender a análise da rede e compreender como um tema se desenvolve com o passar do tempo. O tamanho dos nós e da fonte do rótulo representam a frequência de cada tópico, quanto maior o nó e a fonte, mais frequente o tópico (LI; HALE, 2016).

Os artigos foram ordenados dos mais recentes aos mais antigos, para que em seguida, fosse realizada a leitura mais aprofundada dos artigos com maior relevância encontrados na Web of Science (WOS).

\section{DISCUSSÃO E RESULTADOS}

\subsection{Características da literatura recuperada}

Após a breve contextualização da temática e apresentação da metodologia utilizada no processo de obtenção dos dados, apresenta-se a discussão sobre os dados relacionados às publicações científicas na WoS sobre o ensino de LIBRAS, considerando o período temporal de 2010 a 2020.

A figura 2 mostra o panorama geral dos artigos recuperados e as grandes áreas onde estão inseridos. Nota-se a predominância na área de pesquisa educacional, considerando que o tema está diretamente relacionado com o ensino. A incidência da temática ocorre ainda nas ciências humanas multidisciplinares, linguagem/linguística, ciências multidisciplinares e psicologia. 
Figura 2 - Grandes áreas

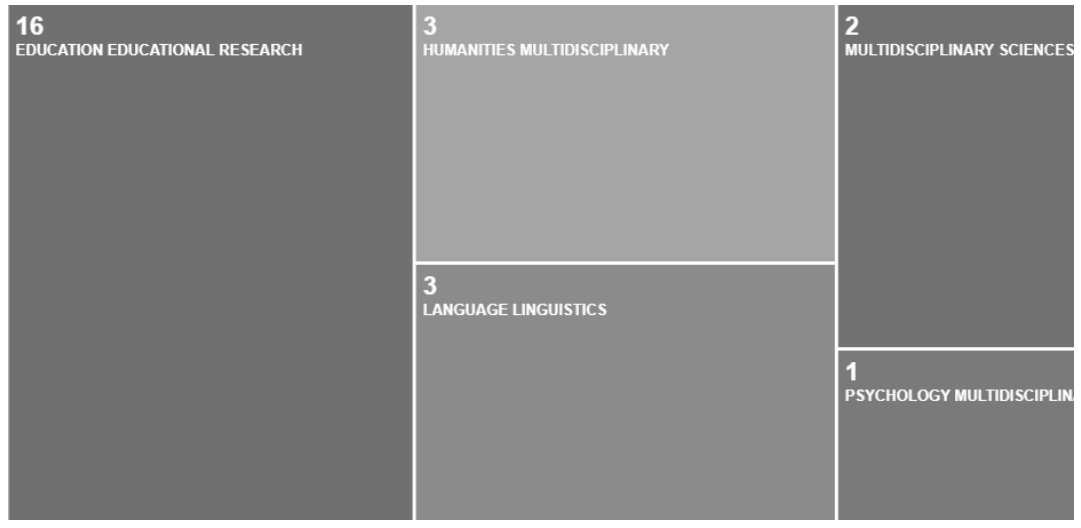

Fonte: Próprio autor (2020).

O ensino de LIBRAS está então inserido em diversos contextos, confirmando a multidisciplinaridade da temática e sua importância na discussão com outras áreas. Ressalta-se que este diálogo é fundamental para o desenvolvimento e divulgação dos aspectos que permeiam o ensino de LIBRAS, contribuindo para a popularização do tema e indicando que contribuições surgirão de diversas áreas.

Embora o período temporal delimitado tenha sido de 2010 a 2020 , foram recuperados documentos a partir de 2015, como informa a figura 3 .

Figura 3 - Publicações por ano.

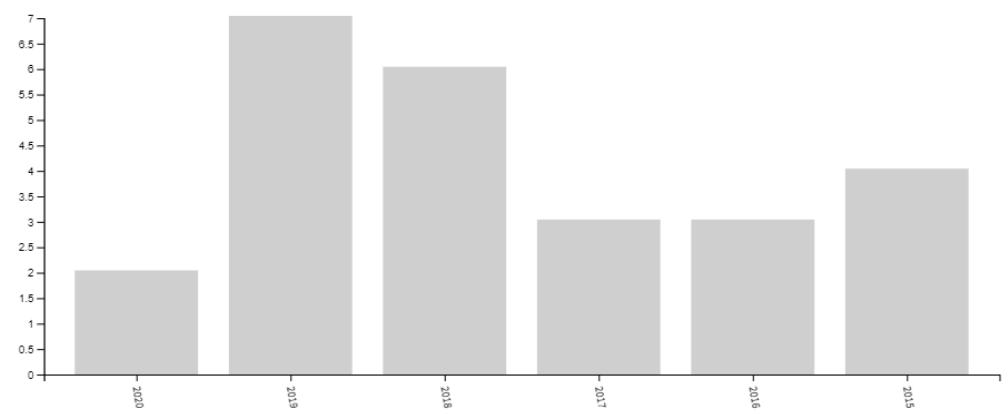

Fonte: Próprio autor (2020). 
Em 2019 visualiza-se o ponto alto das publicações, voltadas principalmente ao ensino de LIBRAS no ensino regular, no ensino fundamental, na composição das licenciaturas e da capacitação de professores para atuarem no ensino da comunidade surda.

Percebe-se que a temática tem sido dialogada a fim de ressaltar a importância de as instituições oferecerem esta capacitação aos professores e futuros professores, objetivando o ensino efetivo e inclusão adequada da comunidade surda nas escolas e faculdades, bem como nos demais espaços sociais.

Figura 4 - Publicações no decorrer dos anos

\begin{tabular}{|lccc} 
Campo: Anos de publicação & Contagem do registro & $\%$ de 25 & Gráfico de barras \\
\hline 2020 & 2 & $8.000 \%$ \\
\hline 2019 & 7 & $28.000 \%$ \\
\hline 2018 & 6 & $24.000 \%$ \\
\hline 2017 & 3 & $12.000 \%$ \\
\hline 2016 & 3 & $12.000 \%$ \\
\hline 2015 & 4 & $16.000 \%$ \\
\hline
\end{tabular}

Fonte: Próprio autor (2020).

$\mathrm{Na}$ figura 4, compreendemos o dimensionamento das publicações no decorrer dos anos, considerando ainda que a bibliografia referente ao ano de 2020 foi recuperada até o dia da busca na base WoS.

Espera-se observar a ascensão das pesquisas sobre o ensino de LIBRAS desde 2018, haja vista que as discussões têm mostrado crescente importância. Em relação às instituições que mais produzem sobre o tema, têm-se as instituições públicas de ensino superior no topo da lista, conforme mostra a figura 5 .

Destaca-se a importância de levantar a discussão junto às universidades particulares, mostrando enfoques de suas realidades e suas contribuições à sociedade. Compreende-se ainda que a cultura da pesquisa acadêmica se dê em maior escala nas instituições públicas tendo em vista o retorno social do investimento realizado para custear tais instituições. Schwartzman (2009) afirma que a existência de recursos públicos, novas fronteiras tecnológicas e fortes interesses sociais faz com que a atividade de pesquisa se organize de forma ativa. 
Figura 5 - Instituições publicadoras

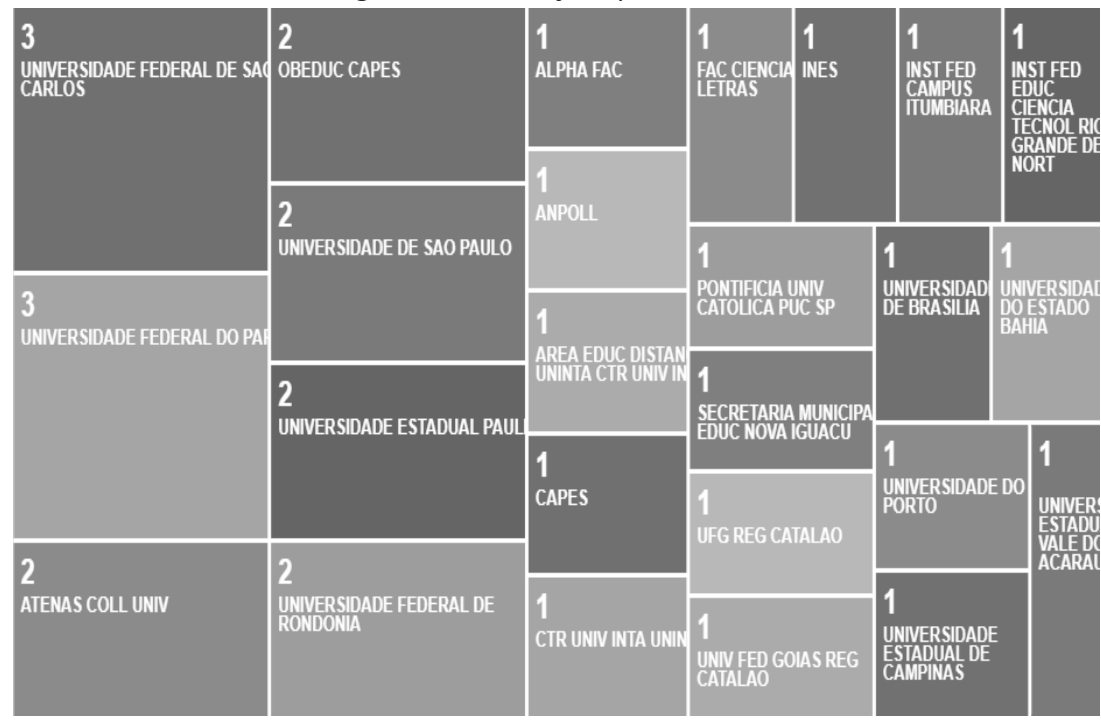

Fonte: Próprio autor (2020).

O caráter multidisciplinar da discussão encontrou espaço nestas instituições, dada a multidisciplinaridade do ambiente universitário, pois entende-se por Multidisciplinar o estudo que agrega áreas do conhecimento em torno de um ou mais temas, no qual cada área ainda preserva sua metodologia e independência (CAPES, 2013).

A partir desta identificação, os dados foram tratados no VOSviewer, para que fosse identificada a evolução da informação científica, a produtividade das instituições, autores e suas associações.

$\mathrm{Na}$ figura 6 observa-se a relação de coautoria entre instituições. Os resultados obtidos anteriormente oscilam entre colaborações entre investigadores na produção de artigos ou trabalho individual. Nesta amostra é bastante recorrente as colaborações na escrita de artigos científicos, como podemos observar, dados os poucos encontros de pontos na imagem. 
Figura 6 - Coautoria e instituições

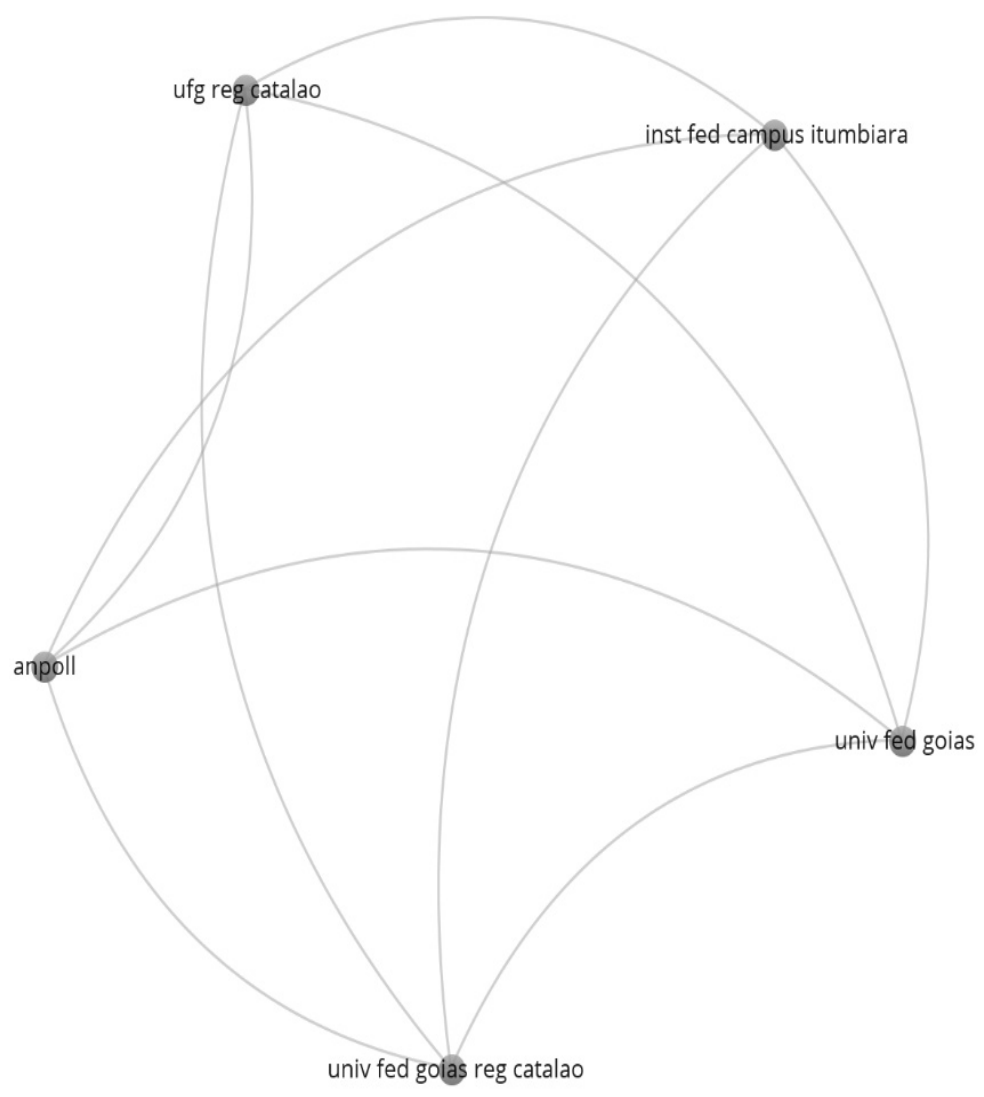

Fonte: Próprio autor (2020).

A análise de colaborações de autores examina a network criada entre os investigadores nas pesquisas científicas. Esta relação é estabelecida quando estes copublicam um artigo. Nota-se a atuação de pesquisadores em conjunto em Universidades Federais como a Universidade Federal de Goiás e o Instituto Federal de Goiás.

A duplicação de pontos ocorre pela inserção de diferentes nomes para a mesma instituição nas bases de dados ou periódicos. Nota-se a relação entre a Associação Nacional de Pós-Graduação e Pesquisa em Letras e Linguística, ANPOLL, com a Universidade de Goiás e o Instituto Federal. 
Percebe-se que estes foram os únicos pontos de relação encontrados, sentiu-se que muitas outras instituições poderiam atuar em conjunto no desenvolvimento de pesquisas em prol do progresso científico na área do Ensino de LIBRAS. Estas publicações em coautoria permitem um maior intercâmbio de informações e experiências, além de ciência de boas práticas adotadas pelos pares em outras instituições.

As publicações em parceria com outras instituições fortalecem os laços e firmam parcerias, além da possibilidade de projetos em conjunto entre os pesquisadores. Nota-se a existência de instituições na mesma região que poderiam ativamente atuar em parceria para a capacitação de alunos, professores e gestores escolares, além de tradutores ou intérpretes em LIBRAS, na oferta de cursos para familiares e para a comunidade surda.

Vanz e Caregnato (2003) afirmam que uma das responsabilidades imputadas aos pesquisadores é a retroalimentação do processo de comunicação científica, afirmando ainda sua importância na vida do pesquisador não apenas como um indicador, mas como o produto final de todo um esforço criativo. Neste contexto, a vontade de contribuir para o bem social é também fonte de motivação para a realização de pesquisas.

Sabe-se que nem todas as instituições dispõem de intérpretes para auxiliar os alunos, funcionários ou terceirizados, desta forma, estas parcerias poderiam articular-se para formar uma rede de apoio para capacitação de pessoas a fim de aumentar este quantitativo por meio de cursos, ainda que básicos, de forma gratuita para a comunidade.

A partir da figura 7 observamos com mais facilidade os termos utilizados para representar a discussão científica. Targino (2000) afirma que a comunicação formal representa a concretude dos resultados de pesquisas e, nesta pesquisa observados a concretude das temáticas analisadas à medida que se compreende as diversas áreas pelas quais o ensino de LIBRAS perpassa, alcançando um público mais amplo. 
Figura 7 - Palavras-chave e coocorrencia

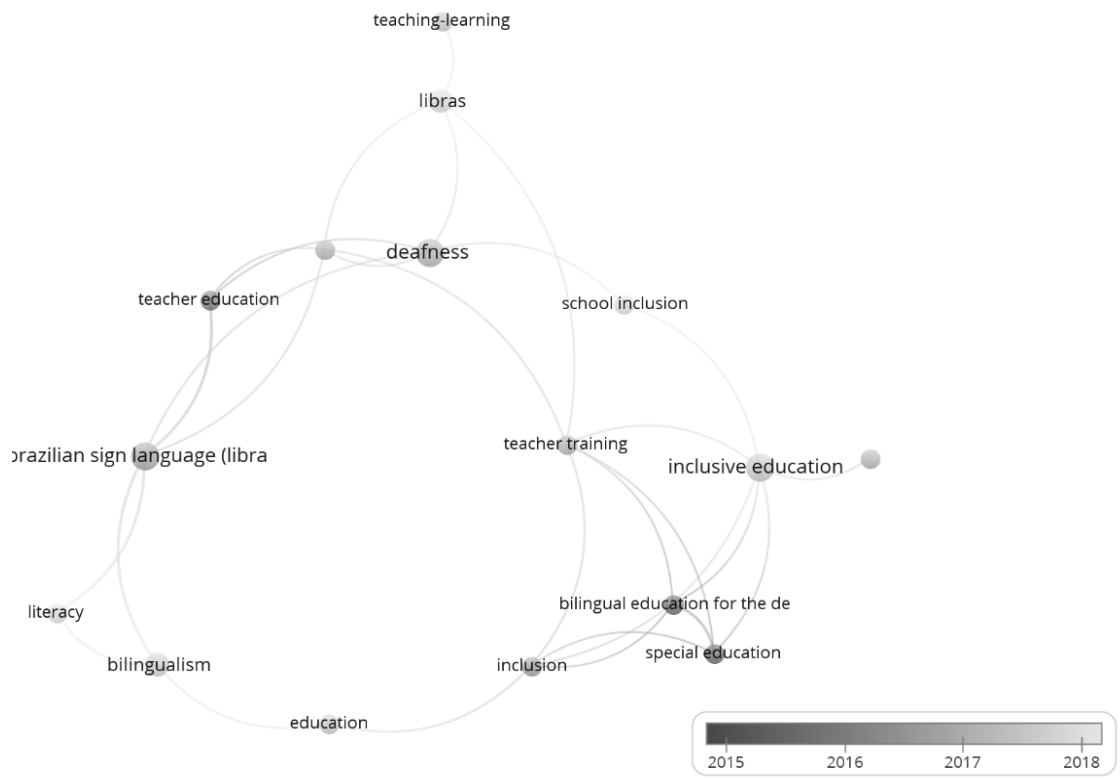

Fonte: Próprio autor (2020).

A rede de coocorrência de palavras-chave gerada utilizando o VOSviewer pode ser compreendida pelas palavras-chave, representadas por um círculo em que o tamanho indica o número de ocorrências de uma palavra-chave específica (Ang, et al., 2019). Para a criação da rede de coocorrência de palavras-chave, foram definidos como sendo 2 o número mínimo de ocorrências de uma palavra-chave mais relevante.

Observou-se então a interação entre os temas: Literatura, educação, bilíngue, inclusão, educação bilíngue, educação especial, Língua Brasileira de Sinais, educação inclusiva, educação de professores, surdez, escolas inclusivas, LIBRAS e ensino-aprendizagem.

Análises das redes de coocorrência de palavras-chave tiveram como função auxiliar no reconhecimento dos principais tópicos e tendências de pesquisa na área. $\mathrm{Na}$ análise de coocorrência, a força do link entre as palavras-chave do autor indica o número de publicações nas quais duas palavras-chave ocorrem juntas (KHUDZARI, et al., 2018) 
Indo de encontro ao referido anteriormente, para compreender qual o foco dos artigos científicos recorreu-se à análise das keywords usadas pelos autores. Deste modo, o mapa bibliográfico criado no VOSviewer representou cada temática por um círculo que por sua vez pode ou não apresentar uma relação com outra temática. A frequência e importância de cada keyword está relacionada com o diâmetro de cada círculo e a distância entre estes permite avaliar o nível de associação.

Esta técnica de análise usa as palavras inseridas nos documentos para estabelecer e construir relações de estrutura conceitual e como tal pode ser aplicada a títulos, palavras-chave, resumos e até mesmo ao corpo do texto. Moreira (2020) afirma que o papel primordial da publicação científica é inegável, sendo considerada como uma eficaz e oportuna maneira de disseminar resultados de pesquisa, que servem para gerar outras pesquisas.

Ao considerar as expressões que mais ocorrem na literatura e reuni-las, é possível não apenas complementar os agrupamentos já observados, como também obter uma aproximação relativamente fidedigna do conteúdo de cada agrupamento em termos de objeto de análise.

\section{CONSIDERAÇÕES FINAIS}

O presente artigo buscou fornecer um panorama abrangente da literatura científica acerca do ensino de LIBRAS a partir de uma abordagem bibliométrica, com o uso do software VOSviewer. Após levantamento na base Web of Science, a partir do acesso mais amplo pelo Portal de Periódicos da CAPES, foi possível recuperar os documentos que se encaixassem no objetivo desta pesquisa.

O agrupamento artigos científicos, autores e termos, pela utilização de técnicas bibliométricas, permitiu identificar determinadas linhas de pesquisa nas quais o tema tem sido atualmente tratado. Desse modo, ainda que se admita a relevância da pesquisa bibliográfica convencional para a organização da literatura sobre determinado objeto, o uso da bibliometria aqui proposto ofereceu uma abordagem mais sistemática à pesquisa. 
Os resultados adquiriram então um contorno mais preciso em termos de subáreas específicas, relacionadas ao Ensino de LIBRAS, pelos autores, de modo a mostrar informações mais precisas sobre a temática e seu desenvolvimento.

A compreensão dos trabalhos já existentes sobre a temática ajuda a traçar um panorama da evolução do tema ao longo dos anos. Conforme se pode depreender do conjunto de análises realizadas, propõe-se que a literatura sobre o Ensino de LIBRAS se apresenta composta por abordagens voltadas às escolas regulares, educação inclusiva, capacitação de professores e ensino-aprendizagem.

Muitas parcerias oriundas das pesquisas realizadas poderiam subsidiar ações de capacitação para professores da educação regular, tendo em vista a melhor recepção dos alunos surdos na sala de aula e o adequado acompanhamento durante a vida escolar.

Sabe-se que a lei de inclusão desses alunos em sala de aula de ensino regular ainda é recente, por isto muitos desses professores não tiveram oportunidade de ter uma disciplina específica no seu curso de graduação, haja vista que esta é também uma exigência recente.

Cabe também à escola promover capacitação, bem como ambientes onde o surdo se encontra, para que a comunicação de fato aconteça. Cursos gratuitos, oficinas e outras atividades podem ser pensadas para o surdo interaja de fato com o ambiente e contribua com este.

Notou-se a ausência de números significativos de pesquisas sobre o tema oriundas de instituições de ensino particulares ou privadas, haja vista que os dados apontam que as instituições públicas atuam ativamente neste contexto. Percebeu-se que o tema perpassa por outras áreas além da Educação, o que traz o tema a um viés multidisciplinar.

Esta multidisciplinaridade impacta diretamente em possíveis soluções para as demandas existentes no Ensino de LIBRAS, haja vista que várias áreas têm se interessado e produzido sobre.

Durante a realização da análise no VOSviewer, localizou-se termos e expressões significativos nos resumos, palavras-chave e títulos das publicações sobre Ensino de LIBRAS. Destaca-se ainda que o período temporal considerado foi de 2010 a 2020, porém não foram encontrados estudos anteriores a 2015 na WoS. 
A análise dos termos recuperados de coocorreência tornam-se relevantes pois mostram, além de informar o que é pesquisado sobre o tema, as principais necessidades de atenção neste cenário, pois se é algo que está sendo constantemente discutido na literatura científica, é provável que seja de fato uma situação-problema em busca de soluções práticas, partindo de estudos e publicações anteriores.

Desta forma, a produção científica tem sido estudada para medir o desenvolvimento científico de um país e de uma instituição, bem como de um tema em específico. Os índices de produções científicas são fontes seguras para a realização da avaliação da produtividade de pesquisadores e não somente, para mensurar a atuação de instituições, cidades e diversos atores na sociedade, como agências de fomento à pesquisa e, também por universidades públicas para analisar o desempenho de seus pesquisadores.

Neste contexto, os estudos que partem de análises bibliométricas podem contribuir fortemente para a obtenção destes dados e para mensurar temas relevantes, seu impacto na sociedade e nas grandes bases de dados científicos internacionais e nacionais.

A presente pesquisa observa então que os temas, dentro do Ensino de LIBRAS, mais discutidos entre os pesquisadores no Brasil são oriundos de pesquisadores de instituições públicas de ensino, seja de um grupo de pesquisa ou departamento da área da educação ou afim, a saber: Literatura, educação, bilíngue, inclusão, educação bilíngue, educação especial, Língua Brasileira de Sinais, educação inclusiva, educação de professores, surdez, escolas inclusivas, LIBRAS e ensino-aprendizagem.

A produção científica e sua análise mostram-se fundamentais para o desenvolvimento da ciência, pois se considera que estas informações não só auxiliam o entendimento da dinâmica de ciência, mas, para além disso, concorrem para subsidiar a tomada de decisões durante o planejamento de políticas públicas, ações educativas, estabelecimento de parâmetros e outras ações dentro da temática que suporte a comunidade surda.

Por fim, espera-se que mais iniciativas sejam realizadas e originem produções científicas a fim de povoar as bases de dados, principalmente 
as de acesso aberto, com estudos voltados ao tema, deixando-os acessíveis para a realização de estudos futuros.

Espera-se que este e outros trabalhos, possam contribuir para fomentar pesquisas, sobre um tema de vital importância para o desenvolvimento de políticas e ações que visem melhorar a qualidade de vida da comunidade surda dos profissionais envolvidos no ensino no país, por meio de condições e suporte.

\section{REFERÊNCIAS}

\section{ALBRES, N. A. História de língua de sinais em Campo Grande} - MS. Petrópolis: ARARA AZUL, 2005.

ALMEIDA, M. P.; ALMEIDA, M. E. História de Libras: característica e sua estrutura. Rio de Janeiro: REVISTA PHILOLOGUS, 2012.

AMORIN, M. I. D. A. et al. A inclusão do aluno surdo na rede regular de ensino. Disponível em: http://www.ufac.br/portal/ unidadesadministrativas/orgaos-complementares/edufac/revistas-eletronicas/revistaramal-de-ideias/edicoes/edicao-1/caminhos-da-educacao/a-inclusao-do-alunosurdo-na-rede-regular-de-ensino. Acesso em: 06 jun. 2020.

ANG, W. L. et al. Forward osmosis research trends in desalination and wastewater treatment: A review of research trends over the past decade. Journal of Water Process Engineering, 31, 100886, 2009. Disponível em: https://doi.org/10.1016/j. jwpe.2019.100886. Acesso em: 03 jun. 2020.

BRASIL. Decreto ${ }^{\circ} \mathbf{5 . 6 2 6}$, de 22 de dezembro de 2005. Regulamenta a Lei no 10.436, de 24 de abril de 2002. Dispõe sobre a Língua Brasileira de Sinais - LIBRAS. Brasília, 2005. Disponível em: http://www.planalto.gov.br/ccivil_03/_ato2004-2006/2005/ decreto/d5626.htm. Acesso em: 08 jun. 2020.

BRASIL. Lei $\mathbf{n}^{\circ} \mathbf{1 0 . 0 9 8}$, de 19 de dezembro de 2000. Estabelece normas gerais e critérios básicos para a promoção da acessibilida- 
de das pessoas portadoras de deficiência ou com mobilidade reduzida, e dá outras providências. Presidência da República. Disponível em: http://www.planalto.gov.br/ccivil_03/LEIS/L10098. htm. Acesso em: 10 jun. 2020.

CAPES. Documentos de Área Interdisciplinar 2013. Disponível em: http://www.capes.gov.br/images/stories/download/avaliacaotrienal/Docs_de_area/Interdiscipli nar_doc_area_e_comiss $\%-$ C3\%A3o_ATT27SET.pdf. Acesso em: 20 jun. 2020.

GARVEY, W. D. Communication: the essence of science. Oxford: Pergamon Press, 1979.

KHUDZARI, J. M. et al. Bibliometric analysis of global research trends on microbial fuel cells using Scopus database. Biochemical Engineering Journal, 136, 51-60, 2018. Disponível em: https://www.sciencedirect.com/science/article/pii/ S1369703X18301414. Acesso em: 10 jun. 2020.

LI, J.; HALE, A. Output distributions and topic maps of safety related journals. Safety Science, 82, 236-244, 2016. Disponível em: https://doi.org/10.1016/j.ssci.2015.09.004. Acesso em: 10 jun. 2020.

MANTOAN, M. T. E. et al. A educação especial na perspectiva da inclusão escolar: a escola comum inclusiva. Brasília: Ministério da Educação, v. 1, 2010. Disponível em: https://acervodigital.unesp.br/handle/123456789/25849?locale=pt_BR. Acesso em: 02 jun. 2020.

MORI, N. N. R.; SANDER, R. E. História da educação dos surdos no Brasil. Maringá, PR: UEM/PPE, 2015. Disponível em: http://www.ppe.uem.br/publicacoes/seminario_ppe_2015/trabalhos/co_04/94.pdf. Acesso em: 02 jun. 2020.

NOVAES, R. G.; TRUGILlO, E. A. O aluno surdo no contexto do ensino regular. Eventos Pedagógicos, v. 2, n. 2, p. 210219, 2011. Disponível em: http://sinop.unemat.br/projetos/re- 
vista/index.php/eventos/article/viewFile/406/249. Acesso em: 02 jun. 2020.

OLIVEIRA, E.; GRACIO, E. F. T. de. Indicadores bibliométricos em ciência da informação: análise dos pesquisadores mais produtivos no tema "estudos métricos" na base Scopus. Perspectivas em Ciência da Informação, Belo Horizonte, v. 16, p, 16-28, out./ dez., 2011. Disponível em: http://portaldeperiodicos.eci.ufmg. br/index.php/pci/article/view/1299. Acesso em: 10 jun. 2020.

OLIVEIRA, F. B. Desafios na inclusão dos surdos e o intérprete de libras. Diálogos \& Saberes, Mandaguari, v. 8, n. 1, p. 93-108, 2012. Disponível em: http://seer.fafiman.br/index.php/dialogosesaberes/article/view/271. Acesso em: 08 jun. 2020.

PALlUDETO, A. W. A.; FELIPINI, A. R. Panorama da literatura sobre financeirização (1992-2017): uma abordagem bibliométrica. Econ. soc., Campinas, v. 28, n. 2, p. 313-337, agosto de 2019. Disponível em: http://www.scielo.br/scielo.php?script=sci_arttext\&pid=S0104-06182019000200313\&lng=en\&nrm=iso. Acesso em: 23 jun. 2020.

PEREIRIA, A. S. et al. Metodologia da pesquisa científica. Santa Maria: Ed. UAB/NTE/UFSM, 2018. Disponível em: https://repositorio.ufsm.br/bitstream/handle/1/15824/Lic_Computacao_ MetodologiaPesquisa-Cientifica.pdf? sequence=1. Acesso em: 09 jun. 2020.

\section{QUADROS, R. M. O Tradutor e intérprete da língua brasileira} de sinais e língua portuguesa. Secretaria de Educação Especial, Programa Nacional de Apoio à Educação de Surdos. Brasília: MEC; SEESP, 2002. Disponível em: http://portal.mec.gov.br/ seesp/arquivos/pdf/tradutorlibras.pdf. Acesso em: 02 jun. 2020.

ROMANELLI, J. P. et al. Assessing ecological restoration as a research topic using bibliometric indicators. Ecological engineering, 120, 311-320, 2018. Disponível em: https://doi.org/10.1016/j. ecoleng.2018.06.015. Acesso em: 02 jun. 2020. 
SCHWARTZMAN, S. A Pesquisa Científica e o Interesse Público. Revista Brasileira de Inovação, v. 1, n. 2, p. 361-395, 14 ago. 2009. Disponível em: https://periodicos.sbu.unicamp.br/ojs/ index.php/rbi/article/view/8648864. Acesso em: 02 jun. 2020.

SEGALA, R. R. Tradução intermodal e intersemiótica/interlingual: Português brasileiro escrito para Língua Brasileira de Sinais, 2010, 115f. Dissertação (Mestrado em Educação) - Universidade Federal de Santa Catarina, Florianópolis, 2010. Disponível em: https://repositorio.ufsc.br/xmlui/handle/123456789/94582. Acesso em:

SELL, F. S. F.; NEVES, B. C. Desafios metodológicos para o desenvolvimento da disciplina de libras no curso de pedagogia na modalidade a distância da Universidade do Estado de Santa Catarina. Revista Em Rede, v. 2, n. 1, p. 51-63, 2015. Disponível em: https://www.aunirede.org.br/revista/index.php/emrede/article/ view/36. Acesso em: 10 jun. 2020.

SKLIAR, C. A surdez: um olhar sobre as diferenças. Atualidades da educação bilíngue para surdos. 4. ed. Porto Alegre: Mediação, 2010.

SILVA, I. R.; KAUCHAKJE, S.; GESUELI, Z. M. Cidadania, surdez e linguagem. São Paulo: Plexus, 2003.

SPENASSATO, D.; GIARETA, M. K. Inclusão de alunos surdos no ensino regular: investigação das propostas didáticometodológicas desenvolvidas por professores de matemática no ensino médio da EENAV. X Encontro Gaúcho de Educação Matemática 2009. Disponível em: http://www.projetos.unijui.edu.br/matematica/ cd_egem/fscommand/CC/CC_60.pdf. Acesso em: 04 jun. 2020.

TARGINO, M. G. Comunicação científica: uma revisão de seus elementos básicos. Informação \& Sociedade: Estudos. João Pessoa, v.10, n.2, 2000. Disponível em: https://www.brapci.inf.br/ index.php/article/view/0000001182/6f78994cb4aa4e65990e1d764d794d5b. Acesso em: 02 jun. 2020. 
VAN ECK, N. J.; WALTMAN, L. Software survey: VOSviewer, a computer program for bibliometric mapping. Scientometrics, v. 84. n. 2, p. 523-538, 2010. Disponível em: https://doi. org/10.1007/s11192-009- 0146-3. Acesso em: 06 jun. 2020.

VANZ, S. S.; CAREGNATO, S. Estudos de citação: uma ferramenta para entender a comunicação científica. Em Questão, Porto Alegre, v.9, n.3, p. 295- 307, 2003. Disponível em: https://seer. ufrgs.br/index.php/EmQuestao/article/view/75. Acesso em: 04 jun. 2020.

YE, Z. et al. A bibliometric investigation of research trends on sulfate removal. Desalination and Water Treatment, 52 (31-33), 60406049, 2014. Disponível em: https://doi.org/10.1080/19443994.2 013.812991. Acesso em: 09 jun. 2020. 


\section{UM OLHAR SOBRE OS DIREITOS DE CRIANÇAS E EQUIPE DOCENTE NO RETORNO ÀS INSTITUIÇÕES EDUCACIONAIS PÓS-PANDEMIA}

Mariana Lopez Expósito

Pâmela Elisabete Julião

\section{INTRODUÇÃO}

Gostaríamos de iniciar nossos diálogos com uma reflexão muito elucidativa sobre o cuidar.

Certo dia, ao atravessar um rio, Cuidado viu um pedaço de barro. Logo teve uma ideia inspirada. Tomou um pouco de barro e começou a dar-lhe forma. Enquanto contemplava o que havia feito, apareceu Júpiter. Cuidado pediu-lhe que soprasse espírito nele. O que Júpiter fez de bom grado. Quando, porém Cuidado quis dar um nome à criatura que havia moldado, Júpiter o proibiu. Exigiu que fosse imposto o seu nome. Enquanto Júpiter e o Cuidado discutiam, surgiu, de repente, a Terra. Quis também ela conferir o seu nome à criatura, pois fora feita de barro, material do corpo da terra. Originou-se então uma discussão generalizada. De comum acordo pediram a Saturno que funcionasse como árbitro. Este tomou a seguinte decisão que pareceu justa: "Você, Júpiter, deu-lhe o espírito; receberá, pois, de volta este espírito por ocasião da morte dessa criatura. 
Você, Terra, deu-lhe o corpo; receberá, portanto, também de volta o seu corpo quando essa criatura morrer. Mas como você, Cuidado, foi quem, por primeiro, moldou a criatura, ficará sob seus cuidados enquanto ela viver. E uma vez que entre vocês há acalorada discussão acerca do nome, decido eu: esta criatura será chamada Homem, isto é, feita de húmus, que significa terra fértil". (BOFF, 2017, p.17).

O mito/fábula nos mostra que é no cuidado que se encontra a essência do homem e não na inteligência ou no corpo.

Cuidamos uns dos outros?

A pandemia global da Covid-19 é simplesmente sem precedentes e, embora afete a todos e todas, isso se dá de diferentes formas.

Isso requer dos Estados providências urgentes e amplas, que sejam capazes de proteger toda a população e garantir os direitos dos diferentes grupos. A Fundação Demócrito Rocha em seu documento intitulado Justiça e Diálogo Social (2020) caracteriza o conceito de Estado como "o protagonismo do poder público, que se encontra praticamente em todas as áreas de relacionamento humano".

Desde a Declaração Universal dos Direitos Humanos (ONU, 1948), elaborada após a segunda guerra mundial, quando representantes de um mundo assolado pelas barbáries mais marcantes da história da humanidade, por meio da recém-criada Organização das Nações Unidas, que a lei garante a proteção a cada indivíduo contra ações que interferem na dignidade humana, seus direitos fundamentais.

O documento composto por 30 artigos baseou-se na Declaração dos Direitos dos Cidadãos dos Estados Unidos e Declaração dos Direitos do Homem e do Cidadão, este último de origem francesa. Entretanto, estes dois documentos não asseguravam direitos amplos a todos da raça humana.

A conceituação dos Direitos Humanos adotada por estados, pesquisadores, formadores e movimentos sociais, no plano internacional, pode ser traduzida em:

"Uma sequência normatizada de direitos e liberdades básicas de todos os seres humanos, englobando, sobretudo, o direito 
à livre expressão de pensamento, à igualdade perante a lei e o acesso a esses direitos". (DEMÓCRITO ROCHA, 2019, p.4)

São garantias de proteção das pessoas contra ações ou falta de ações dos governos que possam colocar em risco a dignidade humana.

Mas qual o sentido ou o significado do Direito?

\begin{abstract}
"Refere-se à ciência do direito ou ao conjunto de normas jurídicas vigentes em um país (direito objetivo). Também pode ter o sentido de íntegro, honrado. Aquilo que é justo, reto e conforme a lei. É ainda uma regalia, um privilégio, uma prerrogativa". (SIGNIFICADO, 2011 p.1)
\end{abstract}

Este momento pandêmico em que estamos vivendo nos mostrou claramente que faltam direitos essenciais à população como um todo. Falta acesso à educação, alimentação, saúde.

$\mathrm{Na}$ realidade, a crise veio nos mostrar o quanto a desigualdade social, que assola o país há tempos, afeta diretamente a estrutura organizacional da sociedade e suas relações.

Mas há políticas públicas para isso?

\title{
OLHAR SOBRE OS DIREITOS
}

Embora seja signatário da Declaração Universal dos Direitos Humanos, membro da ONU, há muito que se discutir sobre direitos humanos no Brasil.

Temos visto nas mídias diversas a grande dificuldade que muitos têm vivenciado nos últimos tempos e, ainda que existam leis que definem os direitos e deveres do cidadão, sabemos que, na prática, a realidade é dicotômica, especialmente nas periferias.

A criação das leis foi impulsionada por movimentos sociais, grupos de pessoas que se sentiam injustiçadas perante uma determinada organização social, e que contribuíram, e continuam contribuindo, para a criação de políticas públicas que garantam igualdade de direitos entre as pessoas.

Dentre as garantias de promoção do direito, no Brasil temos a própria Constituição (1998), inspirada na Declaração Universal dos Di- 
reitos Humanos (ONU, 1948), Lei de Diretrizes e Bases da Educação Nacional (BRASIL, 1996). Diretrizes Curriculares Nacionais para Educação Básica (BRASIL, 2013), Base Nacional Comum Curricular (BRASIL, 2017) e o Estatuto da Criança e do Adolescente (BRASIL, 1990), que trazem à luz questões extremamente pertinentes à segurança e bem estar de crianças e adolescentes, que devem ser assistidas e acompanhadas.

É dever da família, mas não só dela, da sociedade e do Estado assegurar a criança e ao adolescente o direito à vida, à saúde, à educação, ao lazer, à liberdade e a convivência familiar e comunitária. Isso quer dizer que a criança é responsabilidade de todos.

Todos queremos e desejamos a paz, a não violência, uma sociedade equilibrada e justa socialmente, com distribuição de renda, redução de vulnerabilidade e, principalmente, igualdade.

O Brasil é um país assustadoramente desigual. Almejamos esta sociedade, esta educação, estas condições humanas, mas, como alcançá-las considerando o cenário atual?

Não ouvimos as crianças, os adolescentes, as famílias, os professores. O que se ouve diz respeito à uma classe que está no poder: branca, economicamente produtiva, socialmente ativa. As elites controlam os tempos a partir da ocupação dos espaços.

A cidade é hostil, não há lugar para mulheres, crianças e mais velhos. Se você não for produtivo, você não se locomove. Segregamos socialmente por gênero, raça, idade, nível de instrução.

Aqui temos uma pergunta: qual é o nosso projeto de promoção do humano?

\section{EXPERIÊNCIAS VIVIDAS}

Refletindo acerca dos pontos acima mencionados, há uma preocupação imediata quanto ao retorno de crianças bem pequenas às instituições de ensino pós- pandemia da Covid-19 e consequentemente dos professores e outros profissionais da educação.

De acordo com o site G1 (2020), alguns países da Europa têm demonstrado queda nas taxas de infecção, transmissão e mortalidade pelo vírus e se consideraram aptos à reabertura de alguns estabelecimentos 
comerciais e retomada das atividades educacionais, desde que tomadas algumas medidas de proteção e distanciamento.

Em Portugal, as atividades foram retomadas na primeira semana do mês de maio em instituições da primeira infância, considerando: opção aos pais por ficar com suas crianças em casa, neste caso, continuariam recebendo auxílio financeiro do governo por duas semanas; separação das crianças em pequenos grupos; escolas organizando horários diferenciados de aula, intervalos e refeições a fim de evitar contato; estabelecimento de distância mínima de 1,5 entre cada aluno nas salas de aula, a fim de garantir o afastamento físico.

As Forças Armadas portuguesas distribuíram mais de 4 milhões de máscaras, 17 mil litros de desinfetantes e outros equipamentos de proteção e higiene para os centros educacionais.

$\mathrm{Na}$ Coreia do Sul as escolas também foram reabertas com medidas de proteção parecidas, porém, 200 delas fecharam as portas devido a novos casos de contaminação.

$\mathrm{Na}$ França 40 mil escolas foram abertas no início de maio, porém, uma semana depois, 70 delas registraram casos de contaminação por Covid-19 e tiveram que fechar as portas.

A reportagem do jornal El País (ARROYO, 2020), aponta os estudos sobre o retorno na Espanha apresentando os cálculos de pesquisadores da Universidade de Granada sobre a exposição dos alunos: no primeiro dia, numa sala com 20 alunos, tendo apenas um irmão cada aluno, este aluno será exposto a 74 pessoas. Isso se não houver contato com alguém fora da sala de aula e da casa da família.

“A preparação para a volta em setembro não é só insuficiente, mas também foi deixada nas mãos das escolas, algo que "obviamente" excede sua capacidade organizacional e de recursos. O que deve ser feito se uma criança tossir? Quando os professores serão submetidos a um teste? Todos os dias? Às vezes? Se adoecerem?" (ARAGÓN, 2020, p.1).

Concordamos com o professor que salienta a necessidade de um planejamento consciente para o retorno. 
No Brasil, os municípios têm anunciado Planos de Retomada das atividades escolares de forma progressiva, amparados por orientações do Conselho Nacional de Educação.

Em junho, o Governador de São Paulo anunciou o Plano para retorno das aulas, o qual está previsto para o mês de setembro, mesmo quando as taxas de contágio e morte permanecem em crescimento dia após dia.

Considerando as principais medidas de isolamento adotadas nos países mencionados acima e aquelas pretendidas pelos governantes no Brasil, é importante que questionamentos sejam levantados a fim de saber se tais medidas atendem os direitos essenciais de bebês e crianças e seus professores.

\section{OBSERVANDO A CRIANÇA}

Quando se fala sobre os direitos das crianças, faz-se necessário refletir sobre os diversos documentos citados anteriormente, que assumem o importante papel de viabilizar a segurança e proteção das mesmas, assim como, garantir que seus direitos básicos sejam preservados e assegurados.

O Brasil dispõe de marcos legais avançados, que servem, até mesmo, de referências para muitos países, entretanto, não são acompanhados de políticas públicas e monitoramento.

Importante considerar princípios pedagógicos presentes nestes documentos. Inclusive pesquisas e estudos acerca da educação infantil em diálogo com as premissas dos Centros de Educação Infantil. Nos questionamos: como considerar a brincadeira e a interação para a educação infantil no contexto do retorno? Se acreditarmos que na educação infantil a criança aprende nas interações com objetos, pessoas, lugares e situações, como promover interações saudáveis e seguras para todos, bebês, crianças pequenas e professores?

Sabemos ainda que muitas escolas públicas estão inseridas em regiões precárias e de extrema vulnerabilidade social, sendo assim, como garantir espaços adequados e higienizados a fim de que as crianças se desenvolvam de maneira adequada, garantindo seus direitos básicos? 
A infầncia não é influenciada apenas pelo ambiente, mas também por todos os fenômenos sociais como: família; meios de comunicação e também pelas transformações sociais e culturais.

Embora já houvesse um grau de abandono das escolas públicas, antes da pandemia, pois a escola há muito tempo é representada como um lugar de falta, de pobreza e não de potencialidade, de possibilidades, de um espaço de emancipação. Com a pandemia o lugar da escola foi (está sendo) ressignificado, melhor dizendo, há uma intenção em ressignificá-lo, por parte de todo território no qual as mesmas estão inseridas, é muito comum ouvirmos da sua importância, compromisso social e, da falta que os encontros, relações e interações que ali são tecidas fazem, já que são primordiais para o desenvolvimento das crianças, qualificações dos professores e gestores e sua influência na contribuição para a construção da sociedade e democracia.

Pensando sobre o retorno, as escolas precisarão ser proativas e se comunicar-se também com as políticas sociais, entre todos os segmentos e áreas dos territórios, a fim de não perder as crianças. Numa discussão que envolve a dimensão humana e humanizadora da educação, de toda a comunidade escolar e do território no qual a escola se encontra.

O exercício democrático é estritamente conflituoso, difícil e complexo, porque ouvir o outro implica na escuta qualificada e no reconhecimento deste outro, porque muitas vezes, a fala do outro não é o que esperávamos ouvir e considerar esta fala é de fato um importante exercício de empatia.

Sabemos que um professor pode causar impacto em milhares de alunos e modificar muitas realidades, e o professor quer isso, quer também entregar um bom trabalho, uma boa aula, deseja ser um bom professor.

Tal profissional foi formado e, está em constante atualização para avançar em seus conhecimentos, experiências, competências e habilidades e são justamente tais competências que permitem que atuem, junto às crianças, compreendendo-as como sujeitos, históricos e de direitos, potentes, ativas, protagonistas de seu próprio processo de desenvolvimento, na construção de suas identidades e de sua autonomia. 
A reflexão vai mais além, quando pensamos numa educação cujo cuidar e educar são indissociáveis, princípio da educação infantil. A relação deixa de ser transversal quando as orientações se contrapõem diretamente ao conceito básico de criança, criança essa que necessita (e é seu direito fundamental) ser cuidada, amada, educada, querida, alimentada e principalmente tocada.

“A Educação Infantil é o lugar em que a criança deve ser compreendida como sujeito de direitos. Criança é sujeito, não objeto. Se existe algo que sustenta a BNCC da Educação Infantil é a concepção de infância, ao compreender a criança como centro do processo. Trata-se de compreendê-la como capaz. Capaz de fazer, capaz de brincar, de aprender e ensinar. Esse é o desafio da nossa prática”. (SÂMIA, et al, 2020, p.1)

Todo o processo de retorno deverá ser pautado em escuta atenta, escuta essa que ultrapassa o ouvir. Uma escuta sensível e refleti$\mathrm{da}$, que consiga acolher as necessidades do coletivo: profissionais, famílias e, principalmente, bebês e crianças. Inclusive àquelas de ordem emocional. Como estarão todos, psicologicamente falando, pós-pandemia?

Ainda que saibamos que a situação atual do país é extremamente preocupante, e que as medidas de proteção adotadas para retorno são necessárias, nos questionamos: estamos assegurando os direitos básicos de nossos alunos? Direitos referentes à vida, à saúde, à alimentação, ao lazer, à liberdade e, principalmente, à convivência comunitária? Quanto? Como conviver e interagir com seus pares em meio ao distanciamento social? Como assegurar a convivência e interação neste retorno? Como manter o processo de acolhimento quando não podemos sequer nos tocar?

Bittencourt e Markus (2020), ambos médicos, trazem uma pertinente reflexão quanto à importância do breve retorno das crianças aos espaços escolares e quantos benefícios trarão para as mesmas já que, segundo pesquisas realizadas, dentre o grupo de risco da Covid-19, as crianças têm taxa quase nula de contágio. Entretanto, isso não quer dizer que não haja, e, os riscos de transmissão. 
Embora não questionemos suas justificativas para o retorno: aumento do índice de violência doméstica no período da pandemia; disparidade de aprendizado por diferenças socioeconômicas, com prejuízo claramente concentrado nas famílias de baixa renda; necessidade de retorno ao trabalho por parte dos pais dos alunos e, o lugar social da escola, sua competência enquanto formadora das crianças e destas em formar opiniões e levar informações atualizadas para seus e familiares.

Nosso questionamento se pauta em direito à segurança para todos, alunos, profissionais da educação, enfatizando o professor, o qual tem contato direto com as crianças e suas famílias.

Ao fazer uma leitura panorâmica, pouco se fala sobre os profissionais que participam da rotina, diária, com esses bebês e crianças, o que deveria ter uma ponderação ampla, tendo em vista que estão em contato constante com demais integrantes da equipe escolar e comunidade.

Durante este período de isolamento e início de atividades à distância, as pessoas tiveram que adotar papéis que antes não lhes pertenciam. Familiares sendo convocados a aplicar conteúdos pedagógicos para as crianças, professores recebendo títulos de youtubers por suas performances por detrás das câmeras e profissionais de diversas áreas (que não a educacional) opinando sobre assuntos que só dizem respeito àqueles que conhecem e estão cotidianamente no "chão da escola".

Essa é uma questão que deve ser pensada a todo o momento, no sentido de valorização profissional, tendo em vista que há pessoas muito competentes e comprometidas com a saúde e bem estar do coletivo, e que já fazem parte do quadro apoio dessas instituições.

Não, o professor não é youtuber. Faz-se necessário dar voz e visibilidade a esses profissionais, a fim de que seus direitos também sejam garantidos e, que sua fala seja ouvida.

\section{FALANDO SOBRE O RETORNO}

Muito têm sido os debates acerca deste retorno, já o entendemos como necessário, em algum momento. É necessário quando pensamos em crianças que dependem exclusivamente das escolas para manterem-se cuidadas, educadas, limpas e alimentadas; é necessário quando 
refletimos sobre os processos de interação e desenvolvimento humano e social deste sujeito; necessário também quando são consideradas as relações de transformação do meio em que esse bebê e essa criança estão inseridos.

Deixando, momentaneamente de lado o quando, partimos para a reflexão do como.

As orientações para retorno ainda são um tanto quanto vagas, mas os protocolos já estão sendo pensados e discutidos. Em São Paulo, a nível estadual, contamos com o Plano São Paulo (2020) e, apropriando-se do contexto municipal o documento Minuta: Protocolo Volta às Aulas (2020).

Ambos documentos trazem propostas que congregam entre si e outras que se diferem.

Segundo o Plano São Paulo, a data prevista para retomada das aulas presencial será dia 8 de setembro, considerando que todos os Departamentos Regionais de Saúde estejam por 28 dias consecutivos na Fase 3 (amarela) ou superior e que no anúncio do mapa atualizado do Plano SP em 04/09 as áreas estejam, também estabilizadas, na Fase 3 (amarela) ou superior. O documento Minuta sugere a mesma projeção, estando condicionado ao plano anteriormente mencionado.

Ambos documentos propõem um protocolo com algumas medidas que deverão ser adotadas não apenas no retorno das atividades sociais cotidianas como também em instituições educacionais a fim de evitar contágio, são elas: distanciamento social; higiene pessoal; sanitização de ambientes; comunicação e monitoramento.

A fim de reduzir a aproximação e o contato, o primeiro item, que diz respeito ao distanciamento social, orienta a obrigatoriedade do distanciamento de $1.5 \mathrm{~m}$ entre as pessoas, especialmente nas salas de aula (exceto a educação infantil); outra medida adotada é a junção do ensino remoto combinado com o retorno gradual das atividades presenciais e a reorganização dos horários de entrada e saída a fim de evitar aglomerações, revezamento nos intervalos e recreios com turmas em horários alternados.

Em seguida temos a higienização pessoal, a qual orienta que haja uma limpeza frequente das mãos com água e sabão ou álcool em gel 
70\%. As instituições devem fornecer Equipamentos de Proteção Individual (EPIs) necessários aos funcionários para cada tipo de atividade, assim como, permitir que tenham acesso à água potável de forma individualizada (seja por meio de garrafas ou copos).

A medida a seguir trata da sanitização dos ambientes, a qual faz saber que, cada instituição deverá se organizar a fim de que os banheiros, lavatórios e vestuários sejam higienizados antes, a cada três horas e após o funcionamento e que, absolutamente todos os itens dos quais alunos e professores tenham contato como: grade, mesas, carteiras, puxadores de porta e corrimão também o sejam. Lixos deverão ser removidos 3 vezes ao dia.

No que diz respeito à comunicação, a escola deverá comunicar as famílias e estudantes sobre o retorno e os protocolos adotados com, no mínimo, 7 dias de antecedência. Pede-se que sejam priorizados os atendimentos através de canais digitais como telefone, e-mail e aplicativos.

Por último, como forma de monitoramento, pede-se que sejam observadas as respostas físicas, ou seja, não permitir a permanência de pessoas com sintomas de Covid-19 na instituição, aferir temperatura antes de acessarem as dependências da escola e separar uma sala específica para pessoas que apresentarem os sintomas. Neste tópico dar-se-á visibilidade a seguinte recomendação: profissionais e alunos pertencentes ao grupo de risco deverão permanecer em atividade remota na primeira fase do plano.

O documento da Secretaria Municipal de Educação nos é apresentado numa formatação que contempla tanto os itens mencionados acima, como uma gama de informações novas e muito importantes.

Traz à luz um item que diz respeito a formação. Todos os partícipes da organização escolar, com ênfase nos que atuam na limpeza, terão formação específica sobre a doença, suas formas de transmissão, práticas de proteção e segurança, e todos os itens já mencionados para um funcionamento adequado das unidades neste possível regresso.

Conta também com uma série de instruções para o funcionamento do fluxo de pessoal nas atividades cotidianas dentro das instituições, os quais poderão ser consultados diretamente no documento. 
Certamente, são documentos que englobam, mesmo que superficialmente, os pontos principais que devem ser adotados nos cuidados pessoais e com o outro. Mas e as subcamadas das relações interpessoais neste retorno?

Como atender bebês e crianças seguindo critérios tão importantes que, mesmo antes da crise pandêmica, não eram adequadamente aplicados?

Marcelo Cunha Bueno faz uma reflexão muito pertinente em uma vídeo conferência para o canal "De criança para criança" (2020), segundo ele, o primeiro protocolo a ser seguido precede do abraço. Se os pares, puderem se abraçar e manter esses vínculos afetivos estabelecidos, a educação presencial pode retornar sem prejuízos.

Acredita-se que as maiores indagações neste momento partem do micro para o macro. De imediato, nos questionamos sobre como bebês, crianças e profissionais da educação poderão sentir-se seguros neste regresso?

Além disto, é importante que o currículo seja revisitado de forma a acolher a todos, inclusive àquelas famílias que optarem por manter-se em isolamento após o retorno.

Os processos educacionais certamente deverão ser repensados.

\section{OUTRAS ESCUTAS}

Por acreditarmos na escuta, no diálogo, como o melhor caminho para elucidar e traçar caminhos. Organizamos uma pesquisa junto às famílias de bebês de um dos CEIs no qual atuamos.

A pesquisa seguiu os protocolos éticos e usou como estratégia o Google forms. De nove questionários enviados, sete responderam.

Das sete famílias, seis tem crianças de idade até três anos e uma até cinco anos. Todas as crianças estão matriculadas em Instituições de Educação Infantil. Neste período, cinco das mães estão cuidando de seus, incluindo ajuda de avó (2 - nos dias em que a mãe tem que ir trabalhar), vizinha (1) (filho mais velho 1 - nos dias em que a mãe precisa ir trabalhar).

Transcrevemos abaixo os apontamentos feitos pelas famílias. 
- Quanto à rotina das crianças neste período:

$\mathrm{F}^{42} 1$ - "Tentamos realizar as atividades e respeitando o isolamento".

F2 - "Desde 16 de março não saem de casa, aulas online, brincadeiras dentro de casa".

F3 - “Às vezes fazendo atividades às vezes não são 5 crianças em casa."

F4 - "Parcialmente tranquila, não temos horário fixo para realizar cada atividade ou refeição. Mas tento aproveitar nosso tempo da melhor forma possível, dividindo em algumas estampas: brincar, assistir, cantar, fazer as refeições e hora do repouso".

F5 - "Criamos uma rotina desde o início da pandemia, na maioria dos dias seguimos como combinado, outros dias ela não está a fim de fazer nada e eu deixo! Não está fácil pra ela entender que não pode sair para brincar e encontrar os colegas".

F6 - "Está sendo bem difícil, pois elas já estranhavam agora estão piores".

F7 - "Bem complicado dizer, pois estamos tentando inventar muitas coisas em casa, e graças à ajuda que a escola está dando com vídeos com ideias de brincadeira para eles, é o que tem nos ajudado, mas estamos também vendo cada detalhe de crescimento deles, é algo bom, muito bom".

- Quanto às expectativas das famílias para o retorno ao atendimento nas Instituições de Educação Infantil:

F1 - "Não sei como será. Me causa aflição, pois não sei como será visto o menor, de berçário, como será o trato dele visto que os educadores realizam a manipulação completa com as crianças festa idade. Troca, mamada, alimentação, quer dizer tudo."

42 "F" corresponde às famílias que responderam o questionário. 
F2 - "Eu sinceramente espero que a pequena só volte ano que vem".

F3 - "Espero que ocorra tudo bem".

F4 - "Minha expectativa é que retorne o quanto antes, porém, ainda tenho bastante receio em estar expondo minha filha, pois nem todos tem o cuidado necessário. Como irão fazer de forma segura tanto para as profissionais e as crianças".

F5 - “Não acredito que seja o momento".

F6 - "Que tudo se normalize".

F7 - "Sinceramente acho que vai demorar a voltar ao normal, mas espero que melhore um pouco, e que deem mais assistência, pois não acho certo voltar às creches agora, são crianças frágeis, e que não sabem que tem que ficar de máscara, mesmo a gente explicando, que não entendem o que é o afastamento, por ser algo deles, estar perto, compartilhar brinquedos, abraços, afins".

- Sobre questionamentos para o retorno ao atendimento nas Instituições de Educação Infantil:

F1 - "Quais serão os protocolos adotados neste período de pandemia".

F2 - "Como manter distanciamento dos pequenos? Creio não ser possível".

F3 - "Tenho medo de mandar meu filho, pois ele não sai sabe se pode ou não abraçar e beijar o coleguinha e também não sabe cuidar de toda sua higiene, pois em casa está mais seguro são muitas criança para professora fica com todos os cuidados no meio desta pandemia".

F4 - “Como será a higienização do ambiente? Quantas pessoas serão permitidas a terem acesso ao mesmo tempo? Terá álcool em gel disponível para todos? Irá medir a temperatura de todos? Como será a higienização dos brinquedos? Todos os funcionários irão trabalhar com máscara e luva?”. 
F5 - "Como a minha filha irá ver os amigos e entender que não pode abraçar, chegar perto, encostar. Acredito que não vai ser bacana e já decidimos que ela não volta esse ano."

F6 - "Questionamento sobre higiene, quantas crianças estarão em cada sala etc".

F7 - "Como irá funcionar o afastamento, o uso de máscaras, o uso de álcool gel, com crianças pequenas?”.

- Sobre como o retorno deve se dar:

F1 - "Lenta e gradual, de forma segura e muito bem conversada".

F2 - "No caso da Thays espero que ela tenha que retornar apenas no próximo ano, pois creio que até lá tudo já tenha normalizado e também com maior segurança".

F3 - "Particularmente não sei. Porque fala estamos em uma pandemia deveria estamos falando sobre até que tudo isto acabasse de uma vez por todas".

F4 - "Espero que seja da melhor forma possível, que as professoras tenham equipamentos de segurança necessários para que as mesmas estejam "seguras" e assim contribuir com a proteção das crianças".

F5 - "O ideal seria que todos fossem testados, para que pudesse voltar de maneira tranquila, mais isso não vai acontecer e vai ser uma catástrofe, pois acredito que número de contaminação irá triplicar. A verdade é que não estamos preparados para esse retorno".

F6 - "No começo realmente vai ser um caos até porque tem pais que querem mandar, tem outros que não, mais eu viso o bem-estar das minhas filhas acima de tudo".

F7 - "Não acho que tenha que voltar agora às aulas. Acho que tem que ser estudado tudo isso, tem que ser visto o que da para ser feito, visto o que as crianças vão fazer, como vão ficar longe 
dos amiguinhos, para eles isso tudo é muito estranho, é novo. Espero que o retorno de certo, mas também espero que sejam mais cuidadosos, pois o risco vai desde as crianças, aos professores. Não deixa de serem aglomerações".

- Outras considerações sobre o retorno:

F1 - "Minha prioridade é a vida, a saúde e desta forma com os números de casos confirmados de corona vírus e óbitos, neste quadro que se apresenta sou contra a reabertura das escolas e principalmente os de idade menores, creches".

F2 - "Não vejo a menor condição de que nossos pequenos voltem às aulas... Simplesmente porque eles não têm a menor noção de distanciamento".

F4 - "Que a escola tenha o máximo de cuidado possível com os funcionários e principalmente com as crianças”.

F6 - "Espero que todos estejam bem".

F7 - "Serei sincera, sou mãe de dois meninos pequenos, se voltar as aulas agora, não irei mandá-lo, os dois como eu, temos imunidade baixa, qualquer coisa ficamos gripados, não vou colocar meus filhos em risco, com pessoas que não sei com quem convive, se tem ou não contato com pessoas infectados pelo Covid19, se vão ou não passar álcool em gel toda hora em todos, se vão ou não fiscalizar se estão de máscaras, são muitos questionamentos, e muitas preocupações, e não tenho coragem de colocar meus filhos em risco vendo todos os dias o crescimento de casos que anda tendo, o número de mortes, é triste, é preocupante de se ver tudo isso".

\section{CONSIDERAÇÕES FINAIS}

Consideramos que os parâmetros para o retorno devem basear-se em condições sanitárias seguras, para tanto, o estabelecimento de protocolos devem ser dialogados e publicizados. 
A escola deve ser inclusiva em todos os níveis sociais. Uma educação inclusiva diz respeito à quebra de todas as barreiras que se impõem as crianças. Diz respeito também ao acolhimento de ideias, percepções e sugestões daqueles que atuam diariamente com esses bebês e crianças.

Acreditamos sim, enquanto comunidade escolar, incluindo professores, gestores, crianças e famílias, que temos competência para dialogar sobre as possibilidades de retorno com nossos territórios.

Nossa percepção da pesquisa feita com as famílias é que suas angústias, medos e inseguranças corroboram com apontamentos feitos anteriormente.

É preciso cuidado para com todos!

O direito à vida sobrepõe-se a todos os outros. Somos pela vida.

\section{REFERÊNCIAS BIBLIOGRÁFICAS}

ARROYO, Javier. Colocar 20 crianças numa sala de aula implica em 808 contatos cruzados em dois dias, alerta universidade. EL PAÍS, Granada, p. 1, 17 jun. 2020. Disponível em: https://brasil. elpais.com/sociedade/2020-06-17/colocar-20-criancas-numa-sala-de-aula-implica-em-808-contatos-cruzados-em-dois-dias-alerta-universidade.html. Acesso em: 30 jun. 2020.

BITTENCOURT, Marcio; MARKUS, Jandrei. Por que devemos reabrir as escolas. Brazil Journal, São Paulo, p. 1, 28 jun. 2020. Disponível em: https://braziljournal.com/por-que-podemos-e-devemos-reabrir-as-escolas. Acesso em: 29 jun. 2020.

BOFF, Leonardo. A Fábula do Mito do Cuidado. In: HYGINUS, Gaius Julius. Saber Cuidar: ética do humano. Petrópolis, RJ: Vozes, 2017. p. 46. ISBN 978-85-326-5576-9.

BRASIL. Base Nacional Comum Curricular: BNCC. Brasília: MEC, 2019. Disponível em: http://basenacionalcomum.mec. gov.br/images/BNCC_EI_EF_110518_versaofinal_site.pdf. Acesso em: 02 de julho de 2020. 
BRASIL. Constituição da República Federativa do Brasil. Brasília: 1988. Disponível em: http://www.planalto.gov.br/ccivil_03/ constituicao/constituicao.htm. Acesso em: 27 jun. 2020.

BRASIL. Decreto no 99.710, de 21 de novembro de 1990. Convenção sobre os Direitos da Criança. Brasília, 22 nov. 1990. Disponível em: http://www.planalto.gov.br/ccivil_03/decreto/1990-1994/d99710.htm. Acesso em: 28 jun. 2020.

BRASIL. Lei no 8.069, de 13 de julho de 1990. ECA: Estatuto da Criança e do Adolescente, Brasília, 14 jul. 1990. Disponível em: http://www.planalto.gov.br/ccivil_03/leis/18069.htm. Acesso em: 27 jun. 2020.

BRASIL. Ministério da Educação. Secretaria de Educação Básica. Secretaria de Educação Continuada, Alfabetização, Diversidade e Inclusão. Secretaria de Educação Profissional e Tecnológica. Conselho Nacional da Educação. Câmara Nacional de Educação Básica. Diretrizes Curriculares Nacionais Gerais da Educação Básica/Ministério da Educação. Secretaria de Educação Básica. Diretoria de Currículos e Educação Integral. Brasília: MEC, SEB, DICEI, 2013.

BRASIL. Lei no 13.005 , de 25 de junho de 2014. Aprova o Plano Nacional de Educação - PNE e dá outras providências. Diário Oficial da União, Brasília, 26 de junho de 2014. Disponível em: http://pne.mec.gov.br/18-planos-subnacionais-de-educacao/ 543-plano-nacional-de-educacao-lei-n-13-005-2014. Acesso em: 27 jun. 2020.

BRASIL. Ministério da Educação. Diretrizes Curriculares Nacionais para a Educação Infantil. Resolução CNE/CEB n ${ }^{\circ}$ 5/2009.

Enfrentamento à violência sexual contra crianças e adolescentes [coleção] /vários autores; coordenação de conteúdo: Leila Paiva; ilustrações: Rafael Limaverde. -Fortaleza: Fundação Demócrito Rocha, 2019. 
GOV. Plano São Paulo: Plano de Retorno da Educação. São Paulo, 20 jun. 2020. Disponível em: https://saopaulo.sp.gov.br/wp-content/uploads/2020/06/Apresentacao_plano-retorno-educacao. pdf. Acesso em: 2 jul. 2020.

Justiça e diálogo social. Cli_Villar (organizador); Gustavo Brígido (coordenador); Karlson Gracie (ilustrador). - Fortaleza: Fundação Demócrito Rocha, 2020. 12 fascículos.

ONU BRASIL. Resolução no 217 A (III), de 10 de dezembro de 1948. Adotada e proclamada. Declaração Universal dos Direitos Humanos, [S. l.], 10 dez. 1948. Disponível em: https://nacoesunidas.org/direitoshumanos/declaracao/. Acesso em: 27 jun. 2020.

ONU BRASIL. O que são direitos humanos? Disponível em: $<$ http://https://nacoesunidas.org/direitoshumanos/. Acesso em: 26 jun. 2020.

PORFÍRIO, Francisco. Direitos Humanos; Brasil Escola. Disponível em: https://brasilescola.uol.com.br/sociologia/direitos-humanos. htm. Acesso em 02 de julho de 2020.

PORTUGAL tem volta às aulas parcial nesta segunda-feira, com medidas de proteção e distanciamento: Ano letivo será retomado para alunos dos dois últimos anos do ensino médio. G1, p. 1, 18 maio 2020. Disponível em: https://g1.globo.com/educacao/noticia/2020/05/18/portugal-tem-volta-as-aulas-parcial-nesta-segunda-feira-com-medidas-de-protecao-e-distanciamento.ghtml. Acesso em: 28 jun. 2020.

SÂMIA, Monica. A BNCC no cotidiano da Educação Infantil. In: A BNCC no cotidiano da Educação Infantil. [S. l.], 2 mar. 2020. Disponível em: http://avante.org. br/a-bncc-no-cotidiano-da-educacao-infantil/\#: :text=Crian\%C3\%A7a\%20\%C3\%A9\%20sujeito\%2C\%20n\%C3\%A3o\%20 objeto,brincar\%2C\%20de\%20aprender\%20e\%20ensinar. Acesso em: 26 jun. 2020. 
SECRETARIA MUNICIPAL DE EDUCAÇÃO (São Paulo). Minuta: Protocolo Volta às Aulas. São Paulo, jul. 2020.

SIGNIFICADO de Direito. In: Significado de Direito. [S. l.], 1 jan. 2011. Disponível em: https://www.significados.com.br/direito/. Acesso em: 01 jul. 2020.

\section{REFERÊNCIA VIDEOGRÁFICA}

DE CRIANÇA PARA CRIANÇA. As dificuldades das escolas e os procedimentos para o retorno das atividades presenciais. 2020. (1h18m26s). Disponível em: https://www.youtube.com/ watch?utm_campaign=webinar_dificuldade_das_escolas_-_10_ min\&utm_medium $=$ email\&utm_source $=\mathrm{RD}+$ Station $\& v=\mathrm{cS}-$ qOdQeS-Ok. Acesso em 02 de julho 2020. 


\section{A EDUCAÇÃO EM DIREITOS HUMANOS PARA CRIANÇAS E ADOLESCENTES: PISTAS A PARTIR DAS INSTITUIÇÕES DE ENSINO FORMAIS E NÂOO-FORMAIS}

Nei AlBerto Salles Filho

Vania Fernandes Machado

Evenilson Silvestre da Luz

Este estudo objetiva discutir aspectos conceituais sobre a Educação em Direitos Humanos (EDH) no contexto das instituições educacionais formais e não formais do município de Ponta Grossa, Paraná, Brasil.

Apresenta questões referentes aos aspectos teóricos e, ao mesmo tempo, investiga as repercussões conceituais em programas e projetos educacionais inseridos nas instituições que atendem crianças e adolescentes em situação de risco e/ou vulnerabilidade social. Parte do problema de como, e se, os programas e projetos educacionais destinados às crianças e adolescentes incorporam as dimensões dos Direitos Humanos. $\mathrm{O}$ estudo utiliza método misto, com abordagem quanti-qualitativa. Deste modo, aproxima o levantamento bibliográfico sobre o tema e analisa documentos referentes à Educação em Direitos Humanos (EDH) no Brasil, além de ir a campo e realizar levantamento a partir de órgãos ligados à educação, tanto na esfera formal, como em projetos socioeducativos. Os resultados iniciais apontam que na educação formal (rede Municipal e Estadual de ensino) existem projetos 
que atuam superficialmente em questões de direitos humanos, como o meio ambiente, por exemplo, porém, sem aprofundar a discussão.

Nos espaços de educação não formais os projetos seguem orientações do Sistema Único de Assistência Social (SUAS) oferecendo o Sistema de Convivências e Fortalecimento de Vínculo (SCFV), que visa desenvolver a autoestima e potencialidades individuais. Ainda assim, não há clareza sobre processos pedagógicos que desenvolvem a Educação em Direitos Humanos. Evidenciamos que não obstante se discuta muito sobre processos de educação que atinjam reflexões sobre os direitos humanos, estes ainda não estão sistematizados nas práticas educacionais do contexto pesquisado.

Dessa forma, este estudo objetiva entender a perspectiva dos direitos humanos e da Educação em Direitos Humanos (EDH) em instituições educacionais formais e não formais da cidade de Ponta Grossa, Paraná, especialmente em relação às crianças e adolescentes. Para isso, é importante discutir pontos onde ancoramos os pressupostos básicos de nosso entendimento, uma vez que o campo dos direitos humanos se apresenta complexo na abordagem, contraditório nas práticas sociais e interdisciplinar nos estudos e, a EDH ainda é campo relativamente recente de estudos sistemáticos no Brasil. Com suporte em Silva (2014, p. 261), entendemos inicialmente:

Direitos Humanos trata-se de normas mínimas justamente daquilo que é o direito primário a todos os seres humanos: o direito à vida, à integralidade da pessoa, à liberdade pessoal, liberdade de consciência e manifestação do pensamento, direito à saúde e à educação, à moradia, à circulação no território, à reunião e associação, direito ao trabalho, à renda ou subsistência, direito à assistência a quem não tem condições de trabalhar, liberdade contratual, direito ao voto, direito ao acesso aos cargos públicos.

De início, a abordagem ampla dos direitos humanos mostra que são muitos os aspectos que giram ao redor da dignidade da pessoa. A própria vida como direito, passando pela liberdade pessoal e de consciência que podem ser considerados aspectos individuais até as questões 
sociais objetivas como trabalho, moradia, educação e saúde compõem este cenário. Logo, a dignidade não é uma palavra vazia, mas sim, uma declaração de intenções para que homens e mulheres, ao redor do mundo, possam viver suas vidas em condições favoráveis e que permitam o melhor desenvolvimento de pessoas e países.

Com fundo nestas considerações, nos propusemos a investigar quais destes pressupostos são pensados e/ou desenvolvidos nas instituições educacionais formais e não formais da cidade de Ponta Grossa - Paraná, no ano de 2018. Isso serve como aspecto importante para perceber como está sendo pensada a EDH nas instituições e redes de ensino que atuam com crianças e adolescentes. Acreditamos que as pistas encontradas, ao longo da pesquisa, podem servir para ampliar esta discussão fundamental do século XXI, os direitos humanos.

\section{Sobre os Direitos Humanos e Educação em Direitos Humanos}

A importância dos direitos humanos é inegável. Particularmente nas últimas décadas, torna-se campo fundamental de debates e análise. Além disso, implica diretamente na forma de vida das pessoas. É o que salienta Raddatz (2012, p. 312): “Acredita-se que nenhuma forma de poder, seja ela política ou econômica, pode propiciar a tranquilidade e a paz se não respeitar os direitos humanos". Neste ponto, vemos como os direitos humanos são decisivos nos processos civilizatórios, ou seja, com a complexificação social é fundamental a organização da sociedade visando à participação e igualdade de todos como um princípio básico.

Porém, podemos dizer que os direitos humanos ainda são mais presentes em discursos do que na prática humana e social, incluindo as políticas públicas. Este quadro precisa de análise mais detida e aprofundada, que requer entender como esta articulação se dá em nível internacional. Sobre isso, Lucas (2013, p.23) diz:

Apesar dos problemas de efetividade material, a defesa dos direitos humanos tem-se consolidado e envolvido, cada vez mais, os organismos internacionais e as organizações não governamentais, bem como preocupado um número sempre mais sig- 
nificativo de cidadãos individualmente considerados. De fato, a Organização das Nações Unidas transformou os ideais de paz e de proteção dos direitos humanos numa referência importante da agenda internacional. Tais ideais têm servido para o reconhecimento, ainda que parcial, dos interesses históricos de diversos povos "excluídos" do grupo restrito de países desenvolvidos e, de igual modo, indicam um progresso moral da humanidade que não pode sustentar- se apenas por estar associado a determinados grupos nem ter sua validade condicionada apenas a elementos histórico-sociais.

Nas últimas décadas, no mundo, o fortalecimento dos direitos humanos está atrelado ao desenvolvimento econômico e ajustado às políticas públicas, em maior ou menor grau. A Organização das Nações Unidas (ONU) se constituiu em referência para que os países se organizassem em função de suas demandas específicas. Isso endossa a afirmação de Tuvilla Rayo (2004, p. 17): "o respeito aos direitos humanos é essencial para o progresso e o desenvolvimento social e econômico". Também é certo, como argumenta o mesmo autor que muitos direitos fundamentais se encontram, igualmente, em constante ameaça por forças políticas e econômicas, que precisam ser consideradas e enfrentadas. Ao que completa Jares (2002, p. 128): "uma dinâmica de paz implica o cumprimento dos direitos humanos". Portanto, sem um trabalho claro e firme no propósito de elevar os direitos humanos e a EDH, não há perspectiva de uma sociedade que consiga caminhar numa lógica de cultura de paz. Ao contrário, a falta de decisão a favor dos direitos humanos favorece sobremaneira uma cultura de violência no seio de sociedades. Isso nos leva a conceber a EDH como uma ação complexa, com característica coletiva, que vai desde as salas de aula, com práticas pedagógicas estruturadas, chegando às relações humanas e sociais cotidianas. A EDH é uma forma de ensinar, aprender e vivenciar, ao mesmo tempo, uma atitude cidadã e democrática diante da realidade social. Neste sentido Piovesan e Fachin (2017, p.27) discorrem com clareza sobre estas relações:

É importante salientar que a educação é tanto um direito humano, em si mesmo, como um meio indispensável para realizar 
outros Direitos Humanos. A educação em Direitos Humanos deve promover o desenvolvimento da personalidade humana e o senso de dignidade, permitindo às pessoas participarem efetivamente de uma sociedade livre, justa e democrática. A educação dos Direitos Humanos é condição essencial para o exercício desses direitos, da democracia e do desenvolvimento, vocacionada à liberdade e à expansão das potencialidades humanas.

Claramente, são necessárias estas duas dimensões fundamentais para a EDH. A primeira é a educação propriamente dita como um direito, ou seja, o Estado ofertar escolarização com qualidade e responsabilidade para a população. A segunda é uma educação que tenha como tema importante o conjunto da reflexão sobre os direitos humanos, que contemple as questões sobre desigualdade ao acesso aos direitos, à dignidade humana diante da falta de garantia dos direitos, aos modelos de sociedade violentos e excludentes, bem como entender quais as formas de proporcionar maior equilíbrio em relação à concretização dos direitos humanos. Estas questões são fundamentais para nosso estudo e, que, acreditamos, são diretamente relacionadas.

\section{Educação em Direitos Humanos: Diretrizes Nacionais na Educação Básica}

A Lei de Diretrizes e Bases da Educação Nacional (LDB no9394/96) explicita que a Educação Básica compreende a Educação Infantil, o Ensino Fundamental e o Ensino Médio com o objetivo de fazer com que o educando se desenvolva e tenha garantindo os meios para sua formação e para o exercício da cidadania.

Já as Diretrizes Nacionais da Educação em Direitos Humanos (DNEDH, 2013) discutem que a garantia do direito fundamental à educação básica pública, gratuita e laica para todas as pessoas é a primeira iniciativa para estruturar a $(\mathrm{EDH})$, pois efetivando o acesso à informação abre-se oportunidade para a busca, entendimento, e ampliação desses direitos. Ainda de acordo com as DNEDH, com a democratização da sociedade, a mesma passa a exigir informação e conhecimento para que o indivíduo possa se situar no mundo, argumentar, reivindicar 
e compreender o contexto em que vive. Daí a importância de relacionar a educação à EDH.

Ainda, segundo os princípios e concepção para a educação básica, a EDH vai além de uma aprendizagem cognitiva, ela inclui o desenvolvimento social e emocional no processo ensino-aprendizagem, pois uma escola pautada na gestão democrática cria espaços para o desenvolvimento de ações educativas onde os direitos humanos são vivenciados na prática. De acordo com as DNEDH (2013, p. 23) universalizar a Educação Básica “com indicadores precisos de qualidade e de equidade, é condição essencial para a disseminação do conhecimento socialmente produzido e acumulado, e para a democratização da sociedade". Por outro lado, as DNEDH destacam princípios educacionais que a norteiam, e que são definidos no Plano Nacional de Educação em Direitos Humanos (PNEDH, 2006), salientando a importância de se alicerçar Projetos Políticos-Pedagógicos nos princípios, valores e objetivos da EDH para as instituições de ensino. Tais projetos, de acordo com as DNEDH (2013, p. 47) devem levar em conta que:

A escola da educação básica é um espaço privilegiado de formação pelas contribuições que possibilitam o desenvolvimento do ser humano. Tendo em vista que a socialização e a apreensão de determinados conhecimentos acumulados ao longo da história da humanidade podem ser efetivadas na ambiência da educação básica por meio de suas diferentes modalidades e múltiplas dimensionalidades, tais como a educação de jovens e adultos, educação no campo, educação indígena, educação quilombola, educação étnico-racial, educação em sexualidade, educação ambiental, educação especial, dentre outras.

Ao tratarmos de EDH no Brasil faz-se necessário reconhecer que por meio de uma educação humanizadora e cidadã haverá o fortalecimento dos regimes políticos democráticos na sociedade, o que as tornará sujeitos de direitos. A educação escolar é instrumento fundamental neste processo, porém, temos que considerar a importância estratégica da educação não formal, que ocorre em milhares de instituições no país, com o objetivo de oferecer formação educacional estendida, em 
contra turno escolar, finais de semana etc. Da mesma forma, a ampliação da educação em tempo integral contribuir sobremaneira nas possibilidades da EDH. O Programa Mundial de Educação em Direitos Humanos (2005) orienta para que os sistemas de ensino da educação básica implantem políticas educacionais que incorporem conteúdos e práticas de direitos humanos. De acordo com as DNEDH (2013, p. 48) as metodologias de ensino, na educação básica, devem possibilitar:

Construir normas de disciplina e de organização da escola, com a participação direta dos estudantes. Discutir questões relacionadas a vida da comunidade, tais como problemas de saúde, de saneamento básico, educação, moradia, poluição de rios e defesa do meio ambiente, transporte, entre outros. Trazer para a sala de aula exemplos de discriminação e preconceitos comuns na sociedade, a partir da situação-problema e discutir formas de resolvê-las. Tratar as datas comemorativas que permeiam o calendário escolar de forma articulada com os Direitos Humanos de forma transversal, interdisciplinar e disciplinar.

Além disso, a EDH tem a possibilidade de ser articulada com políticas de inclusão e respeito às diversidades como ao combate a xenofobia, discriminação social, cultural, religiosa, sexismo, desenvolvendo campos e mecanismos de proteção. Como vemos, pretender a EDH na educação de crianças e adolescentes, nas escolas ou projetos socioeducativos, é fundamental na sociedade brasileira atual, onde a violência e a intolerância são significativas e impedem a convivência social democrática. Para tanto é necessário que o Projeto Político Pedagógico das escolas e os Projetos Socioeducativos contemplem estratégias como as propostas pelas DNEDH (2013, p.51):

1- Incentivar o trabalho colaborativo. 2- estimular a curiosidade e o espírito investigativo sobre determinado problema e contexto. 3- selecionar conteúdos que contribuam pra o aperfeiçoamento da capacidade de observar, apreender e estabelecer relações entre as transformações que ocorrem e o contexto que está inserido. 4- tornar transdisciplinar a abordagem de con- 
teúdos de modo que o aluno enriqueça a visão de conjunto das diversas inter-relações existentes sem descuidar da dimensão histórica. 5- dar ao ensino uma dimensão mais humana e social sem perder a sua especificidade. 6- construir uma metodologia capaz de oferecer condições para se implementarem práticas educativas que possam vivenciadas no cotidiano escolar dentro de uma perspectiva de construção do conhecimento e que estimulem a criatividade dos alunos.

Os espaços educativos são locais onde se estruturam as concepções de mundo e de consciência social, da circulação de valores humanos e promoção da diversidade cultural, além da formação para a cidadania e da constituição de sujeitos, tudo isso de maneira organizada e pedagógica. Nestes espaços se ampliam as visões e leituras de mundo, partindo da socialização e do respeito às diferenças, mesmo no universo dos conflitos como experiência de diálogo e encontros. Neste caminho, também é fundamental a atenção às pessoas e segmentos sociais historicamente excluídos e discriminados, pois, na construção de dignidade para estes grupos é que se constroem as perspectivas dos direitos humanos em uma sociedade moderna. Por fim, temos orientações interessantes para a EDH, propostas por Candau (2016, s.p):

Um processo sistemático e multidimensional orientado a formação do sujeito de direito e a promoção de uma cidadania ativa e participante. A articulação de diferentes atividades que desenvolvam conhecimentos, atitudes, sentimentos e práticas sociais que afirmem uma cultura de DDHH na escola e na sociedade. Processos em que se trabalhe, no nível pessoal e social, ético e político, cognitivo e celebrativo, o desenvolvimento da consciência da dignidade humana de cada pessoa.

Por acreditar na importância da EDH como modelo estruturado e pedagogicamente viável na educação brasileira, para contribuir em uma cultura de direitos e de paz social, realizamos uma pesquisa de campo na cidade de Ponta Grossa, Paraná, procurando relacionar as discussões teóricas com as práticas educacionais e sociais encontradas. 


\section{Metodologia}

Para o desenvolvimento deste estudo utilizou-se um método misto, com a abordagem quanti-qualitativa. Considerando o objetivo de caracterização das práticas sociais e educacionais que promovam direitos humanos e a EDH em Ponta Grossa - PR, a natureza qualitativa se preocupou do aprofundamento da compreensão de um determinado grupo, sujeito ou atores que estejam envolvidos nessas práticas; muito mais do que, somente, com a representatividade numérica, como dizem Córdova e Silveira (2019). Nesta pesquisa, o universo contemplado será a Secretaria Municipal da Educação, o Núcleo Regional de Educação - Ponta Grossa e Projetos sociais-educacionais.

A revisão bibliográfica foi recurso essencial para a compreensão do fenômeno a ser pesquisado por fornecer subsídio teórico que permite o delineamento do problema/objeto de pesquisa, o reconhecimento do contexto em que ele se insere, bem como dos elementos a ele adjacentes (atores, instituições, informações qualitativas e quantitativas que o caracterizam como universo de pesquisa). A apropriação teórica possibilitou coesão na pesquisa e avanço no estado da arte (conhecimento até então produzido sobre determinado tema), além de contribuir para o reconhecimento dos sujeitos da pesquisa e do melhor instrumento para a sua abordagem e auxiliar no processo de análise dos dados obtidos. Conforme Minayo (2009, p.18):

[...] uma teoria é uma espécie de grade, a partir da qual olhamos e "enquadramos" a interpretação da realidade. Ela é um conhecimento, mas não deve ser uma camisa de força. Ela é feita de um conjunto de proposiçoes. Quer dizer, ela é um discurso sistemático que orienta o olhar sobre o problema em pauta, a obtenção de dados e a análise dos mesmos.

Assim, tratou-se, a pesquisa bibliográfica, de um norte que conduzirá a pesquisa no alcance dos objetivos propostos. Neste estudo tal recurso metodológico serviu de um aporte para o desenvolvimento das ações coletivamente planejadas que tangem ao reconhecimento de práticas sociais que promovam os direitos humanos e a EDH, per- 
passando por discussões inerentes à cidadania e às Políticas Públicas. Coletado as informações através de formulário, os mesmos foram sistematizados e analisados conforme o referencial teórico estabelecido no projeto de pesquisa.

\section{Coleta e análise de dados}

Conforme mencionamos, nosso objeto de pesquisa foram as práticas sociais desenvolvidas no contexto dos direitos humanos e EDH no município de Ponta Grossa, Paraná. Nosso objetivo principal foi caracterizar tais práticas e verificar quais estabelecem interface com questões educacionais de fato. A pesquisa foi realizada na Rede Municipal (Ensino Fundamental I e II), Rede Estadual e nas instituições que ofertam educação não formal.

Para atingirmos os objetivos propostos, na coleta dos dados empíricos utilizamos um formulário impresso. $\mathrm{O}$ formulário continha as seguintes questões/dados: caracterização da Instituição, identificação do projeto, objetivos, estrutura física, composição da equipe, ações, serviços, projetos, programas, demandas, usuários, articulação entre as políticas. Após coleta dos dados empíricos, inicialmente reunimos todas as informações em um quadro contendo os seguintes itens para facilitar a visualização e organização dos dados relevantes para a pesquisa: Instituição, projeto, objetivos, público alvo, políticas contempladas, metodologia.

Dessa forma, na rede Municipal, identificamos 19 projetos que de certa forma trabalham com questões que se aproximam dos direitos humanos. Porém, percebe-se não possuem propostas estruturadas e com objetivos claros e definidos, mas, em suas práticas identificamos políticas públicas relacionadas aos direitos humanos. A maioria dos projetos é voltada para questões relativas ao meio ambiente, entendidos como uma extensão dos direitos fundamentais, isto é, direito a vida e o direito de viver em um planeta sustentável. Projetos como "Hortas escolares", "Semana do Meio Ambiente", "Coleta seletiva", "Reciclagem do óleo" entre outros, compõe este cenário. Desta forma, a inserção dos direitos humanos nas escolas municipais efetiva-se por 
meio de projetos de socialização cultural com a finalidade de promover uma educação voltada para a uma possível transformação social. Isso se aproxima, em parte, ao pensamento de Silva e Tavares (2013, p.53-54) quando escrevem que:

Educar em Direitos Humanos potencializa nas pessoas o respeito ao ser humano e à sua dignidade, os valores democráticos, a tolerância e a convivência dentro das regras do estado de direito, sendo capaz de contribuir para que as pessoas assumam o papel de protagonistas de sua história, conscientes de suas responsabilidades sociais, políticas, culturais e artífices das transformações necessárias a cada realidade.

Não podemos, com estes dados, afirmar que estes projetos realmente abrangem o contexto esperado da EDH, mas atuam na dimensão da sustentabilidade, tema fundamental de discussão na atualidade. Entre estes projetos, destacamos o Programa Agrinho, promovido pelo sistema Federação da Agricultura do Estado do Paraná (FAEP) que envolve a participação de mais de 1,5 milhão de crianças anualmente e aproximadamente 80 mil professores da educação infantil, do ensino fundamental e da educação especial, em todo Estado. O Programa leva às escolas da rede pública de ensino uma proposta pedagógica baseada em visão complexa e na inter e transdisciplinaridade, pensando em vida saudável e sustentável. Não obstante ser uma proposta que se desenvolve há mais de duas décadas no Estado do Paraná, acredita-se que ainda não contempla a complexidade e a perspectiva teórica discutida sobre a EDH. Ainda em relação à rede municipal de educação, que atua na Educação Infantil e anos iniciais do Ensino Fundamental não foram identificadas demais propostas específicas que promovam a discussão da EDH de forma contínua, estruturada e sintonizada com as diretrizes da EDH no Brasil. Isso não quer dizer que elas não existam, uma vez que é uma rede de ensino com dezenas de milhares de alunos e mais de uma centena de estabelecimentos.

Possivelmente as discussões sobre os direitos humanos se deem nas questões cotidianas dos conteúdos e projetos isolados, ainda não identificados nessa fase geral da pesquisa. Em relação à rede estadual 
de educação destacamos a existência de um projeto, que objetiva a formação de grupos representantes dos diferentes sujeitos que compõem a comunidade escolar como agentes de proteção principalmente das crianças e dos adolescentes. Este projeto teve sua origem devido ao apelo da própria comunidade e da sensibilidade dos técnicos do setor de ensino do próprio Núcleo Regional de Educação (NRE-PG) que perceberam a necessidade da abertura de um espaço para o diálogo e a reflexão entre estes sujeitos, para que, juntos tornassem possível minimizar os desdobramentos causados por questões envolvendo atitudes de violência, do consumo do álcool e outras drogas e a consequente identificação e encaminhamento daqueles que apresentarem alguma demanda de transtornos mentais.

O projeto em discussão é denominado Rede de Proteção: uma proposta de capacitação Inter setorial para Servidores Públicos do Sistema de Garantia dos Direitos de Crianças e Adolescentes na região de Ponta Grossa, iniciou no ano de 2018 e já desenvolveu alguns encontros de formação. Ainda, no contexto da rede estadual, que atende alunos do segundo segmento do Ensino Fundamental e do Ensino Médio, existe e menção verbal sobre projetos desenvolvidos nos estabelecimentos de ensino, alguns com características de educação em direitos, educação em valores, cultura de paz, educação ambiental e justiça restaurativa. Porém não há registro oficial destes projetos junto ao NRE- PG, sendo, provavelmente, propostas isoladas das escolas. Ressaltamos que nossa pesquisa, nessa primeira etapa, procurou os órgãos responsáveis pela gerência das instituições escolares de Ponta Grossa, no sentido de saber o que há de sistematização na área da EDH.

A partir da pesquisa nas instituições formais de ensino, tanto da rede municipal quanto estadual, podemos afirmar que: não obstante possam ocorrer práticas pedagógicas isoladas, não há registro, sistematização ou clareza de que o campo EDH é previsto como a ser explorado didaticamente no processo educacional. Acreditamos que, com a aprovação da Lei n. 13.663 de 14/05/18 que insere a cultura de paz e a prevenção de violências nas escolas, este movimento possa ser mais reconhecido. Além disso, temos uma nova demanda para aprofundamento da pesquisa em uma segunda fase, que é inventariar as práticas 
relativas à EDH de forma mais pontual nas escolas. Relembramos que para estar em sintonia com a as DNEDH, sobre o que é EDH, o artigo $3^{\circ}$ das diretrizes (2013, p. 44-45) estabelece os princípios fundamentais da EDH:

A Educação em Direitos Humanos, com a finalidade de promover a educação para a mudança e a transformação social, fundamenta-se nos seguintes princípios: I - dignidade humana; II - igualdade de direitos; III - reconhecimento e valorização das diferenças e das diversidades; IV - laicidade do Estado; V - democracia na educação; VI - transversalidade, vivência e globalidade; e VII - sustentabilidade socioambiental.

Em relação às instituições que ofertam educação não formal pesquisadas (seis instituições), algumas atuam no campo da educação para pessoas com necessidade especiais e outras como contra turno para crianças e jovens em fase de escolarização. Todas elas ofertam o Serviço de Convivência e Fortalecimentos de Vínculos (SCFV) e possuem objetivos semelhantes que foram elaborados conforme as especificidades dos usuários e com o novo reordenamento do Sistema Único de Assistência Social (SUAS). Dessa forma, visam trabalhar com autoestima, identificar potencialidades dos usuários além de promover fortalecimento de vínculos do usuário com sua família e a instituição, bem como promover o acesso aos benefícios, programas e serviços das políticas sociais. Muitas de utilizam de práticas esportivas como forma de cidadania e outras atividades artesanais e música como estratégias de desenvolvimento da autoestima e de potencialidades.

Nas instituições, verificou-se que os profissionais da área da assistência social entrevistados, não tem clareza acerca do que são direitos humanos, para além dos benefícios do estado e, não reconhecem como uma EDH ocuparia espaço no dia a dia das instituições. Nesse sentido, concordamos com RADDAZ (2012, p. 312) que: a "informação é o princípio da cidadania e condição para o cumprimento dos direitos humanos". Assim, detectamos que, nas instituições de educação não 
formal, a EDH não acontece da forma como proposta das diretrizes da área, por falta de informação e discussão sobre a necessidade da mesma. Portanto, não há uma história de EDH, nos moldes propostos na última década de discussão dos direitos humanos no Brasil, sobre como a educação, formal ou não formal possa integrar o conjunto de conhecimentos expresso nas diretrizes destinadas a esta área. Com Silva (2014, 268) nos permitimos dizer e questionar:

A dignidade da vida humana é expressão reconhecida por todos os indivíduos como princípio, meio e fim de todos os esforços que se fazem para melhor organizar a sociedade. Ao compreender este preceito, estamos no início de uma reflexão da justiça, da paz, liberdade, deveres e direitos para todos.

Ao que questionamos: será que há o reconhecimento das pessoas sobre esta dignidade da vida humana? Mais ainda, será que os profissionais que atuam em processos que podem contemplar a EDH têm discutido estas questões em sua formação docente inicial e continuada? Quais os espaços que podem influenciar positivamente estes caminhos? Como pode se dar a informação, conhecimento e as práticas pedagógicas no campo da EDH, visando potencializá-las. As questões silenciadas na pesquisa de campo são as que mais nos impulsionam a continuar pesquisando a EDH e seus desdobramentos na educação e crianças e adolescentes.

\section{Considerações Finais}

Ao analisar os resultados da pesquisa de campo junto à reflexão teórica podemos elencar algumas questões importantes. A primeira é reconhecer que no Brasil dos últimos anos a discussão sobre os direitos humanos e a EDH se deram de forma intensa, porém, ainda muito ligada à academia e aos movimentos sociais. A sociedade de maneira geral, não esteve presente neste processo, ficando sempre dependente de informações da grande mídia, o que gerou bordões como: "direitos humanos para humanos direitos", supondo uma polarização entre 
pessoas que teriam o direito a ter direitos e outras que não; "direitos humanos é coisa para bandidos”, numa alusão aos movimentos que procuram humanizar as condições sub-humanas dos encarcerados brasileiros, dando a entender que estas pessoas não mereceriam ter direitos. Além disso, mesmo entre os profissionais que podem atuar com a EDH isso não aparece de forma sistematizada, podendo supor que tais processos ainda não estão pautados com densidade na formação inicial e continuada de docentes.

É possível reafirmar que a inclusão da cultura de paz e prevenção das violências nas escolas, na LDB 9394/96 seja um dos aspectos importantes na articulação com as DNEDH (2013) e gerar um ciclo positivo na reflexão, análise de experiências e sistematização de conhecimento no campo da EDH para os próximos anos.

Reconhecendo que a educação é um espaço intercultural por natureza, acreditamos e concordamos com Lucas (2013, p. 262):

O diálogo intercultural visa a identificar, nas diferentes culturas, os traços de humanidade que dizem respeito à existência digna do homem, independente de nação, religião ou outro vínculo. Assim, por exemplo, são considerados valores universais a dignidade humana, a identidade, a liberdade de ser e de estar, a inviolabilidade do corpo, o bem-estar humano, entre outros.

A EDH é o campo para se problematizar, analisar e pensar em alternativas para diminuir os problemas das comunidades, sociedades e do planeta. Mas para isso, precisa reconhecer as diferenças, as semelhanças entre indivíduos, grupos e culturas, para aprender a tolerância, o respeito, a paz, a responsabilidade e a não violência. Isso tudo precisa ser realizado a partir de uma transposição didática dos documentos oficiais e chegar às práticas educativas com consistência e objetivos. De outro modo, ficaremos com belas palavras de mundo ideal de um lado, com palavras de ordem por outro lado sem, porém, acessar as verdadeiras demandas e mazelas das pessoas e grupos que ainda vivem à margem da sociedade, mesmo ao final da segunda década do século XXI. 


\section{REFERÊNCIAS}

BRASIL. Secretaria de Direitos Humanos da Presidência da República. Caderno de Educação em Direitos Humanos. Educação em Direitos Humanos: Diretrizes Nacionais - Brasília: Coordenação Geral de Educação em SDH/PR, Direitos Humanos, Secretaria Nacional de Promoção e Defesa dos Direitos Humanos, 2013.

CANDAU, Vera Maria. Educação em Direitos Humanos e diferenças culturais: questões e buscas. Revista Múltiplas Leituras, v.2, n. 1, p. 65-82, jan. / jun. 2009.

JARES, Xesus R. Educação para a paz: sua teoria e sua prática. Tradução de Fátima Murad. Porto Alegre: Artmed, 2002. 271p.

LUCAS, Doglas César. Direitos humanos e interculturalidade: um diálogo entre a igualdade e a diferença. Ijuí: Ed. Unijuí, 2013.

MINAYO, Maria Cecília de Souza (Org). Pesquisa Social: teoria, método e criatividade. 28 ed. Petrópolis, RJ: Vozes, 2009.

PIOVESAN; Flávia; FACHIN, Melina Girardi. Educação em Direitos Humanos no Brasil: desafios e perspectivas. Revista Jurídica da Presidência Brasília v. 19 n. 117 fev./maio 2017 p. 20-38 Disponível em: https://revistajuridica.presidencia.gov.br/ index.php/saj/article/view/1528. Acesso em novembro de 2018.

RADDATZ, Vera Lucia Spacil. Direito à informação: um requisito para a cidadania na sociedade contemporânea. In: BEDIN, Gilmar Antonio. Cidadania, direitos humanos e equidade. Ijuí: Editora Unijuí, 2012. 472p.

SILVA, Ainda Maria Monteiro; TAVARES, Celma. Educação em Direitos Humanos no Brasil: Contexto, processo de desenvolvimento, conquistas e limites. Revistas eletrônicas PUCRS Educação, Porto Alegre, v. 36, n. 1, p. 50-58, jan./abr. 2013. 
SILVA, Enio Waldir da. Estado, sociedade civil e cidadania no Brasil: bases para uma cultura de direitos humanos. Ijuí: Ed. Unijuí, 2014. 304p.

SILVEIRA, Denise Tolfo.; CÓRDOVA, Fernanda Peixoto. A Pesquisa Científica. In: GERHARDT, Tatiana Engel.; SILVEIRA, Denise Tolfo. (Orgs). Métodos de Pesquisa. Porto Alegre, RS: Editora da UFRGS, 2009.

TUVILLA RAYO, Jose. Educação em direitos humanos: rumo a uma perspectiva global. Tradução de Jussara Haubert Rodrigues. Porto Alegre: Artmed, 2004. 247p. 


\section{TRABALHANDO MÚSICA NA ESCOLA - UMA REFLEXÃO SOBRE DESIGUALDE}

Nilton Alex Fernandes Ribeiro

INTRODUÇÃO

"Se a música é o alimento do amor, toque."

(William Shakespeare)

As mudanças da sociedade contemporânea afetaram diversos setores da sociedade, inclusive o educacional. Têm sido requeridas mudanças no processo de ensino-aprendizagem em função das novas tecnologias, pois, a partir delas e com mediação do professor, os alunos podem construir conhecimentos de forma ágil e autônoma.

Assim, ao refletir sobre o processo de ensino-aprendizagem e, ao analisar as mudanças requeridas à educação, percebe-se que o educador se encontra diante do desafio de considerar as novas possibilidades de construção do conhecimento por intermédio das novas tecnologias.

Ao se recomendar aos professores a utilização de uma mensagem mais moderna, não se está absolutamente propondo que transformem suas aulas em espetáculos, mas que reconheçam a concorrência que as escolas sofrem dos meios de comunicação de massa, no intento de conseguir a atenção do público. Nesse sentido, os recursos tecnológicos tornam-se bastante úteis. Quando bem elaborados e apresentados oportunamente, são 
capazes de despertar a atenção dos estudantes de forma bem superior à exposição oral e, consequentemente, de facilitar aquisição de novos conhecimentos e de contribuir para a formação de atitudes (GIL, 2007, p. 221).

Partindo desta perspectiva, compreende-se que, frente às mudanças de paradigma que afetam a educação, os recursos tecnológicos podem ser importantes aliados pedagógicos. Nesse sentido, as aulas devem ser dinâmicas, visto que, atualmente, os alunos têm à disposição dispositivos que sofisticam a aprendizagem, desafiando o educador a também utilizar aparatos que despertem a curiosidade e tornem as aulas mais atrativas. É neste contexto que, a música pode representar um suporte para a construção de aulas mais interativas e dinâmicas (MOREIRA, 2018), sendo os dispositivos tecnológicos uma importante ferramenta de sociabilidade e difusão de identidades culturais por meio da música, fato este que pode contribuir diretamente com o trabalho de questões como aceitação da diversidade cultural e discussão de questões sociais de grande relevância.

Os aparatos tecnológicos podem trazer grandes contribuições para se trabalhar músicas na escola. Podemos usar projetores, aparelhos sonoros, plataformas digitais para fazer associações com a realidade atual dentro da sala de aula. Levando em consideração que a maioria dos aparelhos celulares desfrutam de aplicativos de reprodução de mídia/ áudio, pode-se solicitar que os próprios alunos realizem uma pesquisa de trabalhos musicais que versem sobre assuntos trabalhados em sala de aula. Quando analisamos o livro "Valores de Música", lançado pelo SESI, com intuito de ajudar professores do ensino de música em sua prática pedagógica, podemos perceber o quanto a linguagem musical pode ajudar os alunos em sala de aula, principalmente no desenvolvimento de sua sensibilidade para poder discutir questões voltadas às relações sociais do indivíduo. Assim sendo,

a música, quando aprendida e utilizada como linguagem, oferece acesso a uma educação para a vida que inclui o desenvolvimento da sensibilidade, propiciando a integração do sentimento com o pensamento. E, na verdade, a música como linguagem 
não depende apenas de talento ou dom especial, mas está ao alcance de todos (SESI, 2009, p. 20)

Em concordância com o trecho acima transcrito, entendemos que a música tem um papel fundamental no estímulo à alteridade dos sujeitos e, neste artigo, partimos do pressuposto de que as tecnologias potencializam este processo à medida que difundem modos diversos de expressão cultural. Aliado a isso, vale lembrar que as tecnologias, de fato, aportam na escola, fato visível na forma como os alunos facilmente acessam dispositivos e se isolam do mundo ao redor através do uso de fones de ouvido. Esses dispositivos carregam uma infinidade de apelos sensórios: vídeos, diálogos e, sobretudo, músicas (vide, por exemplo, a importância das lives neste tempo de pandemia), que, por vezes, também sugestionam modos de pensar a prática social.

É preciso observar que todos estes apelos culturais expostos em plataformas de streaming carregam posicionamentos de raça, sexo, etnia e classe social, que precisam ser pautados como objetos de problematização e contextualização na educação formal. Textos musicais do Funk, do Forró, do Sertanejo ou do Axé, por exemplo, contêm posicionamentos de gênero e sexo, que não podem ser negligenciados pelos muitos campos do saber na educação. Desse modo, a música pode ser pensada como meio de sensibilização dos alunos, entendida como um suporte pedagógico interdisciplinar para diversos conteúdos, que, também, fornece importantes problematizações sobre a realidade que contorna a vida social dos educandos.

A música é um dos grandes e ricos elementos presentes em toda sociedade, ela pode contar história, além de conter uma linguagem específica que auxilia no processo de ensino-aprendizagem. Ela tem a capacidade de servir como instrumento que estimula modos plurais de interpretar o mundo por meio da sonoridade, estimulando a criticidade, a sensibilização e a problematização. A música é expressão cultural característica a praticamente todas as culturas (SESI, 2009) e tal fato permite entender que sua inserção na escola também tem a importante função de valorizar as identidades culturais de povos, evitando assim a perda de expressões musicais tão importantes para a memória coletiva e para o senso identitário. Disso, conclui-se que a música 
é um processo dinâmico; transformações (positivas) ocorrem, mesmo quando intencionalmente se visa congelar o tradicional para impedir a sua “deterioração." É possível preservar os objetos, os gestos, as palavras, os movimentos, as características plásticas exteriores, mas não se consegue evitar a mudança de significado que ocorre no momento em que se altera o contexto em que os eventos culturais são produzidos (ARANTES, 1985, p. 32).

Esse debate também oportuniza perceber o quanto o trabalho pedagógico com a música contribui para a consciência criativa dos educandos, despertando habilidades importantes para o processo pedagógico, já que, por meio da música, "adultos e crianças descobrem universo que contribui para o desenvolvimento do raciocínio lógico, da coordenação motora, do sensor rítmico, da percepção auditiva e da sensibilidade estética" (SESI, 2009, p.17).

Por essa razão, defende-se que o trabalho interdisciplinar oferecido pela música pode ser exercitado por vários campos dos saberes; inclusive, por disciplinas, como as da área de exatas, que não costumam associá-la como possibilidade metodológica. A criação de músicas para a memorização de fórmulas, o trabalho com a amplitude e frequência sonora e a marcação do tempo musical são boas sugestões para o ensino de matemática no Ensino Médio, rompendo com o preconceito que a delega às aulas das áreas de Linguagens ou Humanas. A música é também uma maneira de democratizar o conhecimento, visto que

qualquer pessoa pode fazer música e se expressar através dela, desde que sejam oferecidas condições necessárias para sua prática. Quando afirmamos que qualquer pessoa pode desenvolver-se musicalmente, consideramos a necessidade de tornar acessível, às crianças e aos jovens, a atividade musical de forma ampla e democrática. (LOUREIRO, 2004, p. 66)

Quando usamos música no contexto escolar, legitimamos a garantia de que todas as pessoas tenham direito a acessar múltiplas formas de produzir, pensar, debater, apreciar e difundir culturas; é ga- 
rantir o acesso a culturas diferentes e, com isso, estimular a aceitação da diversidade. Além do que a música tem a capacidade de trazer vários signos e significados, nessa vasta aplicabilidade de valores e conhecimentos distintos.

A música, quando utilizada como linguagem, oferece acesso a uma educação para a vida que inclui o desenvolvimento da sensibilidade, propiciando a integração do sentimento com pensamento. E, na verdade, a música como linguagem não depende apenas do talento ou não especial, mas está ao alcance de todos. De fato, quando assumidas como linguagem que incorpora os fundamentos que tornam arte, a música nos permite integrar competências linguísticas, corporais, a espaciais, de raciocínio lógico, percepção de si próprio e percepção do outro, além das músicas propriamente ditas (SESI, 2009, p. 18).

Partindo do pressuposto acima de que a música pode integrar competências linguísticas, artísticas, corporais e até mesmo a lógica, pode-se perceber que existe uma intercomunicação nas diversas áreas do conhecimento, que possibilita o professor a trabalharem conjuntamente suas disciplinas, dialogando com outras áreas do conhecimento.

Além disso, havendo reconhecido a importância da música para a prática pedagógica, somado ao uso das tecnologias como importante auxílio às atividades docentes, chamamos atenção para uma necessidade real e latente de a escola voltar o seu olhar para os sujeitos, outrora excluídos, que lhe adentram os portões e lhe ocupam os espaços. É preciso que conceitos como diversidade e diferença, conceitos muito caros à Educação, adentrem a sala de aula e façam as vozes ressoarem, de modo que esses sujeitos possam reivindicar, não apenas para si, o reconhecimento e a afirmação da diferença como marca identitária, como indicador de pertencimento a determinado coletivo de indivíduos (WERNECK, 2013).

Contudo, vale destacar que, embora os termos diversidade e diferença sejam, por vezes, empregados de maneira indiferenciada ou sinonímica, eles não são iguais, nem mesmo próximos (ABRAMOWICZ et al., 2011). Enquanto a diversidade é vista como uma ca- 
tegoria política não desvinculada das lutas históricas e dos movimentos sociais que debatem sobre gênero, discriminação racial, criança com deficiência, entre outros temas geradores de tensão na sociedade; a diferença, na maioria das vezes, aparece na relação de oposições sejam físicas ou qualquer outro aspecto relacionado aos seres humanos, influenciado por determinantes históricos, sociais, econômicos e desenvolvido em meio aos interesses e relações de poder (MENEZES; MACHADO, 2015).

Por essa razão, para fins de elaboração desse trabalho, consideraremos diversidade como uma construção histórica, social, cultural e política das diferenças que se realiza em meio às relações de poder e ao crescimento das desigualdades e da crise econômica que se acentuam no contexto nacional e internacional (GOMES, 2012). E, diante disso, motivado pelo desejo de compreender os potenciais contidos no binômio música/questões sociais com vistas a minimização de conflitos relacionados às diferenças sociais, o presente relato tem como objetivos: Refletir como a música pode contribuir para a discussão sobre as desigualdades sociais; apontar as possibilidades pedagógicas da música no trabalho educativo, usando também a arte enquanto um componente curricular que ajudará neste processo.

Amparado pelas competências apresentadas pela Base Nacional Curricular Comum (BNCC), o componente Arte assume, também, o compromisso de assegurar aos alunos o desenvolvimento de competências relacionadas à alfabetização e ao letramento; visto que, ao possibilitar o acesso à leitura, à criação e à produção nas diversas linguagens artísticas, contribui para o desenvolvimento de habilidades relacionadas tanto à linguagem verbal quanto às linguagens não-verbais.

Ao pensar nos caminhos que a música pode percorrer na escola, nós voltamos ao ensino da Arte, usando uma abordagem triangular que, segundo Ana Mae Barbosa, está baseada em "ler", "fazer" e "contextualizar". Nesse sentido, a contextualização abrange os aspectos contextuais que envolvem a produção artística como manifestação simbólica histórica e cultural; a leitura organiza-se em entrelace com aspectos simbólicos da produção artística e como o sujeito que interage com o artefato atribui a ele determinados significados, enquanto a produção 
mobiliza conhecimentos tanto conceituais quanto procedimentais, inventando tecnologias, adaptando materiais, articulando ideias. Logo, pensar música dentro da proposta deste artigo é entender que:

a música possibilita uma variedade de modos de percepção e sensações do aluno na sua relação com o mundo, através dos recursos expressivos de que dispõe seu organismo para comunicação e o conhecimento do mundo em que se vive, através das vivências, das dimensões estéticas, sonoras, visuais, plásticas e gestuais, pode-se desenvolver a consciência crítica dos valores humanos e encontrar meios de levar os alunos a atuarem como cidadãos (VISCONTI, 2002, p 11).

Comportando a possibilidade de um diálogo social mediante seu conteúdo e forma, a música pode ser a forma encontrada para que vozes, sociais e históricas, possam se expressar e se posicionar frente aos diferentes discursos correntes socialmente. Dessa forma, ela mesma, em forma de letra e canção, não apenas é capaz de expressar, explicar, denunciar e declarar fatos ocorridos na sociedade, mas também suscitar reflexões e mudanças de pensamentos e atitudes e despertar diferentes emoções em seus apreciadores.

\section{A EXPERIÊNCIA E SEUS MÉTODOS}

Esse relato de experiência se refere a uma atividade realizada na cidade de Cícero Dantas (antiga Vila de Bom Conselho), localizada na região semiárida, próximo a Canudos e Paulo Afonso (Bahia). Com uma população de 32.000 mil habitantes, esse município baiano é membro da Microrregião de Ribeira do Pombal (Nordeste do estado brasileiro da Bahia), limitando-se a leste pelo município de Fátima, a sul com Heliópolis, Ribeira do Pombal e Banzaê, a Oeste com Euclides da Cunha e a Norte com Novo Triunfo e Antas.

Foi o exercício da docência nesta região somado às provocações suscitadas no curso de pós-graduação em "Educação Aberta e Suas Tecnologias" (UFRB), que despertaram o desejo de usar músicas por meio de vídeo clipes na sala de aula. 
A instituição escolar onde esta experiência foi realizada tem em seu Projeto Político Pedagógico a missão de promover um ensino de qualidade, atrelado à participação da comunidade escolar em ações pedagógicas libertadoras pautadas na construção de conhecimentos que visam a formação integral dos alunos, mediante o ensino e aplicação de valores sociais, como ética, inovação, respeito e participação.

As músicas foram associadas ao conteúdo da disciplina "Sociedade e Cultura", ministrada nas turmas de $6^{\circ}, 7^{\circ}, 8^{\circ}$ e $9^{\circ}$ anos do ensino fundamental II. Dentre os conteúdos abordados em sala, pode-se citar: ética e a moral, preconceito, racismo, questões sociais de cuidado com o planeta, violência, saneamento básico, urbanismo, política, teorias de filósofos como Platão, Aristóteles, Marx, Pitágoras, dentre outros pertinentes a questões sociais e filosóficas.

Dentre as músicas de vários artistas trabalhados, podemos citar: Edson Gomes, Banda Raio da Silibrina, Gabriel Pensador, Elza Soares, Helen Oléria, Maycon Mundoca, Clara Nunes, Bia Ferreira, Projota, dentre outros artistas, cujas músicas falam sobre a luta social, questões raciais e econômicas.

Das várias letras trabalhadas em sala de aula, as músicas compostas por Macedo Brilho e interpretadas pela Banda Raio da Silibrina, se destacaram não apenas pelas temáticas abordadas, mas também por serem da primeira banda de forró a tratar de questões sociais em suas músicas. Até mesmo a arte dos seus álbuns remete a ideias decoloniais, algo bastante inovador para os anos 1990. Ao longo desses quase 30 anos de carreira, a banda tem viajado o Brasil e o mundo, em turnês internacionais, cantando e retratando a realidade do nosso país, pedindo solução para os problemas sociais.

A banda Raio da Silibrina é oriunda de Aracaju, capital sergipana, e foi formada em 1991 pelo empresário Macedo Brilho que criou um estilo próprio de arranjos, interpretações modernas dos cantores, com a finalidade de apresentar uma boa música e retratar as questões sociais. Todos esses elementos contribuíram para que a Raio da Silibrina se sagrasse como a única banda de forró a fazer parte de uma gravadora internacional. Além de percorrer mais de 130 países, a banda também 
realizou apresentações em emissoras importantes no cenário nacional, como Globo, Record e SBT.

Em seu terceiro álbum, intitulado: "Cadê a ordem?!", a Banda Raio da Silibrina rompeu com todos os protocolos do meio forrozeiro para denunciar as necessidades sociais do povo brasileiro. A letra da música tema do álbum, por exemplo, levada à sala de aula para audição, leitura e debate, suscitou reflexões a respeito da educação como um importante vetor para o progresso do país.

Cadê a ordem e o progresso da nossa bandeira? Chega de brincadeira, vamos tirar os pés do chão a solução é educação, educação viu, pra construir essa nação, educação viu, pra construir essa nação. Sair para trabalhar, coisas pra conquistar ganhar a vida ter a alegria de viver e a tristeza de poder ver esse país que não vai, mais injustiça se nós é que trabalhamos, se nós é que sustentamos, esse país pra não cair, tanta miséria, o povo está penando a pobreza está aumentando, tem mais crianças com os pés no chão. Cadê a ordem e o progresso da nossa bandeira? chega de brincadeira vamos tirar os pés do chão, a solução é educação, educação viu, pra construir essa nação, educação viu pra construir essa nação (RAIO DA SILIBRINA, 1993).

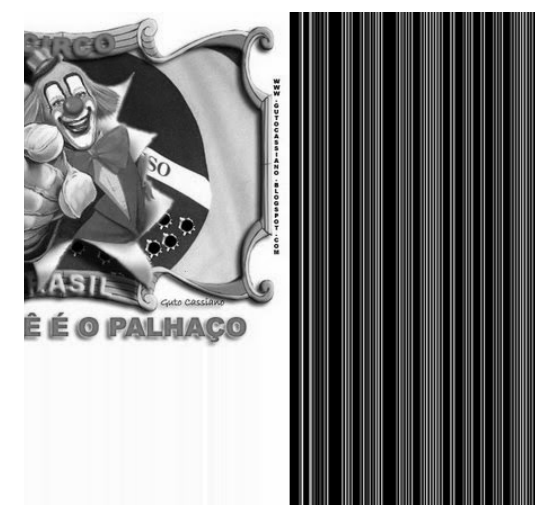

(Foto: Arquivo Pessoal)

Ao levar a música para a sala de aula, esperava-se que os alunos interpretassem a letra e refletissem não apenas sobre o contexto social, 
econômico e histórico que a composição denunciava na época, mas também sobre o aspecto atemporal da denúncia; já que a realidade retratada na música, quase três décadas depois, não mudou.

Dando seguimento à discussão iniciada, na aula anterior, pela música "Cadê a ordem", dessa vez voltando o olhar para as questões políticas que impedem "a ordem e o progresso da nossa bandeira", escolheu-se o forró “Esse País é um Circo”, cuja letra, usando o circo como metáfora, aponta temáticas como: impunidade, corrupção e exploração infantil. Segundo a letra,

Nosso País é um circo não duvide, A impunidade prevalece mais a corrupção O mágico apaga os nossos sonhos $\mathrm{E}$ o palhaço tem na mão a graça da nação Atenção que esse circo é diferente Não há graça onde nós somos os animais O Domador tem na mente a força de explorar E o pobre que só é gente na hora de votar O espetáculo agora é que vai começar Mas não é para aplaudir, a exploração infantil Vocês vão ver as crianças trabalhando cedo com as roupas rasgadas, mendigando pão, pedindo esmola, sem pais, sem morada, vivendo nas ruas e na prostituição $\mathrm{O}$ Que fazer? Com as nossas crianças O Que fazer? É da educação O Que fazer? Com esse mundo animal da exploração O Que fazer? Com as nossas crianças O Que fazer? É da educação O Que fazer? Com esse mundo animal da exploração. Não tem graça não! (RAIO DA SILIBRINA, 2005).

A letra discute toda a atuação política da época, além de sugerir a solução para alguns problemas sociais. Novamente, uma realidade que contextualiza bem o que estamos vivendo hoje, a exemplo da desigualdade social, dos escândalos com desvios de verbas e corrupção e dos problemas com a educação. Por que retratá-los em sala de aula? Porque o ambiente escolar precisa aguçar a análise crítica dos alunos em relação aos aspectos de nossa sociedade e arte é um poderoso instrumento para isso. Para poder retratar melhor e ressignificar a letra dessa música, algumas charges foram utilizadas em sala de aula como mobilizador do debate. Foram elas: 


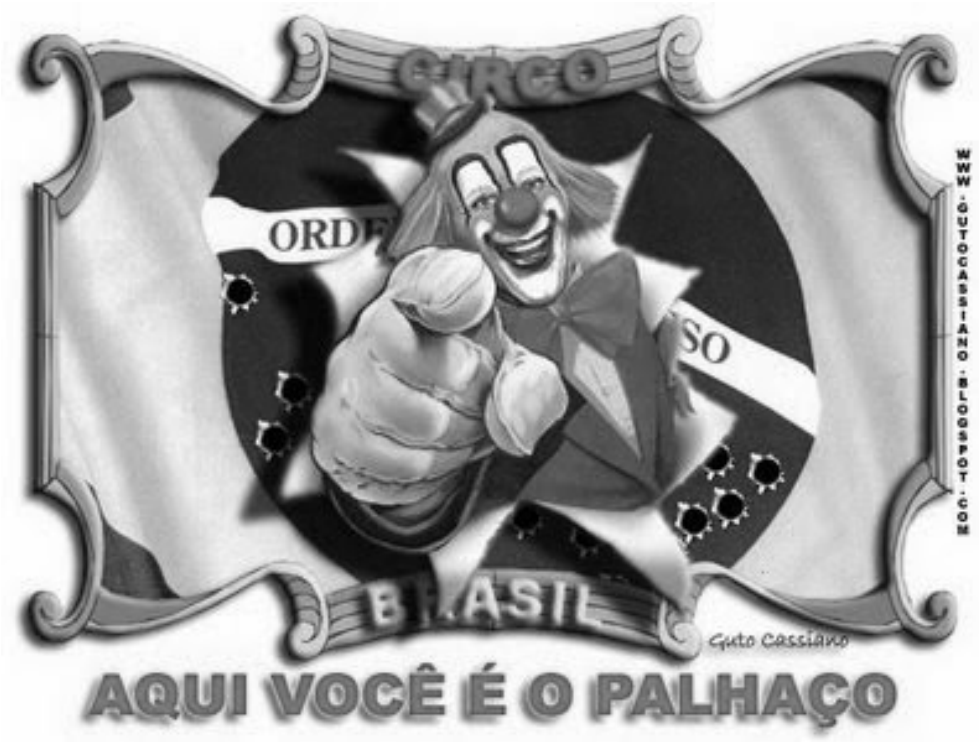

Fonte: http://rpscom.blogspot.com/2010/05/valeriano-diz-que-camara-de-itaporanga.html

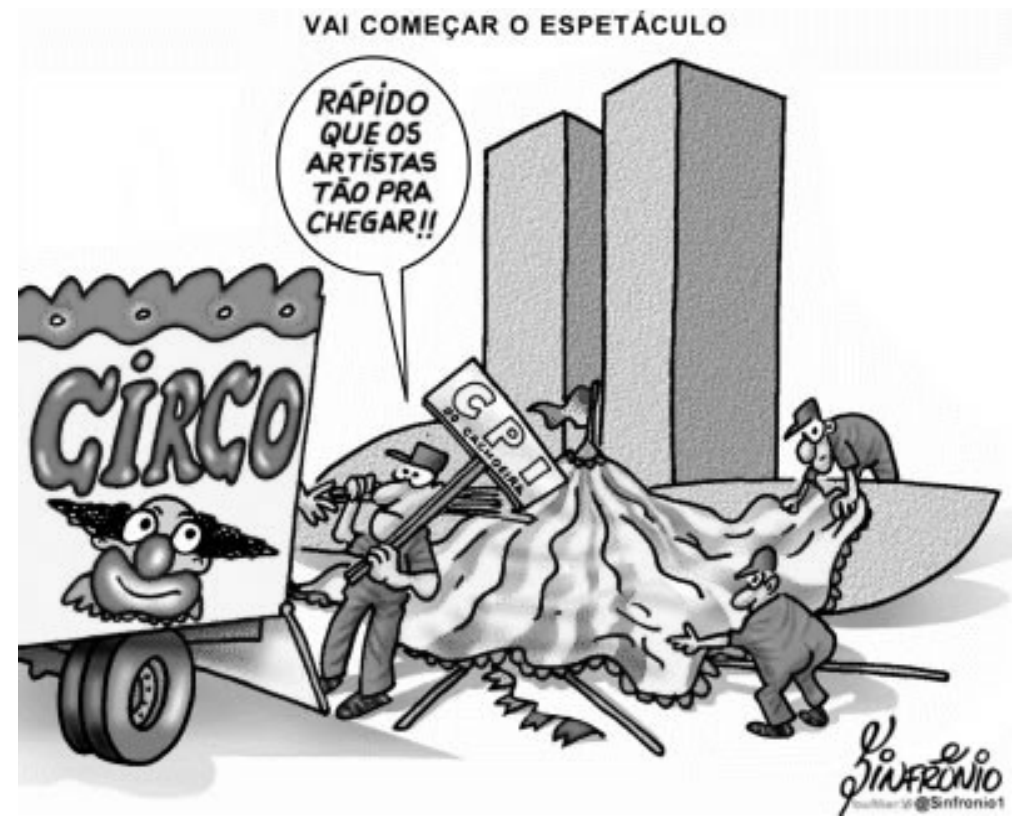

Fonte: http://chargesdejornais.blogspot.com/ 
Dessa maneira, o trabalho com elementos multimodais (música, letra, charges e videoclipe) favoreceu a criação de um ambiente de reflexão sobre a situação política, social e econômica do nosso país, ao mesmo tempo, que possibilitou debater possíveis alternativas de mudanças na sociedade. A partir da apresentação do videoclipe, a fim de relacionar os textos musicados e as charges com o rol de conteúdos propostos na disciplina "Sociedade e Cultura", os alunos foram incentivados a fazerem correlações entre as músicas e alguns aspectos que eles observam na sociedade ou na localidade onde vivem, apontando possíveis soluções para os mesmos.

Por sugestão dos alunos, a fim de debater a invisibilidade e o silenciamento social que acometem pessoas das camadas sociais mais populares, que escolheram a música "O homem que não tinha nada", do artista Projota. Levando em consideração que as turmas possuem em média 15 a 20 alunos, com idades entre 12 e 17 anos, ouvir a sugestão deles é também uma forma de mobilizá-los ao debate. Para o trabalho com essa música, optou-se pela realização de uma grande roda de conversa na qual foram discutidos temas como violência e descaso social com as pessoas de maiores vulnerabilidades. A letra da música narra a história cotidiana de um homem,

O homem que não tinha nada, acordou bem cedo, com a luz do sol já que não tem despertador, ele não tinha nada, então também não tinha medo e foi pra luta como faz um bom trabalhador, o homem que não tinha nada, enfrentou trem lotado a sete horas da manhã com sorriso no rosto se despediu de sua mulher com um beijo molhado pra provar do seu amor e pra marcar seu posto, o homem que não tinha nada, tinha de tudo artrose, artrite, diabetes e o que mais tiver mas tinha dentro da sua alma muito conteúdo e mesmo sem ter quase nada ele ainda tinha fé, o homem que não tinha nada, tinha um trabalho com um esfregão limpando aquele chão sem fim mesmo que alguém sujasse de propósito o assoalho ele sorria alegremente, e dizia assim: o ser humano é falho, hoje mesmo eu falhei, ninguém nasce sabendo, me deixa tentar, Ninguém nasce sabendo (ninguém), então me deixe tentar. $\mathrm{O}$ homem que não 
tinha nada, tinha Marizete Maria Flor, Marina, Mario que era o seu menor, um tinha nove, uma doze, outra dezessete, a de quarenta sempre foi o seu amor maior, o homem que não tinha nada, tinha um problema um dia antes mesmo foi cortado a sua luz subiu no poste, experiente, fez o seu esquema mais à noite reforçou o pedido pra jesus o homem que não tinha nada, seguiu a sua trilha mesmo caminho, mesmo horário, mas foi diferente ligou pra casa pra dizer que amava sua família, acho que ali já pressentia o que vinha na frente, o homem que não tinha nada encontrou outro homem que não tinha nada mas esse tinha uma faca queria o pouco que ele tinha, ou seja nada na paranoia, nóia que não ganha te ataca o homem que não tinha nada, agora já não tinha vida, deixou pra trás três filhos e sua mulher o povo queimou pneu, fechou a avenida e escreveu no asfalto "saudade do Josué". O ser humano é falho, hoje mesmo eu falhei ninguém nasce sabendo, então me deixe tentar (me deixe tentar) o ser humano é falho, hoje mesmo eu falhei ninguém nasce sabendo (ninguém), então me deixe tentar então me deixe tentar então me deixe tentar então me deixe tentar [...] (PROJOTA, 2015)

A narrativa acerca de o "homem que não tinha nada" inspirou o compartilhamento de experiências relacionadas a injustiças sociais. Os exemplos trazidos pelos alunos permitiu relacionar a violência, e toda sua proximidade - visto que todos tinham um caso a retratar, como uma prática social cotidiana. Como pode ser observada na letra acima, as cenas de violência não se limitam a "meras" notícias jornalísticas. Elas estão na vizinhança de alguns alunos, na morte de inocentes, pessoas de bem que saem para trabalhar e não sabem se voltam para seus lares, no uso "proibido" de algum bem - como celulares ou joias - em vias públicas.

Os exemplos trazidos e os rumos que a discussão foi tomando levaram-no ao debate sobre as políticas públicas que precisam ser implementadas no sentido de minimizar os problemas relacionados com a violência. Na oportunidade, convidados a assumirem, numa situação hipotética, o papel da mãe, filho ou pai que perde o filho, pai ou mãe, 
vítima da violência, muitos deles se sensibilizaram ainda mais sobre essas questões. Por fim, surgiram problematizações sobre os motivos que geram o agravamento da violência nas cidades, bem como a forma como o município de Cícero Dantas tem sido impactado pelas questões aqui suscitadas.

A fim de verificar se os objetivos propostos pela atividade - suscitar, a partir das discussões, um olhar sensível para si, para o outro e para o mundo que os cerca - foram alcançados, foi realizada uma avaliação escrita com base nas músicas trabalhadas em sala de aula. A ideia, portanto, consistiu em permitir com que os alunos expressassem seus pontos de vistas a partir das linguagens utilizadas, tendo em vista o estímulo da interpretação pessoal como importante percurso para uma pedagogia da autonomia.

\section{BREVES CONSIDERAÇÕES}

Concebendo a educação como um dos instrumentos capazes de transformar a sociedade, observa-se que o educador contemporâneo deve atualizar constantemente sua dinâmica pedagógica, sendo ela significativa de maneira que os discentes possam repensar e se envolver de forma prazerosa nas atividades propostas, pois, de acordo com Paulo Freire (2003), "ensinar não é transferir conhecimento, mas criar as possibilidades para a sua própria produção ou a sua construção". Como também acrescenta o filósofo REBOUL: "A natureza humana é o que exige ser educado; é também o que faz que a educação não seja tudo inversamente, se a educação não pode tudo, não se pode nada sem ela" (REBOUL, 2000, p. 22).

Pensando dessa maneira, o professor deixa de ser detentor do saber e passa a ser um mediador da aprendizagem. Aquele que se sensibiliza com as dificuldades, complexidades, limitações dos educandos, percebendo-o como ser inteiro, respeitando o processo de crescimento de cada indivíduo, mantendo uma postura flexível nas suas ações, buscando na sua prática constante, primando pelo equilíbrio entre as relações técnicas, pedagógicas e humanas.

Assim sendo, tendo em vista que nos dias atuais não se deve educar somente para a transferência de conteúdos didáticos, é fundamental 
que o professor estimule em seus alunos habilidades de pensar, refletir e propor soluções para os problemas que surgem na atualidade. Para que isso ocorra é necessário que a escola receba investimentos de modo a possibilitar a sensibilizar o professor sobre o uso de tecnologia e de propostas inovadoras, como a música em sala de aula. A partir disso, entendemos que se torna possível falar de uma educação capaz de atender às novas demandas sociais que surgem, não porque a música, por si só o fará, mas porque ela sensibiliza uma linguagem específica que, associada interdisciplinarmente a outros campos do saber, contribui para uma formação crítica e propositiva.

No que tange ao método, é interessante observar que o trabalho com música pode ser realizado de diversas formas: rodas de conversas, debates, atividades de campo, dentre outras alternativas interdisciplinares para estimular o senso crítico nos alunos. Também vale lembrar, que as tecnologias podem servir como importante aliado. $\mathrm{O}$ celular, por exemplo, hoje nos permite fazer uso de diversas plataformas gratuitas que permitem trabalhar com músicas, videoclipes e filmes, o que, além de despertar o interesse do aluno para outras alternativas de expressar emoções, pode contribuir para sensibilizar sobre o poder do questionamento.

Precisamente sobre a experiência aqui relatada, foi possível notar que o trabalho com música, seguido por discussões sobre temas anteriormente planejados, possibilitaram convergir uma grande diversidade de histórias de vida dos alunos e modos diferentes de interpretar a vida. Isso foi notório principalmente quando alguns estudantes expuseram experiências duras de suas realidades sociais, expondo, em seguida, desejos de transformação.

A música foi - e ainda é - um meio de produção e expressão de singularidades discursivas e/ou interpretativas à disposição de produtores e consumidores. Nela, se delinearam (delineiam) as afirmações identitárias necessárias para a constituição e positivação de mulheres e homens negros como indivíduos e grupos, em contextos extremamente desfavoráveis da escravidão e seus períodos subsequentes de exclusão racista. A música permitiu a circulação de informações acerca do regime e suas brechas, 
propiciando o confronto a outros discursos e práticas de subordinação, bem como a elaboração e disseminação de estratégias de liberdade (WERNECK, 2013, p. 266)

Os benefícios do ensino musical vão além da possibilidade de profissionalização. A arte e a prática musical são compreendidas como um poderoso instrumento de transformação individual e de desenvolvimento destes jovens. Ainda mais em um contexto de vulnerabilidade social, o que a música oferece à criança e ao jovem é algo muito maior e necessário: a sensação de pertencimento e a capacidade de, em meio à adversidade, voltar a sonhar.

Assim, a educação artística e musical não é um bem da elite, mas que deve se consolidar como legítimo direito social de nossos povos. Todos têm o direito de usufruí-los, sem discriminação de gênero, etnia ou condição social. É preciso considerar também que a música em si, assume diversas representações para sujeitos e culturas diferentes, mas em todo contexto, ela tem a função de expressar a natureza humana a partir do som, desde o êxtase às apresentações de resistências contra as desigualdades existentes na sociedade.

O intuito do texto, foi trazer a música como possibilidade de trabalho, para se debater questões de diversidade, desigualdade, diferenças, na sala de aula independente do componente curricular, e mostrar como essa experiência pode contribuir para a aprendizagem dos alunos, visto que estão muito ligados a música, e essa aproximação com o universo deles traz grandes contribuições para o aprendizado e a discursão de questões sociais de grandes relevâncias.

\section{REFERÊNCIAS}

ABRAMOWICZ, Anete; RODRIGUES, Tatiane Cosentino; CRUZ, Ana Cristina Juvenal da. A diferença e a diversidade na educação. Contemporânea: Revista de Sociologia da UFSCar, São Carlos, v. 2, p. 85-97, 2011.

ARANTES, Antônio Augusto. O que é cultura popular. $8^{a}$ ed. Editora Brasiliense, 1985. 
BARBOSA, Ana Mae. Arte-Educação-leitura no subsolo. São Paulo: Cortez Editora, 1999.

BRASIL. Base Nacional Comum Curricular (BNCC). Educação é a Base. Brasília, MEC/CONSED/UNDIME, 2017. Disponível em: <http://basenacionalcomum.mec.gov.br/images/BNCC_EI_ EF_110518_versaofinal_site.pdf>. Acesso em: 26 maio. 2020.

BRÉSCIA, Vera Lúcia Pessagno. Educação Musical: bases psicológicas e ação preventiva. São Paulo: Átomo, 2003.

CHIQUETO, Marcia Rosane. ARALDI, Juciane. Música na Educação Básica: Uma experiência com sons alternativos. Artigo Online, disponível em:< http://www.diaadiaeducacao.pr.gov.br/ portals/pde/arquivos/2269-8.pdf>. Acesso em: 20 Maio de 2020.

DEMO, Pedro. Educação hoje: "novas" tecnologias, pressões e oportunidades. São Paulo: Atlas, 2009.

Questões para Teleducação. Petrópolis, RJ: Vozes, 1998.

DOS SANTOS, José Luiz. O que é cultura? 6 ed. São Paulo: Editora Brasiliense, 1983.

FREIRE, Paulo. Pedagogia da Autonomia: saberes necessários à prática educativa. Editora Paz e Terra. Coleção Saberes. 1996 36ª edição. 2003

GIL. A. C. Didática do Ensino Superior. São Paulo: Atlas, 2007.

GOMES, Nilma Lino (Org.) Apresentação: desigualdades e diversidade na educação. In: Revista Educação e Sociedade, vol. 33, n. 120, Campinas, jul.- set. 2012, p. 687-693.

IBGE. Instituto Brasileiro de Geografia e Estatística. Acessado em 05/03/2020, disponível em: http://www.ibge.gov.br

MENEZES, Flávia Maria de; MACHADO, Priscila de Oliveira Dornelles. Atravessando pensamentos: diferença, différance, criança pequena e infância. Horizontes, v. 33, n.2, p. 81-88, 2015. 
MOREIRA, J. Antônio. Reconfigurando ecossistemas digitais de aprendizagem com tecnologias audiovisuais. Em Rede: Revista de Educação à Distância, v. 5, n. 1, jan. 2018. Disponível em: <https://www.aunirede.org.br/revista/index.php/emrede/article/ download/305/313>. Acesso em: 05 de Maio de 2019.

MOREIRA, J. Antônio. Linguagem cinematografia e áudio visual em contexto educativo: aplicações didáticas. Coleção Educação e tecnologia Curso de Especialização. Portugal: Ed. Pixel, 2017.

KENSKI, Vani Moreira. Educação e tecnologia: o novo ritmo da informação. Campinas, SP: Papirus, 2007.

LOUREIRO, Alicia M. A. A educação musical como prática educativa no cotidiano escolar. Revista da ABEM, Porto Alegre, n.10, 2004.

MASCARENHAS, Andrea. A teia da infância e o labirinto dos castigos. São Bernardo dos Campos - SP, Ed. Garcia, 2018.

MORAN, José Manuel. Ensino e aprendizagem inovadores com tecnologias. 1995. Artigo Online, disponível em:< http://www. eca.usp.br/prof/moran>. Acesso em: 05 Maio de 2019.

MORAN, José Manuel, MASETTO, Marcos T., BEHRENS, Marilda A. Novas tecnologias e mediação pedagógica. 16. ed. Campinas, SP: Papirus, 2009. (coleção Papirus Educação). Disponível em: <http://www.uca.gov.br/institucional/noticiasLei12249.jsp.>. Acesso em: 05 de Maio de 2019.

OLIVIER, Reboul. A Filosofia da Educação. Portugal, Edições 70. 2000.

PROJOTA. Foco, força e fé: São Paulo: Gravadora Universal Records, p2014. 1 disco sonoro (72 min). 2014. Disponível em: https://www.youtube.com/watch? $\mathrm{v}=7 \mathrm{~m} 0 \mathrm{kmGKX8o8}$, acesso em 05 de maio de 2020. 
RAIO DA SILIBRINA. Vou vender minha chana. Direção artística: Brilho Produções. Aracaju: Gravadora Independente, p2005. 1 disco sonoro (45 min). 2005.

. Esse país é um circo. Direção artística: Brilho Produções. Aracaju: Gravadora Independente, p1993. 1 disco sonoro (56 min). 1993.

SESI: Cadernos técnicos. Serviço Social Da Indústria. SESI-SP Editora Brasília, 2009.

WERNECK, Jurema Pinto. Macacas de auditório? Mulheres negras, racismo e participação na música popular brasileira. In: BRASIL. Prêmio Mulheres Negras contam sua história. Brasília: Presidência da República, secretaria de políticas para mulheres, 2013. 


\section{UNIDADE, AFETO, COGNIÇÃO E A FORMAÇÃO DA PERSONAĹIDADE COLETIVISTA: A EDUCAÇÃO DE JOVENS E ADULTOS NO SISTEMA PRISIONAL BRASILEIRO.}

Francisco Carneiro Braga

Hellyegenes de Oliveira

Tarciana Cecília de Souza Ferreira

Vanessa Amellyne de Souza Ferreira

\section{INTRODUÇÃO}

A educação auxilia e permite a obtenção dos objetivos centrais no processo de reabilitação, reconstrução e ressignificação que incidem no resgate social e na educação libertadora numa dimensão autônoma, nos processos da sustentabilidade e minimização das discriminações sociais. A relevância da educação prisional como instrumento de ressocialização e de desenvolvimento de habilidades e de educação é notória no sentido de auxiliar os reclusos a reconstruírem um futuro melhor durante e após o cumprimento da sentença.

O Sistema prisional brasileiro vive em uma contínua crise em sua ordem estrutural, tais como: superlotação em suas unidades; precarização física e material; salários defasados das classes profissionais que atuam junto à instituição. Entretanto, alguns direitos dos presidiários, mesmo que em muitas vezes encontrem-se defasados, ganham proporções e assim são colhidos bons frutos, esses: auxílio reclusão - di- 
reito previdenciário, garantindo aos seus dependentes, mesmo que o preso esteja em regime fechado ou semiaberto, durante o período de reclusão ou detenção; Educação - programas voltados para a Educação dos detentos, tais como a Educação de Jovens e Adultos (EJA) - que trata-se de direitos previsto na CF 1988, além de possibilitar meios para a futura ressocialização, na qual possibilitará subsídios para que de forma equiparada possa estar qualificado para se inserir no mercado de trabalho. (UNESCO, 2009). O intuito principal para o processo educacional nas prisões tem finalidade, muito além de alfabetizadora.

Devem ser tomadas medidas no sentido de melhorar a educação de todos os reclusos, incluindo instrução religiosa. A educação de analfabetos e jovens reclusos deve estar integrada no sistema educacional do país, para que depois da sua libertação possam continuar, sem dificuldades, a sua formação. Devem ser proporcionadas atividades de recreio e culturais em todos os estabelecimentos penitenciários em benefício da saúde mental e física. (CARREIRA, 2009, p. 11)

$\mathrm{O}$ intuito de que posterior a pena o sujeito apenado possa estar inserido no mercado de trabalho é um dos pilares do sistema prisional em conjunto com outras políticas, dentre elas a educação. O Estado tem o dever como detentor de disponibilizar mecanismos para que toda a população tenha acesso a eles, esses, os quais de forma conjunta com todas as políticas. A garantia da Educação nas prisões está expressa na Lei $\mathrm{n}^{\mathrm{o}}$ 7.210, de 11 de Julho de 1984, onde esse seu título educacional reafirma o direito e livre acesso a instrução escolar e a formação profissional do apenado.

A constituição federal em seu art. 205 aduz que a educação é dever da família e do estado, devendo ser prestada por todos os entes federados, em colaboração para atingir a universalização do ensino obrigatório, sendo que estados atuarão no ensino fundamental e médio, já os municípios no ensino fundamental e na educação infantil. Fazendo parte do rol dos direitos sociais e servindo como base para a efetivação dos demais direitos constitucionais, pois é responsável pelo desenvolvimento intelectual do individuo para que faça valer os seus direitos em prática. Partindo dessa premissa o direito a educação constitui-se como mecanismo essencial para a concretização do direito a igualdade, previsto no caput do artigo $5^{\circ}$ da Constituição Federal de 1988, todos são iguais perante 
a lei, sem distinção de qualquer natureza, garantindo-se aos brasileiros perante a lei, sem distinção de qualquer natureza, garantindo-se aos brasileiros e aos estrangeiros residentes no país a inviolabilidade do direito à vida, à liberdade, à igualdade, à segurança, e à propriedade.

Contudo a partir da Constituição Federativa do Brasil de 1988, foi reafirmada para todos, o livre acesso, gratuidade do ensino público em estabelecimentos oficiais e será promovida com a colaboração da sociedade, com objetivo da cidadania e a qualificação profissional do educando. Esse quesito e outros são reafirmados nas Diretrizes Nacionais para a Educação nas Prisões em 11 de março de 2009, e ratificada em 2010, pela resolução no 2 de 19 de maio de 2010 do Conselho Nacional de Educação.

A Educação de Jovens e Adultos - EJA, em prisões tem sua proposta curricular própria, dentre legislações, e segue coordenado pelo Departamento de Educação de Jovens e Adultos - DEJA em parceria com a Coordenação de Educação e Cidadania da Secretaria da Justiça, Cidadania e Direitos Humanos, onde tem sua execução através dos Estados, pelas secretarias de Educação e Justiça. É possível observar por meio de variadas experiências tanto práticas como teóricas a ineficiência do sistema prisional brasileiro, inclusive em se tratando de auxilio no convívio social dos detentos. O modelo atual demonstra claramente a violação dos direitos à dignidade humana, bem como é um forte sistema aliado à reincidência, a impunidade, e a grave ameaça para a insegurança dos cidadãos.

Rafael Damasceno de Assis (2007, p. 2), argumenta que o sistema presidiário acaba por gerar uma tendência punitiva que acarreta a reincidência dos presos. Se as técnicas de ressocialização fossem respeitadas e aplicadas, com base na garantia constitucional do Princípio da Dignidade da Pessoa Humana, o tempo de pena seria eficaz atingindo os objetivos do Sistema Penitenciário.

\section{O DIREITO A DIGNIDADE, A EDUCAÇÃO E OS DIREITOS HUMANOS FUNDAMENTAIS.}

Vale ressaltar que o direito penal brasileiro preconiza a intervenção mínima como um dos princípios mais importantes, entre tantos outros 
como o da legalidade, isonomia e proporcionalidade. A intervenção mínima tem como base a aplicação do direito penal apenas em casos excepcionais quando as demais formas de controle social não forem eficazes, em outras palavras, o principal mecanismo para o controle social, deve ser primariamente responsabilidade do estado, da família e da escola. O principio da legalidade surgiu como a carta magna inglesa de 1215, sob a égide de um estado absoluto, no qual o monarca não se submetesse a qualquer limite, durante esse período consolidou-se um ideal iluminista (liberdade, igualdade e fraternidade) que tinha por objetivo limitar os poderes do rei, assim sendo surge o constitucionalismo e, por conseguinte o estado liberal e o principio da legalidade, a partir de então o estado torna-se estado de direito, em outras palavras, o estado cria a lei e se submete a ela.

Partindo dessa premissa o poder punitivo do estado não poderá aplicar penabilidade sem criação prévia de lei. É importante salientar que Araújo (2019), nos informa que o principio da legalidade possui duas funções: a constitutiva (constitui e pena) e a função de garantia que (exclui as penas ilegais). O autor nos informa que se o principio da legalidade impõe certa anterior estrita o principio da intervenção mínima impõe a lei necessária. Neste ponto, é razoável que o direito penal não faça valer sua força em relação àqueles que se encontram em estado de vulnerabilidade tão acentuada em que não há a necessidade de intervenção positiva. (ARAÚJO, 2019)

Outra conquista de relevante importância se dá com o iluminismo através da conquista do principio da dignidade da pessoa humana, disposto no artigo $1^{\circ}$ III da constituição de 1988, o qual veda a aplicação de penas desumanas. Outro dispositivo que assegurava à dignidade da pessoa humana está elencado no artigo 5ํXㄴ ${ }^{\circ}$ que aduz: É assegurado aos presos o respeito à integridade física e moral.

Conforme supracitado, tais direitos configuram-se como conquistas do iluminismo, pois nem sempre foram resguardados no ordenamento jurídico, em outros tempos o direito penal baseava em vinganças privadas que muitas vezes eram chamadas de perdas da paz, neste tipo de sanção o individuo era excluído da sociedade bem como tinha seus bens confiscados. 
Em algumas civilizações mais distantes como, por exemplo, no Egito, pairava na sociedade forte natureza teocrática, por esse motivo condutas que atingissem Deuses ou faraós desencadeavam uma sanção severa como a pena de morte acompanhada ou não de tortura, como mutilações, escravidão, castração e trabalhos forçados, como por exemplo, o código de Manu, legislação indiana que prévia inclusive a separação da sociedade por castas outro documento de extrema importância para evolução da sanção penal foi o código de Hamurabi, pois até então, existia grande desproporcionalidade entre a conduta e a pena. A primeira concepção de obediência a proporcionalidade entre delitos e penas surge com o código Hamurabi que ao institucionalizar a lei de Talião imortalizada na máxima olho por olho, dente por dente preconizou um limite objetivo à reprimenda penal. (ARAÚJO, 2019)

Em outras palavras significa dizer que o código de Hamurabi, trouxe um avanço quanto à aplicação da sanção, haja vista que o réu deveria sofrer tanto quanto a vítima, entretanto, tal legislação não garantia o princípio da pessoalidade da pena, nem da culpabilidade, pois temos como exemplo o fato de que se um agressor matasse o filho de alguém o seu deveria ser morto como forma de reprimenda pelo mal causado. Observa-se então que a pena ultrapassava a pessoa do condenado.

Conforme, Araújo (2019) a laicização do direito penal na Grécia bem como a iminência de um conflito entre classes sociais. Dracon redigiu a primeira lei escrita de Atenas e a partir de então os gregos passaram a ter ciência previa dos fatos enumerados como crimes, entretanto, ainda havia forte desproporcionalidade bem como a ausência de isonomia visto que alguns tinham privilégios sobre outros.

O período de humanização do direito penal surgiu com o combate ao estado absolutista e o arbítrio até então estabelecido na politica foi vencido pelos ideais dos pensadores iluministas que defendiam a humanização da intervenção penal. Conforme Rousseau (1955), afirmava que toda pessoa era possuidora de direitos imanentes a sua própria condição.

Ocorre que apesar do grande avanço alcançado, até então, no quesito de humanização de penalidades ainda, não atinge os níveis almejados, visto que na prática ainda existem acontecimentos que não 
consagram o principio da dignidade da pessoa humana, devido à má estrutura dos sistemas prisionais, bem como falta capacitação profissional adequada.

O comportamento humano pode sofrer graves prejuízos dentro de um sistema desumano e de clausura absoluta. A cognição social, também se transforma dentro deste tipo de ambiente. A formação dos indivíduos, suas crenças, seus comportamentos derivam de um estilo próprio de criação, vindo de pais, mães, avós dentre outros membros da família.

A escola também se torna fundamental na construção de conhecimento e de determinadas posturas as quais as crianças e adolescentes devem seguir, garantindo aceitação social e promovendo integração dos indivíduos, porém nem sempre a família e instituições de ensino conseguem obter êxito. É nesse ponto crucial da formação humana que os desvios de conduta começam a acontecer. A falta de apoio familiar e as crises econômicas também podem contribuir para que o adolescente a ingressar na criminalidade.

De acordo com Antônio Carlos Lacerda (2013, p. 1), “a polícia e os agentes penitenciários brasileiros - dois dos mais imundos cânceres sociais, respeitadas as honrosas e devidas exceções, embora poucas são os mais violentos, selvagens e cruéis de todo o mundo". Se não bastassem as sessões de tortura e humilhações a que são expostos os presidiários em todo o Brasil, outro grave problema são as doenças psicológicas e o desvio de condutas de diversos indivíduos.

A afetividade e a cognição social se abalam dentro de ambientes de extrema tensão e medo. As pessoas que fora da clausura viviam uma rotina específica se veem em meio a uma transformação de valores e de percepção de certo e errado e de convivência.

\section{A AFETIVIDADE, A COGNIÇÃO E A CONSTRUÇÃO EDUCACIONAL NAS PRISÕES.}

A educação no sistema penitenciário é iniciada a partir da década de 1950. Até o principio do século XIX, a prisão era utilizada unicamente como um local de contenção de pessoas. Não havia uma proposta de requalificar os presos, esta proposta veio a surgir somente 
quando se desenvolveu dentro das prisões os programas de tratamento. Antes disso, não havia qualquer forma de trabalho, ensino.

O estabelecimento da prisão como instrumento da pena se deu pelo código Penal Francês em 1971 e generalizou-se no mundo. A criação de uma nova legislação para definir o poder de punir como uma função geral da sociedade, exercida da forma igual sobre todos os seus membros. Foucault (1987), diz que a prisão se fundamenta na "privação da liberdade" salientando que esta liberdade é um bem pertencente a todos da mesma maneira, perde-la tem dessa maneira, o mesmo preço para todos, "melhor que a multa, ela é o castigo" permitindo a quantificação da pena segundo a variável do tempo: "Retriando tempo do condenado, a prisão parece traduzir concretamente a ideia de qu8e a infração lesou, mais além da vitima a sociedade inteira" (FOUCAULT, 1987, p. 196)

Para Goffman (2008) instituições totais (prisões) seriam estufas para mudar pessoas, sendo que criam uma barreira com o mundo externo. "Essa barreira que as instituições totais colocam entre o internado e o mundo externo assinala a primeira mutilação do eu." (GOFFMAN, 2008, p. 24). O crescimento vertiginoso da população prisional e do déficit de vagas, a despeito dos esforços dos governos dos estados e da federação para a geração de novas delas, é por seu turno um elemento revelador de que a construção de novas unidades não pode ser o componente fundamental das políticas penitenciárias, senão apenas mais um componente dentro de um mosaico muito mais amplo e dinâmico.

O Nível educacional geralmente baixo das pessoas que entram no sistema carcerário reduz seus atrativos para o mercado de trabalho, isso sugere que programas educacionais pode ser um caminho importante para preparar os detentos para um retorno bem sucedido à sociedade.

A distinção entre cognição social e neurocognição dentro dos presídios é estudada não só por psicólogos sociais, mas também por pesquisadores na área da biologia evolutiva e comportamento primata. Estes enfatizam que os mecanismos envolvidos no processamento de informação da mente humana não são desenhados para resolver as tarefas de forma arbitraria, mas para resolver problemas biológicos espe- 
cíficos, propostos pelo ambiente físico, ecológico e social enfrentados pelos nossos ancestrais durante o curso da evolução.

Alguns quadros clínicos encontrados em presídios caracterizam-se por uma maior disfunção social, por certo déficit nisto é conhecido como cognição social. É o que observamos, por exemplo, em casos de esquizofrenia, autismo, transtorno bipolar, psicopatia, entre outros. É importante compreender os mecanismos envolvidos nessa "falha do funcionamento social", pois é a partir da compreensão desses déficits cognitivos que podemos pensar em estratégias terapêuticas que beneficiem o paciente em sua interação com o meio.

\subsection{Os conflitos e a cognição da pessoa privada de liberdade.}

Um dos problemas que podem interferir na personalidade do indivíduo encarcerado pode-se citar a angustia, o medo, dentre outras disfunções psicológicas. Foucault (1954) aponta aí se por acaso é possível compreender toda a doença. E a angústia e o conflito estariam então na vida de todas as pessoas, mas algumas aprofundam esses sentimentos, enraízam esses conflitos até o ponto de chegarem ao estado patológico, ficam lembrando as angústias passadas fazendo com que assim os sentimentos que naquela época sentiram voltem à tona, sendo, portanto isso é uma ambivalência, desejando e ao mesmo tempo tendo repulsa.

Além de todas as mudanças, uma pessoa quando entra em uma instituição total como está, tem sua vida marcada por ela pelo resto de sua vida, visto que a sociedade estabelece meios de categorizar as pessoas como forma de definir as diferenças existentes entre as pessoas. (GOFFMAN, 1988).

Algumas diferenças em instituições prisionais são traçadas entre neuro cognição e cognição social em termos de estímulos utilizados em pesquisas, o tipo de resposta esperada do sujeito e a forma de avaliação deste. Porém, o que me parece de crucial importância nessa diferenciação, é saber que, numa avaliação de aspectos como memória, resposta executiva ou atenção, por exemplo, esperamos uma resposta precisa e mensurável (neurocognição); já nos estudos de cognição social, é possível apenas verificar diferenças entre os sujeitos, apreender 
aspectos de sua personalidade. Algumas diferenças são traçadas entre neurocognição e cognição social em termos dos estímulos utilizados em pesquisas, o tipo de resposta esperada do sujeito e a forma de avaliação deste. Porém, o que me parece de crucial importância nessa diferenciação, é saber que, numa avaliação de aspectos como memória, resposta executiva ou atenção, por exemplo, esperamos uma resposta precisa e mensurável (neurocognição); já nos estudos de cognição social, é possível apenas verificar diferenças entre os sujeitos, apreender aspectos de sua personalidade.

Este é um tipo de processamento intencional, voluntário ou envolve esforço, ocorrendo dentro do campo da consciência. É relativamente lento e acessível à regulação, demandando recursos tensionais. O processamento se dá em série, a informação é processada passo a passo e permite lidar com tarefas novas e difíceis. Esse processamento surge tardiamente na evolução e no desenvolvimento, muitas vezes envolvendo linguagem declarativa e baseando-se no raciocínio, no pensamento reflexivo, na análise semântica, síntese e abstração. Esse sistema é importante por sua capacidade de atribuir significados e interpretar informações novas e complexas.

Segundo Couture e colaboradores (2006), a cognição social de modo geral apresenta quatro componentes no processo desta formação, vejamos:

1) Percepção Emocional: Capacidade de inferir informação emocional a partir das expressões emocionais, das inflexões vocais e/ou da prosódia. Processamento das emoções Estudos de neuroimagem sugerem que regiões especificas no córtex ínfero temporal e o temporal inferior são responsáveis pela percepção de faces. Essas regiões contem campos receptores amplos, os quais algumas vezes envolvem todo o campo visual e que são sensíveis tanto as formas como cores. Lesões especificas nessas áreas cerebrais levam a prosopagnosia, quadro neurológico que se refere a uma incapacidade para reconhecer rostos familiares ou famosos, embora esteja preservada a capacidade de reconhecer que o estimulo apresenta.

2) Percepção Social: Capacidade de extrair certas pistas do comportamento manifesto dentro de um determinado contexto social, 
além da capacidade de compreensão das regras e das convenções sociais. Habilidades sociais:

- Iniciar uma conversa e finaliza a conversa;

- Fazer comentários sem agredir o interlocutor;

- Respeito ao outro, cooperação, boas maneiras (educação), limites, regras;

- Assertividade: solicitar algo, dizer sente controlar os impulsos agressivos.

3) Teoria da Mente: A teoria da mente é a capacidade que uma criança tem em atribuir estados mentais a outras pessoas e imaginar o comportamento das mesmas de acordo com essas atribuições. $\mathrm{O}$ impulso inicial para essa habilidade é inato, mas o processo pode ser aprendido, através da interação com outras pessoas e com o meio em que vive assim a criança vai adquirindo o conhecimento disponível em sua cultura através dessa interação.

Alguns teóricos acreditam que a teoria da mente acaba refletindo na capacidade da criança em atribuir para si mesma ou a outros, estados mentais como os desejos, crenças e interações dela com o mundo externo, sendo que muitos problemas na vida adulta, principalmente de conduta, ocorrem porque a criança não foi bem instruída na infância ou não teve afeto familiar.

\section{A INSERÇÃO, A REINTEGRAÇÃO E A REABILITAÇÃO DOS APENADOS NO SISTEMA SÓCIO-EDUCACIONAL BRASILEIRO.}

A população carcerária brasileira constitui-se entre homens e mulheres. São de jovens com idade entre 18 e 29 anos, afrodescendente, sem profissão definida, com nível baixo de escolaridade, baixa renda, vivência de inúmeras vulnerabilidades sociais. Segundo o Sistema de Informações Penitenciárias - Infopen, do Ministério da Justiça, esses praticam geralmente crimes contra o patrimônio (70\%) e tráfico de entorpecentes (22\%); A média das penas é de quatro anos. A conjugação de todos esses fatores negativos acima mencionados, aliados ainda à falta de segurança das prisões e ao ócio dos detentos, leva à deflagração 
de outro grave problema do sistema carcerário brasileiro: as rebeliões e as fugas de presos (ASSIS, 2007). A soma de fatores que revertem e por muitas vezes impossibilita o poder educacional contido, ou seja, nas cadeias são muitas realidades e comportamentos estressantes e degradantes juntos, aliados ao despreparo para receber e tratar por meios de ressocialização efetivos.

Propiciar educação e trabalho ao detendo, tratando-o por sua vez como digno de direito assim como qualquer outro ser, pelas vias de possibilita-lo reconstruir suas possibilidades, tais como, a própria inserção no mercado de trabalho, é uma forma de combater o crime. Essas possibilidades são de vias, disponibilizadas por meio da educação, dai onde se entra o EJA, como forma de mecanismo de aprendizagem, dando aos mesmos subsídios para poderem estar à pá com os demais sujeitos.

Prevista na Lei de Execução Penal a Educação é tratada como dever do Estado para com os indivíduos inseridos nesse sistema, respeitando assim sua escolaridade, sexualidade, dentre outros quesitos, e com o objetivo fundamental de promover a sua ressocialização. Conforme Graciano (2005, p. 29), a educação entrelaça-se em diversas maneiras, tais como direito econômico, social, cultural, além de civil e político, assim situa-se como centro das realizações dos demais direitos. Nesse sentido o processo educacional é a potencializadora de garantia dos demais direitos.

A completude educacional passa por diversas vicissitudes no decorrer da história. Foucalt (1987, p. 208) diz, “[...] conhecem-se todos os inconvenientes da prisão, e sabe-se que é perigosa quando não útil”. Por sua vez, a prisão perpassa a lógica de anulação, e tem o objetivo de disponibilizar víeis necessários para a mudança de comportamento, oferecendo oportunidades para que isso ocorra. Por isso, o governo, e os demais órgãos precisam incentivar a criação de novas oportunidades de trabalho e cursos de capacitação profissional para presos e egressos do sistema carcerário.

Contudo, segundo a análise de Santos (2002), o entendimento da educação pelos detentos, trata-se do acesso à aprendizagem da leitura e da escrita, e ampliação de conhecimentos em outras áreas, como também o espaço para o contato com outros detentos de pavilhões diferen- 
tes, fonte de análise de conduta favorável o que os auxilia em sua pena, além de ser uma forma de passar o tempo.

\subsection{A reintegralização do individuo por meio do sistema educacional.}

A expressão "educação de adultos" designa o conjunto de processos organizados de educação, qualquer que seja o seu conteúdo, o nível e o método, quer sejam formais ou não formais, quer prolonguem ou substituam a educação inicial dispensada nos estabelecimentos escolares e universitários e sob a forma de aprendizagem profissional, as pessoas consideradas como adultas pela sociedade de que fazem parte desenvolvem as suas aptidões, enriquecem os seus conhecimentos, melhoram aos suas qualificações técnicas ou profissionais ou lhe dão uma nova orientação, e fazem evoluir as suas atitudes ou o seu comportamento na dupla perspectiva de um desenvolvimento integral do homem e de uma participação no desenvolvimento socioeconômico e cultural equilibrado e independente. (UNESCO, 2009)

O contexto prisional de educação busca a ativação não só científica, mas como também o comportamento diante da sua subjetividade, além da construção profissional. Deve se então levar em conta as particularidades de cada aluno, pontuando as condições de detento e os agravos que isso traz. O respeito na construção a partir dos princípios da EJA nas prisões, ressaltando os seus conhecimentos de mundo adquiridos no decorrer da vida, onde também é pontuado nas Diretrizes Nacionais para a educação nas prisões (BRASIL, 2010).

A Educação de Jovens e Adultos surge de um assíduo movimento de lutas encabeçada por educadores, ONGs, familiares detentos como pelos próprios encarcerados; desafios e conquistas da educação popular. Dado, que ressalta a importância uma vez que permite a compreensão das condições limitadoras impostas pelo modo rígido da educação formal quando se pensa na EJA, enquanto modalidade educativa.

Entender que as experiências de vida que cada aluno traz são de suma importância, assim, faz com que os mesmos ao compartilharem se sintam parte e importantes na construção do aprendizado. Esse movimento é importância para todo o contexto prisional, pois acentuam 
a criticidade e a autoafirmação de que a educação pode transformar vidas. O reconhecimento dos diferentes sujeitos na EJA é de grande importância para que se possam ter demandas específicas.

A prática docente, na visão de Vasquez (1977, p. 55) se baseia a partir do sentido amplo da educação, quando afirma que "a finalidade é a expressão de certa atitude do sujeito em face da realidade. Pelo fato de traçar-me um objetivo, adoto certa posição diante da realidade". Logo, entender o aluno EJA do sistema prisional necessita de potencialidades para mudança da em face de qual está inserida, no contexto educacional, tanto quando social, e sempre pondo em destaque o seu 'eu', suas escolhas, propostas de vida, e sonhos.

O jovem e o adulto buscam assim ver a aplicação imediata do que estão aprendendo e, ao mesmo tempo, necessitam ser estimulados para resgatarem a seu vigor e autoestima. Pois com o aprisionamento travam uma grande batalha com a ansiedade, angústia e "complexo de inferioridade". Esses jovens e adultos são tão capazes como uma criança em seus primeiros anos escolares, precisando somente de metodologia eficientes para esse tipo de modalidade.

A inserção no âmbito educacional é um direito que assiste a todos e segue como dever do Estado e da família, já nos primeiros anos de vida. Direcionando o sujeito ao desenvolvimento intelectual para que posteriormente seja inserido no mercado de trabalho. A privação de liberdade a qual o sujeito se inclui devido não seguir as normas e preceitos impostos pelo Estado, não lhes tira o direito de darem continuidade aos estudos ou iniciarem do processo educacional. A dignidade concebida com qualidade integrante e irrenunciável da própria condição humana pode e deve ser reconhecida, respeitada, promovida e protegida, não podendo ser criada, concedida ou retirada (embora possa ser violada, como no caso de presos), já que ela existe em cada ser humano como algo que lhe é inerente.

Esse avanço se deu após muitos anos de luta, surgirem à relação de Direito Público entre o Estado e o condenado, respaldado através da constituição dos direitos humanos, especificamente nesse caso, do condenado. A política penal e penitenciária deve atender às demandas da vida pessoal e social dos presos (provisórios e condenados). 
[...] podemos concluir assim que a execução penal não atinge por completa a reabilitação almejada pela lei. (AQUINO, 2001, p. 6). Mesmo inserido em condições indignas e em muitas vezes desumanas, o direito educacional hoje é entendido como fundamental para o progresso e a reinserção após o cumprimento da pena novamente no mercado de trabalho.

Muito se avança diariamente na quebra de paradigmas do processo educacional criado e pelo senso comum, entretanto é de fundamental importância a avaliação continua de como está se dando o processo educacional, evidenciando assim a criticidade dos apenados diante do seu processo de formação, para assim colocar em contraponto se a legislação brasileira de presos está suprindo a necessidade de educação para os mesmos.

Compreende-se, portanto que a temática proposta é de grande valia, por entender que há uma necessidade de estudos contínuos relativos ao processo educacional prisional, que além de conhecimentos científicos promovam a cidadania, ressaltando os valores humanos e sociais dos mesmos.

\section{CONSIDERAÇÕES FINAIS}

A população carcerária no Brasil atingiu a marca de 711.463 presos. Os números apresentados pelo Conselho Nacional de justiça $(\mathrm{CNJ})$ a representantes dos tribunais de justiça brasileiros levam em conta as 147.937 pessoas em prisão domiciliar, colocam o Brasil entre os três países com a maior população carcerária em números absolutos, segundo dados do ICPS, sigla em inglês para o Centro Internacional de Estudos Prisionais, do King's College, de Londres.

A educação é importante na recuperação, muitos detentos têm baixos padrões de escolaridade. Uma parcela significativa não domina as competências básicas de leitura e escrita, esse baixo nível de escolaridade afetou suas vidas e pode ter contribuído para que cometessem delitos, por isso os programas e projetos de educação nos presídios são importantes para desenvolver nos encarcerados seu senso de autovalorização. 
Os programas e projetos educacionais precisam ser desenvolvidos dentro das prisões para que se trabalhe a conscientização dos educandos ajudando a desenvolver suas perspectivas pós-prisão, bem como novas oportunidades para que eles possam ser reintegrar ao sistema social brasileiro, pois nesta perspectiva a educação pode ser utilizada como um caminho promissor para uma reconstrução dos direitos e deveres do cidadão.

A educação é um direito de todos. As políticas e ações apresentadas têm que realmente se constituírem como rotinas nos processos dos indivíduos encarcerados, preocupar-se com a sua situação bem como a forma que os mesmos serão inseridos na sociedade, pós o cumprimento da sua pena é uma preocupação de todos os que compõem a sociedade civil.

A concepção e a implementação de políticas públicas visando o atendimento especial dos segmentos da população estrutural e historicamente fragilizados, constituem um dos modos mais significativos pelos quais o Estado e a Sociedade podem renovar o compromisso para com a realização desse direito e democratização de toda a sociedade. O espaço e o tempo do sistema penitenciário, aliás, confirmam esses pressupostos.

\section{REFERÊNCIAS}

. Educação em Prisões na América Latina: direito, liberdade e cidadania. Brasília: UNESCO, OEI, AECID, 2009.

ARAujO, Fábio Roque. Direito Penal. Salvador. Ed. JusPodivm, 2019.

AQUINO, Romário Freitas de. Bastidores do Cárcere. 2001.

ASSIS, Rafael Damaceno de. A realidade atual do sistema penitenciário Brasileiro. 2017, p. 2. Disponível em: <http://br.monografias.com/trabalhos908/a-realidade-atual/a-realidade-atual. shtml>. Acesso em: 01 julho de 2020.

BARATTA, Alessandro. Criminologia Crítica e Crítica do Direito Penal: introdução à sociologia do direito penal, 6. ed. Rio de Janeiro, Renavan, 2011. 
BRASIL, Código Penal, Constituição Federal. Lei de Execução Penal (LEP): Lei 7.210 de 11 de julho de 1984. BRASIL. Constituição da Republica Federativa do Brasil; promulgada em 5 de outubro de 1988. Organização do texto: Anne Joyce Angher. 6. ed. São Paulo: Rideel, 2008.

CARREIRA, Denise. Relatório nacional para o direito humano à educação: educação nas prisões brasileiras. São Paulo: Plataforma DhESCA Brasil, 2009.11p.

FOUCAULT, M. Vigiar e punir: nascimento da prisão; tradução de Raquel Ramalhete. Petrópolis, Vozes, 1987, 288p.

FOUCAULT, Michel. Doença Mental e personalidade e Doença Mental e Psicologia. 1954.

GOFFMAN, ERVING. Manicômios, prisões e conventos, São Paulo, 2008.

GOFFMAN, Erving. Estigma: notas sobre a manipulação da identidade deteriorada. Rio de Janeiro: Guanabara Koogan, 1988.

GRACIANO, Mariângela. A educação como direito humano: a escola na prisão. Dissertação de Mestrado. FE - USP, 2005

LACERDA, Antonio Carlos. Brasil, tortura coloca o País no 'banco mundial dos réus'. 2013.

MINISTÈRIO DA JUSTIÇA. Departamento Penitenciário Nacional. Sistema Integrado de Informações Penitenciárias - InfoPen. Disponível em <http://www.mj.gov.br/data/Pages/ MJD574E9CEITEMID598A21D892E444B5943A0AEE5DB94226PTBRIE.htm>. Acesso em 05/07/2020

ROUSSEAU Jean Jacques. Du Contrati social. Paris: Editions: Sociales, 1955, p.05.

SANTOS, S. A educação escolar no sistema prisional sob a ótica dos detentos. 2002. 148f Dissertação (Mestrado em Educação) - Pontifícia Universidade Católica de São Paulo, São Paulo, 2002. 
UNESCO. Relatório Global Sobre Aprendizagem e Educação de Adultos. Brasília: UNESCO, 2010. Disponível em: <http:// unesdoc.unesco.org/images/0018/001886/188644por.pdf>. Acesso em 03 de julho de 2020.

VASQUEZ, Adolfo Shaches. Filosofia da práxis. 2ed. Rio de Janeiro: Paz e Terra, 1977. 


\section{REPRESENTAÇÕES SOCIAIS NA INTERFACE DA EDUCAÇÃO ESPECIAL: DISCUSSÕES EPISTEMOLÓGICAS ${ }^{43}$}

Igor Belo dos Santos

\section{Introdução}

O presente artigo traz como foco principal realizar uma discussão teórica acerca da interface entre a Teoria das Representações Sociais e a Educação Especial, de modo a problematizar e tensionar as questões referentes ao fazer docente e sua relação com a representatividade que o educador possui de seu educando.

Como suporte teórico para a discussão serão utilizados os autores Moscovici (2003), Oliveira (2004) e Sá (1993) que trazem contribuições sobre as Representações Sociais em suas obras. Para a contribuição acerca da educação especial foram utilizados os autores Correia (1994), Blanco (1999) e Stainback (1999).

Desta forma, o texto ganha relevância por se tratar de uma temática que aborda temas transversais que verticalizam para a prática pedagógica do professor que atua com alunos da educação especial, uma vez que, a compreensão que os educadores possuem dos seus educandos podem influenciar diretamente em suas práticas desenvolvidas

43 O presente trabalho foi realizado com apoio da Coordenação de Aperfeiçoamento de Pessoal de Nível Superior - Brasil (CAPES) - Código de Financiamento 001. 
com os discentes que possuem alguma necessidade educacional especial. Assim, pretende-se proporcionar uma reflexão crítica sobre esta modalidade educacional que é estigmatizada e muitas vezes silenciada dentro do próprio sistema educacional.

Nesta perspectiva, é válido salutar a relevância que a discussão sobre Educação Especial traz para as práticas pedagógicas dos professores, assim como a interrelação que esta tem com as representações sociais dos docentes para com os seus discentes. Diante disto, surgiu a inquietação particular em produzir este artigo como forma contribuir para a discussão da temática proposta, a fim de corroborar para a produção de conhecimento de uma área que ainda é pouco debatida a nível de academia.

A proposta de pesquisa para a construção do artigo é de cunho bibliográfico, de modo a construir uma linha epistemológica de reflexão entre os conceitos e ideias estabelecidos pelos autores trazidos para cada campo teórico discutido, que são: Representações Sociais e Educação Especial. Por conseguinte, são estabelecidos tópicos de reflexão para cada eixo temático estabelecido e discutido pelos autores propostos com o intuito de basilar a fundamentação teórica do trabalho.

Posteriormente, um tópico versará sobre a interface existente entre representação social e a Educação Especial e de que forma esta relação pode ser relevante para a construção de uma imagem estigmatizada, engessada do aluno, por parte de seu professor, assim como as implicações que essas relações trazem para o espaço escolar.

Por fim, as considerações finais trarão uma análise dos discursos dos autores elucidados com o propósito de estimular um olhar crítico-reflexivo acerca das representações sociais enquanto um dos fundamentos teórico-metodológico da prática docente e forma como isto se encontra atuante no processo de ensino-aprendizagem dos educandos e educadores.

\section{Desenvolvimento Teoria das Representações Sociais}

A representação social é um ramo de estudo da psicologia social que consiste na valorização do saber do senso comum, de modo a tornar familiar o não - familiar, para que desta forma o saber cotidiano 
dos sujeitos possa ser levado em consideração, com o intuito de romper com o paradigma dominante do conhecimento científico como dono absoluto do saber relevante para a sociedade. Assim, Moscovici (2003) entende representações sociais como:

Um conjunto de conceitos, preposições e explicações criado na vida cotidiana no decurso da comunicação interindividual. São o equivalente, na nossa sociedade, dos mitos e sistemas de crenças das sociedades tradicionais, podem ainda ser vistas com a versão contemporânea do senso comum. (MOSCOVICI, 2003, p.28)

Destarte, Moscovici (2003) traz a concepção de que a percepção de mundo que possuímos está atrelada às nossas próprias ideias, que são respostas aos estímulos que sofremos do ambiente físico ou quase-físico no qual vivemos. Ou seja, a forma de enxergar a sociedade ao nosso redor será variável conforme as experiências que por ventura tivermos sobre determinado objeto. Assim, ratifica a importância do não silenciar os sujeitos, mas sim dar voz a tudo e a todos, pois todos os saberes são importantes.

Do mesmo modo, Oliveira (2005) acompanha o pensamento de Moscovici ao elucidar que "ao dizerem a palavra, homens e mulheres expressam em suas falas as suas representações, seus desejos e angústias, sua concepção e posição de mundo". Portanto, os sujeitos silenciados pela práxis segregadora ganham representatividade e voz ativa, a partir do momento em que a teoria das representações sociais leva em conta seus saberes, suas práticas, seu cotidiano e suas experiências como formas de conhecimentos tão importantes quanto o conhecimento científico.

Moscovici (2003) entende que a classificação e denominação que os objetos instituídos ganham dentro da sociedade é definida como ancoragem, desta forma "coisas que não são classificadas nem denominadas são estranhas, não existentes e ao mesmo tempo ameaçadoras" (p.30). Ou seja, ancorar está relacionado ao processo de conhecimentos preexistentes que os indivíduos trazem consigo, e são estes saberes que vão auxiliar o sujeito a construir uma representação de um dado objeto. Jodelet (1984), entende que a ancoragem consiste na integração 
cognitiva do objeto representado - sejam ideias, acontecimentos, pessoas, relações etc. - a um sistema de pensamento social preexistente e nas transformações implicadas.

Estas concepções estão imbricadas nas representações sociais, especialmente quando falamos do público com NEE, que de certa forma são postos em "caixas predefinidas" pelos indivíduos que trazem consigo estas representações. Para Moscovici (2003):

Minhas observações provam que denominar uma pessoa ou coisa é precipitá-la (como uma solução química é precipitada) e que as consequências disso são três: (a) uma vez denominada, a pessoa ou coisa pode ser descrita e adquire certas características, tenências etc.; (b) ela se torna distina de outras pessoas ou coisas através dessas características e tendências; (c) ela se torna o objeto de uma convenção entre aqueles que adotam e partilham a convenção. (MOSCOVICI, 2003, p.39)

\section{Educação Especial e seus pressupostos normativos}

A conquista dos direitos desses alunos inscreve-se numa trajetória histórica de lutas reivindicatórias a favor dos direitos humanos de igualdade de oportunidades, configurando momentos e atitudes diferenciadas relativas ao atendimento dado a esses alunos, que vão de práticas excludentes, que os consideravam como inválidos e incapazes, sem participação na sociedade, às práticas inclusivas, que se fundamentam num contexto que vislumbra a construção de uma sociedade inclusiva, onde seus cidadãos tenham garantias de participação em todos os espaços comuns da vida em sociedade, "sociedade essa que deve ser orientada por relações de acolhimento à diversidade humana, de aceitação das diferenças individuais, de esforço coletivo na equiparação das oportunidades de desenvolvimento, com qualidade, em todas as dimensões da vida”. (MEC/SEESP, 2001, p.14).

No bojo da educação inclusiva, a Educação Especial é entendida como modalidade de educação escolar que se insere na transversalidade dos diferentes níveis de formação escolar, da Educação Infantil à Educação Superior, e na interatividade das demais modalidades 
(Educação Profissional, Educação de Jovens e Adultos e Educação Indígena), constituindo-se como um conjunto de recursos e serviços educacionais especiais, organizados para apoiar, suplementar e, em alguns casos, de modo a garantir a educação formal dos educandos que apresentem necessidades educacionais muito diferentes da maioria das crianças e jovens.

Dentre os estatutos teóricos que sustentam a política da educação especial enquanto modalidade de educação escolar que registram intenções, recomendações e determinações sobre a relevância e necessidade de uma escola para todos ou escola inclusiva, destacam-se:

A Constituição Federal de 1988, que desde sua promulgação já apresentava conteúdos que apontavam para a educação inclusiva, quando estabelece que a educação é direito social de todo brasileiro, garantido pelo Estado (Capitulo II, Artigo6 ${ }^{\circ}$ ). Em seu artigo 208, inciso III, relaciona os deveres do Estado com a educação, garantindo o atendimento especializado às pessoas com necessidades especiais "preferencialmente na rede regular de ensino".

A Política Nacional para Integração da Pessoa Portadora de Deficiência - Lei n 7.853, de 1989, que consolida e estabelece "normas gerais que asseguram o pleno exercício dos direitos individuais e sociais das pessoas portadoras de deficiências, e sua efetiva integração social" (caput do Art. $1^{\circ}$ ).

O Estatuto da Criança e do Adolescente (ECA), aprovado em 1990, reafirma e regulamenta a garantia de direitos já expressos na Constituição Federal, propondo como compromisso uma revisão nas políticas sociais e nas posturas individuais pertinentes à infância e à juventude, a fim de reforçar os direitos constitucionais. O inciso III do artigo 54 estabelece a responsabilidade do Estado em assegurar "atendimento educacional especializado aos portadores de deficiência, preferencialmente na rede regular de ensino".

A Confederação Nacional sobre Educação para Todos: Satisfação das Necessidades Básicas de Aprendizagens, ocorrida em Jomtien, Tailândia, em março de 1990, que resultou na Declaração Mundial sobre Educação para Todos, na qual se deflagram algumas dificuldades existentes relacionadas à garantia do direito à educação e prevê a uni- 
versalização das oportunidades educacionais igualitárias e de qualidade a todos, buscando garantir a igualdade de acesso à escola aos alunos com deficiência.

Carvalho ao referendar-se a essa Declaração diz que,

No que tange aos portadores de deficiência, pode-se dizer que são considerados tanto como cidadãos "comuns" quanto cidadãos "peculiares": são considerados cidadãos comuns ao se propor que o acesso à educação com equidade seja universalizado a todos (Art. $3^{\circ}$ ) e peculiares ao explicitar-se que é preciso garantir-lhes igualdade de acesso á educação como parte integrante do sistema educativo, independente do tipo de deficiência que possuam (Art.5 ). (CARVALHO, 1999.p.23).

A Conferência Mundial sobre Necessidades Educativas Especiais, promovida pelo governo da Espanha e pela UNESCO, em junho de 1994, que resultou na Declaração de Salamanca Sobre princípios, política e prática em Educação Especial, na qual reafirma o "compromisso para com a Educação para Todos, reconhecendo a necessidade e urgência do providenciamento de educação para crianças, jovens e adultos com necessidades educacionais especiais dentro do sistema regular de ensino". (SALAMANCA,1994, p.01).

O Artigo $2^{\circ}$ (Declaração de Salamanca) proclama que toda criança tem direito à educação, devendo ser respeitada no desenvolvimento de sua aprendizagem, levando em conta a diferença, os interesses e as necessidades de aprendizagens, que por sua vez são singulares, e mais:

- Sistemas educacionais deveriam ser designados e programas educacionais deveriam ser implementados no sentido de se levar em conta a vasta diversidade de tais características e necessidades, - aqueles com necessidades educacionais especiais devem ter acesso à escola regular, que deveriam acomodá-lo dentro de uma pedagogia centrada na criança, capaz de satisfazer a tais necessidades,

- Escolas regulares que possuam tal orientação inclusiva constituem os meios mais eficazes de combater atitudes discrimina- 
tórias criando-se comunidades acolhedoras, construindo uma sociedade inclusiva (...) (op.cit.).

O conteúdo do $3^{\circ}$ artigo, da referida Declaração, demanda certas ações para todos os governos, como:

- atribuir prioridade política e financeira para melhoramentos dos sistemas educacionais, para que possam atender todas as crianças, independente das diferenças singulares;

- adotar o principio de educação inclusiva com garantias legais e políticas;

- desenvolver projetos de intercâmbios entre países para troca de experiências;

- estabelecer meios participativos e de descentralização para planejamento, revisão e avaliação da educação de alunos com NEE;

- facilitar e encorajar a participação da família dos alunos especiais no processo educativo;

- investir esforços para identificação e intervenção precoce;

- garantir a formação dos docentes através de programas de treinamento em serviço para atendimento de alunos com NEE.

Ressaltam-se, igualmente, dentre os instrumentos legais mais recentes, que dão conta da sustentação de uma escola inclusiva:

A Lei de Diretrizes e Bases da Educação Nacional - Lei n ${ }^{\circ}$ 9.394, de 1996, que pela primeira vez destina um capítulo a Educação Especial (Capitulo V), cuja relevância do conteúdo dá conta da garantia da matrícula dos alunos com NEE, preferencialmente na rede regular de ensino (Artigo 58).

A Educação Especial passa a ser compreendida como organização das práticas pedagógicas da "Modalidade de Educação Escolar" a ser oferecida a qualquer cidadão brasileiro que dela precise com amplos direitos para seu desenvolvimento humano e contemplação de sua cidadania, estendendo-se desde a educação básica até a educação superior aos alunos com NEE. O parágrafo $1^{\circ}$ do artigo 58 diz que "haverá, quando necessário, serviços de apoio especializados, na rede regular 
para atender às peculiaridades da clientela de educação especial”. No mesmo artigo o parágrafo $2^{\circ}$ define que "o atendimento educacional será feito em classes, escolas ou serviços especializados, sempre que, em função das condições especificas dos alunos, não for possível a sua integração nas classes comuns do ensino regular".

O Plano Nacional de Educação, Lei no 13.005/2014, no tema referente à Educação Especial com 19 estratégias tem como meta:

universalizar, para a população de quatro a dezessete anos com deficiência, transtornos globais do desenvolvimento e altas habilidades ou superdotação, o acesso à educação básica e ao atendimento educacional especializado, preferencialmente na rede regular de ensino, com a garantia de sistema educacional inclusivo, de salas de recursos multifuncionais, classes, escolas ou serviços especializados, públicos ou conveniados.

Nesse Plano Nacional de Educação são definidas as diretrizes para a gestão e o financiamento de educação; as diretrizes e metas para cada nível e modalidade de ensino e também diretrizes e metas para a formação e valorização do magistério e demais profissionais da educação nos próximos dez anos.

A Resolução $C N E / C E B N^{\circ} 2$, de 11 de setembro de 2001, na qual institui-se as Diretrizes Nacionais para a educação especial na educação básica. No artigo $2^{\circ}$ diz que "os sistemas de ensino devem matricular todos os alunos, cabendo às escolas organizar-se para o atendimento aos educandos com necessidades educacionais especiais".

No que tange à formação dos docentes para atuar em escolas inclusivas, declara a Resolução em consonância com o Artigo 59 da LDB 9394/96, que as escolas devem contar com profissionais capacitados e especializados, com nível superior, em curso de licenciatura de graduação plena (Artigo 18), No parágrafo $1^{\circ}$ do mesmo artigo,

São considerados professores capacitados para atuar em classes comuns com alunos que apresentam necessidades educacionais especiais àqueles que comprovem que, na sua formação, de nível médio ou superior, foram incluídos conteúdos sobre edu- 
cação especial adequados ao desenvolvimento de competências e valores (...) (BRASÍLIA - DIÁRIO OFICIAL, 2001.p.03).

As diretrizes atuais da Educação Especial estão regulamentadas no Decreto Federal № 7611/2011, o Art. 2o diz que, “A educação especial deve garantir os serviços de apoio especializado voltado a eliminar as barreiras que possam obstruir o processo de escolarização de estudantes com deficiência, transtornos globais do desenvolvimento e altas habilidades ou superdotação".

\section{E a Lei № 13.146/2015 que institui a Lei Brasileira de In- clusão (LBI) da pessoa com deficiência com o objetivo de asse- gurar e promover em condições de igualdade, o exercício dos seus direitos fundamentais, visando à sua inclusão social e cidadania. \\ Os serviços da educação especial se constituem do Atendimento Educacional Especializado - AEE, que são prestados de acordo com o Inciso $1^{\circ}$ :}

I - complementar à formação dos estudantes com deficiência, transtornos globais do desenvolvimento, como apoio permanente e limitado no tempo e na frequência dos estudantes às salas de recursos multifuncionais; ou

II - suplementar à formação de estudantes com altas habilidades ou superdotação.

A Resolução CNE/CEB no 4/2009, estabelece as diretrizes Operacionais para o AEE na Educação Básica e diz que esse atendimento deve ocorrer, prioritariamente, nas salas de recursos multifuncionais na própria escola onde o aluno com necessidade especial estuda ou em outra escola de ensino regular, no contraturno da escolarização, não sendo substitutivo às classes comuns, podendo ainda ser realizado nas escolas especiais.

As medidas legais expostas evidenciam conquistas e avanços no âmbito do atendimento educacional dos alunos com deficiência. Mas, como bem diz Mazzota (2000), quando se reporta às conquistas no âmbito das normas e recomendações oficiais: 
No entanto, a efetivação da educação escolar para todos, mediante recursos tais como a educação especial preferencialmente na rede regular de ensino para os que a requeiram ou educação inclusiva onde a diversidade de condições dos alunos possa ser competentemente contemplada e atendida, demandará uma ação governamental e não governamental marcada pela sinergia, que algumas vezes parece ser enunciada. Isto sem ignorar que a verdadeira inclusão escolar e social implica essencialmente um sentimento ou atitude de respeito ao outro como cidadão. (MAZZOTA, 2000.p.23).

As políticas públicas educacionais no Brasil revelam a intenção da consolidação de uma escola de qualidade para todos. Neste sentido, será mediante uma atuação cidadã que todos os membros de uma sociedade terão adquirido condições de sujeitos, com plena inserção e atuação social.

\section{A interface entre Educação Especial e as Representações Sociais na Prática Pedagógica.}

Para podermos construir uma interface relevante entre as representações sociais e a educação especial foi feita uma análise das concepções dos autores Oliveira (2004) e Sá (1993) que trazem contribuições acerca das representações sociais e Correia (1994), Blanco (1999) e Stainback (1999) que verticaliza sobre a educação especial, além de outros autores e legislações citados anteriormente para auxiliar no processo de fundamentação teórica.

Apesar de serem assuntos distintos, os autores acabam por se complementar em seu discurso, uma vez que as temáticas trabalhadas atuam de forma interdisciplinar em um processo contínuo de transformação e construção de saberes necessários à prática profissional, humana e social. Assim, é necessário compreender que o atual paradigma da inclusão, da escola inclusiva, propõe mudanças consideráveis quanto ao atendimento educacional dos alunos com deficiência, uma vez que estes alunos deverão compartilhar, com os alunos ditos normais, do mesmo espaço para se educar. 
Educação inclusiva significa provisão de oportunidades equitativas a todos os estudantes, incluindo aqueles com deficiências severas, para que eles recebam serviços educacionais eficazes, com os necessários serviços suplementares de auxílios e apoios em classes adequadas à idade em escolas da vizinhança, a fim de prepará-los para uma vida produtiva como membros plenos da sociedade. (CENTRO NACIONAL DE REESTRUTURAÇÃO E INCLUSÃO EDUCACIONAL, 1994 apud. SASSAKI,1997. p.122).

A partir desta definição de educação inclusiva é possível observar distintos aspectos imbricados no processo de viabilização para essa nova escola, no que concerne às responsabilidades a serem assumidas para concretização do empreendimento. Já que "o conceito de escola inclusiva é ligado à modificação da estrutura, do funcionamento e da resposta educativa, de modo que se tenha lugar para todas as diferenças individuais, inclusive aquelas associadas a alguma deficiência" (BLANCO, 1999, p.10).

Oportunamente, resgatam-se alguns indicadores gerais da educação inclusiva, tais como:

1- Aceitação de todas as crianças e de todos os adultos jovens como pessoas em primeiro lugar.

2- Compromisso de oferecer o máximo de apoio que um estudante necessita para ter êxito em tantos ambientes educacionais comuns e ambientes comunitários quanto possível.

3- Professores terapeutas, paraprofissionais e diretores vendo a si próprios em uma nova perspectiva, como uma equipe que inclui os pais como membros iguais e que enfatiza a criatividade.

4- Enfoque nos sonhos dos pais para o futuro dos seus filhos.

5- Uma compreensão do fato de que não é necessário que todos os estudantes tenham as mesmas metas educacionais para aprenderem juntos em classes comuns.

6- Uso de "um bom ensino" para todos (SASSAKI,1997, p.124). 
Esses indicadores estão em consonância com os princípios estabelecidos na Declaração de Salamanca (1994) quando observa a necessidade de todas as crianças serem educadas juntas, indistintamente, numa tendência que incorpore a integração e a participação no combate a exclusão social, que no âmbito da educação se reflete na busca de procedimentos que vislumbrem a equalização de oportunidades.

A política de inclusão de alunos que apresentam necessidades educacionais especiais na rede regular de ensino não consiste apenas na permanência física desses alunos junto aos demais educandos, mas representa a ousadia de rever concepções e paradigmas, bem como desenvolver o potencial dessas pessoas, respeitando suas diferenças e atendendo suas necessidades. (MEC, SEESP, 2001, p.31).

Neste sentido, além da garantia de acesso à escola, os alunos precisam ter garantias de permanência no interior das mesmas, com uma educação respaldada em suas necessidades e interesses, acrescenta-se que não basta apenas incluir o aluno com deficiência na escola comum, mas também se responsabilizar com o processo de ensino para o sucesso dos alunos, respeitando e valorizando as diferenças. Com isso,

o respeito e a valorização da diversidade dos alunos exigem que a escola defina sua responsabilidade no estabelecimento de relações que possibilitem a criação de espaços inclusivos, bem com procure superar a produção, pela própria escola, de necessidades especiais. (MEC, SEESP, 2001, p.31).

Deste modo, para a inserção do aluno com necessidade especial, de fato e de direito, no ensino regular, emerge a necessidade de revisão da sua organização como um todo, para que possa estar assentada na ideia de preparar-se para a diversidade dos seus alunos. Assim, será a escola que deverá adequar-se às necessidades dos seus alunos, preocupada na busca de alternativas concretas para tais necessidades. "Dessa forma, não é o aluno que se molda ou se adapta à escola, mas é ela que, consciente de sua função, coloca-se à disposição do aluno', tornando-se um espaço inclusivo" (id. Ibid.).

Oliveira (2004) tensiona a seguinte reflexão acerca desta seara:

As pessoas cegas, as pessoas surdas, as pessoas com Síndrome de 
Down ou com paralisia cerebral são referidas no âmbito social e escolar, como pessoas: "inválidas", "defeituosas", "deficientes", “incapazes", “excepcionais" e "portadoras de deficiências".

O olhar sobre essas pessoas no imaginário coletivo social e educacional é o de seres "diferentes" e "incapazes", por isso, não aceitos, não respeitados como cidadãos, rotulados e excluídos pela sociedade. (OLIVEIRA, 2004, p.169)

Portanto, o ensino inclusivo exige uma renovação da escola, para que se torne espaço acolhedor e sensível, capaz de responder de maneira eficiente e humana às necessidades e habilidades especificas de todos os alunos. Tendo em vista que os princípios da educação não são dirigidos apenas para os alunos com deficiência, mas para todos os alunos, tornando-se impossível pensar na reestruturação em sentido fragmentado, visando apenas às necessidades de um grupo-alvo.

No entanto, segundo Correia (1999), algumas questões devem ser avaliadas quanto à inclusão dos alunos na rede regular de ensino, pois apesar de ser evidente que, com serviços e apoio suplementar adequados, os alunos podem atingir os objetivos educacionais propostos, é preciso, na realidade da escola, analisar algumas questões implicadas nas mudanças que devem ocorrer para contemplação de uma educação inclusiva, tais como: os tipos de mudanças que serão realizadas quanto à organização, gestão e apropriação curricular, a formação dos docentes e as redes de apoio.

Releva-se, tal afirmação, devido a dois argumentos suscitados pelo autor,

O primeiro tem a ver com o factor mudança, ou seja, a realização de reformas de fundo não ocorre de um dia para o outro deve ser sempre um processo em curso, devidamente estudado. O segundo relaciona-se com a filosofia do "tudo ou nada", ou seja, não nos parece realista, nem exeqüível, face ao clima educacional do momento e aos recursos existentes, tentar impor uma filosofia que continua a ser tão debatida por investigadores e educadores. (CORREIA, 1999, p.34). 
Para este autor, o conceito de inclusão deve ser flexível, permitindo opções para cada situação apresentada, principalmente quando se trata de alunos com NEE severas.

Somos pela inserção do aluno com NEE, mesmo com NEE, na classe regular, sempre que isso seja possível, mas acreditamos na salva-guarda dos seus direitos, que pode ser posta em causa caso não se respeitem as características e as necessidades especificas desse aluno (op.cit.).

A inclusão de alunos com deficiências severas deve ser feita sempre que possível na rede regular de ensino, mas que lhes seja garantido um apoio apropriado, que atenda suas reais necessidades. "A nosso ver a inclusão baseia-se, portanto, nas necessidades da criança, vista como um todo, e não apenas no seu desempenho acadêmico, comparado, ainda por cima tantas vezes, com o desempenho acadêmico do 'aluno médio" (op.cit.).

A escola como espaço de inclusão deve reconhecer que todos na escola são merecedores de atenção, independentes de suas diferenças, e que "as boas escolas são boas escolas para todos os alunos" (STAINBACK E STAINBACK,1999, p.69).

Correia (1999), cita um conjunto de responsabilidades que estão vinculadas a implementação de um sistema de ensino inclusivo, que dizem respeito ao Estado, à escola, à família e à comunidade.

Quanto às responsabilidades do Estado é relevante que:

- a legislação deve considerar as reformas necessárias para implantação e implementação de um "sistema inclusivo";

- os financiamentos assegurem os recursos humanos e materiais necessários para realizar a inclusão dos alunos com NEE;

- as escolas tenham autonomia para implementarem a inclusão de acordo com sua realidade;

- considere alternativas de formação que levem em conta os princípios da inclusão a nível superior e a nível de formação continuada. 
- A escola, igualmente, deve planejar sua organização no sentido de fazer a inclusão dos alunos com NEE de forma consciente, envolva-se com a família em prol do desenvolvimento global do aluno, compreenda os limites e trabalhe as potencialidades dos alunos, considerando as adaptações curriculares necessárias.

No que diz respeito às responsabilidades da família destaca-se a importância da sua participação ativa na escola, para que possa estar inteirada sobre o que acontece em relação à educação de seu filho e compreenda a dinâmica da inclusão, para que possa desempenhar com sucesso e de forma segura o seu papel.

E, por fim, as responsabilidades da comunidade, na educação e transição para a vida ativa do aluno com deficiência. Assim, sua participação deve ser a "interligação entre os serviços comunitários e a escola para responder às necessidades especificas do aluno e da família, com vista a um desenvolvimento global do aluno". (CORREIA, 1999, p.37). Sá (1993) contribui para esta discussão quando afirma que os sujeitos que integram a sociedade são portadores e usuários das representações coletivas, ou seja, são reprodutores do pensar que já está ancorado pela sociedade em sua representação.

Neste sentido, para a reestruturação da escola são imprescindíveis planejamentos contínuos e consistentes, visando a qualidade do processo educativo através de ações coletivas e responsável em diferentes aspectos, para que se possa implementar a educação inclusiva, visando ajustá-la todos os alunos. Tais aspectos são: missão da escola, contemplada no projeto educativo; papel do gestor; redes de apoio; adequações curriculares, necessárias para a inserção do aluno com deficiência e a formação docente que deve dar conta de uma educação para diversidade.

No âmbito da escola, Stainback; Stainback (1999), afirmam que o primeiro e mais importante passo a ser dado será a definição da missão da escola, pautada em princípios democráticos, igualitários e estabelecimento de um plano de ação prevendo uma educação de qualidade para todos os alunos, no contexto do projeto escolar.

$\mathrm{O}$ ensino deve estar voltado para as necessidades e interesses gerais dos alunos, não apenas para a formação acadêmica, mas para a totalidade, abrangendo as esferas do desenvolvimento acadêmico, 
social, emocional, a responsabilidade pessoal e coletiva e a acima de tudo a cidadania.

No processo de elaboração da missão da escola e do plano estratégico todos os envolvidos devem ser motivados a participar, "pois quaisquer discussões e planejamentos visando a reforma da escola devem incluir as pessoas que estão diretamente envolvidas: alunos, pais, educadores, diretores, pessoal de apoio e membros da comunidade (id.,70).

Outro elemento importante citado por Stainback; Stainback (1999) é o papel do gestor da escola, que deve "reconhecer sua responsabilidade de definir os objetivos da escola e de garantir a tomada de decisões, o enfrentamento dos desafios e o apoio às interações e aos processos que se compatibilizam com a filosofia da escola" (p.71). Neste sentido, o gestor escolar será um líder na busca de garantias de uma educação de sucesso para todos os alunos: oportunizando espaços para qualificação em serviço para os docentes, promovendo bons relacionamentos entre alunos e contribuindo para que toda a escola seja acolhedora e mantenha atitudes de comunidade.

No sistema de ensino inclusivo, portanto, os gestores devem ter a responsabilidade de melhorar os relacionamentos sociais, para que a escola seja verdadeiramente acolhedora e aprecie e acomode a diversidade.

Assim, na escola inclusiva, a reunião dos esforços dos seus membros é importante para garantir conexões sociais, oportunizando relacionamentos tranquilos, criando círculos de amizades que contribuam para um bom ensino, já que "é na escola que as crianças e os jovens passam uma quantidade substancial do seu tempo e é lá que muitas de suas conexões sociais são feitas. Além disso, as amizades e os relacionamentos são realmente pré-condições para a aprendizagem". (FOREST, In: STAINBACK; STAINBACK,1999, p.73).

Desta forma, a escola, como espaço de inclusão, deve reconhecer que todos na escola são merecedores de atenção, independente se suas diferenças, e que "as boas escolas são boas escolas para todos os alunos" (STAINBACK; STAINBACK,1999, p.69). 


\section{Considerações Finais}

No decorrer da pesquisa para esta produção podemos constatar a relevância que as representações sociais possuem para a educação especial e a forma como uma está intrinsecamente ligada e relacionada à outra. As ideias construídas e debatidas no texto nos levaram a refletir sobre o olhar do outro diante do sujeito que possui uma necessidade educacional especial.

O percurso histórico/ normativo construído no tópico que tratou sobre a educação especial pode nos dar embasamento suficiente para compreender a importância que esta possui dentro da educação como um todo. As representações sociais, bem desenvolvidas e com as ideias articuladas de Moscovici, Jodelet e Sá, puderam nos fazer refletir sobre como possuímos enraizado em nós muitas concepções que fazem parte do nosso eu e que nunca percebemos antes.

Estas concepções acabam por nos delimitar uma noção prévia de algo sem ter ao menos vivenciado, e assim passamos a compreender que nossos mínimos gestos ou palavras, acabam por reproduzir um conceito, um ideal que vem impregnado na sociedade. Quando chamamos um usuário de cadeira de rodas de "cadeirante", por exemplo, estamos fazendo uma representação daquela pessoa, como se ela se limitasse apenas àquela cadeira. Quando dizemos que temos um aluno autista, estamos delimitando e restringindo aquele educando à sua peculiaridade. Quando reproduzimos o discurso que é "impossível” alfabetizar um aluno surdo-cego, estamos o categorizando como incapaz.

Portanto, as representações sociais na educação especial atuam numa interface que vem nos fazer refletir sobre nossa práxis, em como estamos representando o indivíduo, o sujeito que possui uma necessidade educacional especial e isto pode ser definitivo para o sucesso ou fracasso daquele ser humano. E quando falo fracasso, não me remeto apenas ao ambiente escolar ou acadêmico, mas sim ao fracasso que podemos estigmatizar enquanto ser humano. Nossa necessidade de "encaixotar" a tudo e a todos em nossos "arquivos pessoais" pode trazer consequências irreversíveis quando tratamos com a interface da educação especial. 
Referências

BAPTISTA, Claudio Roberto; JESUS, Denise Meyrelles de; CAIADO, Katia Regina Moreno. Professores e Educação Especial: formação em foco. 2 v. Porto Alegre: Mediação, 2011.

BLANCO, Rosa. Aprendendo na Diversidade: Implicações Educativas. Artigo anexado Oficio Circular N77/99 - Brasília/FENAPAE.

BRASIL, Direito à Educação: Necessidades Educacionais Especiais: Subsídios para atuação do Ministério Público Brasileiro - Brasília: MEC, SEESP, 2001, 11 - 09.

. Estatuto da Criança e do Adolescente (1990) - 2. ed. rev. e aum. - Brasília: Imprensa Nacional, 1997.

, Ministério da Educação. Secretária de Educação Especial. Parâmetros Curriculares Nacionais - Adaptações Curriculares: Estratégias para Educação de Alunos com Necessidades Educativas Especiais. Brasília: MEC/SEF, 1999.

BRASÍLIA, Salto para o Futuro: Educação Especial a Distancia. Brasília: Ministério da Educação, SEES, 1999.

CORREIA, Luis Miranda. Alunos com Necessidades Educativas Especiais na Classe Regular. Porto Editora: Portugal, 1999.

FREIRE, Paulo. Pedagogia da autonomia: Saberes necessários à prática educativa. 34 ed. São Paulo: Paz e Terra, 1996.

JODELET, D. Représentations Sociales: phénomènes, concept et théorie. In: MOSCOVICI, Se. (ed.). Psychologie sociale. Paris, Presses Universitaires de France, 1984.

MAZZOTA, Marcos J. S., Educação Especial no Brasil: Histórias e Políticas Públicas. 3ª ed., São Paulo: Cortez, 2001.

MOSCOVICI, Serge. Representações sociais: Investigações em psicologia social. Petrópolis, RJ: Vozes, 2003. 
OLIVEIRA, Ivanilde Apoluceno de. Saberes, imaginários e representações na educação especial: A problemática ética da "diferença” e da exclusão social. Petrópolis, RJ: Vozes, 2004.

SÁ, Celso Pereira de. Representações sociais: o conceito e o estado atual da teoria. In Spink, M. J. P. (Ed.), O conhecimento no cotidiano. As representações sociais na perspectiva da psicologia social (pp. 19-45). São Paulo, SP: Brasiliense, 1993.

SASSAKI, Romeu Kazumi. Inclusão: Construindo um mundo para TODOS. Coleção Inclusão. Rio de Janeiro:VWA, 1997.

STAINBACK, Susan; STAINBACK, William. Inclusão: Um guia para educadores. Trad. Magda França Lopes. Porto Alegra: Artes Médicas Sul, 1999. WERNECK, Cláudia. Ninguém mais vai ser bonzinho na sociedade inclusiva. Coleção Inclusão. Rio de Janeiro:WVA, 1997. 


\section{EDUCAÇÃO MATEMÁTICA: O ENSINO POR MEIO DA RESOLUÇÃO DE PROBLEMAS.}

José Antônio de Oliveira Júnior

\section{INTRODUÇÃO}

Sabemos que a educação está presente em todos os lugares, em casa, na escola, ou na rua, seja ela formal ou informal. Deste modo estamos presos a ela, mesmo sem que percebamos. Sendo assim a educação não é algo apenas da vida escolar, mas sim da vida de qualquer ser humano.

Quando passamos a entender Educação Matemática, podemos perceber que a disciplina "Matemática" não pode ser ensinada nem aprendida como um conjunto de conteúdos prontos e acabados sem ligação com os problemas que enfrentamos diariamente.

Muitos estudos foram e continuam sendo feitos na área de Educação Matemática e tem sido comprovado que ela é de fundamental importância na formação do indivíduo, como cidadão crítico e para sua inserção social.

No entanto, alguns professores insistem em usar esta ciência como meio de selecionar os alunos, e classificá-los em "inteligentes" ou "incapazes", como se esta fosse uma disciplina para poucos, provocando assim um alto índice de evasão e reprovação. Assim, a Matemática continua sendo o "bicho papão" da maioria das escolas.

Muitos professores têm tentado modificar esse quadro, usando métodos adequados para fazer o aluno pensar construtivamente e cri- 
ticamente os assuntos trabalhados. Para que isso ocorra é necessário que conheçamos nossos alunos, para assim trabalharmos em cima da problemática e da realidade deles.

\section{A ARTE DE RESOLVER PROBLEMAS.}

O livro aborda o anseio de G. Pólya em ajudar os professores que desejam desenvolver nos seus alunos a capacidade de resolver problemas e estudantes que queiram desenvolver essa capacidade.

Toda a obra baseia-se em uma lista, titulada Como Resolver um Problema, esta procura agrupar as indagações do trabalho em quatro fases: Primeiro temos que compreender o problema; segundo, temos que ver como a incógnita está associada aos dados para estabelecer um plano; terceiro, executar o plano; quarto faz um retrospecto da resolução completa revendo-a e discutindo-a.

O professor tem como um dos principais papéis o de auxiliar o aluno, no entanto, esse auxílio deve ser feito na dosagem certa, nem demais, nem de menos, para que assim, o aluno possa desenvolver o trabalho que lhe cabe.

Devemos ter cuidado ao escolher o problema, é preciso que esteja numa linguagem acessível aos alunos. Ele não pode ser nem muito fácil, nem muito difícil, mas interessante, para que desperte no aluno o desejo de resolvê-lo. Sendo assim, o aluno estará disposto a analisar o problema de forma atenta e repetidamente, analisando todas as possibilidades possíveis.

Se o problema estiver causando um difícil entendimento o professor pode torná-lo mais fácil e interessante concretizando-o, como o exemplo da diagonal de um paralelepípedo retângulo.

Para que possamos estabelecer um plano é preciso primeiramente, que tenhamos uma idéia do que iremos aplicar (contas, cálculos ou desenhos) para podermos selecionar o problema. Essa idéia baseia-se em experiências passadas ou conhecimentos prévios, assim devemos tentar lembrar se já vimos ou resolvemos um problema parecido.

Tendo o plano estabelecido fazemos à verificação de seus passos e os executamos chegando a uma solução que deverá passar por um 
retrospecto, este propiciará uma consolidação do conhecimento e seu aperfeiçoamento para a resolução de problemas. Tanto o professor, quanto o aluno deverão compreender a importância dessa última fase, pois a parir dela o aluno poderá perceber melhor todas as etapas utilizadas para a resolução e poderá fazer uma melhor associação com outros problemas e utilizar o resultado do problema anterior para resolvê-los.

O método de questionar do professor proposto na lista começa por indagações, podendo ir adiante até provocar a resposta na mente do aluno. "O nosso método permite certa elasticidade e variação, admite abordagens diversas, pode e deve ser aplicado de tal maneira que as questões apresentadas pelo professor possam ter ocorridas ao próprio aluno.”(POLYA,1994,p.14)

É necessário fazer indagações e descer gradualmente para que as dúvidas do aluno sejam esclarecidas, mas que sobre uma parcela significativa de trabalho suficiente para que o aluno desenvolva um hábito mental.

\section{DIDÁTICA DA RESOLUÇÃO DE PROBLEMAS.}

Didática da Resolução de Problemas de Luís Roberto Dante baseia-se nas idéias de Pólya buscando despertar a sensibilidade dos mestres para a sua prática pedagógica mostrando a importância e a necessidade da implantação de situações-problemas em suas aulas, e assim, incentivar os alunos a elaborar e resolver problemas naturalmente.

Há uma grande preocupação por parte de professores e equipe pedagógica no cumprimento do programa escolar que é estabelecido antes de se conhecer a turma que será trabalhada, dando assim mais importância à quantidade de conteúdos trabalhados e focalizando sua atenção nas respostas corretas no menor tempo possível, impedindo assim que os alunos mostrem seus conhecimentos adquiridos fora do ambiente escolar e desenvolvam habilidades que serão de maior proveito para eles e para o andamento das aulas.

Dante mostra a visão de o porquê estudar ou ensinar Matemática, usando palavras de outros autores, que de uma forma geral vêem a Matemática como uma importantíssima ferramenta para a resolução de 
problemas de naturezas diversas. "A principal justificativa para se ensinar Matemática é que ela é útil e, em particular, auxilia na solução de muitas espécies de problemas".(DANTE,2002, pág.7).

Encontra-se frequentemente nos livros didáticos, em livros acadêmicos e em muitos textos matemáticos os termos "resolução de problemas" e "situações problemas". Ouvimos todo o tempo os educadores dizerem que temos que contextualizar o ensino da Matemática e para isso um dos recursos seria trabalharmos com problemas que estejam ligados a vivência do aluno. Mas, o que é um problema?

$\mathrm{O}$ autor separa o conceito de problema e problema matemático, no entanto os dois têm quase o mesmo significado. "Problema é qualquer situação que exija o pensar do indivÍduo para solucioná-la". (DANTE,2002,p.9)

Ao aplicarmos um problema matemático, estamos exigindo um pensar que envolve conhecimentos matemáticos.

Dentre vários objetivos, o principal para se estudar problemas é que a parir deles o aluno irá desenvolver o raciocínio lógico e um pensar matemático dando sentido ao estudo da Matemática.

Mas iremos aqui ressaltar e questionar os objetivos da resolução de problemas que Dante considera importantes. Entre eles temos:

- Fazer o aluno pensar produtivamente.

Vemos que existe aluno que se encontra no Ensino Médio, mas não é capaz de elaborar ou desenvolver um problema, talvez não por lhe ter sido apresentado situações problemas que o envolvesse, o desafiasse e o motivasse a resolvê-lo. Tudo isso leva o aluno a se envolver com Matemática de maneira que ele possa pensar de forma produtiva.

- Desenvolver o raciocínio do aluno.

Não basta que o aluno resolva problemas propostos em sala de aula, mas sim que ele seja capaz de desenvolver um raciocínio lógico que o levará a elaborar e executar estratégias necessárias para chegar à solução de qualquer problema. Desenvolvendo esse raciocínio ele poderá solucionar problemas, como: 
Qual o caminho mais curto da escola à sua casa?

De imediato o aluno pode estabelecer que o caminho deva ser aquele que ele percorre todos os dias. No entanto ao ser questionado ele pode começar a pensar em outras hipóteses, podendo assim, utilizar conhecimentos aprendidos na sala de aula como: distância entre dois pontos, unidades de comprimento, dentre outros para se chegar a uma solução satisfatória.

- Ensinar o aluno a enfrentar situações novas.

Hoje não basta que ensinemos aos nossos alunos apenas a aplicação de algoritmos, pois com o avanço cada dia maior da tecnologia, em muitas situações esses conhecimentos será necessário aplica-los. Mas é preciso oferecer ao aluno recursos e condições que os façam pensar de forma rápida, criativa e independente através da resolução de problemas.

- Dar ao aluno a oportunidade de se envolver com as aplicações da Matemática.

Com o uso abusivo de algoritmos e suas aplicações o aluno torna-se desinteressado pela Matemática e passa a detestá-la. Mas se começarmos a ensiná-la de uma maneira mais interessante que o envolva e que melhor se assemelhe a sua condição real, esse trabalho terá um melhor rendimento. No entanto, é preciso quando e como usa-la convenientemente na resolução de situações problemas.

- Tornar as aulas de Matemática mais interessantes e desafiadoras.

A prática pedagógica que foi muito usada e em algumas escolas continua sendo, ou seja, a de explicar e repetir desestimula e causa um desinteresse por parte dos alunos, por isso, é uma condição importante que as aulas de Matemática sejam executadas de forma mais ativa e participativa fazendo o aluno desenvolver uma curiosidade e um interesse ao resolver uma situação problema que exigirá dele um estado de pesquisa. 
- Equipar o aluno com estratégias para resolver um problema.

Deve ser esclarecido ao aluno que para se chegar à solução de um problema é preciso criar-se uma ou várias estratégias que possibilitem chegar à solução desejada.

- Dar boa base matemática às pessoas.

As resoluções de problemas são de fundamental importância no estudo da Matemática, pois ela possibilita que o aluno se torne uma pessoa ativa e participativa, estando assim pronto para tomar decisões rápidas e precisas e sendo capaz de resolver qualquer situação - problema.

Os problemas classificam-se em:

- Exercícios de reconhecimento

- Exercícios de algoritmos

- Problemas-padrão

- Problemas-processos ou heurísticos

- Problemas de aplicação

- Problemas de quebra-cabeça.

Para resolvermos um problema com sucesso è preciso que passemos por algumas etapas. O autor cita as quatro etapas principais segundo Pólya(1994):

- Compreender o problema

- Elaborar um plano

- Executar o plano

- Fazer o retrospecto ou verificação.

Entretanto “.Estudar Matemática é resolver problemas. Portanto, a incumbência dos professores de Matemática, em todos os níveis, é ensina a arte de resolver problemas. O primeiro passo nesse processo é colocar o problema adequadamente".(DANTE,2002,P.43).

O problema deve ser colocado adequadamente, pois não basta trabalhar situações-problemas, se estas não envolvem os alunos, não 
despertam o interesse, não tem nenhuma semelhança com o seu cotidiano, não estiverem elaborados dentro de um contexto que ao ler entenda o que ela quer transmitir e o que está sendo pedido. Precisamos ter cuidado com os dados que vão ser disponibilizados no problema, verificar se esses dados serão suficientes para uma boa interpretação.

Todas estas condições possibilitam à pessoa um melhor entendimento do problema dando condições para que este seja resolvido com sucesso.

Antes de disponibilizar todas estas condições é necessário que o professor saiba distinguir um exercício de um problema.

Exercício como o próprio nome diz serve para exercitar, para aplicar algum conteúdo já trabalhado e verificar se este foi assimilado.

Problema ou situação-problema é uma situação que previamente não se sabe qual processo ou algoritmo deverá ser utilizado. È uma situação que precisará ser analisada, e assim descobrir o elemento desconhecido do problema.

Alguns fatores dificultam o entendimento e a interpretação do problema. Ao os elaborarmos devemos ter cuidado com a linguagem usada, alguns termos comuns a nós professores não são compreendidos pelos alunos. Assim o ideal seria que fossem elaborados usando a linguagem usual.

Costuma-se propor problemas que têm no seu texto uma série de informações, tornando-se extenso e de difícil entendimento. Alguns possuem tanta informação que o aluno ao ler o final não consegue mais fazer uma relação entre seus dados. Assim o ideal seria separar frases longas em duas ou mais frases.

$\mathrm{Na}$ Matemática alguns termos são estranhos ou difíceis de serem entendidos pela criança. È preciso que o professor a ajude mostrando seus significados. Além disso, muitos problemas trazem números muito grandes fazendo com que os alunos voltem sua atenção para os números e algoritmos. Problemas como esses dificultam a interpretação de desempenho do aluno, problemas com números pequenos causarão um impacto menor e será mais bem compreendido. O mesmo ocorre com número de operações e estratégias envolvidas para resolver o problema dificultando o desenrolar do problema, quanto menor o número 
de operações, mais fácil será o entendimento, e se envolver apenas operações precisam buscar outros meios para resolvê-los.

Diante de todas as situações expostas e dificuldades citadas ao trabalhar com resolução de problemas, Dante, sugere aos professores que:

- Mudemos o método de ensino

- Trabalhemos com toda a classe

- Trabalhemos com pequenos grupos

- Ensinemos algumas estratégias

\section{PARÂMETROS CURRICULARES NACIONAIS, MATEMÁTICA NOS ANOS FINAIS DO ENSINO FUNDAMENTAL.}

A resolução de problemas na maioria das vezes não tem desempenhado seu papel nas aulas de Matemática, os problemas propostos são utilizados na aplicação de conteúdos pré-estabelecidos a partir de um currículo que nem sempre está de acordo com as necessidades dos alunos. Assim, a Matemática deixa de desempenhar o seu papel, que é o de formar cidadãos críticos e capazes de resolver qualquer problema, seja este proposto na sala de aula ou, principalmente, aqueles que aparecem no seu cotidiano.

A prática utilizada nas aulas de Matemática estimula a reprodução de procedimentos e ao acúmulo de informações. Utiliza-se a resolução de problemas para confirmar que todos os conceitos e técnicas ensinadas foram compreendidos e assimiladas.

No entanto, a resolução de problemas é vista por educadores matemáticos não da maneira exposta no parágrafo anterior, mas como um dos recursos que possibilitam ao aluno "desenvolver a capacidade para gerenciar informações que estão ao seu alcance". Assim os alunos terão a capacidade de desenvolver e ampliar seus conhecimentos, sejam estes do "seu mundo" ou da vida escolar, e entender o significado de problemas, da Matemática, do cotidiano ou de qualquer outra situação que se encontre, sendo capazes de elaborarem meios e estratégias coerentes e capazes de solucionar esse problema. 
Se lembrarmos um pouco a História da Matemática, podemos verificar que a Matemática foi desenvolvida pela necessidade de resolver alguns problemas que surgiam com o desenvolvimento da humanidade.

Muitas das vezes, os problemas expostos aos alunos em sala de aula não representam verdadeiramente um problema, pois não possuem elementos que constituam uma situação desafiadora interessante, capaz de fazer o aluno refletir e posicionar-se diante dele como se fosse um desafio que precisasse ser vencido. Para isso acontecer é necessário que estes problemas sejam bem elaborados e adaptados à situação real do aluno. "O que é problema para um aluno pode não ser para outro, em função dos conhecimentos que dispõe”.(BRASIL,1998,p.41)

Diante de uma turma que possui entre quarenta e cinquenta alunos, como é normal se encontrar nas escolas públicas, é difícil ou quase impossível encontrarmos um problema que signifique um desafio para todos, enquanto um pode assemelhar-se a situação exposta, o outro pode ver apenas como mais um exercício de aplicação. Assim precisamos mesclar os problemas que serão trabalhados numa mesma turma.

Segundo os Parâmetros Curriculares Nacionais, resolver um problema pressupõe que o aluno:

- Elabore um ou vários procedimentos de resolução (como realizar simulações, fazer tentativas, formular hipóteses);

- Compare seus resultados com os de outros alunos;

- Valide seus procedimentos.

No entanto, o que verificamos na maior parte das vezes é que o aluno mal leu o problema, após essa leitura a única pergunta que se faz é, qual a operação deve ser aplicada, aplica-se o algoritmo e não se preocupa com o verdadeiro sentido e significado do problema. Assim o aluno não desenvolve a capacidade de analisar e verificar a solução do problema." A importância da resposta correta cede lugar à importância do processo de resolução”. (BRASIL,1998,p.42)

$\mathrm{O}$ aluno deve ser estimulado a questionar a sua própria resposta, a questionar e a comparar seu resultado com os de outros colegas, para que assim desenvolva a habilidade para a construção do conhecimento. 


\section{PARÂMETROS CURRICULARES DA MATEMÁTICA NO ENSINO MÉDIO.}

A medida que o mundo vai se tornando mais globalizado vê-se a necessidade de adequar o ensino da Matemática para o desenvolvimento e promoção dos alunos, com diferentes motivações, criando condições para a sua inserção num mundo em mudança e contribuindo para desenvolver as capacidades que serão exigidas na vida social e profissional.

Todas as áreas requerem competência em Matemática, por isso torna-se fundamental compreender conceitos e procedimentos matemáticos.

A Matemática no Ensino Médio é formativa, porém seu papel é instrumental, serve para a vida cotidiana como também, contribui para desenvolver os processos de pensamento. É todo um conjunto de técnicas e estratégias para serem aplicadas a outras áreas do conhecimento permitindo modelar a realidade e interpreta-la.

O autor relata que a Matemática no Ensino Médio é formativa e instrumental, mas deve ser vista como ciência:

"É importante que o aluno perceba que as definições, demonstrações e encadeamentos conceituais e lógicos têm a função de construir novos conceitos e estruturas a partir de outros e que servem para validar intuições e dar sentido às técnicas aplicadas".(BRASIL, 1999, p.252).

Entretanto é necessário que se busque fazer uma reflexão sobre a importância das tecnologias no processo ensino-apredizagem quanto à variedade de dados que pode trazer e ajudar na construção do conhecimento.

São inúmeros objetivos que levam o aluno a compreender conceitos, procedimentos, levando-o a adqirir formação científica geral; aplicar seus conhecimentos em situações da vida; desenvolver a capacidade de raciocínio, etc.

Contudo, não basta a forma ou a metodologia de ensino. Se o conhecimento for restrito a informação, no currículo deve haver seleção 
dos conteúdos e práticas e a possibilidade de abordagem de temas que visem ao desenvolvimento das atitudes e habilidades.

Este currículo garantirá aos alunos entender e aprofundar seus conhecimentos sobre números e álgebra, não isolando de outros conceitos.

Hoje se debate muito a interdisciplinaridade nas áreas, ou seja, é um potencial que permite conexões entre diversos conceitos, formas de pensamento, sendo para o desenvolvimento da própria ciência. "Os conteúdos estarão relacionados ao desenvolvimento de habilidades para a resolução de problemas, à apropriação da linguagem simbólica, à validação de utilizar a Matemática na interpretação e intervenção no real."'( BRASIL,1999, p.257).

Dessa forma é essencial, a busca informações demonstrando habilidades, confiança no pensar, idéias fundamentadas e boas argumentações. Assim, haverá um melhor aprendizado e preocupação para a inserção no mundo do conhecimento e do trabalho.

\section{SEMELHANÇAS ENTRE OS PCNS DO ENSINO FUNDAMENTAL E MÉDIO.}

Em ambos os textos ficam evidentes a idéia de que tanto no Ensino Fundamental, como no PCN do Ensino Médio, a Matemática deve desempenhar o papel de formar cidadãos capazes de aplicar seus conhecimentos escolares em situações do cotidiano, apesar de trabalharem com faixa etárias diferenciadas, e procedimentos adaptados as séries, pois, no Ensino fundamental ainda está descobrindo definições simples, já no Ensino Médio ele começará à utilizar essas definições para demonstrar outros conceitos matemática.

No Ensino Médio os educadores passam a se preocupar com a questão global, que é o avanço tecnológico e os conhecimentos que o indivíduo deve carregar para que possa acompanhar e contribuir, de alguma forma, para que o processo de descobertas de coisas novas que serão úteis na sociedade. No Ensino Fundamental o aluno, principalmente nas séries iniciais, não está muito preocupado, ou pouco tem conhecimento sobre essas questões, por isso, é mais importante aguçar a curiosidade do aluno a partir de conhecimentos presentes no seu dia-a-dia e aos poucos, introduzindo outros fatos mostrando suas importâncias. 
A resolução de problemas, conforme for trabalhada, é essencial para que haja uma relação entre a Matemática e outras áreas do conhecimento, pois como já foi citado no capítulo anterior, todas as áreas requerem competência em Matemática.

Nos dois PCN's é esclarecido também que, não devemos dar importância aos conteúdos de forma isolada, mas deixar claro que estes estão relacionados com o desenvolvimento das habilidades para a resolução de problemas, pois só assim ao fim do Ensino Médio teremos um cidadão capaz de produzir, fundamentar e argumentar idéias, o que lhe tornará destacável perante seu meio social.

\section{CONSIDERAÇÕES FINAIS}

A resolução de problemas não é novidade no estudo da Matemática, no entanto, seu emprego não vem sendo feito de maneira adequada, é necessária no processo de desenvolvimento, tem uma função vital para o indivíduo, principalmente como meio de desenvolvimento do raciocínio lógico que poderá beneficiá-lo nas suas relações sociais, principalmente no trabalho.

Os PCNs ( Parâmetros Curriculares Nacionais) propõem uma mudança de enfoque em relação aos conteúdos curriculares, já que eles zelam por uma formação básica para a cidadania, assim, em vez de um ensino em que o conteúdo é passado de forma abstrata, deverá contribuir para que os alunos desenvolvam as capacidades que lhes permitam produzir e usufruir os bens culturais e econômicos.

Diante dos fatos chegamos a conclusão de que é impossível descrever com palavras um método para resolver qualquer problema, o que podemos fazer é estimular cada vez esta prática pedagógica fazendo o aluno pensar e discutir sobre suas soluções, tornando-o cada vez mais crítico e participativo.

\section{REFERÊNCIAS BIBLIOGRÁFICAS}

\section{BICUDO, Maria Aparecida V. Pesquisa em educação Matemá-} tica. Concepções e perspectivas. São Paulo: UNESP, 1999, p. 41 
BICUDO, Maria Aparecida V. Educação Matemática. São Paulo: Moraes, s/d,

BRASIL, Secretaria de Educação Fundamental. Parâmetros Curriculares Nacionais: Matemática/ Secretaria de Educação Fundamental. - Brasília: MEC/ SEF, 1998.

BRASIL, Ministério da Educação, Secretaria de Educação Média e Tecnológica. Parâmetros Curriculares Nacionais: Ensino Médio./ Ministério da Educação. Secretaria de Educação Média e Tecnológica - Brasília: Ministério da Educação, 1999.

CARRHER, Terezinha, CARRAHER, David e SCHLIEMANN, Analúcia. Na vida dez, na escola Zero. $13^{\underline{a}}$ ed. São Paulo: Cortez, 2003.

DANTE, Luiz Roberto. Didática da Resolução de Problemas de Matemática. São Paulo: Editora Ática, 2002.

LOPES, Antonia Osima (coord.) [et.al.]. Repensando a Didática. $20^{a}$ ed., São Paulo: Papirus, 1991, P. 85.

PAIS; Luiz Carlos. Didática da Matemática; Uma análise da influência Francesa. - $2^{\underline{a}}$ edição. Belo Horizonte: Autêntica, 2002.

POLYA, G. A arte de resolver problemas: Um novo enfoque do método matemático. Rio de Janeiro: Interciência, 1994. 


\section{O DIREITO À EDUCAÇÃO PÓS COVID-19 E A IGUALDADE DE CONDIÇÕES SOB A PERSPECTIVA CONSTITUCIONAL}

Daniele Messias Corrêa Luiz

Caio Silva de Sousa

INTRODUÇÃO

O ano de 2020 trouxe ao mundo o desafio de lidar com um vírus devastador, COVID-19. Isto porque as suas características, ainda desconhecidas em sua integralidade, foram capazes de afetar todas as engrenagens propulsoras do crescimento das economias.

A pandemia exigiu uma rápida resposta do poder público, em especial dos chefes do Poder Executivo, que buscaram a contenção de sua propagação. Contudo, os atos normativos emergenciais repercutiram diretamente em alguns direitos essenciais, quais sejam: educação e saúde, tornando a efetivação desses direitos garantidos pela Constituição ainda mais complexa.

A pesquisa tem como objeto o direito à educação pós COVID-19 e os seus desafios na isonomia de direitos sob a ótica da Constituição de 1988.

A relevância do tema parte de duas questões importantes. A primeira é a manutenção do acesso à educação, direito social protegido pela Constituição de 1988, através da perspectiva da igualdade constitucional, aos alunos da rede pública e privada. A segunda é a premissa 
de que a educação é também ferramenta para a efetivação dos demais direitos, principalmente à saúde.

A metodologia utilizada teve a combinação de dois tipos de fontes: bibliográfica e documental. Analisou-se a legislação pátria, informações coletadas em órgãos oficiais, conteúdo jornalístico de mídias digitais e artigos, tendo como parâmetro o ensino fundamental II nas escolas do município do Rio de Janeiro, além de decretos do Poder Executivo consultados nos portais do Governo do Estado do Rio de Janeiro e do Governo Federal, decisões da Suprema Corte e fontes bibliográficas.

Como objetivo geral, pretende-se ponderar a preservação do direito à educação em relação ao direito à saúde, como forma de garantia da proteção social e preservação dos mandamentos constitucionais.

Os objetivos específicos são entender se todos os alunos foram igualmente afetados pelas normas expedidas pelo Poder Executivo; se as discrepâncias sociais e acadêmicas entre alunos da rede pública e privada serão potencializadas com essas medidas de isolamento; se a pretexto de preservar o direito a saúde, este não fica comprometido ao isolarmos crianças e adolescentes em casa; se há uma relação entre o direito à educação e o direito à saúde; por fim, o novo desafio constitucional para a efetivação do artigo 206 da Constituição de 1988.

A hipótese é que, as medidas de isolamento aumentaram o hiato existente entre estudantes do ensino público e do ensino privado no aspecto acadêmico e que o acesso à educação está diretamente associado à saúde física e mental.

\section{A suspensão do funcionamento escolar no Estado do Rio de Janeiro}

Com o advento da pandemia, a União através da Lei Federal no 13.979, de 6 de fevereiro de 2020, dispôs sobre as medidas de proteção para o enfrentamento da propagação do vírus, dentre elas a adoção de isolamento social (quarentena), a serem aderidos pelas autoridades no âmbito de suas competências de acordo com as complexidades locais.

O Poder Executivo do Estado do Rio de Janeiro, mediante Decreto Estadual no 46.973, de 16 de março de 2020, reconheceu a 
situação de emergência e a necessidade de tomar medidas acerca da redução da propagação da doença. Dentre outras medidas, destaca-se aquela com pertinência para este estudo, que foi a suspensão por um prazo de 15 dias (quinze) dias, das aulas das redes de ensino pública e privada.

\section{$[\ldots]$}

Artigo $4^{\circ}-$ De forma excepcional, com o único objetivo de resguardar o interesse da coletividade na prevenção do contágio e no combate da propagação do coronavírus, (COVID-19), determino a suspensão, pelo prazo de 15 (quinze) dias, das seguintes atividades: $[\ldots]$

VI - aulas, sem prejuízo da manutenção do calendário recomendado pelo Ministério da Educação, nas unidades da rede pública e privada de ensino, inclusive nas unidades de ensino superior, sendo certo, que o Secretário de Estado de Educação e o Secretário de Estado de Ciência, Tecnologia e Inovação deverão expedir em 48 (quarenta e oito horas) ato infralegal para regulamentar as medidas de que tratam o presente Decreto; [...] (RIO DE JANEIRO, 2020).

No âmbito da competência municipal, no Rio de Janeiro, o Decreto Municipal no 47.282, de 21 de março de 2020, determinou "a adoção de medidas adicionais, pelo Município, para enfrentamento da pandemia do novo Coronavírus - COVID - 19", (RIO DE JANEI$\mathrm{RO}, 2020$ ) e dentre as providências, o artigo $1^{\circ}$ trouxe em seu inciso III, alínea "a", o fechamento das escolas que, naquela oportunidade seria apenas até o dia 27 de março.

Ato contínuo, o Ministro da Educação autorizou através da Portaria $n^{\circ}$ 343, em 17 de março de 2020, a substituição das disciplinas presenciais por ferramentas tecnológicas capazes de transmitir a informação. Contudo a portaria se referiu apenas às "instituições de educação superior integrante do sistema federal de ensino, de que trata o

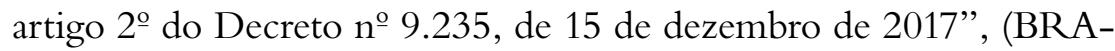
SIL, 2020). 
Ocorre que, com o aumento da curva de contaminação e a redução da capacidade dos leitos nos hospitais, por conta de infectados por COVID-19, desencadearam a prorrogação das medidas de suspensão das aulas e até o fechamento deste estudo, o que se tem é a perspectiva de que nem tão cedo a "normalidade" fará parte da rotina dos estudantes.

${ }^{44}[\ldots]$ É importante que o replanejamento curricular do calendário de 2020 considere as competências da BNCC e selecione os objetivos de aprendizagem mais essenciais relacionados às propostas curriculares das redes e escolas e, no caso de opção para continuidade de 2020-2021, as instituições deverão definir o planejamento de 2021 incluindo os objetivos de aprendizagem não cumpridos no ano anterior. Recomenda-se também a flexibilização dos materiais e recursos pedagógicos; ênfase no ensino híbrido e o aprendizado com base em competências de acordo com as indicações da BNCC. (BRASIL, 2020). Grifou-se.

Dentre as recomendações também apresentadas no documento criado neste encontro, que contou com a participação de conselhos de educação e entidades civis ligadas ao tema, destaca-se a "Flexibilização da frequência escolar presencial," (BRASIL, 2020). Ainda nesta esteira, o Secretário Estadual de Educação, afirmou que "Só voltaremos quando o estado estiver na bandeira verde”, (FERNANDES, 2020) e garantiu que a escola seria a última atividade a voltar.

44 Texto retirado do Parecer do CNE/CP №11/2020. Assunto: Orientações Educacionais para a Realização de Aulas e Atividades Pedagógicas Presenciais e Não Presenciais no Contexto da Pandemia. O Recorte faz parte do item 7.1, Recomendações Gerais Para o Sistema de Ensino e trata da flexibilização curricular, considerando a possibilidade de uma continuidade em 2021 ainda acerca dos objetivos que deveriam ter sido cumpridos em 2020. 


\section{Reflexos das medidas nas instituições de ensino públicas e privadas}

Preliminarmente, é importante compreender que, embora o sistema educacional esteja sujeito às normas federais, estaduais e municipais, a depender da fase de ensino e do ente da federação a ela vinculado, o destinatário principal do sistema educacional são os alunos. Há uma diferença entre as instituições públicas e privadas de ensino, no que diz respeito às partes integrantes da relação de prestação de serviço e das normas de natureza material a elas sujeitas.

Com a suspensão das aulas, grande parte das instituições privadas de ensino, com suas relações sujeitas ao Código de Defesa do Consumidor, precisaram apresentar medidas urgentes em resposta às aflições dos responsáveis pelos alunos, sob pena de dissolução dos contratos junto com a pandemia.

Diante desta celeuma, a maior parte das escolas pertencentes a rede privada de ensino saiu na frente mediante iniciativas que visassem a substituição das aulas em andamento, em todas as etapas de ensino, por meios e tecnologias da informação, para que o conteúdo pudesse chegar até os alunos.

Algumas escolas, inclusive, já possuíam know-how tecnológico de ensino à distância e apenas adaptaram o conhecimento para a rotina de seus alunos e àquelas que ainda não tinham, contrataram serviços de plataforma online em tempos recordes, oferecendo o serviço em até 72 horas após a portaria autorizativa.

Um fator preponderante para o auxílio no desempenho dessas crianças da rede privada de ensino, são as questões relacionadas ao ambiente, normalmente mais propícios para o estudo e ao perfil sociocultural dos representantes legais.

Já na rede de ensino público, a Secretaria Municipal de Educação do município do Rio de Janeiro lançou um aplicativo, SME CARIOCA 2020, disponibilizando o uso no dia 23 de março de 2020, (RIO DE JANEIRO, 2020), com conteúdo pedagógico para que os estudantes sujeitos à sua competência, pudessem manter, em tese, o foco na aprendizagem. E no âmbito da competência estadual, foi disponi- 
bilizada a aula online através do uso da plataforma "Google for education" desde o dia 30 de março, (PLATONOW, 2020).

A Constituição, em seu artigo 206, traz alguns princípios relacionados à educação, dentre eles "igualdade de condições para o acesso e permanência na escola" e "garantia de padrão de qualidade", (BRASIL, 1988).

Entretanto, "Instituto Brasileiro de Geografia e Estatística apurou que até o ano de 2017, apenas 40\% das pessoas que moram nas áreas rurais possuíam acesso à internet. Quando isto acontece, a principal ferramenta de acesso é o celular".

(TOKARNIA, 2020).

Embora os dados possam parecer razoavelmente otimistas ou mesmo um problema de natureza mais isolada, se comparado que na mesma pesquisa apurou-se que 80\% daqueles que moram na área urbana conseguem acessar a internet, há uma disparidade ainda muito grande.

Outrossim, existem outras vertentes capazes de criar obstáculos para o exercício pleno do direito à educação em igualdade de condições.

O primeiro deles é que a transmissão de conteúdo às crianças da fase de alfabetização escolar, assim como as mudanças de paradigmas, para muitos alunos, como os que acontecem quando a criança passa do ensino fundamental I para o ensino fundamental II, onde àqueles normalmente tinham apenas um professor e estes que experimentam novas realidades, como a apresentação de novas disciplinas e o contato com mais profissionais, estão ocorrendo no ambiente virtual.

O agravante desta questão, é pressupor que os pais, que têm participado deste processo de mudança, possuem condições técnicas e psicológicas para colaborar, em especial, com aqueles que possuem déficit educacional, como analfabetismo ou mesmo o analfabetismo funcional.

Uma outra questão é criar medidas uniformes às crianças de diversas realidades socioculturais e psíquicas, pois não se pode esquecer que muitos desses alunos sofrem de transtornos mentais e que a socialização no ambiente escolar é de suma importância para a evolução do tratamento. 
Ademais, segundo matéria publicada por Varella (2018), “40,2\% daqueles que têm até 14 anos vivem em situação de pobreza; cerca de 4 milhões de crianças moram em favelas; e 17,5\% das adolescentes foram mães antes dos 19 anos".

Este cenário traz uma outra questão: como fazer com que crianças em estado de pobreza, que vivem em ambientes insalubres, em espaços apertados, ainda que possuam um celular com internet, tenham a mesma motivação, concentração e perspectiva, no uso da ferramenta virtual, que àquela em condições mais dignas? As políticas adotadas neste período são suficientes para a promoção da isonomia e acesso à educação?

\section{Educação como exercício de cidadania e a responsabilidade do Estado}

Um ponto fundamental é demonstrar a importância do direito à educação para a garantia da cidadania e da dignidade da pessoa humana, fundamentos descritos no artigo 1ํㅡㄴ II e III da Carta Magna (1988).

Aqui se faz necessário compreender a ideia do artigo 205 da Constituição, quando fica claro que a educação é um direito de todos, "sendo dever do Estado e da família, com a promoção e incentivo para a colaboração da sociedade, buscando sempre o pleno desenvolvimento da pessoa" [...], (BRASIL, 1988).

Ou seja, é importante entender que na impossibilidade da garantia da educação para todos os educandos, fica inequívoca a violação ao princípio da Dignidade Humana e ao princípio da Igualdade, valores metajurídicos que sobrepairam e informam os demais princípios constitucionais, possuindo função hermenêutica e servindo de parâmetro na ponderação de interesses em conflito.

Será que os objetivos básicos inseridos no artigo $3^{\circ}$, I, III, e IV da Carta Magna de 1988, que repudiam qualquer forma de preconceito, discriminação e marginalização, foram devidamente atendidos nesse período? E os alunos com deficiência, de que forma os direitos desses cidadãos estão sendo tutelados pelo Estado?

O direito à educação previsto na Lei Federal no 13.146/2015, Lei Brasileira de Inclusão da Pessoa com Deficiência (LBI), designada 
a "assegurar e a promover, em condições de igualdade, o exercício dos direitos e das liberdades fundamentais da pessoa com deficiência, visando à sua inclusão social e cidadania" (BRASIL, 2015), além da Convenção sobre os Direitos das Pessoas com Deficiência, (BRASIL, 2009).

Logo, a discussão se dá sobre a igualdade dos alunos com relação as suas possibilidades ou não de aprendizado, o que aumenta exponencialmente quando se fala sobre a inclusão de educandos com deficiência em escolas, neste momento de pandemia.

Sendo assim, é uma questão social onde deve-se levar em questão os direitos fundamentais e humanos, uma vez que ainda hoje há exclusão de muitos alunos de determinados ambientes por falta de incentivo e estrutura devidamente preparada e que naturalmente se agrava quando no cenário de isolamento social.

A palavra inclusão tornou-se um discurso com diversos significados a serem empregados, o que acabou por dificultar o diálogo entre seus "atores", desde os políticos aos que trabalham no terreno, dando origem a ideias feitas e "(mal)feitas" que objetivam aplicar ou justificar a sua impossibilidade (RODRIGUES, 2003, p. 95).

Portanto, estar incluído é muito mais do que uma presença física, é também um sentimento e uma prática mútua de pertença entre a escola e o educando, significando que o aluno deve sentir que pertence à escola e a escola sentir que é responsável por ele (RODRIGUES, 2003, p. 95)

Em função disso, depreende-se que as instituições de ensino devem garantir a oportunidade de os educandos interagirem em um contexto de pluralidade, com maior potencial em propulsionar suas posteriores competências acadêmicas e sociais, sem as limitações impostas pelo modelo singular e de forma alguma, esta necessidade se desprende em razão de uma situação de isolamento. Pelo contrário, esses cidadãos requerem do Estado, mais do que nunca, o dever de agir e garantir o cumprimento das normas Constitucionais e Infraconstitucionais.

Portanto, incluir todos os alunos no ambiente escolar é sobretudo uma forma de inclui-los na sociedade e se este "provisório ambiente escolar" se tornou uma plataforma digital ou qualquer outro recurso 
de apoio, deve-se pensar nele como ferramenta capaz de promover o acesso a todos, incondicionalmente.

Outrossim, a Carta Magna é clara ao informar em seu artigo 208 que o "não oferecimento do ensino obrigatório pelo Poder Público, ou sua oferta irregular, importa responsabilidade da autoridade competente", (BRASIL, 1988). E nesse caso, o artigo 37 determina que as pessoas "jurídicas de direito público e as de direito privado prestadoras de serviços públicos responderão pelos danos que seus agentes, nessa qualidade, causarem" [...] (BRASIL, 1988).

\section{As repercussões sociais aos alunos de ensino público}

A evasão escolar é um problema notório enfrentado por crianças e jovens do ensino público. Diversas são as medidas na tentativa da redução deste problema e dentre as que se relacionam com o objeto do estudo, estão diretamente ligadas às políticas públicas promovidas no ambiente escolar.

Essas ações passam desde o alimento oferecido neste local até atividades esportivas e culturais engajadas em retirar crianças e jovens das violências enfrentadas em suas comunidades e por vezes círculo familiar.

Longe da escola e, consequentemente, daquelas políticas públicas de resgate e socialização de jovens e crianças das unidades de ensino da rede pública, poderá desencadear um movimento catastrófico de evasão escolar.

Outrossim, o afastamento da escola, por medida de saúde coletiva, pode ser exatamente esta causadora de problemas de natureza psicológica, como quadros depressivos, ansiedade, dentre outros transtornos correlacionados.

O impacto emocional entre alunos, profissionais da educação e famílias é uma realidade que deverá ser enfrentada tão logo haja o retorno das aulas presenciais. Mas esta é apenas uma das consequências.

Independente da rede de ensino, há uma perda para os dois lados, contudo o que se indaga é quanto a estrutura de recuperação deste déficit. Terá a rede pública de ensino estrutura capaz de garantir a restauração da aprendizagem na justa medida? Ou o isolamento social 
provocado pelo COVID-19 veio a distanciar ainda mais as oportunidades e acessos educacionais?

\section{A intercessão entre o Direito à Saúde e o Direito à Educação}

Desde o avanço da pandemia, muito tem se discutido por políticas públicas que assegurem o mínimo necessário de preservação à vida, tendo sido adotado o isolamento social, em um momento mais crítico, como meio para a contenção do vírus.

Porém, é sabido que os gestores públicos têm ainda um outro problema a ser administrado mediante isolamento, a oferta de leitos hospitalares necessários para atender as eventuais demandas.

Para melhor compreensão do que se propõe neste subtítulo, divide-se a seguir sobre duas perspectivas:

A primeira, sob a ótica da política de saúde pública, cujo entende-se o conjunto de programas, ações, metas e planos das três esferas de governo, traçadas para alcançar o bem-estar da sociedade e o interesse público. Tais ações selecionadas pelos representantes públicos são aquelas entendidas ou classificadas como sendo as demandas ou expectativas da sociedade que demandam a necessidade de atendimento imediato. Ou seja, as políticas públicas objetivam responder a demandas, sobretudo dos setores marginalizados da sociedade, considerados em situação de vulnerabilidade social.

Neste olhar, o que se percebe é que a oferta de serviços de saúde não é um problema novo e a dificuldade em operacionalizar direitos sociais tem resultado na efetivação de políticas públicas, especificamente as de saúde através do Poder Judiciário. A materialização desse direito humano fundamental, via tutela jurisdicional, tem um viés garantidor de forma que, o que deveria ser obrigação do poder público na promoção dos direitos sociais se efetiva com a intervenção jurisdicional decorrente da arbitrária renúncia do Estado em concretizar acesso ao direito à saúde.

Assim, não obstante a gravidade da pandemia, esta não é solitariamente a causa de medidas de contingenciamento, talvez melhor se definiria como o holofote que trouxe de forma mais incisiva um problema pré-existente. 
Em seguida, observa-se a relação entre o isolamento social, em especial, no aspecto do afastamento do ambiente escolar e sua repercussão na saúde do aluno.

Um levantamento realizado na província chinesa de Xianxim com 320 crianças e adolescentes revela os efeitos psicológicos mais imediatos da pandemia: dependência excessiva dos pais (36\% dos avaliados), dependência excessiva dos pais (36\% dos avaliados), desatenção (32\%), preocupação (29\%), problemas de sono (21\%), falta de apetite (18\%), pesadelos (14\%) e desconforto e agitação (13\%). (GRINBERGAS, 2020).

Naturalmente estes problemas podem se agravar ou não, de acordo com as realidades sócio econômicas de cada criança e jovem, assim como o ambiente familiar que compartilha. E ainda, como aponta Grinbergas (2020) "o confinamento não limita apenas esses horizontes, mas o próprio gasto de energia da garotada", podendo provocar outros males.

Além disso a Sociedade Brasileira de Pediatria lançou um "manual de recomendação de saúde na era digital” em que um dos itens é "Limitar o tempo de telas ao máximo de uma ou duas horas por dia, sempre com supervisão para crianças com idades entre seis e 10 ano", (RECOMENDAÇÕES..., 2020).

Não obstante todas as complexidades já comentadas sobre o afastamento da atmosfera escolar, o uso das ferramentas digitais fora das recomendações indicadas pela SBP, podem acarretar dentre outros problemas, "Problemas de saúde mental: irritabilidade, ansiedade e depressão; Transtornos do déficit de atenção e hiperatividade; Transtornos do sono; Transtornos de alimentação: sobrepeso/obesidade e anorexia/bulimia; [...], (RECOMENDAÇÕES..., 2020).

Como se pode verificar, o debate sobre o Direito à Educação perpassa pelo Direito à saúde, tendo em vista que Educação não compreende apenas no acesso a oferta de conteúdo escolar, mas todo aparato fornecido pelos profissionais, convivências e experiências vividas pelos jovens e crianças que estão diretamente ligados ao desenvolvimento das emoções, face interações experimentadas e, 
consequentemente, com a própria saúde mental, ficando evidente a intercessão entre os Direitos.

\section{CONCLUSÃO}

O resultado parcial deste estudo, com base em dados empíricos, é que as medidas adotadas pelos chefes dos poderes executivos não foram capazes de proteger em sua integralidade o Direito à educação. Que, embora a adoção das ações tenha tido como fundamento primordial a preservação da saúde e naturalmente da própria vida, trouxe como resultado o desvirtuamento do que se propunha.

Isso porque, a saúde e a vida, possuem relação com outros direitos que se comunicam diretamente e porque não dizer, que auxiliam na promoção daquelas. E nesta esteira, o lazer, a interação social, que são componentes associados ao bem estar, são elementos ofertados no âmbito de convivência escolar que, por assim ocorrer, legitima a escola como colaboradora da própria promoção da saúde física e mental.

Já sob a visão da aplicação da igualdade constitucional de tratamento e da garantia de oferta à educação, sob uma anáise ainda parcial e empírica, verificou-se que

as medidas de isolamento e suas consequências aumentaram o hiato existente entre estudantes do ensino público e do ensino privado, quer seja pelas ferramentas de acesso ao ensino no formato digital, quer seja por conta das condições sociais, econômicas e circunstanciais de cada cidadão, capazes de resultar no aumento da evasão escolar e aumentar o abismo entre conteúdos curriculares fornecidos durante este período pelas instituições de ensino.

É importante frizar que o direito de cidadania dado como favor é uma violência. A esmola do apoio suplicado a projetos e demandas mínimas também é. E é isso que a sociedade precisa combater.

Não é de favores que a população precisa, mas sim do cumprimento do dever do Estado de dar acesso aos serviços educacionais e como percebido, de saúde, que formem e construam a cidadania de cada um dos cidadãos em igualdade de tratamento e condições.

Dessa forma, faz-se necessário, primeiramente, que se pense sobre os Direitos Sociais, como a educação e a saúde, não apenas como 
demandas isoladas, mas sim, como pautas que se comunicam e que possuem uma interdependência. E por último, sem que se esgote as infinitas necessidades, deve o Estado compreender que políticas públicas, ainda que de natureza emergenciais, devem considerar as complexidades de cada comunidade e seus indivíduos, sob pena de criar mais desigualdades em lugar de garantir os poucos direitos arduamente reivindicados diariamente.

\section{REFERÊNCIAS}

BRASIL. [Constituição (1988)]. Constituição da República Federativa do Brasil de 1988. Brasília, DF: Presidência da República. Disponível em: http://www.planalto.gov.br/ccivil_03/Constituicao/Constituiçao.htm. Acesso em: 30 jun. 2020.

BRASIL. Ministério da Educação. Gabinete do Ministro. Portaria no 343. Brasília, DF: Ministério da Educação, de 17 de março de 2020. Disponível em: http://portal.mec.gov.br/component/content/article?id=88631. Acesso em: 20 jun. 2020.

BRASIL. Ministério da Educação. Conselho Nacional de Educação. Parecer CNE/CP no 11/2020. Brasília, DF: Ministério da Educação, de 07 de julho de 2020. Disponível em: http://portal. mec.gov.br/index.php?option=com_docman\&view=download\&alias=148391-pcp011-20\&category_slug=julho-2020-pdf\&Itemid=30192. Acesso em: 20 jun.

BRASIL. Decreto Federal no 6.949, de 25 de agosto de 2009. Promulga a Convenção Internacional sobre os Direitos das Pessoas com Deficiência (CDPD) e seu Protocolo Facultativo, assinados em Nova York, em 30 de março de 2007. Brasília, DF. Disponível em: http://www.planalto.gov.br/ccivil_03/_ato2007-2010/2009/ decreto/d6949.htm. Acesso em: 30 junho. 2020.

BRASIL. Decreto no 9.235, de 15 de dezembro de 2017. Dispõe sobre o exercício das funções de regulação, supervisão e avaliação das instituições de educação superior e dos cursos superiores de gradua- 
ção e de pós-graduação no sistema federal de ensino. Disponível em: http://portal.mec.gov.br/index.php?option=com_docman\&view=download\&alias=78741-d9235-pdf\&category_slug=dezembro-2017-pdf\&Itemid=30192. Acesso em: 20 jun.2020.

BRASIL. Lei Federal no 13.146, de 6 de julho de 2015. Institui a Lei Brasileira de Inclusão da Pessoa com Deficiência (Estatuto da Pessoa com Deficiência). Brasília, DF. Disponível em: <http://www. planalto.gov.br/ccivil_03/_Ato2015-2018/2015/Lei/L13146. htm>. Acesso em: 30 junho. 2020.

BRASIL. Decreto no 13.979, de 06 de fevereiro de 2020. Dispõe sobre as medidas para enfrentamento da emergência de saúde pública de importância internacional decorrente do coronavírus responsável pelo surto de 2019. Brasília, DF. Disponível em: http:// www.planalto.gov.br/ccivil_03/_ato2019-2022/2020/lei/113979. htm. Acesso em: 20 jun 2020.

FERNANDES, Pedro. Só voltaremos quando o Estado estiver na bandeira verde. [Entrevista cedida a] ..., O Globo. Rio de Janeiro, RJ. 07 de jul de 2020. Disponível em: https://oglobo.globo. com/rio/so-voltaremos-quando-estado-estiver-na-bandeira-verde-diz-secretario-de-educacao-1-24519321. Acesso em: 30 jun. 2020 .

GRINBERGAS, Daniella. Saúde dos Pequenos Confinados. Abril. 21 de junho de 2020. Disponível em: https://saude.abril.com. br/familia/pequenos-confinados-como-o-isolamento-impacta-a-saude-das-criancas/. Acesso em: 21 jun. 2020.

PLATONOW, Vladimir. Escolas estaduais começam estudos online no Rio de Janeiro. Agência Brasil. Rio de Janeiro, RJ. 27 de março de 2020. Disponível em: https://agenciabrasil.ebc.com.br/ educacao/noticia/2020-03/escolas-estaduais-comecam-estudos-online-no-rio-de-janeiro. Acesso em: 30 jun. 2020.

RECOMENDAÇÕES sobre saúde de crianças e adolescentes na era digital. Sociedade Brasileira de Pediatria. Rio de Janeiro, RJ. 
11 de fevereiro de 2020. Disponível em: https://www.sbp.com. br/imprensa/detalhe/nid/sbp-atualiza-recomendacoes-sobre-saude-de-criancas-e-adolescentes-na-era-digital/. Acesso em: 20 jun. 2020.

RIO DEJANEIRO. Decreto rio no 47.282, de 21 de março de 2020 . Determina a adoção de medidas adicionais, pelo Município, para enfrentamento da pandemia do novo Coronavírus - COVID 19, e dá outras providências. Rio de Janeiro, RJ. Disponível em: http://www.rio.rj.gov.br/documents/8822216/11086083/DECRETO_47282_2020.pdf. Acesso em: 30 junho. 2020.

RIO DE JANEIRO. Decreto no 46.973, de 16 de Março de 2020. Reconhece a situação de emergência na saúde pública do Estado do Rio de Janeiro em razão do contágio e adota medidas enfrentamento da propagação decorrente do novo coronavírus (COVID-19); e dá outras providências. Disponível em: https://coronavirus.rj.gov.br/decretos/. Acesso em: 30 jun. 2020.

RODRIGUES, D. (Org.) (2003). Perspectivas sobre Inclusão. Da Educação à Sociedade. Porto: Porto Editora.

RODRIGUES, D. (2006). Dez ideias (mal) feitas sobre educação inclusiva. In D. Rodrigues (ed.), Educação Inclusiva. Estamos a fazer progressos? Lisboa: FMH Edições.

TOKARNIA, Mariana. Estrutura de Rede de Ensino On line preocupa Dirigentes. Agência Brasil. Brasília, DF. 26 março de 2020. Disponível em: https://agenciabrasil.ebc.com.br/educacao/noticia/2020-03/estrutura-de-rede-publica-para-ensino-online-preocupa-dirigentes. Acesso em: 30 jun. 2020.

VARELLA, Gabriela. Relatório de pobreza infantil. O Globo. 24 de abril de 2018. Disponível em: https://oglobo.globo.com/sociedade/relatorio-mostra-que-40-das-criancas-no-pais-vivem-na-pobreza-22620890. Acesso em: 30 jun. 2020. 


\section{PERCEÇÃO DOS ESTUDANTES DO ENSINO SUPERIOR SOBRE OS DIREITOS DA CRIANÇA: CURSOS DE EDUCADORES DE INFÂNCIA E PROFESSORES DO 1. CEB}

Maria Fernanda dos Santos Mendes Sampaio

Maria Filomena Tomaz Henriques Serrano Caldeira

"Promover o desenvolvimento da personalidade da criança, dos seus dons e aptidões mentais e físicos na medida das suas potencialidades".

Convenção da ONU sobre os Direitos da Criança (Artigo 29.. )

INTRODUÇÃO

No século XX, surge a preocupação de encarar a criança, como sujeito de direitos. Vários autores consideram o século dos Direitos da Criança, em que emerge uma acrescente preocupação sobre o bem estar e proteção da mesma, assim como, a promoção do desenvolvimento da personalidade desta.

No campo de ação jurídico-legal a necessidade de proteção das crianças e promoção do seu desenvolvimento da personalidade, legitimou o aparecimento de várias instituições, a nível nacional e internacional.

No início da Primeira República, em 1991, Portugal foi um dos pioneiros a aprovar uma lei de Proteção à Infância, sendo posterior- 
mente seguido por outros países. Em 1990, ratifica a Convenção sobre os Direitos da Criança, destacando-se novamente, ao dedicar o lugar privilegiado da Criança na sua lei, na Constituição da República Portuguesa de 1976.

No seguimento da Convenção dos Direitos da Criança (CDC) de 1948, iniciámos um estudo, o qual foi realizado numa instituição privada de Ensino Superior de Educação (ESE) em Lisboa e propôs-se averiguar, as perceções dos estudantes dos Cursos de Educadores de Infância e Professores do $1^{\circ}$ Ciclo do Ensino Básico, em relação aos Direitos da Criança.

Na realização deste estudo foi desenvolvida uma pesquisa exploratória e descritiva, adotando-se uma metodologia quantitativa e qualitativa. Para tal foi implementado como método para recolha de dados, o inquérito por questionário com perguntas fechadas para os estudantes (150) e entrevistas com perguntas predominantemente abertas.

Os principais objetivos deste estudo foram: averiguar se os estudantes da ESE conhecem os Direitos da Criança e se o plano de estudos do seu curso, contempla esta temática; se os Direitos da Criança são assegurados pela escola; indagar a relação dos educadores/professores com as crianças; os estudantes da ESE refletirem sobre o que poderão realizar num futuro próximo, enquanto profissionais da educação, para ajudar a promover os Direitos da Criança.

\section{EDUCAÇÃO}

\subsection{Os objetivos da educação}

A educação tem sido vista ao longo dos tempos de formas diferentes. Na década dos anos 90, Aurélio Ferreira, refere que a educação tem como objetivo que a criança se adapte e satisfaça os interesses da sua organização e “(...) regular a formação dos diferentes aparelhos ou sistemas, em atenção às suas necessidades e formas, é fazer educação, é formar o indivíduo por maneira a que ele seja o melhor que pode ser, isto é, se adapte, satisfazendo os interesses que a sua organização indica e implica, e pela maneira que à sociedade mais convenha". 
Nos dias de hoje, a educação é, associadamente, um Direito Humano em si mesmo e um meio imprescindível para a realização de outros Direitos Humanos. Na perspetiva do Direito para o desenvolvimento pessoal e social, a educação é o principal meio através do qual as crianças segregadas pela sociedade, conseguem ultrapassar as suas dificuldades e obter os meios para uma integração nas comunidades. A educação tem um papel fulcral no desenvolvimento do ser humano, ao nível social, cognitivo, emocional e motor, contribuindo para um ser autónomo, criativo, com capacidade de identificar uma dificuldade, criar estratégias para tentar solucioná-la e ultrapassá-la.

Podemos, também considerar a educação como objeto de estudo, foco, estratégia e discussão em todas as nações do mundo. Nalguns países, ela é vista como libertadora, uma esperança que se perdeu em outras instituições, como a família e o Estado. Noutras situações, é vista como uma espécie de "indústria" para formar pessoas altamente capacitadas. BIESTA (2007), alega que em democracias novas e emergentes a Educação tem um papel central na formação da cidadania democrática e na criação de uma cultura democrática. Em democracias mais antigas e estabelecidas, a Educação é vista como fundamental para a consolidação da vida democrática e atualmente chamada a estimular a face ao exposto, pode-se dizer que a Educação apresenta-se numa dupla encruzilhada. Por um lado necessita de apresentar um bom desempenho na "universalização da educação básica de qualidade" e, por outro lado, "as novas matrizes teóricas ainda não são capazes de apresentar caminhos realmente seguros numa época de profundas e rápidas transformações." (GADOTTI, 2000, p. 6).

\section{OS DIREITOS DA CRIANÇA}

A educação é um dos direitos de todas as crianças, sendo que essa mesma educação tem por base a igualdade de oportunidades (CONVENÇÃO DOS DIREITOS DA CRIANÇA, 1989, art. ${ }^{2} 8$ e 29).

Assim, é importante falar acerca dos Direitos da Criança, tendo estes um papel fundamental no que diz respeito ao atributo e à promoção da educação. No final do século XIX, houve várias tentativas, 
através de várias ações, protestos e estratégias, a fim de combater os mecanismos sociais, jurídicos, políticos e económicos relativamente à desigualdade. Foi no século XIX, que a legislação referente à proteção da criança deixou o seu vestígio, visto que a criança foi objeto do primeiro diploma legal, onde estava estabelecido o limite mínimo de idade para o trabalho nas minas de carvão.

A partir desta conquista, passou-se da descoberta da infância e do seu afastamento do mundo dos adultos, na sociedade como no direito penal (séculos XVI-XVIII), à descoberta da proteção à infầncia (fim do século XIX-XX), à descoberta dos direitos do homem (fim do século XVIII e, principalmente na segunda metade do século XX), depois à descoberta dos direitos das crianças e dos jovens (como aplicação dos direitos do homem a menores, nos últimos 20 anos do século XX) (QUELOZ, 1990, cit. por TOMÁS, 2011, p.65).

Apesar da Organização das Nações Unidas (ONU) ter promovido a Declaração dos Direitos do Ser Humano a 10 de dezembro de 1948, os temas relacionados com a infância ainda não faziam parte da mesma. Só a partir de 1959 é que a Assembleia Geral das Nações Unidas decreta a Declaração dos Direitos da Criança.

A Declaração dos Direitos da Criança baseava-se essencialmente na enumeração de princípios, sem valor jurídico, tendo apenas um carácter simbólico.

No ano de 1979, o governo polaco intercedeu junto das Nações Unidas, pelos Direitos da Criança, estas foram foram recetivas e decidem preparar uma Convenção dos Direitos da Infância. No ano de 1989, a criança passa a ser "considerada como cidadã dotada de capacidade para ser titular de direitos (Tomás, 2002, cit. por Tomás, 2011, p. 67).

A Convenção dos Direitos da Criança (CDC), foi um tratado celebrado a 20 de novembro de 1989 e rapidamente aceite e seguida pelo programa de ação para a aplicação da Declaração Universal sobre Sobrevivência, Proteção e Desenvolvimento da Criança, no ano de 1990, através da Cimeira Mundial da Infância. Esta é constituída por 54 artigos, constituindo o mais completo e importante documento sobre os direitos de todos os seres humanos com menos de 18 anos. 
Este documento veio substituir a conceção tradicional de proteção pelo conceito de participação, reconhecendo à criança direitos semelhantes aos do adulto: direitos civis e liberdades; ambiente familiar e aconselhamento parental; cuidados básicos como a saúde e o bem-estar; educação e lazer.

Porém, nos dias de hoje, é de salientar

que a CDC é o mais ratificado de todos os tratados sobre direitos humanos e implicou um conjunto de alterações importantes para o grupo social da infância, nomeadamente a substituição da conceção tradicional de proteção pelo conceito de participação, reconhecendo às crianças direitos semelhantes aos dos adultos (TOMÁS, 2011, p. 67).

Este tratado internacional é um importante instrumento legal devido ao seu carácter universal e também pelo facto de ter sido ratificado pela quase totalidade dos Estados do mundo. Apenas um país, os Estados Unidos da América, ainda não ratificou a Convenção sobre os Direitos da Criança. Portugal ratificou a CDC em 21 de Setembro de 1990.

Ao debruçarmo-nos sobre o conteúdo da CDC, é inevitável fazermos alusão aos "3P"- participação, proteção e sustento/provisão. Os direitos à participação referem-se ao facto da criança deter o poder de participar, ou seja, as suas intervenções/opiniões devem ser tidas em conta. Em relação às questões de proteção, estas baseiam- se na proteção da criança relativamente a qualquer tipo de violência ou negligência. Finalmente, e não sendo de menor importância, os direitos de sustento ou provisão falam do direito à saúde, educação, segurança social. Os 3P têm a mesma importância e devem ser abordados de forma equitativa nos diferentes contextos em que as crianças vivem.

A Convenção dos Direitos da Criança, assenta em quatro pilares fundamentais que estão relacionados com todos os outros direitos das crianças:

- A não discriminação, que significa que todas as crianças têm o direito de desenvolver todo o seu potencial - todas as crian- 
ças, em todas as circunstâncias, em qualquer momento, em qualquer parte do mundo.

- $\quad \mathrm{O}$ interesse superior da criança deve ser uma consideração prioritária em todas as ações e decisões que lhe digam respeito.

- A sobrevivência e desenvolvimento salienta a importância essencial da garantia de acesso a serviços básicos e à igualdade de oportunidades para que as crianças possam desenvolver-se plenamente.

- A opinião da criança que significa que a voz da criança deve ser ouvida e tida em conta em todos os assuntos que se relacionem com os seus direitos. Em 1991, a UNICEF decidiu que todos os programas a implementar deveriam espelhar os princípios da Convenção, que passaria a servir de ponto de referência, independentemente de um país a ter ratificado ou não.

A 1 de junho, comemora-se o Dia Mundial da Criança e, a 20 de novembro, o Dia dos Direitos Internacionais da Criança.

Todavia, alguns estudos sobre a Educação em Direitos da Criança realizados por diferentes pesquisadores com base nos princípios da Declaração Universal dos Direitos Humanos, bem como, instrumentos internacionais e nacionais, sugerem que esses direitos, infelizmente não são cumpridos na sua totalidade.

\section{ENSINO SUPERIOR}

A educação no ensino superior, através do processo de ensinoaprendizagem, tem um papel decisivo para o desenvolvimento destas competências. Por outro lado, o insucesso académico, ainda significativo no ensino superior, leva a que alguns estudantes excedam os limites temporais estipulados para a conclusão dos seus cursos (Chaleta \& Grácio, 2016). São algumas das preocupações primordiais do ensino superior, que os estudantes alcancem as ferramentas necessárias que lhes permitam construir conhecimento, superar limitações, desenvolver o pensamento crítico, promover competências de auto-formação, de auto-aprendizagem e a capacidade de resolução de problemas (Esteves, 2010). 
O ensino superior manifesta-se crucial para a aquisição de variadas competências através da diversidade de experiências que os estudantes vivenciam.

Os estudantes da área da educação, têm uma responsabilidade acrescida, pois fazem parte da educação da criança. Não basta ter conhecimentos, é importante que estes futuros profissionais, tenham consciência de como vão realizar essa transmissão de conhecimentos, ou seja, devem fazê-lo através de estratégias, indo ao encontro das necessidades e ritmos diferentes de cada criança.

\section{METODOLOGIA}

\subsection{Metodologia da investigação}

O estudo que aqui se apresenta centra-se nas perceções dos estudantes do Ensino Superior, sobre os Direitos das Crianças e de acordo com o curso frequentado (Educação Pré-Escolar e Educação do 1ํㅡclo do Ensino Básico - CEB).

Recorremos às abordagens qualitativas e quantitativas, estas são complementares, segundo (Ribeiro, 2010). A investigação quantitativa dá-nos estrutura, objetividade e a força dos números, procura explicar a existência de relações entre fenómenos, a predição ou o controlo dos fenómenos (Freixo, 2010). A investigação qualitativa procura descrever e compreender o porquê dos pequenos detalhes. Juntas melhoram a investigação na sua capacidade de explicar os resultados (Ribeiro, 2010). Esta complementaridade não significa fazer desaparecer as especificidades metodológicas de cada uma das etapas (qualitativa e quantitativa), mas antes pelo contrário, promove as possibilidades de cada uma delas (Esteves, 2006).

\subsection{Amostra}

A nossa amostra é formada por 150 estudantes dos Cursos de Educação Pré-Escolar e Educação do 1ํㅡㄹ $\mathrm{CEB}$ de uma Escola Superior de Educação (ESE) privada, esta situa-se na cidade de Lisboa. 
Tendo como referência Bogdan e Biklen (1994), seguiu-se uma abordagem objetiva, tendo-se explicitado os interesses do estudo, de modo a que os participantes colaborassem de forma empenhada no mesmo.

Para a realização da investigação, tornou-se determinante o esclarecimento dos objetivos do estudo e a dinâmica do mesmo, garantindo o anonimato dos participantes (Stake, 2009).

\subsection{Instrumentos}

Numa 1. aㅗ, fasecorremos à implementação de questionários. Segundo Vale (2004, os questionários apresentam o mesmo objetivo das entrevistas, sendo totalmente estruturados, com questões abertas ou fechadas, proporcionando respostas diretas sobre determinadas informações, quer factuais quer de atitudes. Neste estudo, aplicou-se um questionário fechado, para melhor compreender o que os estudantes da ESE, consideravam pertinente.

Posteriormente, recorremos à recolha dos dados através da técnica da entrevista, um dos métodos mais utilizados nos estudos de cariz qualitativo solicitando o relacionamento entre o entrevistador-entrevistado, envolvendo a recolha de grande quantidade de informação (Freixo, 2010). De forma mais particular foi utilizada a entrevista semi-estruturada que proporciona uma oportunidade para ouvir a experiência dos sujeitos procurando o esclarecimento acerca do que está a ser dito e do significado atribuído aos seus termos e expressões (Ribeiro, 2010).

As entrevistas exploratórias foram realizadas individualmente aos 150 estudantes de uma ESE de Lisboa, com o objetivo de aferir e explorar alguns aspetos ligados à problemática em estudo e à forma como a mesma é analisada pelos participantes, no sentido de obter dados que permitissem esclarecer as questões da entrevista.

\subsection{Análise de dados}

A análise de dados constituiu um processo de pesquisa e organização regular dos dados recolhidos através de diversas técnicas, 
como: entrevista e questionário. Numa investigação de natureza qualitativa é importante recorrer a uma grande variedade de evidências, o que dá lugar a uma grande quantidade de informação, rica em detalhes descritivos (Patton, 2002). Desta forma, inclui a estruturação e sistematização dos dados, aos quais é indispensável dar sentido para tornar compreensível o fenómeno em estudo, de forma a ser possível apresentá-lo a outros (Bogdan \& Biklen, 1994; Vale, 2004). Stake (2009) refere que numa investigação qualitativa dá-se prioridade à análise indutiva, que expressa-se na pesquisa de modelos ou categorias que surgem das entrevistas ou da análise documental, dando significado aos factos.

Neste estudo, a análise e a recolha dos dados estiveram estreitamente relacionadas, visto que, à medida que os dados foram recolhidos foi ocorrendo o processo de análise, porém, este teve maior expressividade após a conclusão da fase de recolha dos dados.

Relativamente ao conhecimento sobre os Direitos da Criança, apresentamos a síntese desses dados na Tabela 4.1.

Tabela 4.1 - Direitos da Criança

\begin{tabular}{|ccc|}
\hline Respostas & N & $\%$ \\
\hline Sim & 42 & 28 \\
Alguns Artigos & 97 & 64,6 \\
Não & 11 & 7,4 \\
\hline Total & 150 & 100 \\
\hline
\end{tabular}

Relativamente aos Direitos da Criança (DC), 11 (7,4\%) estudantes não tinham conhecimento sobre qualquer artigo. Desses estudantes, 97 $(64,6 \%)$ referiram que sabiam o conteúdo de alguns artigos dos DC e $42(28 \%)$ estudantes têm perceção sobre os artigos.

De seguida, questionámos os estudantes, se consideravam que os Direitos da Crianças eram assegurados pela escola, apresentamos a síntese desses dados na Tabela 4.2. 
Tabela 4.2 - Direitos da Criança assegurados pela escola

\begin{tabular}{|ccc|}
\hline Respostas & N & $\%$ \\
\hline Sim & 102 & 68 \\
Algumas vezes & 33 & 22 \\
Nunca & 15 & 10 \\
\hline Total & 150 & 100 \\
\hline
\end{tabular}

Sobre os Direitos da Criança assegurados pela escola, conforme mostra a Tabela 4.2., registámos que 102 (68\%) estudantes defendem que os DC são assegurados pela escola. Mas 33 (22\&) estudantes dizem que algumas vezes é garantido os DC e 15 (10\%) estudantes não concordam com os outros e dizem que os DC não são assegurados.

$\mathrm{Na}$ tabela 4.3., os estudantes responderam sobre a relação dos educadores/professores com as crianças.

Tabela 4.3 - Relação dos educadores/professores com as crianças

\begin{tabular}{|ccc|}
\hline Respostas & $\mathrm{N}$ & $\%$ \\
\hline Excelente & 28 & 18,6 \\
Muito Boa & 32 & 21,5 \\
Boa & 50 & 33,3 \\
Média & 23 & 15,3 \\
Má & 17 & 11,3 \\
\hline Total & 150 & 100 \\
\hline
\end{tabular}

Os resultados da Tabela 4.3. indicam-nos a relação dos educadores/professores com as crianças. Os estudantes consideram que existe um balanço muito positivo na relação entre ambos.

Os resultados deste estudo poderão revelar-se uma mais-valia para o aumento de conhecimento científico sobre a temática e para recolher bases empíricas possíveis de suportar a intervenção educacional ao nível das perceções dos estudantes do Ensino Superior.

\section{CONCLUSÃO}

O Direito das Crianças e a educação são direitos fundamentais, intrinsecamente relacionados no desenvolvimento da Criança. Encon- 
trar o equilíbrio entre essas duas vertentes é o desafio que se coloca à sociedade, mais especificamente aos profissionais da educação.

A partir desta permissa, a excelência será a formação inicial dos estudantes do Ensino Superiror na área da educação, com o objetivo de desenvolver a aprendizagem sobre os Direitos da Criança, permitindo a defesa e promoção dos seus direitos.

Nas escolas fala-se sobre os Direitos das Crianças, mas por vezes não é explícito para elas, o que são direitos. Deste modo, falar sobre algo, como se fosse um dado adquirido, não traz à criança conhecimentos concretos sobre o tema em questão, pois não conhecem os príncipios básicos. Temos como exemplo, a comemoração do dia da criança, em que se faz referência à Convenção dos Direitos da Criança, porém a abordagem feita pelos educadores/professores, é muitas vezes realizada de forma superficial.

As entrevistas e os inquéritos realizados aos estudantes da área da educação do Ensino Superior, neste estudo ,contribuiram não só para uma reflexão de modo a aprofundar os artigos dos Direitos da Criança, bem como a sua implentação enquanto futuros profissionais e cidadãos. A importância desta temática no desenvolvimento da criança, quando realizada pelos profissionais da educação, chega por vezes, através das crianças de uma forma mais rápida aos adultos.

Fazendo uma análise das entrevistas realizadas, os estudantes consideram que os Direitos da Criança, muitas vezes não passam do papel para a prática dos mesmos.

A forma mais eficaz, de os educadores/professores promoverem os Direitos da Criança, encontra-se na sua formação inicial.

Concluímos, reforçando a importância da fomentação dos Direitos da Criança, numa sociedade como a nossa, num estado de direito como o nosso, pois as crianças devem desde cedo conhecer os seus direitos e os direitos que regulam a sua vida em sociedade.

\section{REFERÊNCIAS BIBLIOGRÁFICAS}

\section{BIESTA, G. J. J.; LAWY, R. S. From teaching citizenship to lear- ning democracy: overcoming individualism in research,}


policy and practice. Cambridge Journal of Education, v. 36, n. 1, p. 63-79, 2006.

BODGAN, R., \& BIKLEN, S. Investigação qualitativa em educação. Porto: Porto Editora, 1994.

CONVENÇÃO DOS DIREITOS DA CRIANÇA. Resolução n.o 44/25 da Assembleia Geral das Nações Unidas, de 20 de novembro de 1989

CONVENÇÃO DOS DIREITOS DAS CRIANÇAS. Paris: UNICEF, 2004

CHALETA, ELISA \& GRÁCIO, LUÍSA. Concepções e Abordagens no Ensino Superior. Editorial Neopatria, 2016.

ESTEVES, Manuela. Análise de conteúdo. Em J.LIMA \& J. PACHECO (Eds). Fazer investigação. Contributos para a elaboração de dissertações e teses (pp.105126). Porto: Porto Editora, 2006.

ESTEVES, MANUELA. Sentidos da inovação pedagógica no Ensino Superior. In C. Leite (org.), Sentidos da Pedagogia no Ensino Superior. Porto: CIIE/Livpsic, 2010.

FERREIRA, Aurélio Da Costa. História Natural da Criança. Aula Oficina de Tipografia do Instituto Médico Pedagógico. Lisboa, 1992.

FREIXO, M. J. V. Metodologia científica: fundamentos, métodos e técnicas. Lisboa: Instituto Piaget, 2010.

GADOTTI, M. Perspectivas atuais da educação. Porto Alegre, Artmed, 2000.

PATTON. Qualitative evaluation and research methods $\left(3^{\mathbf{a}} \mathbf{e d}\right)$. Thousand Oaks: Sage, 2002.

RIBEIRO, Elisa. A perspectiva da entrevista na investigação qualitativa. In: Evidência, olhares e pesquisas em saberes educacionais. Número 4, maio de 2010. Araxá. Centro Universitário do Planalto de Araxá. 
STAKE, R. A arte da investigação com estudos de caso (2..$^{a}$ ed.). Lisboa: Fundação Calouste Gulbenkian, 2009.

TOMÁS, C. (2011). Ensaio sobre os Direitos das Crianças pequenas num contexto de crise. Cadernos de Educação de Infância, 93, 20-23, 2011.

UNESCO. Interdisciplinatity in General Education. Division of Educational Sciences, Contents and Methods of Education, 1986.

VALE, I. Algumas notas sobre investigação qualitativa em educação matemática: o estudo de caso. In J. Portela, \& I. Vale (Eds.), Revista da Escola Superior de Educação, 5, 171-202), 2004. 


\section{A EDUCAÇÃO COMO DIREITO E A QUALIDADE DO ENSINO JURÍDICO}

Roselaine Andrade Tavares

\section{Introdução}

A educação é um tema muito abrangente, e não há dúvidas de que a educação é um direito de todos, garantido no Brasil tanto pela Constituição Federal, como por leis infraconstitucionais sendo, portanto, um direito que deve estar à disposição e acessível a todos os indivíduos.

Além de ser um direito, a educação é também uma responsabilidade do Estado como um todo, cabendo sua competência a todos os entes, como a União, os Estados, os Municípios e o Distrito Federal, cada um com sua abrangência e atribuições.

Cabe ressaltar que por educação não podemos compreender apenas a instrução ou a transmissão de conhecimento. Ela vai além, englobando o desenvolvimento de habilidades, do senso crítico, da percepção do todo e das diversas formas de raciocínio.

Apesar da ampla proteção e garantia destinadas ao ensino fundamental e ao ensino médio, por meio de leis e pela Constituição Federal, não se nota o mesmo tratamento quando se trata do ensino superior, que infelizmente ainda não é oferecido a todos indistinta e gratuitamente pelo Estado.

Portanto, em relação à educação superior, em sua maior parte, conforme pesquisa do INEP ${ }^{45}$, é ministrada por instituições de ensino

45 Segundo o INEP (Instituto Nacional de Estudos e Pesquisas Educacionais), em 2017, 
privadas, cabendo a estes estabelecimentos suprir a falta de oferta de ensino não abrangida ou não garantida pelo Estado.

Este trabalho se propõe então a analisar a oferta da educação como um direito fundamental de todos e a busca da qualidade do ensino, especialmente no que se refere ao ensino superior em Direito, o qual vem passando por tímidas e atrasadas mudanças.

Para alcançar tal objetivo, este artigo foi desenvolvido a partir do método científico hipotético-dedutivo, ou seja, baseado em hipóteses que partem de premissas com alta probabilidade de serem concretizadas e tem o referencial teórico estabelecido na obra de Romualdo Portela de Oliveira, denominada "Da universalização do ensino fundamental ao desafio da qualidade: uma análise histórica", bem como na Constituição da República de 1988, na Lei no 9.394/96 (Lei de Diretrizes e Bases da Educação), na Resolução no 5 de 2018 do MEC, em orientações do Instituto de Pesquisas e Administração da Educação (IPAE), dentre outros.

\section{Desenvolvimento}

Partindo da premissa de que a educação superior não é obrigação constitucional do Estado, ficando, portanto, em sua maior parte a cargo das instituições particulares de ensino, temos que os cursos de Direito, com o passar dos anos, vem sofrendo com a defasagem na qualidade do ensino, assim, pretende-se apresentar de forma conexa a educação, o direito e o que pode ser feito na busca por uma maior qualidade no ensino, especialmente quando se trata do ensino superior em Direito.

\section{Educação}

Há tempos a educação faz parte da vida humana e da sociedade, a exemplo do que acontece com o Direito.

A educação deve ser vista e entendida como bem deixou claro Pontes de Miranda, em seus Comentários à Constituição de 1946:

o Brasil tinha 296 Instituições de Educação Superior (IES) públicas e 2.152 privadas, o que representa $87,9 \%$ da rede. 
A educação somente pode ser direito de todos se há escolas em número suficiente e se ninguém é excluído delas, portanto, se há direito público subjetivo à educação, e o Estado pode e tem de entregar a prestação educacional. Fora daí, é iludir com artigos de Constituição ou de leis. Resolver o problema da educação não é fazer leis, ainda que excelentes; é abrir escolas, tendo professores e admitindo os alunos. (PONTES DE MIRANDA, 1963, p. 29)

Assim, há de se perceber que é preciso ofertar a educação na prática, na realidade, e não apenas normatizá-la em leis, sem torná-la efetiva.

$\mathrm{O}$ artigo 205 da Constituição Federal aponta que:

A educação, direito de todos e dever do Estado e da família, será promovida e incentivada com a colaboração da sociedade, visando ao pleno desenvolvimento da pessoa, seu preparo para o exercício da cidadania e sua qualificação para o trabalho. (CF, 1988)

Portanto, a Educação, que é um direito fundamental de todos, deve ser vista também como um direito ligado ao desenvolvimento humano por meio do ensino e da aprendizagem, voltado a alcançar a capacidade intelectual do indivíduo.

No entanto, este "direito de todos" não está, na prática, acessível a todos, pelo contrário, muitos ainda ficam sem escola, e no que se refere ao ensino superior, precisam pagar para ter acesso a este direito, uma vez que não há universidades públicas suficientes para abarcar toda a demanda que a sociedade dispõe.

$\mathrm{O}$ art. 213 da CF afirma que "os recursos públicos serão destinados às escolas públicas", e ainda traz no artigo 212, e mais explicitamente no artigo 69 da LDB, os percentuais mínimos que devem ser aplicados ao ensino, sendo que a União aplicará, anualmente, nunca menos de dezoito por cento; os Estados e o Distrito Federal no mínimo vinte e cinco por cento da receita resultante de impostos estaduais, compreendida a proveniente de transferências, na manutenção e desenvolvimento do ensino. 
No entanto, esses recursos não são suficientes e assim, a própria Constituição, em seu artigo 209 prevê que "o ensino é livre à iniciativa privada", porém, há diversos tipos de entidades privadas que oferecem serviços no campo do ensino jurídico, visando apenas o caráter econômico, objetivando os fins lucrativos e deixando de lado a essencial qualidade do ensino.

Edgar Morin afirma que "há sete buracos negros da educação completamente ignorados, subestimados ou fragmentados nos programas educativos" (MORIN, 2004, p. 2) e o primeiro deles trata exatamente do conhecimento, pois, de nada adianta passar anos em escolas e universidades se não se detiver o mínimo de conhecimento, sendo este ignorado por instituições que visam apenas o lucro.

Conforme a Ordem dos Advogados do Brasil (OAB), é crescente o número de bacharéis não aprovados em seu exame, bem como também é crescente o número de faculdades que surgem ao longo dos anos, sendo que em menos de 10 anos surgiram mais de 900 faculda$\operatorname{des}^{46}$, fato que diminuiu a qualidade do ensino jurídico.

Assim, é necessário voltar a atenção para este universo, visando melhorar a qualidade do ensino jurídico.

\section{Direito}

O Direito é uma ciência social aplicada que pode ser explicitada nas normas jurídicas, estabelecidas no ordenamento pelas mais diversas fontes tais como lei, costumes, jurisprudência, atos administrativos, contratos, dentre outros, assim, ele pode se relacionar com outros saberes e ciências, especialmente no que se refere a educação.

O Direito e a educação não são saberes excludentes ou inconciliáveis, mas, pelo contrário, são manifestações comunicativas e racionais que se completam, especialmente na perspectiva do ensino, com importantes possibilidades de utilização prática, sobretudo no que diz respeito à argumentação e justificação jurídicas, que podem estar presentes nas petições, nas sentenças e na doutrina, assim como na educação jurídica universitária.

46 Conforme dados de 2012, disponível em https://blogexamedeordem.com.br/segundo-oab-brasil-tem-750-mil-advogados-e-mais-de-1-5-milhao-de-bachareis-em-direito/ 
Com as alterações trazidas ao longo das Constituições brasileiras, especialmente a de 1988, pode-se notar que os brasileiros têm dado mais importância ao direito à educação, buscando-a de modo a exercer a sua cidadania, o que pode ter contribuído com a ampliação do ramo do direito denominado Direito Educacional, definido por Álvaro Melo Filho como "um conjunto de técnicas, regras e instrumentos jurídicos sistematizados, que objetivam disciplinar o comportamento humano relacionado à educação”. (MELO FILHO, 1983, p.54)

Conforme afirma o jurista Lourival Vilanova, há

a possibilidade desse novo ramo da ciência jurídica desdobrar-se em duas questões correlacionadas. Uma, a da existência de normas, cujo conteúdo é dado pelas relações sociais na espécie de relação educacional; outra, a da construção sistematizada de conhecimentos, que tenham por objeto tais normas. Ele sustenta, ainda, que há relações sociais educacionais como há relações econômicas de produção, de consumo, de trabalho, de família e de poder; quer sob a forma de relações de administração dos grupos não políticos, ou relações de administração e governo nos grupos políticos. (VILANOVA, 1982, p. 47)

Assim, o Direito Educacional, mesmo que ainda não seja legalmente definido como um ramo autônomo do Direito, ele conecta normas aplicáveis ao conhecimento e ao ensino em si, e as relaciona com as mais diversas relações sociais.

As leis que compõem a legislação educacional, que regem as relações educacionais, abrangem tanto normas jurídicas quanto normas previstas na legislação de ensino e assim se conectam para dirimir conflitos nestas duas áreas, culminando ao final em uma análise jurídico-pedagógica, sob a ótica tanto do Direito quanto da Educação, visando o bem melhor do aluno.

Dentre estas normas podemos mencionar a LDB (Lei de Diretrizes e Bases da Educação Nacional - Lei no 9.394 de 20 de dezembro de 1996), bem como a Resolução no 5, de 17 de dezembro de 2018, do Ministério da Educação - MEC. Sendo a LDB voltada ao direito à educação em si, com informações acerca do ensino fundamental, mé- 
dio, técnico, especial, etc. enquanto a Resolução no 5 de 2018 do MEC é voltada especificamente às diretrizes curriculares nacionais aplicáveis aos cursos de graduação em Direito, a qual requer atenção.

\section{Qualidade do Ensino Superior em Direito}

A qualidade do ensino é uma questão que, segundo Romualdo Portela de Oliveira é o centro da crítica ao processo de expansão educacional:

A superação da exclusão por falta de escola e pelas múltiplas reprovações tende a visibilizar a exclusão gerada pelo não aprendizado ou pelo aprendizado insuficiente, remetendo ao debate acerca da qualidade do ensino. É a qualidade "que oprime o cérebro dos vivos" e ocupa o centro da crítica ao processo de expansão, tornando-se a questão central da política educacional. (OLIVEIRA, 2007, p. 687)

Dessa forma, destaca-se que o processo central e crítico da educação está diretamente voltado à qualidade do ensino, ou seja, na qualidade da educação oferecida aos alunos, tanto na rede pública quanto na rede particular de ensino.

No que tange ao ensino do Direito no Brasil, apesar de ainda muito tradicional, aos poucos vem passando por algumas necessárias mudanças.

As bases estruturais dessas mudanças, podem ser observadas desde os comandos estabelecidos pela Lei de Diretrizes e Bases da Educação (LDB), Lei no 9.394/1996, segundo a qual:

Art. 43. A educação superior tem por finalidade: I - estimular a criação cultural e o desenvolvimento do espírito científico e do pensamento reflexivo; II - formar diplomados nas diferentes áreas de conhecimento, aptos para a inserção em setores profissionais e para a participação no desenvolvimento da sociedade brasileira, e colaborar na sua formação contínua; III - incentivar o trabalho de pesquisa e investigação científica, visando o desenvolvimento da 
ciência e da tecnologia e da criação e difusão da cultura, e, desse modo, desenvolver o entendimento do homem e do meio em que vive; IV - promover a divulgação de conhecimentos culturais, científicos e técnicos que constituem patrimônio da humanidade e comunicar o saber através do ensino, de publicações ou de outras formas de comunicação; V - suscitar o desejo permanente de aperfeiçoamento cultural e profissional e possibilitar a correspondente concretização, integrando os conhecimentos que vão sendo adquiridos numa estrutura intelectual sistematizadora do conhecimento de cada geração; VI - estimular o conhecimento dos problemas do mundo presente, em particular os nacionais e regionais, prestar serviços especializados à comunidade e estabelecer com esta uma relação de reciprocidade. (BRASIL, 1996)

Dessa forma, a LDB contribui ao elencar as finalidades da educação superior no Brasil e estipular os parâmetros para torná-la uma educação de qualidade e contextualizada com os principais problemas do mundo presente, em particular os nacionais e regionais, vinculados tanto à vida dos alunos quanto a dos professores.

No âmbito específico do curso de Direito, as mudanças verificadas e possíveis, na busca dessa qualidade e contextualização, decorrem também da implementação das diretrizes curriculares estabelecidas pela Resolução nº 5/2018 do MEC, segundo a qual, o ensino jurídico precisa ser inovador, usar metodologias ativas, bem como ser inter, multi e transdisciplinar, incentivando à inovação, a integração entre teoria e prática, além da especificação das metodologias ativas utilizadas.

Veja-se nesse sentido, o disposto no artigo $2^{\circ}$ da referida Resolução, segundo o qual:

Art. $2^{\circ}$ No Projeto Pedagógico do Curso de Direito (PPC) deverão constar:

I - o perfil do graduando;

II - as competências, habilidades e os conteúdos curriculares básicos, exigíveis para uma adequada formação teórica, profissional e prática; 
III - a prática jurídica;

IV - as atividades complementares;

V - o sistema de avaliação;

VI - o Trabalho de Curso (TC);

VII - o regime acadêmico de oferta; e

VIII - a duração do curso.

\$1º O PPC, abrangerá, sem prejuízo de outros, os seguintes elementos estruturais:

I - concepção do seu planejamento estratégico, especificando a missão, a visão e os valores pretendidos pelo curso;

II - concepção e objetivos gerais do curso, contextualizados com relação às suas inserções institucional, politica, geográfica e social; III - condições objetivas de oferta e a vocação do curso;

IV - cargas horárias das atividades didático-formativas e da integralização do curso;

$\mathrm{V}$ - formas de realização de interdisciplinaridade, de mobilidade nacional e internacional, de incentivo à inovação e de outras estratégias de internacionalização, quando pertinente;

VI - modos de integração entre teoria e prática, especificando as metodologias ativas utilizadas;

VII - formas de avaliação do ensino e da aprendizagem;

VIII - modos de integração entre graduação e pós-graduação, quando houver;

IX - incentivo, de modo discriminado, à pesquisa e à extensão, como fator necessário ao prolongamento da atividade de ensino e como instrumento para a iniciação científica;

$\mathrm{X}$ - concepção e composição das atividades de prática jurídica, suas diferentes formas e condições de realização, bem como a forma de implantação e a estrutura do Núcleo de Práticas Jurídicas (NPJ); 
XI - concepção e composição das atividades complementares; e,

XII - inclusão obrigatória do TC.

$\int 2^{\circ}$ Com base no princípio da educação continuada, as IES poderão incluir no PPC a perspectiva da articulação do ensino continuado entre a graduação e a pós-graduação.

$\int 3^{\circ}$ As atividades de ensino dos cursos de Direito devem estar articuladas às atividades de extensão e de iniciação à pesquisa.

$\int 4^{\circ} \mathrm{O}$ PPC deve prever ainda as formas de tratamento transversal dos conteúdos exigidos em diretrizes nacionais específicas, tais como as políticas de educação ambiental, de educação em direitos humanos, de educação para a terceira idade, de educação em políticas de gênero, de educação das relações étnico raciais e histórias e culturas afro-brasileira, africana e indígena, entre outras (BRASIL, 2018).

Considerando todas essas possibilidades e exigências, visando um ensino superior em Direito com mais qualidade, os cursos e instituições podem e devem usar métodos ativos de ensino, métodos inovadores, transdisciplinares, que valorizam o ativismo discente, como por exemplo, os métodos conhecidos por gamificação ${ }^{47}$, da sala de aula invertida $^{48}$, uso de mapas mentais ${ }^{49}$ com imagens e palavras-chave, e as conexões inter, multi e transdisciplinares, relacionando o Direito com as infinitas outras áreas do conhecimento.

47 Gamificação é o uso de técnicas de design de jogos, cuja intenção é aproveitar a diversão, entretenimento e até a competitividade que os jogos trazem, para incentivar e agilizar a transmissão de conhecimentos.

48 Quando o aluno acessa o conteúdo antes da aula e depois, junto à turma, discute os conhecimentos adquiridos e tira possíveis dúvidas com a ajuda e orientação do professor. 49 É um tipo de diagrama, sistematizado pelo psicólogo inglês Tony Buzan, voltado para a gestão de informações e de conhecimento.

Fontes: https://fia.com.br/blog/gamification/ ; https://www.futura.org.br/trilhas/oque-e-sala-de-aula-invertida/ e https://manualdasecretaria.com.br/mapa-mental/ (respectivamente). 
Logo, pode-se também incrementar o uso de metodologias construtivistas e construcionistas, por intermédio de métodos ativos, que incluem a música, a arte, atividades lúdicas, dentre outros, com o fim de engajar, aclarar, incentivar e modernizar a forma como o ensino jurídico vem sendo desenvolvido, tanto no nível da graduação, quanto da pós-graduação, de modo a se atender às exigências do MEC, do Projeto Pedagógico e da instituição.

Assim, de posse das diretrizes trazidas pelas leis e resoluções voltadas ao ensino superior em Direito, e colocando-as em prática, conjuntamente com metodologias ativas de ensino, pode-se alcançar um ensino voltado cada vez mais ao aluno, proporcionando-lhe aprendizado com qualidade, especialmente quando se lhe permite participar ativamente da construção deste aprendizado.

\section{Conclusão}

Apesar de a educação ser um direito constitucional garantido a todos, infelizmente isso ainda não é completamente realidade no Brasil.

Apesar de a legislação pertinente exigir percentuais mínimos de investimento em educação, o Estado ainda investe pouco e investe mal os recursos destinados a tal serviço, o que culmina na existência de um grande número de instituições privadas que não estão preocupadas com a qualidade do ensino, mas, em grande parte, apenas com os fins lucrativos.

Diante da existência de conflitos relacionados à educação e que precisam de uma solução jurídica, faz-se necessária a ampliação das atividades de um ramo do Direito voltado especificamente à área da Educação, o chamado Direito Educacional, o qual abrange tanto normas jurídicas quanto normas previstas na legislação de ensino, e assim se conectam para dirimir conflitos nestas áreas, chegando ao final a uma análise jurídico-pedagógica, sob a ótica tanto do operador do Direito quanto da Educação, visando o bem melhor do aluno.

Quanto ao ensino superior em Direito no Brasil, percebe-se que ainda é muito tradicional, mas, vem passando por mudanças, decor- 
rentes não apenas da evolução social, mas também de comandos normativos específicos, dentre eles a LDB e a Resolução nº 5/2018 do MEC, que determinam a necessidade de formação integral, inovadora e transdisciplinar.

Associando essas diretrizes legais ao uso de metodologias ativas construtivistas e construcionistas, por meio de métodos que valorizam o ativismo discente, colocando o aluno como personagem principal do aprendizado, pode-se ter uma solução para se alcançar uma educação superior em Direito com mais qualidade.

\section{Referências}

BRASIL. Constituição (1988). Constituição da República Federativa do Brasil de 1988. Presidência da República. Casa Civil. Subchefia para Assuntos Jurídicos. Brasília, DF, 05 out. 1988. Disponível em: http://www.planalto.gov.br/ccivil_03/Constituicao/Constituiçao.htm. Acesso em 05 jan. 2020.

BRASIL. Lei no 9.394, de 20 de dezembro de 1996. Estabelece as diretrizes e bases da educação nacional. Disponível em http://www.planalto.gov.br/ccivil_03/leis/19394.htm. Acesso em 14 mar. 2020.

BRASIL, Ministério da Educação. Resolução nº 5, de 17 de dezembro de 2018. Diário Oficial da União, Brasília, 18 de dezembro de 2018, Seção 1, p. 122. Disponível em http://portal.mec.gov.br/index. php?option=com_docman $\&$ view $=$ download $\&$ alias $=104111-r-$ ces005-18\&category_slug=dezembro-2018-pdf\&Itemid=30192 Acesso em 02 dez. 2019.

MELO FILHO, Álvaro. Direito Educacional: aspectos teóricos e práticos. Revista Mensagem. Fortaleza, no 8 (número especial sobre Direito Educacional): 1982/1983. p. 54.

MORIN, Edgar. Os sete saberes necessários à educação do futuro. São Paulo: Cortez, 2004.

OLIVEIRA, Romualdo Portela de. Da universalização do ensino fundamental ao desafio da qualidade: uma análise histórica. Educ. Soc., Cam- 
pinas, vol. 28, n. 100 - Especial, p. 661-690, out. 2007. Disponível em http://www.cedes.unicamp.br. Acesso em 24 jun. 2020.

PONTES DE MIRANDA. Comentários à Constituição de 1946. $2^{2}$ ed. Rio de Janeiro: Borsoi, 1963.

VILANOVA, Lourival. O direito educacional como possível ramo da ciência jurídica. Mensagem da Revista do Conselho de Educação do Ceará. Fortaleza, 1982. 
RESUMOS 



\section{LEVANTAMENTO DOS ATOS NORMATIVOS DO CONSELHO NACIONAL DE EDUCAÇÃO- CNE, QUE TRATAM DA FORMAÇÃO DE PROFESSORES:REFLEXÕES ACERCA DAS VIOLÊNCIAS E DIREITOS HUMANOS-PERIODO ANALISADO 1997 A 2016}

Maria Cristina E. E. Stival

O presente texto objetiva inquirir o processo de elaboração das normatizações aprovadas pelo Conselho Pleno do Conselho Nacional de Educação, no período 1997 a 2016, analisado após a implementação da Lei de Diretrizes e Bases Nacionais nº 9394/96, a fim de ressaltar os pareceres elencados sobre as Diretrizes Curriculares Nacionais, bem como as determinações legais desses marcos regulatórios, que são elaborados de forma centralizada pelo Ministério da Educação neste período histórico, de suas demandas necessárias de acordo com mudanças no cenário educacional, no que tange ao projeto de formação de professores e as questões das violências(conflitos) e direitos humanos. Trata-se de uma pesquisa documental de cunho descritivo-explicativo, cuja teoria de conhecimento fundante é o Materialismo Histórico-Dialético. Foram analisadas com base na teoria de conhecimento supracitada, os 9 Pareceres que tratam 
das Diretrizes Curriculares Nacionais vigentes para a formação de professores da Educação Básica advêm em um momento específico da fase de desenvolvimento das forças produtivas, no qual os processos de formação humana adquirem considerável centralidade após a implementação da LDB, trazendo um arcabouço de legislações no período pesquisado. Nesse sentido, estrategicamente, a formação de professores é elevada a componente essencial ao êxito da reforma recentemente engendrada na Educação Básica e os marcos regulatórios. A análise desses documentos legais, constata-se a institucionalização de uma determinada concepção de educação, de formação humana e de sociedade situados em prol da reprodução das relações sociais de produção regidas sob a lógica do capital.

Palavras- Chave: violências, Direitos Humanos, CNE

Referência

BRASIL. Lei n. ${ }^{\circ}$ 9.394/96 - Estabelece as Diretrizes e Bases da Educação Nacional. Brasília: Presidência da República 1996. Disponível em: <http://www.planalto.gov.br/ccivil_03/leis/ 19394.htm>. Acesso em 15/05/2017 


\section{DIREITO EDUCACIONAL E POLITICAS PÚBLICAS: CAMINHO PARA UMA EDUCAÇÃO DEMOCRÁTICA}

Heryda Carolyne Ferreira Sousa

A democracia, enquanto direito constitucional, expande-se para o âmbito da educação, e sua prática fomenta um contexto de ensino brasileiro com base na qualidade e respeito pela diversidade. A fim de traçar um caminho coerente para o desenvolvimento do presente tema, contextualizou-se a educação brasileira mediante acontecimentos históricos acerca da exclusão e do acesso à educação.

A partir de uma reflexão sobre o direito educacional, aponta-se como a implementação de políticas públicas na educação torna-se um instrumento que visa garantir o direito à educação.

O método de pesquisa empreendido segue natureza qualitativa, com levantamento bibliográfico, a partir de uma análise dedutiva. Para tanto, o estudo fundamenta-se em documentos oficiais publicados por instituições governamentais e intergovernamentais, assim como em compêndios de historiografia da educação brasileira e artigos científicos.

No Brasil, as primeiras escolas foram fundadas por jesuítas, que atuavam na colônia como responsáveis pela educação dos índios e dos filhos dos colonos. A educação destinada aos nativos possuía como finalidade convertê-los a fé católica e facilitar a dominação metropolitana. Enquanto a educação destinada aos colonos era fomentada através 
dos colégios, que dedicavam-se à formação letrada da elite, e dos seminários, que destinavam-se à formação de futuros sacerdotes (ARANHA, 1989).

A educação desde sua origem possui um caráter excludente. Os nativos indígenas recebiam uma educação diferente da educação dos filhos de colonos europeus. A educação dos escravos era inexistente, pois sua própria condição de escravo já denotava a sua exclusão social. A raça preta era demonizada, vista como inferior, e muitos documentos comprovam a visão da sociedade daquela época, ao ponto de que foram criadas teorias científicas (determinismo biológico, craniometria, etc) para respaldar as diferenças entre pretos e brancos, com objetivo de reforçar a ideia de superioridade de uma raça sobre as outras (FERREIRA, 2011).

$\mathrm{Na}$ sociedade patriarcal, o homem branco ocupa o topo da pirâmide social, nele sustenta-se as relações de mando e autoridade, configurando-se como mantedor da organização familiar, sendo a mulher, os filhos e os escravos submetidos à sua autoridade.

Com a Revolução Industrial e as novas demandas da sociedade, muitas transformações ocorreram em diferentes espectros, dentre eles na educação. A instituição escolar tal qual adotado na sociedade moderna é um fenômeno recente na história da humanidade, figurando tão somente como uma prática corrente por conta de crescentes demandas de um mundo que se tornou cada vez mais industrializado e dependente de mão de obra qualificada (SOUSA e FILHO, 2008).

Apesar de todos os países já terem abolido a escravidão, o Brasil somente o fez em 1888, sob forte e contínua pressão da Inglaterra, que se negava a reconhecer a independência brasileira enquanto a escravidão fosse legal no Brasil.

Após a abolição da escravidão não foram implementadas medidas que garantissem a inserção da população preta na sociedade brasileira, inviabilizando o seu acesso à moradia, emprego, saúde e educação. $\mathrm{O}$ destino do preto recém liberto foi uma disputa desigual no mercado de trabalho dominado por brancos e imigrantes, que possuíam posição privilegiada numa sociedade que o escravizou por quatro séculos (FERNANDES, 2008). 
Os pretos estavam livres, mas sem moradia, comida e trabalho. Essa herança escravocrata perpetuou a desigualdade social, o racismo e o genocídio da população preta. É preciso conhecer o passado escravocrata para compreender o presente, entender as raízes do fenótipo marginalizado na sociedade de classes, assim como o destino dos pretos libertos pós-abolição (FERNANDES, 2008; SOUZA, 2019; GOMES, 2019).

Diante o exposto, atenta-se sobre a importância da implementação de políticas públicas que viabilizem o acesso da população preta a educação básica e a uma formação de nível superior, assim como oportunidades no mercado de trabalho, visibilidade e representatividade, como forma de combater e minimizar o legado da escravidão na sociedade brasileira.

Sabe-se que a Educação é um direito fundamental de cada indivíduo. A Declaração Universal dos Direitos Humanos (1948), no que concerne ao direito educacional, garante que todo ser humano tem direito a educação, sendo ela gratuita e orientada no sentido do desenvolvimento do indivíduo e do fortalecimento do respeito aos direitos humanos e liberdades fundamentais.

Com a promulgação da Constituição em 1988, que foi um grande marco para a sociedade brasileira, surgiram medidas legais que pautasse progressivamente avanços para mudanças significativas na educação. No art. 205 percebe-se a importância desse feito, quando afirma-se que a educação é direito de todos e visa o pleno desenvolvimento do sujeito para exercício da cidadania.

A função da escola é promover uma educação libertadora, participativa, contextualizada, onde educador e educando aprendem juntos. Ou seja, é oferecer ao indivíduo oportunidades de socialização, autonomia do pensar, reflexão e racionalização sobre questões cotidianas, a fim de que o educando pense por si mesmo e não seja apenas um reprodutor de conteúdo. Dessa forma, a escola deve estabelecer relação entre teoria e prática, a partir do contexto no qual o aluno encontra-se inserido (FREIRE, 2019).

Na sociedade contemporânea, com o aprofundamento da democracia, a função do Estado sofreu grandes transformações, sendo hoje 
seu principal objetivo promover e garantir o bem estar social. Desse modo, os governos (federal, estadual, municipal) desenvolvem ações em diferentes áreas, como saúde, educação, meio ambiente, para atingir esse fim. Nesse sentido, eles se utilizam de políticas públicas que viabilizem essas ações.

Para Lopes e Amaral (2008), as políticas públicas são um conjunto de ações e decisões do Estado voltadas para solução de problemas da sociedade. Ainda de acordo com as autoras, a sociedade atual se caracteriza por sua imensa diversidade em termos de etnia, religião, gênero, renda, ideias e interesses. As demandas dessa sociedade são apresentadas mediante a mobilização desses grupos da sociedade civil. O desafio está em atender essas demandas com recursos limitados e escassos, quando aqueles que estão no poder visam apenas atender seus próprios interesses e de uma elite empresarial, desconsiderando, dessa forma, os anseios populares por uma melhor qualidade de vida, que lhes garantam os direitos básicos assegurados pela Constituição.

O Sistema Educacional no Brasil é regido por órgãos normativos como Ministério da Educação e Cultura e Conselho Nacional de Educação, sendo estes responsáveis pela estrutura e funcionamento do ensino segundo legislação vigente.

Entretanto, o entrave da dicotomia entre teoria e prática é um problema que ainda persiste na prática educacional contemporânea. Nesse sentido, há esforços para superação desse entrave histórico através de uma gestão participativa, que incluem iniciativas governamentais e não governamentais, como o Projeto Político Pedagógico, Conselhos Escolares, Associações de Pais e Professores, Círculos em Movimento, Movimentos Sociais e Coletivos, que contribuem na tomada de decisões e no funcionamento da organização escolar, a fim de contemplar a participação de todos os autores envolvidos no processo educacional: profissionais da escola, os alunos, família e sociedade.

As políticas públicas implementadas ao longo dos anos buscam garantir que o indivíduo tenha acesso ao ensino universal, gratuito e de qualidade, a fim de alcançar os objetivos proposto pela Constituição. Nesse sentido, a Lei de Diretrizes e Bases da Educação (LDB), o Plano Nacional de Educação (PNE), o Fundo de Manutenção e De- 
senvolvimento da Educação Básica e de Valorização dos Profissionais da Educação (FUNDEB), Política de Cotas (Lei 12.711/12), Política Nacional de Educação Especial, obrigatoriedade do ensino de História e Cultura Afro-Brasileiras nas escolas (Lei 10.639/03) e Indígena (Lei 11.645/08), dentre outras, corroboram como ações voltadas para garantir que a educação, enquanto direito constitucional, torne-se cada vez mais inclusiva e democrática.

Desse modo, foi possível concluir que a educação desde sua origem possui um caráter excludente. Pretos, indígenas, mulheres, dentre outros grupos, sempre ficaram à margem, sob a hegemonia do homem branco, numa sociedade patriarcal e escravocrata. As políticas públicas na educação são ações voltadas para solução de problemas que garantam o acesso a uma educação universal, gratuita e de qualidade. $\mathrm{O}$ direito educacional deve somar vozes de uma sociedade democrática para um futuro inclusivo, que possibilite ações que combatam a desigualdade de oportunidades e exclusão social.

\section{Referências bibliográficas:}

ARANHA, Maria L.A. História da Educação. São Paulo: Moderna, 2006.

Assembleia Geral da ONU. (1948). "Declaração Universal dos Direitos Humanos” (217 [III] A). Paris.

BRASIL. Constituição (1988). Constituição da República Federativa do Brasil. Brasília, DF: Senado Federal: Centro Gráfico, 1988.

FERNANDES, Florestan. A integração do negro na sociedade de classes. São Paulo: Globo, 2008.

FERREIRA, M.E. [et. al.]. Estereótipos e essencialização de brancos e negros: um estudo comparativo. Florianópolis/SC: Revista Psicologia e Sociedade, Vol. 23, № 01, 2011.

FREIRE, Paulo. Pedagogia do Oprimido. Rio de Janeiro: Paz e terra, 2019. 
GOMES, Laurentino. Escravidão: volume 1. Rio de Janeiro: Globo, 2019.

LOPES, B.; AMARAL, J.F. Políticas Públicas: conceitos e práticas. Belo Horizonte: Sebrae, 2008.

ROMANELLI, Otaíza. História da Educação no Brasil. Petrópolis/RJ: Vozes, 2014.

SOUSA, Ana P.; Filho, Mário J. A importância da parceria entre família e escola no desenvolvimento educacional. Revista Iberoamericana de Educación, Vol. 44, №. 7, 2007.

SOUZA, Jessé. A elite do atraso: da escravidão a Bolsonaro. Local: Editora, 2019. 


\section{A PRATICA DOCENTE JUNTO AO SISTEMA PRISIONAL (QUANDO A EDUCAÇÃO ROMPE GRADES E CADEADOS): UM RELATO DE EXPERIÊNCIA NA PENITENCIÁRIA JOSÉ DE DEUS BARROS SITUADA NA CIDADE DE PICOS - PI}

Maurício Pereira Barros

Resumo:

O presente estudo propõe apresentar relatos vivenciados através de uma experiência docente para com um grupo de apenados no Presídio Estadual José de Deus Barros através da troca de experiências no curso de micro empreendedor individual. A educação prisional no Brasil tem uma árdua tarefa: incluir não só quem a sociedade exclui, mas também quem a escola abandonou. Dos 726,7 mil presos em todo o país, 70\% não concluíram o Ensino Fundamental, 92\% não terminaram o Ensino Médio, 8\% são analfabetos e menos de 1\% ingressou ou tem diploma do Ensino Superior. A assistência educacional para indivíduos privados de liberdade é um dos direitos garantidos constitucionalmente e regrados pela Lei de Execução Penal (LEP), que viabiliza remição de pena e, sobretudo, cria condições de ressocialização. Objetiva-se com essa experiencia contribuir para a compreensão dos limites e das possibilidades da educação escolar nas prisões. Com base na me- 
todologia de pesquisa qualitativa e participante, e com fulcro em uma investigação bibliográfica, documental e de campo, o relato pretende problematizar o discurso oficial e a realidade vivenciada pelos internos. O programa federal tem o propósito de reinserir egressos do sistema prisional na sociedade e no mundo do trabalho, através da Secretaria de Estado da Educação, Juventude e Esportes (Seduc), por meio da coordenação-geral do Programa Nacional de Acesso ao Ensino Técnico e Emprego (Pronatec). A investigação que embasou o presente estudo de caso sobre o Pronatec Prisional, enquanto política pública na área da educação, aconteceu na penitenciária José de Deus Barros na cidade de Picos PI. A unidade abriga hoje mais de 400 presos, a expeiriencia vivida veio agregar muito de forma direta e significativa na prática docente, prescedida de um vies e cunho social diferenciado. A partir destas ponderações foi possível aferir que as políticas públicas vinculadas à educação em ambientes prisionais são imprescindíveis para que indivíduos privados de liberdade estejam preparados para um recomeço em sociedade. Diante de todas as ponderações realizadas a partir da análise dos objetivos supramencionados, é possível apresentar um conjunto de considerações acerca de necessidades e melhorias importantes, a evasão no ambiente prisional, por exemplo, não pode ser encarado como a típica evasão que ocorre em turmas regulares, objeto de atendimento pelos programas de permanência e êxito, ela decorre de transferências e progressões de regime, no caso, do fechado para o semiaberto. A referida experiência só veio a corroborar esta necessidade e a constatação de uma receptividade positiva em relação a este tipo de iniciativa, por parte dos apenados. Contudo, pode-se averiguar que a ação foi exitosa, ao tempo que se espera que a mesma tenha vindo a colaborar para a formação e ressocialização destes egressos.

Palavras-chave: Educação prisional; Juventude; Ressocialização.

\section{REFERÊNCIAS}

BRASIL. Lei Federal no 7.210, de 11 de julho de 1984. Diário Oficial da União, Brasília, 13 jul. 1984. Disponível em: . Acesso em: 11 mar. 2011. 
. Constituição da República Federativa do Brasil de 1988.

Brasília, 5 out. 1988. Disponível em: . Acesso em: 11 mar. 2011.

. Lei no 9.394, de 20 de dezembro de 1996. Diário Oficial da União. Brasília, 23 dez. 1996. Disponível em: . Acesso em: 11 mar. 2011.

Ministério da Justiça: Conselho Nacional de Política Criminal e Penitenciária. Resolução no 03 , de 11 de março de 2009. Disponível em: . Acesso em: 15 mar. 2011.

. Ministério da Educação: Conselho Nacional de Educação. Resolução no 02, de 19 de maio de 2010. Disponível em: . Acesso em: 11 mar. 2011.

CARREIRA, Denise. Relatório nacional para o direito humano à educação: educação nas prisões brasileiras. São Paulo: Plataforma DhESCA Brasil, 2009.

CRAIDY, Carmem Maria (Org.). Educação em prisões: direito e desafio. Porto Alegre: UFRGS, 2010.

FRAGOSO, Heleno; CATÃO, Yolanda; SUSSEKIND, Elisabeth. Direito dos presos. Rio de Janeiro: Forense, 1980.

FREIRE, Paulo. Pedagogia da autonomia: saberes necessários à prática educativa. 8. ed. Rio de Janeiro: Paz e Terra, 1998.

GOFFMAN, Erving. Manicômios, prisões e conventos. São Paulo: Perspectiva, 1974. GRACIANO, Mariângela (Org.). Educação também é direito humano. São Paulo: Ação Educativa, Plataforma Interamericana de Direitos Humanos, Democracia e Desenvolvimento, 2005.

HÖFLING, Eloisa de Mattos. Estado e políticas (públicas) sociais. Caderno CEDES, Campinas, v. 21, n. 55, nov. 2001.

HOWLETT, Michael; RAMESH, M. Studying public policy: policy cicles and policy subsystems. Oxford: University Press, 1995. 
JULIÃO, Elionaldo Fernandes. Educação e trabalho como propostas políticas de execução penal. Alfabetização e Cidadania: revista de educação de jovens e adultos, Brasília, n. 19, p. 73-84, jul. 2006.

LEFEBVRE, Henri. La presencia y la ausencia: contribución a la teoría de las representaciones. México: Fondo de Cultura Económica, 1983.

LEMGRUBER, Julita. Cemitério dos vivos: análise sociológica de uma prisão de mulheres. Rio de Janeiro: Forense, 1999.

LEWIN, Kurt. Problemas de dinâmica de grupo. São Paulo: Cultrix, 1970.

MAEYER, Marc de. Na prisão existe perspectiva da educação ao longo da vida? Alfabetização e Cidadania: revista brasileira de educação de jovens e adultos, Brasília, n. 19, p. 17-37, jul. 2006.

MINAS GERAIS. Decreto estadual no 44.196, 28 dez. 2005. Disponível em: . Acesso em: 13 jan. 2012.

SABADELL, Ana Lúcia. Algumas reflexões sobre as funções da prisão na atualidade e o imperativo da segurança. In: OLIVEIRA, Rodrigo Torres; MATTOS, Virgílio (Orgs.). Estudos de execução criminal: direito e psicologia. Belo Horizonte: TJMG/CRP, 2009. 


\section{EDUCAÇÃO E DIREITOS HUMANOS: OS JOVENS MULTIPLICADORES NA CONSTRUÇÃO DO BEM COMUM}

Ralph Schibelbein

A educação não só é um direito humano e fundamental como, também, é meio de acesso para os demais direitos. Desta forma faz-se essencial uma maior reflexão acerca da educação enquanto ferramenta de divulgação, acesso e validação dos direitos humanos. E é através do processo que buscamos alternativa para (re)pensarmos o histórico estigma que o conceito de direitos humanos enfrenta no Brasil. Entendendo a educação como antídoto ao preconceito, apostamos no fortalecimento de uma cultura dos direitos humanos como uma forma de defender a dignidade humana.

Para não deixar a temática somente nas mãos da mídia sensacionalista, dos meios jurídicos ou de ativistas sociais, a educação não formal é uma oportunidade de fomentar a reflexão, o debate e a prática dos direitos humanos. E é entendendo essa condição que o Programa de Oportunidades e Direitos (POD) tem investido na formação de jovens para a educação em direitos humanos e o incentivo na multiplicação desses saberes e práticas.

Em tempos de mudanças aceleradas, assistimos ao paradoxo da globalização reduzindo a pobreza mundial e possibilitando, sobretudo através das mídias sociais, a comunicação e participação dos cidadãos de todo o mundo, mas ao mesmo tempo vemos um aumento das desigualdades sociais e uma ameaça constante à democracia e ao pleno 
exercício da cidadania. Entendendo que a educação é ferramenta para a prática democrática e o desenvolvimento da cidadania, defendemos que fomentarmos políticas públicas educacionais agora é desenharmos a sociedade que queremos ter no futuro.

Em uma abordagem interdisciplinar, apoiamo-nos em autores de diferentes áreas, buscando assim distintos olhares sobre o tema, com objetivo de criar um diálogo mais enriquecedor. Para analisar a relação da sociedade com a educação utilizaremos os pensadores Paulo Freire, Edgar Morin e Pierre Bourdieu. Para tratar mais especificamente do papel da educação não formal colocaremos a ideia de reprodução de Bourdieu para dialogar com a crença de transformação do pensador brasileiro Paulo Freire. Essa educação transformadora proposta por Freire, queremos analisá-la a luz da ideia de cidadania planetária trazida por Morin.

Nos propomos a pensar a complexidade da educação em relação aos conceitos de saber, conhecimento, informação e aprendizagem. Nessa tarefa contaremos com apoio do inglês Peter Burke e das suas reflexões sobre a história do conhecimento. $\mathrm{O}$ historiador propõe que pensemos o conhecimento no plural. Ele faz uma distinção inicial como a informação sendo algo "cru” e o conhecimento algo já processado, "cozido". Sendo assim a informação que seriam dados sistematizados, necessita de um processo para transformar-se em conhecimento. Esse processo se da pela análise, que consiste em transformar a informação em conhecimento por meio de práticas como descrição, quantificação, classificação e verificação. (BURKE, 2016)

De Bourdieu serão importantes as críticas ao modelo de dominação e reprodução de valores através da educação. Principalmente os conceitos de habitus e capital cultural. Para ele, a escola é um espaço de reprodução de estruturas sociais e de transferência de capitais de uma geração para outra. (BOURDIEU, 2009)

De outro lado, Paulo Freire com uma visão mais otimista, vê a educação como um espaço de esperança para a transformação. Criticando o modelo tradicional de educação, classificada por ele de bancária, Freire propõe uma educação libertadora. Segundo ele enquanto a educação bancária da ênfase a permanência, a concepção problemati- 
zadora e libertadora reforça a mudança" (FREIRE, 2011). Dialogando assim, com o que o pensador francês Edgar Morin propõe como uma educação com objetivo de cidadania planetária. Uma educação não somente fragmentada em disciplinas, mas um conhecimento complexo como elemento para a vida em sociedade e uma prática de educação em direitos humanos. Para Morin, a educação deve contribuir para a autoformação da pessoa (ensinar a assumir a condição humana, ensinar a viver) ensinar a como se tornar um cidadão. (MORIN, 2011)

Desta forma, nos parece que a educação em Direitos Humanos é um caminho para o fortalecimento do compromisso com a construção de uma sociedade plenamente democrática, por meio do exercício de cidadania. Mas para tal, essa educação tem que extrapolar a ideia da reprodução observada por Bourdieu e tornar-se libertadora, como propunha Paulo Freire. Uma educação problematizadora que permita que os indivíduos se percebam cidadãos e reconheçam-se como agentes históricos e sociais por determinarem o futuro da sociedade. Esse exercício que é teórico, mas sobretudo prático, acontece em um programa social do Rio Grande do Sul.

O programa (POD) foi criado pela Secretaria de Justiça, Cidadania e Direitos Humanos do Estado do Rio Grande do Sul. O objetivo é fomentar o exercício da cidadania nos jovens, garantindo seus direitos e criando oportunidades para uma vida digna. Com investimentos em educação, esporte, cultura, segurança pública e atendimento socioeducativo, o POD atua como uma política pública pioneira e completa para os jovens e suas comunidades.

Dentro do programa existe um eixo que é nosso objeto de pesquisa: Os Jovens Multiplicadores. A partir de uma formação em direitos humanos, estes jovens possuem o compromisso de multiplicarem os conhecimentos adquiridos através de práticas que levem os direitos humanos ao cotidiano de suas comunidades.

Entendendo a educação como ferramenta para o exercício democrático e o desenvolvimento da cidadania, acreditamos que pensar políticas públicas educacionais hoje é desenharmos a sociedade que queremos ver amanhã. Nesse sentido a questão que nos colocamos a tentar responder é qual o impacto na construção do bem comum, da edu- 
cação em direitos humanos a partir da formação e prática dos jovens multiplicadores no Programa de Oportunidades e Direitos (POD) em Porto Alegre/RS?

Nessa investigação buscamos relacionar a educação em direitos humanos com a construção do bem comum e identificar as práticas em direitos humanos realizadas pelos jovens multiplicadores do POD.

Por meio de suas ações, os jovens exercitam a cidadania e fomentam um cuidado coletivo, através de campanhas, conscientizações, rodas de conversa e demais práticas que contribuem para que eles se reconheçam como sujeitos históricos e sociais, capazes de interferir na construção de um bem comum.

Nosso estudo parte de um modelo empírico e qualitativo, onde a investigação ocorre a partir de análise bibliográfica, documental, entrevistas semiestruturadas e em profundidade, questionários e observação.

Por fim, acreditando que não existe elemento mais transformador que a educação para promover a dignidade humana, o conhecimento, o respeito e a prática dos direitos humanos, apostamos no processo de aprendizagem como meio de desenvolver a cidadania plena e contribuir para a construção do bem comum.

\section{REFERÊNCIAS:}

BOURDIEU, Pierre ; PASSERON, Jean-Claude. A Reprodução: Elementos para uma Teoria do Sistema de Ensino. 2. ed. Petrópolis: Ed. Vozes 2009.

BURKE, Peter. O que é história do conhecimento? São Paulo: Unesp, 2016.

FREIRE, Paulo. Pedagogia do Oprimido. Rio de Janeiro: Paz e Terra, 2011.

MORIN, Edgar. A cabeça bem feita. Repensar a reforma, reformar o pensamento. 19 ed. Rio de Janeiro: Bertrand Brasil. 2011. 


\section{O "BIOHACKING" COMO ALTERNATIVA NA EFETIVAÇÃO DO DIREITO À EDUCAÇÃO INCLUSIVA: O CASO DOS ALUNOS SUPERDOTADOS COM AUTISMO LEVE}

\section{Guilherme Carneiro Leão Farias}

O objetivo geral deste artigo é investigar a aplicabilidade da ideia de melhorar o desempenho humano por meio de manipulações ambientais lícitas (biohacking) como alternativa em políticas públicas de atendimento educacional especializado. Como amostra foi selecionado o grupo com Transtorno do Espectro Autista do tipo 1 (ou Síndrome de Asperger) e superdotação, por representar a intersecção do público-alvo da educação especial: as pessoas com deficiência, com transtornos globais do desenvolvimento e com altas habilidades ou superdotação (artigo $1^{\circ}$, parágrafo $1^{\circ}$, do Decreto n. 7.611/2011).

Os objetivos específicos são dois. O primeiro é identificar as necessidades específicas decorrentes dessa dupla excepcionalidade. $\mathrm{O}$ segundo é propor, com base ideia de paternalismo libertário (nudge), manipulações ambientais lícitas (biohacks) de fácil aplicação, baixo custo e nenhuma ofensividade que tenham grande probabilidade de contribuir para a inclusão desses educandos.

A relevância da pesquisa está no fato de a educação inclusiva ser um direito fundamental cuja efetivação envolve alto grau de personalização e depende de criatividade para lidar com a escassez de recursos. O biohacking alia os mais recentes avanços em áreas do conhecimento 
científico como a Epigenética e a Neurociência à ética hacker de superar limitações sistêmicas por meio de soluções criativas. Nesse sentido, merece ser investigada a aplicabilidade de aspectos dessa estratégia comportamental ao campo das políticas públicas, como alternativa na implementação do atendimento educacional especializado.

Como primeira hipótese, adotou-se a de que a manipulação do ambiente escolar, de modo a permitir um melhor desempenho acadêmico, é uma alternativa não só útil, mas necessária no atendimento educacional especializado a alunos com superdotação que também apresentam o mais brando dos transtornos do neurodesenvolvimento: a Síndrome de Asperger. E como segunda hipótese, adotou-se a de que, dentre as manipulações ambientais mais recomendadas no círculo biohacker, aquelas relacionadas à redução da intensidade dos estímulos luminosos e sonoros são as que tendem a apresentar resultados mais positivos no desempenho de estudantes com essa dupla excepcionalidade, por controlarem a manifestação clínica dos "comportamentos sensoriais incomuns" que caracterizam os transtornos do espectro do autismo.

$\mathrm{Na}$ literatura, o biohacking tem sido predominantemente abordado sob a perspectiva do individualismo, como uma técnica de otimização da performance física e mental capitaneada pelos bem-sucedidos empreendedores do Vale do Silício (ANEDDA, 2019; ASPREY, 2017; GOODWIN, 2019; Kraft, 2018; SOVIJÄRVI et al., 2018). Dessa forma, há lacuna quanto a sua utilidade na formulação de políticas públicas educacionais.

Em relação à metodologia empregada, quanto aos objetivos, a pesquisa realizada classifica-se como exploratória, porque se propôs a conhecer os potenciais benefícios de uma alternativa ainda não testada em matéria de políticas públicas educacionais. No que se refere à abordagem, a pesquisa se caracteriza como qualitativa, por utilizar instrumentos formais e estruturados para a coleta de dados. Nesse sentido, os dados foram obtidos a partir de atos normativos e literatura não só da área das Ciências Sociais Aplicadas, mas também da Medicina (ASSUMPÇÃO JR.; KUCZINSKY, 2011; SABRA et al., 2012), Pedagogia (CUMINALE, 2017; HEYLIGHEN, 2003; KAUFMAN, 
2018; MARLAND JR., 1972; MCTIGHE; WILLIS, 2019), Psicologia (AGUIAR; ROCHA, 2017; ATTWOOD, 2015; GRANDIN; PANEK, 2017; HARE, 2015; LOVECKI, 2004; RENZULLI, 2005; SZALAVITZ, 2012), atendendo, pois, à necessária transversalidade em matéria de análise de políticas públicas.

No que tange ao marco teórico, as conclusões foram norteadas pelo pensamento estoico (GARNETT, 2018; MILLER, 2019; PIGLIUCCI; LOPEZ, 2019), pela Psicologia Comportamental aplicada às políticas públicas (BEKKERS, 2017) e pelo paternalismo libertário (THALER; SUNSTEIN, 2019; WU, 2009).

Os resultados obtidos confirmam as duas hipóteses levantadas. As fontes consultadas indicam que a interação entre os impedimentos de longo prazo de natureza sensorial inerentes ao Transtorno do Espectro Autista - TEA (hipo ou hipersensibilidade a estímulos visuais, auditivos, olfativos e táteis) com barreiras encontradas no ambiente escolar ordinário (como a iluminação intermitente e de alta temperatura de cor, derivada das lâmpadas fluorescentes compactas e das de LED "branco intenso", as cores frias da pintura das paredes, o quadro branco com brilho e alto contraste, a falta de isolamento acústico), contribuem negativamente para a inclusão dos alunos superdotados com Síndrome de Asperger, aumentando o risco de evasão escolar e o de desempenho acadêmico aquém de suas capacidades, se comparados aos alunos superdotados sem Síndrome de Asperger. Dessa forma, é seguro afirmar que algumas manipulações ambientais preconizadas pelo biohacking, como privilegiar a iluminação ambiente natural e permitir o uso de equipamentos de proteção individual contra o excesso de estímulos sensoriais (kindling), configuram, para o alunado com dupla excepcionalidade, "adaptações razoáveis" e "tecnologia assistiva" asseguradas pela Convenção das Nações Unidas sobre os Direitos das Pessoas com Deficiência, pela Lei n. 12.764/2012 e pela Lei n. 13.146/2015 (Estatuto da Pessoa com Deficiência).

A conclusão é no sentido da utilidade do biohacking como alternativa na formulação de políticas públicas de educação especial. Isso porque o uso criativo das recentes descobertas no campo da Epigenética, da Neurociência e da Psicologia Comportamental para adaptar o 
ambiente escolar pode contribuir decisivamente para a efetivação do direito fundamental à educação inclusiva dos alunos com dupla excepcionalidade, sem a necessidade de grande dispêndio de recursos orçamentários e sem oferecer qualquer prejuízo ao alunado sem manifestações clínicas de "comportamentos sensoriais incomuns".

\section{BIBLIOGRAFIA}

ASSUMPÇÃO JR., Francisco B.; KUCZYNSKI, Evelyn. Diagnóstico diferencial no autismo. In: ARAÚJO, Ceres Alves de; SCHWARTZMAN, José Salomão (org.). Transtornos do espectro do autismo. São Paulo: Memnon, 2011.

AGUIAR, Érica; ROCHA, Giovane. É verdade que...? 11 mitos e verdades a respeito do transtorno do espectro autista (TEA). Segredos da mente - autismo, São Paulo, ano 1, n. 1, p. 78, mar. 2017, Alto Astral.

ANEDDA, Isacco. Neuroplasticity biohacking: how to boost neurogenesis and rewire your brain with light. [2019]. Disponível em: https://www.amazon.com/Neuroplasticity-Biohacking-Boost-Neurogenesis-Rewire-ebook/dp/ B07TMNBZ84/ref=sr_1_1?keywords=neuroplasticity+biohacking\&qid $=1561750180 \& \mathrm{~s}=$ gateway $\&$ sr $=8-1$. Acesso em: 24 jun. 2019.

ASPREY, Dave. Head strong: the bulletproof plan to activate untapped brain energy to work smarter and think faster - in just two weeks. Nova York: Harper Wave, 2017.

ATTWOOD, Tony. The complete guide to Asperger's syndrome. 2. ed. rev. Londres: Jessica Kingsley, 2015.

BEKKERS, Victor et al. Public Policy in Action: perspectives on the policy process. Chetenham: Elgar, 2017.

CUMINALE, Natália. Claro enigma. Veja, São Paulo, ed. 2.540, ano 50, n. 30, p. 88, jul. 2017. 
GARNETT, Kevin. Stoicism for beginners: master the art of happiness; learn modern; practical stoicism to create your own daily stoic routine. [2018]. Disponível em: https://www.amazon.com/Stoicism-Beginners-Happiness-Practical-Routine/ dp/1729632599/ref=sr_1_1 ?keywords=stoicism+for+beginners\&qid=1561750929\&s=gateway\&sr=8-1. Acesso em: 2 jul. 2020.

GOODWIN, Ryan. What is biohacking? [2019]. Disponível em: https://medium.com/@mrryangoodwin/what-is-biohacking-14202f726e0e. Acesso em: 2 jul. 2020.

GRANDIN, Temple; PANEK, Richard. O cérebro autista: pensando através do espectro. Tradução 6. ed. de Cristina Cavalcanti. 6. ed. Rio de Janeiro: Record, 2017.

HARE, D. J. et al. Approaching reality: the use of personal construct assessment in working with people with Asperger syndrome. Apud: ATTWOOD, Tony. The complete guide to Asperger's syndrome. 2. ed. rev. Londres: Jessica Kingsley, 2015.

HEYLIGHEN, Francis. Gifted people and their problems. [2003]. Disponível em: http://pespmc1.vub.ac.be/Papers/GiftedProblems.pdf. Acesso em: 2 jul. 2020.

KAUFMAN, Scott Barry (ed.). Twice Exceptional: supporting and educating bright an creative students with learning difficulties. [2018]. Disponível em: https://www.amazon.com/Twice-Exceptional-Supporting-Educating-Difficulties/dp/0190645474/ ref $=$ sr_1_1 ?keywords=twice+exceptional\&qid=1561752241\&s=gateway\&sr=8-1. Acesso em: 2 jul. 2020.

KRAFT, Julia. Biohacking \& superfood: entfachen Sie dees volle Potenzial lhrer Leistungsfahigkeit Optimieren Sie Körper \& Geist Wie Sie Gesundheit \& Wohlgefühl Steigern Selbstoptimierung \& Ernährung Rtgeber Buch. [2018]. Disponível em: https://www. amazon.com/Biohacking-Superfood/dp/3746776368/ref=sr_1_1 ?keywords=julia + kraft + biohacking\&qid $=1561752457 \& s=-$ gateway\&sr=8-1. Acesso em: 2 jul. 2020. 
LOVECKI, Deirdre V. Different minds: gifted children with AD/ HD, Asperger Syndrome, and other learning deficits. Londres: Jessica Kingsley, 2004.

MARLAND JR., Sidney P. Education of the gifted and talented: report to the Congress of the United States by the U.S. Commissioner of Education. [1972]. Disponível em: https://www.valdosta.edu/colleges/education/pcft/document $\% 20 /$ marland-report. pdf. Acesso em: 2 jul. 2020.

MCTIGHE, Jay; WILLIS, Judy. Upgrade your teaching: understanding by design models. Disponível em: https://www.amazon. com/Upgrade-Your-Teaching-Understanding-Neuroscience/ $\mathrm{dp} / 1416627340 /$ ref=sr_1_1 ?keywords=upgrade+your+teaching\&qid $=1561754275 \& s=$ gateway $\& s r=8-1$. [2019]. Acesso em: 2 jul. 2020.

MILLER, Conrad. Stoicism: how to integrate this powerful philosophy to become more balanced, productive, and reach your full potential. Livro eletrônico, 2019.

PIGLIUCCI, Massimo; LOPEZ, Gregory. A handbook for new stoics: how to thrive in a world out of your control. [2019]. Disponível em: https://www.amazon.com/Handbook-New-Stoics-Week-Week/dp/1615195335/ref=sr_1_1 ?keywords=a+han$\mathrm{dbook}+$ for + new + stoics\&qid=1561754149\&s=gateway $\& s r=8-1$. Acesso em: 2 jul. 2020.

RENZULLI, Joseph S. A Concepção de Superdotação no Modelo dos Três Anéis: um modelo de desenvolvimento para a promoção da produtividade criativa. [2005]. In: VIRGOLIM, Angela M. R.; KONKIEWITZ, Elisabete Castelon (org.). Altas habilidades/ superdotação, inteligência e criatividade. Campinas: Papirus, 2014.

SABRA, Aderbal et al. Disfunção gastrointestinal e comportamental em crianças com alergia alimentar não IgE mediada, hiperplasia linfoide ileal-nodular (ILNH) e função de baixo Th1: uma nova 
constelação clínica-imunológica. Journal of Food Allergy, Rio de Janeiro, vol. 1, n. 1, p. 61-68, jan./mar. 2012. Disponível em: https://journaloffoodallergy.com/journal/JFA-V1-N1.pdf\#pa$\mathrm{ge}=62$. Acesso em: 2 jul. 2020.

SOVIJÄRVI, Olli et al. Biohacker's handbook: upgrade yourself and unleash your inner potential. Helsinki: Biohacker Center, 2018.

SZALAVITZ, Maia. What genius and autism have in common. [2012]. Disponível em: http://healthland.time.com/2012/07/10/ what-child-prodigies-and-autistic-people-have-in-common/. Acesso em: 2 jul. 2020.

THALER, Richard; SUNSTEIN, Cass. Nudge: como tomar melhores decisões sobre saúde, dinheiro e felicidade. 2. ed. rev. Tradução de Ângelo Lessa. São Paulo: Objetiva, 2019.

WU, Steven. When is a nudge a shove? The case for preference-neutrality. Columbia Public Law Research, Nova York, abr. 2009. Disponível em: https://papers.ssrn.com/sol3/papers.cfm?abstract_ $\mathrm{id}=1375616$. Acesso em: 2 jul. 2020. 


\section{A ESCOLA PÚBLICA ENQUANTO ESPAÇO DE EXPRESSÃO DA LIBERDADE E DE (RE)CONSTRUÇÃO DE SABERES: UMA ANÁLISE À LUZ DOS DIREITOS E GARANTIAS FUNDAMENTAIS DA CONSTITUIÇÃO FEDERAL DO BRASIL}

Rafael Ramos Longuinhos

\section{INTRODUÇÃO E JUSTIFICATIVA}

O título II da Constituição da República Federativa do Brasil estabelece os direitos e as garantias fundamentais de todos os brasileiros, natos e naturalizados. Esse título é composto por 5 capítulos. Cada capítulo possui um ou mais artigos. Neste estudo, delimitamo-nos a analisar o capítulo I, constituído pelo artigo $5^{\circ}$, que abrange um conjunto de 78 incisivos, nos quais fazem menção aos direitos e deveres individuais e coletivos.

Dentre os direitos e deveres individuais e coletivos, garantidos a todos os cidadãos, sem qualquer distinção, analisamos apenas o conteúdo relacionado com a premissa de a escola pública ser um espaço de expressão da liberdade e de (re)construção de saberes.

Longuinhos (2020, p. 7), defende que “a escola pública é, inicialmente, uma instituição social, composta por pessoas que ensinam, aprendem, refletem, criticam e compartilham experiências de vida.". 
Observamos que os atos de ensinar, aprender, refletir, criticar e compartilhar experiências são direitos garantidos e previstos no inciso IV, que concebe como sendo "[...] livre a manifestação do pensamento [...]”(BRASIL, 1988, n.p.), fomentando nas escolas, especialmente às públicas por seu caráter laico, a formação de sujeitos críticos e reflexivos para a sociedade.

Considerando esse contexto, o presente estudo desloca a sua discussão para o cenário da escola pública, porque

À medida que a escola pública se preocupa em construir e reconstruir o saber científico com seus estudantes, ela acolhe e alimenta sonhos por meio da empatia, da afetividade e do diálogo. Esses momentos de empatia, afetividade e diálogo acabam sendo bem úteis para estimular os estudantes a sonharem por dias melhores e enxergarem que só por meio do Conhecimento, as pessoas conseguem se libertar das correntes que as prendem na caverna de Platão e adentram espaços que antes só uma pequena parcela privilegiada da sociedade tinha "direito". (LONGUINHOS, 2020, p. 7-8).

Logo, "educar é conseguir que a criança [e adolescentes] ultrapasse as fronteiras que, tantas vezes, lhe foram traçadas como destino pelo nascimento, pela família ou pela sociedade. Hoje, a realidade da escola obriga-nos a ir além da escola.” (NÓVOA, 2009, n.p.). Como é possível verificar, esse espaço fecundo que é a escola pública, permite aos envolvidos a liberdade de "[...] expressão da atividade intelectual, artística, científica e de comunicação, independentemente de censura ou licença”" (BRASIL, 1988, n.p.), como prevê o inciso IX da Constituição.

Portanto, à luz dos direitos e garantias fundamentais da Constituição Federal do Brasil, é possível concluir que a escola pública encontra amparo constitucional para a sua atividade enquanto espaço privilegiado de manifestação da liberdade e de (re)construção de saberes.

\section{OBJETIVO}

Ratificar que a escola pública é uma instituição social que realiza um trabalho que vai além da mediação dos conteúdos, conseguindo 
fomentar os ideais constitucionais de liberdade e expressão da atividade intelectual.

\section{METODOLOGIA}

A metodologia adotada neste estudo foi a pesquisa bibliográfica por meio da análise do texto constitucional livros, bem como de artigos em periódicos, revistas e sites acadêmicos acerca do tema investigado. Neste contexto, o presente estudo se caracteriza por ser uma pesquisa básica de natureza qualitativa.

\section{CONSIDERAÇÕES FINAIS}

A partir deste estudo foi possível concluir que exercer a prática da docência na escola pública significa servir a um ideal de sociedade menos desigual. A escola pública, em certos contextos, é percebida pelos estudantes como um lócus de manifestação da liberdade e de transformação social, porque eles, muitas vezes, só encontram na escola um ambiente acolhedor e fomentador de análises e discussões a respeito da realidade que os cercam.

\section{REFERÊNCIAS}

BRASIL. [Constituição (1988)]. Constituição da República Federativa do Brasil. Brasília, DF: Senado Federal, 1988. Disponível em: http://www.planalto.gov.br/ccivil_03/constituicao/ constituicaocompilado.htm. Acesso em: 10 jul. 2020.

NÓVOA, António. Para uma formação de professores construída dentro da profissão. In:

Professores: imagens do futuro presente. Lisboa: Educa, 2009.

LONGUINHOS, Rafael Ramos. Divulgação Científica em Astrobiologia por meio de exposição como promotora do ensino interdisciplinar entre Biologia, Física e Química. 2020. Dissertação (Mestrado Profissional em Ensino de Astronomia) - Departamento de Física, Universidade Estadual de Feira de Santana, Feira de Santana, 2020. 


\section{REFLEXÕES SOBRE O ESPAÇO DAS PESSOAS TRANS NO PROCESSO EDUCACIONAL: UM LUGAR DE EXCLUSÃO}

Ana Carolina Rodrigues de Assis

Bruna Alves de Almeida

Estefânia Moreira dos Reis

Giovanna Rodrigues de Assis

A educação, conforme é previsto na Constituição Federal, é um "direito de todos e dever do Estado e da família" e deve ser "promovida e incentivada com a colaboração da sociedade, visando ao pleno desenvolvimento da pessoa, seu preparo para o exercício da cidadania e sua qualificação para o trabalho" (BRASIL, 1988). A responsabilidade do Estado não se encerra na promoção do acesso isonômico à educação, mas é seu dever garantir um ensino de qualidade, que por meio do respeito às pluralidades, assegure a permanência de todas e todos nas escolas.

É por meio da educação que um indivíduo desenvolve a sua formação intelectual, moral e social, e nessa estrutura de formação o espaço mais constante aos jovens está na escola, lugar em que, na maioria das vezes, se aprende, se assimila e se recria os conhecimentos dados como essenciais pela Base Nacional Comum Curricular brasileira. $\mathrm{Na}$ atual sociedade é mediante da educação escolar que um cidadão se prepara para o exercício da sua autonomia dentro da sociedade. Contudo, a educação, no Brasil, pode ser excludente à determinadas minorias 
sociais, tais como as pessoas transgêneras. Sendo assim, o ambiente escolar não tem sido acolhedor à essas pessoas, apesar do reconhecimento do ordenamento jurídico brasileiro da importância do processo educacional enquanto um direito fundamental e social.

A partir da noção de que "qualquer discriminação é imoral e lutar contra ela é um dever por mais que se reconheça a força dos condicionamentos a enfrentar" (FREIRE, 2019, p. 59), faz-se necessário compreender que a escola, enquanto parte da sociedade, engendra e reproduz o preconceito e a violência relacionados à população trans. As instituições educacionais demonstram-se incapazes de lidar com as diferenças e a pluralidade dos sujeitos, além de ser a maior reprodutora das cis-heteronormas. Sendo assim, a transfobia que permeia a sociedade, resultante da reafirmação dessas normas, está presente nas relações sociais estabelecidas no ambiente escolar, afetando o processo educacional dos alunos e alunas trans sob a prerrogativa de problemas de aprendizagem.

A pesquisa "Juventudes na Escola, Sentidos e Buscas: Por que frequentam”, indica que 19,3\% dos alunos, não queriam ter transexuais, transgêneros, travestis e homossexuais como colega de classe (ABRAMOVAY et al., 2015). Esse dado aponta apenas para uma das formas como a transfobia pode se revelar no ambiente escolar, a qual pode apresentar diversas faces dentro desse espaço. A realidade de exclusão vivenciada por esse grupo transcende a discriminação praticada entre os alunos, não se revelando apenas nos insultos de colegas ou nas agressões físicas que podem sofrer destes. Tal discriminação se apresenta igualmente no despreparo da equipe pedagógica e dos demais profissionais, na falta de laicidade que permeia o processo educacional, nas limitações da estrutura física e curricular das escolas, assim como no uso do nome civil dos alunos e alunas trans ao invés de seu nome social. Nesse viés, tais fatos expõem uma realidade hostil vivenciada por esse grupo social nas instituições de ensino, em que ações preconceituosas e violências físicas, psicológicas e verbais são frequentes.

Sob essa perspectiva, não se trata apenas de evasão quando os estudantes trans deixam a escola por não se encaixarem em padrões de gênero e sexualidade impostos pelo ambiente escolar, mas sim de ex- 
pulsão. Esses fenômenos são diversos de modo que "a natureza da violência que leva uma criança a deixar de frequentar a escola porque tem que trabalhar para ajudar a família, não é da mesma ordem daquela que não consegue se concentrar nos conteúdos transmitidos porque é "diferente" (BENTO, 2012, p. 175). A expulsão desses alunos se dá na reafirmação das cis-heteronormas que obrigam os alunos a se apresentarem de uma forma predeterminada, fato que apaga partes importantes da personalidade e da identidade desses indivíduos. A não aceitação desses sujeitos pela sociedade faz com que aqueles que não estejam situados na normalidade dominante tenham que se ausentar dos espaços educacionais, uma vez que possuem sua identidade marcada e violentada.

A escola é uma extensão da sociedade e, por isso, ao mesmo tempo em que ela assimila elementos do ambiente social, ela influencia neste. Segundo João Paulo Carvalho Dias, presidente da Comissão de Diversidade Sexual da Ordem dos Advogados do Brasil (OAB), estima que o país concentre $82 \%$ de "evasão" escolar dos transgêneros. Tendo em vista o exposto, o alto índice de expulsão desse grupo do espaço escolar reflete a experiência de exclusão vivenciada por esses indivíduos em diversas instâncias da sua vida, ao mesmo tempo que uma mudança iniciada no próprio ambiente escolar seria capaz de influenciar a sociedade de forma a modificar a realidade de vulnerabilidade e constante violação de direitos básicos destes indivíduos.

A atividade educativa e formativa, em todos seus níveis, é uma das possibilidades de recuar os índices de desigualdade social no país, e a conclusão da educação básica é uma porta de acesso à educação superior, ao mesmo tempo em que fornece uma maior probabilidade de um emprego formal. Além disso, as atividades educativas devem corroborar para a formação e o reconhecimento da diversidade de identidade dos indivíduos, juntamente com o desenvolvimento da aprendizagem científica e a socialização entre os seres humanos. Sendo assim, é essencial que a população trans esteja igualmente inserida no mercado de trabalho, uma vez que, segundo a estimativa feita pela Associação Nacional de Travestis e Transsexuais (ANTRA), a transfobia estrutural faz com que 90\% 
das pessoas trans recorram à prostituição em algum momento da vida como única opção de sobrevivência.

"A educação, seja ela dada pela família, pela comunidade ou pela escola, deve antes de mais ajudá-los a descobrir-se a si mesmos. Só então poderão, verdadeiramente, pôr-se no lugar dos outros e compreender as suas reações." (DELORS, 2001, p. 98). Isto é, durante o processo educacional, o intuito da comunidade escolar deve ser sempre acolher as diferenças e não anulá-las. Dessa forma, evidencia-se a urgência de aperfeiçoar o combate nas escolas à exclusão e à discriminação dos indivíduos transgêneros, de modo que as instituições escolares passem a desenvolver grades curriculares que envolvam aulas destinadas à discussão sobre questões de gênero e sexualidade, a prestação de assistência psicológica, bem como a promoção da representatividade no ambiente escolar a partir da diversificação da equipe pedagógica e administrativa.

Haja vista a necessidade de mudar as instituições de ensino para que estas se adequem à população trans, existem projetos que devem ser reconhecidos como parâmetro para as políticas educacionais brasileiras, tais como o LGBT Nuances, pertencente ao Centro Acadêmico Armando de Salles Oliveira da Universidade de São Paulo em São Carlos, que consiste em um curso preparatório para o vestibular do ENEM voltado para esses indivíduos, em que as aulas são preparadas e lecionadas por estudantes LGBT da USP de São Carlos. Além disso, há também a TransVest, uma organização não governamental em Belo Horizonte que fornece supletivos, aulas de idiomas e, também, cursinho para ENEM para o referido grupo social.

É inevitável enfatizar a importância das instituições educacionais que possuem papel revolucionário na formação cidadã de seus estudantes e na desconstituição de um sistema intolerante e opressor. A escola precisa ser o espaço que apoie e acolha alunos e alunas transgêneros para promover a autonomia social desse grupo na sociedade brasileira. Ela necessita conhecer e dar visibilidade a esse grupo social para que as pessoas trans não se sintam expulsas deste espaço. As cis-heteronormas não deveriam determinar a vida escolar e social desses indivíduos, de forma a impedir que esses sujeitos ocupem diversos espaços dentro da 
sociedade. A partir dessa noção, faz-se necessário compreender a importância de uma educação não discriminatória e não determinista, em defesa do lugar do ser humano dentro de uma cis-heteronormatividade vigente.

\section{REFERÊNCIAS}

BENTO, Berenice. O que é transexualidade. 2. ed. São Paulo: Brasiliense, 2012

BRASIL. [Constituição (1988)]. Constituição da República Federativa do Brasil de 1988. Brasília, DF: Presidência da República. Disponível em: https://www.senado.leg.br/atividade/ const/con1988/CON1988_05.10.1988/art_205_.asp Acesso em: $07 / 07 / 2020$

CUNHA, Thais. Transexuais são excluídos do mercado de trabalho. Correio brasilience. Disponível em: http://especiais.correiobraziliense.com.br/transexuais-sao-excluidos-do-mercado-de-trabalho. Acesso em: 7 jul. 2020.

DELORS, J. Educação: um tesouro a descobrir. 2ed. São Paulo: Cortez Brasília, DF: MEC/UNESCO, 2003.

FREIRE, Paulo. Pedagogia da Autonomia, 59ํe ed, Paz \& Terra, 2019.

HANNA, Wellington; CUNHA, Thaís. Expulsos da Escola. Disponível em: http://especiais.correiobraziliense.com.br/violencia-e-discriminacao-roubam-de-transexuais-o-direito-ao-estudo. Acesso em: 7 jul. 2020.

WAISELFISZ, Júlio et al. Juventudes na escola, sentidos e buscas: Por que frequentam? Brasília-DF: Flacso - Brasil, OEI, MEC, 2015. 


\title{
O PAPEL DOS DIREITOS HUMANOS NO ENSINO PRÉ-ESCOLAR
}

\author{
Ana Laura de Azevedo Oliveira
}

O artigo aborda a reflexão sobre a necessidade da pedagogia adotada pelo ensino pré-escolar (público e privado) ser compatível com os valores do Art. XXVI $\$ 2^{\circ}$ da Declaração Universal dos Direitos Humanos, como também a importância do professor como alguém consciente de seu papel em ensinar sobre direitos humanos desde as primeiras fases da vida escolar, mesmo em um momento do desenvolvimento humano em que conceitos e teoria não são compreendidos. Onde o aprendizado ocorre por meio de momentos de brincadeira, acolhimento e desenvolvimento de relacionamentos.

A pesquisa se desenvolveu a partir de análise teórica, relacionando estudos da área do Direito, Pedagogia e Psicologia.

Nota-se a importância do diálogo a respeito do tema devido à preocupação com o grande número de crianças e adolescentes não se desenvolvendo adequadamente nos quesitos emocionais, relacionais e psicológicos (principalmente considerando casos de ansiedade e depressão), e a influência que abordagens escolares que violam direitos, a individualidade da criança e seu processo de adquirir conhecimento, têm sobre isso.

Em um momento em que no Brasil o reconhecimento dos direitos da criança encontrou força legal, onde a Constituição de 1988, em correspondência com a Declaração Universal dos Direitos Humanos (1948), firmou o compromisso do Estado e de toda a sociedade com a educação e proteção da criança e seus interesses, sendo seguida pelo 
Estatuto da Criança e do Adolescente (ECA, 1990), o Plano Nacional de Educação (2014), e a Lei do Marco Legal da primeira infância (2016), o ensino pré-escolar assume um caráter de responsabilidade com os primeiros anos da vida de um ser humano em formação, e exige ainda mais atenção da Academia e sociedade.

Ao enfatizar a necessidade de uma educação que vise o pleno desenvolvimento da personalidade humana, a Declaração nos deu o fundamento sobre como deve ser pensado o ensino infantil. Sendo assim, para que haja correspondência entre a realidade das escolas e o artigo da DUDH já mencionado, faz-se necessário que as decisões tomadas para orientar os processos educacionais tenham como objetivo o "pleno desenvolvimento da personalidade humana e do fortalecimento do respeito pelos direitos humanos e pelas liberdades fundamentais" (Paris, 1948), o que necessariamente compreende os métodos pedagógicos adotados pela escola, seja ela pública ou privada. Tal como seu espaço físico, a formação de seus profissionais e a orientação dos familiares ou responsáveis pela criança.

Sendo assim, a pesquisa teve como objetivo orientar sobre a importância de que a escola possua uma didática adequada com o desenvolvimento pleno do ser humano - que se inicia e tem grande impacto nos primeiros anos de vida - contribuindo para o desenvolvimento de cidadãos aptos a construir uma sociedade mais justa e pacífica.

Além de demonstrar como a manutenção de metodologias tradicionais, em muitos casos, inibe os processos criativos, o desenvolvimento do pensamento crítico e coloca pressão para a obtenção de "resultados" em pessoas que ainda não estão preparadas emocionalmente e psicologicamente para isso, causando insegurança, medo, desconforto, baixo aproveitamento, baixa autoestima e a perda da vontade de aprender e estudar. Resultando, em não poucos casos, também a quadros psicológicos mais graves.

Como resultado, foi analisado como ambientes escolares que se preocupam com uma educação humanizada, vendo a criança como um ser detentor de direitos (e que devem ser preservados pela família e sociedade), contribuem significativamente para o desenvolvimento de cidadãos conscientes, plenos, tolerantes, que valorizam relaciona- 
mentos de amizade e cooperação, além de proporcionar o gosto pelo aprendizado e descoberta, levando em consideração a individualidade de cada aluno e se preocupando com seu desenvolvimento psíquico e emocional.

\section{REFERÊNCIAS BIBLIOGRÁFICAS}

BRASIL. [Constituição (1988)]. Constituição da República Federativa do Brasil: promulgada em 5 de outubro de 1988.

BRASIL. Lei no ${ }^{-}$8.069, de 13 de julho de 1990. Institui o Estatuto da Criança e do Adolescente.

BRASIL. Lei № 13.257, de 8 de março de 2016. Institui o Marco Legal da Primeira infầncia.

BRITES, Clay; BRITES, Luciana. Desenvolvimento Cognitivo Infantil: percepções, reações e competências. [S. l.], 2016. Disponível em: https://neurosaber.com.br/desenvolvimento-cognitivo-infantil-percepcoes-reacoes-e-competencias/. Acesso em: 20 nov. 2019.

FREIRE, Paulo. Educação como prática da liberdade. 1ª ed. Rio de Janeiro: Paz e Terra, 1967.

FREIRE, Paulo. Política e Educação: Questões da Nossa Época. 5. ed. São Paulo/SP: Cortez, 2001. v. 23

HARVARD UNIVERSITY (Center of Developing Child). In: Early Childhood Mental Health. Disponível em: https://developingchild.harvard.edu/science/deep-dives/mental-health/. Acesso em: 12 out. 2019

MINISTÉRIO DA EDUCAÇÃO (Brasil). Diretrizes Nacionais sobre estimulação precoce: o portador de necessidades educativas especiais. livro de domínio público.

MINISTÉRIO DA EDUCAÇÃO (Brasil). Educação e Democracia - Situações e perspectivas. livro de domínio público. 
Ministério DA EDUCAÇÃO (Brasil). Políticas Públicas e Educação. E-book.

MINISTÉRIO DA EDUCAÇÃO (Brasil). Por uma escola de cidadãos. [S. l.]: CODEF, 1995. livro de domínio público.

NUNES, César Augusto R.; POLLI, José Renato. Educação e Direitos Humanos: Uma Perspectiva Crítica. 1. ed. Jundiaí/SP: Fibra, 2019. 516 p.

OLIVEIRA, Simone Barros de; PESSSOA, Elisângela Maia; CANTINI, Adriana Hartemink. Experiência interdisciplinar em educação e direitos humanos: CULTURA DE PAZ EM PERSPECTIVA. Porto Alegre/RS: [s. n.], 2015. E-book.

REVISTA CRESCER. Ansiedade em crianças: entenda o que pode estar por trás. [S. 1.], 14 abr. 2019. Disponível em: https:// revistacrescer.globo.com/Criancas/Saude/noticia/2019/04/ansiedade-em-criancas-entenda-o-que-pode-estar-por-tras.html. Acesso em: 25 out. 2019.

WARAT, Luis Alberto. Educação, Direitos Humanos, Cidadania e Exclusão Social: FUNDAMENTOS PRELIMINARES PARA UMA TENTATIVA DE REFUNDAÇÃO. E-book. 


\section{ALFABETIZAÇÃO E LETRAMENTO: UM RELATO DE EXPERIÊNCIA SOBRE ESTRATÉGIAS DE ENFRENTAMENTO DE DIFICULDADES DE LEITURA E ESCRITA NO ENSINO FUNDAMENTAL}

Ana Paula Rocha da Silva

RESUMO: O presente estudo configura-se como relato de experiência, cujo objetivo principal é analisar estratégias utilizadas na ação docente para minimizar dificuldades de leitura e escrita no $6^{\circ}$ ano do ensino fundamental, considerando articulações entre alfabetização e letramento. Como aporte teórico, foram priorizados os trabalhos que discutem alfabetização e letramento, tendo em vista a complexidade e as conexões indissociáveis desses conceitos. Em termos metodológicos, este estudo constitui-se de uma pesquisa qualitativa com observação participante e como forma de registro um diário etnográfico escolar. Muitos docentes deparam-se com as dificuldades de leitura e escrita de estudantes que iniciam novo segmento do ensino fundamental ( $6^{\circ}$ ano) ainda sem o domínio efetivo de leitura e escrita, repercutindo nas práticas de letramentos. A alfabetização e o letramento são temas recorrentes nas licenciaturas, tendo em vista que esses processos repercutem 
no crescimento do país como um todo. Quando tocamos nesses temas, estamos discutindo, também, exclusão social, uma vez que os sujeitos, ao não desenvolverem essas práticas socialmente construídas, começam a ocupar um lugar de menos privilégio social, ou seja, não estar alfabetizado e letrado implica, muitas vezes em falta de oportunidades de emprego, de ascensão social, de acesso à cultura, à arte e de tantos outros processos. Portanto, nessa perspectiva de ensino, destaca-se a importância de serem criadas condições para novas descobertas e superações dos conflitos cognitivos e das possíveis hipóteses "inventadas" nas etapas evolutivas regulares da construção do conhecimento que cada aprendiz carrega. O impacto disso é que "cada vez mais, a escrita se colocou como obstáculo à participação efetiva do cidadão no mundo social, demonstrando, no cotidiano, a utilidade do saber ler" (BARBOSA, 2013). Quando os processos de alfabetização e letramento não são construídos no tempo regular previsto da escolarização, ou seja, quando ocorrem descontinuidades, seja por meio da repetência, da evasão escolar ou de outros fatores, os estudantes são enquadrados no que chamamos hoje de insucesso escolar, fenômeno comum nas redes de ensino em todo o país. Um fenômeno de fácil identificação e que é o objeto de reflexão deste relato se refere ao fato de alguns estudantes, chegarem ao $6^{\circ}$ ano do ensino fundamental sem o domínio de leitura e de escrita, repercutindo nas práticas de letramentos. Diante disso, o olhar se voltava para a ação docente na busca pela superação dessa situação que causava sofrimento nos estudantes, principalmente através dessa ideia competitiva e menos colaborativa que os sistemas educacionais brasileiros têm demonstrado. Além de abordar questões sobre práticas de letramento na superação de descontinuidades escolar ligado a essas questões, a realização desse trabalho possibilitou constatar, através de nossos interlocutores, o quanto é possível criar e realizar atividades estimulantes da aprendizagem sem "ferir" a natureza humana negligenciando o sujeito da aprendizagem.

Palavras-chave: Práticas Docentes. Aprendizagem. Evasão Escolar. 


\section{REFERÊNCIAS:}

BARBOSA, J. Alfabetização e leitura. Cadernos de Pesquisa, n. 75, p. 87, 2013.

CARVALHO, I. Alfabetização e letramento: caminhos de conhecimento. Trabalho de Conclusão de Curso. Universidade Federal do Rio Grande do Norte, 2016.

CARVAlHO, M. MENDONÇA, R. (Orgs.). Práticas de leitura e escritura, Brasília, Ministério da Educação, 2006. Disponível em: Acesso em 10/05/2019 


\section{A EDUCAÇÃO COMO UM DIREITO HUMANO PARA FORMAÇÃO DA CIDADANIA NA SOCIEDADE BRASILEIRA EM TRANSFORMAÇÃO DIGITAL}

Vanessa Maria de Oliveira Accioly Maia

Thaís do Nascimento Cortez

\section{INTRODUÇÃO}

Com a expansão geográfica da rede mundial de computadores (Internet), especialmente, da Internet sem fio ou wireless por todos os países do globo terrestre, surgiram inúmeros espaços em meios não físicos, isto é, virtual, os quais abrigam a comunicação cibernética realizada entre seres humanos, comunitariamente, e também entre aqueles e máquinas (hardwares e softwares) formada pela interconexão das redes de dispositivos físicos e digitais interligados. Tal avanço tecnológico popularizou-se no Brasil ao ponto da pesquisa TIC Domicílio, realizada pelo Centro Regional de Estudos para o Desenvolvimento da Sociedade da Informação (Cetic) e divulgada em 28 de agosto de 2019, apontar que $70 \%$ (setenta por cento) da população brasileira está conectada à Internet, com o incremento da metade da população rural e das classes D e E, sendo a média das regiões urbanas 74\% (setenta e quatro por cento) um pouco maior que a nacional. Nesse sentido, a sociedade brasileira contemporânea experienciando o que a doutrina classificou de "terceira revolução industrial" ou "revolução informa- 
cional", que trouxe inovações por meio de equipamentos eletrônicos como os "smartphones", tecnologia da informação e das telecomunicações, deverá se preparar para a iminente "quarta revolução industrial" (SCHWAB, 2016) a qual está se materializando com a criação da indústria totalmente automatizada (indústria 4.0). Em que pese o imensurável desenvolvimento tecnológico na conjuntura social e econômica brasileira, a Constituição Federal de 1988, no artigo 170, ao tratar dos princípios da atividade econômica, prevê a conformidade do trabalho humano aos ditames da justiça social, que por sua vez está relacionada com o direito fundamental à educação, sendo esse direito o realizador do primado do trabalho, do bem-estar e da justiça social previstos nos artigos 193 e 205 da Carta Magna. Nessa perspectiva, o presente estudo destaca a relevância do direito fundamental à educação consagrado na Constituição Federal de 1988, como direito humano não somente para obtenção de uma qualificação para o trabalho, mas para o desenvolvimento da cidadania embasada no conteúdo formal e não formal da Educação em Direitos Humanos, especialmente, contextualizada na virtualização das relações humanas. Para isso, pretende-se demonstrar a importância do emprego da Tecnologia da Comunicação e Informação (TCI) nos locais de ensino e aprendizagem, pois com o desenvolvimento da cultura digital, o ciberespaço figura como ambiente promotor das múltiplas conexões, das redes sociais e da inteligência coletiva, além de atuar como mediador entre pesquisas científicas ou aleatórias, estudos, socialização, lazer e consumo, ampliando ainda mais a cidadania participativa.

\section{JUSTIFICATIVA}

A educação é posta no ordenamento jurídico brasileiro como um direito fundamental social, uma vez que, como direito humano, foi incorporado pelo texto constitucional no título que trata dos Direitos e Garantias Fundamentais, especificamente, no Capítulo II, que cuida dos Direitos Sociais, artigo 6ํ․ A educação também é enunciada nos artigos 205 e seguintes, da Constituição Federal, no que tange aos seus mecanismos e aspectos organizacionais. Desse modo, a educação é do- 
tada de fundamentalidade, gozando de normatividade e exigibilidade. Como serviço público essencial, a educação deve ser assegurada pelo Poder Público para que os seus objetivos, encartados no texto constitucional, sejam alcançados, quais seja, o pleno desenvolvimento da pessoa humana, o preparo do indivíduo ao exercício da cidadania e sua qualificação para o trabalho - o que não pode ser visto de modo dissociado das novas tecnologias, ao acompanhar a sociedade na chamada Era Digital. E, neste diapasão, a educação em direitos humanos também deve ser inserida em tal contexto, pois se faz necessário a construção de uma cultura dos direitos humanos na sociedade brasileira, de maneira sistemática e consistente, tendo, neste horizonte, os processos educacionais como meios fundamentais. A Educação em Direitos Humanos é prática recente no Brasil, iniciando-se junto aos movimentos sociais e organizações da sociedade civil, bem como às universidades públicas por meio de suas ações de extensão, nas escolas e nos bairros populares como modo de enfrentamento das situações traumáticas de ditatura, violência institucionalizada, pobreza entre outras problemáticas sociais, vividas pela sociedade brasileira (BENEVIDES, 2000). No contexto brasileiro, a Educação em Direitos Humanos só pode ser uma educação para a mudança, a qual se apresenta como possibilidade que implica a derrocada de valores e princípios arraigados na sociedade. A Educação em e para os Direitos Humanos é uma estratégia de longo prazo direcionada para as necessidades das gerações futuras, e como tal deve estar alinhada com as transformações sociais. E é neste ponto, portanto, que se identifica uma relação intrínseca entre o direito à educação e a Educação em Direitos Humanos, bem como com as novas tecnologias, enxergando-se na aliança entre estas como um caminho a ser percorrido para qualquer mudança social que se deseja realizar dentro de um processo democrático, principalmente, no que se refere à realidade brasileira.

\section{OBJETIVOS DA PESQUISA}

O objetivo geral do presente trabalho científico é relacionar a educação em direitos humanos com o direito digital, tendo em vista a 
sociedade em transformação digital em que estamos inseridos na atualidade. E como objetivos específicos têm-se: situar a educação como direito fundamental perante o ordenamento jurídico brasileiro, relevar a relação do direito constitucional à educação com a educação em direitos humanos e elencar a necessidade do alinhamento desta com a transformação digital e a cidadania.

\section{METODOLOGIA}

Este estudo pretende analisar a relação entre o exercício da cidadania e sua concretude como direito fundamental à educação e educação em direitos humanos, bem assim a atual necessidade de se promover a educação digital inclusiva. Com efeito, pretende-se utilizar metodologicamente a pesquisa aplicada, com abordagem hipotético dedutiva e qualitativa, além de revisão bibliográfica e estatística sobre a situação real do sistema educacional brasileiro relativamente ao ensino básico.

\section{CONSIDERAÇÕES FINAIS}

Sendo a educação e a educação em direitos humanos um direito humano em si mesmas (ADORNO, 2003, p. 143) dotadas de fundamentalidade, consagradas pela Constituição Federal de 1988, necessárias ao pleno exercício da cidadania em um Estado democrático de Direito, é de se pensar na importância da aprendizagem com uso das tecnologias, especialmente, neste momento, em que a sociedade brasileira passa pela transformação digital das mais diversas atividades e modos de produção. Assim, a competência para compreensão dos recursos tecnológicos no ensino brasileiro deverá ser desenvolvida para além do treinamento e da capacitação do uso dos equipamentos e ferramentas em si, visando à concretude da capacidade de "aprender a aprender" (SOARES, 2002) com a maior quantidade e diversidade de informações disponíveis no meio eletrônico, através de um raciocínio crítico pautado na autonomia e no compartilhamento de saberes entre estudantes e professores, proporcionando vivências ricamente elaboradas para a consulta e sobretudo para a produção de informação. Desse modo, apreende-se que a prática da utilização dos computadores, smar- 
tphones, tablets, além da Internet e aplicativos, como propõe Magalhães (1996), “deve ajudar a criar a moderna praça pública eletrônica, promovendo a igualdade de acesso à informação e a criação de comunidades eletrônicas onde possam fermentar experiências de reinvenção das formas de produção, consumo, cultura, interação social e cidadania”.

Palavras-chaves: Direito à educação; Educação em Direitos Humanos; Transformação digital.

\section{REFERÊNCIAS}

ADORNO, Theodor W. Educação e emancipação. 3. ed. São Paulo: Paz e Terra, 2003.

BENEVIDES, Maria Victoria. Educação de Direitos Humanos: de que se trata?, 2000. Disponível em: $<$ http://www.hottopos. com/convenit6/victoria.htm>. Acesso em 10 jul. 2020.

BRASIL. Constituição Federal de 1988. Disponível em: <http:// www.planalto.gov.br/ccivil_03/Constituicao/Constituicao. htm>. Acesso em: 15 mai. 2020.

MAGAlhãeS, José. Novo Roteiro Prático da Internet. 2. ed. Lisboa: Quetzal Editores, 1996.

SCHWAB, Klaus. A Quarta Revolução Industrial [livro eletrônico]; tradução Daniel Moreira Miranda. São Paulo: Edipro, 2016.

SOARES, H. G. S. Nova Cidadania - Um Conceito Pós-Moderno, in Jornal “A Razão” em 26.09.2002. Disponível em <http:// www.angelfire.com/sk/holgonsi/novacidadania.html> Acesso em 28 de abril de 2020. 


\section{A DOCÊNCIA COMO PROMOTORA DE DIREITOS HUMANOS EM ESPAÇOS DESUMANOS}

Rosidalva Pereira Almeida

\section{INTRODUÇÃO}

A escola abriga em seu escopo uma diversidade de componentes que a tornam um ambiente vivo, tanto pelas interações e conexões estabelecidas, como também pelo espaço físico que figura como cenário dessas relações, sendo, pois, um lugar de vivência em suas múltiplas possibilidades. Nesse sentido, a infraestrutura escolar deve ser pensada e implementada com base na Lei de Diretrizes e Bases da Educação Nacional LDBEN, Lei 9.394 de 1996, segundo a qual cabe ao Estado garantir "padrões mínimos de qualidade de ensino definido como a variedade e quantidade mínimas, por aluno, de insumos indispensáveis ao desenvolvimento do processo ensino-aprendizagem", com vistas a viabilizar e concretizar a educação como um direito.

Nessa perspectiva, a organização espacial da escola não deve ser concebida como uma simples edificação, mas um espaço salutar que abriga pessoas cujas aspirações primeiras são a socialização, o convívio com seus pares e a interação. Desse modo, mais do que uma estrutura de concreto, o espaço escolar é constituído por pessoas dotadas de sonhos e aspirações, por isso deve ser um ambiente acolhedor, propício às relações pessoais e interpessoais, à convivência e à aprendizagem. 
Ademais, enquanto ser dotado de direito e humano, o aluno, principalmente da educação e infantil e séries iniciais do ensino fundamental, ávido por descobrir o mundo que se descortina a sua volta, deve ter garantido um espaço para aprender, brincar, conviver, criar laços e desenvolver-se plenamente como postula a LDB alinhada ao arcabouço legal que postula o direito à educação visando ao seu pleno desenvolvimento.

No presente estudo, discorre-se sobre a educação ofertada em locais com infraestrutura inadequada, uma das dimensões da desigualdade social, e o papel da docência como promotora de direitos humanos em espaços desumanos, garantindo em ambiência inóspita, o direito de aprendizagem dos alunos.

\section{AMBIÊNCIA ESCOLAR}

A escola deve ser planejada tendo como foco o aluno, com vistas a assegurar direitos básicos como proteção e aprendizagem, oferecendo, assim, uma educação de qualidade, como postula ESCOLANO (2001, p. 45) "[...] a arquitetura escolar pode ser vista como um programa educador, ou seja, como um elemento do currículo invisível ou silencioso, ainda que ela seja, por si mesma, bem explícita ou manifesta".

Sendo um ambiente acolhedor e atrativo, nos aspectos físico e humano, a escola potencializa as múltiplas aprendizagens, como advoga ESCOLANO (1998, p. 27): “Os espaços educativos, como lugares que abrigam a liturgia acadêmica, estão dotados de significados e transmitem uma importante quantidade de estímulos, conteúdos e valores [...]”. Esses estímulos, quando positivos, contribuem para a formação de cidadãos que primam pelo zelo e cuidado com seus espaços de vivência, fruto das interações vividas e das memórias afetivas relacionadas à escola como um lugar de inclusão social e de aprendizagem.

Por outro lado, os estímulos negativos violam direitos e a educação torna-se apenas arremedo do que preconizam as leis vigentes. Nesse contexto configuram-se os chamados anexos escolares, geralmente espaços alugados ou adaptados para alojar salas de aula excedentes, que a escola considerada polo não comporta. Esses edifícios, com caracte- 
rísticas e funcionalidades que destoam das especificações de uma instituição escolar, abrigam alunos de forma precária, oferecendo uma educação que se processa em condições desumanas e adversas. Na contramão do que advoga (Viñao Frago, 2001, p. 69), segundo o qual “[...] a instituição escolar e o ensino só merecem esse nome quando se localizam ou se realizam num lugar [...] pensado, desenhado, construído e utilizado única e exclusivamente para esse fim."

Este estudo foi realizado numa escola - anexo, da rede pública de ensino que funciona em um edifício malconservado, sem climatização nem conexão à internet, com sérios problemas estruturais, a exemplo do telhado de amianto com goteiras, janelas quebradas, paredes manchadas, banheiros sem insumos básicos que exalam mau cheiro em algumas salas de aula.

Por sua estrutura e pelo estado de conservação, o prédio não apresenta as condições mínimas necessárias para abrigar uma escola, estando, desse modo, em desacordo com a LDB, que postula serem o planejamento e a manutenção do espaço físico condições necessárias para a realização do processo democrático educacional.

Adentrando no espaço escolar, ou seja, no campo de estudo, tem-se um impacto pela visão de deterioração, sobretudo por ser um espaço voltado para alunos de séries iniciais do ensino fundamental, em que o lúdico, o belo, a fantasia fazem parte de seu repertório. Essa visão é mais impactante para alunos oriundos de alguma escola polo ou da rede privada, pois seu olhar de espanto traduz quão inóspito e inadequado é o espaço escolar. Ao professor cabe a difícil tarefa de despertar nesses alunos o prazer de pertencimento e de conectar-se com a escola, uma vez que segundo Carneiro, Martinelli e Sisto (2003, p. 153), "as vivências escolares podem tanto auxiliar o aluno no seu processo de aprendizagem, motivação e autoestima como promover o seu fracasso e dificuldade".

Nesse sentido, a escola falha no cumprimento de sua função social, tendo em vista o que assinala Freitas (op. cit. p. 73), "a função social da escola se cumpre na medida da garantia do acesso aos bens culturais, fundamentais para o exercício da cidadania plena no mundo contemporâneo". As instalações inadequadas subtraem direitos de 
aprendizagem das crianças, sendo, pois, um retrato fidedigno da desigualdade social e do descaso do poder público na prestação de serviços educacionais.

\section{O PAPEL DA DOCÊNCIA}

O educador é o responsável pela gestão da sala de aula, quem organiza e faz acontecer o processo de ensino e aprendizagem, figurando como mediador desse processo, no qual vínculos são construídos, comportamentos são moldados e potencialidades são desenvolvidas. Nessa perspectiva, o docente desempenha um importante papel no sentido de assegurar os direitos de aprendizagem dos alunos.

[...] os profissionais das escolas podem aderir ou resistir a tais políticas e diretrizes do sistema escolar ou dialogar com elas e formular, colaborativamente, práticas formativas e inovadoras em vista de outro tipo de sujeito a ser educado. (LIBÂNEO et al 2017, p. 24).

Em ambiente precário e insalubre é possível perceber a resiliência e o compromisso dos professores em desenvolver um trabalho focado na aprendizagem dos alunos, conforme advoga HENKLAIN e CARMO (2013, p. 706), "as demandas sociais remetem à necessidade de identificação de práticas de ensino que ajudem os alunos a aprender”.

Carências e dificuldades fazem parte do cotidiano dos professores, porém, apesar desses entraves, a aprendizagem acontece, uma vez que nas avaliações de larga escala, o desempenho dos alunos é considerado adequado, tendo em vista os altos índices alcançados. Como destaca FERREIRA (2014, p. 41), "os elementos constitutivos da formação que se estabelecem nas relações humanas, epistemológicas, sociais e cognitivas", são essenciais para que o professor enfrente os desafios da docência.

Apesar da ambiência inóspita, a escola apresenta baixos índices de evasão e reprovação. No tocante ao cotidiano da sala de aula e no convívio escolar em geral, merece destaque o comportamento dos alunos que surpreende por sua normalidade, já que o ambiente conspira para que ocorra o oposto. 
Assim, o trabalho docente é um grande diferencial por sua atuação e seu comprometimento, inclusive em suprir os insumos e recursos básicos para que os alunos tenham seu direito a estudar garantido, ainda que seja em ambiente degradante e desumano.

\section{CONSIDERAÇÕES FINAIS}

A escola deve oferecer os subsídios humanos e materiais necessários para que seja um espaço de excelência e viabilize o pleno desenvolvimento dos aprendizes, o oposto disso acarreta sérios entraves ao pleno desenvolvimento do aluno e de uma aprendizagem significativa.

A arquitetura da escola é reveladora da negação de direito a uma educação de qualidade, pois nem sempre as instituições escolares oferecem as condições mínimas necessárias para que haja um ensino e uma aprendizagem humanizados, sendo oferecidos em espaços insalubres e desprovidos de recursos básicos que assegurem esses direitos fundamentais. Nessa seara, o papel da docência é relevante ao desenvolver um trabalho com foco no aluno, mesmo em condições adversas.

\section{REFERÊNCIAS}

BARTHOLOMEU, Daniel; SISTO, Fermino Fernandes; MARIN RUEDA, Fabián Javier. Dificuldades de aprendizagem na escrita e características emocionais de crianças. Psicol. estud., Abr 2006, vol.11, no.1, p.139-146.

BRASIL. Lei de Diretrizes e Bases da Educação Nacional LDBEN, Lei 9.394 de 1996. Ministério da Educação, Secretaria de Educação Média e Tecnológica, 1999, p.40.

CARNEIRO, Gabriela Raeder da Silva, MARTINELLI, Selma de Cássia e SISTO. Autoconceito e dificuldades de aprendizagem na escrita. Psicol. Reflex. Crit., 2003, vol.16, no.3, p.427434. 
FERREIRA, Jacques de Lima (Org.). Formação de professores: teoria e prática pedagógica. Petrópolis: Vozes, 2014.

FREITAS, Lourival C. de. Mudanças e inovações na educação. 2. ed. São Paulo: EDICON, 2005

HENKLAIN, Marcelo Henrique Oliveira; CARMO, João dos Santos. Contribuições da análise do comportamento à educação: um convite ao diálogo. Cadernos de Pesquisa, Rio de Janeiro, v. 43, no 149 , p. 704-723, maio/ ago. 2013

LIBÂNEO, J. C.; OLIVEIRA, J. F.; TOSCHI, M. S. Educação escolar: políticas, estrutura e organização. São Paulo: Cortez, 2017. 


\section{A IMPORTÂNCIA DAS METODOLOGIAS ATIVAS NOS CURSOS DE DIREITO}

Fabiana David Carles

Vitória Caroline Brandão da Costa Siqueira

\section{INTRODUÇÃO}

O ensino jurídico, desde a criação das primeiras Universidades de Direito, sofre com a perpetuação de uma crise metodológica que afeta diretamente tanto o corpo discente, quanto docente. Tal crise repousa sobre a presença de tecnicismos e métodos que não fomentam a interlocução da teoria com a prática, mas somente corroboram para que os estudantes decorem teorias que pouco lhe servirão na sua futura atuação profissional. Para tanto utilizar-se-á autores a frente de seu tempo, como Dantas de (1955), bem como autores contemporâneos, mostrando que a discussão permeia por muito tempo, mas ainda não consegue encontrar uma solução democrática. Nesse sentido, faz-se necessário analisar novos mecanismos de aprendizagem, que vem sendo alvo de discussão na área menciona. Uma das alternativas que merece ser relatada é a metodologia ativa. Tal procedimento investe na conjugação de esforços no momento da aprendizagem, retirando apenas do docente o dever de repassar o conteúdo. Nessa seara, o discente se torna o protagonista no processo de ensino com o apoio coadjuvante do docente. Essa técnica visa emancipar o aluno daquele processo tradicional, mecânico e enciclopédico aplicado pelo professor, repassando aos alunos 
a responsabilidade de participar ativamente da busca pelo seu próprio conhecimento. Esse tipo de metodologia vem ganhando espaço e se firmando nas universidades, devido a sua visão mais contemporânea, pois visam difundir maneiras mais eficientes na formação dos novos juristas, levando-os a obter uma aptidão mais eficiente na resolução dos conflitos sociais no meio em que estiverem inseridos. Dessa forma, surge a importância de se destacar as metodologias ativas implementadas desde 2018, no Curso de Direito da Universidade Federal do Acre - Campus Floresta/CZS, o qual se adequou as alterações das Novas Diretrizes Curriculares para os cursos de direito elaboradas pelo MEC, na qual pretende quebrar paradigmas e dogmas de que o saber está apenas no repasse de conhecimento vislumbrando uma aprendizagem mais equilibrada e reflexiva das exigências que o atual mercado profissional de litígios exige, principalmente em face as alterações significativas nas normativas brasileiras.

\section{PROCEDIMENTOS METODOLÓGICOS}

A metodologia da pesquisa utilizada num primeiro momento, será de natureza qualitativa, baseando-se em análise bibliográfica focando o parecer sobre as Alterações das Novas Diretrizes dos Cursos de Direito criada pelo MEC, para ao longo do tempo iniciar a aplicação dessas novas técnicas por meio de projetos, cursos, oficinas no Curso de Direito de Cruzeiro do Sul, destacando o aluno como o protagonista da busca pelo conhecimento. O Curso conta com inúmeros projetos ligados a editais de extensão aprovados e implementados pela Proex/Ufac, alguns inclusive com financiamento da própria Universidade devido a sua relevância. Oficinas que levam o discente a perpassar por 3 fases de conhecimento na área jurídica, a primeira: a doutrina, o que os autores ensinam sobre o tema escolhido; a segunda fase: a prática, quando os alunos entram em contato com analises de casos reais sobre o mesmo assunto escolhido; e por ultimo, a parte reflexiva, que cria no aluno o intuito de reflexão sobre a teoria e a prática e o que a reflexão poderia alterar esse contexto fixo e ultrapassado do sistema. 


\section{RESULTADOS E DISCUSSÕES}

As Universidades de Direito ao redor do mundo sofrem há muito tempo com a crise metodológica que afeta diretamente a formação dos estudantes. Esta é ocasionada, dentre outros fatores, devido a existência de currículos enciclopédicos com vastos conteúdos e curto prazo para repassá-los. Nesse sentido, os professores da área passam a disponibilizar aos discentes um aprendizado inferior aquilo que seria possível, não fosse a exigência de cumprir algo extenso e pouco proveitoso. Diante disso, é imprescindível buscar ferramentas metodológicas que possam alterar esse cenário de crise e fornecer uma solução que agrade alunos e professores, devolvendo a fé no ensino jurídico de qualidade. Nota-se que essa discussão vem desde Dantas (1955) propõe que a verdadeira educação jurídica será aquela que fornecerá palco para conflitos de interesse, controvérsias na busca de uma solução, fomentando o raciocínio jurídico dos estudantes, que precisarão buscar resolver os conflitos, que a cada ano que passa se tornam mais complexos e singulares. Além disso, este afirma que mais importante que aulas expositivas de cinquenta minutos, são as aulas de professores que levam consigo casos concretos para que os discentes possam solucionar. Com base nisso, a teoria e prática do direito estarão aliadas, visto que, essa forma de metodologia ativa proposta por Dantas é repleta do ensino de normas, mas também de solução de casos reais, auxiliando no melhor ensino-aprendizagem e na troca de conhecimentos entre professor-aluno. Outrossim vale destacar a relevância de Roberto Mangabeira Unger, autor mais atual, que ganha mais destaque na busca de um ensino jurídico mais eficiente, sendo este o responsável por elaborar um memorando que trata especificadamente sobre a proposta de um novo currículo para as faculdades de direito, demanda que pode ser verificada a partir de um exemplo prático, qual seja, a homologação das alterações das Novas Diretrizes Curriculares dos Cursos de Direito criada pelo MEC, cujo o intuito e promover a formalização de um ensino jurídico pautado na união entre teoria e pratica, possibilitando a formação de profissionais munidos de habilidades e competências tanto inter como transdisciplinares. Portanto, vale destacar o que saliente Giroux (2005), pois este afirma que 
os docentes tem papel fundamental no processo de superação da crise metodológica que aflige as Universidades ao redor do mundo, visto que estes estabelecem a conexão entre ideias, disciplinas e tradições na esfera pública, tornando o direito acessível a sociedade.

\section{CONCLUSÃO}

Diante o exposto, fica evidente que diversos são os fatores que ratificam o agravamento da crise metodológica nos cursos de direito. No entanto, é necessário destacar que não são poucos os esforços do corpo docente para que o ensino jurídico possa finalmente a superar e oferecer a melhor formação aos discentes. Portanto, a aplicação das metodologias ativas no Curso de Direito da Universidade Federal do Acre - Campus Floresta evidenciam uma possível solução a este cenário de crise e, tornam os discentes formados não apenas decoradores das leis, mas juristas capazes de perceber seu papel social dentro da sociedade, alcançando resoluções de conflitos cada vez mais complexos e singulares.

\section{REFERÊNCIAS BIBLIOGRÁFICAS}

DANTAS, San Tiago. "A educação jurídica e a crise brasileira”. Disponível em: Aula inaugural dos cursos da Faculdade Nacional de Direito. 1955.

GIROUX, Henry A. "Qual o papel da Pedagogia Crítica nos estudos de língua e cultura? Uma entrevista om Henry A. Giroux”. Disponível em: Revista Language and Intercultural Communication. 2005.

UNGER, Roberto Mangabeira. Uma Nova Faculdade de Direito no Brasil. Revista de Direito Administrativo: RDA, Belo Horizonte, n. 243, set./dez. 2006. 


\section{A EDUCAÇÃO SUPERIOR E A PANDEMIA DO CORONAVÍRUS: PERSPECTIVAS SOBRE O ENSINO JURÍDICO À LUZ DAS TEORIAS CRÍTICAS E LIBERTADORAS DO DIREITO}

Maria Gabrielle Araujo de Souza

\section{RESUMO}

A pandemia do coronavírus trouxe mudanças significativas, inclusive, para o âmbito educacional. Por tempo indeterminado, aulas presenciais foram suspensas em todo o mundo. De modo geral, na tentativa de garantir os direitos fundamentais à vida e à educação, as faculdades de Direito do Estado do Maranhão implementaram calendários acadêmicos remotos, embora com adesão facultativa. Diante disso, o presente trabalho traça um debate sobre as implicações da pandemia da COVID-19 no Ensino Jurídico, sobretudo nos períodos intermitente e pós-pandêmico. Por meio de pesquisas bibliográficas, documentais e de campo, através do uso de técnicas e métodos qualitativos, o estudo, incialmente, apresenta aspectos gerais da conjuntura brasileira em meio à pandemia, dando enfoque às mudanças ocorridas na Educação Superior. Seguidamente, adentra especificamente no cenário de ensino remoto presente nos cursos de Direito do Estado do Maranhão, objetivando destacar, à luz das teorias críticas e libertadoras: (i) os desafios 
impostos pelas modificações decorrentes da situação pandêmica; (ii) caminhos para um novo modelo de Ensino Jurídico, que seja verdadeiramente democrático e que leve em consideração seu tempo histórico e seu papel social.

PALAVRAS-CHAVE: Educação Superior; Pandemia do Coronavírus; Ensino Jurídico Remoto.

\section{INTRODUÇÃO}

Em diversas faculdades de Direito do Estado do Maranhão, foi implementado o Ensino Remoto Emergencial, buscando-se realizar o calendário acadêmico à distância, através de meios virtuais.

Nesse contexto, o presente estudo objetiva, para além de uma análise sobre as interferências da pandemia do coronavírus nos cursos de graduação em Direito, deslindar sobre o ensino jurídico tradicional, de modo a demonstrar que, mais do que nunca, este se põe à margem de uma educação crítica e emancipatória e, portanto, distancia-se de seu papel social democrático. (SOUSA SANTOS, 2014).

Outrossim, desenvolve-se a partir de um debate sobre as implicações da pandemia da COVID-19 nos cursos de graduação em Direito, principalmente nos períodos intermitente, com intuito de delinear a configuração do Ensino Remoto Emergencial nas faculdades do Estado do Maranhão; e pós-pandêmico, esforçando-se à vislumbrar caminhos possíveis para uma revolução no ensino jurídico, que tenha em sua conta "uma pedagogia intercultural, interdisciplinar e imbuída da ideia de responsabilidade cidadã.". (SOUSA SANTOS, 2014).

\section{DISCUSSÕES E CONCLUSÕES}

O Conselho Nacional de Educação (CNE) aprovou diretrizes para direcionar instituições de ensino superior durante a pandemia do coronavírus. O parecer foi elaborado com a colaboração do Ministério da Educação (MEC) e tem como objetivo principal a organização do calendário escolar e da possibilidade de cômputo de atividades não 
presenciais para fins de cumprimento da carga horária mínima anual. Tal parecer idealizou-se sob a justificativa de amenizar os prejuízos causados, pela pandemia, aos estudantes e às estudantes do país, no que se refere ao calendário acadêmico.

Nesse sentido, o MEC autorizou, através da Portaria n. ${ }^{\circ}$ 544, de 16 de junho de 2020, em caráter excepcional, a substituição das disciplinas presenciais, em cursos regularmente autorizados, por atividades letivas que utilizem recursos educacionais digitais, tecnologias de informação e comunicação ou outros meios convencionais, pelas instituições de Educação Superior integrantes do sistema federal de ensino, pelo menos até 31 de dezembro de 2020.

Naturalmente, este contexto envolve diversas questões, que vão desde as que dizem respeito às falhas pedagógicas profundas que perpassam o ensino superior desde antes da pandemia - e que se intensificam com ela -; até as que se referem às desigualdades sociais e, por consequência, às muitas barreiras ao processo de democratização do acesso às tecnologias de informação. Sobre este último ponto, relembre-se a constatação feita por Sousa Santos (2020): quarentenas são sempre discriminatória, quer dizer, mais difíceis para uns grupos sociais do que para outros. Alguns grupos possuem "especial vulnerabilidade que precede a quarentena e se agrava com ela.” (SOUSA SANTOS, 2020). E assim é por causa da exploração capitalista, da discriminação racial e sexual que envolvem a humanidade há muito tempo. A quarentena e a possibilidade - ou não - do isolamento social reforçam "a injustiça, a discriminação, a exclusão social e o sofrimento imerecido que elas provocam.". (SOUSA SANTOS, 2020).

O curso de Direito da Universidade Federal do Maranhão, por exemplo, em tentativa de decisão conjunta com os estudantes, disponibilizou período letivo especial remoto aos discentes e às discentes que pudessem acessar os meios virtuais disponíveis para tal. Ocorre que, mesmo após a pandemia, por razões de várias naturezas, o hibridismo entre ensino a distância remoto e presencial estará cada vez mais presente nas instituições de ensino.

Frente a estas circunstâncias, reflexões e ações - aqui colocada no sentido pedagógico freiriano -, quanto ao modelo de Ensino Jurídico 
vigente, seja em período pré-pandêmico, intermitente ou pós-pandêmico, são imprescindíveis.

Precisamente, ao voltarmo-nos ao Ensino Jurídico remoto, de muitas maneiras, identificamos o mais claro reflexo das práticas jurídicas tradicionais, fechadas ao formalismo, positivismo e academicismo. Estas operam, ainda que inconscientemente, pela manutenção de um sistema opressor, desassociam-se da realidade fática e prezam pela verticalidade do conhecimento jurídico. (FREIRE, 1987).

Demais disso, sublinhe-se que há muito o ensino jurídico contém em si dois problemas principais: o primeiro, corresponde ao vício de metodologia do modelo tradicional de ensino; o segundo, diz respeito ao ensino de uma concepção errada do Direito e, portanto, dos conteúdos que se pretende ministrar. Sendo que deste último, derivam os demais vícios da pedagogia. (LYRA FILHO,1980).

É sabido que, nos cursos de Direito, a pedagogia geralmente aplicada vincula-se à transmissão da matriz técnico-burocrática da ciência jurídica. Tal paradigma desconsidera práticas pedagógicas libertadoras e, por vezes, de maneira intencional, cria uma cultura de extrema indiferença do Direito em relação às transformações sociais. No contexto atual, de ensino remoto, isso se acentua.

De fato, a transposição do ambiente de ensino presencial para o virtual "não rompeu com as velhas práticas pedagógicas. Pelo contrário, perpetuou a centralidade da figura da professora e as narrativas que ela expõe e reproduz", expondo, pois, "a essência de exclusão, silenciamento e invisibilização das alunas, de suas experiências, de seus corpos.". (MATOS; ROVERE; AKIRA; NOMURA; DESCLOV, 2020).

Sucede que, como aponta Gihardi (2012), o modo como os alunos aprendem a pensar o mundo em sala molda o modo como o pensarão fora dela. A passividade desses sujeitos - intensificada pela conjuntura de crise sanitária -, que se encontram "alheios às decisões sobre aquilo que os afeta, excluídos da responsabilidade de participar ativamente do próprio projeto de formação", tende a implicar na construção de profissionais que se eximam da responsabilidade de participar decisivamente da composição do projeto de uma sociedade mais justa. (GIHARDI, 2012). 
Fazem-se necessárias, portanto, ações-reflexões que, amparados pelas contribuições trazidas pelas teorias críticas e libertadoras do Direito, busquem alternativas ao modelo de ensino bancário posto e que se comprometam com uma educação que assente um potencial transformador da cultura jurídica (SOUSA SANTOS, 2014). Dito de outro modo, uma educação que esteja para além da cultura técnico-burocrática, característica do ensino jurídico tradicional; e que acredite em um ensino que tem o Direito como um válido instrumento para a promoção do acesso à cidadania e da garantia dos Direitos Humanos.

\section{REFERÊNCIAS}

FREIRE, P. Pedagogia do Oprimido. 17 ed. Rio de Janeiro: Paz e Terra, 1987.

GHIRARDI, J. G. O instante do encontro: questões fundamentais para o ensino jurídico. Coleção Acadêmica Livre. Série Didáticos. São Paulo: FGV, 2012.

LYRA FILHO, R. O Direito que se ensina errado: sobre a reforma do ensino jurídico. Brasília: Centro acadêmico de Direito da UNB, 1980.

MATOS, A. M.; ROVERE, A; AKIRA, G.; NOMURA, M. M.; DESCLOV, V. Sem máscaras, sem luvas: em defesa da contaminação por uma pedagogia libertadora. São Paulo: Revista Acadêmica XI de Agosto, 2020. $1^{\text {a }}$ ed.

SOUSA SANTOS, B. de. A cruel pedagogia do vírus. São Paulo: Boitempo Editorial, 2020.

SOUSA SANTOS, B. de. Para um revolução democrática da justiça. São Paulo: Cortez Editora, 2014. 


\section{DIREITO À EDUCAÇÃO E EMANCIPAÇÃO HUMANA PARA JOVENS E ADULTOS}

Adriana de Almeida

Resumo: Os direitos fundamentais representam os elementos basilares do Estado democrático de direito. A sua concretização, todavia, não é acompanhada de maneira equitativa e não contempla todas as pessoas da sociedade. Em particular, àqueles considerados vulneráveis, frequentemente, são privados do exercício de seus direitos. As pessoas em condições de vulnerabilidade encontram-se em uma situação de desigualdade e a proteção constitucional precisa ser diferenciada para esse grupo. Assim, pensar sobre as questões de vulnerabilidade, em particular, dos jovens e adultos trabalhadores, implica adentrar na interrelação entre autonomia e dignidade humana, onde uma vez preservadas corroboram para a promoção da liberdade e garantia do direito à educação articulada ao processo de emancipação humana.

No entanto, há uma ruptura entre a garantia dos direitos materiais e políticos, revelando um processo contraditório na própria gênese formativa dos direitos fundamentais, bem como, parece haver uma interpretação jurídica que estabelece com suas propriedades as fronteiras da invisibilidade, da interdependência e das interrelações. Os estudos de Figueiredo e Noronha (2009) tem demonstrado que, sobretudo a partir dos anos de 1990, o judiciário tem se constituído como uma nova arena política, ocorrendo a transferência do debate político do campo democrático para o judicial. Esse processo, tem centralizado inúmeras ações de diferentes 
temáticas para o STF e essa transferência tem salvaguardado aos grupos vulneráveis a reivindicação de seus direitos negados pelo Estado.

Este trabalho analisa os programas de educação profissional que são destinados aos jovens e adultos trabalhadores que não possuem os anos de escolaridade obrigatória assegurada pela legislação brasileira. Nesse sentido, essas ações são propagadas como viés de garantia do direito à educação para esses cidadãos, no entanto, elas ainda são escassas e não atingem a demanda real e potencial de jovens e adultos que não frequentam os espaços escolares. O Art. 208 da Constituição da República Federal Brasileira (CRF/88) assegura que o dever do Estado com a educação será efetivado mediante a garantia de: I - ensino fundamental, obrigatório e gratuito, inclusive para os que a ele não tiveram acesso na idade própria. Nesse sentido, analisando o Censo de 2018 (PARANÁ, 2018), verificamos que o Brasil possui um total de 7.709.929 pessoas matriculadas no Ensino Médio, sendo 7\% no estado do RJ e desses 75\% alocadas pela SEEDUC. Essa maior alocação de vagas pela rede Estadual segue a recomendação da Lei de Diretrizes e Bases para Educação (LDB) no 9394/96. A metodologia da pesquisa é de natureza qualitativa e consiste na análise documental da Constituição da República do Brasil de 1988 (CRF/88) e na Lei de Diretrizes e Bases da Educação Nacional, n. 9394 de 1996.

Há nos documentos legais, nacionais e internacionais, o reconhecimento da necessidade de atender as especificidades e multiplicidades de jovens e adultos da sociedade brasileira que não tiveram igualdade de condições para o acesso e permanência na escola na idade própria. A CRF/88, em seu art. 205, afirma que a educação é direito de todos e dever do Estado. Para que ela aconteça de forma efetiva deve visar o pleno desenvolvimento da pessoa, seu preparo para o exercício da cidadania e sua qualificação para o trabalho. E, a partir, da LDB n. 9.39/96 e do Plano Nacional de Educação, PNE, meta 10, o objetivo para a Educação de jovens e adultos (EJA) é ofertá-la preferencialmente articulada aos cursos de qualificação profissional.

Um dos debates centrais para a Educação de jovens e adultos (EJA) é a tensão entre as similitudes desses cidadãos e aquelas que procuram atender as múltiplas relações articuladas às identidades raciais, étnicas, de gênero, necessidades especiais, dentre outras. Essas particularidades 
se revelam em diferentes concepções sobre como implementar políticas e abordagens pedagógicas a fim de garantir o direito à educação, pois, conforme determina a $\mathrm{CRF} / 88$ :

Art. 206. O ensino será ministrado com base nos seguintes princípios:

I - igualdade de condições para o acesso e permanência na escola;

II - liberdade de aprender, ensinar, pesquisar e divulgar o pensamento, a arte e o saber;

III - pluralismo de idéias e de concepções pedagógicas, e coexistência de instituições públicas e privadas de ensino;

IV - gratuidade do ensino público em estabelecimentos oficiais;

V - valorização dos profissionais do ensino, garantido, na forma da lei, plano de carreira para o magistério público, com piso salarial profissional e ingresso exclusivamente por concurso público de provas e títulos, assegurado regime jurídico único para todas as instituições mantidas pela União;

VI - gestão democrática do ensino público, na forma da lei;

VII - garantia de padrão de qualidade.

Refletir sobre os programas de qualificação e profissionalização que foram criados em substituição de uma política efetiva para jovens e adultos implica entender a dinâmica que se processa no interior da sociedade. Essa dinâmica revela uma distinção em relação à função que esses programas exercem na conservação ou transformação das relações de poder entre as classes sociais. E esse exercício de poder é mediado por uma relação de hegemonia, construída pela direção política e pelo consenso. Dessa maneira, os grupos e as classes sociais realizam a organização da representação de seus interesses e o encaminhamento de suas manifestações sociopolíticas por meio de "aparelhos privados de hegemonia" (GRAMSCI, 1980), cuja adesão é voluntária ou contratual. 
Esse debate nos leva consequentemente à questão da emancipação. Uma rápida observação mostra-nos um uso indiscriminado desse termo, remetendo a questões diversas: emancipação jurídica, emancipação pela educação, pela cidadania, pela descolonização do "Mundo da Vida", pela "inclusão social”, emancipação da mulher, de uma nação, de um grupo particular etc. Pareceria, assim, que a emancipação estaria representada praticamente por qualquer conquista de direitos sociais ou políticos, ou de redução de certas formas de desigualdade. Afinal, o que é e em que consiste a emancipação?

$\mathrm{Na}$ perspectiva do materialismo histórico dialético, Marx (1989) reitera que a emancipação humana demanda que os homens se reconheçam além de suas individualidades, isto é, como forças sociais capazes de promover mudanças estruturais na sociedade. Assim, a emancipação humana requer a superação dos obstáculos impostos à vida individual e coletiva pela alienação do trabalho no modo de produção capitalista. A emancipação humana, portanto, evidencia-se pelo controle do homem coletivo sobre as condições sociais de produção da existência (MARX, 1989; RUMMERT, 2007).

Ciavatta e Ramos (2012) apontam que no caso do capital, a educação dos trabalhadores é vista como fato de produtividade e de seletividade, em geral, articulada a elementos de filantropia e de controle da ordem social. No caso dos trabalhadores, o direito à educação sempre foi difundido como inegociável, apesar de historicamente negado, como condição necessária para a sua emancipação.

Até o ano de 2019, três grandes programas de educação profissional eram ofertados para os jovens e adultos trabalhadores: 1) Programa Nacional de Integração da Educação Profissional com a Educação Básica na Modalidade de Educação de Jovens e Adultos (Proeja); 2) Educação de Jovens e Adultos (EJA) articulada à educação profissional no âmbito do Programa Nacional de Acesso ao Ensino Técnico e Emprego (Pronatec); 3) Programa Nacional de Inclusão de Jovens (Projovem). Vale lembrar que em 2018, a Secretaria de Educação Continuada, Alfabetização, Diversidade e Inclusão (SECADI), onde a EJA estava alocada foi extinta. Embora ela tenha sido alocada formalmente na Secretaria de Educação Básica (SEB), não há diretoria ou coordenação responsável pela EJA. Ela 
existe só no papel, não há programa, gestor, proposta para a modalidade. Atualmente, o Ministério da Educação tem investido no Exame Nacional para Certificação de Competências de Jovens e Adultos (ENCCEJA) constituindo-se em uma política certificação a curto prazo, indo na contramão do art. 214, incisos III, IV e V que visam a qualidade do ensino, a formação para o trabalho e a promoção humanística, científica e tecnológica do país. Segundo a sinopse estatística do Inep (2018) houve um aumento de 13\% nas inscrições do ENCCEJA.

Tendo como garantia dos direitos constitucionais entende-se que o direito à educação não pode ser legitimada por programas pontuais e/ ou exames certificadores que não compreendam a EJA como direito à uma educação de qualidade. Portanto, modalidade educativa não pode ser reduzida a um programa, essa é a luta dos Fóruns EJA, e também de muitos profissionais que, antes da criação dos Fóruns, já defendiam uma educação pública para todos, independentemente de programas. Para Amorim (2007), no início da implantação do Proeja, já havia a necessidade de ir além das fronteiras restritas, e alargar o direito à educação. O autor dizia que o Programa poderia passar pela história como uma das tentativas de avanço na restrição do direito à educação; entretanto, ele ressaltava que a visão e modo como pensamos os jovens e adultos condicionariam esse projeto de educação.

Compreende-se nesse estudo que o direito à educação ainda que sob bases legais e garantias jurídicas revela-se sob a forma de direito fraturado, concedido em políticas de gotejamento que não favorecem a emancipação humana, ou seja, uma melhoria nas condições reais de vida dos jovens e adultos que não tiveram a oportunidade ou por inúmeras razões não puderam frequentar a escola durante a infância.

Palavras-chave: adultos, direito, educação, emancipação, jovens.

\section{REFERÊNCIAS}

BRASIL. Constituição (1988) Constituição: República Federativa do Brasil. Brasília, DF: Senado Federal, 1988. Disponível em: <https://www2.senado.leg.br/bdsf/bitstream/handle/id /518231/ CF88 Livro_EC91_2016.pdf>. Acesso em julho de 2020. 
BRASIL. Lei no. 9.394. Lei de Diretrizes e Bases da Educação Nacional. Brasília, DF: 20 de dezembro de 1996. Disponível em: <http://www.planalto.gov.br/ccivil_03/leis/19394.htm>. Acesso em 19 maio 2019.

CIAVATTA, M; RAMOS, M. A era das diretrizes: a disputa pelo projeto de educação dos pobres. Revista Brasileira de Educação. v. 17 n.49 jan-abr, 2012.

FIGUEIREDO, I.; NORONHA, R. Direitos postos a efetivação de direitos fundamentais, econômicos, sociais e culturais pelo judiciário nos países do IBSA. GT 31. Políticas dos Direitos Humanos. Anais. 33 Encontro Anual da ANPOCS, Associação Nacional de Pós-graduação em Ciências Sociais, 2009.

GRAMSCI A. Maquiavel: a Política e o Estado Moderno. (Tradução de). Rio de Janeiro Civilização Brasileira, 1980.

INEP. Sinopse Estatística da Educação Básica. Brasília, DF. 2018. Disponível em: <portal.inep. gov.br/sinopses-estatisticas-da-educacao-basica>. Acesso em 19 maio 2019.

MARX, K. Manuscritos Econômicos e Filosóficos. Lisboa: Edições 70, 1989.

PARANÁ. Laboratório de dados educacionais. 2018. Disponível em: https://dadoseducacionais.c3sl.ufpr.br/\#/consultas. Acesso em julho de 2020.

RUMMERT, S. M. A educação de jovens e adultos trabalhadores brasileiros no século XXI:o "novo" que reitera a antiga destituição de direitos. Revista de Ciências da Educação, Sísifo, jan./abr., 07 (p.35-50). Disponível em http://sisifo.fpce.ul.pt. Acesso em setembro de 2009. 


\section{ESCOLA PÚBLICA: PELO DIREITO DE "SER ALGUÉM NA VIDA"}

Janaína da Conceição Santos Dias Almeida

Introdução

O presente trabalho intenta apresentar uma defesa da escola pública como direito do/da jovem das periferias a uma educação critico-reflexiva, emancipadora e gratuita. A discussão é tecida pautando-se nos resultados da pesquisa de mestrado desenvolvida no Programa de Pós-Graduação em Educação - PPGE/UEFS, em 2017, cujo objetivo era compreender e refletir sobre os sentidos atribuídos pelos/as jovens-estudantes à escola em seu processo de escolarização, assim como as relações que estes/as estabeleciam entre a escola e si mesmos, evidenciando as razões que os mobilizavam a frequentá-la e seus anseios e necessidades em relação ao ensino médio. Esta proposta resulta, sobretudo, do particular interesse enquanto professora de escola pública, de jovens, majoritariamente negros, periféricos, com idades entre 15 e 21 anos, estudantes do Ensino Médio, seres em desenvolvimento, que produzem significações de suas experiências na trama das relações sociais e a partir de leituras de textos sobre a relação Juventude(s) e Escola - Dayrell (1996); Leão (2014); Carrano (2016); Laranjeira (2016); Klein (2011).

O trabalho investigativo aqui compartilhado foi tecido, no desenho metodológico de pesquisa qualitativa, através da abordagem teórico-metodológica da Rede de Significações (RedSig), por acreditar que essa daria o suporte necessário para a realização 
e leitura desse percurso. Além disso, os dados foram produzidos processualmente, considerando-se o contexto e as interações, por meio da observação direta do contexto com registros em diários de campo, da aplicação de questionário sociocultural a fim de conhecer os/as dezesseis jovens que colaboraram com este trabalho, de conversas informais pelos corredores e caminhos da escola e de grupos de diálogo.

O caminho percorrido entre a reflexão, a prática e a busca até os sentidos atribuídos pelos/as jovens-estudantes à escola em seu processo de escolarização levou à percepção de que os sentidos atribuídos pelos/as jovens à escola estão relacionados à forma como ele/ela se vê diante do processo de escolarização: as motivações, os laços estabelecidos, as expectativas e as frustrações. Nesta perspectiva, entre os sentidos identificados e debatidos na pesquisa, trar-se-ão as significações da escola.

\section{"Ser alguém na vida": Significações da escola}

A ideia da escola como "lugar que você vai para aprender" é um sentido, há tempos, compartilhado socialmente, fruto de uma "valorização" que a sociedade tem atribuído à escolarização. Ainda que não seja espaço exclusivo do aprender, a escola foi e é a única instituição histórica e socialmente pensada, criada e "estruturada" intencionando esse fim e, portanto, perpetua-se nas narrativas a ideia expressa de que ela é o único espaço reservado para tal. Nesse contexto, passando-se de geração a geração, pais matriculam seus filhos na escola desde a mais tenra idade, sob a seguinte alegação: "para aprender”, legando a escola o título de detentora de um determinado conhecimento que só a ela cabe transmitir.

Face a isso, a aposta pela escolaridade dos/as filhos/as se intensifica objetivando responder a uma expectativa de superação, na maioria dos casos, da pobreza. Para alguns/as pais e mães, espera-se que advenha com a escolaridade melhores oportunidades ocupacionais que possibilitem aos/às jovens investirem em um futuro de estabilidade econômica e na melhoria das condições de vida de si mesmos/as e das famílias. 
Em narrativa, a estudante $M$, ao falar sobre trabalhar no supermercado das sete da manhã às sete da noite, traz a fala do tio como um incentivo para ir à escola: " Você gosta de limpar casa? Você gosta de trabalhar no supermercado? Você quer trabalhar na padaria? Não, né? Então, vai estudar, aprender'... Não sei se muda muita coisa, mas quando eu lembro...". Diante das opções "postas" para a "vida adulta", ela parece não se adaptar a nenhuma delas. Por essa razão, a escola é apontada pela estudante como o lugar do aprender para "fugir daquilo que não gosta", uma tentativa de apontar para um caminho que não reproduza uma história pregressa da família, alimentando a expectativa de um futuro melhor.

Assim como a estudante $\mathrm{M}$, a estudante $\mathrm{R}$ - outra participante da pesquisa, aponta a escola como um requisito essencial para "ser alguém na vida" reforçando a ideia do "ter que ir à escola" como a condição sine qua non. Mesmo apresentando tons diferentes, as narrativas reproduzem a ideia de que é pela escolarização que os/as jovens terão uma maior probabilidade de melhor inserção social e profissional.

Nesse sentido, aparece ainda mais marcante em outras narrativas o fato de, na sociedade moderna, a escolarização ser também uma exigência ou mesmo condição para que "a vontade de trabalhar para ganhar dinheiro para comprar comida” (Estudante N) seja sanada da melhor maneira. Segundo Pereira (2014), trata-se de uma “obrigação oculta” que, embora não seja tão explicitada, se relaciona com as consequências da não ida à escola, devido à dificuldade futura que, provavelmente, terão com a não escolarização, por existir, supostamente, prioridades e benefícios para aqueles que vão e finalizam os níveis escolares.

Muitos/as jovens trouxeram em suas narrativas referências à escola atrelada a um "vir a ser", depositando nela - a escola, expectativas, sonhos e esperanças de uma melhoria de vida, de independência financeira, de construção de uma carreira acadêmica, de ser alguém na vida. Segundo Weller (2014), isso deve ao fato de que tanto a convivência no espaço escolar, os componentes curriculares com todos os seus limites, as atividades que extrapolam o contexto das aulas, as relações e interações estabelecidas consigo e com o/a outro/a, as múltiplas redes de 
significações com que tem contato, a relação da família com o processo de escolarização, quanto os contextos sociais nos quais estão inseridos/ as são elementos que atrelam a escola/escolarização à construção de projetos de vida desses/as jovens.

\section{Considerações Finais}

A ideia de "ir à escola para aprender", "ser alguém na vida", "ir por obrigação" e o discurso meritocrático são significações atribuídas à escola por esses/as jovens-estudantes - que, inclusive, perpassam também por diferentes gerações, classes sociais, gêneros - decorrentes de processos ligados a diferentes tempos históricos e processos sociais, entrelaçados nas múltiplas relações estabelecidas pelos/as jovens consigo mesmos/as, com o/os outro/s e sua relação interna e direta com o contexto intra e extraescolar. Nessa perspectiva, ainda que se reconheçam falhas no processo de construção, aquisição e transmissão dos saberes escolares, estar na escola faz-se necessário visto ser ela quem legitima para a sociedade os saberes necessários para se inserir no mercado de trabalho ou seguir uma carreira acadêmica.

Mesmo sendo um direito garantido por lei, a escola pública tem sofrido "ataques" seja pela falta de investimentos e pelo sucateamento de suas estruturas seja pela desvalorização e descrença de/em seus profissionais. Isso faz com que o "ser alguém na vida" se torne uma busca árdua e, por vezes, inalcançável para aqueles que estão invisibilizados ou à margem do processo. É preciso persistir e resistir pelos/as inúmeros/ inúmeras jovens que adentram os muros da escola na expectativa de ter seus projetos de vida efetivados. Enquanto professores, precisamos voltar nosso olhar para a realidade que se descortina à nossa frente; enquanto cidadão, precisamos lutar para que as políticas públicas se efetivem.

De qualquer sorte, essa ação perpassa por um projeto de Educação que se intente plural, critico-reflexiva e emancipadora, que abale estruturas historicamente construídas em cima de privilégios. Isso gera incômodos, retaliações, ataques, falta de investimentos, sucateamento, desvalorização, descrença... Um ciclo que precisa ser quebrado para um projeto melhor de sociedade. 


\section{Referências}

ALMEIDA, Janaína da Conceição Santos Dias. Meu olhar de encontro ao teu: A escola na ótica dos jovens-estudantes do Colégio Estadual Yeda Barradas Carneiro - Conceição da Feira/Bahia. 2017. 136 f. Dissertação (Mestrado em Educação), Universidade Estadual de Feira de Santana, Feira de Santana-BA.

CARRANO, Paulo. Não se Muda a Realidade do Ensino Médio Apenas Mexendo no Currículo. Portal IG, Entrevista concedida a Priscilla Borges. Brasília, 06 de janeiro de 2014. Disponível em: <http://ultimosegundo.ig.com.br/educacao/2014-01-06/ nao-se-muda-a-realidade-da-escola-apenas-mexendo-no-curriculo.html>

DAYRELL, Juarez Tarcísio. A escola como espaço sócio-cultural. In: Dayrell, J. (Org.). Múltiplos olhares sobre educação e cultura. Belo Horizonte: UFMG, 1996.

KLEIN, Ana Maria. Projetos de Vida e Escola: a percepção de estudantes do ensino médio sobre a contribuição das experiências escolares aos seus projetos de vida. 2011. 292 f. Tese (Doutorado em Educação) - Faculdade de Educação, Universidade de São Paulo, São Paulo, 2011.

LARANJEIRA, Denise Helena Pereira; IRIART, Mirela Figueiredo Santos; RODRIGUES, Milena Santos. Problematizando as Transições Juvenis na Saída do Ensino Médio. Educação \& Realidade. Porto Alegre, v. 41, n. 1, p. 117-133, jan./mar. 2016.

LEÃO, Geraldo. Entre a escola desejada e a escola real: os jovens e o ensino médio. In: CARRANO, Paulo; FÁVERO, Osmar (Orgs.). Narrativas juvenis e espaços públicos: olhares de pesquisas em educação, mídia e ciências sociais. Niterói: UFF, 2014, p. 231-257

PEREIRA, Benedito Fernando. Foucault e a educação libertária: por uma escola transformadora da sociedade. Theoria -Re- 
vista Eletrônica de Filosofia - Faculdade Católica de Pouso Alegre, v. 5, n. 13, p. 80-102.

WELLER, Wivian. Jovens no Ensino Médio: projetos de vida e perspectiva de futuro. In: DAYRELL, Juarez; CARRANO, Paulo; MAIA, Carla Linhares (orgs.). Juventude e ensino médio: sujeitos e currículo em diálogo. Belo Horizonte: UFMG, 2014, p. 135-156. 


\section{A EJA - A EDUCAÇÃO DE JOVENS E ADULTOS E ADOLESCENTES EM SITUAÇÃO DE ACOLHIMENTOS INSTITUCIONAIS: CLAMORES E INQUIETAÇÕES}

João Francisco Ferraz de Lima

Introdução:

O presente artigo pretende suscitar as relações estabelecidas na utilização por adolescente em situação de acolhimento institucional o modelo de escolarização da EJA - Educação de jovens e adultos. Neste sentido quais os diálogos que estão estabelecidos entre as politicas publicas de atenção integral ao adolescente acolhido no serviço do acolhimento institucional de crianças e adolescente através da aplicação da tipificação dos serviços socioassistenciais contidas no SUAS - Sistema Único de Assistência Social e a aplicabilidade das ações descritas na LDB no quesito EJA - educação de jovens e adultos.

Art. 227. É dever da família, da sociedade e do Estado assegurar à criança, ao adolescente e ao jovem, com absoluta prioridade, o direito à vida, à saúde, à alimentação, à educação, ao lazer, à profissionalização, à cultura, à dignidade, ao respeito, à liberdade e à convivência familiar e comunitária, além de colocá-los a salvo de toda forma de negligência, discriminação, exploração, violência, crueldade e opressão. (BRASIL, 2000, p.240) 
Pode se compreender que de acordo com o Estatuto da Criança e do adolescente a situação de acolhimento institucional é aplicado como medida de proteção para salvaguardar o desenvolvimento das crianças e adolescente como seres singulares e as possibilidades de retorno a vida familiar e comunitária. O art. 101 do Estatuto da Criança e Adolescente em seu $\int 1^{\circ}$ e $2^{\circ}$ estabelece:

$\int 1^{\circ} \mathrm{O}$ acolhimento institucional e o acolhimento familiar são medidas provisórias e excepcionais, utilizáveis como forma de transição para reintegração familiar ou, não sendo esta possível, para colocação em família substituta, não implicando privação de liberdade.

$\int 2^{\circ}$ Sem prejuízo da tomada de medidas emergenciais para proteção de vítimas de violência ou abuso sexual e das providências a que alude o art. 130 desta Lei, o afastamento da criança ou adolescente do convívio familiar é de competência exclusiva da autoridade judiciária e importará na deflagração, a pedido do Ministério Público ou de quem tenha legítimo interesse, de procedimento judicial contencioso, no qual se garanta aos pais ou ao responsável legal o exercício do contraditório e da ampla defesa.( BRASIL, 1990, p.100)

No entanto medidas de proteção que indiquem o afastamento da criança e do adolescente de seu contexto familiar ou que ocasionam suspensão temporária dos vínculos atuais, deve ser medida rara, excepcional para que se evitem danos ao desenvolvimento da criança e do adolescente causados por separações bruscas, longas e desnecessárias.

Com isso podemos compreender que este modelo de expressão de cuidados frente à crianças e adolescente que passaram por processos complexos de rupturas de vínculos familiares e comunitários que foi levado ao extremo de onde um processo judicial aplicou uma medida de proteção onde a institucionalização é meio de proteção social e base para um novo processo de reconstrução de vida é forma de encarar o mundo.

Ainda o caderno de orientações técnicas para o trabalho em Acolhimento Institucional de crianças e adolescentes tem como primazia 
a concepção do acolhido como ser singular e postulante a protagonista de sua historia em um processo de construção e /ou reconstrução que utiliza como meio não único mais de singular importância o processo de escolarização.

Observando ainda em nossa carta magna e no ECA a educação e a escolarização é elemento crucial no composição da formação do individuo e ser social. A cultura da escolarização que é preconizada no ECA na CF88 e por vezes não ultrapassa o linear da letra fria da lei. Culturalmente é possível observar familiar que o valor da escolarização frente ao desafio cotidiano da sobrevivência não se faz contundente.

Neste sentido crianças e adolescentes que tiveram rupturas nos vínculos familiares e foram encaminhadas como medida de proteção o acolhimento institucional por vezes foram negligenciadas o direito básico a educação e encontram-se em desacordo de idade e série sem sentido nenhum para continuar na escolarização regular.

Os traços das rupturas de vínculos e as condições de violações direitos se expressam de forma tão severas em sua história de vida que utilizar das estratégias de melhora de vida via escolarização é fato não pensado em seu cotidiano, ainda o acumulo de vivencias complexas apoiam ato de não observar sentido no processo de escolarização.

A nossa LDB expõe em seu texto modelos e modos de fazer a educação e a escolarização e neste modo, ela apresenta a Educação de Jovens e adultos como forma mais inclusiva no sentido de priorizar, horários, matérias, locais e espaços que fogem um pouco do tradicional da escolarização regular, sendo mais acolhedor: A Lei de Diretrizes e Bases da Educação Nacional (Lei 9.394/96) estabeleceu no capítulo II, seção V a Educação de Jovens e Adultos, diz o artigo 37: “A educação de jovens e adultos será destinada àqueles que não tiveram acesso ou oportunidade de estudos no ensino fundamental e médio na idade própria".

Contudo esse artigo almeja colocar luz neste dialogo de importância singular haja vista que uma educação transformadora é o caminho para uma sociedade melhor, justa e igualitária. Buscando compreender como educação transformadora o que Paulo Feire coloca: 
...a educação esteja - em seu conteúdo, em seus programas e em seus métodos - adaptada ao fim que se persegue: permitir ao homem chegar a ser sujeito, construir-se como pessoa, transformar o mundo, estabelecer com os outros homens relações de reciprocidade, fazer a cultura e a história [...] uma educação que liberte, que não adapte, domestique ou subjugue. (FEIRE, 1996, p.46).

Premissa básicas e contextos necessários na relação da EJA e Acolhimentos Institucionais de Crianças e adolescentes. O ECA, ou Lei 8.069 de 1990, é um conjunto de normas jurídicas que complementa o artigo 227 da Constituição Brasileira. Ele representa um divisor de águas na história da infância e da adolescência brasileiras, pois instaurou direitos para todas as crianças e adolescentes, entendendo-os como sujeitos de direitos e garantindo um atendimento integral, que leva em conta as diversas necessidades desse público.

A figura das instituições que prestam o serviços de Acolhimento instrucional de crianças e adolescente apresentasse como serviço de proteção social no Sistema único de Assistência Social como promotora da função conjunta de protetora e possível articuladora e fomentadora do protagonismo dos acolhido e acolhidas, assim é colocada como ator na construção de novos modelos de relacionamento sociais dos acolhidos e acolhidas e deve em conjunto construir meios para que seja atingido as potencialidades dos mesmos.

Toda criança e adolescente tem direito a viver num ambiente que favoreça seu processo de desenvolvimento, que lhe ofereça segurança, apoio, proteção e cuidado. Nesse sentido, quando o afastamento for necessário e enquanto soluções para a retomada do convívio familiar forem buscadas, os serviços de acolhimento deverão prestar cuidados de qualidade, condizentes com os direitos e as necessidades físicas, psicológicas e sociais da criança e do adolescente. Para tanto, o atendimento deverá ser oferecido para um pequeno grupo e garantir espaços privados, objetos pessoais e registros, inclusive fotográficos, sobre a história de vida e desenvolvimento de cada criança e adolescente.(BRASIL, 2010, p.32) 
Neste viés e em consonância com a LDB (Lei de Diretrizes e Bases da Educação) assegura o desenvolvimento integral da criança e do adolescente, nos aspectos físico, psicológico, intelectual e social, orientando a família e a comunidade. Dessa forma, o potencial de escolarização faz mais que necessário para a interação entre o conhecimento e envolvimento com o todo, comunidade, sociedade e visão de mundo. Para se estabelecer vínculos e relações que condicionam e definem as próprias concepções pessoais sobre si mesmo e sobre os demais.

Ainda a constituição trouxe de forma concreta a educação, direito de todos e dever do Estado e da família, será provida e incentivada com a colaboração da sociedade, visando pleno desenvolvimento da pessoa, seu preparo para o exercício da cidadania e sua qualificação para o trabalho. (C.F.88)

No prisma da colocação explicita da C.F. sobre as relações da politica da educação o acesso de adolescente em situação de acolhimento institucional representa a conquista de um direito social. Principalmente para aqueles cidadãos que não tiveram até então o acesso ao ensino público, ou seja, o direito ao ensino com qualidade como meio de crescimento pessoal e de cidadania, onde o Estado tem a plena responsabilidade de garantir a educação para todos. Seja por uma ação de negligencia família seja por ausência de politicas publicas que abrangesse esse publico.

Outrossim, a educação em dialogo com a atuação da politica publica de assistência social no serviço de acolhimento institucional apresente sua significância no momento em que se torna imprescindível no fazer sentido ao acolhido.

Isso tudo tem implicações mais do que importantes para uma educação escolar que tenha por finalidade a formação humana. Em primeiro lugar, é preciso ter presente que não basta formar para o trabalho, ou para a sobrevivência, como parece entender os que veem na escola apenas um instrumento para preparar para o mercado de trabalho ou para entrar na universidade (que também tem como horizonte o mercado de trabalho). Se a escola deve preparar para alguma coisa, deve ser para a própria 
vida, mas esta entendida como o viver bem, no desfrute de todos os bens criados socialmente pela humanidade. E aqui já há um segundo aspecto, corolário do primeiro, a ser considerado: não basta a escola "preparar para" o bem viver, é preciso que, ao fazer isso, ela estimule e propicie esse bem viver, ou seja, é preciso que a escola seja prazerosa para seus alunos desde já. A primeira condição para propiciar isso é que a educação se apresente enquanto relação humana dialógica, que garanta a condição de sujeito tanto do educador quanto do educando. (PARO, 1998, p.305)

A construção de modelos aparentemente alternativos a regularidade da oferta de escolarização contribui pode contribuir para o acesso de jovens em situação de acolhimento institucional, pois fogem da burocratização dos meios de acesse e colocam formatos mais condizentes a realidade diversa que se apresenta no cotidiano.

Igualdade de condições para acesso e permanência na escola. Saviani alerta-nos para o fato de que há uma desigualdade no ponto de partida, mas a igualdade no ponto de chegada deve ser garantida pela mediação da escola. O autor destaca: Portanto, só é possível considerar o processo educativo em seu conjunto sob a condição de se distinguir a democracia como possibilidade no ponto de partida e democracia como realidade no ponto de chegada. Igualdade de oportunidades requer, portanto, mais que a expansão quantitativa de ofertas; requer ampliação do atendimento com simultânea manutenção de qualidade. (VEIGA, 1998, p.25)

Ao olhar da interação entre politicas publica e os processo de os acessos a todos e todas construir meios e modos convergentes no sentido de atender uma demanda mais especifica com caraterísticas e dotada de uma relevância singular frente ao processo de vida e histórico de alternâncias e inconstância na trajetória de via a EJA pode ser alternativa legalmente e cotidianamente utilizada. 


\section{Considerações Finais:}

Vivencias de institucionalizações edificam edemas que só dissolverão com a formação critica da realidade vivenciadas frente a isso demonstrar a complexidade do desafio que os acolhidos encontram ao interagir as formas de escolarização formal é apresentar meios de suas superação. Faz se necessária que estes espaço instiguem o despertar em acolhidos e acolhidas o protagonismo necessário para a busca da autonomia. Embora as marcas histórica das sucessões de abandono, que, por motivos diversos, os fez chegar ao abrigo e permanecerem nesse espaço. Possa ser usadas como alicerces dos homens e mulheres do amanha.

Ainda aliado a uma política educacional, a EJA tem caráter transformador, pois dará condições para que os alunos melhorem suas condições de trabalho, melhorem a sua qualidade de vida e com isso sejam respeitados na sociedade, além de ser um fatos de sociabilidade e interação com demais membros das comunidades, uma vez que acolhidos e acolhidos tem como premissa a interação social no território.

Neste prisma o trabalho nos permite novos olhares, para cada um desses indivíduos, reconhecendo as marcas da violação de direitos, violência, do abandono, da exclusão, porem como sujeitos, buscando compreender que essas histórias podem e devem ser reelaboradas e que o compromisso das politicas publicas e dos atores que protagonizam as mesma é de contribuir de modo efetivo para a superação da atual condição e a busca reta pela construção de relações mais abrangentes no sentido da diversidade para autonomia dos sujeitos e a emancipação da sociedade.

\section{Referencias:}

BRASIL, Orientações Técnicas: Serviços de Acolhimento para Crianças e Adolescentes. 2010.

FREIRE, P. Pedagogia da autonomia: saberes necessários à prática educativa. 25. ed. São Paulo: Paz e Terra, 1996 
LDB, Lei de Diretrizes e Bases da Educação Nacional N 9.394/96

PARO, Vitor Henrique. Trabalho apresentado no V Seminário Internacional Sobre Reestruturação Curricular, realizado de 6 a 11/7/1998, em Porto Alegre, RS. Publicado em: SILVA, Luiz Heron da; org. A escola cidadã no contexto da globalização. Petrópolis, Vozes, 1998. p. 300-307.

VEIGA, Ilma Passos da. Projeto político-pedagógico da escola: uma construção coletiva. In: VEIGA, Ilma. Passos da (org.). Projeto político-pedagógico da escola: uma construção possível. Campinas: Papirus, 1998.p.11-35. 
DANIEL GIOTTI DE PAULA, DIEGO MACHADO MONNERAT, LUCAS MANOEL SILVA CABRAL, ROSANGELA TREMEL (ORGS.) 


\section{DIREITOS SOCIAIS E POLÍTICAS PÚBLICAS - VOL. 1}

Daniel Giotti de Paula, Diego Machado Monnerat, Lucas Manoel Silva Cabral, Rosangela Tremel (orgs.)

Tipografias utilizadas:

Família Museo Sans (títulos e subtítulos)

Bergamo Std (corpo de texto)

Papel: Offset $75 \mathrm{~g} / \mathrm{m} 2$

Impresso na gráfica Trio Studio

Setembro de 2020 